\title{
Verdediging in transitie : rechtsbijstand in strafzaken in post-communistisch Polen
}

Citation for published version (APA):

de Vocht, D. L. F. (2009). Verdediging in transitie : rechtsbijstand in strafzaken in post-communistisch Polen. [Doctoral Thesis, Maastricht University]. Wolf Legal Publishers.

https://doi.org/10.26481/dis.20090213dv

Document status and date:

Published: 01/01/2009

DOI:

$10.26481 /$ dis.20090213dv

Document Version:

Publisher's PDF, also known as Version of record

\section{Please check the document version of this publication:}

- A submitted manuscript is the version of the article upon submission and before peer-review. There can be important differences between the submitted version and the official published version of record.

People interested in the research are advised to contact the author for the final version of the publication, or visit the DOI to the publisher's website.

- The final author version and the galley proof are versions of the publication after peer review.

- The final published version features the final layout of the paper including the volume, issue and page numbers.

Link to publication

\footnotetext{
General rights rights.

- You may freely distribute the URL identifying the publication in the public portal. please follow below link for the End User Agreement:

www.umlib.nl/taverne-license

Take down policy

If you believe that this document breaches copyright please contact us at:

repository@maastrichtuniversity.nl

providing details and we will investigate your claim.
}

Copyright and moral rights for the publications made accessible in the public portal are retained by the authors and/or other copyright owners and it is a condition of accessing publications that users recognise and abide by the legal requirements associated with these

- Users may download and print one copy of any publication from the public portal for the purpose of private study or research.

- You may not further distribute the material or use it for any profit-making activity or commercial gain

If the publication is distributed under the terms of Article $25 \mathrm{fa}$ of the Dutch Copyright Act, indicated by the "Taverne" license above, 


\section{Verdediging in transitie \\ Rechtsbijstand in strafzaken in postcommunistisch Polen}


Verdediging in transitie

Rechtsbijstand in strafzaken in postcommunistisch Polen

D. de Vocht

ISBN 978-90-5850-408-1

Wolf Legal Publishers

POB 31051

6503 CB Nijmegen

The Netherlands

www.wolflegalpublishers

(C) D. de Vocht 2009

Ontwerp omslag: Dennis de Vocht

Layout: Boekopmaak Nettie Litjens, Maastricht 


\title{
Verdediging in transitie \\ Rechtsbijstand in strafzaken in postcommunistisch Polen
}

\author{
PROEFSCHRIFT \\ ter verkrijging van de graad van doctor \\ aan de Universiteit Maastricht, \\ op gezag van de Rector Magnificus, Prof. mr. G.P.M.F. Mols, \\ volgens het besluit van het College van Decanen, \\ in het openbaar te verdedigen \\ op vrijdag 13 februari 2009 om 12.00 uur
}

door

Dorris Lucia Francisca de Vocht 


\section{Promotores:}

Prof. mr. T.N.M.B. Spronken

Prof. mr. T. Prakken

\section{Beoordelingscommissie:}

Prof. mr. J. Boksem (voorzitter)

Dr. P.L. Bal

Prof. mr. F.A.W. Bannier (Universiteit van Amsterdam)

Dr. W.M.B. Dreissen

Prof. mr. A.A. Franken (Universiteit van Utrecht)

Dit onderzoek werd gesteund door de Nederlandse Organisatie voor Wetenschappelijk Onderzoek (NWO). 


\section{Dankwoord}

Het schrijven van een proefschrift wordt vaak omschreven als een eenzame aangelegenheid. Dat is maar voor een deel waar: vele collega's, vrienden en familieleden hebben bijgedragen aan de uitvoering en de afronding van dit onderzoek.

First of all, I would like to express my sincere gratitude to the many lawyers in Poland who helped me gather the necessary data for this research. Even in cold winter weather, the Polish hospitality always made me feel warm and welcome. Many thanks go to $\mathrm{mr}$. Cyrson and $\mathrm{mr}$. Sendecki for allowing me to spend time at their law offices and offering me an inside look at everyday practice. Also, special thanks to prof. dr. Kruszyński, mr. Hermeliński, dr. Gwirdoyń and dr. WąsekWiaderek who - despite their busy schedules - were always willing to meet with me during my visits to Poland and never stopped answering my many, annoying questions.

Ties en Taru, mijn promotoren en niet voor niets 'coryfeeën' op het gebied van de verdediging in strafzaken ben ik dankbaar voor het vertrouwen dat ze in me stelden en de ruimte die ze me gaven om een eigen invulling te geven aan dit onderzoeksproject. Ties, dank voor je scherpe blik, je nuchterheid en je inspirerende visie op het strafproces en de rol van de verdediging daarin. Taru, dank voor je waardevolle inhoudelijke begeleiding, je enorme betrokkenheid en je efficiënte aanpak van praktische problemen.

De leden van de leescommissie dank ik voor de snelle doch kritische lezing van het manuscript.

Dan is er nog de vakgroep strafrecht en criminologie van de Universiteit Maastricht. Een bonte verzameling vakgenoten waarin - ondanks onderlinge verschillen - een sterke verbondenheid en altijd een prettige, gemoedelijke sfeer heerst. Van mijn collega's binnen en buiten deze vakgroep noem ik in het bijzonder mijn voormalig kamergenote Katrien Lauwaert, Jacques Claessen, Fleur Claessens, Marelle Attinger en Patricia Croes die ieder op eigen wijze hebben bijgedragen aan het plezier waarmee ik de afgelopen jaren heb gewerkt.

Marta Konarzewska-Cox wil ik bedanken voor de lessen in de Poolse taal en voor de vriendschap die daar uit voortvloeide.

Dank gaat ook uit naar de student-assistenten Steffi Menz en Joost Groenhuijsen voor hun hulp bij de afronding van het manuscript, naar Wies Rayar voor de revisie van de Engelstalige versie van de samenvatting en naar Agata Malecka die binnen zeer korte termijn de vertaling van de samenvatting in het Pools wist te verzorgen. Ten slotte, heel veel dank aan Nettie Litjens voor de efficiënte en professionele wijze waarop zij de opmaak van dit boek voor haar rekening heeft genomen.

Dan zijn er uiteraard nog de vele mensen uit mijn directe omgeving die mij de afgelopen jaren op allerlei manieren hebben gesteund.

Lieve Peet, hoewel we elkaar tijdens onze studie en onze (korte) gezamenlijke periode bij de vakgroep strafrecht slechts oppervlakkig kenden, is onze band de laatste jaren steeds hechter geworden. Jij en Kees zijn heel belangrijk voor me. 
Lieve Ingrid, vanaf dag één in Maastricht vormden we een onlosmakelijk duo. Ondanks de afstand tussen Middelburg en Maastricht en het feit dat onze levens de afgelopen jaren behoorlijk verschillende wendingen namen, is de nauwe verbondenheid en de vriendschap gebleven. Daar ben ik heel blij om.

En dan mijn familie. Steeds vaker realiseer ik me dat wat vroeger zo vanzelfsprekend leek, eigenlijk heel bijzonder is. De warmte en hechtheid van het Brabantse nest waarin ik opgroeide, de liefde en steun van mijn (schoon)familie en het plezier dat we beleven als we samen zijn. Lieve papa en mama, mijn dankbaarheid betreft zoveel meer dan jullie aandeel bij de totstandkoming van dit proefschrift. Gelukkig weten jullie dat. Dennis - de liefste en grappigste broer van de wereld het is altijd fijn om bij jou en Mirjam te zijn en ik kijk er naar uit na onze verhuizing (nog) meer tijd met jullie te kunnen doorbrengen. Ik hou van jullie.

Mijn lieve Roel, de laatste woorden zijn voor jou. De beruchte laatste loodjes wogen zwaar en jij hebt het meest van iedereen helpen tillen. Dat was lang niet altijd leuk en je hebt in verschillende opzichten heel veel geduld met me gehad. Ik ben dankbaar voor je rust, je vertrouwen, je optimisme, je relativerend vermogen en al het andere dat zich niet in woorden laat uitdrukken. Aan jou draag ik dit boek op. 


\section{Inhoudsopgave}

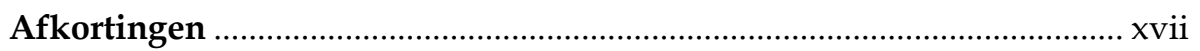

\section{Hoofdstuk 1 \\ Inleiding}

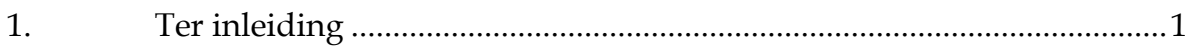

2. Effectieve verdediging: een Europese uitdaging ......................................1

3. Het belang van de postcommunistische context ........................................ 3

4. Vraagstelling.......................................................................................

5. Reikwijdte onderzoek............................................................................

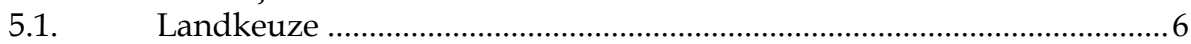

5.2. Interne rechtsvergelijking ................................................................... 6

5.3. Perspectief van de raadsman................................................................. 6

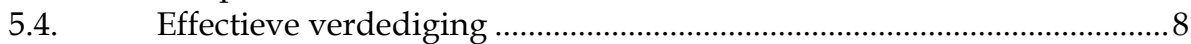

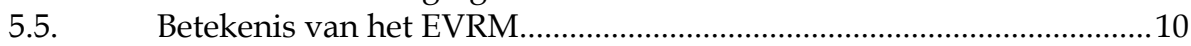

6. Methodologie ....................................................................................... 12

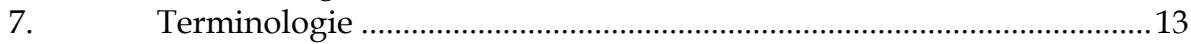

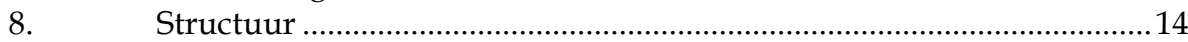

\section{Hoofdstuk 2}

\section{Geschiedenis en hoofdlijnen van het Poolse strafproces}

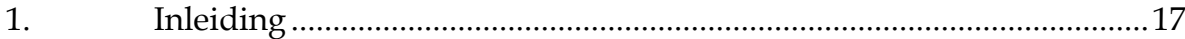

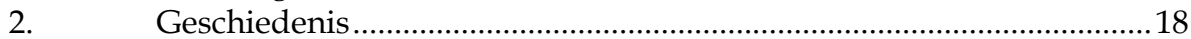

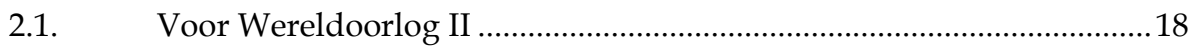

2.2. Communistische periode (1944-1989) ……………………………….....2

2.2.1. Stalinistische periode (1944-1956) …………………………………........2

2.2.1.1. Aanpassingen eerste jaren stalinisme …………………………….......2

2.2.1.2. Grootschalige hervormingen (1949 en 1950) …………………….........2

2.2.2. Poststalinistische periode (1956-1989) ......................................................32

2.2.2.1. Tweede helft jaren vijftig: incidentele verbeteringen strafrechtspleging .............................................33

2.2.2.2. Jaren zeventig: nieuwe strafrechtelijke codificaties en toenemende repressie ...............34

2.2.2.3. Staat van beleg en gevolgen voor het strafproces .....................................38

2.2.2.4. Tweede helft jaren tachtig: afbrokkeling communistisch regime en eerste hervormingen ...............42

2.3. Ontwikkelingen na 1989 ........................................................................ 45

2.3.1. Erkenning individuele rechten en vrijheden............................................. 45

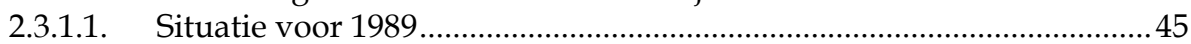

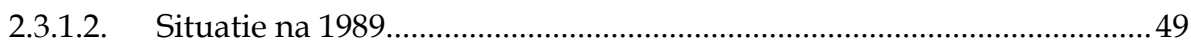

2.3.2. Nieuwe strafrechtelijke codificaties (1997) ............................................53

2.3.3. Hoofdpunten postcommunistische hervorming strafproces ..................56

2.3.3.1. Verhouding voor- en eindonderzoek........................................................56

2.3.3.2. Adversair karakter eindonderzoek ..........................................................58

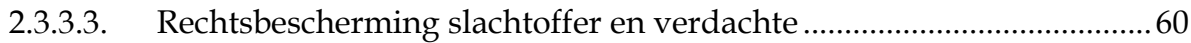

2.3.4. Wijzigingen na 1997 .............................................................................. 62 


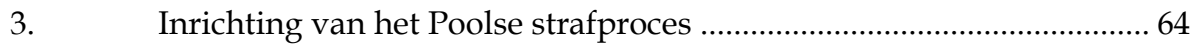

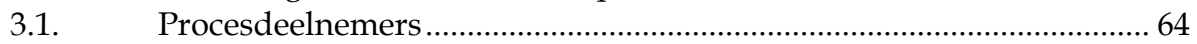

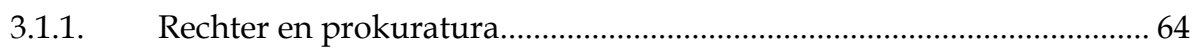

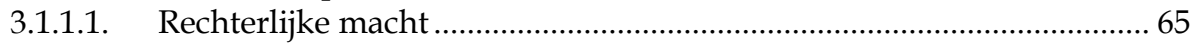

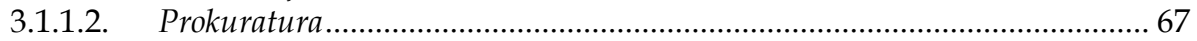

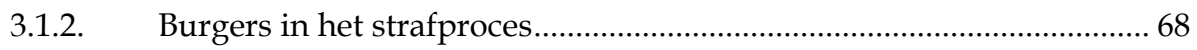

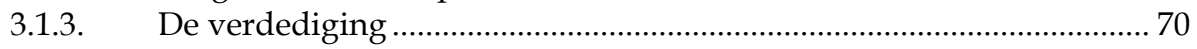

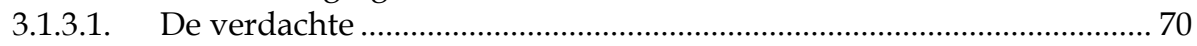

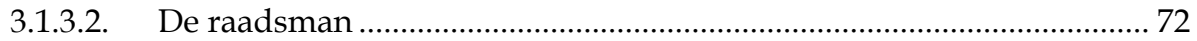

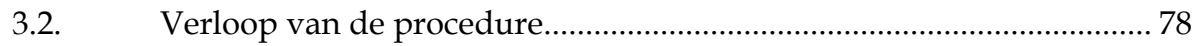

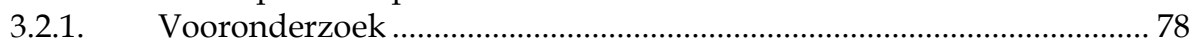

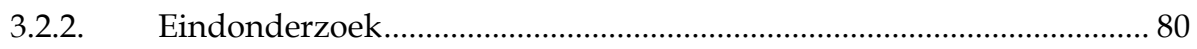

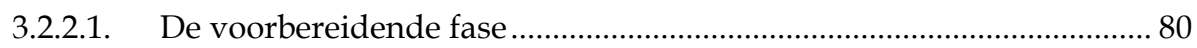

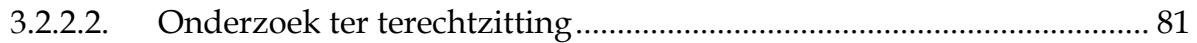

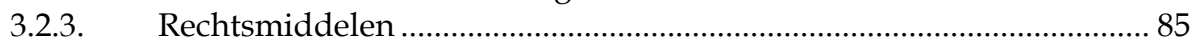

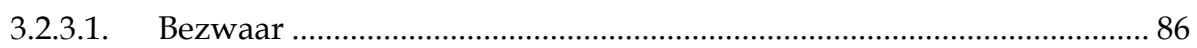

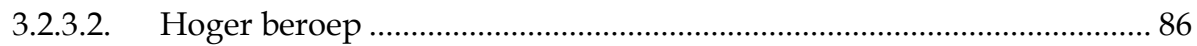

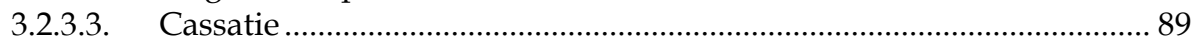

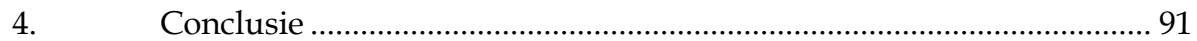

\section{Hoofdstuk 3}

De functie van de raadsman in historisch perspectief

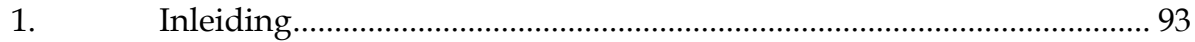

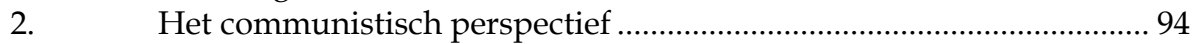

2.1. Het strafproces binnen de socialistische rechtsfamilie ..........................96

2.1.1. Gemeenschappelijke uitgangspunten................................................ 97

2.1.2. Gemeenschappelijke kenmerken........................................................99

2.2. Het communisme en de taakopvatting van de raadsman ................... 100

2.2.1. De complexe positie van de advocaat in strafzaken ............................ 100

2.2.2. Grenzen aan het optreden van de raadsman:

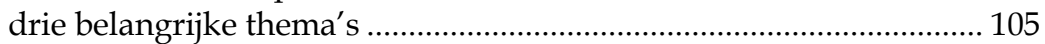

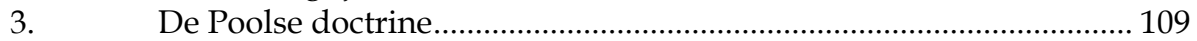

3.1. Relevantie onderscheid communisme-postcommunisme ................. 109

3.2. Verschillende typeringen van de functie van de raadsman ............... 110

3.2.1. De raadsman als 'helper van de rechtbank' ('pomocnik sqdu') ............ 110

3.2.2. De raadsman als 'medewerker van de rechtspleging'

('wspótczynnik wymiaru sprawiedliwości') .............................................. 111

3.2.3. De raadsman als 'helper van verdachte'

('koncepcja pomocnika procesowego oskarżonego') ..................................... 115

3.2.4. De raadsman als procesvertegenwoordiger van verdachte
('koncepcja przedstawiciela procesowych interesów oskarżonego') .............. 116

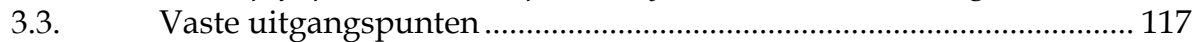

3.3.1. Handelen in het voordeel van verdachte ............................................ 120

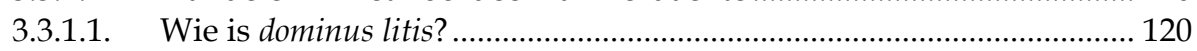

3.3.1.2. Hoe dient 'voordeel' te worden beoordeeld? ....................................... 121

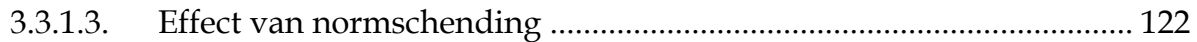

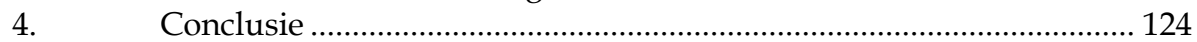




\section{Hoofdstuk 4}

\section{Toegang tot rechtsbijstand}

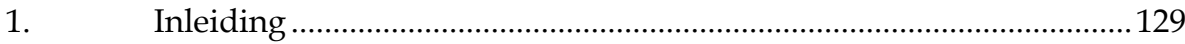

2. $\quad$ Aanvang recht op rechtsbijstand .........................................................130

2.1. Recht op rechtsbijstand en de status van verdachte.............................130

2.2. Rechtsbijstand na aanhouding .............................................................131

2.2.1. Situatie voor inwerkingtreding van het nieuwe strafprocesrecht......131

2.2.2. Huidig juridisch kader .........................................................................133

2.2.2.1. Reikwijdte art. 245 lid 1 KPK 1997.........................................................134

2.2.2.3. De aangehoudene en het zwijgrecht ………………...........................138

2.3. Evaluatie juridisch kader ....................................................................... 140

2.4. Aanvang rechtsbijstand in de praktijk ................................................... 142

2.5. Aanvang rechtsbijstand en het EVRM ..................................................144

2.6. Conclusie.................................................................................... 147

3. Toegevoegde rechtsbijstand .............................................................. 148

3.1. Huidig juridisch kader ..........................................................................149

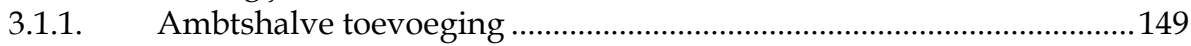

3.1.2. Toevoeging op verzoek verdachte........................................................153

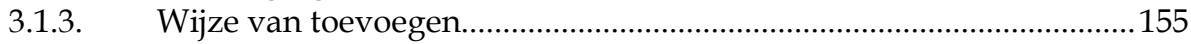

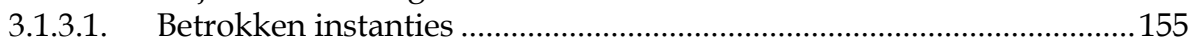

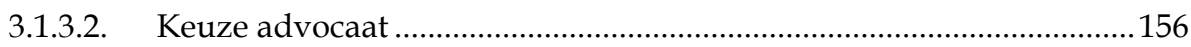

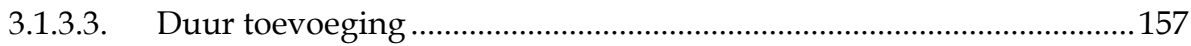

3.1.3.4. Vergoeding toegevoegde rechtsbijstand................................................160

3.2. Situatie voor inwerkingtreding van het nieuwe strafprocesrecht......162

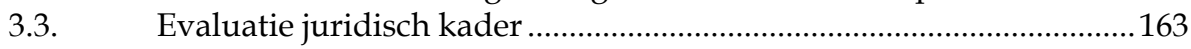

3.4. Kosteloze rechtsbijstand in de praktijk .................................................. 165

3.4.1. Behandeling van verzoeken ..................................................................165

3.4.2 Kosteloze rechtsbijstand in het vooronderzoek.......................................166

3.4.3. De kwaliteit van kosteloze rechtsbijstand .................................................169

3.4.3.1. Hoge werklast en vervanging .............................................................171

3.4.3.2. Rol van de balie in het toevoegingstelsel...............................................173

3.4.3.3. Ontbreken effectieve kwaliteitscontrole .................................................174

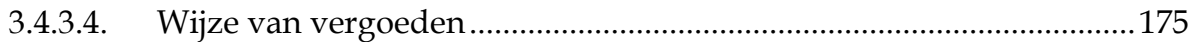

3.5. Het recht op kosteloze rechtsbijstand en het EVRM .............................176

3.5.1. Vrije advocatenkeuze in geval van toevoeging ....................................177

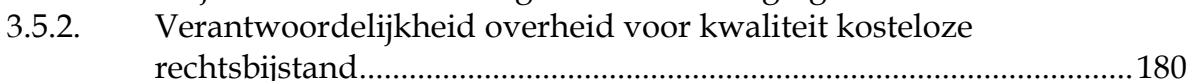

3.5.3 Ten onrechte geen toevoeging gedurende vooronderzoek...................181

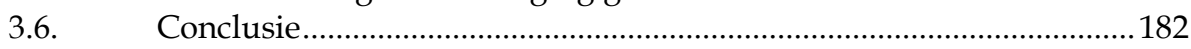

\section{Hoofdstuk 5}

\section{Verdediging in het vooronderzoek}

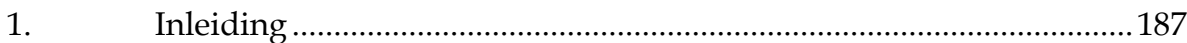

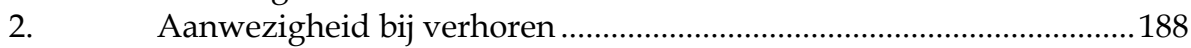

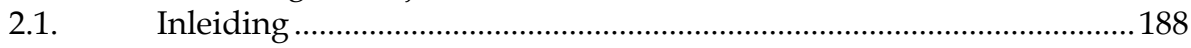

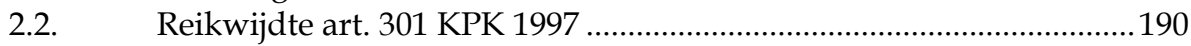

2.3. Bijstand bij één of verschillende verhoren? ............................................191 
2.4. Rechtsbijstand tijdens verhoor in de praktijk ...................................... 192

2.5. Recht op rechtsbijstand tijdens het politieverhoor en het EVRM ...... 193

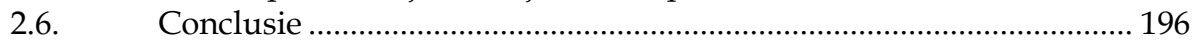

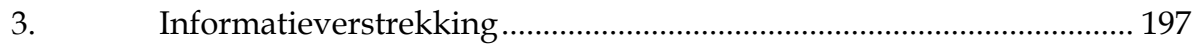

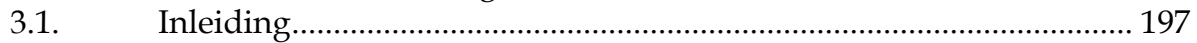

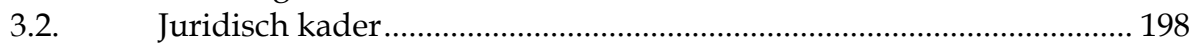

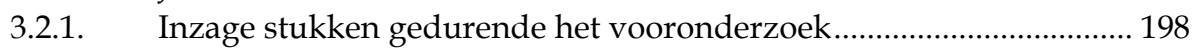

3.2.2. Inzage voor sluiting vooronderzoek.................................................. 200

3.2.3. Overige manieren ter verkrijging van informatie .............................. 202

3.3. Situatie voor inwerkingtreding nieuw strafprocesrecht .................... 204

3.3.1. Inzage stukken gedurende het vooronderzoek ................................... 204

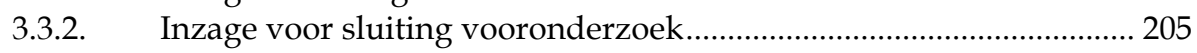

3.3.3. Overige manieren ter verkrijging van informatie................................ 206

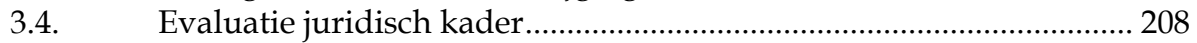

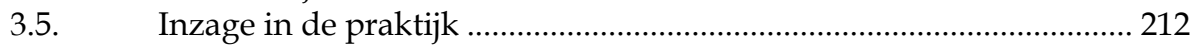

3.6. Recht op inzage van processtukken volgens het EVRM .................... 215

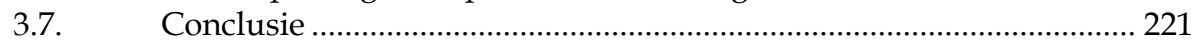

4. Mogelijkheden ten aanzien van voorlopige hechtenis ........................ 224

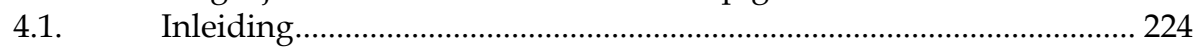

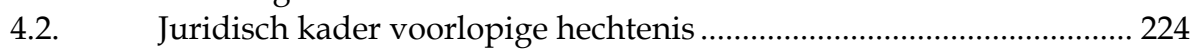

4.3. Mogelijkheden van de verdediging ................................................... 227

4.3.1 De beslissing tot toepassing en verlenging van voorlopige

4.3.2. Situatie voor inwerkingtreding nieuw strafprocesrecht ...................... 229

4.3.3. Het verzoek tot opheffing of omzetting van de voorlopige

4.3.4. Situatie voor inwerkingtreding nieuw strafprocesrecht ...................... 231

4.3.5. Het instellen van rechtsmiddelen ....................................................... 231

4.3.6. Situatie voor inwerkingtreding nieuw strafprocesrecht .......................2 234

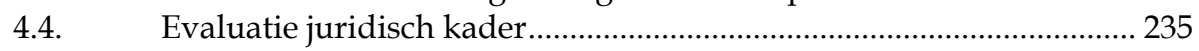

4.5. Voorlopige hechtenis in de praktijk .................................................... 237

4.6. Rechten van de verdediging inzake voorlopige
hechtenis en het EVRM

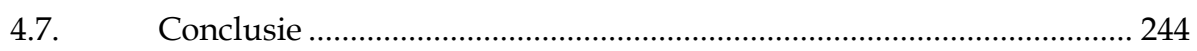

5. Mogelijkheden ten aanzien van bewijsvergaring ............................. 247

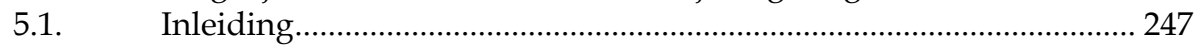

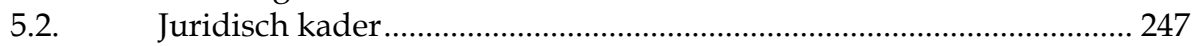

5.2.1. Mogelijkheden verdediging bij ambtshalve onderzoek...................... 249

5.2.1.1. Hoofdregel: deelname op verzoek, tenzij............................................ 249

5.2.1.2. Uitzondering I: handelingen die niet ter zitting kunnen worden

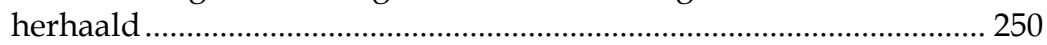

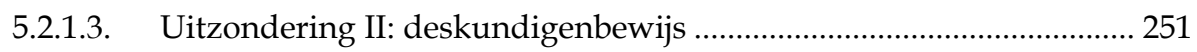

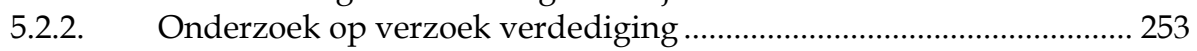

5.2.3. Horen van getuigen door de rechtbank .............................................. 255

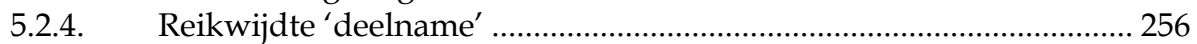

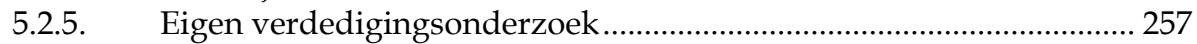

5.3. Situatie voor inwerkingtreding nieuw strafprocesrecht .................... 258

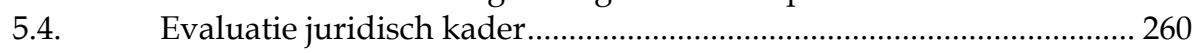


5.5. Verdediging en ambtshalve bewijsvergaring in de praktijk .............. 262

5.6. $\quad$ Eigen verdedigingsonderzoek in de praktijk ........................................ 264

5.7. Bewijsvergaring in het vooronderzoek en het EVRM.........................265

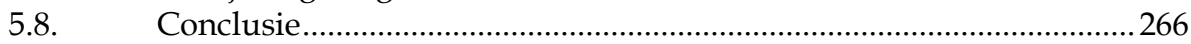

6. Conclusie verdediging in het vooronderzoek...................................269

\section{Hoofdstuk 6}

\section{Verdediging in het eindonderzoek}

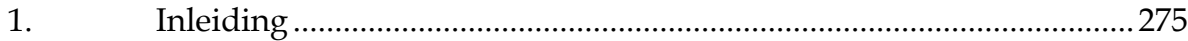

2. Verdediging in de fase voor het onderzoek ter terechtzitting .............276

2.1. Reactie op akte van beschuldiging .....................................................277

2.2. Indienen bewijsverzoeken ..................................................................2.279

2.3. Zittingen voorafgaand aan onderzoek ter terechtzitting.....................280

2.3.1. Situatie voor inwerkingtreding nieuw strafprocesrecht.................... 280

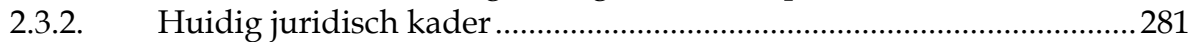

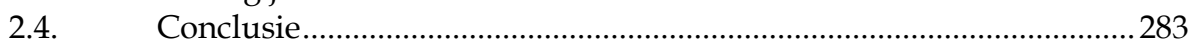

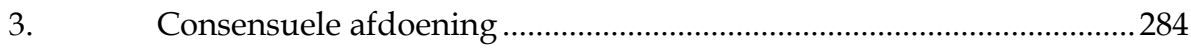

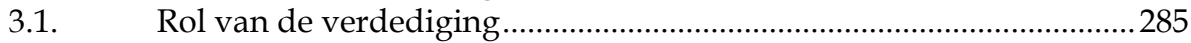

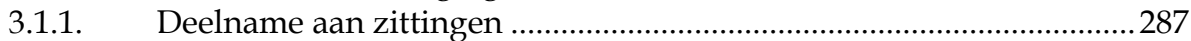

3.1.2. Het standpunt van de raadsman .......................................................... 287

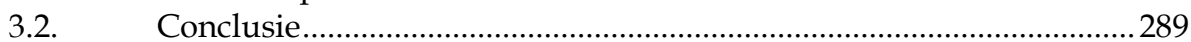

4. Verdediging op het onderzoek ter terechtzitting ...............................290

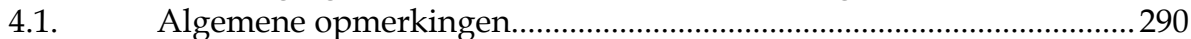

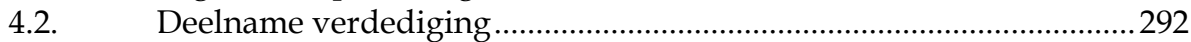

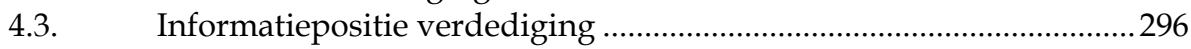

4.4. Bewijsvoering op het onderzoek ter terechtzitting .............................297

4.4.1. Onmiddellijkheid: regel of uitzondering? ..........................................297

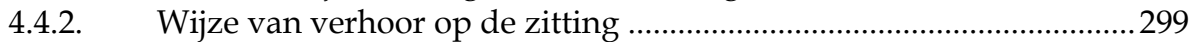

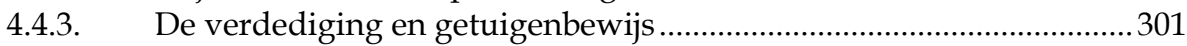

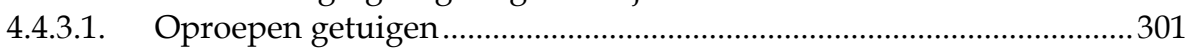

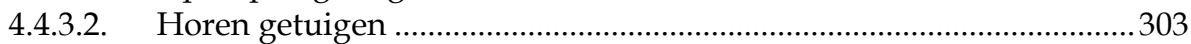

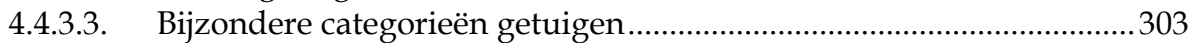

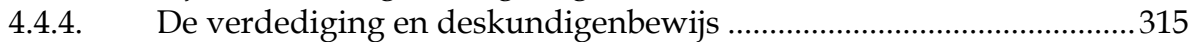

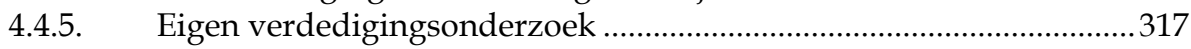

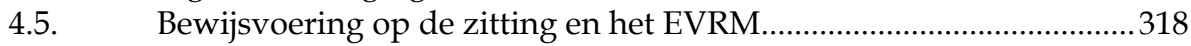

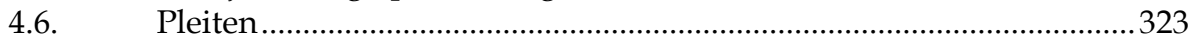

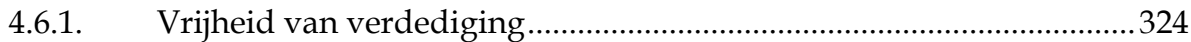

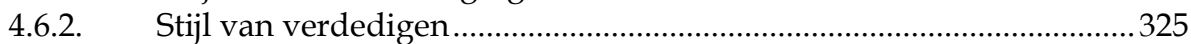

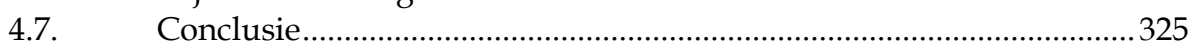

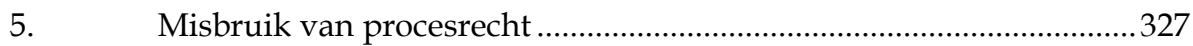

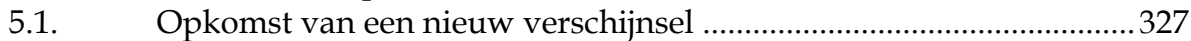

5.2. Wetswijzigingen gericht op voorkoming misbruik ..............................329

5.2.1. Verplichte deelname verdachte en/of raadsman .................................329

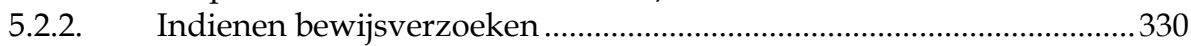

5.2.3. Neerleggen verdediging in geval van verplichte rechtsbijstand.........333

5.2.3.1. Situatie voor inwerkingtreding nieuw strafprocesrecht.......................333

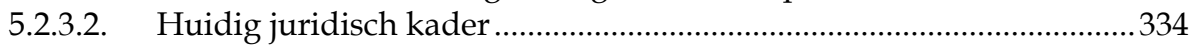




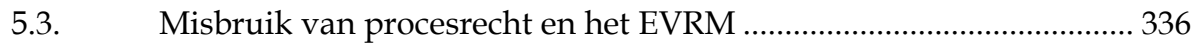

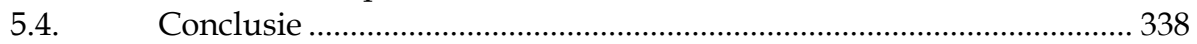

6. Conclusie verdediging in het eindonderzoek........................................ 339

\section{Hoofdstuk 7}

Vrij verkeer en verschoningsrecht

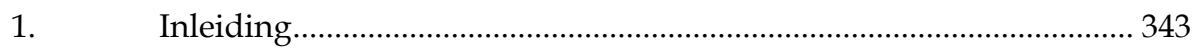

Deel I Vrij verkeer

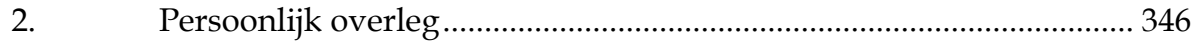

2.1. Situatie voor inwerkingtreding nieuw strafprocesrecht .................... 346

2.2. Huidig juridisch kader: stadium van politiedetentie ........................... 349

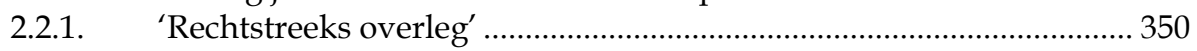

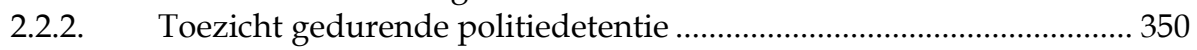

2.3. Huidig juridisch kader: fase van voorlopige hechtenis...................... 351

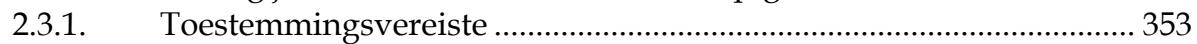

2.3.2. Toezicht gedurende voorlopige hechtenis .......................................... 354

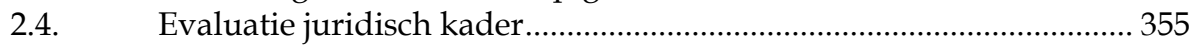

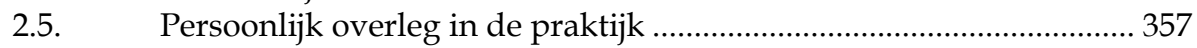

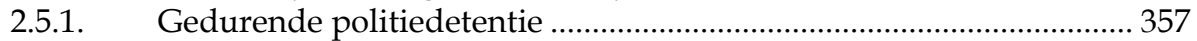

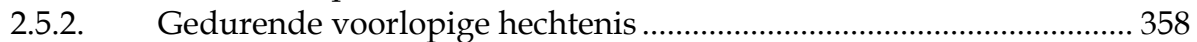

2.6. Toezicht op overleg: schending recht op verdediging? .........................359

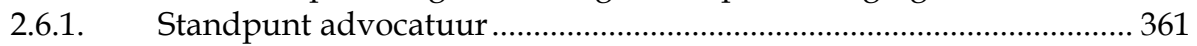

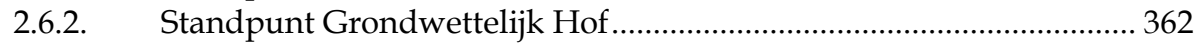

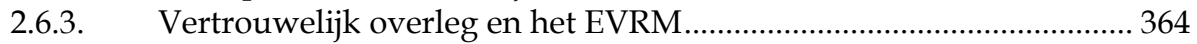

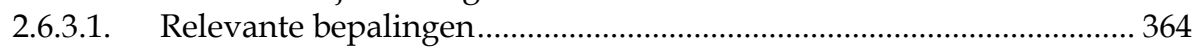

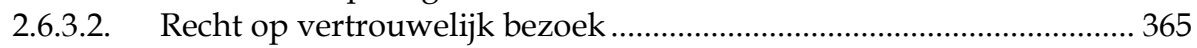

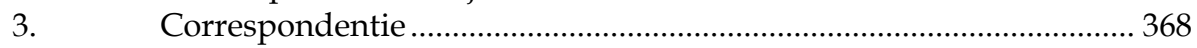

3.1. Situatie voor inwerkingtreding nieuw strafprocesrecht .................... 368

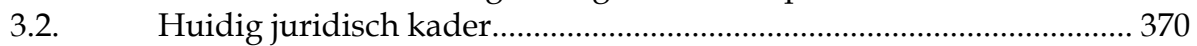

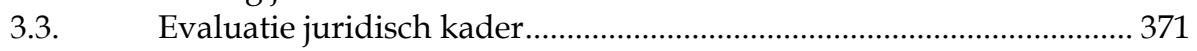

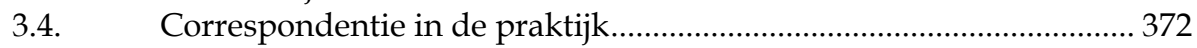

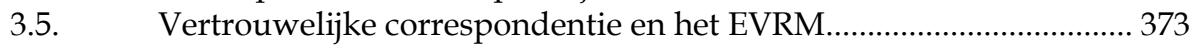

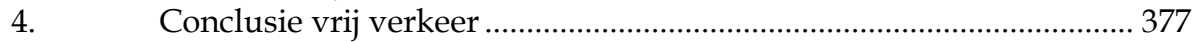

Deel II Verschoningsrecht

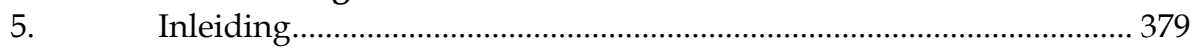

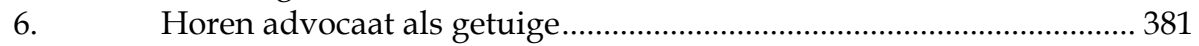

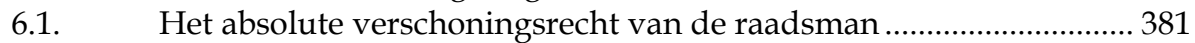

6.2. Het relatieve verschoningsrecht van de advocaat ................................383

6.3. Situatie voor inwerkingtreding nieuw strafprocesrecht .......................38

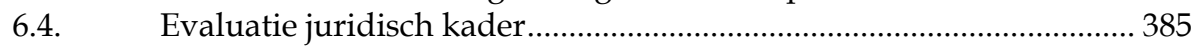

6.5. Verhouding art. 180 KPK 1997 en art. 6 Advocatenwet....................... 386

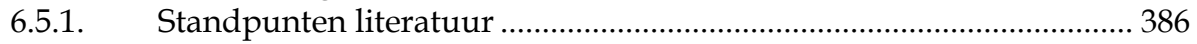

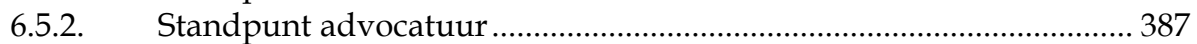

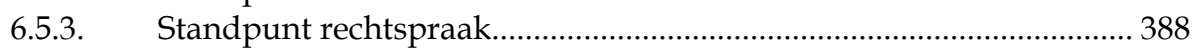

6.6. Verschoningsrecht in de praktijk ......................................................... 390

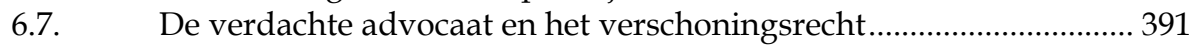

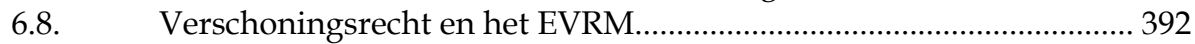


7. Huiszoeking en inbeslagneming bij advocaten 393

7.1. Algemene regels huiszoeking en inbeslagneming ...............................393

7.2. Bijzondere regels huiszoeking en inbeslagneming bij advocaten .......394

7.3. Gebruik voor het bewijs van vertrouwelijke informatie .....................396

7.4. De verdachte advocaat en huiszoeking/inbeslagneming ...................397

7.5. Situatie voor inwerkingtreding nieuw strafprocesrecht......................397

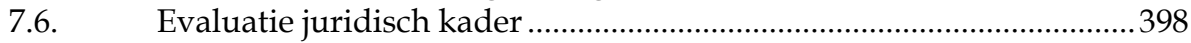

7.7. Huiszoeking en inbeslagneming bij advocaten in de praktijk............ 401

7.8. Huiszoeking en inbeslagneming bij advocaten en het EVRM............ 401

8. Tappen telefoongesprekken waaraan advocaat deelneemt ..................403

8.1. Algemene regels afluisteren en opnemen telecommunicatie ...............404

8.2. Toelaatbaarheid afluisteren en opnemen telefoongesprekken

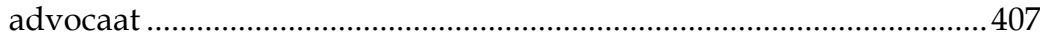

8.3. Situatie voor inwerkingtreding nieuw strafprocesrecht......................408

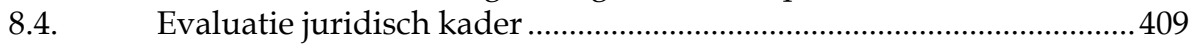

8.5. Telefoontap bij advocaten in de praktijk ............................................ 411

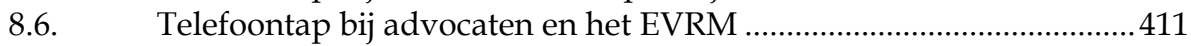

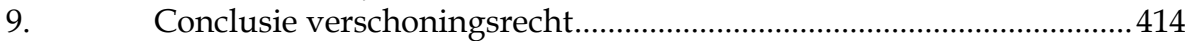

\section{Hoofdstuk 8}

\section{De Poolse advocatuur: organisatie, beroepscultuur en ethiek}

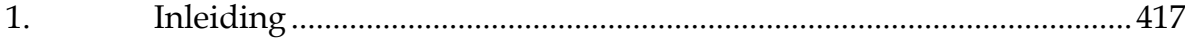

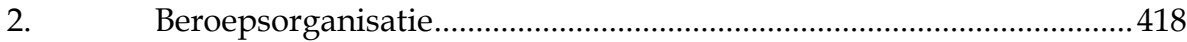

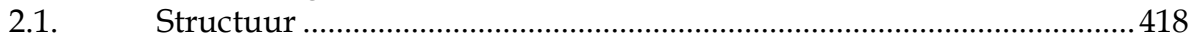

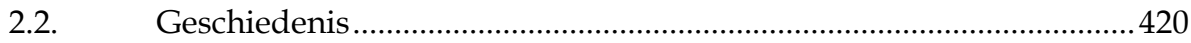

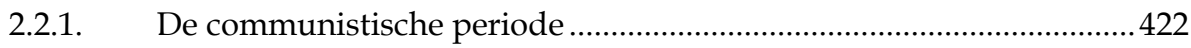

2.2.1.1. De Advocatenwet van 1950: inperking van de autonomie ..................423

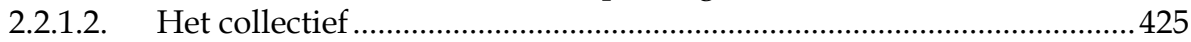

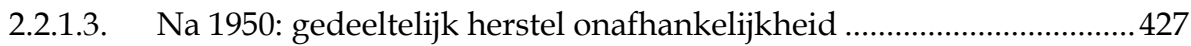

2.2.1.4. Eind jaren vijftig: verscherpt toezicht ................................................. 428

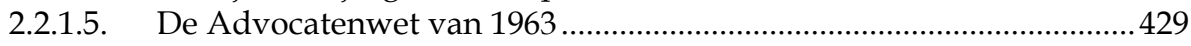

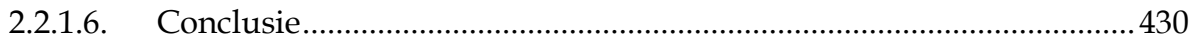

2.2.2. Totstandkoming van de huidige Advocatenwet ...................................430

2.3. Algemene opmerkingen over onafhankelijkheid ................................ 432

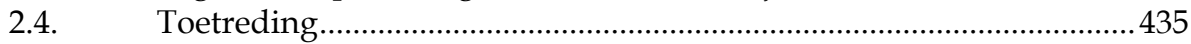

2.4.1. Situatie voor wijziging Advocatenwet (juni 2005) ................................435

2.4.2. De advocatuur: een gesloten beroepsgroep?........................................437

2.4.2.1. Aantal advocaten ontoereikend ............................................................437

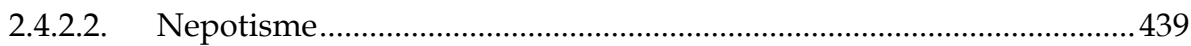

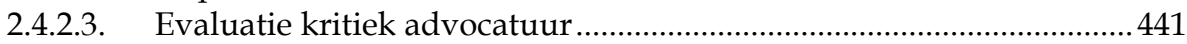

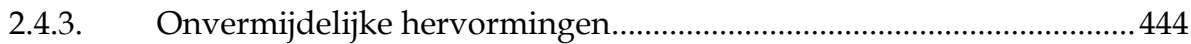

2.4.3.1. Het oordeel van het Grondwettelijk Hof ...............................................44

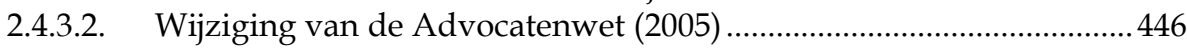

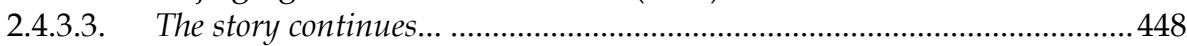

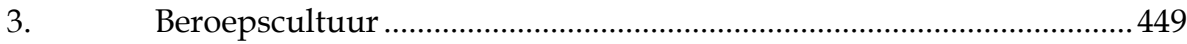

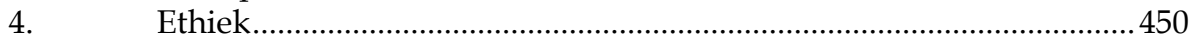

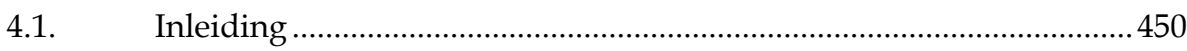




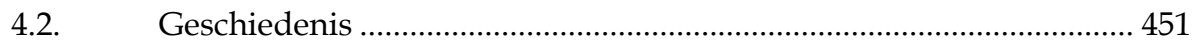

4.3. Belangrijkste gedragsrechtelijke bepalingen voor de raadsman........ 453

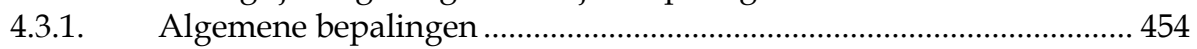

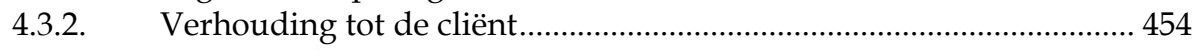

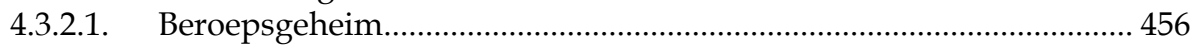

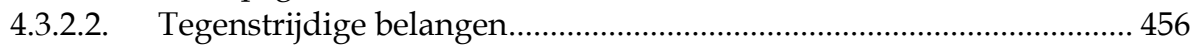

4.3.2.3. Weigeren of neerleggen verdediging …............................................... 457

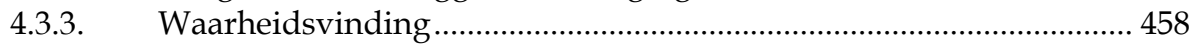

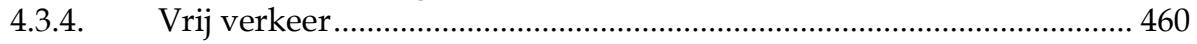

4.3.5. Immuniteit en vrijheid van meningsuiting ........................................ 461

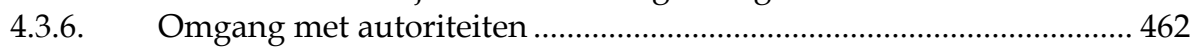

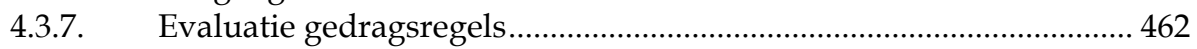

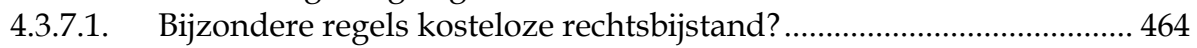

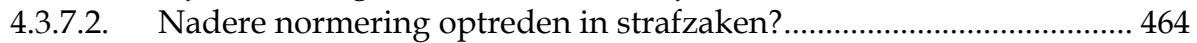

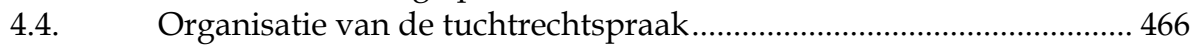

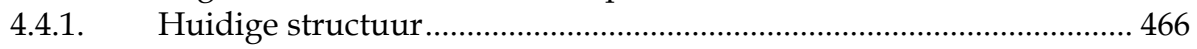

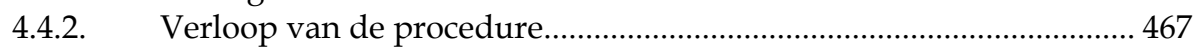

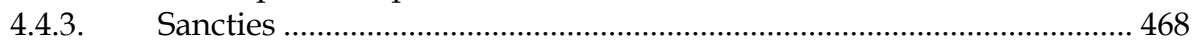

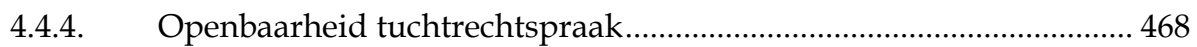

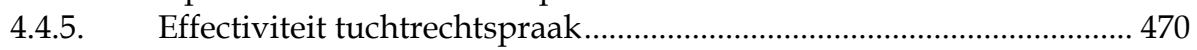

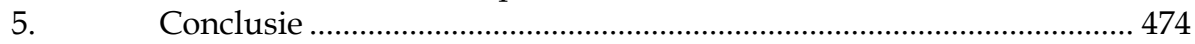

\section{Hoofdstuk 9}

\section{Eindconclusies}

1. Inleiding

2. Postcommunistische hervormingen gericht op een effectieve verdediging ..................................................................................... 479

2.1. Verdediging in strafzaken gedurende het communisme....................479

2.1.1. Tussen wetgeving en cultuur: obstakels voor effectieve verdediging gedurende het communisme........................................... 480

2.1.2. De beperkte doorwerking van het communistisch gedachtegoed .... 481

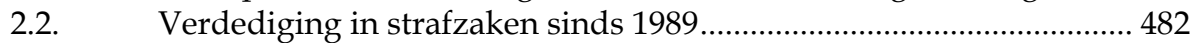

2.2.1. Algemene constateringen over de transitie van het strafprocesrecht ............................................................................. 483

2.2.2. Voornaamste wijzigingen gericht op effectieve verdediging............. 485

3. De impact van hervormingen: relevante factoren? ............................... 485

3.1. Het effect van hervormingen gericht op effectieve verdediging ....... 486

3.1.1. Op wezenlijke punten resterende tekortkomingen in wettelijke

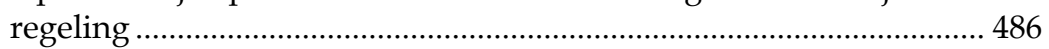

3.1.2. Ontbreken praktische randvoorwaarden................................................489

3.1.3. Verschuivende zwaartepunten: ontwikkelingen in criminele

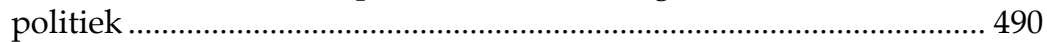

3.1.4. Cultuur binnen de advocatuur: 'old habits die hard' .............................. 493

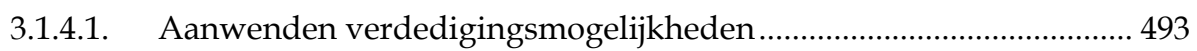

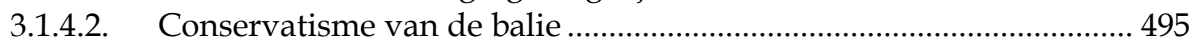

3.2. De normerende werking van het EVRM.............................................. 496

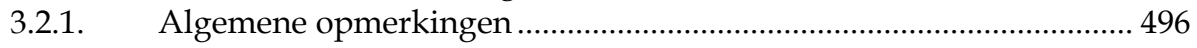


3.2.2. Straatsburgse criteria voor effectieve verdediging en het Poolse strafprocesrecht

4. Slotbeschouwing: Poolse lessen over de 'maakbaarheid' van effectieve verdediging

4.1. De waarde van wetgeving: formulering, effectief toezicht en onderlinge samenhang.

4.2. Effectuering van wettelijke normen: praktische randvoorwaarden, rechtscultuur en stabiliteit in regelgeving

4.3. De betrekkelijkheid van de normerende werking van het EVRM .....506

4.4. Effectieve verdediging als 'maakbaar' recht: mogelijkheden en beperkingen van juridische instrumenten............................................507

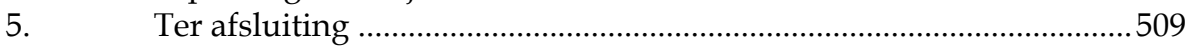

Bijlage 1 Relevante wetsbepalingen............................................................511

Bijlage 2 Informatie die conform art. 300 KPK 1997 voorafgaand aan het verhoor schriftelijk aan de verdachte wordt overhandigd....517

Summary

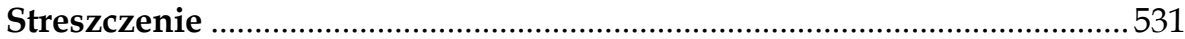

Literatuur en jurisprudentie ............................................................... 545

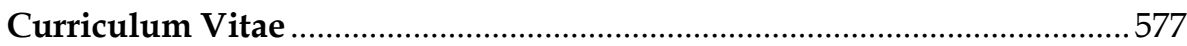





\section{Afkortingen}

\begin{tabular}{|c|c|}
\hline CCBE & Council of Bars and Law Societies of Europe \\
\hline CPT & $\begin{array}{l}\text { European Comittee for the Prevention of Torture and Inhuman } \\
\text { or Degrading punishment }\end{array}$ \\
\hline ECRM & Europese Commissie voor de rechten van de mens \\
\hline EVRM & $\begin{array}{l}\text { Europees Verdrag tot bescherming van de rechten van de mens } \\
\text { en de fundamentele vrijheden }\end{array}$ \\
\hline EHRM & Europees Hof voor de rechten van de mens \\
\hline EU & Europese Unie \\
\hline DR & $\begin{array}{l}\text { Decisions and Reports of the European Commission of Human } \\
\text { Rights }\end{array}$ \\
\hline Dz. U. & Dziennik Ustaw (Pools Staatsblad) \\
\hline HFHR & Helsinki Foundation for Human Rights \\
\hline IBA & International Bar Association \\
\hline IBAHRI & International Bar Association's Human Rights Institute \\
\hline IVBP & Internationaal Verdrag inzake burgerrechten en politieke rechten \\
\hline KKP & Kodeks Postepowanie Karnego (Wetboek van Strafvordering) \\
\hline KK & Kodeks Karny (Wetboek van Strafrecht) \\
\hline KKW & $\begin{array}{l}\text { Kodeks Karny Wykonawczy (Wetboek betreffende de } \\
\text { tenuitvoerlegging van sancties) }\end{array}$ \\
\hline NRA & Naczelna Rada Adwokacka (Hoogste Raad van de balie) \\
\hline ORA & Okręgowa Rada Adwokacka (regionale raad van de balie) \\
\hline OSNKW & $\begin{array}{l}\text { Orzecznictwo Sądu Najwyższego Izba Karna i Wojskowa } \\
\text { (Rechtspraak van de straf- en militaire kamer van het } \\
\text { Hooggerechtshof) }\end{array}$ \\
\hline OSPiKA & $\begin{array}{l}\text { Orzecznictwo Sądów Polskich i Komisji Arbitrażowych (Rechtspraak } \\
\text { van Poolse rechterlijke instanties en Arbitragecommissies) }\end{array}$ \\
\hline PILI & Public Interest Law Initiative \\
\hline PiS & Prawo i Sprawiedliwośc (Recht en Rechtvaardigheid) \\
\hline PG & Prokurator Generalny (Procureur Generaal) \\
\hline PKWN & $\begin{array}{l}\text { Polski Komitet Wyzwolenia Narodowego (Nationaal Comité voor de } \\
\text { Bevrijding van Polen) }\end{array}$ \\
\hline Prok. i Prawo & Prokuratura i Prawo \\
\hline SA & $\begin{array}{l}\text { Orzecznictwo Sąów Apelacyjnych (Rechtspraak van hoger } \\
\text { beroepsinstanties) }\end{array}$ \\
\hline SR & Sąd Rejonowy (disctrictsrechtbank) \\
\hline $\mathrm{SO}$ & Sad Okregowy (provinciale rechtbank) \\
\hline SA & Sad Apelacyjny (hoger beroepsinstantie) \\
\hline SN & Sad Najwyższy (Hooggerechtshof) \\
\hline t. & tegen \\
\hline USSR & Unie van Socialistische Sovjetrepublieken \\
\hline VK & Verenigd Koninkrijk \\
\hline $\mathrm{VN}$ & Verenigde Naties \\
\hline VS & Verenigde Staten \\
\hline
\end{tabular}





\section{Hoofdstuk 1}

\section{Inleiding}

\section{Ter inleiding}

Dit boek gaat over verdediging in strafzaken in Polen. Voor een Nederlandse onderzoeker is dat geen vanzelfsprekend onderwerp. De afgelopen jaren is mij in ieder geval veelvuldig - en met wisselende graad van verbazing - de vraag gesteld: waarom Polen? Regelmatig heb ik me daarbij afgevraagd of ik mijn landkeuze net zo vaak zou hebben moeten 'verdedigen' als mijn onderzoek betrekking had gehad op bijvoorbeeld Duitsland, Frankrijk of Engeland. Hoewel de meeste landen van het voormalig Oostblok al in de jaren negentig zijn toegetreden tot de Raad van Europa en een deel daarvan inmiddels ook al een aantal jaren tot de Europese Unie (EU) behoort, is mijn indruk dat deze categorie landen in de Westerse rechtsvergelijking nog steeds een ondergeschikte rol speelt.

Dit neemt niet weg dat ik de verbazing wel begrijp. In deze inleiding zal ik duidelijk maken waarom dit boek betrekking heeft op het Poolse rechtssysteem. Voordat ik daartoe overga, zal eerst de aanleiding voor het onderzoek worden geschetst.

\section{Effectieve verdediging: een Europese uitdaging}

Het recht op verdediging behoort als noodzakelijke voorwaarde voor verwezenlijking van het recht op een eerlijk proces tot de fundamenten van de democratische rechtsstaat. De wijze waarop en de mate waarin de positie van de verdediging wordt vormgegeven, verschilt uiteraard per rechtssysteem. Inherent aan alle systemen van strafrechtspleging is echter dat continu wordt gezocht naar het 'juiste' evenwicht tussen de instrumentele, op misdaadbestrijding gerichte doelstellingen die men met het strafrecht beoogt te bereiken en de mate waarin aan de verdachte procedurele waarborgen worden geboden. Dit evenwicht tussen instrumentaliteit en rechtsbescherming is uiterst kwetsbaar omdat een sterkere nadruk op het ene consequenties heeft voor het andere. Zo zal toenemende aandacht voor repressie en efficiëntie in het strafproces vrijwel altijd gevolgen hebben voor de rechtspositie van verdachten. In een rechtsstaat dient daarbij telkens te worden gewaarborgd dat het voeren van een effectieve verdediging onder de gewijzigde omstandigheden nog mogelijk is.

Het is niet eenvoudig het begrip 'effectieve verdediging' nader te definiëren. ${ }^{1}$ Binnen Europa is voor een antwoord op de vraag welke randvoorwaarden aan een effectieve verdediging worden gesteld in ieder geval het Europees Verdrag tot bescherming van de rechten van de mens en de fundamentele vrijheden (EVRM) en bijbehorende rechtspraak van het Europese Hof voor de rechten van de mens (EHRM) van belang. Ook binnen de context van de Europese Unie wordt sinds een aantal jaren nagedacht over de garanties die in het strafproces aan de verdediging moeten worden geboden. Dit als reactie op de kritiek dat de steeds verder toenemende integratie op het gebied van criminaliteitsbestrijding niet werd 'gecompenseerd' door vergelijkbare initiatieven op het terrein van

1 Zie $\$ 5.4$ van deze inleiding waarin wordt beschreven aan welke criteria voor een effectieve verdediging in dit onderzoek aandacht zal worden besteed. 
rechtsbescherming. Om tegenwicht te bieden aan alle repressieve maatregelen zoals het Europees Arrestatiebevel en het Europees Aanhoudingsbevel - maar ook om te bewerkstelligen dat (rechters van) lidstaten meer vertrouwen in elkaars rechtspleging krijgen en daarmee de grensoverschrijdende strafrechtelijke samenwerking te versoepelen, heeft de Europese Commissie getracht gemeenschappelijke minimumwaarborgen te formuleren voor het bieden van rechtsbescherming aan burgers binnen de EU. Het opstellen van dergelijke minimumgaranties is echter allesbehalve eenvoudig gebleken. Het door de Europese Commissie opgestelde Groenboek Procedurele waarborgen voor verdachten in strafzaken in de gehele Europese Unie ${ }^{2}$ vormde het begin van een moeizaam onderhandelingsproces waarbij een aantal lidstaten zich heftig heeft verzet. De argumenten van de tegenstanders ${ }^{3}$ zijn verschillend van aard en betreffen niet alleen de omvang en inhoud van de te garanderen rechten maar ook meer formele bezwaren zoals de rechtsgrondslag van het voorgenomen instrument. Bovendien vragen de tegenstanders zich af of het voorgenomen kaderbesluit verenigbaar is met het beginsel van subsidiariteit, hoe procedurele waarborgen op EU-niveau zich dienen te verhouden tot het EVRM en of het bestaan van het EVRM een vergelijkbare regeling door de EU niet overbodig maakt. ${ }^{4}$ Ook bestaat de vrees dat de Europese onderhandelingen over minimumwaarborgen tot zodanige nivellering zullen leiden dat het (hoogstwaarschijnlijk magere) eindresultaat naar verwachting toch niet aan een daadwerkelijke optimalisering van verdedigingsrechten zal kunnen bijdragen. Dat laatste lijkt gelet op de wijze waarop de onderhandelingen tot op heden zijn verlopen geen onterechte vrees te zijn. Op verschillende punten zijn de rechten zoals ze oorspronkelijk in het Groenboek waren opgenomen door verzet van lidstaten steeds verder 'uitgekleed' en in sommige gevallen zelfs geschrapt. De meerwaarde van het ontwerp kaderbesluit - dat in april 2004 door de Europese Commissie als vervolg op het Groenboek werd gepubliceerd - is door alle aanpassingen steeds verder afgenomen. ${ }^{5}$ Dit geldt onder meer voor het recht op rechtsbijstand: waar aanvankelijk was bepaald dat dit recht zou moeten gelden vanaf het eerste moment van arrestatie en tijdens politieverhoren is dit uiteindelijk gereduceerd tot de regel dat recht op rechtsbijstand 'zo spoedig mogelijk' moet worden gegarandeerd. ${ }^{6}$ Blijkbaar leeft bij verschillende lidstaten

2 Greenpaper on Procedural Safeguards for Suspects and Defendants throughout the European Union), Brussel, 19-2-2003, COM (2003) 75. In het groenboek - bedoeld als consultatiedocument om uiteindelijk tot een (ontwerp) kaderbesluit te komen - waren de volgende rechten opgenomen: 1 . het recht op rechtsbijstand, 2 . het recht op tolkenbijstand en vertaling, 3. het recht op informatie, 4 . bijzondere bescherming voor kwetsbare categorieën verdachten en 5 . het recht op consulaire bijstand.

3 Waaronder Oostenrijk, Denemarken, Frankrijk, Duitsland, Spanje, Ierland, het Verenigd Koninkrijk en Nederland.

4 Zie voor een bespreking van de belangrijkste bezwaren van de Nederlands regering: Röttgering 2006.

5 Ontwerp kaderbesluit met betrekking tot bepaalde procedurele rechten in strafzaken in de EU, Proposal on a Framework Decision on Certain Procedural Rights in Criminal Proceedings Throughout the European Union, Brussel 28-4-2004, COM (2004) 328.

6 Ook de regel dat verdachten in iedere geval voor het eerste verhoor een advocaat moeten kunnen raadplegen, heeft het onderhandelingsproces niet overleefd en is vervangen door de bepaling dat lidstaten tijdens het onderzoek het recht op rechtsbijstand in uitzonderlijke omstandigheden enige tijd kunnen opschorten of daaraan - bijvoorbeeld in 
de angst dat een hogere graad van rechtsbescherming dan reeds in het nationale strafproces is voorzien tot (te) vergaande aanpassingen zou dwingen die een efficiënt procesverloop in gevaar zouden kunnen brengen. De moeilijkheden en twistpunten in de onderhandelingen over het ontwerp kaderbesluit hebben uiteindelijk de overhand gekregen en tot een impasse geleid waardoor het momenteel allesbehalve zeker is of het ooit tot een juridisch bindend instrument zal komen.

Dit boek gaat niet als zodanig over de wenselijkheid van Europese minimumwaarborgen en de vele - overigens zeer interessante - vragen die in dat verband zouden kunnen worden gesteld. ${ }^{7}$ Voor dit onderzoek is van belang dat genoemde Europese ontwikkelingen illustreren hoe moeilijk het is te komen tot gemeenschappelijke minimumgaranties die een bepaald niveau van rechtsbescherming kunnen waarborgen. ${ }^{8}$ Dit vraagt om bezinning over de (mogelijke) effecten van dergelijke instrumenten waarin garanties zijn opgenomen die in nationale rechtsstelsels moeten worden geïmplementeerd en de meer abstracte vraag of - en zo ja, in welke mate - dit soort supranationale geschreven normen bij kunnen dragen aan een hogere graad van rechtsbescherming en een versterking van de positie van de verdediging. Met andere woorden: hoe 'maakbaar' zijn verdedigingsrechten en welke factoren spelen een rol bij de implementatie van wijzigingen die een effectieve verdediging beogen te garanderen? Deze problematiek staat centraal in dit onderzoek maar daarmee is nog niet verklaard waarom voor de beantwoording ervan de ontwikkelingen in een Oost-Europees land onder de loep worden genomen. Dit zal in het onderstaande worden toegelicht.

\section{Het belang van de postcommunistische context}

De positie die de verdediging in een bepaald strafproces inneemt, is onlosmakelijk verbonden met de structuur, aard en cultuur van het betreffende proces. Zoals geanalyseerd door Damaška is de wijze waarop een strafrechtelijke procedure is vormgegeven weer afhankelijk van de manier waarop het overheidsgezag van een land is gestructureerd. ${ }^{9}$ Deze correlaties impliceren dat een (wezenlijke) verandering in overheidsstructuur ook consequenties heeft voor het strafproces en de positie van de verdediging daarin.

het belang van het onderzoek - voorwaarden kunnen verbinden. Een voorbeeld van een recht dat wel in het Groenboek was opgenomen maar in latere versies van het ontwerp kaderbesluit als zodanig niet meer terug te vinden is, betreft de zogenaamde letter of rights: de verplichting iedere verdachte direct na aanhouding een formulier te overhandigen waarop hij wordt geïnformeerd over de hem toekomende rechten. Zie Röttgering 2006, p. 160-165.

7 Zoals welke garanties in ieder geval in een dergelijk instrument zouden moeten worden opgenomen, op welke wijze deze zouden moeten worden geformuleerd, hoe de verschillende categorieën bezwaren die door sommige lidstaten tegen het kaderbesluit worden ingebracht, dienen te worden beoordeeld et cetera.

8 Dat vergelijkbare initiatieven op het terrein van criminaliteitsbestrijding doorgaans wel op brede steun kunnen rekenen, laat duidelijk zien dat EU-lidstaten overwegend meer prioriteit toekennen aan instrumentaliteit dan aan rechtsbescherming.

9 Voor een uitgebreide bespreking van deze verbanden wordt verwezen naar Damaška 1975 en 1986, zie ook hoofdstuk 3, § 1. 
De voormalige communistische landen van Centraal- en Oost-Europa nemen in dit verband een interessante positie in. Gedurende het communisme werd in al deze landen op uiterst instrumentele wijze gebruik gemaakt van het strafrecht en was effectieve verdediging in veel gevallen onmogelijk. Hoewel de wortels van de rechtssystemen in dit deel van Europa in de continentale, civil law rechtstraditie liggen, vertoonde de rechtspleging in deze periode zulke specifieke karaktertrekken dat ook wel van een aparte socialistische rechtsfamilie - en een socialistisch strafproces - wordt gesproken. ${ }^{10}$

De ineenstorting van het communistisch regime aan het eind van de jaren tachtig betekende het startsein van een omvangrijk transitieproces. De overgang van een totalitair regime naar een democratische rechtsstaat die hiermee werd ingezet, had ingrijpende gevolgen voor de verschillende rechtssystemen in het algemeen en de strafrechtspleging in het bijzonder. De landen van het voormalig Oostblok zagen zich hierbij gesteld voor de opgave hun straf(proces)recht binnen korte tijd in overeenstemming te brengen met de eisen die daaraan in een rechtsstaat worden gesteld. De noodzaak voor deze hervormingen werd versterkt door het feit dat het gros van deze landen al snel toetrad tot de Raad van Europa: ratificatie van het EVRM betekent immers dat de nationale rechtspleging in overeenstemming moet zijn met de eisen van dit verdrag. ${ }^{11}$ Voor een aantal landen werd de internationale druk nog verhoogd door de wens zo spoedig mogelijk aan te kunnen sluiten bij de Europese Unie. In laatstgenoemd verband is van belang dat voor aspirant-lidstaten uit het voormalig Oostblok in ieder geval de zogenaamde Kopenhagen-criteria gelden. ${ }^{12}$ De eerste van die voorwaarden luidt 'that candidate countries achieve stable institutions that guarantee democracy, legality, human rights and respect for and protection of minorities'.

Net zoals op Europees niveau met het kaderbesluit procedurele rechten wordt getracht, is door de postcommunistische landen gezocht naar manieren om door aanpassing van het strafproces een bepaalde standaard van rechtsbescherming te garanderen. Doel van dit onderzoek is om door een nadere bestudering van dit transitieproces aan het licht te brengen wat er gebeurt wanneer door de overheid maatregelen worden genomen die de positie van de verdediging beogen te versterken en daarbij te analyseren waardoor het effect van genomen maatregelen wordt beïnvloed. Om deze ontwikkeling zo goed mogelijk in beeld te kunnen brengen en in een historische context te kunnen plaatsen, is er voor gekozen het onderzoek te beperken tot één specifiek postcommunistisch land: Polen. ${ }^{13}$ Enigszins vooruitlopend op de bevindingen van het onderzoek dient hierbij te worden opgemerkt dat niet alle ontwikkelingen die het Poolse strafproces sinds het eind van de jaren tachtig heeft doorgemaakt door het transitieproces zijn te verklaren. De Poolse samenleving heeft sinds de politieke omwenteling uiteraard niet stilgestaan en bepaalde trends die de laatste jaren in andere Europese landen - en daarbuiten - zichtbaar zijn geweest (zoals een toenemende behoefte aan efficiëntie

10 Zie onder meer David en Brierly 1978, p. 143-283.

11 Zie ook art. 3 van het Statuut van de Raad van Europa waarin is vastgelegd dat 'every member of the Council of Europe must accept the principles of the rule of law and of the enjoyment by all persons within its jurisdiction of human rights and fundamental freedoms'.

12 Vastgesteld door de Europese Raad op 21 en 22 juni 1993 te Kopenhagen.

13 De keuze voor Polen zal nader worden toegelicht in § 5.1. 
in het strafproces en een sterke nadruk op de repressieve kant van het strafrecht) hebben ook hun invloed gehad op het Poolse rechtssysteem.

\section{Vraagstelling}

Dit onderzoek beoogt inzicht te verschaffen in de gevolgen van postcommunistische hervormingen voor de verdediging in het Poolse strafproces. In de eerste plaats om duidelijkheid te verkrijgen over het verloop van een dergelijk transitieproces en in de tweede plaats om te kunnen beoordelen waardoor het effect van gerealiseerde hervormingen wordt bepaald. Streven is om aan de hand van het Poolse voorbeeld bloot te leggen wat er gebeurt wanneer op relatief korte termijn van overheidswege maatregelen worden genomen die de positie van de verdediging in het strafproces beogen te versterken en welke factoren daarbij een rol spelen. Hoe bepalend is de wettelijke normering van verdedigingsrechten en welke invloed hebben andere - bijvoorbeeld rechtsculturele - factoren op het effect van hervormingen? Om het effect van de in het Poolse strafproces doorgevoerde wijzigingen te kunnen beoordelen, worden de standaard van het EVRM en de randvoorwaarden die op basis daarvan aan een effectieve verdediging kunnen worden gesteld als maatstaf genomen. ${ }^{14}$ Eerder is besproken dat een van de argumenten van de tegenstanders in het onderhandelingsproces over het ontwerp kaderbesluit procedurele waarborgen betrekking had op het EVRM: dit verdrag zou in voldoende mate voorzien in de behoefte aan gemeenschappelijke minimumnormen op het terrein van rechtsbescherming en een tweede Europees instrument overbodig maken. Door te analyseren in hoeverre de Poolse hervormingen aansluiten bij de normen van het EVRM en de rechtspraak van het EHRM kan zichtbaar worden gemaakt in hoeverre van genoemd verdrag daadwerkelijk een normerende werking op het transitieproces is uitgegaan en wat de feitelijke (meer)waarde van dit soort verdragsnormen is wanneer men op nationaal niveau een verhoging van de graad van rechtsbescherming tracht te realiseren.

Het voorgaande leidt tot de volgende centrale probleemstelling:

'In hoeverre en op welke wijze zijn in het Poolse postcommunistische transitieproces wijzigingen doorgevoerd die een effectieve verdediging in strafzaken beogen te garanderen, welke factoren hebben een rol gespeeld bij de implementatie van deze wijzigingen en welke lessen kunnen hieruit worden getrokken over de (mogelijke) effecten van een door de overheid geïnitieerde optimalisering van verdedigingsrechten?'

Ter beantwoording van deze probleemstelling zullen de volgende deelvragen worden behandeld:

1. Op welke wijze is de positie van de verdediging in de huidige Poolse wet- en regelgeving genormeerd?

2. In hoeverre verschilt de huidige normering ten opzichte van de situatie gedurende het communisme?

3. Hoe verhoudt de huidige situatie zich tot de voorwaarden voor een effectieve verdediging die aan het EVRM kunnen worden ontleend?

14 Op de betekenis en consequenties van het EVRM als toetsingskader wordt teruggekomen in $\S 5.5$. 
4. Welke factoren beïnvloeden het effect van gerealiseerde hervormingen op de positie van de verdediging?

\section{Reikwijdte onderzoek}

\subsection{Landkeuze}

De beslissing dit onderzoek tot Polen te beperken is geen willekeurige geweest. Polen is een van de grootste Oost-Europese landen dat als eerste de ineenstorting van het communistisch regime meemaakte (of beter: wist te realiseren). Op het moment van aanvang van dit onderzoek was duidelijk dat binnen het Poolse strafrechtssysteem al de nodige hervormingen waren gerealiseerd en dat interessante ontwikkelingen binnen de advocatuur gaande waren. Aan het eind van de jaren negentig zijn in Polen nieuwe strafrechtelijke codificaties in werking getreden die de socialistische wetgeving van 1969 hebben vervangen. Het feit dat nu ongeveer tien jaren zijn verstreken sinds de inwerkingtreding van deze nieuwe wetten maakt het mogelijk niet alleen de wijzigingen ten opzichte van de oude regelgeving te analyseren maar ook om een inschatting te maken van de effecten van de geconstateerde veranderingen.

\subsection{Interne rechtsvergelijking 15}

Er is bewust voor gekozen dit onderzoek te beperken tot één land. Bij het maken van deze keuze hebben praktische redenen (betreffende taal, beschikbaarheid en toegankelijkheid van materiaal et cetera) een rol gespeeld maar er ligt ook een inhoudelijk argument aan ten grondslag. Gelet op de doelstelling van dit onderzoek - het verschaffen van inzicht in de gevolgen van postcommunistische hervormingsprocessen voor de positie van de verdediging - is als uitgangspunt genomen dat het zinvol is de ontwikkeling in één rechtssysteem nauwkeurig te bestuderen en deze in historisch perspectief te plaatsen. Gekozen is dus voor een intern, historisch perspectief waarbij de huidige situatie wordt vergeleken met de situatie gedurende het communisme. ${ }^{16}$

\subsection{Perspectief van de raadsman}

De positie van de verdediging kan als graadmeter voor het rechtsstatelijk karakter van het strafproces worden beschouwd. Dit vanuit de overtuiging dat een strafrechtssysteem zijn rechtsstatelijkheid niet zozeer ontleent aan de bescherming

15 Het begrip 'interne rechtsvergelijking' wordt - in ieder geval in de Nederlandse rechtswetenschap - vaak gebruikt ter aanduiding van onderzoek naar de oplossing van een bepaald probleem in verschillende rechtsgebieden (bijvoorbeeld het straf- en het bestuursrecht). Deze uitleg wordt hier niet gehanteerd. In dit onderzoek wordt met de term 'interne rechtsvergelijking' gedoeld op de historische ontwikkeling van een bepaald aspect van één rechtsgebied binnen twee rechtssystemen (het socialistische en het huidige) in één land.

16 Hiermee is overigens niet gezegd dat een onderlinge vergelijking van de voormalig communistische landen van Europa op dit punt niet interessant zou kunnen zijn - integendeel. Zeker het vergelijken van landen met verschillende historische, culturele en sociale achtergronden zoals enerzijds de landen van Centraal Europa en anderzijds de voormalige Sovjetstaten zou tot interessante inzichten kunnen leiden over de betekenis van deze verschillen voor de wijze waarop hervorming wordt vormgegeven en het succes van de gerealiseerde veranderingen. 
van de gemeenschap tegen alle mogelijke vormen van criminaliteit maar juist aan de mate waarin (en de wijze waarop) individuen die worden verdacht van een strafbaar feit bescherming worden geboden tegen de vervolgende overheid. ${ }^{17}$ Dat een verdachte zich in een strafzaak kan laten bijstaan door een raadsman, geldt als noodzakelijke voorwaarde voor verwezenlijking van genoemde bescherming tegen de overheid.

Het recht op professionele rechtsbijstand neemt een prominente plaats in ten opzichte van de andere verdedigingsrechten waardoor de wijze waarop hieraan invulling wordt gegeven van doorslaggevende invloed is op de vraag of effectieve verdediging mogelijk is. ${ }^{18} \mathrm{Om}$ die reden heeft dit onderzoek betrekking op verdediging in strafzaken met behulp van een advocaat. Dat betekent dat wordt bekeken hoe een verdachte in het Poolse strafproces bijgestaan door een raadsman invulling kan geven aan zijn recht op verdediging. Met andere woorden: niet het recht op verdediging in zijn geheel maar éen aspect ervan - het recht op rechtsbijstand - staat centraal.

Consequentie van de gekozen benadering is dat niet alleen wordt gekeken naar strafvorderlijke bevoegdheden die de raadsman met zijn cliënt deelt (zelfs aan hem ontleent) maar dat ook aandacht wordt besteed aan onderwerpen die specifiek betrekking hebben op de raadsman, zoals (de historische ontwikkeling van) het denken over de rol en taakopvatting van de advocaat in strafzaken, zijn privileges (vrij verkeer en verschoningsrecht) en verschillende aspecten van de beroepsgroep zoals de organisatie, cultuur en professionele ethiek die evenzeer van invloed zijn op het functioneren van de verdediging in het strafproces.

Hoewel de positie van de raadsman dus centraal staat, is het onmogelijk deze los te zien van de verdachte. De verdachte is immers procespartij en zonder hem zou de raadsman geen functie kunnen vervullen in het strafproces. Het is dan ook niet mogelijk iets over de advocaat in strafzaken te zeggen zonder daarbij tevens de verdachte te betrekken: ze vormen als het ware één geheel. Vandaar dat in dit onderzoek vaak wordt gesproken over 'de verdediging' ter aanduiding van zowel de raadsman als de verdachte. ${ }^{19}$

17 Zoals door Peters is betoogd in zijn oratie 'Het rechtskarakter van het strafrecht' behoren juist de normen en beginselen van het strafprocesrecht die zijn afgestemd op de bescherming van het individu tegen de staat tot de meest fundamentele van de rechtsstaat: Peters 1972.

18 In het eerder genoemde Groenboek Procedurele waarborgen voor verdachten in strafzaken in de gehele Europese Unie (COM (2003) 75) wordt het recht op rechtsbijstand 'de grondslag van alle andere rechten' genoemd (\$ 2.5, p. 16). Spronken heeft deze interpretatie in haar oratie 'A Place of Greater Safety' bestreden: volgens haar is de grondslag van alle aan de verdachte toebedeelde rechten - inclusief het recht op rechtsbijstand - dat de verdachte in staat moet worden gesteld zich te verdedigen en daarbij een eerlijke kans moet krijgen. Zij ziet het recht op rechtsbijstand dan ook niet als grondslag van de verdedigingsrechten maar als een noodzakelijke voorwaarde om die verdedigingsrechten effectief te kunnen uitoefenen: Spronken 2003, p. 13-14.

19 De term 'verdediging' wordt echter ook gebruikt als synoniem voor de activiteit van het voeren van de verdediging in strafzaken. 


\subsection{Effectieve verdediging}

Gelet op de vraagstelling die in dit onderzoek centraal staat, is het noodzakelijk te inventariseren welke condities een effectieve verdediging mogelijk maken. Het onderzoek is immers gericht op die aspecten van het Poolse transitieproces die een effectieve verdediging beogen te garanderen: dit veronderstelt dat duidelijk moet zijn welke waarborgen het strafproces dient te bevatten voor verwezenlijking van het recht op verdediging en - meer specifiek - het recht op rechtsbijstand. In deze inleiding zal worden volstaan met een opsomming van de factoren die relevant zijn voor de vraag of effectieve verdediging mogelijk is en die om die reden in het onderzoek centraal zullen staan. Voor de concrete, normatieve invulling van deze factoren zal zoals eerder opgemerkt in de hiernavolgende hoofdstukken aansluiting worden gezocht bij de normen van het EVRM en de rechtspraak van het EHRM. ${ }^{20}$

Voor verwezenlijking van een effectieve verdediging is om te beginnen van belang vanaf welk moment het recht op rechtsbijstand kan worden geëffectueerd. Dit geldt in het bijzonder voor het continentale strafproces waarin het vooronderzoek veelal inquisitoir van aard is en verdedigingsrechten in dit stadium van de procedure doorgaans vrij eenvoudig ondergeschikt kunnen worden gemaakt aan het onderzoeksbelang. Gelet op de bewijswaarde die in inquisitoire processystemen in de regel wordt toegekend aan verklaringen die zijn afgelegd in het vooronderzoek is het moment waarop het recht op rechtsbijstand ontstaat van grote betekenis voor effectuering van het recht op verdediging. ${ }^{21} \mathrm{Zo}$ is van belang of een verdachte in de gelegenheid wordt gesteld een advocaat te spreken voorafgaand aan zijn eerste verhoor waarin hij zijn proceshouding zal moeten bepalen en beslissingen zal moeten nemen die doorslaggevend kunnen zijn voor het verdere verloop van zijn strafzaak. ${ }^{22}$ Een ander belangrijk criterium voor effectieve verdediging betreft de kosteloze rechtsbijstandvoorziening. De voorwaarden en omstandigheden waaronder verdachten gebruik kunnen maken van gefinan-

20 Zie hierna $§ 5.5$.

21 Zie over het belang van het vooronderzoek in Europese strafrechtsystemen: Cape e.a. 2007, p. 8-11.

22 Juist vanwege de betekenis van deze eerste procesfase voor de waarheidsvinding is de aanvang van het recht op rechtsbijstand - en onlosmakelijk daarmee verbonden de vraag of de raadsman tot de verhoren van zijn cliënt moet worden toegelaten - in de meeste Europese, continentale rechtssystemen een netelige kwestie: zo blijkt onder meer uit de eerder genoemde discussie in het kader van de Europese besluitvorming over procedurele waarborgen voor verdachten in strafzaken in de Europese Unie waarbij de oorspronkelijke regel dat verdachten vanaf het eerste moment van aanhouding recht hebben op rechtsbijstand en ook tijdens hun verhoren moeten kunnen worden bijgestaan door hun advocaat op veel verzet van lidstaten is gestuit en het onderhandelingsproces uiteindelijk niet heeft overleefd. In dit verband kan ook worden gewezen op de moeizame totstandkoming van het experiment raadsman bij politieverhoor in Nederland (waar advocaten vooralsnog geen wettelijk afdwingbaar recht hebben aanwezig te zijn bij verhoren van hun cliënten). De oorspronkelijke plannen hebben tot verzet van met name de politie geleid waardoor het eindresultaat - het experiment zoals dat in 2008 wordt uitgevoerd en waarbij de advocaat zich onder meer niet inhoudelijk met het verhoor mag bemoeien en geen oogcontact met zijn cliënt mag hebben - volgens velen nauwelijks enige meerwaarde heeft. 
cierde rechtsbijstand (in hoeverre daarbij rekening wordt gehouden met een eventuele voorkeur van verdachte voor een bepaalde advocaat, de wijze waarop door de advocatuur invulling wordt gegeven aan deze vorm van rechtsbijstand et cetera) is voor verdachten die niet zelf in de kosten van een advocaat kunnen voorzien van doorslaggevende invloed op de effectiviteit van hun verdediging.

Behalve het moment waarop het recht op rechtsbijstand ontstaat en de voorziening van door de overheid gefinancierde rechtshulp is voor adequate rechtsbijstand ook vereist dat de raadsman over de nodige instrumenten beschikt die hem in staat stellen invloed uit te oefenen op het verloop van de strafzaak. Het gaat hierbij om de procedurele bevoegdheden die de raadsman in de verschillende fasen van het strafproces samen met of namens zijn cliënt moet kunnen uitoefenen waarbij voor de effectiviteit van de verdediging van groot belang is dat ze kunnen worden benut op de momenten in de procedure die ertoe doen. De bevoegdheden die voor de effectuering van het recht op verdediging van groot belang zijn en in dit onderzoek aan de orde zullen komen, betreffen: het recht aanwezig te zijn bij (politie)verhoren in het vooronderzoek, het recht op informatie over de strafzaak, de procedurele mogelijkheden die kunnen worden aangewend tegen de toepassing van voorlopige hechtenis, het recht om deel te kunnen nemen aan en initiatief te kunnen nemen tot onderzoekshandelingen die in het vooronderzoek worden verricht, de mogelijkheden om een rol van betekenis te spelen in verschillende wijzen van alternatieve afdoening, het recht om deel te nemen aan zittingen en de mogelijkheden die de verdediging op het onderzoek ter terechtzitting heeft om invloed uit te oefenen op de bewijsvergaring (zoals het horen van getuigen en deskundigen) en de uiteindelijke besluitvorming van de rechter.

Een ander belangrijk aspect van effectieve verdediging is het recht op vertrouwelijke communicatie tussen advocaat en cliënt. Dat de raadsman vertrouwelijk contact kan hebben met zijn cliënt is een onmisbare voorwaarde voor effectieve rechtsbijstand die vooral wanneer de verdachte van zijn vrijheid is beroofd met voldoende waarborgen moet zijn omkleed. De voorwaarden en omstandigheden waaronder een gedetineerde cliënt met zijn advocaat kan overleggen - in persoon of via briefwisseling - zijn immers van wezenlijke invloed op de effectuering van zijn recht op verdediging. De vertrouwelijkheid die tussen advocaat en cliënt moet (kunnen) bestaan, vereist bovendien dat advocaten niet gedwongen kunnen worden informatie prijs te geven die onder hun geheimhoudingsplicht valt en dat het beroepsgeheim ook wordt beschermd bij de toepassing van strafvorderlijke dwangmiddelen en opsporingsbevoegdheden die in conflict kunnen komen met de professionele geheimhouding die de advocaat in acht dient te nemen.

Ten slotte is de advocatuur zelf een relevante factor bij het realiseren van een effectieve verdediging: niet als waarborg die door het strafprocesrecht - en dus de overheid - moet worden geboden maar wel als een element dat van invloed is op de effectiviteit van rechtsbijstand in strafzaken. Op de beroepsgroep rust de (maatschappelijke) plicht juridische bijstand van een bepaalde kwaliteit te verlenen. Dit betekent niet alleen dat individuele advocaten zich op een adequate manier in moeten zetten voor hun cliënten maar legt ook een verantwoordelijkheid bij de beroepsorganisatie. Die verantwoordelijkheid houdt onder meer in dat door een efficiënt (tuchtrechtelijk) toezichtmechanisme en een gedegen opleiding wordt bijgedragen aan een hoog niveau van rechtsbijstandverlening en dat stelling 
moet worden genomen wanneer garanties en randvoorwaarden voor een effectieve verdediging op welke manier dan ook in gevaar dreigen te komen.

\subsection{Betekenis van het EVRM}

Een ander aspect van dit onderzoek dat verantwoording behoeft, betreft de rol van het Europees Verdrag tot bescherming van de rechten van de mens. Kort na de val van het communisme is Polen net als de meeste andere 'nieuwe democratieën' van Oost-Europa toegetreden tot de Raad van Europa en daarmee ook tot het EVRM. ${ }^{23}$ Het EVRM is zonder twijfel de meest invloedrijke Europese regeling op het gebied van burgerrechten en bevat normen die - ingevuld door de rechtspraak van het Europese Hof voor de rechten van de mens - grote betekenis hebben voor de strafrechtspleging in de lidstaten van de Raad van Europa.

Dàt de normen van het Europees Verdrag een rol hebben gespeeld bij de postcommunistische hervorming van de Poolse strafrechtspleging en de totstandkoming van nieuwe wet- en regelgeving staat vast maar hoe groot de Straatsburgse invloed op dit aspect van het transitieproces nu eigenlijk is (geweest), is niet zo eenvoudig vast te stellen. Een manier om hier inzicht in te krijgen zou zijn om de dialoog die sinds het begin van de jaren negentig tussen de Raad van Europa en het Poolse ministerie van Justitie is gevoerd (welke vormen van samenwerking en monitoring zijn er geweest?) nader te bestuderen. Voor die optie is in dit onderzoek niet gekozen. Niet alleen omdat een dergelijke exercitie naar verwachting te ver zou afdwalen van de centrale probleemstelling maar ook omdat de Straatsburgse bemoeienis met de Poolse transitie tamelijk gering is geweest. ${ }^{24}$ Zoals (in $\S 4$ ) is beschreven, zal de invloed van het EVRM op de Poolse hervormingen op het terrein van verdedigingsrechten in dit onderzoek in kaart worden gebracht door te analyseren in hoeverre de postcommunistische wetgever daadwerkelijk aansluiting heeft gezocht bij de voorwaarden die in het EVRM en in de rechtspraak van het EHRM aan een effectieve verdediging worden gesteld. Op basis hiervan kan het effect van de hervormingen worden beoordeeld en uiteindelijk ook een inschatting worden gemaakt van de mate waarin en de wijze waarop het EVRM een relevante factor is geweest in dit onderdeel van het transitieproces.

Het belang van het EVRM voor dit onderzoek beperkt zich tot een aantal artikelen. Verreweg de belangrijkste bepaling is art. 6 EVRM waarin het recht op

23 Overigens is het historisch niet helemaal correct Polen als 'nieuwe democratie' aan te merken: daarmee wordt de sterke democratische traditie die de Poolse geschiedenis voor Wereldoorlog II laat zien, tekort gedaan. Zie hierover hoofdstuk 2, § 2.1.

24 Belangrijkste reden hiervoor is het feit dat Polen tot de categorie nieuwe lidstaten behoorde waar de problemen vanuit rechtsstatelijk perspectief - zeker in vergelijking tot andere Oost-Europese landen zoals Rusland, Albanië of Moldavië - niet zo groot waren. De aandacht van de Raad van Europa is meer uitgegaan naar laatstgenoemde categorie landen waar de behoefte aan toezicht en begeleiding vanwege de moeilijke uitgangspositie het grootst was. De nieuwe lidstaten van de Raad van Europa kunnen in dit verband in drie categorieën worden verdeeld: de high compliance group (waarvan behalve Polen ook Tsjechië, Estland, Hongarije, Letland, Litouwen en Slovenië deel uitmaken), de medium compliance group (waar onder meer Bulgarije, Kroatië en Roemenië toe behoren) en de low compliance group (bestaand uit onder andere Albanië, Armenië, Georgië, Rusland en Oekraïne). Een van de kenmerken van eerstgenoemde groep is dat het hervormingsproces van deze landen niet onder toezicht van de Parlementaire Vergadering of het Comité van Ministers heeft gestaan. Zie uitgebreider hierover Jordan 2003. 
een eerlijk proces (fair trial) is gegarandeerd. De notie van een eerlijk proces heeft - samen met een aantal specifieke verdedigingsrechten neergelegd in art. 6 lid 3 EVRM $^{25}$ - grote betekenis voor de positie van de verdachte en zijn raadsman. Behalve art. 6 zijn ook art. 5 (dat betrekking heeft op persoonlijke vrijheid en veiligheid) en art. 8 EVRM (waarin het recht op privacy is vastgelegd) van belang voor de verdediging in strafzaken. Art. 5 heeft vooral betekenis voor de verdediging in procedures die betrekking hebben op de voorlopige hechtenis en art. 8 beschermt op verschillende wijzen de vertrouwelijkheid van de relatie tussen advocaat en cliënt.

Het EVRM is overigens zeker niet de enige internationale regeling waaraan normen voor de verdediging in strafzaken kunnen worden ontleend. Het recht op verdediging is bijvoorbeeld ook vastgelegd in belangrijke VN-documenten als de Universele verklaring van de rechten van de mens en het Internationaal Verdrag inzake burgerrechten en politieke rechten (IVBP). Omdat van het EVRM verreweg de grootste invloed uitgaat op de Poolse wetgeving en praktijk staat dit verdrag in de analyse centraal. Aan andere Europese en internationale regelingen zal slechts incidenteel aandacht worden besteed.

Hoe vanzelfsprekend toetsing aan het EVRM ook moge lijken, aan het gebruik van dit verdrag als normatief kader zijn wel de nodige beperkingen gebonden. Belangrijk is vooral dat de rechtspraak van het Europese Hof niet in abstracto aangeeft in welke gevallen wel en in welke gevallen niet (meer) van een eerlijk proces kan worden gesproken. ${ }^{26}$ Bij toetsing aan art. 6 EVRM (en in zekere zin ook art. 5 ) wordt achteraf beoordeeld of de procedure in zijn geheel nog als eerlijk kan worden aangemerkt. Het is dus mogelijk dat een gebrek in het vooronderzoek in een later stadium van het strafproces gecompenseerd wordt. Ook de rechten neergelegd in art. 8 EVRM zijn niet absoluut: beperking is toegestaan onder de in het tweede lid genoemde voorwaarden. ${ }^{27}$ Als gevolg hiervan is de rechtspraak van het EHRM sterk casuïstisch waardoor het moeilijk is er algemene conclusies aan te verbinden. De uitspraken geven niet of nauwelijks harde regels die zonder problemen op een andere zaak - en vaak ook een ander rechtssysteem - kunnen

25 Op grond van art. 6 lid 3 EVRM heeft eenieder tegen wie een vervolging is ingesteld onder meer het recht te beschikken over de tijd en faciliteiten die nodig zijn voor de voorbereiding van de verdediging, het recht zichzelf te verdedigen of bijstand te hebben van een (gekozen of toegevoegde) raadsman, en het recht getuigen te ondervragen. Dit is overigens geen limitatieve opsomming: aan het begrip 'eerlijk proces' genoemd in lid 1 kunnen nadere criteria worden ontleend. Dit betekent voor de verhouding tussen de verschillende artikelleden dat '(...) on the one hand, a negative answer to the question of whether the first paragraph has been violated renders an investigation of an alleged infringement of the third paragraph superfluous, while, on the other hand, the investigation of a possible violation of the fair trial principle laid down in the first paragraph must not be confined to an examination of the third paragraph': Van Dijk e.a. 2006, p. 580 en 631.

26 '(...) the Court has avoided giving an enumeration of criteria in the abstract. In each individual case the course of the proceedings has to be assessed to decide whether the hearing concerned has been a fair one. What counts is the picture which the proceedings as a whole present (...)': Van Dijk e.a. 2006, p. 579.

27 Inperking van de door art. 8 EVRM beschermde rechten is slechts toegestaan voorzover voorzien bij wet, noodzakelijk in een democratische samenleving en ter realisatie van een van de in lid 2 genoemde doelstellingen. 
worden geprojecteerd. Dit betekent dat aan de Straatsburgse jurisprudentie slechts redeneringen kunnen worden ontleend op basis waarvan een inschatting kan worden gemaakt over de verhouding tot of de verenigbaarheid met het EVRM. Beantwoording van de vraag of een bepaald aspect van nationale wetgeving of praktijk 'Straatsburgproof' is, dient dus steeds met de nodige voorzichtigheid te gebeuren.

\section{Methodologie}

In dit onderzoek worden verschillende juridische kaders die de positie van de verdediging in het Poolse strafproces bepalen, beschreven en in een historische context geplaatst. Daarbij worden de keuzes van de postcommunistische wetgever geanalyseerd, geëvalueerd en afgezet tegen het normatieve kader van het Europees Verdrag tot bescherming van de rechten van de mens. Omdat democratisering en de bijbehorende hervorming van het strafrechtssysteem een dynamisch, continu proces is, is de gekozen tijdspanne (ontwikkelingen sinds de inwerkingtreding van de nieuwe strafrechtelijke codificaties van 1997 tot juli 2008) niet zaligmakend. Dat het niet om een afgerond proces gaat, is gelet op de vraagstelling die in dit onderzoek centraal staat echter niet problematisch. Doel is immers om de ontwikkelingen die zich tot nu toe hebben voorgedaan te analyseren om zodoende inzicht te verschaffen in het verloop van het transitieproces en antwoord te kunnen geven op de vraag welke factoren een rol spelen bij de implementatie van wijzigingen die een effectieve verdediging beogen te garanderen.

Het grootste deel van dit onderzoek is gebaseerd op geschreven bronnen: wetgeving, literatuur en - in mindere mate - jurisprudentie. Dat daarbij veelal gebruik is gemaakt van Poolse bronnen heeft niet alleen consequenties voor de gebruikte terminologie ${ }^{28}$ maar ook voor de inhoud van het onderzoek. De Poolse rechtswetenschappelijke literatuur heeft een zeer legistisch karakter. In de meeste bijdragen wordt het strafproces - en ook de positie van de verdediging - besproken door het onder de loep nemen van wettelijke bepalingen waarbij de door de wetgever gekozen bewoordingen zorgvuldig worden geanalyseerd en geïnterpreteerd. Er is een enorme verscheidenheid aan artikelsgewijze commentaren op het wetboek van strafvordering en ook de belangrijkste handboeken straf(proces) recht bevatten voornamelijk beschrijvingen van relevante wet- en regelgeving met slechts zeer beperkte aanvullingen van jurisprudentiële of praktische aard. ${ }^{29}$ Aangezien dit onderzoek voor een belangrijk deel op genoemde bronnen is gebaseerd, wordt ook in dit boek veel aandacht besteed aan de uitleg van wettelijke bepalingen en de discussies die daarover in de Poolse doctrine worden gevoerd. Hierbij dient bovendien te worden benadrukt dat in Poolse juridische bronnen opvallend weinig aandacht wordt besteed aan de historische achtergrond van wetgeving: het is niet gebruikelijk dat in literatuur of rechtspraak wordt verwezen naar

28 Zie hierna $\S 7$.

29 Zeker in meer recente literatuur is opvallend weinig aandacht voor de praktijk Een mogelijke verklaring voor de grote aandacht voor de letter van de wet kan worden gevonden in het feit dat rechtswetenschappers er - door de vele wetswijzigingen die sinds het eind van de jaren tachtig zijn (en nog steeds worden) doorgevoerd - al een dagtaak aan hebben de gewijzigde juridische kaders in kaart te brengen. 
stukken die over een wetsontwerp zijn uitgewisseld waaruit de bedoeling van de wetgever zou kunnen worden afgeleid. Belangrijkste reden hiervoor is dat dit soort stukken nauwelijks beschikbaar zijn: toelichtingen op wetsontwerpen worden slechts incidenteel gepubliceerd en zijn vaak van algemene aard waardoor ze weinig toegevoegde waarde hebben. Om die reden speelt de wetsgeschiedenis ook in dit onderzoek slechts een uiterst beperkte rol.

De jurisprudentie die in dit onderzoek aan bod komt, betreft voornamelijk Straatsburgse rechtspraak en een beperkt aantal uitspraken van hogere Poolse instanties (hoofdzakelijk het Hooggerechtshof en het Grondwettelijk Hof). Lagere nationale rechtspraak is slechts incidenteel verwerkt. De reden hiervoor is niet alleen gelegen in de - voor de niet-Poolse jurist - beperkte beschikbaarheid van deze uitspraken maar ook ingegeven door de doelstelling van dit onderzoek: omdat centraal staat op welke wijze de wetgever na 1989 opnieuw heeft vormgegeven aan de positie van de verdediging in strafzaken zal de vraag hoe deze wettelijke normen door de feitenrechter worden toegepast en geïnterpreteerd grotendeels buiten beschouwing blijven. ${ }^{30}$

De in kaart gebrachte juridische kaders worden zoveel mogelijk aangevuld met kennis over de praktijk. Om inzicht te krijgen in de gevolgen van het nieuwe strafprocesrecht voor de positie van de verdediging in de dagelijkse praktijk zijn gesprekken gevoerd met onder anderen advocaten, rechters van verschillende rechterlijke instanties en wetenschappelijk medewerkers van een aantal Poolse rechtenfaculteiten. ${ }^{31}$ Ook is gedurende zes weken de dagelijkse praktijk van de Poolse strafrechtadvocaat gevolgd in respectievelijk Poznań (kantoor dhr. Cyrson) en Lublin (kantoor dhr. Sendecki). Er is bewust voor gekozen dit niet in Warschau te doen omdat de praktijk in deze hoofdstad niet representatief is voor de rest van Polen. De keuze voor beide steden is ingegeven door hun verschillende achtergrond. ${ }^{32}$ Het moge duidelijk zijn dat het hier niet om een grootschalig praktijkonderzoek gaat en dat de verkregen resultaten vooral bedoeld zijn ter illustratie. Ter aanvulling van eigen inzichten over de praktijk is dankbaar gebruik gemaakt van resultaten van door Poolse wetenschappers of internationale organisaties verrichte onderzoeken naar verschillende aspecten van de Poolse strafrechtspraktijk. ${ }^{33}$

\section{Terminologie}

Ieder rechtssysteem heeft zijn eigen juridische terminologie. Het is een van de aspecten van de rechtsvergelijking deze begrippen op de juiste wijze te gebruiken en te vertalen. Dat is geen gemakkelijke opgave omdat sommige termen zozeer zijn verweven met het onderliggende rechtssysteem dat ze zich moeilijk laten

30 Slechts op een aantal incidentele punten - waar de vraag of bepaalde leemtes of onduidelijkheden in de wettelijke regeling door de rechtspraak zijn opgeheven zeer prangend was - is aandacht besteed aan feitenrechtspraak.

31 Aan het eind van deze inleiding wordt een opsomming gegeven van de personen met wie is gesproken.

32 Poznań - een grote, moderne stad gelegen in het Westen van Polen - verschilt in historisch, economisch en sociaal opzicht van het meer traditionele, conservatieve Lublin dat in het zuidoosten is gelegen.

33 Zoals onderzoeken door de Poolse Helsinki Foundation for Human Rights (HFHR). 
omschrijven in de taal van een land dat een vergelijkbaar verschijnsel niet kent of - nog moeilijker - daaraan een geheel andere betekenis geeft.

Dit onderzoek is voor het grootste gedeelte gebaseerd op Poolstalige geschreven bronnen. Er is vooralsnog geen juridisch woordenboek Pools-Nederlands beschikbaar en er bestaan geen - officiële of officieuze - vertalingen van Poolse strafwetgeving naar het Nederlands. De verantwoordelijkheid voor de vertaalde juridische begrippen en wetsartikelen komt dan ook volledig voor rekening van de auteur. Bij belangrijke juridische termen wordt steeds (tussen haakjes) de Poolse term aangegeven.

\section{Structuur}

De Poolse strafrechtspleging heeft sinds het einde van Wereldoorlog II ingrijpende veranderingen doorgemaakt: eerst door de introductie van het communistisch systeem en later - aan het eind van de jaren tachtig - als gevolg van de ineenstorting van dat systeem en de overgang naar een democratische rechtsstaat. Aangezien enig inzicht in deze geschiedenis noodzakelijk is voor een beoordeling van de huidige situatie zal in hoofdstuk 2 worden begonnen met een beschrijving van de historische ontwikkeling van het Poolse strafproces. In het tweede deel van dit hoofdstuk zullen vervolgens de hoofdlijnen van het huidige strafproces (de verschillende procesfasen en -deelnemers) worden besproken.

Het functioneren van de raadsman en de wijze waarop zijn positie is vormgegeven, wordt in belangrijke mate mede beïnvloed door de dominante opvatting over zijn rol en functie in het strafproces. In hoofdstuk 3 zal aandacht worden besteed aan de historische ontwikkeling van het denken over de rol en taakopvatting van de advocaat in strafzaken. Centraal daarbij staat de vraag in hoeverre de huidige heersende opinie verschilt van de standpunten die gedurende het communisme in de Poolse doctrine werden verdedigd.

Hierna zal in hoofdstuk 4, 5 en 6 aandacht worden besteed aan de wijze waarop de positie van de verdediging in het Poolse strafproces is vormgegeven en de instrumenten waarover de advocaat in strafzaken beschikt. Zoals eerder opgemerkt in deze inleiding, is voor het voeren van een effectieve verdediging onder meer van belang vanaf welk moment de verdachte recht heeft op rechtsbijstand en onder welke voorwaarden de verdachte gebruik kan maken van door de overheid gefinancierde rechtsbijstand. Deze twee thema's - de vraag naar de aanvang van het recht op rechtsbijstand en de voorziening van kosteloze rechtsbijstand - worden onder de noemer 'toegang tot rechtsbijstand' besproken in hoofdstuk 4 . In hoofdstuk 5 staat de positie van de raadsman in het vooronderzoek centraal. Aan de hand van een aantal bevoegdheden - de mogelijkheid bij verhoren aanwezig te zijn, inzage in de processtukken te hebben, invloed uit te oefenen op beslissingen inzake de voorlopige hechtenis en op de bewijsvergaring - zullen de verschillende verdedigingsmogelijkheden vóór aanvang van het eindonderzoek in kaart worden gebracht. In hoofdstuk 6 wordt vervolgens bekeken hoe de positie van de verdediging in het eindonderzoek is vormgegeven. Aangezien postcommunistische hervormingen voornamelijk betrekking hebben gehad op de mogelijkheden die de verdediging in het vooronderzoek heeft, ligt daar (in hoofdstuk 4 en 5) ook het zwaartepunt voor dit onderzoek. De rechten die de raadsman zijn toebedeeld om zijn functioneren als verdediger te vergemakkelijken en die vertrouwelijkheid in 
het contact met zijn cliënt dienen te garanderen - de zogenaamde 'privileges' van de advocaat in strafzaken: het vrij verkeer en het verschoningsrecht - komen in hoofdstuk 7 aan de orde. Om inzicht te verkrijgen in de vraag op welke punten de wettelijke normering in het transitieproces veranderingen heeft ondergaan en in hoeverre daarbij een normerende werking is uitgegaan van het EVRM zal in hoofdstuk 4, 5, 6 en 7 waar relevant bij de verschillende thema's een vergelijking worden gemaakt met de juridische kaders die gedurende het communisme golden (voornamelijk het wetboek van strafvordering van 1969) en de randvoorwaarden die op grond van het Europees Verdrag tot bescherming van de rechten van de mens aan een effectieve verdediging worden gesteld.

Gelet op de bijzondere rol van de Poolse advocatuur in het transitieproces en de invloed die de beroepsgroep heeft gehad op de implementatie van wijzigingen die een effectieve verdediging beogen te garanderen, wordt in hoofdstuk 8 uitgebreid aandacht besteed aan de gevolgen van het democratiseringsproces voor de balie en de bijzondere plaats die zij in de maatschappij inneemt. Daarbij zullen achtereenvolgens de historische ontwikkeling van de organisatie, de beroepscultuur en de beroepsethiek aan bod komen.

Ten slotte zal in hoofdstuk 9 aan de hand van een analyse van de bevindingen uit de voorgaande hoofdstukken een antwoord op de centrale probleemstelling worden geformuleerd.

Het onderzoek is afgerond op 1 juli 2008. Gebeurtenissen en ontwikkelingen van na die datum zijn slechts incidenteel verwerkt.

\section{In Warschau, Lublin en Poznań zijn gesprekken gevoerd met:}

Dhr. W. Hermeliński (rechter Grondwettelijk Hof, voormalig advocaat en vicepresident van de Poolse balie)

Dhr. Ślazki (vice-president hoger beroepsinstantie Lublin)

Dhr. Ozimek (rechter provinciale rechtbank Lublin)

Dhr. Z. Mielnik (rechter districtsrechtbank Poznań)

Dhr. Maciejewski (officier van justitie Poznań)

Dhr. P. Kruszyński (hoogleraar straf(proces)recht Universiteit van Warschau, tevens advocaat)

Mevr. E. Zielinska (hoogleraar straf(proces)recht Universiteit van Warschau)

Dhr. D. Swenson (hoogleraar Katholieke Universiteit Lublin en voormalig coördinator van Central and Eastern European Law Initiative van de American Bar Association in Polen)

Dhr. Z. Hołda (hoogleraar penitentiair recht, Jagiellonische Universiteit Krakau, advocaat en verbonden aan Polish Helsinki Foundation for Human Rights)

Dhr. Ł. Bojarski (Polish Helsinki Foundation for Human Rights)

Dhr. P. Sendecki (advocaat)

Dhr. L. Cyrson (advocaat)

Dhr. P. Paradowski (advocaat)

Dhr. A. Woźny (advocaat)

Dhr. Michałek (advocaat)

Dhr. P. Sendecki (advocaat)

Dhr. T. Rowiński (advocaat)

Mevr. B. Jurkiewicz (advocaat) 
Mevr. E. Stępniak (advocaat)

Dhr. Wróblewski (advocaat en 'aanklager' in tuchtzaken tegen advocaten)

Mevr. M. Wąsek-Wiaderek (Katholieke Universiteit Lublin, tevens werkzaam bij

Hooggerechtshof)

Dhr. P. Gwirdoyn (Universiteit van Warschau)

Mevr. K. Kurowska (Universiteit van Warschau) 


\title{
Hoofdstuk 2
}

\section{Geschiedenis en hoofdlijnen van het Poolse strafproces}

\author{
'Under capitalism, man exploits man. Under communism, it's just the opposite' \\ J.K. Galbraith
}

\section{Inleiding}

Ieder onderzoek naar de positie van de advocaat in strafzaken vereist enige kennis van het strafproces in zijn algemeenheid. De rol van de raadsman kan immers alleen worden begrepen vanuit het geheel waarvan hij onderdeel uitmaakt en dit maakt inzicht in de structuur van het strafproces en de functies van verschillende procesdeelnemers noodzakelijk. Wanneer een dergelijk onderzoek niet het eigen rechtssysteem maar een 'vreemd' land als Polen betreft, kan deze algemene kennis niet zonder meer als bekend worden verondersteld.

Een bespreking van de wijze waarop het strafproces vandaag de dag in Polen wordt gevoerd, is niet compleet zonder een blik op het verleden. Dit geldt des te meer nu in dit onderzoek juridische hervormingen centraal staan die het gevolg zijn van historische ontwikkelingen en decennialange politieke beïnvloeding van de strafrechtspleging.

Het Poolse rechtssysteem behoort van oorsprong tot de continentale (civil law) rechtstraditie en hoewel de basis hiervan gedurende het communisme niet is verlaten, waren de veranderingen die na 1944 zijn doorgevoerd zo ingrijpend dat van een socialistisch rechtssysteem en meer specifiek een socialistisch strafproces kon worden gesproken. Om postcommunistische hervormingen en de structuur en inhoud van het huidige strafproces goed te kunnen begrijpen, dient daarom eerst duidelijk te worden wat het vertrekpunt voor deze hervormingen was. Daartoe zal in het eerste deel van dit hoofdstuk de ontwikkeling van het Poolse strafproces vanaf het interbellum tot aan de nieuwe strafrechtelijke codificaties van 1997 worden besproken. ${ }^{1}$ Centraal daarbij staat welke gevolgen het communistisch regime voor het strafprocesrecht heeft gehad en wat de belangrijkste doelstellingen waren van de hervormingen die in de jaren na 1989 zijn doorgevoerd. Vervolgens zullen in het tweede deel van dit hoofdstuk de hoofdlijnen van het huidige strafproces worden uitgezet. In het kader daarvan wordt eerst aandacht besteed aan de belangrijkste procesdeelnemers: de rechter en openbaar aanklager, de verschillende functies die burgers in het strafproces kunnen vervullen en ten slotte de verdachte en zijn raadsman. Ten aanzien van de raadsman geldt dat met de bespreking van een aantal algemene thema's ${ }^{2}$ zal worden volstaan. Onderwerpen die meer specifiek betrekking hebben op de positie van de raadsman in het strafproces - zijn strafprocessuele bevoegdheden en de tuchtrechtelijke grenzen die aan zijn optreden worden gesteld - komen in latere hoofdstukken aan de

1 Ter aanduiding van de verschillende strafrechtelijke codificaties zullen de afkortingen KPK (Kodeks Postepowanie Karnego: wetboek van strafvordering), KK (Kodeks Karny: wetboek van strafrecht) en KKW (Kodeks Karny Wykonawczy: wetboek betreffende de tenuitvoerlegging van straffen) worden gebruikt.

2 Zoals de vraag wie als raadsman kan optreden, wie een raadsman kan benoemen en wanneer rechtsbijstand in strafzaken verplicht is. 
orde. Ten slotte zal in het tweede deel van dit hoofdstuk het globale verloop van het strafproces worden besproken waarbij de verschillende stadia van de procedure en de rechtsmiddelen die tijdens of na afloop daarvan kunnen worden ingesteld aan bod zullen komen.

\section{Geschiedenis}

De geschiedenis van Polen is roerig en wordt gekenmerkt door periodes van onafhankelijkheid afgewisseld door (vaak langdurige) onderdrukking en bezetting door buurlanden. ${ }^{3}$ De installatie van het communistisch regime aan het eind van Wereldoorlog II heeft ingrijpende consequenties gehad voor de strafrechtspleging. Binnen de 'communistische periode' die van 1944 tot 1989 heeft geduurd, kunnen verschillende tijdvakken worden onderscheiden die meer of minder repressief waren. Het eerste decennium na Wereldoorlog II - ook wel aangeduid als de stalinistische periode - is zonder twijfel de meest repressieve periode geweest. Als reactie hierop kon na de dood van Stalin in de tweede helft van de jaren vijftig een verzachting van het regime worden geconstateerd. In de loop van de jaren zestig en zeventig was echter opnieuw sprake van toenemende repressie. Als gevolg van groeiend maatschappelijk verzet (opkomst van de oppositiebeweging Solidarnośc) besloot de communistische partij de teugels steeds strakker aan te trekken hetgeen uiteindelijk resulteerde in de staat van beleg (1981-1982). Dit militaire regime heeft de ondergang van het communistisch regime echter niet kunnen voorkomen: Solidarność groeide uit tot een politieke partij die in 1989 de verkiezingen won en daarmee de communisten van de troon wist te stoten.

Bovengenoemde politieke golfbewegingen hebben uiteraard ook gevolgen gehad voor de vormgeving van het straf(proces)recht. Vandaar dat de hiernavolgende bespreking van relevante ontwikkelingen op het gebied van het strafrecht gedurende het communisme ook aan de hand van genoemde periodes zal plaatsvinden. Voordat daartoe wordt overgegaan, zal eerst kort aandacht worden besteed aan de periode voor Wereldoorlog II waarin de eerste Poolse strafrechtelijke codificaties tot stand kwamen die ook na 1944 nog lange tijd van kracht zijn gebleven.

\subsection{Voor Wereldoorlog II}

Toen Polen aan het einde van de achttiende eeuw door buurlanden werd bezet, kwam een einde aan een lange periode van bloei waarin ook de democratie tot volle ontwikkeling was gekomen. Met een gekozen koning en de erkenning van burgerlijke rechten en vrijheden die uiteindelijk werden vastgelegd in de eerste Grondwet van Europa (mei 1791) kon het land tot de meest democratische staten van Europa worden gerekend. ${ }^{4}$ Er bestond in deze periode nog geen wetboek van strafvordering in de strikte zin van het woord: de wijze waarop het strafproces gevoerd diende te worden was geregeld in het zogenaamde Formula Processus dat regels bevatte voor zowel het straf- als het civiel recht. Toen het Poolse grondgebied in 1795 door buurlanden Rusland, Pruissen en Oostenrijk werd ingenomen

3 Voor een uitgebreide beschrijving van de Poolse geschienis wordt verwezen naar Davies 2005.

4 Dit gold voornamelijk voor de tweede helft van de zestiende eeuw waarin Polen samen met Litouwen een adelsrepubliek vormde. Zie hierover: Gubanksi 2004, p. 18. 
verdween Polen als zelfstandige mogendheid van de wereldkaart. Plannen om een apart wetboek van strafvordering in het leven te roepen, werden hierdoor in de kiem gesmoord: vanaf 1795 gold de wetgeving van de bezettende staten. ${ }^{5}$ Pas aan het einde van Wereldoorlog I kreeg Polen na een bezetting van meer dan 120 jaar zijn onafhankelijkheid terug en werd de behoefte aan eigen nationale wetgeving steeds groter. De ontwikkeling van het rechtssysteem werd een van de belangrijkste agendapunten van de Tweede Republiek (zoals Polen gedurende het interbellum werd genoemd) en reeds in 1919 werd een codificatiecommissie in het leven geroepen die op verschillende gebieden nieuwe wetgeving diende voor te bereiden. In deze periode tussen de twee wereldoorlogen kreeg het Pools strafrechtelijk systeem vorm en werd een wetboek van strafvordering (1928) en een wetboek van strafrecht uitgevaardigd (1932). Beide codificaties hadden een liberaal karakter. Voor het materiële strafrecht kwam dit onder andere tot uitdrukking in het feit dat enkele in die tijd op zedelijk vlak omstreden gedragingen - zoals vrijwillig homoseksueel contact tussen volwassenen en overspel - in tegenstelling tot de situatie in sommige andere landen niet strafbaar waren gesteld. De regeling van het formele strafrecht - het eerste Poolse wetboek van strafvordering - was voornamelijk geënt op de Franse Code d'Instruction Criminelle en bestond uit een combinatie van adversaire en inquisitoire elementen. ${ }^{6}$ In de fase voorafgaand aan het onderzoek ter terechtzitting werden twee soorten vooronderzoek onderscheiden die beide een sterk inquisitoir karakter hadden: één onder leiding van de officier van justitie dat uitgevoerd kon worden door de politie (dochodzenie) en één onder leiding van een rechter-commissaris dat in zwaardere strafzaken diende te worden toegepast (śledztwo). ${ }^{7}$ De regeling werd gekenmerkt door een duidelijk afgebakende taakverdeling tussen de officier van justitie en de rechter-commissaris. Verschillende bevoegdheden zoals het bevelen van voorlopige hechtenis en het uitvoeren van bepaalde onderzoekshandelingen als huiszoeking en inbeslagneming behoorden tot de exclusieve bevoegdheid van de rechter-commissaris. Op deze wijze hoopte de wetgever de rechtsbescherming van verdachte gedurende het vooronderzoek te garanderen en de macht van het openbaar ministerie binnen de perken te houden. Deze taakverdeling heeft echter niet kunnen voorkomen dat de vervolging in de loop der jaren een steeds machtigere positie ging innemen. Dit kwam onder andere tot uiting in de wijze waarop en de mate waarin resultaten van het vooronderzoek voor het bewijs konden worden gebruikt. Volgens het wetboek van 1928 konden resultaten van onderzoekshandelingen die niet door de rechter-commissaris waren uitgevoerd geen deel uitmaken van het bewijs op de openbare terechtzitting. ${ }^{8}$ Deze regel werd in de praktijk echter steeds verder afgezwakt waardoor het exclusieve karakter van het onderzoek door de rechter-commissaris verminderde en de positie van

5 Dit betekende dat de wijze waarop strafrechtelijke procedures moesten worden gevoerd in de verschillende voormalig Poolse gebieden werd bepaald door vier uitheemse wetboeken van strafprocesrecht: het Oostenrijkse van 1873, het Duitse van 1877, het Hongaarse van 1896 en het Russische van 1864.

6 Op het onderscheid adversair-inquisitoir zal worden teruggekomen in § 2.3.3.2.

7 Zoals later nog zal blijken, wordt dit onderscheid ook vandaag de dag nog gehanteerd.

8 Van dit soort handelingen verricht tijdens de dochodzenie werden door politie of openbaar ministerie wel (informele) notities gemaakt maar deze konden slechts een informatieve functie vervullen. 
de officier van justitie alsmaar sterker werd. Laatstgenoemde ontwikkeling werd door het politieke klimaat van de jaren dertig nog verder versterkt: als gevolg van autoritaire tendensen (opkomend fascisme en nationaal-socialisme) vond een verharding van zowel het materiële als het formeel strafrecht plaats waarbij onder meer de bevoegdheden van politie en openbaar ministerie werden uitgebreid. ${ }^{9}$ Het - op papier - gematigd inquisitoire karakter van het strafproces werd hierdoor in de praktijk steeds minder gematigd: het onderzoek ter terechtzitting hield in veel gevallen niet meer in dan reproductie van de door politie of openbaar ministerie verzamelde bewijzen waardoor het zwaartepunt van het strafproces duidelijk in het vooronderzoek was komen te liggen. ${ }^{10}$

\subsection{Communistische periode (1944-1989)}

Het duurde niet lang voordat Polen de in 1918 herwonnen onafhankelijkheid opnieuw verloor. In 1944 werd onder strenge regie van de Sovjet-Unie het communistisch Nationaal Comité voor de Bevrijding van Polen ${ }^{11}$ opgericht dat in december van genoemd jaar tot voorlopige regering werd uitgeroepen. Uiteindelijk werd dit als enig legitiem gezag in Polen erkend waardoor de Poolse regering die tot dan toe in ballingschap in Engeland verbleef volledig buiten spel werd gezet. Deze gebeurtenissen luidden een nieuwe periode in de Poolse geschiedenis in: gedurende de volgende vijfenveertig jaar zou het land in de ban zijn van een totalitair communistisch regime.

Alvorens dieper in te gaan op de gevolgen van het communistisch regime voor de Poolse strafrechtspleging, zal kort aandacht worden besteed aan de ideologie die ten grondslag lag aan de socialistische systemen van Centraal- en OostEuropa: het marxisme-leninisme. ${ }^{12}$

In de werken van de grondleggers van het communisme - Marx en Engels - wordt nauwelijks tot geen aandacht besteed aan het (straf)recht. Enerzijds omdat hun ideeëngoed in de eerste plaats een economisch - en geen juridisch - karakter had ${ }^{13}$ maar ook vanwege het feit dat het recht binnen de communistische ideologie als een uitstervend systeem werd beschouwd. Het marxistisch-leninistisch ideeën-

9 Zie voor een beschrijving van de antiliberale wetswijzigingen die in de jaren dertig in het strafprocesrecht zijn doorgevoerd: Marszał 1997.

10 Over het Poolse strafproces voor Wereldoorlog II: Waszczynski 1966, p. 257 en 260261, Waltoś 1979, p. 5-12, Frankowski 1992, p. 243-250, Wąsek en Frankowski 1995, p. 275-281, Janik 1977, p. 1-5 en Waltoś 2002 I, p. 122-127

11 Polski Komitet Wyzwolenia Narodowego (PKWN).

12 De term marxisme-leninisme wordt hier gebruikt ter aanduiding van het ideeëngoed van Marx en Engels zoals dat later - ten behoeve van verwezenlijking in Rusland c.q. de Sovjet-Unie - is uitgewerkt door Lenin. Zie kort hierover: David en Brierly 1978, p. 161-165. De hiernavolgende bespreking van dit onderwerp is sterk vereenvoudigd en geenszins volledig. Slechts die aspecten zullen worden besproken die de plaats en functie van het (straf)recht binnen een communistisch systeem kunnen helpen verklaren.

13 'The writings of Marx and Engels do not contain any systematic theorizing about the law. Contemporary elaborations of a Marxist theory of law are, and must be constructions of what Marx and Marxism would or should say about the subject. If one compares the depth of Marx's analysis of economic matters in his mature writings with the perfunctory character of his analyses of law, the contrast is striking. There is no mystery about this. The thinness of Marx's analysis of law is a corollary of the centrality in his analysis, of economics and "material life": Krygier 1990, p. 648. 
goed is gebaseerd op de overtuiging dat de kapitalistische maatschappij wordt gekenmerkt door een oneerlijke verdeling van productiemiddelen die de samenleving verdeelt in twee lijnrecht tegenover elkaar staande groepen: de bezitters en de bezitlozen. Zowel de staat als het recht - door communisten als een eenheid beschouwd - bestaan alleen bij de gratie van deze klassentegenstelling. Rechtsregels worden gebruikt ter onderdrukking van de bezitlozen en instandhouding van de ongelijkheid binnen de samenleving en georganiseerde overheidsmacht is noodzakelijk om naleving van de regels af te dwingen. Met andere woorden: de staat en het recht ontlenen hun bestaansrecht aan elkaar. Aangezien vanuit communistisch oogpunt een rechtvaardige samenleving alleen kan bestaan wanneer de productiemiddelen toebehoren aan eenieder en niet langer in het bezit zijn van een selecte groep die de ander domineert, dient deze klassentegenstelling zo snel mogelijk te worden opgeheven. Dat laatste kan worden gerealiseerd door individueel eigendom af te schaffen en gemeenschappelijk bezit op zo groot mogelijke schaal te realiseren.

Het uitgangspunt dat zowel de staat als het recht hun bestaansrecht ontlenen aan de ongelijkheid binnen de samenleving verklaart de overtuiging dat met het verdwijnen van de klassenstrijd tevens de georganiseerde overheid en het recht zullen ophouden te bestaan. Dit om de eenvoudige reden dat ze in de communistische maatschappij geen functie meer hebben: wanneer rechtsregels niet meer nodig zijn, hoeft de staat niet langer de naleving ervan te garanderen en zijn beide dus overbodig geworden. Zowel de overheid als het recht zullen in de aanloop naar de communistische samenleving uit zichzelf geleidelijk aan verdwijnen en hoeven dus niet actief te worden afgeschaft. ${ }^{14}$

Dit bleek in de praktijk echter minder eenvoudig dan de werken van Marx en Engels hadden doen vermoeden. Gedurende de eerste decennia van het communistisch regime in de Sovjet-Unie werd duidelijk dat volledige realisatie van het communisme veel langer zou gaan duren dan de nieuwe machthebbers oorspronkelijk hadden gehoopt. De economische transitie was een omvangrijke operatie die behoorlijk wat tijd zou gaan kosten en in de overgangsfase bleek het recht een onmisbaar instrument te zijn. ${ }^{15}$ Onder deze nieuwe omstandigheden kreeg het recht drie hoofdfuncties:

14 Over 'the withering away of law': Sypnowich 1990, p. 1-27.

15 Deze constatering heeft Russische rechtsgeleerden heel wat hoofdbrekens gekost: hoe kon het voortbestaan van het recht worden verenigd met de uitstervingstheorie van Marx? De vraag naar het bestaansrecht van socialistisch recht heeft gedurende de eerste decennia van de Sovjet-Unie belangrijke ontwikkelingen doorgemaakt. In de eerste periode - tot circa de helft van de jaren dertig - overheerste de theorie van 'withering away of law' die door de beroemde jurist Pashukanis was uitgewerkt tot de 'commodity exchange theory'. Deze leer hield - kort weergegeven - in dat iedere rechtsregel zijn bestaansrecht ontleent aan het voorkomen van conflicten (in de zin van tegengestelde individuele belangen) binnen de maatschappij. In de visie van Pashukanis was de oorsprong van het recht te vinden in commodity exchange - het uitwisselen van goederen ter beslechting van een geconstateerd belangenconflict - waardoor de kern van iedere rechtsregel bestond uit het reguleren van een transactie ter oplossing van een bepaald geschil. Dit 'economische karakter' van het recht bracht hem tot de conclusie dat rechtsregels slechts bestaansrecht hadden in kapitalistische maatschappijen die immers gekenmerkt worden door belangentegenstellingen. In de communistische samenleving zou dit soort 
1. bieden van bescherming tegen interne en externe vijanden,

2. verwezenlijken van economische doeleinden en

3. onderwijzen c.q. opvoeden van de burger zodat deze zijn plaats in de communistische samenleving leert kennen en begrijpen. ${ }^{16}$

Het straf(proces)recht speelde met name een belangrijke rol bij verwezenlijking van bovengenoemde eerste en derde functie ${ }^{17}$ en deze nieuwe doelstellingen hadden ingrijpende consequenties voor de gehele strafrechtspleging. Criminaliteit werd door Marx en Engels beschouwd als een verschijnsel dat door het kapitalistische stelsel werd veroorzaakt, ook Lenin en Stalin waren van mening dat misdadigheid een erfenis van het kapitalisme was die tot de zogenaamde 'moedervlekken van de socialistische maatschappij' behoorden. ${ }^{18}$ Een harde aanpak was dus noodzakelijk. Op het terrein van het materieel strafrecht dienden nieuwe, vaag geformuleerde strafbepalingen ${ }^{19}$ mogelijk te maken dat eenieder die op een

conflicten niet meer voorkomen en het recht derhalve geen functie meer hebben. Zelfs het strafrecht waarin de 'commodity exchange' volgens Pashukanis zeer duidelijk zichtbaar was (de schuldige 'betaalt' na veroordeling door middel van vrijheidsbeneming of schadevergoeding een prijs voor het strafbare feit dat hij heeft begaan, vergelijkbaar met een schadevergoeding na wanprestatie of onrechtmatige daad) zou uiteindelijk verdwijnen. Zie onder anderen: Beirne en Sharlett 1980. In de loop van de jaren dertig - toen men in de USSR ging inzien dat het recht voorlopig nog een belangrijke rol zou spelen in de socialistische maatschappij - werd Pashukanis' 'nihilistische houding' ten opzichte van het recht onder leiding van de Russische openbaar aanklager Vyshinsky expliciet verworpen. Deze nieuwe stroming was gebaseerd op de overtuiging dat gedurende de overgangsfase socialistisch recht wel degelijk bestaansrecht had: het werd beschouwd als een hogere vorm van recht die anders dan in de visie van Pashukanis niet onlosmakelijk was verbonden met het kapitalisme. Over deze ontwikkelingen: Ludwikowksi 1987 en Gsovksi en Grzybowksi 1959, p. 49-52.

16 'The criminal process was to be made an effective instrument for the government to repress conduct dangerous to the state and to educate the masses': Damaška 1986, p. 194. Over de 'three tasks of Soviet law': David en Brierly 1978, p. 176-180. Onlosmakelijk verbonden met genoemde taken van het sovjetrecht zijn de drie (door Feldbrugge genoemde) 'Sowjet opvattingen over staat en recht':

a. recht ontleent zijn inhoud niet aan een of ander begrip van Gerechtigheid, maar aan wat nuttig is voor de heersende klasse, voor de staat.

b. recht is een instrument in handen van de heersende klasse ter bevordering van haar belangen: het is naar zijn aard partijdig en

c. de staat is niet onderworpen aan het recht. Zie Feldbrugge 1959, p. 8.

17 Wat echter niet wegneemt dat het strafrecht door middel van economische delicten ook een belangrijke bijdrage diende te leveren aan hervorming en instandhouding van het economisch systeem (de tweede functie). De opvoedende functie van het socialistisch strafrecht is treffend omschreven door Hazard: 'The criminal law has many conventional features in defining what will not be permitted to nonconforming citizens, but it goes beyond the normal confines in an attempt to create a new "socialist man", aware not only of the rule that "thou shalt not kill" but also of the rule that "he who does not work shall not eat"': Hazard 1969 , p. 524.

18 Feldbrugge 1959, p. 14-15: misdaad wordt veroorzaakt door de resten van het kapitalisme in het bewustzijn van de sovjetburger en invloeden van buitenaf (p. 15).

19 Gekenmerkt door moeilijk te omlijnen begrippen als 'anti-sovjet propaganda' en 'belastering van de staat en het politieke en maatschappelijke stelsel'. Deze onduidelijke formuleringen maakten het mogelijk om 'reeds tegen iedere uiting die blijk geeft van een 
of andere wijze een gevaar vormde voor het communistisch regime kon worden uitgeschakeld. Binnen deze nieuwe functies van het strafrecht kwam het accent te liggen op de zogenaamde 'sociaalgevaarlijkheid' van strafbare handelingen. Dit hield in dat een gedraging pas strafrechtelijk relevant was wanneer deze op enigerlei wijze gevaar opleverde voor de gemeenschap of voor de vertegenwoordiger van de gemeenschap: de overheid. ${ }^{20}$

Om invulling te geven aan de 'opvoedende' functie van het recht kreeg de strafrechtelijke procedure een educatief karakter. Door de verdachte in het openbaar aan te spreken op zijn 'sociaalgevaarlijk' handelen en nadrukkelijk te wijzen op het gevaar dat hij daardoor vormde voor het welzijn van de gehele maatschappij werd de voltrekking van het strafproces - met als hoogtepunt een (dikwijls) belerende uitspraak van de rechter - een belangrijk middel om de samenleving bekend te maken met de eisen die aan de 'sovjetburger' werden gesteld.

Aan dit alles lag een opvatting over recht ten grondslag die wezenlijk verschilt van de Westerse rechtsstaatgedachte: rechtsregels werden 'slechts' beschouwd als een van de instrumenten waarmee de machthebbers hun politieke doelstellingen konden bereiken. ${ }^{21}$

Behalve deze instrumentele functie werd aan het recht geen zelfstandige, 'hogere' waarde toegekend: het was niet bedoeld om overheidsmacht aan banden te leggen of burgers te beschermen. ${ }^{22}$ Een dergelijke bescherming van de burger tegen de staat was vanuit communistisch oogpunt overbodig omdat overheid en individu hetzelfde belang nastreefden: het bereiken van de hoogst mogelijke vorm van samenleven - de communistische maatschappij. ${ }^{23}$

mening die van die van de machthebbers afwijkt in het geweer te komen': Feldbrugge 1985, p. 685.

20 Ook wel nullem crimen sine periculo sociali: Pomorski 1981, p. 16. Dit materiële criterium gold naast de formele eis dat de gedraging op het moment van handelen door de strafwet moest zijn verboden (nulla poena sine praevia lege poenali) waardoor het in theorie strafbaarheid zou moeten beperken. Door de vage formulering van delictsomschrijvingen was dit in de praktijk echter niet altijd het geval. Zie over de eis van sociaalgevaarlijkheid in het Poolse wetboek van strafrecht van 1969 hierna § 2.2.2.2.

21 In die hoedanigheid is strafrecht ook niet langer een afspiegeling van morele waarden en normen die bij de bevolking leven maar 'slechts' een beleidsinstrument dat eenvoudig van inhoud kan veranderen. In de woorden van Siekanowicz: 'Legislative acts have been treated by the Communists as matters of policy and not of principle', Siekanowicz 1959 I, p. 729. Om deze instrumentele functie te kunnen vervullen, dienden de regels wel nauwkeurig te worden nageleefd. Deze eis van strikte gebondenheid aan de wet werd ook wel 'socialistische wettelijkheid' genoemd en heeft vooral betekenis gehad gedurende de stalinistische periodes van de communistische regimes in Centraal- en Oost-Europa. Zie over het begrip 'socialistische wettelijkheid': Malfliet 1987, p. 70-73.

22 Naleving van het recht werd beschouwd als een verplichting van de burger: het bood hem voor wat betreft het optreden van de overheid geen waarborg in de zin van rechtszekerheid of rechtsbescherming. In de woorden van Razi: 'In the Soviet world, law is not placed above the Government, but it is recognized that the Government must rule others by means of law to promote its ends. For the Soviet rulers law is an option. It is used when it is convenient and is discarded when it is not': Razi 1960, p. 792-793.

23 Rechtssystemen in de communistische landen van Centraal- en Oost-Europa kregen door deze ontwikkelingen een geheel eigen karakter waardoor ze ondanks hun sterke verbondenheid met de continentale rechtsstraditie en het civil law systeem in de 
Het spreekt welhaast voor zich dat de tamelijk liberale strafrechtelijke codificaties van voor Wereldoorlog II de nodige aanpassing en aanvulling behoefden voordat ze voor bovengenoemde communistische doeleinden konden worden ingezet. Aan de hand van de verschillende perioden die in het tijdvak 1944-1989 kunnen worden onderscheiden, zal in het onderstaande worden besproken welke gevolgen dit in grote lijnen heeft gehad voor het strafprocesrecht. ${ }^{24} \mathrm{Om}$ deze ontwikkelingen in hun historische context te kunnen plaatsen, zal daarbij telkens eerst kort op de belangrijkste politieke gebeurtenissen van de betreffende periode worden ingegaan. ${ }^{25}$

\subsubsection{Stalinistische periode (1944-1956)}

Het door de Russen opgelegde regime werd door de Polen niet met open armen ontvangen. Op het moment dat de communistische regering werd gevestigd, voelde de meerderheid van de Poolse bevolking geen enkele verbondenheid met de communistische partij en de daaraan ten grondslag liggende marxistischleninistische ideologie. ${ }^{26} \mathrm{Al}$ snel werd duidelijk dat realisatie van de communistische doelstellingen niet automatisch zou verlopen en gepaard zou moeten gaan met een krachtig overheidsoptreden. De eerste jaren na Wereldoorlog II kenmerkten zich dan ook door een uiterst strenge en repressieve politiek die van 1947 tot 1956 onder leiding stond van Bierut, een communist die zeer nauwe banden met de Sovjet-Unie onderhield. Gedurende deze periode zette hij zich in voor realisatie van het communisme naar sovjetvoorbeeld waarbij het harde beleid dat Stalin vanuit de Sovjet-Unie uitzette, op de voet werd gevolgd en gekopieerd. De stalinistische methodes waren uiterst repressief en werden gekenmerkt door willekeur, intimidatie en gewelddadig overheidsoptreden. Personen en groeperingen die op enigerlei wijze een (potentiële) bedreiging vormden voor de naoorlogse politieke structuur werden op grote schaal aangehouden, gedetineerd en soms zelfs geëxecuteerd. Deze praktijk maakte de eerste twaalf jaren van het communistisch regime tot een zwarte periode in de Poolse geschiedenis.

rechtsvergelijking wel als een aparte rechtsfamilie worden aangemerkt. Meer hierover in hoofdstuk 3, § 2.1 .

24 Het materiële strafrecht zal slechts zijdelings aan de orde komen.

25 Voor de hiernavolgende bespreking van de politieke ontwikkelingen gedurende het communisme is gebruik gemaakt van: Holmes 1997, p. 68-72, Vos 2000, p. 219-244, Gökay 2001, p. 25-32 en p. 75-76, White 2001, p. 35-40 en 53-56 en Hoon Chun 2001, p. 10-15.

26 De wijze waarop het communisme door de Sovjet-Unie werd ingevuld en uitgedragen, was moeilijk verenigbaar met een aantal belangrijke tradities en opvattingen van het Poolse volk: zo stond de door de communisten voorgestane secularisatie lijnrecht tegenover de nauwe verbondenheid met de rooms-katholieke kerk en druisten de plannen tot collectivisering van de landbouw in tegen de Poolse agrarische traditie die voornamelijk was geënt op individueel grondbezit. Tevens betekende de allesoverheersende macht van de communistische partij en de daarmee gepaard gaande vereenzelviging van individuele belangen met het belang van de staat een onaanvaardbare inbreuk op Poolse democratische traditie. Dit is tot op bepaalde hoogte gedurende de gehele communistische periode zo gebleven - in de woorden van Łos: 'Despite its strenous efforts, the Polish communists have not been able to eliminate or even weaken the Catholic Church's moral authority, and the party's monopoly over the people's lives has never been extended over their souls as well': Łos 1988, p. 295. 


\subsubsection{Aanpassingen eerste jaren stalinisme}

Het feit dat de wetboeken van 1928 en 1932 waren ontworpen in een parlementaire democratie die op geen enkele wijze verband hield met het communistische ideeëngoed zou de verwachting kunnen wekken dat het behoud van deze tamelijk liberale wetgeving geen lang leven was beschoren. Niets was echter minder waar: beide strafrechtelijke codificaties bleven na de installatie van het communistisch regime maar liefst vijfentwintig jaar van kracht. Pas in 1969 zouden ze plaats moeten maken voor een nieuw wetboek van strafrecht en strafprocesrecht. ${ }^{27}$

Aan het behoud van de vooroorlogse wetgeving dient echter niet teveel betekenis te worden toegekend: het was in veel opzichten niet meer dan een formaliteit voornamelijk bedoeld om de schijn van continuïteit en normaliteit te wekken. ${ }^{28}$ Het wekt ten onrechte de indruk dat de strafrechtspleging op dezelfde wijze werd voortgezet als voor Wereldoorlog II terwijl inhoudelijk op vele punten ingrijpende veranderingen werden doorgevoerd om het straf(proces)recht te laten aansluiten bij communistische doelstellingen. Gedurende de eerste jaren van het stalinisme werden deze aanpassingen hoofdzakelijk gerealiseerd door enerzijds oude regels een nieuwe invulling te geven en anderzijds het bestaande systeem met nieuwe regelgeving en bijzondere rechterlijke instanties aan te vullen.

Wat de nieuwe invulling van oude regels betreft, geldt dat veel regelgeving die haar geldingskracht had behouden gedurende de stalinistische periode een andere betekenis kreeg. De rechter diende bij de interpretatie van rechtsregels het beleid en de doelstellingen van de communistische partij als uitgangspunt te nemen waarbij hij niet was gebonden aan de betekenis die voorheen aan bepalingen werd gegeven. ${ }^{29}$ De rechtspraktijk had de moeilijke taak in ieder concreet geval vast te stellen welke regels van toepassing waren en hoe deze geïnterpreteerd dienden te worden. Een verdere aanpassing en - zoals nog zal blijken - verharding van het

27 Het nieuwe wetboek van strafvordering trad in werking op 1 januari 1970 (wet van 19 april 1969, Dz. U. nr. 13, 96). Het behoud van vooroorlogse wetgeving was overigens geen typisch Pools verschijnsel: ook in andere Centraal- en Oost-Europese landen zoals Hongarije en (voormalig) Tsjecho-Slowakije bleef een groot deel van de oude wetgeving na Wereldoorlog II van kracht: Garlicki 1980, p. 489.

28 Als zodanig is behoud van (oud) recht een kenmerk van totalitaire systemen te noemen: 'As a traditional source of form and order, justice and the legitimacy of state action, law mustprecisely in a substantively lawless order of domination - fulfil the vital task of "faking" to both domestic and foreign audiences the continuity of a legal, constitutional 'normality'. Law thus becomes a camouflaging structure in an elaborate staging of violence-based domination in an otherwise power-stabilizing 'shapelessness' (Hanna Arendt) or at least a "dual state"(Ernst Fraenkel)': Gessner e.a. 1996, p. 173.

29 Dit bracht met betrekking tot het strafrecht met zich dat de wetgeving en de daarop gebaseerde rechtspraak van voor 1944 nauwelijks duidelijkheid boden voor de beantwoording van de vraag wat nu wel of niet strafbaar was: in ieder concreet geval dienden 'oude' bepalingen en uitspraken te worden getoetst aan de nieuwe politieke en sociaaleconomische omstandigheden. Wat de vooroorlogse jurisprudentie betreft, bepaalde het Hooggerechtshof in november 1948 dat diens beslissingen van voor 1939 - die als strijdig met de communistische orde en wetgeving dienden te worden beschouwd - in de nieuwe situatie slechts historische betekenis konden hebben. Overige uitspraken behielden hun geldingskracht. Vanwege de vage formulering bood dit standpunt van het hoogste rechtscollege nauwelijks aanknopingspunten en bleef onduidelijkheid bestaan over de toepassing van oude rechtspraak en wetgeving. 
strafrechtelijk systeem werd bereikt door middel van bijzondere regelgeving die in deze beginperiode van het communisme werd uitgevaardigd. ${ }^{30}$

De opbouw en instandhouding van een sociaal-economische structuur volgens de communistische ideologie was een omvangrijke en ingewikkelde activiteit die de medewerking van de gehele maatschappij vereiste waarbij eenieder die dit proces op enigerlei wijze verstoorde als vijand van de samenleving ofwel de staat kon worden aangemerkt. Het strafrecht diende met name in de eerste onzekere jaren van het communisme de mogelijkheden te bieden om daadkrachtig op te kunnen treden tegen dergelijk gedrag en het spreekt welhaast voor zich dat het voororlogse materiële strafrecht in dat opzicht te kort schoot. Vandaar dat al snel een grote behoefte bestond aan nieuwe strafbaarstellingen waarin door de invoering van een aantal bijzondere regelingen werd voorzien. Nog voor het einde van Wereldoorlog II werd in september 1944 het militair wetboek van strafrecht uitgevaardigd hetgeen met name gevolgen had voor de zogenaamde 'contrarevolutionaire' feiten. Deze codificatie voorzag in een aantal zeer ruim geformuleerde strafbepalingen die konden worden toegepast in geval van 'anticommunistische' activiteiten. Dit arsenaal delictsomschrijvingen werd in oktober van datzelfde jaar nog verder aangevuld door een verordening waarin eveneens een aantal gedragingen strafbaar werd gesteld die gevaar op konden leveren voor de staat zoals illegaal wapenbezit, valsemunterij en deelname aan een organisatie gericht op het plegen van strafbare feiten. ${ }^{31}$ Het gros van deze activiteiten werd bedreigd met de doodstraf. De regelgeving van oktober 1944 werd later vervangen door een nieuwe verordening ('betreffende feiten bijzonder gevaarlijk in de periode van wederopbouw') waarvan de eerste versie werd uitgevaardigd op 16 november 1945 en de tweede onder dezelfde naam op 13 juni 1946. Deze uiterst repressieve regelgeving - gekenmerkt door vage delictsomschrijvingen en hoge straffen zou ondanks het uit de titel blijkende voornemen de inhoud alleen gedurende de wederopbouw te laten gelden, tot de inwerkingtreding van het nieuwe wetboek van strafrecht (1970) van kracht blijven.

Behalve de hiervoor genoemde aanpassingen van het materiële strafrecht, werd ook het een en ander gewijzigd in de wijze waarop stafrechtelijke procedures werden gevoerd. In dit verband dient in ieder geval het besluit van 16 november 1945 betreffende noodprocedures te worden genoemd. In deze regeling werd op een aanzienlijk aantal elders strafbaar gestelde feiten een sterk vereenvoudigde procedure van toepassing verklaard. ${ }^{32}$ Volgens deze 'noodprocedure' diende een zaak in korte tijd te worden afgehandeld. ${ }^{33}$ Wanneer een feit volgens deze proce-

30 Voor de hiernavolgende bespreking is gebruik gemaakt van: Siekanowicz 1959 I, p. 737-741, Frankowski 1982 I, p. 140-145, Płachta 1990, p. 68-75, Frankowski en Wąsek 1993, p. 143-146 en Wąsek en Frankowski 1995, p. 282-289.

31 Het decreet van 30 oktober 1944 'betreffende de bescherming van de staat'.

32 Deze procedure diende onder andere te worden toegepast bij de berechting van strafbare gedragingen neergelegd in het reeds vermelde militair wetboek van strafrecht en het decreet van 16 november 1945 betreffende feiten bijzonder gevaarlijk in de periode van wederopbouw.

33 De akte van beschuldiging - het document waarmee in het Poolse strafproces de zaak voor de rechter aanhangig wordt gemaakt - behoorde binnen dertig dagen na aanhouding van verdachte te worden ingediend waarna binnen vierentwintig uur een zittingsdatum moest worden vastgesteld. 
dure werd afgedaan, diende te allen tijde voorlopige hechtenis te worden toegepast en waren de mogelijkheden van de verdediging tot een absoluut minimum beperkt. Hoger beroep kon alleen worden ingesteld door de regering en stond derhalve niet open voor de verdachte. Dit terwijl juist in de zaken die volgens de noodprocedure werden behandeld zeer hoge straffen ${ }^{34}$ konden worden opgelegd. Hoewel het reguliere strafprocesrecht van voor Wereldoorlog II officieel nog van kracht was, maakten rechterlijke instanties in veel politiek gevoelige en derhalve zware strafzaken gebruik van deze vereenvoudigde procedure waardoor het besluit van november 1945 in belangrijke mate bijdroeg aan de verharding van de strafrechtspleging na 1944.

Het moge duidelijk zijn dat de strafrechtelijke regelgeving er door bovenstaande ontwikkelingen niet overzichtelijker op werd. In feite bestonden er twee 'soorten' strafprocesrecht naast elkaar: één op basis van het wetboek van strafvordering van 1928 en een tweede voortvloeiend uit de bijzondere regelgeving van na 1944. Vooral in politieke strafzaken ${ }^{35}$ - waarin niet alleen voor de overheid maar met name ook voor de verdachte vaak het meest op het spel stond - werd de wijze waarop de procedure moest worden gevoerd, bepaald door laatstgenoemde regelgeving waardoor rechtsbeschermende waarborgen juist in die gevallen waarin de behoefte eraan het grootst was tot een minimum werden gereduceerd.

Ten slotte is van belang dat de rechtsmacht ten aanzien van veel van de nieuwe strafbare feiten werd overgedragen aan speciaal daarvoor in het leven geroepen bijzondere rechterlijke instanties omdat de gewone rechterlijke macht volgens de communisten onvoldoende loyaal en dus onbetrouwbaar was. Verschillende soorten bijzondere instanties speelden in deze periode een rol. Om te beginnen werd de berechting van veel strafbare feiten overgedragen aan militaire rechtbanken die voornamelijk tot taak hadden politiek verzet de kop in te drukken en daarbij ook rechtsmacht in strafzaken tegen burgers kregen. Bovendien werden bij veel van de gewone rechtbanken bijzondere secties in het leven geroepen om zaken op basis van het decreet van 16 november 1945 af te handelen en werden in 1950 bij de provinciale rechtbank van Warschau en binnen de organisatie van het Hooggerechtshof geheime afdelingen opgericht waar politieke strafzaken volgens een geheel eigen procedure en op een niet-openbare terechtzitting werden afgedaan. ${ }^{36}$ Ten slotte werden in 1945 bijzondere colleges in het leven geroepen - de zogenaamde Bijzondere Raden ter bestrijding van Misbruik en Daden die schadelijk zijn voor de Nationale Economie - die zich bezig hielden met economische delicten. Personen die door deze raden werden berecht, konden zich niet laten bijstaan door een raadsman en tegen einduitspraken waarin onder andere langdurige opsluiting in werkkampen kon worden opgelegd, stond geen rechtsmiddel open. ${ }^{37}$

34 Doodstraf, levenslang of een gevangenisstraf van ten minste drie jaar. Welke sanctie oorspronkelijk op het strafbare feit was gesteld, deed daarbij niet meer ter zake.

35 Met politieke strafzaken wordt hier gedoeld op procedures waarin verdachte een anticommunistische houding werd verweten.

36 Siekanowicz 1959 I, p. 739-740 en Kubiak 1996, p. 237-241.

37 Siekanowicz 1959 I, p. 740-741. 


\subsubsection{Grootschalige hervormingen (1949 en 1950)}

De hierboven weergegeven aanpassingen die gedurende de eerste jaren van de stalinistische periode werden doorgevoerd, hadden gemeen dat ze een bijzonder karakter hadden en het reguliere straf(proces)recht in ieder geval formeel grotendeels in tact lieten. Aan het eind van de jaren veertig, toen het strafrechtelijk systeem enkele jaren aan de hand van de nieuwe uitgangspunten had gefunctioneerd, leek de tijd rijp voor meer algemene aanpassingen van de strafwetgeving van voor Wereldoorlog II. Hervorming van het reguliere strafprocesrecht werd in 1949 en 1950 gerealiseerd toen het wetboek van strafvordering van 1928 op een aantal fundamentele punten werd gewijzigd. De belangrijkste veranderingen betroffen:

- het verdwijnen van de rechter-commissaris uit het strafproces.

- de structuur van het vooronderzoek. Zoals eerder aangegeven bestonden er op basis van het wetboek van strafvordering van 1928 twee soorten vooronderzoek: één in handen van de vervolgende instantie en een tweede onder leiding van een rechter-commissaris. Dit onderscheid kwam tegelijk met met de functie van rechter-commissaris te vervallen waardoor voortaan nog slechts één vooronderzoek bestond dat volledig onder supervisie van leden van het openbaar ministerie of de geheime politie viel. ${ }^{38}$

- de regeling van voorlopige hechtenis. In de eerste plaats werd de wet zodanig aangepast dat toepassing van de vrijheidsbeneming voortaan in geval van verdenking van alle strafbare feiten geoorloofd was. Bovendien werd voorlopige hechtenis voor een aanzienlijk aantal strafbare feiten dwingend voorgeschreven. Ten slotte werd het dwangmiddel aan iedere vorm van rechterlijke controle onttrokken: de mogelijkheid om rechtmatigheid van de voorlopige hechtenis te laten toetsen door de rechter werd geschrapt. ${ }^{39}$

38 In de onderhavige periode werd in de praktijk nog nauwelijks toezicht uitgeoefend op politieactiviteiten gedurende het vooronderzoek: de geheime politie - onderdeel van het in 1944 opgerichte ministerie van openbare veiligheid - domineerde het gros van de strafzaken. Dit gebeurde eerst op basis van bevoegdheden in bijzondere regelgeving, later werd het wetboek van strafvordering 1928 op dit punt gewijzigd. De geheime politie nam hierdoor feitelijk de plaats in van de uit het strafproces verdwenen rechtercommissaris. Zie Siekanowicz 1959 I, p. 764.

39 Voortaan kon alleen nog beroep worden ingesteld bij de vervolgende instantie: een beroepsmogelijkheid die de verdachte weinig bescherming kon bieden aangezien dit de instantie was die zelf de beslissing tot toepassing van voorlopige hechtenis nam. Gezien de sterk hiërarchische en centralistische structuur van het openbaar ministerie was het niet waarschijnlijk dat eigen beslissingen - of die van lager geplaatste leden serieus zouden worden heroverwogen. Het onttrekken van voorlopige hechtenis aan rechterlijke controle was overigens geen typisch Pools verschijnsel: ook in andere Centraal- en Oost-Europese communistische landen zoals Bulgarije, Roemenië, Hongarije, (voormalig) Tsjecho-Slowakije en de Sovjet-Unie was uitsluitend de openbaar aanklager bevoegd voorlopige hechtenis te bevelen en te controleren: Waltoś 1991, p. 249. Het dwangmiddel onderging door bovengenoemde wijzigingen een ingrijpende karakterverandering: het was niet langer een middel dat alleen gerechtvaardigd was in het belang van een goed procesverloop maar het kreeg ook een belangrijke repressieve en 'opvoedende' functie. Door middel van voorlopige hechtenis kon men de verdachte in afwachting van en vooruitlopend op zijn uiteindelijke straf alvast laten voelen dat hij fout was geweest. Zie hierover: Frankowski 1992, p. 254-259. 
Bovendien vonden eind jaren veertig, begin jaren vijftig belangrijke wijzigingen in de structuur van het openbaar ministerie en de rechterlijke macht plaats. Eerstgenoemde instantie was op basis van de vooroorlogse wetgeving naar Frans model opgebouwd hetgeen betekende dat het onderdeel uitmaakte van de rechterlijke macht en onder leiding stond van de minister van Justitie. Deze structuur werd door de inwerkingtreding van de nieuwe wet ten aanzien van de prokuratura (zoals het Poolse openbaar ministerie ook vandaag de dag nog wordt genoemd) in 1950 drastisch gewijzigd. Naar voorbeeld van de Sovjet-Unie werd de instantie losgekoppeld van de minister van Justitie en de rechterlijke macht waardoor het de vorm kreeg van een afzonderlijke staatsmacht die alleen verantwoording was verschuldigd aan de Staatsraad. ${ }^{40}$

Behalve de structuur veranderde ook het takenpakket van de prokuratura: gedurende het interbellum en de eerste jaren na de oorlog was de opdracht van openbaar aanklagers grotendeels beperkt tot vervolging van strafbare feiten maar na 1950 kregen ze de veel ruimere opdracht toe te zien op de naleving van wet- en regelgeving binnen de Poolse Volksrepubliek. ${ }^{41}$ Bij uitvoering van deze taak diende de wettigheid van het handelen van onder andere overheidsorganen en burgers te worden gecontroleerd. Hoewel dit officieel betekende dat de prokuratura ook belast was met het toezicht op de naleving van individuele rechten en vrijheden en in die hoedanigheid een vorm van rechtsbescherming diende te garanderen, kwam daar met name in strafrechtelijke procedures weinig tot niets van terecht. ${ }^{42}$

Ook de rechterlijke organisatie werd in de stalinistische periode flink onder handen genomen. Een nieuwe wet met betrekking tot de rechterlijke macht van juli

40 De Grondwet van 1952 die in belangrijke mate was gebaseerd op de Grondwet van de Sovjet-Unie van 1936 had de staatsrechtelijke structuur van Polen ingrijpend gewijzigd: de scheiding der machten die zich niet liet verenigen met de centralistische, politieke structuur die door de communisten werd voorgestaan, werd vervangen door de eenheid van staatsmacht, de functie van president kwam te vervallen en de superioriteit van de wetgever werd tot grondwettelijk beginsel verheven. Dat de wetgevende macht (de volksvertegemwoordigende Sejm) boven alles en iedereen diende te staan, was gebaseerd op het uitgangspunt dat dit orgaan de wil van het volk personifieerde. In de praktijk was de superioriteit van de wetgever met name gedurende de stalinistische periode een illusie: in werkelijkheid was de Staatsraad (samengesteld uit vijftien leden gekozen door en uit de Sejm) het hoogste overheidsorgaan.

41 Hiermee werd aansluiting gezocht bij de functie van de prokuratura zoals die oorspronkelijk door Peter de Grote was bedoeld: om als 'oog van de tsaar' toezicht uit te oefenen op de naleving en uitvoering van zijn talrijke bevelen. Het ontstaan van de prokuratura in Rusland dient dus ver voor de komst van de communisten - om precies te zijn in 1722 - te worden geplaatst. Zie hierover: Malfliet 1987, p. 101-107.

42 In de praktijk concentreerde de prokuratura zich alleen op haar opsporende en vervolgende taak waarbij de nadruk lag op een effectieve bestrijding van criminaliteit ter bescherming van de nog kwetsbare communistische structuren. Binnen een dergelijk instrumentalistisch gebruik van het straf(proces)recht was maar weinig ruimte voor effectieve rechtsbescherming van verdachten: de prokuratura nam een uiterst eenzijdige positie in waarbij de belangen van de staat - zoals voorgeschreven door de partij - ver boven de rechten en vrijheden van het individu werden geplaatst. Dat de rechtsbeschermende functie van de prokuratura gedurende de gehele communistische periode onderbelicht is gebleven, werd duidelijk tijdens een opiniepeiling in 1986 waaruit bleek dat slechts $17 \%$ van de ondervraagden op de hoogte was van deze taak van de vervolgende instantie: Frankowski 1987 I, p. 1322. 
1950 bracht de verdeling van de rechterlijke instanties over het Poolse grondgebied in lijn met de bestuurlijke indeling van het land. Deze aanpassing was erop gericht de politieke supervisie op de rechterlijke activiteiten te vergemakkelijken en te vergroten. ${ }^{43} \mathrm{Om}$ beter aan te sluiten bij provinciale en lokale bestuurlijke eenheden werd een uniform systeem van districts- en provinciale rechtbanken geïntroduceerd (respectievelijk sądy powiatowy en sądy wojewódzkie). De hoger beroepsinstanties - de derde trede in de trap van de rechterlijke organisatie kwamen als zodanig te vervallen en werden omgevormd tot provinciale rechtbanken. De rechtsmiddelen van voor wereldoorlog II (hoger beroep en cassatie) werden vervangen door een naar sovjetvoorbeeld vormgegeven uniforme beroepsmogelijkheid genaamd rewizja (letterlijk: revisie of herziening). ${ }^{44}$ Voortaan kon tegen een vonnis in eerste aanleg dus slechts een keer in beroep worden gegaan: eenvoudige zaken werden in eerste aanleg behandeld door de districtsrechtbanken waarna beroep openstond bij de provinciale rechtbank en tegen uitspraken in zwaardere strafzaken die in eerste aanleg waren behandeld door laatstgenoemde instantie kon beroep worden aangetekend bij het Hooggerechtshof.

Aangezien dit samen met het wegvallen van de cassatiemogelijkheid betekende dat niet alle zaken ter beoordeling aan het Hooggerechtshof konden worden voorgelegd en daarmee aan centraal toezicht waren onttrokken, werd het middel van 'buitengewoon beroep' ('rewizja nadzwyczajna') geïntroduceerd. Dit typisch socialistische rechtsmiddel stond in vrijwel alle zaken open voor de minister van Justitie, de Procureur Generaal (Prokurator Generalny) en de president van het Hooggerechtshof en groeide uit tot een belangrijk politiek instrument om in te kunnen grijpen in reeds afgedane strafzaken. ${ }^{45}$

Bovengenoemde maatregelen stonden echter niet op zichzelf: ook op talrijke andere punten werden (wets)wijzigingen doorgevoerd die - op zijn zachtst gezegd - de rechterlijke onafhankelijkheid en onpartijdigheid ernstig aantastten. Zo konden te 'eigenzinnige' leden van de rechterlijke macht zonder moeite uit hun functie worden gezet en werd bij de aanstelling van nieuwe rechters hoofdzakelijk waarde gehecht aan politieke voorkeur. ${ }^{46}$

43 Siekanowicz 1959 I, p. 746-747. Ook ten aanzien van de rechterlijke macht was de communistische opvatting over gecentraliseerde staatsmacht dus duidelijk merkbaar: rechters dienden ondergeschikt te zijn aan politieke machthebbers.

44 Aan de hand van dit rechtsmiddel werd de eerste uitspraak gecontroleerd op strijd met de wet, fouten in de bewijswaardering of -vergaring of een onjuiste sanctieoplegging.

45 Behalve deze mogelijkheid om invloed uit te oefenen op vonnissen in incidentele zaken werd in deze periode ook een instrument gecreëerd dat in meer algemene zin eenheid in de Poolse rechtspraak diende te bewerkstelligen. In 1949 kreeg het Hooggerechtshof (wederom naar voorbeeld van de Sovjet-Unie) de bevoegdheid om voor alle rechterlijke instanties bindende richtlijnen uit te spreken. In de eerste jaren na 1949 werd deze mogelijkheid voornamelijk gebruikt ter aanvulling en interpretatie van de vooroorlogse strafrechtelijke codificaties die zoals eerder opgemerkt in veel gevallen niet voldeden aan de eisen van de nieuwe politieke realiteit. De richtlijnen werden '(...) a useful tool to adapt the inadequate legislation to the new conditions and to streamline the activities of the courts and other law enforcement agencies which were staffed by people who, for various reasons could not be fully trusted': Frankowski 1982 II, p. 58. Ook na de inwerkingtreding van de nog te bespreken nieuwe strafrechtelijke codificaties van 1969 zou het Hooggerechtshof zelfs op grotere schaal dan voorheen - genoemde richtlijnen blijven uitvaardigen.

46 Een juridische opleiding was formeel nog wel vereist maar deze voorwaarde kon op 
Eind jaren vijftig werd ook de lekenrechtspraak in het Poolse strafproces aanzienlijk uitgebreid: gedurende de eerste jaren van het communisme beperkte het aandeel van de lekenrechter zich tot militaire en andere bijzondere instanties maar door wetswijzigingen in 1949 en 1950 werd dit uitgebreid tot gewone rechterlijke instanties. ${ }^{47}$ Alle strafzaken werden in eerste aanleg voortaan in beginsel door een meervoudige kamer van twee leken en een professionele rechter afgedaan. De lekenrechter stemde mee over schuld en op te leggen straf en zijn stem woog even zwaar als die van de professionele rechter. Ook de invoering van de lekenrechtspraak was er - net als eerder genoemde wijzigingen ten aanzien van de rechterlijke macht - op gericht de gehoorzaamheid van de rechterlijke macht te vergroten. Daarom werden ook aan lekenrechters uitsluitend politieke voorwaarden gesteld en was het feitelijk aan de communistische partij om te bepalen of daar in concrete gevallen aan werd voldaan. ${ }^{48}$

basis van een nieuwe bepaling in de wet betreffende de rechterlijke macht van 1950 door de minister van Justitie buiten toepassing worden gelaten. Uit het feit dat een niet-jurist zelfs tot president van het Hooggerechtshof werd benoemd, kan worden afgeleid dat van deze mogelijkheid geen terughoudend gebruik werd gemaakt: Siekanowicz 1959 I, p. 748. Voor een meer uitgebreide bespreking van bovengenoemde en andere maatregelen die een loyale opstelling van de rechterlijke macht dienden te waarborgen: Siekanowicz 1959 I, p. 741-752 en Frankowski 1991, p. 33-52. Opvallend genoeg werden Poolse rechters gedurende het communisme formeel wel voor het leven benoemd (met uitzondering van leden van het Hooggerechtshof die voor vijf jaar werden aangesteld). In alle andere communistische landen van Centraal en Oost-Europa werden rechters tijdelijk benoemd. Dit vanuit de overtuiging dat benoeming voor het leven in beginsel niet binnen de communistische overheidsstructuur past: Garlicki 1980, p. 503.

47 Voor wat betreft de deelname van burgers aan het strafproces werd dus gekozen voor samengestelde kamers van professionele en lekenrechters en niet voor het alternatief van een jurysysteem. Voor Wereldoorlog II werden in Polen op beperkte schaal strafzaken met behulp van een jury afgedaan maar deze vorm van rechtspleging werd in 1938 afgeschaft en is tot op heden niet opnieuw geïntroduceerd.

48 Formeel werden ze voor een vastgestelde termijn gekozen door zogenaamde lokale volksraden (bestuurlijke organen vergelijkbaar met de Sovjets in de Sovjet-Unie) maar daarbij werd grote invloed uitgeoefend door de partij: kandidaten werden zorgvuldig gescreend en er werden lijsten van politiek betrouwbare personen samengesteld zodat de keuzevrijheid uiteindelijk tot een minimum werd beperkt. Gevolg van deze werkwijze was dat het grootste deel van de lekenrechters uit partijleden bestond. De vraag welke rol lekenrechters gedurende het communisme in de strafrechtelijke procedure hebben gespeeld, wordt in de literatuur niet eenduidig beantwoord. Sommige auteurs zijn hierover weinig positief: '(...) "Iron Party Activists" who constituded the majority of the people's assessors, due to their political engagements, often gave too little time and attention to court proceedings and hastened the trials, thereby creating a nervous atmosphere in the courtroom. Under such circumstances people's assessors regarded their duties as a personal burden and career judges regarded the assessors as a burden to the courts, and even as "political commissars" and supervisors over them. On the other hand people's assessors yielded to the pressure of the judges who, also acting under pressure "were made responsible for the judgment". In many instances people's assessors did not satisfy the political expectations of the Party as they were lenient toward defendants charged with crimes involving government economic interests, crimes directed against government authorities and agencies, and crimes involving whispering propaganda campaigns against the government. These additional "deficiencies" were attributed to a "lack of political consciousness", to "not understanding the role and duties of the administration of justice in the people's state", and to the fact that "some of the people's assessors did 
Samenvattend geldt dat de stalinistische jaren een grote invloed hebben gehad op de Poolse strafrechtspleging. Door de enorme uitbreiding van het aantal (vaag geformuleerde) strafbare feiten kon vrijwel iedere gedraging die schadelijk was voor de gemeenschap c.q. het regime als politiek strafbaar feit worden gekwalificeerd en vervolgd en in dergelijke 'politieke' strafzaken speelde het procesrecht zoals het oorspronkelijk was geregeld in het wetboek van 1928 nauwelijks nog een rol. De bijzondere regelgeving met de vereenvoudigde procedures, de totale overheersing van het vooronderzoek door het openbaar ministerie en de vergaande wijzigingen die de rechterlijke macht hadden getransformeerd tot spreekbuis van de communistische partij maakten het strafproces tot een politiek instrument waarin de belangen van het individu (de verdachte) volledig ondergeschikt waren gemaakt aan de door de overheid vertegenwoordigde belangen van 'het collectief'.

\subsubsection{Poststalinistische periode (1956-1989)}

De tweede helft van de jaren vijftig luidde een nieuwe periode in die in direct verband stond met het overlijden van Stalin (maart 1953). Zijn dood had grote gevolgen voor de Sovjet-Unie en de onder haar invloed vallende landen. De uiterst repressieve wijze waarop Stalin het communisme in de praktijk had gebracht, behoorde met het wegvallen van zijn persoon tot het verleden waardoor het regime verslapte en er meer ruimte voor oppositie en hervorming ontstond. Ook in Polen lieten de reacties niet lang op zich wachten: de veranderingen die met de dood van Stalin gepaard gingen, maakten de weg vrij voor meer verzet tegen het bestaande regime en de onderdrukking door de Sovjet-Unie. De toenemende oppositie culmineerde in juni 1956 toen in Poznań een grote volksopstand plaatsvond. Hoewel de directe aanleiding hiervoor een relatief klein geschil met betrekking tot een loonmaatregel van een locomotievenfabriek betrof, groeide het conflict al snel uit tot een protestdemonstratie van enorme omvang. Het verzet resulteerde in een gewelddadig treffen waarbij de communisten de opstand met

not represent the interests of the working masses"': Siekanowicz 1959 I, p. 756 en daar genoemde verwijzingen. Zo ook Frankowski: 'Theoretically, each member of the panel had equal rights. In practice, as has been mentioned, the professional judge easily dominated over the two lay judges and the instances when the case was decided by two-vote majority of lay judges were infrequent': Frankowski 1987 II, p. 255. Murzynowski kent de lekenrechter - later in de communistische periode - echter wel een belangrijke plaats in de Poolse strafrechtspleging toe: '(...) it should be stressed emphatically that despite the shortcomings the layassessors play a significant role in shaping justice administration and exert an impact on many of the verdicts pronounced. This is also supported by findings of the Polish Academy of Sciences team which show that half of surveyed judges admit to be influenced by lay-assessors in deciding cases with their participation and that the assessors exerted a real impact on the substance of verdicts in $30 \%$ of cases under anonymous observation as part of the studies': Murzynowski 1984, p. 335. Resultaten van genoemd empirisch onderzoek naar de rol van lekenrechters in het Poolse strafproces dat tussen 1964 en 1967 is uitgevoerd (en volgens critici niet onafhankelijk zou zijn vanwege de banden van de onderzoeksleider Zawidzki met het communistisch regime: zie Kurczewski 2001, p. 88) zijn gepubliceerd in: Zawadzki en Kubicki 1970. Voor een beschrijving in anderstalige (niet-Poolse) literatuur: Pomorski 1975, p. 198-209 en Zawadzki en Kubicki 1969, p. 919-935. Ondanks eerder genoemde kritiek heeft de lekenrechter zijn plaats in het Poolse strafproces tot op de dag van vandaag weten te behouden. Zie hierna $§$ 3.1.1.1. 
harde hand de kop in drukten. In politiek opzicht was deze gebeurtenis van grote betekenis aangezien het de eerste keer was dat arbeiders zich op deze wijze tegen het bestaande regime keerden. ${ }^{49}$ De gebeurtenissen in 1956 deden de communistische partij beseffen dat ze het contact met de arbeidersbevolking aan het verliezen was. Om dit te herstellen, dienden hervormingen plaats te vinden en moest de partij zoveel mogelijk ruimte maken voor een eigen en dus niet door de SovjetUnie bepaalde koers. Enkele maanden na de Poznań-rellen werd hiertoe een eerste initiatief genomen door de benoeming van de nationaal-communist Gomułka tot partijleider in oktober $1956 .{ }^{50}$ Gomułka stond bekend als groot voorstander van een onafhankelijke opstelling ten opzichte van de Sovjet-Unie waardoor zijn (her) benoeming als politiek leider bij de bevolking grote verwachtingen wekte.

\subsubsection{Tweede helft jaren vijftig: incidentele verbeteringen strafrechtspleging}

De verzachting van het politieke regime leidde ertoe dat reeds voor de aanstelling van Gomułka wijzigingen werden doorgevoerd die de strafrechtspleging humaner dienden te maken. Om te beginnen werden in 1954 de eerder genoemde Bijzondere Raden ter bestrijding van Misbruik en Daden die schadelijk zijn voor de Nationale Economie afgeschaft. Een jaar later werd het strafprocesrecht op een aantal punten gewijzigd (wet van december 1955). Deze wetswijziging had onder andere de volgende hervormingen tot gevolg:

- De rechtsmacht van militaire instanties werd beperkt: de berechting van een aanzienlijk aantal politieke strafbare feiten werd aan de gewone rechterlijke macht overgedragen.

- Het onderscheid tussen de twee soorten vooronderzoek dat in 1949 was opgeheven, werd opnieuw in ere hersteld. De functie van de rechter-commissaris werd echter niet opnieuw geïntroduceerd: beide soorten vooronderzoek vielen onder supervisie van de prokuratura. ${ }^{51}$

- De regeling van voorlopige hechtenis werd op een aantal punten 'verzacht' ${ }^{52}$

49 Voorheen werd 'slechts' oppositie gevoerd vanuit de rooms-katholieke kerk en intellectuele kringen.

50 Het jaar waarin Bierut overleed.

51 Het verschil tussen de twee modaliteiten bestond er nu in dat in zware strafzaken het vooronderzoek door de vervolgende instantie zelf moest worden verricht (śledztwo) en dat dit onderzoek in minder ernstige gevallen - weliswaar onder leiding van laatstgenoemde instantie - aan politiefunctionarissen mocht worden overgelaten (dochodzenie). Dit onderscheid is (weliswaar in aangepaste vorm) tot op de dag van vandaag in het Poolse strafprocesrecht behouden. Zie hierover hierna § 3.2.1.

52 Zo werd wettelijk vastgelegd dat een verdachte pas in hechtenis kon worden genomen wanneer hij officieel op de hoogte was gesteld van de tegen hem bestaande beschuldigingen, werd de zogenaamde verplichte voorlopige hechtenis die in 1949 voor een aanzienlijk aantal strafbare feiten was geïntroduceerd, afgeschaft zodat de vrijheidsbeneming in geen enkel geval meer dwingend was voorgeschreven en werden de regels ten aanzien van de duur van de voorlopige hechtenis behoorlijk aangescherpt. Het nieuwe systeem kwam er kort gezegd op neer dat naarmate de hechtenis langer duurde de beslissing tot verlenging door steeds hogere instanties moest worden genomen. De prokuratura kon voorlopige hechtenis voortaan voor maximaal drie maanden opleggen. Over deze wijzigingen: Frankowski 1992, p. 261-264. 
Ten slotte werden in de tweede helft van de jaren vijftig maatregelen met betrekking tot het gevangeniswezen genomen die de (rechts)positie van gedetineerden dienden te verbeteren..$^{53}$

Hoewel bovengenoemde ontwikkelingen wel degelijk een lichte versoepeling van het strafrechtelijk regime en meer aandacht voor de positie van verdachten en gedetineerden tot gevolg hadden, was de omvang en het effect van de doorgevoerde hervormingen beperkt. Veel bleef bij het oude - zoals ook bleek uit het van kracht blijven van de uiterst repressieve bijzondere regelgeving die rond de helft van de jaren veertig was uitgevaardigd - zodat van een daadwerkelijke breuk met de stalinistische periode niet kon worden gesproken.

\subsubsection{Jaren zeventig: nieuwe strafrechtelijke codificaties en toenemende repressie}

Hoewel aanvankelijk veelbelovend ${ }^{54}$ bleek het leiderschap van Gomułka op lange termijn weinig veranderingen teweeg te brengen. De uitblijvende hervormingen deden het verzet onder de bevolking groeien wat in maart 1969 opnieuw tot een grootschalige opstand leidde. Ditmaal echter niet onder arbeiders maar onder studenten. ${ }^{55}$ Wederom trad de overheid hard op tegen deelnemers aan (en verantwoordelijken voor) de ontstane rellen en opnieuw werd duidelijk dat dergelijke demonstraties niet werden getolereerd. Kort daarna - in 1970 - resulteerde de steeds slechter wordende economische situatie opnieuw in een omvangrijke opstand tegen het regime wat Gomułka uiteindelijk deed besluiten af te treden als leider van de communistische partij. Hij werd opgevolgd door Gierek die de moeilijke taak kreeg de economische crisis waarmee Polen eind jaren zestig werd geconfronteerd te bezweren.

Ook de strafrechtspleging was in toenemende mate onderwerp van felle kritiek en de roep om hervormingen nam toe. Aan het eind van de jaren vijftig werden vanuit de rechtsgeleerde wereld vooruitstrevende voorstellen tot wijziging van het strafproces gedaan en werd uiteindelijk officieel begonnen aan het ontwer-

53 Er werd een amnestiewet uitgevaardigd op basis waarvan 35.000 gedetineerden die wegens politieke of militaire strafbare feiten tot maximaal vijf jaar gevangenisstraf veroordeeld waren, in vrijheid werden gesteld. Bovendien werden straffen hoger dan vijf jaar verlaagd. Een tweede wijziging had betrekking op de supervisie op het gevangeniswezen: waar dit voorheen tot het takenpakket van de minister van Binnenlandse Zaken behoorde, werd deze verantwoordelijkheid in 1956 overgedragen aan de minister van Justitie. Ratio van deze wijziging was de veronderstelling dat de minister van Justitie beter dan zijn ambtsgenoot op Binnenlandse Zaken de bescherming van rechten van gedetineerden zou kunnen garanderen. Een veronderstelling die later overigens niet op waarheid bleek te berusten: Frankowski 1982 I, p. 144.

54 Gomułka wist aan het begin van zijn regeerperiode door middel van onderhandelingen met de Sovjet-Unie enkele belangrijke resultaten te boeken in de strijd om Poolse onafhankelijkheid. Zo slaagde hij erin de collectivisering van de landbouw stop te zetten en ontdeed hij het Poolse leger van sovjetsupervisie.

55 Aanleiding voor het studentenprotest was een door de regering opgelegd verbod een als anti-Russisch aangemerkt toneelstuk op te voeren waartegen door studenten in Warschau hevig werd geprotesteerd. Solidariteitsacties in andere universiteitssteden waren het gevolg waardoor het verzet zich niet langer tot de hoofdstad beperkte maar uiteindelijk bijna nationale omvang aannam. 
pen van volledig nieuwe strafrechtelijke codificaties. ${ }^{56}$ In 1969 was het eindelijk zover: op 19 april werden een nieuw wetboek van strafrecht en strafprocesrecht aangenomen die in werking traden op 1 januari 1970.57

De nieuwe regeling van het strafprocesrecht was vanuit rechtsbeschermend perspectief teleurstellend. ${ }^{58}$ Met name de regeling van het vooronderzoek en de voorlopige hechtenis voldeden absoluut niet aan de hooggespannen verwachtingen van (met name) de doctrine. Ten aanzien van het vooronderzoek gold dat werd aangesloten bij de structuur die door eerder genoemde wetswijziging van 1955 in het leven was geroepen: twee soorten onderzoek, beide onder leiding van de vervolgende instantie. Ondanks voorstellen daartoe uit de literatuur werd de functie van rechter-commissaris niet opnieuw in het strafproces geïntroduceerd. Gevolg was dat de machtsverhoudingen in het vooronderzoek nauwelijks veranderden: de vervolgende instantie bleef de gang van zaken in deze fase van de procedure volledig bepalen. Ten aanzien van de voorlopige hechtenis gold dat

56 Zie Frankowski 1992, p. 267-268 waar ook een korte bespreking wordt gegeven van de verschillende ontwerpen die tussen 1959 en 1967 werden gepresenteerd.

57 Tegelijk met deze twee codificaties werd ook een nieuw wetboek betreffende de tenuitvoerlegging van straffen uitgevaardigd dat hier verder buiten beschouwing zal worden gelaten. Bij de bespreking van het vrij verkeer in hoofdstuk 7 zal op onderdelen van deze regeling worden teruggekomen.

58 Dat gold overigens ook voor het nieuwe wetboek van strafrecht dat in een aantal opzichten socialistische en repressieve elementen eerder versterkte dan verzwakte. Een typisch socialistische 'nieuwigheid' die in 1969 werd geïntroduceerd was het maatschappelijk gevaar criterium dat - op grond van het nieuwe art. 1 wetboek van strafrecht - inhield dat pas van een strafbaar feit kon worden gesproken wanneer een gedraging die bij de wet verboden was (nulla poena sine praevia lege poenali) op enige wijze gevaar opleverde voor de gemeenschap of de vertegenwoordiger van de gemeenschap: de overheid (nullem crimen sine periculo sociali). Dat de wetgever veel belang hechtte aan bescherming van de gemeenschap bleek ook uit de opsomming van strafbare feiten: maar liefst tweederde van de strafbaarstellingen betrof gedragingen tegen het collectief (de gemeenschap of de staat). Ten slotte was een verharding van het strafrecht merkbaar op het gebied van sancties: een aantal straffen werd aanzienlijk verhoogd (bijvoorbeeld de minimumstraf op moord werd gewijzigd van vijf in acht jaar), de algemene minimumduur voor absolute vrijheidstraffen veranderde van een week in drie maanden en voor de aanpak van recidivisten werd een nieuwe, strenge maatregel geïntroduceerd: de mogelijkheid tot plaatsing in een instelling voor rehabilitatie die na een eventuele gevangenisstraf tot vijf jaar kon duren. Het meest controversiële onderdeel van de sancties uit het wetboek van 1969 betrof ongetwijfeld de doodstraf. Al ruim voor de invoering van de nieuwe codificaties werd vanuit verschillende hoeken geprotesteerd tegen deze sanctie en velen hadden gehoopt (en verwacht) dat zij na 1969 niet meer in de Poolse strafwetgeving te vinden zou zijn. De teleurstelling was dan ook groot toen bleek dat de straf toch was behouden. In geringe mate werd echter aan het protest tegemoet gekomen door het aantal feiten waarvoor de doodstraf kon worden opgelegd te reduceren van vierennegentig(!) tot twaalf en door een clausule op te nemen waarin stond dat de rechter in geen enkel geval verplicht was de doodstraf op te leggen en de sanctie derhalve voor exceptionele gevallen diende te reserveren. Ondanks deze twee wijzigingen steeg het aantal opgelegde doodstraffen in de eerste jaren na de invoering van het nieuwe wetboek aanzienlijk: tussen 1965 en 1969 werd deze straf zevenentwintig keer uitgesproken terwijl dat van 1970 tot 1974 in maar liefst vierennegentig gevallen gebeurde. Zie Grajewski en Lammich 1981, p. 414-415. Voor een Engelse vertaling van het wetboek van strafrecht van 1969 wordt verwezen naar: Kenney 1973. 
de repressieve wijzigingen die in de eerste helft van de jaren vijftig waren doorgevoerd voor het overgrote deel in het nieuwe wetboek van strafvordering werden overgenomen. Een eerste belangrijk aspect betrof de duur van de voorlopige hechtenis: ook in het nieuwe wetboek was geen maximumtermijn opgenomen. ${ }^{59}$ Een tweede 'zwakte' in de regeling van de voorlopige hechtenis betrof de persoon die deze vorm van vrijheidsbeneming kon bevelen: gedurende het vooronderzoek werden beslissingen tot toepassing van voorlopige hechtenis nog altijd genomen door de met opsporing en vervolging belaste prokurator en niet door een rechter of rechtbank. ${ }^{60}$ Een derde onderdeel van de regeling van voorlopige hechtenis dat moeilijk de toets der kritiek kon doorstaan, betrof de ruime formulering van een van de gronden waarop het dwangmiddel kon worden toegepast. In het nieuwe wetboek van strafvordering werden meer traditionele gronden als vluchten collusiegevaar aangevuld met de formule dat voorlopige hechtenis kon worden toegepast wanneer de verdachte werd beschuldigd 'van een gedraging die een ernstig maatschappelijk gevaar oplevert' ${ }^{61}$ Een uiterst vage en rekbare formule die er in belangrijke mate aan heeft bijgedragen dat voorlopige hechtenis na 1969 op grote schaal kon worden toegepast: de maatschappelijk gevaarformule groeide uit tot de meest gehanteerde grond voor voorlopige hechtenis. ${ }^{62}$ Het feit dat de wetgever in een aantal andere bepalingen had benadrukt dat van het dwangmiddel terughoudend gebruik moest worden gemaakt, had in de praktijk dan ook weinig effect. ${ }^{63}$

59 De hoofdregel was weliswaar dat gedurende het vooronderzoek voorlopige hechtenis voor maximaal drie maanden kon worden opgelegd maar de wetgever had voorzien in een uitgebreide mogelijkheid tot verlenging van deze periode in geval van 'bijzondere omstandigheden waardoor het vooronderzoek niet binnen de in het eerste lid genoemde termijn kan worden afgerond' (art. 222 KPK 1969). Over verlenging tot zes maanden kon de prokuratura zelf beslissen, daarna was het aan de rechtbank om de vrijheidsbeneming voor een nader te bepalen - niet door de wetgever gelimiteerde - periode te verlengen.

60 Art. 210 lid 1 KPK 1969. Er werden wel mogelijkheden gecreëerd om beslissingen inzake voorlopige hechtenis ter beoordeling voor te leggen aan de rechter. Zo kon tegen de beslissing tot toepassing of verlenging van voorlopige hechtenis voortaan beroep worden ingesteld bij de rechtbank of het Hooggerechtshof (art. 212 lid 1 en 222 lid 3 KPK 1969).

61 Art. 217 lid 1 sub 4 KPK 1969.

62 Frankowski 1992, p. 276. Dit was niet verwonderlijk gezien het feit dat het maatschappelijk gevaar criterium ook een beslissende factor was voor het instellen van strafvervolging. In aansluiting op het eerder genoemde art. 1 KK 1969 (strafbaar feit moet niet alleen wettelijk verboden maar ook maatschappelijk gevaarlijk zijn) was namelijk in art. 11 KPK 1969 geregeld dat een strafrechtelijke procedure niet kon worden ingesteld of voortgezet wanneer het omstreden gedrag slechts een onbeduidend maatschappelijk gevaar had opgeleverd.

63 Dat voorlopige hechtenis als ultimum remedium moest worden beschouwd, bleek onder meer uit de regel dat deze vorm van vrijheidsbeneming alleen mocht worden toegepast wanneer niet kon worden volstaan met andere (minder ingrijpende) maatregelen als borgstelling en politietoezicht. Bovendien was voorgeschreven dat voorlopige hechtenis onmiddellijk diende te worden opgeheven wanneer de grondslag ervoor was komen te vervallen of wanneer sprake was van nieuwe omstandigheden die opheffing konden rechtvaardigen (respectievelijk art. 225 en art. 213 KPK 1969). Algemeen over voorlopige hechtenis volgens het wetboek van strafvordering van 1969: Murzynowski 1989, p. 63-64 en Frankowski 1992, p. 269-283. Voor vertalingen van het wetboek van strafvordering in het Engels en het Duits wordt verwezen naar respectievelijk Waltoś 1979 en Janik 1977. 
Behalve de reguliere voorlopige hechtenis voorzag het wetboek van strafvordering van 1969 ook in de mogelijkheid van detentie door de politie. De politie was bevoegd een verdachte aan te houden en voor maximaal achtenveertig uur van zijn vrijheid te beroven wanneer er 'goede reden' was om aan te nemen dat hij een strafbaar feit had gepleegd en gevaar voor vlucht of het wegmaken van bewijsmateriaal bestond. ${ }^{64}$ Deze ruime formulering gecombineerd met het feit dat geen rechtsmiddelen openstonden tegen de detentie en de politie niet wettelijk verplicht was de verdachte op de hoogte te stellen van de tegen hem bestaande beschuldigingen hadden tot gevolg dat op grote schaal misbruik werd gemaakt van deze bevoegdheid. ${ }^{65}$

Hiermee is slechts een fractie van het wetboek van strafvordering van 1969 kort besproken, maar uit de regeling van het vooronderzoek en de voorlopige hechtenis kan een algemene tendens worden afgeleid die illustratief is voor de gehele codificatie en haar gevolgen voor de praktijk. Samengevat kwam het er op neer dat op bepaalde punten wel meer rechtswaarborgen in het leven werden geroepen (zoals de herintroductie van rechterlijke controle op de voorlopige hechtenis) ${ }^{66}$ maar deze waren niet van zodanige aard dat van een fundamentele hervorming van het strafprocesrecht en daadwerkelijke verbetering van de positie van verdachten kon worden gesproken. Als gevolg hiervan bleven de harde karaktertrekken die tijdens de stalinistische periode kenmerkend waren geworden voor de Poolse strafrechtspleging ook na 1969 het strafrechtelijk systeem bepalen. ${ }^{67}$ In de woorden van Frankowski:

64 Art. 206 lid 1 KPK 1969. Voor deze vorm van vrijheidsberoving - die in het Pools wordt aangeduid als 'zatrzymanie' wat eveneens 'aanhouding' betekent - zal hierna ook de term 'politiedetentie' worden gebruikt.

65 Met name gedurende de tweede helft van de jaren zeventig werd deze vorm van detentie veelvuldig gebruikt in de strijd tegen politieke dissidenten: Frankowski 1982 I, p. 156-157 en Frankowski 1992, p. 285-286.

66 Overigens werd ook in het algemene deel van het strafprocesrecht enige vooruitgang geboekt. Enkele fundamentele beginselen zoals de onschuldpresumptie en de in dubio pro reo regel die eerder wel in doctrine en rechtspraak waren erkend, hadden in de nieuwe codificatie eindelijk wettelijke status gekregen (art. 3 lid 2 en 3 KPK 1969). Meer uitgebreid hierover: Cieślak 1970, p. 26-30 en Waltoś 1979.

67 Een sprekend voorbeeld van het repressieve karakter van het Poolse strafrechtsysteem in de jaren zeventig kan worden gevonden in de memoires van een Poolse verzetsactivist: 'In the course of the proceedings, another bandit, or more properly speaking, not a bandit but a shred of a bandit, a total ruin, gave his testimony. He was to testify in the court room that, as he had been testifying in the pre-trial investigation, he had seen, as this prostitute and the lover of Ewa killed Zbrożyna and threw him through the window. In the proceedings he withdrew his testimony. Answering the question of the judge, why he was testifying like this, he said:

- Because they were beating me!

And as the judge asked, why he was retracting the testimony:

- Because I am a human being - this very ill alcoholic said.

He died a few days later in custody. It was clear to us that Militia was standing behind this murder but we have unfortunately lost. The man spent six years in prison for nothing. (...) The boozer said in the court room: because I am a human being, and, after all, he was it more than the judge who handed down the judgment.' Vertaald citaat uit het werk van J. Kuron (Gwiezdny Czas, Londen 1991, p. 47-48) opgenomen in: Milej 2004, p. 507. 
'(...) the roots of the contemporary Polish criminal justice system may be found in the period between 1944 and 1955, that is, in Stalin's era. While reviewing the post-War evolution of the system, one finds that it is the continuity which prevails over the changes. ${ }^{6} 68$

Een en ander werd bevestigd in de jaren zeventig toen een verdere verharding van de strafrechtspleging kon worden gesignaleerd die onder andere tot uitdrukking kwam in een ruime toepassing van voorlopige hechtenis en hogere vrijheidsstraffen. ${ }^{69}$ De Poolse gevangenispopulatie groeide in deze periode uit tot een van de grootste van Europa. ${ }^{70}$ Ter illustratie: het aantal gevangenen per 100.000 inwoners bedroeg in 1972 maar liefst 190, een cijfer dat vergeleken met gegevens van andere Europese landen uit die periode uiterst hoog is. ${ }^{71}$ De verharding die in de jaren na inwerkingtreding van de nieuwe codificaties zichtbaar werd, hing nauw samen met het feit dat de binnen het strafproces geldende machtsverhoudingen niet of nauwelijks waren veranderd. De prokuratura had immers ook in de nieuwe regeling haar dominante positie weten te behouden: ze had nog altijd de volledige leiding over het vooronderzoek en was het belangrijkste orgaan voor wat betreft de toepassing van dwangmiddelen. Daar kwam bij dat de regeling van het meest ingrijpende dwangmiddel - voorlopige hechtenis - op een aantal essentiële punten tekortschoot waardoor de waarborgen die de wet op dit punt wel bood zonder al te veel moeite konden worden omzeild. Voorlopige hechtenis bleef hierdoor ook na inwerkingtreding van het wetboek van strafvordering van 1969 een van de zwakste punten van het Poolse strafprocesrecht. ${ }^{72}$

\subsubsection{Staat van beleg en gevolgen voor het strafproces}

Het uitblijven van hervormingen was in toenemende mate aanleiding voor grootschalig verzet. In de jaren na het overlijden van Stalin was het de Poolse bevolking pijnlijk duidelijk geworden dat - hoewel het stalinisme officieel was verlaten en enige verzachting ten opzichte van de eerste tien jaren van het communistisch regime merkbaar was - een nationale, meer democratische politiek nog altijd niet was gerealiseerd. De ontevredenheid van de bevolking nam aan het eind van de jaren zeventig dermate grote vormen aan, dat de oprichting van een georganiseerde verzetsbeweging niet uit kon blijven. Toen in 1980 de voedselprijzen opnieuw werden verhoogd, leidde dit wederom tot grootschalig protest. In de scheepswerven van Gdańsk nam dit verzet uiteindelijk een georganiseerde vorm aan hetgeen resulteerde in een nationaal overkoepelend stakingscomité onder leiding van Lech Wałęsa. Door de toenemende politieke spanningen zag de communistische partij zich genoodzaakt de eisen van dit comité gedeeltelijk in te willigen ${ }^{73}$ wat onder meer tot gevolg had dat zij het recht op zelfbesturende vak-

68 Frankowski 1982 I, p. 144.

69 Niet-vrijheidsbenemende sancties speelden in de jaren zeventig en tachtig nauwelijks een rol van betekenis binnen de Poolse strafrechtspleging: 30 tot $40 \%$ van de opgelegde straffen bestond uit gevangenisstraf terwijl de boete als zelfstandige straf slechts in 10 tot $20 \%$ van de gevallen werd opgelegd, Stando-Kawecka 2001, p. 509.

70 Frankowski 1982 I, p. 150-153.

71 Nederland kende in 1971 een gemiddelde van 22 gedetineerden per 100.000 inwoners: Dodge 1979, p. 259.

72 Frankowski 1982 I, p. 153.

73 Een historische gebeurtenis die bekend staat als 'de Akkoorden van Gdanśk'. 
bonden moest erkennen. Deze concessie van communistische kant leidde tot de oprichting van verschillende vakbonden die zich uiteindelijk (in september 1981) samenvoegden tot de landelijke vakvereniging Solidarność (Solidariteit). Deze beweging onder voorzitterschap van Wałęsa was de eerste partijonafhankelijke organisatie sinds Wereldoorlog II en had in die hoedanigheid enorme invloed op de politieke verhoudingen van na 1981. De bevolking gaf uiting aan haar ontevredenheid door Solidarność massaal te steunen waardoor de organisatie binnen korte tijd een enorme aanhang kreeg.

Opnieuw had de ontevredenheid van de bevolking voor een belangrijk deel betrekking op de nog altijd repressieve strafrechtspleging waardoor de roep om hervormingen op dit gebied aan het begin van de jaren tachtig sterk toenam. Dit bleef niet zonder gevolgen: min of meer gedwongen door de maatschappelijke onrust besloot de minister van Justitie in 1980 een commissie voor de hervorming van het strafrecht samen te stellen die de taak kreeg de wetgeving van 1969 aan te passen aan de eisen van de tijd. Het ontwerp dat door de commissie in 1981 werd afgerond, bevatte enkele belangrijke voorstellen tot wijziging van het strafprocesrecht. ${ }^{74}$ Ongeveer gelijktijdig met het voorstel van de commissie van justitie werden ontwerpen tot wijziging van het straf(proces)recht geschreven door afgevaardigden van Solidarność. ${ }^{75}$ Ondanks onderlinge verschillen vertoonden de door Solidarność voorgestelde wijzigingen in een aantal opzichten gelijkenis met de regeringsvoorstellen - beide benadrukten dat de garanties voor een eerlijk proces dienden te worden verbeterd en de rechten van de verdediging moesten worden uitgebreid - wat in ieder geval aangaf dat overeenstemming bestond over de gebreken in de bestaande regelgeving en de noodzaak tot wijziging daarvan. ${ }^{76}$ Dat van overheidswege en vanuit de maatschappij hard gewerkt werd aan voorstellen tot wijziging van de bestaande regelgeving betekende dat belangrijke stappen in de richting van daadwerkelijke hervorming en humanisering van het straf(proces)recht werden gezet. Helaas werd deze positieve ontwikkeling abrupt onderbroken door de politieke gebeurtenissen van 1981.

\section{De staat van beleg}

De enorme groei van Solidarność ging ten koste van de toch al weinig stabiele positie van de communistische partij wat de spanningen tussen beide organisaties hoog deed oplopen. De communisten zagen hun aanhang steeds kleiner worden waardoor het besef ontstond dat de ontwikkelingen wel eens in het nadeel van het bestaande regime konden gaan uitpakken. Deze vrees bracht de in oktober

74 Zo werd ten aanzien van voorlopige hechtenis voorgesteld de eerder beschreven 'maatschappelijk gevaar'-grond te schrappen en de verplichting op te nemen dat ieder bevel tot toepassing van het (te) populaire dwangmiddel voortaan schriftelijk diende te worden gemotiveerd. Tevens introduceerde de commissie een soort anticipatietoets: wanneer redelijkerwijze kon worden verwacht dat de op te leggen straf slechts een boete, een vrijheidsbeperkende maatregel of een vrijheidsstraf van kortere duur dan de voorlopige hechtenis zou zijn, diende vrijheidsberoving achterwege te blijven: Frankowski 1992, p. 286-288. Hoewel sommigen van mening waren dat het ontwerp nog niet ver genoeg ging, bestond consensus over het feit dat het belangrijke verbeteringen bevatte.

75 Deel uitmakend van het tot de vakbeweging behorende 'Instituut voor burgerlijke wetgevingsinitiatieven'.

76 Wiliński 2006, p. 110. 
1981 tot partijleider benoemde generaal Jaruzelski ertoe rigoureuze maatregelen te treffen: in de nacht van 12 op 13 december 1981 riep hij de staat van beleg uit. Deze beslissing 77 was er op gericht de groeiende oppositie te onderdrukken en een klimaat te creëren waarin de communistische partij in alle rust haar machtspositie zou kunnen herstellen. Om dit te bereiken werden verstrekkende maatregelen getroffen: Solidarność werd verboden en vrijwel alle leidinggevenden van deze vakbond - inclusief Wałęsa - werden direct gearresteerd en gevangengenomen. De macht was nu officieel in handen van het leger dat met harde hand regeerde. Vele burgerlijke rechten en vrijheden werden voor de duur van de staat van beleg opgeschort en door de invoering van een arbeidsplicht en de aanstelling van militaire controleurs in bedrijven hoopte men de economie weer op de rails te krijgen. Dit zeer autoritaire regime duurde voort tot 31 december 1982 toen werd besloten de staat van beleg op te schorten. ${ }^{78}$

De gevolgen die de staat van beleg heeft gehad voor de strafrechtspleging kunnen het best worden omschreven als een enorme sprong terug in de tijd. Een grote hoeveelheid zeer repressieve regelgeving werd uitgevaardigd die onder andere voor wat betreft de uitbreiding van opsporings- en vervolgingsbevoegdheden en de beperking van de rechten van de verdediging niet onderdeden voor de eerder besproken stalinistische regelgeving uit de tweede helft van de jaren veertig. ${ }^{79}$ Het doel was duidelijk: door middel van een grootschalige en uiterst repressieve toepassing van het strafrecht diende de oppositiebeweging de kop ingedrukt te worden en hoopte men de bevolking weer terug in het gareel te krijgen. Regels van zowel het formele als het materiele strafrecht werden om die reden ingrijpend gewijzigd. Zo werd gelijktijdig met het uitroepen van de staat van beleg een aantal nieuwe strafbare feiten geïntroduceerd die een harde aanpak van vrijwel ieder 'non-conform' gedrag mogelijk moesten maken. ${ }^{80}$ Deze

77 Die was gebaseerd op een bepaling uit de Grondwet waarin was geregeld dat de staat van beleg gerechtvaardigd was wanneer de verdediging of de veiligheid van de staat in gevaar was. Jaruzelski heeft altijd beweerd dat het uitroepen van deze toestand in 1981 noodzakelijk was ter voorkoming van een gewelddadige inval van de Sovjet-Unie. Jaren later zou het Hooggerechtshof bepalen dat de inwerkingtreding van genoemd besluit in strijd was met het verbod van terugwerkende kracht (beslissing van 20 september 1991). Reden hiervoor was het feit dat het besluit op 12 december was aangenomen en pas twee dagen later werd gepubliceerd in het Staatsblad (Dziennik Ustaw) dat op 17 december werd uitgebracht. Artikel 61 van het besluit bepaalde echter dat de bepalingen in werking traden op de dag van aanname (12 december) waardoor gedurende enkele dagen een regeling van kracht was die nog niet officieel bekend was gemaakt. In april 2007 heeft het Poolse openbaar ministerie laten weten de inmiddels bejaarde Jaruzelski alsnog te gaan vervolgen voor het uitroepen van de staat van beleg in 1981.

78 Ondanks deze opschorting bleven enkele zeer repressieve maatregelen van kracht waardoor er in de praktijk niet veel veranderde. Enkele maanden later (op 21 juli 1983) vond de definitieve opheffing plaats: het leger trok zich terug waardoor de leidinggevende positie van de communistische partij - in ieder geval tijdelijk - kon worden hersteld. Algemeen over deze regelgeving: Fitzpatrick 1983, p. 87-93.

80 Bijvoorbeeld het voortzetten van activiteiten binnen een verboden organisatie - waaronder uiteraard Solidarność - of het organiseren of leiding geven aan een staking of andersoortige protestactie werd bedreigd met een gevangenisstraf van respectievelijk drie tot vijf jaar en voor het verkondigen of verspreiden van 'onjuiste' informatie die op enigerlei wijze schadelijk kon zijn voor de Volksrepubliek Polen kon een vrijheidsstraf 
aanvulling en uitbreiding van het materiële strafrecht ging gepaard met enkele vergaande veranderingen in de wijze waarop strafzaken werden behandeld. In de eerste plaats werd de berechting van een groot aantal feiten net als gedurende de stalinistische periode overgedragen aan militaire instanties. ${ }^{81}$ Omdat de hiervoor genoemde uitbreiding van strafbare feiten een toename van het aantal strafzaken tot gevolg had die toch snel en effectief moesten worden afgehandeld, werd tevens voorzien in een aantal vereenvoudigde procedures die de positie van verdachten uiteraard niet ten goede kwamen. De belangrijkste procesvorm die op de eerste dag van de staat van beleg in het leven werd geroepen, betrof de zogenaamde summiere procedure die in grote lijnen overeenkwam met de noodprocedure die in november 1945 in het Poolse strafprocesrecht was geïntroduceerd. ${ }^{82}$ Deze summiere procedure werd onder meer gekenmerkt door verkorte termijnen (een vooronderzoek van maximaal vijftien dagen waarna de zaak binnen vijf dagen ter terechtzitting moest worden behandeld), hogere straffen dan bij gewone procedures, verplichte toepassing van voorlopige hechtenis en het voor verdachten ontbreken van de mogelijkheid een rechtsmiddel in te stellen tegen de einduitspraak. ${ }^{83}$

Ten slotte is van belang te vermelden dat aanhouding en vrijheidsbeneming gedurende de staat van beleg niet noodzakelijk was verbonden aan (de intentie tot)

van maximaal tien jaar worden opgelegd. De vage en algemene bewoordingen van deze strafbepalingen hadden tot gevolg dat eenieder die nog op een of andere wijze uiting durfde te geven aan zijn bezwaren tegen het bestaande regime voor lange tijd achter de tralies kon verdwijnen.

81 Dit gebeurde net als in de beginjaren van het communisme vanuit de overtuiging dat de gewone rechterlijke macht onvoldoende garanties bood voor een 'juiste' afhandeling van politiek gevoelige zaken. In het besluit betreffende militaire rechterlijke instanties dat tegelijk met het uitroepen van de staat van beleg op 12 december 1981 was uitgevaardigd, was de regel opgenomen dat 'de meest ernstige inbreuken op de fundamentele politieke belangen van de Poolse Volksrepubliek en op het bestaande rechtssysteem' dienden te worden behandeld door militaire rechters.

82 In geval van verdenking van een strafbaar feit waaruit - naar het oordeel van de prokuratura of de geheime politie - een 'aanzienlijk maatschappelijk gevaar' voortvloeide, diende deze vereenvoudigde procesvorm te worden toegepast wat in de praktijk betekende dat de belangrijkste politieke strafzaken op deze wijze werden afgehandeld. Deze regel gold voor zowel militaire als gewone rechterlijke instanties. Over de summiere procedure: Swidlicki 1988, p. $52-57$ en Fitzpatrick 1983, p. 89-92.

83 Behalve de summiere procedure voorzag de regelgeving van de staat van beleg ook in een uitbreiding van de bijzondere procedures die reeds in het wetboek van strafvordering 1969 waren opgenomen: de zogenaamde 'versnelde' en 'vereenvoudigde' procedures. Eerstgenoemde vorm kon in minder zware zaken worden toegepast wanneer de verdachte op heterdaad of direct na het begaan van een strafbaar feit was aangehouden. In dergelijke gevallen kon gebruik worden gemaakt van een soort snelrecht: de verdachte diende binnen achtenveertig uur voor de rechter te worden geleid die onmiddellijk uitspraak deed. De vereenvoudigde procedure - waarin zaken door een alleensprekende rechter en in afwezigheid van verdachte konden worden afgedaan - kon worden toegepast in geval van verdenking van een strafbaar feit waarop maximaal drie jaar gevangenisstraf was gesteld en wanneer geen voorlopige hechtenis was toegepast. Over de versnelde en vereenvoudigde procedures: Swidlicki 1988, p. 57-61 en Frankowski 1982 I, p. 159. Van de verschillende bijzondere procedures werd gedurende de staat van beleg op grote schaal gebruik gemaakt. 
het instellen van een strafrechtelijke vervolging. De regelgeving die op 12 december 1981 bij het uitroepen van de staat van beleg was uitgevaardigd, voorzag namelijk in een volledig nieuwe maatregel - de internering - die het mogelijk maakte burgers zonder redelijk vermoeden van schuld aan een strafbaar feit gevangen te nemen. De vrees dat iemand in vrijheid mogelijk de rechtsorde niet zou respecteren of een gevaar op zou kunnen leveren voor de veiligheid van de staat was voldoende rechtvaardiging voor deze vorm van hechtenis. Het spreekt voor zich dat deze ruim geformuleerde gronden grootschalig misbruik van het dwangmiddel mogelijk maakten wat nog werd versterkt door het feit dat er geen enkele vorm van rechterlijke controle op werd uitgeoefend. ${ }^{84}$

Samenvattend kan worden gesteld dat de staat van beleg enorme gevolgen had voor de strafrechtspleging. De voorzichtige stappen die in de jaren voor december 1981 op de weg naar hervorming van het straf(proces)recht waren gezet, werden door het militaire regime in één klap teniet gedaan. Toch bleven de door de communisten gewenste effecten op de langere termijn uit. In de loop van de jaren tachtig zou blijken dat het verlangen naar hervorming alleen maar sterker werd en uiteindelijk niet langer genegeerd of onderdrukt kon worden.

\subsubsection{Tweede helft jaren tachtig: afbrokkeling communistisch regime en eerste hervormingen}

Hoewel met de opheffing van de staat van beleg in beginsel ook de wetgeving uit deze periode kwam te vervallen, werkte de repressieve tendens die eraan ten grondslag lag nog geruime tijd door. Nadat ze de macht weer had overgenomen van het leger zag de communistiche partij al snel in dat de politieke situatie nog net zo instabiel was als voor 1981. Het regime van Jaruzelski had de ontwikkelingen slechts tijdelijk bevroren zonder de ontstane spanningen tussen de partij en de sterk groeiende verzetsbeweging structureel op te lossen. Nu het land niet meer onder strenge leiding van het leger viel, moest derhalve opnieuw gebruik worden gemaakt van het strafrecht om de toenemende protesten de kop in te drukken. Met dit doel werd in 1985 de 'wet betreffende bijzondere strafrechtelijke verantwoordelijkheid' in het leven geroepen. Deze regeling zorgde ervoor dat enkele repressieve bepalingen uitgevaardigd tijdens de staat van beleg ook na opheffing van het militaire regime konden voortduren. ${ }^{85}$ Aangezien bij inwerking-

84 De beslissing tot opsluiting was voorbehouden aan regionale politiecommissarissen die de vrijheidsbeneming - tenminste voor de duur van de staat van beleg - onbeperkt konden laten voortduren. In de praktijk had dit tot gevolg dat de maatregel op grote schaal werd ingezet om personen van wie men ook maar het geringste vermoeden had dat ze op enig moment 'ordeverstorend gedrag' zouden kunnen gaan vertonen van hun vrijheid te beroven. Over deze praktijk: Swidlicki 1988, p. 25-27: 'Internees were in fact political prisoners deprived of their liberty on the basis of an arbitrary police decision without recourse to legal procedure or the right of appeal. (...) In some cases no reasons were given for the decision to intern; in others, the reasons were so general as to be meaningless. The decision on internment did not, moreover, make any mention of the duration of internment. (...) Throughout 1982 internment was used as a repressive measure, largely as a substitute for court proceedings which were lengthier, drew more publicity and did not always guarantee the outcome desired by the authorities.'

85 Zo werd de mogelijkheid tot toepassing van de hiervoor genoemde bijzondere procesvormen opnieuw uitgebreid zodat strafzaken in bepaalde gevallen - uiteraard ten nadele van de rechten van verdachte - sneller dan wel eenvoudiger konden worden afgedaan. 
treding van de wet in mei 1985 was bepaald dat deze 'slechts' voor drie jaar van kracht zou zijn, verloor de regeling in juni 1988 haar gelding. Hierdoor rees de vraag hoe het nu verder moest met het strafrecht. De vastberadenheid waarmee de Poolse bevolking zich tegen het bestaande regime bleef verzetten, had de partij inmiddels doen beseffen dat ook op het gebied van de strafrechtspleging veranderingen niet uit konden blijven en in 1987 werd wederom een poging gedaan om tot hervormingen te komen. Er werd opnieuw een commissie voor de hervorming van het strafrecht in het leven geroepen die haar resultaten in de zomer van 1988 presenteerde. De inhoud van het rapport werd door velen als mager bestempeld: het bevatte weliswaar enkele richtlijnen voor de toekomstige ontwikkelingen van het materiële en formele strafrecht maar daarbij werden geen concrete voorstellen en ontwerpen gepresenteerd. ${ }^{86}$ Discussie over de vraag of en zo ja, op welke wijze, de voorgestelde hervormingen zouden moeten worden doorgevoerd, werd echter net als in 1981 onderbroken door allerlei nieuwe politieke gebeurtenissen.

Aangezien de politieke situatie in 1988 als gevolg van een nieuwe golf stakingen wederom onhoudbaar was geworden, besloot de regering overleg te plegen met de inmiddels gereorganiseerde maar nog steeds verboden vakbeweging Solidarność. Deze beslissing resulteerde uiteindelijk in de Rondetafelgesprekken die in 1989 van februari tot april werden gevoerd. Uiteindelijk bereikten de vertegenwoordigers van Solidarność op een aantal belangrijke punten overeenstemming met hun communistische gesprekspartners. Solidarność werd gelegaliseerd en de eerstvolgende parlementsverkiezingen zouden gedeeltelijk vrij zijn. Met laatstgenoemde beslissing tekende de communistische partij haar doodvonnis: de verkiezingen die in mei en juni 1989 plaatsvonden, werden glansrijk gewonnen door Solidarność dat inmiddels was uitgegroeid tot een politieke partij. ${ }^{87}$ Met deze verkiezingsuitslag nam Polen als eerste Oost-Europees land definitief afscheid van het commu-

Tevens stelde genoemde wet de toepassing van voorlopige hechtenis in meer gevallen verplicht dan onder de regeling van 1969 en werd de mogelijkheid vrijheidsstraffen voorwaardelijk op te leggen aanzienlijk ingeperkt. Zie Tylman 1994, p. 538.

86 Volgens sommigen was de tegenvallende uitkomst van het project een direct gevolg van de wijze waarop de commissie was samengesteld: de zeer uiteenlopende (professionele) achtergronden van de leden zorgden voor veel onenigheid waardoor moeilijk overeenstemming kon worden bereikt over de omvang en invulling van de noodzakelijke hervormingen. Wetenschappers en advocaten waren voorstander van een ingrijpende aanpassing van het bestaande bestel maar werden daarin tegengewerkt door met name leden van de prokuratura en de rechterlijke macht die blijkbaar niet ontevreden waren met de bestaande regels en slechts beperkte wijzigingen noodzakelijk achtten: Murzynowski 1989, p. 58-59.

87 Zoals gezegd, waren de verkiezingen slechts gedeeltelijk vrij: slechts 161 van de 460 zetels van de Sejm waren beschikbaar. De overige 299 zetels bleven gereserveerd voor de communistische partij om zo een al te dramatische nederlaag te voorkomen. De 100 zetels van de Senaat (Eerste kamer) waren wel allemaal vrij verkiesbaar. Deze kamer was na de installatie van het communistisch regime opgeheven en pas na de Rondetafelgesprekken weer in ere hersteld. Het feit dat de verkiezing voor de Sejm slechts gedeeltelijk vrij was, maakte de overwinning van Solidarność relatief: de nieuwe partij won alle 161 beschikbare zetels van de Sejm en 99 van de 100 plaatsen in de Senaat. 
nistisch regime waarna de eerste stappen in de richting van een democratische rechtsstaat en vrije markteconomie naar westers model konden worden gezet.

Hoewel Solidarność met betrekking tot hervorming van het straf(proces)recht nogal wat eisen had geformuleerd, waren de uitkomsten van de onderhandelingen op dit punt mager. ${ }^{88}$ Op een aantal belangrijke punten werd echter wel vooruitgang geboekt. Met name de afhankelijkheid van de rechterlijke macht werd door de nieuwe afspraken grondig aangepakt: er werd onder meer een nieuwe structuur voor de rechterlijk macht en de oprichting van een Nationale Raad voor de Rechtspraak (Krajowa Rada Sadownictwa) overeengekomen. ${ }^{89}$

De meest omvangrijke hervormingen zouden pas plaatsvinden nadat definitief afscheid was genomen van het communistisch regime maar een aantal wijzigingen werd reeds voor de omwenteling gerealiseerd. Bij wet van 29 mei 1989 - vlak voor bovengenoemde verkiezingsnederlaag van de communistische partij - werd het straf(proces)recht aangepast op punten die zo dringend om verbetering vroegen dat de politieke ontwikkelingen niet konden worden afgewacht. Een van de belangrijkste wijzigingen betrof de introductie van de mogelijkheid bij de rechtbank bezwaar in te stellen tegen aanhouding en detentie door de politie. ${ }^{90}$ Genoemde wetswijziging had tevens gevolgen voor de regeling van voorlopige hechtenis: de prokuratura was alleen nog bevoegd het dwangmiddel voor de maximale duur van drie maanden te bevelen, daarna kon de vrijheidsbeneming alleen worden verlengd door de rechtbank. Verlenging van voorlopige hechtenis was voortaan dus in een eerder stadium voorbehouden aan de rechter. ${ }^{91}$ Ook de regeling van het vrij verkeer werd in het voordeel van de verdediging gewijzigd. Op laatstgenoemde wijziging zal in hoofdstuk 7 worden teruggekomen.

Samengevat betekende de wet van mei 1989 op een aantal belangrijke punten een verbetering van de rechtspositie van verdachten. Dit was echter slechts het begin van een omvangrijk transitieproces dat het Poolse straf(proces)recht de komende jaren zou ondergaan.

88 Hołda 1991, p. 14: 'The talks were difficult. 'Round Table' agreement in the field of the criminal justice system was not one of Solidarity's great successes.'

89 Laatstgenoemd orgaan zou een belangrijke rol gaan spelen in de versterking van de zelfstandigheid en onafhankelijkheid van de rechterlijke macht.

90 Art. 207 KPK 1969 zoals gewijzigd in 1989: hetzelfde rechtsmiddel is nu voorzien in art. 246 KPK 1997. De rechtbank dient de rechtmatigheid van de vrijheidsbeneming onmiddellijk te toetsen en de verdachte direct in vrijheid te stellen wanneer ze van oordeel is dat de detentie onrechtmatig is. Voor de wetswijziging van 1989 stond tegen de vrijheidsbeneming door de politie die maximaal achtenveertig uur kon duren geen enkel rechtsmiddel open.

91 Voorheen kon de prokuratura de tenuitvoerlegging van de voorlopige hechtenis immers - zonder tussenkomst van een rechter - verlengen tot 6 maanden (art. 222 lid 2 KPK 1969). Na de wetswijziging van mei 1989 was de rechtbank bevoegd te verlengen tot maximaal één jaar. Deze termijn kon door tussenkomst van het Hooggerechtshof worden overschreden: Frankowski 1992, p. 292-294 en Frankowski en Wąsek 1993, p. 161. 


\subsection{Ontwikkelingen na 1989}

Dat Polen niet langer als volksrepubliek maar als democratische rechtsstaat moest worden aangemerkt, werd in november 1989 verankerd in de Grondwet. ${ }^{92}$ De kwalificatie 'rechtsstaat' impliceert dat aan een aantal voorwaarden moet worden voldaan zoals de eis dat zowel de burger als de overheid aan de wet zijn gebonden en dat het toezicht op de naleving van wettelijke regels is overgelaten aan onafhankelijke rechters. Bovendien dienen in een rechtsstaat bepaalde (klassieke) grondrechten te worden gegarandeerd en in dat opzicht hebben zich na 1989 in Polen belangrijke ontwikkelingen voorgedaan die nauw zijn verbonden met de hervorming van het straf(proces)recht.

\subsubsection{Erkenning individuele rechten en vrijheden}

De overgang van een totalitair communistisch regime naar een democratisch systeem dat rechtsstatelijke principes nastraaft, heeft grote gevolgen gehad voor de status van individuele rechten en vrijheden in de Poolse rechtsorde. Niet alleen de mate waarin en de wijze waarop nationale regelingen - in het bijzonder de Grondwet - rechten en vrijheden aan de burger toekennen maar ook de geldigheid en doorwerking van internationale en Europese mensenrechten zijn in dit opzicht van groot belang. Op beide niveaus hebben zich na 1989 ontwikkelingen voorgedaan die onlosmakelijk zijn verbonden met de postcommunistische hervorming van de strafrechtspleging. Zo is het onbetwist dat het nieuwe Poolse strafprocesrecht (het wetboek van strafvordering van 1997) in belangrijke mate is geïnspireerd en beïnvloed door het Europees Verdrag tot bescherming van de rechten van de mens dat kort na de val van het communistisch regime door Polen werd geratificeerd. Voorafgaand aan de bespreking van de postcommunistische hervormingen van het strafprocesrecht zal daarom eerst enige aandacht worden besteed aan de ontwikkelingen die zich eind jaren tachtig begin jaren negentig in Polen op het gebied van de mensenrechten hebben voorgedaan.

\subsubsection{Situatie voor 1989}

Voor 1989 was de status van burgerlijke rechten en vrijheden onlosmakelijk verbonden met de communistische opvattingen over vrijheid en gelijkheid. In een notendop komt deze visie erop neer dat volledige en daadwerkelijke vrijheid van burgers alleen mogelijk is wanneer economische gelijkheid is gerealiseerd..$^{93}$

92 Bedoeld is de Grondwet van 1952. In de huidige Grondwet van 1997 vloeit dit voort uit art. 2: 'The Polish Republic is a democratic state, governed by law and implementing rules of social justice.'

93 Patyulin 1981, p. 7: 'Can there be real equality between, say, Henry Ford and his workers? Do the press tycoon Henry Luce and the black unemployed in Harlem have the same rights in the exercise of freedom of speech and the press? Certainly not. In a society where there is no equality in ownership of the means of production the will of one person always encroaches on that of another and the freedom of one means the submission of others.' Gedurende de overgangsfase naar de communistische samenleving waarin individuele en gemeenschappelijke belangen samensmelten, dienen dan ook de omstandigheden te worden gecreëerd die realisatie van echte vrijheid mogelijk maken: 'Under socialism the putting of the interests of society before those of the individual is not an end in itself. What is more, the consistent implementation of this principle in the long run creates the best possible conditions for the development of the individual. This merging of public and individual interests, while ensuring the most effective functioning of the social system, guarantees the rights of every citizen and the steady and consistent extension of the 
Volgens Marx was materiële gelijkheid dan ook veel belangrijker dan (de onrealistisch geachte) gelijkheid voor de wet. Door de communisten werd - anders dan in westerse kapitalistische rechtssystemen - niet erkend dat de wet de burger diende te beschermen tegen de overheid. Dat laatste werd ook niet noodzakelijk gevonden omdat de belangen van het individu in de overgang naar de communistische maatschappij ondergeschikt behoorden te zijn aan de belangen van het collectief zoals vertegenwoordigd door de overheid. De functie van het recht werd beperkt tot de zogenaamde 'socialistische wettelijkheid' (socialist legality) wat niet meer was dan de voor iedere burger geldende verplichting om het recht na te leven. ${ }^{94}$ Op deze wijze werd dus wel bescherming van de overheid tegen de burger gerealiseerd terwijl een vergelijkbare bescherming andersom - burger tegen overheid - niet bestond.

Dit verkaart de status van de verschillende categorieën mensenrechten gedurende het communisme. De nadruk lag met name op de sociale en economische rechten terwijl aan persoonlijke rechten weinig belang werd toegekend. ${ }^{95}$ In deze situatie kwam echter reeds voor de regimewisseling van 1989 al enige verandering. Vanaf 1980 werden verschillende instanties in de Poolse rechtspleging geïntroduceerd die in belangrijke mate hebben bijgedragen aan de bestendiging en bescherming van burgerlijke rechten en vrijheden. Met name de oprichting van het Grondwettelijk Hof (Trybunat Konstytucyjny) in 1985 en de installatie van de Nationale Ombudsman (Rzecznick Praw Obywatelskich) in 1987 dienen in dit verband te worden genoemd. ${ }^{96}$

De oprichting van een Grondwettelijk Hof dat werd belast met de taak Poolse wet- en regelgeving aan de Grondwet te toetsen was geenszins vanzelfsprekend aangezien een dergelijke toetsing - hoewel destijds gebruikelijk in veel democratische Europese rechtssystemen - moeilijk verenigbaar was met de opvattingen over eenheid van staatsmacht en superioriteit van de wetgever zoals die in de Volksrepubliek Polen officieel golden. Het ontstaan van het Hof kan dan ook alleen worden verklaard vanuit de politieke onrust van de jaren tachtig die het regime ertoe noodzaakten enige concessies te doen aan de alsmaar sterker wordende hervormingsbeweging. ${ }^{97}$

Vanwege de communistische weerstand tegen constitutionele toetsing waren de mogelijkheden van het Grondwettelijk Hof gedurende de eerste jaren van zijn bestaan beperkt. Zo werden beslissingen van het Hof waarin ongrondwettelijkheid van parlementaire wetgeving was geconstateerd pas bindend na bekrachtiging door de Sejm: het parlement kon het Grondwettelijk Hof dus overrulen zodat de door de communisten gewenste machtsverhoudingen zo min mogelijk werden verstoord. Bovendien was het Hof niet bevoegd te toetsen aan bepalingen van internationale overeenkomsten die voor Polen bindend waren (zoals het Inter-

rights and freedoms of all' (p. 10-11).

94 Kurczewski 1999, p. 193-196. Over dit thema ook: Krygier 1990, p. 633-663. Meer specifiek over het begrip socialistische wettelijkheid: Malfliet 1987, p. 70-73.

95 Dat laatstgenoemde categorie een ondergeschikte positie innam, bleek ook uit het feit dat deze rechten in de Poolse Grondwet van 1952 slechts summier in een van de laatste hoofdstukken werden geregeld en bovendien aan aanzienlijke beperkingen onderhevig waren.

96 Over beide instanties: Klich 1996, p. 33-63.

97 Brzezinski 1993, p. 159. 
nationaal Verdrag inzake burgerrechten en politieke rechten dat in 1977 was geratificeerd) wat een direct gevolg was van de hierna te bespreken communistische visie ten aanzien van de doorwerking van dergelijke internationale regelingen.

De in 1987 geïnstalleerde Nationale Ombudsman kreeg als voornaamste taak het behandelen van klachten van burgers over schending van hun rechten door de overheid. ${ }^{98}$ Van groot belang voor de ontwikkeling van burgerrechten in Polen is dat met de installatie van de Nationale Ombudsman werd erkend dat tussen overheid en burger wel degelijk een belangenconflict kan bestaan en dat collectieve en individuele belangen dus niet noodzakelijk gelijk hoeven te zijn. De Ombudsman speelt tot vandaag de dag een belangrijke rol in de bescherming van individuele rechten en vrijheden.

Het zal gelet op het bovenstaande weinig verbazing wekken dat ook de status van mensenrechten die in internationale verdragen waren vastgelegd gedurende het communisme allesbehalve vanzelfsprekend was. ${ }^{99}$ Ten aanzien van deze normen gold overigens nog een extra bezwaar: ze waren totstandgekomen buiten de directe invloedssfeer van de nationale wetgever. Hoewel dus voorzichtigheid en terughoudendheid moest worden betracht in het aannemen van dergelijke vreemde, supranationale regels betekende dit niet dat door het communistisch regime geen internationale overeenkomsten werden ondertekend. Integendeel: Polen is gedurende de communistische periode partij geworden bij een groot aantal verdragen waarbij in het kader van de mensenrechten met name het IVBP moet worden genoemd. ${ }^{100}$ De gevolgen hiervan bleven echter uiterst beperkt: in het gros van de gevallen was ondertekening en ratificatie niet meer dan een formaliteit die erop was gericht het vertrouwen van de internationale gemeenschap te winnen zonder dat dit daadwerkelijk consequenties had voor de nationale rechtsorde of (meer specifiek) de rechtspositie van individuele burgers. Zo had ook de ratificatie van het IVBP slechts een symbolische functie:

'(...) from the point of view of changes to the Polish legislation and of judicial practice, this event [ratificatie van het IVBP, toev. DdV] was only of symbolic significance at the time. No effective measures were undertaken to adapt Polish law, including criminal law, to the

98 Zoals eerder gezegd, was deze vorm van rechtsbescherming voorheen opgedragen aan de prokuratura. Uit het feit dat behoefte bestond aan een instituut als de Nationale Ombudsman wordt wel afgeleid dat de prokuratura inderdaad in zijn rechtsbeschermende functie tekortschoot: Wierzbowksi 2001, p. 8.110.7.

99 Drzemczewski en Nowicki verwoorden de 'communistische' houding ten opzichte van het EVRM als volgt: 'In countries of the former Soviet bloc, Poland included, the ECHR was for many years a document known to a few people only. According to the official ideology of those days, it reflected an alien bourgeois concept of human rights. The Convention was quoted as an example of the hypocrisy of the West, creating formal paper guarantees but unable to stand the test of real life. Human rights, it was argued, could only find an appropriate place in the Socialist system (...). Others, who had never excepted the grim and hypocritical reality east of the Laba River, saw the text of the Convention and their own study of that document, if incidental, as either an expression of their honesty as researchers or a manifestation of a rebellious attitude, similar to the practice of wearing bright socks or playing jazz under Stalin and even later on': Drzemczewski en Nowicki 2001, p. 657.

100 Zoals eerder opgemerkt, werd het IVBP in 1977 geratificeerd. Voor een opsomming van een aantal andere belangrijke mensenrechtenverdragen waar Polen tussen 1944 en 1989 tot is toegetreden: Przyborowska-Klimczak 1996, p. 96-97. 
provisions of this Covenant. Under the Polish People's Republic there was a patent reluctance on the part of the authorities with respect to the guarantees ensuing from this Covenant, and especially to the potential for the exercise of international supervisory procedures on Polish Legislation and on the sentences and decisions passed by Polish authorities. ${ }^{\prime 101}$

De vraag naar de gevolgen van toetreding tot een internationale overeenkomst is natuurlijk onlosmakelijk verbonden met de traditionele vraag of internationale normen automatisch (ex proprio vigore) onderdeel uitmaken van het geldende nationale recht of dat daarvoor omzetting noodzakelijk is. In de Poolse Grondwet van 1952 was zoals in alle andere communistische Grondwetten uit die periode niets geregeld over de verhouding tussen nationaal en internationaal recht. In de doctrine overheerste weliswaar de opvatting dat bepalingen van geratificeerde verdragen automatisch onderdeel uitmaakten van het nationale recht maar het officiële standpunt was anders en werd in 1987 door een uitspraak van het Hooggerechtshof bevestigd: zolang normen van door Polen geratificeerde verdragen niet op rechtsgeldige wijze waren omgezet in nationaal recht konden ze geen bindende kracht hebben en waren ze voor de rechter én de burger betekenisloos. ${ }^{102}$

101 Szewczyk 1997, p. 83-84. Deze mening wordt gedeeld door Hofmański: 'Even though Poland ratified the 1966 United Nations Human Rights Covenants in 1977, it neither adjusted its national legislation nor submitted to the implementation procedures foreseen by the Optional Protocol. Consequently, not much change resulted from its ratification': Hofmański 1995, p. 45 en door Drzemczewski en Nowicki: 'This fact [that the Realsozialismus states were party to a variety of international agreements on human rights inluding the UN Convenant of Civil and Political Rights, toev. DdV] was of very little practical importance, especially for the citizens of those states. The documents were, in the eyes of most observers, ratified with no intention whatever of fulfilling the resultant obligations': Drzemczewski en Nowicki 2001, p. 657. Een meer genuanceerd standpunt wordt ingenomen door Pomorski en Defert die van mening zijn dat een aantal wijzigingen dat eind jaren zeventig in het straf- en strafprocesrecht is ingevoerd wel degelijk is beïnvloed door het IVBP. Zij noemen in dat verband onder andere het intrekken van het uiterst repressieve besluit van november 1945 aangaande noodprocedures, de wijzigingen in de nieuwe strafrechtelijke codificaties van 1969 die het aantal opgelegde doodstraffen dienden terug te dringen en de in dezelfde wetgeving gerealiseerde uitbreiding van het rechterlijk toezicht over de toepassing van voorlopige hechtenis. Ook zij zijn echter sceptisch over het daadwerkelijk effect van deze wijzigingen: '(...) one may say that all the aforecited changes introduced into Polish criminal law have three characteristic features in common: they are changes of low cost, insubstantial practicality, but high visibility. Actually, one cannot expect more from reluctantly espoused concessions devised primarily for foreign consumption' maar dit betekent volgens hen niet dat ze geen enkele betekenis hebben gehad: '(...) the changes actually introduced, however modest, should not be underestimated. They had been deemed important enough by the authorities to be resisted for some twenty years against a strong current of professional, especially academic, opinion in Poland. (...) True, until recently, judging from available sources, statutory changes have not altered law enforcement patterns. Nevertheless, they represent tangible potential for future change': Pomorski en Defert 1980, p. 499-500. Overigens was het IVBP op het moment dat deze wijzigingen werden ingevoerd (1969) nog niet door Polen geratificeerd maar vaststond wel dat dit binnen niet al te lange tijd zou gaan gebeuren. Na ratificatie van het verdrag in 1977 duurde het nog lange tijd voordat ook het individueel klachtrecht behorend bij het IVBP werd erkend: dat gebeurde pas in 1992.

102 Uitspraak van 25 augustus 1987 in een zaak met een sterk politiek karakter. Het betrof een beroep van Solidarność op het IVBP en het Internationaal Arbeidsverdrag in hun streven een onafhankelijke vakbond op te richten. Met genoemde uitspraak weigerde het Hooggerechtshof de door de communisten als gevaarlijk beschouwde vakbond te 


\subsubsection{Situatie na 1989}

Na 1989 veranderden bovengenoemde opvattingen over mensenrechten geleidelijk. Het heeft echter even geduurd voordat dat ook tot uitdrukking kwam in de Grondwet. Pas in de nieuwe Grondwet van 1997 werd een nieuwe verzameling burgerrechten geformuleerd en tot die tijd bleef de volledig ontoereikende mensenrechtenregeling van de communistische Grondwet van 1952 formeel van kracht. ${ }^{103}$ Burgerlijke rechten en vrijheden zijn nu vastgelegd in het tweede hoofdstuk van de Grondwet: uit deze plaatsing (vooraan in plaats van achteraan zoals in 1952) en uit de omvang van het hoofdstuk (het meest omvangrijke van de gehele Grondwet van 1997) ${ }^{104}$ kan worden afgeleid dat deze rechten hiermee eindelijk de plaats in de constitutionele orde hebben gekregen die hun in een rechtsstaat toekomt. ${ }^{105}$ In de ontwikkeling van burgerlijke rechten en vrijheden heeft de rechtspraak van het Grondwettelijk Hof een niet te onderschatten rol gespeeld. Na 1989 werden de beperkingen ten aanzien van de rechtsmacht van het Hof ${ }^{106}$ opgeheven en kreeg de instantie de politiek onafhankelijke status die voor het goed functioneren van een dergelijk orgaan noodzakelijk is. Op basis van de nieuwe Grondwet van 1997 zijn uitspraken van het Hof bindend en definitief en bovendien hebben anders dan voorheen ook burgers de mogelijkheid een kwestie voor te leggen aan deze instantie (individueel klachtrecht). ${ }^{107}$ Inmiddels is de rechtspraak van het Grondwettelijk Hof ook al lang niet meer een puur nationale aangelegenheid: de rechtsmacht is zodanig uitgebreid dat nationale wetgeving ook op overeenstemming met internationale verdragen kan worden getoetst wat het Hof in staat stelt een belangrijke schakel te zijn in de doorwerking van mensenrechtenverdragen zoals het EVRM in de Poolse rechtsorde. In zijn nieuwe, versterkte

legaliseren. Overigens geldt deze opvatting over de doorwerking van internationaal recht vandaag de dag nog steeds in verschillende rechtsystemen zoals het Verenigd Koninkrijk en Duitsland.

103 De totstandkoming van de nieuwe Poolse Grondwet kent een lange geschiedenis waarin grofweg drie periodes kunnen worden onderscheiden:

1. 1989-1992: behoud van de Grondwet van 1952 (die overigens wel op belangrijke punten werd aangepast),

2. 1992-1997: totstandkoming van de zogenaamde 'kleine Grondwet' in 1992 die slechts als partiële Grondwet werd beschouwd omdat er geen regeling van mensenrechten in was opgenomen zodat de oude Grondwet van 1952 op dit punt behouden bleef (reden hiervoor was het feit dat geen overeenstemming kon worden bereikt over hoe de nieuwe regeling er moest komen uit te zien: Henckaerts en Van der Jeught 1998, p. 478),

3. 1997 en daarna: De totstandkoming van de nieuwe Grondwet van 1997 die nog steeds van kracht is en waarin mensenrechten wel afzonderlijk en meer uitgebreid dan in de regeling van 1952 zijn geregeld. Over deze constitutionele ontwikkelingen tussen 1989 en 1997: Kosowska-Gąstoł 2004, p. 85-87.

104 Cholewinski 1998, p. 251.

105 Ook uit het feit dat de persoonlijke rechten en vrijheden nu als eerste zijn geregeld - en daarna pas de politieke en economische, sociale en culturele rechten - blijkt dat aan eerstgenoemde categorie meer betekenis wordt toegekend dan voorheen.

106 Zie hiervoor $\$$ 2.3.1.1.

107 Het toetsen van wetgeving aan de Grondwet is een exclusieve bevoegdheid van het Grondwettelijk Hof: reguliere rechterlijke instanties dienen een rechtsvraag aan het Hof voor te leggen wanneer twijfel bestaat over de vraag of een bepaalde wettelijke regel verenigbaar is met de Grondwet. 
positie heeft het Grondwettelijk Hof een belangrijke bijdrage geleverd aan de invulling van het begrip 'rechtsstaat' en de betekenis van deze kwalificatie voor het Poolse rechtssysteem. ${ }^{108}$ Dit blijkt onder andere uit het feit dat een aantal belangrijke rechten die in de huidige Grondwet zijn opgenomen, zijn ontleend aan de rechtspraak van het Grondwettelijk Hof. Dit geldt onder meer voor het recht op een eerlijk proces voor een onafhankelijke rechter (art. 45), het recht op bescherming van het privéleven (art. 47) en het uitgangspunt dat beperkingen op grondrechten alleen door de formele wetgever kunnen worden gemaakt (art. 31 lid 3). Vóór de totstandkoming van de nieuwe Grondwet werden deze rechten - die nog geen grondwettelijke status hadden - door het Hof ontleend aan het rechtsstaatprincipe. ${ }^{109}$ Ook vandaag de dag nog speelt de rechtspraak van het Hof een zeer belangrijke rol bij de vormgeving en implementatie van rechtsstatelijke principes in het Poolse strafproces. ${ }^{110}$

In de Grondwet van 1997 is een aparte bepaling gewijd aan fair trial zodat voor de invulling van dit begrip niet meer hoeft te worden teruggegrepen naar het algemene art. 2 waarin Polen als rechtsstaat wordt bestempeld. ${ }^{111}$ Dit is overigens niet de enige voor de strafrechtspleging relevante grondwettelijke bepaling. Eveneens van groot belang zijn art. 40, 41 en 42 waarin onder andere het verbod van onmenselijke behandeling en bestraffing, het materieelrechterlijke legaliteitsbeginsel (nullem crimen, nulla poena sine legia praevia), de onschuldspresumptie en het recht op verdediging is vastgelegd. Het in de Grondwet opnemen van deze fundamentele beginselen was al door veel auteurs bepleit ${ }^{112}$ en het feit dat dit in 1997 werd gerealiseerd, heeft in belangrijke mate bijgedragen aan verhoging van het rechtsstatelijk karakter van het strafproces.

\section{Mensenrechtenverdragen}

Net zoals de gebeurtenissen van 1989 niet direct hebben geleid tot een nieuwe regeling van burgerrechten op nationaal niveau bleef ook lange tijd onduidelijkheid bestaan over de status en geldingskracht van internationale mensenrechten in de Poolse rechtsorde. Omdat de Grondwet gedurende de eerste jaren van de rechtsstaat nog altijd geen antwoord gaf op deze vraag bleef de kwestie rechtsgeleerden bezighouden. ${ }^{113}$ Ook de rechtspraak hield zich ermee bezig en in 1991 leek de definitieve omslag (naar directe doorwerking van internationale normen) dichterbij dan ooit. Het Hooggerechtshof zette in zijn uitspraak van 20 september 1991 een belangrijke stap in nieuwe richting door rechtstreekse werking toe te

108 Brzezinski 1993, p. 153-200, p. 33-35, Brzezinski en Garlicki 1995 I, Brzezinski en Garlicki 1995 II, p. 13-59 en Kosowska-Gąstoł 2004, p. 85-105.

109 Kosowska-Gąstoł 2004, p. 97-105. Zie ook Zakrewska 1992.

110 Op de website van het Grondwettelijk Hof is van een aantal belangrijke uitspraken een Engelse vertaling beschikbaar: <www.trybunal.gov.pl/eng/index.htm>.

111 Wąsek-Wiaderek 2000, p. 14. Art. 45 Grondwet 1997 luidt: '1. Eenieder heeft het recht op een eerlijke en openbare behandeling van zijn zaak, binnen een redelijke termijn en door een bevoegde, onpartijdige en onafhankelijke rechterlijke instantie, 2. Uitzonderingen op het openbare karakter van de zitting zijn toegestaan in het belang van de moraliteit, staatsveiligheid, openbare orde, bescherming van het privé-leven van een der partijen of andere zwaarwegende persoonlijke belangen.'

112 Frankowski en Wąsek 1993, p. 165.

113 Over deze discussie: Zajadło 1990, p. 15-24 en Kedzia 1991, p. 133-140. 
kennen aan een bepaling uit het IVBP. ${ }^{114}$ Hoewel het Hooggerechtshof de eerste jaren na deze uitspraak geen verdere uitwerking aan zijn opvattingen over directe doorwerking van internationale bepalingen heeft gegeven, dient deze beslissing als belangrijk precedent in de discussie over de verhouding tussen nationaal en internationaal recht te worden beschouwd. ${ }^{115}$ De lijn die het Hooggerechtshof in augustus 1987 had uitgezet door te bepalen dat normen van door Polen geratificeerde verdragen pas bindend zijn wanneer ze op de juiste wijze zijn omgezet in nationaal recht bleek in ieder geval niet langer maatgevend te zijn. De Grondwet van 1997 maakte aan alle onduidelijkheid een einde door te voorzien in een heldere - overigens naar Nederlands voorbeeld vormgegeven ${ }^{116}$ - regeling waarin is bepaald dat internationale overeenkomsten die door Polen zijn geratificeerd na publicatie in het Staatsblad (Dziennik Ustaw) onderdeel uitmaken van de nationale rechtsorde, in beginsel directe werking hebben en voorrang dienen te krijgen op nationale wettelijke voorschriften die ermee in strijd zijn. ${ }^{117}$

Voor de erkenning van individuele rechten en vrijheden was de toetreding tot de Raad van Europa in 1991 en de ratificatie van het EVRM dat voor Polen op 19 januari 1993 in werking trad van groot belang. Met ingang van 1 mei 1993 werd ook het individuele klachtrecht erkend waardoor voor Poolse burgers een nieuwe weg werd geopend om bescherming van hun burgerrechten te effectueren. Het aanvaarden van de rechtsmacht van het Europese Hof voor de rechten van de mens betekende een belangrijke koerswijziging: de heersende (officiële) visie van voor 1989 volgens welke bescherming van mensenrechten als puur nationale aangelegenheid werd beschouwd en internationale organen die met deze taak waren belast met argwaan werden bekeken, werd hiermee duidelijk verlaten. ${ }^{118}$

Reeds in de eerste jaren na inwerkingtreding van het EVRM heeft de rechtspraak van het Europese Hof grote invloed gehad op de ontwikkelingen binnen de Poolse strafrechtspleging. ${ }^{119}$ Deze invloed betreft met name de totstandkoming van nieuwe wetgeving en de rechtspraak van hogere rechterlijke instanties. In uitspraken van het Hooggerechtshof en het Grondwettelijk Hof wordt sinds 1989

114 Het betrof een strafzaak waarin verdachte in eerste en tweede aanleg was veroordeeld voor het leiden van een staking gedurende de staat van beleg. De staking was begonnen nadat de staat van beleg op 12 december 1981 was uitgeroepen maar voordat het besluit waarop deze handeling was gebaseerd in het Staatsblad was gepubliceerd. Het Hooggerechtshof sprak de verdachte vrij omdat de veroordeling in strijd was met het verbod van terugwerkende kracht zoals vastgelegd in het algemeen verbindende art. 15 IVBP. Zie over deze uitspraak eerder ook § 2.2.2.3.

115 Leszczyński 1995, p. 689-690.

116 Kamiński 2004, p. 222.

117 Art. 91 Grondwet.

118 '(...) Therefore occured a total change of the concept concerning human rights protection, since until 1989 this matter was considered to belong exclusively to State's internal competence and official opinions were voiced against institutionalisation of international protection of rights and freedoms': Wołpiuk 1994, p. 99.

119 Algemene beschouwingen over het toenemende belang van het EVRM bij de totstandkoming van wetgeving en rechtspraak in de eerste jaren na inwerkingtreding: Hofmański 1995, p. 45-55 en Leszczyński 1996, p. 19-39. Meer specifiek over de toetsing aan het EVRM bij de voorbereiding van nieuwe wetgeving: Drzemczewski en Nowicki 2001, p. 661-664. 
regelmatig verwezen naar bepalingen uit het EVRM. ${ }^{120}$ Voor de lagere, feitelijke instanties speelt het EVRM en de Straatsburgse rechtspraak in strafzaken een uiterst beperkte rol. ${ }^{121}$ Hiervoor kunnen verschillende oorzaken worden genoemd. In de eerste plaats zijn er praktische redenen zoals het feit dat veel rechters de Engelse taal onvoldoende machtig zijn en slechts beperkt toegang hebben tot internetbronnen zoals Hudoc. ${ }^{122}$ Meer inhoudelijk is ook van belang dat internationale mensenrechtenverdragen als het EVRM tot een aantal jaren geleden volgens de heersende opinie geen onderdeel uitmaakten van het nationale recht. Mede als gevolg hiervan werd ook in de rechtenopleiding tot voor kort nauwelijks aandacht besteed aan het EVRM en bijbehorende rechtspraak. Straatsburg is voor de meeste rechters letterlijk en figuurlijk ver weg. ${ }^{123}$ Voor de meeste straf-

120 Zo deed het Hooggerechtshof in juli 1997 een belangrijke uitspraak die er geen twijfel over liet bestaan dat Straatsburgse normen dienen te worden gerespecteerd. De zaak betrof het lot van twee Chinese staatsburgers die volgens een uitspraak van de hoger beroepsinstantie van Warschau moesten worden uitgeleverd aan China. Het Hooggerechtshof vernietigde deze beslissing door te oordelen dat uitlevering aan China een schending van art. 3 en art. 6 EVRM zou opleveren. Voor de schending van art. 3 (verbod van foltering en onmenselijke behandeling of bestraffing) werd daarbij expliciet verwezen naar relevante Straatsburgse rechtspraak (voor de vermeende schending van art. 6 EVRM was dit niet mogelijk omdat er (nog) geen Straatsburgse rechtspraak was die een dergelijk standpunt bevestigde). Zie over deze uitspraak van 29 juli 1997 (II KKN 313/97 Mandugeqi en Jinge): Drzemczewski en Nowicki 2001, p. 666-667.

121 'At present, verdicts of the Strasbourg Court are quoted in many judicial decisions of the highest legal institutions when Polish law is interpreted and applied. This practice is a very important and promising factor as it creates good judicial patterns. But at the same time lower courts usually do not mention the Strasbourg case law at all, even though there are verdicts of the European Court evidently relevant to the national cases. Ordinary judges do not notice international law because they consider the issue of international rules and their application as a hard legal problem. Therefore the Polish judiciary leaves such problems to high rank judges sitting at the Supreme Court, Chief Administrative Court and Constitutional Tribunal': Kamiński 2004, p. 222-223.

122 Het gebeurt wel dat uitspraken in het Pools worden vertaald en dat het ministerie van Justitie de rechterlijke macht informeert over belangwekkende uitspraken maar dat betreft doorgaans (alleen) uitspraken die directe gevolgen hebben voor de Poolse rechtspleging. De meeste rechters beschikken dus niet over algemene kennis van de belangrijkste rechtspraak van het EHRM. Zie hierover Kamiński, p. 227: 'Although local audiences know its general text [of the European Convention, toev. DdV] (...), they are often not familiar with the case law of the Convention institutions, despite the fact that it is the case law that elucidates what the Convention actually is and what requirements it imposes upon member states. Without a firm grasp of the Strasbourg jurisprudence, judges cannot use it when deciding on domestic cases related to Convention rights. It is not surprising, therefore, that they prefer to wait for higher courts to settle Convention issues. The relatively simple task of translating the main case law of the European Court of Human Rights or preparing its comprehensive description in local languages could eliminate this glaring lack of judicial material. Although some initiatives aimed to resolve this problem have been financed by the Council of Europe, in many cases, these efforts consisted of translating particular judgments only when their content was relevant to specific legal proceedings pending in a given country. Such 'targeted' activity cannot fill the gap.'

123 Illustratief is de opmerking van een rechter van de provinciale rechtbank van Lublin: 'Judges did not learn about this part of law during their studies. Sometimes we are informed about Polish cases but we think it does not concern our work. There are a lot of practical problems. I think the minister of justice should act to improve this situation: he should tell 
rechtadvocaten is de situatie (grotendeels om dezelfde redenen als ten aanzien van de rechterlijke macht) overigens niet veel anders. In strafzaken wordt door de verdediging in de regel geen beroep gedaan op Straatsburgse normen, deels ook omdat men vermoedt dat de rechter niet gevoelig zal zijn voor dergelijke argumenten. ${ }^{124}$ Hierdoor houdt de situatie zichzelf in stand. Een en ander betekent overigens niet dat Poolse burgers de gang naar Straatsburg niet weten te vinden: integendeel. Sinds de erkenning van het individueel klachtrecht behoort Polen regelmatig tot de top drie van landen met het hoogste aantal klachten. ${ }^{125}$

\subsubsection{Nieuwe strafrechtelijke codificaties (1997)}

Dat de strafwetgeving na de politieke omwenteling van 1989 ingrijpend moest worden herzien, stond als een paal boven water. De vorm die het straf(proces)recht gedurende de communistische periode had gekregen, was op belangrijke punten onverenigbaar met de eisen die in een rechtsstaat aan een eerlijk strafproces mogen worden gesteld en de in het EVRM vastgelegde standaard die ook voor Polen zou gaan gelden. Hervorming werd echter niet alleen gezien als een verplichting maar ook als vervulling van een langgekoesterde wens die gedurende het gehele communistische regime bij het gros van de bevolking en de juridische doctrine ${ }^{126}$ had geleefd. De aanzetten en pogingen tot hervorming die voor 1989 tot teleurstellende resultaten hadden geleid of door politieke ontwikkelingen de kop in waren gedrukt, konden nu eindelijk doorgang vinden. Na de politieke omwenteling van 1989 hervatte de in 1987 in het leven geroepen codificatiecommissie haar taak maar het zou enige tijd duren voordat volledig nieuwe strafrechtelijke codificaties het licht zouden zien. Pas in juni 1997 - acht jaar later - werden een nieuw wetboek van strafrecht, strafprocesrecht en tenuitvoerlegging

judges where they can find the case law and how they should use it.' Bron: gesprek rechter provinciale rechtbank Lublin, oktober 2004 Lublin.

124 Zie ook hoofdstuk 8, § 3. Dat Straatsburgse normen geen onderdeel uitmaken van de dagelijkse (strafrechts)prakijk kan overigens niet kenmerkend worden genoemd voor Polen of de Centraal- en Oost-Europese regio: er zijn immers ook West-Europese systemen waar het EVRM niet of nauwelijks is 'ingebakken' in de rechtscultuur. Zo wordt onder meer ook in Frankrijk door advocaten zeer terughoudend gebruik gemaakt van de mogelijkheden die het EVRM biedt. Zie Prakken 2003, p. 954.

125 Klachten worden soms met en soms zonder de hulp van een advocaat ingediend. Er is - zoals waarschijnlijk in alle lidstaten - een beperkt aantal Poolse advocaten die regelmatig procederen in Straatsburg. Het hoge aantal klachten had volgens Drzemczewski en Nowicki oorspronkelijk ook te maken met het feit dat veel Polen verkeerde verwachtingen hebben van Straatburgse instanties: 'Many persons who lodge complaints from Poland mistakenly believe that all perceived harm to them can be put right in Strasbourg. People appeal against what they consider unjust convictions, failing to realize that the Strasbourg Court is not another appeal instance. Some even ask for a job, financial relieve, or lodgings.' De laatste jaren kan op dit punt echter een verbetering worden waargenomen: 'With time, however, favourable changes can be observed in this respect: applications now tend to be better prepared, and even fewer of them concern events from the distant past. Also, applicants now seem to have a better understanding of the limits of the protection offered by the Convention': Drzemczewski en Nowicki 2001, p. 678 en 673.

126 De kritische houding die Poolse rechtsgeleerde auteurs ten tijde van het communisme innamen, zal in de hiernavolgende hoofdstukken nog nader worden toegelicht. 
van straffen door de Sejm (Poolse parlement) aangenomen. ${ }^{127}$ Dat het lang duurde had in de eerste plaats te maken met de enorme omvang van de opdracht maar was ook een gevolg van het feit dat moeilijk overeenstemming kon worden bereikt over de precieze omvang en inhoud van de door te voeren wijzigingen. De zwakke plekken van het socialistische strafproces waren duidelijk - de onevenredig grote machtspositie van de prokuratura, de regeling en praktijk ten aanzien van de voorlopige hechtenis, het tekort aan rechterlijke controle op het vooronderzoek, de onevenwichtige verhouding tussen voor- en eindonderzoek en de ontoereikende rechtsbescherming voor verdachte - maar over de vraag hoe deze moesten worden aangepakt werd verschillend gedacht. ${ }^{128}$ Daar kwam bij dat de criminaliteit in Polen in de loop van de jaren negentig net als in veel andere postcommunistische landen sterk leek te groeien en in ieder geval een andere, meer georganiseerde vorm aannam. Hoewel over de vraag of criminaliteit sinds de val van het communisme daadwerkelijk is toegenomen verschillend wordt gedacht, staat vast dat gevoelens van onveiligheid en daarmee - zoals gebruikelijk ook de roep om een efficiënt en effectief strafproces in deze periode sterker werden. ${ }^{129}$ Ook daarmee werden de opstellers van de nieuwe wetgeving geconfronteerd wat ongetwijfeld van invloed is geweest op hun werk.

Het feit dat de nieuwe codificaties een aantal jaren op zich lieten wachten, wil echter niet zeggen dat in de tussenliggende periode het oude straf(proces)recht zoals dat tijdens het communisme gold onverkort van toepassing bleef. In navolging van de in de eerder genoemde wet van mei 1989 die reeds voor de politieke omwenteling een aantal belangrijke wijzigingen had geïntroduceerd, werden in de periode tot 1997 verschillende wetswijzigingen doorgevoerd die blijkbaar zo

127 Het nieuwe wetboek van strafvordering trad in werking op 1 september 1998 (wet van 6 juni 1997, Dz. U. nr. 89, 555).

128 Cieślak en Janczukowicz merken in dit verband op dat het wetgevingsproces werd beheerst door vier - op sommige punten conflicterende - stromingen, te weten:

1. een rechtsbeschermende stroming gestimuleerd door het streven naar Europese integratie en gericht op versterking van de rechten van de burger,

2. een praktische en opportunistische stroming: rekening houdend met de behoeften van de rechtspraktijk en de mogelijkheden en beperkingen van de daarin werkzame organen,

3. een stroming gericht op het Westen gebaseerd op de Poolse voorliefde voor het volgen van 'vreemde' voorbeelden en

4. een nostalgische en conservatieve stroming gericht op het rechtssysteem van voor Wereldoorlog II: Cieślak en Janczukowicz 1998, p. 22.

129 Weigend 2003, p. 155. Zie over de toename van criminaliteit als postcommunistisch verschijnsel onder meer: Lévay 2000 en Krajewksi 2004. Krajewski is van mening dat de aard en de omvang van het criminaliteitsprobleem sinds 1989 wel degelijk is veranderd: 'In quantitive terms, Poland, like other countries of central and eastern europe, experienced a substantial and continuing growth of crime. In qualitive terms, there were also major changes in the nature and pattern of crime. First, organized crime and serious ecenomic crime started to flourish amidst economic transformation and privatization. Second, street crime also changed significantly. Violent crime, including its serious forms involving firearms (something unheard of before 1989), became much more common. Juvenile delinquency, previously dominated by petty property offences, became more violent and grew in volume. Also, use of illicit drugs, although not unknown under communism, established itself on a pattern fairly similar to that in the countries of Western europe, with all its consequences - from illegal drug dealing to public health and public order problems': Krajewski 2004, p. 379. 
urgent werden geacht dat de nieuwe wetgeving niet kon worden afgewacht. Tot de meest belangrijke in die categorie moeten in ieder geval de wijzigingen op het gebied van de rechtsmiddelen en de beslissingsbevoegdheid ten aanzien van de toepassing van voorlopige hechtenis worden gerekend. Zoals in § 2.2.1.2 duidelijk is geworden, was het systeem van rechtsmiddelen gedurende de communistische periode ingrijpend veranderd: het hoger beroep en de gewone cassatie zoals die voor Wereldoorlog II in het Poolse strafprocesrecht voorkwamen, werden in de eerste jaren van het stalinisme geschrapt en vervangen door rewizja (een soort herziening) en een bijzondere vorm van cassatie: rewizja nadzwyczajna. In 1996 kwam hier verandering in en werd grotendeels teruggekeerd naar de situatie van het interbellum: de twee laatstgenoemde rechtsmiddelen kwamen te vervallen en hoger beroep en cassatie werden opnieuw in het Poolse strafprocesrecht geïntroduceerd. Ten aanzien van voorlopige hechtenis gold dat de bevoegdheid om deze vorm van vrijheidsneming te bevelen voortaan was voorbehouden aan de rechter. ${ }^{130}$ De prokurator die voorheen gedurende het vooronderzoek zelfstandig over voorlopige hechtenis kon beslissen, diende de rechtbank voortaan om toepassing van het dwangmiddel te verzoeken. De noodzaak van deze wijziging - die door velen tot een van de meest belangrijke postcommunistische wijzigingen van het strafprocesrecht wordt gerekend - werd al snel bevestigd door het EHRM. In een reeks uitspraken tegen Polen heeft het Hof uitgemaakt dat de prokurator niet als judicial officer in de zin van art. 5 lid 3 EVRM kon worden aangemerkt omdat hij vanwege het feit dat hij onderdeel uitmaakt van de uitvoerende macht en vanwege zijn opsporende en vervolgende taken niet beschikte over de daarvoor noodzakelijke garanties voor wat betreft onafhankelijkheid en onpartijdigheid. ${ }^{131}$

\section{Nieuw strafprocesrecht 1997}

Het nieuwe wetboek van strafvordering heeft op een groot aantal punten veranderingen teweeggebracht maar betekende geen radicale breuk met het strafprocesrecht van voor 1989. Zo is de structuur van het strafproces in beginsel hetzelfde gebleven: het vooronderzoek kent net als voorheen twee vormen (śledztwo en dochodzenie) en ook het onderzoek ter terechtzitting is in hoofdlijnen op dezelfde manier opgebouwd als gedurende het communisme. Bovendien zijn de belangrijkste procesdeelnemers dezelfde gebleven en is bijvoorbeeld niet gekozen voor afschaffing van de lekenrechtspraak of (her)introductie van de rechter-commissaris. De wetgever van de jaren negentig heeft dus niet een volledig nieuw strafproces willen introduceren maar vooral gestreefd naar herstel van de onevenwichtige verhoudingen tussen de verschillende fasen van de strafrechtelijke procedure ener-

130 Wetswijziging van juni 1995, inwerking getreden in augustus 1996.

131 Voor het eerst uitgemaakt in Niedbata t. Polen, EHRM 4-7-2000, nr. 27915/95 en later herhaald in onder andere Dacewicz t. Polen, EHRM 2-7-2002, nr. 34611/97, Eryk Kawka t. Polen, 27-6-2002, nr. 33885/96 en M.B. t. Polen, 27-4-2004, nr. 34091/96. Uit deze rechtspraak volgt dat het horen van verdachten door de prokurator voorafgaand aan de toepassing van voorlopige hechtenis onvoldoende tegemoetkomt aan de door art. 5 lid 3 EVRM gestelde eis dat een aangehouden of in hechtenis genomen verdachte 'shall be brought promptly before a judge or other officer authorised by law to exercise judicial power'. Door de Poolse regering gevoerde verweren dat de prokuratura destijds ook een rechtsbeschermende taak had en dat bovendien tegen de toepassing van voorlopige hechtenis beroep kon worden ingesteld bij de rechter, deden daar volgens het Hof niets aan af. 
zijds en tussen de verschillende procesdeelnemers anderzijds. ${ }^{132}$ Dit streven kwam tot uitdrukking in de volgende sterk met elkaar samenhangende doelstellingen:

- het realiseren van meer rechterlijke controle op het vooronderzoek en een evenwichtiger verhouding tussen voor- en eindonderzoek,

- het versterken van het adversair karakter van het onderzoek ter terechtzitting door meer gelijkheid te creëren tussen vervolging en verdediging en

- het verbeteren van de rechtspositie van verdachte en slachtoffer.

Door de ontwerpers van het nieuwe wetboek werd expliciet benadrukt dat bij realisatie van deze doelstellingen nauw aansluiting moest worden gezocht bij het EVRM zodat het nieuwe strafprocesrecht daarmee zoveel mogelijk in overeenstemming zou zijn. ${ }^{133}$

\subsubsection{Hoofdpunten postcommunistische hervorming strafproces}

Hierna zal worden beschreven op welke wijze in het nieuwe wetboek van strafvordering invulling is gegeven aan bovengenoemde doelstellingen. De focus ligt daarbij op een aantal onderwerpen die voor het eerst of anders dan voorheen zijn geregeld: het is dus niet bedoeld als uitputtende weergave van het nieuwe strafprocesrecht. Een meer uitgebreide beschrijving van de strafrechtelijke procedure zoals die in het wetboek van 1997 is vormgegeven, volgt in § 3 waar de hoofdlijnen van het huidige strafproces zullen worden besproken.

\subsubsection{Verhouding voor-en eindonderzoek}

In het kader van de uitbreiding van het rechterlijk toezicht op het vooronderzoek is zoals gezegd niet gekozen voor herintroductie van de rechter-commissaris. Wel heeft de gewone rechter beduidend meer zeggenschap gekregen in deze fase van de procedure. Om te beginnen is een aantal ingrijpende beslissingen die voorheen door niet-rechterlijke organen - meestal de prokurator - werden genomen voortaan voorbehouden aan de rechter. In dit opzicht is de reeds genoemde wijziging ten aanzien van de voorlopige hechtenis de belangrijkste. Het is een aanzienlijke verbetering dat beslissingen over de toepassing en verlenging van dit dwangmiddel nu zijn voorbehouden aan een onafhankelijke rechter en niet langer zijn overgelaten aan de met opsporing en vervolging belaste prokuratura. Andere onderwerpen waarover volgens het huidige strafprocesrecht gedurende het vooronderzoek alleen door de rechter kan worden beslist, zijn bijvoorbeeld (niet limitatief): het opnemen van een verdachte in een kliniek ten behoeve van psychiatrisch onderzoek, het afluisteren en opnemen van telefoongesprekken en de vraag of verklaringen van kroongetuigen voor het bewijs kunnen worden gebezigd. Behalve beslissingen die aan de rechtbank zijn voorbehouden, zijn er op grond van het nieuwe strafprocesrecht twee onderzoekshandelingen die gedurende het vooronderzoek alleen door de rechter kunnen worden verricht: het gaat daarbij om het horen van de verdachte voorafgaand aan de beslissing over toepassing van voorlopige hechtenis en om het horen van getuigen van wie gevreesd wordt dat ze niet op de zitting zullen kunnen verschijnen. ${ }^{134}$ Ten slotte heeft de recht-

132 Wiliński 2006, p. 117.

133 Fredrich-Michalska en Stachurska-Marcińczak 1997, p. 393 en 420.

134 Respectievelijk art. 249 lid 3 art. 316 lid 3 KPK 1997. Beide regelingen zijn nieuw ten 
bank in het nieuwe strafprocesrecht een belangrijke functie in het vooronderzoek voor wat betreft de behandeling van klachten ('bezwaren') die kunnen worden ingesteld tegen beslissingen van niet rechterlijke organen zoals de prokuratura. ${ }^{135}$ Meer nadruk op het eindonderzoek heeft men met name willen realiseren door benadrukking en versterking van het uitgangspunt dat alle bewijs in beginsel mondeling op het onderzoek ter terechtzitting moet worden gepresenteerd (onmiddellijkheidsbeginsel). Dit komt in het wetboek van strafvordering van 1997 onder meer tot uitdrukking in het aan banden leggen van de mogelijkheden om bewijs uit het vooronderzoek te gebruiken. Deze beperkingen - die af moesten rekenen met de praktijk van voor 1989 waarin het onderzoek ter terechtzitting vaak niet of nauwelijks toegevoegde waarde had - hebben voornamelijk betrekking op verklaringen: zo is bijvoorbeeld een nadere omschrijving gegeven van de omstandigheden waaronder verklaringen van verdachten en getuigen uit het vooronderzoek op het onderzoek ter terechtzitting mogen worden voorgelezen. ${ }^{136}$ Een verdere beperking is gerealiseerd door introductie van het verbod aantekeningen voor te lezen van handelingen waarvan eigenlijk proces verbaal had moeten worden opgemaakt en het aan banden leggen van de mogelijkheid stukken aan te nemen zonder ze op de zitting voor te lezen. ${ }^{137}$ De nadruk op onmiddellijkheid blijkt ook uit de beperking van het aantal gevallen waarin de zaak gedurende het eindonderzoek voor aanvulling van het onderzoek wordt terugverwezen naar het vooronderzoek. ${ }^{138}$ Ten slotte is van belang dat de wetgever de doelstellingen van het vooronderzoek in het nieuwe wetboek van strafvordering minder 'ambitieus' heeft geformuleerd dan in het oude wetboek. Waar het oude strafprocesrecht 'het aan het licht brengen van de omstandigheden van de zaak vanuit

opzichte van voor 1989: voorheen werd voorlopige hechtenis gedurende het vooronderzoek immers door de prokuratura bevolen en de verdachte voorafgaand door de prokurator - en niet de rechtbank - gehoord en een met art. 316 lid 3 KPK 1997 vergelijkbare bepaling bestond in het strafprocesrecht van 1969 niet. In de toelichting op het wetboek wordt art. 316 lid 3 KPK 1997 karakteristiek genoemd voor de nieuwe rol van de rechter in het vooronderzoek: Fredrich-Michalska en Stachurska-Marcińczak 1997, p. 425. Meer over laatstgenoemde bevoegdheid in hoofdstuk 5 , § 5.2.3.

135 De rechtbank behandelt bijvoorbeeld het bezwaar dat een verdachte indient tegen zijn aanhouding of tegen beslissingen tot doorzoeking en inbeslagneming (respectievelijk art. 246 en 236 KPK 1997). Op het bezwaar wordt teruggekomen in § 3.2.3.1. Zie ook: Wiliński 2006, p. 118-119 en Grajewski 2005, p. 101-111. Over bovengenoemde drie functies van de rechter in het vooronderzoek: Weigend 2003, p. 158-159.

136 Art. 389, 391 en 392 KPK 1997.

137 Respectievelijk art. 393 lid 1 laatste zin en 394 lid 1 en 2 KPK 1997. Over deze nieuwe regelingen: Bieńkowska 1997, p. 58. Overigens blijkt uit deze en andere bepalingen dat het nieuwe wetboek van strafvordering afwijking van onmiddellijkheid in een aantal gevallen afhankelijk maakt van de vraag of partijen er mee instemmen (zie bijvoorbeeld art. 392 en 394 lid 1 KPK 1997). Vergelijkbare regelingen bestonden ook in het strafprocesrecht van 1928 en 1969 en werden in de doctrine bekritiseerd. Veel auteurs waren van mening dat het realiseren van onmiddellijkheid niet mag afhangen van de wens van partijen maar slechts afhankelijk kan zijn van de vraag op welke wijze de waarheid het best aan het licht kan worden gebracht: Bieńkowska 1997, p. 58 en 59 en daar genoemde literatuur.

138 Art. 344 lid 1 en 2 KPK 1969 en art. 345 en 397 KPK 1997. Zie hierover: Bieńkowska 1998, p. 27. 
alle mogelijke perspectieven' tot de doelstellingen van het vooronderzoek rekende, is tegenwoordig slechts geregeld dat de omstandigheden van de zaak aan het licht moeten worden gebracht: de zinsnede 'vanuit alle mogelijke perspectieven' ('wszechstronne') is komen te vervallen. Bovendien is tegenwoordig bepaald dat het verzamelen van bewijsmateriaal gedurende het vooronderzoek slechts nog 'in de mate waarin het noodzakelijk is' ('w niezbędnym zakresie') hoeft plaats te vinden. ${ }^{139}$ Door op deze wijze de bewijsopdracht voor politie en prokuratura meer 'bescheiden' te formuleren, heeft de wetgever het zwaartepunt van de bewijsvoering meer naar het onderzoek ter terechtzitting willen verschuiven.

\subsubsection{Adversair karakter eindonderzoek}

Voor de de typering van verschillende processtijlen - en met name ter verduidelijking van het onderscheid tussen common law en civil law rechtssystemen worden van oudsher de termen adversair (of accusatoir) en inquisitoir gebruikt. Tussen de common law en civil law rechtsfamilies bestaan principiële verschillen in opvatting over de wijze waarop de waarheid aan het licht dient te worden gebracht en deze verschillen hebben consequenties voor de vormgeving van het strafproces. Kort weergegeven, ligt aan een adversaire processtijl de idee ten grondslag dat de waarheid het beste kan worden achterhaald door partijen in een gelijkwaardige strijd hun versie van de waarheid te laten presenteren. De rechter speelt in dit proces een passieve rol en heeft als voornaamste taak te controleren of procedureregels worden nageleefd. In de inquisitoire procesvorm wordt waarheidsvinding hoofdzakelijk als taak van de overheid beschouwd. Volgens deze opvatting dient het onderzoek ter terechtzitting - onder leiding van een actieve rechter - vooral ter verificatie van de onderzoeksresultaten die staatsfunctionarissen in het vooronderzoek hebben verzameld. ${ }^{140}$ Benadrukking van het adversair karakter van het eindonderzoek heeft dus vooral betrekking op de verhouding tussen procesdeelnemers, hun aandeel in de waarheidsvinding en - daarmee onlosmakelijk verbonden - de mate van tegenspraak in dit stadium van de procedure. Voor een daadwerkelijk adversair eindonderzoek zijn twee zaken van essentieel belang: in de eerste plaats dat vervolging en verdediging zoveel mogelijk gelijke rechten en bevoegdheden en dus een gelijkwaardige positie hebben en in de tweede plaats dat de rechter onpartijdig is en niet de taken van een van beide procespartijen voor zijn rekening neemt. Met het oog op dat laatste punt heeft de Poolse wetgever een tweetal wijzigingen doorgevoerd om te voorkomen dat de rechter net als voor 1989 te veel op de stoel van de prokurator gaat zitten. Ten eerste wordt de akte van beschuldiging anders dan voorheen niet meer door de

139 Respectievelijk art. 261 sub 2 KPK 1969 vergeleken met art. 297 lid 1 sub 4 KPK 1997 en art. 261 sub 5 KPK 1969 vergeleken met art. 297 lid 1 sub 5 KPK 1997.

140 Zie onder meer Damaška 1973, Hermann 1996 en Brants 2008. Bovengenoemde typering van de adversaire processtijl wordt doorgaans ook wel met de term accusatoir aangeduid: beide begrippen worden veelal als synoniemen gebruikt. Hier wordt de voorkeur gegeven aan de term adversair omdat deze - zoals eerder benadrukt door Brants - beter weergeeft waar het om gaat (tegenstanders die de strijd om de waarheid uitvechten). Brants noemt overigens nog een tweede argument waarom de term adversair te prefereren is boven accusatoir: laatstgenoemd begrip wordt in Duitsland ook wel gebruikt ter aanduiding van de inquisitoire processtijl waardoor het tot veel verwarring kan leiden. Zie Brants 2008, p. 229. 
rechter maar door de prokurator voorgelezen. ${ }^{141}$ Ten tweede is een nieuwe volgorde voor het stellen van vragen aangenomen die dient te bewerkstelligen dat de ondervraging van verdachten, getuigen en deskundigen op het onderzoek ter terechtzitting minder wordt gedomineerd door de rechter en meer een verantwoordelijkheid van de procespartijen wordt. Volgens de nieuwe regeling stelt de voorzitter pas als laatste - na alle andere procesdeelnemers - vragen aan personen die ter zitting worden gehoord. ${ }^{142}$ Hoewel met deze wijzigingen is getracht de rechter een minder sturende rol te laten spelen in het onderzoek ter terechtzitting is hij ook volgens het nieuwe wetboek van strafvordering nog altijd de leider van het eindonderzoek. In die hoedanigheid is hij verantwoordelijk voor het juiste verloop van de zitting en als enige bevoegd om over de toelaatbaarheid van bewijsmiddelen te beslissen. ${ }^{143}$

Om meer gelijkheid tussen vervolging en verdediging te realiseren is in het nieuwe wetboek voor verdachte de mogelijkheid gecreëerd om schriftelijk te reageren op de akte van beschuldiging. ${ }^{144}$ Wanneer van dit recht gebruik wordt gemaakt, wordt de rechtbank reeds voor de aanvang van het onderzoek ter terechtzitting met de standpunten van de verdachte c.q. de verdediging geconfronteerd wat kan voorkomen dat de rechter - eenzijdig beïnvloed door de akte van beschuldiging - bevooroordeeld aan het eindonderzoek begint. ${ }^{145}$

In het nieuwe strafprocesrecht zijn echter ook enkele wijzigingen doorgevoerd die vanuit het verlangen om tot een efficiënter strafproces te komen juist tot gevolg hebben dat niet in alle strafzaken een volledig contradictoir eindonderzoek hoeft te worden gerealiseerd. Zo is de mogelijkheid om het onderzoek ter terechtzitting in afwezigheid van de verdachte uit te voeren - wat voorheen alleen mogelijk was in een aantal bijzondere procedures - uitgebreid tot het gewone strafproces. ${ }^{146}$ Bovendien zijn er in het nieuwe wetboek meer mogelijkheden om een strafzaak zonder (volledig) onderzoek ter terechtzitting af te doen. Naast de reeds bestaande mogelijkheid om met toestemming van procespartijen de bewijsvoering op het onderzoek ter terechtzitting sterk te reduceren, ${ }^{147}$ zijn twee nieuwe alternatieven geïntroduceerd:

141 Alleen bij afwezigheid van de prokurator - in bepaalde bijzondere procedures is zijn aanwezigheid niet verplicht - wordt de akte nog door een van de leden van de rechtbank voorgelezen.

142 Art. 370 lid 1 KPK 1997. Volgens de oude regeling werden eerst vragen gesteld door de voorzitter en daarna pas door procespartijen wat tot een passieve opstelling van partijen leidde (art. 314 lid 1 KPK 1969). Meer over het ondervragen van personen op de zitting in hoofdstuk 6, § 4.4.2.

143 Art. 366 en 369 KPK 1997.

144 Art. 338 lid 2 KPK 1997.

145 Bovendien hoopte men dat deze mogelijkheid de verdediging zal stimuleren om in een vroeg stadium van de procedure actief te worden en bewijsverzoeken in te dienen: Weigend 1991, p. 38. Meer hierover in hoofdstuk 6, § 2.1.

146 In art. 376 en 377 KPK 1997 is een aantal situaties genoemd waarin de rechtbank de procedure zonder de verdachte kan voeren. Ook het aantal gevallen waarin een gedetineerde verdachte niet aanwezig hoeft te zijn bij het uitspreken van het vonnis is uitgebreid: art. 419 lid 2 KPK 1997.

147 Art. 388 KPK 1997, voorheen geregeld in art. 333 KPK 1969. 
- strafoplegging op verzoek van de prokurator zonder onderzoek ter terechtzitting 148

- strafoplegging op verzoek van verdachte zonder bewijsvoering ter terechtzitting. ${ }^{149}$

Op beide laatstgenoemde regelingen en de uitzonderingen op de regel dat de verdachte aanwezig moet zijn op het onderzoek ter terechtzitting wordt teruggekomen in hoofdstuk 6.150

\subsubsection{Rechtsbescherming slachtoffer en verdachte}

Uitbreiding van de rechten van het slachtoffer is onder meer gerealiseerd door hem naast de verdachte de officiële status van partij in het vooronderzoek toe te kennen. ${ }^{151}$ Veel van de aan de verdachte toegekende rechten en bevoegdheden komen daardoor nu ook aan het slachtoffer toe waardoor deze actief kan deelnemen aan dit stadium van de procedure. ${ }^{152}$ Bovendien zijn de mogelijkheden voor slachtoffers om in de hoedanigheid van hulpaanklager (oskarżyciel posiłkowy) vervolging in te stellen uitgebreid. 153

De positie van de verdachte heeft op een groot aantal punten veranderingen ondergaan. Tot een van de belangrijkste wijzigingen wordt het nieuwe art. $300 \mathrm{KPK}$ 1997 gerekend. Deze bepaling regelt dat een verdachte voorafgaand aan zijn eerste verhoor mondeling en schriftelijk van een aantal belangrijke rechten en plichten op de hoogte moet worden gesteld. ${ }^{154}$ Tot deze verzameling rechten die aan de verdachte moet worden medegedeeld - in de praktijk gebeurt dit door middel van overhandiging van een standaardformulier dat door verdachte moet worden ondertekend (letter of rights) - behoren onder meer het zwijgrecht, het recht om verzoeken in te dienen tot het verrichten van bepaalde onderzoekshandelingen gedurende het vooronderzoek, het recht om gebruik te maken van de bijstand van een raadsman en om te verzoeken deze raadsman aanwezig te laten zijn bij (politie)verhoren. In het oude wetboek van strafvordering was niet met zoveel woorden bepaald dat verdachten op de hoogte moesten worden gesteld van hun zwijgrecht. Het Hooggerechtshof bepaalde in 1973 zelfs dat autoriteiten op basis van de wettelijke bepaling waarin het recht om geen verklaring af te leggen was vastgelegd (art. 63 KPK 1969) niet verplicht waren om verdachten hiervan op de hoogte te stellen. ${ }^{155}$ Op grond van het nieuwe strafprocesrecht kan er geen twijfel meer over bestaan dat de verdachte voorafgaand aan zijn eerste verhoor - gedurende het vooronderzoek en opnieuw ter terechtzitting - moet worden geïnformeerd over zijn zwijg-

148 Art. 335 jo. 339 KPK 1997.

149 Art. 387 KPK 1997.

150 Respectievelijk § 3 en 4.2.

151 Art. 299 KPK 1997.

152 Zo kan hij verzoeken indienen tot het uitvoeren van onderzoekshandelingen, aan deze handelingen deelnemen en in de door de wet omschreven gevallen bezwaar aantekenen tegen bepaalde beslissingen.

153 Zie over deze mogelijkheid ook $\S 3.1 .2$.

154 Zie hierover: Stachowiak 2001.

155 Uitspraak van 25 juli 1979 (V KRN 102/79 en V KRN 1213/79) genoemd in Wiliński 2006, p. 110. 
recht. ${ }^{156}$ Ook van belang is dat het nieuwe wetboek van strafvordering meer aandacht besteedt aan de wijze waarop het verhoor van verdachten dient plaats te vinden. Zo is bijvoorbeeld veel nauwkeuriger omschreven welke verhoormethoden ontoelaatbaar zijn. ${ }^{157}$ De wetgever heeft met deze nieuwe bepalingen willen afrekenen met de praktijk van voor 1989 waarin het afleggen van verklaringen voor verdachten met weinig wettelijke waarborgen was omkleed. De verklaring van verdachte werd wel als volwaardig bewijsmiddel erkend maar het wetboek van strafvordering besteedde er nauwelijks enige aandacht aan. ${ }^{158}$ Hoewel verklaringen vaak niet in vrijheid werden afgelegd, vormden ze in een aanzienlijk deel van de strafzaken wel het voornaamste bewijs. ${ }^{159}$

Verbetering van de positie van verdachten had ten slotte voor een belangrijk deel betrekking op het recht op rechtsbijstand en de wijze waarop dit recht met name gedurende het vooronderzoek geëffectueerd kan worden. Een van de doelstellingen van de wetgever was om de advocaat een actievere rol te laten spelen in het vooronderzoek. Omdat in de hiernavolgende hoofdstukken uitgebreid aandacht zal worden besteed aan de postcommunistische wetswijzigingen die betrekking hebben op de verdediging wordt hier volstaan met een korte weergave van de meest belangrijke hervormingen:

- De gevallen van verplichte rechtsbijstand zijn uitgebreid. Aangezien een aantal gevallen van verplichte rechtsbijstand zich ook uitstrekt over het vooronderzoek zou deze wijziging moeten leiden tot meer activiteit van advocaten in het vooronderzoek. ${ }^{160}$

156 Voor de situatie voorafgaand aan het eerste verhoor blijkt dit uit eerder genoemd art. 300 KPK 1997. Daarnaast is in de huidige wettelijke regeling van het zwijgrecht expliciet bepaald dat de verdachte moet worden ingelicht over dit recht (art. 175 lid 1 laatste zin KPK 1997) en is bovendien geregeld dat de zittingsrechter deze informatie opnieuw aan de verdachte moet meedelen bij aanvang van het onderzoek ter terechtzitting (art. 386 lid 1 KPK 1997). Wanneer de verdachte ten onrechte niet over zijn zwijgrecht is geinformeerd, geldt de algemene regel van art. 16 lid 1 KPK 1997: indien autoriteiten verplicht zijn procesdeelnemers te informeren over bepaalde rechten of plichten en ze laten dat na, dan mag dat geen 'nadelige procedurele consequenties' ('ujemnych skutków procesowych') hebben voor de betreffende persoon. Dit houdt in dat een belastende verklaring van een verdachte die ten onrechte niet over zijn zwijgrecht is geïnformeerd niet voor het bewijs kan worden gebruikt. Er kan dan wel nog steeds een veroordeling volgen: niets staat er aan in de weg dat op basis van ander bewijsmateriaal tot een bewezenverklaring wordt gekomen. Zie Hofmański e.a. 2007 I, p. 796-797.

157 Onder meer het stellen van suggestieve vragen en het gebruik van hypnose tijdens verhoren is expliciet verboden (art. 171 lid 4 en 5 KPK 1997). Over deze bepalingen: Grzeszczyck 1997, p. 61-65.

158 Cieślak 1992, p. 481.

159 Overigens was in het wetboek van strafvordering van 1969 in tegenstelling tot de meeste andere socialistische wetboeken van strafprocesrecht uit Centraal- en Oost-Europa wel het pressieverbod en daaraan gekoppeld een bewijsuitsluitingsregel opgenomen. Die bepaling (art. 157 lid 2 KPK 1969) heeft echter niet aan bovengenoemde praktijk in de weg gestaan.

160 Art. 79 en 80 KPK 1997. Zoals hierna nog zal blijken, zijn sinds inwerkingtreding van het nieuwe wetboek van strafvordering verschillende wetswijzigingen doorgevoerd die het aantal gevallen van verplichte rechtsbijstand weer hebben verminderd. Meer hierover in hoofdstuk $4, \S 3.1 .1$. 
- Er is een nieuwe bepaling opgenomen waarin is geregeld dat een advocaat op verzoek van verdachte aanwezig mag zijn bij (politie)verhoren van zijn cliënt. ${ }^{161}$

- Het vrij verkeer is met meer garanties omkleed. Belangrijkste wijziging is dat beperkingen van het vrij verkeer in de vorm van toezicht op bezoek en controle van correspondentie alleen nog gedurende de eerste veertien dagen van de voorlopige hechtenis zijn toegestaan. ${ }^{162}$

- De regeling ten aanzien van de inzage van processtukken gedurende het vooronderzoek is enigszins verbeterd. Voor een aantal categorieën stukken is bepaald dat een verzoek tot inzage te allen tijde moet worden ingewilligd en de mogelijkheid bezwaar aan te tekenenen tegen de weigering inzage te verlenen is wettelijk vastgelegd. ${ }^{163}$

- Ook een aangehouden persoon die nog niet officieel als verdachte is aangemerkt, heeft voortaan een expliciet wettelijk recht op rechtsbijstand waaronder het recht om in contact te treden en overleg te voeren met een advocaat. ${ }^{164}$

Hoewel verbeteren van de positie van de verdachte een van de primaire doelstellingen van het nieuwe strafprocesrecht was, zijn na 1989 ook wijzigingen doorgevoerd die negatieve consequenties hebben gehad voor de positie van de verdediging. Zo is bijvoorbeeld in 1995 een anonieme getuigeregeling in werking getreden die vergaande gevolgen heeft voor de mogelijkheden van de verdediging om getuigen te ondervragen. ${ }^{165}$ Andere voorbeelden zullen in de hiernavolgende hoofdstukken nog aan de orde komen.

\subsubsection{Wijzigingen na 1997}

Het nieuwe wetboek van strafvordering is sinds zijn inwerkingtreding een groot aantal keren gewijzigd. Verreweg de belangrijkste en meest omvangrijke wetswijziging van de afgelopen jaren is die van 10 januari 2003 (in werking getreden op 1 juli van dat jaar). ${ }^{166}$ Deze wet betrof maar liefst een derde van de gehele

161 Art. 301 KPK 1997. Meer hierover in hoofdstuk 5, § 2.

162 Art. 73 KPK 1997. Meer hierover in hoofdstuk 7.

163 Een dergelijk bezwaar moet worden ingesteld bij de prokuratura: art. 157 lid 3 en 159 KPK 1997. Meer hierover in hoofdstuk 5, § 3.

164 Art. 245 KPK 1997. Op grond van het oude wetboek van strafvordering bestond hierover twijfel omdat het recht op verdediging slechts was toegekend aan de (officeel als zodanig aangemerkte) verdachte terwijl iemand op het moment van zijn aanhouding en ook in de eerste periode daarna die status nog niet noodzakelijk bezat. Zie over deze problematiek hoofdstuk $4, \S 2.2 .1$ en hoofdstuk 5, § 2.1. De wetgever heeft met deze regel - net als met de bepaling ten aanzien van rechtsbijstand tijdens verhoren - willen stimuleren dat advocaten eerder dan voorheen bij de strafrechtelijke procedure betrokken raken en meer actief deelnemen aan het vooronderzoek: Fredrich-Michalska en Stachurska-Marcińczak 1997, p. 418. Zoals in hoofdstuk 4, § 2.2.2.3 nog zal worden uiteengezet, is de rechtspositie van de aangehouden persoon op grond van het huidige strafprocesrecht nog wel onduidelijk voor wat betreft de plicht van de politie om te informeren over het zwijgrecht.

165 Art. 184 KPK 1997. Zie hoofstuk 6, § 4.4.3.3.

166 Dz. U. nr. 17, 155. Hierna aangeduid als 'de wetswijziging van 2003'. Andere voorbeelden zijn de wetswijzigingen van januari 2000 en maart en april 2004 die noodzakelijk waren in het kader van de toetreding tot de Europese Unie. Zie Bieńkowska e.a. 2004, p. 15 e.v. Zie meer specifiek over de wetswijziging van 2003 onder meer: Wiliński 2006, p. 119 e.v., Greszczyk 2003 en Waltoś 2003. 
codificatie. De voornaamste wijzigingen hadden onder meer betrekking op: de structuur van het vooronderzoek, de gevallen van verplichte rechtsbijstand, de mogelijkheden een verdachte te veroordelen zonder onderzoek ter terechtzitting en het recht van procespartijen om deel te nemen aan zittingen. Op de inhoud van verschillende van deze wijzigingen - die voor het grootste deel vooral gericht waren op een sneller en efficiënter strafproces - zal later nog worden teruggekomen. In grote lijnen kan worden gezegd dat de wetgever met deze aanpassingen het evenwicht tussen rechtsbescherming en instrumentaliteit dat volgens velen in de oospronkelijke versie van het wetboek van 1997 teveel in het voordeel van de verdediging was uitgevallen ${ }^{167}$ heeft willen herstellen. Dit is onlosmakelijk verbonden met de steeds verder toenemende werklast van de strafrechtspleging en de gemiddeld lange duur van strafrechtelijke procedures. ${ }^{168}$ De roep om meer repressie, die overigens niet alleen in Polen maar wereldwijd hoorbaar is, heeft de laatste jaren een duidelijke invloed op de criminele politiek gehad. Vanaf ongeveer 1998 - tegelijk met de inwerkingtreding van de nieuwe strafwetgeving werd de hervorming van de strafrechtspleging steeds meer gedomineerd door populistische politici die een hardere aanpak van criminaliteit propageerden. ${ }^{169}$ Deze ontwikkeling is nog verder versterkt door het aan de macht komen van Kaczyński (de huidige president van Polen) wiens conservatieve en patrottistische politieke partij Prawo i Sprawiedliwośc (Recht en Rechtvaardigheid, PiS) zich onder meer richt op een meer effectieve en efficiënte strafrechtspleging. Door meer recente politieke ontwikkelingen is de macht van deze partij echter aan het wankelen gebracht: de parlementsverkiezingen die in oktober 2007 werden gehouden, resulteerden in een nederlaag voor PiS en een overwinning voor het Burgerplatform (Platforma Obywatelska), een conservatief liberale partij. Laatstgenoemde partij leverde de nieuwe premier (Donald Tusk) waardoor het verbond van de tweelingbroers Kaczyński die samen de post van respectievelijk president en premier bezet hielden, werd verbroken. De verwachting is dat de regering onder leiding van Tusk een meer open beleid zal voeren maar wat dit concreet gaat betekenen voor de strafrechtspleging is op dit moment nog moeilijk te zeggen. ${ }^{170}$ Wel is al bekend dat het Burgerplatform een commissie in het leven heeft geroepen om een grootschalige herziening van het wetboek van strafvordering voor

167 '(...) there is a view that the tendency to establish extended systems of procedural safeguards for the accused has violated the principle of equality before the law so that the law protects those who are in conflict with the law instead of protecting the victims of unlawful acts': Zielinski 2003, p. 118.

168 Zie hierover hoofdstuk 6, § 4.1.

169 Dit in tegenstelling tot de situatie voor 1998 toen de hervorming van de strafrechtspleging vooral in handen van experts was: 'In the 1990's, Polish criminal justice policy and criminal law reform were quite clearly dominated by experts; specifically, they were directed by a group of like-minded experts who were somehow able to convince the various political coalitions that formed governments during this period that such direction was proper. (...) This changed around 1998. (...) This new legislation [the new criminal codes, toev. DdV], considered as the final achievememt of criminal law reform and the rationalization of criminal justice policy, immediately came under strong fire from the media and from some politicans. It was mainly criticized as being too liberal and lenient at a time of rising crime, and also as contrary to the prevailing public mood': Krajewski 2004, p. 401-402.

170 Kaczyński kan wetsvoorstellen van de nieuwe regering echter nog dwarsbomen door een veto uit te spreken. 
te bereiden. Het eerste ontwerp van deze commissie was op het moment van afronding van dit onderzoek nog in bewerking.

\section{Inrichting van het Poolse strafproces}

Het Poolse strafproces bestaat uit drie fasen: een vooronderzoek waarin de verdachte object van onderzoek is en de toepassing van dwangmiddelen dient te dulden, een eindonderzoek waarin gelijkheid tussen het openbaar ministerie en verdachte het uitgangspunt is en de fase van tenuitvoerlegging. In het opsporingsonderzoek dient door instanties ook aandacht te worden besteed aan ontlastend bewijsmateriaal - verzamelen van dergelijk bewijs is niet de taak (althans niet een verplichting) van de verdediging - en op het onderzoek ter terechtzitting heeft de rechter de leiding over de bewijsvoering. Deze structuur wordt wel getypeerd als gematigd accusatoir ${ }^{171}$ en is kenmerkend voor de meeste continentale systemen. In het historische deel van dit hoofdstuk zijn al verschillende kenmerken van het Poolse strafproces aan de orde gekomen. Deze zullen in het onderstaande worden aangevuld door de strafrechtelijke procedure zoals die vandaag de dag in Polen wordt gevoerd in hoofdlijnen te bespreken. Daarbij zal eerst aandacht worden besteed aan de belangrijkste procesdeelnemers. Zoals in de inleiding aangegeven, zal in het kader van dit hoofdstuk voor wat betreft de raadsman worden volstaan met een aantal algemene thema's zoals wie er als raadsman op kan treden en hoe en door wie een advocaat in een strafzaak kan worden benoemd. Onderwerpen die betrekking hebben op de rechten en bevoegdheden van de verdediging in strafzaken komen in de hiernavolgende hoofdstukken meer uitgebreid aan de orde. Het tweede gedeelte van deze paragraaf is gewijd aan de structuur van het strafproces. Aan bod zal komen hoe de procedure volgens het huidige strafprocesrecht is opgebouwd, welke stadia kunnen worden onderscheiden en wat de rol van de verschillende procesdeelnemers daarin is.

\subsection{Procesdeelnemers}

\subsubsection{Rechter en prokuratura}

De rechter en de openbaar aanklager (prokurator) behoren - naast de verdachte en zijn eventuele raadsman - tot de belangrijkste deelnemers aan het strafproces. In het eerste deel van dit hoofdstuk is in grote lijnen duidelijk geworden welke gevolgen het communisme heeft gehad voor zowel de rechterlijke macht als de prokuratura en wat dit betekende voor de machtsverhoudingen tussen beide instanties. Herstel van deze onevenwichtige machtsverhouding was een van de belangrijkste doelstellingen van de postcommunistische hervorming van de strafrechtspleging. Dit heeft tot belangrijke veranderingen in de structuur van beide organen geleid.

171 Of getemperd inquisitoir: Corstens 2005, p. 8. Wanneer net als in Polen het zwaartepunt van de procedure in ieder geval voor wat betreft de bewijsvoering in het meer inquisitoire vooronderzoek ligt, is deze laatste typering wellicht het meest passend. 


\subsubsection{Rechterlijke macht}

Wat de organisatie van de rechterlijke macht betreft, zijn er momenteel vier verschillende instanties die kennis nemen van strafzaken: ${ }^{172}$

1. Sad Rejonowy (SR, districtsrechtbank, voorheen Sąd Powiatowy),

2. Sąd Okręgowy (SO, provinciale rechtbank, voorheen Sąd Wojewódzki),

3. Sąd Apelacyjny (SA, hoger beroepsinstantie),

4. Sąd Najwyższy (SN, Hooggerechtshof). ${ }^{173}$

In het Poolse strafrecht worden verschillende soorten strafbare feiten onderscheiden. Een strafbaar feit (przestępstwo) kan de vorm van een zbrodnia of een występek hebben. Eerstgenoemde categorie is zwaarder en betreft feiten waarop ten minste drie jaar gevangenisstraf staat. Laatstgenoemde categorie heeft betrekking op feiten die worden bedreigd met vrijheidsbeperking dan wel vrijheidsontneming van minimaal een maand. ${ }^{174}$

Strafzaken worden in beginsel in eerste aanleg door de districtsrechtbank (SR) behandeld, tenzij de wet anders bepaalt. Ten aanzien van zwaardere strafbare feiten (zbrodnie) en een aantal minder ernstige strafbare feiten (występki) heeft de wetgever bepaald dat deze in eerste aanleg door de provinciale rechtbank (SO) dienen te worden behandeld. ${ }^{175}$ Tegen uitspraken van de districtsrechtbank staat hoger beroep open bij de provinciale rechtbank en tegen uitspraken van laatstgenoemde instantie kan beroep worden ingesteld bij de appelrechter (SA). Naast twee bovengenoemde soorten strafbare feiten bestaat nog een derde categorie: overtredingen (wykroczenia) waarvoor afzonderlijke codificaties in het leven zijn geroepen waaronder een apart wetboek waarin het procesrecht is geregeld dat in overtredingszaken moet worden nageleefd. ${ }^{176}$ De bevoegdheid om kennis te nemen van overtredingen was voor 2001 in handen van quasi-judiciële colleges (kollegia do spraw wykroczeń) die geen onderdeel uitmaakten van de rechterlijke macht. Sinds oktober 2001 zijn deze colleges verdwenen en is de berechting van overtredingen (en een aantal andere eenvoudige strafbare feiten) overgedragen aan de sady grodzkie die onderdeel uitmaken van de districtsrechtbanken. ${ }^{177}$

172 Art. 175 Grondwet bepaalt dat het Hooggerechtshof, gewone, bestuurlijke en militaire rechterlijke instanties met rechtspraak zijn belast. Hier zal alleen aandacht worden besteed aan de gewone instanties.

173 Het Grondwettelijk Hof is vanwege zijn aparte status bewust niet in deze opsomming opgenomen. De bijzondere positie van het Grondwettelijk Hof is niet alleen gelegen in de specifieke taak die deze instantie heeft maar blijkt ook uit een aantal institutionele verschillen (zoals het feit dat de rechters van dit Hof een andere selectieprocedure doorlopen dan rechters van reguliere instanties en niet voor het leven zijn benoemd maar voor een bepaalde termijn worden gekozen door het parlement).

174 Of een geldboete boven een bepaald bedrag. Bovendien geldt dat zbrodnie alleen opzettelijk kunnen worden verricht, terwijl dat voor występki in de door de wet genoemde gevallen niet noodzakelijk is: art. 7, 8 en 9 KK 1997.

175 Art. 24 en 25 lid 1 KPK 1997.

176 Dit procesrecht zal verder buiten beschouwing worden gelaten. In dit onderzoek zal het gewone strafproces als uitgangspunt worden genomen. In overtredingszaken wordt overigens weinig gebruik gemaakt van rechtsbijstand door advocaten zodat de vraag naar de positie van de raadsman daar sowieso een minder grote rol speelt.

177 Tegen een veroordeling door sąd grodzki kan hoger beroep worden ingesteld bij de provinciale rechtbank (SO). 
Wat de samenstelling van rechterlijke colleges betreft, gold oorspronkelijk net als voor 1989 de hoofdregel dat strafzaken in eerste aanleg worden behandeld door een kamer die is samengesteld uit een professionele rechter (altijd de voorzitter) en twee lekenrechters. In 2007 is het aandeel van lekenrechters in strafzaken echter aanzienlijk teruggedrongen. ${ }^{178}$ Sindsdien geldt de hoofdregel dat zaken die in eerste aanleg voor de districts- of provinciale rechtbank komen, in beginsel door één professionele rechter worden behandeld tenzij het gaat om zwaardere strafbare feiten (zbrodie): dan wordt net als voorheen rechtgesproken door een kamer van één professionele rechter en twee lekenrechters. ${ }^{179}$ Lekenrechters worden voor een periode van vier jaar op lokaal niveau gekozen. Burgers kunnen zich hiervoor kandidaat stellen. In de praktijk gebeurt dat hoofdzakelijk door mensen van hogere leeftijd omdat het geld dat ermee verdiend kan worden een welkome aanvulling is op het doorgaans lage pensioen. Er is bovendien geen maximumleeftijd aan het ambt verbonden waardoor de gemiddelde leeftijd van lekenrechters tamelijk hoog is. Overigens is de positie van de lekenrechter niet vrij van kritiek omdat zijn benoeming anders dan die van professionele rechters weinig garanties biedt voor onafhankelijkheid en onpartijdigheid. Ze worden immers slechts tijdelijk benoemd door politieke stadsraden en hebben doorgaans een laag inkomen waardoor ze volgens critici gevoelig(er) zouden kunnen zijn voor steekpenningen. ${ }^{180}$

Het versterken van de rechterlijke onafhankelijkheid en onpartijdigheid was een van de speerpunten van de postcommunistische hervorming van de strafrechtspleging. De rechterlijke macht had gedurende het communisme veel gezichtsverlies geleden en om het vertrouwen in de rechtspraak te herstellen, moesten verschillende maatregelen worden genomen. In dit verband kunnen onder meer worden genoemd: de invoering van de Raad voor de Rechtspraak (Krajowa Rada Sądownictwa), de beperking van de invloed van de uitvoerende macht op de aanstelling en promotie van rechters en de afschaffing van de bevoegdheid van het Hooggerechtshof om voor lagere rechterlijke instanties bindende richtlijnen uit te spreken. ${ }^{181}$ Bovendien zijn verschillende garanties voor onafhankelijkheid na 1989 tot grondwettelijke principes verheven. ${ }^{182}$ Het is onbetwist dat op dit punt de laatste vijftien jaar veel vooruitgang is geboekt. Voor het gros van de rechters betekende de val van het communistisch regime een langverwachte verlossing uit

178 Wijziging van het wetboek van strafvordering van 27 juli 2007.

$179 \mathrm{Er}$ is echter een aantal uitzonderingen. Zo kan vanwege de ingewikkeldheid van de zaak in eerste aanleg worden besloten een kamer van drie professionele rechters in te stellen. Zaken waarin levenslange gevangenisstraf kan worden opgelegd, dienen door een grotere kamer van twee professionele en drie lekenrechters te worden behandeld. Aan de behandeling in hoger beroep nemen in beginsel geen lekenrechters deel en wordt in de regel rechtgesproken door drie professionele rechters. Bovendien geldt dat lekenrechters in beginsel niet deelnemen aan een aantal bijzondere procedures. In zaken die volgens de (minder formele) vereenvoudigde procedure (postępowanie uproszczone) of de procedure op private aanklacht (postępowanie z oskarżenia prywatnego) worden behandeld, treedt in de regel alleen een professionele rechter op.

$180 \mathrm{Er}$ is wel een (klein) aantal gevallen bekend van omkoping van lekenrechters maar dergelijke berichten doen ook wel eens de ronde over professionele rechters.

181 Zie over laatstgenoemde bevoegdheid van het Hooggerechtshof: § 2.2.1.2.

182 Zoals de regel dat rechters in hun taakuitoefening alleen gebonden zijn aan de (Grond)wet en dat ze voldoende betaald dienen te krijgen (art. 178 lid 1 en 2 Grondwet). 
een keurslijf waar ze decennialang in waren geperst ${ }^{183}$ maar door de enorme veranderingen die daarna in het Poolse rechtssysteem werden doorgevoerd, werd een groot beroep op hun aanpassingsvermogen gedaan. Bovendien veranderde het recht na 1989 zo snel en ingrijpend dat het bijhouden van deze wijzigingen bijna onbegonnen werk was terwijl dat van hen die de nieuwe regels in de praktijk moesten brengen uiteraard wel werd verwacht. Hoewel hier niet dieper zal worden ingegaan op de vele moeilijkheden en uitdagingen die de rechterlijke macht in de transitie van het Poolse rechtssysteem heeft ondervonden (en nog steeds ondervindt) dient te worden benadrukt dat in relatief korte tijd belangrijke vorderingen zijn gemaakt. ${ }^{184} \mathrm{Er}$ zijn echter nog steeds punten voor verbetering vatbaar. Zo wordt van verschillende zijden kritiek uitgeoefend op het feit dat veel rechters tevens een post vervullen op het Ministerie van Justitie wat moeilijk verenigbaar is met de rechterlijke onafhankelijkheid en onpartijdigheid. ${ }^{185}$ Bovendien - maar dat is een punt dat waarschijnlijk niet alleen de rechterlijke macht kan worden verweten - duren zowel civiele als strafrechtelijke procedures gemiddeld veel te lang wat uiteraard niet bijdraagt aan het versterken van het maatschappelijk vertrouwen in de effectiviteit van de Poolse rechtspleging. ${ }^{186}$

\subsubsection{Prokuratura}

Zoals eerder beschreven, vormde de prokuratura gedurende het communisme een afzonderlijke, vierde staatsmacht die alleen verantwoording schuldig was aan de Staatsraad. Dit beeld is na 1989 ingrijpend gewijzigd. Wijzigingen in de Wet op de Prokuratura die dateert uit 1985 en nog altijd van kracht is, hebben de structuur van de organisatie weer omgevormd tot de naar Frans voorbeeld vormgegeven organisatie zoals die voor 1950 bestond. De prokuratura is weer ondergebracht bij het Ministerie van Justitie - met aan het hoofd de minister van Justitie als Procureur Generaal - en heeft een sterk hiërarchische structuur. Sinds 1996 is er een landelijk parket (prokuratura krajowa) en zijn er afdelingen op het niveau van de verschillende rechterlijke instanties: prokuratury apelacyjne bij de hoger beroepsinstanties, prokuratury okregowe bij de provinciale rechtbanken en prokuratury rejonowe bij de disctrictsrechtbanken. ${ }^{187}$

De belangrijkste taak van de organisatie bestaat uit het leiden van het vooronderzoek in strafzaken en het deelnemen aan strafzittingen in de hoedanigheid van openbaar aanklager. ${ }^{188}$ De prokurator is overigens niet de enige die strafzaken voor

183 Dat de rechterlijke macht met name in de laatste fase van het communisme hevig naar hervorming verlangde, bleek onder andere uit het feit dat een aanzienlijk deel van hen zich had aangesloten bij de vrijheidsbeweging Solidarność.

184 Algemeen over de gevolgen van het democratiseringsproces voor de rechterlijke macht in Centraal- en Oost-Europese landen: Ginter 2004 en Milej 2004.

185 Zie uitgebreider het rapport Judicial Independence in Poland 2001.

186 Op de redelijke termijn-problematiek in strafzaken wordt teruggekomen in hoofdstuk $6, \S 4.1$.

187 Zie voor een uitgebreide bespreking van de structuur van de prokuratura (in het Engels): Marguery 2008, p. 177-223.

188 De feitelijke uitvoering van het opsporingsonderzoek is doorgaans in handen van de politie. Ook dat orgaan heeft sinds de val van het communisme - voor 1989 aangeduid als 'militie' - belangrijke veranderingen doorgemaakt. Zie voor een beschrijving: Haberfield 1997. Meer algemeen over de rol van de politie in postcommunistische systemen: 
de rechter kan brengen: ook burgers zijn daar onder bepaalde omstandigheden toe bevoegd. ${ }^{189}$

Het Poolse vervolgingssysteem is gebaseerd op het legaliteitsbeginsel hetgeen betekent dat de prokuratura in beginsel verplicht is ieder strafbaar feit te vervolgen. ${ }^{190}$ 'In beginsel' omdat de wetgever wel een bepaalde beoordelingsmarge heeft opengelaten: de verplichting tot vervolging geldt niet voor feiten die slechts een 'geringe schade' opleveren voor de maatschappij. ${ }^{191}$ Omdat het begrip strafbaar feit dus niet alleen een formele betekenis (is het door de wet verboden?) maar ook een materiële invulling heeft (levert het schade op voor de maatschappij?) wordt het legaliteitsbeginsel zoals het in Polen geldt ook wel het 'beginsel van materiële legaliteit' (zasada legalizmu materialnego) genoemd. ${ }^{192}$ Vanwege genoemd legaliteitsbeginsel zijn er in beginsel geen richtlijnen of andere bindende regels voor de invulling van het vervolgingsbeleid: uitgangspunt is immers dat alle strafbare feiten worden vervolgd. 193

\subsubsection{Burgers in het strafproces}

Het Poolse strafproces laat van oudsher veel ruimte voor deelname van burgers. Eerder in dit hoofdstuk is beschreven hoe het aandeel van burgers in de strafrechtelijke procedure gedurende het communisme werd versterkt om de democratische legitimatie van het strafproces te vergroten. Dat inbreng vanuit de samenleving ook vandaag de dag nog tot een van de uitgangspunten van het strafprocesrecht behoort, wordt bevestigd door art. 3 KPK 1997: 'Het strafproces zal binnen de grenzen van de wet plaatsvinden met deelname van een vertegenwoordiger van de samenleving. ${ }^{\prime} 194$ Genoemde bepaling ziet in de eerste plaats op de reeds besproken lekenrechter maar er zijn nog andere hoedanigheden waarin de burger aan het strafproces kan deelnemen. Zo kan het slachtoffer van een strafbaar feit als aanklager optreden in een strafrechtelijke procedure. ${ }^{195}$ Burgers kunnen zich behalve met de berechting dus ook met de vervolging van strafbare feiten bezig houden. Dat laatste kan gebeuren in de hoedanigheid van private aanklager

Uildriks en Van Reenen 2003 en Uildriks 2005.

189 Zie hierna § 3.1.2.

190 Deze verplichting is vastgelegd in art. 10 lid 1 KPK 1997. Tegenover het legaliteitsbeginsel staat het - onder andere in Nederland geldende - opportuniteitsbeginsel op grond waarvan het openbaar ministerie de vrijheid heeft om te bepalen of strafvervolging in een bepaald geval wenselijk (opportuun) is.

191 Art. 17 lid 1 sub 3 KPK 1997. Het 'maatschappelijk gevaar'-criterium dat in de codificaties van 1969 centraal stond, speelt dus nog steeds een rol in het straf(proces)recht.

192 Waltoś 2002 I, p. 288-290.

193 Wel zijn er circulaires van de Procureur Generaal waarin wordt vastgelegd welk soort criminaliteit 'bijzondere aandacht' dient te krijgen.

194 De wetgever is met deze formulering echter meer terughoudend dan in 1969 toen ongeclausuleerd was bepaald dat 'strafrechtelijke procedures met deelname van een vertegenwoordiger van de samenleving dienen te worden gevoerd' (art. 2 lid 2 KPK 1969). Dat dat nu alleen 'binnen de grenzen van de wet' kan gebeuren, is het gevolg van toenemende kritiek op het functioneren van leken in de Poolse strafrechtspleging: Grzegorczyk 2004, p. 34.

195 Als slachtoffer (pokrzywdzony) wordt aangemerkt: 'Iedere natuurlijke of rechtspersoon wiens eigendom of rechten rechtstreeks door het strafbaar feit zijn geschonden of bedreigd': art. 49 lid 1 KPK 1997. 
(oskarżyciel prywatny) of als hulpaanklager (oskarżyciel positkowy). ${ }^{196}$ Het belangrijkste onderscheid tussen deze twee vormen is dat eerstgenoemde slechts kan optreden in een beperkt aantal zaken (te weten die betreffende strafbare feiten die op private aanklacht moeten worden vervolgd) terwijl een hulpaanklager kan deelnemen aan op openbare aanklacht te vervolgen strafzaken. ${ }^{197}$ De private aanklager kan zelfstandig een akte van beschuldiging indienen en - zonder tussenkomst van de prokurator - de rol van aanklager in het strafproces vervullen. Het is echter niet uitgesloten dat de prokurator zich mengt in de vervolging van strafbare feiten die op private aanklacht dienen te worden vervolgd: hij dient zich in de procedure te voegen (en alsnog een openbare aanklacht in te dienen) wanneer het algemeen belang dat verlangt. ${ }^{198}$ De private aanklager kan deze aanklacht van de prokurator vervolgens 'ondersteunen' in welk geval hij niet langer als private aanklager maar als hulpaanklager optreedt. De hulpaanklager kan namelijk 'naast' of 'in plaats van' de openbaar aanklager aan de strafzaak deelnemen. Van de eerste variant is sprake wanneer de openbaar aanklager ook een akte van beschuldiging heeft ingediend (deze vorm van vervolging wordt wel aangeduid als oskarżyciel uboczny). Vervolging op aanklacht van de benadeelde 'in plaats van' de prokurator kan in twee situaties gebeuren: ten eerste wanneer de openbaar aanklager geen akte van beschuldiging heeft ingediend en dus niet is overgegaan tot vervolging (in welk geval wordt gesproken van oskarżyciel subsidiarny) en ten tweede wanneer het slachtoffer zijn recht om aan te klagen onafhankelijk van de openbaar aanklager uitoefent (oskarżyciel konkurencyjny). ${ }^{199}$

Behalve bovengenoemde mogelijkheden ten aanzien van de vervolging kan het slachtoffer zich ook nog in het strafproces voegen als civiele partij (powód cywilny) ter verkrijging van schadevergoeding. ${ }^{200}$

Het optreden van slachtoffers hoeft zich echter niet tot het eindonderzoek te beperken. In het nieuwe wetboek van strafvordering is bepaald dat het slachtoffer gedurende het vooronderzoek formeel de status van procespartij heeft. ${ }^{201}$ Deze status gaat gepaard met een aantal rechten en bevoegdheden dat tot gevolg heeft dat slachtoffers ook voorafgaand aan het onderzoek ter terechtzitting actief aan de strafrechtelijke procedure kunnen deelnemen. ${ }^{202}$ Zo kan het slachtoffer gedurende het vooronderzoek bewijsverzoeken indienen of deelnemen aan onderzoekshandelingen die op initiatief van de autoriteiten of de verdediging worden

196 Geregeld in respectievelijk art. 59-61 en art. 53-58 KPK 1997. De hulpaanklager - deze term is taalkundig het meest correct maar dekt de lading niet helemaal - is in 1969 in het Poolse strafprocesrecht geïntroduceerd terwijl de private aanklager reeds daarvoor bestond: Cieślak 1970, p. 31.

197 Welke strafbare feiten op private aanklacht moeten worden vervolgd, wordt bepaald door het materiële strafrecht. Zie bijvoorbeeld de strafbaarstelling van smaad in art. 212 lid 4 KK 1997.

198 Art. 60 lid 1 KPK 1997.

199 Over de drie soorten hulpaanklagers: Grzegorczyk 2004, p. 221-222. Zie ook Cieślak 1970, p. 31.

200 Art. 62-70 KPK 1997.

201 Zie eerder § 2.3.3.3. De mogelijkheden van het slachtoffer om als partij deel te nemen aan het vooronderzoek zijn niet afhankelijk van de vraag of hij later in de procedure als private aanklager of civiele partij zal optreden.

202 Art. 299 KPK 1997. 
verricht. Het slachtoffer kan zich laten bijstaan door een advocaat of een juridisch adviseur. ${ }^{203}$

Een laatste functie die hier vermelding verdient, is de zogenaamde 'maatschappelijk vertegenwoordiger' ('przedstawiciel spoteczny') waarmee wordt voorzien in de mogelijkheid om namens een bepaalde maatschappelijke organisatie aan het strafproces deel te nemen om zo de belangen die door die organisatie worden beschermd (en die door de betreffende strafzaak zijn getroffen) te vertegenwoordigen. Wanneer de rechtbank daarmee instemt, kan een dergelijke vertegenwoordiger aan het onderzoek ter terechtzitting deelnemen, het woord voeren en schriftelijke verklaringen indienen. ${ }^{204}$ In de praktijk wordt deze mogelijkheid vooral benut door de Polish Helsinki Foundation for Human Rights (HFHR).

\subsubsection{De verdediging}

\subsubsection{De verdachte}

In het Poolse strafprocesrecht worden afhankelijk van het stadium van de procedure verschillende verdachtenbegrippen gehanteerd:

1. verdachte persoon (osoba podejrzana),

2. verdachte (podejrzany),

3. beschuldigde (oskarżony).

Eerstgenoemde categorie betreft personen die worden verdacht van een strafbaar feit maar nog niet officieel op de hoogte zijn gesteld van de tegen hen bestaande beschuldigingen. In deze hoedanigheid zijn zij geen partij bij het vooronderzoek en hebben dus nog niet de aan de status van verdachte verbonden rechten en plichten. Tegen de verdachte persoon kunnen echter wel verschillende dwangmiddelen worden toegepast - zo kan hij worden aangehouden en voor een bepaalde termijn door de politie van zijn vrijheid worden beroofd - en hij heeft een aantal bevoegdheden om zich daartegen te verweren. ${ }^{205}$

203 Art. 87 lid 1 jo. 82 en 88 KPK 1997.

204 Art. 90 en 91 KPK 1997, de wet noemt als voorbeeld van te beschermen belangen expliciet de mensenrechten. De rechtbank dient te beslissen of deelname van een 'maatschappelijk vertegenwoordiger' - die overigens zowel in het belang van de verdachte als in het belang van het slachtoffer kan optreden - in het concrete geval kan bijdragen aan een behoorlijke rechtspleging. Zie Hofmański e.a. 2007 I, p. 493-499.

205 De verdachte persoon kan bijvoorbeeld bezwaar aantekenen tegen beslissingen tot doorzoeking en inbeslagneming, tegen het opnemen en afluisteren van telefoongesprekken en hij kan tegen zijn aanhouding in beroep gaan bij de rechter (respectievelijk art. 236, 240, 302 en art. 246 KPK 1997). Na zijn aanhouding wordt een 'verdachte' ook wel aangeduid met zatrzymany of osoba zatrzymana (de aangehoudene of de aangehouden persoon). Over de rechtspositie van verdachte personen: Grzegorczyk 2004, p. 260. Zie over het onderscheid tussen verdachte en verdachte persoon ook Kruszyński 2007 I, p. 184: 'To understand the status of the detained person at the initial stage it is important to know that before they are officialy charged, the detained person does not have the status of 'suspect' but the status of 'a suspected person'. As long as a person is not officially charged, certain secret methods of investigation may be used, such as observation, 'pseudo-purchase', or interceptions of communications. In addition, certain investigative measures explicitly stipulated in the Code of Criminal Procedure, may be used such as arrest and detention of the 'suspected person' for a maximum of 48 hours, inspection, photographing, and the taking of fingerprints, hair, blood and intimate samples.' 
Indien een verdachte persoon eenmaal op de hoogte is gesteld van datgene waarvan hij wordt verdacht, wordt hij voortaan als 'verdachte' ('podejrzany') aangemerkt en krijgt hij de status van partij bij het vooronderzoek. Het aanmerken als officiële verdachte kan op twee manieren gebeuren: ten eerste door het opstellen van een schriftelijke beslissing tot bekendmaking van de beschuldiging (postanowienie o przedstawieniu zarzutów) en ten tweede door de verdachte - zonder een dergelijke schriftelijke beslissing - voorafgaand aan een verhoor mondeling op de hoogte te stellen van de tegen hem bestaande beschuldigingen. ${ }^{206}$ De schriftelijke beslissing wordt opgesteld zodra er voldoende aanwijzingen zijn (voor de verdenking dat) een strafbaar feit is gepleegd door een bepaalde persoon. ${ }^{207} \mathrm{De}$ graad van verdenking die daarvoor wordt vereist, is hoger dan voor aanhouding noodzakelijk is: voor aanhouding is voldoende dat jegens een bepaalde persoon sprake is van een 'gerechtvaardigd vermoeden dat een strafbaar feit is gepleegd' ('uzasadnione przypuszczenie, że popetniła ona przestepstwo') terwijl voor de bekendmaking van de beschuldiging jegens de betreffende persoon sprake moet zijn van een 'voldoende gerechtvaardigde verdenking dat een strafbaar feit is gepleegd' ('dostatecznie uzasadnione podejrzenie, że czyn popetnita określona osoba'). ${ }^{208}$

Wanneer de beslissing is opgesteld, dient deze onmiddellijk (niezwłocznie) aan de verdachte te worden bekendgemaakt. ${ }^{209}$ Van belang is dat de status van verdachte wordt verkregen op het moment dat de beslissing (tot bekendmaking van de beschuldigingen) wordt opgesteld en niet pas wanneer de inhoud ervan aan de betreffende persoon bekend wordt gemaakt. ${ }^{210}$

De tweede manier waarop iemand als verdachte kan worden aangemerkt (door in het kader van een verhoor op de hoogte te worden gesteld van de verdenking) kan in twee gevallen plaatsvinden: ten eerste in spoedeisende gevallen waarin het opstellen van een schriftelijke beslissing in het belang van de waarheidsvinding niet kan worden afgewacht. ${ }^{211}$ In dergelijke situaties kan iemand meteen als verdachte worden verhoord. Ten tweede kan het opstellen van een beslissing tot bekendmaking achterwege blijven wanneer het vooronderzoek de vorm van een dochodzenie heeft: een verdachte persoon kan dan aan het begin van zijn verhoor op de hoogte worden gesteld van de tegen hem bestaande beschuldigingen en dient vanaf dat moment als verdachte te worden aangemerkt. ${ }^{212}$ Deze minder formele procedure kan overigens niet worden gevolgd wanneer de 'verdachte' in de betreffende strafzaak van zijn vrijheid is beroofd.

206 Art. 71 lid 1 en 299 KPK 1997.

207 Deze schriftelijke beslissing - niet te verwarren met de akte van beschuldiging waarmee een zaak aan het einde van het vooronderzoek voor de rechter wordt gebracht - dient de persoonsgegevens van de verdachte, een nauwkeurige omschrijving van de feiten waarvan hij wordt beschuldigd en de juridische kwalificatie ervan te bevatten.

208 Zie respectievelijk art. 244 lid 1 en art. 313 lid 1 KPK 1997.

209 Art. 313 lid 1 en 2 KPK 1997. Hierop mag alleen een uitzondering worden gemaakt wanneer de verdachte onvindbaar is of zich in het buitenland bevindt.

210 Dit volgt rechtstreeks uit art. 71 lid 1 KPK 1997: 'Als verdachte wordt aangemerkt degene jegens wie een beslissing tot bekendmaking van de beschuldigingen is opgesteld (...).'

211 Art. 308 lid 2 KPK 1997. Bijvoorbeeld omdat het gevaar bestaat dat bewijsmiddelen worden weggemaakt of verklaringen op elkaar zullen worden afgestemd.

212 Art. 325g lid 1 en 2 KPK 1997. 
De kwalificatie verdachte heeft een aantal belangrijke rechtspositionele consequenties: zo zal de verdachte nadat hij als zodanig is aangemerkt en voorafgaand aan het eerste verhoor op de hoogte moeten worden gesteld van verschillende fundamentele rechten zoals het recht op rechtsbijstand en het zwijgrecht, kan hij een raadsman benoemen en heeft hij recht op informatie aangaande het vooronderzoek. ${ }^{213}$ Bovendien is de verdachte procespartij bij het vooronderzoek. Wanneer de akte van beschuldiging is ingediend, transformeert de verdachte in 'beschuldigde' ('oskarżony'). ${ }^{214}$ Overigens dient waar in het wetboek van strafvordering de term 'beschuldigde' in algemene zin wordt gebruikt ook de verdachte daaronder te worden begrepen. ${ }^{215}$ De rechten die aan de beschuldigde worden toegekend, komen dus in beginsel ook de verdachte toe.

\subsubsection{De raadsman}

Een van de voornaamste rechten van verdachte is het recht op verdediging. In Polen is dit recht in algemene bewoordingen vastgelegd in de Grondwet en in het wetboek van strafvordering. Art. 42 lid 2 van de Grondwet van 1997 luidt:

'Eenieder jegens wie een strafrechtelijke procedure is aangevangen heeft het recht op verdediging gedurende alle fasen van deze procedure. Hij kan, in het bijzonder, een raadsman benoemen of - volgens de uitgangspunten neergelegd in de wet - gebruikmaken van de bijstand van een toegevoegde raadsman.'216

In art. 6 KPK 1997 is bepaald:

'Aan verdachte komt het recht op verdediging toe, waaronder begrepen het recht op bijstand van een raadsman, waarover hij dient te worden geïnformeerd.'

Het wetboek van strafvordering van 1969 bevatte ook een dergelijke bepaling maar deze was iets anders geformuleerd: 'Aan verdachte komt het recht op verdediging toe en het recht op gebruikmaking van de hulp van een raadsman' (art. 9 KPK 1969). Verschil tussen beide bepalingen is dus dat het huidige artikel duidelijk maakt dat het recht op rechtsbijstand onderdeel uitmaakt van het recht op verdediging terwijl het oude art. 9 KPK 1969 ze als twee afzonderlijke rechten presenteerde. Bovendien expliciteert het huidige art. 6 KPK 1997 dat de verdachte van dit recht op de hoogte moet worden gesteld. ${ }^{217}$

Dat het recht op rechtsbijstand niet als afzonderlijk recht maar als onderdeel van het recht op verdediging wordt aangemerkt, betekent niet dat wanneer de verdachte wordt bijgestaan door een raadsman hij zelf de verdediging niet meer

213 Over deze rechten van verdachte: Grzegorczyk en Tylman 2001, p. 315.

214 Art. 71 lid 2 KPK 1997, volgens de laatste zin van deze bepaling wordt ook de verdachte in wiens zaak de prokurator een verzoek tot voorwaardelijke beëindiging van het strafproces heeft ingediend (zie hierna) als zodanig aangemerkt. Algemeen over de drie definities van verdachte: Grzegorczyk 2004, p. 258-260 en Grzegorczyk en Tylman 2001, p. 304-306.

215 Art. 71 lid 3 KPK 1997.

216 Over het recht op verdediging zoals geformuleerd in de Grondwet: Wiliński 2006, p. 236-248.

217 Voorheen bestond deze verplichting alleen op basis van het algemene art. 10 KPK 1969 op grond waarvan autoriteiten ook verplicht waren de verdachte 'voor zover noodzakelijk' ('w miare potrzeby') te informeren over zijn rechten en plichten wanneer die verplichting niet met zoveel woorden door de wetgever was geformuleerd. Zie Wiliński 2006, p. 106-107 en 117. 
zou kunnen voeren. Integendeel: de wetgever heeft benadrukt dat het optreden van een raadsman persoonlijke deelname van de verdachte niet uitsluit (art. 86 lid 2 KPK 1997). Aan deze regel ligt ten grondslag dat raadsman en verdachte worden beschouwd als zelfstandige procesdeelnemers die ook onafhankelijk van elkaar kunnen optreden. ${ }^{218}$

Het recht op verdediging heeft betrekking op de gehele strafrechtelijke procedure. Dit volgt rechtstreeks uit de grondwettelijke bepaling ('gedurende alle fasen van de procedure') en voor wat betreft art. 6 KPK 1997 kan het worden afgeleid uit de ongeclausuleerde formulering van het artikel en de plaatsing ervan vooraan in het wetboek bij de inleidende (algemene) bepalingen. Uitgangspunt is dat de verdachte zelf bepaalt of - en zo ja, op welke wijze - hij dit recht wenst te effectueren. Het staat hem dus in beginsel vrij zich in het geheel niet te verdedigen, ${ }^{219}$ zijn verdediging zelf te voeren of daarbij gebruik te maken van de hulp van een advocaat. In dit verband wordt in de Poolse doctrine wel het onderscheid gemaakt tussen materiële en formele verdediging (obrona materialna en obrona formalna): met de eerste term worden alle activiteiten aangeduid die gedurende een strafrechtelijke procedure in het belang van de verdediging kunnen worden verricht terwijl het tweede begrip ziet op het effectureren van verdedigingsrechten door de raadsman. ${ }^{220}$

De verdachte is echter niet altijd vrij om zelf te bepalen of hij zich wil laten bijstaan: de wetgever heeft een aantal situaties beschreven waarin bijstand van een advocaat vanwege de persoonlijke omstandigheden van de verdachte of de ernst van de zaak verplicht is. ${ }^{221}$ De belangrijkste gevallen waarin rechtsbijstand wordt voorgeschreven, zijn:

- Verdachte is minderjarig, doof stom of blind (art. 79 lid 1 sub 1 en 2).

- Er bestaan gerechtvaardigde redenen om aan zijn geestelijke gezondheid te twijfelen (art. 79 lid 1 sub 3).

218 Voor een aantal handelingen is dit echter niet mogelijk: zo kan hoger beroep dat in het belang van verdachte is ingesteld alleen met instemming van verdachte worden ingetrokken (art. 431 lid 3 KPK 1997). Bovendien is een aantal proceshandelingen zo persoonlijk of zo sterk afhankelijk van de wil van verdachte dat deze slechts door hemzelf - of in ieder geval met zijn uitdrukkelijke instemming - kunnen worden verricht. Een voorbeeld daarvan is het verzoek de zaak zonder bewijsvoering op het onderzoek ter terechtzitting af te doen (art. 387 KPK 1997): Grzegorczyk 2004, p. 302. In dergelijk gevallen dient de rechtbank de expliciete wil van verdachte in aanmerking te nemen, die overigens wel door de advocaat kan worden overgebracht: Grzegorczyk en Tylman 2001, p. 334. Zie hierover ook hoofdstuk 6, §3.1.

219 Art. 42 Grondwet en 6 KPK 1997 spreken immers van een recht en niet van een plicht tot verdediging.

220 Zie uitgebreid over dit onderscheid: Wiliński 2006, p. 202-213. De termen materiële en formele verdediging zijn ook terug te vinden in de rechtspraak, zie bijvoorbeeld SN 4 februari 2003 (IV KK 379/02, LEX nr. 75448): 'Art. 6 KPK 1997 [waarin het recht op verdediging is vastgelegd, toev. DdV] bevat een van de belangrijkste procesgaranties voor de verdachte: het recht op verdediging in materiële zin, wat wordt uitgelegd als het recht zich tegen de beschuldigingen te verweren en het recht op verdediging in formele zin, waaronder het recht op bijstand van een raadsman wordt begrepen.'

221 Zie over het verschijnsel verplichte rechtsbijstand in de common law rechtstraditie enerzijds en civil law systemen anderzijds: Hermann 1996, p. 141. 
- Er is sprake van 'omstandigheden die de verdediging bemoeilijken' (art. 79 lid 2).

- De strafzaak wordt in eerste aanleg behandeld door een provinciale rechtbank en de verdachte wordt beschuldigd van een strafbaar feit waarop minimaal drie jaar gevangenisstraf staat (zbrodnia) of wordt van zijn vrijheid beroofd (art. 80 eerste zin).

Wanneer een verdachte die volgens de wet moet worden bijgestaan door een raadsman niet zelf een advocaat heeft gekozen, dient de president van de rechtbank ambtshalve een advocaat toe te voegen.222 Naast deze vorm van ambtshalve toevoeging kan een advocaat ook worden toegevoegd op verzoek van verdachte wanneer deze aan weet te tonen dat hij niet in staat is de kosten van de verdediging zelf te dragen. ${ }^{223} \mathrm{Op}$ beide vormen van toevoeging wordt uitgebreid teruggekomen in hoofdstuk 4 , § 3 .

\section{Optreden als raadsman}

De vraag wie in een strafrechtelijke procedure als raadsman kan optreden, wordt beantwoord door art. 82 KPK 1997. Volgens deze bepaling kan alleen 'een persoon die volgens de Advocatenwet gerechtigd is tot het voeren van de verdediging' strafzaken in behandeling nemen. Laatstgenoemde wet stelt in de eerste plaats een aantal algemene eisen waaraan een jurist moet voldoen om te kunnen worden toegelaten tot de balie. ${ }^{224}$ De Advocatenwet bevat echter geen specifieke regels of voorwaarden voor het verlenen van rechtsbijstand in strafzaken: iedere advocaat die is toegelaten tot de balie is dus in beginsel gerechtigd de functie van raadsman te vervullen. Dit uitgangspunt is nauw verbonden met de binnen de Poolse advocatuur heersende overtuiging dat een advocaat in beginsel van alle markten (en dus van alle rechtsgebieden) thuis moet zijn. ${ }^{225}$ De enige beperking die de wet wel stelt, heeft betrekking op advocaat-stagiaires.226 Wanneer de stageperiode is afgerond, het examen met goed gevolg is afgelegd en de advocaat is toegelaten tot de balie kan hij dus in beginsel voor alle rechterlijke instanties in strafzaken optreden.

Advocaten hebben sinds een aantal jaren niet langer het monopolie om verdachten in strafzaken bij te staan. Op basis van een nieuwe wet waarin het procesrecht voor overtredingen is opgenomen, kan behalve de advocaat voortaan ook de juridisch adviseur (radca prawny) als raadsman in overtredingszaken optreden.

222 Art. 81 lid 1 KPK 1997. Uit de formulering van deze bepaling volgt dat verplichte rechtsbijstand een aanvullend karakter heeft: pas wanneer blijkt dat de verdachte geen gekozen raadsman heeft, wordt over de toevoeging beslist: Grzegorczyk 2004, p. 285.

223 Art. 78 lid 1 jo. art. 81 lid 1 KPK 1997.

224 Zie over deze voorwaarden hoofdstuk 8, § 2.1.

225 Zoals in hoofdstuk 4 zal worden uitgewerkt, blijkt ook uit het toevoegingssysteem dat ervan uit wordt gegaan dat iedere advocaat in staat is strafzaken te behandelen. Binnen de Poolse advocatuur werd met name voor 1989 dan ook weinig gespecialiseerd maar hierin lijkt de laatste jaren verandering te komen.

$226 \mathrm{Zij}$ kunnen na een half jaar stage advocaten vervangen in procedures voor de districsrechtbank of ten overstaan van vervolgende instanties. Na verloop van anderhalf jaar kunnen zij in strafzaken optreden voor alle rechterlijke instanties met uitzondering van het Hooggerechtshof en het Grondwettelijk Hof. Zie art. 77 Advocatenwet. 
Deze juridisch adviseurs vormen een afzonderlijke beroepsgroep met een eigen balie die oorspronkelijk niets met strafzaken van doen had. Het werkterrein van de juridisch adviseur concentreerde zich gedurende het communisme vooral op het verlenen van juridische bijstand aan (staats)ondernemingen maar is in de loop van de tijd aanzienlijk uitgebreid. Vandaag de dag hebben ze dus zelfs de bevoegdheid natuurlijke personen in kleine strafzaken bij te staan. In de praktijk wordt hier echter weinig gebruik van gemaakt omdat het gros van de overtredingszaken zonder rechtsbijstand wordt afgedaan.

De beroepsorganisatie van de advocatuur heeft de laatste jaren behoorlijk onder vuur gelegen. Voornaamste punt van kritiek betrof het gesloten karakter van de beroepsgroep: de balie werd beticht van nepotisme en zou bovendien het aantal leden bewust klein houden om concurrentie te voorkomen. De toenemende kritiek en politieke bemoeienis met de kwestie heeft uiteindelijk geleid tot een ingrijpende wijziging van de Advocatenwet waardoor de toetredingsprocedure voor een belangrijk deel onder toezicht van de minister van Justitie is komen te staan.227

\section{Benoemen raadsman}

Hoofdregel is dat de verdachte zijn raadsman zelf benoemt. Wanneer hij echter van zijn vrijheid is beroofd, kan de benoeming ook plaatsvinden door een derde. ${ }^{228}$ De kring van personen die gerechtigd is een raadsman aan te wijzen voor de gedetineerde verdachte is in 1997 uitgebreid. Werd deze bevoegdheid in het wetboek van strafvordering van 1969 slechts toegekend aan een 'naaste' ('osoba najbliższa dla oskarżonego'): op basis van het nieuwe strafprocesrecht kan voortaan iedere derde een advocaat benoemen mits hij de verdachte daarover direct informeert. ${ }^{229}$ Deze door een derde gerealiseerde benoeming heeft overigens een tijdelijk karakter: de benoeming wordt pas definitief wanneer de verdachte daarmee heeft ingestemd. Dit neemt echter niet weg dat de raadsman daarvoor al wel handelingen ten behoeve van de verdediging kan verrichten: zo kan hij bijvoorbeeld beroep instellen tegen de voorlopige hechtenis voordat de machtiging door verdachte is bekrachtigd. ${ }^{230} \mathrm{Op}$ het moment dat de verdachte een andere raadsman benoemt of aangeeft helemaal geen gebruik te willen maken van de hulp van een advocaat verliest de tijdelijke machtiging zijn rechtsgeldigheid. ${ }^{231}$

Ten slotte is ook voor minderjarige en onder curatele gestelde verdachten geregeld dat een ander voor hen een advocaat kan benoemen: dat kan gebeuren door de

227 Meer uitgebreid over deze en andere ontwikkelingen ten aanzien van de balie: hoofdstuk 8, § 2.4 .

228 Art. 83 lid 1 KPK 1997.

229 Tot de kring van derden kunnen onder anderen vrienden, buren maar ook rechtspersonen zoals een vakbond worden gerekend: Czekaj 1998, p. 39 en Grzegorczyk 2004, p. 293. Deze uitbreiding wordt in de literatuur positief beoordeeld omdat het onder de oude regeling in de praktijk geregeld voorkwam dat de derde die een advocaat wenste te benoemen - bijvoorbeeld een kennis of collega - niet tot de kring van 'naasten' behoorde.

230 Grzegorczyk 2004, p. 293.

231 Grzegorczyk en Tylman 2001, p. 339-340. De plicht verdachte onverwijld op de hoogte te stellen van de benoeming kwam niet voor in de regeling van 1969 en is waarschijnlijk het gevolg van genoemde uitbreiding van de kring van gerechtigden. 
wettelijk vertegenwoordiger of de persoon onder wiens zorg de verdachte is geplaatst. 232

Wanneer een advocaat is aangewezen dient deze zich voordat hij als raadsman van verdachte op kan treden als zodanig schriftelijk of mondeling aan te melden bij het orgaan dat de strafrechtelijke procedure leidt. ${ }^{233}$ Gedurende het vooronderzoek is het de politie of de prokuratura en daarna de rechtsmacht hebbende rechtbank die deze melding in het dossier dient op te nemen.

\section{Maximum aantal advocaten en verdediging medeverdachten}

Een verdachte mag zich in een en dezelfde zaak door maximaal drie advocaten laten bijstaan. ${ }^{234}$ Dit wettelijk maximum is reeds in jaren dertig in het wetboek van strafvordering van 1928 opgenomen naar aanleiding van een politieke strafzaak waarin een groep advocaten hun krachten had gebundeld om samen de verdediging te voeren als protest tegen het landsbestuur. ${ }^{235}$ Momenteel ligt aan de regel het meer algemene uitgangspunt ten grondslag dat meer dan drie advocaten teveel in de weg zouden kunnen staan aan een regelmatig en efficiënt procesverloop. Een dergelijke wettelijke beperking is overigens verenigbaar met het EVRM. ${ }^{236}$

Wanneer een verdachte wordt bijgestaan door twee of drie advocaten kan ieder van hen de gehele verdediging op zich nemen maar het is uiteraard ook mogelijk dat een bepaalde taakverdeling wordt overeengekomen. Elke afzonderlijke advocaat heeft het recht deel te nemen aan proceshandelingen en dient over het plaatsvinden daarvan te worden geïnformeerd.

In het wetboek van strafvordering is bepaald dat het verlenen van bijstand aan medeverdachten niet is toegestaan wanneer sprake is van tegenstrijdige belangen. ${ }^{237}$ De betekenis van het begrip 'tegenstrijdige belangen' is uitgewerkt in de (tucht)rechtspraak. Uit uitspraken van het Hooggerechtshof blijkt dat belangen in ieder geval strijdig zijn wanneer verdachten elkaar beschuldigen of wanneer een verklaring van de ene verdachte (of bewijs dat in zijn voordeel is) in strijd is met het belang van de andere verdachte. Ook blijkt uit de rechtspraak dat tegenstrijdigheid concreet moet zijn: de enkele schijn ervan is niet voldoende. Dus wanneer twee medeverdachten geen schuld bekennen maar elkaar ook niet beschuldigen, is er geen sprake van tegenstrijdigheid en is het dus toegestaan dat hun verdediging door een en dezelfde raadsman wordt gevoerd. ${ }^{238}$

232 Art. 76 KPK 1997.

233 Art. 83 lid 2 KPK 1997.

234 Art. 77 KPK 1997.

235 Het betrof de zogenaamde 'Brześć'-processen waarin een aantal tegenstanders van de destijds aan de macht zijnde regering werd vervolgd. Gedurende het communisme was Polen overigens het enige socialistische rechtssysteem van Centraal- en Oost-Europa dat een dergelijk maximum hanteerde: Gajewska-Kraczkowska en Palmer (1991), p. 97-98. Zie hierover ook Wiliński 2006, p. 308-309.

236 Spaniol 1990, p. 66 ('Entscheidend sei daß dem Beschuldigten effektiver Beistand Gewährt werde. Die Beschränkung der Verteidigerzahl schließe dies nicht aus') en Grzegorczyk 2004, p. 272-273.

237 Art. 85 lid 1 KPK 1997.

238 Uitspraken van respectievelijk 15 juli 1980, 26 oktober 1971 en 19 december 1988 genoemd in Grzegorczyk 2004, p. 298. Zie over tegenstrijdige belangen ook hoofdstuk 8, § 4.3.2.2. 
Hoewel het in de eerste plaats aan de raadsman zelf is om te waken voor het bestaan (of ontstaan) van tegenstrijdige belangen heeft de wetgever er in het nieuwe wetboek van strafvordering voor gekozen dit te onderwerpen aan rechterlijke controle. ${ }^{239}$ Regel is dat wanneer de bij de zaak betrokken rechtbank het bestaan van tegenstrijdige belangen constateert een termijn wordt vastgesteld waarbinnen de verdachte een andere raadsman kan benoemen (art. 85 lid 2 KPK 1997). In het geval van een toegevoegde advocaat benoemt de rechtbank zelf een nieuwe raadsman. Tegen deze beslissingen van de rechtbank kan zowel door verdachte als door de raadsman bezwaar worden aangetekend. In juli 2003 is aan deze bepaling nog een derde lid toegevoegd waarin is geregeld wat dient te gebeuren wanneer de zaak zich nog in de fase van het vooronderzoek bevindt: wanneer het orgaan dat het vooronderzoek leidt, vaststelt dat de raadsman verdachten met tegenstrijdige belangen verdedigt, dient het zich te wenden tot de president van de rechtbank die bevoegd is van de zaak kennis te nemen. Tegen de beslissing van de president staat net als gedurende het onderzoek ter terechtzitting bezwaar open voor verdachte en advocaat.

\section{Positie raadsman}

De raadsman wordt niet beschouwd als procespartij: hij treedt op namens de verdachte die uiteraard wel procespartij is. Uitgangspunt is dat de raadsman alle rechten en bevoegdheden kan uitoefenen die aan de verdachte zijn toegekend tenzij wettelijk is bepaald dat een bepaalde handeling alleen door verdachte persoonlijk kan worden verricht dan wel zijn uitdrukkelijke instemming vereist. Een van de belangrijkste richtlijnen voor het optreden van de advocaat is dat hij enkel in het voordeel van verdachte mag handelen (art. 86 lid 1 KPK 1997). Op de rol en functie van de raadsman wordt uitgebreid teruggekomen in hoofdstuk 3. Iedere advocaat dient de voor de beroepsgroep geldende gedragsregels in acht te nemen waarvan de naleving is onderworpen aan tuchtrechtelijk toezicht. ${ }^{240}$ Niet alleen een ontevreden cliënt maar ook een rechter of prokurator kunnen over het optreden van een advocaat een klacht indienen bij de balie. Behalve over de voor (potentiële) advocaat-stagiaires geldende toetredingsprocedures is de laatste jaren ook veel discussie gevoerd over het tuchtrechtelijk toezicht op de advocatuur. De balie zou niet adequaat reageren op klachten en haar leden te veel de hand boven het hoofd houden. ${ }^{241}$

239 Onder de regeling van 1969 bestond geen duidelijkheid over de vraag wie actie diende te ondernemen wanneer gedurende de procedure tegenstrijdigheid werd vastgesteld en de verdediging desalniettemin werd voortgezet. Sommige auteurs waren van mening dat beslissingen daaromtrent waren voorbehouden aan de balie omdat de rechter het recht van verdachte op vrije advocatenkeuze niet zou kunnen beperken: Grzegorczyk 2004, p. 298 en daar genoemde literatuur en rechtspraak.

240 De gedragsregels ('Zbiór zasad etyki adwokackiej i godności zawodu uchwalony przez Naczelnq Radę Adwokacka': 'Een verzameling regels betreffende gedragsnormen voor de advocaat en de waardigheid van het beroep') zijn door de balie vastgesteld op 10 oktober 1998 en te raadplegen via: <www.nra.pl/nra.php>.

241 Op de gedragsregels en het tuchtrechtelijk toezicht wordt teruggekomen in hoofdstuk 8. 


\subsection{Verloop van de procedure}

\subsubsection{Vooronderzoek}

Wanneer het gegronde vermoeden bestaat dat een strafbaar feit is gepleegd, dient een vooronderzoek te worden geopend. ${ }^{242}$ De verdenking kan dus alleen betrekking hebben op een bepaald feit: er hoeft nog geen verdachte te zijn. De wet onderscheidt verschillende doelstellingen die met het vooronderzoek kunnen worden bereikt:

1. het vaststellen of een strafbaar feit is gepleegd,

2. het opsporen en aanhouden van de dader, ${ }^{243}$

3. het verzamelen van gegevens over de verdachte,

4. het aan het licht brengen van de omstandigheden van het geval waaronder vaststellen van de identiteit van eventuele slachtoffers en de omvang van de geleden schade en ten slotte

5. het verzamelen, veilig stellen en voor zover noodzakelijk vastleggen van bewijs voor de rechtbank. ${ }^{244}$

Het huidige vooronderzoek bestaat net als voor 1989 uit twee verschillende vormen: śledztwo en dochodzenie. ${ }^{245}$ Dat deze verdeling - na in 1955 opnieuw in het Poolse strafprocesrecht te zijn geïntroduceerd - in de codificaties van 1969 en 1997 is behouden, wil echter niet zeggen dat de structuur en vormgeving van het vooronderzoek in al die jaren onveranderd is gebleven: de regeling zoals die in het oorspronkelijke wetboek van strafvordering van 1997 was opgenomen, is met name door de wetswijziging van juli 2003 op belangrijke punten gewijzigd. Het onderscheid tussen śledztwo en dochodzenie hield van oudsher in dat eerstgenoemd onderzoek was gereserveerd voor de zwaardere strafzaken en in beginsel door de prokurator werd uitgevoerd ${ }^{246}$ terwijl de dochodzenie een minder formele onderzoeksvariant betrof die in eenvoudigere zaken onder leiding van de prokuratura werd uitgevoerd door de politie. Belangrijkste gevolg van de wetwijziging van 2003 is dat niet langer kan worden gezegd dat de śledztwo het domein van de prokurator is. Om de efficiëntie van het vooronderzoek te vergroten, heeft de wetgever de bevoegdheden van de politie in beide soorten vooronderzoek aanzienlijk uitgebreid. Hierdoor is tussenkomst van de prokuratura in het vooronderzoek niet alleen in de dochodzenie maar ook in de śledztwo - meer uitzondering dan regel geworden. ${ }^{247}$ De verwachting is dan ook dat het vooronderzoek in de $21 \mathrm{e}$ eeuw voornamelijk door de politie zal worden gedomineerd. ${ }^{248}$ Omdat het prak-

242 Art. 303 jo. 325a KPK 1997.

243 De wet gebruikt in deze context niet de term 'verdachte' ('podejrzany') maar 'dader' ('sprawca').

244 Art. 297 lid 1 KPK 1997.

245 Naar het Engels wel vertaald als respectievelijk investigation en inquiry en naar het Frans als l'instruction en l'enquête. Omdat het onderscheid tussen beide begrippen zich moeilijk laat weergeven in het Nederlands worden hier de Poolse termen gebruikt.

246 Hoofdregel was dat de prokurator alle onderzoeksactiviteiten in śledztwo verrichtte met de mogelijkheid om bepaalde handelingen te delegeren aan de politie.

247 Grzegorczyk en Tylman 2001, p. 744-747 en 826-827. De situatie is door een wetswijziging van juli 2007 weer iets gewijzigd maar deze nuances zullen hier verder buiten beschouwing worden gelaten.

248 Waltoś 2002 II, p. 14. 
tisch onderscheid tussen beide soorten vooronderzoek gering is, zal in het hiernavolgende de algemene term 'vooronderzoek' worden gebruikt waarmee tenzij anders aangegeven zowel de śledztwo als de dochodzenie wordt bedoeld. ${ }^{249}$

Behalve de door de wet gehanteerde verdeling in twee soorten vooronderzoek wordt in de doctrine nog een tweede - meer theoretisch onderscheid - gemaakt tussen het vooronderzoek dat wordt verricht voordat er officieel een verdachte is aangewezen en het vooronderzoek na dit procesmoment. Eerstgenoemde fase wordt wel het vooronderzoek in rem (ofwel postępowanie przygotowawcze w sprawie: het vooronderzoek in de zaak) genoemd terwijl het onderzoek nadat een verdachte op de hoogte is gesteld van de tegen hem bestaande beschuldigingen wordt aangeduid als het onderzoek in personam (postepowanie przygotowawcze przeciwko podejrzanemu: het vooronderzoek tegen verdachte). ${ }^{250}$

Zoals eerder aangegeven, bestaat er in het huidige strafproces geen rechter-commissaris: deze is eind jaren veertig uit het strafprocesrecht verdwenen en nooit opnieuw geïntroduceerd. ${ }^{251}$ Ter compensatie daarvan is het aandeel van de rechtbank in het vooronderzoek in 1997 wel aanzienlijk uitgebreid. ${ }^{252}$ Ondanks deze uitbreiding is de prokurator nog altijd dominus litis van het vooronderzoek hetgeen onder meer blijkt uit het feit dat de verdediging voor gebruikmaking van de meeste rechten en bevoegdheden - zoals inzage in de processtukken of deelname aan een getuigenverhoor - afhankelijk is van toestemming van de prokurator. Wanneer de akte van beschuldiging is ingediend, verschuift deze verhouding echter volledig: de prokurator krijgt de hoedanigheid van procespartij en vanaf dat moment is zijn positie in beginsel gelijk aan die van de verdediging. Volledige gelijkheid is gezien de verschillende achtergronden van beide procespartijen echter illusoir. Een groot deel van de bewijsvoering heeft - zoals gebruikelijk in continentale systemen - immers al plaatsgehad voor aanvang van het onderzoek ter terechtzitting en de zittingsrechter is door het lezen van het dossier bekend geworden met de voor de verdachte belastende resultaten van dit onderzoek. Dit levert een belangrijke voorsprong op voor de vervolgende instantie die onmogelijk volledig kan worden gecompenseerd door het meer adversaire karakter van het eindonderzoek. ${ }^{253}$

249 Zie over de gevolgen van de wetswijziging van 2003 voor het vooronderzoek onder meer: Waltoś 2003, p. 9-15, Grzeszczyk 2003, p. 7-12, Zbrojewska 2003, p. 42-43, Bieńkowska e.a. 2004 , p. 312 e.v.

250 Over dit onderscheid: Waltoś 2002 I, p. 473-476.

251 Hoewel zowel voor als na 1989 in de doctrine voor herintroductie van de rechtercommissaris werd gepleit, zijn niet alle auteurs onverdeeld positief over het instituut. Krajewski heeft bijvoorbeeld aangegeven dat herintroductie van de rechter-commissaris vanuit het oogpunt van een evenwichtiger verdeling tussen voor- en eindonderzoek wellicht niet zo verstandig zou zijn. Ervan uitgaande dat een zittingsrechter eerder geneigd is een kritische houding aan te nemen ten overstaan van een prokurator dan ten opzichte van onderzoek dat door of onder leiding van een rechter-commissaris is verricht, zou de herinvoering van genoemde functie de balans tussen voor- en eindonderzoek nog verder kunnen verstoren: Krajewski 1985, p. 77-78.

252 Zie hiervoor $\$$ 2.3.3.1.

253 In de hoofdstukken 5 en 6 zal dieper worden ingegaan op de gelijkheid tussen vervolging en verdediging in de verschillende fasen van het strafproces. 


\subsubsection{Eindonderzoek}

De zaak wordt bij de rechter aangebracht door het indienen van de akte van beschuldiging (akt oskarżenia) wat binnen veertien dagen na sluiting van het vooronderzoek dient te gebeuren. ${ }^{254}$ In het gros van de gevallen dient de prokurator een akte van beschuldiging in met als doel de zaak op het onderzoek ter terechtzitting en ten overstaan van de verdachte door de rechter te laten beoordelen. Soms is het verzoek van de prokurator echter beperkter. Hij kan de rechtbank namelijk ook vragen een straf of maatregel op te leggen zonder onderzoek ter terechtzitting (art. 335 KPK 1997) of de zaak voorwaardelijk te beëindigen (art. 336 KPK 1997). ${ }^{255}$ Voorwaardelijke beëindiging houdt in dat de prokurator van vervolging afziet maar de rechter wel vraagt aan deze beslissing bepaalde voorwaarden te verbinden zoals het vergoeden van veroorzaakte schade of het maken van excuses aan het slachtoffer. Aan dergelijke voorwaarden wordt een proeftijd van 1 of 2 jaar verbonden. Deze wijze van afdoening is slechts mogelijk bij strafbare feiten die met niet meer dan drie jaar gevangenisstraf worden bedreigd.

Dergelijke verzoeken - tot voorwaardelijke beëindiging en tot veroordeling zonder onderzoek ter terechtzitting - worden in de zogenaamde 'voorbereidende fase' (zie hierna) door de rechtbank beoordeeld tijdens een zitting waaraan verdachte en zijn raadsman mogen deelnemen. ${ }^{256}$

\subsubsection{De voorbereidende fase}

De fase ter voorbereiding op het onderzoek ter terechtzitting bestaat uit twee stadia: enerzijds de fase waarin de akte van beschuldiging op formele vereisten en inhoudelijke aspecten wordt gecontroleerd en anderzijds de handelingen ter voorbereiding op het onderzoek ter terechtzitting. ${ }^{257}$ In de literatuur wordt ter aanduiding van deze twee procesfasen wel de term postępowanie przejściowe (letterlijk: overgangsprocedure) gebruikt. ${ }^{258}$ Dit deel van het strafproces is vooral ingegeven door proceseconomische overwegingen: belangrijkste doel is, vaststellen of er gronden zijn om de zaak zonder onderzoek ter terechtzitting tot een einde te brengen en - indien onderzoek ter terechtzitting wel noodzakelijk blijkt dit stadium van de procedure zo goed mogelijk voor te bereiden. ${ }^{259}$

Wanneer de akte van beschuldiging niet aan de formele eisen voldoet, wordt de prokurator in de gelegenheid gesteld de gebreken binnen zeven dagen te herstellen. Indien de akte wel aan alle wettelijke voorwaarden voldoet, geeft de president van de rechtbank opdracht een kopie aan de verdachte te doen toekomen waarbij deze wordt opgeroepen binnen zeven dagen bewijsverzoeken in te dienen. ${ }^{260}$ Boven-

254 Art. 331 lid 1 en 3 KPK 1997: wanneer de verdachte zich in voorlopige hechtenis bevindt, is deze termijn zeven dagen. Indien onvoldoende grond voor het indienen van een akte van beschuldiging bestaat, kan het vooronderzoek uiteraard ook worden gesloten zonder dat de zaak bij de rechter wordt aangebracht: art. 322 KPK 1997.

255 Zie ook hoofdstuk 6, § 3.

256 Art. 339 lid 1 sub 2 en 3 en lid 5 KPK 1997.

257 Geregeld in respectievelijk hoofdstuk 40 en 41 KPK 1997.

258 Zie onder meer Waltoś 2002 I, p. 491 e.v. en Wiliński 2006, p. 572.

259 Wiliński 2006, p. 572.

260 Art. 337 lid 1 en 338 lid 1 KPK 1997. 
dien heeft verdachte anders dan onder het oude wetboek van strafvordering van 1969 voortaan het recht schriftelijk te reageren op de akte van beschuldiging. ${ }^{261}$

Behalve de controle van de akte van beschuldiging kunnen nog andere zaken aan de orde komen in de eerste fase van de 'overgangsprocedure'. Bijvoorbeeld wanneer de prokurator een verzoek tot toepassing van bepaalde beschermende (of veiligheids-)maatregelen (środki zabezpieczajace) zoals plaatsing van verdachte in een psychiatrische inrichting heeft ingediend of de rechtbank heeft verzocht een bepaalde straf op te leggen zonder onderzoek ter terechtzitting, dient de president van de rechtbank de zaak voorafgaand aan het onderzoek ter terechtzitting naar de zitting te verwijzen. ${ }^{262}$ Een dergelijke zitting kan ook plaatsvinden wanneer de procedure moet worden beëindigd omdat de aanklacht ongegrond is of wanneer de zaak moet worden terugverwezen naar de prokurator om gebreken in het vooronderzoek te herstellen. ${ }^{263}$ De verdachte en zijn raadsman hebben het recht aan deze zittingen deel te nemen. ${ }^{264}$

De tweede fase van de overgangsprocedure is gericht op de formele voorbereiding van het onderzoek ter terechtzitting. Wanneer de president verwacht dat dit zal bijdragen aan een betere organisatie en een efficiënter verloop van het onderzoek ter terechtzitting kan er reeds in dit stadium een (soort pro forma) zitting worden belegd waarop het verloop van het uiteindelijke onderzoek ter terechtzitting wordt voorbereid. ${ }^{265}$ De president van de rechtbank legt de gegevens voor het eindonderzoek vervolgens vast in een schriftelijke beslissing: welke rechters op welke datum van de zaak kennis zullen nemen, welke personen zullen worden opgeroepen ter zitting te verschijnen et cetera. ${ }^{266}$

\subsubsection{Onderzoek ter terechtzitting}

Het onderzoek ter terechtzitting wordt te allen tijde geleid door een professionele rechter (de voorzitter) die in de meeste strafzaken wordt bijgestaan door twee lekenrechters. In zo'n meervoudige kamer neemt de voorzitter plaats tussen de twee andere rechters aan de tafel waaraan ook de griffier (protokolant) zit. Vanuit het oogpunt van de rechter zitten rechts tegenover hem de aanklager (prokurator en/of private- of hulpaanklager en eventueel de civiele partij die zich in de strafzaak heeft gevoegd) en links tegenover hem de verdachte en zijn eventuele raadsman. Beide posities zijn dus op gelijke afstand van de rechterstafel en recht tegen over elkaar wat de gelijkheid tussen de twee procespartijen en het adversaire karakter van de strafzitting symboliseert. In de regel zit de raadsman op een aparte

261 Art. 338 lid 2 KPK 1997, verdachte moet van dit recht op de hoogte worden gesteld. Zie over de schriftelijke reactie op de akte van beschuldiging hoofdstuk 6, § 2.1.

262 Art. 339 lid 1 KPK 1997.

263 Respectievelijk art. 339 lid 3 sub 2 - een dergelijke toetsing vindt altijd plaats wanneer de aanklacht is ingediend door een burger (art. 339 lid 2) - en art. 339 lid 3 sub 4 KPK 1997.

264 In sommige gevallen is deelname van de verdediging zelfs verplicht. Zoals in hoofdstuk 6 , § 2.3 nog zal worden uitgewerkt, zijn de mogelijkheden van de verdediging om deel te nemen aan zittingen in de voorbereidende fase van het strafproces sinds de inwerkingtreding van het nieuwe wetboek van strafvordering aanzienlijk uitgebreid.

265 Art. 349 KPK 1997. Zaken die kunnen worden besproken zijn: welke personen wanneer zullen worden opgeroepen om ter zitting te verschijnen en welke onderzoekshandelingen de rechtbank op welk moment in de procedure zal verrichten: Grzegorczyk 2004, p. 924.

266 Art. 350 KPK 1997. 
bank voor de verdachte maar het komt - bijvoorbeeld in kleinere zittingzalen ook voor dat hij naast zijn cliënt plaats kan nemen. In zwaardere zaken is het niet ongebruikelijk dat (potentieel) gevaarlijke verdachten plaats dienen te nemen in een stalen kooi. De raadsman zit in zo'n geval voor de kooi hetgeen de communicatie met zijn client kan bemoeilijken. ${ }^{267}$

Vanuit zijn 'beklaagdenbank' legt de verdachte ook verklaringen af terwijl getuigen en deskundigen wanneer ze worden gehoord, plaats nemen in het midden van de zittingzaal, recht tegenover de rechter(s). Door de centrale positie van getuigen en deskundigen is het niet nodig dat procespartijen zich - zoals bijvoorbeeld in het Amerikaanse strafproces gebeurt - gedurende de ondervraging door de zittingzaal bewegen. ${ }^{268}$

De verschillende professionele procesdeelnemers zijn herkenbaar aan de kleur van de rand van hun toga: voor de rechter is deze paars, ${ }^{269}$ voor de prokurator rood, voor de juridisch adviseur blauw en voor de advocaat groen.

\section{Verloop onderzoek ter terechtzitting}

Het onderzoek ter terechtzitting (rozprawa główna) neemt aanvang door het uitroepen van de zaak. Vervolgens wordt een aantal formaliteiten afgehandeld: de aanwezigheid van de opgeroepen personen wordt gecontroleerd en eventuele preliminaire kwesties zoals verzoeken om wraking van de rechter(s) en voeging van burgerlijke partijen kunnen worden behandeld. ${ }^{270}$ Wanneer dit geen aanleiding geeft de zaak aan te houden, wordt de akte van beschuldiging voorgelezen door de prokurator waarmee de fase van de bewijsvoering (przewód sądowy) aanvangt. In deze fase kunnen de verdachte, eventuele getuigen en deskundigen worden gehoord en bewijsstukken worden gepresenteerd en beoordeeld. ${ }^{271}$

Bewijsvoering vindt plaats op verzoek van partijen of ambsthalve door de rechter. ${ }^{272}$ Feiten van algemene bekendheid of feiten die de leden van de rechtbank ambtshalve bekend zijn, behoeven geen bewijs. ${ }^{273}$ Het wetboek van strafvordering geeft geen limitatieve opsomming van de toegestane (soorten) bewijsmiddelen en kent geen bewijsminima. Alles dat kan bijdragen aan de waarheidsvinding kan in beginsel voor het bewijs worden gebezigd. ${ }^{274}$ De wetgever heeft - hoogst-

267 Ten aanzien van de Russische strafrechtspleging - waar vergelijkbare situaties voorkomen - is in dit verband in de literatuur terecht opgemerkt: 'Whether in a dock or in a cage, the defendant is usually some distance from the defense counsel, making attorney-client communication somewhat difficult and the need for it a public matter': Burnham e.a. 2004, p. 517.

268 Waltoś 2002 I, p. 41.

269 De voorzitter is te herkennen aan zijn ambtsketen: een ketting met een adelaar (het symbool van de Poolse republiek).

270 Waltoś 2002 I, p. 501-502.

271 Meer uitgebreid hierover: hoofdstuk 6, § 4.4.

272 Art. 167 KPK 1997.

273 Art. 168 KPK 1997.

274 Op deze vrijheid gelden twee belangrijke uitzonderingen. In de eerste plaats zijn bepaalde bewijsmiddelen - of de wijze waarop ze totstandkomen - verboden: dit zijn de zogenaamde bewijsverboden (zakazy dowodowe). Voorbeeld is het verbod een getuige te horen die gebruik wenst te maken van zijn verschoningsrecht. Ten tweede heeft de wetgever in sommige gevallen een bepaalde vorm van bewijsvoering dwingend voorgeschreven. Zo is wanneer voor de vaststelling van bepaalde (voor de zaak essentiële) feiten bepaalde expertise nodig is, inschakeling van een deskundige verplicht (art. 193 lid 1 KPK 1997). Zie 
waarschijnlijk vanwege de grote vrijheid ten aanzien van de toegestane bewijsmiddelen - veel aandacht besteed aan de wijze waarop bewijsmiddelen tot stand dienen te komen. Belangrijke bewijsmiddelen zijn: de verklaring van de verdachte (wyjaśnienie), de verklaring van een getuige (zeznanie), deskundigerapportage (opinia) en processen-verbaal van onderzoekshandelingen.

De verdachte is, tenzij de wet anders bepaalt, verplicht om op de zitting aanwezig te zijn. ${ }^{275}$ Omdat de verplichting de verdachte te allen tijde bij het onderzoek ter terechtzitting aanwezig te hebben in het verleden geregeld tot ongewenste vertraging van procedures leidde, zijn de mogelijkheden om de zaak in afwezigheid van verdachte af te doen in het nieuwe wetboek van strafvordering aanzienlijk uitgebreid. ${ }^{276}$ Indien de rechtbank de aanwezigheid van een niet verschenen verdachte toch noodzakelijk acht, kan ze zijn medebrenging gelasten. Bovendien kan ze de verdachte tijdelijk verbieden het gerechtsgebouw te verlaten. ${ }^{277}$

Het feitelijke onderzoek ter terechtzitting begint met het horen van verdachte: de voorzitter wijst hem op zijn zwijgrecht en vraagt hem vervolgens of hij schuld wenst te bekennen en of hij een verklaring wil afleggen. ${ }^{278}$ Hierna krijgen procespartijen de gelegenheid de verdachte vragen te stellen. Het huidige strafprocesrecht vertoont voor wat betreft het stellen van vragen aan verdachten, getuigen en deskundigen een belangrijk verschil met de regeling van voor 1997: ondervraging geschiedt nu eerst door procespartijen en daarna pas door de rechter(s). ${ }^{279}$ In Poolse strafzaken wordt doorgaans veel gebruik gemaakt van getuigen en deskundigen waardoor dit deel van het onderzoek ter terechtzitting veel tijd in beslag kan nemen. Dit is onlosmakelijk verbonden met het eerder genoemde feit dat in het Poolse strafproces veel belang wordt gehecht aan onmiddellijkheid (zasada bezpośredniości) wat betekent dat bewijs zo veel mogelijk op de zitting ten overstaan van de rechter moet worden gepresenteerd. Het beginsel is nergens expliciet in de wet vastgelegd maar ligt onder meer ten grondslag aan art. 174 KPK 1997 waarin is geregeld dat bewijs uit verklaringen van verdachten en getuigen slechts op basis van deze verklaringen mag worden gebruikt en niet mag worden vervangen door documenten en aantekeningen. Deze personen moeten dus in beginsel ook wanneer ze tijdens het vooronderzoek reeds een verklaring hebben afgelegd ter terechtzitting opnieuw worden gehoord. Het onmiddellijkheidsbeginsel heeft in Polen net als in veel andere continentale rechtssystemen

Hofmański e.a. 2007 I, p. 743. Zie over bewijs in het Poolse strafproces verder onder meer: Waltoś 2002 I, p. 335-400.

275 Art. 374 lid 1 KPK 1997. Uitzonderingen op de aanwezigheidsplicht gelden bijvoorbeeld in meer eenvoudige strafzaken zoals wanneer een vereenvoudigde procedure (postępowanie uproszczone) - een van de bijzondere procedures waarin het Poolse strafprocesrecht voorziet - wordt gevolgd. Zie art. 479 KPK 1997. Indien in een dergelijk geval ook de raadsman niet verschijnt, kan veroordeling bij verstek plaatsvinden (wyrok zaoczny).

276 Zie hierover: hoofdstuk 6, § 4.2.

277 Art. 382 en 374 lid 2 KPK 1997.

278 Art. 386 lid 1 KPK 1997. Pas nadat de verdachte op deze wijze door de voorzitter is gehoord, wordt hij geïnformeerd over het recht de personen die ter zitting zullen worden gehoord vragen te stellen en te reageren op bewijsstukken die worden gepresenteerd (art. 386 lid 2 KPK 1997).

279 Zie hoofdstuk 2, § 2.3.3.2 en hoofdstuk 6, § 4.4.2. 
echter geen absoluut karakter. De wet voorziet in een aantal belangrijke uitzonderingen die het mogelijk maken verklaringen van verdachten en getuigen afgelegd in het vooronderzoek op het onderzoek ter terechtzitting voor te lezen.280

De bewijsvoering kan onder omstandigheden worden overgeslagen of ingekort: de wet voorziet in de mogelijkheid deze fase van het onderzoek ter terechtzitting volledig achterwege te laten of slechts gedeeltelijk te laten plaatsvinden. ${ }^{281}$ Ook deze mogelijkheden relativeren de betekenis van het onmiddellijkheidsbeginsel in het Poolse strafproces.

Nadat de bewijsvoering op de terechtzitting is afgesloten, vinden de slotpleidooien (głosy stron) plaats. Partijen komen in de volgende volgorde aan de beurt: prokurator, de hulpaanklager, de private aanklager, de civiele partij, de entiteit genoemd in art. 416 KPK 1997 (dit is een natuurlijke- of rechtspersoon die materieel voordeel heeft verkregen door het strafbaar feit en in wiens naam of belang de verdachte handelde ${ }^{282}$ ), de raadsman en ten slotte de verdachte. In het geval dat de prokurator of de civiele partij opnieuw het woord krijgt, dienen ook de

280 In de literatuur worden vier categorieën uitzonderingen onderscheiden. Beknopt weergegeven zijn dat:

1. Het gebruik van 'indirect' bewijs wanneer direct bewijs niet bestaat of niet toegankelijk is. Wanneer een verdachte ter zitting weigert te verklaren, mogen de verklaringen die hij eerder in de betreffende of een andere zaak in de hoedanigheid van verdachte heeft afgelegd ter zitting worden voorgelezen (art. 389 lid 1 KPK 1997). Indien een getuige zonder gerechtvaardigde reden weigert een verklaring af te leggen, kunnen zijn verklaringen die in de betreffende of een andere zaak eerder zijn afgelegd, worden voorgelezen (art. 391 lid 1 KPK 1997). In vereenvoudigde procedures kan de verklaring afgelegd gedurende het vooronderzoek door een verdachte die niet aanwezig is op de zitting aldaar worden voorgelezen (art. 479 lid 2 KPK 1997).

2. Het gebruik van 'indirect' bewijs wanneer dat noodzakelijk is voor de controle van het directe bewijs. Indien een verdachte of een getuige ter terechtzitting in strijd met zijn eerder afgelegde verklaringen verklaart, kunnen de eerder afgelegde verklaringen ter zitting worden voorgelezen (art. 389 lid 1 en 391 lid 1 en 2 KPK 1997).

3. Het gebruik van bewijzen die van nature 'indirect' zijn zoals meningen van deskundigen, processen verbaal van een schouw et cetera: dit soort bewijs mag in beginsel ter zitting worden voorgelezen (art. 393 lid 1 KPK 1997).

4. Het gebruik van 'indirect' bewijs wanneer dat voor een efficiënte procesvoering noodzakelijk is en procespartijen ermee instemmen. In het kader hiervan is met name het ruim geformuleerde art. 392 KPK 1997 van belang: 'de rechtbank mag verklaringen van getuigen en verdachten afgelegd gedurende het vooronderzoek voorlezen wanneer directe bewijsvoering (lees rechtstreeks horen/ondervragen) niet onontbeerlijk is en de aanwezige partijen zich er niet tegen verzetten: Waltoś 2002 I, p. 262-264. Art. 392 KPK 1997 heeft in juli 2003 een belangrijke wijziging ondergaan: voorheen gold namelijk dat het voorlezen van de verklaringen slechts was toegestaan wanneer het rechtstreeks horen was 'bemoeilijkt' ('utrudnione'). Volgens de huidige redactie van het artikel is voorlezen derhalve in een groter aantal gevallen toegestaan: ook wanneer horen ter zitting wel zonder problemen kan worden gerealiseerd, kan het achterwege blijven indien het niet noodzakelijk wordt geacht. Deze wijziging past in het streven van de wetgever het strafproces sneller en efficiënter te laten verlopen. Zie over onmiddellijkheid in het eindonderzoek ook: hoofdstuk 6, § 4.4.1.

281 Zie $\S$ 2.3.3.2 van dit hoofdstuk. Meer over deze alternatieve wijzen van afdoening in hoofdstuk $6, \S 3$.

282 Bijvoorbeeld een bedrijf dat financieel voordeel heeft genoten als gevolg van frauduleuze handelingen van een medewerker. 
raadsman en de verdachte nog een keer te kunnen spreken. ${ }^{283}$ Wanneer een verdachte meer dan één advocaat heeft, hebben ze beiden of alle drie - drie is immers het wettelijke maximum - afzonderlijk het recht het woord te voeren. ${ }^{284}$ De verdachte heeft te allen tijde het laatste woord. ${ }^{285} \mathrm{Na}$ de slotpleidooien trekt de rechtbank zich terug voor beraadslaging. Beslissing over schuld, kwalificatie van het feit en de op te leggen sanctie worden - zoals gebruikelijk in continentale systemen - tegelijkertijd en bij meerderheid genomen. De stemmen van leken- en professionele rechters wegen even zwaar: in een meervoudige kamer met twee lekenrechters en een professionele rechter (de meest gangbare samenstelling in eerste aanleg) is het dus mogelijk dat de lekenrechters de professionele voorzitter 'overrulen'. De beraadslaging is geheim maar iedere rechter - ook de niet professionele - heeft het recht bij het ondertekenen van het vonnis een dissenting opion (votum seperatum) uit te brengen. ${ }^{286}$ Hierdoor kunnen partijen en het publiek toch inzicht krijgen in de wijze waarop de beslissing tot stand is gekomen. ${ }^{287}$

\subsubsection{Rechtsmiddelen}

Omdat dit onderzoek zich beperkt tot de strafrechtelijke procedure in eerste aanleg, zal slechts kort aandacht worden besteed aan de verschillende (gewone en buitengewone) rechtsmiddelen die tegen einduitspraken kunnen worden aangewend. De belangrijkste rechtsmiddelen binnen het Poolse strafprocesrecht zijn:

1. bezwaar (zażalenie),

2. hoger beroep (apelacja) en

3. cassatie (kasacja).

Het onderscheid tussen de twee eerstgenoemde middelen wordt hoofdzakelijk bepaald door de vorm van de bestreden beslissing. In het Poolse strafprocesrecht worden verschillende soorten beslissingen onderscheiden:

- wyrok (einduitspraak),

- postanowienie (beslissing door de rechtbank genomen wanneer de wet geen einduitspraak voorschrijft) en

- zarzadzenie (beslissing genomen door de voorzitter van een afdeling van de rechtbank of een andere bevoegde rechter wanneer een beslissing door de president van de rechtbank niet noodzakelijk is).

Gedurende het vooronderzoek worden postanowienia en zarzadzenia in de door de wet voorziene gevallen door de rechtbank genomen en overigens door de prokurator of een ander orgaan dat de leiding heeft over het vooronderzoek. ${ }^{288}$ Voor de rechtsmiddelen betekent dit onderscheid het volgende: tegen einduitspraken (wyroki) kan hoger beroep (apalacja) worden ingesteld en tegen een groot

283 Art. 406 lid 2 KPK 1997.

284 Grzegorczyk 2004, p. 1039.

285 Art. 367 lid 2 laatste zin KPK 1997.

286 Art. 111 lid 1 en 114 lid 1 KPK 1997.

287 Zie over de verschillende fasen van het onderzoek ter terechtzitting onder meer: Grajewski 2005, p. 160-2245.

288 Art. 93 KPK 1997. Wyroki en postanowienia worden samen tot de orzeczenia (letterlijk: uitspraken) gerekend, terwijl zarzadzenia daar niet toe behoren en als ‘beslissingen niet zijnde uitspraken' een aparte categorie vormen. 
aantal beslissingen die geen einduitspraak zijn (postanowienia of zarzadzenia) - en in sommige gevallen ook tegen handelingen - kan bezwaar (zażalenie) worden aangetekend. ${ }^{289}$

\subsubsection{Bezwaar}

Op grond van het huidige wetboek van strafvordering staat bezwaar open tegen

- beslissingen van de rechtbank die in de weg staan aan een einduitspraak,

- beslissingen ten aanzien van beschermende maatregelen zoals plaatsing van verdachte in een psychiatrische inrichting of een afkickkliniek en ten slotte - en dat is een ruime restcategorie -

- tegen alle andere beslissingen waarvoor de wetgever dat expliciet mogelijk heeft gemaakt. ${ }^{290}$

Afhankelijk van de vraag wie de bestreden beslissing heeft genomen, dient bezwaar te worden gericht tot de rechtbank of de prokuratura. De rechtbank kan bezwaren in behandeling nemen die zijn gericht tegen bepaalde beslissingen die door de prokurator zijn genomen en tegen rechterlijke beslissingen. In dat laatste geval gebeurt dat doorgaans door een hogere rechterlijke instantie maar soms is de rechtbank die de bestreden beslissingen genomen heeft ook de instantie die het bezwaar (weliswaar in een andere samenstelling) behandelt. Een bezwaar dat wordt ingediend bij de prokuratura kan zich uitstrekken over beslissingen van lager geplaatste leden van deze organisatie of van een ander persoon die in het vooronderzoek optreedt. ${ }^{291}$ Gerechtigd tot het instellen van bezwaar zijn - tenzij de wet anders bepaalt - partijen en personen die rechtstreeks door de beslissing worden getroffen. ${ }^{292}$

\subsubsection{Hoger beroep}

Het rechtsmiddel hoger beroep staat open tegen in eerste aanleg gedane einduitspraken. ${ }^{293}$ Voor wat de competentieverdeling betreft, betekent dit dat tegen vonnissen van districtsrechtbanken (SR, inclusief uitspraken van de grodzki-afdelingen) hoger beroep open staat bij de provinciale rechtbank (SO) en dat tegen einduitspraken van laatstgenoemde instantie hoger beroep kan worden ingesteld

289 Zażalenie betekent letterlijk 'klacht' maar zal hier met de meer juridische term 'bezwaar' worden aangeduid.

290 Art. 459 lid 1 en 2 KPK 1997. Deze bepaling spreekt weliswaar alleen van postanowienia maar is ingevolge art. 466 lid 1 KPK 1997 van overeenkomstige toepassing op zarzadzenia. Omdat het te ver voert hier een limitatieve opsomming te geven van de vele bepalingen waarin de wetgever van die mogelijkheid gebruik heeft gemaakt, zal worden volstaan met de verwijzing naar een aantal voorbeelden: art. 69 lid 3, 85 lid 2, 105 lid 4, 165 lid 2, 180 lid 2, 290 lid 2 en 302 lid 1 KPK 1997. In sommige van deze gevallen gaat het niet om een echte beslissing maar om een handeling van de rechtbank, de prokurator of een ander orgaan: zoals het bezwaar dat tegen aanhouding en daaropvolgende vrijheidsbeneming door de politie kan worden ingesteld (art. 246 lid 1 KPK 1997).

291 Art. 465 lid 2 en 3 KPK 1997.

292 Art. 459 lid 3 KPK 1997. Hoofdregel is dat het binnen zeven dagen na bekendmaking van de bestreden beslissing moet worden ingesteld bij het orgaan dat laatstgenoemde beslissing heeft genomen.

293 Art. 444 KPK 1997. 
bij de hoger beroepsinstantie (SA). Voor de samenstelling van de rechterlijke colleges geldt dat in hoger beroep in beginsel alleen professionele rechters zitting nemen.

Het rechtsmiddel kan betrekking hebben op zowel de feitelijke als de juridische aspecten van de zaak en kan worden ingesteld tegen de uitspraak in zijn geheel of betrekking hebben op slechts een deel ervan. ${ }^{294}$ De appelrechter is echter niet gebonden aan de grenzen van datgene wat door de appellant aan de orde wordt gesteld: de wet voorziet in een aantal gevallen waarin de bestreden uitspraak sowieso - ongeacht de inhoud van het rechtsmiddel - moet worden vernietigd. ${ }^{295}$ Een procespartij is bevoegd binnen veertien dagen nadat het bestreden vonnis aan hem is uitgereikt hoger beroep aan te tekenen bij de instantie die de beslissing in eerste aanleg heeft genomen. ${ }^{296}$ Voor de verdediging geldt dat zowel de raadsman als de verdachte het rechtsmiddel kunnen instellen. De verdachte kan dit onder bepaalde omstandigheden niet alleen: wanneer hij hoger beroep wenst in te stellen tegen een uitspraak van de provinciale rechtbank dient het rechtsmiddel te worden opgesteld en ondertekend door een advocaat. ${ }^{297}$ De verdediging kan het rechtsmiddel alleen aanwenden voor zover de bestreden uitspraak in haar nadeel is. ${ }^{298}$ Deze beperking geldt niet voor de prokurator: hij kan ook beroep aantekenen ten voordele van verdachte. ${ }^{299}$

De inhoudelijke behandeling van een zaak in hoger beroep verschilt wezenlijk van het onderzoek ter terechtzitting in eerste aanleg. Anders dan in eerste aanleg neemt de behandeling geen aanvang door het voorlezen van de akte van beschuldiging maar door een mondelinge rapportage door de voorzitter waarin het verloop van de betreffende strafzaak en met name de inhoud van de bestreden uitspraak en de bezwaren van de appellerende partij worden toegelicht. Partijen kunnen mondeling of schriftelijk verklaringen afleggen en verzoeken indienen. ${ }^{300}$ Wat de aanwezigheid van procespartijen betreft, geldt dat alleen de prokurator - en in de in art. 79 en 80 KPK 1997 genoemde gevallen van verplichte rechtsbijstand ook de raadsman van verdachte - te allen tijde verplicht aanwezig dienen te zijn op de zitting. Aanwezigheid van andere partijen zoals de verdachte en de raadsman in situaties die niet onder de reikwijdte van art. 79 en 80 KPK 1997 vallen, is

294 Art. 425 lid 2 KPK 1997, sinds het nieuwe wetboek van strafvordering kan het beroep zelfs worden beperkt tot alleen de motivering van de beslissing in eerste aanleg.

295 Art. 439 KPK 1997: bijvoorbeeld wanneer de zaak een geval van verplichte rechtsbijstand betrof maar de verdachte desondanks in eerste aanleg geen bijstand van een advocaat heeft gehad (art. 439 lid 1 sub 10 KPK 1997). Dit zijn de zogenaamde 'absolute gronden' voor hoger beroep.

296 Art. 444 en 445 lid 1 KPK 1997

297 Art. 446 lid 1 KPK 1997. Meer over deze vorm van verplichte rechtsbijstand in hoofdstuk $4, \S 3.1$.

298 Letterlijk: een 'schending van hun recht of benadeling van hun belangen' inhoudt (art. 425 lid 3 KPK 1997).

299 Art. 425 lid 4 KPK 1997. Het staat de hoger beroepsinstantie vrij het vonnis in het voordeel van verdachte te wijzigen: de mogelijkheid om veranderingen in zijn nadeel aan te brengen zijn echter aanzienlijk beperkt. Het reformatio in peius verbod komt er voor de hoger beroepsinstantie in hoofdlijnen op neer dat de uitspraak in hoger beroep in beginsel alleen in het nadeel van verdachte mag zijn wanneer het rechtsmiddel ook in zijn nadeel (tegen hem) is ingesteld.

300 Art. 453 KPK 1997. 
slechts verplicht wanneer de president of de rechtbank dat noodzakelijk achten. ${ }^{301}$ In andere gevallen heeft de verdachte (en zijn raadsman) niet de plicht maar het recht om aan de zitting deel te nemen. Voor de gedetineerde verdachte is dit recht echter niet absoluut: zijn verzoek om bij de zitting in hoger beroep aanwezig te kunnen zijn, kan door de appelrechter worden afgewezen wanneer de aanwezigheid van een raadsman voldoende wordt geacht. ${ }^{302}$

Hoofdregel is dat er op de zitting in hoger beroep geen bewijsvoering plaatsvindt. De zaak wordt dus in beginsel behandeld aan de hand van het dossier. ${ }^{303}$ De hoger beroepsinstantie kan in haar einduitspraak de bestreden beslissing in stand houden, vernietigen of wijzigen. ${ }^{304}$

301 Art. 450 lid 1 en 2 KPK 1997.

302 Art. 451 KPK 1997. Wanneer de rechter aanwezigheid van de raadsman voldoende acht en verdachte nog geen bijstand heeft, wordt hem ambtshalve een advocaat toegevoegd. Genoemde regeling heeft sinds de inwerkingtreding van het nieuwe wetboek van strafvordering verschillende wijzigingen ondergaan. Oorspronkelijk waren de mogelijkheden voor gedetineerde verdachten om deel te nemen aan de zitting in hoger beroep nog beperkter. Op grond van het oude strafprocesrecht gold slechts de regel dat de hoger beroepsinstantie kon bepalen dat de gedetineerde naar de zitting zou worden gebracht (art. 401 KPK 1969). In de praktijk gebeurde dit alleen wanneer aanvullend bewijs zou worden gepresenteerd: in alle andere gevallen vond de zitting uitsluitend in aanwezigheid van de prokurator plaats. Deze praktijk werd vrijwel direct nadat Polen het individueel klachtrecht had erkend in Straatsburg aan de kaak gesteld: in Belziuk t. Polen (EHRM 25-3-1998, Reports 1998-II, nr. 23103/93) stelde het Europese een schending van art. 6 lid 1 en 3(c) EVRM vast vanwege het feit dat klager niet in gelegenheid was gesteld de behandeling van zijn hoger beroep bij te wonen. Gelet op wat er voor Belziuk op het spel stond, had de zaak volgens het Europese Hof niet 'as a matter of fair trial' in zijn afwezigheid afgedaan mogen worden. Daarbij speelde volgens het EHRM ook een rol dat 'the applicant's interests were not in fact represented at the appeal since there was no counsel present on his behalf'. Als gevolg van deze uitspraak werd de regeling in het wetboek van strafvordering van 1997 - die in hoofdlijnen overeenkwam met de regeling in art. 401 KPK 1969 - zodanig gewijzigd dat hoger beroepsinstanties voortaan in beginsel (dus ongeacht de inhoud van het hoger beroep) de gedetineerde verdachte in de gelegenheid dienen te stellen bij de behandeling van zijn hoger beroep aanwezig te zijn tenzij aanwezigheid van een raadsman voldoende wordt geacht. Hoewel dit uiteraard een verbetering moet worden genoemd, is het nog maar de vraag of de huidige situatie in alle gevallen 'Straatsburgproof' is. Zoals erkend in de rechtspraak van het EHRM kunnen zich immers situaties voordoen waarin aanwezigheid van de raadsman vanuit het oogpunt van een eerlijk proces persoonlijke deelname van de verdachte niet of onvoldoende kan compenseren (zie bijvoorbeeld Kremzow t. Oostenrijk, EHRM 21-9-1993, A268-B, nr. 12350/86 en Zana t. Turkije, EHRM 25-11-1997, Reports 1997-VII, nr. 18954/91). Voor een uitgebreide bespreking van de problematiek rond de deelname van gedetineerden aan appelzittingen wordt verwezen naar: Wąsek-Wiaderek 2000 en Wąsek-Wiaderek 2003 II, p. 359-374.

303 Art. 452 lid 1 KPK 1997. In bepaalde gevallen kan echter van deze regel worden afgeweken: namelijk wanneer er sprake is van een uitzonderlijk geval, het door de hoger beroepsinstantie noodzakelijk wordt geacht, de procedure erdoor versneld zal worden en het niet nodig is het gehele onderzoek - of een substantieel deel ervan - opnieuw plaats te laten vinden. Deze voorwaarden zijn cumulatief. 


\subsubsection{Cassatie}

De hiervoor besproken rechtsmiddelen bezwaar en hoger beroep worden aangemerkt als gewone rechtsmiddelen omdat ze kunnen worden ingesteld tegen nog niet definitieve beslissingen. Wanneer daarvan gebruik is gemaakt (of indien na een vonnis in eerste aanleg de termijn voor het instellen van hoger beroep ongebruikt is verstreken) is de strafrechtelijke procedure in beginsel beëindigd en staat in de door de wet omschreven gevallen alleen nog gewone of buitengewone cassatie open. Beide worden als buitengewone rechtsmiddelen gekwalificeerd.

Gewone cassatie kan door procespartijen worden ingesteld tegen iedere uitspraak in hoger beroep die in kracht van gewijsde is gegaan. ${ }^{305}$ Voor het instellen van cassatie is rechtsbijstand voor alle procespartijen behalve de prokurator verplicht. Een verdachte kan dus alleen cassatieberoep opstellen en indienen met behulp van een advocaat of een raadsman. ${ }^{306}$ Omdat het uitgangspunt is dat een strafzaak na behandeling in hoger beroep officieel is beëindigd waardoor de machtiging van een toegevoegd advocaat komt te vervallen, dient de verdachte om voor kosteloze rechtsbijstand ten behoeve van de cassatiefase in aanmerking te komen opnieuw een toevoeging aan te vragen. Voor de minder draagkrachtige verdachte kan deze verplichting problematisch zijn: wanneer zijn verzoek om toevoeging van een advocaat op financiële gronden wordt afgewezen, wordt feitelijk de gang naar het Hooggerechtshof afgesloten. ${ }^{307}$

Een advocaat die wordt toegevoegd ten behoeve van de cassatieprocedure is overigens niet verplicht ook daadwerkelijk cassatie in te stellen. ${ }^{308}$ Ook dit heeft in het verleden tot problemen geleid: met name in toevoegingszaken kwam het regelmatig voor dat advocaten aangaven geen heil te zien in de gang naar het Hooggerechtshof en weigerden cassatie in te stellen. Hiermee was de zaak voor de

305 Art. 519 eerste zin en 520 KPK 1997. Procespartijen dienen cassatie in bij de hoger beroepsinstantie die de zaak vervolgens doorstuurt naar het Hooggerechtshof. De eis dat de uitspraak in kracht van gewijsde moet zijn gegaan, betekent niet dat het instellen van cassatie geen gevolgen kan hebben voor de tenuitvoerlegging van het vonnis: het Hooggerechtshof is bevoegd de tenuitvoerlegging van de bestreden uitspraak te schorsen.

306 Art. 526 lid 2 KPK 1997. Voor juli 2000 kon dit alleen door advocaten worden gedaan maar inmiddels is het ook mogelijk dat de juridisch adviseur deze vorm van rechtsbijstand verleent.

307 Dit was onder meer het geval in de zaak van R.D. die in eerste aanleg en hoger beroep vanwege zijn financiële situatie wel een advocaat toegevoegd had gekregen maar wiens verzoek om toevoeging van een raadsman voor de cassatieprocedure werd afgewezen. Hij diende hierover een klacht in het bij het EHRM, en met succes: het Europese Hof was van oordeel dat de afwijzing van het verzoek om toevoeging - vanwege het feit dat eerdere verzoeken waren ingewilligd en niet was gebleken van een wezenlijke verandering van de financiële situatie van klager - onbegrijpelijk. Als gevolg hiervan en gelet op het feit dat de afwijzing van het verzoek zo kort voor het aflopen van de termijn voor het instellen van het cassatieberoep aan klager bekend werd gemaakt waardoor nauwelijks nog tijd was zelf een advocaat te contacteren, kwam het EHRM tot de conclusie dat voor R.D. geen 'concrete en effectieve' weg openstond om zijn zaak voor het Hooggerechtshof te brengen. Dit leverde een schending op van art. 6 lid 1 jo. lid 3(c) EVRM: R.D. t. Polen, EHRM 18-12-2001, nr. 29692/96, 34612/97. Zie ook hoofdstuk 4, §3.5.

308 Wanneer de advocaat na bestudering van de zaak tot de conclusie komt dat daarvoor geen grond bestaat, dient hij de rechtbank daarvan schriftelijk op de hoogte te stellen (art. 84 lid 3 KPK 1997). 
verdachte afgedaan: er bestaat geen recht op toevoeging van een tweede advocaat voor een second opinion en een cassatieberoep dat (zonder tussenkomst van een advocaat) door verdachte zelf werd ingediend, werd niet ontvankelijk verklaard. Tegen laatstgenoemde beslissing die wordt genomen door de hoger beroepsinstantie staat weliswaar bezwaar open bij het Hooggerechtshof maar - tot voor kort - gold ook daarvoor de eis van verplichte rechtsbijstand waardoor dit rechtsmiddel illusoir was. ${ }^{309}$ Een recente wetswijziging die in februari 2007 in werking is getreden, heeft de mogelijkheden voor verdachten op dit punt iets verbeterd. De eis van verplichte rechtsbijstand voor het aantekenen van bezwaar tegen de niet-ontvankelijkverklaring is komen te vervallen zodat de verdachte het feit dat zijn cassatieberoep niet in behandeling wordt genomen zelfstandig door het Hooggerechtshof kan laten beoordelen. ${ }^{310}$

De gronden voor cassatie worden onderscheiden in absolute en relatieve gronden. Cassatie kan worden ingesteld wanneer een van de wettelijke schendingen genoemd in art. 439 lid 1 KPK 1997 zich voordoet of sprake is van een andere flagrante schending van het recht die van grote invloed zou kunnen zijn (geweest) op de einduitspraak. ${ }^{311}$ Eerstgenoemde categorie omvat de absolute gronden: de in art. 439 lid 1 KPK 1997 opgesomde 'procedurefouten' - zoals het behandelen van de zaak in afwezigheid van verdachte die volgens de wet aanwezig dient te zijn - zijn dus niet alleen voor de beslissing in hoger beroep maar ook voor de cassatiefase van belang. De tweede (rest)categorie bevat de zogenaamde relatieve cassatiegronden waartoe in beginsel alle schendingen van het recht kunnen behoren 'voor zover deze van wezenlijke betekenis kunnen zijn geweest voor de uitspraak'. ${ }^{312}$

Behalve de gewone cassatie kent het Poolse strafprocesrecht net als voor 1989 ook nog een vorm van buitengewone cassatie (kasacja nadzwyczajna). Het bijzondere karakter van dit rechtsmiddel is toe te schrijven aan twee aspecten. Ten eerste het feit dat het alleen kan worden aangewend door de Procureur Generaal (de minister van Justitie) en de Nationale Ombudsman en dus niet openstaat voor procespartijen en ten tweede dat het kan worden ingesteld tegen iedere in kracht van gewijsde gegane uitspraak waarmee de strafrechtelijke procedure tot een einde is gekomen. Het hoeft dus niet zoals bij gewone cassatie noodzakelijk een uitspraak in hoger beroep te betreffen. Nadat buitengewone cassatie is ingediend, kan het hoogste rechtscollege het cassatieberoep verwerpen of de bestreden beslissing geheel of gedeeltelijk vernietigen. ${ }^{313}$

Wanneer een strafrechtelijk vonnis onherroepelijk is geworden, neemt de fase van de tenuitvoerlegging aanvang. Dit stadium wordt geregeld in een afzonderlijke

309 In de regel was de toegoevoegde advocaat die had geweigerd cassatie in te stellen uiteraard ook niet bereid bezwaar aan te tekenen tegen de niet-ontvankelijkverklaring van het door de verdachte zelf ingestelde cassatieberoep.

310 Wijziging van art. 530 KPK 1997 d.d. 12 januari 2007.

311 Art. 523 lid KPK 1997.

312 Art. 525 lid 1 KPK 1997. Over het onderscheid absolute en relatieve cassatiegronden: Waltoś 2002 I, p. 541.

313 In het laatste geval kan de zaak worden (terug)verwezen voor nieuwe behandeling door een feitelijke instantie, de procedure worden beëindigd of de verdachte in geval van een klaarblijkelijk onterechte veroordeling worden vrijgesproken: art. 537 lid 2 KPK 1997. 
codificatie: het eerder genoemde wetboek betreffende de tenuitvoerlegging van straffen (Kodeks Karny Wykonawczy). ${ }^{314}$

\section{Conclusie}

In het historische deel van dit hoofdstuk is duidelijk geworden dat de jaren tussen 1944 en 1989 golfbewegingen vertonen van meer en minder repressieve perioden en dat het straf(proces)recht zich parallel daaraan heeft ontwikkeld. Met name in het eerste decennium na Wereldoorlog II degradeerde het strafrecht tot een politiek instrument en werden vergaande wijzigingen doorgevoerd die het tamelijk liberale vooroorlogse strafrecht dienden aan te passen aan de eisen van de tijd. Hoewel als gevolg van de dood van Stalin in de tweede helft van de jaren vijftig een versoepeling van het regime merkbaar was die ook tot een verzachting van het strafrechtelijk klimaat leidde, zouden daadwerkelijke, grootschalige hervormingen nog tot het eind van de jaren tachtig op zich laten wachten. Na de laatste poging van de communisten om hun machtspositie te herstellen (de staat van beleg van 1981 en 1982) werd duidelijk dat hervormingen niet langer uit konden blijven: reeds voor de val van het communistisch regime werd begonnen met de voorbereiding van nieuw straf(proces)recht hetgeen uiteindelijk resulteerde in de nieuwe strafrechtelijke codificaties van 1997.

Belangrijkste doelstellingen van de postcommunistische wetgever op het gebied van het strafprocesrecht waren: het realiseren van meer rechterlijke controle op het vooronderzoek, een evenwichtiger verhouding tussen voor- en eindonderzoek, het versterken van het adversaire karakter van het onderzoek ter terechtzitting en het bieden van meer individuele rechtsbescherming aan verdachten en slachtoffers. Tot de - in ieder geval op papier - belangrijkste strafvorderlijke wijzigingen kunnen onder meer worden gerekend: dat beslissingen over toepassing van voorlopige hechtenis niet langer door de prokurator maar door de rechtbank worden genomen, dat personen die op het onderzoek ter terechtzitting worden gehoord in de regel eerst door procespartijen en pas daarna door de rechter worden gehoord, dat de verdachte voorafgaand aan zijn eerste verhoor zowel mondeling als schriftelijk op de hoogte moet worden gesteld van een aantal belangrijke rechten en plichten, dat eenieder die is aangehouden het recht heeft onmiddellijk een avocaat te contacteren, dat vrij verkeer tussen raadsman en verdachte niet langer kan worden verboden en alleen nog gedurende de eerste veertien dagen van de voorlopige hechtenis kan worden beperkt en dat de verdachte het recht heeft te worden verhoord in aanwezigheid van zijn raadsman. ${ }^{315}$ Hoewel door deze en andere wijzigingen een nieuw evenwicht tussen rechtsbescherming en instrumentaliteit werd geïntroduceerd, betekende de wetgeving van 1997 geen radicale breuk met het verleden: de hoofdlijnen van het strafproces - de structuur van het voor- en eindonderzoek en ook de rol van verschillende procesdeelnemers daarin - bleven grotendeels hetzelfde.

314 Aangezien deze fase van de procedure hier in zijn algemeenheid buiten beschouwing wordt gelaten, zal genoemde wettelijke regeling hierna slechts incidenteel aan de orde komen. Het wetboek betreffende de tenuitvoerlegging van straffen heeft voor wat betreft de thematiek van dit onderzoek vooral betekenis voor het vrij verkeer - zie hoofdstuk 7 .

315 De wijzigingen die betrekking hebben op of relevant zijn voor de positie van de verdediging komen in de hiernavolgende hoofdstukken nog uitgebreid aan de orde. 
Inmiddels is het 'nieuwe' wetboek van strafvordering alweer tien jaar oud en heeft het diverse veranderingen ondergaan. Meer recente wetswijzigingen waaronder die van juli 2003 benadrukken de noodzaak van een snel en efficiënt strafproces. De toenemende belasting van de strafrechtspleging, de trage afhandeling van strafzaken en de roep op meer repressie vanuit de samenleving hebben tot gevolg dat de wetgever zich de laatste jaren vooral heeft laten leiden door de wens strafzaken zo snel en daadkrachtig mogelijk af te handelen. Het moge duideljk zijn dat het hernieuwde evenwicht tussen instrumentaliteit en rechtsbescherming - zoals oorspronkelijk door de postcommunistische wetgever beoogd en vormgegeven hierdoor ernstig onder druk is komen te staan. 


\title{
Hoofdstuk 3
}

\section{De functie van de raadsman in historisch perspectief}

\author{
'One must rule the advokat with an iron hand and keep him in a state of siege, \\ for this intellectual scum often plays dirty
}

V.I. Lenin

\section{Inleiding}

In de hiernavolgende hoofdstukken zal aandacht worden besteed aan de meer specifieke vraag hoe de positie van de verdediging in het huidige strafproces is vormgegeven en hoe deze situatie zich verhoudt tot het communistisch verleden. Een bespreking van de mogelijkheden en beperkingen van de verdediging in de verschillende fasen van het strafproces is nauw verbonden met de vraag hoe over de functie van de advocaat in strafzaken wordt gedacht. Laatstgenoemde vraag is onlosmakelijk verbonden met de aard en structuur van het strafproces en die eigenschappen zijn weer volledig afhankelijk van de mate waarin de overheid het strafproces uitsluitend beschouwt als instrument om bepaalde politieke doelstellingen te verwezenlijken. Deze onderlinge verbanden staan in dit hoofdstuk centraal.

Damaška - een van oorsprong Kroatische rechtsgeleerde - heeft in zijn werk uitgebreid aandacht besteed aan de correlatie tussen structuren van overheidsgezag enerzijds en doelstelling en vormgeving van gerechtelijke procedures anderzijds. ${ }^{1}$ Hij onderscheidt daarbij twee archetypes van overheidsvormen: enerzijds de activist state waarin de overheid een eigen zelfstandig belang heeft met als gevolg dat afwijkende individuele belangen van de burger niet worden erkend ${ }^{2}$ en anderzijds de reactive state waarin de overheid geen zelfstandig belang heeft en gekenmerkt wordt door een terughoudende opstelling die het zelfregulerend vermogen van de samenleving zoveel mogelijk tot zijn recht moet laten komen. Aan deze twee typeringen ${ }^{3}$ kunnen twee onderling zeer verschillende typen procesvormen worden gekoppeld: de beleidsimplementerende en de conflictoplossende policyimplementing en conflictsolving). In laatstgenoemd proces staat - kort gezegd - de autonomie en gelijkheid van partijen centraal hetgeen belangrijke consequenties heeft voor de inrichting van de procedure en de rol van procesdeelnemers daarin: partijen bepalen de inhoud, het verloop en tot op zekere hoogte ook de uitkomst van de procedure. In de beleidsimplementerende procesvorm daarentegen vormen niet de procespartijen maar een door of vanwege de overheid uitgevoerd onderzoek de kern van de procedure. De overheid bepaalt in beginsel of, en zo ja op welke gronden en met welk doel, een procedure in gang wordt gezet.

Het Poolse strafrecht fungeerde vooral in de meer repressieve perioden van voor 1989 - zoals gedurende het stalinisme en de staat van beleg - in de eerste plaats als een politiek instrument dat door communistische machthebbers werd gebruikt

Damaška 1986. Zie ook: Damaška 1973 en 1975.

Of in ieder geval minder waard worden geacht.

Die in werkelijkheid in verschillende gradaties kunnen voorkomen maar ten behoeve van hun onderscheidend vermogen in de rechtsvergelijking door Damaška als twee uitersten worden gepresenteerd. 
om overheidsdoelstellingen te verwezenlijken. ${ }^{4}$ Onder deze omstandigheden werd de functie van de advocaat in strafzaken bijzonder complex.

De raadsman neemt - in ieder rechtssysteem - een bijzondere positie in. Hij is anders dan de opsporende, vervolgende en rechtsprekende instanties niet direct gelieerd aan de overheid: zijn taak bestaat er juist uit de belangen van zijn cliënt ten overstaan van deze autoriteiten te beschermen. Omdat zijn optreden binnen communistische structuren niet schadelijk mag zijn voor de 'hogere' belangen die met de strafrechtspleging zijn gemoeid, ligt het voor de hand dat aan de raadsman eerst en vooral een publieke functie wordt toebedeeld. Deze publieke taak houdt onder meer in dat de raadsman verantwoordelijkheden heeft ten aanzien van de waarheidsvinding (en ruimer: het bereiken van een 'correct' resultaat) waarmee hij bij de uitoefening van zijn in beginsel partijdige functie rekening dient te houden. ${ }^{5}$

In dit hoofdstuk zal wat langer worden stilgestaan bij de vraag welke gevolgen het communistisch regime zoals dat werd vormgegeven in Polen en de andere landen van het voormalig Oostblok heeft gehad voor het denken over de rol van de raadsman. Deze historische achtergrond is van belang om (het denken over) de huidige positie van de verdediging in het Poolse strafproces tegen de juiste achtergrond te kunnen plaatsen. De hedendaagse strafprocessuele normering van de bevoegdheden van de raadsman en de verschillen of overeenkomsten die daarbij ten opzichte van de situatie voor 1989 kunnen worden geconstateerd, zullen beter kunnen worden begrepen wanneer duidelijk is of, en zo ja, hoe het denken over de positie van de advocaat in strafzaken zich parallel aan de politieke omwenteling heeft ontwikkeld.

Het ligt voor de hand voor de beantwoording van de vraag naar de gevolgen van een communistisch regime voor het denken over de positie van de raadsman eerst aandacht te besteden aan de Russische (of sovjet)literatuur op dit punt. In de eerste plaats omdat - zoals hierna nog zal worden uiteengezet - de ontwikkeling van een socialistische rechtsleer vooral moet worden toegeschreven aan Russische rechtsgeleerden. De Sovjet-Unie heeft in allerlei opzichten maar vooral ook voor wat betreft de ontwikkeling van de strafrechtspleging na Wereldoorlog II een 'voorbeeldfunctie' vervuld voor de landen van Centraal- en Oost-Europa.

In dit hoofdstuk zal worden bekeken of in de Poolse doctrine voor wat betreft het denken over de rol van de raadsman aansluiting is gezocht bij sovjetliteratuur, of de Poolse opvattingen over de functie van de advocaat in strafzaken in de periode 1945-1989 daadwerkelijk zijn beïnvloed door het communistisch regime en - parallel daaraan - of de huidige doctrine op dit punt wezenlijk verschilt van de opvattingen van voor de laatste politieke omwenteling.

\section{Het communistisch perspectief}

Eerder is al beschreven dat de grondleggers van het communisme - Marx en Engels - in hun werken weinig aandacht hebben besteed aan de vraag naar de

4 Zie hoofdstuk 2, § 2.2.

5 In dit verband kan bijvoorbeeld de eigen opvatting over de schuld van een verdachte een rol spelen: mag een raadsman nog voor vrijspraak pleiten wanneer hij overtuigd is van de schuld van zijn cliënt? 
functie van het (straf)recht. ${ }^{6}$ Belangrijkste reden hiervoor was hun overtuiging dat het recht een typisch 'kapitalistisch' verschijnsel was dat met de totstandkoming van de communistische maatschappij samen met de staat geleidelijk aan zou verdwijnen. Voor beantwoording van de in de inleiding genoemde vraag naar de communistische visie op de functie van strafrechtelijke procedures in het algemeen en de rol van de advocaat in het bijzonder kunnen in de werken van Marx en Engels dan ook geen directe aanknopingspunten worden gevonden. De totstandkoming van een Marxistische rechtsleer is, zoals gezegd, vooral de verdienste van Russische rechtsgeleerden geweest: na de revolutie van 1917 is in de Russische (en later sovjet)doctrine op grote schaal aandacht besteed aan de vraag naar de betekenis van het recht in een socialistische maatschappij. ${ }^{7}$ Aan beantwoording van deze vraag was ook behoefte omdat al snel duidelijk werd dat realisatie van de communistische maatschappij een langdurig en moeilijk proces was dat alleen zou kunnen worden voltooid met behulp van een sterk overheidsapparaat en instrumenteel gebruik van het recht. Dus hoewel het recht ideologisch gezien als uitstervend instituut werd beschouwd, groeide het in de overgangsfase naar het communisme uit tot een zeer belangrijk politiek instrument. De doctrine stond voor de moeilijke taak voor het voortbestaan van het recht een met de communistische ideologie verenigbare rechtvaardiging te vinden.

Vooral van het strafrecht werd instrumenteel gebruik gemaakt. Communistische machthebbers beschouwden criminaliteit als een grote bedreiging waartegen met harde hand moest worden opgetreden. ${ }^{8}$ Vanuit deze overtuiging kreeg het strafproces een zuiver instrumentele functie: het diende voornamelijk bescherming te bieden tegen interne en externe 'vijanden' zodat deze niet aan implementatie van overheidsbeleid in de weg konden staan. Bovendien diende de strafrechtspleging

\section{Zie hoofdstuk 2 , § 2.2 . \\ Zie Feldbrugge 1959, p. 6.}

Met name de aanpak van economische criminaliteit stond hoog op de politieke agenda. Communistische doelstellingen konden alleen worden bereikt wanneer burgers voldoende respect toonden voor gemeenschappelijke (genationaliseerde) eigendommen. Omdat individueel bezit van productiemiddelen niet langer was toegestaan maar ondernemers toch hun werk wilden voortzetten, kwam het regelmatig voor dat deze werden gestolen: ' $A$ typical feature of Soviet life is that people often steal socialist property not for personal use but as a means of carrying on their lawful occupations': Łoś 1988, p. 206 (citaat van Chalidze). Hoewel de strafwaardigheid van deze feiten vanuit Westers oogpunt twijfelachtig is - arbeiders handelden in veel gevallen uit pure noodzaak om een inkomen te kunnen blijven genereren - was het gedrag een doorn in het oog van de communisten en er werd dan ook met harde hand tegen opgetreden: 'Constitutions, criminal codes and criminal policies of communist countries indicate clearly how important this kind of property [state property, toev. DdV] is to the ruling élite. They actively confirm and reinforce the ideological dogma that the individual, as well as his personal property, has to be sacrificed in the process of building the new society, and that the sacred value of state property has to be preserved above all. The extraordinary severity of sanctions for violations against it, is the best indicator of its ideogical importance': Łoś 1988, p. 207. De enorme nadruk op economische criminaliteit - en de in verhouding minder strenge aanpak van bijvoorbeeld levensdelicten - laten duidelijk zien waar voor communistische machthebbers de prioriteit lag: behoud van gemeenschappelijk eigendom werd hoger gewaardeerd dan bescherming van het individu. Volgens Hazard bestaat juist op dit punt het duidelijkste onderscheid tussen communistische en niet communistische landen: 'The contrast between Marxian socialist definition of crime and that of non-Marxian socialist lands suggests that novelty appears primarily in the category of "economic crimes"': Hazard 1969, p. 478. 
de burger 'op te voeden' door duidelijk te maken wat binnen de communistische maatschappij van hem werd verwacht. ${ }^{9}$ Voordat zal worden ingegaan op de vraag hoe de positie van de raadsman binnen dit kader werd ingevuld, zal eerst aandacht worden besteed aan een aantal algemene kenmerken van het socialistische strafproces.

\subsection{Het strafproces binnen de socialistische rechtsfamilie}

Een bespreking van de overeenkomsten tussen de socialistische rechtssystemen van Centraal- en Oost-Europa zou ten onrechte de indruk kunnen wekken dat de landen van het voormalig Oostblok in juridisch opzicht een homogene groep zijn die nauwelijks noemenswaardige verschillen vertonen. Niets is echter minder waar: ieder land heeft na Wereldoorlog II op eigen wijze invulling gegeven aan de nieuwe (politieke) taak van de rechtspleging waarbij het ene land meer aansluiting heeft gezocht bij de situatie in de Sovjet-Unie dan het andere. ${ }^{10}$

Ondanks het belang van deze onderlinge verschillen worden de socialistische landen van Centraal- en Oost-Europe binnen de rechtsvergelijking wel aangeduid als een aparte rechtsfamilie. Deze 'socialistische rechtsfamilie' vertoont weliswaar een aantal belangrijke kenmerken van de Westerse civil law rechtstraditie maar bevat voldoende eigen karaktereigenschappen om als afzonderlijke categorie te kunnen worden aangemerkt. ${ }^{11}$

9 Het verbaast dan ook niet dat Damaška 'the soviet model of criminal justice' als voorbeeld noemt van een beleidsimplementerende procedure: Damaška 1986, p. 194-198.

10 Zie over rechtsontwikkeling in de volksdemocratieën van Centraal- en Oost-Europa en de vraag in hoeverre het positieve recht van de Sovjet-Unie daarbij model heeft gestaan: Slapnicka 1963. De landen van Oost-Europa vertonen overigens ook op andere (nietjuridische) terreinen meer diversiteit dan vaak gedacht wordt: 'De Oost-Europese staten waren - ondanks de wijdverspreide tegengestelde opvatting - nooit een ondeelbaar cultureel, sociaal, economisch, politiek of rechtsuniform blok. Bovendien zijn de verborgen conflicten tussen die staten altijd blijven bestaan als gevolg van een gebrek aan intensieve wederzijdse relaties, of van traumatische historische ervaringen. (...) De Oost-Europese landen hadden twee gemeenschappelijke trekken, te weten de machtsconcentratie in een communistische partij en de controle door de staat van de produktiemiddelen in een centraal geleide planeconomie': Kubiak 1989, p. 10.

11 Voor een uitgebreide bespreking van deze rechtsfamilie: David en Brierly 1978, p. 143-283. De overeenkomsten met de Westerse, continentale systemen zijn voornamelijk te vinden in de terminologie en het feit dat beide rechtsfamilies de geschreven rechtsregel als belangrijkste rechtsbron beschouwen. Afgezien van deze gelijkenis die voornamelijk de uiterlijke verschijningsvorm betreft en daardoor door sommige auteurs als misleidend wordt bestempeld - zie Chloros 1992, p. 93 waar hij spreekt over '(...) misleading similarities with the Civil Law systems. For, traditionally, the Socialist countries belonged to the Romanistic family of laws and the terminology and technique of Socialist law is superficially attached to the Civil law. But the similarity ends at that point' - onderscheidt het socialistisch rechtssysteem zich van Westerse rechtsstelsels met name voor wat betreft de functie die het recht binnen de samenleving vervult. Volgens Hazard worden deze verschillen dan ook pas duidelijk wanneer we het recht niet beschouwen als 'technique but as a reflection of social values and as an instrument of social change': Hazard 1969, p. 521. In soortgelijke bewoordingen: David en Brierly 1978, p. 20: 'Two laws cannot be considered as belonging to the same family, even though they employ the same concepts and techniques, if they are founded on opposed philosophical, political or economic principles, and if they seek to achieve two entirely different types of society'. Er zijn echter ook auteurs die van mening zijn dat de rechtssystemen van de communistische landen van Centraal- en Oost-Europa zich onvoldoende onderscheiden van de civil law 
Dezelfde redenering geldt ook voor het strafproces. De situatie in de Sovjet-Unie heeft model gestaan voor (de inrichting van) de strafrechtelijke procedures van de Europese landen waar na Wereldoorlog II communistische regimes werden gevestigd. Dit betekent echter niet dat het sovjetmodel in alle volksdemocratieën klakkeloos werd gekopieerd. ${ }^{12}$ Toch geldt ook in dit verband dat de strafrechtelijke procedures in genoemde regio een aantal belangrijke overeenkomsten vertoonden die de kwalificatie 'socialistisch strafproces' rechtvaardigen. ${ }^{13}$

\subsubsection{Gemeenschappelijke uitgangspunten}

De socialistische rechtssystemen van de landen van Centraal- en Oost-Europa hadden zoals bekend dezelfde ideologische basis: het communisme. Ondanks eerder genoemde onderlinge verschillen en variaties betekende dit dat binnen de strafrechtspleging van deze landen een aantal gemeenschappelijke uitgangspunten gold. Het strafrecht was vanuit communistisch perspectief voornamelijk een politiek instrument: met het strafrecht dienden bepaalde doelstellingen te worden bereikt hetgeen grote consequenties had voor de wijze waarop over waarheidsvinding werd gedacht. Voor de verwezenlijking van de politieke doelstellingen was het van groot belang dat procedures uitmondden in rechterlijke uitspraken

rechtstraditie om als aparte rechtsfamilie te kunnen worden aangemerkt. Zie voor de weergave van een aantal standpunten: Hazard 1971, p. 646.

12 Gajewska-Kraczkowska en Palmer 1991, p. 3.

13 'Socialistisch' dient in dit verband te worden onderscheiden van het - eveneens in de literatuur veelvuldig gehanteerde - begrip 'sovjet' (in de zin van sovjetrecht, sovjetstrafprocesrecht, sovjetliteratuur et cetera). Laatstgenoemde term is beperkter aangezien daarmee de situatie in de Sovjet-Unie wordt aangeduid. Vandaar dat voor de aanduiding van alle strafrechtelijke procedures van de communistische rechtssystemen geïnspireerd door maar zeker niet identiek aan het eveneens tot genoemde categorie behorende strafproces in de Sovjet-Unie - het meeromvattende begrip 'socialistisch' wordt gebruikt. Volgens Bárd moet de veronderstelling dat er een socialistisch strafproces bestaat dat zich onderscheidt van het West-Europese strafproces in twee opzichten worden genuanceerd. In de eerste plaats het (reeds genoemde) feit dat de strafrechtelijke procedure in de Sovjet-Unie in de verschillende landen van Centraalen Oost-Europa niet overal in dezelfde mate en op dezelfde wijze is overgenomen. Ten tweede dienen binnen de ontwikkeling van het socialistisch strafproces in de Centraalen Oost-Europese regio verschillende fasen te worden onderscheiden die kort weergegeven, neerkomen op de volgende ontwikkeling: na Wereldoorlog II werden eerst belangrijke wijzigingen doorgevoerd in het strafrechtssysteem (met name met betrekking tot de organisatie van de rechterlijke macht), vervolgens werd aan het begin van de jaren vijftig nieuwe - naar voorbeeld van de Sovjet-Unie vormgegeven - strafvorderlijke regelgeving geïntroduceerd, rond de helft van de jaren vijftig werd als reactie op de excessen van het stalinisme in de wetgeving van verschillende landen meer aandacht besteed aan rechtsbescherming en ten slotte werd bij de totstandkoming van nieuwe codificaties in de jaren zestig en zeventig - in afwijking van de sovjetdoctrine waarin van oudsher het bestaan van een uniforme procedure voor alle soorten strafbare feiten werd verdedigd - onder meer aandacht besteed aan differentiatie van het strafproces: verschillende soorten bijzondere procedures werden (opnieuw) geïntroduceerd. De onderlinge verschillen die de strafrechtelijke procedures van de volksrepublieken op het moment van de val van het communistisch regime vertoonden, hangen sterk samen met de vraag welke van bovengenoemde perioden de meeste invloed heeft gehad op nationale wet- en regelgeving: Bárd 1999, p. 434-435. 
die zoveel mogelijk in overeenstemming waren met het werkelijk gebeurde. Vanuit de overtuiging dat een juiste vaststelling van de materiële feiten zou bijdragen aan effectieve implementatie van overheidsbeleid - een beslissing die op 'waarheid' is gebaseerd zal eerder door de samenleving worden geaccepteerd - werd in het socialistische strafproces dan ook veel nadruk gelegd op de materiële waarheidsvinding. Zoals hierna nog verder zal worden uitgewerkt, werd het bereiken van een correcte beslissing vanuit deze visie beschouwd als verantwoordelijkheid van alle procesdeelnemers waaronder de verdediging. Overigens betekende dit alles niet dat de 'echte' waarheid ook altijd aan het licht kwam. Het kwam in de praktijk regelmatig voor dat een versie van de waarheid werd geaccepteerd die het beste paste binnen het politieke beleid en datgene wat met het strafproces moest worden bereikt. Daarin schuilde een van de belangrijkste paradoxen van het systeem: waarheidsvinding was zo essentieel voor verwezenlijking van de instrumentele functie van het strafproces dat de waarheid daaraan kon worden aangepast. ${ }^{14}$

Ook de verhouding tussen het algemene en het individuele belang - de staat en de burger - is van invloed geweest op de inrichting van het socialistisch strafproces. De communistische visie dat er in de socialistische maatschappij slechts één gemeenschappelijk belang bestaat dat gelijk is voor iedereen en (afwijkende) individuele belangen derhalve niet als legitiem erkent, was van invloed op de positie van de verdachte in het strafproces. ${ }^{15}$ Het strafproces werd niet beschouwd als een conflict of geschil tussen overheid en burger: vervolgende instantie en verdediging werden - anders dan in een procesvorm waarin individuele belangen van verdachte die losstaan van en mogelijk in strijd zijn met het algemeen belang wel worden erkend - geacht hetzelfde doel na te streven. ${ }^{16}$ Aangezien het belang van de burger gelijk werd gesteld aan het belang van de overheid (de gemeenschap) werd bescherming van het individu tegen deze overheid niet noodzakelijk geacht: dit zou immers hetzelfde zijn als bescherming van verdachte tegen zichzelf.

Nauw verbonden met de gelijkschakeling van individuele en gemeenschappelijke belangen was de veronderstelling dat autoriteiten (opsporende, vervolgende en

14 Ook Damaška benadrukt dat zelfs in (de meest zuivere vorm van) beleidsimplementerende procedures grenzen aan de waarheidsvinding worden gesteld: 'Even were an activist state to embrace no values that constrain the search for the truth, the attempt to attain the highest possible standard of proof would impose unnacceptable costs in terms of delay and various other vexations. Not only must decisions often be rendered on the basis of quite uncertain knowledge, but state policy may dictate that one factual hypothesis be accepted although another is somewhat more likely to be valid. (...) Thus, rather than saying that the policyimplementing process strives to maximize the chances of discovering the truth, one might prefer to say that it tries to obtain optimal levels of fact-finding accuracy, given the various constraints imposed in its operation': Damaška 1986, p. 161.

15 Deze gelijkschakeling van algemeen en individueel belang in het strafproces was voornamelijk gebaseerd op de overtuiging dat het in ieders belang is dat schuldigen (naar mate van hun schuld) worden gestraft en dat onschuldigen worden vrijgesproken.

16 Dit uitgangspunt is in de loop der jaren overigens wel afgezwakt. Gaandeweg de jaren vijftig en zestig werd in de sovjetliteratuur geconstateerd dat het individuele belang van verdachte wel degelijk afzonderlijke bescherming verdiende. Parallel aan de ontwikkeling van dit gedachtegoed werd door verschillende Russische auteurs gepleit voor een uitbreiding van de bevoegdheden van de verdediging. 
berechtende instanties) het beste met de verdachte voor hadden. Als vertegenwoordigers van het algemeen belang - waarin het belang van verdachte onmiskenbaar lag besloten - werden zij geacht alleen handelingen te verrichten en beslissingen te nemen die in het voordeel van de samenleving waren. Typerend in dit verband is dat bescherming van de belangen van de verdachte in het vooronderzoek in verschillende socialistische rechtssystemen waaronder Polen voornamelijk werd gezien als taak van de met vervolging belaste prokurator. De inrichting van het strafproces was zodoende niet gebaseerd op wantrouwen jegens de overheid maar op de overtuiging dat men moest vertrouwen op de goede bedoelingen van de staat. ${ }^{17}$

\subsubsection{Gemeenschappelijke kenmerken}

Zoals gezegd vertoonden de strafrechtelijke procedures van de communistische landen van het voormalig Oostblok een aantal belangrijke gemeenschappelijke kenmerken. De meeste daarvan vinden hun oorsprong in Rusland (c.q. de SovjetUnie) en zijn later door de andere landen overgenomen. Wat de deelnemers aan het strafproces betreft, kunnen als belangrijkste kenmerken worden genoemd:

- Een machtig en grotendeels onafhankelijk openbaar ministerie dat het vooronderzoek volledig regeert en zelfstandig beslissingen neemt over de toepassing van voorlopige hechtenis en andere dwangmiddelen.

- Een ondergeschikte rol voor de zittende magistratuur wat enerzijds tot uitdrukking komt in zeer beperkt rechterlijk toezicht op het vooronderzoek en anderzijds in het feit dat het in de opsporingsfase verzamelde bewijsmateriaal van doorslaggevende betekenis is voor de einduitspraak.

- Lekenrechtspraak: deelname van lekenrechters dient het democratisch karakter van de strafrechtspleging te verhogen.

- Ruime bevoegdheden voor de politie (militie).

Ook ten aanzien van de inrichting van de procedure is een aantal belangrijke overeenkomsten te ontdekken:

- Procedures moeten eenvoudig en niet teveel aan vormen of formaliteiten gebonden zijn: dit is ideologisch gezien onlosmakelijk verbonden met het streven de rechtspleging 'democratisch' en dus voor alle lagen van de bevolking begrijpelijk te maken ('bring justice closer to the people') maar praktisch gezien vooral een manier om het strafproces in instrumentele zin zo efficiënt mogelijk te laten zijn.

- Materiële waarheidsvinding is de belangrijkste taak van de rechter. Dit geldt wellicht ook voor de meeste West-Europese rechtssystemen maar de socialistische systemen gaan op dit punt een stapje verder: waarheidsvinding heeft absolute prioriteit en wordt daardoor boven alle andere rechtsbeschermende beginselen en uitgangspunten van het strafproces gesteld ('the search for mate-

17 Dit vertrouwen is noodzakelijk voor effectieve beleidsimplementatie. Ten aanzien van 'the soviet model of criminal justice' merkt Damaška hierover op: 'If the state is to transform society, it has to be trusted', Damaška 1986, p. 194. Paradoxaal genoeg had het repressieve en instrumentele karakter van de strafrechtspleging - in de Sovjet-Unie en in verschillende gradaties ook in de andere communistische landen van Centraal- en Oost-Europa - juist tot gevolg dat de overheid door de burger werd gevreesd en gewantrouwd. 
rial truth opresses the requirement of procedural fairness' ${ }^{\prime 18}$ ). Dit verklaart ook de afwijzing van het formalisme: vormvoorschriften mogen niet in de weg staan aan het achterhalen van de materiële waarheid.

- Grotendeels geheim vooronderzoek met zeer beperkte mogelijkheden voor de verdediging.

- Voor wat betreft de rechtsmiddelen: een algemeen erkend recht tot het instellen van hoger beroep (waarbij - vanwege het verlangen een zo correct mogelijk resultaat te bereiken - de hoger beroepsinstantie de zaak opnieuw integraal beoordeelt) en het bestaan van bijzondere rechtsmiddelen die bestuurlijke controle - door bijvoorbeeld de minister van Justitie - op strafrechtelijke uitspraken mogelijk dienen te maken. ${ }^{19}$

\subsection{Het communisme en de taakopvatting van de raadsman}

Het heeft de Russische rechtsgeleerden - vanwege de marxistisch-leninistische overtuiging dat het recht in een communistische maatschappij geen bestaanrecht meer heeft - heel wat hoofdbrekens gekost om de functie van het (straf)recht te verklaren en te rechtvaardigen..$^{20}$ Daarbij is veel aandacht besteed aan de rol van de raadsman en de grenzen die gelet op de instrumentele functie van het socialistisch strafproces aan zijn optreden moeten worden gesteld. Wat maakte de positie van de raadsman nu zo ingewikkeld?

\subsubsection{De complexe positie van de advocaat in strafzaken}

Het behoeft nauwelijks betoog dat de algemene uitgangspunten van het socialistisch strafproces (nadruk op waarheidsvinding, doorslaggevende betekenis gemeenschappelijk belang en groot vertrouwen in de overheid) de rol van de raadsman als partijdige verdediger van individuele belangen problematiseren.

In een communistisch systeem wordt van alle procesdeelnemers en dus ook van de advocaat loyaliteit ten opzichte van het algemeen belang (lees: het regime) verlangd. ${ }^{21}$ Dat de raadsman - anders dan de vervolgende en berechtende instanties -

18 Bárd 1999, p. 5.

19 Zie over deze kenmerken van het socialistisch strafproces: Gajewska-Kraczkowska en Palmer 1991, p. 9 e.v. en Bárd 1999, p. 435-438. Volgens Feldbrugge toont het primaat van de machtshandhaving binnen het sovjetstrafprocesrecht zich vooral door de afhankelijkheid van de rechter en door de mogelijkheid die hogere instanties steeds hebben om een ongewenst vonnis te vernietigen: Feldbrugge 1959, p. 51. Zie ook Damaška 1986, p. 194-198. Over de kenmerken van het strafproces volgens het sovjetmodel (onder meer de machtige positie van de prokurator in vergelijking tot de rechter en de mogelijkheid de raadsman uit te sluiten van deelname aan het vooronderzoek totdat het belangrijkste bewijsmateriaal is verzameld) merkt Damaška op dat het in de ogen van West-Europese juristen wordt beschouwd als 'a partial throwback to Continental inquisitorial procedure after the abolition of judicial torture but before liberals began to leaven it with elements of the contest style'. Dat deze kritiek betrekkelijk is, blijkt volgens hem uit het feit dat common law juristen op vrijwel dezelfde gronden het reguliere (West-Europese) continentale strafproces afkeuren: 'Observe the subtle irony, however: such assessments reproduce almost exactly the impressions which common lawyers regularly express about the conventional Continental amalgan - impressions dismissed as caricatures by classical Continental lawyers, much as the similar impressions just registered are dismissed by officials in the Soviet judicial apparatus' (p. 195).

20 Zie ook hoofdstuk 2, § 2.2.

21 In het werk van Kálmán - een Hongaarse jurist die zijn land in de jaren vijftig moest ont- 
niet rechtstreeks aan de overheid is gebonden, maakt hem tot de meest 'gevaarlijke' professionele procesdeelnemer. Aangezien hij niet van overheidswege is belast met de vervolging of berechting van strafbare feiten (dat wil zeggen met de realisatie van de doelstellingen die met het strafrecht moeten worden bereikt) staat het hem in beginsel vrij zijn juridische kennis en ervaring in te zetten om het verloop en de uitkomst van de procedure in het voordeel van zijn cliënt te beïnvloeden. Problematischer nog, is het feit dat de raadsman het strafproces kan gebruiken als forum om de overheid te bekritiseren en de legitimiteit van het regime aan de kaak te stellen. In de woorden van Pipko en Pipko:

'The officialdom must see the advocate as potentially the most dangerous opponent, because he possesses a legal right to oppose the system in a courtroom.'22

Dit 'gevaarlijke karakter' van de advocaat geldt in het bijzonder in strafzaken omdat de raadsman direct betrokken is bij de eliminering van een van de grootste bedreigingen voor het communisme: de criminaliteit. In geen enkele andere juridische procedure is de inzet voor de overheid zo hoog en de botsing tussen gemeenschappelijke en individuele belangen - die hoewel ze ideologisch gezien tot het verleden behoorden in de communistische rechtssystemen van Centraalen Oost-Europa feitelijk natuurlijk nog steeds bestonden - zo evident als in het strafproces:

'There is nothing in Marxist theory or in the spirit of Bolshevism which explains the utility for a socialist society of preserving the office of the professional legal representative, whose task is to present his client's cause in the best possible light and not to pass judgment on the claims or defenses or on the client himself. Indeed, from a Marxist-Leninist standpoint the lawyer's role appears especially dubious when he is defense counsel in a criminal case: the client has been charged by a responsible state official with the commission of an offense against society and the lawyer must do everything possible, within the limits set by law, to protect the client and frustrate the state. ${ }^{23}$

In het socialistisch strafproces staat de sociaalgevaarlijkheid van het (vermeende) strafbare feit centraal. Een ruime toepassing van dit begrip heeft tot gevolg dat

vluchten omdat hij dreigde te worden geliquideerd door de geheime politie - wordt opgemerkt dat alle juristen tot het uitschot van de communistische maatschappij behoren: 'Let us not deceive ourselves! In Communism and in Communist society the lawyers are but the enemies of the society, the remnants of a rotten social class, who are destined to extinction. This is true irrespective of race, religion or political background. Lawyers in the Communist orbit who devote themselves to the cause of justice and truth are staking their lives be they attorneys or judges (...)': Kálmán 1960, p. 17. Zijn boek geeft een levendige en indrukwekkende beschrijving van de gevolgen van de eerste jaren van het communisme voor juristen in Hongarije.

22 Pipko en Pipko 1987, p. 854.

23 Barry en Berman 1968, p. 11-12. Dit alles neemt echter niet weg dat de positie van de raadsman als partijdige belangenbehartiger - gelet op de schadelijke gevolgen van criminaliteit en het belang van de samenleving daartegen op te kunnen treden - in vrijwel ieder rechtssysteem tot op bepaalde hoogte 'problematisch' kan worden genoemd. De raadsman die de belangen van zijn cliënt behartigt kan zich immers lijnrecht tegenover de belangen van de overheid geplaatst zien. Kenmerkend voor het socialistisch strafproces is echter dat - aangezien een belangenconflict tussen gemeenschap en individu niet wordt erkend en in het strafproces slechts het algemeen belang centraal kan staan - de positie van een onafhankelijke verdediger niet alleen problematisch is maar ideologisch gezien niet eens bestaansrecht heeft. 
vrijwel iedere strafbare gedraging als schadelijk voor het algemeen belang en dus als bedreiging voor de overheid kan worden beschouwd. Gevolg hiervan is dat strafzaken per definitie een politiek karakter hebben waardoor de rol van de raadsman als verdediger van de belangen van zijn cliënt steeds conflicteert met zijn publieke taak als beschermer van het algemeen belang:

'In the area of strictly private disputes over divorces, alimony, apartment leases and so forth, there are, of course, cases where the incidence of "socialist legality" may be remote. But this is a small area indeed in a legal system where conceptual differentiation between public and private interests is in fact nonexistent, where the concept of "social danger" is applied to all actions touching upon wide-ranging state interests and where the legal assessment and the political assessment are deemed inseparable. (...) In such circumstances, where the area of offense to the state is castly enlarged, the lawyer's duty of promoting socialist legality constantly comes in conflict with that of ensuring a full defense of his clients. The Soviet lawyer is constantly reminded that it is not by justifying, but by condemning crime that he helps in 'education of man's moral qualities.'24

Het uitgangspunt dat het in belang van de gemeenschap - en (gelet op de gelijkschakeling van individuele en gemeenschappelijke belangen) dus ook in belang van de verdachte - is dat degene die zich schuldig heeft gemaakt aan een strafbaar feit op passende wijze wordt gestraft, rechtvaardigt dat ook de raadsman verantwoordelijk is voor de oplegging van een passende straf:

'What is in the interest of the accused? (...) In our country building socialism the interest of the state is identical with the interest of the entire society. The interest in the security of the state and of the society is identical with the interest of every citizen. These interests require, (1) that the culprit be justly punished. This interest of every citizen is also the interest of the accused and the counsel must defend it as the justified interest (of his client)... If, however, the defendant desires to avoid the punishment or tries to get away with mild, undeserved punishment, this is not the interest the counsel is allowed to defend. ${ }^{25}$

Het moge duidelijk zijn dat het optreden van de raadsman binnen een dergelijke context moeilijker wordt naarmate de strafzaak een meer (expliciet) politiek karakter heeft. Verdediging van burgers die worden verdacht van 'antirevolutionaire' feiten is een hachelijke onderneming in een systeem dat - vanuit de overtuiging dat iedere aantasting van het gezag van de overheid schadelijk is voor de realisatie van de utopische communistische maatschappij - geen enkele oppositie duldt. Bij een al te ijverige opstelling bestaat immers het risico dat de advocaat net als zijn cliënt als gevaar voor de maatschappij wordt beschouwd.

Dat de positie van de raadsman in het socialistisch strafproces op zijn zachtst gezegd complex is, komt ook tot uitdrukking in de sovjetliteratuur waarin veel over het thema is gediscussieerd. ${ }^{26}$ Aanvankelijk werd in deze discussie zelfs de

24 Razi 1960, p. 795-796.

25 Citaat van de Tsjechische jurist Cisarova opgenomen in: Ulč 1972, p. 101.

26 Hoe moeilijk het was om een binnen de nieuwe ideologische en politieke kaders een passende status voor de advocaat te vinden, blijkt ook uit de roerige geschiedenis van de Russische balie gedurende het communisme: 'The successive forms taken by the Soviet Bar have emphazised the difficulty of finding a status for lawyers in a regime which does not believe in law other than as an expeditious and profitable means of administration for carrying out the political objectives of the Soviet Government and the Communist Party': Razi 1960, p. 792. 
vraag opgeworpen of de advocaat in strafzaken wel bestaansrecht had. In de eerste decennia van het Russisch communisme werd deze vraag door veel auteurs negatief beantwoord: de advocaat werd voorgesteld als een uitstervend ras voor wie geen plaats was binnen het sovjetsysteem. In vroege sovjetliteratuur werd onder meer betwijfeld of verdachten van politieke misdrijven wel recht hadden op (enige vorm van) rechtsbescherming. Deze twijfel over de noodzaak van rechtsbijstand kwam ook tot uitdrukking in de wettelijke regeling van het strafprocesrecht. Illustratief in dit verband is dat de raadsman in de jaren twintig op grond van het Russische wetboek van strafvordering volledig was uitgesloten van deelname aan het vooronderzoek. ${ }^{27}$

Hoewel het voortbestaan van de functie van advocaat ideologisch gezien dus niet vanzelfsprekend was, kwamen sovjetauteurs in de loop der jaren tot het inzicht dat de advocaat wel degelijk een belangrijke bijdrage kon leveren aan het strafproces. Dit had natuurlijk alles te maken met het feit dat men gaandeweg tot de conclusie was gekomen dat het (straf)recht als discipline niet zo snel overbodig zou worden als in eerste instantie werd gedacht. Het nut van de advocaat in de socialistische maatschappij werd onder meer benadrukt door Vyshinsky (openbaar aanklager en een van de belangrijkste rechtsgeleerden van zijn tijd). Hij bepleitte dat de taak van de raadsman als verdediger in de rechtszaal niet minder verantwoordelijk en eervol was dan die van openbaar aanklager. Professionele rechtsbijstand was immers niet alleen in het belang van verdachte maar diende door bij te dragen aan een correct verloop van de procedure en het voorkomen van gerechtelijke dwalingen - de gehele maatschappij. ${ }^{28}$ Een gelijkluidend stand-

27 Optreden in dit stadium van de procedure was door de wetgever weliswaar niet met zoveel woorden verboden maar hetzelfde effect werd bereikt door de raadsman in deze fase geen procedurele bevoegdheden toe te kennen. Voor het uitsluiten van de raadsman werden verschillende argumenten genoemd: Hazard 1978, p. 267-272. Daarbij speelde in de eerste plaats het 'gevaarlijke karakter' van de vertrouwensrelatie tussen advocaat en cliënt een rol: de raadsman zou staatsgevaarlijke informatie van zijn cliënt immers kunnen misbruiken ('The one danger (...) was relevation of facts to an attorney who could remain free in the community after execution of sentence against his client to whisper what he had learned to those who might use the information in an attempt to unseat the regime', Hazard 1978, p. 267). Andere argumenten waren meer verbonden met de structuur en aard van het strafproces: optreden van de raadsman in het vooronderzoek werd overbodig geacht omdat het vooronderzoek inquisitoir van aard was en omdat de prokurator reeds tot taak had de belangen van de verdachte te beschermen. Bovendien kon de rechtmatigheid van eventuele vrijheidsberoving ter toetsing worden voorgelegd aan de rechter. Genoemde argumenten verloren in de loop der jaren hun overtuigingskracht met als gevolg dat het belang van rechtsbijstand in het vooronderzoek in de sovjetliteratuur van de jaren dertig (en opnieuw na de oorlog) steeds vaker werd benadrukt. Het zou echter enige tijd duren voordat deze trend ook in wetswijzigingen resulteerde: aan het eind van de jaren vijftig werd het strafprocesrecht op dit punt gewijzigd en kreeg de raadsman ook bevoegdheden in het vooronderzoek. Uitgebreid over de ontwikkeling van het recht op rechtsbijstand in het vooronderzoek in de Sovjet-Unie: Huskey 1986.

28 'Defense of personal interests before the court is explained by Vyshinsky as being in harmony with the interests of society as a whole. Such importance is attached to the interests of the individual that a defense attorney is not allowed to reject a case to which he is assigned, or resign after he has assumed his duties, since this would leave the accused without protection. The lawyer must remain and do his best under the circumstances, since justice must be done. The theory underlying this point of view is that the future of a society which convicts persons 
punt werd onder meer ingenomen door Strogovich (met Vyshinsky een van de meest gezaghebbende strafrechtjuristen van de Sovjet-Unie) die van mening was dat het de taak van de overheid was de individuele belangen van de sovjetburger te beschermen, ook wanneer deze werd beschuldigd van een strafbaar feit. Ook hij benadrukte daarbij dat bescherming van het individu het belang van de gehele gemeenschap diende en dus ook in het voordeel van de overheid was. De functie van de raadsman werd door deze auteurs dus voornamelijk gezocht in het algemeen belang: een 'sterke, gezonde staat' kon alleen bestaan wanneer geen onschuldige burgers werden gestraft ${ }^{29}$ en men erkende dat de raadsman in dat verband een belangrijke bijdrage kon leveren. Het ontstaan van dit inzicht was onlosmakelijk verbonden met gewijzigde opvattingen over de (on)feilbaarheid van de staat. Waar men er aanvankelijk van uitging dat de staat zich niet kon vergissen en (externe) controle op fouten niet noodzakelijk was, werd in de loop der jaren duidelijk dat de overheid niet onfeilbaar was en dat de advocaat een belangrijke rol kon spelen bij de voorkoming van gerechtelijke dwalingen. ${ }^{30}$

unjustly cannot be assured, and would certainly not be the kind of a future which a state, seeking support on the grounds of greater justice than can be offered by other types of states, would want': Hazard 1946: p. 100-101.

29 Citaat van Strogovich, opgenomen in Hazard 1941, p. 221-222.

30 Dat de vraag naar de noodzaak c.q. het nut van rechtsbijstand in een strafproces dat gericht is op beleidsimplementatie onlosmakelijk is verbonden met de vraag of het optreden van de raadsman het algemeen belang dient, wordt ook aangegeven door Damaška: 'Is it compatible with the policy-implementing process to allow private counsel to assist the party in confronting the officials in charge of the proceedings? The general answer turns on whether state authorities regard such assistance as useful to the attainment of the goals of justice. It can be argued that, in the absence of private legal counsel, some legitimate interests of a person implicated in proceedings might be overlooked by busy officials or that his interests may be pursued ineffectively by an inexperienced and anxiety-ridden party. It may also be urged that counsel provide a check on the conduct of officials in charge: by keeping them alert, counsel help reduce slackness; by monitoring excesses of zeal, they help reduce irregular official behavior. To the extent that such arguments seem persuasive to state authority, a space opens up for the participation of counsel in the administration of justice: lawyers' participation now is thought to advance the likelihood of reaching the correct procedural outcome. Arguments pro and con may be weighed differently for different types of proceedings or for different procedural stages. Counsel may thus be excluded from certain cases, or from certain phases of the legal process, but not from the administration of justice generally. If counsel's role is assessed as useful, it may be made mandatory, so that a party who refuses to retain a lawyer will have one appointed to represent him anyway; where individuals are not sovereign in pursuing their forensic fortunes, there can be no right to stand alone and act pro se': Damaška 1986, p. 174. Damaška voegt hier nog aan toe dat de raadsman - binnen de gestelde grenzen - wel degelijk een rol van betekenis kan spelen in een beleidsimplementerende procedure: zelfs wanneer weinig invloed kan worden uitgeoefend op de uitkomst van de zaak kan zijn aanwezigheid een belangrijke psychologische steun voor verdachte zijn en er bovendien aan bijdragen dat autoriteiten zich aan de regels houden (en zodoende de rechtsstatelijkheid van de procedure bewaken): 'It would be an unpardonable exaggeration to say that counsel's role in the policyimplementing process is merely cosmetic: within the range of officially appointed views, the lawyer can locate aspects of the case both favorable to his clients and acceptable from the state's point of view, so that the outcome of the case can be materially affected by his efforts' (p. 178). 


\subsubsection{Grenzen aan het optreden van de raadsman: drie belangrijke thema's}

Uit het voorgaande kan worden afgeleid dat het optreden van de raadsman vanuit communistisch perspectief geen problemen opleverde zolang en voor zover daarmee het algemeen belang werd gediend. Strikt genomen bood dit uitgangspunt een oplossing voor alle mogelijke ethische kwesties:

'Arguments about the dependence of counsel upon his client, his duty of secrecy, his right to defend a hopeless and unjust case by all means... are intolerable and out of place as far as our Soviet lawyers are concerned. Under conditions of socialist justice, there is no place for such problems. The Marxist-Leninist science on state and law and our communist morality eliminate such questions (...) reasoning about special moral norms of behavior are characteristic of venal bourgeois lawyers who are ready to make any deal with their conscience in order to defend the interest of the money-bag and their own profit. '31

Het was dus de taak van de advocaat in strafzaken de 'rechtmatige belangen' van zijn cliënt te beschermen: een van de voornaamste belangen in dit verband is het recht niet te worden gestraft in geval van onschuld. Dat de rol van de raadsman in geval van een onschuldige cliënt niet problematisch is, heeft alles te maken met het feit dat het belang van verdachte in dergelijke omstandigheden wordt geacht gelijk te zijn aan het algemeen belang: zowel de overheid als de verdachte zijn dan immers gebaat bij een 'correcte' uitspraak. In alle andere gevallen is deze gelijkschakeling van belangen in het socialistisch strafproces echter minder vanzelfsprekend en wordt de raadsman geconfronteerd met de ingewikkelde vraag hoe hij zich voor zijn cliënt in kan zetten zonder daarmee schade te berokkenen aan het algemeen belang:

'The Soviet defense lawyer cannot convert himself into the servant of his client, blindly following him in the defense of his interests, even though those interests are not legal and detract from, rather than contribute to, the interests of Socialist justice. In defending the rights and legal interests of his clients, the Soviet defense lawyer must stop short at the brink where truth ends and falsehood begins, where the interests of the State and society are damaged by the counterposing to them of the illegal interests of (the) client.' 32

Hoewel in theorie dus duidelijk was dat de grenzen van het optreden van de raadsman werden bepaald door het algemeen belang, bestond veel onduidelijkheid over de vraag wat de (benadrukking van de) publieke taak van de raadsman in concreto diende te betekenen voor de invulling van de verdediging. Hierover werd veel gediscussieerd in de sovjetliteratuur. Een van de belangrijkste discussiepunten die in dat kader bestonden, betrof de vraag of de verdediging mocht worden voortgezet wanneer een advocaat overtuigd raakte van de schuld van zijn cliënt. Over deze kwestie bestond geen eensgezindheid. Sommige auteurs waren van mening dat de raadsman in een dergelijk geval zijn activiteiten wel degelijk mocht staken aangezien de openbaar aanklager op (volgens hen) vergelijkbare wijze de vervolging mocht stopzetten wanneer er onvoldoende belastend bewijsmateriaal voorhanden bleek te zijn. ${ }^{33}$ Feitelijk kwam dit standpunt dat voornamelijk

31 Citaat van Kudryavstsev, vervangend minister van Justitie in de USSR in 1951, geciteerd in: Kucherov 1970, p. 518.

32 Citaat van Perlov genoemd in Razi 1960, p. 797. Zie in dit verband ook Révész 1967, p. 44.

33 Naarmate in de loop der jaren meer aandacht kwam voor de positie van de verdediging - en het inzicht ontstond dat professionele rechtsbijstand ook het algemeen belang 
in de eerste jaren van de Sovjet-Unie werd verdedigd erop neer dat alleen verdachten die - naar de mening van de advocaat - onschuldig in een strafrechtelijke procedure verzeild waren geraakt recht hadden op bijstand van een raadsman. Een groot aantal andere auteurs was echter van mening dat de raadsman de verdediging moest voortzetten wanneer hij zeker dacht te weten dat zijn cliënt schuldig was. In zo'n geval diende de raadsman zich volgens de heersende mening echter wel te beperken tot het voeren van een strafmaatverweer: pleiten voor een vrijspraak was dus geen optie meer.

Een tweede punt van discussie betrof de vraag of de publieke verantwoordelijkheid van de raadsman zover diende te gaan dat van hem mocht worden verwacht dat hij onder bepaalde omstandigheden een actieve bijdrage leverde aan de veroordeling van zijn cliënt. Een auteur die deze vraag positief beantwoordde was Czelcow: hij was van mening dat de taak van de raadsman om de rechtbank behulpzaam te zijn bij de waarheidsvinding zo ver ging dat advocaten de juistheid van verklaringen van hun cliënt in twijfel mochten trekken en zich (ten nadele van verdachte) mochten uitlaten over de schuldvraag. Volgens Czelcow kon een dergelijk optreden worden gerechtvaardigd door het feit dat als uitgangspunt voor het handelen van de raadsman de belangen van de socialistische staat ${ }^{34}$ dienden te gelden. Dit standpunt van Czelcow - dat dateert uit de jaren vijftig werd zeker niet algemeen geaccepteerd in de sovjetliteratuur. Met name in latere decennia (jaren vijftig en zestig) werd door het gros van de Russische auteurs benadrukt dat de advocaat in strafzaken alleen in het voordeel van zijn cliënt mocht handelen en dus niet behulpzaam mocht zijn bij de verwezenlijking van een bewezenverklaring door bijvoorbeeld belastend bewijs aan te dragen. ${ }^{35}$ Een dergelijk standpunt werd onder meer vertegenwoordigd door eerder genoemde Strogovich en Perlov die benadrukten dat de raadsman zich moest laten leiden door het belang van zijn cliënt en dat het niet zijn taak was behulpzaam te zijn bij het realiseren van een veroordeling. ${ }^{36}$ Dit neemt overigens niet weg dat het in de praktijk wel degelijk voorkwam dat advocaten zich in hun pleidooi meer als aanklager dan als verdediger opstelden. ${ }^{37}$

diende - werd de positieve beantwoording van de vraag naar het neerleggen van de verdediging van een (kennelijk) schuldige verdachte minder vanzelfsprekend. Voor een weergave van de discussie: Kucherov 1956, p. 461-463.

34 En dus niet een daarvan afwijkend individueel belang van verdachte.

35 Daszkiewicz 1957, p. 78-81, Grzegorczyk 1988, p. 22 en Kruszyński 1991, p. 19-20 en daar genoemde literatuur.

36 Barry en Berman 1968, p. 15. Zie over de standpunten van Strogovich en Perlov ook: Friedman en Zile 1964, p. 37. Ook Damaška benadrukt dat - in tegenstelling tot wat soms wordt gedacht - de heersende doctrine in communistische systemen ervan uitging dat advocaten zich niet tegen hun cliënt mochten keren: wanneer de verdediging in strijd zou kunnen komen met het algemeen belang, diende de advocaat passief te blijven en zich in het uiterste geval terug te trekken uit de zaak: Damaška 1986, p. 175-176.

37 Zie voor een voorbeeld en de daaropvolgende discussie in de literatuur: Hazard 1978, p. 292: 'It was one thing to defend a guilty person in an effort to obtain clemency and another to join with the prosecutor in castigating the defendant. The commentator [N.N. Polianski in zijn boek 'Waarheid en onjuistheid in strafrechtelijke verdediging'uit 1927, toev. DdV] rejected as unsound an article in a contemporary legal journal approving the action of a lawyer who in his closing speech supported the prosecutor's demand for a sentence of ten years' imprisonment. 
In de door sovjetauteurs gevoerde discussie over de rol van de raadsman is ook veel aandacht besteed aan de vraag naar het (al dan niet) absolute karakter van de geheimhoudingsplicht: kon de raadsman onder omstandigheden verplicht worden informatie prijs te geven die zijn cliënt hem had toevertrouwd? Ook op dit punt liepen de meningen sterk uiteen. ${ }^{38}$ Men was het er echter over eens dat de raadsman in ieder geval verplicht was vertrouwelijke informatie prijs te geven wanneer daarmee een 'wezenlijk staatsbelang' werd gediend. Over de vraag wanneer sprake was van een 'wezenlijk staatsbelang' verschilde men van mening. Sommige auteurs stelden zich op het standpunt dat de raadsman alle (van zijn cliënt vernomen) informatie die op enigerlei wijze van betekenis zou kunnen zijn voor de uitkomst van de zaak aan de rechtbank ter beschikking zou moeten stellen. ${ }^{39}$ Het behoeft geen betoog dat de betekenis van de geheimhoudingsplicht volgens deze redenering tot een absoluut minimum werd gereduceerd. Hoewel niet alle auteurs zover wilden gaan, bestond in de doctrine wel eensgezindheid over het feit dat de raadsman in ieder geval verplicht was informatie prijs te geven die betrekking had op de voorbereiding of de uitvoering van een 'contrarevolutionair' (staatsgevaarlijk) strafbaar feit. ${ }^{40}$ In dit soort zaken met een expliciet politiek karakter ${ }^{41}$ was vertrouwelijkheid tussen advocaat en cliënt dus allesbehalve vanzelfsprekend.

The charge had been seduction of young girls and the defending counsel had been moved to say that there was no reason for a lesser sentence for such a truly dangerous criminal. The commentator took the view that the lawyer's code of ethics forbad conscious injury to a client's case even in the name of justice.'

38 Enkele auteurs waren van mening dat de taak van de raadsman om behulpzaam te zijn bij de vervolging en berechting van strafbare feiten zo ver ging dat hij in de regel verplicht was informatie die hij van zijn cliënt had gekregen met de rechtbank te delen waarbij slechts een uitzondering kon worden gemaakt voor strikt persoonlijke gegevens die niet relevant konden zijn voor de uitkomst van de zaak. Andere schrijvers meenden dat een dergelijke algemene verwerping van de professionele geheimhoudingsplicht het werk van de raadsman onmogelijk zou maken: Kucherov 1956, p. 463-466.

39 Een dergelijk extreem standpunt werd onder meer ingenomen door Kruglov die van mening was dat de raadsman de rechtbank onvoldoende behulpzaam zou kunnen zijn wanneer hij van zijn cliënt verkregen informatie achter zou mogen houden. Het achterhouden van informatie zou de strafrechtelijke procedure immers kunnen compliceren en verwarring kunnen wekken wat zelfs een strafbaar feit tegen de overheid zou kunnen opleveren. Op de informatieplicht van de raadsman kon volgens Kruglov slechts een uitzondering worden gemaakt wanneer het ging om strikt persoonlijke feiten en omstandigheden die niet van invloed konden zijn op de uitkomst van de zaak: Kucherov 1956, p. 464.

$40 \quad$ Bonsal 1961, p. 6 en Razi 1960, p. 796.

41 Eerder in dit hoofdstuk is opgemerkt dat door een ruime toepassing van de kwalificatie 'sociaalgevaarlijkheid' vrijwel iedere strafbare gedraging als schadelijk voor het algemeen belang en dus als bedreiging voor de overheid kon worden beschouwd waardoor strafzaken per definitie een politiek karakter hadden. Dit betekent echter niet dat alle strafbare feiten ook daadwerkelijk met een 'anticommunistisch' oogmerk werden gepleegd - zie bijvoorbeeld eerder genoemde vormen van economische criminaliteit (toe-eigenen van gemeenschappelijk eigendom om inkomen te kunnen genereren). Vandaar dat in het bovenstaande wordt gesproken over 'zaken met een expliciet politiek karakter' om aan te geven dat het in deze context gaat om feiten die overduidelijk en met opzet tegen het heersende regime waren gericht. 
Hoewel bovenstaande bespreking van de Russische doctrine slechts enkele grote lijnen weergeeft, kan hieruit in ieder geval worden afgeleid dat de publieke taak van de raadsman met name in de eerste decennia van de Sovjet-Unie in de literatuur de overhand heeft gehad. Kenmerkend is het vrij absolute idee over waarheidsvinding en de invloed van deze opvatting op de grenzen die aan het optreden van de raadsman werden gesteld. De functie van de raadsman als partijdige beschermer van de belangen van verdachte werd in de loop der jaren wel erkend maar over de vraag hoe deze taak moest worden verenigd met de communistische overtuiging dat de advocaat net als alle andere procesdeelnemers eerst en vooral gebonden was aan de (politieke doelstellingen van de) overheid werd veel gediscussieerd. Genoemde discussiepunten over de vraag of de raadsman de verdediging van een kennelijk schuldige verdachte mag neerleggen en over de reikwijdte van de geheimhoudingsplicht geven weer hoe zeer dit dilemma de sovjetauteurs heeft beziggehouden. Afgezien van de verschillende standpunten die hierover bestonden, is - binnen de context van dit hoofdstuk - voornamelijk van belang dat de vraag naar het neerleggen van de verdediging bij schuldige verdachten en het absolute karakter van de geheimhoudingsplicht überhaupt aan de orde werden gesteld. Dat het antwoord op de schuldvraag van invloed kon zijn op de (omvang van) het recht op verdediging van verdachte en dat eensgezindheid bestond over het feit dat een 'wezenlijk staatsbelang' de raadsman kon verplichten vertrouwelijke informatie prijs te geven, geeft aan hoe ruim de publieke taak van de advocaat door sommige auteurs werd uitgelegd. Dat deze discussiepunten typerend zijn voor het denken over de rol van de raadsman in een communistisch systeem kan worden afgeleid uit het feit dat ze in de Russische literatuur van voor 1917 geen enkele rol speelden. Zowel in de doctrine als in de praktijk was men het er over eens dat de raadsman niet gerechtigd was de verdediging neer te leggen vanwege de overtuiging van de schuld van zijn cliënt en ook over het absolute karakter van de geheimhoudingsplicht bestond geen discussie. ${ }^{42}$

Tot slot dient te worden opgemerkt dat het toekennen van een publieke taak aan de raadsman niet alleen in socialistische rechtssystemen gebeurt: ook in veel niet-communistische landen geldt het uitgangspunt dat de raadsman als professionele procesdeelnemer bepaalde verantwoordelijkheden heeft ten aanzien van de waarheidsvinding en een behoorlijk procesverloop. ${ }^{43}$ Zo mag de raadsman geen bewijsmateriaal aanvoeren waarvan hij weet dat het vals is, een getuige niet overhalen in strijd met de waarheid te verklaren et cetera. Het moge duidelijk zijn dat het verschil zit in de gradatie en dat de publieke verantwoordelijkheid van de raadsman volgens het communistisch perspectief (veel) verder gaat dan het niet betrokken raken bij de voorbereiding of uitvoering van strafbare feiten en een verbod moedwillig de waarheidsvinding te verstoren. ${ }^{4}$

42 Kucherov 1956, p. 447-448 en 465-466.

43 Dit geldt onder meer voor het (in bepaalde mate) op beleidsimplementatie gerichte Nederlandse strafproces.

44 Verdediging in strafzaken kan niet bestaan uit 'exculpating the accused regardless of incontestable facts or minimizing the danger of his crime. Such a defense (...) would be directed against the interests of society and the state'. De raadsman behartigt immers niet alleen de belangen van zijn cliënt maar is ook een 'active participant in the trial who cooperates in truth finding, 


\section{De Poolse doctrine}

Uit het voorgaande blijkt welke invloed het communistisch regime heeft gehad op het denken over verdediging in strafzaken in de sovjetliteratuur. Hoewel auteurs onderling op verschillende punten van mening verschilden en opvattingen in de loop der jaren veranderden, ${ }^{45}$ woog de publieke taak van de raadsman volgens de heersende mening zwaarder dan zijn taak als partijdige behartiger van de belangen van zijn cliënt. De vraag die in deze paragraaf centraal zal staan, is of de Poolse doctrine gedurende de communistische periode een zelfde tendens laat zien. Werd de publieke functie van de raadsman in de Poolse literatuur op dezelfde wijze benadrukt als in de Sovjet-Unie en stonden daarbij dezelfde discussiepunten centraal? Deze vraag is met name relevant omdat Polen niet vrijwillig heeft gekozen voor het communistisch regime en de bijbehorende wijzigingen in het rechtssysteem: deze werden van bovenaf door de Sovjet-Unie opgelegd. Aangezien binnen de Poolse grenzen weinig affiniteit met de communistische ideologie bestond, kan niet zonder meer worden aangenomen dat de doctrine voor de invulling van de functie van de raadsman direct aansluiting heeft gezocht bij de literatuur van haar oosterburen. Dat neemt echter niet weg dat de Poolse strafrechtspleging na 1945 werd geconfronteerd met een nieuw type strafproces dat op wezenlijke punten verschilde van de procesvorm die men tot dan toe gewend was en dus noopte tot (in ieder geval enige mate van) herbezinning van de functie van de advocaat in strafzaken.

\subsection{Relevantie onderscheid communisme-postcommunisme}

Vooruitlopend op de hiernavolgende bespreking dient te worden opgemerkt dat in de discussie over de positie van de raadsman in de Poolse literatuur in de periode na Wereldoorlog II tot vandaag de dag dezelfde thema's centraal staan. ${ }^{46}$ De discussie concentreert zich op twee (voor de hand liggende) perspectieven: enerzijds op de positie van de raadsman ten opzichte van de overheid en anderzijds op de interne verhouding tussen raadsman en cliënt. Slechts ten aanzien van het eerste perspectief is een gradueel verschil te ontdekken tussen de literatuur van de communistische periode en de huidige doctrine. De discussie over de (interne) verhouding tussen raadsman en cliënt wordt in beide periodes op dezelfde wijze ingevuld. Hierbij staat van oudsher de vraag centraal of de raadsman nu wel of niet als procesvertegenwoordiger van zijn cliënt moet worden aangemerkt. ${ }^{47}$ De doctrine is verdeeld op dit punt. Omdat het onderscheid communisme-postcommunisme dus slechts van beperkte betekenis is voor de inhoud

in passing a sentence which conforms to the essence of the case and to the interests of the state, which on the one hand require the most strict punishment of a criminal and on the other do not tolerate the punishment of an innocent person': Kucherov 1956, p. 467.

45 Zoals eerder aangegeven, werd het belang van rechtsbijstand in strafzaken in de loop der jaren steeds meer erkend waardoor meer aandacht voor de positie van de verdediging ontstond.

46 'There has been little change in the perceived role of the defence lawyer in criminal proceedings in Poland since the decline of communism, either in theory or practice': Kruszyński 2007 I, p. 199.

47 Een discussie die overigens ook in veel andere rechtssystemen wordt gevoerd. In de Poolse doctrine wordt in dit verband wel gesproken over 'de juridische status van de raadsman' ('status prawny obrońcy'). 
van de discussie over de functie van de raadsman, zal bij onderstaande bespreking geen verschil worden gemaakt tussen de periode voor en na 1989: de vier opvattingen die de revue zullen passeren, spelen in beide periodes een belangrijke rol.

\subsection{Verschillende typeringen van de functie van de raadsman}

De vier belangrijkste typeringen van de functie van de raadsman die aan de Poolse literatuur kunnen worden ontleend, zijn:

- helper van de rechtbank (pomocnik sadu),

- medewerker van de rechtspleging (wspótczynnik wymiaru sprawiedliwości),

- helper van verdachte (koncepcja pomocnika procesowego oskarżonego) en

- procesvertegenwoordiger van verdachte (koncepcja przedstawiciela procesowych interesów oskarżonego).

Reeds zonder toelichting zal duidelijk zijn dat de eerste twee typeringen betrekking hebben op de verhouding tot de overheid, terwijl de laatste twee de relatie tot de cliënt betreffen. De vier begrippen zullen in het onderstaande nader worden uitgewerkt. ${ }^{48}$

\subsubsection{De raadsman als 'helper van de rechtbank' ('pomocnik sadu')}

Het standpunt dat de raadsman als hulp van de rechtbank moet worden beschouwd is in de Poolse doctrine slechts incidenteel verdedigd en dan met name in de beginperiode van het communisme. De belangrijkste auteurs die in dit verband moeten worden genoemd, zijn Peiper en Schaff. Laatstgenoemde benadrukt in zijn boek 'Het Poolse strafproces in de Volksrepubliek Polen' (1953) dat de raadsman in een socialistisch strafproces een volledig andere rol vervult dan in de strafrechtspleging van een kapitalistisch systeem:

'De belangrijkste taak [decurs. DdV] van de raadsman in strafzaken is samenwerking met de rechtbank (...), met het doel de waarheid aan het licht te brengen. Het is zeker niet de taak van de verdediging, de rechtbank te hinderen bij de waarheidsvinding of voor de raadsman om te veranderen in een aanklager. De raadsman dient er bij zijn deelname juist naar te streven dat de rechtbank de materiële waarheid kan achterhalen en dat de onschuld van de verdachte aan het licht komt, en in geval van zijn schuld - dat hij wijst op omstandigheden die de schuld verminderen. Deze functie van de raadsman heeft net als de functie van de aanklager invloed op het belangrijkste beginsel van het socialistisch strafproces: de materiële waarheidsvinding. ${ }^{4} 9$

48 Voor de weergave van de verschillende door de Poolse doctrine erkende functies van de raadsman is gebruik gemaakt van Kruszyński 1991, p. 13-22. Zie ook Grzegorczyk 1979.

49 Schaff 1953, p. 313. Dit alles is volgens hem onlosmakelijk verbonden met het feit dat de belangen van het individu in een socialistisch systeem - en dus ook in het socialistisch strafproces - volledig gelijk zijn aan de belangen van de gemeenschap. Het is immers zowel in het belang van de maatschappij als van verdachte dat onschuldigen worden vrijgesproken en dat schuldigen worden gestraft naar de mate van hun schuld: Schaff 1953, p. 173-176. Het - typisch communistische - standpunt dat in het socialistisch strafproces tussen de verdachte en de overheid geen tegengestelde belangen bestaan, is in de Poolse literatuur veelvuldig bekritiseerd: zie Grzegorczyk 1979, p. 2 waar hij er op wijst dat het juist inherent is aan het strafproces dat tussen het individu en de overheid een conflict bestaat en dat van overeenstemming tussen beide belangen slechts sprake kan zijn wanneer de verdachte onschuldig is. 
Zoals reeds uit bovenstaand citaat blijkt ('het is niet de taak (...) van de raadsman om te veranderen in een aanklager') zijn er volgens Schaff wel grenzen aan de publieke taak van de raadsman:

'(...) de hulp van de raadsman dient er niet uit te bestaan dat hij omstandigheden die nadelig zijn voor verdachte aan het licht brengt of helpt brengen of dat hij tegen alle gerechtelijke vergissingen ingaat. Hij dient zich slechts tegen die vergissingen te verzetten die voor de verdachte nadelig zijn of kunnen zijn, het is daarentegen zijn verplichting slechts te wijzen op die omstandigheden, die op een of andere wijze voordelig kunnen zijn voor verdachte. Het tegenspreken van andere vergissingen en het aan het licht brengen van omstandigheden die in het nadeel van verdachte zijn, behoort tot de taak van de prokurator.'50

Hoewel Schaff hiermee benadrukt dat het niet de bedoeling is dat de raadsman op de stoel van de aanklager gaat zitten, is duidelijk dat hij de bijdrage aan de waarheidsvinding - en dus niet de bescherming van individuele belangen van verdachte - als belangrijkste taak van de advocaat beschouwt. Hij gaat echter niet zover als het door Czelcow in de sovjetliteratuur verdedigde standpunt dat de raadsman als helper van de rechtbank het recht heeft te verklaren dat hij twijfelt aan de onschuld van zijn cliënt of aan de juistheid van zijn verklaringen. ${ }^{51}$

\subsubsection{De raadsman als 'medewerker van de rechtspleging' ('współczynnik wymiaru sprawiedliwości')}

Een tweede manier waarop de publieke functie van de raadsman in de Poolse doctrine is benadrukt, is door hem aan te merken als 'medewerker van de rechtspleging'. Belangrijke auteurs in dit verband zijn: Śliwiński, Dąb, Migdał, Lipczyńska, en Kalinowksi. Hoewel er zeker overeenkomsten zijn tussen eerstgenoemde omschrijving van de raadsman als helper van de rechtbank en de typering 'medewerker van de rechtspleging' - beide benadrukken de verantwoordelijkheid van de advocaat ten aanzien van de waarheidsvinding52 - zijn ze zeker niet identiek. Voornaamste onderscheid tussen beide begrippen is dat ervan uit wordt gegaan dat de raadsman als 'helper van de rechtbank' in een ondergeschikte verhouding staat tot de justitiële autoriteiten. Auteurs die van mening zijn dat de raadsman medewerker van de rechtspleging is, willen zover niet gaan: uitgangspunt is dat de raadsman niet in een hiërarchische verhouding staat tot de overheid maar daaraan gelijkwaardig is. ${ }^{53}$ Vandaar dat in het kader van dit standpunt, nog sterker

50 Schaff 1953, p. 313.

51 Zie hiervoor § 2.2.2.

52 Vandaar dat de twee functies door sommige auteurs zoals Kruszyński ook wel onder een en dezelfde categorie worden gebracht: de raadsman als subject optredend in het algemeen belang ('koncepcja obrońcy jako podmiotu działającego w interesie publicznym'): Kruszyński 1991, p. 17 e.v.

53 Grzegorczyk 1988, p. 23. De typering 'medewerker van de rechtspleging' dient ook te worden onderscheiden van het - overigens niet duidelijk afgebakende - Duitse begrip 'organ der rechtspflege' dat in het Pools wordt vertaald als 'organ wymiaru sprawiedliwosći' maar in de Poolse discussie over de rol van de advocaat geen zelfstandige betekenis toekomt. Over de betekenis van het begrip 'organ der rechtspflege' bestaat in de Duitse literatuur veel discussie: 'Die Frage nach dem rechtlichen Inhalt der Organstellung und den daraus folgenden Rechten und Pflichten des Verteidigers ist Gegenstand einer wohl nie endenden Diskussion. Die Spanne der Auffassungen reicht vom "staatlich gebundenen Vertrauensberuf" über den 
dan door de in de voorgaande paragraaf genoemde auteurs wordt benadrukt dat de advocaat slechts tot op bepaalde hoogte het algemeen belang behoort te dienen. Dąb verwoordde dit reeds in de jaren vijftig door aan te nemen dat de raadsman slechts behulpzaam mag zijn bij de het zoeken naar de waarheid voor zover dat in het voordeel van zijn cliënt is. Auteurs die de publieke functie van de raadsman uitbreiden tot helper van de rechtbank en daarbij de advocaat medeverantwoordelijk houden voor de waarheidsvinding ook voor zover deze in het nadeel is van verdachte gaan volgens Dąb te ver. Het is immers juist in het belang van de rechtspleging dat de raadsman de verdachte slechts verdedigt en niet bijdraagt aan de aanklacht tegen hem. ${ }^{54}$ Dat de raadsman als medewerker van de rechtspleging alleen een bijdrage mag leveren aan de waarheidsvinding voor zover dat in het voordeel van verdachte is, is in dezelfde periode ook verdedigd door Lypczyńska en Migdał. Eerstgenoemde heeft in een handboek over de positie van de verdachte in de Poolse Volksrepubliek - verschenen in de nadagen van de stalinistische periode - benadrukt dat het noch een recht noch een plicht van de advocaat in een socialistisch strafproces is om voor de verdachte belastende omstandigheden aan te voeren: dat is immers de taak van de vervolging. ${ }^{55}$ Eenzelfde standpunt werd ingenomen door Migdał: de raadsman is verplicht tot samenwerking met de rechtbank maar dat betekent niet dat hij een bijdrage moet leveren aan het bewijs van de schuld van zijn cliënt. Van een raadsman kan immers niet worden verwacht dat hij als aanklager optreedt. Een van de consequenties die Migał verbindt aan de verplichting van de raadsman de waarheidsvinding niet te hinderen, is dat het hem niet vrij staat voor vrijspraak te pleiten wanneer hij overtuigd is van de schuld van zijn cliënt. In zijn hoedanigheid van medewerker van de rechtspleging mag hij immers geen bijdrage leveren aan het verbergen van de waarheid en het is de taak van de raadsman dat uit te leggen aan zijn cliënt. ${ }^{56}$

"unabhängigen, jedoch in die Funktion der Rechtspflege integrierten Beistand" bis zum nahezu schrankenlos auschließlich "Parteigebundenen Helfer politisch/sozialer Gegenmacht" zur staatlichen Rechtspflege', Dahs 2005, p. 13. Zie voor een uitgebreide beschrijving van de historische ontwikkeling van de term: Knapp 1974.

54 Dąb 1954, p. 448.

55 Lipczyńska 1956, p. 170-175.

56 Een standpunt dat - zoals eerder besproken - ook in de sovjetliteratuur werd verdedigd. Zie Migdał 1954, p. 37-48. Een andere Poolse auteur die in de jaren vijftig uitgebreid aandacht heeft besteed aan de vraag of de overtuiging van de raadsman over de schuld van verdachte een rol mag spelen bij de verdediging is Daszkiewicz. Hij benadrukt dat voor beantwoording van deze vraag relevant is wanneer en op welke grond(en) de raadsman overtuigd is geraakt van de schuld van zijn cliënt: wanneer het vermoeden van schuld is gebaseerd op het bewijsmateriaal, brengen de onschuldpresumptie en het in dubio pro reo beginsel mee dat de raadsman gewoon de verdediging zal moeten voeren zonder zijn eigen opvattingen daarbij een rol te laten spelen. De raadsman heeft wel het recht - en zelfs de plicht - de verdediging neer te leggen wanneer de verdachte wil dat hij vals bewijsmateriaal overlegt. Wanneer het vermoeden van schuld bij de raadsman is ontstaan doordat de verdachte tegenover hem heeft bekend, gelden volgens Daszkiewicz andere uitgangspunten. Hij onderscheidt in dit verband drie situaties: 1. de raadsman is ervan overtuigd dat zijn cliënt onschuldig is, ondanks dat hij tegenover hem heeft bekend 2. de raadsman is overtuigd van de schuld van zijn cliënt, die tegenover hem heeft bekend en dat ook tegenover de autoriteiten doet, en 3 . de raadsman is overtuigd 
In de jaren zestig is de maatschappelijke functie van de raadsman als medewerker van de rechtspleging onder meer benadrukt door Kalinowski. Dat de advocaat in strafzaken een publiekrechtelijk karakter heeft, blijkt volgens hem vooral uit het systeem van de wet: de positie van de raadsman wordt geregeld door het publiekrecht en het recht op verdediging is vastgelegd in de Grondwet. Ook uit het verschijnsel van de verplichte rechtsbijstand en het feit dat advocaten hun beroep uitoefenen vanuit collectieven en bureaus voor rechtshulp ${ }^{57}$ kan volgens Kalinowski worden afgeleid dat de raadsman een publieke functie vervult. Een en ander betekent zijns inziens dat de raadsman zich vooral verbonden dient te voelen met de belangen van de rechtspleging en zich niet (teveel) met de positie van de verdachte mag identificeren. ${ }^{58}$

Hoewel de in $\S 3.2 .1$ en deze paragraaf genoemde standpunten voornamelijk dateren uit het eerste deel van de communistische periode (jaren vijftig en zestig), mag daaruit niet worden afgeleid dat in latere literatuur geen aandacht meer is voor de publieke functie van de raadsman. Het thema is in de loop der jaren echter wel meer naar de achtergrond verschoven. Het tweede perspectief (de interne verhouding tussen raadsman en cliënt) is de discussie steeds meer gaan overheersen. In huidige literatuur over de functie van de raadsman wordt nog wel regelmatig naar genoemde typeringen (helper van de rechtbank en medewerker rechtspleging) en de daarbij behorende auteurs uit vroegere tijden verwezen.

Een meer recente invulling van het begrip 'publieke functie' wordt onder meer door Kruszyński en Grzegorczyk gegeven. Kruszyński geeft in zijn proefschrift over de positie van de raadsman (1991) een eigen formulering van de functie van de advocaat in strafzaken waarbij ook aandacht wordt besteed aan zijn verantwoordelijkheden ten aanzien van het algemeen belang:

'De raadsman is "helper" van verdachte die zijn taak binnen de grenzen van het recht en de beroepsethiek slechts in het voordeel van verdachte mag uitvoeren maar tegelijkertijd het algemeen belang in ogenschouw dient te houden, wat inhoudt dat in geen geval mag worden toegestaan dat foutieve beslissingen worden genomen over het vermeende feit, gebaseerd op eenzijdige of onvolledige beoordeling van het bewijsmateriaal alsmede dat ervoor wordt ingestaan dat de regels van het procesrecht nauwkeurig in acht worden genomen. 59

van de schuld van zijn cliënt die tegenover hem heeft bekend maar die ten opzichte van de autoriteiten volhoudt onschuldig te zijn en van zijn raadsman verwacht zijn onschuld te bepleiten. In het eerste geval mag de raadsman tegen de wil van verdachte proberen zijn onschuld aan te tonen. In het tweede geval kan de raadsman gewoon de verdediging voeren, die zich dan voornamelijk zal beperken tot een strafmaatverweer. Ten slotte dient de raadsman - in het derde geval - zijn cliënt erop te wijzen dat hij niet in strijd met de waarheid mag handelen en is het onder bepaalde omstandigheden gerechtvaardigd de verdediging neer te leggen. Zie Daszkiewicz 1957, p. 69-86.

57 Zoals in hoofdstuk 8, § 2.2.1.2 nog zal worden uitgewerkt, kon het beroep van advocaat gedurende een deel van de communistische periode in Polen alleen worden uitgeoefend vanuit bepaalde collectieve samenwerkingsvormen.

58 Kalinowski 1961, p. 3-20. Wat dit concreet voor de verdediging betekent, wordt door Kalinowski niet aangegeven. Verder dan de opmerking dat de raadsman de rechtbank niet mag hinderen in het aan het licht brengen van de waarheid gaat hij niet.

59 Kruszyński 1991, p. 37. Volgens Kruszyński moet hier echter niet uit worden afgeleid dat 
Opvallend is dat Kruszyński ervan uit gaat dat nu juist het feit dat de raadsman de individuele belangen van verdachte beschermt het algemeen belang dient: door op te treden als procesbewaker kunnen foutieve beslissingen worden voorkomen. Hij ziet de publieke functie van de raadsman vooral als een garantie voor de bescherming van de rechten van verdachte. ${ }^{60}$ Ook Grzegorczyk benadrukt dat de publieke taak van de raadsman vooral bestaat uit het mogelijk maken van contradictoire procesvoering - door te voorkomen dat het standpunt van de vervolging te veel overheerst - en zodoende bij te dragen aan een juiste besluitvorming. Volgens hem kunnen advocaten slechts in die zin worden aangemerkt als 'medewerker van de rechtspleging'. Bovendien ziet Grzegorczyk de publieke functie van de raadsman ook als een factor die grenzen stelt aan zijn eigen optreden. Hij stelt dat de grenzen aan het optreden van de raadsman aan de ene kant worden bepaald door het belang van de verdachte - als stimulerende factor - en aan de andere kant door het publieke karakter van zijn deelname waarvan een beperkende werking uitgaat. ${ }^{61}$ Dit wordt ook erkend door Kruszyński: dat de raadsman rekening moet houden met het algemeen belang verklaart (onder meer) waarom hij niet mag liegen en waarom hem een zelfstandige positie in het strafproces wordt toegedicht.

Deze standpunten uit de meer recente literatuur maken duidelijk dat de publieke functie vandaag de dag vooral in een rechtsstatelijk kader wordt geplaatst: het algemeen belang is gebaat bij effectieve rechtsbijstand aan verdachten, niet alleen omdat daarmee rechterlijke dwalingen kunnen worden voorkomen maar ook omdat het bieden van rechtsbescherming en het bewaken van procedurele voorschriften als zelfstandige rechtsstatelijke belangen worden erkend. De opvatting dat de raadsman als hiërarchisch ondergeschikte 'helper van de rechtbank' vooral tot taak heeft een bijdrage te leveren aan de waarheidsvinding, lijkt hiermee tot het verre verleden te behoren. Dit is niet zo vreemd aangezien dit standpunt zelfs in de stalinistische periode slechts incidenteel is bepleit in de Poolse litera-

de raadsman in alle gevallen dient te voorkomen dat een foutieve beslissing wordt genomen. Van hem kan immers niet worden verwacht dat hij ingrijpt wanneer een 'incorrecte' beslissing wordt genomen die voordelig is voor zijn cliënt. De publieke functie van de raadsman - in de zin van de grenzen die aan zijn optreden moeten worden gesteld - worden immers slechts bepaald door de wet en de gedragsregels en niet door (het belang van) de waarheidsvinding. Bron: gesprek Kruszyński, januari 2007 Warschau.

60 Kulesza 2005, p. 376.

61 Grzegorczyk 2004, p. 291: 'Het instituut van de raadsman die de verdachte verdedigt, dient het publiek belang en dat vereist dat individuele rechten binnen de grenzen van het recht naar behoren worden verdedigd en dat de doelstellingen van het proces op zodanige wijze worden gerealiseerd dat de rechten van de verdediging effectief kunnen worden beschermd' ('Institucja obrońcy broniącego oskarżonego leży w interesie publiczym, który wymaga, aby prawa jednostki były należycie chronione w ramach prawem przewidzianych $i$ by cele procesu realizowane były w warunkach zabezpieczajacych realność procesowego prawa do obrony'). Net als Kalinowski besteedt ook Grzegorczyk niet veel aandacht aan de vraag welke grenzen deze publieke functie stelt aan het optreden van de raadsman in de praktijk: hij geeft wel enkele ruime grenzen aan - zoals het feit dat de raadsman geen bewijsmateriaal mag aandragen waarvan hij weet dat het vals is en dat hij niemand mag aanzetten tot het afleggen van een bepaalde verklaring - maar daar blijft het bij. Zie over het standpunt van Grzegorczyk ook Kulesza 2005, p. 376. 
tuur en dus nooit veel ondersteuning heeft gekregen. De huidige invulling van de publieke functie lijkt vooral op een gematigde versie van het type 'medewerker van de rechtspleging'. De 'medewerking' van de raadsman wordt daarbij niet meer zozeer uitgelegd als een verplichting in actieve zin behulpzaam te zijn bij de waarheidsvinding maar als het vervullen van een positie die een eerlijke en contradictoire procesvoering mogelijk maakt.

\subsubsection{De raadsman als 'helper van verdachte' ('koncepcja pomocnika procesowego oskarżonego')}

In de discussie over de verhouding tussen raadsman en cliënt staan twee standpunten lijnrecht tegenover elkaar waarbij het verschil van mening betrekking heeft op de vraag of het verlenen van rechtsbijstand aan de verdachte nu wel of niet een vorm van procesvertegenwoordiging (in gebruikelijke, civielrechtelijke zin) is. Auteurs die het standpunt huldigen dat dit niet zo is, typeren de raadsman als 'helper van verdachte'. Gedurende de communistische periode werd dit onder anderen gedaan door Śliwiński en Kalinowski. ${ }^{22}$ Wat de meer recente literatuur betreft, dient in dit verband vooral Kruszyński te worden genoemd. Hij benadrukt dat er in het Poolse recht twee vormen van procesvertegenwoordiging zijn - enerzijds de vertegenwoordiging op grond van de wet (de wettelijk vertegenwoordiger: przedstawiciel ustawowy) en anderzijds het optreden met instemming van de cliënt (de gevolmachtigde: petnomocnik) - die zijns inziens geen van beide van toepassing zijn op de positie van de advocaat in strafzaken. De raadsman is volgens hem geen wettelijk vertegenwoordiger omdat zijn deelname aan het strafproces niet op een wettelijke bepaling maar op instemming van zijn cliënt is gebaseerd. ${ }^{63}$ Dat de (gekozen of toegevoegde) raadsman niet als gevolmachtigde kan worden beschouwd, blijkt volgens Kruszyński vooral uit het systeem van de wet en de door de wetgever gekozen formuleringen. De titel van het hoofdstuk dat handelt over het verlenen van bijstand in strafzaken luidt immers 'de raadsman en de gevolmachtigde'. Hier kan uit worden afgeleid dat beide als aparte procesdeelnemers moeten worden beschouwd en dat de raadsman in de visie van de wetgever dus niet als gevolmachtigde kan worden aangemerkt. Bovendien wordt in de bepaling waarin is geregeld hoe de raadsman gemachtigd dient te worden niet gesproken van het verlenen van een volmacht maar van 'machtigen tot de verdediging' ${ }^{64}$ Ook uit die bewoordingen kan volgens Kruszyński worden afgeleid dat de raadsman geen gevolmachtigde is. Bovendien - en dat is een meer inhoudelijk argument - impliceert procesvertegenwoordiging dat alle (in beginsel ook nadelige) handelingen van de vertegenwoordiger voor

62 Śliwiński 1961, p. 199-211 en Kalinowski 1962, p. 3-20. Kalinowski is dus een van de auteurs die zich over beide perspectieven van de functie van de raadsman (de verhouding tot de overheid en de relatie met de cliënt) heeft uitgelaten - zie sub 2 voor zijn standpunten over de publieke functie van de advocaat in strafzaken. Het spreekt overigens voor zich dat deze twee standpunten naast elkaar kunnen bestaan: de kwalificatie 'helper van de verdachte' zegt immers alleen iets over de onderlinge verhouding tussen raadsman en cliënt en niet over de verhouding tot de overheid.

63 Dit geldt weliswaar niet onverkort voor de toegevoegde raadsman maar ook in dergelijke gevallen kan volgens Kruszyński niet van wettelijke vertegenwoordiging worden gesproken omdat de raadsman niet 'in plaats van' maar 'naast' de verdachte optreedt. 
rekening van de cliënt komen terwijl handelingen van de raadsman alleen in het voordeel van de cliënt mogen zijn. ${ }^{65}$

Tegenstanders van het standpunt dat de raadsman als helper van verdachte moet worden aangemerkt, hebben er vooral problemen mee dat de terminologie ('hel-

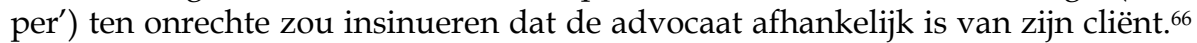
In zijn algemeenheid geldt dat tegenstand voornamelijk afkomstig is uit de groep van auteurs die de raadsman als procesvertegenwoordiger aanmerken (zie hierna).

\subsubsection{De raadsman als procesvertegenwoordiger van verdachte ('koncepcja przedstawiciela procesowych interesów oskarżonego')}

Ander auteurs - onder wie Cieślak, Daszkiewicz, Grgegorzyk en Waltoś - verdedigen dat de raadsman wel degelijk als procesvertegenwoordiger van verdachte moet worden aangemerkt. Belangrijkste argumenten die hiervoor genoemd worden, zijn dat:

- hij niet een eigen belang vertegenwoordigt maar dat van de verdachte,

- zijn handelingen in beginsel voor rekening van verdachte komen,

- de omvang van zijn rechten in beginsel wordt bepaald door de omvang van de rechten van verdachte,

- hij zich net als de vertegenwoordiger door een collega kan laten vervangen en

- de verdachte net als de volmachtgever op ieder moment in de procedure bevoegd is de machtiging in te trekken.

Volgens deze redenering ontleent de raadsman zijn bevoegdheid tot vertegenwoordiging aan de volmacht van zijn cliënt of - in geval van toegevoegde rechtsbijstand aan de beslissing van de rechter tot toevoeging. Enigszins tegemoetkomend aan de kritiek van aanhangers van het 'helpers'-standpunt wordt door auteurs die de raadsman als procesvertegenwoordiger aanmerken wel benadrukt dat het hier gaat om een sui generis vorm van vertegenwoordiging die op sommige punten verschilt van de reguliere wettelijk vertegenwoordiger en de gevolmachtigde. Daarbij wordt erkend dat een belangrijk onderscheid tussen de raadsman als procesvertegenwoordiger en andere vormen van vertegenwoordiging is dat de raadsman slechts in het voordeel van verdachte mag handelen en dat handelingen die in zijn nadeel worden verricht in beginsel geen effect kunnen sorteren. ${ }^{67}$ Een tweede verschil is dat de raadsman anders dan de gevolmachtigde een zelfstandige positie inneemt wat betekent dat hij niet gebonden is aan de wil van zijn cliënt en onder omstandigheden zelfs tegen de uitdrukkelijke wil van verdachte in kan gaan. ${ }^{68}$ Overigens geldt volgens Grzegorczyk dat de tweede typering (raadsman als proces-

65 Kruszyński 1991, p. 13-14 en 23-27.

66 Łyczywek 1989, p. 11.

67 Terwijl dat niet onverkort voor de gevolmachtigde geldt: wanneer een gevolmachtigde handelingen in het nadeel van zijn cliënt verricht, kunnen deze ook effect sorteren indien en voor zover ze onder de reikwijdte van de volmacht vallen. Zie over de regel dat de raadsman alleen in het voordeel van verdachte mag handelen hierna § 3.3.1.

68 Over overeenkomsten en verschillen tussen de raadsman en andere vormen van vertegenwoordiging: Grzegorczyk 1988, p. 28-34. Zie ook Waltoś 2002, p. 190 e.v. 
vertegenwoordiger) ook in de rechtspraak van het Hooggerechtshof als uitgangspunt wordt genomen. ${ }^{69}$

Kijkend naar de twee standpunten over de verhouding tussen raadsman en cliënt en de juridische grondslag daarvan valt op dat het verschil van mening vooral een theoretische kwestie is: het gaat vooral over de 'naam van het beestje'. Het antwoord op de vraag of de raadsman nu wel of niet als procesvertegenwoordiger moet worden aangemerkt, heeft niet of nauwelijks inhoudelijke consequenties voor de positie van de advocaat en de verhouding tot zijn cliënt. Bovendien zijn beide visies dicht bij elkaar komen te liggen doordat aanhangers van het vertegenwoordigers-standpunt een eigen invulling hebben gegeven aan de vertegenwoordiging door de raadsman (sui generis vorm).

\subsection{Vaste uitgangspunten}

Het is van belang op te merken dat er - afgezien van bovengenoemde discussies over de typering van de functie van de raadsman - een aantal belangrijke, vaste uitgangspunten over de rol en positie van de advocaat in strafzaken is die zowel in de literatuur (en wetgeving) van voor als na 1989 algemeen zijn aanvaard. Niet ter discussie staat dat de raadsman:

a. alleen in het voordeel van zijn cliënt mag handelen,

b. een zelfstandige positie inneemt in het strafproces,

c. naast de verdachte optreedt: deelname van de raadsman sluit niet uit dat verdachte zelf zijn verdediging voert,

d. geen procespartij en geen bron van bewijs is en

e. in beginsel beschikt over dezelfde procedurele bevoegdheden als verdachte.

Omdat de onder a genoemde regel een wat uitgebreidere toelichting behoeft, zal eerst kort worden stilgestaan bij de betekenis van de overige uitgangspunten (b tot en met e).

De zelfstandige positie van de raadsman (b) houdt in dat hij zelf verantwoordelijkheid draagt voor zijn optreden en geen spreekbuis is van zijn cliënt. Dit komt ook tot uitdrukking in de voor de advocatuur geldende gedragsregels waarin is bepaald dat de advocaat bij de uitoefening van zijn professionele werkzaamheden 'vrij en onafhankelijk' is en de 'beginselen van objectiviteit' in acht dient te nemen. ${ }^{70}$ Bovendien geldt dat een advocaat een inbreuk op de gedragsregels of de waardigheid van zijn beroep niet kan rechtvaardigen door te wijzen op de opdracht van zijn cliënt. ${ }^{71}$ De advocaat is dus te allen tijde zelf verantwoordelijk voor zijn handelen en dient er zelfstandig op toe te zien dat hij daarbij binnen de grenzen van de wet en de beroepsethiek blijft.

Dat het optreden van de raadsman niet uitsluit dat de verdachte zelf actief aan zijn strafzaak deelneemt en zelfstandig gebruik maakt van zijn verdedigingsrechten (c) is een wettelijk erkend principe: art. 86 lid 2 KPK 1997 bepaalt dat deelname van de raadsman aan het strafproces persoonlijke deelname van verdachte niet

69 Grzegorczyk 2004, p. 290 en daar genoemde rechtspraak van het Hooggerechtshof.

70 Respectievelijk art. 7 en 13 van de gedragsregels van 1998. Op de inhoud en historie van genoemde gedragsregels wordt teruggekomen in hoofdstuk 8 .

71 Art. 10 gedragsregels. 
uitsluit. ${ }^{72}$ Raadsman en verdachte kunnen onafhankelijk van elkaar gebruik maken van hun procedurele bevoegdheden. Dit houdt onder meer in dat beide procesdeelnemers afzonderlijk een rechtsmiddel kunnen indienen en dat het in beginsel in strijd met art. 86 lid 2 KPK 1997 is om de verdachte in de uitoefening van zijn rechten te beperken op de enkele grond dat van een bepaald recht reeds gebruik is gemaakt door zijn advocaat. Zo staat het de rechter niet vrij deelname van de verdachte aan een zitting te weigeren (enkel en alleen) omdat de raadsman aanwezig zal zijn. Ook is het niet toegestaan de verdachte te beperken in zijn recht het laatste woord te voeren vanwege het feit dat zijn advocaat reeds uitgebreid aan het woord is geweest. ${ }^{73}$ Dat de raadsman en zijn cliënt zelfstandige posities vervullen in het strafproces wordt ook bevestigd in de rechtspraak. Zo heeft het Hooggerechtshof in verschillende uitspraken benadrukt dat het feit dat de rechter in hoger beroep wel het door de prokurator en de raadsman ingestelde beroep heeft beoordeeld maar daarbij het door de verdachte ingestelde rechtsmiddel buiten beschouwing heeft gelaten, een schending oplevert van procesrecht die van invloed kan zijn geweest op de inhoud van de uitspraak. ${ }^{74}$ Wanneer de raadsman en de verdachte tegelijkertijd rechtsmiddelen indienen die onderling tegenstrijdig zijn, dient de rechter het middel in aanmerking te nemen dat het meest gunstig is voor verdachte. ${ }^{75}$

Wat betreft de vraag wat nu precies de meerwaarde is van het optreden van de raadsman dient vooral te worden verwezen naar het werk van Waltoś. Volgens hem zijn er vier redenenen waarom de raadsman als afzonderlijke procesdeelnemer naast de verdachte van belang kan zijn:

1. vanwege zijn vakkundigheid (racja fachowości): de raadsman beschikt over de noodzakelijke juridische kennis die de verdachte in de meeste gevallen ontbeert. ${ }^{76}$

2. vanwege zijn psychische toestand (racja stanu psychicznego): omdat voor de raadsman geen persoonlijke belangen op het spel staan, is hij minder emotioneel betrokken bij de zaak dan zijn cliënt waardoor hij beter in staat is de feiten en het recht nuchter te beoordelen en de juiste verdedigingstactiek te kiezen. ${ }^{77}$

72 Deze regel was ook reeds vastgelegd in het oude wetboek van strafvordering (art. 77 lid 2 KPK 1969).

73 Waltoś 2002, p. 305. Dat de verdachte op grond van art. 6 lid 3 sub c EVRM het recht heeft om naast zijn advocaat persoonlijk te kunnen deelnemen aan het proces wordt ook bevestigd in de rechtspraak van het EHRM: zie onder meer F.C.B. t. Italië, EHRM 28-8-1991, nr. 12151/86. Over het recht van de verdediging om deel te nemen aan zittingen meer in hoofdstuk $6, \S 4.2$.

74 Grzegorczyk 2004, p. 301-302. De regel dat de overtreden norm een schending oplevert van procesrecht 'die van invloed kan zijn op de uitspraak' is een standaardformulering die wordt gebruikt bij de vaststelling van schending van het recht in hoger beroep of cassatie.

75 Wiliński 2006, p. 316.

76 'De vakkennis van de raadsman compenseert de ongelijkheid die bestaat tussen de professionele prokurator en de niet juridisch geschoolde verdachte': Lipczyńska 1956, p. 88.

77 Deze taak van de raadsman wordt - in ieder geval ten aanzien van gedetineerde cliënten ook in de Straatsburgse rechtspraak erkend. Zo overwoog de Europese Commissie voor de rechten van de mens in de zaak Can t. Oostenrijk dat het ook tot de taak van de raadsman behoort '(...) to assist the accused who by his detention is removed from his normal environment': ECRM 12-7-1984, B79, nr. 9300/81, § 55. Zie hierover Spaniol 1990, p. 62-65. 
3. vanwege het feit dat hij in naam van de verdachte kan optreden ('hem kan vervangen': racja zdolności wyręczania): de verdachte is niet altijd even goed in staat zelf gebruik te maken van zijn procedurele bevoegdheden zoals wanneer hij van zijn vrijheid is beroofd, bovendien moet ervan uit worden gegaan dat het voor advocaten vaak eenvoudiger is toegang te krijgen tot bepaalde binnen de strafrechtspleging werkzame instanties.

4. vanwege het feit dat hij de verdachte psychische bijstand kan bieden (racja pomocy psychicznej): de advocaat is niet alleen juridisch adviseur maar ook een belangrijke vertrouwenspersoon voor de verdachte die zich als object van onderzoek in een strafzaak in een benarde en stressvolle situatie bevindt. ${ }^{78}$

Ondanks zijn zelfstandige positie wordt de raadsman niet als procespartij aangemerkt: hij treedt 'slechts' op namens de verdachte die - uiteraard - wel partij is in de procedure. Onlosmakelijk hiermee verbonden is de algemeen aanvaarde opvatting dat de raadsman geen bron van bewijs is: hij 'vertegenwoordigt' de verdachte slechts als partij en niet als bron van bewijs (d). Dit betekent onder meer dat de raadsman geen verklaringen kan afleggen namens zijn cliënt. Ook de regel dat de raadsman in beginsel over alle procedurele bevoegdheden beschikt die aan de verdachte toekomen (e) is algemeen aanvaard. ${ }^{79}$ Dit ook in de rechtspraktijk erkende beginsel heeft tot gevolg dat wanneer het wetboek van strafvordering een bepaalde bevoegdheid toekent aan de verdachte (of meer algemeen: aan partijen) zonder expliciet de raadsman te noemen, deze in beginsel ook door de raadsman moet kunnen worden benut. ${ }^{80}$ Dit is slechts anders wanneer uit de wettelijke bepaling blijkt dat een bepaalde handeling alleen met (expliciete) instemming van verdachte kan worden verricht. ${ }^{81}$ Bovendien kent het wetboek van strafvordering ook een aantal handelingen die alleen door de raadsman kunnen worden uitgevoerd. ${ }^{82}$

78 Volgens Waltoś gaat de vertrouwensband met de raadsman soms zover dat alleen de advocaat in staat is de verdachte uit te leggen waarom de rechter tot een veroordeling is gekomen. Zie voor de vier redenen: Waltoś 2002, p. 299-300.

79 Eerder is al gebleken dat auteurs die van mening zijn dat de raadsman als 'procesvertegenwoordiger van verdachte' moet worden aangemerkt, op dit punt een belangrijke overeenkomst zien tussen die gevolmachtigde en de raadsman: het feit dat de omvang van de rechten bij zowel de raadsman als de gevolmachtigde wordt bepaald door de omvang van de rechten van de partij die wordt vertegenwoordigd, wordt als argument genoemd voor het aanmerken van de raadsman als vertegenwoordiger: Grzegorczyk 1988, p. 28 e.v.

80 Hierbij verdient opmerking dat de Poolse wetgever niet consequent is op dit punt: in sommige bepalingen worden alleen 'de verdachte' of 'partijen' genoemd terwijl in andere gevallen bevoegdheden expliciet worden toegekend aan zowel de raadsman als verdachte. Zoals benadrukt in de Poolse literatuur mogen hieraan geen consequenties worden verbonden: rechten die aan de verdachte als procespartij worden toegekend, kunnen ook door de raadsman worden uitgeoefend ongeacht of de betreffende bepaling slechts de verdachte noemt: Wiliński 2006, p. 317 en daar genoemde literatuur.

81 Dit geldt bijvoorbeeld voor het intrekken van een rechtsmiddel dat in het voordeel van verdachte is ingediend (art. 431 lid 3 KPK 1997), voor de beëindiging van een procedure waarin op private aanklacht wordt vervolgd en de aanklacht voor het einde van de zaak wordt ingetrokken (art. 496 lid 1 KPK 1997) en voor het opleggen van straf zonder onderzoek ter terechtzitting (art. 335 lid 1 KPK 1997).

82 Zoals deelname aan het getuigenverhoor van een minderjarig slachtoffer van een (vermeend) zedenmisdrijf en het indienen van een verzoek de leden van een rechterlijk college 


\subsubsection{Handelen in het voordeel van verdachte}

Dat de raadsman alleen in het voordeel van verdachte mag handelen, is een van de belangrijkste richtlijnen voor het optreden van de advocaat in strafzaken in Polen die sinds lange tijd ook door de wetgever wordt erkend..$^{83}$ Een en ander ligt ook ten grondslag aan art. 6 van de gedragsregels: 'Het doel van de beroepsuitoefening door advocaten is bescherming van de belangen van de cliënt.' Er is - anders dan bijvoorbeeld in Nederland - geen gedragsregel die bepaalt dat een advocaat niet tegen de uitdrukkelijke wil van zijn cliënt mag handelen. ${ }^{84}$

Hoe eenvoudig en vanzelfsprekend deze bepalingen op het eerste gezicht ook moge lijken, de invulling ervan roept verschillende vragen op. In de eerste plaats is niet duidelijk wie dient te bepalen wat in het voordeel van verdachte is: mag de raadsman dit zelfstandig beslissen of heeft de verdachte daarin een doorslaggevende stem? Ten tweede is van belang hoe moet worden vastgesteld of een actie van de raadsman in het voordeel van verdachte is. Zoals hierna nog zal blijken, bestaat ten aanzien van dit laatste punt veel discussie binnen de Poolse literatuur. Ten slotte roept de regel de vraag op wat dient te gebeuren wanneer de raadsman - in strijd met genoemd voorschrift - toch een handeling heeft verricht die nadelig is voor zijn cliënt: komt deze dan toch voor rekening van verdachte of blijft een dergelijke actie automatisch zonder effect?

\subsubsection{Wie is dominus litis?}

Ten aanzien van de eerste vraag - waarmee in wezen aan de orde wordt gesteld hoe binnen het Poolse strafproces wordt aangekeken tegen het dominus litis principe $^{85}$ - geldt dat deze in de literatuur eenduidig wordt beantwoord: men is het er over eens dat de raadsman zelfstandig dient te bepalen wat in het voordeel van zijn cliënt is. ${ }^{86}$ Volgens Kruszyński heeft dit alles te maken met het feit dat de raadsman naast zijn functie als 'helper van verdachte' ook een publieke functie vervult die met zich brengt dat hij (mede) verantwoordelijk is voor de juiste afloop van een strafzaak. Het algemeen belang is erbij gebaat dat onschuldigen niet worden gestraft en dat de straf bij een schuldige verdachte niet hoger is dan de mate van zijn schuld. Om daaraan bij te kunnen dragen, dient de raadsman zijns inziens onafhankelijk van zijn cliënt te kunnen handelen en zelfstandig te kunnen bepalen wat in het voordeel van de verdediging is. Wat in het voordeel van verdachte is, behoort dus te worden geobjectiveerd en hoeft niet noodzakelijk overeen te stemmen met de wens van de cliënt. Zo staat het de raadsman bijvoorbeeld vrij

in geval van een strafbedreiging van 25 jaar of levenslang te laten kiezen door loting (respectievelijk art. 185a en 351 lid 2 KPK 1997). Dat het hier om exclusieve bevoegdheden van de advocaat gaat, blijkt uit het feit dat de bepaling alleen de raadsman en niet de verdachte noemt.

83 Momenteel verwoord in art. 86 lid 1 KPK 1997, voorheen in art. 77 lid 1 KPK 1969.

$84 \quad$ Zie ook hoofdstuk 8, § 4.3.2.

85 Dit principe betreft de vraag wie uiteindelijk bepaalt hoe de verdediging in een strafzaak wordt vormgegeven: de raadsman of zijn cliënt.

86 Zie onder meer Kalinowksi 1962, 8-10 en Kruszyński: '(...) the defence lawyer must act independently in determining the defence strategy; they must act in such a way that their participation in the proceedings does not prevent the the accused from acting independently and vice versa. However, the defence lawyer may take actions which are contrary to their clients will, provided that they are to the clients benefit': Kruszyński 2007 I, p. 200. 
tegen de wil van zijn cliënt - die reeds schuld heeft bekend - in bewijsverzoeken in te dienen om zijn onschuld aan te tonen of een ontoerekeningsvatbaarheidverweer te voeren. Kruszyński noemt het voorbeeld van een verdachte die wel een alibi heeft maar dit niet openbaar wil maken omdat hij op het moment van het vermeende strafbare feit bij zijn minnares was, in zo'n geval dient de raadsman de ontlastende feiten tegen de wil van zijn cliënt bekend te maken. Dit standpunt wordt ook door andere auteurs onderschreven. ${ }^{87}$ Kruszyński wijst er overigens wel op dat een en ander niet betekent dat de raadsman geen rekening moet houden met de mening van zijn cliënt. De advocaat zal moeten proberen of hij de door hem gewenste doelstelling ook kan bereiken op een wijze waar de cliënt zich wel mee kan verenigen. Wanneer de onschuld van verdachte maar op één manier kan worden aangetoond (en de verdachte is het daar om welke reden dan ook niet mee eens) zal het individuele belang van de cliënt echter moeten wijken voor het publieke belang. ${ }^{88}$

\subsubsection{Hoe dient 'voordeel' te worden beoordeeld?}

De raadsman bepaalt dus zelfstandig en met inachtneming van het algemeen belang wat in het voordeel van verdachte is. De tweede vraag is hoe moet worden vastgesteld of een handeling al dan niet in het voordeel van verdachte is. Dient dit ex post - dus wanneer het effect van de gekozen strategie duidelijk is - of juist ex ante te worden bepaald? En is de intentie van de raadsman daarbij relevant of moet alleen het karakter van de handeling worden beoordeeld? ${ }^{89}$ Deze vragen hebben in de Poolse doctrine tot veel discussie geleid en worden niet eenduidig beantwoord. Drie hoofdstromingen kunnen worden onderscheiden: ${ }^{90}$

1. De objectieve beoordeling (Śliwiński, Daszkiewicz), waarbij er van uit wordt gegaan dat alle handelingen ontoelaatbaar zijn die in objectieve zin - en dus naar hun effect en ongeacht de intentie van de raadsman - negatief blijken te zijn voor verdachte. Ook Kruszyński is van mening dat de objectieve beoordeling het enige juiste criterium is. Toch plaatst hij enige kritische opmerkingen: volgens hem heeft

87 Kruszyński 1991, p. 38-50 en Kruszyński 1994, p. 5-19. Aangehaald voorbeeld is te vinden in Kruszyński 1991, p. 38 en Kruszyński 1994, p. 5. Zie ook Grzegorczyk 1988, p. 31, Waltoś 2002, p. 303 en Gajewska-Kraczkowska 1992, p. 1138-1139: 'As an officer in the legal system, an advocate also acts in the public interest. This public interest means, among other things, that an innocent person should not be subjected to criminal responsibility and that the perpetrator ought not to be sentenced more severely than is justified by the circumstances of the crime. This "public role" of the advocate is recognized as a justification for actions that are performed for the benefit of the client, although against his will. The process of determining "the benefit of the accused" includes not only the subjective view of the client, but also the public values. When the accused's goals conflict with the public values, the public interest shall be the controlling factor.'

88 Ook benadrukt hij dat dit soort situaties waarin raadsman en verdachte het niet eens zijn, zeker in geval van gekozen rechtsbijstand slechts zelden voorkomen: Kruszyński 1991, p. 45.

89 De vraag of art. 86 lid 1 KPK 1997 door de raadsman is geschonden, kan zowel in het kader van een tuchtrechtelijke procedure als in de strafzaak waarin het gewraakte optreden van de advocaat zich heeft voorgedaan een rol spelen. Zie respectievelijk hoofdstuk 8, § 4.3.2 en de hiernavolgende paragraaf.

90 Over deze drie categorieën: Kruszyński 1991, p.51-67, Kruszyński 1994, p. 5-19, Grzegorczyk 1988, p. $34-37$ en Grzegorczyk 2004, p. 300. 
Śliwiński bij zijn beschrijving van het objectief criterium ten onrechte niet gespecificeerd of het bepalen van de aard van de handeling alleen ex ante of ook ex post wanneer het effect duidelijk is, mag gebeuren. Kruszyński is van mening dat alleen de beoordeling ex ante openstaat. ${ }^{91}$

2. De subjectieve beoordeling (Cieślak) waarbij niet het uiteindelijke effect van de handeling maar de intentie van de raadsman bepalend is. Volgens deze redenering schendt de raadsman de regel dat hij in het voordeel van verdachte moet handelen alleen wanneer hij welbewust de belangen van zijn cliënt schaadt. Omdat de bedoelingen van de raadsman moeilijk aan te tonen zijn, moet volgens Cieślak uit worden gegaan van een vermoeden van goede trouw dat slechts uitzondering geniet wanneer uit de aard van de handeling of uit een andere omstandigheid het tegendeel blijkt. Voorbeelden van handelingen die naar hun aard nadelig zijn voor verdachte - en waaruit de verkeerde bedoelingen van de raadsman dus direct kunnen worden afgeleid - zijn het indienen van een bewijsverzoek waarvan bij voorbaat duidelijk is dat het tot belastend bewijsmateriaal zal leiden, het verzoek aan de rechtbank om een hoge straf op te leggen of het niet instellen van hoger beroep binnen de gestelde wettelijke termijn (het 'optreden' van de raadsman dat in het nadeel van verdachte is, kan dus ook een nalaten betreffen). Het standpunt van Cieślak is door verschillende auteurs bekritiseerd. Daszkiewicz heeft twee - mijns inziens terechte - punten van kritiek: enerzijds het feit dat de redenering van Cieślak innerlijk tegenstrijdig is. Laatstgenoemde gaat er immers vanuit dat het vermoeden van goeder trouw niet opgaat wanneer de raadsman een handeling verricht die 'naar zijn aard' nadelig is voor de verdachte. Daarmee hanteert Cieślak een objectief criterium terwijl hij daar (door introductie van een subjectief criterium) nu juist afstand van heeft willen nemen. Ten tweede gaat Cieślak volgens Daskiewicz ten onrechte uit van de fictie dat een handeling die naar zijn aard nadelig is voor verdachte altijd met slechte bedoelingen is gedaan. ${ }^{92}$

3. De gemengde opvatting (Grzegorczyk). Grzegorczyk heeft beide bovengenoemde standpunten verenigd en een deels objectief, deels subjectief criterium voorgesteld. In zijn visie zijn zowel handelingen die in objectieve zin (naar hun aard) nadelig zijn voor verdachte als handelingen die dat niet zijn maar waarvan op het moment dat ze verricht worden (ex ante) al duidelijk is dat ze nadelig effect kunnen hebben ontoelaatbaar. ${ }^{93}$

\subsubsection{Effect van normschending}

De derde vraag - wat het effect dient te zijn van de constatering dat de door de advocaat gevolgde werkwijze in het concrete geval in het nadeel van verdachte is geweest - speelt in de literatuur een minder prominente rol. De auteurs die op deze kwestie ingaan, lijken het er over eens te zijn dat handelingen die volgens de door hen voorgestane toets nadelig zijn voor verdachte zonder effect dienen te blijven. Zo gaat Cieślak (die de intentie van de raadsman als uitgangspunt neemt)

91 Kruszyński 1991, p. 54-55. Op dit standpunt van Kruszyński wordt hierna nog teruggekomen in $\$ 3.3 .1 .3$.

92 Deze kritiek wordt gedeeld door Kruszyński. Over de kritiek van Daskiewicz en Kruszyński op het standpunt van Cieślak: Kruszyński 1991, p. 52 e.v.

93 Onder anderen: Grzegorczyk 1979, p. 14-17 en Grzegorczyk 2004, p. 300. 
er van uit dat de raadsman slechts bevoegd is in het voordeel van verdachte te handelen. Wanneer duidelijk is dat het zijn bedoeling was de belangen van zijn cliënt te schaden, heeft de raadsman buiten de grenzen van zijn bevoegdheid gehandeld en kunnen om die reden geen gevolgen aan zijn optreden worden verbonden. Kruszyński is ook van mening dat de raadsman alleen bevoegd is in het voordeel van zijn cliënt op te treden: handelingen die naar hun aard nadelig zijn voor de verdachte dienen zonder effect te blijven om de eenvoudige reden dat ze door een onbevoegd persoon zijn verricht. ${ }^{44}$ Zoals al eerder duidelijk werd, is hij het niet eens met de maatstaf die Cieślak hanteert om vast te stellen of in het voordeel van verdachte is gehandeld. Volgens Kruszyński is niet de intentie van de raadsman maar de aard van de handeling bepalend. Aan handelingen die naar hun aard niet nadelig zijn voor verdachte maar om welke reden ook wel zodanig effect sorteren, dient volgens deze redenering dan ook gewoon gevolg te worden gegeven, ook wanneer de raadsman ze met de verkeerde bedoelingen heeft verricht. Alleen handelingen waarvan op voorhand duidelijk is dat ze niet in het voordeel van verdachte zijn, ${ }^{95}$ dienen volgens deze redenering dus zonder effect te blijven. Wanneer pas achteraf duidelijk wordt dat het optreden van de advocaat de verdachte in zijn belangen heeft geschaad, staat slechts de mogelijkheid open een klacht in te dienen bij de balie teneinde een tuchtrechtelijk onderzoek uit te lokken. ${ }^{96}$ Hetzelfde standpunt wordt vertegenwoordigd door Grzegorczyk. Ook hij is van mening dat aan het optreden van de raadsman alleen geen gevolgen mogen worden verbonden wanneer vooraf duidelijk is dat het nadelig zal zijn voor verdachte. Wanneer het nadelig effect pas achteraf duidelijk wordt, behoudt de handeling volgens Grzegorczyk zijn effect ongeacht de intentie van de raadsman en resteert slechts de mogelijkheid van een tuchtrechtelijke procedure. ${ }^{97}$

Hoe gaat de rechtspraktijk nu met deze kwestie om? Uit rechtspraak van het Hooggerechtshof blijkt in ieder geval dat het feit dat een raadsman heeft verzuimd iets te doen of onbevoegd heeft gehandeld, dit niet ten nadele van de verdachte mag werken wanneer laatstgenoemde 'als bevoegde partij in het proces geen enkele schuld heeft aan het feit dat de raadsman zijn verplichtingen niet is nagekomen'. ${ }^{98}$ Het kan daarbij dus zowel om een handelen als een nalaten van een advocaat gaan. Een belangrijk voorbeeld van verwijtbaar nalaten is het laten verstrijken van de hoger beroepstermijn. Wanneer duidelijk is dat instellen van

94 Concreet betekent dit bijvoorbeeld dat een bewijsverzoek dat in het nadeel van verdachte is, door de rechtbank zal moeten worden afgewezen en dat wanneer een getuige die door de raadsman is opgeroepen belastend verklaart de rechtbank de balie daarover zal moeten informeren. Zie Kruszyński 1985, p. 106.

95 Daarbij kan het om bewijshandelingen gaan (bijvoorbeeld het horen van een getuige die beschikt over belastende informatie over een ontkennende verdachte) maar ook andersoortige handelingen kunnen naar hun aard nadelig zijn voor verdachte (bijvoorbeeld het indienen van een verzoek tot toepassing van voorlopige hechtenis of opleggen van een zware straf): Kruszyński 1991, p. 55.

96 Kruszyński 1991, p. 52-58 en Kruszyński 1994, p. 13-19. Op grond van art. 20 KPK 1997 kunnen ook de prokurator en de rechtbank een dergelijke klacht indienen bij de balie. Zie over art. 20 KPK: hoofdstuk 4, § 3.4.3.3 en hoofdstuk 8, § 4.4.1.

97 Onder meer: Grzegorczyk 1979, p. 16-17.

98 Uitspraak van 24 november 1973 (II KZ 220/73, OSNKW 1974, nr. 3, 56) genoemd in Wiliński 2006, p. 323. 
hoger beroep wel (mogelijk) in het voordeel van verdachte zou zijn geweest en laatstgenoemde in dit verband geen verwijt kan worden gemaakt, kan de rechtbank bijvoorbeeld een verlenging van de termijn toestaan. Ten aanzien van actieve gedragingen geldt volgens het Hooggerechtshof dat handelingen waarvan op het moment dat ze worden verricht (in objectieve zin) duidelijk is dat ze schadelijk zijn voor verdachte zonder effect dienen te blijven. Daarbij zal het vooral gaan om handelingen die naar hun aard nadelig zijn voor verdachten, niet om handelingen waarvan ex ante niet duidelijk was dat ze dergelijk negatief effect zouden (kunnen) hebben. ${ }^{99}$ Een bewijsverzoek waarvan op voorhand duidelijk is dat het niet in het voordeel van verdachte is, zal door de rechtbank geweigerd moeten worden. ${ }^{100}$ Zittingsrechters nemen overigens geen actieve houding aan waar het gaat om de beoordeling van de (mogelijke) effecten van het optreden van de raadsman. Als de rechter zich uitlaat over de kwaliteit van rechtsbijstand betreft dat meestal passiviteit van de raadsman (niet aanwezig zijn bij zitting, onvoldoende voorbereiding van de zaak et cetera): over dit soort situaties kan door de rechterlijke macht een klacht worden ingediend bij de balie. ${ }^{101}$ Dat een rechter ingrijpt wanneer hij van oordeel is dat een actieve gedraging van een raadsman nadelig zal zijn voor verdachte - bijvoorbeeld het om die reden afwijzen van een bewijsverzoek - komt hoogst zelden voor. ${ }^{102}$ Dit uiteraard ook omdat het geen dagelijkse praktijk is dat advocaten handelingen verrichten die evident nadelig zijn voor hun cliënt.

Ten slotte dient te worden opgemerkt dat de regel dat de advocaat te allen tijde in het voordeel van verdachte dient te handelen, uiteraard niet kan betekenen dat het optreden van de advocaat de verdachte de facto voordeel moet hebben opgeleverd: bepalend is slechts of de raadsman zijn handelen heeft afgestemd op wat in het voordeel van verdachte is. De cliënt kan aan genoemde regel dus geen 'garantie tot succes' ontlenen. Met andere woorden: dat een strafrechtelijke procedure uiteindelijk niet uitmondt in de gevraagde vrijspraak of dat door de verdediging aangevoerde gronden voor strafuitsluiting of -vermindering door de rechter niet worden geaccepteerd, betekent niet automatisch dat de advocaat in strijd met art. 86 lid 2 KPK 1997 heeft gehandeld. Daarvan kan immers slechts sprake zijn wanneer handelingen 'naar hun aard' (in abstracto) of gelet op de omstandigheden van het geval in de betreffende zaak (in concreto) evident nadelig waren voor de verdachte. Handelingen die wel in het belang van de cliënt worden verricht maar uiteindelijk niet het gewenste resultaat bereiken, leveren in beginsel dus geen schending van genoemde bepaling op.

\section{Conclusie}

In dit hoofdstuk is stilgestaan bij de consequenties van het communisme als politieke ideologie voor het denken over de rol van de advocaat in strafzaken.

99 Uitspraak van 19 maart 1997 (IV KKN 326/96, OSNKW 1997, nr. 7/8, 64) genoemd in Hofmański e.a. 2007 I, p. 482.

100 Zie over de gronden waarop bewijsverzoeken van de verdediging kunnen worden geweigerd: hoofdstuk 5, § 5.2.2 en hoofdstuk 6, § 4.4.3.1.

101 Eerder genoemd art. 20 lid 1 KPK 1997.

102 Bron: gesprek Hermeliński, januari 2007 Warschau. 
De algemene uitgangspunten en kenmerken van het socialistisch strafproces maken de positie van de raadsman - als partijdige belangenbehartiger van de individuele verdachte - in een dergelijke procedure op zijn zachtst gezegd complex. Wanneer criminaliteit wordt beschouwd als een van de grootste bedreigingen van de overheid en het strafrecht het belangrijkste instrument is om die dreiging zo efficiënt en effectief mogelijk aan te pakken, kan partijdige verdediging van een (ogenschijnlijk) schuldige verdachte in de weg staan aan verwezenlijking van de doelstellingen die met het strafproces moeten worden bereikt.

Een en ander komt duidelijk tot uitdrukking in de Russische literatuur over de positie van de raadsman. De discussies over de betekenis van de schuldvraag voor de invulling (of zelfs voortzetting) van de verdediging en over de reikwijdte van de geheimhoudingsplicht laten zien dat de raadsman in een socialistisch strafproces in sommige gevallen meer verplichtingen had ten aanzien van de overheid dan ten opzichte van zijn cliënt.

De bespreking van de Poolse literatuur heeft in de eerste plaats duidelijk gemaakt dat de discussie over de functie van de raadsman voor en na 1989 inhoudelijk niet veel verschilt. Opvallend daarbij is dat de publieke functie van de raadsman in de eerste decennia van de communistische periode wel door verschillende auteurs is benadrukt maar dat de Poolse doctrine op dit punt zeer terughoudend is geweest. Het meest vergaande standpunt (waarbij de raadsman als 'helper van de rechtbank' wordt aangemerkt) is slechts incidenteel vertegenwoordigd door Peiper en Schaff, het andere standpunt (raadsman als medewerker van de rechtspleging) is gematigder en - hoogstwaarschijnlijk ook om die reden - door meer auteurs onderschreven. Aangezien nooit ter discussie heeft gestaan dat de raadsman alleen in het voordeel van verdachte mag handelen, is altijd uitgangspunt geweest dat hij slechts behulpzaam mag zijn bij de waarheidsvinding voor zover dat zijn cliënt niet schaadt. In de sovjetliteratuur werd - zij het incidenteel - nog wel verdedigd dat het de advocaat vrijstaat de juistheid van verklaringen van zijn cliënt in twijfel te trekken of om zich ten nadele van de cliënt uit te laten over de schuldvraag (Czelcow). Zulke vergaande standpunten zijn voor zover bekend door Poolse auteurs nooit ingenomen. ${ }^{103}$

In dit verband is tevens van belang dat in de Poolse literatuur uit de communistische periode niet of nauwelijks wordt verwezen naar Russische bronnen over de rol van de raadsman of - meer algemeen - naar de communistische ideologie zoals vormgegeven door haar grondleggers (Marx en Engels). De thema's die in

103 In de Poolse literatuur is incidenteel wel aangevoerd dat het feit dat de raadsman overtuigd is van de schuld van zijn cliënt onder bepaalde omstandigheden tot gevolg kan hebben dat hij de zaak zal moeten neerleggen - zie de standpunten van Migdał en Daszkiewicz genoemd in §3.2.2 - maar het bepleiten van de schuld van verdachte wordt door de vertegenwoordigers van dit standpunt niet als een toelaatbare verdedigingsstrategie beschouwd. Daszkiewicz verwijt Czelcow dan ook dat hij er ten onrechte van uit gaat dat de raadsman (in een socialistisch strafproces) in zijn hoedanigheid van 'helper van de rechtbank' altijd actief moet zijn en de rechter altijd zijn persoonlijke visie duidelijk zal moeten maken over alle aspecten van de zaak. Hiermee wordt volgens Daszkiewicz miskend dat de raadsman er ook voor kan kiezen niets te zeggen (over zijn persoonlijke opvattingen ten aanzien van de schuld van zijn cliënt) en - onder bepaalde omstandigheden - de verdediging neer kan leggen wanneer hij in strijd met de waarheid zou moeten handelen. Zie Daszkiewicz 1957, p. 80-81. 
de sovjetliteratuur een prominente plaats innemen, komen in de Poolse doctrine niet op vergelijkbare wijze of in dezelfde mate terug. Door een aantal auteurs (onder meer Migdał) is wel betoogd dat het de raadsman niet vrij staat voor vrijspraak te pleiten van een schuldige verdachte maar de discussie over de betekenis van de schuldvraag voor de invulling van de verdediging is niet op dezelfde schaal gevoerd als in de Russische literatuur. Dit geldt nog sterker ten aanzien van de vraag naar de reikwijdte van de geheimhoudingsplicht. Waar in de Russische doctrine veel werd gesproken over uitzonderingen op geheimhouding in geval van staatsgevaarlijke informatie, heeft een dergelijke discussie in Polen niet plaatsgevonden. ${ }^{104}$ Dit alles leidt tot de conclusie dat het denken over de positie van de raadsman in de Poolse literatuur slechts in (zeer) beperkte mate lijkt te zijn beïnvloed door het communistisch regime van na Wereldoorlog II: meer dan een tijdelijke en beperkte benadrukking van de publieke functie van de raadsman heeft het niet tot gevolg gehad. Hierbij is ook van belang dat de Poolse doctrine gedurende de gehele communistische periode uiterst kritisch is geweest over de beperkingen voor de verdediging in het socialistisch strafproces en altijd op grote schaal en met veel inzet voor uitbreiding van de rechten van de raadsman (in met name het vooronderzoek) heeft gepleit. ${ }^{105}$ Hieruit kan worden geconcludeerd dat de Poolse rechtsgeleerden zich op dit punt nooit aan het communisme en haar repressieve gevolgen voor de strafrechtspleging hebben willen conformeren.

Ten aanzien van de vergelijking van de literatuur van voor en na 1989, kan worden gezegd dat steeds minder aandacht wordt besteed aan de publieke functie van de raadsman en de discussie zich steeds meer heeft toegespitst op de - vooral theoretische - vraag naar de verhouding tussen advocaat en cliënt. Hoewel op dit punt twee categorieën auteurs kunnen worden onderscheiden die lijnrecht tegenover elkaar staan, geldt dat over een groot aantal algemene uitgangspunten over de positie van de raadsman en de verhouding tot zijn cliënt overeenstemming bestaat. Zo wordt niet betwist dat hij een zelfstandige positie inneemt in het strafproces, naast de verdachte optreedt, geen procespartij of bron van bewijs is en in beginsel beschikt over dezelfde procedurele bevoegdheden als verdachte. Bovendien - en dat is en blijft de belangrijkste richtlijn voor het optreden van de advocaat - dient te allen tijde alleen in het voordeel van verdachte te worden gehandeld. Hoewel dit uitgangspunt op zichzelf duidelijk is, bestaat van oudsher wel discussie over de wijze waarop moet worden vastgesteld of een handeling al dan niet voordelig is voor verdachte.

Wat de publieke functie betreft, geldt dat deze nog wel een rol speelt in de huidige literatuur maar een iets andere inhoud heeft gekregen. Schrijvers als Kruszyński en Grzegorczyk zijn - vanuit de overtuiging dat de verwezenlijking van een eerlijk proces ook het algemeen belang dient - van mening dat de publieke taak van de raadsman vooral bestaat uit het realiseren van een contradictoire procesvoering

104 Dit is met name een gevolg van het feit dat de regelgeving ten aanzien van de advocatuur (Advocatenwet en gedragsregels) er ook ten tijde van het communisme geen twijfel over lieten bestaan dat op de geheimhoudingsplicht van de advocaat in geen enkel geval uitzonderingen konden worden gemaakt. Zie uitgebreider over de geheimhoudingsplicht en het verschoningsrecht: hoofdstuk 8 .

105 Zie over de levendige discussie ten aanzien van de positie van de verdediging in het vooronderzoek zoals die in de jaren zestig en zeventig werd gevoerd: hoofdstuk 5, § 6 . 
en het bieden van rechtsbescherming aan de verdachte. ${ }^{106}$ Anders dan tijdens de eerste decennia van het communisme staat hierbij dus niet zozeer de instrumentaliteit maar vooral de integriteit van de strafrechtspleging centraal. Zoals hierna nog duidelijk zal worden, wordt deze opvatting - en met name de verwezenlijking van deze functie van de raadsman - de laatste jaren echter steeds minder vanzelfsprekend. Allerlei factoren waaronder de opkomst van het tot voor kort in Polen onbekende verschijnsel 'misbruik van procesrecht' wijzen erop dat de advocaat in strafzaken in toenemende mate verantwoordelijk wordt gehouden voor de efficiëntie en effectiviteit van de strafrechtspleging.

106 Overigens blijft het in de meeste gevallen bij de constatering dat de raadsman een publieke functie heeft: welke consequenties dat precies heeft voor het optreden van de raadsman wordt niet of nauwelijks uitgewerkt. 



\section{Hoofdstuk 4}

\section{Toegang tot rechtsbijstand}

\section{Inleiding}

In de historische analyse in het voorgaande hoofdstuk is beschreven hoe het denken over de rol van de raadsman zich de laatste decennia heeft ontwikkeld en door welke centrale uitgangspunten het optreden van de advocaat in strafzaken wordt beheerst. Na dit dogmatische deel zal in de komende drie hoofdstukken de aandacht worden gevestigd op de - meer concrete - vraag naar de positie van de verdediging in de verschillende fasen van het strafproces.

Voordat in hoofdstuk 5 en 6 de verschillende strafvorderlijke bevoegdheden van de verdediging in respectievelijk het voor- en het eindonderzoek aan de orde zullen komen, zal in dit hoofdstuk eerst stil worden gestaan bij twee vragen die van wezenlijk belang zijn voor de effectuering van rechtsbijstand:

1. vanaf welk moment in de procedure de verdachte zich mag (of kan) laten bijstaan door een raadsman ${ }^{1}$ en

2. onder welke voorwaarden en onder welke omstandigheden door de overheid in de toevoeging van kosteloze rechtsbijstand wordt voorzien.

Beide thema's (de aanvang van het recht op rechtsbijstand en de toevoeging van rechtsbijstand) horen aan de bespreking van strafvorderlijke bevoegdheden van de verdediging vooraf te gaan omdat ze dienen te worden beschouwd als 'randvoorwaarden' die van fundamenteel belang zijn voor verwezenlijking van het recht op rechtsbijstand en de bijbehorende strafprocessuele mogelijkheden.

Het Poolse strafproces wordt - zoals de meeste Europese continentale strafrechtsystemen - getypeerd als gematigd accusatoir of getemperd inquisitoir.2 Dit betekent onder meer dat de verdachte in de fase van het vooronderzoek object van onderzoek is en dat resultaten uit deze fase van het strafproces in beginsel voor het bewijs kunnen worden gebezigd. Deze structuur bevestigt het belang van de vraag naar de aanvang van rechtsbijstand. Omdat de verdachte in een vroeg stadium van de procedure als bron van bewijs wordt beschouwd en beslissingen zal moeten nemen die van grote invloed kunnen zijn op het verdere verloop en de uitkomst van zijn strafzaak, is het belangrijk te weten vanaf welk moment hij zich door een raadsman mag laten bijstaan. Aangezien effectuering van het recht op rechtsbijstand voornamelijk problematisch is voor verdachten die van hun vrijheid zijn beroofd en voor verdachten die niet zelf in de kosten van de verdediging kunnen voorzien, zal daar in dit hoofdstuk de nadruk op liggen.

Zoals eerder besproken, behoorde het tot de doelstellingen van de postcommunistische wetgever de rechtspositie van verdachten te verbeteren en het aandeel van advocaten in het vooronderzoek te vergroten. ${ }^{3}$ In dit hoofdstuk zal worden bekeken op welke wijze de wetgever de toegang tot rechtsbijstand na 1989 heeft

1 Of bezien vanuit het perspectief van de raadsman: vanaf welk moment hij bevoegd is op te treden.

2 Zie ook hoofdstuk 2, § 3 .

3 Zie hoofdstuk 2, § 2.3.3. 
willen vergemakkelijken en zal ten slotte de vraag worden beantwoord of hij daar - gelet op de huidige praktijk en de Straatsburgse normen die in dit verband gelden - ook daadwerkelijk in is geslaagd.

\section{Aanvang recht op rechtsbijstand}

De huidige Poolse regelgeving laat er geen twijfel over bestaan dat het recht op rechtsbijstand zich uitstrekt over de gehele strafrechtelijke procedure. In de Grondwet is vastgelegd dat het recht op verdediging - waaronder het recht op bijstand van een gekozen of toegevoegde advocaat - in alle fasen van de strafrechtelijke procedure moet kunnen worden geëffectueerd. ${ }^{4}$ In het wetboek van strafvordering is dit niet met zoveel woorden bepaald maar uit de plaatsing van het artikel waarin het recht op verdediging in algemene bewoordingen is vastgelegd $\mathrm{d}^{5}$ en uit het feit dat het recht op verdediging daarin niet is beperkt tot bepaalde fasen van het strafproces kan worden afgeleid dat het betrekking heeft op alle stadia van de strafrechtelijke procedure. ${ }^{6}$ Dat het recht op verdediging in het wetboek van strafvordering wordt toegekend aan de 'beschuldigde' ('oskarżony') doet hier niets aan af: uitgangspunt is immers dat daar waar de wetgever deze term in algemene zin heeft gebruikt de betreffende bepaling van overeenkomstige toepassing is op de verdachte (podejrzany) en dus ook betrekking heeft op de fase van het vooronderzoek. ${ }^{7}$

\subsection{Recht op rechtsbijstand en de status van verdachte}

Iemand die feitelijk wordt verdacht van een strafbaar feit kan op twee manieren de status van verdachte krijgen: enerzijds wanneer tegen hem een beslissing tot bekendmaking van de beschuldigingen wordt opgesteld (postanowienie o przedstawieniu zarzutów) en anderzijds wanneer hij - zonder een dergelijke schriftelijke beslissing - in de hoedanigheid van verdachte wordt gehoord. ${ }^{8}$ Ook wanneer geen van deze handelingen nog heeft plaatsgevonden, kan echter wel degelijk sprake zijn van een feitelijke verdenking jegens een bepaalde persoon. ${ }^{9}$ Deze feitelijke verdenking kan aanleiding zijn voor de toepassing van bepaalde dwangmiddelen. In dit verband is met name van belang dat iemand die wordt verdacht van een strafbaar

4 Art. 42 lid 2 Grondwet 1997: 'Eenieder jegens wie een strafrechtelijke procedure is aangevangen, heeft het recht op verdediging gedurende alle fasen van deze procedure. Hij kan, in het bijzonder, een raadsman benoemen of - volgens de uitgangspunten neergelegd in de wet - gebruikmaken van de bijstand van een toegevoegde raadsman.' Aan deze bepaling kunnen drie afzonderlijke rechten worden ontleend:

1. het recht zichzelf te verdedigen,

2. het recht bijstand te hebben van een (zelf benoemde) raadsman en

3. het recht om - in de door de wet omschreven gevallen - bijstand te hebben van een toegevoegde (kosteloze) raadsman.

5 Art. 6 KPK 1997 dat onderdeel uitmaakt van de algemene inleidende bepalingen van het huidige wetboek van strafvordering.

6 Art. 6 KPK 1997: 'Aan verdachte komt het recht op verdediging toe, waaronder begrepen het recht op bijstand van een raadsman, waarover hij dient te worden geïnformeerd.'

7 Art. 71 lid 3 KPK 1997.

8 Art. 71 lid 1 KPK 1997.

9 In zo'n geval wordt de (feitelijke) verdachte aangeduid als 'verdachte persoon' ('osoba podejrzana'). Zie hoofdstuk 2, §3.1.3.1. 
feit kan worden aangehouden en door de politie voor een aantal dagen van zijn vrijheid kan worden beroofd. ${ }^{10}$ Ook kunnen in dit stadium verschillende maatregelen in het belang van het onderzoek worden genomen zoals het nemen van vingerafdrukken, het maken van foto's en het afnemen van lichaamsmateriaal (bloed, speeksel, haar et cetera). ${ }^{11} \mathrm{Na}$ verloop van de eerste 48 uur dient de aangehoudene te worden vrijgelaten of moet door de prokurator een verzoek tot toepassing van voorlopige hechtenis bij de rechtbank worden ingediend. Het bevel voorlopige hechtenis dient vervolgens binnen 24 uur te worden afgegeven. De aangehoudene kan voorafgaand aan de voorlopige hechtenis dus maximaal 72 uur van zijn vrijheid worden beroofd.

In de praktijk heeft de aangehouden persoon in het gros van de gevallen op het moment van aanhouding nog niet de officiële status van verdachte. ${ }^{12}$ Dit roept de vraag op of hij dan wel recht heeft op bijstand van een advocaat.

\subsection{Rechtsbijstand na aanhouding}

\subsubsection{Situatie voor inwerkingtreding van het nieuwe strafprocesrecht}

Ook onder het oude wetboek van strafvordering (1969) stond op grond van algemene bepalingen in de Grondwet en het wetboek van strafvordering vast dat het recht op verdediging zich tevens uitstrekte over het vooronderzoek. ${ }^{13}$ Over de vraag vanaf welk moment dit recht daadwerkelijk kon worden geëffectueerd, bestond echter veel onduidelijkheid. De strafvorderlijke bepalingen waarin het recht op verdediging was uitgewerkt, waren immers stuk voor stuk gericht tot de 'beschuldigde' en de 'verdachte'. Ook onder het oude strafprocesrecht gold de regel dat iemand pas als verdachte kon worden aangemerkt wanneer de beslissing omtrent de bekendmaking van de beschuldigingen was opgesteld. ${ }^{14}$ Aangezien

10 Aanhouding en daaropvolgende vrijheidsberoving door de politie is mogelijk wanneer gerechtvaardigd vermoeden bestaat dat iemand een strafbaar feit heeft gepleegd en gevreesd wordt dat hij zal vluchten of bewijsmateriaal zal wegmaken of wanneer zijn identiteit niet vaststaat (art. 244 lid 1 KPK 1997). Zie over de politiedetentie (zatrzymanie) ook hoofdstuk 2, § 2.2.2.2.

11 Kruszyński 2007 II, p. 259-260.

12 Hofmański e.a. 2007 I, p. 1095.

13 Art. 9 KPK 1969: 'Aan de beschuldigde komt het recht op verdediging en het recht op bijstand van een raadsman toe' en art. 63 lid 2 Grondwet 1952: 'Aan de beschuldigde komt het recht op verdediging toe. De beschuldigde kan een gekozen of een door de rechtbank toegewezen raadsman hebben'. In laatstgenoemde grondwettelijke bepaling werd anders dan in de huidige Grondwet weliswaar niet met zoveel woorden gezegd dat het recht op verdediging betrekking had op alle fasen van de strafrechtelijke procedure maar dit kon wel worden afgeleid uit het wetboek van strafvordering: op grond van art. 61 lid 2 KPK 1969 (voorganger van het huidige art. 71 lid 3 KPK 1997) gold immers ook toen al het uitgangspunt dat wanneer de term 'beschuldigde' in algemene zin werd gebruikt de betreffende bepaling van overeenkomstige toepassing diende te zijn op de 'verdachte'. Dit neemt echter niet weg dat de huidige formulering (art. 42 lid 2 Grondwet: 'Eenieder jegens wie een strafrechtelijke procedure is aangevangen $\left.(. . .)^{\prime}\right)$ ruimer is aangezien niet de formele status van beschuldigde c.q. verdachte maar de feitelijke verdenking als uitgangspunt wordt genomen.

14 Art. 61 lid 1 KPK 1969, anders dan in het huidige strafprocesrecht (art. 71 lid 1 KPK 1997) werd de kwalificatie van verdachte op grond van het oude strafprocesrecht niet gekoppeld aan het feit dat iemand in de hoedanigheid van verdachte was verhoord. 
het wetboek van strafvordering van 1969 - net als het huidige strafprocesrecht voorzag in de mogelijkheid de nog niet als verdachte aangemerkte persoon aan te houden, was onduidelijk of deze categorie gedetineerden in dit stadium van de procedure recht had op bijstand van een advocaat. In rechtspraak van het Hooggerechtshof werd de beslissing tot bekendmaking van de beschuldigingen als uitgangspunt genomen: vanaf dat moment kon de raadsman deelnemen aan het strafproces. ${ }^{15}$

In de literatuur werd wel betoogd dat het recht op rechtsbijstand ook moest kunnen worden gerealiseerd door personen die nog niet als verdachte waren aangemerkt maar van wie door bepaalde handelingen zoals een aanhouding, een verhoor of een huiszoeking wel duidelijk was dat ze onderwerp waren van een strafrechtelijk onderzoek. Zo werd door Murzynowski verdedigd dat voor het ontstaan van het recht op rechtsbijstand niet bepalend diende te zijn of de beslissing tot bekendmaking van de beschuldigingen was opgesteld maar of iemand feitelijk van een strafbaar feit werd verdacht. ${ }^{16}$ Nog verder ging Dąb die van mening was dat het recht op rechtsbijstand al ontstond op het moment dat een strafbaar feit werd gepleegd. ${ }^{17}$

Hoewel met genoemde standpunten uit de doctrine ongetwijfeld recht werd gedaan aan de ratio van het grondwettelijk gegarandeerde recht op verdediging kon de juridische grondslag voor deze aanvangsmomenten van het recht op rechtsbijstand niet in het toenmalige wetboek van strafvordering worden gevonden. Mede daardoor kwam het in de praktijk zelden tot nooit voor dat in het stadium van de politiedetentie rechtsbijstand werd genoten. Zo blijkt onder meer uit een naar aanleiding van een eerste bezoek aan Polen opgesteld rapport van de European Comittee for the Prevention of Torture and Inhuman or Degrading punishment (CPT). Tijdens genoemd bezoek vernam het CPT dat het in theorie wel mogelijk was dat een prokurator een aangehouden persoon in de fase voorafgaand aan de voorlopige hechtenis toegang tot een advocaat zou toestaan, maar dat uit gesprekken met gedetineerden, politieambtenaren en de prokuratura bleek dat '(...) persons detained by the police were not informed to this effect and that in practice it was extremely rare for a lawyer to be present at that stage. In fact, it transpired that the police were keen to avoid the involvement of lawyers during the initial period of police custody'. ${ }^{18}$ Het Comité benadrukte daarbij dat '(...) it is during the period immediately following deprivation of liberty that the risk of intimidation and ill-treatment is greatest. Consequently, the possibility for persons taken into police custody to have access to a lawyer during that period is a fundamental safeguard against ill-treatment' en om die reden werd aan de Poolse regering de aanbeveling gedaan rechtsbijstand ook te garanderen in de eerste fase van detentie. ${ }^{19}$

15 SN 9 juni 1967 (VI KZP 68/65, OSPiKa 1967, nr. 9, 89).

16 Murzynowski 1989, p. 39-41. Ook Prusak pleitte ervoor het recht op rechtsbijstand te laten uitstrekken over de fase voorafgaand aan de bekendmaking van de beschuldiging: Prusak 1973, p. 45-47. Zie over dit thema ook Czekaj 1998, p. 40 en Maciejewska 2000, p. 122-122.

17 Dąb 1954, p. 449. Onduidelijk is hoe volgens dit standpunt (de aanvang van) het recht op rechtsbijstand van de onschuldige verdachte moest worden verklaard.

18 Report CPT 1996, p. 26.

19 Report CPT 1996, p. 26-27. 
Wellicht mede geïnspireerd door de opmerkingen van het CTP heeft de wetgever deze problematiek in het nieuwe wetboek van strafvordering grotendeels opgeheven door introductie van een nieuwe - hierna te bespreken - bepaling.

\subsubsection{Huidig juridisch kader}

Dat het recht op rechtsbijstand direct na aanhouding moet kunnen worden geeffectueerd, is in het huidige strafprocesrecht geregeld in art. 245 lid 1 KPK 1997. Dit artikellid luidt als volgt:

'De aangehoudene dient op zijn verzoek en op een wijze die de omstandigheden toelaten onmiddellijk in de gelegenheid te worden gesteld een advocaat te contacteren en rechtstreeks met hem overleg te voeren; degene die de aanhouding heeft verricht, kan bepalen dat hij bij dit overleg aanwezig zal zijn.'

Duidelijk is dat aan deze bepaling twee afzonderlijke rechten kunnen worden ontleend:

- het recht om contact op te nemen met een advocaat ${ }^{20}$ en

- het recht om met hem overleg te voeren.

Deze rechten zijn toegekend aan 'de aangehoudene' ('zatrzymany') en dus niet beperkt tot de arrestant die reeds als verdachte is aangemerkt. Zo blijkt ook uit de rechtspraak van het Hooggerechtshof: in een uitspraak van februari 2004 heeft het hoogste rechtscollege benadrukt dat het wetboek van strafvordering aan de aangehoudene verschillende rechten toekent die onlosmakelijk zijn verbonden met het recht op verdediging en dat deze geëffectueerd moeten kunnen worden zodra sprake is van een gerechtvaardigd vermoeden dat de betreffende persoon een strafbaar feit heeft begaan. Voor het ontstaan van dit vermoeden is volgens het Hooggerechtshof niet vereist dat de formele beschuldigingen reeds bekend zijn gemaakt: een en ander kan blijken uit iedere handeling van de autoriteiten die op vervolging van de betreffende persoon is gericht. ${ }^{21}$

Art. 245 lid 1 KPK 1997 heeft alleen betrekking op de fase na aanhouding waarin de verdachte persoon door de politie van zijn vrijheid is beroofd. Voor het realiseren van het recht op rechtsbijstand gedurende de fase van de voorlopige hechtenis geldt art. 73 KPK 1997.22 Daarin is geregeld dat de beschuldigde ${ }^{23}$ die zich in voorlopige hechtenis bevindt, het recht heeft om in afwezigheid van anderen te overleggen met zijn raadsman en met hem te corresponderen. Gedurende de eerste veertien dagen van de voorlopige hechtenis kan de prokurator bepalen dat het persoonlijk of schriftelijk contact tussen advocaat en cliënt alleen onder toezicht mag plaatsvinden. ${ }^{24}$ Voorafgaand aan zijn eerste verhoor dient de verdachte op de

20 Teneinde hem te informeren over de aanhouding.

21 SN 9 februari 2004, V KK 194/03.

22 Aangezien voor de tenuitvoerlegging van voorlopige hechtenis vereist is dat ten aanzien van de betreffende persoon een beslissing tot bekendmaking van de beschuldigingen is uitgegeven (art. 249 lid 2 KPK 1997) is in dit stadium altijd sprake van een (officiële) verdachte.

23 En dus ook de verdachte (art. 71 lid 3 KPK 1997).

24 De betekenis en reikwijdte van deze bepaling en de vraag op welke punten de huidige regeling afwijkt van het oude strafprocesrecht komt meer uitgebreid aan de orde in hoofdstuk 7 bij de bespreking van het vrij verkeer. 
hoogte te worden gesteld van zijn recht zich door een advocaat te laten bijstaan (art. 300 KPK 1997) en het recht in aanwezigheid van laatstgenoemde te worden verhoord (art. 300 jo. $301 \mathrm{KPK}$ 1997). ${ }^{25}$

Omdat art. 245 KPK 1997 het vroegste moment in de procedure regelt waarop iemand die van zijn vrijheid is beroofd, gebruik kan maken van de hulp van een advocaat zal in het onderstaande dieper op de betekenis van deze bepaling worden ingegaan.

\subsubsection{Reikwijdte art. 245 lid 1 KPK 1997}

'Op zijn verzoek'

Bij het lezen van art. 245 lid 1 KPK 1997 valt een aantal dingen op. In de eerste plaats de zinsnede 'op zijn verzoek' ('na jego żąanie'). Hiermee heeft de wetgever willen benadrukken dat de arrestant zelf dient aan te geven dat hij bijstand van een advocaat wenst: de autoriteiten hoeven op dit punt dus geen initiatieven te ontplooien en zijn alleen verplicht actie te ondernemen wanneer om contact met een advocaat wordt gevraagd. Het spreekt voor zich dat het in dit verband van groot belang is dat degene die is aangehouden op de hoogte is van zijn recht een advocaat te mogen raadplegen. Op dit punt wordt wel enige activiteit van de betrokken instanties verwacht: de aangehoudene dient 'onmiddellijk' ('natychmiast') op de hoogte te worden gesteld van de hem toekomende rechten waaronder het recht om contact te hebben met een advocaat. ${ }^{26}$

Dat de wet bepaalt dat de aangehoudene zelf om bijstand van een advocaat moet hebben gevraagd, sluit overigens niet uit dat laatstgenoemde zelf het initiatief neemt om zijn cliënt te bezoeken. ${ }^{27}$ Wanneer de cliënt aangeeft het bezoek (of het telefoontje) te willen ontvangen, zal de advocaat dus in beginsel moeten worden toegelaten. Overigens kan zich dan wel het probleem voordoen dat de advocaat niet over de noodzakelijke machtiging beschikt, om die reden geen toegang krijgt en daardoor ook niet in de gelegenheid wordt gesteld de machtiging van zijn cliënt te verkrijgen. Op dit punt zal worden teruggekomen in § 2.4.

25 Zie uitgebreider hoofdstuk 5, § 2.

26 Art. 244 lid 2 KPK 1997. Andere rechten waarover de aangehoudene dient te worden geinformeerd zijn: het recht te verzoeken dat een naaste of de werkgever op de hoogte wordt gesteld van de aanhouding, het recht om bezwaar in te stellen tegen de aanhouding en het recht om te reageren op de gronden voor de aanhouding (respectievelijk art. 245 lid 2 jo. 261 lid 1 en 3, art. 246 en art. 244 lid 2 jo. 244 lid 3 tweede zin KPK 1997): Grzegorczyk 2004, p. 631. Art. 244 lid 2 KPK 1997 vermeldt overigens niet met zoveel woorden van welke rechten de aangehoudene op de hoogte moet worden gesteld maar bepaalt slechts dat hij moet worden geïnformeerd 'over de rechten die hem toekomen'. Op het moment van afronding van dit onderzoek is een wetsvoorstel aanhangig waarin wordt voorgesteld expliciet in art. 244 lid 2 KPK 1997 te vermelden dat de aangehoudene moet worden geïnformeerd over zijn recht op bijstand van een advocaat (wetsvoorstel van 19 mei 2008, te raadplegen op: <www.ms.gov.pl/>). Onduidelijk is of de aangehoudene - die nog niet als verdachte is aangemerkt - ook dient te worden geïnformeerd over het zwijgrecht. Meer daarover in \$ 2.2.2.3 van dit hoofdstuk.

27 Grzegorczyk 1988, p. 173 en Ludwiczek 2003, p. 225. 
'Op een wijze die de omstandigheden toelaten'

Eveneens opmerkelijk zijn de woorden 'op een wijze die de omstandigheden toelaten' (' $w$ dostepnej formie'). ${ }^{28}$ Deze vage formulering laat in het midden op welke manier de aangehoudene een advocaat moet kunnen contacteren. Onduidelijk is of hij daartoe te allen tijde gebruik moet kunnen maken van de telefoon of dat ook andere communicatiemiddelen zoals fax, email of briefwisseling kunnen volstaan. Hoewel de wetgever dit niet heeft gespecificeerd en in beginsel dus alle mogelijkheden openstaan, wordt aangenomen dat het schrijven van een brief gelet op het spoedeisende karakter van het verzoek in de regel ontoereikend zal zijn. ${ }^{29}$ Doorgaans zal met het verzenden van een brief en het wachten op antwoord immers meer tijd verloren gaan dan dat de arrestant voorafgaand aan de voorlopige hechtenis van zijn vrijheid kan worden beroofd. Het meest voor de hand ligt dan ook gebruikmaking van meer directe vormen van communicatie zoals telefoon of fax. Dit zijn ook de communicatiemiddelen die in de praktijk doorgaans worden gebruikt. ${ }^{30}$

Het gebruik van de term 'onmiddellijk' ('niezwłocznie') in art. 245 KPK 1997 laat er weinig twijfel over bestaan dat in beginsel direct - en dus zonder uitstel - actie moet worden ondernomen wanneer een aangehoudene verzoekt met een advocaat te kunnen overleggen. Vanwege de relatief korte termijn gedurende welke gebruik kan worden gemaakt van het in art. 245 KPK 1997 neergelegde recht is het van groot belang dat in de praktijk ook daadwerkelijk direct wordt gereageerd op een verzoek van een arrestant om in contact te treden met een advocaat.

\section{Rechtstreeks overleg}

De aangehoudene heeft behalve het recht om zijn advocaat te contacteren ook het recht om 'rechtstreeks met hem overleg te voeren' ('bezpośrednia z nim rozmowę'). Wat daaronder precies moet worden verstaan, is niet duidelijk. Het spreekt voor zich dat het onder vier ogen spreken van een advocaat - die zich daartoe dus in persoon naar de plaats van detentie (politiebureau) zal moeten begeven - onder deze vorm van communiceren moet worden begrepen maar of ook een telefonisch gesprek daartoe moet worden gerekend, laat de wettekst in het midden. Deze kwestie is van groter belang dan zij op het eerste gezicht lijkt: het is immers afhankelijk van de uitleg van genoemde bewoordingen of de aangehoudene aan art. 245 KPK 1997 het recht kan ontlenen een advocaat niet alleen telefonisch op de hoogte te stellen van zijn aanhouding en te vragen om hem te bezoeken maar ook om zijn zaak - tijdens dat eerste telefoongesprek - inhoudelijk met hem te bespreken en advies te krijgen. Dat laatste kan van groot belang zijn wanneer de gecontacteerde advocaat niet in staat is om direct naar de plaats van detentie te komen. Aangezien een dergelijke situatie vanwege de relatief korte duur van de politiedetentie, het feit dat in Polen geen piketdienst (of soortgelijk instituut) wordt

28 Letterlijk vertaald betekenen de woorden ' $w$ dostępnej formie': 'op een toegankelijke/beschikbare manier'.

29 Musiałik 2000, p. 51 en Gwirdoyń 2004, p. 62-63.

30 Daniuk e.a. 2006, p. 25 en Hofmański e.a. 2007 I, p. 1096. Eerstgenoemde bijdrage is een rapport dat is opgesteld door vijf auteurs uit verschillende juridische beroepsgroepen - rechterlijke macht, prokuratura, advocatuur en wetenschap - geschreven ten behoeve van een conferentie over rechtsbijstand in het vooronderzoek in vijf Europese landen (Londen, november 2005). 
gehanteerd en de gemiddeld hoge werklast van de advocatuur heel goed denkbaar is, dient er vanuit te worden gegaan dat de inhoudelijke bespreking ook telefonisch moet kunnen plaatsvinden. ${ }^{31}$ Een dergelijke uitleg stemt het meest overeen met de ratio van de bepaling die er immers op is gericht om verwezenlijking van het recht op rechtsbijstand in het vroege stadium na aanhouding mogelijk te maken. Ook het feit dat de wetgever de term 'rechtstreeks' en niet woorden als 'in persoon' heeft gebruikt, pleit voor een dergelijke ruime interpretatie.

Uit de laatste zinsnede van art. 245 lid 1 KPK 1997 vloeit voort dat degene die de aanhouding heeft verricht, kan bepalen dat het gesprek tussen de arrestant en zijn advocaat onder toezicht dient plaats te vinden. Tegen deze beslissing kan door de verdediging geen rechtsmiddel worden ingesteld. ${ }^{32}$ Aangezien de wetgever niet heeft gespecificeerd welke omstandigheden een dergelijke beslissing kunnen rechtvaardigen, is het toezicht in beginsel in alle gevallen toegestaan. In hoofdstuk 7 wordt in het kader van het vrij verkeer dieper ingegaan op de deze en andere vormen van toezicht op mondelinge en schriftelijke communicatie tussen een advocaat en zijn gedetineerde cliënt.

\subsubsection{Optreden na aanhouding en de kwalificatie als raadsman (obrońca)}

Een advocaat die in het kader van art. 245 lid 1 KPK 1997 rechtsbijstand verleent, doet dat niet altijd in de hoedanigheid van raadsman (obrońca). Laatstgenoemde kwalificatie is volgens het Poolse strafprocesrecht namelijk alleen van toepassing op de advocaat die optreedt namens een - officieel als zodanig aangemerkte - verdachte (podejrzany): alleen een verdachte kan een advocaat als raadsman benoemen zodat de status van de advocaat afhankelijk is van de status van zijn cliënt. Zolang de aangehoudene (nog) niet als verdachte is aangemerkt, is hij geen procespartij33 en kan hij alleen een advocaat als gevolmachtigde (petnomocnik) aanwijzen. ${ }^{34}$ Het is overigens ook mogelijk dat een advocaat eenmalig bijstand verleent in het kader van art. 245 lid 1 KPK 1997 zonder dat de aangehoudene hem een volmacht verleent. In zo'n geval treedt de advocaat niet als gevolmachtigde maar gewoon als advocaat (adwokat) op. Samengevat zijn er dus drie verschillende hoedanigheden waarin een advocaat bijstand kan verlenen aan een aangehouden cliënt: als raadsman (wanneer de aangehoudene als verdachte is aangemerkt en reeds voor zijn aanhouding of kort erna een raadsman heeft benoemd), als gevolmachtigde (wanneer de nog niet als verdachte aangemerkte aangehoudene zijn advocaat daartoe een volmacht verleent) of als advocaat (wanneer zonder volmacht incidenteel rechtsbijstand wordt verleend). ${ }^{35}$

31 In de Poolse literatuur wordt dit standpunt verdedigd door aan te nemen dat van 'rechtstreeks overleg' kan worden gesproken wanneer gesprekspartners elkaar vragen kunnen stellen en daarop direct antwoord kunnen krijgen. Aangezien dit zowel bij een gesprek onder vier ogen als bij een telefoongesprek mogelijk is, vallen beide vormen van overleg volgens deze redenering onder de reikwijdte van art. 245 lid 1 KPK 1997: Ludwiczek 2003, p. 228 en Gwirdoyń 2004, p. 63.

32 Grzegorczyk 2004, p. 633.

33 Alleen het slachtoffer en de verdachte zijn partij bij het vooronderzoek (art. 299 lid 1 KPK 1997).

34 Art. 87 lid 2 KPK 1997: 'Een persoon die geen partij is kan een gevolmachtigde benoemen wanneer dat zijn belangen in de procedure dient.'

35 Over deze drie categorieën: Ludwiczek 2001, p. 104-109. Over de status van de advocaat 
Een vraag die uit het bovenstaande voortvloeit, is of de advocaat die als gevolmachtigde in het kader van art. 245 lid 1 KPK 1997 rechtsbijstand heeft verleend een nieuwe volmacht dient te krijgen wanneer zijn cliënt eenmaal als verdachte is aangemerkt of dat de 'transformatie' van 'gevolmachtigde' naar 'raadsman' automatisch verloopt. Deze vraag is door de wetgever niet beantwoord. In de literatuur wordt hierover opgemerkt dat laatstgenoemde gang van zaken (uiteraard) het meest praktisch is maar dat een nieuwe volmacht wel meer duidelijkheid verschaft over de precieze status van de advocaat. ${ }^{36}$

Het onderscheid tussen de drie verschillende kwalificaties is overigens niet louter theoretisch: alleen de gemachtigde raadsman of gevolmachtigde kunnen handelingen in naam van hun cliënt verrichten en ook de wetgever hanteert het begrip 'raadsman' waardoor aan deze status bepaalde bevoegdheden en privileges zijn gekoppeld. ${ }^{37}$ Een van de belangrijkste handelingen die de advocaat in dit vroege stadium van de procedure namens de verdachte kan verrichten, is het aantekenen van bezwaar (zażalenie) tegen de vrijheidsbeneming. ${ }^{38}$

die optreedt in het kader van art. 245 lid 1 KPK 1997: Grzegorczyk 2004, p. 633.

36 Ludwiczek 2001, p. 109.

37 Zoals in hoofdstuk 7, § 6.1 en 6.2 nog zal worden uiteengezet, is het onderscheid tussen de raadsman en de advocaat (die niet als raadsman optreedt) onder meer van belang in het kader van het verschoningsrecht.

38 De aangehoudene kan tegen zijn vrijheidsbeneming binnen zeven dagen bezwaar (zażalenie) aantekenen bij de rechtbank. Van deze mogelijkheid dient hij direct na zijn aanhouding op de hoogte te worden gesteld. Dit rechtsmiddel - dat in 1989 met het oog op de eisen van art. 5 lid 4 EVRM in het Poolse strafprocesrecht is geïntroduceerd (zie hoofdstuk 2, § 2.2.2.4) - dient onmiddellijk te worden beoordeeld door de rechtbank (SR) van het rechtsgebied waar de aanhouding is verricht of waar de procedure aanhangig is. Wanneer de rechter van oordeel is dat de detentie onrechtmatig is, dient de aangehoudene onmiddellijk in vrijheid te worden gesteld. Recent is een belangrijke wetswijziging gerealiseerd ten aanzien van de mogelijkheid van de verdediging om zittingen waarop over dit bezwaar wordt beslist bij te wonen. Voorafgaand aan deze wijziging had de verdediging geen onvoorwaardelijk recht bij dit soort zittingen aanwezig te zijn: regel was dat de rechtbank deelname kon toestaan wanneer de advocaat of de verdachte verscheen. Dat dit 'verschijnen' voor de gedetineerde problematisch was, spreekt voor zich: hij kon immers wel verzoeken naar de zitting te worden gebracht, maar een dergelijk verzoek kon eenvoudig worden geweigerd. Bovendien hoefde de verdediging niet (ambtshalve) op de hoogte te worden gesteld van de datum en tijd waarop het bezwaar zou worden behandeld waardoor ook deelname van de advocaat niet gegarandeerd was. Deze praktijk - gebaseerd op art. 464 KPK 1997 - is door het Hooggerechtshof in een uitspraak van 6 december 2004 (SK 29/04) in strijd met het grondwettelijk recht op verdediging geoordeeld. Als reactie hierop heeft de wetgever genoemde bepaling aangepast waardoor voortaan geldt dat de verdachte naar de zitting moet worden gebracht, tenzij de rechtbank van oordeel is dat deelname van een advocaat voldoende is. Wanneer in dat laatste geval de aangehoudene (nog) door een advocaat wordt bijgestaan, dient hem voor de behandeling van het bezwaar ambtshalve een advocaat te worden toegevoegd (wetswijziging van 7 juli 2005, in werking getreden op 21 september 2005). Dit is hetzelfde regime als ten aanzien van de behandeling van hoger beroep geldt - zie daarover hoofdstuk 2, §3.2.3.2. Met deze nieuwe regeling is persoonlijke deelname van de aangehoudene weliswaar nog altijd niet gegarandeerd maar het is desalniettemin een belangrijke verbetering ten opzichte van de oude situatie. Bovendien kan door de toevoeging worden gerealiseerd dat de aangehoudene - die om welke reden dan ook nog geen rechtsbijstand had - in een vroeg stadium bijstand van een advocaat krijgt. 


\subsubsection{De aangehoudene en het zwijgrecht}

Nauw verbonden met de vraag naar het recht op verdediging van de (nog niet als verdachte aangemerkte) aangehoudene is de vraag of hij in dit stadium van de procedure al moet worden geïnformeerd over zijn zwijgrecht.

Hoewel er geen twijfel over bestaat dat de aangehoudene - ook wanneer hij nog niet als verdachte is aangemerkt - geen verklaring hoeft af te leggen, ${ }^{39}$ is op grond van het huidige strafprocesrecht niet duidelijk of de politie verplicht is hem op de hoogte te stellen van zijn zwijgrecht. Met betrekking tot het zwijgrecht geldt art. 175 lid 1 KPK 1997:

'De beschuldigde heeft het recht verklaringen af te leggen; hij kan echter zonder opgave van redenen weigeren antwoord te geven op bepaalde vragen of weigeren een verklaring te geven. Van dit recht dient hij op de hoogte te worden gesteld.'

Aangezien de term 'beschuldigde' in algemene zin is gebruikt, geldt ook hier dat de bepaling van overeenkomstige toepassing is op de verdachte. ${ }^{40}$ Dit wordt bevestigd door art. 300 KPK 1997 waarin is bepaald dat de verdachte voorafgaand aan zijn eerste verhoor over een aantal fundamentele rechten - waaronder het zwijgrecht - schriftelijk moet worden geïnformeerd. ${ }^{41}$ Duidelijk is dus dat de (formele) verdachte het recht heeft om te zwijgen en daarover aan het begin van zijn eerste verhoorop de hoogte moet worden gesteld. Maar hoe zit het met de arrestant die nog niet officieel als verdachte is aangemerkt?

De letterlijke tekst van art. 175 en 300 KPK 1997 - die beide slechts zijn gericht tot de beschuldigde en de verdachte en nergens van overeenkomstige toepassing worden verklaard op de aangehoudene - noopt tot de conclusie dat het wetboek van strafvordering autoriteiten in ieder geval niet verplicht iemand die is aangehouden maar nog niet als verdachte is aangemerkt, op de hoogte te stellen van zijn zwijgrecht. ${ }^{42}$ Een dergelijke verplichting kan ook niet worden gevonden in de bepalingen die betrekking hebben op de aanhouding. Daar is weliswaar geregeld dat de aangehoudene onmiddellijk dient te worden geïnformeerd over de 'hem toekomende rechten' 43 maar de wetgever heeft niet gespecificeerd welke rechten dat zijn. In handboeken en commentaren strafprocesrecht wordt echter algemeen aangenomen dat het daarbij gaat om een limitatief aantal specifieke rechten van de aangehoudene (het recht een advocaat te contacteren, de rechtmatigheid van zijn vrijheidsberoving te laten beoordelen door een rechter, een naaste te informeren over zijn aanhouding en contact te leggen met een consulaat) waartoe het zwijgrecht niet wordt gerekend. ${ }^{44}$ Sommige auteurs menen

39 Onder meer Chankowska 2003, p. 136 en Klejnowska 2004, p. 225.

$40 \quad$ Art. 71 lid 3 KPK 1997.

41 De eis dat de verdachte door de autoriteiten op de hoogte moet worden gesteld van zijn zwijgrecht is overigens nieuw in het wetboek van strafvordering van 1997: in het oude strafprocesrecht was een dergelijke expliciete verplichting niet opgenomen. Zie hierover hoofdstuk 2, § 2.3.3.3.

42 Ook het in art. 74 lid 1 KPK 1997 neergelegde nemo tenetur beginsel ('De beschuldigde is niet verplicht zijn onschuld te bewijzen of bewijzen te leveren die in zijn nadeel zijn') heeft alleen betrekking op de verdachte en de beschuldigde. Over deze problematiek: Kmiecik 2000.

43 Zie art. 244 lid 2 KPK 1997 en eerder § 2.2.2.1.

44 Stefański 1997, p. 51, Kmiecik 2000, p. 20-22, Chankowska 2003, p. 136 en Boratyński e.a. 
echter dat de politie - ondanks het ontbreken van een expliciete wettelijke grondslag daartoe - wel verplicht is de aangehoudene op de hoogte te stellen van zijn zwijgrecht. ${ }^{45}$ Het is niet duidelijk of dit in de praktijk ook gebeurt (en zo ja op welke schaal) maar voor bovenstaande discussie is vooral van belang dat er in ieder geval geen wettelijke verplichting bestaat. Uit het (standaard) proces-verbaal dat bij aanhouding dient te worden opgemaakt (protokół zatrzymania osoby) blijkt dat de aangehoudene in ieder geval niet standaard op de hoogte wordt gesteld van zijn recht te zwijgen: in dit document is opgenomen dat hij moet worden geinformeerd over een aantal rechten (zie eerder genoemde limitatieve opsomming: recht om bezwaar aan te tekenen tegen de vrijheidsberoving, een advocaat te contacteren et cetera) maar het zwijgrecht wordt daarbij niet genoemd. ${ }^{46}$ Dit alles terwijl in het stadium direct na aanhouding wel degelijk (belastende) verklaringen kunnen worden afgelegd. De politie is verplicht iedere arrestant onmiddellijk op de hoogte te stellen van zijn 'recht' te reageren op de reden(en) voor zijn aanhouding: eventuele verklaringen die in dat verband worden afgelegd, dienen te worden opgenomen in het proces-verbaal van aanhouding waarvan een kopie moet worden overhandigd aan de arrestant. ${ }^{47}$ Een dergelijke verklaring moet wel worden onderscheiden van een verklaring die tijdens een formeel verhoor is afgelegd: wanneer een aangehoudene in de gelegenheid wordt gesteld te reageren op zijn aanhouding is geen sprake van 'verhoren' ('przestuchać) maar van '(aan)horen' ('wystuchać') en wordt een afgelegde verklaring niet aangeduid als 'oświadzenie' (zoals een verklaring wordt genoemd die tijdens een verhoor door een verdachte is afgelegd) maar als 'wyjaśnienie'. ${ }^{48}$ Hoewel het in het kader van het 'aanhoren' van de arrestant dus niet de bedoeling is dat specifieke vragen worden gesteld over zijn betrokkenheid bij het strafbare feit en een en ander officieel slechts is bedoeld om hem de gelegenheid te geven feiten of omstandigheden aan te voeren die tot zijn vrijlating zouden kunnen leiden ${ }^{49}$, is het maar zeer de vraag of dit theoretische onderscheid in de praktijk ook duidelijk is voor de aangehoudene. Deze bevindt zich immers in een stressvolle situatie waarin de neiging om te gaan praten - verantwoording af te leggen voor bepaalde feiten - vaak groter zal zijn dan de innerlijke kracht die is vereist om onder dergelijke omstandigheden te blijven zwijgen. Het is dus zeker niet uitgesloten dat dit soort 'spontane' verklaringen ${ }^{50}$ die voorafgaand aan het officiële verhoor worden afgelegd belastende informatie bevat die later in de procedure in het nadeel van verdachte kan werken. Belangrijke vraag is dan ook of dergelijke verklaringen - die niet zijn afgelegd in het kader van een officieel verhoor en dus niet vooraf zijn gegaan door de cautie - voor het bewijs mogen worden gebruikt. Vaststaat in ieder geval dat ze niet als

2005, p. 455.

45 Zagórski 2004, p .90-91.

46 Kudrulek en Kwasiński 2006, p. 350 e.v.

47 Art. 244 lid 2 en lid 3 tweede en derde zin KPK 1997.

48 Het verschil tussen oświadzenie en wyjaśnienie komt in de vertaling naar het Nederlands niet goed tot zijn recht (beide begrippen worden vertaald als 'verklaring'). De vertaling naar het Engels biedt op dit punt meer helderheid: oświadzenie = declaration of statement en wyjaśnienie = explanation of clarification.

49 Kmiecik 2000, p. 21 en daar genoemde literatuur. Zie ook Hofmański e.a. 2007 I, p. 1088.

50 Waarvan de spontaniteit en vrijwilligheid uiteraard kan worden betwist omdat ze volgen op de vraag van een verbalisant of de aangehoudene 'iets kwijt wil' over de zaak. 
verklaring van de verdachte voor het bewijs mogen worden gebezigd. ${ }^{51}$ Dat wil echter niet zeggen dat ze geen enkele waarde kunnen hebben in een strafproces. Sommige auteurs verdedigen dat opmerkingen van de aangehoudene als onderdeel van het proces-verbaal van aanhouding wel ter zitting mogen worden voorgelezen en in die hoedanigheid de verklaringen van verdachte afgelegd tijdens verhoren in het vooronderzoek of ter zitting weliswaar niet kunnen vervangen maar wel zelfstandig (in het voor- of nadeel van verdachte) kunnen meewerken voor het bewijs. ${ }^{52}$ Bovendien schijnt het in de praktijk regelmatig voor te komen dat politieagenten ter zitting als getuige worden gehoord over de wijze waarop een aanhouding heeft plaatsgevonden en wat bij die gelegenheid door de aangehoudene werd gezegd. ${ }^{53}$ Zelfs wanneer de onofficiële verklaring van de aangehoudene niet op een van bovengenoemde manieren voor het bewijs wordt gebezigd, is niet uitgesloten dat de inhoud van de verklaring wel degelijk van betekenis kan zijn voor het strafrechtelijk onderzoek: het kan immers aanleiding vormen om nader onderzoek te verrichten. Ten slotte is zeer goed denkbaar dat het de verklaringsvrijheid van verdachte tijdens het eerstvolgende (officiële) verhoor aanzienlijk beperkt. Hij kan zich immers gedwongen voelen bij zijn eerder afgelegde verklaring te blijven en de politie kan de informatie gebruiken tijdens het verhoor. Hierdoor wordt de keuze voor de verdachte om te zwijgen - op het moment dat hij over die mogelijkheid wordt geïnformeerd - in ieder geval minder vanzelfsprekend.

\subsection{Evaluatie juridisch kader}

De wetgever heeft in het nieuwe wetboek van strafvordering op een aantal manieren getracht de mogelijkheden van de verdediging in de eerste fase van het strafproces te vergroten. Met de introductie van art. 245 KPK 1997 is benadrukt dat het aanvangsmoment van rechtsbijstand vroeg in de procedure ligt en niet afhankelijk is van de formele status van verdachte. Bovendien is wettelijk geregeld dat de verdachte voorafgaand aan zijn eerste verhoor op de hoogte moet worden gesteld van het recht op rechtsbijstand en de mogelijkheid in aanwezigheid van een advocaat te worden verhoord (art. 300 jo. 301 KPK 1997). Hierdoor biedt de huidige wettelijke regeling vergeleken met het oude strafprocesrecht - waarin het recht op toegang tot een advocaat pas na aanvang van de voorlopige hechtenis was gegarandeerd - meer garanties voor effectuering van het recht op rechtsbijstand in de eerste fase na aanhouding.

Het huidige juridische kader roept wel een aantal interpretatievragen op (zoals de betekenis van de begrippen 'op zijn verzoek' en 'op een wijze die de omstandigheden toelaten' genoemd in art. 245 KPK 1997) maar deze lijken slechts beperkte

51 Dit vloeit voort uit art. 174 jo. 389 KPK 1997: Kmiecik 2000, p. 22 en Chankowska 2003, p. 138-139. Een officieel verhoor van een aangehoudene die nog niet als verdachte is aangemerkt, kan alleen plaatsvinden in de hoedanigheid van getuige. In dat geval dient hij echter op de hoogte te worden gesteld van zijn recht geen antwoord te geven op vragen wanneer hij zichzelf daarmee zou kunnen belasten (art. 183 KPK 1997). Wanneer de getuige later toch als verdachte wordt aangemerkt mag deze verklaring niet voor het bewijs worden gebruikt. Overigens is het horen als getuige alleen toegestaan wanneer (nog) geen gronden bestaan voor het opmaken van een beslissing tot bekendmaking van beschuldigingen jegens de betreffende persoon: Wiliński 2006, p. 266.

52 Klejnowska 2004, p. 227-228.

53 Daniuk e.a. 2006, p. 30-31. 
betekenis te hebben in de praktijk. Een vraag die wel van groot belang is, is of de aangehoudene die nog niet als verdachte is aangemerkt, moet worden geïnformeerd over zijn zwijgrecht. Wellicht dat dit op het eerste gezicht een puur academische kwestie lijkt te zijn - aangezien verklaringen die in dit stadium worden afgelegd toch niet voor het bewijs mogen worden gebruikt - maar dat is het zeker niet. In de praktijk is het immers niet ongebruikelijk dat politieagenten ter terechtzitting worden gehoord over hetgeen de (nog niet als zodanige aangemerkte) verdachte tijdens of direct na zijn aanhouding heeft verklaard. Bovendien kunnen de uitlatingen die de aangehoudene in dit stadium doet, wel degelijk van invloed zijn op zijn verklaringsvrijheid bij latere, officiële verhoren. De periode tussen aanhouding en het eerste officiële verhoor ${ }^{54}$ is een heel belangrijk stadium waarin de aangehoudene dus wel degelijk uitlatingen kan doen die later op één of andere wijze in zijn nadeel kunnen werken. Door sommige Poolse auteurs wordt dan ook terecht betoogd dat de aangehoudene niet pas voorafgaand aan zijn eerste verhoor maar direct bij zijn aanhouding op de hoogte zou moeten worden gesteld van zijn zwijgrecht. ${ }^{55}$ Ook vanuit de praktijk wordt hiervoor gepleit. ${ }^{56}$ Net als het recht op verdediging dient de plicht te informeren over het zwijgrecht niet afhankelijk te zijn van formaliteiten - zoals de officiële status van verdachte - maar van de vraag of jegens de betreffende persoon bepaalde handelingen zijn verricht waaruit blijkt dat hij (wellicht nog niet formeel maar wel) feitelijk verdachte is. Een eenvoudige wetswijziging zou verandering aan kunnen brengen in de huidige situatie: door een verwijzing naar art. 175 lid 1 KPK 1997 zou het zwijgrecht kunnen gaan behoren tot de categorie rechten waarvan iedere burger bij zijn aanhouding onmiddellijk op de hoogte dient te worden gesteld. ${ }^{57}$ Door sommige auteurs wordt als bezwaar tegen dit voorstel geuit dat het tot gevolg zou hebben dat bepalingen (rechtswaarborgen) die duidelijk betrekking op de verdachte en het verhoor van toepassing worden verklaard op de aangehoudene die de status van verdachte nog niet heeft en dus ook niet kan worden verhoord..$^{58}$ Hoewel in de Poolse literatuur opvallend weinig aandacht wordt besteed aan de ratio van het onderscheid 'verdachte persoon' - 'verdachte' lijkt de status van verdachte persoon vooral te worden beschouwd als iets dat de burger bescherming kan bieden: het betekent immers dat autoriteiten beperkt zijn in de dwangmiddelen en opsporingsbevoegdheden die ze jegens de betreffende persoon kunnen toepassen. ${ }^{59}$ Daarbij wordt mijns inziens echter te eenvoudig voorbij gegaan aan de (mogelijke) gevolgen van het feit dat de verdachte persoon niet dezelfde rechts-

54 Of de beslissing tot bekendmaking van de beschuldiging.

55 Kmiecik 2000, p. 22.

56 Daniuk e.a. 2006, p. 54-55.

57 Kmiecik 2000, p. 22. Wanneer deze wijziging is gerealiseerd, kunnen verklaringen van de aangehoudene volgens Kmiecik ook gewoon voor het bewijs worden gebezigd.

58 Hofmański e.a. 2007 I, p. 1088 en Chankowska 2003, p. 137-140. Chankowska voert aan dat het zwijgrecht in strikte zin (zoals vastgelegd in art. 175 KPK 1997) onlosmakelijk is verbonden met het recht een formele verklaring (wyjaśnienie) af te leggen - een recht dat slechts toekomt aan de verdachte en dus niet aan de aangehoudene. Vandaar dat zij voorstelt een 'surrogaat-zwijgrecht' te introduceren: een zwijgrecht speciaal voor de aangehoudene zonder dat dat tot gevolg heeft dat de verklaringen die hij aflegt voor het bewijs mogen worden gebruikt.

59 Zie ook Hofmański e.a. 2007 I, p. 400-401. 
bescherming geniet als de verdachte. Alle onduidelijkheid en de - tamelijk formalistische - bezwaren die vanuit de doctrine worden ingebracht tegen de invoering van de plicht iedere aangehoudene direct op de hoogte te stellen van zijn zwijgrecht, zouden eenvoudig kunnen worden opgeheven door het bestaande onderscheid tussen verdachte persoon en verdachte te schrappen en ruimer verdachtenbegrip te introduceren. ${ }^{60}$

\subsection{Aanvang rechtsbijstand in de praktijk}

Door het nieuwe art. 245 lid 1 KPK 1997 bestaat niet langer onduidelijkheid over de vraag of een arrestant gedurende de periode dat hij door de politie van zijn vrijheid wordt beroofd recht heeft op bijstand van een advocaat. Hoewel de wetgever hiermee heeft willen benadrukken dat rechtsbijstand in een zo vroeg mogelijk stadium van de procedure dient te kunnen worden geëffectueerd, heeft de wettelijke bepaling slechts een zeer beperkte betekenis in de praktijk: het komt - om verschillende redenen - zelden voor dat van de mogelijkheid genoemd in art. 245 lid 1 KPK 1997 gebruik wordt gemaakt. ${ }^{61}$

Een van de belangrijkste redenen voor deze praktijk is het feit dat de meeste aangehoudenen geen advocaat kennen en dus niet weten wie ze kunnen contacteren. De autoriteiten zijn niet verplicht de arrestant behulpzaam te zijn op dit punt: de Poolse strafrechtspleging kent geen piketdienst of soortgelijk instituut en politiebureaus beschikken niet over lijsten met telefoonnummers van advocaten die in geval van een aanhouding gebeld kunnen worden. Het komt er op neer dat de aangehoudene zijn recht op rechtsbijstand in dit stadium alleen kan effectueren wanneer hij tenminste de achternaam van een advocaat kan noemen. Hier komt bij dat in de fase na aanhouding in de regel nog geen recht op kosteloze rechtsbijstand bestaat. Dit recht komt alleen toe aan de (formele) verdachte en aangezien voor de toevoeging van een advocaat een rechterlijke beslissing nodig is, biedt de zitting waarop over de voorlopige hechtenis wordt besloten ${ }^{62}$ de eerste mogelijkheid om op dit punt een beslissing te nemen. ${ }^{63}$ Bovendien krijgt de aangehoudene doorgaans van de politie te horen dat hij recht heeft op één telefoontje. Meestal geeft men er dan de voorkeur aan deze mogelijkheid te benutten om een familielid te bellen in plaats van een advocaat. ${ }^{64}$

Zelfs wanneer een aangehoudene wel een advocaat kent en kan betalen, is het niet vanzelfsprekend dat deze ook op korte termijn (en eventueel buiten de reguliere werktijden) naar de plaats van detentie zal kunnen komen. Zoals eerder

60 Daniuk e.a. 2006, p. 54-55. In de conclusie van het rapport wordt - behalve voor invoering van de verplichting iedere aangehoudene op zijn zwijgrecht te wijzen - gepleit voor uitbreiding van het begrip 'verdachte': de kwalificatie dient toe te komen aan eenieder die is aangehouden in verband met de verdenking een strafbaar feit te hebben gepleegd of ten aanzien van wie gerechtvaardigde gronden bestaan om aan te nemen dat hij/zij een strafbaar feit heeft gepleegd.

61 Daniuk e.a. 2006, p. 24-33. Zie ook het door de Helsinki Foundation for Human Rights opgestelde rapport over (met name kosteloze) rechtsbijstand in de Poolse strafrechtspleging: '(...) the actual use of legal advice during and immediately after the arrest is rare in practice': Monitoring Report 2003, p. 92. Meer over dit rapport in $\S 3$ van dit hoofdstuk.

62 Maximaal 72 uur na aanhouding.

63 Op de voorziening van kosteloze rechtsbijstand wordt hierna uitgebreid teruggekomen in $\S 3$.

64 Daniuk e.a. 2006, p. 29. 
opgemerkt, bestaat in Polen geen piketdienst of enige andere vorm van georganiseerde rechtsbijstandvoorziening aan arrestanten zodat het aan de advocaat is om te bepalen of en - zo ja - wanneer hij naar het politiebureau gaat. Wanneer de advocaat zich wel naar het politiebureau begeeft, kan zich daar nog het probleem van de machtiging voordoen: indien er geen familielid of andere naaste beschikbaar is om een (tijdelijke) machtiging voor de advocaat te ondertekenen, kan het zijn dat de advocaat geen toegang tot de aangehoudene krijgt. ${ }^{65}$

Ten slotte speelt bij de vraag naar het optreden van advocaten in het kader van art. 245 lid 1 KPK 1997 mogelijk ook een rol dat de Poolse advocatuur van oudsher gewend is weinig activiteiten te ontplooien gedurende het vooronderzoek (mede) vanuit de overtuiging dat het beter is te wachten tot het onderzoek ter terechtzitting. In hoofdstuk 5 wordt nog teruggekomen op dit verschijnsel en de mogelijke oorzaken ervan.

Als gevolg van dit alles heeft art. 245 KPK 1997 in de praktijk slechts voor een selecte groep betekenis: zij die in staat zijn de kosten van rechtsbijstand zelf te dragen en reeds een advocaat hebben benoemd, weten wie ze moeten contacteren of voor wie door tussenkomst van een naaste bezoek van een advocaat wordt geregeld. De problemen in het kader van rechtsbijstand na aanhouding zijn ook geconstateerd door het CPT. In het rapport naar aanleiding van een bezoek in 2000 werd opgemerkt dat de - sinds de inwerkingtreding van het nieuwe wetboek van strafvordering - gewijzigde nationale regelgeving op dit punt niet altijd wordt nageleefd:

'(...) the information gathered in the course of the 2000 visit would suggest that the application of the above-mentioned right [the right of detained persons to have access to a lawyer, toev. DdV] is not yet fully guaranteed in practice. Some police officers met by the delegation affirmed that detained persons could not meet their lawyers prior to the first interrogation; others stated that no visits by lawyers were allowed until a court decision for temporary arrest had been issued. The CPT recommends that appropriate steps be taken to ensure that the provisions of the 1998 Code of Criminal Procedure concerning access to a lawyer for persons in police custody are fully complied with.'66

Tijdens het laatste bezoek van het CPT aan Polen (in 2004) bleek op dit punt nog weinig te zijn veranderd:

'With regard to access to a lawyer [decurs. DdV], most detained persons interviewed by the delegation indicated that they had received information on their right to contact a lawyer upon apprehension or shortly afterwards. However, it became clear during the visit that, in practice, it was extremely rare for persons in police custody to have a lawyer. By way of example, at the Provincial Police Command in Cracow, a senior police officer indicated that she could not recall a single case of a lawyer coming to meet a person detained at the establishment. ${ }^{6} 7$

65 Hier ontstaat een vicieuze cirkel: de advocaat kan alleen toegang tot de aangehoudene krijgen wanneer hij over een machtiging beschikt maar om laatstgenoemde machtiging te krijgen, dient hij zijn cliënt eerst te kunnen bezoeken. Volgens eerder genoemd rapport van Daniuk e.a. is dit in de praktijk een belangrijk probleem: Daniuk e.a. 2006, p. 31.

66 Report CPT 2000, p. 25.

67 Report CPT 2004, p. 15. 
Het CPT merkt op dat hierbij een belangrijke rol speelt dat in dit stadium van de procedure nog geen recht op kosteloze rechtsbijstand bestaat en spoort de Poolse regering aan hierin verandering aan te brengen:

'The Polish authorities informed the delegation that there was no provision in law for the appointment of an ex officio lawyer before the stage of court proceedings. As a result, persons in police custody who were not in a position to pay for legal services were effectively deprived of the right to access to a lawyer. For as long as there is not an effective system of free legal aid for indigent persons at the stage of police custody, any right of access to a lawyer will remain, in most cases, purely theoretical. The CPT suggests that a fully fledged and properly funded system of legal aid for persons in police custody who are not in a position to pay for a lawyer be developed as a matter of urgency, and be applicable from the very outset of police custody. ${ }^{6} 8$

Het antwoord op de vraag naar de toegang tot rechtsbijstand verandert - in ieder geval voor wat de wettelijke regeling betreft - wanneer de aangehoudene eenmaal als verdachte is aangemerkt. Vanaf dat moment wordt het contact tussen advocaat en verdachte beheerst door de regeling van het vrij verkeer zoals neergelegd in art. 73 KPK 1997. ${ }^{69}$ De aanmerking als verdachte betekent zeker niet dat alle praktische problemen ten aanzien van de verwezenlijking van het recht op rechtsbijstand komen te vervallen. De verdachte dient weliswaar voorafgaand aan zijn eerste verhoor op de hoogte te worden gesteld van zijn recht een raadsman te benoemen en te verzoeken in zijn aanwezigheid te worden verhoord ${ }^{70}$ maar ook in dit verband geldt dat de verdachte wel een advocaat moet kennen. De verdachte heeft - anders dan de aangehoudene die nog niet als zodanig is aangemerkt - wel recht op toevoeging van een raadsman. Zoals hierna nog zal worden uiteengezet, kan dit op twee manieren gebeuren (ambtshalve in geval van verplichte rechtsbijstand of op verzoek van verdachte wanneer hij niet in staat is zelf in de kosten van rechtsbijstand te voorzien ${ }^{71}$ ) maar is het om verschillende redenen zeldzaam dat een toevoeging in een vroeg stadium van het vooronderzoek wordt gerealiseerd.

\subsection{Aanvang rechtsbijstand en het EVRM}

Het recht op bijstand van een advocaat is vastgelegd in art. 6 lid 3 sub c EVRM ('een ieder tegen wie een vervolging is ingesteld, heeft in het bijzonder de volgende rechten: (c) zich zelf te verdedigen of daarbij de bijstand te hebben van een raadsman naar eigen keuze (...)'. Zoals reeds opgemerkt in hoofdstuk 1 beoordeelt het Europese Hof - bij toetsing aan art. 6 EVRM - steeds of de procedure in zijn geheel nog als eerlijk kan worden aangemerkt. Consequentie hiervan is dat verdedigingsrechten in beginsel niet absoluut zijn en dat tekortkomingen in het vooronderzoek niet automatisch tot een verdragsschending hoeven te leiden wanneer ze in een later stadium worden gecompenseerd. Dat neemt echter niet weg dat in de Straatsburgse rechtspraak wel wordt benadrukt dat verdediging

68 Report CPT 2004, p. 15. Tot op heden zijn op dit punt geen wijzigingen doorgevoerd.

69 Waarover meer in hoofdstuk 7.

70 Respectievelijk art. 300 en 301 KPK 1997. Beide artikelen zijn nieuw ten opzichte van het oude wetboek van strafvordering: zie hoofdstuk 2 , § 2.3.3.3 en - meer uitgebreid hoofdstuk $5, \S 2$.

$71 \quad$ Zie $\S 3.1 .1$ en 3.1.2. 
in het vooronderzoek mogelijk moet zijn op het moment dat het ertoe doet. In deze paragraaf zal worden bekeken wat dat betekent voor de aanvang van het recht op rechtsbijstand.

Het antwoord op de vraag vanaf welk moment het recht op rechtsbijstand zoals neergelegd in art. 6 EVRM moet kunnen worden geëffectueerd, is onlosmakelijk verbonden met de meer algemene vraag of de rechten van genoemd verdragsartikel ook betrekking hebben op het vooronderzoek. Volgens vaste rechtspraak van het EHRM geldt dat onderdelen van art. 6 EVRM ook van belang (kunnen) zijn voor de fase voorafgaand aan het onderzoek ter terechtzitting. ${ }^{72}$ De betekenis van de garanties van het artikel voor het vooronderzoek is afhankelijk van de structuur en inrichting van het nationale strafproces: wanneer dit stadium van de procedure - zoals in de meeste Europese, continentale systemen - van groot belang is voor het verdere verloop van de strafzaak dient de verdediging in beginsel reeds dan gebruik te kunnen maken van de in art. 6 genoemde rechten. De vraag in hoeverre de verschillende verdedigingsrechten van betekenis zijn voor het vooronderzoek wordt daarbij gekoppeld aan het doel van het verdragsartikel: het verwezenlijken van een fair trial. Gevolg van deze benadering is dat omdat de procedure altijd in zijn geheel wordt bezien - slechts in concreto kan worden beoordeeld vanaf welk moment iemand (tegen wie een strafvervolging is gericht) zijn rechten genoemd in art. 6 EVRM moet kunnen toepassen. In de Straatsburgse rechtspraak wordt dus niet in algemene bewoordingen aangegeven vanaf welk moment een verdachte het recht op rechtsbijstand moet kunnen effectueren. Er zijn echter wel aanknopingspunten te vinden voor beantwoording van de vraag onder welke omstandigheden een beperking van het recht op rechtsbijstand in de eerste fase van het strafproces strijd oplevert met art. 6 EVRM. Hierbij is van belang dat het Europese Hof herhaaldelijk heeft benadrukt dat het recht op rechtsbijstand onder omstandigheden reeds in de fase van het politieverhoor moet kunnen worden geëffectueerd. Dit geldt in ieder geval wanneer de verdachte in dit stadium van de procedure met een fundamenteel dilemma wordt geconfronteerd waarvan de uitkomst van wezenlijk belang kan zijn voor het verdere verloop van zijn strafzaak..$^{73}$ Overigens dient in dit verband onderscheid te worden gemaakt tussen het recht van verdachte om voorafgaand aan zijn verhoor een

72 Zie onder meer Can t. Oostenrijk, ECRM 12-7-1984, B79 en EHRM 30-9-1985, A96, nr. 9300/81, Quaranta t. Zwitserland, EHRM 24-5-1991, nr. 127441/87 en Imbrioscia t. Zwitserland, EHRM 24-11-1993, nr. 13972/88.

73 Dit is onder meer expliciet aan de orde geweest in de zaak Murray $t$. Verenigd Koninkrijk (EHRM 8-2-1996, nr. 18731/91) waarin klager gedurende de eerste 48 uur van zijn detentie geen contact had mogen hebben met zijn raadsman terwijl hij in die periode voor een lastige keuze werd gesteld (zwijgen of verklaren: beide opties konden op grond van de Noord-Ierse regelgeving negatieve consequenties hebben voor Murray). Het belang van rechtsbijstand in de eerste fase van de politieverhoren is door het Europese Hof in verschillende latere uitspraken opnieuw benadrukt. Zie bijvoorbeeld: Magee t. Verenigd Koninkrijk, EHRM 6-6-2000, nr. 28135/95, Averill t. Verenigd Koninkrijk, EHRM 6-6-2000, nr. 36408/ 97 en Öcalan t. Turkije, EHRM 12-3-2003 en 12-5-2005 (Grand Chamber), nr. 46221/99. In de zaak Öcalan leverde het feit dat klager gedurende zeven dagen geen contact had mogen hebben met zijn advocaten (terwijl in deze periode verschillende belastende verklaringen werden afgelegd die uiteindelijk van groot belang waren voor de aanklacht en de veroordeling) een schending van art. 6 EVRM op. 
advocaat te spreken en het recht om tijdens dat verhoor rechtsbijstand te hebben. Wat dat laatste betreft, is van belang dat volgens het EHRM aan art. 6 EVRM geen onvoorwaardelijk recht op fysieke aanwezigheid van een raadsman tijdens de politieverhoren kan worden ontleend. ${ }^{74}$

De algemene regel dat een verdachte in ieder geval een advocaat moet kunnen raadplegen in de eerste fase van de politieverhoren wanneer hij belangrijke beslissingen moet nemen die van invloed (kunnen) zijn op het verdere verloop en de uitkomst van zijn strafzaak, is echter niet absoluut. Specifieke omstandigheden van het geval - zoals het feit dat in de bijstandsloze fase geen bekennende verklaringen zijn afgelegd - kunnen tot gevolg hebben dat het verhoren van een verdachte voordat hij overleg heeft kunnen voeren met zijn advocaat geen schending van art. 6 EVRM oplevert. ${ }^{75}$ Het Europese Hof lijkt als uitgangspunt te nemen dat wanneer een verdachte niet belastend heeft verklaard in de periode waarin hij geen contact mocht hebben met zijn advocaat hij niet door het contactverbod in zijn belangen is geschaad. Aangezien de betreffende rechtspraak niet uitsluit dat ook andere omstandigheden ertoe kunnen leiden dat uitzonderingen op het consultatierecht zijn toegestaan, is niet volledig duidelijk in welke gevallen aan art. 6 EVRM nog een onvoorwaardelijk recht op bijstand van een advocaat gedurende de eerste fase van de politieverhoren kan worden ontleend.

74 Dougan t. Verenigd Koninkrijk, EHRM 14-12-1999, nr. 44738/98 (ontvankelijkheidsbeslissing) en Brennan t. Verenigd Koninkrijk, EHRM 16-10-2001, nr. 39846/98. Op deze kwestie wordt teruggekomen in hoofdstuk 5, § 2.5 .

75 Zo bleek onder meer in de zaak Brennan t. Verenigd Koninkrijk (EHRM 16-10-2001, nr. 39846/98). Het feit dat Brennan in de eerste periode na zijn aanhouding geen contact had mogen hebben met zijn advocaat leverde volgens het EHRM geen schending van art. 6 lid 1 en 3 EVRM op. Ter ondersteuning van dit standpunt wordt met name belang gehecht aan het feit dat de toegang tot de advocaat slechts gedurende de eerste 24 uur was ontzegd: na verloop van dit etmaal was contact tussen raadsman en cliënt niet langer verboden. Dat Brennan vervolgens pas meer dan twee dagen na zijn aanhouding bezoek krijgt van zijn advocaat - die volgens de nationale rechter op de hoogte was gesteld van bovengenoemde periode - is niet toe te rekenen aan de autoriteiten en komt dus voor rekening van de verdediging zelf. Een tweede (minstens zo belangrijke) factor die meeweegt in de beslissing van het EHRM is het feit dat Brennan pas belastend was gaan verklaren nadat de beperking van zijn recht op rechtsbijstand was opgeheven. Ook in dit opzicht acht het EHRM niet doorslaggevend dat hij op het moment van zijn eerste bekentenis feitelijk nog geen contact met zijn raadsman had gehad: bepalend is dat dit recht hem toen niet meer werd ontzegd zodat overleg wel mogelijk was. Dat het feit dat er in een bijstandsloze fase wel een bekennende verklaring is afgelegd niet automatisch een schending van art. 6 oplevert, blijkt onder meer uit Salduz t. Turkije (EHRM 26-4-2007, nr. 36391/02). Het EHRM achtte het feit dat klager in de eerste fase na zijn aanhouding geen advocaat had mogen raadplegen niet in strijd met art. 6 lid 3 sub c EVRM omdat de bekennende verklaring die in deze periode was afgelegd niet 'the sole basis for his conviction' vormde. Bovendien was Salduz bij de behandeling van zijn strafzaak in eerste aanleg en in hoger beroep wel bijgestaan door een raadsman en had hij op gelijke voet met de openbaar aanklager de tegen hem gerichte beschuldigingen kunnen betwisten (\$ 23). Zie in gelijke zin ook Dikme t. Turkije, EHRM 11-7-2000, nr. 20869/92, Zhelezov t. Rusland, EHRM 23-4-2002, nr. 48040/99 (ontvankelijkheidsbeslissing), Mamaç e.a. t. Turkije, EHRM 20-4-2004, nr. 29486/95, 29487/95, 29853/96, Sarikaya t. Turkije, EHRM 22-4- 2004, nr. 25143/94, 27098/95 en Ahmet Mete $t$. Turkije, 25-4-2006, nr. 77649/01. 


\subsection{Conclusie}

Uit de rechtspraak van het EHRM ten aanzien van het aanvangsmoment van het recht op rechtsbijstand kan in ieder geval worden afgeleid dat dit recht (zoals neergelegd in art. 6 lid 1 en 3 EVRM) in beginsel ook betrekking heeft op het vooronderzoek en dus in deze fase van de procedure moet kunnen worden geëffectueerd. Zoals alle verdedigingsrechten is echter ook het recht op rechtsbijstand in de eerste fase van de procedure niet absoluut: beperkingen zijn toegestaan zolang de procedure in zijn geheel nog als eerlijk kan worden aangemerkt. Een verdachte dient in ieder geval voorafgaand aan een verhoor een advocaat te kunnen raadplegen wanneer hij in het vooronderzoek met een fundamenteel dilemma wordt geconfronteerd waarvan de uitkomst van invloed kan zijn op het verdere verloop van zijn strafzaak. Het is de vraag of de overwegingen van het EHRM in dit verband zo dienen te worden uitgelegd dat ook in een (gematigd) inquisitoir strafproces zoals het Poolse, waarin het zwaartepunt duidelijk in het vooronderzoek ligt, de houding die de verdachte vanaf het eerste verhoor inneemt van zodanige invloed is op de rest van de strafzaak dat van een 'fundamenteel dilemma' in de zin van genoemde rechtspraak kan worden gesproken. Gelet op de algemene bewoordingen die het EHRM hierbij hanteert ${ }^{76}$ en uitgaande van het belang van de verdediging bij een zo vroeg mogelijk contact tussen advocaat en cliënt, dient aan het consultatierecht mijns inziens een ruime invulling te worden gegeven. Hierbij dient vooral doorslaggevend te zijn of een door de verdachte afgelegde verklaring later voor het bewijs kan worden gebruikt. Toegepast op de Poolse situatie betekent dit dat aan art. 6 EVRM in beginsel het recht moet kunnen worden ontleend om voorafgaand aan het eerste verhoor - waarbij de verdachte zal moeten kiezen tussen zwijgen of verklaren en waarbij geldt dat afgelegde verklaringen later voor het bewijs kunnen worden gebruikt - een advocaat te mogen raadplegen. ${ }^{77}$

Zoals gezegd heeft het nieuwe art. 245 KPK 1997 verwezenlijking van dit recht realistischer gemaakt waardoor de overeenstemming van het strafprocesrecht met het EVRM - in ieder geval in theorie - is vergroot. ${ }^{78}$ Voor effectuering in de praktijk is echter meer nodig dan het in de wet opnemen van bepaalde rechten en bevoegdheden. In de voorgaande paragrafen is duidelijk geworden dat art. 245 KPK 1997 zeer beperkte betekenis heeft in de praktijk. Doordat de noodzakelijke praktische randvoorwaarden onvoldoende zijn vervuld, kan niet worden ge-

76 In eerder genoemde zaak Murray t. Verenigd Koninkrijk (EHRM 8-2-1996, nr. 18731/91) wordt bijvoorbeeld gesproken van: 'a fundamental dilemma relating to his defence' en 'a situation where the rights of the defence may well be irretrievably prejudiced', een formulering die ook in latere uitspraken consequent wordt herhaald.

77 'In beginsel' omdat in latere rechtspraak (zoals Brennan t. Verenigd Koninkrijk en Salduz t. Turkije) is gebleken dat bepaalde omstandigheden uitzonderingen op deze regel kunnen rechtvaardigen. Dat ook in Polen uitgangspunt dient te zijn dat een verdachte reeds in de fase van de politieverhoren bijstand van een advocaat moet kunnen hebben, is onder meer duidelijk geworden in de zaak Berliński t. Polen (EHRM 20-6-2002, nr. 27715/95, 30209/96), zie over deze uitspraak hierna $\S 3.5 .3$.

78 Bovendien is met het eveneens nieuwe art. 300 KPK 1997 gegarandeerd dat de verdachte voorafgaand aan zijn eerste verhoor op de hoogte wordt gesteld van zijn recht op bijstand van een raadsman en het recht om deze aanwezig te hebben bij het verhoor. 
sproken van een 'praktisch en effectief' recht. ${ }^{79}$ Voor het feit dat verdachten in de eerste fase na aanhouding zelden worden bijgestaan door een advocaat kunnen verschillende oorzaken worden genoemd. Met name het ontbreken van de mogelijkheid in dit stadium een beroep te doen op kosteloze rechtsbijstand, de afwezigheid van een piketdienst (of soortgelijke regeling) en het feit dat verdachten minstens een achternaam van een advocaat moeten kunnen noemen, hebben tot gevolg dat art. 245 KPK 1997 vooral een papieren recht is..$^{80}$

Met een aantal eenvoudige wijzigingen - zoals het beschikbaar stellen van lijsten met namen van advocaten op politiebureaus - zou waarschijnlijk al enige verbetering kunnen worden gerealiseerd. Wil art. 245 KPK 1997 echt betekenis krijgen dan zullen echter ook meer ingrijpende, structurele veranderingen moeten worden doorgevoerd. Daarbij moet dan vooral gedacht worden aan een uitbreiding van het recht op kosteloze rechtsbijstand zodat verdachten ook in de eerste fase na aanhouding aanspraak kunnen maken op een toegevoegde advocaat. ${ }^{81}$ Mogelijk dat ook de introductie van een piketdienst in overweging zou kunnen worden genomen zodat de advocatuur beter voorbereid is op het verlenen van rechtsbijstand in noodsituaties. ${ }^{82}$

\section{Toegevoegde rechtsbijstand}

Eenieder jegens wie een strafrechtelijke procedure is aangevangen, heeft op grond van de Poolse Grondwet het recht op bijstand van een raadsman die hij zelf benoemt of die hem - in de door de wet genoemde gevallen - wordt toegevoegd. ${ }^{83}$ De vraag naar het recht op toegevoegde rechtsbijstand is met name van belang voor de verdachte die om welke reden dan ook niet in staat is zichzelf te verdedigen of over onvoldoende financiële middelen beschikt om zelf in de kosten van de verdediging te voorzien. ${ }^{84}$ Dat onvermogende verdachten onder bepaalde omstandigheden recht hebben op door de overheid gefinancierde rechtsbijstand vloeit ook voort uit art. 6 lid 3 sub c van het EVRM waarin is bepaald dat eenieder tegen wie een vervolging is ingesteld (onder andere) het recht heeft zelf zijn verdediging te voeren, daarbij bijstand te hebben van een gekozen raadsman of 'indien hij niet over voldoende middelen beschikt om een raadsman te bekostigen, kosteloos door een toegevoegde advocaat te kunnen worden bijgestaan, indien de belangen van een behoorlijke rechtspleging dit eisen'.

79 Een standaardoverweging in de Straatsburgse rechtspraak is dat overheden verplicht zijn rechten te garanderen die 'practical and effective' zijn: Artico t. Italië, EHRM 13-51980, A37, nr. 6694/74, § 33: '(...) the Convention is intended to guarantee not rights that are theoretical and illusionary but rights that are practical and effective; this is particularly so of the rights of the defence in view of the prominent place held in a democratic society by the right to a fair trial, from which they derive (...).' Zie over deze uitspraak ook § 3.5.3.

80 Als gevolg hiervan hebben de meeste verdachten ook voorafgaand aan en tijdens hun eerste verhoor nog niet de beschikking over een raadsman. Zie daarover verder hoofdstuk $5, \S 2.4$.

81 Zie ook de eerder in $\S 2.4$ genoemde aanbeveling van het CPT (Report 2004, p. 15) en Daniuk e.a. 2006, p. 33-34.

82 Een dergelijke vorm van rechtsbijstandverlening (piketdienst) bestaat inmiddels in verschillende Europese landen waaronder Engeland, Frankrijk en Nederland.

83 Art. 42 lid 2 Grondwet.

84 Beide situaties kunnen zich uiteraard ook gelijktijdig voordoen. 
In het onderstaande zal worden bekeken op welke wijze in de Poolse strafrechtspleging invulling wordt gegeven aan bovengenoemde rechten en of op dit punt noemenswaardige verschillen kunnen worden geconstateerd ten opzichte van de situatie voor 1989. Ook zal aandacht worden besteed aan de vraag hoe de huidige wettelijke regeling - en met name ook de daarop gebaseerde praktijk - zich verhoudt tot de standaard van het EVRM.

\subsection{Huidig juridisch kader}

Het Poolse strafprocesrecht kent verschillende situaties waarin de rechter bevoegd of verplicht is een advocaat toe te voegen. ${ }^{85}$ Een dergelijke toevoeging dient ambtshalve te gebeuren wanneer zich een van de door de wetgever omschreven gevallen van verplichte rechtsbijstand voordoet en in de betreffende zaak geen gekozen raadsman optreedt. Daarnaast kan toevoeging van een advocaat op verzoek van verdachte plaatsvinden wanneer hij de rechter ervan weet te overtuigen dat hij niet in staat is de kosten van de verdediging zelf te dragen. Beide vormen van toevoeging zullen hierna worden besproken.

\subsubsection{Ambtshalve toevoeging}

Volgens art. 79 en art. 80 KPK 1997 is bijstand van een raadsman verplicht wanneer:

- de verdachte minderjarig, doof, stom of blind is (art. 79 lid 1 sub 1 en 2),

- er gerechtvaardigd wordt getwijfeld aan zijn geestelijke gezondheid (art. 79 lid 1 sub 3),

- er omstandigheden bestaan die naar het oordeel van de rechtbank de verdediging bemoeilijken (art. 79 lid 2) en

- de zaak in eerste aanleg voor een provinciale rechtbank (SO) dient én de verdachte wordt beschuldigd van een strafbaar feit waarop minimaal drie jaar gevangenisstraf staat (zbrodnia) of van zijn vrijheid wordt beroofd (art. 80 eerste zin).

Oorspronkelijk behoorde ook het niet beheersen van de Poolse taal tot deze categorie maar deze grond is bij de wetswijziging van juli 2003 komen te vervallen. ${ }^{86}$

85 Zie hoofdstuk 2, § 3.1.3.2.

86 Art. 79 lid 1 sub 4 KPK 1997 (oud). Reden hiervoor was dat bij gelegenheid van genoemde wetswijziging aan verdachten een algemeen recht op bijstand van een tolk werd toegekend (art. 72 KPK 1997 - voorheen was dit recht beperkt tot het recht op vertaling van bepaalde processtukken): Hofmański e.a. 2007 I, p. 437. De redenering van de wetgever dat de noodzaak tot verplichte bijstand van een advocaat hierdoor automatisch komt te vervallen, doet wat vreemd aan. Het gaat immers om verschillende vormen van bijstand waarbij ervan uit moet worden gegaan dat bijstand van een tolk (die 'slechts' als vertaler optreedt) de behoefte aan professionele rechtsbijstand niet wegneemt. Het zal vaak gaan om een vreemdeling die wordt geconfronteerd met een aanhouding in een land waar hij de regels niet kent, hoogstwaarschijnlijk niet beschikt over gegevens van een lokale advocaat en ver verwijderd is van de contacten (familie, vrienden) die normaal gesproken zaken voor hem zouden kunnen regelen. Met andere woorden: ook wanneer de verdachte die de Poolse taal niet of onvoldoende beheerst, wordt bijgestaan door een tolk kan ambtshalve toevoeging van een advocaat noodzakelijk zijn. De huidige wettelijke regeling laat deze mogelijkheid nog wel open - toevoeging kan immers nog worden gebaseerd op de grond dat naar het oordeel van de rechtbank vanwege de taalproblemen sprake is van omstandigheden die de verdediging bemoeilijken - maar anders dan voorheen is dit dus niet langer verplicht. 
Zoals hierna nog zal blijken, heeft genoemde wetswijziging op verschillende punten gevolgen gehad voor de regeling van verplichte rechtsbijstand.

Wanneer zich een geval van verplichte rechtsbijstand voordoet, geldt nog steeds het uitgangspunt dat de verdachte in beginsel zelf een advocaat benoemt: pas wanneer geen gekozen raadsman optreedt, is de rechter verplicht ambtshalve een advocaat toe te voegen. ${ }^{87}$ Dat een dergelijke toevoeging ambtshalve dient te gebeuren, houdt in dat de verdachte er niet om hoeft te verzoeken. Sterker nog, aangezien bijstand van een raadsman in deze gevallen dwingend is voorgeschreven, kan de toevoeging zelfs tegen de uitdrukkelijke wil van verdachte plaatsvinden. ${ }^{88}$

Het voorgaande laat zien dat de in art. 79 omschreven gevallen persoonlijke omstandigheden van de verdachte betreffen terwijl art. 80 voorwaarden beschrijft die los staan van de persoon van verdachte. Behalve dit onderscheid is er nog een belangrijk verschil tussen beide bepalingen: verplichte rechtsbijstand op grond van art. 79 ziet op de gehele strafrechtelijke procedure - en strekt zich dus ook uit over het vooronderzoek - terwijl de verplichting op basis van art. 80 alleen betrekking heeft op het onderzoek ter terechtzitting. ${ }^{89}$ Dat de regeling van art. 79 betrekking heeft op de gehele strafrechtelijke procedure betekent echter niet dat de raadsman ook bij alle procedurele handelingen aanwezig moet zijn: sinds de wetswijziging van juli 2003 is deelname van de raadsman op geen enkel moment in het vooronderzoek verplicht..$^{90}$ Voor de advocaat die op grond van art. 80 KPK 1997 wordt toegevoegd, geldt dat hij slechts verplicht is deel te nemen aan het onderzoek ter terechtzitting. ${ }^{91}$

De eerste categorie gevallen van verplichte rechtsbijstand (verdachte is minderjarig, doof, stom of blind) is eenvoudig vast te stellen. De tweede categorie (twijfel aan geestelijke gezondheid van verdachte) is minder evident. Voor de vraag of zich een geval van verplichte rechtsbijstand voordoet, dient de rechter zich op basis van de beschikbare stukken en eventueel eigen indrukken van verdachte een oordeel

87 Art. 79 lid 1 en 2 jo. art. 81 lid 1 KPK 1997. De toevoeging heeft dus een secundair (of aanvullend) karakter ten opzichte van gekozen rechtsbijstand: Grzegorczyk 2004, p. 285.

88 Of een dergelijke gang van zaken verenigbaar is met het recht op verdediging - waaruit mogelijk ook het recht om zich niet te verdedigen kan worden afgeleid - zal in § 3.5.1 aan de orde komen.

89 En eventueel de appel- en cassatiefase die hier verder buiten beschouwing zullen blijven.

90 De op grond van art. 79 KPK 1997 toegevoegde raadsman is slechts verplicht deel te nemen aan het onderzoek ter terechtzitting en aan de (overige) zittingen waarvoor aanwezigheid van verdachte is voorgeschreven (art. 79 lid 3 KPK 1997). Voor de wetswijziging van juli 2003 was de raadsman wanneer zich een van de gevallen genoemd in art. 79 voordeed ook verplicht aanwezig te zijn bij de laatste inzage van de processtukken voor sluiting van het vooronderzoek (art. 321 lid 3 laatste zin KPK 1997 oud). Omdat dit in de praktijk vaak betekende dat de handeling - en daarmee ook de sluiting van het vooronderzoek - door het niet verschijnen van de raadsman moest worden uitgesteld, heeft de wetgever er vanuit efficiëntie overwegingen voor gekozen deze verplichting te schrappen. Momenteel is de raadsman (verplicht of niet) nog wel bevoegd bij deze activiteit aanwezig te zijn maar zijn afwezigheid is in beginsel geen reden meer voor uitstel van de inzage: Grzegorczyk 2004, p. 813. Gevolg van deze wijziging is dat het optreden van de raadsman op geen enkel moment in het vooronderzoek meer dwingend is voorgeschreven wat er mogelijk toe bijdraagt dat advocaten in toevoegingzaken nog later dan voorheen bij de procedure betrokken raken.

91 Art. 80 tweede zin KPK 1997. 
te vormen over zijn geestelijke gezondheid. Uitgangspunt is dat de twijfel 'reëel en concreet' moet zijn en moet blijken uit objectieve omstandigheden. ${ }^{92}$

Wanneer wordt vastgesteld dat de verdachte vanwege zijn psychische toestand inderdaad bijstand van een raadsman dient te hebben en om die reden een advocaat wordt toegevoegd, is echter niet uitgesloten dat later in de procedure op deze beslissing wordt teruggekomen. Wanneer gedurende het strafproces door een gedragsdeskundige wordt vastgesteld dat geen reden bestaat om aan de geestelijke gezondheid van de verdachte te twijfelen, kan de eerder verleende toevoeging alsnog worden ingetrokken. ${ }^{93}$ Deze mogelijkheid is met eerder genoemde wetswijziging van juli 2003 in het Poolse strafprocesrecht geïntroduceerd: daarvoor gold dat wanneer in de loop van de procedure door een psychiater werd vastgesteld dat verdachte geestelijk niets mankeerde hij toch zijn toegevoegde advocaat diende te behouden. ${ }^{94}$ Deze regel was gebaseerd op het uitgangspunt dat alleen de rechter definitieve beslissingen over de toerekeningsvatbaarheid van verdachte kon nemen en dat rapportages van gedragsdeskundigen dus geen gevolgen konden hebben voor de rechtsbijstand aan verdachte. ${ }^{95}$ Hoewel niet kan worden gezegd dat dit standpunt met genoemde wetswijziging definitief is verlaten - de rechter heeft immers slechts de bevoegdheid en niet de plicht om de toevoeging in te trekken - staat wel vast dat toevoegingen die worden verleend op grond van twijfel aan de geestelijke gezondheid van verdachte niet langer onaantastbaar zijn. Met deze wijziging hoopt de wetgever het aantal 'onterecht' verleende toevoegingen (en daarmee de kosten voor toegevoegde rechtsbijstand) te kunnen terugdringen.

De categorie 'omstandigheden die de verdediging bemoeilijken' (art. 79 lid 2 KPK 1997 ) is de meest ruime grondslag voor verplichte rechtsbijstand en biedt de rechter de ruimte ook in de gevallen die niet onder art. 79 lid 1 of art. 80 vallen maar waarin rechtsbijstand desalniettemin onontbeerlijk is toch een advocaat te kunnen toevoegen. Of sprake is van 'omstandigheden die de verdediging bemoeilijken' is ter beoordeling aan de rechtbank. Die kan daarover een beslissing nemen tijdens het onderzoek ter terechtzitting of al eerder in de procedure tijdens het vooronderzoek. ${ }^{96} \mathrm{Bij}$ de persoonlijke omstandigheden van verdachte dient in het kader van art. 79 lid 2 KPK 1997 te worden gedacht aan fysieke, psychische en intellectuele eigenschappen van verdachte die de verdediging wel aanzienlijk

92 Witkowska 2002, p. 280 e.v. en daar genoemde rechtspraak en literatuur.

93 Art. 79 lid 4 KPK 1997. Bevoegd tot intrekken van de toevoeging is de president van de rechtbank en gedurende het onderzoek ter terechtzitting de rechtbank. Uit het feit dat in genoemd artikellid het werkwoord 'kunnen' ('może') wordt gebruikt, moet worden afgeleid dat de rechter wel bevoegd maar nooit verplicht is de toevoeging in te trekken. Wanneer hij de toevoeging in stand laat, kan hij er ook voor kiezen de grondslag ervan te wijzigen van art. 79 lid 1 sub 3 (twijfel aan geestelijke gezondheid) in art. 79 lid 2 (omstandigheden die de verdediging bemoeilijken): Grzegorzyk 2004, p. 280. Art. 79 lid 4 voor de wijziging van juli 2003.

95 Grzegorczyk en Tylman 2001, p. 308 en Grzegorczyk 2004, p. 279.

96 In het laatste geval kan de rechter bijvoorbeeld tijdens de zitting waarop over de voorlopige hechtenis wordt beslist ambtshalve of op verzoek van een belanghebbende bepalen dat de verdachte moet worden bijgestaan door een advocaat. Zie Grzegorczyk en Tylman 2001, p. 308 en Grzegorczyk 2004, p. 281. 
bemoeilijken maar niet onmogelijk maken in de zin van art. 79 lid $1 .{ }^{97}$ Gedacht kan worden aan stotteren, slechtziendheid of zwakzinnigheid die niet als geestelijke stoornis in de zin van art. 79 lid 1 sub 3 kan worden aangemerkt. ${ }^{98}$ Ook uit de rechtspraak van het Hooggerechtshof kan worden afgeleid dat 'omstandigheden die de verdediging bemoeilijken' vooral samenhangen met de persoonlijke eigenschappen van verdachte, die het weliswaar niet onmogelijk maar wel moeilijk maken dat hij zelf de verdediging voert. Er bestaat discussie over de vraag of daarbij ook de complexiteit van de zaak een rol mag spelen. In de doctrine is wel beargumenteerd dat de ernst en ingewikkeldheid van de strafzaak in het kader van art. 79 lid 2 KPK 1997 niet mogen worden meegewogen. ${ }^{99}$ Het Hooggerechtshof heeft echter aangegeven deze interpretatie van art. 79 lid 2 te eng te vinden: het feit dat een zaak - gelet op de feiten of het recht - gecompliceerd is, kan op zich zelf geen reden zijn om het bestaan van 'omstandigheden die de verdediging bemoeilijken' aan te nemen maar kan wel een rol spelen in de besluitvorming wanneer het in verband wordt gebracht met de persoonlijke omstandigheden van verdachte. ${ }^{100}$

Voor wat betreft de categorie genoemd in art. 80 KPK 1997 dient te worden benadrukt dat het feit dat de strafzaak in eerste aanleg voor de provinciale rechtbank (SO) wordt behandeld alleen dan een grond voor toevoeging oplevert wanneer de verdachte van zijn vrijheid is beroofd of wordt beschuldigd van een strafbaar feit waarop een minimumstraf van drie jaar gevangenisstraf is gesteld (zbrodnia). ${ }^{101}$ Deze aanvullende voorwaarden worden wel bekritiseerd omdat door de provinciale rechtbank in eerste aanleg ook strafbare feiten kunnen worden beoordeeld waarop niet een minimumstraf van drie jaar staat maar die desalniettemin tot het opleggen van een aanzienlijke gevangenisstraf kunnen leiden. ${ }^{102}$ Een verdachte kan dus tot een hoge gevangenisstraf (maximaal 12 jaar) worden veroordeeld zonder bijstand van een raadsman te hebben gehad. ${ }^{103}$ Uiteraard kan de verdachte dan nog

97 Kulesza 2005, p. 384.

98 Met andere woorden afgezwakte vormen van de in art. 79 lid 1 KPK 1997 genoemde beperkingen: Grzegorczyk 2004, p. 278.

99 Een van de argumenten voor dit standpunt wordt ontleend aan het systeem van de wet: het criterium 'omstandigheden die de verdediging bemoeilijken' maakt onderdeel uit van art. 79 waarin slechts persoonlijke eigenschappen van de verdachte centraal staan. Factoren die samenhangen met de ernst of ingewikkeldheid van de zaak spelen volgens deze redenering pas (en uitsluitend) een rol in het kader van art. 80: Kulesza 2005, p. 383-384 en daar genoemde literatuur.

100 SN 17 februari 2004, II KK 277/02, OSNKW 2004, nr. 4, 43. Over deze rechtspraak van het Hooggerechtshof: Kulesza 2005, p. 381-385 en Wiliński 2006, p. 302.

101 De huidige regeling vertoont op dit punt een verschil met het strafprocesrecht van 1969, zie hierna $\S 3.2$.

102 Het wetboek van strafrecht kent namelijk een aantal strafbare feiten die niet tot de categorie zbrodnia worden gerekend (omdat het strafminimum lager is dan drie jaar) maar waarop desalniettemin een hoge maximumstraf tot maar liefst twaalf jaar is gesteld. Bijvoorbeeld: zware mishandeling waarop de dood van het slachtoffer is gevolgd (art. 156 lid 3 KK 1997), bepaalde feiten tegen de openbare veiligheid wanneer het tot de dood van een persoon of ernstig lichamelijk letstel van meerdere personen heeft geleid (art. 163 lid 3 KK 1997) en kaping van een schip of vliegtuig (art. 166 lid 1 KK 1997).

103 Country Report 2002, p. 9 (zie over dit landenrapport hierna $\S 3.3$ ). Sommige auteurs zijn om die reden van mening dat verdachten wiens strafzaak in eerste aanleg door de 
wel een verzoek indienen tot toevoeging op de financiële grond van art. 78 lid 1 KPK 1997 maar dat een dergelijk verzoek ook wordt ingewilligd, is allesbehalve zeker.

Ten slotte is van belang dat het voor de vraag of verdachte van zijn vrijheid is beroofd geen verschil maakt of hij in het kader van de strafzaak waarin de vraag naar verplichte rechtsbijstand speelt of in het kader van een andere strafzaak is gedetineerd. Wel geldt sinds de wetswijziging van juli 2003 dat de grondslag voor toevoeging komt te vervallen wanneer de verdachte in vrijheid wordt gesteld. ${ }^{104}$ Gevolg is dat een op grond van art. 80 verleende toevoeging wordt ingetrokken tenzij er (nog) een andere grond voor verplichte rechtsbijstand aanwezig is. ${ }^{105}$

Het absolute karakter van de verplichte rechtsbijstand blijkt uit het feit dat de omstandigheid dat een verdachte die in een geval genoemd in art. 79 of $80 \mathrm{KPK}$ 1997 tijdens de behandeling van zijn zaak in eerste aanleg geen bijstand van een advocaat heeft gehad een absolute grond voor hoger beroep is. ${ }^{106}$ Deze constatering dwingt de appelrechter de uitspraak in eerste aanleg te vernietigen waarop de zaak opnieuw moet worden behandeld. ${ }^{107}$

\subsubsection{Toevoeging op verzoek verdachte}

Een verdachte kan buiten de in het voorgaande genoemde gevallen van ambtshalve toevoeging ook voor gefinancierde rechtshulp in aanmerking komen wanneer hij aannemelijk maakt dat hij niet zelf in de kosten van de verdediging kan voorzien. De juridische grondslag voor een toevoeging op financiële gronden is te vinden in art. 78 lid 1 KPK 1997:

'De beschuldigde, die geen gekozen raadsman heeft, kan verzoeken dat hem ex officio een raadsman wordt toegevoegd, wanneer op passende wijze wordt aangetoond dat hij niet in staat is de kosten van de verdediging te dragen zonder daarmee nadeel toe te brengen aan zijn eigen noodzakelijke levensonderhoud en dat van zijn familie. ${ }^{\prime} 108$

provinciale rechtbank wordt behandeld altijd door een raadsman moeten worden bijgestaan: Bieńkowska e.a.2004, p. 203.

104 Voor genoemde wetswijziging bleef de toevoeging ook na invrijheidstelling van verdachte van kracht. Dit is het gevolg van een redactionele wijziging van het artikel waardoor wordt benadrukt dat de verdachte om aanspraak te maken op toegevoegde verplichte rechtsbijstand wel daadwerkelijk van zijn vrijheid moet zijn beroofd ('jest pozbawiony wolności'): het einde van de detentie betekent nu dus ook het einde van de toevoeging. Zie Hofmański e.a. 2007 I, p. $450-451$.

105 Bijvoorbeeld een omstandigheid die de verdediging bemoeilijkt in de zin van art. 79 lid 2 KPK 1997: Grzegorczyk 2004, p. 283. Ook geldt dat de grond voor verplichte rechtsbijstand kan herleven wanneer de verdachte opnieuw van zijn vrijheid wordt beroofd: Wiliński 2006, p. 301 en daar genoemde literatuur.

106 Zie over het onderscheid tussen relatieve en absolute gronden voor hoger beroep hoofdstuk 2, § 3.2.3.2 en 3.2.3.3.

107 Art. 439 lid 1 sub 10 KPK 1997. Hetzelfde geldt wanneer wel een advocaat aan de verdachte was toegevoegd maar deze niet aanwezig was op momenten - bijvoorbeeld tijdens een zitting - dat zijn deelname verplicht was. Vernietiging van de uitspraak in eerste aanleg op deze gronden vindt echter alleen plaats wanneer dat in het voordeel van verdachte is (art. 439 lid 2 KPK 1997).

108 Ook hier geldt de regel dat waar het begrip 'beschuldigde' in algemene zin wordt gehanteerd, de betreffende bepaling van overeenkomstige toepassing is op de 'verdachte' 
Een verzoek om toevoeging kan in beginsel in alle fasen van de strafrechtelijke procedure worden gedaan. Er bestaat voor de politie geen algemene wettelijke verplichting om de verdachte op de hoogte te stellen van zijn recht op kosteloze rechtsbijstand. Ook in de letter of rights die de verdachte voorafgaand aan zijn verhoor krijgt overhandigd, wordt hiervan geen melding gemaakt. ${ }^{109}$ De prokurator is wel verplicht de verdachte over deze mogelijkheid te informeren wanneer gedurende het vooronderzoek blijkt dat er omstandigheden zijn die toevoeging op grond van art. 78 KPK 1997 zouden kunnen rechtvaardigen. ${ }^{110}$ Gedurende het onderzoek ter terechtzitting kan de rechtbank de verdachte hierover zelf inlichten.

De wijze waarop art. 78 is geformuleerd, roept een aantal vragen op. In de eerste plaats is onduidelijk hoe een verdachte zijn verzoek om gefinancierde rechtsbijstand moet vormgeven. In de tweede plaats is het criterium voor toekenning van deze vorm van kosteloze rechtsbijstand zeer vaag. Op beide punten wordt teruggekomen in $\S 3.3$.

Een verdachte kan tegen de afwijzing van zijn verzoek om in aanmerking te komen voor kosteloze rechtsbijstand geen rechtsmiddel instellen. ${ }^{111}$ Het staat de verdachte wel vrij om na een afwijzende beslissing opnieuw een verzoek in te dienen: de wetgever heeft geen beperking gesteld aan het aantal keren dat een toevoeging op grond van art. 78 KPK 1997 kan worden aangevraagd. ${ }^{112}$ Ook kan de verdachte in hoger beroep aanvoeren dat hij bij de behandeling van zijn zaak in eerste aanleg ten onrechte geen bijstand heeft gehad op grond van art. $78 \mathrm{KPK}$ 1997. Anders dan in geval van verplichte rechtsbijstand (zie § 3.1.1) heeft het feit dat een verdachte ten onrechte geen bijstand op grond van art. 78 lid 1 KPK 1997 heeft gehad niet automatisch gevolgen voor de geldigheid van het vonnis in eerste aanleg. Of hieraan procedurele consequenties worden verbonden, is - volgens rechtspraak van het Hooggerechtshof - afhankelijk van de vraag of vaststaat dat de bijstand van een raadsman in het betreffende geval van invloed zou kunnen zijn geweest op de einduitspraak. ${ }^{113}$ Dus alleen wanneer de appelrechter van oordeel

('podejrzany'): art. 71 lid 3 KPK 1997. Meer over het recht op kosteloze rechtsbijstand gedurende het vooronderzoek in §3.4.2.

109 Zie hierna §3.4.2.

110 Zo is geregeld in art. 138 lid 1 van een verordening van de minister van Justitie inzake de interne organisatie van de prokuratura d.d. 27 augustus 2007 (Rozporzadzenie Ministra Sprawiedliwości regulamin wewnętrznego urzędowania powszechnych jednostek organizacyjnych prokuratury).

111 Opmerkelijk is dat tegen dezelfde weigering in civiele zaken wel beroep kan worden aangetekend (art. 394 lid 1 sub 2 wetboek van burgerlijk procesrecht).

112 Een dergelijk nieuw verzoek kan bijvoorbeeld zinvol zijn wanneer de financiële situatie van verdachte gedurende de procedure verandert (verslechtert) of wanneer de rechter - in strijd met eerder genoemde regelgeving - het eerste verzoek heeft afgewezen omdat de gestelde feiten onvoldoende waren gedocumenteerd zonder de aanvrager de gelegenheid te bieden de noodzakelijke stukken alsnog te overleggen.

113 SN 13 november 2002, V KKN 375/01 en ook SN 5 augustus 1998, III KKN 307/98. Zie hierover onder meer Czernicka en Tuleya 2005, p. 136 en Boratyński e.a. 2005, p. 182-183. Dit standpunt van het Hooggerechtshof wordt bekritiseerd door Wiliński die van mening is dat het ten onrechte niet verlenen van een toevoeging altijd een absolute grond voor hoger beroep dient te zijn: Wiliński 2006, p. 2006, p. 305. Overigens beschouwt het Hooggerechtshof het feit dat ten onrechte geen advocaat is toegevoegd op grond van art. $78 \mathrm{KPK}$ 
is dat rechtsbijstand mogelijk tot een andere uitkomst van de zaak had geleid, dient het vonnis te worden vernietigd.

Wanneer het verzoek van verdachte wel wordt ingewilligd, is niet uitgesloten dat later in deze procedure op deze beslissing wordt teruggekomen. De rechtbank kan een verleende toevoeging namelijk weer intrekken wanneer in de loop van de procedure blijkt dat de omstandigheden waarop de toevoeging was gebaseerd niet (meer) bestaan. ${ }^{114}$ Voor de wetswijziging van juli 2003 gold deze mogelijkheid alleen wanneer gedurende het proces aan het licht kwam dat een toevoeging onterecht was verleend - bijvoorbeeld omdat de verdachte in het kader van zijn aanvraag onjuiste gegevens had verstrekt aan de rechtbank. Als gevolg van genoemde wijziging is het voortaan ook mogelijk een oorspronkelijk terecht verleende toevoeging in te trekken op basis van omstandigheden die later zijn ontstaan. ${ }^{115}$ Hierbij kan gedacht worden aan een plotselinge verbetering van de financiële situatie van verdachte die hem in staat stelt de kosten van de verdediging zelf te gaan dragen. Net als bij de verplichte toevoeging in geval van een mogelijke geestelijke stoornis van verdachte geldt dus ook in het kader van de kosteloze rechtsbijstand niet langer de regel 'eenmaal toegevoegd blijft toegevoegd'. ${ }^{116}$ Ook tegen de beslissing tot intrekking van de toevoeging op basis van art. 78 lid 2 KPK 1997 staat geen rechtsmiddel open.

\subsubsection{Wijze van toevoegen}

\subsubsection{Betrokken instanties}

Zowel de beslissing dat een verdachte in aanmerking komt voor kosteloze rechtsbijstand als de feitelijke toevoeging van een bepaalde advocaat is overgelaten aan de president van de rechtbank die bevoegd is van de zaak kennis te nemen. ${ }^{117}$ Hoewel het wetboek van strafvordering er geen twijfel over laat bestaan welke rechter dergelijke beslissingen dient te nemen, blijkt het in de praktijk geregeld voor te komen dat niet de president maar de voorzitter van de afdeling strafrecht van de betreffende rechtbank of zelfs de zittingsrechter deze taken verricht. ${ }^{118}$ Praktisch gezien is deze werkwijze wel te verklaren: wanneer een verzoek op grond van art. 78 lid 1 KPK 1997 niet gedurende het vooronderzoek maar op het

1997 wel als een schending van laatstgenoemde bepaling en het recht op verdediging zoals neergelegd in art. 6 KPK 1997 (SN 29 januari 2002, II KKN 386/99, Prok. i Prawo 2002, nr. 10, p. 6).

114 Art. 78 lid 2 KPK 1997.

115 Dit is net als in het kader van de wijziging van art. 80 (einde detentie betekent einde toevoeging) het gevolg van een redactionele verandering van het artikellid. Intrekking van de toevoeging is gerechtvaardigd wanneer blijkt dat omstandigheden waarop de beslissing tot toevoeging was gebaseerd 'niet langer bestaan' ('że nie istnieja') Voorheen was bepaald dat intrekking kon plaatsvinden wanneer aan het licht kwam dat deze omstandigheden 'nooit hadden bestaan'('że nie istniaty'): Grzegorczyk 2004, p. 274 en Hofmański e.a. 2007 I, p. 432.

116 Zoals eerder opgemerkt, geldt sinds de wetswijziging van 2003 dat een toevoeging die oorspronkelijk was verleend vanwege twijfel aan de geestelijke gezondheid van verdachte weer mag worden ingetrokken wanneer komt vast te staan dat deze twijfel niet terecht was (art. 79 lid 4 KPK 1997).

117 Art. 78 lid 1, art. 79 lid 1 en 2 en art. 80 jo. 81 lid 1 KPK 1997.

118 Monitoring Report 2003, p. 101. 
onderzoek ter terechtzitting wordt gedaan, richt het zich immers niet tot de (president van) de rechtbank maar tot de zittingsrechter die hierop vervolgens zelf een beslissing kan nemen. Een dergelijke gang van zaken is vanwege de aan de zittingsrechter te stellen eisen van onpartijdigheid en onafhankelijkheid echter problematisch. Het antwoord op de vraag of een verdachte in aanmerking dient te komen voor gefinancierde rechtsbijstand dient immers alleen te worden gebaseerd op de (objectief waarneembare) financiële omstandigheden van de verdachte. Wanneer een zittingsrechter die kennis heeft van de zaak en de persoonlijke omstandigheden van verdachte deze vraag beantwoordt, bestaat het risico dat ook andere, meer subjectieve factoren mee worden genomen in deze besluitvorming. ${ }^{119}$

De rol van de balie in de procedure van toevoeging is beperkt tot het leveren van ledenlijsten aan rechterlijke instanties. Op deze lijsten - die per lokale balie worden opgesteld - staat vermeld welke advocaten beschikbaar zijn voor het behandelen van zaken op basis van toevoeging. Anders dan in civiele zaken is de beroepsorganisatie dus niet actief betrokken bij de beslissing of iemand in aanmerking komt voor gefinancierde rechtsbijstand of de keuze voor een bepaalde advocaat. ${ }^{120}$ Ook kent het Poolse systeem geen met de Nederlandse Raad voor de Rechtsbijstand (Legal Aid Board) vergelijkbaar onafhankelijk orgaan: besluitvorming over kosteloze rechtsbijstand is volledig in handen van de rechterlijke macht.

\subsubsection{Keuze advocaat}

Voor beantwoording van de vraag welke advocaat in een specifieke zaak moet worden toegevoegd, biedt de wet geen aanknopingspunten. Ongeschreven regel is dat de rechter de (alfabetische) volgorde van de lijst volgt die door de lokale balie is aangeleverd. ${ }^{121}$ Alle actieve leden van de balie zijn in beginsel verplicht kosteloze rechtsbijstand te verlenen. Slechts voor enkele tientallen advocaten die een bestuursfunctie binnen de balie vervullen, geldt dat ze van deze plicht kunnen worden ontheven. De praktijk hoort te zijn dat de rechter de volgorde van de lijst zonder aanziens des persoons volgt: er wordt in beginsel niet gekeken naar het soort zaak, de ingewikkeldheid ervan of de specialisatie van de advocaat die volgens de lijst aan de beurt is om te worden toegevoegd. ${ }^{122}$ Het kan dus gebeuren

119 Zo zou bijvoorbeeld - bewust of onbewust - een rol kunnen spelen dat naar het oordeel van de zittingsrechter het bewijs tegen een verdachte zo sterk is dat bijstand van een raadsman toch niets meer uit kan maken. Volgens een rechter uit Poznań komt het in de praktijk wel degelijk voor dat collega's zich bij de beslissing over toekenning van gefinancierde rechtsbijstand laten leiden door dit soort 'oneigenlijke' argumenten. Bron: gesprek rechter districtsrechtbank Poznań, september 2004 Poznań. Zie hierna § 3.4.1.

120 In civiele zaken wordt de vraag of iemand in aanmerking komt voor toevoeging ook beantwoord door de rechter maar in plaats van zelf een advocaat aan te wijzen doet deze zijn positieve beslissing toekomen aan de lokale balie die vervolgens een advocaat of juridisch adviseur in de zaak benoemt. De feitelijke toevoeging wordt in die gevallen dus wel uitgevoerd door de balie.

121 Op basis van het wetboek van strafvordering van 1969 kon de rechter ook een advocatencollectief aanwijzen dat vervolgens intern diende te bepalen welke advocaat de zaak zou behandelen (art. 74 KPK 1969). Vandaag de dag kunnen alleen individuele advocaten worden toegevoegd.

122 Dat geen rekening wordt gehouden met de vraag welk soort zaken normaliter door de advocaat wordt behandeld, is onlosmakelijk verbonden met de (van oudsher binnen 
dat een in het civiele recht gespecialiseerde advocaat met weinig kennis van (en praktijkervaring in) het strafrecht een grote strafzaak krijgt toegewezen. Dit is een van de factoren die mogelijk van invloed is op de kwaliteit van de verleende rechtsbijstand in toevoegingzaken waarover later meer.

Dat in beginsel de volgorde van de door de balie beschikbaar gestelde lijst moet worden gevolgd, betekent echter niet dat daar nooit van wordt afgeweken. Volgens de Helsinki Foundation for Human Rights (HFHR) maken sommige rechters wel degelijk een bewuste keuze voor bepaalde advocaten. ${ }^{123}$ Deze praktijk is ook tijdens mijn vraaggesprekken met rechters in Poznań en Lublin bevestigd. Afwijking van de regel kan om verschillende redenen gebeuren. Mogelijk is dat een rechter voor een bepaalde advocaat kiest omdat hij weet dat deze garant staat voor een goede verdediging. Een voorbeeld: een rechter van de districtsrechtbank (SR) in Poznań gaf aan meestal te kiezen voor advocaten die hij - bijvoorbeeld van tijdens zijn studie - persoonlijk kent omdat hij weet dat zij zich zullen inzetten voor hun cliënt. Een dergelijke keuze kan natuurlijk ook 'negatief' plaatsvinden in die zin dat een rechter bewust niet kiest voor de advocaat die eigenlijk aan de beurt is omdat hij vreest dat deze de zaak niet goed zal behandelen. Behalve de verwachte kwaliteit van de rechtsbijstand kan ook de wens van bepaalde advocaten om veel zaken op basis toevoeging te doen een rol spelen in de besluitvorming van de rechter. Er zijn advocaten die graag zaken op basis van toevoeging doen omdat ze op die wijze ervaring kunnen opdoen of omdat ze onvoldoende betalende cliënten hebben om hun praktijk draaiende te houden. Voor laatstgenoemde categorie vormen de door veel andere advocaten als ontoereikend beschouwde vergoedingen die voor toevoegingzaken worden verleend een behoorlijk (en noodzakelijk) inkomen.

De rechter houdt bij de keuze voor een bepaalde advocaat in beginsel geen rekening met een eventuele voorkeur van verdachte. In de praktijk wordt doorgaans de advocaat toegevoegd die volgens de volgorde van de lijst aan de beurt is of die de rechter om andere (eerdergenoemde) redenen geschikt acht om de zaak te behandelen. Dat daarbij rekening moet worden gehouden met een eventuele voorkeur van verdachte is nergens met zoveel woorden bepaald. ${ }^{124}$

Ook rechters in Poznań en Lublin gaven aan dat een verdachte wel om een bepaalde advocaat mag vragen maar dat niets hen verplicht een dergelijk verzoek daadwerkelijk in overweging te nemen. ${ }^{125}$

\subsubsection{Duur toevoeging}

Op het moment dat een advocaat (op grond van art. 78, 79 of 80 KPK 1997) wordt toegevoegd, geldt de verplichting in de betreffende zaak op te treden in beginsel

de Poolse advocatuur heersende) opvatting dat een advocaat veelzijdig hoort te zijn en dus in beginsel alle soorten zaken moet kunnen behandelen.

123 Monitoring Report 2003, p. 104.

124 In § 3.5.1 zal worden besproken of een dergelijk recht (op vrije keuze van een advocaat in geval van toevoeging) aan art. 6 EVRM kan worden ontleend.

125 Een rechter van de provinciale rechtbank (SO) te Lublin merkte op wel eens mee te maken dat een verdachte vraagt om toevoeging van een advocaat die hem al in eerder strafzaken heeft bijgestaan. Hij zei geen reden te zien dit soort verzoeken te negeren en er doorgaans mee in te stemmen. Bron: gesprek Ozimek, oktober 2004 Lublin. 
voor de rest van de procedure. ${ }^{126}$ Dit betekent concreet dat de toegevoegde raadsman de belangen van zijn cliënt moet behartigen totdat de strafrechtelijke procedure op rechtsgeldige wijze is afgesloten. Dit alles neemt echter niet weg dat de betrekking tussen een toegevoegde raadsman en verdachte op initiatief van een van beiden of op gezamenlijk verzoek onder bepaalde omstandigheden voortijdig kan worden beëindigd. Na aanvang van het onderzoek ter terechtzitting geldt dat in gevallen van verplichte rechtsbijstand (art. 79 en 80) daartoe een gemotiveerd verzoek kan worden gedaan aan de rechtbank die - wanneer het verzoek wordt ingewilligd - de advocaat van zijn verplichtingen ontheft en een nieuwe advocaat toevoegt. ${ }^{127}$ Ook in de rechtspraak van het Hooggerechtshof wordt benadrukt dat het verzoek een andere advocaat toe te voegen toereikend gemotiveerd moet worden:

'De verklaring van een beschuldigde, afgelegd op het onderzoek ter terechtzitting, dat hij in een geval van verplichte rechtsbijstand het vertrouwen in de hem toegevoegde raadsman heeft verloren, die met geen enkel argument is onderbouwd, levert op zich zelf geen grond op voor benoeming van een andere advocaat. ${ }^{\prime 2} 28$

Vanwege de beperkte reikwijdte van art. 378 KPK 1997 - het heeft slechts betrekking op gevallen van verplichte rechtsbijstand in de fase van het eindonderzoek is in juli 2003 nog een algemene bepaling aan de problematiek ten aanzien van intrekking van toevoegingen gewijd. Sindsdien is in een nieuw tweede lid van art. 81 KPK 1997 geregeld dat de president van de rechtbank die bevoegd is van de zaak kennis te nemen op een gemotiveerd verzoek van verdachte of advocaat een nieuwe advocaat kan benoemen ter vervanging van de eerste. Deze bepaling ziet dus ook op toevoegingen buiten de gevallen van verplichte rechtsbijstand en heeft ook betrekking op de fase van het vooronderzoek waarmee het een belangrijke aanvulling op het oudere art. 378 KPK 1997 is. Dat het verzoek 'gemotiveerd' ('uzasadniony') moet zijn, betekent - net als in het kader van art. 378 KPK 1997 - dat de verdachte en/of zijn advocaat duidelijk moeten aangeven waarom de verdediging niet kan worden voortgezet.

Uit de Advocatenwet vloeit voort dat een advocaat zich (zowel in zaken op basis van toevoeging als wanneer hij is gekozen door zijn cliënt) slechts op grond van

126 Deze hoofdregel vloeit voort uit art. 84 lid 1 KPK 1997 waarin is geregeld dat de benoeming of toevoeging van een advocaat voor de duur van de gehele procedure geldt, tenzij uitdrukkelijk is bepaald dat de rechtsbijstand slechts betrekking heeft op een beperkte periode.

127 Art. 378 lid 2 KPK 1997. Wanneer dat gebeurt, dient de rechtbank eveneens te bepalen of de oude advocaat zonder daarmee afbreuk te doen aan verdachte's recht op verdediging zijn activiteiten kan voortzetten totdat de nieuwe advocaat de zaak heeft overgenomen (art. 378 lid 3 KPK 1997). Omdat het in het verleden regelmatig voorkwam dat de mogelijkheid van art. 378 werd gebruikt (of misbruikt) om de procedure te vertragen, is deze bepaling de afgelopen jaren verschillende keren door de wetgever aangepast. Meer hierover in hoofdstuk 6, § 5.2.3.

128 SN 20 maart 1986, I KR/86, OSPiKA 1987, nr. 7-8. Het Hooggerechtshof erkent dus wel dat het bestaan van een vertrouwensrelatie tussen advocaat en cliënt ook in geval van toegevoegde rechtsbijstand essentieel is maar het lijkt erop dat aan de bewering dat dat vertrouwen niet langer bestaat (of altijd al heeft ontbroken) in geval van toegevoegde rechtsbijstand strengere eisen worden gesteld dan in geval van gekozen rechtsbijstand: Wiliński 2006, p. 321-322. 
'belangrijke redenen' mag terugtrekken. Ten aanzien van toevoegingen geldt dat alleen het orgaan dat de advocaat heeft benoemd hem kan ontheffen van de plicht in de betreffende zaak op te treden. ${ }^{129}$ Tussenkomst van de rechter is in die gevallen dus te allen tijden vereist. Hoewel in genoemde regeling niet is gespecificeerd welke gronden belangrijk genoeg zijn om de verdediging te weigeren of neer te leggen, staat vast dat het feit dat tussen advocaat en cliënt geen vertrouwensband (meer) bestaat, betekent dat de betrekking moet worden opgeheven. ${ }^{130}$ Daarnaast kunnen ook meer objectieve omstandigheden aanleiding geven tot een verzoek op grond van art. 81 lid 2 of art. 378 KPK 1997: de advocaat kan bijvoorbeeld ziek worden of voor het einde van de strafzaak met pensioen gaan. ${ }^{131}$ Tegen de weigering een toegevoegde advocaat te laten vervangen, kan geen rechtsmiddel worden ingesteld.

De rechter kan een toevoeging verleend op grond van twijfel aan de geestelijke gezondheid van een verdachte of vanwege zijn financiële situatie in de loop van de procedure ook op eigen initiatief intrekken wanneer de omstandigheden die aanleiding vormden voor de toevoeging niet (meer) blijken te bestaan. ${ }^{132}$ Wanneer een toevoeging op deze wijze wordt ingetrokken, zal de verdachte de kosten van de verdediging zelf moeten gaan dragen of het voor het vervolg van de procedure zonder bijstand van een raadsman moeten doen. ${ }^{133}$

Ten slotte verdient opmerking dat het Poolse strafprocesrecht behalve in bovengenoemde toevoegingen op grond van art. 78, 79 en 80 die voor de duur van de gehele procedure gelden ook een aantal gevallen kent waarin een advocaat voor een bepaalde handeling wordt toegevoegd. Het gaat daarbij in de eerste plaats om een aantal proceshandelingen die alleen door een advocaat of juridisch adviseur kan worden verricht: in het Pools wordt dit verschijnsel wel aangeduid als 'przymus adwokacki' of 'przymus radcowski' ('verplichte bijstand van een advocaat' of 'verplichte bijstand van een juridisch adviseur'). ${ }^{134}$

129 Art. 28 lid 1 en 2 Advocatenwet.

130 Dit blijkt ook uit art. 51 van de gedragsregels: 'De relatie tussen een advocaat en zijn cliënt is gebaseerd op vertrouwen. Een advocaat is verplicht zijn volmacht te beëindigen wanneer uit omstandigheden blijkt dat zijn cliënt geen vertrouwen meer in hem heeft.'

131 Grzegorczyk 2004, p. 969-970.

132 Eerder genoemd art. 78 lid 2 en 79 lid 4 KPK 1997.

133 Wanneer de oorspronkelijke toevoeging was gebaseerd op de geestelijke gesteldheid (en niet op de financiële draagkracht) van verdachte staat het hem uiteraard wel vrij alsnog een verzoek tot toevoeging op grond van art. 78 KPK 1997 in te dienen.

134 Deze verplichting heeft overigens niet alleen betrekking op de verdachte maar kan onder omstandigheden ook van toepassing zijn op het slachtoffer dat in de hoedanigheid van aanklager of civiele partij een bepaalde handeling in de strafrechtelijke procedure wil verrichten. Voorbeelden van incidentele handelingen waarvoor rechtsbijstand is vereist, zijn: het instellen van cassatie, het instellen van hoger beroep tegen uitspraken van een provinciale rechtbank (SO) en het indienen van een akte van beschuldiging door een hulpaanklager (oskarżyciel positkowy). Respectievelijk: art. 526 lid 2, 446 lid 1 en 55 lid 2 KPK 1997 waaruit volgt dat dergelijke aktes moeten worden opgesteld en ondertekend door een advocaat of - in het geval van cassatie - door een advocaat of juridisch adviseur. Deze verplichting geldt uiteraard niet wanneer hoger beroep of cassatie worden ingesteld door een prokurator. 
In de Poolse literatuur wordt benadrukt dat de wetgever met deze vormen van verplichte rechtsbijstand niet de (financiële) belangen van de juridische beroepsgroepen heeft willen dienen maar slechts de inhoudelijke kwaliteit van bepaalde schriftelijke stukken - en daarmee de efficiëntie van de betreffende procedures heeft willen waarborgen. ${ }^{135}$ Wanneer zich een van bovengenoemde situaties voordoet en de verdachte - aan wie eerder nog geen raadsman was toegevoegd - niet in staat is om zelf de kosten van de rechtsbijstand te dragen, dan dient hem voor het verrichten van de betreffende handeling op grond van art. 78 lid 1 KPK 1997 een raadsman te worden toegevoegd. ${ }^{136}$

Behalve voor het verrichten van specifieke handelingen kan toevoeging ook op een bepaald moment in de procedure noodzakelijk zijn. Ook dan wordt rechtsbijstand niet voor de duur van de gehele procedure maar ad hoc verleend. Het belangrijkste voorbeeld in dit verband is de regeling van art. 387 KPK 1997 waarin is bepaald dat de verdachte onder bepaalde omstandigheden de rechtbank kan verzoeken zonder bewijsvoering ter terechtzitting te worden veroordeeld tot een bepaalde straf of maatregel. ${ }^{137}$ Wanneer een verdachte in zo'n geval niet over een gekozen raadsman beschikt, kan de rechtbank hem - op verzoek van eerstgenoemde - een advocaat toevoegen. Verdachte hoeft in zo'n geval niet aan te tonen dat hij niet in staat is de kosten van de rechtsbijstand zelf te dragen. ${ }^{138}$ De toegevoegde advocaat treedt dan op om de verdachte bij te staan bij het formuleren en indienen van het verzoek tot veroordeling zonder bewijsvoering ter zitting: wanneer uiteindelijk niet met dit voorstel wordt ingestemd, komt de toevoeging van rechtswege te vervallen. ${ }^{139}$

\subsubsection{Vergoeding toegevoegde rechtsbijstand}

Door de minister van Justitie zijn minimumbedragen voor de vergoeding van kosteloze rechtsbijstand vastgelegd. ${ }^{140}$ Voor het optreden in strafzaken gelden de

135 Wanneer het rechtsmiddel wel door een advocaat is ondertekend maar de (van weinig deskundigheid blijk gevende) inhoud de twijfel wekt of het document ook door deze advocaat is opgesteld, heeft de rechtbank niet alleen het recht maar zelfs de plicht om te controleren of de verdediging haar verplichting op dit punt is nagekomen: Grzegorczyk 2004, p. 1174 en Bieńkowska e.a. 2004, p. 204.

136 De verdachte die zelf advocaat is, wordt geacht dit soort handelingen zelf te kunnen verrichten en heeft dus geen recht op deze toevoeging: Grzegorczyk 2000, p. 314. Zie over de problematiek met betrekking tot verplichte rechtsbijstand in cassatie hoofdstuk 2, § 3.2.3.3.

137 Zie over deze wijze van afdoening hoofdstuk 2, § 2.3.3.2 en hoofdstuk 6, § 3. Een tweede voorbeeld heeft betrekking op de fase in hoger beroep: wanneer een gedetineerde verdachte verzoekt de behandeling van het appel ter terechtzitting te kunnen bijwonen, kan de rechter dit afwijzen indien deelname van de raadsman toereikend wordt geacht. Als een verdachte in zo'n geval nog geen raadsman heeft, wordt een advocaat toegevoegd. Een en ander is geregeld in art. 451 KPK 1997. Zie over de problematiek van deelname van de verdediging aan de behandeling van het hoger beroep hoofdstuk 2, § 3.2.3.2.

138 Grzegorczyk 2004, p. 986. De rechtbank dient de verdachte te informeren over de mogelijkheid een dergelijk verzoek in te dienen wanneer duidelijk is dat hij (nog) niet op de hoogte is van dit recht en indien rechtsbijstand in de gegeven omstandigheden onontbeerlijk is.

139 Grzegorczyk 2004, p. 986.

140 Besluit van 28 september 2002 inzake advocatenkosten en de kosten van ambtshalve 
volgende bedragen (ter vergelijking: in betalende zaken geldt een gemiddeld uurtarief van ongeveer 100 euro):

- voor bijstand van een verdachte in het vooronderzoek: 180 złotych voor dochodzenie en 300 złotych voor śledztwo (respectievelijk circa 48 en 80 euro). ${ }^{141}$

- voor optreden in het eindonderzoek gelden verschillende bedragen afhankelijk van het soort strafzaak. Een gewone procedure voor de disctrictsrechtbank (SR) brengt 420 złotych (ongeveer 112 euro) op, hetzelfde geldt voor de behandeling van het hoger beroep bij de provinciale rechtbank (SO). Voor een bijzondere procedure of een overtredingszaak voor de districtsrechtbank staat respectievelijk 360 złotych (ongeveer 96 euro) en 180 złotych (ongeveer 48 euro). De hoogste vergoedingen gelden voor strafzaken die in eerste aanleg voor de provinciale rechtbank of voor het Hooggerechtshof dienen: 600 złotych (ongeveer 160 euro). ${ }^{142}$

- voor het opstellen en indienen van cassatie(middelen) gelden afzonderlijke minimum vergoedingen: 360 złotych (ongeveer 96 euro) wanneer de uitspraak in eerste aanleg door de districtsrechtbank is gedaan en 600 złotych (ongeveer 160 euro) wanneer de bestreden uitspraak afkomstig is van de provinciale rechtbank. ${ }^{143}$

- wanneer de zaak niet in een dag wordt afgedaan, worden de minimumvergoedingen voor iedere volgende dag met $20 \%$ verhoogd. ${ }^{144}$

- wanneer meer personen in dezelfde zaak worden bijgestaan, geldt voor de bijstand aan ieder van hen een afzonderlijke vergoeding. ${ }^{145}$

De rechter heeft de bevoegdheid meer dan het minimumbedrag te vergoeden. Reden hiervoor kan zijn de ingewikkeldheid van de zaak en de (bovengemiddelde hoeveelheid) tijd die de advocaat er dientengevolge aan heeft moeten besteden. Het is ook mogelijk extra kosten - zoals reis- en kopieerkosten - vergoed te krijgen. Een verzoek tot vergoeding van dergelijke extra uitgaven dient uiteraard te worden gedocumenteerd (door overlegging van bonnen et cetera). ${ }^{146}$ Het blijkt in de praktijk echter niet gebruikelijk te zijn dat meer dan het minimumbedrag wordt gegeven en ook de vergoeding van gemaakte kosten is allesbehalve vanzelfsprekend.

De kosten van toegevoegde rechtsbijstand komen in beginsel voor rekening van de staat. In gevallen van verplichte rechtsbijstand is het mogelijk dat de verdachte

verleende rechtsbijstand die door de overheid worden vergoed (Rozporządzenie Ministra Sprawiedliwości w sprawie optat za czynnosći adwokackie oraz ponoszenia przez Skarb Państwa kosztów nieopłaconej prawnej udzielonej z urzędu). Hierna aangegeven als Besluit kosten rechtsbijstand 2002.

141 Art. 14 lid 1 Besluit kosten rechtsbijstand 2002.

142 Art. 14 lid 2 Besluit kosten rechtsbijstand 2002.

143 Art. 14 lid 3 Besluit kosten rechtsbijstand 2002. Voor het optreden in de cassatiefase gelden dus relatief hoge vergoedingen: ten eerste voor het opstellen en indienen van een cassatieschriftuur en vervolgens voor de behandeling van de zaak voor het Hooggerechtshof. Voor activiteiten in de fase van tenuitvoerlegging gelden afzonderlijke bedragen die hier verder buiten beschouwing zullen blijven.

144 Art. 16 Besluit kosten rechtsbijstand 2002.

145 Art. 17 Besluit kosten rechtsbijstand 2002.

146 Art. 19 sub 2 en art. 20 Besluit kosten rechtsbijstand 2002. 
- wanneer hij schuldig wordt bevonden - de kosten van de toegevoegde rechtsbijstand alsnog zelf moet betalen. Dit komt in de praktijk echter zelden voor. ${ }^{147}$

\subsection{Situatie voor inwerkingtreding van het nieuwe strafprocesrecht}

Ook het wetboek van strafvordering van voor 1989 voorzag in een aantal gevallen van verplichte rechtsbijstand. Het huidige art. 79 en 80 KPK 1997 komt in grote lijnen overeen met de regeling van 1969 maar vertoont ook een aantal belangrijke verschillen. Gronden voor verplichte rechtsbijstand waren het feit dat:

- de verdachte doof stom of blind was (art. 70 lid 1 sub 1 KPK 1969),

- er gerechtvaardigd werd getwijfeld aan zijn geestelijke gezondheid (art. 70 lid 1 sub 2 KPK 1969) en

- zijn zaak in eerste aanleg werd behandeld door de provinciale rechtbank (art. 71 eerste zin KPK 1969).

Minderjarigheid en de aanwezigheid van omstandigheden die de verdediging bemoeilijken, werden in het wetboek van strafvordering van 1969 niet als grond voor verplichte rechtsbijstand genoemd en zijn dus nieuw in het huidige strafprocesrecht. Met name de 'omstandigheden die de verdediging bemoeilijken' is een belangrijke uitbreiding omdat het een restcategorie vormt die de rechter de mogelijkheid biedt zelf te bepalen dat bijstand van een advocaat noodzakelijk is.

De derde grond voor verplichte rechtsbijstand (zaak in eerste aanleg behandeld door provinciale rechtbank) was in het wetboek van strafvordering van 1969 ruimer dan vandaag de dag. Momenteel is het feit dat een zaak in eerste aanleg voor de provinciale rechtbank dient immers niet meer voldoende: er dient tevens een strafbaar feit te zijn tenlastegelegd waarop ten minste drie jaar gevangenisstraf staat (zbrodnia) of de verdachte dient van zijn vrijheid te zijn beroofd. Wanneer geen van deze twee aanvullende voorwaarden zich voordoet, is rechtsbijstand niet dwingend voorgeschreven en hoeft de rechter dus geen advocaat toe te voegen wanneer geen gekozen raadsman optreedt. ${ }^{148}$

Samenvattend kan worden gesteld dat de gevallen van verplichte rechtsbijstand bij de totstandkoming van het nieuwe wetboek van strafvordering aanvankelijk zijn uitgebreid maar dat de wetswijziging van juli 2003 - vanuit overwegingen van efficiëntie en kostenbesparing - de regeling weer op verschillende punten aanzienlijk heeft ingeperkt. Met betrekking tot 79 en art. 80 KPK 1997 zijn in 2003 immers de volgende (eerder genoemde) veranderingen doorgevoerd:

- het niet beheersen van de Poolse taal is niet langer een zelfstandige grond voor verplichte rechtsbijstand,

- de toevoeging kan worden ingetrokken wanneer blijkt dat ten onrechte is getwijfeld aan de geestelijke gezondheid van verdachte,

- deelname van een raadsman aan de laatste inzage voor sluiting van het vooronderzoek is in geval van verplichte rechtsbijstand op grond van art. 79 niet langer verplicht en

147 Monitoring Report 2003, p. 102. Wanneer een toevoeging is verleend op grond van de financiële situatie van verdachte (art. 78 KPK 1997) is een dergelijk verhaal in geval van veroordeling uiteraard niet mogelijk.

148 Zie eerder § 3.1.1. 
- indien een toevoeging is gebaseerd op het feit dat de zaak in eerste aanleg voor de provinciale rechtbank dient èn het feit dat verdachte van zijn vrijheid is beroofd, komt deze te vervallen op het moment dat de verdachte in vrijheid wordt gesteld.

Ook wat de toegevoegde rechtsbijstand op verzoek van verdachte betreft, geldt dat het huidige art. 78 KPK 1997 in grote lijnen overeenkomt met de regeling van het wetboek van 1969: de verdachte zonder gekozen raadsman kon om toevoeging van een advocaat verzoeken waarbij hij moest aantonen dat hij de kosten van de verdediging niet zelf kon dragen zonder daarmee nadeel toe te brengen aan zijn eigen noodzakelijke levensonderhoud en dat van zijn familie (art. 69 KPK 1969). De huidige bepaling vertoont slechts op twee punten verschillen met haar voorganger. Ten eerste is aan art. 78 KPK 1997 toegevoegd dat de verdachte 'op passende wijze' ('w sposób należyty') dient aan te tonen dat hij de advocaatkosten niet zelf kan betalen. Hiermee heeft de wetgever blijkbaar willen benadrukken dat aan het verzoek van de verdachte bepaalde eisen mogen worden gesteld. Gezien de vaagheid van de gebruikte bewoordingen - die nergens nader zijn uitgewerkt heeft deze toevoeging echter nauwelijks toegevoegde waarde.

Het tweede punt waarop de huidige regeling zich onderscheidt van de oude situatie is het feit dat een reeds verleende toevoeging in de loop van de procedure kan worden ingetrokken wanneer blijkt dat deze ten onrechte is verleend of (sinds de wijziging van juli 2003) wanneer verdachte's situatie zodanig is veranderd dat de hij de kosten zelf kan gaan dragen. Het wetboek van 1969 regelde deze kwestie niet: in art. 69 was slechts vastgelegd onder welke voorwaarden een toevoeging kon worden verleend, niet hoe deze kon worden opgeheven.

\subsection{Evaluatie juridisch kader}

De wettelijke regeling van toegevoegde rechtsbijstand overziend, kan worden geconcludeerd dat voor de ambtshalve toevoeging (art. 79 en 80 KPK 1997) redelijk duidelijke criteria zijn gesteld terwijl de toevoeging op verzoek van verdachte (art. 78 KPK 1997) nogal wat vragen oproept. De huidige regeling van toevoeging op verzoek van verdachte verschilt nauwelijks van de regeling in het oude wetboek van strafvordering. De wetgever heeft de gelegenheid van het nieuwe wetboek van strafvordering dus niet benut om de onduidelijke en te beknopte bepaling (destijds art. 69 KPK 1969) opnieuw vorm en inhoud te geven. In art. 78 KPK 1997 is weliswaar geregeld dat de verdachte 'op passende wijze' moet aantonen dat hij niet in staat is de kosten van de verdediging te dragen maar nergens is uitgewerkt aan welke eisen een verzoek van verdachte moet voldoen om in aanmerking te kunnen worden genomen. Hierdoor is onduidelijk in welke vorm de aanvraag moet geschieden (kan het bijvoorbeeld alleen schriftelijk of mag het ook mondeling?) en op welke wijze de aanvraag moet worden gemotiveerd en/of gedocumenteerd. Min of meer vanzelfsprekend is dat de verdachte zijn stelling dat hij de kosten van de verdediging niet zelf kan dragen met schriftelijke bewijsstukken zal moeten staven maar welke documenten daarbij overgelegd moeten worden en hoe een gedetineerde verdachte daarover de beschikking kan krijgen, is niet duidelijk. ${ }^{149}$ Wel is wettelijk geregeld dat de rechter een onvol-

149 Grzegorczyk leidt uit het woord 'należyte' ('passende' in 'op passende wijze') af dat het in ieder geval om schriftelijke stukken moet gaan: Grzegorczyk 2004, p. 274. 
doende of niet op de juiste wijze gedocumenteerd verzoek niet zonder meer mag afwijzen. Wanneer de verdachte omstandigheden heeft aangevoerd die weliswaar niet uit bijgevoegde documenten blijken maar wel tot een positieve beslissing zouden kunnen leiden indien het bestaan ervan zou worden aangetoond, dient de rechter een termijn te stellen waarbinnen de verdachte de aanvraag alsnog kan aanvullen. ${ }^{150}$ Wanneer deze termijn ongebruikt verstrijkt of twijfel bestaat over de wijze waarop verdachte heeft aangetoond dat hij niet in staat is de kosten van de verdediging zelf te dragen, dient de zaak naar de zitting te worden verwezen zodat de kwestie daar kan worden behandeld. Volgens een rapport van de HFHR over kosteloze rechtsbijstand in Polen wordt deze verplichting in de praktijk echter niet of nauwelijks nageleefd. ${ }^{151}$ Zoals Grzegorczyk terecht opmerkt en in de rechtspraak is bevestigd, komt een dergelijke handelwijze er feitelijk op neer dat de verdachte zijn recht op rechtsbijstand wordt ontnomen. ${ }^{152}$

Behalve dat niet duidelijk is hoe een verzoek moet worden ingediend, is ook het criterium voor het al dan niet inwilligen ervan zeer vaag. Zoals gezegd, is volgens art. 78 KPK 1997 bepalend of de verdachte de kosten van de verdediging zelf kan dragen 'zonder daarmee nadeel toe te brengen aan zijn eigen noodzakelijke levensonderhoud en dat van zijn familie'. Nu de wetgever deze norm niet nader heeft gepreciseerd - door bijvoorbeeld een minimum jaarinkomen vast te stellen waarbij een verdachte in ieder geval in aanmerking zou moeten komen voor gefinancierde rechtsbijstand - is de beoordelingsvrijheid van de rechter op dit punt heel groot terwijl tegen een afwijzende beslissing geen rechtsmiddel openstaat. Zoals hierna in $\S 3.4$.1 zal worden uiteengezet, leidt dit tot een uiterst grillige praktijk waarbij verdachten moeilijk kunnen inschatten of hun verzoek kans van slagen heeft.

150 Deze verplichting is vastgelegd in art. 284 lid 1 van een verordening van de minister van Justitie inzake de interne organisatie van gewone rechterlijke instanties d.d. 23 februari 2007 (Rozporządzenie Ministra Sprawiedliwości Regulamin urzędowania sądów powszechnych).

151 Country Report 2002. Dit landenrapport is het resultaat van een grootschalig project getiteld 'Promoting Access to Justice in Central and Eastern Europe' dat door Public Interest Law Initiative (PILI, Columbia Law School) in samenwerking met verschillende non-gouvernementele organisaties zoals de Polish Helsinki Foundation for Human Rights is uitgevoerd. In het kader van dit project waarbij onderzoek werd gedaan naar (de noodzaak tot hervorming) van systemen van kosteloze rechtsbijstand in landen van Centraalen Oost-Europa zijn in Boedapest twee internationale bijeenkomsten gehouden (European Forum on Access to Justice in juni 2002 en Second European Forum on Access to Justice in februari 2005). Landenrapporten, verslagen van genoemde bijeenkomsten en andere relevante publicaties die betrekking hebben op het project zijn te raadplegen via: <www. pili.org/>. Het Country Report 2002 dat voor het eerst werd gepresenteerd op de bijeenkomst in Boedapest 2002 is later - in 2003 - in meer uitgebreide vorm door de Helsinki Foundation of Human Rights uitgegeven onder de titel Access to Legal Aid in Poland: Monitoring Report (eerder genoemd Monitoring Report 2003). Omdat de inhoud van beide documenten voor een belangrijk deel overeenkomt zal hierna in beginsel alleen naar laatstgenoemd rapport worden verwezen. Wanneer gegevens worden vermeld die alleen in het Country Report terug te vinden zijn, zal dat apart worden vermeld.

152 Grzegorczyk 2004, p. 276 en daar genoemde uitspraak van Hooggerechtshof 8 september 1996, III KKN 67/96, Wokanda 1-2, 1997, p. 8. 


\subsection{Kosteloze rechtsbijstand in de praktijk}

$\mathrm{Nu}$ de relevante wettelijke kaders in kaart zijn gebracht, zal in deze paragraaf aandacht worden besteed aan de vraag hoe het systeem van kosteloze rechtsbijstand in de praktijk functioneert.

\subsubsection{Behandeling van verzoeken}

Eerder is al benadrukt dat het wettelijke criterium voor de vraag of een verdachte in aanmerking dient te komen voor kosteloze rechtsbijstand uiterst vaag is waardoor de rechter bij het nemen van deze beslissing veel beoordelingsvrijheid heeft. Het feit dat voor de beoordeling van een verzoek op grond van art. 78 lid 1 KPK 1997 geen heldere richtlijnen bestaan, creëert ruimte om ook andere factoren mee te laten wegen in de besluitvorming. In dit verband is met name van belang dat de toegevoegde rechtsbijstand uit een algemeen budget van de rechtbank moet worden betaald waardoor de beslissing van de rechter wordt beïnvloed door de beperkingen van deze doorgaans krappe begroting en mogelijk dus niet alleen rekening wordt gehouden met de financiële situatie van de verdachte maar ook met die van de overheid. ${ }^{153}$ In de woorden van respectievelijk Bojarski en Rekosh:

'In the present financial situation of the administration of justice, when deciding about granting legal aid, courts when forced to make savings may be led by considerations not related to the merits but rather of a financial nature. 154

'Finances play a large role. The justice systems are generally resource-poor, aggravated by the tendency to lump legal aid funding together in the same budgetary pool with court administration. As one Polish judge put it starkly in a survey conducted by the Polish Helsinki Foundation for Human Rights, the president of his court gave the judges a choice: decrease legal aid or wear their coats in the courtroom in the coming winter.' 155

Bovendien is onduidelijk welke gegevens een rol mogen spelen bij de beoordeling van een verzoek om gefinancierde rechtsbijstand. Uit onderzoek van de HFHR blijkt dat sommige rechters ook de financiële situatie van familieleden - zoals grootouders - meenemen in hun beoordeling. Tevens komt het voor dat niet alleen naar de huidige toestand van verdachte wordt gekeken maar ook naar zijn arbeidsverleden waardoor het bijvoorbeeld mogelijk is dat bij een verdachte die

153 Uit genoemd budget (voor 'kosten van procedures voor rechterlijke instanties en de prokuratura') dienen behalve de vergoedingen voor toegevoegde advocaten een groot aantal andere kosten te worden betaald. Hierbij moet bijvoorbeeld gedacht worden aan kosten die gemaakt worden bij een schouw (plaatsopneming door de rechtbank), voor het transport van een verdachte naar de rechtbank, voor getuigen en deskundigen, het uitbrengen van dagvaardingen en andere officiële stukken, het geven van persvoorlichting et cetera. Zie: Monitoring Report 2003, p. 45.

154 Bojarski 2003, p. 431. Hij voegt daaraan toe dat uit door rechters verstrekte gegevens blijkt dat '(...) the problem of lack of funds and a motion from persons managing courts to limit any expenses, including for legal aid, has been constantly present' (p. 434).

155 Rekosh 2002. Genoemde tendens is tijdens mijn verblijf in Lublin ook bevestigd door een rechter van de districtsrechtbank van Puławy (omgeving Lublin) die - op mijn vraag naar de praktijk ten aanzien van toevoeging binnen zijn rechtbank - antwoordde dat vanwege het beperkte budget slechts een klein deel van de verzoeken om kosteloze rechtsbijstand kan worden ingewilligd (ongeveer 10\%). Alleen verdachten met zeer slechte financiële omstandigheden komen hierdoor voor kosteloze rechtsbijstand in aanmerking. 
gedurende zijn strafzaak geen inkomsten heeft, wordt meegewogen dat hij tot voor kort wel een inkomen heeft gehad. ${ }^{156}$

Ook de vraag of bijstand van een advocaat in de betreffende zaak naar het oordeel van de rechter noodzakelijk is, kan een rol spelen in de beslissing over de toevoeging van kosteloze rechtsbijstand. Een rechter van de districtsrechtbank in Poznań gaf aan van mening te zijn dat veel van zijn collega's verzoeken om kosteloze rechtsbijstand afwijzen vanuit de overtuiging dat het aandeel van een advocaat geen toegevoegde waarde voor de zaak zal hebben of misschien zelfs ongewenste vertraging van de procedure kan opleveren. Het standpunt van de rechter in Poznań is uiteraard slechts een enkele persoonlijke mening waaraan geen algemene conclusies mogen worden verbonden maar feit is wel dat het ontbreken van heldere criteria voor de toekenning van gefinancierde rechtsbijstand in ieder geval het risico creëert dat dit soort argumenten worden meegewogen bij de beslissing over toekenning van gefinancierde rechtsbijstand. ${ }^{157}$ Dat terwijl daarvoor geen wettelijke grondslag bestaat (volgens art. 78 lid 1 KPK 1997 moet immers alleen de financiële situatie van verdachte in aanmerking worden genomen) en tegen een afwijzende beslissing geen rechtsmiddel openstaat. In rechtspraak van het Hooggerechtshof wordt wel benadrukt dat de rechter zijn beslissingen op dit punt dient te motiveren maar het ontbreken van duidelijke wettelijke criteria stimuleert de rechter niet tot het benoemen van de specifieke omstandigheden die tot afwijzing van het verzoek hebben geleid. Met de constatering dat niet is komen vast te staan dat de verdachte niet in staat is 'de kosten van de verdediging te dragen zonder daarmee nadeel toe te brengen aan zijn eigen noodzakelijke levensonderhoud en dat van zijn familie' kan in beginsel worden volstaan. Dat de rechter zich niet genoodzaakt voelt zijn beslissing te motiveren, wordt nog verder versterkt door het feit dat verdachten tegen afwijzing van hun verzoek geen rechtsmiddel kunnen instellen. ${ }^{158}$

\subsubsection{Kosteloze rechtsbijstand in het vooronderzoek}

Het recht op verdediging waaronder het recht op kosteloze rechtsbijstand strekt zich ook uit over het vooronderzoek. ${ }^{159}$ Dit vloeit voor wat betreft de toevoeging

156 Monitoring Report 2003, p. 100-108. Met betrekking tot deze praktijk wordt in genoemd rapport terecht opgemerkt dat de wetgever in art. 78 KPK 1997 niet voor niets de tegenwoordige tijd heeft gehanteerd: '(...) indien hij op passende wijze aantoont, dat hij niet in staat is [decurs. DdV] de kosten van de verdediging te dragen zonder daarmee nadeel toe te brengen aan zijn eigen noodzakelijke levensonderhoud en dat van zijn familie.' Hieruit mag worden afgeleid dat de financiële situatie van verdachte moet worden beoordeeld zoals die is op het moment van de aanvraag en dus alleen actuele gegevens mogen worden meegewogen (p. 105).

157 Wat nogmaals onderstreept dat het problematisch kan zijn de beslissing over kosteloze rechtsbijstand aan de zittingsrechter over te laten. Zie eerder §3.1.3.2.

158 Daniuk e.a. 2006, p. 17. Zoals eerder besproken, is de enige mogelijkheid om in hoger beroep aan te voeren dat in eerste aanleg ten onrechte geen raadsman is toegevoegd. Het voeren van een succesvol verweer op dit punt is - juist wanneer geen professionele rechtsbijstand wordt genoten - echter niet eenvoudig. De verdachte moet immers aannemelijk maken dat bijstand van een raadsman zeer waarschijnlijk tot een andere uitspraak zou hebben geleid: zie § 3.1.2 en daar genoemde rechtspraak van het Hooggerechtshof.

159 Zie hoofdstuk 2, § 3.1.3.2 en hoofdstuk 4, § 2 . 
op verzoek van verdachte voort uit art. 78 lid 1 jo. 71 lid 3 KPK 1997: een verzoek om toevoeging kan worden ingediend door eenieder die de status van verdachte (of beschuldigde) heeft. De aangehoudene die nog niet als verdachte is aangemerkt, komt niet in aanmerking voor gefinancierde rechtsbijstand. Hij kan zijn rechten in het kader van art. 245 lid 1 KPK 1997 (contact en persoonlijk overleg met advocaat) dus alleen verwezenlijken wanneer hij zelf in deze kosten kan voorzien. Deze situatie is terecht bekritiseerd door het CPT:

'For as long as there is not an effective system of free legal aid for indigent persons at the stage of police custody, any right of access to a lawyer will remain, in most cases, purely theoretical.' 160

Of een verdachte gedurende het vooronderzoek een verzoek om gefinancierde rechtsbijstand indient, is uiteraard afhankelijk van de vraag of hij van deze mogelijkheid op de hoogte is. Volgens het huidige strafprocesrecht zijn de autoriteiten weliswaar verplicht de verdachte voorafgaand aan zijn eerste verhoor op de hoogte te stellen van zijn recht gebruik te maken van de bijstand van een raadsman maar in de schriftelijke informatie (zogenaamde letter of rights) die hem in dit verband wordt overhandigd is het recht op kosteloze rechtsbijstand niet met zoveel woorden genoemd. ${ }^{161}$ Wanneer wordt volstaan met de overhandiging van dit (standaard) formulier en mondeling geen aanvullende informatie wordt verstrekt, wordt de verdachte niet geïnformeerd over de mogelijkheid de rechter om toevoeging te verzoeken. Er bestaat voor de politie dus geen algemene wettelijke verplichting om de verdachte voorafgaand aan zijn verhoor op de hoogte te stellen van de mogelijkheid een advocaat toegevoegd te krijgen of - belangrijker nog - van de wijze waarop het recht op kosteloze rechtsbijstand kan worden geëffectueerd. ${ }^{162}$ Op grond van een verordening van de minister van Justitie geldt onder bepaalde omstandigheden wel een inlichtingenplicht voor de prokurator:

160 Report CPT 2004, p. 15. Een van de aanbevelingen van het CPT is dan ook om te zorgen voor 'a fully fledged and properly funded system of legal aid for persons in police custody who are not in a position to pay for a lawyer to be developed as a matter of urgency [decurs. DdV], and to be applicable from the very outset of police custody. If necessary, the relevant legislation should be amended'. (p. 62). Zie eerder in dit hoofdstuk § 2.4. De Poolse regering reageert in haar antwoord op het rapport van 2004 als volgt op deze aanbeveling: 'The legal provisions in force (Code of Criminal Procedure) stipulate precisely cases and ways of receiving lawyers services. There are no the so-called "law of poor", however, in a criminal case a party can always have ex officio lawyer aid.' Hieruit lijkt te moeten worden afgeleid dat de regering het gesignaleerde probleem niet erkent en (dus) ook niet van plan is wijzigingen door te voeren op dit punt: Response government report CPT 2004, p. 10.

161 Art. 300 KPK 1997. 'The standardized forms of the records of hearing as well as instructions mention both the legal grounds and the contents of the right or duty concerned, but fail to indicate in a detailed and self-evident manner how the "right to be assisted by a defense counsel"can be exercised in practice, and how a person deprived of liberty can give a lawyer the power of attorney to appear in the case. At this stage of the proceedings, the suspect who is ignorent of legal provisions is not provided with written information about the possibility of applying to the court for appointment of ex officio defense counsel, either': Country Report 2002, p. 34-36, p. 42-43. Zie ook Daniuk e.a. 2006, p. 26-27.

162 Het is overigens de vraag of het ontbreken van een dergelijke specifieke inlichtingenplicht strijd oplevert met het EVRM. In Kornienko t. Polen (ECRM 10-9-1997, nr. 29261/95) werd door klager aangevoerd dat hij ten onrechte niet was geïnformeerd over de mogelijkheid 
'Indien uit de omstandigheden van de zaak blijkt, dat de verdachte niet in staat is de kosten van de verdediging te dragen, dient de prokurator hem op de hoogte te stellen van het recht een verzoek tot toevoeging van een raadsman in te dienen. ${ }^{\prime} 163$

De vraag of een verdachte al dan niet wordt ingelicht over zijn in art. 78 lid 1 KPK 1997 neergelegde recht is volgens deze bepaling dus volledig afhankelijk van het oordeel van de prokurator. Hij beoordeelt immers of sprake is van omstandigheden die een dergelijk verzoek zouden kunnen rechtvaardigen waardoor hij vrij is te bepalen of - en zo ja, op welk moment in het vooronderzoek - de verdachte van genoemd recht op de hoogte wordt gesteld. Deze regel biedt de prokurator die als leider van het vooronderzoek in een vroeg stadium van de procedure mogelijk liever (nog) niet door de bemoeienissen van een advocaat 'gehinderd' zal willen worden - de vrijheid om de verdachte niet in te lichten zolang hij dat wenselijk acht. Bovendien is niet vanzelfsprekend dat de prokurator in iedere strafzaak over voldoende informatie beschikt om zich een deugdelijk oordeel te kunnen vormen over de financiële achtergrond van de verdachte.

Hoewel hierover geen kwantitatieve gegevens beschikbaar zijn, zijn er aanwijzingen dat toevoeging op grond van art. 78 lid 1 KPK 1997 in de fase van het vooronderzoek zeldzaam is. ${ }^{164}$ Het komt wel voor dat verdachten in dit stadium van de procedure bijstand hebben van een toegevoegde raadsman maar dit betreft hoofdzakelijk de gevallen van verplichte rechtsbijstand (art. 79 KPK 1997). In de meeste gevallen zal tijdens het vooronderzoek reeds duidelijk zijn dat sprake is van een van de persoonlijke omstandigheden die verdediging door de verdachte zelf onmogelijk maken. In zo'n geval is de prokurator verplicht onmiddellijk een verzoek tot toevoeging in te dienen bij de rechtbank. ${ }^{165}$ Zelfs wanneer de prokurator zijn verplichtingen op dit punt onverwijld nakomt, vindt de toevoeging in de praktijk doorgaans pas plaats na de zitting over de beslissing tot toepassing van voorlopige hechtenis. ${ }^{166}$

een advocaat toegevoegd te krijgen. De Europese Commissie voor de rechten van de mens verklaarde deze klacht niet ontvankelijk omdat Kornienko voorafgaand aan zijn eerste verhoor schriftelijk op de hoogte was gesteld van de mogelijkheid zelf een advocaat te benoemen wat later mondeling nogmaals werd bevestigd door een tolk: 'Therefore, insofar as Article 6 para. 3 (c) (...) of the Convention may have required that the applicant be informed expressly of his right to free legal assistance, the Commission is satisfied that the applicant was provided with information which was sufficient, at the very least, to prompt to enquire about the possibilities to appoint a lawyer. The applicant does not claim that had he done so, he would not have obtained more detailed information as regards the appointment of ex officio legal counsel or would not have been able to lodge a request for free legal asistance.' De Commissie stelt dus geen vergaande eisen op dit punt en legt een grote eigen verantwoordelijkheid bij de verdachte.

163 Art. 138 lid 1 van een verordening van de minister van Justitie inzake de interne organisatie van de prokuratura d.d. 27 augustus 2007 (Rozporządzenie Ministra Sprawiedliwości regulamin wewnętrznego urzędowania powszechnych jednostek organizacyjnych prokuratury). Zie eerder $\$ 3.1 .2$.

164 Country Report 2002, p. 44-45.

165 Art. 138 lid 2 van een verordening van de minister van Justitie inzake de interne organisatie van de prokuratura d.d. 27 augustus 2007 (Rozporządzenie Ministra Sprawiedliwości regulamin wewnętrznego urzędowania powszechnych jednostek organizacyjnych prokuratury).

166 Daniuk e.a. 2006, p. 34-36. 
Dat het in de praktijk weinig voorkomt dat een advocaat gedurende het vooronderzoek wordt toegevoegd op grond van art. 78 KPK 1997 is ook bevestigd tijdens mijn verblijf in Poznań en Lublin. Advocaten in beide steden en een rechter in Poznań gaven aan zelden of nooit mee te maken dat tijdens het vooronderzoek een advocaat wordt toegevoegd op grond van art. 78 KPK 1997. Wat de oorzaak van deze situatie betreft, is echter onduidelijk of het een gevolg is van het feit dat de meeste verdachten niet op de hoogte zijn van de mogelijkheid (en dus geen verzoek indienen) of dat het gros van de verzoeken wordt afgewezen.

\subsubsection{De kwaliteit van kosteloze rechtsbijstand}

Er bestaan aanwijzingen dat aan toevoegingzaken niet altijd evenveel tijd en aandacht wordt besteed als aan zaken van betalende cliënten. De HFHR ontvangt veel klachten van burgers die ontevreden zijn over hun toegevoegde raadsman. ${ }^{167}$ Veelgehoorde klachten zijn: mijn advocaat neemt geen contact met me op, antwoordt niet op brieven of telefoontjes, komt niet naar de zitting, kent het dossier niet, doet geen voorstellen, informeert me niet, legt moeilijke juridische kwesties en terminologie niet uit of vraagt mij of mijn familie - ondanks dat het om gratis bijstand gaat - toch om een financiële vergoeding voor een handeling of ontmoeting. In dit verband is ook onderzoek van de HFHR van belang waarbij ten behoeve van eerder genoemde rapporten 23 advocaten (uit Kraków en Wałbrzych) zijn ondervraagd over rechtsbijstandverlening in zaken op basis van toevoeging. Vanwege het geringe aantal respondenten kunnen geen algemene conclusies aan de antwoorden worden verbonden maar het is vermeldenswaard dat op de vraag naar de kwaliteit van rechtsbijstand in toegevoegde zaken in vergelijking tot bijstand aan 'betalende' cliënten meer dan de helft van de geïnterviewden aangaf dat het aantal ontmoetingen met de cliënt in zaken op basis van toevoeging gemiddeld lager is dan in 'gewone' zaken. Een vierde van de respondenten gaf bovendien aan dat de kwaliteit minder was voor wat betreft procesactiviteit, frequentie van vervanging en andere professionele handelingen. Een derde van de advocaten vond dat dit (ook) tot uitdrukking kwam in het lezen van het dossier. ${ }^{168}$ Het HFHR heeft aan de hand van vragenlijsten ook onderzoek gedaan naar de tevredenheid van cliënten met de verleende rechtsbijstand. De groep ondervraagden bestond uit twee categorieën: enerzijds gedetineerden wiens strafzaak reeds was beëindigd en anderzijds verdachten wiens procedure nog liep. Eerstgenoemde groep bleek in de waardering van verleende rechtsbijstand geen onderscheid te maken tussen gekozen en toegevoegde advocaten. De tweede groep

167 Bojarski 1999, p. 52-62. Zie ook Daniuk e.a. 2006, p. 51 e.v.

168 Monitoring Report 2003, p. 78. De meningen van de advocaten die ik in Poznań en Lublin heb gesproken, zijn op dit punt verdeeld: een aantal gaf aan in de dagelijkse praktijk geen verschil te maken tussen toegevoegde en 'gewone' zaken terwijl anderen toegaven minder tijd en aandacht aan toevoegingzaken te besteden en bij gelijktijdige zittingen in een zaak van een betalende cliënt en een toevoegingzaak de voorkeur aan de eerste te geven en voor de toevoeging een vervanger te regelen. Een rechter in de regio van Lublin - voorzitter van de afdeling strafrecht van de districtsrechtbank in Krasnystaw - was van mening dat de kwaliteit van rechtsbijstand op basis van toevoeging wel degelijk lager is dan in andere zaken. Een veelgehoord standpunt bij andere rechters was dat er goede en slechte advocaten zijn: de laatste groep is slecht in iedere zaak en een goede advocaat presteert altijd op hoog niveau. 
was echter minder tevreden over de toegevoegde advocaten: 55\% gaf aan tevreden te zijn, 35\% was ontevreden of tamelijk ontevreden - voor wat betreft de zelf gekozen advocaten waren deze percentages respectievelijk $80 \%$ en $15 \%$. Opvallend is ook dat de redenen voor tevredenheid in geval van een gekozen advocaat anders waren dan bij toegevoegde rechtsbijstand. De drie meest genoemde argumenten voor een positieve beoordeling van de gekozen advocaat waren:

1. hij zet zich in/toont betrokkenheid,

2. is goed op de hoogte van de zaak en het dossier en

3. informeert over de ontwikkelingen in de zaak.

In geval van toegevoegde rechtsbijstand was tevredenheid vooral gebaseerd op het feit dat de advocaat:

1. naar de zitting komt,

2. vriendelijk/beleefd is en

3. goed op de hoogte is van de zaak en het dossier.

Volgens Bojarski roept dit de vraag op of uit deze resultaten moet worden afgeleid dat cliënten andere (lagere) verwachtingen hebben van een toegevoegde advocaat en '(...) that the very fact of the ex officio attorney's presence at hearings is worthy of praise?'. ${ }^{169}$

De lagere kwaliteit van kosteloze rechtsbijstand blijkt voornamelijk betrekking te hebben op de fase van het vooronderzoek. Uit gegevens die de HFHR heeft verkregen van de prokuratura en van cliënten die zich tot de organisatie wenden in verband met problemen met hun advocaat blijkt dat in veel zaken die op basis van toevoeging plaatsvinden de eerste ontmoeting tussen advocaat en cliënt pas hetzij tijdens de laatste inzage van de processtukken of - na sluiting van het vooronderzoek - op de eerste zitting plaatsvindt. ${ }^{170}$ Ten aanzien van de laatste inzage van de processtukken geldt dat deze handeling voor juli 2003 in gevallen van verplichte rechtsbijstand op grond van art. 79 KPK 1997 alleen in aanwezigheid van de raadsman mocht plaatsvinden: de advocaat was dus verplicht te verschijnen waardoor de eerste ontmoeting met de cliënt vaak bij deze gelegenheid (vlak voor sluiting van het vooronderzoek) was. ${ }^{171} \mathrm{Nu}$ deze verplichting door de wetswijziging van juli 2003 is komen te vervallen, is de raadsman nog wel bevoegd maar niet langer verplicht aan deze of enige andere handeling gedurende het vooronderzoek deel te nemen. Mogelijk dat deze wijziging tot gevolg heeft dat het eerste contact tussen raadsman en cliënt (nog) vaker niet in het vooronderzoek maar pas op het onderzoek ter terechtzitting plaatsvindt. ${ }^{172}$

Voor de effectiviteit van rechtsbijstand is uiteraard ook van belang op welk moment en binnen welke termijn een toevoeging gedurende het vooronderzoek wordt gerealiseerd. Dat is in geval van verplichte rechtsbijstand in de eerste plaats afhankelijk van de vraag hoe snel de prokurator een verzoek tot toevoeging indient bij de rechtbank. Bij toevoeging op verzoek van verdachte is uiteraard bepalend

169 Monitoring Report 2003, p. 125-126.

170 Monitoring Report 2003, p. 94.

171 Art. 321 lid 3 KPK 1997 voor genoemde wetswijziging. Zie ook § 3.1.1 en hoofdstuk 5, § 3.2.2.

172 Monitoring Report 2003, p. 94. 
of - en zo ja op welk moment in de procedure - de verdachte wordt geïnformeerd over de mogelijkheid een dergelijk verzoek in te dienen. ${ }^{173}$ Vervolgens is in beide situaties van belang hoe veel tijd verstrijkt voordat een advocaat wordt toegevoegd. De advocaat wordt schriftelijk op de hoogte gesteld van zijn benoeming en hij kan pas aan de slag wanneer hij dit bericht van de rechtbank heeft ontvangen. Hiermee kunnen enkele dagen verloren gaan. In het kader van het onderzoek van de HFHR is door de ondervraagde advocaten (als een van de tekortkomingen van het huidige systeem) aangegeven dat rechters in de praktijk soms verzuimen de adresgegevens of plaats van detentie van de cliënt te vermelden wat vanzelfsprekend extra vertraging oplevert. Met name in het vooronderzoek en in het geval van een gedetineerde verdachte kunnen dit essentiële dagen zijn waarin de verdachte feitelijk is verstoken van rechtsbijstand.

Voor de aanvang van de gefinancierde rechtsbijstand is ten slotte natuurlijk van belang hoe snel de toegevoegde advocaat na ontvangst van bovengenoemde brief uiteindelijk actie onderneemt. ${ }^{174}$

Overigens dient wat de kwaliteit van rechtsbijstand in het vooronderzoek betreft, te worden opgemerkt dat passiviteit van advocaten in het vooronderzoek een verschijnsel is dat zich niet alleen in zaken op basis van toevoeging voordoet: het is een algemene tendens die ook kan worden geconstateerd in strafzaken waarin de advocaat door zijn cliënt wordt betaald. In hoofdstuk 5 wordt hier op teruggekomen.

Voor de vermoede lagere kwaliteit van rechtsbijstand in toevoegingszaken kunnen verschillende mogelijke oorzaken worden genoemd. De belangrijkste zullen in het onderstaande worden besproken.

\subsubsection{Hoge werklast en vervanging}

In de eerste plaats speelt de gemiddeld hoge werklast van de advocatuur ongetwijfeld een rol. Het aantal advocaten in Polen is ten opzichte van het aantal inwoners relatief laag: er zijn circa 5.500 actieve advocaten in verhouding tot 39 miljoen inwoners. ${ }^{175}$ Voor de volledigheid dient er wel op te worden gewezen dat het aantal juridisch adviseurs - die ook een belangrijk deel van de rechtsbijstandverlening voor hun rekening nemen - vele malen groter is. Het aandeel van juridisch adviseurs in strafzaken is echter uiterst beperkt: ze zijn alleen bevoegd op te treden in overtredingzaken. Formeel bestaat de mogelijkheid dat ze in dergelijke zaken worden toegevoegd maar dit gebeurt zelden tot nooit zodat hun bijdrage aan het verlenen van kosteloze rechtsbijstand in strafzaken verwaarloosbaar is. Deze verplichting komt dus vrijwel geheel voor rekening van de advocatuur die de laatste jaren ook nog geconfronteerd wordt met een groeiend aantal

173 Zie eerder $\S 3.1 .2$.

174 Ter illustratie: uit gesprekken met een advocaat in Poznań bleek dat hij - wanneer hij een dergelijke kennisgeving van toevoeging ontvangt - in de regel een brief stuurt naar de cliënt waarin hij zijn gegevens vermeldt zodat laatstgenoemde met hem contact op kan nemen. Volgens de betreffende advocaat hoort hij in veel gevallen dan niets meer van de cliënt. Op deze wijze wordt het initiatief weer bij de cliënt gelegd voor wie het leggen van contact - met name wanneer hij van zijn vrijheid is beroofd - vaak minder eenvoudig is. Bovendien gaat met het schrijven en verzenden van de brief aan de cliënt wederom kostbare tijd verloren.

175 Zie uitgebreider over het aantal advocaten in Polen: hoofdstuk 8, § 2.4.2.1. 
strafzaken dat aanvankelijk nauwelijks werd gecompenseerd door een evenredige toename van het aantal advocaten. Ter illustratie: tussen 1997 en 2002 is het aantal strafzaken dat jaarlijks door de gewone rechterlijke instanties wordt behandeld meer dan verdubbeld (van 762.000 in 1997 tot 1.862.000 in 2002) terwijl het aantal leden van de balie in dezelfde periode niet noemenswaardig is toegenomen: van 7.260 (1997) tot 7.449 (2002). ${ }^{176}$

Individuele advocaten geven aan van mening te zijn dat ze te veel toevoegingen hebben. Uit eerdergenoemd onderzoek van de HFHR blijkt dat de 23 ondervraagde advocaten gemiddeld 40 zaken (zowel straf-, civiel als - zij het in mindere mate - bestuursrecht) per jaar op basis van toevoeging doen wat neerkomt op ongeveer $30 \%$ van het totaal aantal zaken dat jaarlijks wordt behandeld. Van de respondenten vond een grote meerderheid van 18 advocaten het aantal toevoegingzaken te hoog: op de vraag hoeveel zaken zij wel zouden kunnen of willen doen werd gemiddeld het aantal 27 genoemd. ${ }^{177}$

De hoge werkdruk heeft logischerwijze gevolgen voor de tijd en aandacht die aan toevoegingzaken kan worden besteed. Omdat de hoge werklast regelmatig tot conflicterende verplichtingen leidt, komt het veel voor dat voor optreden in toevoegingzaken een vervanger wordt geregeld. ${ }^{178}$ Hoezeer dit vanuit praktisch oogpunt ook te begrijpen is (een advocaat kan immers niet op twee zittingen tegelijk aanwezig zijn): het kan een nadelig effect hebben op de kwaliteit van de kosteloze rechtsbijstand. Om te beginnen is de waarnemende advocaat vaak een minder ervaren collega (meestal een jonge advocaatstagiaire van het eigen of een bevriend kantoor). Hoewel deze beginnende advocaten doorgaans gemotiveerd zullen zijn om zich van hun beste kant te laten zien, kan hun gebrek aan ervaring wel degelijk gevolgen hebben voor de wijze waarop de zaak wordt behandeld. Veel is daarbij afhankelijk van de voorbereiding en begeleiding door de advocaat van wie de zaak wordt overgenomen waarbij natuurlijk geldt dat ook dat veel kostbare tijd in beslag neemt.

Het overdragen van een toevoegingzaak aan een minder ervaren collega betreft meestal incidentele vervanging: slechts op de momenten waarop de oorspronkelijk toegevoegde advocaat (die de zaak onder zijn hoede houdt en dus eindverantwoordelijke blijft) verhinderd is, treedt de vervanger op. Het spreekt voor zich dat een dergelijke gang van zaken - zeker wanneer het vaker in een zaak voorkomt - weinig stabiliteit en zekerheid voor de cliënt biedt wat uiteindelijk weer ten koste kan gaan van de vertrouwensrelatie die hij met zijn raadsman heeft of in ieder geval zou moeten hebben. ${ }^{179}$ Bovendien mag worden aangenomen dat

176 Monitoring Report 2003, p. 51 en 54. De beperkte groei van het aantal advocaten heeft alles te maken met het (vroegere) beleid van de balie ten aanzien van toetredingen dat de laatste jaren een belangrijk onderwerp van discussie is geweest. Op dit thema wordt teruggekomen in hoofdstuk 8.

177 Monitoring Report 2003, p. 76. Drie advocaten gaven aan meer toevoegingen te kunnen behandelen en twee vonden het huidige aantal precies goed.

178 Hierbij moet echter niet worden vergeten dat ook in 'gewone' zaken regelmatig vervangers optreden. Zie ook Wiliński 2006, p. 632 die overigens wel opmerkt dat in dit verband de laatste jaren een verandering lijkt te kunnen worden geconstateerd: advocaten tonen meer interesse voor het optreden in zaken op basis van toevoeging.

179 Wiliński 2006, p. 325-326. 
de vervanger in de regel minder goed op de hoogte zal zijn van de ins en outs van de zaak dan de toegevoegde advocaat die de zaak normaliter behandelt.

Naast incidentele vervanging komt het ook voor dat een toegevoegde zaak volledig wordt overgedragen aan een collega, bijvoorbeeld wanneer de oorspronkelijk aangewezen advocaat van mening is dat hij niet (voldoende) gekwalificeerd is om de betreffende zaak te behandelen. Zoals besproken, houdt de rechter bij de beslissing tot toevoeging in beginsel geen rekening met de specialisaties van advocaten. Als gevolg hiervan kan een advocaat met weinig kennis van en ervaring in het strafrecht een ingewikkelde strafzaak toegewezen krijgen. Sommige advocaten lossen dit op door de zaak - meestal tegen betaling - over te dragen aan een collega die wel bekwaam is in het strafrecht (het zogenaamde 'selling off' van toevoegingen). ${ }^{180}$

\subsubsection{Rol van de balie in het toevoegingstelsel}

Ook de wijze waarop het toevoegingstelsel is georganiseerd, is mogelijk van invloed op de kwaliteit van de verleende rechtsbijstand. Zoals eerder is beschreven, heeft de balie in strafzaken immers geen aandeel in de beslissing op de vraag of toevoeging noodzakelijk is en - zo ja - welke advocaat moet worden toegewezen: de beslissing over toevoeging, de keuze voor een bepaalde advocaat en zijn benoeming en honorering behoren allemaal tot de verantwoordelijkheid van de rechterlijke macht. Mogelijk dat de advocatuur het verlenen van kosteloze rechtsbijstand aan onvermogende verdachten hierdoor meer beschouwd als een door de overheid opgelegde verplichting dan als een maatschappelijke taak die onlosmakelijk met het beroep van advocaat is verbonden. Dat eerstgenoemde opvatting onder advocaten leeft, werd pijnlijk duidelijk toen een cliënt die eerst bij de HFHR had geklaagd over het optreden van zijn toegevoegde raadsman, op aanraden van laatstgenoemde organisatie een brief had geschreven aan de lokale balie. De cliënt - die zich in voorlopige hechtenis bevond en onder andere aanvoerde dat zijn advocaat hem nog nooit had bezocht, zijn telefoontjes en brieven niet beantwoordde en op geen van de zes zittingen was verschenen - kreeg een korte schriftelijke reactie van de deken die als volgt begon:

'Responding to your letter (...) I would suggest that you should address your question ("what is ex officio defense for?") directly at the legislators. As it has been they who, in

180 Ter illustratie: tijdens het Legal Aid Forum in het Poolse Parlement in juni 2002 (een meer nationaal gerichte bijeenkomst in het kader van eerder genoemd Access to Justice Project) gaf een in het civiel recht gespecialiseerde advocate uit Poznań aan veel moeite te hebben met de strafzaken die ze regelmatig krijgt toebedeeld. Vanwege het feit dat ze zich niet voldoende gekwalificeerd acht om strafzaken te behandelen, zoekt ze telkens een collega die tegen betaling de zaak van haar wil overnemen. Dit kost haar naar eigen zeggen jaarlijks ongeveer 15.000 złotych (circa 4000 euro) terwijl ze als vergoeding van de overheid tussen de 2000 en 3000 złotych (circa 535 tot 800 euro) ontvangt. Het resterende bedrag komt daarmee voor rekening van het kantoor: Monitoring Report 2003, p. 85-86. Het feit dat zaken ondanks de financiële gevolgen toch worden overgedragen aan een collega dient positief te worden uitgelegd: het geeft immers blijk van een gevoel van verantwoordelijkheid voor de kwaliteit van rechtsbijstand. Toch kan het niet de bedoeling zijn dat een advocaat door gebrek aan kennis van en ervaring met een bepaald rechtsgebied feitelijk gedwongen wordt een grotere financiële bijdrage te leveren aan de gefinancierde rechtsbijstand dan de overheid. 
provisions on criminal procedure, burdened lawyers with that undoubtedly toilsome duty [decurs. DdV].' 181

Hoewel deze uitspraak slechts aan de betreffende deken kan worden toegeschreven en niet als officieel standpunt van de balie mag worden beschouwd, is het toch merkwaardig dat een dergelijke opmerking wordt gemaakt in een formele reactie op een serieuze klacht.

Overigens dient te worden opgemerkt dat de problematiek van het huidige systeem van kosteloze rechtsbijstand de balie zeker niet koud laat. Niet voor niets is in 2002 op landelijk niveau van de balie een werkgroep opgericht die zich met dit thema bezighoudt. Doel van deze werkgroep is het onderzoeken van mogelijke hervormingen van het huidige stelsel. Er is in dit verband reeds veel onderzoek verricht naar de voor- en nadelen van systemen die in andere landen worden gehanteerd maar voor zover bekend heeft de balie tot op heden geen concrete voorstellen tot hervorming gepresenteerd.

\subsubsection{Ontbreken effectieve kwaliteitscontrole}

De lage(re) kwaliteit van rechtsbijstand in toevoegingzaken wordt mogelijk ook in stand gehouden door een gebrek aan effectieve kwaliteitscontrole. Op grond van art. 20 KPK 1997 kan de rechter een klacht indienen bij de balie wanneer een advocaat zijn verplichtingen in het strafproces overduidelijk schendt. Een dergelijke klacht ${ }^{182}$ kan resulteren in een tuchtrechtelijke procedure. Uit gesprekken die de HFHR met rechters heeft gevoerd, blijkt echter dat van deze mogelijkheid nauwelijks gebruik wordt gemaakt. De ondervraagde rechters waren over het algemeen van mening dat een dergelijke actie weinig zin heeft omdat de balie er in de regel toch niet adequaat op reageert. ${ }^{183}$ Hermelinski - voormalig advocaat, vicepresident van de balie en momenteel rechter bij het Grondwettelijk Hof - is daarentegen van mening dat nalatigheid van advocaten door de tuchtrechter streng wordt gestraft, in het bijzonder wanneer het toegevoegde rechtsbijstand betreft. ${ }^{184}$ Volgens de HFHR zou ook de minister van Justitie die een tuchtrechtelijke procedure kan initiëren maar van deze mogelijkheid nooit gebruik maakt zich meer met de kwaliteit van kosteloze rechtsbijstand moeten bemoeien. ${ }^{185} \mathrm{Om}$ die reden adviseert de organisatie ontevreden cliënten een brief te schrijven aan de Minister. ${ }^{186}$

181 Vervolgens meldde de deken dat hij met de betreffende advocaat had gesproken en dat deze beloofd had een bezoek te zullen brengen aan zijn cliënt: Monitoring Report 2003, p. $124-125$.

182 Die gedurende het vooronderzoek door de prokurator kan worden ingediend.

183 Monitoring Report 2003, p. 123 -124. Zie ook Bojarski 1999, p. 53.

184 Hermeliński 1998, p. 181. Hij verwijst daarbij naar tuchtrechtspraak waarin wordt gesteld dat de benoeming van een advocaat in een zaak op basis van toevoeging hem verplicht zijn taak net zo nauwgezet en zorgvuldig te vervullen als in het geval van een betalende cliënt. Zie over deze tuchtrechtspraak: Krzemiński 2003, p. 59-60. In dezelfde (weliswaar enigszins verouderde) bijdrage merkt Hermeliński wel op dat inderdaad veel geklaagd wordt over de kwaliteit van toegevoegde rechtsbijstand: 'Generally, there are no statistics revealing the number of cases where lawyers breach their duties as ex officio defense counsel, but information from various sources reveals that numerous complaints are submitted by accused detainees accusing their lawyers of having an overly 'friendly' attitude towards investigative bodies (police and prosecutors)' (p. 182).

185 'The Minister of Justice has certain supervisory powers towards the legal professional corporations, 
Een verdachte die ontevreden is over zijn toegevoegde raadsman kan behalve (of naast) het indienen van een klacht bij de balie ook de rechter verzoeken een andere advocaat aan te wijzen. ${ }^{187}$ Een dergelijk verzoek dient echter toereikend te worden gemotiveerd en wordt niet snel gehonoreerd. Of ontevredenheid over de kwaliteit van de verleende rechtsbijstand in dit opzicht voldoende is, zal afhangen van de omstandigheden van het geval. Tegen de weigering van de rechter een andere advocaat toe te voegen staat geen rechtsmiddel open. ${ }^{188}$

Bij het ontbreken van een effectieve kwaliteitscontrole speelt volgens de HFHR ook een rol dat er geen afzonderlijke normen voor het verlenen van kosteloze rechtsbijstand bestaan. ${ }^{189}$ De huidige gedragsregels ${ }^{190}$ bevatten geen bepalingen die specifiek betrekking hebben op de behandeling van zaken op basis van toevoeging en er bestaat ook geen aparte regeling over dit thema.

Op de (in)effectiviteit van tuchtrechtelijk toezicht en de behoefte aan meer specifieke gedragsregels wordt teruggekomen in hoofdstuk 8, § 4.3.7 en 4.4.5.

\subsubsection{Wijze van vergoeden}

Uit onderzoek van de HFHR en mijn gesprekken met advocaten blijkt dat de wijze waarop individuele advocaten tegen toegevoegde rechtsbijstand aankijken (logischerwijze) onlosmakelijk is verbonden met de relatief lage vergoedingen die er tegenover staan. Zoals eerder weergegeven zijn in een verordening van de minister van Justitie minimumvergoedingen vastgesteld. Deze zijn de laatste jaren verhoogd maar de bedragen zijn (gemiddeld) nog steeds aanzienlijk lager dan in geval van gekozen rechtsbijstand. ${ }^{191}$ Bovendien gelden de vastgestelde bedragen per vooronderzoek - en gedurende het eindonderzoek - per zitting en niet per uur waardoor een actief optreden van de advocaat niet bepaald wordt gestimuleerd. Een advocaat kan bijvoorbeeld vanwege de ingewikkeldheid van de zaak of extra gemaakte kosten wel om een hogere vergoeding vragen maar rechters blijken in de praktijk zelden meer dan het minimum te geven. Bovendien worden vergoedingen pas uitgekeerd wanneer een zaak is beëindigd. Het is zelfs mogelijk dat de behandeling van het hoger beroep wordt afgewacht voordat declaraties worden uitgekeerd. Alle kosten die gedurende de procedure worden gemaakt - waaronder niet alleen het honorarium maar ook extra uitgaven als reis- en kopieerkosten -

which he does not use in practice. Thus, the failure of the Ministry of Justice to undertake actions is not a result of the lack of statutory powers or lack of issues to be dealt with, but rather of the lack of will to act. It is worth remembering that in ex officio cases the State is an employer of lawyers and should be interested in the quality of services paid for with public funds and in the control of efficiency of their spending': Monitoring Report 2003, p. 128.

186 Bron: gesprek Bojarski, juni 2003 Warschau.

187 Art. 81 lid 2 en 378 lid 2 KPK 1997: zie § 3.1.3.3.

188 Grzegorczyk 2004, p. 288.

189 Monitoring Report 2003, p. 129.

190 De 'verzameling regels betreffende gedragsnormen voor de advocaat en de waardigheid van het beroep' ('Zbiór zasad etyki adwokackiej i godności zawodu uchwalony przez Naczelna Radę Adwokacką') door de Nationale Raad van de balie vastgesteld op 10 oktober 1998 en te raadplegen op: <www.nra.pl/nra.php>.

191 Zie hiervoor § 3.1.3.4: 180 złotych voor dochodzenie en 300 złotych voor śledztwo (respectievelijk circa 48 en 80 euro) voor optreden in het vooronderzoek op basis van toevoeging tegenover een gemiddeld uurtarief van ongeveer 100 euro in betalende zaken. 
komen dus voor rekening van de advocaat zonder dat zeker is of, wanneer en voor welk deel deze uiteindelijk door de overheid zullen worden vergoed.

\subsection{Het recht op kosteloze rechtsbijstand en het EVRM}

Artikel 6 lid 3 sub c EVRM garandeert een ieder jegens wie een strafrechtelijke vervolging is ingesteld het recht:
'zich zelf te verdedigen of daarbij de bijstand te hebben van een raadsman naar eigen keuze of, indien hij niet over voldoende middelen beschikt om een raadsman te bekostigen, koste- loos door een toegevoegd raadsman te kunnen worden bijgestaan, indien de belangen van een behoorlijke rechtspleging dit eisen'.

Uit deze formulering kunnen twee cumulatieve voorwaarden voor de voorziening van kosteloze rechtsbijstand worden afgeleid. Het eerste is een objectief criterium en betreft de vraag of degene jegens wie een strafrechtelijke vervolging is ingesteld over onvoldoende financiële middelen beschikt om zelf in de kosten van de rechtsbijstand te voorzien. Het tweede criterium heeft betrekking op de vraag of bijstand van een advocaat in de betreffende zaak 'in het belang van de rechtspleging' is. ${ }^{192}$ Over het eerste punt bestaat weinig jurisprudentie: het EHRM laat het in beginsel aan nationale autoriteiten over om te bepalen of burgers gezien hun financiële situatie voor gefinancierde rechtshulp in aanmerking dienen te komen. ${ }^{193}$ Dat het EHRM de beoordeling van een lidstaat of in een concreet geval aan het financiële criterium is voldaan niet altijd onaantastbaar acht, werd onder meer duidelijk in de zaak R.D. t. Polen. ${ }^{194}$ R. D. die in eerste aanleg en in hoger beroep bijstand van een toegevoegde raadsman had genoten, vroeg na zijn veroordeling in appel om toevoeging van een raadsman ten behoeve van de cassatieprocedure. Dit verzoek werd door de appelinstantie (tot wie volgens Pools strafprocesrecht een dergelijk verzoek moet worden gericht) afgewezen omdat niet was aangetoond dat de aanvrager niet zelf in de kosten van rechtsbijstand kon voorzien. Het EHRM achtte deze beslissing in de gegeven omstandigheden onbegrijpelijk. Gezien het feit dat de appelinstantie twee maanden eerder had geoordeeld dat de kosten van rechtsbijstand voor de procedure in hoger beroep vanwege de slechte financiële situatie van verdachte voor rekening van de overheid diende te komen, deze situatie in de tussentijd niet was verbeterd en ook niet uit het besluit van de appelinstantie kon worden afgeleid welke concrete omstandigheden de afwijzing van het verzoek rechtvaardigden, was het Europese Hof van oordeel dat in deze zaak wel degelijk sprake was van 'strong indications that he did not have sufficient means to pay for legal assistance'. ${ }^{195}$

192 Zie uitgebreid over art. 6 EVRM en het recht op kosteloze rechtsbijstand: Spaniol 1990, p. 67-90 en Stavros 1993, p. 207-221.

193 Wel heeft het Europese Hof in de zaak Pakelli t. Duitsland aangegeven dat niet al te strenge eisen mogen worden gesteld aan het bewijs van een dergelijke situatie: de aanvrager hoeft niet 'buiten alle twijfel' aan te tonen dat hij over onvoldoende middelen beschikt (Pakelli $t$. Duitsland, EHRM 25-4-1983, nr. 8398/78). In de betreffende zaak werd het aanbod van Pakelli om zijn gebrek aan vermogen aan te tonen terwijl er geen duidelijke aanwijzingen bestonden dat van het tegendeel moest worden uitgegaan voldoende geacht.

194 EHRM 18-12-2001, nr. 29692/96, 34612/97.

$195 \S 46$. In het kader van de vraag of rechtsbijstand in deze zaak in het belang van de rechtspleging was, hechtte het EHRM waarde aan het feit dat volgens Pools strafprocesrecht 
Voor het antwoord op de vraag of bijstand van (een door de overheid gefinancierde) raadsman 'in het belang van de rechtspleging is' zijn in de Straatsburgse rechtspraak verschillende aanknopingspunten te vinden. Grofweg worden drie criteria onderscheiden die in dit kader relevant kunnen zijn:

- de persoonlijke omstandigheden van verdachte,

- de ernst van de beschuldiging en de hoogte van de mogelijke sanctie en

- de complexiteit van de zaak. ${ }^{196}$

Wat de hoogte (of zwaarte) van de mogelijke sanctie betreft, neemt het Hof als uitgangspunt dat een verdachte in beginsel in aanmerking dient te komen voor gratis rechtsbijstand wanneer hem een vrijheidsberovende straf kan worden opgelegd. ${ }^{197}$ Van de autoriteiten mag in dit verband een actieve opstelling worden verwacht: ze dienen zich er van te vergewissen dat de verdachte begrijpt dat hij recht op kosteloze rechtsbijstand heeft. ${ }^{198}$

\subsubsection{Vrije advocatenkeuze in geval van toevoeging}

Voor de Poolse situatie is in ieder geval relevant of het recht op kosteloze rechtsbijstand zoals vastgelegd in art. 6 lid 3 sub c EVRM tevens een recht op vrije advocatenkeuze in geval van toevoeging inhoudt. Centrale vraag hierbij is hoe het recht op bijstand van een raadsman naar keuze en het recht op kosteloze rechtsbijstand zich tot elkaar verhouden: zijn het alternatieve rechten zodat in geval van gefinancierde rechtsbijstand geen recht op vrije advocatenkeuze bestaat of dienen ze zo te worden geïnterpreteerd dat bij verwezenlijking van het één (gefinancierde rechtsbijstand) ook nog recht op het ander (vrije advocatenkeuze)

cassatie alleen door een raadsman kan worden ingesteld. Nu de appelinstantie de afwijzing slechts acht werkdagen voor het verstrijken van de termijn voor het instellen van cassatie aan klager had doen toekomen was het voor laatstgenoemde feitelijk onmogelijk nog gebruik te maken van deze rechtsgang. Dit alles bracht het EHRM tot de conclusie dat art. 6 lid 1 in samenhang met art. 6 lid 3 sub c EVRM was geschonden (\$ 47-52). De uitspraak in bovengenoemde zaak heeft in Polen behoorlijk wat stof doen opwaaien. Duidelijk was dat de rechterlijke macht - gezien de verplichte rechtsbijstand in cassatie - soepeler zou moeten omspringen met verzoeken om toevoeging. Zie ook hoofdstuk 2, § 3.2.3.3. Dat autoriteiten gemotiveerd dienen te beslissen op verzoeken tot kosteloze rechtsbijstand kan ook worden afgeleid uit Tabor t. Polen (EHRM 27-6-2006, nr. 12825/02) waarin de nationale rechter in een civiele zaak rechtsbijstand ten behoeve van de cassatieprocedure had geweigerd zonder die beslissing te motiveren. Het Hof gaf aan dat - hoewel het Poolse recht de rechter geen motiveringsplicht oplegt - '(...) the principle of fairness required the court to give reasons for rejecting the applicant's request' (\$ 45$)$.

196 Zie de uitspraak Quaranta t. Zwitserland (EHRM 24-5-1991, nr. 127441/87) waarin deze drie punten worden genoemd. Hierbij moet worden opgemerkt dat het Hof niet consequent in elke zaak aan elk criterium toetst en dat de benadering van het Hof verschilt wanneer het gaat om een zaak in eerste aanleg of in hoger beroep of cassatie. Bovendien kan datgene wat de belangen van de rechtspleging vereisen, veranderen naarmate de procedure voortduurt. Wanneer bijvoorbeeld in het begin van een strafzaak is geoordeeld dat de belangen van de rechtspleging niet vereisen dat kosteloze rechtsbijstand wordt toegekend, sluit dit niet uit dat op een later moment alsnog in gratis bijstand moet worden voorzien: Van der Velde 2004 I, 3.6.11, p. 8.

197 Benham t. Verenigd Koninkrijk (EHRM 10-6-1996, nr. 19380/92): '(...) where deprivation of liberty is at stake, the interests of justice in principle call for legal representation (...)' (§ 61).

198 Padalov t. Bulgarije, EHRM 10-8-2006, nr. 54784/00, § 54. 
bestaat? In de eerder genoemde zaak Pakelli t. Duitsland heeft het Europese Hof ter beantwoording van deze vraag onderzocht hoe het laatste gedeelte van art. 6 lid 3 sub c - 'to defend himself (...) through legal assistance of his own choosing or, if he has not sufficient means to pay for legal assistance, to be given it free when the interests of justice so require' - moet worden gelezen. Het EHRM heeft daarbij de Engelse en de Franse verdragstekst vergeleken: de Engelse versie verbindt de verschillende in art. 6 lid 3 sub c genoemde rechten met het woordje 'or' ('of') waardoor de indruk ontstaat dat het inderdaad om alternatieve rechten gaat. De Franse vertaling verbindt het recht op bijstand van een advocaat naar keuze en het recht op kosteloze rechtsbijstand daarentegen met het woordje ' $e t$ ' (en) waardoor de rechten cumulatief worden voorgesteld. Volgens het Europese Hof verdient de Franse tekst - mede gezien de doelstelling van dit deel van de bepaling: het garanderen van effectieve bescherming van verdedigingsrechten - de voorkeur. ${ }^{199}$ Uit het feit dat de woorden 'such assistance' en 'it' (in 'to be given it free') verwijzen naar 'legal assistance of his own choosing' kan worden afgeleid dat het EHRM het recht op vrije advocatenkeuze in geval van toevoeging in beginsel erkent. ${ }^{200}$

Dat dit recht op vrije advocatenkeuze niet absoluut is, is onder meer duidelijk geworden in de zaken Croissant $t$. Duitsland en Lagerblom t. Zweden. ${ }^{201}$ Croissant - een Duitse advocaat die vervolgd werd voor zijn activiteiten als verdediger van enkele leden van de Rote Armee Fraktion - had bijstand van twee toegevoegde advocaten naar keuze en een derde advocaat die tegen zijn wil op verzoek van het Openbaar Ministerie aan hem was toegevoegd en was na afloop van zijn strafzaak veroordeeld tot betaling van de kosten van alledrie de advocaten. Klager voerde in Straatsburg aan dat de toevoeging van de derde pflichtverteidiger in wie hij geen vertrouwen had in strijd was met zijn recht op vrije advocatenkeuze voortvloeiend uit art. 6 lid 1 en lid 3 sub c EVRM. De reactie van het Hof maakt in de eerste plaats duidelijk dat wettelijk verplichte rechtsbijstand op zichzelf niet onverenigbaar is met EVRM:

'(...) The requirement that a defendant be assisted by counsel at all stages of the Regional Court's proceedings (...) - which finds parallels in the legislation of other Contracting States - cannot, in the Court's opinion, be deemed incompatible with the Convention.'202

Het Europese Hof redeneert vervolgens dat art. 6 lid 3 sub c inderdaad het recht op vrije advocatenkeuze toekent aan eenieder jegens wie een strafrechtelijke vervolging is ingesteld maar dat dit recht - ondanks en niettegenstaande het belang van een vertrouwensrelatie tussen advocaat en cliënt ${ }^{203}$ - niet absoluut is en derhalve aan beperkingen onderhevig kan zijn:

199 Pakelli t. Duitsland, EHRM 25-4-1983, nr. 8398/78, § 31.

200 Spronken 2001, p. 449-450. Uit oude(re) rechtspraak van de Europese Commissie voor de rechten van de mens kan worden afgeleid dat de Commissie er oorspronkelijk van uitging dat de verdachte die gebruik maakte van toegevoegde rechtsbijstand niet het recht had zelf een advocaat te kiezen. Zie Spaniol 1990, p. 77 e.v.

201 EHRM 25-9-1992, nr. 13611/88 en EHRM 14-1-2003, nr. 26891/95.

$202 \S 27$.

203 Dat het recht op vrije advocatenkeuze onlosmakelijk is verbonden met dit belang en dat het feit dat een advocaat is gekozen door de verdachte in beginsel een positieve invloed op de verdediging zal hebben, was reeds erkend in Goddi t. Italië, EHRM 9-4-1984, nr. 8966/80. 
'(...) It [the right of "everyone charged with a criminal offence" to be defended by counsel of his own choosing, toev. Dd]) is necessarily subject to certain limitations where free legal aid is concerned and also where, as in the present case, it is for the Courts to decide whether the interests of justice require that the accused be defended by counsel appointed by them. When appointing defence counsel the national courts must certainly have regard to the defendant's wishes; (...). However, they can override those wishes when there are relevant and sufficient grounds for holding tat this is necessary in the interest of justice.'204

In de zaak Lagerblom voerde klager - een Fin - aan dat hij niet goed met zijn toegevoegde (Zweedstalige) advocaat had kunnen communiceren en dat zijn herhaaldelijke verzoeken deze te vervangen door een advocaat die beter Fins sprak ten onrechte waren afgewezen waardoor zijn recht op bijstand van een advocaat naar keuze was geschonden. Het EHRM herhaalde onder verwijzing naar de zaak Croissant dat het aan art. 6 lid 3 sub c ten grondslag liggende recht op vrije advocatenkeuze met name in geval van kosteloze rechtsbijstand niet absoluut is. Volgens het Europese Hof had Lagerblom zijn verzoeken om vervanging van zijn advocaat op een zodanig laat tijdstip in de procedure gedaan dat toewijzing ervan de procedure te veel zou ophouden en te veel extra kosten met zich zou brengen. ${ }^{205}$ Mede gelet op het feit dat niet was gebleken dat Lagerblom geen effectieve bijstand had genoten van de advocaat die hem was toegevoegd, concludeerde het EHRM dat art. 6 EVRM niet was geschonden.

De Straatsburgse rechtspraak stelt dus wel grenzen aan het recht op vrije advocatenkeuze in geval van toevoeging. Dit neemt echter niet weg dat de keuze van verdachte - ook in geval van kosteloze (al dan niet verplichte) rechtsbijstand - in beginsel moet worden gerespecteerd en dat daar slechts van mag worden afgeweken wanneer sprake is van 'relevant and sufficient grounds' die aantonen dat negeren van de voorkeur noodzakelijk is in het belang van de rechtspleging. ${ }^{206}$

$204 \S 29$. Volgens het Hof waren er in de zaak van Croissant verschillende omstandigheden die een uitzondering op de regel van vrije advocatenkeuze rechtvaardigden waarbij met name waarde werd gehecht aan het feit dat Croissant reeds twee advocaten naar keuze had, dat de derde advocaat in nauwe samenwerking met zijn twee collega's actief betrokken was geweest bij de verdediging en bovendien kantoor hield in het district van de rechtbank (wat vanuit praktisch oogpunt voordelig was wanneer de andere twee verhinderd zouden zijn om op een zitting te verschijnen). Overigens had het Europese Hof al eerder in de uitspraak aangegeven dat dergelijke overwegingen die betrekking hebben op het efficiënte verloop van een strafzaak een rol kunnen spelen bij de beoordeling van de vraag of het recht op vrije advocatenkeuze mag worden beperkt: '(...) avoiding interruptions or adjournments corresponds to an interest of justice which is relevant in the present context and may well justify an appointment against the accused's wishes.' (\$ 28). Dit alles bracht het EHRM tot de conclusie dat de toevoeging van de drie advocaten (en met name de derde) geen strijd opleverde met art. 6 lid 1 en lid 3 sub c EVRM.

205 '(...) it is clear that the proceedings had reached a stage where the requested replacement would have caused certain inconvenience and entailed additional costs. The Court does not find it unreasonable, in view of the general desirability of limiting the total costs of legal aid, that national authorities take a restrictive approach to requests to replace public defence counsel once they have been assigned to a case and have undertaken certain activities' (\$ 59).

206 Dat de keuze voor een bepaalde advocaat ook in geval van toevoeging in beginsel gerespecteerd moet worden, blijkt eveneens uit een aanbeveling van de Raad van Europa waarin lidstaten wordt aangeraden effectieve toegang tot de rechter voor zeer arme burgers te vergemakkelijken door onder meer 'the right to be assisted by an appropriate 


\subsubsection{Verantwoordelijkheid overheid voor kwaliteit kosteloze rechtsbijstand}

Vast uitgangspunt van het EHRM is dat de wijze waarop de verdediging wordt vormgegeven in beginsel is overgelaten aan de advocaat en zijn cliënt. Dit betekent echter niet dat de overheid geen enkele verantwoordelijkheid heeft voor de door haar gefinancierde rechtsbijstand. In Artico t. Italië ${ }^{207}$ - waarin klager aanvoerde dat de advocaat die hem ten behoeve van de cassatieprocedure was toegevoegd, weigerde mee te werken en zich niet had ingezet voor de zaak oordeelde het EHRM dat:

"Article 6 par. 3 (c) speaks of "assistance" and not of "nomination". Again, mere nomination does not ensure effective assistance since the lawyer appointed for legal aid may die, fall seriously ill, be prevented for a protracted period from acting or shirk his duties. If they are notified of the situation, the authorities must either replace him or cause him to fulfill his obligations.'208

De Italiaanse regering voerde in deze zaak het verweer dat voor het vaststellen van een schending van art. 6 lid 3 sub c EVRM zeker moest zijn dat de verdachte door het ontbreken van rechtsbijstand daadwerkelijk in zijn belangen was geschaad. ${ }^{209}$ Deze beperkte uitleg werd door het EHRM echter niet geaccepteerd:

'(...) Above all, there is nothing in Article 6 par. 3 (c) indicating that such proof [that a substitute (...) would have convinced the Court of Cassation when the applicant did not succeed in doing so, toev. DdV] is necessary; an interpretation that introduced this requirement would deprive it in large measure of its substance.' 210

De verantwoordelijkheid van de overheid eindigt dus niet op het moment dat een advocaat wordt toegevoegd: tijdens de procedure kunnen zich verschillende omstandigheden voordoen die ingrijpen noodzakelijk maken. Het gaat daarbij volgens het Europese Hof niet alleen om gevallen waarin het voor de toegevoegde advocaat door ziekte of zelfs overlijden feitelijk onmogelijk is geworden om de verdediging te voeren maar ook om situaties waarin de advocaat zijn professionele verplichtingen niet nakomt ('shirk his duties'). Dit betekent echter niet dat iedere tekortkoming van een toegevoegde advocaat aan de overheid kan worden toegerekend: zoals gezegd geldt als uitgangspunt dat de wijze waarop de verdediging wordt ingevuld is overgelaten aan de advocaat en zijn cliënt en dat ingrijpen van overheidswege slechts onder bepaalde omstandigheden noodzakelijk is. ${ }^{211}$

counsel, as far as possible of one's choice [decurs. DdV], who will receive adequate remuneration': regel III sub c van Recommendation No. $R$ (93) 1 of the Committee of Ministers to member states on effective access to the law and to justice for the very poor d.d. 8 januari 1993.

207 EHRM 13-5-1980, nr. 6694/74.

$208 \S 33$.

209 Met andere woorden: of een andere advocaat zonder twijfel een voor de verdachte positieve beslissing zou hebben kunnen afdwingen.

$210 \S 35$.

211 'It follows from the independence of the legal profession from the State that the conduct of the defense is essentially a matter between the defendant and his counsel, whether counsel be appointed under a legal aid scheme or be privately financed. The Court agrees with the Commission that the competent national authorities are required under Article $6 \S 3(c)$ to intervene only if a failure by legal aid counsel to provide effective representation is manifest or sufficiently brought to their attention in some other way': Kamasinski t. Oostenrijk, EHRM 19-12-1989, nr. 9783/82 (§ 65), dit standpunt is herhaald in onder meer: Imbrioscia t. Zwitserland, EHRM 24-11-1993, nr. 13972/88, Daud $t$. 
Wanneer de overheid door informatie van de verdachte of op andere wijze op de hoogte raakt van het feit dat een toegevoegde advocaat zijn professionele verplichtingen in een bepaalde zaak niet nakomt (waardoor geen sprake is van effective representation in de zin van art. 6 lid 3 sub c EVRM) ontstaat dus de verplichting actie te ondernemen. De overheid kan de betreffende advocaat laten vervangen of - wanneer dat nog tot de mogelijkheden behoort - hem wijzen op zijn professionele verplichtingen en hem aansporen deze alsnog te vervullen.212

\subsubsection{Ten onrechte geen toevoeging gedurende vooronderzoek}

Het feit dat een verdachte gedurende het vooronderzoek tegen zijn wil wordt onthouden van (kosteloze of door hem zelf gefinancierde) rechtsbijstand kan onder omstandigheden een schending van art. 6 EVRM opleveren. Zo is onder andere bevestigd in Berliński t. Polen. ${ }^{213}$ Deze zaak betrof twee broers die tijdens een bezoek aan een sportschool in Lublin door de politie waren aangehouden omdat ze ondanks herhaalde verzoeken van de manager weigerden te vertrekken. Een dag na hun aanhouding (de dag van hun invrijheidstelling) deden de broers een schriftelijk verzoek tot toevoeging van een door de overheid gefinancierde advocaat. Dit verzoek bleef echter onbeantwoord waardoor klagers een groot deel van hun strafzaak ${ }^{214}$ geen rechtsbijstand genoten: pas meer dan één jaar na hun aanhouding beval de rechtbank tijdens het onderzoek ter terechtzitting de toevoeging van een advocaat. ${ }^{215}$ Klagers voerden aan dat deze gang van zaken - het feit dat niet op hun oorspronkelijke verzoek om toevoeging was gereageerd en vervolgens pas zoveel later in de procedure een advocaat werd toegevoegd - een schending van art. 6 lid 3 sub c EVRM opleverde. De regering gaf toe dat door niet te reageren op het verzoek niet was voldaan aan de eisen van genoemd artikellid. Zo oordeelde ook het Europese Hof: onder verwijzing naar de zaken Brennan en Murray werd herhaald dat de garanties van art. 6 lid 3 sub c EVRM wel degelijk van belang kunnen zijn voor de fase van het vooronderzoek (zie ook $\S 2.5)$ wat in beginsel betekent dat een verdachte al in het vroege stadium van politieverhoren bijstand van een raadsman moet kunnen hebben. De vraag of de procedure van de broers Berliński door de beperkingen op hun recht op rechtsbijstand in zijn geheel nog als eerlijk kon worden aangemerkt, werd door het Europese Hof negatief beantwoord:

'The Court observes that it is undisputed that the applicants lacked means to employ a private representative in the context of criminal proceedings against them. It is also uncontested that the applicants' request for an official lawyer to be appointed was ignored by

Portugal, EHRM 21-4-1998, nr. 22600/93, Czekalla t. Portugal, EHRM 10-10-2002, nr. 38830/ 97, Lagerblom t. Zweden, EHRM 14-1-2003, nr. 26891/95 en Sannino t. Italië, EHRM 27-4-2006, nr. 30961/03. Overigens gaf het Europese Hof ook in Artico t. Italië (EHRM 13-5-1980, A37, nr. 6694/74) reeds aan dat '(...) a state cannot be held responsible for every shortcoming on the part of the lawyer appointed for legal aid purposes (...)' (\$36).

212 Zie bijvoorbeeld Artico t. Italië, EHRM 13-5-1980, A37, nr. 6694/74, § 36.

213 EHRM 20-6-2002, nr. 27715/95, 30209/96.

214 Ze werden vervolgd voor geweldpleging tegen de politieagenten die de aanhouding hadden verricht.

215 Deze toevoeging werd door de rechtbank overigens noodzakelijk geacht vanwege twijfel aan de geestelijke gezondheid van de twee verdachten en was dus niet gebaseerd op de onmogelijkheid om zelf in de kosten van de verdediging te voorzien. 
the authorities, with the result that they had no defence counsel for more than a year. Given that a number of procedural acts, including questioning of the applicants and their medical examinations, were carried out during that period (...), the Court finds no justification for this restriction which deprived the applicants of the right to adequately defend themselves during the investigation and trial. Accordingly, there has been a breach of Article $6 \S \S 1$ and 3 (c) of the Convention.' 216

\subsection{Conclusie}

Het huidige systeem van kosteloze rechtsbijstandvoorziening is ontoereikend. Dat op dit punt urgente problemen bestaan, wordt niet alleen gesignaleerd door (rapporten van) mensenrechtenorganisaties als de HFHR maar wordt ook onderkend door de strafrechtspraktijk. ${ }^{217}$ Samengevat betreffen de belangrijkste tekortkomingen van het huidige systeem de volgende punten:

- De schriftelijke informatie die de verdachte voorafgaand aan zijn eerste verhoor ontvangt, vermeldt niet op welke wijze het recht op kosteloze rechtsbijstand kan worden geëffectueerd.

- De wettelijke grondslag voor toekenning van kosteloze rechtsbijstand biedt onvoldoende houvast: er is geen (objectief vast te stellen) minimuminkomensgrens en onduidelijk is hoe de verdachte moet aantonen dat hij zelf niet in de kosten van de verdediging kan voorzien en op welke grond(en) de rechter over een verzoek tot toevoeging moet beslissen.

- Met name vanwege budgettaire problemen wordt slechts een klein deel van de aanvragen die voor vergoeding in aanmerking zou moeten komen, ingewilligd: toegevoegde rechtsbijstand wordt betaald uit een algemeen budget van de rechtbank waardoor de beslissing wordt beïnvloed door de beperkingen van deze doorgaans krappe begroting.

- Toevoeging gedurende het vooronderzoek is buiten de gevallen van verplichte rechtsbijstand zeldzaam en in de eerste fase na aanhouding bestaat geen recht op kosteloze rechtsbijstand.

- De beslissing op het verzoek om toevoeging wordt vaak door de zittingsrechter genomen wat problematisch is vanuit het oogpunt van onpartijdigheid.

- Tegen een afwijzende beslissing op een verzoek om kosteloze rechtsbijstand kan geen rechtsmiddel worden ingesteld en de mogelijkheid om in hoger beroep over de afwijzing te klagen is bij gebrek aan de daarvoor vereiste professionele rechtsbijstand in de meeste gevallen illusoir.

- De kwaliteit van kosteloze rechtsbijstand laat in veel gevallen te wensen over waarbij onder meer een rol speelt dat bij het verlenen van toevoegingen niet wordt gelet op de specialisatie van de advocaat en dat de vergoeding die de advocaat ontvangt aan de magere kant is.

Voor wat betreft de verenigbaarheid van het huidige toevoegingssysteem met Straatsburgse normen is in de eerste plaats van belang dat een verdachte op grond van art. 6 EVRM recht heeft op kosteloze rechtsbijstand wanneer hij niet over de middelen beschikt zelf in de kosten van een advocaat te voorzien en wanneer professionele bijstand in het belang van de rechtspleging is. Het Poolse strafproces

$216 \S 77$ en 78.

217 Advocatuur, prokuratura en rechterlijke macht. Zie Daniuk e.a. 2006, p. 14-18 en 51 e.v. 
kent een aantal gevallen van verplichte rechtsbijstand waardoor toevoeging van een kosteloze raadsman onder bepaalde omstandigheden is gegarandeerd. Alle gronden voor verplichte rechtsbijstand betreffen situaties waarin toevoeging van een advocaat - vanwege de persoonlijke omstandigheden van de verdachte of de ernst/ingewikkeldheid van de zaak - in het belang van de rechtspleging is. Dit neemt echter niet weg dat er buiten de gevallen van verplichte rechtsbijstand situaties mogelijk zijn waarin een verdachte op grond van art. 6 EVRM over kosteloze rechtsbijstand moet kunnen beschikken. ${ }^{218}$ In alle Poolse zaken die niet onder art. 79 of 80 KPK 1997 vallen, dient de verdachte op grond van art. 78 KPK zelf een verzoek tot toevoeging in te dienen. Laatstgenoemde bepaling bevat geen inhoudelijk criterium: uitgaande van de wettekst dient de rechter bij de beoordeling van de aanvraag alleen rekening te houden met de financiële status van de aanvrager en niet met omstandigheden van de zaak die bijstand van een advocaat 'in het belang van de rechtspleging' noodzakelijk maken. De praktijk is echter dat ook verzoeken die gezien de financiële positie van de aanvrager wel zouden moeten worden ingewilligd om verschillende redenen worden afgewezen. ${ }^{219}$ Dat de verdachte in alle gevallen de kosteloze rechtsbijstand geniet waarop hij volgens art. 6 EVRM recht heeft, is dus zeker niet gegarandeerd.

Wat het recht op vrije advocatenkeuze in geval van toevoeging betreft, is in de vorige paragraaf duidelijk geworden dat - gelet op de geldende Straatsburgse jurisprudentie - nationale instanties bij de toewijzing van een raadsman de keuze van een verdachte in beginsel zullen moeten respecteren en dat van deze hoofdregel slechts kan worden afgeweken indien er 'relevante en toereikende gronden' zijn dat dit in het belang van een behoorlijke rechtspleging noodzakelijk is. ${ }^{220}$ Toegepast op de Poolse situatie brengt dit met zich dat de rechter wanneer een verdachte bij een verzoek om toevoeging op grond van art. 78 KPK 1997 de voorkeur voor een bepaalde advocaat kenbaar maakt deze keuze niet zonder meer mag negeren en zelfs in beginsel zal moeten respecteren. ${ }^{221}$ Aangezien - een klein aantal uitzonderingen daargelaten - alle leden van de balie verplicht zijn strafzaken op basis van toevoeging te doen en de rechter bij zijn keuze doorgaans toch geen rekening houdt met de specialisatie en werkdruk van de betreffende advocaat zijn maar weinig redenen denkbaar die afwijking van deze regel (vrije advocatenkeuze) zouden kunnen rechtvaardigen.

Veel van de eerdergenoemde tekortkomingen in het stelsel van kosteloze rechtsbijstand zijn overigens geen typisch Pools verschijnsel.222 In sommige Centraal-

218 Er zijn genoeg situaties denkbaar die niet vallen onder art. 79 of 80 KPK 1997 maar waarin bijstand van een raadsman bijvoorbeeld vanwege de ernst of de ingewikkeldheid van de zaak wel degelijk noodzakelijk is. Hierbij is van belang dat art. $80 \mathrm{KPK}$ 1997 slechts betrekking heeft op een beperkte categorie: een strafzaak die in eerste aanleg voor de districtsrechtbank dient of wel door de provinciale rechtbank wordt behandeld maar waarin de verdachte niet van zijn vrijheid is beroofd en geen zbrodnia in de tenlastelegging is opgenomen, komt niet in aanmerking voor ambtshalve toevoeging.

219 Met name omdat rechters zich daartoe vanwege krappe begrotingen genoodzaakt zien.

220 Van der Velde 2004 I, 3.6.11, p. 6.

221 Iets dat in de huidige praktijk niet of nauwelijks blijkt te gebeuren.

222 Niet alleen postcommunistische landen maar ook veel Westerse staten zoals Frankrijk, België, Italië en Duitsland kampen met problemen op het terrein van de gefinancierde rechtsbijstandvoorziening. Zie over de situatie in landen van het voormalig Oostblok het 
en Oost-Europese landen - zoals Litouwen - heeft dit al tot grootschalige hervormingen geleid. ${ }^{223}$ In Polen verloopt het hervormingsproces echter uiterst moeizaam. Om te beginnen is pas relatief laat aandacht voor het probleem ontstaan. Zoals in dit hoofdstuk duidelijk is geworden, heeft de voorziening van kosteloze rechtsbijstand op verzoek van verdachte met de inwerkingtreding van het nieuwe wetboek van strafvordering geen noemenswaardige veranderingen ondergaan ten opzichte van het oude strafprocesrecht: wijzigingen in de regeling en het systeem van kosteloze rechtsbijstand hebben duidelijk niet tot de prioriteiten van de postcommunistische wetgever behoord. Organisaties zoals de HFHR hebben zich de afgelopen jaren ingezet om de toevoegingsproblematiek op de politieke agenda te krijgen en verschillende voorstellen gedaan voor hervorming. Het onderzoek dat HFHR in het kader van het Promoting Access to Justice project heeft verricht naar kosteloze rechtsbijstand in Polen heeft geleid tot de formulering van een aanzienlijk aantal aanbevelingen. ${ }^{224}$ Daarbij is ook een aantal alternatieve modellen ter overweging voorgelegd, zoals de ontwikkeling van een (pilot) public defender office program waarbij advocaten worden aangesteld die zich enkel en alleen met kosteloze rechtsbijstand bezighouden, ${ }^{225}$ het contracteren van advocaten(kantoren) voor de behandeling van toevoegingzaken tegen een vast tarief en de oprichting van een soort piketdienst voor de verlening van rechtsbijstand in noodgevallen zoals na aanhouding. ${ }^{226}$ Stuk voor stuk mooie plannen die tot op heden niet in acties zijn omgezet omdat de overheid zich geen raad lijkt te weten met het probleem. In 2002 werd tijdens het eerste European Forum on Access to Justice door vertegenwoordigers van het parlement, het Ministerie van Justitie en

rapport Access to Justice in Central and Eastern Europe 2003 waarin de resultaten van verschillende landenrapportages die in het kader van het Promoting Access to Justice zijn opgesteld, worden vergeleken. Te raadplegen op: <www.pili.org/en/content/view/51/53/>.

223 De hervormingen in Litouwen hebben onder andere geresulteerd in volledig nieuwe wetgeving, de oprichting van een nationaal Legal Aid Coordination Council (een orgaan dat zich bezig houdt met coördinatie en management van door de overheid gefinancierde rechtsbijstand - een novum in de Oost-Europese regio) en de oprichting van zogenaamde public defender offices die voorzien in gratis rechtsbijstand in strafzaken.

224 Die overigens niet beperkt zijn tot toevoegingen in strafzaken maar betrekking hebben op alle vormen van kosteloze rechtsbijstand. De voorstellen tot hervorming betreffen onder meer: (1) de introductie van een heldere vragenlijst (means test) op basis waarvan de financiële situatie van de aanvrager kan worden bepaald, (2) het overwegen van de mogelijkheid een gedeeltelijke vergoeding toe te kennen aan degenen die de kosten wel gedeeltelijk maar niet volledig zelf kunnen dragen, en (3) het opstellen van minimumeisen die mogen worden gesteld aan de wijze waarop rechtsbijstand door toegevoegde advocaten wordt verleend, aangevuld met (nog te ontwerpen) beoordelingsprocedures zoals evaluatieformulieren. Ook heeft het HFHR een aantal meer systematische wijzigingen voorgesteld zoals het vaststellen van een apart budget voor de financiering van toegevoegde rechtsbijstand en het in het leven roepen van een onafhankelijk orgaan (Legal Aid Board) dat zich bezig dient te houden met problemen ten aanzien van de toegang tot kosteloze rechtsbijstand en de uitvoering van het systeem.

225 Een dergelijk instituut kan op verschillende manieren worden vormgegeven bijvoorbeeld als (de)centraal overheidsorgaan, als door de overheid gefinancierde non-gouvernementele organisatie of als onderdeel van de balie.

226 Aanbevelingen zijn te vinden in Country Report 2002, p. 34-36 en Monitoring Report 2003, p. 12-16. Zie in gelijke zin ook Daniuk e.a. 2006, p. 14-18 en 51 e.v. 
de juridische beroepsgroepen beloofd dat op korte termijn zou worden begonnen met hervorming van het systeem maar het heeft uiteindelijk jaren geduurd voordat op dit punt concrete stappen werden ondernomen. Pas eind 2004 werd - mede onder druk van de Nationale Ombudsman - door een werkgroep van het Ministerie van Justitie gestart met de voorbereiding van een wetsvoorstel betreffende kosteloze rechtsbijstand. 227 Door allerlei politieke ontwikkelingen en het controversiële karakter van de voorgestelde wijzigingen bleef dit wetsvoorstel echter 'steken' bij het parlement waarop de regering besloot een nieuw project voor te bereiden. ${ }^{228}$ In dit nieuwe project werd het oorspronkelijke ontwerp echter zodanig aangepast dat het geen betekenis meer had voor verdachten in strafzaken: alleen slachtoffers kwamen op grond van de nieuwe voorgestelde regeling nog voor kosteloze rechtsbijstand in aanmerking. Met de aantreding van de nieuwe regering in de herfst van 2007 is ook laatstgenoemd project weer van tafel verdwenen en is een commissie in het leven geroepen die een nieuw voorstel dient voor te bereiden. Op moment van afronding van dit onderzoek was nog onduidelijk wat de inhoud van deze nieuwe plannen zal zijn.

Bovengenoemde ontwikkelingen laten zien hoe moeizaam de (voorbereidingen van de) hervormingen verlopen. De overheid heeft zichtbaar moeite met de omvang van de problematiek en de ingrijpendheid van de operatie die noodzakelijk is om het toevoegingssysteem aan te pakken. De huidige problemen zijn immers niet alleen een gevolg van tekortschietende wetgeving maar onlosmakelijk verbonden met de wijze waarop de wettelijke mogelijkheden in de praktijk (kunnen) worden benut. Het gaat dus niet alleen om het doorvoeren van een aantal relatief eenvoudige wetswijzigingen maar ook om vele organisatorische, institutionele hervormingen die zich niet beperken tot het terrein van het strafrecht en waarbij bovendien rekening moet worden gehouden met aanzienlijke financiële beperkingen. ${ }^{29}$ Hierdoor is het - zeker gelet op de wijze waarop het hervormingsproces tot op heden is verlopen - maar zeer de vraag of op korte termijn concrete wijzigingen te verwachten zijn.

227 Een eerste resultaat werd begin 2005 gepresenteerd en voorzag - in grote lijnen - in de geleidelijke invoering van een netwerk van 42 rechtsbijstandbureaus die zouden voorzien in het geven van (basis) juridisch advies op allerlei rechtsgebieden waaronder het strafrecht. Op deze wijze zou een extra mogelijkheid worden gecreëerd voor burgers met een inkomen onder een bepaald minimum om kosteloze rechtsbijstand te krijgen: de reeds bestaande mogelijkheden om voor toevoeging in aanmerking te komen - waaronder de regeling van art. 78 tot en met 80 KPK 1997 - zouden daarbij in tact blijven. Bedoeling was wel dat het nieuwe systeem na de gefaseerde invoering het oude geleidelijk zou gaan vervangen.

228 Het wetsvoorstel 'over toegang tot kosteloze rechtsbijstand door de staat toegekend aan natuurlijke personen' (Projekt ustawy o dostęie do nieodpłatnej pomocy prawnej przyznawanej przez państwo osobom fizycznym) d.d. 29 november 2006.

229 Een probleem waar overigens veel rechtssystemen mee kampen. In de woorden van Stavros: 'The right to free legal assistance for the accused who has not sufficient means to instruct a lawyer of his own choice is one of the most sensitive issues arising from Art. 6 of the European Convention. (...) it is concerned with a most serious challenge which currently faces the majority of the legal systems of the State Parties. It involves, inter alia, the problem of the appropriate use of public funds in the administration of justice, the availibility of which does not always keep pace with ever increasing demands': Stavros 1993, p. 207. 



\section{Hoofdstuk 5}

\section{Verdediging in het vooronderzoek}

\section{Inleiding}

Het Poolse vooronderzoek in strafzaken staat - zoals in de meeste gematigd inquisitoire continentale systemen - in het teken van een ambtshalve uitgevoerd onderzoek naar de materiële waarheid. Uitgangspunt is dat het bewijs dat in het vooronderzoek is verzameld, volledige bewijswaarde heeft mits het wordt gepresenteerd op het onderzoek ter terechtzitting. Op de hoofdregel dat bewijs ten overstaan van de zittingsrechter tot stand dient te komen, is door de wetgever echter een aantal uitzonderingen geformuleerd. Zo mag de verklaring van een getuige uit het vooronderzoek worden gebruikt wanneer (bijvoorbeeld) die getuige op het onderzoek ter terechtzitting weigert te verklaren, aangeeft zich bepaalde feiten niet meer te kunnen herinneren of afwijkt van zijn eerder afgelegde verklaring. Onder dezelfde omstandigheden kunnen ook verklaringen van de verdachte uit het vooronderzoek worden gebruikt. Gevolg van deze uitzonderingen is dat een groot deel van de waarheidsvinding plaatsvindt in het vooronderzoek waarbij het onderzoek ter terechtzitting vooral dient ter reproductie en evaluatie van bewijsmateriaal dat eerder is verkregen.

Bovengenoemde inquisitoire procescultuur heeft gevolgen voor de positie van de verdediging in het vooronderzoek. Het feit dat waarheidsvinding eerst en vooral als taak van de autoriteiten wordt beschouwd, betekent dat de mogelijkheden van de verdediging om hier een bijdrage aan te leveren of invloed op uit te oefenen in beginsel beperkt zijn. Dit gold nog sterker dan vandaag de dag ook gedurende het communisme. De positie van de verdediging in het vooronderzoek was voor 1989 uiterst precair. De prokurator kon de raadsman volledig buiten spel zetten door hem bijvoorbeeld geen inzage te geven in het dossier of niet toe te laten tot zijn gedetineerde cliënt. Hierdoor was het vaak onmogelijk gebruik te maken van de mogelijkheden die op papier wel aan de verdediging toekwamen.

Bij de totstandkoming van het nieuwe strafprocesrecht is ernaar gestreefd de verdediging in het vooronderzoek meer ruimte te geven door de mogelijkheden van de raadsman om effectief te kunnen deelnemen aan dit stadium van de procedure uit te breiden. ${ }^{1}$ In dit hoofdstuk zal aan de hand van een aantal thema's worden bekeken op welke wijze aan dit streven is vormgegeven. Daarbij zal telkens (per thema) eerst aandacht worden besteed aan de huidige juridische kaders en hoe die zich verhouden tot het oude strafprocesrecht. Na een bespreking van de praktijk zal vervolgens de aandacht worden gevestigd op de normen van het EVRM om uiteindelijk te kunnen beoordelen in hoeverre doorgevoerde wijzigingen het aandeel van de verdediging in het vooronderzoek daadwerkelijk hebben vergroot. Zonder de intentie (of de illusie) allesomvattend te zijn, is wat betreft de thema's die in dit hoofdstuk centraal staan, gekozen voor een aantal procedurele bevoegdheden die voor de verdediging in het vooronderzoek van groot belang zijn:

1 Zie hoofdstuk 2, § 2.3.3. 
- de mogelijkheid van de raadsman bij verhoren van zijn cliënt aanwezig te zijn,

- het recht op informatie over de strafzaak,

- de mogelijkheden van de verdediging in het kader van de voorlopige hechtenis en

- de mogelijkheden van de verdediging ten aanzien van de bewijsvergaring.

Het recht op vrij verkeer - de wijze waarop en de mate waarin een gedetineerde cliënt in het vooronderzoek vertrouwelijk met zijn advocaat kan communiceren wordt afzonderlijk besproken in hoofdstuk 7 .

\section{Aanwezigheid bij verhoren}

\subsection{Inleiding}

De verhoren van verdachte behoren tot de meest cruciale momenten van het vooronderzoek. ${ }^{2}$ De verdachte bevindt zich in een uiterst kwetsbare positie terwijl hij beslissingen moet nemen die van doorslaggevende betekenis kunnen zijn voor het verloop en de uitkomst van zijn proces. In het voorgaande hoofdstuk is in het kader van de aanvang van het recht op rechtsbijstand besproken vanaf welk moment een aangehoudene een advocaat moet kunnen consulteren. ${ }^{3}$ In deze paragraaf zal aandacht worden besteed aan de meer specifieke vraag of de raadsman het recht heeft fysiek aanwezig te zijn bij de verhoren van zijn cliënt.

Deelname van de raadsman aan het verhoor van verdachte kan verschillende doelen dienen. Om te beginnen kan de advocaat zijn cliënt wijzen op de hem toekomende rechten (met name het zwijgrecht) en er persoonlijk op toezien dat deze niet worden geschonden. Omdat de advocaat vaak beter in staat is de juridische consequenties van het afleggen van verklaringen en het antwoorden op bepaalde vragen te overzien, kan hij door interventies en advies bovendien voorkomen dat de verdachte zijn procespositie tijdens de verhoren onherstelbare schade toebrengt. Ook kan de raadsman controleren of de verklaringen die zijn cliënt aflegt, op de juiste wijze in het proces-verbaal van het verhoor worden opgenomen en kan hij - door zelf vragen te stellen of opmerkingen te plaatsen - bewerkstelligen dat tijdens het verhoor tevens aandacht wordt besteed aan ontlastende feiten. ${ }^{4} \mathrm{De}$ aanwezigheid van de advocaat biedt compensatie voor de onevenredige machtsverhouding die kenmerkend is voor de verhoorsituatie: de verhorende ambtenaar heeft vanwege zijn functie, als vertegenwoordiger van de overheid met de daarbij behorende bevoegdheden, in beginsel een superieure positie ten opzichte van de verdachte en de bijstand van een advocaat kan deze verhouding enigszins bij-

2 Het gaat in deze paragraaf om de zogenaamde materiële verhoren van verdachten: de situaties waarin de verdachte object van onderzoek is en waarvan het resultaat (zijn verklaring) voor het bewijs kan worden gebruikt. Formele verhoren - waarbij de verdachte voorafgaand aan een door de vervolgende instantie of de rechter te nemen beslissing in de hoedanigheid van procespartij wordt gehoord - blijven hier buiten beschouwing en zullen voor zover relevant in andere paragrafen aan de orde komen. Zie bijvoorbeeld $\S 4.3 .1$ over het recht van de raadsman deel te nemen aan het verhoor van verdachte voorafgaand aan de beslissing tot toepassing van voorlopige hechtenis. Algemeen over het onderscheid materiële en formele verhoren: Spronken 2001, p. 228-229.

3 Zie hoofdstuk 4, § 2.

4 Zie over verdedigingsstrategie en het verhoor van verdachte: Gwirdoyń 2004, p. 166-177. 
stellen en intimidatie voorkomen. ${ }^{5}$ Meer algemeen kan de advocaat door zijn aanwezigheid ook mentale steun geven aan de verdachte die zich in een benarde en stressverhogende situatie bevindt. De advocaat kan dus niet alleen juridische maar ook morele hulp verlenen. Ten slotte dient te worden benadrukt dat met deze vorm van rechtsbijstand niet alleen individuele belangen van de verdachte maar ook gemeenschappelijke belangen worden gediend. Een regelmatig verloop van het verhoor waarbij geen ontoelaatbare druk wordt uitgeoefend en ook aandacht wordt besteed aan ontlastende feiten, is immers in het belang van de waarheidsvinding en - meer algemeen - een behoorlijke strafrechtspleging. Dit weegt des te zwaarder wanneer zoals in het Poolse systeem het zwaartepunt van het strafproces in het vooronderzoek ligt.

Dit alles neemt natuurlijk niet weg dat er ook argumenten tegen het recht op rechtsbijstand bij politieverhoor bestaan. Deze hebben (uiteraard) hoofdzakelijk betrekking op het opsporingsbelang: zo zou de aanwezigheid van de advocaat tot gevolg kunnen hebben dat meer verdachten gebruik maken van hun zwijgrecht, het opbouwen van een vertrouwensrelatie tussen de verhoorder en de verdachte kunnen worden gefrustreerd, de verdachte uit zijn concentratie kunnen worden gehaald et cetera. ${ }^{6}$

Het wetboek van strafvordering van 1969 kende aan de raadsman geen expliciet recht toe om aanwezig te zijn bij verhoren van zijn cliënt in het vooronderzoek. De raadsman kon op grond van zijn algemene bevoegdheid deel te nemen aan onderzoekshandelingen weliswaar verzoeken tot het verhoor te worden toegelaten maar een dergelijk verzoek kon onder verwijzing naar het onderzoeksbelang eenvoudig worden geweigerd. ${ }^{7}$ Met de inwerkingtreding van het nieuwe strafprocesrecht is hier verandering in gekomen. In een nieuwe bepaling - art. $301 \mathrm{KPK}$ 1997 - is wettelijk vastgelegd dat de verdachte het recht heeft om in aanwezigheid van zijn raadsman te worden verhoord.

5 Deze compenserende functie wordt ook erkend door het EHRM. Zo werd bijvoorbeeld in Condron t. Verenigd Koninkrijk (EHRM 2-5-2000, nr. 35718/97) geoordeeld dat '(...) the physical presence of a solicitor during police interview, must be considered am important safeguard for dispelling any compulsion to speak (...)'. Zie hierna § 2.5 .

6 De Nederlandse raadsman heeft geen wettelijk en afdwingbaar recht aanwezig te zijn bij de politieverhoren van zijn cliënt. Na decennialange discussie is in juli 2008 in twee grote arrondissementen wel begonnen met een tijdelijk experiment waarbij de raadsman de mogelijkheid krijgt aanwezig te zijn bij het politieverhoor wanneer zijn cliënt wordt verdacht van een levensdelict. Zie voor een bespreking van de argumenten in de Nederlandse discussie onder meer Spronken 2001, p. 107-119. Fijnaut signaleert onder verwijzing naar Engels onderzoek dat een effect van de aanwezigheid van de raadsman bij het politieverhoor kan zijn dat het zwaartepunt van het vooronderzoek verder naar voren wordt geplaatst - de autoriteiten zullen immers reeds voor de aanvang van het verhoor zoveel mogelijk bewijzen tegen de verdachte verzameld willen hebben: Fijnaut 2001, p. 753. Een tweede onbedoelde consequentie die het aanwezigheidsrecht tot gevolg kan hebben is volgens Fijnaut de 'toename van polarisatie tussen (bepaalde categorieën) advocaten en (bepaalde categorieën) politie(mensen)' en 'de doorwerking van dit institutionele conflict op de gang van zaken in het opsporingsonderzoek en met name op het verdachtenverhoor' (p. 753).

$7 \quad$ Art. 273 KPK 1969. Zie hierover § 5.3. 


\subsection{Reikwijdte art. 301 KPK 1997}

Art. 301 KPK 1997 luidt:

'Op zijn verzoek dient de verdachte in aanwezigheid (letterlijk: met deelname) van een benoemde raadsman te worden verhoord. Het niet verschijnen van de raadsman staat er niet aan in de weg dat het verhoor doorgang vindt.'

Het recht te verzoeken in aanwezigheid van een raadsman te worden verhoord, is toegekend aan de verdachte (podejrzany) die daarover voorafgaand aan zijn eerste verhoor op de hoogte moet worden gesteld. ${ }^{8}$ Een dergelijk verzoek mag niet worden geweigerd.

Art. 301 KPK 1997 regelt dat de verdachte recht heeft op deelname van een 'benoemde raadsman'('ustanowionego obrońcy'). Dit houdt (vanzelfsprekend) in dat de raadsman reeds in de strafzaak moet zijn benoemd: hetzij door de verdachte zelf hetzij op last van de rechtbank in een geval van verplichte of kosteloze rechtsbijstand. Het recht om aan het verhoor deel te nemen komt dus behalve aan de gekozen advocaat ook toe aan de raadsman die door de rechter aan de verdachte is toegevoegd. ${ }^{9}$ Dat het in het kader van art. 301 KPK 1997 om een benoemde raadsman moet gaan, heeft in ieder geval tot gevolg dat een verdachte aan de bepaling niet het recht kan ontlenen om een advocaat te contacteren die nog niet bij de zaak is betrokken. Aangenomen wordt dat de verdachte die voorafgaand aan zijn verhoor een verzoek op grond van art. 301 KPK 1997 indient wel in de gelegenheid dient te worden gesteld een raadsman te benoemen en de raadsman te informeren over tijd en plaats van het verhoor. ${ }^{10}$ Wanneer de verdachte heeft aangegeven in aanwezigheid van zijn raadsman verhoord te willen worden, dienen de autoriteiten laatstgenoemde op de hoogte te stellen. Zij zijn echter niet verplicht een gepland verhoor uit te stellen om de komst van de raadsman af te wachten. De verdachte kan uiteraard volhouden geen verklaring af te willen leggen in afwezigheid van zijn raadsman en op die manier uitstel van het verhoor afdwingen. Indien de raadsman niet verschijnt, heeft dat - zelfs wanneer er goede reden zijn voor het oponthoud - gezien de laatste volzin van art. 301 KPK 1997 geen gevolgen voor de voortgang van het verhoor. ${ }^{11}$

Dat art. 301 KPK 1997 als recht van de verdachte is geformuleerd, neemt niet weg dat het initiatief om bij een verhoor aanwezig te zijn ook van de raadsman zelf of van de autoriteiten uit kan gaan. ${ }^{12}$ Gelet op de ratio van art. 301 KPK 1997 en het algemene uitgangspunt dat rechten die aan de verdachte toekomen in beginsel ook door de raadsman kunnen worden aangewend, dient er vanuit te worden gegaan dat de raadsman - wanneer zijn cliënt daarmee instemt - ook op eigen verzoek tot het verhoor moet worden toegelaten.

8 Overeenkomstig art. 300 KPK 1997. Het recht te verzoeken om in het bijzijn van een raadsman te worden gehoord, maakt deel uit van de verzameling rechten waarover de verdachte voorafgaand aan zijn eerste verhoor schriftelijk moet worden geïnformeerd.

Zie hoofdstuk 2, § 2.3.3.3.

9 Stachowiak 1997, p. 21.

10 Hofmański e.a. 2007 II, p. 22-23.

11 Grzegorczyk 2004, p. 757.

12 Grajewski 2006, p. 794. 
Aangezien art. 301 KPK 1997 niet is beperkt tot verhoren door de politie mag worden aangenomen dat het recht betrekking heeft op alle materiële (inhoudelijke) verhoren die gedurende het vooronderzoek worden afgenomen. ${ }^{13}$ Hoewel het daarbij in de regel om politieverhoren zal gaan, dient de raadsman dus ook te worden toegelaten tot verhoren die door de prokurator worden afgenomen. ${ }^{14}$ Het feit dat de wetgever in het kader van art. 301 KPK 1997 de term 'deelname' ('z udziałem') heeft gebruikt, impliceert dat de advocaat tijdens het verhoor van verdachte een actieve opstelling mag aannemen: hij mag interveniëren, opmerkingen maken, vragen stellen, overleggen met zijn cliënt et cetera. Van de aanwezigheid van de raadsman dient melding te worden gemaakt in het proces-verbaal van het

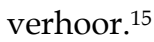

\subsection{Bijstand bij één of verschillende verhoren?}

In de doctrine bestaat discussie over de vraag of art. 301 KPK 1997 verdachten het recht geeft om (slechts) eenmalig in het bijzijn van een advocaat te worden verhoord of dat een dergelijk verzoek meer dan eens kan worden ingediend en ingewilligd. Hofmański gaat ervan uit dat de het recht op bijstand van een raadsman niet alleen bij het eerste maar bij alle daaropvolgende verhoren moet kunnen worden geëffectueerd. ${ }^{16}$ Stachowiak daarentegen interpreteert de bepaling zo dat wanneer een verhoor eenmaal in aanwezigheid van een raadsman heeft plaatsgevonden, het recht van art. 301 KPK 1997 is 'opgebruikt'. Hij sluit echter niet uit dat bepaalde omstandigheden uitzonderingen op deze hoofdregel kunnen rechtvaardigen: bijvoorbeeld wanneer een verdachte heeft aangegeven zijn eerder afgelegde verklaring te willen aanvullen of wijzigen of wanneer de raadsman vanwege een legitieme reden een eerder verhoor waarbij zijn aanwezigheid door cliënt was verzocht niet heeft kunnen bijwonen. ${ }^{17}$ Ook Grzegorczyk gaat ervan uit dat het recht in beginsel slechts eenmalig benut kan worden. Hij baseert dit standpunt op het feit dat de wettelijke bepaling het woord 'verhoor' ('przestuchanie') in enkelvoud en niet in meervoud gebruikt waaruit volgens hem dient te worden afgeleid dat een verdachte na eenmalig te zijn verhoord in aanwezigheid van een raadsman hier in beginsel niet opnieuw aanspraak op kan maken. Net als Stachowiak is Grzegorczyk van mening dat dit anders kan zijn wanneer een advocaat om legitieme redenen niet heeft kunnen voldoen aan een eerste verzoek van verdachte - in dit geval is het recht zoals neergelegd in art. 301 KPK 1997 immers nog niet verwezenlijkt - of wanneer de beschuldigingen jegens verdachte worden gewijzigd. De suggestie van Stachiowak dat het recht op bijstand tijdens verhoren

13 Het recht van de raadsman om aanwezig te zijn bij formele verhoren zoals voorafgaand aan de toepassing van voorlopige hechtenis is afzonderlijk geregeld. Zie § 4.3.

14 Zie over het verhoor in het vooronderzoek Kruszyński 2007 I, p. 185: 'In the course of the investigative process the suspect may be interviewed on several occasions depending on the requirements of the investigation. Both the police and the Public Prosecutor can conduct interviews of suspects. In practice, it depends upon who is conducting the investigation. However, in view of the supervisory role of the Public Prosecutor, they may always interview a suspect even if the police have already done so.'

15 Czekaj 1998, p. 42.

16 Hofmański e.a. 2007 II, p. 23: '(...) het recht te verzoeken om deelname van een raadsman betreft niet alleen het eerste verhoor maar ook de daaropvolgende verhoren in het vooronderzoek.'

17 Stachowiak 1997, p. 24. 
mogelijk ook herleeft wanneer de verdachte zijn verklaring wijzigt, wordt door Grzegorczyk echter in twijfel getrokken: dit zou namelijk beteken dat de verdachte bij ieder verhoor recht kan hebben op deelname van een raadsman en zover heeft de wetgever volgens hem niet willen gaan. ${ }^{18}$

De beperkte uitleg die in de doctrine aan art. 301 KPK 1997 wordt gegeven, is verbazingwekkend omdat de letterlijke wettekst geen enkele grond biedt om aan te nemen dat het recht op aanwezigheid van een raadsman slechts voor één enkel verhoor geldt. Aan het door Grzegorczyk genoemde feit dat het woord 'verhoor' in de bepaling in het enkelvoud is gehanteerd, vloeit niet noodzakelijk voort dat het recht slechts eenmalig kan worden benut: in de Poolse tekst van art. 301 KPK 1997 komt het woord 'verhoor' alleen in de tweede zin voor, de eerste zin hanteert slechts het werkwoord 'verhoren' ('przestuchać'). Dus alleen het deel van de bepaling waarin is geregeld dat het niet verschijnen van de raadsman geen gevolgen hoeft te hebben voor de voortgang van het verhoor gebruikt het zelfstandig naamwoord 'verhoor' in het enkelvoud. Dat is mijns inziens slechts een logische wijze van formuleren waaruit niet hoeft te worden afgeleid dat verdachte het genoemde recht dus maar één keer zal kunnen effectueren. Daar komt bij - en dat is een inhoudelijk argument - dat het belang van de aanwezigheid van de raadsman dat met de introductie van art. 301 KPK 1997 door de wetgever is erkend, in beginsel bij alle verhoren van verdachte een rol speelt. Uiteraard is bijstand in het bijzonder gedurende het eerste verhoor van grote betekenis (verdachte kan dan immers op de hoogte worden gesteld van zijn rechtspositie en de mogelijke consequenties van het afleggen van een verklaring voordat hij met vragen over zijn betrokkenheid bij het betreffende strafbare feit wordt geconfronteerd) maar ook bij latere verhoren kan de verdachte behoefte hebben aan en baat hebben bij de aanwezigheid van zijn raadsman. Niet alleen als waarborg tegen het uitoefenen van ongeoorloofde pressie maar ook om te adviseren over het (al dan niet) beantwoorden van bepaalde vragen, er op toe te zien dat verklaringen van verdachte juist worden weergegeven in het proces-verbaal et cetera. Uitgaande van de ratio en de tekst van de bepaling moet dan ook worden aangenomen dat wanneer een verdachte een raadsman heeft benoemd ${ }^{19}$ een verzoek overeenkomstig art. 301 KPK 1997 bij ieder verhoor en in iedere fase van het vooronderzoek opnieuw kan worden gedaan en in beginsel ook zal moeten worden ingewilligd. Voor zover kan worden overzien, geldt dat standpunt ook in de praktijk en wordt door politie en prokuratura niet de beperkte uitleg aan art. 301 KPK 1997 gegeven zoals verwoord door Stachowiak en Grzegorczyk.

\subsection{Rechtsbijstand tijdens verhoor in de praktijk}

Het komt niet heel veel voor dat verhoren in aanwezigheid van een raadsman worden gehouden. Belangrijkste reden voor het feit dat art. 301 KPK 1997 in de praktijk slechts beperkte betekenis heeft, is dat de verdachte slechts recht heeft op aanwezigheid van een 'reeds benoemde' raadsman. In het overgrote deel van de gevallen heeft de verdachte op het moment dat hij voor het eerst wordt verhoord nog geen beschikking over een raadsman. ${ }^{20}$ Omdat de autoriteiten niet

18 Grzegorczyk 2004, p. 757.

19 De enige voorwaarde c.q. beperking die het artikel aangeeft.

20 Verschillende factoren spelen daarbij een rol: zie over verwezenlijking van het recht 
verplicht zijn het verhoor uit te stellen om hem in de gelegenheid te stellen een advocaat te benoemen, vindt het eerste verhoor in de regel zonder rechtsbijstand plaats. Zoals eerder opgemerkt, wordt in de literatuur aangenomen dat de verdachte die een verzoek indient op grond van art. 301 KPK 1997 (eerst) in de gelegenheid dient te worden gesteld een advocaat te benoemen. Hoe wenselijk deze uitleg ook moge zijn, op grond van de huidige wettelijke regeling bestaat daartoe geen verplichting. ${ }^{21}$

In zijn algemeenheid geldt dat het recht van art. 301 KPK 1997 in de praktijk vooral wordt benut door verdachten die beschikken over een gekozen raadsman. ${ }^{22}$ Wanneer de raadsman aanwezig is, wordt hij in de gelegenheid gesteld actief deel te nemen aan het verhoor. Hij mag zijn cliënt adviseren op bepaalde vragen wel of niet te antwoorden, om onderbreking van het verhoor ten behoeve van overleg vragen en verzoeken dat vragen worden gesteld over bepaalde feiten. Het is dus niet uitgesloten dat de raadsman invloed uitoefent op de inhoud van het verhoor (en daarmee op de waarheidsvinding). Onduidelijk is of de verdachte voorafgaand aan zijn verhoor nog de gelegenheid krijgt met zijn raadsman te overleggen - daartoe bestaat in ieder geval geen wettelijk afdwingbaar recht.

Het is wel mogelijk maar niet gebruikelijk dat verhoren van verdachte worden opgenomen. Van het verhoor wordt te allen tijde proces-verbaal opgemaakt dat door de verdachte dient te worden ondertekend. Indien de verdachte weigert te ondertekenen, dient dat - samen met de reden voor weigering - in het procesverbaal te worden vermeld. ${ }^{23}$

\subsection{Recht op rechtsbijstand tijdens het politieverhoor en het EVRM}

$\mathrm{Nu}$ het huidige Poolse strafprocesrecht verdachten blijkbaar een recht op fysieke aanwezigheid van de raadsman bij verhoren toekent, is het de moeite waard om te bekijken of een dergelijk recht ook aan art. 6 EVRM kan worden ontleend. Lange tijd bood de Straatsburgse rechtspraak op deze vraag geen eenduidig antwoord. Aanvankelijk leek het Europese Hof in de richting van een dergelijk recht te redeneren ${ }^{24}$ maar aan het eind van de jaren negentig werd duidelijk dat aan art. 6 EVRM

op rechtsbijstand na aanhouding hoofdstuk $4, \S 2$.

21 Wiliński 2006, p. 562-563.

22 Zie ook Kruszyński 2007 I, p. 195: 'During the interview a lawyer may be present if the suspect so requests. In practice, a request for a lawyer to advise at this stage is made, most frequently, by suspects who are able to pay privately. In other cases, it is unusal for a lawyer to attend the interview.' Volgens Kruszyński kan ook het opleidingsniveau van verdachte in dit verband van belang zijn: 'The right to interview in the presence of a defence lawyer is observed in practice, although generally the right is only exercised by educated persons of means, who are aware of their rights and the consequences that may flow from the interview': Kruszyński 2007 II, p. 263.

23 Kruszyński 2007 II, p. 264.

24 In Imbrioscia t. Zwitserland (EHRM 24-11-1993, nr. 13972/88, zie ook hoofdstuk 4, § 2.5) werd geklaagd over het feit dat de verdachte verschillende keren in afwezigheid van zijn advocaat was verhoord. Het EHRM oordeelde echter dat dit - de gehele procedure bezien - geen schending van art. 6 EVRM opleverde. Daarbij werd met name belang gehecht aan het feit dat klager wel voor en na de politieverhoren met zijn advocaat had kunnen overleggen. Bovendien was de advocaat wel aanwezig geweest bij het laatste verhoor dat gedurende het vooronderzoek was gehouden en hadden de behandelingen in eerste aanleg en in appel in aanwezigheid van de advocaat plaatsgevonden die daarbij voldoende 
in zijn algemeenheid geen recht op fysieke aanwezigheid van een advocaat tijdens verhoren kan worden ontleend. In de zaak Dougan $t$. Verenigd Koninkrijk ${ }^{25}$ werd de klacht dat de verklaringen die Dougan zonder bijstand van een raadsman had afgelegd niet voor het bewijs hadden mogen worden gebruikt, als volgt door het Europese Hof weerlegd:

'The Court (...) notes that in the appeal proceedings the applicant's lawyers, as they had done at the beginning of the trial, changed their defence strategy. Before the Court of Appeal they argued for the first time that the statements made by the applicant to the police should have been declared inadmissible on account of the absence of a solicitor during interview. However the merits of that argument must be tested against the circumstances of the case. Quite apart from the consideration that this line of defence should have been used at first instance, the Court considers that an applicant cannot rely on Article 6 to claim the right to have a solicitor physically present during interview [decurs. DdV].'

Ongeveer een half jaar later lijkt deze stelling door nieuwe rechtspraak van het Europese Hof weer enigszins te worden afgezwakt. In Condron t. Verenigd Koninkrijk had de betreffende verdachte zowel voorafgaand als tijdens de politieverhoren bijstand van een raadsman gehad. Dit is voor het Europese Hof aanleiding om het belang van dergelijke bijstand te benadrukken:

'The fact that an accused person who is questioned under caution' 26 is assured access to legal advice, and in the applicants' case the physical presence of a solicitor during police interview, must be considered a particularly important safeguard for dispelling any compulsion to speak which may be inherent in terms of the caution. ${ }^{27}$

gelegenheid had gehad de verdediging te voeren. Deze uitspraak deed de vraag rijzen of uit de overwegingen van het Europese Hof kon worden afgeleid dat een verdachte in beginsel recht heeft op bijstand van een advocaat bij politieverhoren. Het oordeel van het EHRM dat Imbrioscia in de eerste fase van het vooronderzoek niet de noodzakelijke rechtsbijstand had genoten ('(...) the applicant did not at the outset have the necessary legal support' (§ 41): het ging daarbij om het feit dat de oorspronkelijk door hem benoemde advocate geen enkel bezoek aan haar cliënt had gebracht voordat ze zich na minder dan drie weken uit de zaak terugtrok) zou zo kunnen worden geïnterpreteerd dat bijstand bij politieverhoren - waarop de klacht van Imbrioscia immers betrekking had - onderdeel uitmakt van deze 'noodzakelijke rechtsbijstand' en dus volgens het Europese Hof een van de garanties van art. 6 EVRM vormt. Zie hierover Fijnaut 2001, p. 680. In 1996 kreeg het EHRM in de zaak Murray t. Verenigd Koninkrijk (EHRM 8-2-1996, nr. 18731/91) opnieuw de gelegenheid zich over onderhavige kwestie uit te laten: Murray klaagde onder meer over het feit dat hij in afwezigheid van zijn raadsman was verhoord. Het Hof ging echter bewust niet in op dit onderdeel van de klacht: dit op de tamelijk formele grond dat dit punt bij de behandeling van de zaak door de Commissie niet was beoordeeld (mogelijk omdat Murray deze klacht pas later had ingediend) en - meer inhoudelijk - dat nu reeds was vastgesteld dat klager toegang tot een advocaat had moeten hebben het niet meer noodzakelijk was om te onderzoeken of de raadsman bij de verhoren aanwezig had moeten zijn (§ 69). Zie over Murray ook hoofdstuk 4, § 2.5 .

25 EHRM 14-12-1999, nr. 44738/98 (ontvankelijkheidsbeslissing).

26 Een verdachte die wordt verhoord 'under caution' wordt - voorafgaand aan zijn verhoor geïnformeerd over zijn zwijgrecht en er tevens op gewezen dat het zijn verdediging kan schaden wanneer hij feiten verzwijgt die hij later wel voor de rechter aanvoert.

27 Condron t. Verenigd Koninkrijk, EHRM 2-5-2000, nr. 35718/97, § 60. 
Hoewel in deze uitspraak niet op de overwegingen in Dougan wordt teruggekomen door te oordelen dat het recht om te worden verhoord in het bijzijn van een advocaat besloten ligt in art. 6 EVRM, is van belang dat het Europese Hof een dergelijke vorm van rechtsbijstand in de gegeven omstandigheden als een belangrijke waarborg tegen het onvrijwillig afleggen van belastende verklaringen beschouwd. Een gelijksoortige overweging wordt gedaan in Magee $t$. Verenigd Koninkrijk waarin klager ondanks zijn verzoek om rechtsbijstand pas na het afleggen van een bekennende verklaring in de gelegenheid was gesteld om met zijn advocaat te overleggen. Bovendien waren de detentie- en verhooromstandigheden ${ }^{28}$ gericht op het doorbreken van Magee's stilzwijgen. Dit alles bracht volgens het Europese Hof mee dat:

'(...) the applicant, as a matter of procedural fairness, should have been given access to a solicitor at the initial stages of the interrogation as a counterweight to the intimidating atmosphere specifically devised to sap his will and make him confide in his interrogators'.29

Opvallend is wel dat het EHRM in Magee - anders dan in Condron - niet expliciet het recht op bijstand tijdens politieverhoren noemt maar meer algemeen oordeelt dat klager in de gegeven omstandigheden 'should have been given access to a solicitor at the initial stages of the interrogation' ${ }^{30}$ Zie ook de op dezelfde dag als Magee gedane uitspraak in de zaak Averill $t$. Verenigd Koninkrijk waarin het EHRM gelet op de omstandigheden van het geval oordeelt dat 'as a matter of fairness, access to a lawyer should have been guaranteed to the applicant before his interrogation began'. ${ }^{31}$ Gelet op deze conclusie vindt het EHRM het niet meer noodzakelijk om in te gaan op de klacht ten aanzien van de rechtsbijstand tijdens de politieverhoren. ${ }^{32}$ Deze beide uitspraken benadrukken het belang van rechtsbijstand in de eerste fase van politieverhoren (als compensatie voor intimiderende omstandigheden waaraan verdachten kunnen worden blootgesteld teneinde verklaringen uit te lokken) maar daarbij wordt niet gezegd dat de verdachte ook tijdens zijn verhoor te allen tijde door een advocaat moet kunnen worden bijgestaan. ${ }^{33}$ Dat het Europese Hof wat dat laatste betreft bij haar eerdere standpunt blijft, is onder meer duidelijk geworden in Brennan $t$. Verenigd Koninkrijk. ${ }^{34}$ Daarin werd de positieve werking van rechtsbijstand tijdens het politieverhoor opnieuw benadrukt maar tevens het algemene standpunt uit Dougan herhaald dat een dergelijk recht geen absolute voorwaarde is voor een eerlijk proces in de zin van art. 6 lid 1 EVRM:

28 De specifieke omstandigheden in het Castlereagh Holding Centre waar hij werd vastgehouden, de wijze van verhoren en het feit dat hij geen enkel contact mocht hebben met de buitenwereld.

EHRM 6-6-2000, nr. 36408/97, § 43.

30 Net als in Murray t.Verenigd Koninkrijk lijkt het EHRM hier de termen interrogation en detention - ten onrechte - als synoniemen te gebruiken: Fijnaut 2001, p. 682 en 688, Fijnaut merkt in deze context terecht op dat men iemand '(...) tijdens zijn detention best een recht op vrij verkeer met een raadsman kan geven zonder dat dit een recht op aanwezigheid tijdens de interrogation impliceert'.

31 EHRM 6-6-2000, nr. 36408/97, § 60.

$32 \S 62$.

33 Uitgebreider over deze rechtspraak ten aanzien van art. 6 EVRM en het recht een advocaat te consulteren in de eerste fase na aanhouding: hoofdstuk $4, \S 2.5$. 
'The Court agrees that the recordig of interviews provides a safeguard against police misconduct, as does the attendance of the suspect's lawyer. However, it is not persuaded that these are an indispensable precondition of fairness within the meaning of Article 6 par. 1 of the Convention.' 35

\subsection{Conclusie}

Het is vanuit het oogpunt van een effectieve verdediging in het vooronderzoek van groot belang dat de verdachte in aanwezigheid van zijn raadsman kan worden verhoord. Dat het huidige strafprocesrecht aan de verdachte in dit verband een expliciet wettelijk recht toekent, is een belangrijke verbetering ten opzichte van het oude strafprocesrecht waarin een dergelijke mogelijkheid niet was opgenomen. Met de introductie van art. 301 KPK 1997 heeft de Poolse wetgever gelet op de huidige Straatsburgse rechtspraak in een hogere mate van rechtsbescherming voorzien dan op grond van art. 6 EVRM is vereist. ${ }^{36}$

Positief is dat de wettelijke bevoegdheid ruim en ongeclausuleerd is geformuleerd: ze is niet beperkt tot bepaalde soorten of een bepaald aantal verhoren. In het voorgaande is duidelijk geworden dat in de literatuur wel een beperking wordt ingelezen (namelijk dat de verdachte slechts eenmaal in aanwezigheid van zijn raadsman zou mogen worden verhoord) maar aangezien de wettekst voor een dergelijke uitleg geen enkele aanleiding biedt, dient deze in de praktijk naar mijn mening niet te worden geaccepteerd. Voor zover bekend, gebeurt dat ook niet. De enige voorwaarde die de wetgever stelt, is dat de verdachte verzoekt om bijstand van zijn raadsman. Ook deze voorwaarde dient ruim te worden uitgelegd aangezien deelname aan een verhoor ook op iniatief van de raadsman zou moeten kunnen plaatsvinden.

Hoewel art. 301 KPK 1997 op papier dus een belangrijk en waardevol recht van de verdediging is, blijkt de verwezenlijking ervan te wensen over te laten. Dat de bepaling in de praktijk - vooral in de eerste fase van het vooronderzoek - een beperkte betekenis heeft, hangt nauw samen met de in hoofdstuk 4 gesignaleerde problemen ten aanzien van de effectuering van rechtsbijstand in de eerste periode na aanhouding. ${ }^{37}$ De verdachte kan slechts om deelname van een 'reeds benoemde raadsman' vragen en aangezien maar weinig verdachten op het moment van of direct na hun aanhouding over een advocaat beschikken, komt het weinig voor dat het eerste verhoor (of de eerste verhoren) in aanwezigheid van een raadsman plaatsvindt. Hoewel geen gegevens beschikbaar zijn over de vraag of advocaten die later in de procedure bij een zaak betrokken raken nog gebruik maken van

$35 \S 53$.

36 Het is echter algemeen erkend dat het EVRM slechts minimumwaarborgen biedt en dat het de lidstaten van de Raad van Europa vrij staat hun burgers meer garanties te bieden. Polen is zeker niet het enige Europese land dat op dit punt verder gaat dan de Straatsburgse norm (en de jurisprudentiële uitleg ervan): in het gros van de lidstaten van de Europese Unie is het recht op rechtsbijstand tijdens politieverhoren gegarandeerd. Zie hierover Spronken en Attinger 2005, p. 80: het recht bestaat behalve in Polen in Cyprus, Denemarken, Duitsland, Engeland, Estland, Finland, Hongarije, Italië, Letland, Litouwen, Luxemburg, Oostenrijk, Portugal, Spanje, Tsjechië en Zweden. Zie over het recht op rechtsbijstand tijdens politieverhoren in Europees perspectief ook: Spronken 2006.

37 Zie met name $\S 2.3,2.6$ en 3.6 van hoofdstuk 4 . 
het aanwezigheidsrecht kan natuurlijk een demotiverende werking uitgaan van het feit dat in een eerste - in afwezigheid van de raadsman afgenomen - verhoor al een verklaring is afgelegd.

Om zo effectief mogelijk gebruik te kunnen maken van het recht op rechtsbijstand tijdens verhoren, zou voorafgaand aan het verhoor (vertrouwelijk) overleg moeten kunnen plaatsvinden tussen advocaat en cliënt. Dit geldt uiteraard in het bijzonder wanneer de raadsman zijn cliënt sinds zijn aanhouding nog niet heeft kunnen spreken. Het huidige art. 301 KPK 1997 voorziet echter niet in een dergelijk consultatierecht.

Ten slotte dient te worden benadrukt dat - zoals voor alle in dit hoofdstuk te bespreken procedurele mogelijkheden geldt - het succes van nieuwe strafvorderlijke mogelijkheden van de verdediging niet alleen afhangt van het creëren van de noodzakelijke wettelijke garanties maar ook afhankelijk is van de inzet van de advocatuur. De bevoegdheid politieverhoren bij te wonen is een groot goed maar tegelijkertijd ook een tijdrovende bezigheid waar misschien niet iedere advocaat op zit te wachten. ${ }^{38}$ Toch mag van de strafrechtadvocatuur op dit punt het een en ander worden verwacht: nieuwe rechten en bevoegdheden kunnen immers slechts betekenis krijgen wanneer ze op behoorlijke wijze en in voldoende mate door de strafrechtadvocaat worden benut. ${ }^{39}$

\section{Informatieverstrekking}

\subsection{Inleiding}

Het recht op informatie van de verdediging kan grofweg in twee categorieën worden verdeeld: enerzijds het recht van verdachte om op bepaalde momenten in de procedure over zijn rechten en bevoegdheden te worden geïnformeerd en anderzijds het recht van zowel raadsman als verdachte om op de hoogte te worden gehouden van de ontwikkelingen die zich in de betreffende strafzaak voordoen en daarbij inzage te kunnen hebben in het procesdossier. Laatstgenoemde categorie staat in deze paragraaf centraal. ${ }^{40}$

38 En die bovendien met name in toegevoegde zaken vanwege de geringe vergoedingen ook in financieel opzicht niet erg aantrekkelijk is. Zie over kosteloze rechtsbijstand hoofdstuk 4 , § 3 .

39 Boksem verwoordde dit in de Nederlandse discussie naar aanleiding van het eerder genoemde experiment (tijdelijk systeem rechtsbijstand tijdens politieverhoor) als volgt: 'Een effectieve verdediging betekent niet alleen dat de overheid van alles moet maar legt ook een verantwoordelijkheid bij de raadsman neer. In het geval van het recht om politieverhoren bij te wonen, is het evident dat de mogelijkheden van de verdediging om bij te dragen aan de resultaten van het strafproces enorm toenemen. In een cruciale fase van het strafproces, kan de raadsman een rol van betekenis gaan spelen - door bijvoorbeeld zijn cliënt te informeren, hem te adviseren, tijdens het verhoor in te grijpen en door alert te zijn bij het opstellen van het proces-verbaal van het verhoor. De bevoegdheid betekent wel - zeker wanneer het een algemene bevoegdheid zou worden om bij alle politieverhoren aanwezig te zijn-, dat de raadsman zijn kantoororganisatie daarop zal moeten aanpassen. Dat is dan maar de prijs die hij moet betalen voor een belangrijke versterking van de verdedigingsmogelijkheden'. Zie Boksem 2007, p. 31-32.

40 Voor wat betreft het recht van verdachte om te worden geïnformeerd over zijn rechtspositie wordt verwezen naar hoofdstuk 2, § 2.3.3.3 en hoofdstuk 4, § 2.2.2.3. Zoals daar besproken, is in dit verband voornamelijk het moment van aanhouding en de aanvang van het eerste verhoor van belang. De politie dient de aangehoudene onmiddellijk op de hoogte te stellen van een aantal rechten (het recht een advocaat te contacteren, de recht- 
Voor een effectieve verdediging is het van groot belang dat de raadsman op de hoogte is van de ontwikkelingen in de zaak van zijn cliënt, welk bewijsmateriaal er tegen hem is verzameld, welke onderzoekshandelingen zijn (of worden) verricht et cetera. Van veel procedurele bevoegdheden - zoals het verzoeken om bepaalde onderzoekshandelingen en het instellen van rechtsmiddelen tegen de voorlopige hechtenis - kan alleen effectief gebruik worden gemaakt wanneer de verdediging over voldoende informatie beschikt. Dit ligt ook ten grondslag aan art. 6 lid 3 sub b EVRM: de eisen die aan een eerlijk proces mogen worden gesteld, brengen met zich dat een verdachte over de faciliteiten moet kunnen beschikken die nodig zijn voor de voorbereiding van zijn verdediging. Het recht het procesdossier in te zien wordt tot die benodigde faciliteiten gerekend.

In het Poolse strafproces is de verdediging voor wat betreft haar informatiepositie sterk benadeeld ten opzichte van de vervolging. De prokurator beschikt over alle relevante informatie terwijl de verdediging afhankelijk is van de mate waarin en de wijze waarop een en ander aan haar ter beschikking wordt gesteld. In het onderstaande zal worden besproken op welke wijze informatieverstrekking aan de verdediging gedurende het vooronderzoek in het huidige Poolse strafprocesrecht is vormgegeven.

\subsection{Juridisch kader}

Het recht op informatie omvat in de eerste plaats het recht om inzage te hebben in het dossier en kopieën te maken van processtukken. Behalve door middel van inzage van het dossier kan de verdediging ook op andere wijze informatie verkrijgen over de zaak. In sommige gevallen dient het initiatief daartoe van de autoriteiten uit te gaan. Zo behoort de verdediging ambtshalve op de hoogte te worden gesteld van bepaalde (procedurele) beslissingen en heeft de verdachte recht op een mondelinge of schriftelijke motivering van de aanklacht.

\subsubsection{Inzage stukken gedurende het vooronderzoek}

Het recht van de verdediging om gedurende het strafproces kennis te nemen van de processtukken is geregeld in de art. 156 tot en met 159 KPK 1997. Hoofdregel is dat de verdachte en zijn raadsman recht hebben op inzage van de stukken en het verkrijgen van afschriften ervan. ${ }^{41} \mathrm{Zij}$ kunnen bovendien op hun verzoek en tegen betaling kopieën maken van stukken uit het dossier. ${ }^{42}$ De kosten voor het maken van kopieën en het afgeven van gewaarmerkte afschriften zijn door de minister van Justitie geregeld in een verordening. ${ }^{43}$ Ten slotte is bepaald dat al

matigheid van zijn vrijheidsberoving te laten beoordelen door een rechter, een naaste te informeren over zijn aanhouding en contact te leggen met een consulaat) en voorafgaand aan zijn eerste verhoor krijgt de verdachte een schriftelijk formulier overhandigd waarop een aantal belangrijke rechten - waaronder het zwijgrecht - staat vermeld (de zogenaamde letter of rights, nieuw ingevoerd in het wetboek van strafvordering van 1997).

41 Art. 156 lid 1 KPK 1997.

42 Art. 156 lid 2 KPK 1997. Voor het verkrijgen van gewaarmerkte (officiële) afschriften is toestemming van de president van de rechtbank vereist (156 lid 3 KPK 1997).

43 Art. 156 lid 6 KPK 1997. In deze verordening is bepaald dat voor een kopie van een processtuk 1 złoty (circa 25 eurocent) per pagina moet worden betaald en dat een gewaarmerkt afschrift per bladzijde 6 złotych (circa 1,60 euro) kost: art. 1 en 2 van het besluit inzake de hoogte van kosten voor de afgifte van kopieën van documenten en gewaar- 
deze activiteiten (inzage, het maken van kopieën en gewaarmerkte afschriften) wanneer gevaar voor onthulling van een staatsgeheim ontstaat, alleen kunnen plaatsvinden onder door de rechtbank gestelde voorwaarden. ${ }^{44}$

Bovenstaande regels hebben in de eerste plaats betrekking op de fase nadat de prokurator de zaak door het indienen van de akte van beschuldiging aan de rechter heeft overgedragen (het eindonderzoek). ${ }^{45}$ Ze zijn echter ook van toepassing op de fase voorafgaand aan het onderzoek ter terechtzitting: de verdediging heeft dus ook in het vooronderzoek het recht het dossier in te zien en kopieën of gewaarmerkte afschriften van stukken te verkrijgen. In dit stadium van de procedure geldt echter wel een belangrijke beperking: gedurende het vooronderzoek is inzage in de processtukken, het maken van kopieën en de afgifte van gewaarmerkte afschriften (tenzij de wet anders bepaalt) alleen mogelijk 'met toestemming van degene die het vooronderzoek leidt' ('za zgoda prowadzacego postępowanie przygotowawcze'): dit is de prokurator of de politie. ${ }^{46}$ Ook wanneer het dossier zich tijdens het vooronderzoek bij de rechtbank bevindt - omdat bijvoorbeeld over de voorlopige hechtenis moet worden beslist - is het de leider van het vooronderzoek (en dus niet de rechter) die op verzoeken om inzage beslist. ${ }^{47}$ Van groot belang is dat de beslissing gedurende het vooronderzoek inzage te weigeren niet aan nadere voorwaarden of criteria is verbonden. ${ }^{48}$ Tegen de weigering inzage te verlenen kan door de verdachte of zijn raadsman wel bezwaar (zażalenie) worden aangetekend. ${ }^{49}$ Een dergelijk bezwaar wordt behandeld door de prokuratura..$^{50}$

Inzage vindt plaats bij de prokurator, politie of op de rechtbank en slechts afschriften en kopieën van processtukken kunnen worden meegenomen.

Dat inzage gedurende het vooronderzoek alleen mogelijk is met toestemming van de politie of de prokurator betekent niet dat het gehele dossier geheim kan worden gehouden. Ten aanzien van een aantal categorieën documenten is bepaald dat toestemming niet kan worden geweigerd:

1. processen-verbaal van handelingen waaraan de verdediging heeft deelgenomen of (op grond van een wettelijke bevoegdheid of toestemming van het betrokken procesorgaan) had mogen deelnemen en

2. documenten die van de verdediging zijn verkregen of met haar medewerking zijn opgesteld.

merkte afschriften uit het dossier d.d. 2 juni 2003 (Rozporządzenie Ministra Sprawiedliwości w sprawie wysokości opłaty za wydanie kserokopii dokumentów oraz uwierzytelnionych odpisów z akt sprawy).

$44 \quad$ Art. 156 lid 4 KPK 1997.

45 Dit blijkt ook uit feit dat in art. 156 lid 1 KPK 1997 wordt gesproken van 'het gerechtelijk dossier' ('akta sprawy sadowej').

$46 \quad$ Art. 156 lid 5 jo. art. 311 KPK 1997.

47 Czekaj 1998, p. 44.

48 Zie hierna §3.3.4.

49 Art. 159 KPK 1997.

50 Art. 465 lid 2 en 3 KPK 1997. Wanneer de bestreden beslissing door een prokurator is genomen, wordt het bezwaar behandeld door een collega die hoger in rang is. Wanneer de politie inzage heeft geweigerd, is beoordeling van het rechtsmiddel ook overgelaten aan de prokuratura. 
Dit soort stukken dient dus ook gedurende het vooronderzoek te allen tijde ter beschikking te worden gesteld aan de verdachte en zijn raadsman. ${ }^{51}$ Het gaat hier bijvoorbeeld om processen-verbaal van onderzoekshandelingen die op verzoek van de verdediging hebben plaatsgevonden of van activiteiten die naar alle waarschijnlijkheid niet op het onderzoek ter terechtzitting zullen kunnen worden herhaald.52 Voor beantwoording van de vraag of een processtuk tot een van de bovengenoemde categorieën behoort - en dus zonder meer ter beschikking moet worden gesteld aan de verdediging - is niet relevant of de verdachte en/of zijn raadsman daadwerkelijk bij de betreffende handeling aanwezig zijn geweest: ook wanneer zij het recht daartoe hadden maar daarvan geen gebruik hebben gemaakt is de regeling van toepassing.

De prokurator is verantwoordelijk voor de inhoud van het dossier. Gelet op het beginsel van objectiviteit ${ }^{53}$ is hij verplicht ook aandacht te besteden aan (eventueel) ontlastend bewijsmateriaal en dient hij de stukken die daarop betrekking hebben op te nemen in het dossier. Het wetboek van strafvordering bevat - anders dan de wettelijke bepalingen waarin is vastgelegd op welke wijze proces-verbaal moet worden opgemaakt - geen nadere regels over de inhoud van het procesdossier. Uitgangspunt is dat alleen irrelevante stukken die geen bewijswaarde hebben niet in het dossier hoeven worden opgenomen. De verdediging kan gedurende het vooronderzoek de prokurator verzoeken stukken aan het dossier toe te voegen.

\subsubsection{Inzage voor sluiting vooronderzoek}

De mogelijkheid van advocaat en cliënt om het dossier in te zien, is tot vlak voor sluiting van het vooronderzoek afhankelijk van toestemming. De prokurator (of politie) kan bepalen dat sommige stukken niet mogen worden bekeken of dat zelfs het gehele dossier geheim dient te blijven.54 Vanaf het moment dat er 'gronden bestaan voor sluiting van het vooronderzoek' geldt er een onbeperkt inzagerecht en kunnen de verdachte en zijn raadsman een verzoek indienen tot bekendmaking van al het materiaal dat gedurende het vooronderzoek is verzameld. ${ }^{55}$ Wanneer een dergelijk verzoek wordt ingediend, stelt het orgaan dat het onderzoek leidt (politie of prokurator) de verdachte en zijn raadsman op de hoogte van de datum waarop de bekendmaking zal plaatsvinden. De verdediging wordt daarbij tevens geïnformeerd over de mogelijkheid de stukken eerder dan genoemde (uiterste) datum in te zien. Deze eerdere datum dient in overeenstemming met 'het belang en de complexiteit van de zaak' te worden vastgesteld.

Het recht op bekendmaking van het materiaal (zaznajomienie końcowe) en het recht de stukken eerder in te zien (prawo przejrzenia akt) zijn twee afzonderlijke

$51 \quad$ Art. 157 lid 3 KPK 1997.

52 Art. 315 en 316 KPK 1997. Deelname van de verdediging aan deze handelingen kan in beginsel niet worden geweigerd. Meer hierover in § 5.2.1.2.

53 Dat op grond van art. 4 KPK 1997 tot een van de basisprincipes van het Poolse strafproces behoort ('De organen die het strafproces leiden, zijn verplicht aandacht te besteden aan zowel omstandigheden in het voordeel als in het nadeel van verdachte en dienen deze in aanmerking te nemen').

54 Dit met uitzondering van de in de vorige paragraaf genoemde categorieën documenten die te allen tijde aan de verdediging ter beschikking moeten worden gesteld.

55 Art. 321 lid 1 KPK 1997. 
procedurele mogelijkheden en dienen als zodanig van elkaar te worden onderscheiden. Belangrijkste verschil is dat de bekendmaking onder leiding van de politie of prokuratura gebeurt - zij informeren bij die gelegenheid de verdediging over de inhoud van het dossier - terwijl de (eerdere) inzage betekent dat de verdachte en/of de raadsman het dossier persoonlijk inzien. Op de vraag hoe dit in de praktijk wordt vormgegeven, wordt teruggekomen in § 3.4.

Voor de verdediging is de mogelijkheid de stukken voor sluiting van het vooronderzoek in te zien met name van belang om te beoordelen of er nog aanvullend onderzoek moet worden gedaan. Binnen drie dagen na de inzage kan de verdachte of zijn raadsman een verzoek indienen tot aanvulling van het vooronderzoek. ${ }^{56}$ Wanneer een dergelijk verzoek niet wordt ingediend of wordt afgewezen ${ }^{57}$ en de autoriteiten ook zelf geen redenen voor verder onderzoek zien, wordt het vooronderzoek door de prokurator gesloten en de verdediging daarvan op de hoogte gesteld. ${ }^{58}$

De voorwaarde dat de verdediging zelf om deze inzage moet verzoeken, geldt pas sinds 2003.59 Daarvoor waren autoriteiten verplicht de verdediging ambtshalve te informeren over de inzagemogelijkheid zodra er gronden voor sluiting van het vooronderzoek bestonden. Dit is nu dus afhankelijk gemaakt van het initiatief van de verdediging: als noch de verdachte noch zijn raadsman te kennen heeft gegeven de stukken te willen inzien, kan het vooronderzoek worden gesloten zonder dat er inzage heeft plaatsgevonden. De verdachte dient voorafgaand aan zijn eerste verhoor op de hoogte te worden gesteld van zijn recht een dergelijk verzoek in te dienen: een en ander is opgenomen in art. 300 KPK 1997 en maakt dus onderdeel uit van de schriftelijke informatie (letter of rights) die verdachte aan het begin van zijn verhoor krijgt overhandigd. Ook dat de eerdere datum waarop de verdediging de stukken mag inzien overeen moet komen met 'het belang en de complexiteit van de zaak' is in 2003 aan de wettelijke regeling toegevoegd. Voorheen was slechts bepaald dat een eerdere 'geschikte' datum ('w odpowiednim (...) terminie') kon worden vastgesteld. Momenteel geldt dat bij het vaststellen van deze datum rekening moet worden gehouden met de tijd die de verdediging gezien de omvang en de inhoud van het dossier nodig zal hebben om de stukken te bestuderen. Tussen de dag waarop de inzage mogelijk is en de datum waarop de verdediging hierover wordt ingelicht, dient een termijn van ten minste zeven dagen te zitten. ${ }^{60}$

$56 \quad$ Art. 321 lid 5 KPK 1997.

57 De gronden voor afwijzing van bewijsverzoeken zijn opgesomd in art. 170 KPK 1997: bijvoorbeeld wanneer het verzoek overduidelijk is bedoeld om de procedure te vertragen of feiten betreft die irrelevant zijn voor de behandeling van de zaak.

58 Art. 321 lid 6 KPK 1997. Wanneer wel aanvullend onderzoek wordt verricht, dient de verdediging opnieuw in de gelegenheid te worden gesteld kennis te nemen van alle processtukken: de procedure van art. 321 KPK 1997 dient dan opnieuw te worden doorlopen.

59 Bij gelegenheid van de wetswijziging van juli 2003 is in art. 321 lid 1 KPK 1997 'op verzoek van verdachte of zijn raadsman' opgenomen.

$60 \quad$ Art. 321 lid 2 KPK 1997. 
De raadsman heeft het recht aan de inzage deel te nemen en kan dus zelfstandig het dossier inkijken. ${ }^{61}$ Ook op dit punt heeft de regeling in 2003 een belangrijke wijziging ondergaan. In het oorspronkelijke derde lid van art. 321 KPK 1997 was namelijk niet alleen bepaald dat de raadsman het recht had aan de inzage deel te nemen maar tevens dat zijn aanwezigheid in geval van verplichte rechtsbijstand op grond van art. 79 KPK 1997 (bijvoorbeeld bij twijfel aan de geestelijke gezondheid van verdachte) noodzakelijk was. In laatstgenoemde situaties kon de inzage niet in afwezigheid van een advocaat plaatsvinden. ${ }^{62}$ Omdat het in het verleden geregeld gebeurde dat advocaten niet kwamen opdagen bij de inzage waardoor een nieuwe datum moest worden bepaald en de sluiting van het vooronderzoek moest worden uitgesteld, is er voor gekozen deze verplichting te schrappen. ${ }^{63}$ Hierdoor kan de procedure voortaan gewoon doorgang vinden wanneer een advocaat - wiens bijstand ingevolge art. 79 KPK 1997 verplicht is - zonder voorafgaande kennisgeving niet verschijnt. De algemene regel luidt nu immers dat het geen consequenties heeft voor de voortgang van de procedure wanneer de verdachte, zijn (al dan niet verplichte) raadsman of beiden zonder voorafgaande kennisgeving niet bij de mogelijkheid tot inzage aanwezig zijn. ${ }^{64}$ In een dergelijk geval hoeft dus geen nieuwe mogelijkheid te worden verleend en kan het onderzoek gewoon worden gesloten. Wanneer verdachte en/ of raadsman van te voren hebben aangegeven niet aanwezig te kunnen zijn, dient de inzage in beginsel wel te worden uitgesteld.

\subsubsection{Overige manieren ter verkrijging van informatie}

Inzage van de processtukken is weliswaar de belangrijkste maar niet de enige manier waarop de verdediging informatie kan verkrijgen over de stand van zaken gedurende het vooronderzoek. De belangrijkste andere wijzen van informatieverstrekking zullen in deze paragraaf aan de orde komen.

Zoals in hoofdstuk 2, § 3.1.3.1 is opgemerkt, wordt de verdachte aan het begin van het vooronderzoek door de politie of de prokurator op de hoogte gesteld van de tegen hem bestaande beschuldigingen: hetzij door middel van een schriftelijke beslissing hetzij mondeling in het kader van een verhoor. Genoemde schriftelijke beslissing (postanowienie o przedstawieniu zarzutów) dient in ieder geval de persoon van de verdachte aan te wijzen, een nauwkeurige omschrijving te geven van datgene waarvan hij wordt verdacht en te bepalen welk strafbaar feit deze gedraging oplevert. ${ }^{65}$ Aangezien politie en prokuratura in dit vroege stadium van de procedure doorgaans weinig openheid van zaken willen geven, wordt de informatie die in dit kader aan verdachte worden verstrekt in de regel tot het absoluut noodzakelijke beperkt. In verband hiermee is van groot belang dat de verdachte gedurende het grootste deel van het vooronderzoek - namelijk tot het moment dat hij wordt geïnformeerd over de mogelijkheid het gehele dossier in

$61 \quad$ Art. 321 lid 3 KPK 1997.

62 Dit kon worden afgeleid uit het oorspronkelijke art. 321 lid 4 KPK 1997 waarin was bepaald dat 'het niet verschijnen van de verdachte of - met uitzondering van de gevallen genoemd in art. 79 - zijn raadsman, niet in de weg staat aan de voortgang van de procedure'.

63 Zie hierover ook hoofdstuk 4, § 3.2 en 3.4.3.

64 Art. 321 lid 4 KPK 1997.

65 Art. 313 lid 2 KPK 1997. 
te zien ${ }^{66}$ - kan verzoeken dat '(...) de gronden voor zijn verdenking mondeling aan hem worden toegelicht en dat deze motivering op schrift wordt gesteld' ${ }^{67}$ Hoewel de wettekst de indruk wekt dat verdachte zowel om een mondelinge als om een schriftelijke toelichting kan vragen, wordt in de literatuur benadrukt dat slechts van een van beide mogelijkheden gebruik kan worden gemaakt. ${ }^{68}$ Wanneer de verdachte om een mondelinge toelichting vraagt, dient deze hem onmiddellijk te worden gegeven. Indien om een schriftelijke motivering wordt gevraagd, dient deze binnen veertien dagen aan zowel de verdachte als zijn raadsman te worden overhandigd. Inhoudelijk moet de schriftelijke motivering in ieder geval duidelijk maken welke feiten en aanwijzingen aan de verdenking ten grondslag liggen. ${ }^{69}$ Dit vereist weliswaar niet dat getuigen met naam en toenaam worden genoemd maar wel dat wordt beschreven welke bewijselementen er zijn en welke feiten daaraan worden ontleend, bijvoorbeeld dat er een getuigenverklaring is die inhoudt dat (...). ${ }^{70}$ Het verzoek om de motivering kan namens de verdachte ook door de raadsman worden ingediend. ${ }^{71}$

Bovendien is in het kader van de informatieverstrekking aan de verdediging van belang dat bepaalde documenten (beslissingen en andere stukken) ambtshalve aan verdachte moeten worden gezonden. Dit geldt bijvoorbeeld voor de mededeling dat de akte van beschuldiging naar de rechtbank is gestuurd, voor de akte van beschuldiging zelf, voor beslissingen (orzeczenia en zarzadzenia) die niet op een zitting zijn genomen en voor de kennisgeving dat een ingesteld hoger beroep ontvankelijk is verklaard. ${ }^{72}$ De wetgever heeft bepaald dat in dergelijke gevallen - waarin de wet verzending aan de verdachte voorschrijft - de raadsman ook telkens een afschrift dient te ontvangen. ${ }^{73}$

66 Conform art. 321 KPK 1997.

67 Art. 313 lid 3 KPK 1997. De verdachte dient op de hoogte te worden gesteld van dit recht dat overigens ook geldt wanneer er geen schriftelijke beslissing tot bekendmaking van de beschuldigingen is opgesteld. De motivering kan dus ook betrekking hebben op de informatie die tijdens een verhoor mondeling aan de verdachte is medegedeeld.

68 De relevante bepaling luidt immers: 'De verdachte kan (...) verzoeken dat de gronden voor de beschuldigingen hem mondeling worden medegedeeld en eveneens (a także) [decurs. DdV] dat een schriftelijke motivering wordt opgesteld.' (art. 313 lid 3 KPK 1997). Hofmański e.a. 2007 II, p. 102: 'Van deze rechten kan hij [verdachte, toev. DdV] slecht op een van de twee eerder genoemde wijzen gebruik maken, wat betekent dat slechts een van de in lid 3 genoemde mogelijkheden door verdachte kan worden benut.'

69 Art. 313 lid 4 KPK 1997. De inhoud van de mondelinge toelichting is door de wetgever niet nader bepaald. Logischerwijze zal daarin in ieder geval melding moeten worden gemaakt van de bewijsmiddelen die ten grondslag liggen aan de beschuldiging en de juridische kwalificatie ervan moeten worden uiteengezet: Hofmański e.a. 2007 II, p. 102.

70 Grzegorczyk 2004, p. 797.

71 De raadsman ontleent dit recht aan de verdachte en is dus niet bevoegd de motivering - zonder instemming van zijn cliënt - voor zichzelf aan te vragen: Grzegorczyk 2004, p. 79.

72 Respectievelijk art. 334 lid 2, 338 lid 1, 100 lid 2 en 448 lid 1 KPK 1997.

73 Art. 140 KPK 1997. Ten aanzien van sommige documenten is dit afzonderlijk bepaald (bijvoorbeeld in art. 448 lid 1 KPK 1997: het bericht dat het hoger beroep ontvankelijk is verklaard, dient aan de raadsman en verdachte te worden verzonden) maar voor de gevallen waarin dit niet is gebeurd, voorziet genoemde bepaling in de algemene verplichting ook de raadsman te informeren. 
Ook dient de verdachte op zijn verzoek kosteloos een gewaarmerkt afschrift te krijgen van alle rechterlijke beslissingen (orzeczenia): dus wanneer verzending daarvan niet ambtshalve plaatsvindt, kan de verdediging erom verzoeken. ${ }^{74}$

Ten slotte kan in geval van voorlopige hechtenis ook (extra) informatie worden ontleend aan de beslissing tot toepassing van dit dwangmiddel. Genoemde beslissing moet worden gemotiveerd en dient in ieder geval aanwijzingen te bevatten die aannemelijk maken dat verdachte het betreffende feit heeft gepleegd en melding te maken van de feiten en omstandigheden die de grond(en) voor voorlopige hechtenis opleveren. ${ }^{75}$ Ten slotte dient in de motivering ook te worden aangegeven waarom andere - minder ingrijpende - preventieve maatregelen niet toereikend zijn. ${ }^{76}$

\subsection{Situatie voor inwerkingtreding nieuw strafprocesrecht}

De wijze waarop de informatiepositie van de verdediging vandaag de dag is geregeld, vertoont geen fundamentele verschillen ten opzichte van het oude strafprocesrecht: de regeling is in hoofdlijnen hetzelfde. Ook op grond van het oude wetboek van strafvordering kon inzage van processtukken gedurende vrijwel het gehele vooronderzoek worden geweigerd en werd voorzien in een speciale regeling voor de laatste fase van het vooronderzoek waarin de verdediging met het gehele dossier bekend werd gemaakt.

\subsubsection{Inzage stukken gedurende het vooronderzoek}

Belangrijkste overeenkomst tussen de oude en de nieuwe regeling is dat inzage in het dossier - en het verkrijgen van kopieën en gewaarmerkte afschriften van delen eruit - onder het oude strafprocesrecht ook alleen mogelijk was met toestemming van de leider van het vooronderzoek. ${ }^{77}$ Een wezenlijk verschil is echter dat de mogelijkheid inzage te weigeren onder de oude regeling betrekking had op het gehele dossier: de regel dat inzage van bepaalde categorieën processtukken niet kan worden geweigerd (huidig art. 157 lid 3 KPK 1997) is nieuw in het wetboek van $1997 .{ }^{78}$

Een ander verschil dat vermelding verdient, is dat in de oude regeling niet was bepaald dat tegen de weigering inzage te verlenen bezwaar kon worden aangetekend. Over de vraag of een dergelijk rechtsmiddel kon worden ingesteld, bestond

$74 \quad$ Art. 157 lid 1 KPK 1997. Orzeczenia bestaan uit wyroki (einduitspraken) en postanowienia (andere door de rechtbank genomen beslissingen). Postanowienia kunnen zowel in het vooronderzoek als in het eindonderzoek worden genomen en kunnen betrekking hebben op bijvoorbeeld de toepassing en verlenging van voorlopige hechtenis, de medebrenging van verdachte naar de zitting of de toepassing van bepaalde opsporingsmethoden zoals de telefoontap. Zie over de verschillende soorten rechterlijke beslissingen ook hoofdstuk 2, § 3.2.3.

75 Art. 251 lid 3 KPK 1997. Het Poolse strafprocesrecht verlangt een algemene en een bijzondere grond voor de toepassing van voorlopige hechtenis. Zie over de gronden voor voorlopige hechtenis: $§ 4.2$.

76 Dat voorlopige hechtenis ultimum remedium dient te zijn blijkt uit art. 257 lid 1 KPK 1997: 'Voorlopige hechtenis vindt niet plaats wanneer een andere preventieve maatregel toereikend is.'

77 Art. 143 lid 3 KPK 1969. In het wetboek van strafvordering van 1969 was het recht op inzage in de processtukken geregeld in art. 142 tot en met 144.

78 Deze aanvulling is voor de inwerkingtreding van het nieuwe wetboek van strafvordering veelvuldig bepleit door de doctrine. 
zowel in de doctrine als in de praktijk veel discussie. De controverse was hoofdzakelijk het gevolg van een verschillende uitleg van de algemene wetsbepalingen waarin het recht op het aanwenden van rechtsmiddelen tegen verschillende soorten beslissingen was geregeld. ${ }^{79}$ Grzegorczyk behoorde tot de categorie juristen die van mening was dat uit het systeem en de letterlijke tekst van de wet moest worden afgeleid dat tegen beslissingen die gedurende het vooronderzoek werden genomen alleen een rechtsmiddel kon worden ingesteld wanneer de wetgever dat uitdrukkelijk had bepaald. ${ }^{80}$ Grzegorczyk betreurde het resultaat van zijn uitleg overigens wel: het was volgens hem wel wenselijk dat tegen de weigering inzage te verlenen in het dossier bezwaar zou kunnen worden ingesteld maar daarvoor zou een wetswijziging noodzakelijk zijn. ${ }^{81}$ Voor wat de praktijk betreft, is van belang dat ook de prokuratura er ten tijde van het oude strafprocesrecht in beginsel van uit ging dat een dergelijk bezwaar niet openstond. ${ }^{82}$

Het nieuwe wetboek van strafvordering heeft aan alle onzekerheid op dit punt een einde gemaakt door het rechtsmiddel in art. 159 KPK 1997 van een expliciete wettelijke grondslag te voorzien.

\subsubsection{Inzage voor sluiting vooronderzoek}

Ook voor wat betreft de kennisneming van processtukken vlak voor sluiting van het vooronderzoek komt de huidige regeling in de kern overeen met die van het wetboek van 1969.83 Toch is er een aantal verschillen.

Een eerste verschil betreft het moment waarop verdachte laatste inzage moet (kunnen) krijgen: in de regeling van 1969 diende de verdachte bekend te worden gemaakt met al het materiaal en op de hoogte worden gesteld van zijn recht alle stukken in te zien wanneer er gronden waren voor het opstellen van een akte van beschuldiging. ${ }^{84}$ Momenteel ontstaat de verplichting de verdediging hierover in te lichten 'wanneer er gronden bestaan voor de sluiting van het vooronderzoek' $^{85}$ Deze nieuwe formulering maakt duidelijk dat onbeperkte inzage voor sluiting van het vooronderzoek ook mogelijk moet zijn wanneer in plaats van een akte van beschuldiging bijvoorbeeld een verzoek om voorwaardelijke beëindiging van de procedure wordt ingediend. Voor procedures waarin 'gewoon' een akte van

79 Het ging hierbij met name om art. 268, 409, 413 en 414 KPK 1969. Zie onder meer: Mazur 1971, p. 71-73.

80 Grzegorczyk 1980, p. 68-70 en Grzegorczyk 1988, p. 156-168.

81 Grzegorczyk 1980, p. 70 en Grzegorczyk 1988, p. 165.

82 De prokuratura baseerde zich daarbij op het eerder genoemde standpunt dat tegen een beslissing op een verzoek van een raadsman alleen een rechtsmiddel kon worden ingesteld wanneer de wet dat uitdrukkelijk bepaalde: Mazur 1971, p. 71. Uit onderzoek dat in de jaren zeventig is verricht, blijkt echter dat de discussie toch zijn weerslag heeft gehad op de praktijk: het kwam wel eens voor dat de prokuratura bezwaren tegen de weigering inzage te verlenen in aanmerking nam, Grzegorczyk 1988, p. 165.

83 Art. 277 KPK 1969.

84 'Jeżeli istnieja podstawy do sporządzenia aktu oskarżenia' (art. 277 lid 1 KPK 1969). Het moment waarop de verdediging over de laatste mogelijkheid tot inzage werd ingelicht, was overigens ook in ander opzicht van groot belang: wanneer de verdediging deze mededeling had ontvangen, waren beperkingen op het vrij verkeer niet meer toegestaan. Dit betekende dat het overleg tussen raadsman en cliënt niet langer onder toezicht kon plaatsvinden of kon worden verboden (art. 64 lid 2 tweede zin KPK 1969). Meer hierover in hoofdstuk 7. 
beschuldiging volgt, heeft de wijziging echter nauwelijks betekenis omdat beide momenten (indienen akte en sluiting vooronderzoek) zich gelijktijdig voordoen. Een tweede verschil heeft betrekking op het recht van de verdediging de stukken voorafgaand aan de bekendmaking in te kunnen zien: onder de oude regeling was dit recht ook zowel aan de verdachte als de raadsman toegekend maar was alleen ten aanzien van laatstgenoemde bepaald dat hij het recht had de stukken zeven dagen voor de bekendmaking te bestuderen. ${ }^{86}$ In de huidige bepaling wordt benadrukt dat niet alleen de raadsman maar ook de verdachte zelf voldoende tijd moet worden geboden om de stukken persoonlijk te kunnen inzien. ${ }^{87}$

Bovendien is - zoals in het voorgaande duidelijk is geworden - door de wetswijziging van juli 2003 een aantal nieuwe verschillen tussen het oude en het huidige strafprocesrecht ontstaan:

- Door de toevoeging 'op verzoek verdachte of zijn raadsman' ('na wniosek podejrzanego lub jego obrońcy') zijn autoriteiten anders dan onder het oude wetboek van strafvordering alleen nog maar verplicht de verdediging in te lichten over de mogelijkheid tot inzage voor sluiting van het vooronderzoek wanneer zij te kennen heeft gegeven daarvan gebruik te willen maken. ${ }^{88}$

- In gevallen van verplichte rechtsbijstand is de advocaat niet langer verplicht bij de inzage aanwezig te zijn. ${ }^{89}$

- Het is voortaan wettelijk vastgelegd dat autoriteiten bij het bepalen van het moment waarop de verdediging de stukken eerder kan inzien rekening moeten houden met de ernst en complexiteit van de zaak ('w terminie odpowiednim do wagi lub zawiłości sprawy').90

\subsubsection{Overige manieren ter verkrijging van informatie}

De mogelijkheden van de verdediging om - behalve door inzage van het dossier gedurende het vooronderzoek informatie te verkrijgen, zijn in het nieuwe strafprocesrecht op een aantal punten uitgebreid. Deze uitbreiding betreft in de eerste plaats het recht van verdachte om wanneer hij schriftelijk of mondeling op de hoogte is gesteld van de tegen hem bestaande verdenking daarop een toelichting te ontvangen. Deze mogelijkheid bestond op grond van het oude strafprocesrecht ook (art. 269 lid 3 KPK 1969) maar in meer beperkte vorm:

- Om te beginnen voorzag de regeling van het wetboek van strafvordering van 1969 alleen in de mogelijkheid van een schriftelijke motivering: het onvoorwaardelijke recht om een mondelinge toelichting te ontvangen, is nieuw in het wetboek van strafvordering van 1997 ingevoerd. Deze uitbreiding is belangrijk omdat voor het opstellen van de schriftelijke motivering - zowel op grond van het oude als het nieuwe strafprocesrecht - een termijn van 14 dagen wordt gesteld. Wanneer de verdachte om een mondelinge toelichting vraagt, dient

$86 \quad$ Art. 277 lid 1 KPK 1969.

87 Art. 321 lid 2 KPK 1997.

88 Art. 321 lid 1 KPK 1997. Op grond van het oude wetboek van strafvordering was de leider van het vooronderzoek verplicht deze informatie ambtshalve aan de verdediging te verstrekken.

89 Art. 321 lid 3 tweede zin is geschrapt.

90 Art. 321 lid 1 KPK 1997. Zie over deze verschillen: Hofmański e.a. 2007 II, p. 122-123. 
deze echter onmiddellijk te worden gegeven waardoor de verdediging sneller over extra informatie kan beschikken.

- Ook de regel dat behalve de verdachte tevens de raadsman een afschrift van de motivering dient te ontvangen (art. 313 lid 3 tweede zin KPK 1997) was niet in de oude codificatie opgenomen. Over de vraag of de raadsman een dergelijk recht had, werd onder het oude wetboek van strafvordering dan ook verschillend gedacht. ${ }^{91}$

- Onder het oude strafprocesrecht was niet duidelijk tot op welk moment of binnen welke termijn de verdachte de autoriteiten om een dergelijke motivering kon vragen. In de huidige regeling is expliciet bepaald dat het verzoek om een mondelinge of schriftelijke toelichting kan worden ingediend 'tot het moment waarop hij [de verdachte, toev. DdV] wordt geïnformeerd over de bekendmaking van de in het vooronderzoek verzamelde stukken' ${ }^{\prime}{ }^{92}$

- Ten slotte was de inhoud van de motivering in de oude regeling niet gespecificeerd: in de huidige bepaling is duidelijk aangegeven dat in ieder geval de feiten en bewijsmiddelen moeten worden opgenomen die de basis vormen voor de verdenking. ${ }^{93}$

Voor wat betreft de verplichting van de autoriteiten om bepaalde documenten (beslissingen en andere stukken) automatisch aan verdachte te zenden, bestaan geen noemenswaardige verschillen tussen het oude en het nieuwe strafprocesrecht. ${ }^{94}$ Een belangrijk onderscheid bestaat wel ten aanzien van de verplichting de raadsman een afschrift te sturen. Onder het oude wetboek van strafvordering was bepaald dat in de gevallen waarin de wet verzending aan de verdachte voorschrijft het sturen van een afschrift aan de raadsman slechts verplicht was wanneer de verdachte van zijn vrijheid was beroofd. ${ }^{95}$ Laatstgenoemde beperking is komen te vervallen: de wettelijke verplichting de verdachte een afschrift te sturen, betekent in alle gevallen dat ook de raadsman moet worden geïnformeerd. ${ }^{96}$

Een laatste verschil tussen het oude en het nieuwe strafprocesrecht dat van invloed is op de informatiepositie van de verdediging gedurende het vooronder-

91 Deze twijfel was volgens Grzegorczyk echter onterecht: in (lagere) regelgeving die betrekking had op de prokuratura was immers expliciet bepaald dat ook de raadsman een verzoek om motivering kon indienen. Bovendien diende het uitgangspunt te zijn dat bevoegdheden die aan de verdachte zijn toegekend ook door de raadsman (als procesvertegenwoordiger van zijn cliënt) moeten kunnen worden uitgeoefend: Grzegorczyk 1988, p. 134.

92 Art. 313 lid 3 eerste zin KPK 1997. Er hoeft dus geen twijfel meer over te bestaan dat de verdediging tot aan de laatste fase van het vooronderzoek om een toelichting van de beschuldiging mag vragen. De wetgever is er van uitgegaan dat de verdediging hieraan geen behoefte meer zal hebben wanneer ze - aan het einde van het vooronderzoek - op de hoogte is gesteld van de datum waarop ze bekend zal worden gemaakt met het gehele dossier: alle gewenste informatie zal dan immers uit de processtukken kunnen worden verkregen.

93 Art. 321 lid 4 KPK 1997. Over de verschillen tussen art. 269 KPK 1969 en art. 313 KPK 1997: Hofmański e.a. 2007 II, p. 95-96.

94 Hetzelfde geldt voor de mogelijkheid kosteloos een gewaarmerkt afschrift van beslissingen (orzeczenia) te ontvangen.

95 Art. 126 KPK 1969.

96 Art. 140 KPK 1997. 
zoek heeft betrekking op de motivering van de beslissing tot toepassing van de voorlopige hechtenis. In het nieuwe wetboek van strafvordering is namelijk expliciet bepaald dat het bevel voorlopige hechtenis met redenen omkleed moet zijn en dat de motivering in ieder geval aan moet geven op welke aanwijzingen de verdenking is gebaseerd, welke omstandigheden tenuitvoerlegging van voorlopige hechtenis noodzakelijk maken en waarom niet kan worden volstaan met de toepassing van een andere - minder ingrijpende - preventieve maatregel. ${ }^{97}$ In het wetboek van strafvordering van 1969 bestond een dergelijke motiveringsplicht niet. Aan de beslissing tot toepassing van de voorlopige hechtenis zou de verdediging vandaag de dag dus meer informatie moeten kunnen ontlenen dan onder het oude wetboek van strafvordering. De praktische (meer)waarde van deze motivering is in veel gevallen echter beperkt. ${ }^{98}$

\subsection{Evaluatie juridisch kader}

Uit de vergelijking met het oude strafprocesrecht blijkt dat de wetgever de informatiepositie van de verdediging gedurende het vooronderzoek op een aantal punten heeft willen verbeteren:

- Inzage van bepaalde categorieën documenten kan niet langer worden geweigerd.

- Tegen de weigering inzage te verlenen staat een rechtsmiddel open.

- De verdediging moet - niet alleen wanneer een akte van beschuldiging wordt ingediend maar ook wanneer het vooronderzoek op andere wijze wordt beëindigd - op haar verzoek op de hoogte worden gesteld van de mogelijkheid voor de sluiting van het vooronderzoek bekend te worden gemaakt met alle stukken.

- Benadrukt is dat niet alleen de raadsman maar ook de verdachte in de gelegenheid moet zijn ruim (ten minste zeven dagen) voor de bekendmaking met de stukken zelf inzage te hebben en dat bij het bepalen van de datum voor eerdere inzage rekening moet worden gehouden met de ernst en ingewikkeldheid van de zaak.

- Wanneer iemand als verdachte is aangemerkt, kan hij niet alleen vragen om een schriftelijke motivering van de tegen hem bestaande verdenking maar heeft hij ook het recht die toelichting onmiddellijk mondeling te krijgen,

- Het is expliciet bepaald tot welk moment in de procedure de verdachte om een dergelijke (mondelinge of schriftelijke) motivering kan verzoeken, welke feiten en omstandigheden er in ieder geval in op moeten worden genomen en dat ook de raadsman een afschrift van de motivering dient te ontvangen,

- In de gevallen waarin wettelijk is voorgeschreven dat een beslissing ambtshalve aan de verdachte bekend moet worden gemaakt, dient in alle gevallen (en dus niet alleen in geval van voorlopige hechtenis) ook een afschrift aan de raadsman te worden verzonden en

97 Art. 251 lid 3 KPK 1997. De eerste twee eisen die aan de motivering worden gesteld gelden overigens niet alleen ten aanzien van het bevel voorlopige hechtenis maar gelden ook voor de beslissing tot toepassing van andere preventieve maatregelen.

98 Het komt regelmatig voor dat de rechtbank standaardformuleringen gebruikt en vaak wordt niet duidelijk gemaakt welke feiten of omstandigheden toepassing van voorlopige hechtenis noodzakelijk maken: Wąsek-Wiaderek 2003 II, p. 246. 
- De beslissing tot toepassing van voorlopige hechtenis dient uitgebreider te worden gemotiveerd.

Een beoordeling van de huidige regeling dient echter niet alleen betrekking te hebben op wat de wetgever wél heeft geregeld: ook van belang is welke wijzigingen - ondanks daartoe strekkende voorstellen in de doctrine - niet zijn doorgevoerd. De belangrijkste betreffen de hiernavolgende punten.

\section{Behoud toestemmingsvereiste zonder specificatie omstandigheden}

In de huidige wettelijke regeling is niet opgenomen dat het weigeren van toestemming tot inzage gedurende het vooronderzoek alleen in uitzonderlijke gevallen is toegestaan. De formulering van art. 156 lid 5 KPK 1997 lijkt eerder het tegenovergestelde te veronderstellen: de verdediging kan het dossier niet inzien, tenzij daarvoor toestemming wordt verleend. Bovendien heeft de wetgever niet aangegeven welke grond(en) kunnen rechtvaardigen dat inzage wordt geweigerd. Hierdoor is het voor de politie of de prokuratura heel eenvoudig bij de beoordeling van een verzoek tot inzage het opsporingsbelang zwaarder te laten wegen dan het belang dat de verdediging heeft bij inzage van het dossier. ${ }^{99}$

\section{Geen bijzondere waarborgen voor verdachten in voorlopige hechtenis}

De huidige regeling is onverkort van toepassing op verdachten die zich in voorlopige hechtenis bevinden: ook ten aanzien van hen bestaat de mogelijkheid inzage van het dossier tot aan de eindfase van het vooronderzoek te weigeren. Dat terwijl deze categorie verdachten er een bijzonder belang bij heeft goed geïnformeerd te zijn. Om effectief gebruik te maken van de wettelijke mogelijkheden de rechtmatigheid van de vrijheidsbeneming te laten toetsen door een rechter dient de verdediging over de daarvoor relevante informatie te kunnen beschikken. Zoals hierna nog zal worden uitgewerkt, kan het onthouden van stukken in het kader van procedures ten aanzien van de voorlopige hechtenis strijd opleveren met art. 5 lid 4 EVRM. ${ }^{100}$ Wąsek-Wiaderek is om die reden van mening dat de wettelijke regeling van art. 156 KPK 1997 zou moeten worden aangevuld met de bepaling dat inzage van processtukken door de raadsman van een voorlopig gehechte cliënt alleen in uitzonderingsgevallen kan worden geweigerd. ${ }^{101}$ Vlak voor afronding van dit onderzoek (juni 2008) is in een uitspraak van het Grondwettelijk Hof bevestigd dat de ruime formulering van art. 156 lid 5 KPK inderdaad problemen oplevert met het grondwettelijk recht op verdediging van voorlopig gehechte verdachten. Meer over deze uitspraak in § 3.6.

\section{Mogelijkheid weigeren inzage niet gebonden aan termijn}

Een ander punt van kritiek betreft het feit dat de mogelijkheid inzage te weigeren in de huidige regeling niet is verbonden aan een bepaalde termijn. In de literatuur wordt in dit verband terecht opgemerkt dat het geheim houden van (bepaalde) processtukken in het begin van het vooronderzoek - wanneer nog weinig bewijs-

99 Wąsek-Wiaderek 2003 I p. 65 en Wąsek-Wiaderek 2003 II, p. 260. Dat beperkingen op de mogelijkheid het dossier in te zien niet de regel maar de uitzondering zouden moeten zijn, werd ook reeds voor de inwerkingtreding van het nieuwe wetboek van strafvordering in de literatuur benadrukt: zie bijvoorbeeld Kruszyński 1989, p. 80 en Kruszyński 1993, p. 377.

100 Zie $§ 3.5$.

101 Wąsek-Wiaderek 2003 II, p. 260. 
materiaal is verzameld - onder bepaalde omstandigheden noodzakelijk kan zijn ten behoeve van de waarheidsvinding maar steeds minder vanzelfsprekend is naarmate de procedure langer voortduurt. ${ }^{102}$ Daarbij is door sommige auteurs bepleit de mogelijkheid inzage te weigeren te verbinden aan een wettelijke termijn. ${ }^{103}$

\section{Geen rechterlijke toetsing weigering inzage}

Hoewel de introductie van art. 259 KPK 1997 (bezwaarmogelijkheid) in ieder geval in theorie een vooruitgang betekent ten opzichte van het oude strafprocesrecht omdat een soortgelijk expliciet recht destijds niet bestond, is minder positief dat de wetgever beoordeling van het rechtsmiddel niet - zoals voorgesteld in de doctrine - aan een onafhankelijke rechter maar aan de prokuratura zelf heeft toegekend. ${ }^{104}$ Volgens sommige auteurs is de bezwaarmogelijkheid hierdoor volledig illusoir. Kruszyński heeft in dit verband opgemerkt dat de mogelijkheid rechtsmiddelen te laten beoordelen door de prokuratura meestal een 'fictie' is. ${ }^{105}$ Dit is - gelet op de partijdige positie die de prokurator in het vooronderzoek inneemt een begrijpelijk standpunt. Er zijn aanwijzingen dat de verwachte effectiviteit van het rechtsmiddel van invloed is op de beslissing van de verdediging om er geen gebruik van te maken. ${ }^{106}$

Ten slotte dient erop te worden gewezen dat de wetswijziging van 2003 gevolgen heeft gehad voor de (informatie)positie van de verdediging. Als gevolg van genoemde wetswijziging is de regeling van art. 321 KPK 1997 zodanig gewijzigd dat:

- de verdediging slechts hoeft te worden geïnformeerd over de laatste bekendmaking met de processtukken (voor sluiting van het vooronderzoek) wanneer de verdachte of zijn raadsman daarom heeft gevraagd, en

- aanwezigheid van de raadsman bij die gelegenheid in gevallen van verplichte rechtsbijstand niet langer noodzakelijk is.

Op beide punten heeft de wetgever duidelijk meer waarde gehecht aan een efficiënte afsluiting van het vooronderzoek dan aan een effectieve mogelijkheid van de verdediging om op de hoogte te raken van het bewijsmateriaal. Met eerst-

102 Bieńkowska 1998, p. 14.

103 Voor de totstandkoming van het nieuwe wetboek stelde Kruszyński een termijn van veertien dagen voor: Kruszyński 1989, p. 80 en Kruszyński 1991, p. 182-183. Eenzelfde termijn werd voorgesteld door Kaftal: Kaftal 1989, p. 48. Kruszyński heeft zijn standpunt overigens ook na inwerkingtreding van het nieuwe wetboek van strafvordering nog herhaald: Kruszyński 1998, p. 148-149.

104 Bij de totstandkoming van het nieuwe wetboek van strafvordering leek het er even op dat de wetgever de doctrine op dit punt zou volgen - in eerdere projecten van het nieuwe wetboek van strafvordering was opgenomen dat het bezwaar zou moeten worden behandeld door de rechtbank, zie Grzegorczyk en Tylman 1998, p. 409 - maar uiteindelijk is er toch voor gekozen het rechtsmiddel te laten indienen bij de prokurator zonder mogelijkheid van beroep bij de rechter.

105 Kruszyński 1998, p. 148.

106 Tijdens mijn gesprekken met advocaten in Polen bleek men over het algemeen wel op de hoogte te zijn van de mogelijkheid bezwaar aan te tekenen tegen de weigering inzage te verlenen (slechts één advocaat in Poznań kende de mogelijkheid niet). Over de effectiviteit van dit rechtsmiddel werd verschillend gedacht maar het merendeel van de advocaten gaf aan van de mogelijkheid geen gebruik te maken hoofdzakelijk omdat men van mening was dat op het bezwaar toch niet anders zou worden beslist. 
genoemde wijziging heeft de wetgever de verantwoordelijkheid voor het verkrijgen van informatie (nog) meer bij de verdediging gelegd: de autoriteiten hoeven geen actie te ondernemen wanneer de verdachte of zijn raadsman niet de wens te kennen hebben gegeven aan het eind van het vooronderzoek op de hoogte te worden gesteld van het verzamelde bewijsmateriaal. Het is de vraag of op deze wijze met name van de verdachte die geen rechtsbijstand heeft niet te veel initiatief wordt verwacht. ${ }^{107}$

De tweede wetswijziging heeft tot gevolg dat in gevallen van verplichte rechtsbijstand (genoemd in art. 79 KPK 1997) de verdachte bij de bekendmaking met de processtukken niet noodzakelijk hoeft te worden bijgestaan door zijn raadsman. Deze wijziging is een reactie op het feit dat het onder de oude regeling regelmatig voorkwam dat de verplichte raadsman niet bij de laatste inzage verscheen waardoor er een nieuwe mogelijkheid gepland moest worden. ${ }^{108}$ Door verschillende Poolse auteurs is - vanwege deze praktijk - begripvol op de wetswijziging gereageerd. ${ }^{109}$ Dit alles doet er echter niet aan af dat de gevallen van verplichte rechtsbijstand situaties betreffen ten aanzien waarvan de wetgever er geen twijfel over heeft laten bestaan dat rechtsbijstand vanwege de persoonlijke omstandigheden van verdachte noodzakelijk is voor een effectieve en eerlijke verdediging. Aangenomen mag worden dat deze noodzaak tot bijstand zich uitstrekt over alle voor de verdachte relevante procesmomenten waartoe de laatste bekendmaking met het dossier zeker moet worden gerekend. ${ }^{110}$ Vooral in grotere strafzaken met omvangrijke dossiers vervult de raadsman in dit opzicht een belangrijke rol: hij kan zijn cliënt duidelijk maken welke stukken relevant zijn voor de verdediging en waar nodig uitleg geven. ${ }^{111}$ Dit geldt in het bijzonder voor de verdachte die onder een van de in art. 79 KPK 1997 genoemde categorieën valt: vanwege zijn persoonlijke omstandigheden kan van hem op dit punt minder zelfstandigheid worden verwacht en zal bijstand van een raadsman in veel gevallen onontbeerlijk

107 De verdachte dient weliswaar op de hoogte te worden gesteld van het recht een dergelijk verzoek in te dienen maar aangezien dit voorafgaand aan zijn eerste verhoor gebeurt en vele maanden kunnen verstrijken tot de eindfase van het vooronderzoek is niet ondenkbaar dat de verdachte - die niet onmiddellijk tijdens of na zijn eerste verhoor heeft verzocht te zijner tijd het gehele dossier te willen inzien - zijn rechten op dit punt is vergeten op het moment dat het kan worden geëffectueerd. Voor de verdachte die wel professionele rechtsbijstand heeft, is het bezwaar van genoemde wetswijziging uiteraard minder groot omdat van de advocaat mag worden verwacht dat hij - wanneer hij dat noodzakelijk acht namens zijn cliënt tijdig een verzoek tot inzage zal indienen.

108 En de sluiting van het vooronderzoek moest worden uitgesteld. Het zijn dus vooral efficiëntie-overwegingen geweest die de wetgever hiertoe hebben gebracht en niet - of in ieder geval in mindere mate - het feit dat dit soort wettelijke verplichtingen moeilijk verenigbaar is met de onafhankelijkheid van de advocaat en het uitgangspunt dat verdachte en raadsman zelf moeten kunnen bepalen hoe de verdediging wordt vormgegeven.

109 Zie bijvoorbeeld Masłowska die in dit verband opmerkt dat de verplichte aanwezigheid van de raadsman bij de laatste inzagemogelijkheid vaak toch niet meer dan een fictie is omdat veel advocaten helemaal niet actief betrokken willen raken bij het vooronderzoek: Masłowska 2004, p. 355.

110 Ook Kulesza is van mening dat de wetswijziging een effectieve verdediging in het vooronderzoek wel eens zou kunnen bemoeilijken. Hij maakt echter niet duidelijk waaruit die moeilijkheden zijns inziens bestaan. Zie Kulesza 2004, p. 207.

111 Hofmański e.a. 2007 II, p. 125. 
zijn voor beoordeling van de stukken en het inschatten van de noodzaak tot aanvulling van het vooronderzoek.

Meer algemeen is het überhaupt opvallend dat het wetboek van strafvordering door het schrappen van bovengenoemde verplichte aanwezigheid - deelname van de raadsman op geen enkel moment in de procedure meer dwingend voorschrijft. Verplichte aanwezigheid van de raadsman kon weliswaar tot 'oponthoud' leiden maar betekende wel dat de advocaat zich in een relatief vroeg stadium in de zaak diende te mengen. Iets wat gelet op de traditionele passieve houding van de Poolse advocaat in het vooronderzoek (waarover later in dit hoofdstuk meer) niet vanzelfsprekend is. Het schrappen van de verplichte aanwezigheid draagt dan ook niet bij aan vergroting van het aandeel van advocaten in het vooronderzoek wat toch een van de doelstellingen van het nieuwe wetboek van strafvordering was.

\subsection{Inzage in de praktijk}

In de jaren zeventig is binnen de advocatuur en de prokuratura een drietal praktijkonderzoeken uitgevoerd die inzicht bieden in de wijze waarop de destijds geldende wettelijke regeling betreffende inzage in de processtukken gedurende het vooronderzoek functioneerde. ${ }^{112}$ Hoewel de methoden en resultaten van de afzonderlijke onderzoeken verschillend zijn, is een aantal overeenkomsten te ontdekken die in ieder geval de conclusie rechtvaardigen dat door advocaten gedurende het communisme terughoudend gebruik werd gemaakt van de mogelijkheid in het vooronderzoek het dossier in te zien. Dit werd zowel door leden van de advocatuur als de prokuratura onderkend. Men verschilde echter wel van mening over de oorzaak van deze terughoudendheid. De advocatuur gaf vooral aan dat een verzoek om inzage niet zinvol zou zijn omdat het toch zou worden geweigerd of omdat de stukken niet volledig zouden zijn. Uit ondervraging van leden van de prokuratura volgde daarentegen dat het gros van de verzoeken wel degelijk werd ingewilligd en dat de verdediging hoogstwaarschijnlijk om andere - bijvoorbeeld strategische - redenen geen actie ondernam op dit punt. ${ }^{113}$ Uit genoemd onderzoek

112 Het betreft de volgende projecten:

- een studie uitgevoerd onder auspiciën van een onderzoeksbureau van de prokuratura (1970),

- een onderzoek door de landelijke balie (Naczelna Rada Adwokacka) (1977) en

- een enquête (wederom in het kader van onderzoek door de prokuratura) uitgevoerd door Grzegorczyk (1979).

113 Het onderzoek uit 1970 - waarbij zowel advocaten als leden van de prokuratura werden betrokken - liet zien dat van het ondervraagde aantal advocaten (257) ongeveer $82 \%$ aangaf gedurende het vooronderzoek geen inzage in het dossier te hebben. Tweederde van deze respondenten wees in dit verband op het feit dat geen toestemming voor inzage werd verkregen. Het overige deel gaf een andere verklaring voor deze situatie waaronder de (vermeende) onvolledigheid van dossiers, het feit dat inzage bij politie en prokuratura niet onder de juiste omstandigheden zou kunnen plaatsvinden en de vrees om opsporings- en vervolgingsinstanties tegen zich in het harnas te jagen. Volgens vertegenwoordigers van de prokuratura diende de verdediging de oorzaak voor de beperkte mate waarin inzage werd verkregen vooral bij zichzelf te zoeken: zij gaven aan dat de advocatuur simpelweg te weinig gebruik maakte van haar wettelijke mogelijkheden op dit punt. Van de 277 ondervraagde leden van de prokuratura verklaarden er slechts 15 dat advocaten vaak gebruik maakten van de mogelijkheid de stukken in te zien, 95 gaven aan dat dit helemaal nooit gebeurde en 135 waren van mening dat dit zelden voorkwam. Op de vraag wat de reden 
bleek bovendien dat door advocaten eveneens terughoudend gebruik werd gemaakt van de mogelijk inhoud van het gehele dossier. Hoewel dit recht wel vaker werd benut dan de heid aan het eind van het vooronderzoek kennis te nemen van de mogelijkheid de stukken met toestemming van de prokurator of politie eerder in te zien, was het zeker geen vanzelfsprekendheid: de advocatuur gaf aan in circa de helft van alle zaken van het recht gebruik te maken en de prokuratura zei dat dit in ongeveer $40 \%$ van de gevallen gebeurde. ${ }^{114}$

Grote vraag is uiteraard of de wijzigingen in de wettelijke regeling ertoe hebben geleid dat de huidige praktijk een ander beeld laat zien. Voor zover bekend is sinds de inwerkingtreding van het nieuwe wetboek van strafvordering op dit punt geen grootschalig empirisch onderzoek verricht zoals in de jaren zeventig. Ook zonder dergelijke statistische gegevens kunnen echter wel enkele algemene opmerkingen worden gemaakt over de praktijk. Vast staat in ieder geval dat het in strafzaken van enig gewicht nog altijd allesbehalve eenvoudig is om gedurende het vooronderzoek inzage te krijgen in het dossier, in het bijzonder wanneer de zaak nog in ontwikkeling is of wanneer sprake is van meer dan één verdachte. Volgens Hofmański zijn - voor wat betreft de vraag of in de praktijk inzage wordt verleend - drie factoren van belang:

1. de aard van het strafbare feit (bijvoorbeeld in gevallen van georganiseerde criminaliteit wordt zeer terughoudend inzage verleend),

2. de persoonlijkheid van de dader (de 'brave burger' die een verkeersongeval heeft veroorzaakt zal zelden inzage worden geweigerd) en

hiervoor was, antwoordde een overgrote meerderheid (78\%) dat advocaten simpelweg geen verzoeken op grond van art. 143 lid 3 KPK 1969 indienden, slechts iets minder dan 6\% gaf aan dat geen toestemming voor dergelijke inzage werd verleend. Dat advocaten weinig gebruik maakten van de mogelijkheid de stukken in te zien, werd ook bevestigd door het tweede onderzoek uit 1977 dat alleen de advocatuur betrof. Hoewel de percentages per onderzochte regio aanzienlijk verschilde, bleek uit dit onderzoek dat slechts in ongeveer 20 tot $25 \%$ van de zaken een verzoek tot inzage van het dossier werd ingediend. Ten slotte volgde uit de antwoorden van de prokuratura in het kader van de in 1979 door Grzegorczyk uitgevoerde enquête dat van de 1382 zaken waarin een raadsman optrad, in slechts 121 gevallen een verzoek tot inzage werd ingediend waarvan bijna $78 \%$ werd ingewilligd. De antwoorden van de advocatuur lieten een ander beeld zien: in 1324 zaken zouden 331 verzoeken zijn ingediend (25\% van de gevallen) waarvan slechts iets meer dan een derde zou zijn ingewilligd. Volgens de advocatuur kon het geringe aantal verzoeken met name worden verklaard door het feit dat dergelijke verzoeken niet tot het gewenste resultaat leidden (82 antwoorden). Andere redenen die werden genoemd, waren: de onvolledigheid van het dossier, verdedigingstactiek en het ontbreken van de juiste omstandigheden om de stukken in te kunnen zien (respectievelijk 52, 37 en 25 antwoorden). Zie Grzegorczyk 1988, p. 140-142. Grzegorczyk wijst er ten aanzien van het door hem verrichtte derde onderzoek op dat het onderscheid tussen de resultaten van de advocatuur en de prokuratura mogelijk kan worden verklaard door het feit dat verzoeken om inzage van de processtukken niet altijd door de prokuratura (maar ook door de politie) worden behandeld. Zie over de toepassing van art. 143 lid 3 KPK 1969 in de praktijk ook: Mazur 1971, p. 64 en Prusak 1973, p. 34 e.v.

114 Het betreft hier de resultaten van het in 1979 door Grzegorczyk uitgevoerde onderzoek: Grzegorczyk 1988, p. 215-217. 
3. de mate waarin tegen de betreffende verdachte op het moment dat inzage wordt verzocht reeds voldoende bewijsmateriaal is verzameld (het onderzoeksbelang). ${ }^{115}$

Het is in de praktijk eerder regel dan uitzondering dat volledige inzage in het dossier voor de verdediging pas mogelijk is in de eindfase van het vooronderzoek. Opvallend is dat de belangrijkste reden voor beperkte inzage gedurende het vooronderzoek volgens de advocatuur niet wordt gevormd door het feit dat geen toestemming wordt verleend maar door praktische bezwaren die door de prokurator worden aangevoerd: de advocaat die zich bij de bevoegde prokurator meldt met het verzoek de stukken in te zien, krijgt blijkbaar geregeld te horen dat dit niet mogelijk is omdat het dossier zich tijdelijk bij de politie (of een ander orgaan) bevindt en de betrokken personen daar op het moment niet kunnen worden bereikt. ${ }^{116}$ Op deze wijze kan zonder toestemming tot inzage (officieel) te weigeren eenvoudig hetzelfde effect worden bereikt. ${ }^{117}$

$\mathrm{Nu}$ kennisneming van de processtukken gedurende het vooronderzoek op grond van art. 156 KPK 1997 in de praktijk vaak moeilijk is, komt des te meer betekenis toe aan de andere mogelijkheden voor de verdediging om informatie te verkrijgen over de strafzaak. Zo kan de mondelinge of schriftelijke toelichting op de verdenking (art. 313 KPK 1997) de verdediging in een vroeg stadium van de procedure extra informatie bieden die van belang kan zijn voor het voorbereiden van een effectieve verdediging. Ook de mogelijkheid voor sluiting van het vooronderzoek bekend te worden gemaakt met het volledige dossier is met het oog op de in het voorgaande beschreven praktijk van groot belang. In veel gevallen zal dit immers de eerste mogelijkheid voor de verdediging zijn om kennis te nemen van alle stukken. Zoals eerder opgemerkt, bestaat de bekendmaking er meestal uit dat de prokurator of politieambtenaar de verdediging mondeling op de hoogte stelt van de belangrijkste onderdelen van het dossier. Hierbij kunnen (delen van) processtukken worden voorgelezen. Soms wordt volstaan met het geven van een samenvatting. ${ }^{118}$ De verdachte en zijn raadsman kunnen commentaar leveren op het gepresenteerde materiaal en waar nodig om opheldering vragen. Wat betreft

115 Hofmański en Zabłocki 2008, p. 684.

116 Daniuk e.a. 2006, p. 44-45. Zie over praktische beperkingen op het recht van de verdediging het dossier in te zien ook: Wiliński 2006, p. 376.

117 Ook tijdens mijn verblijf in Poznań en Lublin is duidelijk geworden dat het net als onder het oude strafprocesrecht voor de verdediging nog steeds erg moeilijk is om gedurende het vooronderzoek inzage te krijgen in het dossier. Vrijwel alle advocaten met wie ik in beide steden heb gesproken, noemden het niet kunnen inzien van het dossier de belangrijkste beperking van hun mogelijkheden gedurende het vooronderzoek. Sommigen gaven aan soms niet eens meer de moeite te nemen om een verzoek op grond van art. 156 lid 5 KPK 1997 in te dienen omdat dergelijke verzoeken doorgaans toch worden geweigerd. Een advocaat in Lublin gaf bovendien aan dat het vanuit strategisch oogpunt in sommige zaken beter is de stukken niet in te zien voor de sluiting van het vooronderzoek: kennis van zaken zou immers - met name onder druk van cliënt die graag het tegendeel wil aantonen van datgene wat in het dossier wordt vermeld - tot gevolg kunnen hebben dat de advocaat te vroeg in de procedure actie zal moeten ondernemen en zodoende troeven moet prijsgeven die hij liever bewaart voor het (voor de verdediging) gunstiger forum van het onderzoek ter terechtzitting.

118 Grajewski 2005, p. 69. 
de duur van de bekendmaking geldt dat het doorgaans enkele uren en nooit meer dan één dag in beslag neemt. Meestal maakt de raadsman gebruik van zijn recht de stukken eerder in te zien om bij de bekendmaking de verdachte op het belangrijkste bewijsmateriaal te kunnen wijzen. Van de bekendmaking - die doorgaans plaatsvindt op het kantoor van het orgaan dat de leiding heeft over het vooronderzoek (dus bij politie of prokuratura) of in een penitentiaire inrichting wanneer de verdachte van zijn vrijheid is beroofd - dient proces-verbaal te worden opgemaakt dat door alle aanwezigen moet worden ondertekend. ${ }^{119}$ Helaas zijn ook geen statistische gegevens beschikbaar over de mate waarin in de praktijk gebruik wordt gemaakt van genoemde mogelijkheden om vlak voor sluiting van het vooronderzoek inzage te hebben in het dossier. Volgens sommige advocaten is dit echter volledig afhankelijk van de vraag hoe de prokurator zich in de zaak opstelt en is het eerder regel dan uitzondering dat het dossier pas voor het eerst wordt ingezien na aanvang van het eindonderzoek. ${ }^{120}$

\subsection{Recht op inzage van processtukken volgens het EVRM}

$\mathrm{Nu}$ duidelijk is geworden dat de informatiepositie van de verdediging op grond van het Poolse strafprocesrecht in het vooronderzoek aanzienlijke beperkingen kent, dient te worden beoordeeld hoe die situatie zich verhoudt tot de normen van het EVRM.

Hoewel het recht op (inzage van) stukken in art. 6 EVRM niet expliciet wordt genoemd, geldt wel dat de verdediging gedurende de strafzaak over voldoende relevante informatie moet kunnen beschikken: een voorwaarde die onder meer ligt besloten in lid 3 sub b waarin is bepaald dat eenieder jegens wie een strafrechtelijke vervolging is ingesteld recht heeft op 'de tijd en faciliteiten die nodig zijn voor de voorbereiding van zijn verdediging'. ${ }^{121}$

Dat het recht op inzage van de stukken een wezenlijk onderdeel is van het recht op een eerlijk proces zoals gegarandeerd in art. 6 lid 1 EVRM is onder meer benadrukt in Edwards t. Verenigd Koninkrijk waarin het Europese Hof heeft geoordeeld dat '(...) it is a requirement of fairness under paragraph I of Article 6 (...) that the prosecution authorities disclose to the defence all material evidence for or against the accused (... ').122 De verdediging dient een actieve opstelling aan te nemen om inzage in de stukken te krijgen: van haar mag worden verwacht dat ze duidelijke verzoeken indient en daarbij aangeeft waarom kennis van de betreffende informatie noodzakelijk is voor de voorbereiding van de verdediging. ${ }^{123}$ De overheid mag zich echter niet verschuilen achter de (verwachte) actieve proceshouding van de verdediging en dient er ook zelf zorg voor te dragen dat het recht op inzage

119 Over art. 321 KPK 1997 in de praktijk: Daniuk e.a. 2006, p. 46-51.

120 Informatie verkregen van Kruszyński, juni 2006.

121 Onder het begrip faciliteiten wordt (onder andere) het recht op inzage van het procesdossier en toegang tot het bewijsmateriaal gerekend. Ook het recht op overleg met een advocaat en het recht op kennis van het vonnis ter voorbereiding van het hoger beroep vallen daaronder. Zie Van der Velde 2004 I, 3.6.10, p. 4.

122 Edwards t. Verenigd Koninkrijk, EHRM 16-12-1992, nr. 13071/87, § 36. In de zaak van Edwards was (mogelijk) ontlastend bewijsmateriaal niet in het dossier opgenomen. Zie ook Jespers t. België, EHRM 14-12-1981, nr. 8403/78.

123 Zie onder meer Bricmont t. België, EHRM 7-7-1989, nr. 10857/84, § 91 e.v. 
in acht wordt genomen. ${ }^{124}$ Het is op zichzelf niet onverenigbaar met het EVRM dat inzage wel aan de raadsman en niet aan de verdachte wordt toegestaan. ${ }^{125}$ Het recht van de verdediging om te kunnen beschikken over al het relevante ontlastende en belastende bewijsmateriaal is echter niet absoluut: specifieke belangen - zoals nationale veiligheid, bescherming van getuigen of de geheimhouding van opsporingsmethoden - kunnen rechtvaardigen dat bepaalde informatie aan de verdediging wordt onthouden. Een dergelijke beperking is slechts toegestaan voor zover strikt noodzakelijk en de inperking van de rechten van de verdediging dient voldoende te worden gecompenseerd. ${ }^{126}$

De rechtspraak van het EHRM verzet zich er in beginsel niet tegen dat het dossier gedurende het vooronderzoek tijdelijk (geheel of gedeeltelijk) geheim blijft. Op de vraag wanneer een beperking van het inzagerecht in het vooronderzoek in abstracto in conflict komt met art. 6 EVRM wordt in de Straatsburgse rechtspraak geen antwoord gegeven. Waar het gaat om de informatiepositie van verdachten die zich in voorlopige hechtenis bevinden, biedt de rechtspraak van het Hof wel (meer) concrete richtlijnen: beperkingen op het inzagerecht gedurende het vooronderzoek kunnen in geval van voorlopige hechtenis in conflict komen met art. 5 EVRM. In het vierde lid van genoemde verdragsbepaling is geregeld dat eenieder die door arrestatie of detentie van zijn vrijheid is beroofd, het recht heeft de rechtmatigheid van zijn detentie spoedig te laten beoordelen door een rechterlijke instantie. Procedures die onder de reikwijdte van art. 5 lid 4 EVRM vallen, dienen bepaalde waarborgen te bieden wat onder meer gevolgen kan hebben voor de informatie waarover de verdediging moet kunnen beschikken. ${ }^{127}$ In Lamy t. België $e^{128}$ werd door het EHRM een schending van art. 5 lid 4 EVRM vastgesteld

124 Zie onder meer Mattoccia t. Italië, EHRM 25-7-2000, nr. 23969/94, § 65 en Schöps t. Duitsland, EHRM 13-2-2001, nr. 25116/94, §52. Zie hierover Kwakman 2006.

125 Zie Kamasinski t. Oostenrijk, EHRM 19-12-1989, nr. 9783/82, § 88 en Kremzow t. Oostenrijk, EHRM 21-9-1993, nr. 12350/86, § 52. Of het in een concrete situatie verenigbaar is met het EVRM inzage van het dossier wel aan de raadsman en niet aan de verdachte toe te staan, is volledig afhankelijk van de omstandigheden van het geval. Zo blijkt ook uit de zaak Öcalan $t$. Turkije. Het feit dat Öcalan - die pas in een zeer laat stadium van de procedure inzage mocht hebben - slechts twintig dagen had om kennis te nemen van het uiterst omvangrijke (17.000 pagina's tellende) dossier terwijl zijn advocaten eerder geen kopieën aan hem hadden mogen verstrekken, betekende volgens het Hof dat de voorbereiding van de verdediging ernstig was bemoeilijkt: Öcalan t. Turkije, EHRM 12-5-2005, nr. 46221/99, § 138 e.v.

126 Zie onder meer Jasper t. Verenigd Koninkrijk, EHRM 16-2-2000, nr. 27052/95, § 52 e.v. en Fitt t. Verenigd Koninkrijk, EHRM 16-2-2000, nr. 29777/96, § 45. Nota bene: het gaat hier om gevallen waarin bepaalde informatie gedurende het gehele strafproces aan de verdediging wordt onthouden.

127 Door in deze gevallen de kwestie van inzage onder de noemer van art. 5 lid 4 te behandelen, kan het Europese Hof buiten beschouwing laten of art. 6 lid 3 sub b EVRM van overeenkomstige toepassing is op de fase van het vooronderzoek. Hierdoor is niet duidelijk welke betekenis overwegingen zoals gedaan in Edwards $t$. Verenigd Koninkrijk hebben voor deze onderzoeksfase. Dat procedures genoemd in art. 5 lid 4 EVRM gelijkheid tussen procespartijen dienen te garanderen, heeft behalve voor de kennisneming van processtukken overigens ook gevolgen voor de mogelijkheden die de verdediging moet hebben om aan zittingen deel te nemen waarop over de voorlopige hechtenis wordt geoordeeld. Over dit laatste thema meer in $\S 4.6$.

128 EHRM 30-3-1989, nr. 10444/83. 
op basis van het feit dat klager en zijn raadsman gedurende de eerste dertig dagen van de voorlopige hechtenis geen inzage hadden mogen hebben in het dossier terwijl in deze periode de rechtmatigheid van de voorlopige hechtenis door de Belgische rechter (chambre $d u$ conseil) was getoetst. Het feit dat het openbaar ministerie wel volledige inzage in de stukken had kunnen hebben, maakte dat de posities van beide procesdeelnemers onvoldoende gelijk waren geweest. Het Europese Hof benadrukte daarbij dat de verdediging in het kader van voorlopige hechtenis procedures in ieder geval inzage moet kunnen hebben in die stukken die van belang zijn om de rechtmatigheid van de detentie te beoordelen en te betwisten. ${ }^{129}$ Dit uitgangspunt is later verder uitgewerkt in drie Duitse zaken waarin het Europese Hof op dezelfde dag uitspraak heeft gedaan: Garcia Alva, Lietzow en Schöps t. Duitsland. ${ }^{130}$ In Garcia Alva herhaalt het EHRM dat rechterlijke procedures waarin rechtsmiddelen tegen de detentie worden beoordeeld 'must provide guarantees of a judicial procedure' en 'be adversarial and must always ensure "equality of arms" between the parties, the prosecutor and the detained person' en dat van dergelijke gelijkheid geen sprake is wanneer 'counsel is denied access to those documents which are essential in order effectively to challenge the lawfulness of his client's detention'. ${ }^{131}$ Het Europese Hof erkent daarbij dat het opsporingsbelang kan eisen dat resultaten van het vooronderzoek gedeeltelijk geheim dienen te blijven om collusie en obstructie van een juiste rechtsgang te voorkomen maar

'this legitimate goal cannot be pursued at the expense of substantial restrictions on the rights of the defence. Therefore, information which is essential for the assessment of the lawfulness of a detention should be made available in an appropriate manner to the suspect's lawyer'.132

In de zaak Schöps wordt voor het eerst met zoveel woorden gezegd dat de procedurele waarborgen die bij toetsing van de voorlopige hechtenis in acht moeten worden genomen, worden ontleend aan art. 6 EVRM. ${ }^{133}$ Bovendien blijkt uit deze uitspraak dat van autoriteiten een actieve opstelling mag worden verwacht waar het gaat om het verlenen van inzage, dat de verdediging ambtshalve door de overheid dient te worden geïnformeerd wanneer - na een verzoek om inzage een aanzienlijke hoeveelheid nieuwe informatie aan het dossier wordt toegevoegd

129 Zie met name § 29.

130 EHRM 13-2-2001, respectievelijk nr. 23541/94, 24479/94 en 25116/94. Zie verder ook (onder meer): Shishkov t. Bulgarije, EHRM 9-1-2003, nr. 38822/97, Kehayov t. Bulgarije, EHRM 18-1-2005, nr. 41035/98 en Turcan en Turcan t. Moldavië, EHRM 23-10-2007, nr. $39835 / 05$.

131 § 39. De informatie die in deze zaak wel ter beschikking was gesteld aan de verdediging (het bevel voorlopige hechtenis, de processen-verbaal van verklaringen die door Garcia ten overstaan van politie en onderzoeksrechter waren afgelegd en van de bij klager uitgevoerde huiszoeking) werd door het Europese Hof ontoereikend bevonden.

$132 \S 42$. Aan de hand van dezelfde overwegingen als in Garcia wordt in Lietzow t. Duitsland ook een schending van art. 5 lid 4 EVRM vastgesteld: in beide zaken ging het met name om verklaringen van medeverdachten die vanwege collusiegevaar niet aan de verdediging beschikbaar waren gesteld maar wel een grote rol hadden gespeeld in de beslissingen ten aanzien van de voorlopige hechtenis.

$133 \S 44$. 
en dat niet te snel mag worden aangenomen dat de verdediging afstand heeft gedaan van het recht de stukken in te zien. ${ }^{134}$

In Migon t. Polen zijn de uitgangspunten die het EHRM in bovengenoemde rechtspraak heeft geformuleerd, toegepast op de Poolse regelgeving en praktijk. ${ }^{135}$ In deze zaak stond nog wel het oude strafprocesrecht centraal maar aangezien de huidige bepalingen ten aanzien van kennisneming van processtukken gedurende het vooronderzoek in grote lijnen overeenkomen met de regeling van 1969 hebben de overwegingen van het Europese Hof hun betekenis voor de Poolse situatie zeker nog niet verloren. Migon - verdacht van fraude en valsheid in geschrifte voerde onder meer aan dat noch hijzelf noch zijn raadsman gedurende het eerste jaar van zijn voorlopige hechtenis inzage had kunnen hebben in de processtukken waardoor de procedures die in deze periode over de rechtmatigheid van de detentie waren gevoerd niet in overeenstemming waren geweest met de eisen van art. 5 lid 4 EVRM. Het EHRM merkt in deze zaak op dat bij toetsing aan de uitgangspunten genoemd in Lamy, Garcia Alva, Lietzow en Schöps moet worden gekeken naar de specifieke omstandigheden van het geval te weten:

- de aard van de documenten die de verdediging wel tot haar beschikking had,

- het aantal van deze documenten,

- de mate waarin ze van belang zijn voor de beoordeling van de rechtmatigheid van de voorlopige hechtenis en

- de periode gedurende welke inzage van het dossier niet mogelijk was.

Toegepast op de situatie van Migon stond vast dat de verdediging gedurende de verschillende procedures waarin de rechtmatigheid van de detentie werd getoetst alleen de beschikking had gehad over de beslissing tot bekendmaking van de be-

134 Ten aanzien van het eerste punt was van belang dat de autoriteiten niet direct actie hadden ondernomen na het verzoek van de verdediging om inzage van het dossier omdat de originele stukken - volgens het verweer van de Duitse regering - nodig waren voor de voortzetting van het onderzoek en de kopieën reeds aan de rechtbank waren verzonden. Het EHRM gaat hier niet in mee: de rechtbank had ruim de tijd (meer dan zes weken) om de stukken te bestuderen zodat het zeker mogelijk moest zijn geweest het dossier in deze periode tijdelijk ter beschikking te stellen aan de verdediging. Op een ander moment in de procedure was de omvang van het dossier - na het verzoek van de verdediging om inzage - aanzienlijk toegenomen. De verdediging had geen inzage gehad in deze nieuwe delen omdat daartoe geen verzoek was ingediend en volgens het verweer van de Duitse regering kon niet van de autoriteiten worden verwacht dat ze in dit opzicht initiatieven ontplooien. Het Europese Hof denkt hier echter anders over: '(...) by its previous requests for full access to the file, the defence had indicated the urgency of its interest in being kept informed about the content of the file and a renewed request for the applicant's continued detention had been made. In view of this, it is an over-formalistic and disproportionate response to require yet another request for access to the numerous new volumes of the case file which had been compiled since access to the file had been granted in November 1993 (...)' (§ 52). De verdediging had dus ook zonder een expliciet verzoek daartoe in de gelegenheid moeten worden gesteld om de aanvullende delen in te zien. Ten slotte wordt ook het argument van de regering dat de advocaat van Schöps namens zijn cliënt telefonisch afstand zou hebben gedaan van zijn inzagerecht niet geaccepteerd: een dergelijke 'waiver' kan alleen worden aangenomen wanneer deze op onmiskenbare wijze is gedaan en in onderhavige zaak bestond veel onduidelijkheid over wat de raadsman in het betreffende telefoongesprek precies had gezegd.

135 EHRM 25-6-2002, nr. 24244/94. 
schuldigingen en het bevel tot toepassing van de voorlopige hechtenis. ${ }^{136}$ Het EHRM stelde een schending van art. 5 lid 4 EVRM vast aangezien de nationale rechterlijke instanties zich bij de beslissingen tot verlenging van de voorlopige hechtenis hadden gebaseerd op documenten en bewijzen die niet door klager konden worden ingezien terwijl de documenten waarover de verdediging wel beschikte

'did not provide an adequate basis (...) on which to address the arguments relied on both by the prosecution and by the courts in support of the decisions to prolong his detention, and secure thereby any effective defence in the detention proceedings, in particular in the light of the progress of the investigations, in which new evidence was gradually coming to light'.137

Dat ook de huidige regelgeving en praktijk problemen op kunnen leveren in het licht van art. 5 lid 4 EVRM is meer recent duidelijk geworden in Chruścinssi $t$. Polen. ${ }^{138}$ Klager en zijn raadsman hadden gedurende twintig maanden van het vooronderzoek geen inzage kunnen hebben in de processtukken. Tegen deze weigering was verschillende keren zonder succes geappelleerd bij een hogere prokurator waarbij de verdediging had aangevoerd dat het onthouden van informatie gelet op de voorlopige hechtenis van Chruściński een schending opleverde van haar verdedigingsrechten op grond van het EVRM. ${ }^{139}$ Het argument van de Poolse regering dat inzage in de stukken gedurende het vooronderzoek niet kon worden toegestaan vanwege de ingewikkeldheid van de zaak en het geheime karakter van een deel van het dossier overtuigt het EHRM niet. Het Hof stelt vast dat Chruściński weliswaar de beschikking had over de verzoeken tot toepassing en verlenging van de voorlopige hechtenis van de prokurator en de rechterlijke beslissingen hierop maar dat deze verzoeken en beslissingen waren gebaseerd op verschillende bewijsmiddelen die de verdediging niet had kunnen inzien. Het EHRM concludeert dat hierdoor geen sprake was van equality of arms in de procedures betreffende de voorlopige hechtenis en stelt een schending van art. 5 lid 4 EVRM vast.

136 De Poolse regering was echter van mening dat een dergelijke (tijdelijke) beperking van de informatiepositie van de verdediging kon worden gerechtvaardigd door het onderzoeksbelang: '(...) a hypothetical legal regulation that was radically different from the solution adopted in Article $142 \S 3$ of the Code of Criminal Procedure [het huidige art. 156 lid 5 KPK 1997, toev. DdV] would not ensure the interest of effective investigations. It was in the nature of things that the due course of such investigations often depended on keeping strictly secret certain circumstances of the case until it was established that there was a sufficient basis on which to bring the case before the criminal court. Under Polish law (...) there had been no impediment to allowing full access to the case-file from that moment on' $(\S 75)$.

$137 \S 86$.

138 EHRM 6-11-2007, nr. 22755/04.

139 Opmerkelijk - en moeilijk verenigbaar met de presumptie van onschuld - is de reactie van de hogere prokurator op het EVRM-argument van de verdediging: 'As regards the ECHR invoked by the [applicant] it should be noted that the overriding aim of criminal proceedings is to establish all the circumstances in which the offence was committed and to find the perpetrators. It is a concrete aim and in achieving it the prosecutors and the courts aim at ensuring respect for the rule of law and the security of the State and its citizens. Therefore, it is not the intention of the Convention to disregard those rules by making the rights of the citizens who breached the laws absolute [decurs. DdV]. A premature disclosure of the documents in the case-file could prevent the achievement of the aims of the proceedings.' Geciteerd in de uitspraak van het EHRM in $§ 22$. 
Een tweede recente zaak waarin de weigering inzage te verlenen aan een voorlopig gehechte verdachte centraal stond, is Łaszkiewicz t. Polen. ${ }^{140}$ Łaszkiewicz verdacht van grootschalige, internationale drugshandel - klaagde onder meer over het feit dat de verdediging niet had kunnen beschikken over de verzoeken tot verlengingen van de prokurator en geen inzage had mogen hebben in de processtukken. ${ }^{141} \mathrm{Op}$ grond hiervan werd door klager aangevoerd dat:

'(...) Article $156 \S 5$ of the Code of Criminal Procedure which vested the power to grant access to the file in an authority conducting the investigation could not be fully reconciled with the principle of equality of arms. The interim appeal available against a refusal to grant access to the file appeared ineffective due to the fact that such appeal was examined by a higher prosecutor'. ${ }^{142}$

De Poolse regering gaf toe dat de verdediging tot aan de vrijlating van verdachte geen inzage had kunnen hebben in de stukken maar was van mening dat:

'(...) those refusals had been in accordance with the law and had been fully justified by the particular circumstances of the case. (...) Providing such access to the applicants' counsel could have an adverse impact on the investigation'.143

Het EHRM is hierdoor niet overtuigd en constateert een schending van art. 5 lid 4 EVRM. Volgens het Hof heeft Łaszkiewicz gedurende een periode van ongeveer één jaar niet de mogelijkheid gehad de rechtmatigheid van haar vrijheidsberoving effectief aan te vechten. Het feit dat ze op de zittingen waarop over de voorlopige hechtenis werd beslist, werd bijgestaan door een advocaat doet daar niets aan af. Hierbij wordt meegewogen dat de verdediging bij de verschillende zittingen - ondanks daartoe strekkende verzoeken - niet vooraf een kopie van het verlengingsverzoek van de prokurator had ontvangen en dat de prokurator een dergelijk verzoek van de verdediging in ieder geval bij één gelegenheid, tamelijk formalistisch had afgedaan met een verwijzing naar art. 156 lid 5 KPK 1997:

'In the Court's view that can be viewed as an over-formalistic and disproportionate response on the part of the prosecution authorities which implied that it would not be possible under Article $156 \S 5$ of the Code of Criminal Procedure to grant access to certain documents from the file or a part of the file. The Court recalls in that connection that it is for the authorities to organise their procedure in such a way as to meet the procedural requirements laid down in Article $5 \S 4$, since the Convention is intended to guarantee rights that are not theoretical or illusory, but practical and effective. '144

140 EHRM 15-1-2008, nr. 28481/03.

141 Ook werd geklaagd over het feit dat de advocaat van klager te laat zou zijn geïnformeerd over de zittingen waarop over de verlengingsverzoeken zouden worden behandeld - zo was het eerste verlengingsverzoek al op 19 maart 2003 door de rechtbank ontvangen terwijl de advocaat pas in de namiddag van 25 maart 2003 telefonisch op de hoogte werd gesteld van het feit dat de zitting de volgende ochtend om 8.40 uur zou plaatsvinden. Over dit punt heeft het EHRM zich echter niet uitgelaten omdat reeds op basis van de andere klachten een schending van art. 5 lid 4 EVRM werd vastgesteld (zie hierna).

$142 \S 73$.

$143 \S 75$.

$144 \S 83$. Ten aanzien van het argument van de regering dat inzage van de stukken in conflict zou komen met zwaarwegende opsporingsbelangen wordt daar nog aan toegevoegd dat: 'the Court acknowledges the need for criminal investigations to be conducted efficiently, which may 
Deze rechtspraak bevestigt dat ook onder het huidige Poolse strafprocesrecht een al te rigide besluitvorming op grond van art. 156 lid 5 KPK 1997 in geval van een voorlopig gehechte verdachte in conflict kan komen met art. 5 lid 4 EVRM.

\subsection{Conclusie}

Het huidige strafprocesrecht heeft de informatiepositie van de verdediging slechts in beperkte mate verbeterd ten opzichte van de situatie op grond van het oude wetboek van strafvordering. Het belangrijkste probleem is dat de prokurator nog altijd de mogelijkheid heeft inzage van het dossier gedurende het grootste deel van het vooronderzoek te weigeren wat in strafzaken van enig gewicht in de praktijk eerder regel dan uitzondering is. Dit kan vanuit Straatsburgs perspectief problemen opleveren: vooral wanneer de verdachte van zijn vrijheid is beroofd. De rechtspraak van het EHRM laat zien dat wanneer voorlopige hechtenis wordt toegepast strengere eisen worden gesteld aan de interne openbaarheid van het strafproces. Om in procedures waarin de rechtmatigheid van de voorlopige hechtenis wordt getoetst ${ }^{145}$ een rol van betekenis te kunnen spelen, dient de verdediging in ieder geval te kunnen beschikken over die documenten die van wezenlijk belang zijn voor de beoordeling van de rechtmatigheid van het dwangmiddel. Onder die omstandigheden kan het in strijd zijn met art. 5 lid 4 EVRM wanneer de prokurator de verdediging geen inzage verleend in de processtukken. ${ }^{146}$ Wanneer gebruik wordt gemaakt van de ruime mogelijkheid om inzage in het dossier gedurende het vooronderzoek te weigeren, zal de verdediging bij aanwending van de rechtsmiddelen tegen de voorlopige hechtenis of op andere momenten waarop ze de gelegenheid heeft de rechtmatigheid van de detentie te betwisten, haar argumenten moeten ontlenen aan de (beperkte) informatie die wel tot haar beschikking staat. ${ }^{147}$ Of die informatie toereikend is in het licht van art. 5 lid 4 EVRM zal telkens afhangen van de concrete omstandigheden van het geval:

imply that part of the information collected during them is to be kept secret in order to prevent suspects from tampering with evidence and undermining the course of justice. However, this legitimate goal cannot be pursued at the expense of substantial restrictions on the rights of the defence. Therefore, information which is essential for the assessment of the lawfulness of a detention, such as reasons which, in the prosecutor's view, justify continued deprivation of liberty, should be made available in an appropriate manner to the suspect's lawyer' (\$ 84).

145 Uit de rechtspraak van het EHRM blijkt dat de reikwijdte van art. 5 lid 4 EVRM zich uitstrekt over verschillende procedures waarin (of procesmomenten waarop) over de rechtmatigheid van de hechtenis wordt geoordeeld. Voor wat de Poolse situatie betreft, staat vast dat de garanties van art. 5 lid 4 EVRM niet alleen betrekking hebben op de procedure waarin over toepassing of verlenging van voorlopige hechtenis wordt beslist maar ook op de behandeling van verzoeken om opheffing of het bezwaar (zażalenie) tegen de beslissing tot toepassing of verlenging van het dwangmiddel. Op de verschillende rechtsmiddelen tegen de voorlopige hechtenis wordt teruggekomen in § 4.3. Zie Wąsek-Wiaderek 2003 I, p. 56 en 66 en Wąsek-Wiaderek 2003 II, p. 241-242 en daar genoemde rechtspraak.

146 Zie ook Wąsek-Wiaderek 2003 I, p. 69-70.

147 Dat is in ieder geval de (al dan niet schriftelijke) omschrijving van datgene waarvan verdachte wordt verdacht, de op schrift gestelde argumenten voor deze verdenking (indien de verdediging daarom heeft verzocht) en wanneer voorlopige hechtenis reeds is toegepast de motivering van de beslissing daartoe. Bovendien dienen bepaalde categorieën documenten zoals eerder beschreven ook gedurende het vooronderzoek onbeperkt door de verdediging te kunnen worden ingezien (art. 157 lid 3 KPK 1997). 
bepalend is immers of de stukken waarover de verdediging wel kan beschikken relevant zijn voor beantwoording van de vraag of voorlopige hechtenis moet worden toegepast. ${ }^{148}$

Dat het Poolse strafprocesrecht op dit punt dient te worden gepreciseerd, is vlak voor afronding van dit onderzoek ook bevestigd in een uitspraak van het Grondwettelijk Hof. Laatstgenoemde instantie heeft in juni 2008 naar aanleiding van een klacht van de Nationale Ombudsman bepaald dat art. 156 lid 5 KPK 1997 in de gevallen waarin over de toepassing of voortzetting van voorlopige hechtenis moet worden beslist onverenigbaar is met (onder meer) art. 42 lid 2 van de Grondwet waarin het recht op verdediging is vastgelegd. ${ }^{149}$ Samengevat komt het oordeel van het Grondwettelijk Hof er op neer dat het feit dat in art. 156 lid 5 KPK 1997 niet is gespecificeerd op welke grond(en) inzage geweigerd kan worden onvoldoende garandeert dat de verdediging kan beschikken over de informatie die van belang is om de rechtmatigheid van de voorlopige hechtenis te kunnen beoordelen. Ter ondersteuning van dit standpunt verwijst het Grondwettelijk Hof naar art. 5 lid 4 EVRM en de rechtspraak van het EHRM in de in § 3.5 genoemde zaken. De wetgever is nu aan zet en zal de bepaling met inachtneming van de opmerkingen van het Grondwettelijk Hof binnen anderhalf jaar aan moeten passen.

De vraag is natuurlijk op welke wijze de wettelijke regeling aan zal moeten worden gepast om te garanderen dat voldoende rekening wordt gehouden met de bijzondere situatie van de voorlopig gehechte verdachte. Door Wąsek-Wiaderek is in dit verband voorgesteld art. 156 KPK 1997 aan te vullen met de bepaling dat inzage van processtukken door de raadsman van een voorlopig gehechte cliënt alleen in uitzonderingsgevallen kan worden geweigerd. ${ }^{150}$ Aangezien de toepassing van voorlopige hechtenis op zichzelf geen grond voor verplichte rechtsbijstand is ${ }^{151}$ en het dus niet vanzelfsprekend is dat elke voorlopig gehechte verdachte door een advocaat wordt bijgestaan, verdient het mijns inziens de voorkeur deze regel niet te beperken tot de raadsman maar ook van toepassing te laten zijn op inzage door de verdachte zelf. Bovendien zou nauwkeurig moeten worden omschreven welke omstandigheden een uitzondering op de regel (weigering inzage in geval van voorlopige hechtenis) kunnen rechtvaardigen. Het Grondwettelijk Hof heeft in eerder genoemde uitspraak in ieder geval al duidelijk gemaakt dat een algemene formulering als 'het belang van een behoorlijke rechtspleging' onvoldoende specifiek is.

148 In de zaak van Migoń achtte het Europese Hof de beslissing tot bekendmaking van de beschuldigingen en het bevel tot toepassing van de voorlopige hechtenis in ieder geval ontoereikend.

149 Uitspraak d.d. 3 juni 2008, K 42/07. De Nationale Ombudsman heeft in de procedure bij het Grondwettelijk Hof aangegeven regelmatig klachten te ontvangen van verdachten en hun advocaten die stellen in procedures over de rechtmatigheid van de voorlopige hechtenis niet over voldoende relevante informatie te hebben kunnen beschikken.

150 Wąsek-Wiaderek 2003 II, p. 260. Zie § 3.3.4.

151 Daarvoor is immers bovendien vereist dat sprake is van een van de persoonlijke omstandigheden genoemd in art. 79 KPK 1997 of dat de strafzaak in eerste aanleg door een provinciale rechtbank wordt behandeld. In laatstgenoemd geval is bijstand echter slechts gedurende het eindonderzoek verplicht en is dus ook niet gegarandeerd dat de verdachte in het vooronderzoek wordt bijgestaan. 
Zoals besproken, hebben sommige Poolse auteurs bovendien voorgesteld de mogelijkheid inzage te weigeren te verbinden aan een termijn (het dossier zou dan bijvoorbeeld slechts gedurende de eerste veertien dagen van het vooronderzoek aan de verdediging kunnen worden onthouden). Het opnemen van een dergelijke termijn wordt mijns inziens overbodig wanneer de weigering zoals hierboven voorgesteld aan duidelijke, nadere voorwaarden zou worden verbonden.

Ten slotte verdient aanbeveling dat de beoordeling van het rechtsmiddel - dat tegen de weigering inzage te verlenen, kan worden ingesteld - wordt overgedragen aan de rechtbank. ${ }^{152}$ Hoewel er geen reden is om aan te nemen dat de prokuratura eigen beslissingen nooit serieus zal heroverwegen, staat in ieder geval vast dat van de rechterlijke macht een hogere mate van objectiviteit en onafhankelijkheid mag worden verwacht. Beoordeling door de rechter zou de effectiviteit van het rechtsmiddel - of in ieder geval de schijn ervan - dan ook zeker ten goede komen wat mogelijk tot gevolg zal hebben dat vaker van de bezwaarmogelijkheid gebruik wordt gemaakt. Bovendien zou rechterlijke controle op de weigering inzage te verlenen een gunstig effect kunnen hebben op de machtsverhoudingen in deze fase van de procedure: nu heeft de prokurator gedurende het gehele vooronderzoek volledige macht over het dossier en kan daarmee de mogelijkheden van de verdediging in deze fase in belangrijke mate bepalen.

Nog een laatste opmerking over de mogelijkheid van de verdediging voor sluiting van het vooronderzoek het gehele dossier in te zien. Vastgesteld is dat autoriteiten sinds 2003 niet meer verplicht zijn de verdediging ambtshalve over deze mogelijkheid te informeren. ${ }^{153}$ Mijns inziens is hierdoor het initiatief teveel bij de verdediging gelegd. Zeker een verdachte die niet over rechtsbijstand beschikt, kan eenvoudig vergeten een dergelijk verzoek in te dienen en daarmee een belangrijke mogelijkheid verloren zien gaan. Ook bij de andere wijziging uit 2003 - als gevolg waarvan de laatste inzage in gevallen van verplichte rechtsbijstand ook zonder aanwezigheid van de raadsman kan plaatsvinden - heeft de wetgever het belang van een efficiënt verloop van het vooronderzoek te veel laten prevaleren boven de rechten van de verdediging. Dat terwijl in veel gevallen niet valt in te zien hoe iemand die (bijvoorbeeld vanwege zijn geestelijke gesteldheid of andere persoonlijke omstandigheden) gedwongen bijstand van een raadsman geniet zonder aanwezigheid van die advocaat effectief gebruik kan maken van zijn recht op laatste inzage. Aangezien kennisnemning van de stukken gedurende vrijwel het gehele onderzoek kan worden geweigerd, is deze laatste inzagemogelijkheid vaak het eerste en enige moment waarop de verdediging in het vooronderzoek kennis kan nemen van het dossier. Met deze wijzigingen van 2003 is dan ook geen recht gedaan aan het belang van dit procesmoment en de betekenis ervan voor de verdediging.

152 Zoals ook veelvuldig bepleit in de Poolse literatuur. Zie § 3.3.4.

153 Deze verplichting bestaat slechts wanneer de verdachte of zijn raadsman op enig moment in de procedure te kennen heeft gegeven van de mogelijkheid gebruik te willen maken. 


\section{Mogelijkheden ten aanzien van voorlopige hechtenis}

\subsection{Inleiding}

Wanneer in een strafzaak voorlopige hechtenis wordt toegepast, heeft dat behalve voor de verdachte persoonlijk ook vergaande gevolgen voor de verdediging. Een van de belangrijkste gevolgen is uiteraard dat het overleg tussen raadsman en cliënt aan meer beperkingen is gebonden dan wanneer de verdachte zich op vrije voeten bevindt: dit betreft het thema van het vrij verkeer dat in hoofdstuk 7 aan de orde zal komen. Een andere kwestie die in het kader van de voorlopige hechtenis aandacht verdient, is de vraag welke mogelijkheden de verdediging heeft om de besluitvorming ten aanzien van dit dwangmiddel te beïnvloeden. Met andere woorden: op welke wijze kan invloed worden uitgeoefend op de beslissing tot toepassing of verlenging van voorlopige hechtenis en bestaan er - buiten deze beslismomenten om - nog andere mogelijkheden om de voorlopige hechtenis te (laten) beëindigen?

Deze problematiek beperkt zich overigens niet tot de fase van het vooronderzoek: voorlopige hechtenis kan immers ook na aanvang van het onderzoek ter terechtzitting voortduren. De hiernavolgende bespreking heeft daarom deels ook betrekking op de fase na sluiting van vooronderzoek. Het thema wordt in dit hoofdstuk behandeld omdat de vraag naar de mogelijkheden van de verdediging met name interessant is in deze fase van de procedure waarin de machtsverhoudingen meer in het nadeel van de verdachte en zijn raadsman zijn dan op het onderzoek ter terechtzitting. ${ }^{154}$ Anders dan na aanvang van het onderzoek ter terechtzitting waar de verdediging de rechtmatigheid van de voorlopige hechtenis tijdens de inhoudelijke behandeling van de zaak bij de rechtbank aan de orde kan stellen - is rechterlijke controle op de vrijheidsbeneming tijdens het vooronderzoek minder vanzelfsprekend en afhankelijk van de vraag welke mogelijkheden de wetgever op dit punt heeft gecreëerd.

In dit deel van het hoofdstuk zal worden bekeken op welke wijze de verdediging kan opkomen tegen de voorlopige hechtenis: welke rechtsmiddelen in dit verband kunnen worden aangewend en of - en zo ja, op welke momenten en in welke mate - de verdediging de kans heeft haar standpunten over de vrijheidsberoving kenbaar te maken aan de rechter. Voordat daartoe wordt overgegaan, zal echter eerst in hoofdlijnen worden weergegeven hoe de voorlopige hechtenis wettelijk is geregeld.

\subsection{Juridisch kader voorlopige hechtenis}

Voorlopige hechtenis behoort in het Poolse strafproces tot de zogenaamde preventieve maatregelen (środki zapobiegawcze) die ten aanzien van een verdachte kunnen worden toegepast wanneer dat noodzakelijk wordt geacht voor een behoorlijk verloop van de strafrechtelijke procedure. ${ }^{155}$ Zo kan voorlopige hechtenis nodig zijn om te garanderen dat de verdachte beschikbaar is voor het strafrechtelijk onderzoek of om te voorkomen dat de waarheidsvinding wordt verstoord

154 Voordat de zaak door de akte van beschuldiging aan de rechtbank wordt overgedragen, heeft de prokurator immers de leiding over de strafzaak en hij staat in de hoedanigheid van onderzoeksleider meer boven dan naast de verdediging.

155 Art. 249 lid 1 KPK 1997: 'Preventieve maatregelen kunnen worden toegepast teneinde het regelmatig verloop van de procedure veilig te stellen (...).' 
door bijvoorbeeld het wegmaken van bewijsmateriaal of het beïnvloeden van getuigen. Andere preventieve maatregelen waarin het Poolse strafprocesrecht voorziet, zijn: borgstelling, politietoezicht, het verbod een bepaald beroep uit te oefenen, bepaalde voertuigen te besturen of bepaalde activiteiten te verrichten en het verbod het land te verlaten. ${ }^{156}$

Gedurende het vooronderzoek wordt voorlopige hechtenis op verzoek van de prokurator bevolen door de rechtbank. ${ }^{157}$ Voor de toepassing van het vrijheidsbenemende dwangmiddel gelden de volgende cumulatieve voorwaarden:

a. Aanwezigheid van een algemene grond: voor alle preventieve maatregelen geldt dat deze alleen mogen worden toegepast wanneer dat noodzakelijk is voor een behoorlijk verloop van het strafproces en - in uitzonderlijke gevallen om te voorkomen dat de verdachte zich opnieuw schuldig maakt aan een ernstig strafbaar feit. ${ }^{158}$

b. Aanwezigheid van een bijzondere grond: de wetgever heeft vier bijzondere gronden onderscheiden waarvan telkens ten minste één van toepassing moet zijn. Deze hebben kort gezegd betrekking op

1. vluchtgevaar,

2. collusiegevaar,

3. de zwaarte van de (bedreigde of in eerste aanleg opgelegde) straf en - in uitzonderlijke gevallen -

4. de vrees dat verdachte een misdrijf tegen het leven, de gezondheid of de openbare veiligheid zal begaan. ${ }^{159}$

156 Respectievelijk art. 266, 271, 271, 275, 276 en 277 KPK 1997. De borgstelling kent een individuele en een maatschappelijke (of gemeenschappelijke) variant (poręczenie majątkowe en poręczenie spoteczne). In het eerste geval wordt vermogen afgegeven door verdachte of een derde en in het tweede geval staat een derde - bijvoorbeeld de werkgever van verdachte ervoor garant dat de verdachte te allen tijde beschikbaar zal voor het strafrechtelijk onderzoek en op alle oproepen zal verschijnen. Politietoezicht (dozór Policji) houdt in dat de verdachte dient te voldoen aan de door de prokurator gestelde voorwaarden en kan bestaan uit verschillende vrijheidsbeperkende maatregelen zoals de eis zich op gezette tijden te melden op het politiebureau.

157 Art. 250 lid 2 KPK 1997. Bevoegd is de rechtbank binnen wiens rechtsgebied de strafzaak loopt of - in gevallen die geen uitstel dulden - een andere rechtbank. Wanneer de akte van beschuldiging is ingediend (en het vooronderzoek dus is gesloten) beslist de rechtbank die kennis neemt van de zaak over toepassing van het dwangmiddel. Voorlopige hechtenis is overigens de enige preventieve maatregel waarvoor gedurende het vooronderzoek een rechterlijke beslissing noodzakelijk is: de andere preventieve maatregelen kunnen in deze fase van de procedure zonder tussenkomst van de rechter door de prokurator worden opgelegd. Zoals in hoofdstuk 2 is besproken, behoort het feit dat het bevel voorlopige hechtenis vandaag de dag door de rechtbank wordt gegeven tot een van de belangrijkste hervormingen die na 1989 in het Poolse strafprocesrecht zijn doorgevoerd.

158 Art. 249 lid 1 KPK 1997.

159 Art. 258 lid 1, 2 en 3 KPK 1997. Ook ten aanzien van de bijzonder gronden zijn na 1989 belangrijke wetswijzigingen doorgevoerd. In hoofdstuk 2 is duidelijk geworden dat voorlopige hechtenis gedurende het communisme op grote schaal werd toegepast en een van de meest repressieve elementen van de Poolse strafrechtspleging vormde. Behalve het feit dat beslissingen tot toepassing van voorlopige hechtenis zonder rechterlijke inmenging door de prokurator konden worden genomen, boden ook de wettelijke gronden voor toepassing aanleiding tot misbruik van het dwangmiddel. Voorlopige hechtenis kon immers 
c. Er dient sprake te zijn van een 'hoge mate van waarschijnlijkheid' dat de verdachte het vermeende strafbare feit heeft begaan. ${ }^{160}$

d. Aan verdachte dient een beslissing tot bekendmaking van de beschuldigingen te zijn overhandigd. ${ }^{161}$

Wanneer aan de voorwaarden a tot en met $d$ is voldaan, dient toepassing van voorlopige hechtenis alsnog achterwege te blijven wanneer:

- andere preventieve maatregelen volstaan,

- de vrijheidsbeneming mogelijk ernstig gevaar oplevert voor het leven of de gezondheid van verdachte ofwel een onevenredige belasting zou opleveren voor hemzelf of zijn naaste familie,

- het vermoeden bestaat dat de verdachte slechts tot een voorwaardelijke gevangenisstraf (of een minder zware sanctie) zal worden veroordeeld of dat de termijn van voorlopige hechtenis de duur van de op te leggen onvoorwaardelijke gevangenisstraf zal overstijgen, of

- het vermeende strafbare feit met gevangenisstraf van minder dan één jaar wordt bedreigd. ${ }^{162}$

Uit het voorgaande kan worden afgeleid dat de toepassing van voorlopige hechtenis niet is beperkt tot bepaalde categorieën strafbare feiten: de enige beperking die de wetgever op dit punt heeft geformuleerd, is dat meer dan één jaar gevangenisstraf op het betreffende feit moet zijn gesteld. In theorie is toepassing van voorlopige hechtenis dus mogelijk bij (ernstige) verdenking van ieder strafbaar feit waarvan de strafbedreiging hoger is dan één jaar gevangenisstraf.

Gedurende het vooronderzoek wordt voorlopige hechtenis door de rechtbank voor ten hoogste drie maanden opgelegd. ${ }^{163}$ Wanneer het vooronderzoek van-

ook worden toegepast wanneer het vermeende strafbare feit een 'ernstig maatschappelijk gevaar' opleverde (art. 217 lid 1 sub 4 KPK 1969). Hoewel destijds ook gold dat preventieve maatregelen alleen mochten worden toegepast wanneer dat noodzakelijk was voor een regelmatig verloop van de procedure werd het maatschappelijk gevaar criterium in de praktijk op grote schaal als zelfstandige grond voor voorlopige hechtenis gehanteerd, ook wanneer niet werd gevreesd dat de verdachte zou vluchten of op andere wijze de voortgang van het strafproces zou bemoeilijken: Grzegorczyk en Tylman 1998, p. 517. Dat deze grond in het nieuwe strafprocesrecht niet is gehandhaafd, dient dan ook als een belangrijke verbetering van de wettelijke regeling op dit punt te worden beschouwd.

160 Art. 249 lid 1 KPK 1997. De 'hoge mate van waarschijnlijkheid' vereist een hogere graad van verdenking dan bijvoorbeeld voor aanhouding is voorgeschreven: daarvoor volstaat het vermoeden dat degene die wordt aangehouden zich heeft schuldig gemaakt aan een strafbaar feit (art. 244 lid 1 KPK 1997).

161 Art. 249 lid 2 KPK 1997.

162 Respectievelijk art. 257 lid 1 (voorlopige hechtenis is ultimum remedium), 259 lid 1, 2 en 3 KPK 1997.

163 Art. 263 lid 1 KPK 1997. Dit is ook de periode waarbinnen het vooronderzoek in zwaardere strafzaken (śledztwo) in beginsel moet worden afgerond. 'In gerechtvaardigde gevallen' ('w uzasadnionych wypadkach') kan de drie maanden termijn door de prokurator worden verlengd tot maximaal één jaar. Zolang de totale duur van het vooronderzoek niet meer dan één jaar bedraagt, kan een dergelijke verlenging verschillende keren plaatsvinden. In 'uitzonderlijke gevallen' ('w szczególnie uzasadnionych wypadkach') kan een hogere prokurator (hoger dan zijn collega die het vooronderzoek leidt) de onderzoekstermijn nog 
wege 'de bijzondere omstandigheden van de zaak' niet binnen drie maanden kan worden afgerond, kan de rechtbank die bevoegd is van de zaak kennis te nemen de voorlopige hechtenis op verzoek van de prokurator verlengen tot maximaal 12 maanden. De totale termijn van voorlopige hechtenis mag tot aan de uitspraak in eerste aanleg niet meer dan twee jaar bedragen: een verdachte mag zich dus niet langer dan 24 maanden in voorlopige hechtenis bevinden voordat er vonnis is gewezen in zijn zaak. Deze maximumtermijnen van één en twee jaar zijn echter niet absoluut: onder bepaalde omstandigheden kan de hoger beroepsinstantie (SA) van het rechtsgebied waar de zaak aanhangig is de voorlopige hechtenis nog verder verlengen. ${ }^{164}$ Detentie gedurende de behandeling van het hoger beroep geldt ook als voorlopige hechtenis.

\subsection{Mogelijkheden van de verdediging}

De verdediging kan de rechtmatigheid en noodzakelijkheid van de voorlopige hechtenis op verschillende manieren en op verschillende momenten in de procedure aanvechten. Deze mogelijkheden kunnen grofweg in drie categorieën worden verdeeld. Bezwaren tegen de vrijheidsbeneming kunnen kenbaar worden gemaakt:

1. op de zitting waarop over de beslissing tot toepassing of verlenging van voorlopige hechtenis wordt beslist,

2. door het indienen van een verzoek tot opheffing of omzetting van het dwangmiddel of

3. door het aantekenen van bezwaar (zażalenie) tegen de beslissing tot toepassing of verlenging of de afwijzing van een verzoek tot opheffing of omzetting.

Genoemde mogelijkheden zullen in het onderstaande worden toegelicht. ${ }^{165}$

verder verlengen. Voor de andere vorm van het vooronderzoek - de meer informele dochodzenie - geldt in beginsel een kortere termijn van twee maanden die door de prokurator kan worden verlengd tot drie maanden.

164 Art. 263 lid 2, 3 en 4 KPK 1997. Verlenging met overschrijding van de wettelijke maximumtermijnen is mogelijk wanneer het noodzakelijk is in verband met schorsing van de strafzaak, langdurige psychiatrische observatie van verdachte, tijdrovende deskundigenrapportage, het verrichten van onderzoek in een bijzonder ingewikkelde zaak of in het buitenland, opzettelijke vertraging van de procedure door de verdachte of in geval van 'andere belangrijke obstakels waarvan is gebleken dat ze niet kunnen worden opgeheven'. Laatstgenoemde restcategorie creëert - in ieder geval in theorie - een ruime grondslag voor overschrijding van genoemde maximumtermijnen. Overschrijding van de maximumtermijn van twee jaar (tot de uitspraak in eerste aanleg) komt vooral voor in ingewikkelde strafzaken waarin het gaat om economische en georganiseerde criminaliteit: Kruszyński 2007 I, p. 186. De duur van de voorlopige hechtenis speelt een belangrijke rol in de Straatsburgse rechtspraak tegen Polen, zie daarover: § 4.5 en 4.6.

165 Eerder is al aan de orde geweest dat iedere aangehoudene het recht heeft de rechtmatigheid van zijn aanhouding en daaropvolgende (politie)detentie door een rechter te laten beoordelen (art. 246 KPK 1997). Omdat in dit stadium nog geen sprake is van voorlopige hechtenis zal deze mogelijkheid hier verder buiten beschouwing worden gelaten. Dit neemt echter niet weg dat het een zeer belangrijk rechtsmiddel betreft dat de verdachte in staat stelt zijn vrijheidsbeneming voor de eerste maal te laten toetsen door een rechterlijke instantie. Zie hoofdstuk 4, § 2.2.2.2 waar is besproken hoe de mogelijkheden van de verdediging om deel te nemen aan de zitting waarop over dit bezwaar wordt beslist als gevolg van een uitspraak van het Grondwettelijk Hof in 2005 aanzienlijk zijn uitgebreid. 


\subsubsection{De beslissing tot toepassing en verlenging van voorlopige hechtenis}

Het bevel voorlopige hechtenis wordt gedurende het vooronderzoek op verzoek van de prokurator afgegeven door de rechtbank. Voordat de prokurator een dergelijk verzoek indient, wordt de verdachte door hem gehoord. ${ }^{166}$ Dit formele verhoor is niet wettelijk voorgeschreven maar in de praktijk nodig om te kunnen bepalen of voorlopige hechtenis in het concrete geval inderdaad noodzakelijk is. ${ }^{167}$ Indien de verdachte op dat moment reeds over (een gekozen of toegevoegde) raadsman beschikt, kan deze verzoeken bij genoemd verhoor door de prokurator aanwezig te zijn. Aangezien het horen niet wettelijk is geregeld, bestaat ook voor de deelname van de raadsman geen expliciete wettelijke grondslag.

Wanneer de raadsman niet aan het verhoor door de prokurator heeft kunnen deelnemen, rest er nog één kans om invloed uit te oefenen op de beslissing tot toepassing van voorlopige hechtenis. Voordat de rechtbank een beslissing neemt op het verzoek van de prokurator wordt de verdachte opnieuw gehoord. ${ }^{168}$ Wanneer de raadsman ter zitting verschijnt om bij dit verhoor aanwezig te zijn, dient hij te worden toegelaten. Hij hoeft echter niet op de hoogte te worden gesteld van de datum en het tijdstip waarop de zitting zal plaatsvinden: verondersteld wordt dat hij deze informatie zelf kan achterhalen of via zijn cliënt kan vernemen. ${ }^{169}$ Op deze regel geldt echter één uitzondering: de autoriteiten zijn wel verplicht de raadsman op de hoogte te stellen wanneer

1. de verdachte daarom verzoekt en

2. het informeren van de raadsman 'het uitvoeren van de handeling (i.e. het horen van verdachte) niet bemoeilijkt' ('nie utrudni to przeprowadzenia czynności'). ${ }^{170}$

Dat de raadsman na een daartoe strekkend verzoek van verdachte slechts behoeft te worden geïnformeerd wanneer dat praktisch mogelijk is, heeft alles te maken met de strenge beslistermijnen waar de rechtbank in deze fase van de procedure aan is gebonden. Op het verzoek van de prokurator dient binnen 24 uur te worden beslist: wanneer binnen deze termijn geen bevel voorlopige hechtenis wordt afgegeven, moet de verdachte onmiddellijk in vrijheid worden gesteld. Er is dus vaak haast bij het horen van de verdachte door de rechtbank.

De prokurator dient wel in alle gevallen van de zitting op de hoogte te worden gesteld ${ }^{171}$ waardoor de positie van de raadsman op dit punt niet gelijk is aan die van de openbaar aanklager. In de Poolse literatuur is wel opgemerkt dat deze ongelijkheid in strijd is met het recht op verdediging. ${ }^{172}$

166 Wanneer de verdachte door de politie van zijn vrijheid wordt beroofd, dient de prokurator zijn verzoek tot toepassing van voorlopige hechtenis binnen 48 uur na aanhouding aan de rechter voor te leggen.

167 Waltoś 2002 I, p. 420.

168 Dit verhoor is wel wettelijk geregeld (art. 249 lid 3 eerste zin KPK 1997). De rechtbank kan hier alleen van af zien wanneer de verdachte zich verborgen houdt of zich in het buitenland bevindt.

169 Hofmański 1999, p. 916.

170 Art. 249 lid 3 tweede zin KPK 1997.

171 Art. 249 lid 3 derde zin KPK 1997. Zijn deelname is echter niet verplicht: wanneer een prokurator die op de juiste wijze is opgeroepen niet verschijnt, kan de zitting ook in zijn afwezigheid plaatsvinden: Grzegorczyk 2004, p. 650.

172 Zie bijvoorbeeld Dudek 1999, p. 296-297. Wąsek-Wiaderek is van mening dat - hoewel 
Naarmate de voorlopige hechtenis langer duurt, neemt voor wat betreft de mogelijkheid om aan zittingen deel te nemen ook de gelijkheid tussen prokurator en raadsman toe: de raadsman is - net als de prokurator - bevoegd om deel te nemen aan de zitting waarop door de rechtbank over de verlenging van de voorlopige hechtenis wordt beslist. Voor zowel de prokurator als de raadsman geldt dat de zitting in hun afwezigheid kan plaatsvinden wanneer ze op de juiste wijze zijn opgeroepen maar toch niet zijn verschenen. ${ }^{173}$ Anders dan bij de behandeling van het (eerste) verzoek tot toepassing van voorlopige hechtenis gaat de wetgever er ten aanzien van de verlenging dus wel vanuit dat de raadsman te allen tijde dient te worden geïnformeerd over tijd en plaats van de zitting: een daartoe strekkend verzoek van verdachte is in dit verband niet vereist. De verplichting de raadsman ambtshalve te informeren is in dit stadium van de procedure ook minder bezwaarlijk omdat de zitting waarop over de verlenging wordt beslist doorgaans eerder van te voren bekend is en aan minder korte termijnen gebonden zal zijn dan de behandeling van het eerste verzoek tot toepassing van voorlopige hechtenis. Het is allesbehalve vanzelfsprekend dat ook de verdachte bij de behandeling van het verzoek tot verlenging aanwezig kan zijn. Anders dan bij de behandeling van het verzoek tot toepassing van voorlopige hechtenis is de rechtbank niet verplicht de verdachte te horen voordat over de verlenging wordt beslist. Weliswaar geldt in dit verband de algemene regel dat de verdachte aan een zitting kan deelnemen wanneer hij verschijnt ${ }^{174}$ maar het spreekt voor zich dat het realiseren van dit aanwezigheidsrecht - in geval van vrijheidsberoving - afhankelijk is van de autoriteiten. Aangezien de wetgever nergens heeft bepaald dat de verdachte naar de zitting moet worden gebracht waarop het verzoek tot verlenging wordt behandeld, heeft hij geen absoluut (of afdwingbaar) recht om bij dit soort zittingen aanwezig te zijn. Overigens is ook niet vanzelfsprekend dat de verdediging van te voren wordt geïnformeerd over de argumenten die aan het verlengingsverzoek ten grondslag liggen: de prokurator is niet verplicht voorafgaand aan de zitting een afschrift van zijn verlengingsverzoek te doen toekomen aan de verdachte en zijn eventuele raadsman. ${ }^{175}$

\subsubsection{Situatie voor inwerkingtreding nieuw strafprocesrecht}

Voor wat betreft de mogelijkheden van de verdediging om invloed uit te oefenen op de (eerste) beslissing tot toepassing van voorlopige hechtenis is uiteraard van belang dat deze beslissing volgens het oude strafprocesrecht niet door de recht-

inderdaad kritiek kan worden uitgeoefend op het feit dat art. 249 lid 3 KPK 1997 geen absolute verplichting bevat om de raadsman in te lichten - dit niet wegneemt dat de beslissing wel in aanwezigheid (en na een verhoor) van verdachte wordt genomen zodat de procedure op dit punt voldoende contradictoir is en voldoet aan de eisen van equality of arms: Wąsek-Wiaderek 2003 II, p. 264.

173 Art. 249 lid 5 KPK 1997.

174 Art. 96 lid 2 KPK 1997. De volledige bepaling luidt: '1: Partijen en personen die geen partij zijn hebben, wanneer dat van belang is voor de bescherming van hun rechten of belangen, in de door de wet bepaalde gevallen het recht deel te nemen aan een zitting van de rechtbank, tenzij ze daartoe verplicht zijn. 2: In andere gevallen hebben deze partijen en personen, tenzij anders is bepaald door de wet, het recht deel te nemen aan zittingen wanneer zij ter terechtzitting verschijnen.'

175 Kritisch hierover: Wąsek-Wiaderek 2003 II, p. 267. 
bank maar door de prokurator werd genomen. Voordat voorlopige hechtenis kon worden toegepast, diende de prokurator de verdachte wel te horen maar de raadsman had geen onvoorwaardelijk recht om bij dit verhoor aanwezig te zijn. Het stond de raadsman vrij in dit verband een verzoek (tot deelname) in te dienen maar de prokurator was niet verplicht dit toe te staan. Er was - anders dan vandaag de dag - dus geen zitting waarop de verdachte al dan niet in aanwezigheid van een raadsman ten overstaan van een onafhankelijke rechter zijn visie over de noodzaak van voorlopige hechtenis duidelijk kon maken.

Ook in procedures tot verlenging van de voorlopige hechtenis waren de mogelijkheden van de verdediging onder het oude strafprocesrecht aanzienlijk beperkter dan vandaag de dag. In de eerste plaats was op grond van het oorspronkelijke wetboek van strafvordering van 1969 pas rechterlijke inmenging vereist wanneer de voorlopige hechtenis langer dan zes maanden had geduurd. ${ }^{176}$ Gedurende het eerste half jaar kon de prokuratura de vrijheidsbeneming dus zelfstandig en zonder tussenkomst van de rechter verlengen.

Wanneer na de eerste zes maanden door de rechter over verlenging van de voorlopige hechtenis werd beslist, had de verdediging geen recht om bij de behandeling ter terechtzitting aanwezig te zijn. Deze kwestie viel onder de reikwijdte van het algemene art. 88 KPK 1969 dat luidde:

'De prokurator is bevoegd deel te nemen aan zittingen van de rechtbank of schriftelijk verzoeken in te dienen, andere partijen mogen deelnemen aan zittingen van de rechtbank wanneer de wet in die bevoegdheid voorziet.'

Aangezien de wet van 1969 niet voorzag in de bevoegdheid van de raadsman of de verdachte om deel te nemen aan zittingen waarop over de verlenging van voorlopige hechtenis werd beslist, vonden dergelijke zittingen in afwezigheid van de verdediging plaats. Zij kon haar bezwaren tegen de verlenging wel schriftelijk kenbaar maken aan de rechtbank maar deze mogelijkheid was in de meeste gevallen illusoir omdat noch de verdachte noch de raadsman op de hoogte was van de inhoud (en motivering) van het verlengingsverzoek. Bovendien kon de verdediging in de schriftelijke reactie niet vooruitlopen op datgene wat de prokurator ter zitting nog zou aanvoeren.

Het moge duidelijk zijn dat de procedure inzake toepassing en verlenging van voorlopige hechtenis op grond van het oude wetboek van strafvordering een weinig tegensprekelijk karakter had. De prokurator besliste zelfstandig over de toepassing van voorlopige hechtenis. De verdachte diende daarbij weliswaar te worden gehoord maar inmenging van de raadsman kon eenvoudig worden geweerd. Beslissingen tot verlenging van de voorlopige hechtenis werden in feite volledig buiten de verdediging om genomen.

176 De procedure was als volgt: de prokurator legde voorlopige hechtenis voor maximaal drie maanden op en indien het vooronderzoek 'vanwege de bijzondere omstandigheden van de zaak' niet binnen deze termijn kon worden afgerond, kon de hechtenis door een hoger geplaatste prokurator (prokurator wojewódzki) tot maximaal zes maanden worden verlengd. Daarna kon verlenging op verzoek van dezelfde prokurator door de rechtbank worden bevolen voor zolang noodzakelijk was voor de afronding van het onderzoek. Voorlopige hechtenis kon in de praktijk dus onbeperkt worden verlengd. In 1989 werden de eerste wetswijzigingen op dit punt doorgevoerd: zie hoofdstuk 2, § 2.2.2.4. 


\subsubsection{Het verzoek tot opheffing of omzetting van de voorlopige hechtenis}

De verdediging kan de voorlopige hechtenis ook nog op andere manieren aanvechten. Belangrijk in dit verband is de mogelijkheid opheffing of omzetting van de voorlopige hechtenis te verzoeken. Omzetting betekent het wijzigen van de voorlopige hechtenis in een minder beperkende preventieve maatregel zoals borgstelling of politietoezicht. Verzoeken tot opheffing en omzetting kunnen in elke fase van de strafrechtelijke procedure (herhaaldelijk) worden gedaan en dienen gedurende het vooronderzoek te worden behandeld door de prokurator. ${ }^{177}$ De voorlopige hechtenis kan overigens ook zonder een dergelijk verzoek van de verdediging worden opgeheven of omgezet: de rechtbank en (gedurende het vooronderzoek) de prokurator zijn ambtshalve verplicht om toezicht uit te oefenen op de tenuitvoerlegging van preventieve maatregelen en dienen in het kader daarvan de voorlopige hechtenis uit eigen beweging op te heffen of om te zetten zodra blijkt dat de gronden ervoor zijn komen te vervallen of zich nieuwe omstandigheden voordoen die opheffing of omzetting rechtvaardigen. ${ }^{178}$ Opmerkelijk is dat deze regeling de prokurator de bevoegdheid geeft zonder tussenkomst van de rechter een einde te maken aan de voorlopige hechtenis die door de rechtbank is bevolen. Een dergelijk ingrijpen is zelfs mogelijk wanneer op een door de verdediging ingediend rechtsmiddel tegen de voorlopige hechtenis - waarover hierna meer - nog niet is beslist door de rechter. ${ }^{179}$

\subsubsection{Situatie voor inwerkingtreding nieuw strafprocesrecht}

Het huidige strafprocesrecht vertoont op dit punt geen noemenswaardige verschillen met het wetboek van strafvordering van 1969. Laatstgenoemd wetboek regelde op soortgelijke wijze dat de verdachte (en dus ook de raadsman) op ieder moment om opheffing of omzetting van preventieve maatregelen kon verzoeken en dat een dergelijk verzoek gedurende het vooronderzoek binnen drie dagen door de prokurator moest worden afgehandeld. ${ }^{180}$

\subsubsection{Het instellen van rechtsmiddelen}

Het huidige strafprocesrecht voorziet in een ruime mogelijkheid rechtsmiddelen in te stellen tegen beslissingen die betrekking hebben op de voorlopige hechtenis. Op grond van art. 252 lid 1 KPK 1997 kan bezwaar worden ingesteld 'tegen beslissingen inzake preventieve maatregelen' ('na postanowienie w przedmiocie środka zapobiegawczego') wat voor de verdediging inhoudt dat - onder de nog te bespreken voorwaarden - een rechtsmiddel kan worden ingesteld tegen:

- de beslissing tot toepassing van voorlopige hechtenis,

- de beslissing tot verlenging van voorlopige hechtenis en

- tegen de afwijzing van een verzoek om opheffing of omzetting. ${ }^{181}$

177 De prokurator dient binnen drie dagen een beslissing te nemen op het verzoek (art. 254 lid 1 KPK 1997). Na sluiting van het vooronderzoek, beslist de rechtbank over opheffing of omzetting van de voorlopige hechtenis.

178 Art. 253 en art. 256 KPK 1997.

179 Izydorczyk 2002, p. 92.

180 Art. 214 KPK 1969.

181 Art. 252 KPK 1997. Onder de categorie 'beslissingen inzake voorlopige hechtenis' vallen overigens niet de beslissingen die reeds naar aanleiding van een ingesteld bezwaar zijn 
Tegen iedere beslissing tot toepassing en verlenging van voorlopige hechtenis kan door de verdediging eenmaal bezwaar worden ingesteld. Van deze mogelijkheid dient binnen zeven dagen na de bestreden beslissing gebruik te worden gemaakt. Wat de behandeling van het bezwaar betreft, geldt in beginsel de algemene regel dat beslissingen van de rechtbank worden getoetst door de rechterlijke instantie die daar direct bovenstaat: tegen een bevel voorlopige hechtenis van de districtsrechtbank staat dus bezwaar open bij de provinciale rechtbank van hetzelfde arrondissement. ${ }^{182}$ Binnen 48 uur dient op het bezwaar te worden beslist. ${ }^{183}$ Anders dan bij beslissingen inzake toepassing en verlenging van voorlopige hechtenis kan niet tegen iedere afwijzende beslissing op een verzoek om opheffing of omzetting bij de rechter bezwaar worden aangetekend: die mogelijkheid is aan extra beperkingen gebonden en staat slechts open wanneer ten minste drie maanden zijn verstreken tussen de beslissing tot toepassing (waaronder verlenging) van de voorlopige hechtenis en het verzoek tot opheffing of omzetting. ${ }^{184}$ Ratio van deze beperking is het feit dat verzoeken om opheffing en omzetting telkens opnieuw kunnen worden herhaald zodat de wetgever een ongelimiteerde bezwaarmogelijkheid niet noodzakelijk en - gelet op de efficiëntie van het strafproces - vooral ook niet wenselijk heeft geacht. ${ }^{185}$

Laatstgenoemde beperking kan in de praktijk vergaande consequenties hebben: aangezien de eerste termijn van de voorlopige hechtenis altijd maximaal drie maanden bedraagt, kan gedurende deze eerste periode geen bezwaar worden aangetekend tegen een afwijzende beslissing op een verzoek om opheffing of omzetting. Gevolg hiervan is dat gedurende deze eerste termijn alleen bezwaar kan worden ingesteld tegen de beslissing van de rechtbank tot toepassing van de voorlopige hechtenis. Verzoeken om opheffing c.q. omzetting kunnen dus wel (herhaaldelijk) bij de prokurator worden ingediend maar de afwijzing ervan kan in deze periode niet aan de rechter worden voorgelegd. Bovendien gaat de drie maanden termijn na een beslissing tot verlenging van de voorlopige hechtenis opnieuw lopen: de verdediging moet na de beslissing tot verlenging dus weer lange tijd wachten voordat bezwaar tegen een weigering tot opheffing of omzetting kan worden ingediend. ${ }^{186}$

genomen: de verdediging kan bijvoorbeeld dus niet opnieuw bezwaar aantekenen tegen een afwijzende beslissing op bezwaar tegen verlenging.

182 Deze hoofdregel - dat het bezwaar wordt behandeld door een hogere rechterlijke instantie - kent een aantal uitzonderingen. Zo dient het bezwaar tegen de beslissing van SA tot verlenging van de voorlopige hechtenis met overschrijding van de 1 of 2 jaar termijn te worden behandeld door een meervoudige kamer ( 3 personen) van dezelfde instantie (art. 263 lid 5 KPK 1997).

183 Art. 463 lid 2 KPK 1997.

184 Art. 254 lid 2 KPK 1997. Het feit dat de rechtbank ook bevoegd is wanneer het bezwaar is gericht tegen een afwijzende beslissing van een prokurator (die zoals bekend gedurende het vooronderzoek bevoegd is om op verzoeken tot opheffing of omzetting te beslissen) vormt een uitzondering op de hoofdregel dat bezwaar tegen een beslissing van een prokurator wordt behandeld door een hoger geplaatste collega binnen de prokuratura.

185 Zie in dit verband ook de bespreking van het thema 'misbruik van procesrecht' in hoofdstuk $6, \S 5$.

186 In het ongunstige geval dat de eerste termijn van de voorlopige hechtenis minder dan drie (bijvoorbeeld twee maanden) is, kan het dus vijf maanden duren voordat dit rechtsmiddel tegen de weigering tot opheffing of omzetting openstaat. Art. 254 schrijft immers voor dat 
Ondanks bovengenoemde beperkingen vormt de mogelijkheid bezwaar aan te tekenen tegen de afwijzing van een verzoek om opheffing of omzetting een belangrijke aanvulling op de andere twee rechtsmiddelen (bezwaar tegen toepassing en verlenging voorlopige hechtenis). Hierbij is van belang dat de rechter die over de verlenging van de voorlopige hechtenis beslist slechts is gebonden aan de eerder genoemde maximumtermijn van één jaar: ${ }^{187}$ hij is niet verplicht de vrijheidsbeneming opnieuw voor maximaal drie maanden op te leggen maar kan deze onmiddellijk met negen maanden verlengen. Aangezien in zo'n geval gedurende het gehele jaar maar één verlengingsbeslissing wordt genomen, kan de verdediging daartegen ook maar één keer bezwaar instellen. ${ }^{188}$ Zonder de mogelijkheid bezwaar in te stellen tegen een door de prokurator afgewezen verzoek tot opheffing of omzetting zouden in een periode van 12 maanden dus slechts twee rechtsmiddelen kunnen worden benut: eenmaal bezwaar tegen de beslissing tot toepassing en eenmaal bezwaar tegen de beslissing tot verlenging.

Deelname van de verdediging

Een volgende vraag is of de verdediging het recht heeft deel te nemen aan de zittingen waarop eerdergenoemde rechtsmiddelen worden behandeld. Bij beantwoording van deze vraag dient onderscheid te worden gemaakt tussen de mogelijkheden van enerzijds de raadsman en anderzijds de verdachte.

Voor de raadsman geldt dat hij een expliciet wettelijk recht heeft deel te nemen aan de zitting waarop over het bezwaar tegen toepassing of verlenging van de voorlopige hechtenis wordt beslist. Op dezelfde wijze als ten aanzien van de behandeling van beslissingen tot verlenging geldt dat hij op de hoogte moet worden gesteld van de zitting waarop het rechtsmiddel wordt behandeld maar dat zijn afwezigheid - wanneer hij op de juiste wijze is opgeroepen - geen reden vormt voor uitstel. ${ }^{189}$

Voor de verdachte bestaat geen vergelijkbare regeling: voor hem geldt de hoofdregel dat de rechtbank hem kan toestaan aan de zitting deel te nemen. ${ }^{190}$ Dit betekent dat hij kan verzoeken naar de zitting te worden gebracht maar het staat de rechter volledig vrij een dergelijk verzoek af te wijzen en het bezwaar in afwezigheid van de verdachte af te doen. Hij is niet verplicht daarbij in aanmerking te nemen of de belangen van de verdachte ter zitting zullen worden vertegenwoordigd door een raadsman: ook de verdachte die geen rechtsbijstand heeft, kan deelname aan de zitting op bezwaar worden geweigerd. Voor de wetswijziging van juli 2003 was dit anders. Toen gold dat de voorlopig gehechte verdachte in beginsel naar de zitting moest worden gebracht tenzij de rechter aanwezigheid van de raadsman voldoende achtte: in het laatste geval kreeg de verdachte zonder

drie maanden moeten zijn verstreken 'sinds de dag waarop de beslissing inzake de voorlopige hechtenis met betrekking tot de verdachte' is genomen ('od dnia wydania postanowienia w przedmiocie tymczasowego aresztowania dotyczacego tego samego oskarżonego'), de beslissing tot verlenging valt hier ook onder: Grzegorczyk 204, p. 666.

187 Neergelegd in art. 263 lid 2 KPK 1997.

188 Wąsek-Wiaderek 2003 I, p. 266-267.

189 Art. 249 lid 5 KPK 1997. Dit artikellid heeft dus betrekking op zowel de behandeling van de beslissing tot verlenging als de behandeling van het bezwaar tegen beslissingen tot toepassing of verlenging van de voorlopige hechtenis.

190 Art. 464 lid 2 KPK 1997. 
rechtsbijstand een advocaat toegevoegd. Gevolg van deze constructie was dat behandeling van bezwaar tegen toepassing en verlenging van voorlopige hechtenis alleen in afwezigheid van de verdachte kon plaatsvinden wanneer deelname van de raadsman toereikend werd geacht. Nu deze verplichting in 2003 is komen te vervallen, heeft de verdachte op dit punt geen garanties meer en is het volledig afhankelijk van de goede wil van de rechter of hij bij de zitting aanwezig zal kunnen zijn.

Ten aanzien van de behandeling van het bezwaar tegen een afwijzing van een verzoek om opheffing of omzetting geldt dat de raadsman mag deelnemen indien hij verschijnt en de rechtbank hem dat toestaat. ${ }^{191}$ Zijn recht op deelname vloeit dus niet voort uit een expliciete wettelijke bepaling - waardoor de autoriteiten in ieder geval niet verplicht zijn hem op te roepen - maar de rechtbank zal deelname van de verschenen advocaat in beginsel niet mogen weigeren.

Voor de mogelijkheid van de verdachte om deel te nemen, geldt dezelfde regeling als met betrekking tot de behandeling van het bezwaar tegen toepassing of verlenging van voorlopige hechtenis: hij heeft dus geen afdwingbaar recht bij de zitting aanwezig te zijn.

\subsubsection{Situatie voor inwerkingtreding nieuw strafprocesrecht}

Op grond van het wetboek van strafvordering van 1969 kon - bij de rechtbank of in geval van bepaalde verlengingsbeslissingen bij het Hooggerechtshof - bezwaar worden ingesteld tegen

- de beslissing van de prokurator tot toepassing van voorlopige hechtenis ${ }^{192}$ en

- de beslissing tot verlenging van de voorlopige hechtenis. ${ }^{193}$

Wat betreft de vraag of de verdediging het recht had deel te nemen aan de zittingen waarop bovengenoemde rechtsmiddelen werden behandeld, gold net als ten aanzien van de beslissing tot verlenging art. 88 KPK 1969. ${ }^{194}$ Aangezien nergens in het wetboek van strafvordering van 1969 was bepaald dat de verdachte of zijn raadsman het recht hadden deel te nemen aan de zitting op bezwaar was alleen de prokurator hiertoe bevoegd. Gevolg hiervan was dat de verdediging haar bezwaren slechts schriftelijk kenbaar kon maken en niet kon reageren op hetgeen door de prokurator - die wel te allen tijde op de zitting aanwezig mocht zijn - werd aangevoerd.

191 Art. 464 lid 2 KPK 1997.

192 Dit bezwaar diende te worden beoordeeld door de rechtbank die bevoegd was van de zaak kennis te nemen.

193 Zoals eerder aangegeven, kon voorlopige hechtenis op grond van het wetboek van strafvordering van 1969 tot maximaal 6 maanden worden verlengd door een hoger geplaatste prokurator (prokurator wojewódzki). Daarna kon verlenging op verzoek van dezelfde prokurator door de rechtbank worden bevolen voor zolang noodzakelijk was voor de afronding van het onderzoek. Tegen eerstgenoemde verlenging door de prokurator stond bezwaar open bij de rechtbank en tegen verlengingen uitgesproken door laatstgenoemde instantie kon bezwaar worden ingesteld bij het Hooggerechtshof (art. 212 lid 2 en 222 lid 3 KPK 1969).

194 'De prokurator is bevoegd deel te nemen aan zittingen van de rechtbank of schriftelijk verzoeken in te dienen, andere partijen mogen deelnemen aan zittingen van de rechtbank wanneer de wet in die bevoegdheid voorziet.' 
Tegen de afwijzing van een verzoek tot opheffing of omzetting van de voorlopige hechtenis kon wel een rechtsmiddel worden ingesteld maar de beoordeling daarvan was gedurende het vooronderzoek niet overgelaten aan de rechtbank. Tegen de afwijzing (gedaan door de prokurator) kon alleen worden geklaagd bij een hogere prokurator. ${ }^{195}$ Als gevolg van deze regeling was de eerste mogelijkheid voor de verdediging om in een contradictoire setting argumenten naar voren te brengen tegen het voortduren van de voorlopige hechtenis de eerste zitting waarop de zaak inhoudelijk werd behandeld. ${ }^{196}$ Voor aanvang van het onderzoek ter terechtzitting bestond geen enkele afdwingbare mogelijkheid voor de verdachte en/of zijn raadsman om ten overstaan van de rechter mondeling verweer te voeren tegen de vrijheidsberoving. Een situatie die - zoals in $\S 4.6 \mathrm{nog}$ zal worden uiteengezet zonder twijfel onverenigbaar was met het EVRM.

\subsection{Evaluatie juridisch kader}

Uit het voorgaande kan worden opgemaakt dat de mogelijkheden van de verdediging om de voorlopige hechtenis aan te vechten in het nieuwe strafprocesrecht aanzienlijk zijn uitgebreid. In dit verband is vooral van belang dat de beslissing over toepassing van de vrijheidsbeneming voortaan is voorbehouden aan de rechter. Gedurende het communisme werd deze beslissing zelfstandig door de prokurator genomen - bovendien kon hij de voorlopige hechtenis gedurende de eerste zes maanden zonder tussenkomst van een rechter verlengen - en had de verdediging nauwelijks mogelijkheden om invloed uit te oefenen op deze besluitvorming. De raadsman had geen absoluut recht om deel te nemen aan het verhoor van zijn cliënt door de prokurator. Het moge duidelijk zijn dat de zitting waarop vandaag de dag over toepassing van voorlopige hechtenis wordt beslist de verdediging een gunstiger forum biedt: verondersteld mag worden dat een onafhankelijke rechter in de regel ontvankelijker zal zijn voor argumenten tegen toepassing van voorlopige hechtenis dan de prokurator die als leider van het vooronderzoek direct belang heeft bij (voortzetting van de) detentie van de verdachte. Bovendien is in het huidige strafprocesrecht wettelijk gegarandeerd dat de raadsman het recht heeft deel te nemen aan de zitting waarop over het verzoek tot toepassing van voorlopige hechtenis wordt beslist. ${ }^{197}$ Voor wat de betekenis van deze wettelijke mogelijkheid in de praktijk betreft, dient echter wel in herinnering te worden geroepen dat slechts een klein deel van de verdachten in dit stadium van de procedure reeds over een (gekozen of toegevoegde) raadsman beschikt. ${ }^{198}$

De verschillende rechtsmiddelen die de verdediging tegenwoordig tegen de voorlopige hechtenis kan aanwenden, bestonden ook reeds op grond van het oude stafprocesrecht. Belangrijk is wel dat wanneer gedurende het vooronder-

195 Dit vloeide voort uit art. 212 lid 1: 'Beslissingen inzake voorlopige hechtenis zijn vatbaar voor bezwaar volgens de algemene regels [over bezwaar, toev. DdV] (....'. Dit betekende dat de hoofdregel gold: tegen beslissingen van de prokurator dient bezwaar te worden ingediend bij een hogere prokurator en bezwaar tegen beslissing van de rechtbank wordt beoordeeld door een hogere rechtbank.

196 Bij welke gelegenheid om opheffing of omzetting van de voorlopige hechtenis kon worden gevraagd.

197 Art. 249 lid 3 KPK 1997.

198 Zie voor de praktische problemen die verwezenlijking van het recht op rechtsbijstand in de eerste fase na aanhouding bemoeilijken: hoofdstuk $4, \S 2.4$. 
zoek door de prokurator afwijzend wordt beslist op een verzoek tot opheffing of omzetting de verdediging tegen deze afwijzing - weliswaar onder bepaalde voorwaarden - voortaan bezwaar kan aantekenen bij de rechtbank: tot een aantal jaren geleden (2003) werd dit rechtsmiddel door de prokuratura zelf beoordeeld en was rechterlijke toetsing van deze beslissing dus niet mogelijk. De meest voorname verandering heeft echter geen betrekking op de soorten rechtsmiddelen of de vraag door wie ze worden behandeld maar op de mogelijkheid van de verdediging om deel te nemen aan de zitting waarop erover wordt beslist. Zoals in het voorgaande is beschreven, werden zittingen waarop het bezwaar tegen toepassing of verlenging van de voorlopige hechtenis door de rechter werd behandeld in afwezigheid van de verdachte en zijn eventuele raadsman afgedaan. De rechtsmiddelen waren hierdoor niet meer dan een mogelijkheid om bezwaren tegen de vrijheidsbeneming schriftelijk kenbaar te maken bij de rechter. Hetzelfde gold voor de zitting waarop over verlenging van de hechtenis werd beslist. ${ }^{199}$ De prokurator had - in tegenstelling tot de verdediging - wel het recht deel te nemen aan genoemde zittingen waardoor de verdediging ernstig werd benadeeld: ze kreeg immers niet de mogelijkheid standpunten mondeling toe te lichten of te reageren op datgene wat ter zitting nog door de prokurator werd aangevoerd. Het huidige strafprocesrecht heeft deze situatie - in ieder geval voor wat betreft de raadsman - aanzienlijk verbeterd: de advocaat van verdachte heeft het recht deel te nemen aan alle zittingen waarop over (toepassing, verlenging, opheffing of omzetting van de) voorlopige hechtenis wordt beslist.

Toch vertoont de huidige regeling nog een aantal 'zwakke plekken'. Dit geldt in de eerste plaats voor de beperkte informatieplicht ten aanzien van de zitting waarop voor het eerst over toepassing van de voorlopige hechtenis zal worden beslist. Autoriteiten zijn in de regel niet verplicht een raadsman op de hoogte te stellen van de datum en het tijdstip waarop deze zitting zal plaatsvinden: een dergelijke verplichting bestaat slechts wanneer de verdachte erom verzoekt en zelfs dan kan er van worden afgezien wanneer men van mening is dat het er aan in de weg zal staan dat de zitting tijdig kan plaatsvinden. Zoals ook is opgemerkt in de Poolse literatuur bestaat op dit punt een ongerechtvaardigde ongelijkheid tussen de

199 Het is mede hierdoor zeer de vraag hoe effectief rechterlijke controle op de voorlopige hechtenis gedurende het communisme was. De schaarse gegevens die hierover beschikbaar zijn (waaronder een aantal gepubliceerde uitspraken van het Hooggerechtshof) lijken erop te wijzen dat rechterlijke instanties zelden in het voordeel van de verdachte oordeelden. Volgens Pomorski en Defert was er sprake van een 'high regard for the needs of the investigation and relaxed standards of application of preliminary detention': Pomorski en Defert 1980, p. 526. Ter illustratie: bij de provinciale rechtbank van Wrocław werd in 1971 in totaal 9 keer bezwaar ingesteld tegen verlenging van de voorlopige hechtenis en in alle gevallen zonder het door de verdachte gewenste resultaat. De rechtbank ontving bovendien 39 verzoeken tot verlenging van de voorlopige hechtenis (na de eerste zes maanden): deze werden allemaal ingewilligd. Door 15 gedetineerden werd tegen deze verlenging bezwaar ingesteld bij het Hooggerechtshof maar allemaal zonder succes: Pomorski en Defert 1980, p. 525-526. Dat rechterlijk toezicht op voorlopige hechtenis voor 1989 weinig voorstelde, heeft natuurlijk alles te maken met het feit dat de rechterlijke macht gedurende het communisme volledig ondergeschikt was aan het regime en dus niet beschikte over de onpartijdigheid en onafhankelijkheid die noodzakelijk is voor effectieve controle. Zie hierover hoofdstuk $2, \S 2.2$. 
raadsman en de prokurator die immers wel te allen tijde van de zitting op de hoogte moet worden gesteld. ${ }^{200}$

In de tweede plaats is problematisch dat de verdachte op grond van het huidige strafprocesrecht geen afdwingbaar recht heeft om aanwezig te zijn bij zittingen waarop over een verzoek tot verlenging of een door de verdediging ingesteld bezwaar (tegen toepassing, verlenging of afwijzing van een verzoek om opheffing of omzetting) wordt beslist. De enige keer dat de rechtbank verplicht is de verdachte persoonlijk te horen, is wanneer het verzoek van de prokurator tot toepassing van voorlopige hechtenis wordt behandeld. Alle overige zittingen kunnen in afwezigheid van verdachte worden afgedaan. In de praktijk gebeurt dit doorgaans ook. ${ }^{201}$ In veel gevallen betekent dit dat de eerstvolgende keer dat de verdachte persoonlijk door de rechtbank wordt gehoord op het onderzoek ter terechtzitting is. Wanneer het onderzoek ter terechtzitting binnen twee of drie maanden aanvangt, hoeft dit geen probleem te zijn. Maar wanneer - zoals in de Poolse praktijk zeker niet ondenkbaar is - de periode tussen aanvang van de voorlopige hechtenis en de eerste zittingsdag een veel langere periode bestrijkt, is het zeer de vraag of het feit dat de van zijn vrijheid beroofde verdachte niet tussentijds door de rechter wordt gehoord verenigbaar is met de eisen van art. 5 lid 4 EVRM. ${ }^{202}$ Hoewel het probleem pregnanter is voor de verdachte die niet over rechtsbijstand beschikt - hij kan zich op de zittingen over de voorlopige hechtenis immers ook niet door een raadsman laten vertegenwoordigen - is een tweede vraag of aanwezigheid van de advocaat in alle gevallen voldoende compensatie kan vormen voor de afwezigheid van verdachte. Op beide vragen zal worden teruggekomen in § 4.6.

\subsection{Voorlopige hechtenis in de praktijk}

Zoals reeds in hoofdstuk 2 aan de orde is geweest, behoorde de voorlopige hechtenis gedurende het communisme tot een van de meest bekritiseerde onderdelen van de Poolse strafrechtspleging. Van het dwangmiddel werd op grote schaal gebruik gemaakt en verdachten konden lange tijd van hun vrijheid worden beroofd. De procedurele waarborgen die aan voorlopig gehechten werden geboden, lieten veel te wensen over. In het bovenstaande is duidelijk geworden dat de wetgever deze problematiek heeft willen aanpakken door de wettelijke regeling met meer garanties te omkleden. Dit heeft onder meer tot gevolg gehad dat het ultimum remedium karakter van de voorlopige hechtenis is benadrukt, de rechterlijke controle op toepassing van het dwangmiddel is toegenomen en de mogelijkheden van de verdediging in dit verband zijn uitgebreid.

Hier staan slechts laatstgenoemde mogelijkheden van de verdediging centraal: de vraag of de wetgever er - in zijn algemeenheid - in is geslaagd de problemen bij de toepassing van voorlopige hechtenis aan te pakken, valt buiten het bestek van dit onderzoek. ${ }^{203}$ Voor enig inzicht in het functioneren van voorlopige hechte-

200 Zie $\S 4.3 .1$ voor verwijzing naar relevante literatuur.

201 Bron: gesprek Wąsek-Wiaderek, januari 2007 Warschau.

202 Wąsek-Wiaderek 2003 II, p. 261 e.v.

203 Een blik op de Straatsburgse rechtspraak tegen Polen laat echter zien dat op dit punt nog steeds problemen bestaan. Voorlopige hechtenis wordt nog altijd op grote schaal toegepast en vaak voor lange duur. Er zijn talloze uitspraken tegen Polen waarin vanwege onterechte of (met name) te langdurige voorlopige hechtenis een schending van art. 5 lid 3 EVRM wordt vastgesteld. Zie bijvoorbeeld (het betreft hier slechts een selectie): Czarnecki t. Polen, 
nis in de praktijk kan worden verwezen naar de resultaten van door Izydorczyk verricht onderzoek. ${ }^{204}$ Izydorczyk heeft binnen vier disctrictsrechtbanken onderzocht in hoeveel zaken een verzoek tot toepassing van voorlopige hechtenis werd ingediend. Binnen de vier arrondissementen varieerde het percentage (op openbare aanklacht vervolgde) strafzaken waarin voorlopige hechtenis werd verzocht tussen de 5 en $20 \%$. Van deze verzoeken werd het overgrote deel ingewilligd: het hoogste percentage geweigerde verzoeken bedroeg $10 \% .{ }^{205}$ Voor wat betreft de vraag op welke wettelijke grond(en) het bevel voorlopige hechtenis het meest wordt gebaseerd, bleek het in art. 258 lid 1 genoemde vlucht- of collusiegevaar in de praktijk het vaakst te worden gehanteerd. ${ }^{206}$

Izydorczyk heeft in zijn onderzoek ook aandacht besteed aan de rol van de raadsman in de procedure van toepassing en verlenging van de voorlopige hechtenis. Zoals reeds eerder is aangegeven en later in dit hoofdstuk nog verder zal worden uitgewerkt, maakt de raadsman over het algemeen slechts in (zeer) beperkte mate gebruik van zijn procedurele mogelijkheden gedurende het vooronderzoek. De in het voorgaande beschreven mogelijkheden om op te komen tegen de voorlopige hechtenis worden nog relatief vaak gebruikt. Zo blijkt ook uit genoemd onderzoek. Wat de aanwending van rechtsmiddelen tegen de voorlopige hechtenis betreft, varieerde het percentage gevallen waarin bezwaar tegen het bevel voor-

EHRM 28-7-2005, nr. 75112/01 (waarin het EHRM de nationale rechter kwalijk neemt dat nergens uit blijkt dat alternatieven voor voorlopige hechtenis in overweging zijn genomen: de voorlopige hechtenis van Czarnecki duurde meer dan 5 jaar), Gotek t. Polen, EHRM 25-42006, nr. 31330/02, Celejewski t. Polen, EHRM 4-5-2006, nr. 17584/04, Drabek t. Polen, EHRM 20-6-2006, nr. 5270/04, Telecki t. Polen, EHRM 6-7-2006, nr. 56552/00, Kaszczyniec t. Polen, EHRM 22-5-2007, nr. 59526/00 en Marczuk t. Polen, EHRM 8-1-2008, nr. 4646/02. In de meeste gevallen oordeelt het EHRM dat de door de nationale rechter opgegeven gronden oorspronkelijk de voorlopige hechtenis wel konden 'dragen' maar dat voor latere verlengingen geen 'relevant and sufficient grounds' bestonden. Dit heeft alles te maken met het algemene uitgangspunt van het Hof dat naarmate de vrijheidsbeneming langer duurt zwaardere eisen worden gesteld aan de rechtvaardiging van de beslissing: 'The persistence of reasonable suspicion that the person arrested has committed an offence is a conditio sine qua non for the lawfulness of the continued detention, but after a certain lapse of time it no longer suffices. In such cases, the Court must establish whether the other grounds given by the judicial authorities continued to justify the deprivation of liberty', (onder meer): Drabek t. Polen, EHRM 20-6-2006, nr. 5270/04, § 42 .

204 Izydorczyk 2002, p. 145-172. De daar vermelde gegevens over toepassing van voorlopige hechtenis in de praktijk zijn gebaseerd op dossieronderzoek dat tussen 1998 en 2001 in 1173 strafzaken bij verschillende rechterlijke instanties (4 SR, $1 \mathrm{SO}$ en 1SA) is verricht. Bij beoordeling van de resultaten - die grotendeels in percentages zijn weergegeven - dient wel in aanmerking te worden genomen dat het aantal onderzochte zaken in de 4 districtsrechtbanken (SR) aanzienlijk verschilde (respectievelijk 4151, 656, 788 en 267).

205 Izydorczyk 2002, p. 138-142. Izydorcyzk heeft ook onderzocht wat de meest voorkomende redenen voor weigering waren. Binnen de districtsrechtbank waar het grootste aantal weigeringen voorkwam - op 65 van de 649 verzoeken werden positief beslist - was de meest voorkomende motivering: het ontbreken van een grond (in 20 gevallen), negatief uitvallen van de anticipatietoets (16 gevallen), ontbreken van de vereiste graad van verdenking (15 gevallen), de conclusie dat andere preventieve maatregelen toereikend zijn (15 gevallen) en het feit dat vrijheidsbeneming gevaar zou opleveren voor de gezondheid van verdachte of hemzelf of zijn naasten onevenredig zou belasten ( 3 gevallen).

206 Izydorczyk 2002, p. 146-152. 
lopige hechtenis werd ingesteld binnen de 4 districtsrechtbanken tussen de 7 en $32 \%$. In het overgrote deel (variërend van 89 tot $100 \%$ van de gevallen) had het rechtsmidel geen effect en werd het bevel voorlopige hechtenis in stand gehouden. ${ }^{207}$ Het aantal gevallen waarin tegen de beslissing tot verlenging bezwaar werd aangetekend varieerde van 14 tot $30 \%$. De resultaten van dit bezwaar wisselden sterk in de vier onderzochte arrondissementen: bij een districtsrechtbank werd in de 57 zaken waarin bezwaar werd aangetekend tegen verlenging deze beslissing in 48 gevallen in stand gehouden (84\%), in 4 gevallen omgezet in een andere maatregel $(7 \%)$ en in 5 gevallen opgeheven (8\%). In een ander arrondissement werd 4 keer bezwaar ingesteld waarvan de helft werd ingewilligd (eenmaal opheffing en eenmaal omzetting). In de andere twee arrondissementen werd slechts eenmaal (zonder succes) bezwaar ingesteld tegen de respectievelijk 7 en 5 verlengingsbeslissingen. ${ }^{208}$ Hoewel het bezwaar tegen de toepassing en verlenging van de voorlopige hechtenis in de onderzochte zaken dus slechts in een beperkt aantal gevallen tot het gewenste resultaat heeft geleid, lijkt dit aantal groot genoeg om te kunnen concluderen dat aanwending van deze rechtsmiddelen wel degelijk zinvol kan zijn. Het onderzoek van Izydorczyk bevat geen gegevens over het aantal door de verdediging ingediende verzoeken tot opheffing of omzetting. Volgens Grzegorczyk wordt daar in de praktijk echter veel gebruik van gemaakt. ${ }^{209}$

Izydorczyk heeft ook onderzocht in welke mate advocaten deelnemen aan zittingen waarop over de toepassing en verlenging van voorlopige hechtenis wordt beslist. Zijn conclusie is dat het niet vaak voorkomt dat advocaten op dit soort zittingen verschijnen. Dat terwijl de advocatuur volgens hem doorgaans wel op de juiste wijze wordt geïnformeerd over de zitting en deelname te allen tijde door de rechtbank wordt toegestaan. Uit het onderzoek blijkt dat slechts een beperkt aantal zittingen waarop het verzoek tot toepassing van voorlopige hechtenis werd behandeld in aanwezigheid van een raadsman plaatsvond. Bij de vier verschillende arrondissementen waren de cijfers als volgt: deelname van de raadsman in 79 van 649 zittingen (12\%), 9 van de 135 (6\%), 15 van de $80(17 \%)$ en 0 van de 14 $(0 \%)$. Izydorczyk wijst er in dit verband op dat de termijn voor het nemen van de beslissing tot toepassing van voorlopige hechtenis kort is en dat zeer veel verdachten in dit stadium van de procedure (nog) geen bijstand van een advocaat hebben. Dat het bevel voorlopige hechtenis in het overgrote deel van de gevallen in afwezigheid van een raadsman wordt genomen, is dus met name een gevolg van het feit dat op dat moment meestal nog geen advocaat bij de zaak betrokken is. Advocaten nemen vaker deel aan zittingen waarop over de verlenging van de voorlopige hechtenis wordt beslist. Deelname van de raadsman vondt plaats in respectievelijk 58 van de 190 zittingen (30\%), 6 van de $19(31 \%), 0$ van de $7(0 \%)$ en 1 van de $5(20 \%) .{ }^{210}$ Hierbij dient echter te worden opgemerkt dat Izydorczyk in zijn resultaten alleen heeft gelet op de feitelijke deelname van advocaten aan zittingen in de onderzochte zaken: daarbij is niet betrokken in hoeveel van de zaken een raadsman was benoemd. Hierdoor kunnen aan de resultaten van het onderzoek moeilijk conclusies worden verbonden over de activiteit van advocaten in dit soort

207 Izydorczyk 2002, p. 141-142.

208 Izydorczyk 2002, p. 143-146.

209 Grzegorczyk 1988, p. 221.

210 Izydorczyk 2002, p. 158-161. 
procedures omdat niet duidelijk is of in de gevallen waarin geen raadsman op de zitting aanwezig was überhaupt een advocaat in de zaak was benoemd.

\subsection{Rechten van de verdediging inzake voorlopige hechtenis en het EVRM}

Gelet op het feit dat voorlopige hechtenis nog altijd een zeer prominente plaats inneemt in de Poolse strafrechtspleging is het van belang aandacht te besteden aan de garanties die de verdediging op dit punt aan het EVRM kan ontlenen. Met name de vraag of - en zo ja onder welke omstandigheden - beslissingen over (verlenging) van voorlopige hechtenis in afwezigheid van de verdachte mogen worden genomen, verdient gelet op de Poolse situatie bijzondere aandacht. Eerst zal echter een aantal algemene Straatsburgse uitgangspunten met betrekking tot voorlopige hechtenis en de rechten van de verdediging de revue passeren.

Art. 5 EVRM - dat betrekking heeft op het recht op vrijheid en veiligheid - bevat belangrijke normen voor de verdachte die van zijn vrijheid is beroofd. ${ }^{211}$ Een van de eisen die uit genoemde verdragsbepaling voortvloeit, is dat eenieder die is gearresteerd of gedetineerd, onmiddellijk na zijn aanhouding dient te worden voorgeleid voor een 'judicial officer' in de zin van art. 5 lid 3 EVRM. Zoals verschillende keren door het EHRM is bevestigd, kan de Poolse prokurator niet als zodanig worden aangemerkt. De situatie op grond van het oude strafprocesrecht waarin de prokurator de verdachte hoorde voordat hij zelfstandig een beslissing nam over de toepassing van de voorlopige hechtenis was dan ook niet in overeenstemming met het EVRM. ${ }^{212}$ In het nieuwe strafprocesrecht is deze onverenigbaarheid opgeheven door de beslissing over de toepassing van voorlopige hechtenis over te dragen aan de rechtbank.

Een andere voorwaarde die het EHRM stelt, is dat de verdachte de gelegenheid moet hebben de rechtmatigheid van zijn vrijheidsberoving te laten toetsen. Dergelijke procedures - die onder de reikwijdte van art. 5 lid 4 EVRM vallen - hoeven niet te allen tijde dezelfde garanties te bieden als op grond van art. 6 EVRM geldt voor strafrechtelijke en civiele procedures maar zij dienen wel aan bepaalde voorwaarden te voldoen: zo moeten ze in ieder geval een tegensprekelijk karakter hebben en onder alle omstandigheden gelijkheid tussen de procespartijen (equality of arms) garanderen..$^{213}$

211 Zie eerder § 3.5.

212 Voor het eerst uitgemaakt in Niedbała t. Polen, EHRM 4-7-2000, nr. 27915/95 en later herhaald in onder andere Dacewicz t. Polen, EHRM 2-7-2002, nr. 34611/97, Eryk Kawka t. Polen, EHRM 27-6-2002, nr. 33885/96 en M.B. t. Polen, EHRM 27-4-2004, nr. 34091/96. Zie ook hoofdstuk 2, § 2.3.2. Tegen sommige andere Oost-Europese landen - waar de prokurator gedurende het communisme een gelijksoortige functie vervulde - bestaat vergelijkbare Straatsburgse rechtspraak. Zie bijvoorbeeld Nikolova $t$. Bulgarije, ECRM 20-5-1998, nr. 31195/96.

213 Zie onder meer: Brogan e.a.t. Verenigd Koninkrijk, EHRM 29-11-1988, A145-B, Kampanis t. Griekenland, EHRM 13-6-1995, A324, nr. 17977/91, Assenov e.a. t. Bulgarije, EHRM 2810-1998, Reports 1998-VIII, nr. 24760/94, Nikolova t. Bulgarije, EHRM 25-3-1999, nr. 31195/96, Depa t. Polen, EHRM 12-12-2006, nr. 62324/00 en Lanz t. Oostenrijk, EHRM 31-1-2001, nr. 24430/94. 
In geval van voorlopige hechtenis dient de rechtmatigheid van de vrijheidsberoving met redelijke tussenpozen te worden getoetst. ${ }^{214}$ Daarbij geldt dat - afhankelijk van de duur van de voorlopige hechtenis - een eenmalige rechterlijke toetsing in de zin van art. 5 lid 4 EVRM onvoldoende kan zijn. ${ }^{215}$ Lidstaten zijn niet verplicht een rechtsmiddel tegen beslissingen over voorlopige hechtenis open te stellen ${ }^{216}$ maar indien dit wel gebeurt, dient de behandeling ervan ook aan de eisen van art. 5 lid 4 EVRM te voldoen. ${ }^{217}$ Wanneer de verdediging een rechtsmiddel wordt geboden, dient de procedure die daarop betrekking heeft in beginsel dus dezelfde waarborgen te bieden als de procedure in eerste aanleg (tegensprekelijk karakter en equality of arms).

Dat het EHRM eist dat in procedures waarin de rechtmatigheid van de voorlopige hechtenis wordt getoetst, sprake moet zijn van gelijkheid tussen vervolging en verdediging heeft niet alleen consequenties voor de informatiepositie van de verdachte en zijn raadsman ${ }^{218}$ maar betreft ook de mogelijkheid deel te nemen aan de zittingen waarop de voorlopige hechtenis wordt beoordeeld. Zoals in het voorgaande aan de orde is geweest, had de verdediging in Polen onder het oude strafprocesrecht geen recht deel te nemen aan zittingen waarop de rechtmatigheid van de voorlopige hechtenis werd getoetst. Deze praktijk - gebaseerd op art. 88 KPK 1969 waarin alleen aan de prokurator een aanwezigheidsrecht werd toegekend - is door het EHRM verschillende keren in strijd met art. 5 lid 4 EVRM geoordeeld. ${ }^{219}$ Standaardoverweging uit deze rechtspraak is dat

'the impossibility for a detainee to attend the session of a court dealing with his detention, to respond to the prosecutor's submissions and to challenge - either himself or through his

214 '(...) the nature of detention on remand calls for short intervals; there is an assumption in the Convention that detention on remand is to be of strictly limited duration (...), because its raison d'etre is essentially related to the requirements of an investigation which is to be conducted with expedition': Bezicheri t. Italië, EHRM 25-10-1989, nr. 11400/85, § 21. Op de vraag welke tussenpozen nog als redelijk kunnen worden beschouwd, wordt door het Hof geen algemeen antwoord gegeven: de jurisprudentie is sterk casuïstisch op dit punt. Zie bijvoorbeeld Herczegfalvy t. Oostenrijk, EHRM 24-9-1992, nr. 10533/83, § 75-77 en Silva Rocha t. Portugal, EHRM 25-11-1996, nr. 18165/91, § 31. Zie ook Van der Velde 2004 II, p. 80.

215 Assenov e.a. t. Bulgarije, EHRM 28-10-1998, Reports 1998-VIII, nr. 24760/94. In geval van Assenov was het feit dat hij gedurende de twee jaar van zijn voorlopige hechtenis slechts eenmaal de rechtmatigheid had kunnen laten toetsen door een rechter, bij welke gelegenheid geen mondelinge behandeling had plaatsgevonden, in strijd met art. 5 lid 4 EVRM.

216 Het is vaste rechtspraak dat art. 5 lid 4 EVRM geen afdwingbaar recht omvat de beslissing tot toepassing of verlenging van voorlopige hechtenis door een tweede instantie te laten beoordelen: de interventie van één enkel orgaan is voldoende mits de gevolgde procedure aan de eisen van art. 5 lid 4 EVRM voldoet.

217 '(...) a second level of jurisdiction for the examination of applications for release from detention must in principle accord to the detainee the same guarantees on appeal as at first instance': Toth $t$. Oostenrijk, EHRM 12-12-1991, nr. 11894/85, § 84.

218 Zie over de Straatsburgse rechtspraak op dat punt: $\S 3.5$.

219 Zie bijvoorbeeld: Niedbała t. Polen, EHRM 4-7-2000, nr. 27915/95, Trzaska t. Polen, EHRM 117-2000, nr. 25792/94, Wtoch t. Polen, EHRM 19-10-2000, nr. 2778/95, Klamecki t. Polen (no. 2), EHRM 3-4-2003, nr. 31583/96, G.K. t. Polen, EHRM 20-1-2004, nr. 38816/97, M.B. t. Polen, EHRM 27-4-2004, nr. 34091/96 en Wedler t. Polen, EHRM 16-1-2007, nr. 4415/98. Hierbij dient te worden opgemerkt dat al deze uitspraken plaatsvonden na inwerkingtreding van het nieuwe wetboek van strafvordering. 
lawyer - grounds for his continued detention, an impossibility which was inherent in Polish legislation applicable at the material time, was incompatible with the requirements of art. $5 \S 4 E C H R^{\prime} .220$

De verdediging dient dus in de gelegenheid te zijn zittingen waarop de rechtmatigheid van de voorlopige hechtenis wordt getoetst, bij te wonen. Betekent dit ook dat de verdachte te allen tijde persoonlijk moet worden gehoord? Of is deelname van een raadsman voldoende om aan de eisen van art. 5 lid 4 EVRM te voldoen? De rechtspraak van het EHRM is niet eenduidig op dit punt. In Graužinis $t$. Litouwen $^{221}$ heeft het Hof de vraag of deelname van de raadsman voldoende was onder de in die zaak geldende omstandigheden negatief beantwoord. Daarbij werd om te beginnen benadrukt dat de eis van equality of arms in procedures die onder art. 5 lid 4 EVRM vallen in beginsel betrekking heeft op de verhouding tussen de openbaar aanklager en de voorlopig gehechte verdachte. ${ }^{222}$ In deze zaak had klager bezwaar aangetekend tegen het bevel voorlopige hechtenis en bij de behandeling daarvan had hij - in tegenstelling tot zijn raadsman - zelf niet aanwezig mogen zijn. Enkele weken later werd (wederom in zijn afwezigheid) de verlenging van de voorlopige hechtenis uitgesproken. Bij die laatste gelegenheid werd de grond voor de vrijheidsberoving gewijzigd. ${ }^{223}$ Volgens het EHRM had Graužinis aanwezig moeten zijn bij zowel de behandeling van het bezwaar als de behandeling van de verlenging:

'(...) given what was at stake for the applicant, i.e. his liberty, as well as the lapse of time between the various decisions, and the re-assessment of the basis for the remand, the applicant's presence was required throughout the pretrial remand hearings (...) in order to be able to give satisfactory information and instructions to his counsel.'224

Dat de raadsman wel aan de betreffende zittingen had kunnen deelnemen, deed aan de geconstateerde schending van art. 5 lid 4 EVRM niets af: Graužinis had immers in de gelegenheid moeten worden gesteld zijn raadsman van de nodige informatie en instructies te voorzien.

Ook in een zaak tegen Polen heeft het Hof het feit dat verdachte niet persoonlijk was gehoord een rol laten spelen bij de constatering dat art. 5 EVRM was geschonden. In M.B. t. Polen ${ }^{225}$ werd aan de algemene overweging dat de verdediging op grond van het destijds geldende strafprocesrecht geen recht had deel te nemen aan zittingen waarop de rechtmatigheid van de voorlopige hechtenis werd getoetst, door het EHRM nog toegevoegd dat persoonlijk horen van de verdachte in de gegeven omstandigheden wel wenselijk was geweest:

'(...) the applicant's worsening state of health, which finally lead to his death, was a factor which should have militated in favour of his appearing in person. There is a strong proba-

220 Als zodanig verwoord in (onder meer): Klamecki t. Polen (no. 2), EHRM 3-4-2003, nr. $31583 / 96, \S 129$.

221 EHRM 10-10-2000, nr. 37975/97.

222 En dus niet - of in ieder geval niet alleen - op de raadsman en de openbaar aanklager: 'The proceedings must be adversarial and must always ensure equality of arms between the parties - the prosecutor and the detainee [decurs. DdV]' ( § 31).

223 Van recidicegevaar in vlucht- en collusiegevaar.

$224 \S 34$.

225 EHRM 27-4-2004, nr. 34091/96. Let wel: het betrof hier het oude strafprocesrecht. 
bility that the applicant's presence could have convinced the authorities that he should be released. In the light of the foregoing the Court concludes that the applicant did not receive the benefit of procedure that was really adversarial.'226

Hoewel vooral de uitspraak in Graužinis de conclusie lijkt te rechtvaardigen dat de verdachte in beginsel persoonlijk aanwezig moet kunnen zijn op zittingen waarop de rechtmatigheid van zijn voorlopige hechtenis wordt getoetst, is het EHRM in latere rechtspraak wat voorzichtiger op dit punt. In een aantal uitspraken tegen Polen is in ieder geval duidelijk gemaakt dat het feit dat de verdachte niet aanwezig is bij de behandeling van een verzoek tot verlenging - wat op grond van het huidige strafprocesrecht eerder regel dan uitzondering is - in beginsel geen strijd oplevert met art. 5 lid 4 EVRM. Zo is onder meer benadrukt in Celejewski t. Polen. ${ }^{227}$ De klacht van Celejewski dat hij in strijd met art. 5 lid 4 EVRM niet in de gelegenheid was gesteld de zittingen waarop over de verlenging van voorlopige hechtenis werd beslist, bij te wonen, werd door het EHRM kennelijk ongegrond verklaard. Als reden hiervoor werd genoemd dat de rechtbank Celejewski - zoals voorgeschreven door het huidige strafprocesrecht - wel persoonlijk had gehoord voordat het bevel voorlopige hechtenis werd gegeven. Bovendien was de raadsman op grond van art. 249 lid 5 KPK 1997 wel opgeroepen om de betreffende zittingen bij te wonen. ${ }^{228}$ Het EHRM was gelet hierop van oordeel dat de verlengingsprocedure zoals die momenteel in het Poolse strafprocesrecht is vormgegeven, voldoet aan de eisen van art. 5 lid 4 EVRM.

Ook in Depa t. Polen $^{229}$ werd erover geklaagd dat een aantal zittingen waarop over de voorlopige hechtenis werd geoordeeld in afwezigheid van verdachte was afgedaan. ${ }^{230}$ Het EHRM benadrukt in die uitspraak dat persoonlijk horen van de verdachte onder bepaalde omstandigheden noodzakelijk is maar dat van dergelijke omstandigheden in deze zaak geen sprake was:

'(...) the Court reiterates that in cases where characteristics pertaining to the applicant's personality and level of maturity and reliability are of importance in deciding on his dangerousness, Article $5 \S 4$ requires an oral hearing in the context of an adversarial procedure involving legal representation (...). The Court considers, however that in the present case the questions of assessment of the applicant's character or mental state did not arise. His personal attendance at all of the sessions at which his detention on remand was prolonged was therefore not required, and the presence of his lawyers ensured respect for equality of arms in those proceedings.' 231

$226 \S 66$.

227 EHRM 4-5-2006, nr. 17584/04.

228 Hij had echter niet alle keren van deze gelegenheid gebruik gemaakt.

229 HRM 12-12-2006, nr. 62324/00.

230 Klager was bij het gros van de zittingen waarop over de verlenging van voorlopige hechtenis werd beslist samen met zijn raadsman aanwezig geweest en '(...) was therefore able to personally support his applications for release' (\$ 48). Voor de overige zittingen gold dat zijn advocaten op de juiste wijze waren opgeroepen en in de meeste gevallen ook aanwezig waren geweest. $\mathrm{Zij}$ hadden ook deelgenomen aan de vele zittingen waarop over verzoeken tot opheffing en bezwaar tegen verlenging was beslist.

$231 \S 48$. Zie in dezelfde zin: Telecki t.Polen, EHRM 3-7-2003, nr. 56552/00 (ontvankelijkheidsbeslissing) en Duda t. Polen, EHRM 19-12-2006, nr. 67016/01. 
Op grond hiervan oordeelt het EHRM dat de gevolgde procedures in overeenstemming waren met art. 5 lid 4 EVRM en verklaart de klacht kennelijk ongegrond.

Uit bovengenoemde rechtspraak kan worden afgeleid dat een verdachte geen absoluut recht heeft telkens wanneer de rechtbank over (de voortzetting van) zijn voorlopige hechtenis oordeelt persoonlijk te worden gehoord. Of persoonlijk horen noodzakelijk is, hangt sterk af van de omstandigheden van het geval. In de uitspraken van het Europese Hof spelen in ieder geval de volgende factoren een rol:

a. het feit dat er voor verdachte veel op het spel staat. ${ }^{232}$

b. of de advocaat van verdachte in staat is gesteld de zitting bij te wonen.

c. het tijdsverloop tussen de verschillende beslissingen over de voorlopige hechtenis.

d. een wijziging van de gronden voor de voorlopige hechtenis.

e. een verslechterde gezondheidstoestand van verdachte.

f. het feit dat het karakter en de geestelijke gesteldheid van een verdachte moet worden beoordeeld om zijn gevaarlijkheid in te schatten.

\subsection{Conclusie}

De positie van de verdediging in voorlopige hechtenis procedures is op grond van het huidige strafprocesrecht aanzienlijk sterker dan op basis van het oude wetboek van strafvordering. De belangrijkste verbeteringen kunnen als volgt worden samengevat:

1. De beslissing tot toepassing van voorlopige hechtenis wordt voortaan door de rechtbank genomen op een zitting waaraan de verdachte moet en de raadsman mag deelnemen: voorheen werd hierover beslist door de prokurator waarbij de mogelijkheden van de verdediging om invloed uit te oefenen op deze besluitvorming uiterst beperkt waren.

2. De raadsman heeft een onvoorwaardelijk recht om deel te nemen aan zittingen waarop over de verlenging van de voorlopige hechtenis en over het bezwaar tegen toepassing of verlenging wordt beslist: op grond van het oude strafprocesrecht (art. 88 KPK 1969) bestond een dergelijk recht alleen voor de prokurator en vonden deze zittingen in afwezigheid van de verdediging plaats.

3. Tegen de beslissing van de prokurator tot afwijzing van een verzoek om opheffing of omzetting van de voorlopige hechtenis kan (sinds juli 2003) bezwaar worden ingesteld bij de rechtbank: voorheen kon daarover slechts worden geklaagd bij een hogere prokurator zodat deze beslissingen gedurende het vooronderzoek niet aan de rechter konden worden voorgelegd.

Als gevolg van deze wijzigingen is de wettelijke regeling meer in overeenstemming met het EVRM gebracht. Zoals in de vorige paragraaf aan de orde is geweest, heeft het EHRM er - voor wat betreft het eerste en het tweede punt - geen

232 In Graužinis t. Litouwen (EHRM 10-10-2000, nr. 37975/97) oordeelde het Hof immers dat persoonlijke verschijning wenselijk was '(...) given what was at stake for the applicant, i.e. his liberty (...)'. Omdat (voortzetting van) vrijheidsberoving in alle zaken waarin over voorlopige hechtenis wordt beslist, tot de mogelijkheden behoort, lijkt deze factor op zichzelf weinig toegevoegde waarde te hebben. In Graužinis werden daarnaast ook nog de hierna te noemen factor van het tijdsverloop en de wijziging van de gronden van de voorlopige hechtenis meegewogen. 
twijfel over laten bestaan dat de oude situatie onverenigbaar was met de Straatsburgse norm. Uit rechtspraak tegen Polen blijkt dat het feit dat de verdediging op grond van het oude art. 88 KPK 1969 niet de mogelijkheid had deel te nemen aan zittingen waarop over voortzetting van de voorlopige hechtenis werd beslist, strijd opleverde met art. 5 lid 4 EVRM.

Door sommige Poolse auteurs wordt wel het standpunt verdedigd dat de regeling van de voorlopige hechtenis door eerdergenoemde wijzigingen volledig 'Straatsburg-proof' is geworden. ${ }^{233}$ Het is echter de vraag of dit optimisme volledig terecht is. De grote hoeveelheid Straatsburgse uitspraken tegen Polen waarin de toepassing van voorlopige hechtenis in strijd met het verdrag wordt geoordeeld, doet in ieder geval anders vermoeden. ${ }^{234}$ Hierbij is van belang dat de huidige regeling nog een aantal probleempunten bevat. Om te beginnen het feit dat de raadsman in beginsel niet hoeft te worden geïnformeerd over de datum en het tijdstip waarop de zitting waarop voor het eerst over toepassing van voorlopige hechtenis wordt beslist, zal plaatsvinden. ${ }^{235}$ Hierdoor bestaat op dit punt ongelijkheid tussen de raadsman en de prokurator die wel in alle gevallen van de zitting op de hoogte moet worden gesteld. Hoewel duidelijk is dat de zitting binnen de door de wet gestelde termijnen zal moeten kunnen plaatsvinden en het verschijnen van de raadsman in de regel dus niet zal kunnen worden afgewacht, is mijns inziens niet vanzelfsprekend dat om die reden ook van het informeren van de raadsman moet worden afgezien. Het kan voor de autoriteiten niet bezwaarlijk zijn om zodra een tijdstip voor de zitting is bepaald de raadsman hiervan telefonisch op de hoogte te stellen. ${ }^{236}$ Dit hoeft er immers niet aan in de weg te staan dat de zitting tijdig kan plaatsvinden. Ook wanneer dit kort voor de zitting gebeurt - wat met het oog op de 24 uurs termijn waar de rechter aan is gebonden eerder regel dan uitzondering zal zijn - kan de raadsman alsnog zelf bepalen of het hem lukt daarbij aanwezig te zijn.

Een tweede probleem betreft de deelname van verdachte aan zittingen waarop over de voorlopige hechtenis wordt geoordeeld. De verdachte heeft op grond van het huidige strafprocesrecht geen afdwingbaar recht om gehoord te worden over een verzoek tot verlenging of een door de verdediging ingesteld bezwaar. ${ }^{237}$ Afgezien van de zitting waarop een beslissing wordt genomen over de toepassing van voorlopige hechtenis, kunnen alle andere zittingen in zijn afwezigheid worden afgedaan. Dit geldt ook wanneer de betreffende verdachte niet wordt bijgestaan

233 Wąsek-Wiaderek 2003 II.

$234 \mathrm{Al}$ dient hierbij wel te worden opgemerkt dat in deze rechtspraak vooral kritiek wordt uitgeoefend op de praktijk en niet - of in ieder geval in mindere mate - op de wetgeving. Dit neemt echter niet weg dat wanneer schending van een verdragsartikel op een bepaald terrein zo structureel voorkomt (zoals de ontoereikende motivering van verlengingsbeslissingen), dit aanleiding kan vormen om de daaraan ten grondslag liggende wetgeving eens kritisch te bekijken.

235 Dit is slechts anders wanneer de verdachte erom verzoekt en een en ander er niet aan in de weg staat dat de zitting binnen de gestelde termijn kan plaatsvinden.

236 De wetgever heeft niet gespecificeerd hoe de raadsman op de hoogte moet worden gesteld: autoriteiten mogen zelf bepalen op welke wijze dit gebeurt. Zie Hofmański e.a. 2007 I, p. 1123 en daar genoemde rechtspraak.

237 Tegen toepassing, verlenging of afwijzing van een verzoek om opheffing of omzetting. 
door een raadsman. ${ }^{238}$ In de praktijk komt het dan ook regelmatig voor dat verdachten nadat het bevel voorlopige hechtenis eenmaal is afgegeven niet meer persoonlijk door de rechtbank worden gehoord totdat de zaak inhoudelijk wordt behandeld. Wanneer een lange periode verstrijkt tussen het moment van aanvang van de voorlopige hechtenis en de eerste zittingsdag - wat in de Poolse strafrechtspleging niet ongebruikelijk is - kan dit in conflict komen met art. 5 lid 4 EVRM. Uit de Straatsburgse rechtspraak blijkt dat het EHRM er waarde aan hecht dat preventief gehechte verdachten periodiek worden gehoord. Daarbij geldt dat deelname van de raadsman persoonlijke aanwezigheid van verdachte niet in alle gevallen voldoende zal kunnen compenseren. ${ }^{239}$ Het deelnamerecht van verdachte is op grond van het EVRM echter niet absoluut. Uit recente uitspraken tegen Polen blijkt dat het feit dat verlengingsbeslissingen in afwezigheid van de verdachte worden genomen op zich zelf geen strijd met art. 5 lid 4 EVRM oplevert: de wettelijke regeling lijkt op dit punt de Straatsburgse toets der kritiek te kunnen doorstaan. Hierbij dient echter wel te worden benadrukt dat de verdachten in genoemde zaken tegen Polen werden bijgestaan door een raadsman die bij de meeste zittingen wel aanwezig had mogen zijn. Het is de vraag of het oordeel van het EHRM gelijkluidend zal zijn wanneer het gaat om verdachten die geen rechtsbijstand hebben. Veel zal daarbij afhangen van de omstandigheden van het geval (met name de duur van de voorlopige hechtenis, de tussenpozen tussen de verschillende beslissingen en de persoonlijke situatie van verdachte) maar dat neemt niet weg dat het huidige strafprocesrecht de voorlopig gehechte verdachte op dit punt te weinig garanties biedt. Wąsek-Wiaderek - die ook de noodzaak van wetswijziging benadrukt - heeft geopperd dat de wetgeving zodanig zou kunnen worden gewijzigd dat wanneer de zitting waarop over de voorlopige hechtenis wordt beslist noch door verdachte noch door zijn raadsman kan worden bijgewoond, deelname van de prokurator ook niet zou moeten worden toegestaan. De rechtbank zou in zo'n geval haar beslissing moeten nemen op een besloten zitting waarbij beide procespartijen hun standpunt voorafgaand schriftelijk kenbaar kunnen maken. ${ }^{240}$ Hoewel met dit voorstel de gelijkheid tussen prokurator en verdediging onmiskenbaar zou worden vergroot, lost het mijns inziens niet alle problemen op. Het laat immers nog steeds de mogelijkheid open dat de verdachte niet persoonlijk wordt gehoord door de rechtbank op een moment in de procedure dat dat - mede gelet op de Straatsburgse rechtspraak - wel noodzakelijk is. Voor de verdachte die niet over rechtsbijstand beschikt, zou de rechtbank een verzoek van de verdachte om naar de zitting te worden gebracht eenvoudig kunnen afwijzen door ook de prokurator niet aan de zitting te laten deelnemen. Dit betekent slechts dat de verdediging op gelijke voet staat met de prokurator voor wat betreft de onmogelijkheid om ter zitting het woord te voeren: een negatieve vorm van equality of arms. Het zou vanuit het oogpunt van effectieve verdediging beter zijn wanneer een verzoek tot deelname slechts zou kunnen worden geweigerd indien de rechtbank

238 Deelname van een verdachte die niet over rechtsbijstand beschikt, kan onder dezelfde omstandigheden worden geweigerd als deelname van een verdachte die wel door een advocaat wordt bijgestaan. Bovendien is weigering van een dergelijk verzoek geen zelfstandige grond voor toevoeging van een advocaat.

239 Of persoonlijke verschijning noodzakelijk is, hangt af van verschillende factoren - zie § 4.6.

240 Wąsek-Wiaderek 2003 II, p. 274-277 
deelname van de raadsman toereikend acht en dat in zo'n geval een advocaat wordt toegevoegd wanneer de verdachte niet over rechtsbijstand beschikt. Bij de beoordeling van de vraag of aanwezigheid van de raadsman persoonlijke deelname van de verdachte volledig zal kunnen compenseren zou de rechtbank rekening moeten te houden met de factoren die uit de rechtspraak van het EHRM kunnen worden afgeleid.

Ten slotte dient op deze plaats te worden herinnerd aan de problemen die de verdediging gedurende het vooronderzoek kan ondervinden bij het inzien van de processtukken. Iedere wettelijke uitbreiding van de mogelijkheden in het kader van de voorlopige hechtenis is immers illusoir wanneer de verdediging niet over de daarvoor benodigde informatie kan beschikken. Wanneer de raadsman geen - of slechts beperkte - inzage heeft in de processtukken is het voeren van een effectieve verdediging moeilijk en zal hij doorgaans genoodzaakt zijn zich te beperken tot het aanvoeren van persoonlijke omstandigheden van zijn cliënt die zich tegen detentie verzetten. Zoals in $\S 3$ is besproken, sluit het huidige strafprocesrecht niet uit dat een voorlopig gehechte verdachte gedurende het gehele vooronderzoek geen inzage heeft in zijn dossier wat onder omstandigheden een schending van art. 5 lid 4 EVRM kan opleveren.

\section{Mogelijkheden ten aanzien van bewijsvergaring}

\subsection{Inleiding}

Bewijsmateriaal dat in het vooronderzoek is verzameld heeft volledige bewijswaarde en kan - mits op het onderzoek ter terechtzitting gepresenteerd - de basis vormen voor de bewezenverklaring. Formeel uitgangspunt is dat bewijsmateriaal ten overstaan van de rechter tot stand moet komen (onmiddellijkheidsbeginsel) maar het wetboek van strafvordering voorziet in belangrijke uitzonderingen op deze regel waardoor het in veel gevallen mogelijk is verklaringen van verdachten of getuigen afgelegd in het vooronderzoek voor het bewijs te bezigen zonder dat ze (opnieuw) door de rechter worden gehoord. ${ }^{241}$

Dit alles brengt met zich dat de fase van het vooronderzoek van groot belang is voor de bewijsvergaring en dat het de moeite waard is te bekijken welke mogelijkheden de verdediging heeft om invloed uit te oefenen op de verzameling en totstandkoming van bewijs. De rechten en bevoegdheden die de verdediging op dit punt toekomen, kunnen grofweg in drie categorieën worden verdeeld:

1. het recht deel te nemen aan onderzoekshandelingen die op initiatief van de politie of prokuratura plaatsvinden;

2. de mogelijkheden van de verdediging om bepaalde onderzoekshandelingen te laten verrichten door de autoriteiten en

3. de mogelijkheden van de verdediging om zelfstandig bewijsmateriaal te verzamelen (eigen verdedigingsonderzoek).

\subsection{Juridisch kader}

Bewijsvoering kan zowel op initiatief van partijen als ambtshalve plaatsvinden. ${ }^{242}$ In de fase van het vooronderzoek worden onderzoekshandelingen doorgaans

241 Zie hoofdstuk 6, § 4.4.1.

242 Art. 167 KPK 1997: 'Bewijsvoering vindt plaats op verzoek van partijen (...) of ambtshalve.' 
ambtshalve - dat wil zeggen op initiatief van de politie of de prokuratura - verricht. ${ }^{243}$ Autoriteiten zijn daarbij verplicht zich niet alleen te concentreren op bewijsmateriaal dat de verdenking bevestigd maar ook aandacht te besteden aan (eventuele) ontlastende feiten en omstandigheden. Deze regel wordt ook wel het beginsel van objectiviteit (zasada objektywizmu) genoemd. ${ }^{244}$

Het Poolse strafproces voorziet in een groot scala aan onderzoekshandelingen die kunnen worden verricht om bewijsmateriaal te verzamelen. Het voert te ver hier alle mogelijke onderzoeksactiviteiten in extenso te bespreken: slechts de belangrijkste zullen hier worden genoemd.

Zeer belangrijk zijn uiteraard het verhoor van de verdachte, het horen van getuigen en het inschakelen van deskundigen. De bevoegdheid van de raadsman om deel te nemen aan de verhoren van zijn cliënt is reeds aan de orde geweest in $\S 2$. Een bijzondere vorm van verhoren is de confrontatie (konfrontacja) waarbij twee personen wier verklaringen tegenstrijdig zijn tegelijkertijd over dezelfde feitelijke omstandigheden worden gehoord. ${ }^{245}$ Een dergelijk verhoor - dat zowel betrekking kan hebben op verdachten als op getuigen - is er op gericht tegenstrijdigheden in eerder afgelegde verklaringen op te helderen. De term confrontatie (konfrontacja) wordt in het Poolse strafproces dus niet gebruikt ter aanduiding van de opsporingsmethode waarbij een getuige - door middel van een foto, videobeelden of in persoon - ter identificatie met de verdachte wordt geconfronteerd. Dergelijke methoden worden in het Pools aangeduid als 'okazanie'. In het kort komt dit erop neer dat aan een persoon die wordt verhoord ter identificatie een andere persoon, diens foto of een object wordt getoond. ${ }^{246}$ Daarnaast is er nog de bezichtiging of de schouw (oględziny) die in de eerste plaats betrekking kan hebben op een bepaalde locatie zoals de plaats delict. Met dezelfde term wordt echter ook de inspectie van een object of een lichaam (van bijvoorbeeld het slachtoffer) aangeduid. ${ }^{247} \mathrm{De}$ laatste onderzoekshandelingen die hier vermelding verdienen, zijn de doorzoeking (przeszukanie), de inbeslagneming van goederen (zatrzymanie rzeczy) en het afluis-

243 Hofmański e.a. 2007 I, p. 742.

244 Dat autoriteiten ook aandacht dienen te besteden aan eventuele ontlastende feiten en omstandigheden is vastgelegd in art. 4 KPK 1997: deze bepaling heeft betrekking op alle fasen van de strafrechtelijke procedure en richt zich dus zowel tot de zittingsrechter als de organen die actief zijn in het vooronderzoek. Ook in de rechtspraak wordt benadrukt dat het beginsel van objectiviteit ook de prokurator (en de politie) betreft: Hofmański e.a. 2007 I, p. 43 en daar genoemde rechtspraak.

245 Art. 172 KPK 1997.

246 Art. 173 KPK 1997. De bepaling heeft betrekking op 'de persoon die wordt gehoord' wat betekent dat dit soort confrontaties niet alleen ten aanzien van getuigen kunnen plaatsvinden maar ook op verdachten en deskundigen kunnen worden toegepast. In de praktijk wordt de methode vooral gebruikt bij getuigen: Hofmański e.a. 2007 I, p. 780. Wat betreft de uitvoering van de confrontatie heeft de wetgever in ieder geval vastgelegd dat herkenning van een persoon slechts kan plaatsvinden wanneer deze temidden van tenminste vier anderen wordt geplaatst en dat confrontaties 'niet op suggestieve wijze' mogen plaatsvinden (art. 173 lid 1 tweede zin en lid 3 KPK 1997). Nadere regels voor de uitvoering van confrontaties kunnen worden gevonden in een verordening van de minister van Justitie en de jurisprudentie. Deze zullen hier verder buiten beschouwing blijven.

247 De bezichtiging is geregeld is art. 207 tot en met 212 KPK 1997. 
teren en opnemen van telecommunicatie. ${ }^{248}$ Op deze categorieën onderzoekshandelingen wordt - in het kader van het vrij verkeer - teruggekomen in hoofdstuk 7 , $\S 7$ en $\S 8$.

\subsubsection{Mogelijkheden verdediging bij ambtshalve onderzoek}

Zoals gezegd, vinden de meeste onderzoekshandelingen in het vooronderzoek plaats op initiatief van de autoriteiten. De leiding van het onderzoek ligt dan bij de politie of de prokuratura: zij bepalen wat er wordt onderzocht, op welke wijze en op welk moment dat gebeurt. Dit betekent echter niet dat de verdediging hierbij geen enkele rol van betekenis kan spelen.

\subsubsection{Hoofdregel: deelname op verzoek, tenzij...}

Hoofdregel is dat de verdachte en zijn raadsman op hun verzoek dienen te worden toegelaten tot onderzoekshandelingen die in het vooronderzoek worden verricht. ${ }^{249}$ Een dergelijk verzoek kan onder omstandigheden echter worden geweigerd: in 'uitzonderlijke gevallen' ('w szczególnie uzasadnionym wypadku')250 kan de prokurator met het oog op 'zwaarwegende onderzoeksbelangen' ('ważny interes śledztwa') bepalen dat de verdachte en zijn raadsman niet mogen deelnemen aan een onderzoekshandeling. ${ }^{251}$ Wat onder een 'bijzonder gerechtvaardigd geval' dient te worden verstaan, is nergens uitgewerkt. Van een zwaarwegend onderzoeksbelang kan bijvoorbeeld sprake zijn wanneer wordt verwacht dat een getuige in aanwezigheid van de verdediging niet in vrijheid zal kunnen verklaren. De verdediging kan tegen de afwijzing van haar verzoek tot deelname geen rechtsmiddel instellen.

Afgezien van bovengenoemde mogelijkheid deelname van de verdediging te weigeren op grond van het onderzoeksbelang geldt nog een extra beperking ten aanzien van de gedetineerde verdachte: de prokurator kan het verzoek van een van zijn vrijheid beroofde verdachte om aan een onderzoekshandeling deel te nemen, afwijzen wanneer het realiseren van zijn aanwezigheid 'bijzondere moeilijkheden' ('poważne trudności') met zich brengt. 252

Wanneer de verdediging gedurende het vooronderzoek een bepaalde handeling - bijvoorbeeld het verhoor van een getuige - wenst bij te wonen, dient daartoe dus een verzoek te worden ingediend bij het orgaan dat het vooronderzoek leidt. Een dergelijk verzoek moet voldoende concreet zijn en in ieder geval aangeven om welke handeling het gaat. Van belang is voorts dat andere organen dan de prokuratura die in het vooronderzoek actief zijn - met name de politie - het verzoek van de verdediging wel kunnen inwilligen maar dat een weigering slechts mag worden afgegeven door de prokurator. ${ }^{253}$

248 Art. 237 e.v. Over bovengenoemde onderzoekshandelingen onder meer: Bieńkowska e.a. 2004, p. 263-276.

249 Art. 317 lid 1 KPK 1997.

250 Letterlijk vertaald 'in een bijzonder gerechtvaardigd geval'.

251 Art. 317 lid 2 KPK 1997.

252 Art. 317 lid 2 KPK 1997: 'In uitzonderlijke gevallen kan de prokurator met het oog op zwaarwegende onderzoeksbelangen deelname aan handelingen weigeren of weigeren de aanwezigheid van een gedetineerde verdachte te realiseren wanneer dat bijzondere moeilijkheden met zich zou brengen.'

253 Wanneer de politie van oordeel is dat er gronden bestaan om deelname van de verdediging te weigeren, dient het verzoek met een motivering waarom het zou moeten worden 
De autoriteiten zijn slechts verplicht de verdediging op de hoogte te stellen van de datum, tijd en plaats van de geplande onderzoekshandeling wanneer de verdediging heeft verzocht aanwezig te mogen zijn en dit verzoek is ingewilligd.254 Deze regel lijdt uitzondering wanneer deelname van de verdediging in de gegeven omstandigheden in het belang van het onderzoek moet worden geacht: in dat geval is de prokurator verplicht de verdachte en zijn raadsman ambtshalve op de hoogte te stellen. Dit schijnt in de praktijk echter zelden te gebeuren. ${ }^{255}$

Op de in het voorgaande beschreven hoofdregel dat de verdediging kan verzoeken deel te nemen aan onderzoekshandelingen en dat een dergelijk verzoek in het belang van het onderzoek kan worden geweigerd, wordt in twee gevallen uitzondering gemaakt. De rechten van de verdediging zijn afzonderlijk geregeld waar het gaat om:

1. onderzoekshandelingen die niet ter terechtzitting kunnen worden herhaald en

2. het verkrijgen van deskundigenbewijs.

\subsubsection{Uitzondering I: handelingen die niet ter zitting kunnen worden herhaald}

Wanneer een handeling die gedurende het vooronderzoek wordt verricht niet op het onderzoek ter terechtzitting zal kunnen worden herhaald, hebben de verdachte en zijn raadsman het recht daaraan deel te nemen tenzij het gevaar bestaat dat uitstel van de onderzoekshandeling 'verlies of aantasting van het bewijsmateriaal' tot gevolg zal hebben. ${ }^{256}$ Ten aanzien van laatstgenoemde uitzondering geldt dat het gevaar wel reëel (en dus niet slechts hypothetisch) dient te zijn en dat het bestaan ervan aannemelijk moet worden gemaakt aan de verdediging. ${ }^{257}$

Verschillende soorten handelingen kunnen onder deze categorie vallen: het gaat daarbij zowel om handelingen die normaliter wel maar onder de gegeven omstandigheden hoogstwaarschijnlijk niet ter terechtzitting zullen kunnen worden herhaald (zoals het horen van een getuige die ernstig ziek is of op het punt staat het land te verlaten ${ }^{258}$ als om onderzoekshandelingen die naar hun aard bij voorkeur zo vroeg mogelijk in de procedure dienen te worden verricht (zoals doorzoekingen, schouwen en confrontaties). In afwijking van de eerder genoemde hoofdregel geldt dat de verdediging wel ambtshalve moet worden uitgenodigd deel te nemen aan handelingen die niet ter terechtzitting kunnen worden herhaald: deze informatieplicht is dus niet afhankelijk van een verzoek van de verdachte of zijn raadsman. ${ }^{259}$

afgewezen aan de prokurator te worden gezonden: Grzegorczyk 2004, p. 806-807.

254 Art. 117 lid 1 KPK 1997: het recht om genoemde informatie te ontvangen komt slechts toe aan degenen die het recht hebben om deel te nemen - laatstgenoemd recht ontstaat pas wanneer de politie of prokurator daarmee heeft ingestemd. Deze constructie roept echter de vraag op hoe de verdediging een verzoek kan indienen wanneer zij niet weet dat een bepaalde onderzoekshandeling plaats zal gaan vinden.

255 Bron: gesprek Hermeliński januari 2007, Warschau.

256 Art. 316 lid 1 KPK 1997.

257 Hofmański e.a. 2007 II, p. 110-111.

258 Een getuige die naar alle waarschijnlijkheid niet op het onderzoek ter terechtzitting zal kunnen verschijnen, kan in het vooronderzoek - onder meer op verzoek van de verdediging - door de rechtbank worden gehoord. Meer hierover in § 5.2.3.

259 Dit vloeit voort uit eerder genoemd art. 117 lid 1 KPK 1997: degene die het recht heeft om aan een proceshandeling deel te nemen, moet worden geïnformeerd over de tijd en plaats van deze handeling. 
Hoewel de letterlijke tekst van de wet meebrengt dat wanneer uitstel van de handeling gevaar oplevert voor het behoud of de kwaliteit van het bewijsmateriaal deelname van de verdediging kan worden geweigerd, ${ }^{260}$ kunnen dergelijke omstandigheden slechts tot gevolg hebben dat de autoriteiten niet verplicht zijn de verdediging over de handeling te informeren: wanneer de verdachte en/of zijn raadsman op andere wijze op de hoogte raken van de geplande onderzoekshandeling en verschijnen op het moment dat deze zal worden uitgevoerd, dienen zij alsnog te worden toegelaten. ${ }^{261}$ Deze uitleg lijkt het meest in overeenstemming met de bedoeling van de wetgever te zijn. Immers, de 'tenzij formule' heeft alleen betrekking op spoedeisende situaties waarin uitstel van het onderzoek nadelige gevolgen voor het bewijsmateriaal zou kunnen hebben. Begrijpelijk is dat het uitnodigen van de verdachte en zijn eventuele raadsman onder bepaalde omstandigheden tot dergelijke ongewenste vertraging zou kunnen leiden en dus achterwege zal moeten blijven. ${ }^{262}$ Wanneer de verdediging echter uit eigen beweging op tijd bij de geplande handeling verschijnt, hoeft geen sprake te zijn van uitstel en dient zij dus gewoon in staat te worden gesteld de onderzoekshandeling bij te wonen. Ook voor de van zijn vrijheid beroofde verdachte geldt dat hij niet naar de onderzoekshandeling hoeft te worden gebracht 'wanneer uitstel dreigt te leiden tot verlies of aantasting van het bewijsmateriaal' ${ }^{263}$ De wetgever lijkt hier - anders dan volgens de in 'normale' gevallen geldende hoofdregel op grond waarvan puur praktische bezwaren tegen het vervoer van de gedetineerde toereikend zijn - wel een link met het onderzoeksbelang te hebben willen leggen: aanwezigheid van een gedetineerde verdachte mag immers slechts worden geweigerd wanneer de vertraging die daarvan het gevolg zou zijn gevaar zou kunnen opleveren voor het bewijsmateriaal. De weigering lijkt in deze context dus aan zwaardere eisen te zijn verbonden wat gezien het karakter van de onderzoekshandeling ook logisch is: deze zal later in de procedure niet kunnen worden herhaald zodat de verdachte maar één kans heeft om eraan deel te nemen. Die kans moet dan ook in zoveel mogelijk gevallen kunnen worden benut.

\subsubsection{Uitzondering II: deskundigenbewijs}

Behalve ten aanzien van onderzoekshandelingen die niet ter terechtzitting kunnen worden herhaald, gelden ook aparte regels wanneer in het vooronderzoek een deskundige wordt geraadpleegd. Inschakeling van een deskundige is noodzakelijk wanneer voor de vaststelling van bepaalde feiten die van wezenlijk belang zijn voor het nemen van een beslissing in de strafzaak bijzondere wetenschap is

260 Art. 316 lid 1 KPK 1997 luidt immers (voor zover hier relevant): ‘Wanneer een onderzoekshandeling niet ter terechtzitting kan worden herhaald, dienen de verdachte (...) en zijn raadsman (...) te worden toegelaten tot deze handeling, tenzij het gevaar bestaat dat uitstel van de handeling zal leiden tot verlies of aantasting van het bewijsmateriaal.'

261 Grzegorczyk 2004, p. 804.

262 Trzcińska merkt in dit verband echter terecht op dat dit gelet op de huidige communicatietechnieken niet snel voor zal komen. In geval van spoed mag immers worden volstaan met een telefoontje (of een andere geschikte manier zoals het sturen van een fax, zie art. 137 KPK 1997) wat - gelet op de geringe hoeveelheid tijd en moeite die daarmee gepaard gaan - in de meeste gevallen mogelijk moet zijn: Trzcińska 2002, p. 262.

263 Art. 316 lid 2 KPK 1997. 
vereist. ${ }^{264}$ In een aantal gevallen heeft de wetgever deelname van een deskundige zelfs dwingend voorgeschreven, zoals wanneer duidelijkheid moet worden verkregen over de geestelijke gesteldheid van de verdachte. ${ }^{265}$ In het vooronderzoek wordt het verhoor van de deskundige in beginsel door de prokurator geleid. Het wetboek van strafvordering geeft een ruime definitie van het begrip 'deskundige': naast de vaste gerechtelijk deskundigen die op een lijst van de rechtbank zijn geplaatst kan eenieder van wie bekend is dat hij 'voldoende kennis op een bepaald terrein heeft' ad hoc als zodanig worden aangemerkt. ${ }^{266}$ Ten aanzien van een aantal categorieën personen heeft de wetgever expliciet bepaald dat ze niet als deskundige mogen optreden. ${ }^{267}$

Een deskundige kan afhankelijk van het verzoek van de autoriteiten schriftelijk of mondeling rapporteren. Voorafgaand aan die rapportage dient hij te beloven zijn taken onpartijdig en naar eer en geweten te zullen verrichten. ${ }^{268}$

In het kader van deskundigenbewijs heeft de verdediging het recht om:

1. op de hoogte te worden gesteld van het feit dat in de zaak een deskundige is benoemd,

2. deel te nemen aan een eventueel verhoor van de deskundige en

3. kennis te nemen van de schriftelijke rapportage van de deskundige. ${ }^{269}$

De verdediging wordt geïnformeerd over het feit dat een deskundige bij de zaak wordt betrokken door overhandiging van het besluit tot benoeming van de betreffende deskundige. Dit besluit dient onder meer melding te maken van het onderwerp en de reikwijdte van het deskundigenonderzoek, eventueel aangevuld met specifieke vragen die in de rapportage dienen te worden beantwoord. 270 Wanneer de verdediging hiervan kennis heeft genomen, kan ze een verzoek indienen tot uitbreiding van het onderzoek door bijvoorbeeld zelf vragen op te geven. Niet in

264 Art. 193 lid 1 KPK 1997.

265 Art. 202 lid 1 KPK 1997. Wanneer twijfel bestaat over de psychische gesteldheid van een verdachte dient de prokurator ten minste twee psychiaters te raadplegen. Na aanvang van het eindonderzoek geschiedt een dergelijke benoeming door de rechtbank. Zoals in hoofdstuk 4, § 3.1.1 is aangegeven, kan zo'n rapportage van groot belang zijn voor de verdediging. Immers, wanneer gedragsdeskundigen vaststellen dat aan de geestelijke gezondheid van de verdachte niet hoeft te worden getwijfeld, kan een - in het kader van de verplichte rechtsbijstand - eerder verleende toevoeging alsnog worden ingetrokken.

266 Art. 195 KPK 1997. Deskundigenrapportages kunnen worden verricht door individuen maar ook door wetenschappelijke of gespecialiseerde instituten (art. 206 KPK 1997). Behalve deskundigen (biegły) kent het Poolse strafprocesrecht ook specialisten (specjaliści). Zie over laatstgenoemde categorie - die in het vorige wetboek van strafvordering nog niet met zoveel woorden werd genoemd - hoofdstuk 6, § 4.4.4.

267 Dit geldt onder meer voor de advocaat in strafzaken die op grond van art. 178 KPK 1997 niet als getuige mag worden gehoord (zie hierover hoofdstuk $7, \S 6$ ) en voor de getuige aan wie vanwege zijn verwantschap met de verdachte een verschoningsrecht toekomt. Genoemde uitzonderingen zijn noodzakelijk om te voorkomen dat het verschoningsrecht dat deze personen in de hoedanigheid van getuige toekomt, wordt omzeild door hun als deskundige te horen.

268 Art. 197 lid 1 KPK 1997. De deskundige is net als de getuige strafrechtelijk verantwoordelijk wanneer hij bewust in strijd met de waarheid een verklaring aflegt.

269 Art. 318 KPK 1997.

270 Art. 194 lid 2 KPK 1997. 
alle gevallen hoeft de deskundige ook te worden gehoord: de schriftelijke rapportage kan zo duidelijk zijn dat een mondelinge toelichting overbodig is. Wanneer de verdediging de deskundige wel wenst te horen, kan zij daartoe een verzoek indienen. De verdachte en zijn raadsman dienen te allen tijde te worden toegelaten tot het verhoor van de deskundige, ongeacht de vraag op wiens verzoek dit horen plaatsvindt. ${ }^{271}$ De enige uitzondering die op deze regel kan worden gemaakt, heeft - wederom - betrekking op de gedetineerde verdachte: zijn deelname aan het verhoor van een deskundige kan worden geweigerd wanneer verwezenlijking van zijn aanwezigheid tot 'ernstige moeilijkheden' zou leiden. ${ }^{272}$

\subsubsection{Onderzoek op verzoek verdediging}

Zowel de verdachte als zijn raadsman hebben gedurende het vooronderzoek het recht mondeling of schriftelijk verzoeken in te dienen tot het verrichten van onderzoekshandelingen. ${ }^{273}$ De verdachte dient voorafgaand aan zijn eerste verhoor van dit recht op de hoogte te worden gesteld. ${ }^{274}$

Een bewijsverzoek van de verdediging kan betrekking hebben op de vaststelling van ieder feit of elke omstandigheid die van belang kan zijn voor de zaak: de wetgever heeft de op dit punt geen beperkingen geformuleerd. ${ }^{275} \mathrm{Zo}$ kan bijvoorbeeld verzocht worden een bepaalde getuige te verhoren, een deskundige te raadplegen, of een confrontatie uit te voeren. In het bewijsverzoek dient in ieder geval te worden aangegeven welke feiten of omstandigheden men wenst te bewijzen. De wijze waarop dit dient te gebeuren, kan door de verzoekende partij worden gespecificeerd maar dat is niet noodzakelijk. ${ }^{276}$ Hoewel de wet daar over zwijgt, moet worden aangenomen dat het verzoek moet worden ingediend bij het orgaan dat het vooronderzoek leidt (prokuratura of politie). De politie kan een verzoek wel inwilligen maar voor een weigering is een gemotiveerde beslissing van de prokurator vereist. ${ }^{277}$ Tegen een weigering staat geen rechtsmiddel open. ${ }^{278}$ Het staat de verdediging - ook wanneer geen sprake is van nieuwe feiten of omstandigheden wel vrij het verzoek opnieuw in te dienen maar de kans van slagen van een dergelijk herhaald verzoek zal bij gelijkblijvende omstandigheden klein zijn.

De gronden waarop een bewijsverzoek mag worden geweigerd, zijn limitatief opgesomd in de wet. Afwijzing is slechts mogelijk wanneer:

271 Grzegorczyk 2004, p. 808-809. Een verzoek van de verdediging te kunnen deelnemen aan de uitvoering van het deskundigenonderzoek zal door de prokurator worden beoordeeld op grond van art. 317 KPK 1997 (zie eerder § 5.2.1.1). Zie voor de Straatsburgse visie hierop: Mantovanelli t. Frankrijk, EHRM 18-3-1997, nr. 21497/93.

272 Art. 318 laatste zin KPK 1997.

273 Art. 315 lid 1 KPK 1997. Voor art. 315 en de eerder besproken artikelen 316, 317 en 318 geldt dat ze betrekking hebben op beide vormen van het vooronderzoek: ze maken deel uit van het hoofdstuk over de śledztwo maar zijn in art. 325a van overeenkomstige toepassing verklaard op de dochodzenie.

274 Art. 300 KPK 1997.

275 Trzcińska 2002, p. 258 en Wiliński 2006, p. 383.

276 Art. 169 lid 1 KPK 1997.

277 Art. 170 lid 3 jo. 93 lid 3 KPK 1997.

278 Volgens Wiliński is dit een begrijpelijke keuze van de wetgever geweest: de mogelijkheid bezwaar aan te tekenen zou - met name wanneer grote aantallen bewijsverzoeken worden ingediend - teveel in de weg staan aan een efficiënt verloop van de procedure: Wiliński 2006, circa p. 383. 
1. de gevraagde bewijslevering niet is toegestaan (bijvoorbeeld horen van een getuige die zich op zijn verschoningsrecht beroept),

2. de omstandigheid die men wenst te bewijzen niet relevant is voor de te nemen beslissing of reeds is gebleken dat deze omstandigheid in overeenstemming met de beschuldigingen van de eisende partij is,

3. het bewijs niet relevant is voor de vaststelling van de omstandigheden waar het om draait,

4. de gevraagde bewijslevering niet mogelijk is (bijvoorbeeld het horen van een getuige die reeds is overleden) of

5. het bewijsverzoek op overduidelijke wijze is gericht op vertraging van de procedure. ${ }^{279}$

Wanneer een bewijsverzoek door de verdachte of zijn raadsman is ingediend en de handeling daadwerkelijk wordt uitgevoerd, mag de verdediging niet worden geweigerd deel te nemen. ${ }^{280}$ Zowel de verdachte als zijn raadsman dienen in zo'n geval van het plaatsvinden van de handeling (datum, tijd en plaats) op de hoogte te worden gesteld. 281

De enige uitzondering die op het aanwezigheidsrecht van de verdediging kan worden gemaakt, heeft wederom betrekking op de verdachte die van zijn vrijheid is beroofd: net als ten aanzien van de deelname aan het verhoor van een deskundige geldt dat wanneer het vervoer van een gedetineerde verdachte 'ernstige moeilijkheden' ('poważne trudności') met zich brengt zijn deelname kan worden geweigerd. ${ }^{282}$ Hiervan kan bijvoorbeeld sprake zijn wanneer de afstand tussen de plaats van detentie en de locatie van de onderzoekshandeling te groot is. Zoals eerder opgemerkt, zijn zuiver praktische bezwaren in dit verband voldoende: niet hoeft te worden aangetoond dat het realiseren van de aanwezigheid van de verdachte nadelige gevolgen zou kunnen hebben voor het (te verkrijgen) bewijs.

Het recht van de verdediging om bewijsverzoeken in te dienen, is ook vastgelegd in de regeling van de kennisneming van processtukken. Zoals eerder in § 3.2.2 is beschreven, heeft de verdediging vlak voor sluiting van het vooronderzoek de mogelijkheid kennis te nemen van al het materiaal dat tot dan toe is verzameld. Binnen drie dagen na die laatste inzage van het dossier kan door de verdachte of zijn raadsman om aanvulling van het vooronderzoek worden gevraagd. ${ }^{283}$ Voor

279 Art. 170 lid 1 sub 1 tot en met 5 KPK 1997. Deze weigeringsgronden gelden zowel voor de fase van het vooronderzoek als voor het onderzoek ter terechtzitting. Zie voor een nadere uitwerking hoofdstuk 6, § 4.4.3.1. De onder 5 genoemde categorie is overigens relatief nieuw in het Poolse strafprocesrecht: deze grond is in juli 2003 ingevoerd om misbruik van de bevoegdheid tot het indienen van bewijsverzoeken door de verdediging tegen te gaan. Zie hierover hoofdstuk 6, § 5.2.2.

280 Art. 315 lid 2 KPK 1997 eerste zin.

281 Art. 117 lid 1 KPK 1997. Daarvoor is dus niet vereist dat de verdediging expliciet heeft verzocht om ook aan de handeling te kunnen deelnemen: de autoriteiten dienen de verdediging ambtshalve te informeren.

282 Art. 315 lid 2 KPK 1997.

283 Art. 321 lid 5 KPK 1997. De drie dagen termijn is overigens niet fataal: na verloop van deze termijn heeft de verdediging nog steeds de bevoegdheid verzoeken in te dienen. Wanneer het bewijsverzoek wel binnen drie dagen na de laatste kennisneming wordt ingediend, heeft dit wel tot gevolg dat het vooronderzoek nog niet kan worden gesloten. 
wat betreft de deelname van de verdachte en zijn raadsman aan deze handelingen geldt het hiervoor beschreven regime: aangezien de verdediging zelf heeft verzocht om de handeling mag ze niet worden geweigerd eraan deel te nemen, tenzij het gaat om een gedetineerde verdachte wiens transport 'ernstige moeilijkheden' met zich brengt.

\subsubsection{Horen van getuigen door de rechtbank}

Zoals eerder opgemerkt, kan een bewijsverzoek van de verdediging alle mogelijke onderzoekshandelingen betreffen. Voor het horen van getuigen geldt onder bepaalde omstandigheden een afzonderlijk regime: wanneer het gevaar bestaat dat een getuige niet op het onderzoek ter terechtzitting zal kunnen worden gehoord, kan de verdediging verzoeken dat de getuige door de rechtbank wordt gehoord. ${ }^{284}$ De mogelijkheid bepaalde getuigen voor aanvang van het onderzoek ter terechtzitting door de rechtbank te laten horen, is in het wetboek van strafvordering van 1997 nieuw ingevoerd en diende bij te dragen aan de gewenste uitbreiding van rechterlijke controle op het vooronderzoek. ${ }^{285}$

Het verzoek dient - anders dan de overige bewijsverzoeken in het vooronderzoek - niet te worden gericht aan de politie of de prokurator maar aan de rechtbank. Die toetst vervolgens of de vrees dat de getuige niet op het onderzoek ter terechtzitting zal kunnen worden gehoord gerechtvaardigd is: het staat de rechter vrij een verzoek af te wijzen wanneer de noodzaak ervan niet is komen vast te staan. ${ }^{286}$ Het horen van de getuige gebeurt door een enkelvoudige kamer van de rechtbank op een zitting waaraan in beginsel zowel de prokurator als de verdediging mag deelnemen. Omdat dit verhoor onder de categorie 'handelingen die niet ter terechtzitting zullen kunnen worden herhaald' valt, geldt ook hier dat de verdediging ervoor uitgenodigd dient te worden tenzij het gevaar bestaat dat uitstel van het verhoor tot verlies of aantasting van het bewijsmateriaal zal leiden. ${ }^{287}$ Hoewel de herinnering van een getuige met het verstrijken van de tijd uiteraard kan vervagen (en de betrouwbaarheid van zijn verklaring dus kan verminderen), zal van spoedeisendheid in bovengenoemde zin bij het horen van getuigen in de regel geen sprake zijn. Bovendien moet ervan uit worden gegaan dat wanneer een getuige op verzoek van de verdediging wordt gehoord, de verdachte en zijn raadsman te allen tijde zullen moeten worden uitgenodigd voor het verhoor en

284 Art. 316 lid 3 KPK 1997. Een dergelijk verzoek kan ook door een andere partij (bijvoorbeeld het slachtoffer) of de prokuratura worden ingediend. Wanneer de politie het vooronderzoek leidt, kan ook zij verzoeken dat een getuige in het vooronderzoek door de rechtbank wordt gehoord.

285 Zie over het vergroten van het aandeel van de rechter in het vooronderzoek als een van de doelstellingen van de postcommunistische hervorming van het strafproces: hoofdstuk 2, § 2.3.3.1. In de toelichting op het wetboek van strafvordering van 1997 noemt de wetgever de mogelijkheid neergelegd in art. 316 lid 3 KPK 1997 'karakteristiek voor de nieuwe rol van de rechtbank in het vooronderzoek': Fredrich-Michalska en StachurskaMarcińczak 1997, p. 425.

286 Zoals inmiddels door de rechtspraak is bevestigd, kunnen deze verhoren alleen plaatsvinden op verzoek van partijen en behoort het dus niet tot de taak van de rechtbank om op dit punt initiatieven te ontplooien: Grzegorczyk 2004, p. 805 en daar genoemde rechtspraak.

287 Art. 316 lid 1 KPK 1997. 
in de gelegenheid moeten worden gesteld daaraan deel te nemen. ${ }^{288}$ Wel bestaat in alle gevallen - ook wanneer het verhoor op verzoek van de verdediging plaatsvindt - de mogelijkheid deelname van een gedetineerde verdachte te weigeren. ${ }^{289}$

Er is behalve bovengenoemde mogelijkheid nog een situatie waarin een getuige gedurende het vooronderzoek op verzoek van de verdediging door de rechtbank kan worden gehoord. In 2003 is een bepaling geïntroduceerd op grond waarvan minderjarige slachtoffers van bepaalde emotioneel zeer belastende feiten in beginsel slechts eenmaal mogen worden gehoord. ${ }^{290}$ Het verhoor dient - ongeacht in welk stadium van de procedure het plaatsvindt en dus ook gedurende het vooronderzoek - te worden uitgevoerd door de rechtbank in aanwezigheid van een psycholoog en mag worden bijgewoond door de prokurator, de raadsman van verdachte en de advocaat van het slachtoffer. ${ }^{291}$ Op deze bijzondere categorie getuigen en de consequenties van de regeling voor de rechten van de verdediging wordt teruggekomen in hoofdstuk 6, § 4.4.3.3.

\subsubsection{Reikwijdte 'deelname'}

In de in het voorgaande genoemde bepalingen ${ }^{292}$ wordt gesproken van 'deelname' ('wzięcia udziatu') door de verdediging. Deze terminologie impliceert dat de verdachte en zijn raadsman niet slechts ter observatie aanwezig mogen zijn maar een actieve opstelling mogen aannemen. Dat wil zeggen dat vragen mogen worden gesteld aan bijvoorbeeld getuigen en deskundigen, verzoeken mogen worden ingediend, opmerkingen mogen worden gemaakt et cetera. ${ }^{293}$ Op deze manier kan richting worden gegeven aan het onderzoek en toezicht worden uitgeoefend op het rechtmatige verloop ervan. Van groot belang is ook dat de raadsman kan verifiëren of door de autoriteiten op de juiste wijze verslag wordt opgemaakt van de onderzoekshandeling. In de Poolse literatuur wordt opgemerkt dat de kwaliteit van processen-verbaal in veel gevallen te wensen overlaat. Belangrijkste problemen betreffen onder meer: onvolledigheid van de verslaglegging, chaotische weergaven (bijvoorbeeld door handelingen niet in chronologische volgorde te beschrijven), geen eenduidigheid in gebruikte terminologie en gebrek aan objectiviteit. ${ }^{294}$ Het moge duidelijk zijn dat onvolledige en slordige verslaglegging tot gevolg kan hebben dat informatie blijvend aan de verdediging wordt onthouden: een probleem dat volledig losstaat van de wettelijke regeling van het inzagerecht zoals besproken in $\S 3$.

288 Dan geldt immers het regime van art. 315 lid 2 KPK 1997: de verdediging mag niet worden geweigerd deel te nemen aan handelingen die op haar eigen verzoek plaatsvinden.

289 In beginsel geldt ook in dit verband (zoals ten aanzien van alle andere handelingen die niet ter terechtzitting kunnen worden herhaald) dat de aanwezigheid van de gedetineerde niet hoeft te worden gerealiseerd 'wanneer uitstel zal leiden tot verlies of aantasting van het bewijsmateriaal'.

290 Art. 185a KPK 1997.

291 Art. 185a lid 2 KPK 1997.

292 Art. 315 tot en met 318 KPK 1997.

293 Zie Wiliński en Górecki 2006, p. 51.

294 Bovendien blijken processen-verbaal vaak niet aan de formele vereisten - zoals de voorwaarde dat alle deelnemers aan de onderzoekshandeling het proces-verbaal dienen te ondertekenen - te voldoen: Gwirdoyń 2004, p. 29-30. 


\subsubsection{Eigen verdedigingsonderzoek}

In het bovenstaande is alleen gesproken over onderzoekshandelingen die (al dan niet op initiatief van de verdediging) door de autoriteiten zelf worden verricht. Dit roept de vraag op of de raadsman ook zelfstandig onderzoek in een zaak mag verrichten. ${ }^{295}$

Het Poolse strafprocesrecht geeft op deze vraag geen antwoord: nergens is geregeld of - en zo ja op welke wijze - de raadsman zelf onderzoek mag doen. De gedragsregels zwijgen eveneens op dit punt: daarin is weliswaar geregeld dat de advocaat de rechtbank niet welbewust van valse informatie mag voorzien (art. 11) en dat hij terughoudend moet zijn in het aanvoeren van 'drastische en weinig waarschijnlijke' omstandigheden (art. 15) maar over de toelaatbaarheid van zelfstandig onderzoek wordt niets gezegd. Ook door de doctrine wordt niet of nauwelijks aandacht besteed aan dit thema. ${ }^{296}$

Aangezien noch de strafrechtelijke wetgeving noch de gedragsregels de raadsman verbieden zelfstandig onderzoek te doen naar ontlastende feiten en omstandigheden dient er van uit te worden gegaan dat het is toegestaan.

Een belangrijke vorm van eigen onderzoek door de verdediging is het contacteren van getuigen waarbij onderscheid moet worden gemaakt tussen getuigen die reeds als zodanig zijn aangemerkt en personen die nog niet in die hoedanigheid zijn gehoord of benaderd (potentiële getuigen). Nu de strafwetgeving en de gedragsregels hierover zwijgen, mag ervan uit worden gegaan dat het de advocaat in ieder geval vrij staat laatstgenoemde categorie (potentiële) getuigen te contacteren en informatie van hen te verkriigen. Voor de getuigen die reeds als zodanig zijn aangemerkt, is dit echter minder vanzelfsprekend. In tuchtrechtspraak op basis van de gedragsregels van 1961 is (eveneens in 1961) door de hoogste tuchtrechtelijke instantie bepaald dat 'het door de advocaat verkriigen van informatie over een strafzaak van een cliënt van een persoon die reeds in de hoedanigheid van getuige (...) in dezelfde zaak is gehoord' een schending vormt van 'de waardigheid van het beroep en de professionele verplichtingen van de advocaat'. ${ }^{297}$ Aangezien de gedragsregels van 1961 inmiddels zijn vervangen door nieuwe - en in het huidige gedragsrecht een gelijkluidend verbod niet voorkomt en voor zover bekend ook niet wordt ingelezen - is onduidelijk welke grenzen op dit punt aan het optreden van de raadsman moeten worden gesteld. ${ }^{298}$ Door Gwirdoyń verricht onderzoek laat zien dat hierover binnen de advocatuur verschillend wordt gedacht: $60 \%$ van de door hem ondervraagde advocaten is van mening dat het

295 In het Pools wordt zelfstandig verdedigingsonderzoek aangeduid met de term prywatne śledztwo.

296 Gwirdoyń 2004, p. 106. Hierbij speelt Polen's continentale rechtstraditie onmiskenbaar een rol: eigen verdedigingsonderzoek is een verschijnsel dat meer in de Angelsaksische traditie thuishoort waar de structuur van het strafproces zodanig is dat beide procespartijen (vervolging en verdediging) een evenwaardige bijdrage aan de waarheidsvinding kunnen leveren. Toch kan dit de Poolse desinteresse niet volledig verklaren: in de Duitse doctrine bijvoorbeeld wordt van oudsher wel veel over de onderzoekstaak van de raadsman geschreven terwijl het Duitse strafproces toch ook tot de continentale civil law rechtsfamilie wordt gerekend. Zie over het verband tussen de structuur van het strafproces, opvattingen over waarheidsvinding en de rol van procesdeelnemers daarin: hoofdstuk 3.

297 Gwirdoyń 2004, p. 115-116.

298 Ook de doctrine is verdeeld op dit punt - zie daarover hoofdstuk 8, § 4.3.3. 
ethisch gezien 'absoluut ontoelaatbaar', 'ontoelaatbaar' of 'tamelijk ontoelaatbaar' is om gedurende het vooronderzoek contact te hebben met getuigen. Iets minder dan een derde van de ondervraagde advocaten gaf aan niet in te zien waarom een dergelijk optreden in strijd met de gedragsregels zou zijn. Opvallend is dat advocaten - ook zonder een uitdrukkelijk verbod in een wettelijke of gedragsrechtelijke bepaling - er blijkbaar van uitgaan dat bepaalde initiatieven in het kader van de waarheidsvinding ontoelaatbaar of in ieder geval verdacht zijn. ${ }^{299}$

Een tweede wijze waarop de verdediging gedurende het vooronderzoek zelfstandig onderzoek kan doen, is door het raadplegen van een (eigen) deskundige. Genoemd onderzoek van Gwirdoyń laat zien dat de toelaatbaarheid van een dergelijk optreden niet of nauwelijks door de advocatuur wordt betwist. ${ }^{300}$ Wat de mogelijkheden van de verdediging op dit punt betreft, is de toelaatbaarheid van dergelijk contact dan ook zeker niet het probleem. Veel problematischer is het feit dat het oordeel van een deskundige die niet door de prokurator of de rechter is benoemd volgens het huidige strafprocesrecht niet ter terechtzitting mag worden voorgelezen en dus niet als bewijsmiddel kan worden aangewend. ${ }^{301}$

Naast het contacteren van getuigen en deskundigen zijn er uiteraard ook nog andere manieren waarop de verdediging zelfstandig onderzoek kan verrichten. Hierbij kan bijvoorbeeld gedacht worden aan het maken van foto's of schetsen van de plaats delict en het zelfstandig uitvoeren van een reconstructie. Het gebruiken van andere bronnen (dan getuigen en deskundigen) voor eigen verdedigingsonderzoek wordt door de advocatuur blijkbaar niet problematisch gevonden. ${ }^{302}$ De vraag of dit ook betekent dat in de praktijk veel gebruik wordt gemaakt van de mogelijkheid zelfstandig onderzoek te doen, komt aan de orde in § 5.6.

\subsection{Situatie voor inwerkingtreding nieuw strafprocesrecht}

In het voorgaande is duidelijk geworden welke wettelijke mogelijkheden de verdediging vandaag de dag heeft om invloed uit te oefenen op de bewijsvergaring die in het vooronderzoek plaatsvindt. Deze regeling is in hoofdlijnen gelijk aan de situatie op grond van het oude wetboek van strafvordering. Ook daarin werd onderscheid gemaakt tussen vier verschillende categorieën onderzoekshandelingen: handelingen die niet ter terechtzitting konden worden herhaald (1), betrekking hadden op deskundigenbewijs (2), op verzoek van de verdediging plaatsvonden (3) en overige handelingen (4). ${ }^{303}$ Ook toen vielen de mogelijkheden van de verdediging uiteen in enerzijds het recht om zelf bewijsverzoeken in te dienen en anderzijds om aanwezig te zijn bij onderzoek dat - al dan niet op haar eigen initiatief - door politie of pokurator werd verricht. Hoewel de verdediging ook op grond van het oude strafprocesrecht redelijk ruime bevoegdheden had op dit

299 Kruszyński 1991, p. 21 en Gwirdoyń 2004, p. 116-117. Zie ook Kulesza 2005, p. 429 e.v.

300 Meer dan $80 \%$ van de ondervraagden was van mening dat het contacteren van een deskundige toelaatbaar is: Gwirdoyń 2004, p. 127.

301 Zie hierover hoofdstuk 6, § 4.4.4.

302 Alle ondervraagde advocaten gaven aan dit soort onderzoek geoorloofd te vinden: Gwirdoyń 2004, p. 131.

303 De huidige artikelen 315, 316, 317 en 318 KPK 1997 komen overeen met respectievelijk art. 271, 272, 273 en 274 KPK 1969. 
punt werd daarvan in de praktijk zeer weinig gebruik gemaakt. ${ }^{304}$ Bovendien was er net als vandaag de dag niets geregeld over de mate waarin en de wijze waarop de verdediging bevoegd was zelfstandig onderzoek te verrichten.

Afgezien van deze overeenkomsten verschilt de huidige regeling op een aantal punten van het oude strafprocesrecht. De belangrijkste veranderingen zullen hier worden weergegeven.

\section{Aanscherping van de gronden waarop een verzoek van de verdediging tot deelname} kan worden geweigerd

Ten aanzien van onderzoekshandelingen die vermoedelijk wel op de zitting kunnen worden herhaald en geen betrekking hebben op deskundigenbewijs gold op grond van het oude strafprocesrecht dat aanwezigheid van raadsman en verdachte 'in het belang van het vooronderzoek' ('ze względu na interes śledztwa lub dochodzenia') kon worden geweigerd. ${ }^{305}$ Deze uitzonderingsmogelijkheid is in het nieuwe wetboek van strafvordering aangescherpt door de toevoeging dat dit slechts in 'uitzonderlijke gevallen' ('w szczególnie uzasadnionym wypadku') en met het oog op zwaarwegende onderzoeksbelangen ('na ważny interes śledztwa') is toegestaan. ${ }^{306}$ Hiermee is benadrukt dat de verdachte en zijn raadsman in de regel tot dit soort handelingen moeten worden toegelaten en dat deelname slechts in uitzonderlijke gevallen mag worden geweigerd.

\section{Expliciet recht tot deelname aan handelingen die op verzoek van de verdediging worden verricht}

In het oude strafprocesrecht was niet afzonderlijk geregeld of de verdediging het recht had aanwezig te zijn bij onderzoekshandelingen die op haar verzoek werden verricht: de verdachte en zijn raadsman hadden net als vandaag de dag het recht dergelijke verzoeken in te dienen maar dat ze ook bij de uitvoering ervan aanwezig zouden mogen zijn, was niet vanzelfsprekend. In dat verband gold net als ten aanzien van onderzoekshandelingen die niet op verzoek van verdachte plaatsvonden dat aanwezigheid eenvoudig kon worden geweigerd wanneer dat in het belang van het vooronderzoek werd geacht. ${ }^{307}$ Het feit dat volgens de huidige regeling alleen de gedetineerde verdachte kan worden geweigerd deel te nemen aan dit soort handelingen heeft de mogelijkheden van de verdediging op dit punt in belangrijke mate verruimd. ${ }^{308}$

Introductie van de mogelijkheid een getuige in het vooronderzoek door de rechtbank te laten horen

Getuigen konden op grond van het oude strafprocesrecht in deze fase van de procedure - ook wanneer gevreesd werd dat ze niet op het onderzoek ter terechtzitting zouden kunnen verschijnen - alleen door politie of prokurator worden gehoord.

304 Zie onder meer Polony 1974, p. 154-156. Volgens Polony lagen hier drie oorzaken aan ten grondslag: 1. tijdgebrek, 2. verdedigingstactiek en 3. het feit dat alle bewijsverzoeken op de zitting kunnen worden herhaald. Zie hierna § 5.5 .

305 Art. 273 KPK 1969.

306 Art. 317 KPK 1997.

307 Art. 271 jo. 273 lid 2 KPK 1969. Voor handelingen die niet ter terechtzitting konden worden herhaald en die betrekking hadden op deskundigenbewijs gold wel een afzonderlijke regeling.

308 Art. 315 lid 2 KPK 1997. 
Het dient als een verbetering van de positie van de verdediging te worden beschouwd dat nu de mogelijkheid bestaat deze categorie getuigen reeds in het vooronderzoek in een volledig contradictoire setting ten overstaan van een rechter te horen.

Beperking van de mogelijkheid deelname van gedetineerde verdachten aan bepaalde categorieën onderzoekshandelingen te weigeren

Het oude strafprocesrecht regelde dat deelname van deze categorie verdachten aan handelingen die niet ter terechtzitting zouden kunnen worden herhaald, kon worden geweigerd wanneer verwezenlijking van hun aanwezigheid tot ernstige moeilijkheden of vertraging van de procedure zou leiden. In de huidige regeling is deze mogelijkheid beperkt tot de situatie dat uitstel tot verlies of vervorming van het bewijsmateriaal zal leiden. ${ }^{309}$ Praktische bezwaren verbonden aan het transport van de verdachte zijn dus niet langer voldoende reden om deelname te weigeren. Ook ten aanzien van handelingen die betrekking hadden op deskundigenbewijs gold op basis van het oude strafprocesrecht dat deelname van gedetineerde verdachten kon worden geweigerd wanneer verwezenlijking van hun aanwezigheid tot ernstige moeilijkheden of vertraging van de procedure zou leiden. Op grond van de huidige regeling is weigering slechts mogelijk wanneer verwezenlijking van de aanwezigheid van de verdachte ernstige moeilijkheden met zich brengt. ${ }^{310}$ Toch kan nog steeds de vraag worden gesteld of de mogelijkheden van deze categorie verdachten om deel te nemen aan onderzoekshandelingen in het vooronderzoek niet te beperkt zijn. Meer daarover in de volgende paragraaf.

\subsection{Evaluatie juridisch kader}

Uit de vorige paragraaf kan worden afgeleid dat het huidige strafprocesrecht de verdediging - vergeleken met het oude wetboek van strafvordering - betere (afdwingbare) mogelijkheden biedt om aanwezig te zijn bij en invloed uit te oefenen op de totstandkoming van bewijsmateriaal in het vooronderzoek. Samengevat heeft de verdediging het recht om:

- te verzoeken dat een bepaalde handeling wordt verricht. Deelname kan niet worden geweigerd, behalve in geval van een gedetineerde verdachte wiens vervoer 'ernstige moeilijkheden' met zich zou brengen.

- te worden ingelicht over en deel te nemen aan handelingen die niet op het onderzoek ter terechtzitting kunnen worden herhaald. Informeren van de verdediging mag dan alleen achterwege blijven wanneer het gevaar bestaat dat uitstel van de onderzoekshandeling verlies of aantasting van het bewijsmateriaal tot gevolg zal hebben. Op dezelfde grond kan deelname van de gedetineerde verdachte worden geweigerd.

- een verzoek in te dienen tot het horen van een getuige door de rechtbank wanneer verwacht wordt dat deze niet op het onderzoek ter terechtzitting zal kunnen verschijnen. De verdediging is gerechtigd aan het verhoor deel te nemen en dient daarover te worden ingelicht, enige uitzondering geldt ten aanzien van de gedetineerde verdachte: hem mag deelname worden geweigerd wanneer

309 Art. 272 lid 2 KPK 1969 en art. 316 lid 2 KPK 1997.

310 Art. 273 lid 1 tweede zin jo. 272 lid 2 KPK 1969 en art. 318 laatste zin KPK 1997. 
het verhoor ervoor zou moeten worden uitgesteld en uitstel tot verlies of aantasting van het bewijsmateriaal (de te verkrijgen verklaring) zal leiden.

- op de hoogte te worden gesteld van het feit dat een deskundige in de zaak is benoemd, deel te nemen aan een eventueel verhoor van deze deskundige en kennis te nemen van zijn schriftelijke rapportage. Enige uitzondering in dit verband heeft wederom betrekking op de gedetineerde verdachte: zijn deelname aan het verhoor mag worden geweigerd wanneer het 'ernstige moeilijkheden' met zich zou brengen.

- een verzoek in te dienen tot deelname aan alle overige (onderzoeks)handelingen die in de loop van het vooronderzoek worden verricht. Dergelijke verzoeken kunnen alleen worden geweigerd in 'uitzonderlijke gevallen' en wanneer dat noodzakelijk is vanwege 'zwaarwegende onderzoeksbelangen'. Deelname van gedetineerde verdachten mag worden geweigerd wanneer het realiseren van hun aanwezigheid 'ernstige moeilijkheden' met zich zou brengen.

Toch dient bij de huidige regeling een tweetal kanttekeningen te worden geplaatst.

- In de eerste plaats heeft de wetgever bij het aanscherpen van de mogelijkheid deelname van de verdediging te weigeren vage bewoordingen gehanteerd. Niet duidelijk is wat onder een 'uitzonderlijke geval' moet worden verstaan en wanneer een onderzoeksbelang 'zwaarwegend' mag worden genoemd. ${ }^{311}$ Deze gebruikte bewoordingen benadrukken weliswaar dat deelname in beginsel zal moeten worden toegestaan maar bieden veel interpretatievrijheid aan de prokuratura waardoor weigering in ieder geval in theorie nog steeds op grote schaal mogelijk is. ${ }^{312}$ Dat terwijl tegen een afwijzende beslissing geen rechtsmiddel openstaat zodat geen controle op de besluitvorming kan worden uitgeoefend. ${ }^{313}$

- Ten tweede is de positie van de gedetineerde verdachte problematisch. Ten aanzien van alle categorieën onderzoekshandelingen heeft de wetgever voorzien in de mogelijkheid deelname van de verdachte die van zijn vrijheid is beroofd te weigeren. Dit geldt zelfs ten aanzien van het onderzoek dat op verzoek van de verdediging plaatsvindt en dat niet ter terechtzitting zal kunnen worden herhaald. In die gevallen gelden weliswaar strengere weigeringsgronden maar het is de vraag of daar in de praktijk ook daadwerkelijk een beperkende werking vanuit gaat. Wanneer het niet gaat om een handeling die waarschijnlijk

311 Art. 317 lid 2 KPK 1997. De vaagheid van deze nieuwe formuleringen is ook in de literatuur bekritiseerd. Zie bijvoorbeeld Bieńkowska 1998, p. 16 (waar wordt opgemerkt dat de aanvulling 'zwaarwegend' niet meer is dan woordenspel en nauwelijks toegevoegde waarde heeft) en Bieńkowska e.a. 2004, p. 201. Zie ook: Wiliński 2006, p. 484.

312 Niet duidelijk is of het op grond van art. 317 lid 2 KPK 1997 in vergelijking met de situatie op grond van het oude strafprocesrecht minder vaak voorkomt dat een verzoek van de verdediging tot deelname wordt geweigerd.

313 In de aanloop naar het nieuwe wetboek van strafvordering werd de mogelijkheid bezwaar in te stellen tegen deze categorie beslissingen wel serieus overwogen (de voorstellen uit 1990 en 1994 voorzagen in een dergelijk rechtsmiddel) maar uiteindelijk niet opgenomen in de codificatie van 1997: Grzegorczyk 2004, p. 807. Kritisch hierover: Bieńkowska 1998, p. 20. Overigens is voor de totstandkoming van het nieuwe wetboek van strafvordering door sommige auteurs ook bepleit dat deelname door de verdediging slechts gedurende een bepaalde (begin)periode van het vooronderzoek zou moeten kunnen worden geweigerd. Zie bijvoorbeeld Kruszyński 1991, p. 164 en Kruszyński 1989, p. 82. 
niet ter terechtzitting zal kunnen worden herhaald, kan deelname van de gedetineerde verdachte worden geweigerd wanneer 'ernstige moeilijkheden' zijn verbonden aan het transport van verdachte. ${ }^{314}$ Ook dit zijn vage bewoordingen die veel beoordelingsvrijheid laten aan de autoriteiten. De wetgever heeft niet gespecificeerd welke omstandigheden een dergelijke weigering rechtvaardigen zodat het aan de prokurator is om te bepalen welke 'moeilijkheden' in dit verband voldoende ernstig zijn. ${ }^{315}$ Bovendien hoeft daarbij niet te worden meegewogen of de betreffende verdachte wordt bijgestaan door een advocaat. Dat terwijl een dergelijke weigering vooral problematisch zal zijn wanneer de gedetineerde verdachte niet over rechtsbijstand beschikt. In dat geval zal de onderzoekshandeling immers volledig in afwezigheid van de verdediging worden uitgevoerd terwijl het goed mogelijk is dat de resultaten ervan toch voor het bewijs worden gebezigd. ${ }^{316}$

\subsection{Verdediging en ambtshalve bewijsvergaring in de praktijk}

In het voorgaande is duidelijk geworden dat de verdediging verschillende wettelijke mogelijkheden heeft om deel te nemen aan en invloed uit te oefenen op de bewijsvergaring in het vooronderzoek. Hoewel is gebleken dat de wettelijke regeling op een aantal specifieke punten kan worden bekritiseerd, geldt over het algemeen dat het huidige strafprocesrecht de verdediging in theorie in staat stelt actief deel te nemen aan onderzoekshandelingen die op initiatief van politie of prokuratura worden verricht en daarnaast ook zelf onderzoek uit te (laten) voeren. Op papier heeft het vooronderzoek in dit opzicht dus een tegensprekelijk karakter. Van werkelijke tegenspraak kan echter pas worden gesproken wanneer genoemde mogelijkheden ook daadwerkelijk (kunnen) worden benut en dat lijkt in de praktijk slechts op zeer beperkte schaal het geval te zijn. Eerder is al opgemerkt dat Poolse advocaten in de regel een passieve houding innemen in het vooronderzoek. Dit betekent onder meer dat ze zich niet actief bemoeien met het proces van bewijsvergaring. ${ }^{317}$ Het komt weinig voor dat de verdediging in het het vooronderzoek bewijsverzoeken indient: bewijsvergaring vindt in dit stadium van de procedure vooral plaats op initiatief van de autoriteiten. ${ }^{318}$ Wanneer de verdediging

314 Deelname aan handelingen die niet kunnen worden herhaald, is slechts mogelijk wanneer uitstel dreigt te leiden tot 'verlies of vervorming van het bewijsmateriaal' (art. 316 lid 2 KPK 1997).

315 Een en ander wordt ook opgemerkt in de Poolse literatuur. Zie onder meer: Bieńkowska 1998, p. 15-16, Wiliński 2006, p. 388 en daar genoemde literatuur en Hofmański e.a. 2007 II, p. 113-114.

316 Immers, de wetgever heeft de mogelijkheid om processen-verbaal uit het vooronderzoek ter terechtzitting voor te lezen en voor het bewijs te gebruiken niet afhankelijk gemaakt van de vraag of een en ander in aanwezigheid van de verdediging tot stand is gekomen.

317 Dat dit ook gedurende het communisme zo was, blijkt uit praktijkonderzoek dat in de jaren zeventig is verricht: zie Grzegorczyk 1988, p. 229-231. Zie over deze onderzoeken eerder $\S 3.4$.

318 Gajewska-Kraczkowska 1992, p. 1131: 'Within the preliminary proceedings, the advocate may request that all relevant evidence be taken by the prosecutor. In practice, defense counsel prefer to wait until the trial itself. It seems to be part of the strategy to present the prosecutor with as many surprises as possible.' Zie ook Waltoś 2002 I, p. 351. Waltoś merkt op dat dit beeld in het eindonderzoek anders is: dan vinden de meeste onderzoekshandelingen plaats op verzoek van partijen (waartoe dan ook de prokurator behoort). 
wel een bewijsverzoek indient en dit wordt ingewilligd, is de kans klein dat een advocaat van de mogelijkheid gebruik maakt om bij de handeling aanwezig te zijn. Uit het door Gwirdoyń uitgevoerde onderzoek blijkt dat de meeste advocaten 'tamelijk zelden' ('raczej rzadko') (40\%) of 'zelden' (32,5\%) verzoeken deel te mogen nemen aan de onderzoekshandelingen die op hun verzoek plaatsvinden. ${ }^{319}$ De meest gehoorde redenen die hiervoor werden opgegeven, betroffen: tijdgebrek, de onmogelijkheid om invloed uit te oefenen op het verloop van de handeling en verdedigingstactiek. ${ }^{320}$

Wat de handelingen die niet ter terechtzitting kunnen worden herhaald betreft, geldt dat de meerderheid van de ondervraagde advocaten aangeeft daar niet aan deel te nemen. ${ }^{321}$ Als belangrijkste redenen hiervoor werden genoemd: het feit dat de verdediging niet of te laat op de hoogte wordt gesteld van de handeling en de overtuiging dat weinig invloed op de gang van zaken zal kunnen worden uitgeoefend. Een enkele keer werd ook tijdgebrek of tactiek genoemd. Opvallend is ook dat meer dan de helft (55\%) de toegankelijkheid van dit soort handelingen omschrijft als 'tamelijk onbevredigend', 'zeer onbevredigend' of 'onbevredigend'. 322 Advocaten blijken bovendien bijna nooit een verzoek in te dienen deel te kunnen nemen aan andere onderzoekshandelingen (art. 317 KPK 1997): 77,5\% van de ondervraagden gaf aan dat 'zelden' of 'tamelijk zelden' te doen. Tegelijk blijkt de advocatuur ook hier niet tevreden te zijn over de toegankelijkheid: meer dan $60 \%$ omschrijft de toegankelijkheid als 'onbevredigend' of 'tamelijk onbevredigend'. Als belangrijkste reden hiervoor werd genoemd dat de verdediging niet op de hoogte wordt gesteld van dit soort handelingen. Opvallend genoeg lijkt het niet vaak voor te komen dat een verzoek tot deelname met een beroep op zwaarwegende onderzoeksbelangen (art. 317 lid 2 KPK 1997) wordt geweigerd. ${ }^{323}$ Het onder-

319 Gwirdoyń 2004, p. 18: 27,5\% van de ondervraagden gaf aan dit vaak te doen. Het onderzoek geeft helaas geen antwoord op de vraag hoe vaak advocaten gemiddeld een bewijsverzoek indienen.

320 Gwirdoyń 2004, p. 18-19.

321 De antwoorden variëren: vrijwel nooit $(12,5 \%)$, zelden (32,5\%), tamelijk zelden $(22,5 \%)$, uiterst vaak $(17,5 \%)$ en in de helft van de gevallen (15\%), Gwirdoyń 2004, p. 19.

322 Gwirdoyń 2004, p. 19-20. Helaas wordt niet uitgewerkt waaruit die slechte toegankelijkheid bestaat. Gwirdoyń besteedt in zijn werk bijzondere aandacht aan drie soorten onderzoekshandelingen die niet ter terechtzitting kunnen worden herhaald en een belangrijke rol spelen in het Poolse strafproces: de schouw (oględziny), de doorzoeking (przeszukanie) en de confrontatie (okazanie). Ondanks de ruime bevoegdheden die de verdediging op dit punt heeft (omdat het handelingen zijn die niet ter zitting kunnen worden herhaald, kan deelname in beginsel niet worden geweigerd) komt het weinig voor dat dit soort onderzoek in aanwezigheid van de raadsman wordt verricht. Dat terwijl toezicht van de verdediging - zo benadrukt Gwirdoyń - zeker wenselijk zou zijn: vooral de wijze waarop confrontaties in de praktijk worden uitgevoerd, laat in de praktijk nogal eens te wensen over terwijl de resultaten wel degelijk bewijswaarde hebben. Het feit dat bovengenoemde soorten onderzoek meestal in afwezigheid van advocaten plaatsvinden, heeft overigens niet altijd met een passieve opstelling van de verdediging te maken: dit soort activiteiten vindt doorgaans in een heel vroeg stadium van het vooronderzoek plaats waardoor vaak nog geen raadsman bij de zaak betrokken is. Gwirdoyń 2004, p. 25-46.

$323 \mathrm{Al}$ zijn de antwoorden van de ondervraagde advocaten niet eenduidig op dit punt: volgens 51,3\% worden verzoeken op grond van art. 317 KPK 1997 'tamelijk vaak', 'vaak' of 'vrijwel altijd' geweigerd. Iets meer dan $10 \%$ was van mening dat dit in de helft van de gevallen 
zoek maakt echter niet duidelijk of dit niet slechts een gevolg is van het feit dat dit soort verzoeken weinig wordt ingediend.

Ten slotte heeft ook de in het nieuwe strafprocesrecht geïntroduceerde mogelijkheid om getuigen gedurende het vooronderzoek door de rechtbank te laten horen slechts een (uiterst) beperkte betekenis in de praktijk. ${ }^{324}$

\subsection{Eigen verdedigingsonderzoek in de praktijk}

Zoals het gebrek aan aandacht voor dit thema in regelgeving en literatuur al doet vermoeden, wordt er in het vooronderzoek door de verdediging nauwelijks eigen onderzoek verricht. Opvallend daarbij is dat Poolse advocaten er ondanks het ontbreken van een wettelijke regeling op dit punt van overtuigd lijken te zijn dat het niet is toegestaan zelfstandig op zoek te gaan naar ontlastende feiten en omstandigheden. In de woorden van Kruszyński:

'Defence lawyers are not forbidden to conduct their own investigations of the circumstances of the alleged offence. However it is generally agreed, including by defence laywers themselves, that investigation of the alleged offence is exclusively the preserve of the prosecution authorities. ${ }^{3} 25$

Dit wordt ook bevestigd door eerder genoemd onderzoek van Gwirdoyń. Maar liefst honderd procent van de door hem ondervraagde advocaten gaven aan van mening te zijn dat eigen onderzoek geen genade zou kunnen vinden in de ogen van de rechter. ${ }^{326}$ Nog opmerkelijker is dat geen van de respondenten dit standpunt motiveert met een concrete rechtsregel of rechterlijke uitspraak waaruit een verbod op eigen onderzoek door de verdediging zou blijken. De motiveringen die wel werden gegeven, waren in de trant van 'zou strijdig zijn met beginselen van ons strafproces', 'privé-onderzoek past niet in onze (strafrechtelijke) traditie', 'het zou het strafproces bemoeilijken', 'Poolse rechterlijke instanties zijn te conservatief' et cetera. ${ }^{327}$

Ten aanzien van het contacteren van getuigen bestaan een gelijksoortig beeld: een ruime meerderheid (60\%) van de ondervraagde advocaten gaat er ondanks het ontbreken van een wettelijke bepaling op dit punt van uit dat het niet is toegestaan gedurende het vooronderzoek contact te zoeken met een (reeds als zodanig aangemerkte) getuige. ${ }^{328}$ Hoewel daarover geen gegevens beschikbaar zijn, zal het - gelet op deze heersende mening - in de praktijk waarschijnlijk niet vaak voorkomen dat advocaten contact zoeken met getuigen. Of dezelfde terughoudendheid wordt betracht wanneer het gaat om potentiële getuigen is niet duidelijk.

Hoewel de meeste advocaten van mening zijn dat het wel toelaatbaar is om in het kader van de verdediging zelf een deskundige te raadplegen, gebeurt ook dit in de praktijk zelden omdat de kans uiterst klein is dat het deskundigenoordeel

gebeurt. 38,5\% gaf echter aan dat een weigering 'tamelijk zelden' of 'vrijwel nooit' wordt gegeven. Gwirdoyń 2004, p. 20.

324 Bron: gesprek Kruszyński, december 2005 Warschau.

325 Kruszyński 2007 I, p. 195.

326 De antwoorden waren als volgt samengesteld: $40 \%$ 'absoluut ontoelaatbaar', 32,5\% 'ontoelaatbaar' en 27,5\% 'tamelijk ontoelaatbaar': Gwirdoyń 2004, p. 116.

327 Gwirdoyń 2004, p. 107.

328 Gwirdoyń 2004, p. 116. Het gaat hier niet om potentiële getuigen maar om personen die reeds als zodanig zijn aangemerkt of verhoord. Zie hierover ook hoofdstuk 8, § 4.3.3. 
uiteindelijk voor het bewijs zal kunnen worden gebezigd. ${ }^{329}$ Bovendien zijn dergelijke rapportages kostbaar en blijven de kosten voor rekening van de verdediging wanneer een door haar geraadpleegde deskundige uiteindelijk niet door de rechter wordt benoemd: een groot risico dat veel advocaten liever niet nemen. ${ }^{330}$ Wat alle andere vormen van zelfstandig onderzoek (maken van foto's, realiseren eigen reconstructie et cetera) betreft, zijn de ondervraagde advocaten het erover eens dat die in beginsel toelaatbaar zijn maar de overgrote meerderheid van de advocaten geeft aan dit soort handelingen zelden tot nooit te ondernemen. ${ }^{331}$

\subsection{Bewijsvergaring in het vooronderzoek en het EVRM}

Aan het EVRM en de rechtspraak van het EHRM kunnen niet of nauwelijks algemene regels worden ontleend over de rechten van de verdediging bij bewijsvergaring in het vooronderzoek. Dit heeft in de eerste plaats te maken met de werkwijze van het Europese Hof. Bij toetsing aan art. 6 EVRM wordt altijd de strafrechtelijke procedure in zijn geheel bekeken: centrale vraag is dan of het gehele proces nog als eerlijk kan worden beschouwd. ${ }^{332}$ Gevolg van deze benadering is dat tekortkomingen in het vooronderzoek later in de procedure nog kunnen worden gecompenseerd. Hierdoor is het in veel gevallen moeilijk of zelfs onmogelijk om uit Straatsburgse rechtspraak af te leiden welke mogelijkheden de verdediging in het vooronderzoek behoort te hebben (of negatief geformuleerd: wanneer het feit dat de verdediging in dit stadium van de procedure bepaalde mogelijkheden niet heeft, in conflict komt met het EVRM). Dit geldt in het bijzonder voor het thema bewijsvoering omdat het daarbij om een activiteit gaat die ook nog centraal staat in het eindonderzoek en waarbij tekortkomingen in het vooronderzoek dus 'bij uitstek' nog gecompenseerd kunnen worden in een latere fase van de procedure. Het is dus niet mogelijk in abstracto vast te stellen wanneer in dit verband nog wel of niet van een eerlijk proces kan worden gesproken.

Behalve bovengenoemde benaderingswijze is bovendien van belang dat het EHRM doorgaans een terughoudende opstelling aanneemt waar het gaat om bewijs. Het Europese Hof laat zich in beginsel niet uit over de wijze waarop bewijsvoering dient plaats te vinden en de vraag of bepaalde bewijsmiddelen toelaatbaar zijn. De beoordeling van bewijsmateriaal wordt als een taak van de nationale rechter beschouwd. ${ }^{333}$ Dit neemt echter niet weg, dat aan art. 6 EVRM wel bepaalde criteria kunnen worden ontleend over de wijze waarop bewijs tot stand dient te komen en welke mogelijkheden daarbij aan de verdediging moeten worden geboden. De belangrijkste uitgangspunten komen aan de orde in hoofdstuk $6, \S 4.5$. Hier zal worden volstaan met een aantal algemene overwegingen die (mede) van belang zijn voor de fase van het vooronderzoek.

329 Zie § 5.2.5 en hoofdstuk 6, § 4.4.4.

330 Gwirdoyń 2004, p. 130.

331 Gwirdoyń 2004, p. 131.

332 Zie hoofdstuk 1, § 5.4.

333 Zie bijvoorbeeld Barberà, Messegué and Jabardo t. Spanje, EHRM 6-12-1988, nr. 10590/83: 'As a general rule it is for the national courts, and in particular the court of first instance to assess the evidence before them as well as the relevance of the evidence which the accused seeks to adduce (...). The Court must however, determine (...) whether the proceedings as a whole, including the way in which prosecution and defence ecidence was taken, were fair as required by Article 6 para. 1 (art. 6-1)' (§ 68). 
Het belangrijkste verdedigingsrecht in het kader van bewijsvergaring is de mogelijkheid getuigen op te roepen en te ondervragen. Dit recht is vastgelegd in art. 6 lid 3 sub d EVRM waarin is bepaald dat eenieder tegen wie een vervolging is ingesteld het recht heeft getuigen à charge te ondervragen of te doen ondervragen en het oproepen en ondervragen van getuigen à décharge te doen geschieden onder dezelfde voorwaarden als getuigen à charge. Genoemd artikellid heeft volgens de letterlijke tekst alleen betrekking op getuigen, maar het is vaste rechtspraak dat de eisen van art. 6 EVRM van overeenkomstige toepassing zijn op het aanstellen en horen van deskundigen. ${ }^{334}$ Ook het aan art. 6 lid 1 EVRM ten grondslag liggende beginsel van equality of arms brengt met zich dat partijen gelijke mogelijkheden moeten hebben om getuigen en deskundigen op te roepen. Klachten in het kader van art. 6 lid 3 sub d worden dan ook doorgaans in samenhang met art. 6 lid 1 EVRM behandeld. ${ }^{335}$ Het ondervragingsrecht van de verdediging is niet absoluut. Centrale vraag is steeds of de beperkingen die de verdediging op dit punt heeft ondervonden, de conclusie rechtvaardigen dat het proces niet eerlijk is geweest in de zin van art. 6 lid 1 EVRM. ${ }^{336}$ Het gebruik van verklaringen uit het vooronderzoek is op zichzelf niet onverenigbaar met het EVRM

'(...) provided that the rights of the defence have been respected. As a rule these rights require that the defendant be given an adequate and proper opportunity to challenge and question a witness against him either when he was making his statements or at a later stage of the proceedings'.337

Bepalend is dus of de beperkingen van de verdediging in voldoende mate zijn gecompenseerd. Of een adequate and proper opportunity is geboden, hangt telkens af van de omstandigheden van het geval en kan dus alleen tegen de achtergrond van een concrete strafzaak worden beoordeeld. Als de verdediging gelet op de maatstaf van art. 6 EVRM geen toereikende ondervragingsmogelijkheid heeft gehad, kan de veroordeling van verdachte niet 'solely or mainly' op de verklaring van de betreffende getuige worden gebaseerd. 338

\subsection{Conclusie}

Het Poolse strafprocesrecht biedt de verdediging - in ieder geval op papier - voldoende mogelijkheden om een bijdrage te leveren aan de bewijsvergaring in het vooronderzoek. Ze kan (actief) deelnemen aan onderzoekshandelingen die op initiatief van de justitiële autoriteiten plaatsvinden, verzoeken dat bepaalde han-

334 Zie onder meer Bönisch t. Oostenrijk, EHRM 6-5-1989, nr. 8656/97 en Brandstetter $t$. Oostenrijk, EHRM 28-8-1991, nr. 11170/84, 12876/87, 13468/87.

335 Van Dijk e.a. 2006, p. 583-584 en daar genoemde rechtspraak.

336 Zie uitgebreider hoofdstuk 6, § 4.5. Zoals daar nog aan de orde zal komen, maakt de toetsing aan art. 6 lid 1 EVRM het mogelijk ook rekening te houden met andere belangen zoals het belang van bepaalde categorieën kwestbare getuigen om niet ter terechtzitting met de verdachte te hoeven worden geconfronteerd. Over art. 6 EVRM en het recht getuigen te ondervragen: Beyer e.a. 1995.

337 Zie onder meer Kostovski t. Nederland, EHRM 20-11-1989, nr. 11454/85, Asch t. Oostenrijk, EHRM 26-4-1991, A203, Lüdi t. Zwitserland, EHRM 15-6-1992, A238, Egmez t. Cyprus, EHRM 21-12-2000, nr. 30873/96 en Van Mechelen e.a. t. Nederland, EHRM 23-4-1997, 21363/93, 21364/93, 21427/93.

338 Gebruik van de getuigenverklaring is dus niet uitgesloten indien er steunbewijs voorhanden is: Van Dijk e.a. 2006, p. 644-645. 
delingen door de politie, de prokurator of de rechtbank worden verricht en bovendien in beginsel onbeperkt zelfstandig verdedigingsonderzoek verrichten.

Hoewel op dit punt geen grote verschillen kunnen worden geconstateerd tussen het oude en het nieuwe strafprocesrecht, is de positie van de verdediging in het nieuwe wetboek van strafvordering in een aantal opzichten verbeterd: de gronden waarop de prokurator een verzoek van de verdediging tot deelname kan weigeren, zijn aangescherpt (1), aan de verdediging is een expliciet recht toegekend deel te nemen aan handelingen die op haar verzoek plaatsvinden (2), het is voortaan mogelijk een getuige in het vooronderzoek door de rechtbank te laten horen (3) en het is in bepaalde gevallen minder eenvoudig geworden deelname van gedetineerde verdachten te weigeren (4)..$^{339}$

Toch is ook geconstateerd dat de huidige regeling - waaronder bepaalde aspecten van bovengenoemde wijzigingen - nog een aantal punten van kritiek oplevert. Dit geldt in de eerste plaats voor het feit dat de mogelijkheid deelname van de verdediging aan onderzoekshandelingen te weigeren met vage bewoordingen is omschreven: niet duidelijk is wat onder 'uitzonderlijke gevallen' moet worden verstaan en wanneer sprake is van een 'zwaarwegend' onderzoeksbelang. Dat terwijl de verdediging tegen een afwijzende beslissing geen rechtsmiddel kan instellen. Ten tweede heeft de gedetineerde verdachte nog altijd slechts beperkte rechten om deel te nemen aan onderzoekshandelingen in het vooronderzoek. Ten aanzien van alle categorieën onderzoekshandelingen is immers voorzien in de mogelijkheid deelname van de gedetineerde verdachte te weigeren zonder dat daarbij moet worden meegewogen of de betreffende verdachte wordt bijgestaan door een advocaat. Aangezien zeker niet alle gedetineerde verdachten gedurende het vooronderzoek worden bijgestaan door een (gekozen of toegevoegde) raadsman ${ }^{340}$ kan de weigering de verdachte aan de onderzoekshandeling deel te laten nemen belangrijke consequenties hebben voor de verwezenlijking van het recht op verdediging.

Zoals in de voorgaande paragraaf is besproken, is het moeilijk - zo niet onmogelijk om aan de Straatsburgse rechtspraak algemene regels te ontlenen over bewijsvergaring in het vooronderzoek en de rechten die in dat verband aan de verdediging moeten worden geboden. Voor het EHRM is doorslaggevend of een strafrechtelijke procedure in zijn geheel nog als eerlijk kan worden bestempeld en dat betekent onder meer dat beperkingen in het vooronderzoek in een later stadium van de procedure kunnen worden gecompenseerd. Als gevolg hiervan is het niet mogelijk in zijn algemeenheid antwoord te geven op de vraag of de Poolse situatie op dit punt voldoet aan de Straatsburgse norm. Gelet op de Straatsburgse rechtspraak over het ondervragingsrecht van de verdediging is in ieder geval van belang dat het huidige strafprocesrecht de mogelijkheid biedt een getuige reeds in het vooronderzoek te laten horen door de rechtbank. ${ }^{341}$ Door een getuige die vermoedelijk niet meer op het onderzoek ter terechtzitting zal kunnen worden gehoord, reeds in het vooronderzoek in een contradictoire setting door de rechtbank te laten horen, wordt de verdediging een effectieve mogelijkheid geboden van haar ondervragingsrecht gebruik te maken.

\section{Zie $\S 5.4$.}

340 Zie over de toegang tot rechtsbijstand in het vooronderzoek: hoofdstuk 4.

341 Art. 316 lid 3 KPK 1997. Zie over deze bepaling tegen de achtergrond van de eisen van het EVRM: Wąsek-Wiaderek 2003 II, p. 238 
De vraag of de eerdergenoemde punten van kritiek op de huidige regeling problemen (kunnen) opleveren in het licht van het EVRM is uiteraard volkomen afhankelijk van de wijze waarop er in de praktijk mee wordt omgegaan. Dat neemt echter niet weg dat problemen zouden kunnen worden voorkomen door op deze punten meer wettelijke garanties te bieden. Voor wat betreft de onduidelijke weigeringsgronden ('zwaarwegend onderzoeksbelang' en 'uitzonderlijke gevallen') lijkt de oplossing voor de hand liggend: een minder vage omschrijving van de gronden waarop deelname kan worden geweigerd, zou het voor de prokurator minder eenvoudig maken de verdediging bij bepaalde onderzoekshandelingen in het vooronderzoek te weren. Ook introductie van de mogelijkheid een rechtsmiddel in te stellen tegen de weigering deelname toe te staan, zou in dit verband goede diensten kunnen bewijzen. Het zou de prokuratura dwingen verzoeken van de verdediging goed te overwegen, afwijzende beslissingen behoorlijk te motiveren en hantering van het rechtsmiddel zou - wanneer de beoordeling ervan zou worden overgelaten aan de rechtbank - duidelijkheid kunnen creëren over de vraag welke omstandigheden een weigering al dan niet rechtvaardigen. Wat de deelname van de gedetineerde verdachte betreft, zou de mogelijkheid participatie te weigeren slechts open dienen te staan wanneer de betreffende verdachte bijstand heeft van een raadsman. Indien dat niet het geval is, zou de verdachte in beginsel in de gelegenheid moeten worden gesteld deel te nemen aan de onderzoekshandeling.

Wat de praktijk betreft, is gebleken dat van de wettelijke mogelijkheden die de verdediging op dit punt in het vooronderzoek heeft nog steeds bijzonder weinig gebruik wordt gemaakt. Advocaten zijn uiterst terughoudend als het gaat om bewijsvergaring: dit geldt zowel voor wat betreft deelname aan (of het nemen van initatief tot) ambsthalve onderzoekshandelingen als voor het verrichten van eigen verdedigingsonderzoek. Het komt in het vooronderzoek weinig voor dat onderzoek op aangeven van de verdediging wordt verricht en advocaten nemen zelden deel aan onderzoekshandelingen die in dit stadium van de procedure worden uitgevoerd. Het feit dat de autoriteiten in de meeste gevallen niet verplicht zijn de verdediging op de hoogte te stellen van het feit dat bepaalde onderzoekshandelingen zullen worden uitgevoerd, speelt hierbij een belangrijke rol. Zelfstandig verdedigingsonderzoek gebeurt niet of nauwelijks terwijl het op grond van het straf(proces)recht of de gedragsregels niet verboden is. De advocatuur beschouwt bewijsvergaring duidelijk als een taak van de justitiële autoriteiten en niet van de verdediging: een opvatting die gelet op de inquisitoire procescultuur van het Poolse vooronderzoek weinig verrassend en op zichzelf ook begrijpelijk is. Dit neemt echter niet weg dat door deze passieve houding het risico bestaat dat belangrijke kansen voor de verdediging onbenut blijven en dat van daadwerkelijke tegenspraak in het vooronderzoek niet of nauwelijks sprake is. De autoriteiten zijn weliswaar verplicht ook aandacht te besteden aan ontlastend bewijsmateriaal maar de praktijk laat zien dat dat lang niet altijd (in voldoende mate) gebeurt. ${ }^{342}$ Door zelf initiatieven te nemen kan de verdediging een ander licht op de zaak werpen en door deel te nemen aan onderzoekshandelingen die ambtshalve worden uitgevoerd, kan erop worden toegezien dat het onderzoek recht-

342 Trzcińska 2002, p. 258. 
matig verloopt en dat daarvan op de juiste wijze verslag wordt gelegd. Op die wijze kan de verdediging een belangrijke bijdrage leveren aan de betrouwbaarheid van het verkregen bewijsmateriaal. ${ }^{343}$ Zeker gelet op de waarde die door de zittingsrechter aan in het vooronderzoek verkregen bewijsmateriaal kan worden gehecht, is het van groot belang dat de verdediging gebruik maakt van de mogelijkheden die het strafprocesrecht haar op dit punt biedt.

Ten aanzien van het zelfstandig verdedigingsonderzoek is hoogstwaarschijnlijk een cultuuromslag noodzakelijk: tot op heden bestaat er - zoals overigens in de meeste continentale rechtssystemen - geen enkele traditie op dit punt en het is gelet op de heersende opvattingen over de rol van de verdediging in het vooronderzoek maar zeer de vraag of de advocatuur het wenselijk (of noodzakelijk) vindt daar verandering in aan te brengen. Incidenteel wordt de advocatuur wel aangespoord op dit punt een actievere rol in te gaan nemen ${ }^{344}$ maar of, en in hoeverre, dit in de praktijk daadwerkelijk zal gebeuren, is van vele factoren afhankelijk en zal de toekomst moeten uitwijzen.

\section{Conclusie verdediging in het vooronderzoek}

De wettelijke regeling van het vooronderzoek heeft sinds het eind van de jaren negentig belangrijke veranderingen ondergaan. Daarbij heeft de wetgever er aanvankelijk vooral naar gestreefd een meer evenwichtige verhouding tussen het voor- en en het eindonderzoek te creëren en een actief optreden van de raadsman in het vooronderzoek te stimuleren. ${ }^{345}$

In dit hoofdstuk is voor een viertal belangrijke verdedigingsrechten bekeken op welke wijze invulling is gegeven aan laatstgenoemd streven. Op papier is op een aantal punten vooruitgang geboekt. Om overbodige herhaling te voorkomen, zal hier worden volstaan met een weergave van de meest in het oog springende constateringen.

In de eerste plaats is aan de raadsman een expliciet recht toegekend aanwezig te zijn bij de verhoren van zijn cliënt. Deze bevoegdheid stelt de raadsman in staat zijn cliënt op een cruciaal moment in het vooronderzoek te adviseren over zijn rechten en plichten en de in te nemen proceshouding. Bovendien kan hij erop toezien dat het verhoor rechtmatig verloopt en dat daarvan op de juiste wijze verslag wordt gelegd. Aangezien het inmiddels vaste rechtspraak van het EHRM is dat aan art. 6 EVRM geen onvoorwaardelijk recht op fysieke aanwezigheid van de raadsman bij het politieverhoor kan worden ontleend, biedt het Poolse strafprocesrecht op dit punt meer bescherming dan door Straatsburg wordt 'voorgeschreven'.

Het tweede thema dat in dit hoofdstuk centraal staat - de informatiepositie van de verdediging - heeft slechts zeer beperkte verbeteringen ondergaan. De huidige

343 Zie ook Wiliński en Górecki 2006, p. 51: 'Deelname aan bewijshandelingen stelt de verdediging in staat invloed uit te oefenen op de totstandkoming van bewijsmateriaal en zich een oordeel te vormen over de betrouwbaarheid ervan.'

344 Zie bijvoorbeeld aanbeveling nr. 10 in Daniuk e.a. 2006, p. 56: de raadsman dient vanaf het begin van de strafrechtelijke procedure een sleutelrol te kunnen spelen en daarbij de mogelijkheid te hebben zelf bewijsmateriaal te verzamelen door bijvoorbeeld te spreken met (potentiële) getuigen of personen.

345 Zie hoofdstuk $2, \S 2.3 .3$ over de aandachtspunten van het postcommunistisch hervormingsproces. 
wettelijke regeling laat nog steeds toe dat inzage van het dossier (met uitzondering van een beperkt aantal categorieëen documenten) tot vlak voor sluiting van het vooronderzoek vrij eenvoudig kan worden geweigerd. Een situatie die vooral in het kader van rechtmatigheidstoetsing van de voorlopige hechtenis in conflict kan komen met de eisen van art. 5 lid 4 in samenhang met art. 6 EVRM: zo blijkt niet alleen uit rechtspraak van het EHRM maar ook uit een recente uitspraak van het Grondwettelijk Hof (juni 2008) als gevolg waarvan art. 156 lid 5 KPK 1997 op korte termijn zal moeten worden aangepast. Bovendien laten meer recente wetswijzigingen (2003) zien dat het initiatief op dit punt steeds meer bij de verdediging is komen te liggen ${ }^{346}$ en dat bijstand van een raadsman in gevallen van verplichte rechtsbijstand niet onontbeerlijk wordt geacht. ${ }^{347}$

Hier staat tegenover dat de mogelijkheden van de verdediging ten aanzien van voorlopige hechtenis - in overeenstemming met de eisen van het EVRM - wel aanzienlijk zijn verbeterd. Er is meer rechterlijke controle op deze vorm van vrijheidsbeneming en de mogelijkheden van de raadsman om deel te nemen aan zittingen waarop over (de verlenging van of een rechtsmiddel tegen) de voorlopige hechtenis wordt beslist, zijn in belangrijke mate uitgebreid ten opzichte van het oude strafprocesrecht. Opvallend is wel dat deze uitbreiding hoofdzakelijk de raadsman en niet de verdachte zelf betreft. De rechtbank is niet verplicht de verdachte persoonlijk te horen voorafgaand aan een beslissing over verlenging of over een ingediend bezwaar. Hoewel aan het EVRM in dit verband geen absoluut aanwezigheidsrecht kan worden ontleend, blijkt uit de Straatsburgse rechtspraak wel dat persoonlijk horen van verdachte - afhankelijk van verschillende factoren zoals het tijdsverloop tussen de verschillende beslissingen over de voorlopige hechtenis en de persoonlijke situatie van verdachte - onder bepaalde omstandigheden noodzakelijk kan zijn en dat deelname van de raadsman afwezigheid van de verdachte niet in alle gevallen voldoende kan compenseren.

Wat de bewijsvergaring in het vooronderzoek betreft, geldt dat de mogelijkheden van de verdediging op een aantal punten zijn uitgebreid: het recht om deel te nemen aan onderzoekshandelingen is versterkt en de introductie van de mogelijkheid getuigen door de rechtbank te laten horen, garandeert dat de verdediging reeds in het vooronderzoek onder gunstige omstandigheden een getuige kan horen wanneer deze vermoedelijk niet op het onderzoek ter terechtzitting zal kunnen verschijnen.

Het is een bekend gegeven dat het recht in de boeken wezenlijk kan verschillen van het recht in de praktijk. Dat dit ook voor de verdedigingsrechten in het Poolse vooronderzoek geldt, is reeds gebleken in hoofdstuk 4 en wordt ook in dit hoofdstuk opnieuw bevestigd.

Het recht aanwezig te zijn bij verhoren heeft in de praktijk niet de betekenis die het - gelet op de waarde die het voor de verdediging vertegenwoordigt - zou moeten hebben. Dat het geen dagelijkse praktijk is, wordt deels veroorzaakt door het feit dat de verdachte in een doorsnee strafzaak in het stadium van de eerste verhoren doorgaans nog niet over een raadsman beschikt. Hierbij speelt ook een

\footnotetext{
346 De verdediging hoeft slechts over de laatste inzage voor sluiting van het vooronderzoek te worden geïnformeerd wanneer daartoe een verzoek is ingediend.

347 Laatste inzage kan ook in afwezigheid van de verplichte raadsman plaatsvinden.
} 
belangrijke rol dat in de eerste fase na aanhouding nog geen recht op gefinancierde rechtsbijstand bestaat. ${ }^{348}$

Van groot belang is dat is het in de praktijk eerder uitzondering dan regel is dat de verdediging in het vooronderzoek inzage krijgt in het dossier. In strafzaken van enig gewicht wordt door de prokurator op grote schaal gebruik gemaakt van de mogelijkheid openbaarmaking van de stukken tot vlak voor sluiting van het vooronderzoek te weigeren. Dit heeft grote consequenties voor de verwezenlijking van het recht op verdediging in deze fase van het strafproces.

De mogelijkheden die de verdediging in het kader van de voorlopige hechtenis heeft, worden in vergelijking met andere rechten en bevoegdheden in de praktijk nog relatief vaak benut. Ook hier geldt echter dat de feitelijke mogelijkheden van de raadsman worden beïnvloed door de (vaak beperkte) hoeveelheid informatie waarover hij kan beschikken. Bovendien wordt door advocaten - vanwege het feit dat in de eerste fase van het vooronderzoek doorgaans nog geen raadsman bij de zaak betrokken is - vaker deelgenomen aan zittingen waarop over verlenging of bezwaar wordt beslist dan aan zittingen waarop het eerste bevel voorlopige hechtenis wordt gegeven. Het is van groot belang dat de advocatuur een actieve en kritische opstelling aanneemt waar het gaat om de toepassing van voorlopige hechtenis. De rechtspraak van het EHRM laat immers zien dat op dit punt nog altijd aanzienlijke problemen bestaan.

Wat de bewijsvergaring betreft, geldt dat de verdediging daarin - gedurende het vooronderzoek - een uiterst beperkte rol vervult. Van de wettelijke mogelijkheden om deel te nemen aan (of het initiatief te nemen tot) onderzoekshandelingen die ambtshalve worden verricht, wordt slechts zeer terughoudend gebruik gemaakt. Dat de raadsman zelfstandig op zoek gaat naar bewijs komt zelden tot nooit voor en hoewel wetgeving en jurisprudentie hierover zwijgen, blijkt de advocatuur er vanuit te gaan dat een dergelijke vorm van onderzoek niet is toegestaan.

Dit alles rechtvaardigt de conclusie dat het vooronderzoek slechts in beperkte mate een meer tegensprekelijk karakter heeft gekregen. Op papier is in dit verband duidelijk vooruitgang geboekt maar er zijn geen aanwijzingen dat het feitelijke aandeel van de raadsman in het vooronderzoek wezenlijk verschilt van de situatie op grond van het oude strafprocesrecht. ${ }^{349}$ In het bovenstaande is duidelijk geworden dat hierop verschillende - onderling samenhangende factoren - van invloed zijn.

In de eerste plaats geldt dat de wettelijke regeling ondanks de vele verbeteringen op verschillende punten nog tekort schiet. Voor de in dit hoofdstuk behandelde thema's geldt dat relatief eenvoudige aanpassingen van het huidige juridische kader zouden kunnen bijdragen aan een betere effectuering van het recht op verdediging in het vooronderzoek. In sommige gevallen is een dergelijke aanpassing niet alleen wenselijk maar naar mijn mening zelfs onontbeerlijk gelet op de eisen van het EVRM. ${ }^{350}$

348 Zie over de problemen bij het effectueren van het recht op rechtsbijstand na aanhouding: hoofdstuk $4, \S 2$.

349 Zie ook Waltoś 2002 I, p. 280-281.

350 Voor de verschillende mogelijke wijzigingen wordt verwezen naar de bijbehorende paragrafen: zie met name $\S 2.6,3.3 .4,3.6,4.4,4.7,5.4$ en 5.8 . 
In de tweede plaats geldt dat de beperkte informatiepositie van de verdediging ook onlosmakelijk verbonden met het feit dat de wetgever op dit punt te weinig waarborgen heeft geboden - van invloed is op de wijze waarop en de mate waarin van alle andere bevoegdheden in het vooronderzoek gebruik wordt gemaakt. Voor een raadsman die niet weet wat er in een zaak allemaal gebeurt en welk bewijsmateriaal tegen zijn cliënt is verzameld, is het immers zeer moeilijk actief op te treden. Veel zal afhangen van de wijze waarop art. 156 lid 5 KPK ${ }^{351}$ met inachtneming van de uitspraak van het Grondwettelijk Hof d.d. 3 juni 2008 zal worden gewijzigd.

In de derde plaats is verwezenlijking van het recht op rechtsbijstand in het vooronderzoek moeilijk vanwege allerlei praktische problemen. Zoals in hoofdstuk 4 is gebleken, komt het zelden voor dat een advocaat direct na aanhouding van zijn cliënt bij de zaak wordt betrokken. Dit is niet alleen het gevolg van een gebrek aan verschillende praktische faciliteiten (zoals een piketdienst) maar ook van het feit dat de voorziening van kosteloze rechtsbijstand in dit stadium in verschillende opzichten ernstig tekortschiet.

In het bovenstaande wordt wellicht de indruk gewekt dat de wijze waarop en de mate waarin advocaten actief zijn in het vooronderzoek slechts beïnvloed wordt door wet- en regelgeving en dat alle oplossingen moeten worden gezocht in wijzigingen die de overheid dient te verwezenlijken. Een laatste - zeer bepalende factor moet echter niet over het hoofd worden gezien: de houding van de advocatuur zelf. In dit hoofdstuk is verschillende keren aan het licht gekomen dat de Poolse advocatuur niet gewend is actief op te treden in het vooronderzoek. Dit was reeds zo gedurende het communisme en dat is ondanks alle inspanningen van de wetgever in de huidige praktijk niet veel anders. Opvallend is dat de Poolse doctrine voor 1989 meer aandacht besteedde aan het (gebrek aan) optreden van de advocaat in strafzaken in het vooronderzoek dan vandaag de dag. Voornamelijk in de jaren zeventig werd veel geschreven over de mogelijke redenen voor deze passiviteit en de vraag of een meer actieve deelname aan het vooronderzoek niet wenselijk was. ${ }^{352}$ Bovendien was het optreden van de advocaat in het vooronderzoek in die periode - zoals eerder in dit hoofdstuk vermeld - ook verschillende keren onderwerp van empirisch onderzoek. ${ }^{353}$ Vergelijkbare, grootschalige onderzoeken zijn sinds de inwerkingtreding van het nieuwe wetboek van strafvordering voor zover bekend niet meer verricht. Gedurende het communisme waren er weliswaar meer wettelijke beperkingen die optreden in het vooronderzoek bemoeilijkten maar ook toen bestond de algemene overtuiging dat het gros van de advocaten niet actief wílde zijn in dit stadium van de procedure. Dat advocaten vandaag de dag ondanks een veel gunstiger juridisch kader voorafgaand

351 Op grond waarvan inzage van het dossier gedurende het grootste deel van het vooronderzoek eenvoudig kan worden geweigerd.

352 Dit was overigens niet een puur academische discussie: ook leden van de prokuratura (bijvoorbeeld Prusak en Polony) en de advocatuur (zoals Mazur) namen er aan deel. Zie onder meer Mazur 1971, Prusak 1973 en de reeks artikelen die in 1974 in advocatenblad Palestra verscheen ('Het contradictoire karakter van het vooronderzoek' ('Kontradyktoryjność postępowanie przygotowawczego') met bijdragen van Gorgul, Prusak, Szlaszewski, Lewiński, Mazur en De Virion). Zie uit dezelfde periode ook: Polony 1974, Mendys 1974, Jarocki en Kruszewski 1974 en Grzegorczyk 1980.

353 Zie daarover Grzegorczyk 1988. 
aan het onderzoek ter terechtzitting nog steeds weinig activiteiten ontplooien, kan als een bevestiging van deze overtuiging worden gezien. ${ }^{354}$

354 Hoewel het onderwerp zoals gezegd veel minder aandacht krijgt in de Poolse literatuur wordt passiviteit in het vooronderzoek nog altijd als een welbewuste verdedigingstactiek beschouwd. Zie bijvoorbeeld Gajewska-Kraczkowska 1992, p. 1130: 'In practice advocates are not active in the preliminary proceedings. It seems to be a tradition that the courtroom is the primary place for the adversary process' en Bieńkowska 1998, p. 16-17: volgens Bieńkowska is de tactiek van de raadsman gebaseerd op de overtuiging dat het onderzoek ter terechtzitting het meest geschikte forum voor de verdediging is. Als gevolg hiervan wordt het vooronderzoek vaak als 'een fase van afwachten' ('etap na przeczekanie') beschouwd: de raadsman wil zich niet in een te vroeg stadium in de kaart laten kijken door de prokurator. Met name gelet op de beperkte mogelijkheden het dossier in te zien, is afwachten in veel gevallen de meest veilige tactiek. Zie ook Waltoś 2002 I: 'De raadsman wil zijn troeven voor het onderzoek ter terechtzitting bewaren (...) Het is niet in het belang van de verdediging de prokurator de gelegenheid te geven argumenten en bewijzen te verzamelen die tegen de standpunten van de verdediging kunnen worden ingebracht' (p. 281). Over de terughoudende opstelling van de raadsman in het vooronderzoek ook: Czekaj 1998, p. 41-42 en Gwirdoyń 2004, p. 18-19. 



\section{Hoofdstuk 6}

\section{Verdediging in het eindonderzoek}

\section{Inleiding}

In het voorgaande is gebleken dat advocaten van de verdedigingsmogelijkheden die in het vooronderzoek bestaan slechts terughoudend gebruik maken. Hoewel niet met zekerheid kan worden gezegd of deze praktijk het gevolg is van een bewust gekozen verdedigingstactiek of vooral samenhangt met tijdgebrek of misschien zelfs luiheid staat vast dat binnen de advocatuur de overtuiging bestaat dat verdediging in strafzaken op het onderzoek ter terechtzitting gebeurt. Vandaar dat het de moeite waard is te bekijken hoe de positie van de verdediging in dit laatste en doorslaggevende stadium van de strafrechtelijke procedure is vormgegeven.

Hierbij is van belang dat postcommunistische hervormingen van het strafproces veel minder gevolgen hebben gehad voor het eindonderzoek dan voor het vooronderzoek. De structuur en vormgeving van het eindonderzoek is met de inwerkingtreding van het nieuwe strafprocesrecht niet of nauwelijks gewijzigd en de positie van de verdediging in dit stadium van de procedure heeft slechts op een aantal punten veranderingen ondergaan. Met het oog op de probleemstelling die in dit onderzoek centraal staat, is er voor gekozen vooral die thema's te bespreken die illustreren hoe (de normering van) de positie van de verdediging in het eindonderzoek zich sinds de inwerkingtreding van het nieuwe strafprocesrecht heeft ontwikkeld. Daarbij zal om te beginnen aandacht worden besteed aan de mogelijkheden die de verdediging heeft in de fase voor aanvang van het onderzoek ter terechtzitting en in de verschillende consensuele procedures waarin het huidige Poolse strafprocesrecht voorziet. Daarna zal aan de hand van verschillende thema's de positie van de verdediging op het onderzoek ter terechtzitting worden geschetst en ten slotte de opkomst van een voor Polen relatief nieuwe discussie, over het verschijnsel misbruik van procesrecht worden besproken.

Een bespreking van de situatie voor inwerkingtreding van het nieuwe wetboek van strafvordering zal slechts plaatsvinden indien en voor zover de huidige regelgeving daarvan afwijkt. Wat de toetsing aan het EVRM betreft, geldt dat een dergelijke exercitie voor veel onderwerpen die in dit hoofdstuk centraal staan irrelevant ${ }^{1}$ of overbodig ${ }^{2}$ is. Om die reden zal het EVRM hier slechts aan de orde komen in het kader van de bewijsvoering op de zitting en bij bespreking van het thema misbruik van procesrecht.

1 Omdat de situatie in Polen daartoe geen aanleiding geeft. Dit geldt bijvoorbeeld ten aanzien van de aanwezigheid van de verdediging op het onderzoek ter terechtzitting. Omdat de raadsman te allen tijde - ook in afwezigheid van zijn cliënt zonder dat daarvoor bijzondere voorwaarden gelden - bevoegd is de verdediging te voeren, is een bespreking van de Straatsburgse rechtspraak op dit punt niet relevant.

2 Omdat het thema reeds in eerdere hoofdstukken in Straatsburgs verband is besproken. Zoals het recht op inzage van de stukken dat wordt besproken in $\S 4.3$ : de normen van het EVRM en de standpunten van het EHRM over het recht van de verdediging op inzage van het dossier is reeds aan de orde geweest in hoofdstuk $5, \S 3.5$. 


\section{Verdediging in de fase voor het onderzoek ter terechtzitting}

Tussen het indienen van de akte van beschuldiging door de prokurator en de behandeling van de zaak op het onderzoek ter terechtzitting zitten twee procesfasen waarin zich voor de verdediging relevante momenten kunnen voordoen:

1. het stadium waarin de akte van beschuldiging wordt gecontroleerd (wstepna kontrola oskarżenia) en

2. de organisatorische voorbereiding van het onderzoek ter terechtzitting (przygotowanie organizacyjne rozprawy głównej). ${ }^{3}$

Met name in eerstgenoemd stadium kunnen belangrijke beslissingen worden genomen: de rechter kan bijvoorbeeld een besluit nemen over voorwaardelijke beëindiging van de zaak, ${ }^{4}$ de voorlopige hechtenis of over de mogelijkheid de verdachte te veroordelen zonder onderzoek ter terechtzitting. Deze beslissingen worden genomen op niet openbare zittingen die op grond van het oude strafprocesrecht in de meeste gevallen wel door de prokurator maar niet door de verdediging konden worden bijgewoond. Met de inwerkingtreding van het nieuwe wetboek van strafvordering zijn de mogelijkheden van de verdediging om deel te nemen aan dit soort zittingen aanzienlijk vergroot. ${ }^{5}$

In de tweede tussenfase - die waarin het onderzoek ter terechtzitting organisatorisch wordt voorbereid - worden doorgaans geen inhoudelijke beslissingen meer genomen en is de rol van de verdediging dan ook meer beperkt. De president van de rechtbank stelt in dit stadium schriftelijk vast door welke rechter(s) de zaak zal worden behandeld, waar en wanneer de zitting zal plaatsvinden, wie over deze zittingsdatum moeten worden geïnformeerd et cetera. ${ }^{6}$ In sommige gevallen kan de zaak in het kader van de voorbereiding op het onderzoek ter terechtzitting naar de zitting worden verwezen: de president van de rechtbank kan daartoe beslissen wanneer hij van mening is dat het - bijvoorbeeld vanwege de ingewikkeldheid van de zaak - zal bijdragen aan een efficiënt procesverloop. ${ }^{7}$

Rechters worden in beginsel volgens een vaste volgorde en dus willekeurig aan een zaak gekoppeld. ${ }^{8}$ De procespartijen zijn hier niet bij betrokken tenzij het gaat om een zaak waarin een veroordeling tot 25 jaar of levenslange gevangenisstraf

Zie hoofdstuk 2, § 3.2.2.1. Over de voorbereidende fase: Razowski 2005.

4 Zie hierover hoofdstuk 2, §3.2.2.

5 Zie hierna $\$ 2.3$.

6 Art. 350 KPK 1997.

7 Art. 349 KPK 1997. Op zo'n 'regiezitting' kan alvast worden besloten welke handelingen in welke volgorde op het onderzoek ter terechtzitting zullen worden verricht. Volgens Wiliński wordt van deze mogelijkheid - gelet op de toenemende werkdruk van de rechterlijke macht en de schaarse zittingscapaciteit - in de praktijk te weinig gebruik gemaakt: Wiliński 2006, p. 579.

$8 \quad$ Art. 351 lid 1 KPK 1997. De namen van de rechters zijn op een lijst geplaatst en de volgorde van deze lijst dient in beginsel te worden gevolgd. Hiervan kan slechts worden afgeweken in geval van ziekte van de betreffende rechter of vanwege een andere zwaarwegende grond. Deze regeling - die overigens alleen voor professionele rechters en dus niet voor de lekenrechters geldt - is in het wetboek van strafvordering van 1997 nieuw ingevoerd. In het oude strafprocesrecht was hierover niets geregeld en konden bepaalde rechters bewust aan bepaalde zaken worden gekoppeld wat uiteraard schadelijk kon zijn voor de rechterlijke onpartijdigheid. Zie hierover: Bieńkowska 1997, p. 61. 
kan worden uitgesproken. In dat geval kan toewijzing van de zaak plaatsvinden onder toezicht van procespartijen: de prokurator en de raadsman kunnen verzoeken dat de samenstelling van het rechterlijk college in hun aanwezigheid door middel van loting zal plaatsvinden. ${ }^{9}$ Deze mogelijkheid is nieuw ten opzichte van het oude wetboek van strafvordering en dient volgens de toelichting op de codificatie te voorkomen dat de samenstelling van rechterlijke colleges in dit soort belangrijke zaken wordt gemanipuleerd. ${ }^{10}$

In het onderstaande zal nader worden toegelicht welke mogelijkheden de verdediging heeft om invloed uit te oefenen op de gang van zaken voorafgaand aan de inhoudelijke behandeling van de zaak en hoe het huidige strafprocesrecht op dit punt verschillen vertoont met het oude wetboek van strafvordering.

\subsection{Reactie op akte van beschuldiging}

De akte van beschuldiging speelt een belangrijke rol in het strafproces: met de indiening ervan vangt de fase van het eindonderzoek aan en de inhoud van het document bepaalt de grenzen van de strafzaak. ${ }^{11}$ Dit is ook in het belang van de verdediging omdat het ervoor zorgt dat men weet wat de inzet van het geding is en waartegen verweer moet worden gevoerd. ${ }^{12}$

Gelet op deze betekenis van de akte van beschuldiging is het van belang dat de verdediging in het nieuwe wetboek van strafvordering de mogelijkheid heeft gekregen schriftelijk op het document te reageren vóórdat de zaak op het onderzoek ter terechtzitting wordt behandeld. Op grond van het nieuwe art. 338 lid 2 KPK 1997 heeft de verdachte het recht om binnen zeven dagen na ontvangst van de akte een schriftelijke reactie in te dienen. ${ }^{13}$ Hoewel genoemde bepaling alleen over de verdachte spreekt, kan de reactie ook namens de verdachte door een raadsman worden ingediend. Het is van belang te benadrukken dat het hier om een recht en dus niet om een plicht van de verdediging gaat.

De wetgever heeft met de mogelijkheid schriftelijk te reageren op de akte van beschuldiging het contradictoire karakter van het eindonderzoek willen vergroten. Het stelt de rechter in staat al in een vroeg stadium van het eindonderzoek op de

$9 \quad$ Art. 351 lid 2 KPK 1997.

10 Zie Fredrich-Michalska en Stachurska-Marcińczak 1997, p. 429. Dat het verzoek alleen door de raadsman en niet door de verdachte kan worden ingediend, hoeft overigens geen problemen op te leveren omdat deze situaties altijd gevallen van verplichte rechtsbijstand zullen betreffen (zie hierover hoofdstuk $4, \S 3.1 .1$ ).

11 Het onderzoek ter terechtzitting mag alleen betrekking hebben op de in de akte van beschuldiging beschreven feiten: de omvang van de vervolging wordt dus bepaald door de prokuratura en niet door de rechter. In Nederland - waar de tenlastelegging een zelfde functie vervult in het strafproces - wordt de beslissende rol van de tenlastelegging wel omschreven als de grondslagleer. De Hoge Raad spreekt in dit verband van een aan het Nederlands strafproces ten grondslag liggend 'beschuldigingsbeginsel'. Deze term wordt in dezelfde context ook in Polen gehanteerd (zasada skargowości): Grajewski 2005, p. 143. Zie over de reikwijdte van dit beginsel in het Poolse strafproces ook Waltoś 2002, p. 268-272 en Bieńkowska e.a. 2004, p. 45-53.

12 Corstens 2005, p. 610.

13 De verdachte dient over dit recht te worden geïnformeerd. Dit recht komt hem ook toe wanneer in plaats van de akte van beschuldiging een verzoek tot voorwaardelijke beeindiging van de procedure is ingediend (art. 336 lid 5 jo. art. 338 lid 1 en 2 KPK 1997). 
hoogte te raken van de standpunten van de verdediging wat het tegensprekelijk karakter van dit stadium van de procedure kan verhogen. ${ }^{14}$ Immers, voor introductie van art. 338 lid 2 KPK 1997 was de rechter bij aanvang van het onderzoek ter terechtzitting alleen bekend met de akte van beschuldiging en het gedurende het vooronderzoek verzamelde (belastende) bewijsmateriaal. Onder dergelijke omstandigheden bestaat het risico dat de rechter bevooroordeeld raakt voordat partijen zich op de zitting over de feiten hebben kunnen uitlaten en hun standpunten hebben kunnen toelichten. ${ }^{15}$ De schriftelijke reactie kan dit risico verkleinen: het stelt de verdediging in staat de rechter voorafgaand aan het onderzoek ter terechtzitting ook kennis te laten nemen van haar kant van het verhaal. Wanneer de zaak uiteindelijk op het onderzoek ter terechtzitting komt, wordt de inhoud van de schriftelijke reactie van de verdediging na voordracht van de akte van beschuldiging door de voorzitter voorgelezen. De reactie kan niet als bewijsmiddel worden gebruikt: het dient niet als verklaring van de verdachte (in de hoedanigheid van bron van bewijs) maar als het standpunt van verdachte als procespartij te worden beschouwd. ${ }^{16}$

De verdediging kan in de reactie ingaan op alles wat met de vermeende strafrechtelijke verantwoordelijkheid van verdachte te maken heeft waaronder zowel formele als inhoudelijke kwesties. Hierbij hoeft dus niet alleen te worden gedacht aan een ontkenning van het tenlastegelegde: de mogelijkheid kan ook worden benut om bijvoorbeeld een verzoek tot voorwaardelijke beëindiging van de procedure of een veroordeling zonder bewijsvoering op het onderzoek ter terechtzitting in te dienen. ${ }^{17}$ De schriftelijke reactie kan met name een rol van betekenis spelen wanneer de aanklacht door een burger is ingediend omdat dergelijke aanklachten vaak emotioneel geladen zijn: een reactie van de verdediging kan dit compenseren en bijdragen aan een objectieve beoordeling van de zaak door de rechter. ${ }^{18}$

De introductie van art. 338 lid 2 KPK 1997 is in de Poolse literatuur positief ontvangen: het zou de gelijkheid tussen partijen vergroten en daarmee een belangrijke bijdrage leveren aan het realiseren van een eerlijk proces in de zin van art. 6 EVRM. ${ }^{19}$ Toch blijkt de bepaling in de praktijk niet of nauwelijks te worden benut. ${ }^{20}$ Volgens Hermeliński wordt gebruik van genoemde mogelijkheid door de

14 Zo wordt ook benadrukt in de Poolse literatuur: Fredrich-Michalska en StachurskaMarcińczak 1997, p. 427 en Bieńkowska 1997, p. 56.

15 Een bezwaar dat van oudsher overigens een grotere rol speelt in common law systemen dan in de civil law rechtstraditie. Zie in dit verband Damaška over 'het ideaal van tabula rasa' in procedures gericht op conflictoplossing: 'If in the conflict-solving process the decision is to emerge form the dialectic of party debate, ideally the decision maker must enter the case unprepared, unaware of all matters specifically related to the issues. He should have "a virgin mind", to be tutored only through the bilateral process of evidentiary presentation and argument': Damaška 1986, p. 137-138.

16 Grzegorczyk 2004, p. 891

17 Wąsek-Wiaderek 2003 II, p. 307 en daar genoemde literatuur, Grzegorczyk 2004, p. 891 en Wiliński 2006, p. 573.

18 Grajewski 2005, p. 147. Zie over private vervolging hoofdstuk 2, § 3.1.2.

19 Volgens Wąsek-Wiaderek doet genoemde bepaling recht aan het - aan art. 6 EVRM ten grondslag liggende - beginsel van equality of arms: Wąsek-Wiaderek 2003 II, p. 308 en daar genoemde literatuur.

20 Informatie verkregen van Kruszyński, juni 2008. Zie ook Wiliński 2006, p. 573. Wiliński 
advocatuur niet gestimuleerd omdat de vrees bestaat dat de schriftelijke reactie de vrijheid van de verdediging op het onderzoek ter terechtzitting te veel zal beperken. $^{21}$

\subsection{Indienen bewijsverzoeken}

Tegelijk met het afschrift van de akte van beschuldiging wordt de verdachte opgeroepen om binnen zeven dagen bewijsverzoeken in te dienen. ${ }^{22}$ De verdediging is in dit stadium van de procedure doorgaans veel beter op de hoogte van de stand van zaken dan gedurende het vooronderzoek: ze heeft nu immers volledige inzage in het dossier en is in de akte van beschuldiging geïnformeerd over de bewijsmiddelen die de prokurator op de zitting zal presenteren. ${ }^{23}$ De oproep aan de verdediging om ook voor de aanvang van het onderzoek ter terechtzitting bewijsverzoeken in te dienen, heeft uiteraard alles te maken met de wens de zaak op de eerste zitting - en binnen een redelijke termijn in de zin van art. 6 lid 1 EVRM - af te kunnen doen. ${ }^{24}$ Dit betekent echter niet dat de verdediging op dit punt verplichtingen heeft: ze kan ervoor kiezen geen bewijsverzoeken in te dienen of om dit in een later stadium te doen. De zeven dagen termijn is dus slechts een richtlijn en aan de overschrijding ervan kunnen geen consequenties worden verbonden. Zolang het onderzoek ter terechtzitting nog niet is gesloten, staat het de verdediging vrij op ieder later moment in de procedure bewijsverzoeken in te dienen..$^{25}$

Het huidige strafprocesrecht vertoont op dit punt een verschil met het wetboek van strafvordering van 1969. Op grond van het oude strafprocesrecht werd de verdediging tegelijk met de akte van beschuldiging niet alleen opgeroepen om binnen zeven dagen bewijsverzoeken in te dienen: ze diende binnen deze termijn ook alle (voor de verdediging relevante) bewijsmiddelen te overleggen die haar bekend waren en die noodzakelijk waren om een beslissing te nemen in de zaak. ${ }^{26}$ Hoewel ook deze termijn niet dwingend was en aan de overschrijding ervan geen consequenties konden worden verbonden, werd hiermee (te) veel druk op de verdediging gelegd om actief mee te werken aan een snelle en efficiënte behandeling van de zaak. Een dergelijke regel is moeilijk verenigbaar met het recht van verdachte zijn verdediging zelf in te vullen (waaronder het recht zich niet te verdedigen). Vandaar dat voorafgaand aan de totstandkoming van het nieuwe wetboek van strafvordering in de literatuur voor afschaffing van genoemd artikellid werd

betreurt dat van dit belangrijke recht zo weinig gebruik wordt gemaakt.

21 De zittingsrechter zou de verdachte bijvoorbeeld kunnen houden aan ingenomen standpunten of weergaven van feiten zoals ze in de schriftelijke reactie zijn vastgelegd, bron: gesprek Hermeliński, januari 2007 Warschau.

22 Art. 338 lid 1 eerste zin KPK 1997.

23 Dat in de akte van beschuldiging melding wordt gemaakt van het bewijsmateriaal dat door de vervolging op de zitting zal worden gepresenteerd, is wettelijk voorgeschreven (art. 333 lid 1 KPK 1997).

24 Hofmański e.a. 2007 II, p. 280. Zie ook Wiliński 2006, p. 573: 'Het indienen van bewijsverzoeken heeft slechts organisatorische betekenis, aangezien ze in dit stadium nog niet door de rechtbank zullen worden beoordeeld.'

25 Het spreekt voor zich dat het bepalen van het juiste moment in de meeste gevallen een kwestie van verdedigingstactiek zal zijn en derhalve niet door procesorganen mag worden beïnvloed: Grajewski 2005, p. 146-147.

26 Art. 302 lid 2 KPK 1969. 
gepleit. ${ }^{27}$ Aan deze kritiek is gehoor gegeven en de bepaling is niet behouden in het nieuwe strafprocesrecht.

Over de mate waarin in de praktijk gebruik wordt gemaakt van deze mogelijkheid om bewijsverzoeken in te dienen voorafgaand aan het onderzoek ter terechtzitting zijn helaas geen statistische gegevens beschikbaar. Zowel onder advocaten als onder rechtswetenschappers bestaat echter de indruk dat de meeste advocaten er de voorkeur aan geven pas bewijsverzoeken in te dienen wanneer het onderzoek ter terechtzitting eenmaal is aangevangen. ${ }^{28}$

\subsection{Zittingen voorafgaand aan onderzoek ter terechtzitting}

In de periode na indiening van de akte van beschuldiging en voor aanvang van het onderzoek ter terechtzitting kunnen verschillende belangrijke beslissingen worden genomen door de rechter. ${ }^{29}$ In een groot aantal gevallen gebeurt dat op een zitting (rozprawa) die anders dan het onderzoek ter terechtzitting (posiedzenie) niet openbaar is. ${ }^{30}$ Omdat de beslissingen die op dit soort zittingen worden genomen de positie van de verdachte aanzienlijk kunnen beïnvloeden, ${ }^{31}$ is het voor de verdediging van groot belang hierbij aanwezig te kunnen zijn. De mogelijkheden voor de verdediging om deel te nemen aan deze zittingen zijn de laatste jaren aanzienlijk uitgebreid. Voor een duidelijk beeld van de vooruitgang op dit punt zal eerst aandacht worden besteed aan de situatie onder het oude strafprocesrecht.

\subsubsection{Situatie voor inwerkingtreding nieuw strafprocesrecht}

Op grond van het oude wetboek van strafvordering waren de mogelijkheden voor de verdediging om deel te nemen aan zittingen in de voorbereidende fase voorafgaand aan het onderzoek ter terechtzitting uiterst beperkt. De wetgever had in dit opzicht een duidelijk onderscheid gemaakt tussen de prokurator en de verdediging door te bepalen dat

- de prokurator te allen tijde het recht had deel te nemen aan zittingen (buiten het onderzoek ter terechtzitting om) terwijl

- alle andere partijen slechts mochten deelnemen wanneer de wet dat uitdrukkelijk bepaalde. ${ }^{32}$

Dat laatste - toekenning van een expliciet aanwezigheidsrecht - was slechts in een beperkt aantal gevallen gebeurd waardoor de prokurator op dit punt werd bevoordeeld ten opzichte van de verdediging. ${ }^{33}$ Een van de weinige zittingen waaraan de

27 Kruszyński 1991, p. 215.

28 Informatie verkregen van Gwirdoyń, Wąsek-Wiaderek en Kruszyński, juni 2008.

29 Zie ook hoofdstuk 2, § 3.2.2.1.

30 Verwijzing naar de zitting is - afhankelijk van het onderwerp waarover moet worden beslist - verplicht of facultatief. Zie voor de gevallen van verplichte verwijzing: Grajewski 2005, p. 148. Verwijzing kan ook op verzoek van de verdediging plaatsvinden.

31 Denk aan de beslissing over voorwaardelijke beëindiging van de procedure of tot veroordeling zonder onderzoek ter terechtzitting. Wanneer de rechter instemt met een verzoek tot voorwaardelijke beëindiging van de procedure of veroordeling zonder onderzoek ter terechtzitting wordt de zaak zelfs op de zitting in de voorbereidende fase afgedaan.

32 Art. 88 KPK 1969.

33 Hierbij dient echter wel te worden opgemerkt dat het aantal gevallen waarin de rechter de 
verdediging buiten het onderzoek ter terechtzitting om mocht deelnemen was die waarop over de voorwaardelijke beëindiging van de procedure werd beslist. ${ }^{34}$ Wanneer de zaak in de voorbereidende fase naar de zitting moest worden verwezen voor een andere kwestie - zoals een beslissing over toepassing van voorlopige hechtenis of beëindiging van de procedure vanwege het feit dat de beschuldiging overduidelijk ongegrond was - kon alleen de prokurator daaraan deelnemen. ${ }^{35}$ Deze situatie werd in de literatuur bekritiseerd. ${ }^{36}$ Kruszyński pleitte er ten tijde van het oude strafprocesrecht voor het deelnamerecht van de verdediging - dat volgens hem slechts om redenen van efficiëntie zo beperkt in omvang was - in ieder geval uit te strekken tot alle zittingen waarop een voor verdachte nadelige beslissing zou kunnen worden genomen. ${ }^{37}$

\subsubsection{Huidig juridisch kader}

Bovengenoemde kritiek heeft aanvankelijk niet tot grootschalige veranderingen geleid. Bij de totstandkoming van het nieuwe wetboek van strafvordering werd nauw aangesloten bij de oude regeling. De twee hoofdregels (prokurator altijd recht op deelname, verdediging alleen in geval van expliciet wettelijk recht) bleven behouden met de toevoeging dat andere partijen dan de prokurator - waaronder de verdediging - hun standpunt ook schriftelijk kenbaar konden maken. ${ }^{38}$ Laatstgenoemde aanvulling had echter niet of nauwelijks toegevoegde waarde omdat partijen altijd de mogelijkheid hebben hun visie schriftelijk aan de rechter kenbaar te maken. ${ }^{39}$ Het aantal gevallen waarin de wetgever de verdediging het recht toekende om deel te nemen aan specifieke zittingen werd in het nieuwe wetboek wel aanzienlijk uitgebreid. ${ }^{40}$

Zes jaar na de inwerkingtreding van het nieuwe strafprocesrecht is de ongelijkheid tussen prokurator en verdediging op dit punt alsnog definitief opgeheven.

zaak in de voorbereidende fase naar de zitting moest verwijzen onder het oude wetboek van strafvordering kleiner was dan op grond van het huidige strafprocesrecht. De voorbereidende fase heeft in het nieuwe wetboek van strafvordering meer betekenis gekregen. beschuldiging waaraan de verdediging op grond van art. 88 en 299 KPK 1969 niet mocht deelnemen. Kruszyński benadrukte daarbij dat een behandeling op tegenspraak de waarheidsvinding en dus de betrouwbaarheid van de uitspraak ten goede zou komen: Kruszyński 1991, p. 214.

38 Zo was bepaald in het oorspronkelijke art. 96 KPK 1997 - de opvolger van art. 88 KPK 1969.

39 Dat de introductie van het nieuwe wetboek van strafvordering niet was benut om de ongelijkheid tussen prokurator en verdediging op dit punt definitief tot het verleden te laten behoren, stuitte op veel kritiek in de literatuur. Zie bijvoorbeeld Bieńkowska die in dit verband heeft opgemerkt dat de 'correctie op het oude art. 88 ontoereikend lijkt te zijn': Bieńkowska 1997, p. 63.

40 De belangrijkste categorie gevallen is opgenomen in art. 339 KPK 1997. Op genoemde bepaling wordt hierna nog teruggekomen. Meer uitgebreid over de groei van het aantal mogelijkheden voor de verdediging om deel te nemen aan zittingen buiten het onderzoek ter terechtzitting om (op grond van het huidige strafprocesrecht): Wąsek-Wiaderek 2003 II, p. 309 e.v. en Czechowicz 1998, p. 77-80. 
Sinds de wetswijziging van 2003 gelden ten aanzien van alle zittingen die buiten het onderzoek ter terechtzitting om worden gehouden voor alle partijen dezelfde twee hoofdregels:

- partijen hebben het recht deel te nemen aan zittingen wanneer de wet dat bepaalt tenzij hun deelname verplicht is en

- in overige gevallen hebben ze - tenzij de wet anders bepaalt - het recht deel te nemen aan de zitting 'wanneer ze verschijnen'. ${ }^{41}$

Voor beantwoording van de vraag of de verdediging het recht heeft deel te nemen aan een zitting dient dus eerst te worden bekeken of de wetgever dat in een aparte bepaling expliciet heeft geregeld. Indien dat niet is gebeurd, geldt de tweede regel en heeft de verdediging het recht deel te nemen wanneer ze op de betreffende zitting verschijnt. ${ }^{42}$ Belangrijk verschil is dat procesorganen in laatstgenoemd geval niet verplicht zijn de verdediging op de hoogte te stellen van de datum en het tijdstip waarop de zitting zal plaatsvinden. ${ }^{43}$ Het is voor de verdediging dus gunstiger wanneer haar aanwezigheidsrecht expliciet door de wet is geregeld.

Een uitdrukkelijk recht tot deelname geldt onder meer voor zittingen waarop wordt beslist over: 44

- toepassing van beschermende maatregelen (środki zabezpieczające) zoals plaatsing in een psychiatrische inrichting,

- voorwaardelijke beëindiging van de procedure,

- veroordeling zonder onderzoek ter terechtzitting,

- beëindiging van de procedure omdat de feitelijke grondslag voor de beschuldiging overduidelijk ontbreekt of op een van de andere wettelijke gronden ${ }^{45}$ en

- toepassing van voorlopige hechtenis of een andere preventieve maatregel. ${ }^{46}$

41 Deze regels zijn ook van toepassing op personen die geen partij zijn voor zover hun deelname aan de zitting van belang is voor de bescherming van hun rechten of belangen. Deze categorie zal hier verder buiten beschouwing worden gelaten.

42 Dit alles behoudens de door de wet gestelde uitzonderingen: voor sommige zittingen is bepaald dat ze in afwezigheid van (alle) partijen dienen plaats te vinden Voor geen van de zittingen die alleen in de voorbereidende fase kunnen plaatsvinden, heeft de wetgever een dergelijke uitzondering gecreëerd. Voorbeelden van zittingen die in afwezigheid van partijen moeten worden gehouden, zijn: de zitting waarop wordt beslist over de noodzaak een getuige als anonieme getuige aan te merken of wanneer de rechter een spoedbevel van de prokurator tot afluisteren en opnemen van telefoongesprekken moet goedkeuren.

43 Art. 117 lid 1 KPK 1997 a contrario ('Degene die het recht heeft aan een proceshandeling deel te nemen, dient te worden geïnformeerd over waar en wanneer deze handeling zal plaatsvinden').

44 De hierna volgende opsomming is zeker niet limitatief. Voor een volledige weergave wordt verwezen naar: Grzegorczyk 2004, p. 329-330.

45 Deze ('andere wettelijke') gronden zijn opgenomen in art. 17 lid 1 sub 2 tot en met $11 \mathrm{KPK}$ 1997. Voorbeelden zijn: het overlijden van verdachte of de constatering dat het tenlastegelegde feit een onbeduidend maatschappelijk gevaar oplevert en dus niet kan worden vervolgd.

46 Art. 339 lid 5, art. 341 lid 1 en art. 343 lid 5 KPK 1997. In een aantal van deze gevallen geldt voor de verdachte of de raadsman zelfs een plicht tot deelname: zo is deelname van de verdachte aan zittingen over voorwaardelijke beëindiging of veroordeling zonder onderzoek ter terechtzitting verplicht wanneer de rechter dat noodzakelijk acht. Deelname van de raadsman is verplicht wanneer over de toepassing van bepaalde beschermende maat- 
In de praktijk is de voorwaardelijke beëindiging van de procedure de belangrijkste categorie: het merendeel van de zittingen in de voorbereidende fase heeft betrekking op deze beslissing. Een dergelijke behandeling kan ook op verzoek van de verdediging plaatsvinden wat in de praktijk ook regelmatig gebeurt. ${ }^{47}$ Voorbeelden van zittingen waarvoor geen expliciete regeling is getroffen, zijn: de zittingen waarop wordt uitgesproken dat de rechtbank in de betreffende zaak geen rechtsmacht heeft of wordt besloten de zaak terug te sturen naar de prokurator om tekortkomingen in het vooronderzoek te herstellen. Ook voor de 'regiezittingen' die in het tweede stadium van de voorbereidende fase kunnen worden gehouden, geldt de regel dat partijen niet hoeven te worden opgeroepen maar mogen deelnemen wanneer ze op de zitting verschijnen. ${ }^{48}$

In bovengenoemde bepalingen waarin het recht tot deelname is geregeld, worden overigens verschillende formuleringen gebruikt: in sommige artikelen wordt het deelnamerecht alleen aan de verdachte toegekend terwijl in andere ook de raadsman wordt genoemd. Voor de praktijk maakt dit echter geen verschil omdat de raadsman zijn recht tot deelname in eerstgenoemde situaties aan zijn cliënt ontleent (in plaats van rechtstreeks aan de wet). Deze redenering kan echter niet worden omgedraaid: wanneer het recht tot deelname alleen aan de raadsman wordt toegekend - zoals in art. 249 lid 5 KPK 1997 ten aanzien van de zitting waarop over de verlenging of het bezwaar tegen de voorlopige hechtenis wordt beslist - heeft de verdachte geen recht om aan de zitting deel te nemen. ${ }^{49}$

\subsection{Conclusie}

In de fase tussen sluiting van het vooronderzoek en aanvang van het onderzoek ter terechtzitting kunnen zich belangrijke - en soms zelfs bepalende - procesmomenten voordoen. Het nieuwe strafprocesrecht biedt de verdediging op verschillende manieren meer mogelijkheden om op die momenten een rol van betekenis te spelen. De mogelijkheid om reeds voor aanvang van het onderzoek ter terechtzitting te reageren op de akte van beschuldiging stelt de verdediging in staat de rechter in een vroeg stadium van de procedure met haar standpunten te confronteren en kan zodoende een bijdrage leveren aan het contradictoire karakter van het eindonderzoek. In de praktijk blijkt dit verdedigingsrecht echter een uiterst beperkte betekenis te hebben. Hetzelfde geldt voor de mogelijkheid voorafgaand aan het onderzoek ter terechtzitting bewijsverzoeken in te dienen. Belangrijker is dat de mogelijkheden van de verdediging om deel te nemen aan zittingen in de voorbereidende fase aanzienlijk zijn toegenomen ten opzichte van het wetboek van strafvordering van 1969. Op grond van het oude strafprocesrecht gold voor het gros van deze zittingen alleen een recht tot deelname voor de prokurator waardoor de verdediging in veel gevallen - waarin wel degelijk voor de verdachte belangrijke beslissingen konden worden genomen - buiten spel werd gezet. Deze situatie verbeterde enigszins met de totstandkoming van het nieuwe wetboek

regelen - zoals opname in een psychiatrische inrichting - moet worden beslist.

47 Bron: gesprek Hermeliński, januari 2007 Warschau. Voorwaardelijke beëindiging kan overigens ook nog na aanvang van het onderzoek ter terechtzitting plaatsvinden (art. 414 KPK 1997).

48 Art. 96 lid 2 KPK 1997. Zie hierover ook Bieńkowska e.a. 2004, p. 358.

49 Zie hierover ook hoofdstuk 5, § 4. 
van strafvordering maar heeft met de wetswijziging van 2003 pas echt een metamorfose ondergaan. De verdediging kan behoudens een klein aantal wettelijke uitzonderingen voortaan deelnemen aan alle zittingen en bovendien is het aantal gevallen waarin ze vanwege een expliciet recht op deelname over de zittingsdatum moet worden geïnformeerd verder uitgebreid. De ongelijkheid die op dit punt bestond tussen prokurator en verdediging is hiermee tot het verleden gaan behoren.

\section{Consensuele afdoening}

De Poolse strafrechtspleging is sinds de inwerkingtreding van het nieuwe wetboek van strafvordering steeds meer gebruik gaan maken van alternatieve methoden voor de afhandeling van strafzaken die sterke overeenkomsten vertonen met het typisch Anglo-Amerikaanse verschijnsel van plea bargaining..$^{50}$ Deze ontwikkeling - die overigens niet alleen in Polen maar ook in andere Europese rechtssystemen kan worden waargenomen ${ }^{51}$ - is onlosmakelijk verbonden met de overbelasting van de strafrechtspleging en de wens om zaken sneller en efficiënter af te doen. ${ }^{52}$ Behalve de mogelijkheid tot voorwaardelijke beëindiging van de procedure (art. 336 KPK 1997) en het beperken van de bewijsvoering op het onderzoek ter terechtzitting (art. 388 KPK 1997) - welke ook reeds in het oude strafprocesrecht bestonden - kan de verdachte op grond van het nieuwe wetboek van strafvordering onder bepaalde voorwaarden op verzoek van de prokurator worden veroordeeld zonder onderzoek ter terechtzitting (art. 335 KPK 1997) of instemmen met een bepaalde straf zonder bewijsvoering ter terechtzitting (art. 387 KPK 1997)..$^{53}$ Inwilliging van een verzoek op grond van art. 335 KPK 1997 is aan bepaalde voorwaarden verbonden: het is alleen mogelijk in geval van een strafbaar feit (wystepek) waarop maximaal tien jaar gevangenisstraf staat, wanneer de omstandigheden waaronder het strafbaar feit is gepleegd geen reden tot twijfel geven en uit de houding van verdachte - die met het verzoek moet instemmen - blijkt dat de doelstellingen van de strafrechtelijke procedure ook op deze alternatieve wijze kunnen worden bereikt. ${ }^{4}$ Voor de verdachte heeft de art. 335-procedure het voordeel dat

50 Zie hoofdstuk 2, § 2.3.3.2.

51 Toenemende aandacht voor alternatieve, consensuele procedures kan de laatste jaren onder meer worden gesignaleerd in Nederland, Spanje, Italië, Frankrijk en België.

52 Zie Bieńkowska 1997, p. 55.

53 Zie over genoemde alternatieve wijzen van afdoening onder meer: Stefański 2003, Ważny 2004, Kruk 2005 en Steinborn 2005. De legitimiteit van de consensuele procedures is in de Poolse literatuur veelvuldig onderwerp van discussie geweest: belangrijkste punt van kritiek is dat bestraffing zonder dat de schuld in een volwaardig strafproces is komen vast te staan op gespannen voet staat met het vermoeden van onschuld: zie Hofmański en Zabłocki 2008. Met de invoering van het wetboek van strafvordering van 1997 is ook mediation (mediacja) in het Poolse strafproces geïntroduceerd. Deze procedure zal hier verder buiten beschouwing worden gelaten. Ook de kroongetuige - waarvoor eveneens sinds 1997 een wettelijke regeling bestaat - kan tot de consensuele methoden van afdoening worden gerekend: door het afleggen van een belastende verklaring over een andere verdachte kan de kroongetuige immers onderhandelen over zijn eigen straf of zelfs straffeloos blijven. Op de kroongetuige wordt teruggekomen in §4.4.3.3.

54 De reikwijdte van art. 335 KPK 1997 is met de wetswijziging van 2003 aanzienlijk ruimer geworden. Belangrijkste wijziging is dat het bereik van de regeling is uitgebreid van feiten waarop maximaal vijf jaar gevangenisstraf staat tot feiten die met maximaal tien jaar 
een mildere sanctie zal worden opgelegd dan hoogstwaarschijnlijk na een volledig onderzoek ter terechtzitting zou volgen. Het verzoek van de prokurator wordt in de voorbereidende fase ${ }^{55}$ door de rechtbank beoordeeld tijdens een zitting waaraan de verdediging mag deelnemen. ${ }^{56}$

Ingevolge art. 387 lid 1 KPK 1997 kan een verdachte die wordt beschuldigd van een minder ernstig strafbaar feit (wystepek) verzoeken zonder bewijsvoering ter zitting te worden veroordeeld tot een bepaalde straf of maatregel. ${ }^{57}$ De rechtbank kan een dergelijk verzoek alleen inwilligen wanneer de omstandigheden waaronder het strafbaar feit is gepleegd geen reden tot twijfel geven, de doelstellingen van het strafproces ook zonder de bewijsvoering ter zitting kunnen worden bereikt en indien de prokurator en het eventuele slachtoffer geen bezwaar hebben tegen het volgen van een dergelijke verkorte procedure.

De mogelijkheid de bewijsvoering ter terechtzitting slechts gedeeltelijk te laten plaatsvinden (art. 388 KPK 1997) staat open wanneer de aanwezige partijen - waaronder de verdachte zelf - daarmee instemmen en wanneer de verklaringen van de bekennende verdachte geen aanleiding tot twijfel geven. ${ }^{58}$ Gevolg van een dergelijke beslissing is bijvoorbeeld dat minder getuigen ter terechtzitting zullen worden gehoord dan normaal gesproken het geval zou zijn. ${ }^{59}$

\subsection{Rol van de verdediging}

Bovengenoemde afdoeningsmodaliteiten zijn alle gebaseerd op overeenstemming: de verdachte dient met de afwijkende gang van zaken in te stemmen en in geval van veroordeling zonder onderzoek ter terechtzitting zelfs het initiatief ertoe te nemen. ${ }^{60}$ De genoemde procedures hebben behalve (vereiste) instemming van

gevangenisstraf worden bedreigd. Uitgebreider over de punten waarop het artikel is aangepast: Hofmański e.a. 2007 II, p. 351-252.

55 Zie hiervoor $\S 2$.

56 Art. 339 lid 1 sub 3 en 5 KPK 1997. Tijdens deze zitting wordt slechts bekeken of aan de voorwaarden van art. 335 is voldaan: de zaak wordt dus niet inhoudelijk onderzocht. De rechtbank is niet gebonden aan het verzoek van de prokurator en kan besluiten de zaak alsnog naar het onderzoek ter terechtzitting te verwijzen. Wanneer wel met het verzoek wordt ingestemd, zal ook de door de prokurator voorgestelde sanctie moeten worden opgelegd: de rechtbank kan daar niet van af wijken. Zie Stefański 1998 I, p. 56.

57 Een dergelijk verzoek is mogelijk tot aan het einde van het verhoor van alle (mede) verdachten Ook de regeling van art. 387 KPK is in 2003 uitgebreid. Voor de wetswijziging van juli 2003 stond de mogelijkheid alleen open voor feiten waarop maximaal acht jaar gevangenisstraf stond. Dit strafmaximum is komen te vervallen waardoor veroordeling zonder bewijsvoering ter terechtzitting mogelijk is bij verdenking van elk (minder ernstig) strafbaar feit (występek). Uitgebreider over alle punten waarop de regeling is aangepast: Hofmański e.a. 2007 II, p. 437.

58 Uit de rechtspraak van het Hooggerechtshof blijkt dat de bekennende verklaring van verdachte wel op het onderzoek ter terechtzitting moet zijn afgelegd: voorlezen van een verklaring uit het vooronderzoek is onvoldoende. De procedure van art. $388 \mathrm{KPK}$ 1997 staat niet open wanneer de ter terechtzitting afgelegde verklaring afwijkt van een verklaring die in het vooronderzoek is afgelegd: Hofmański e.a. 2007 II, p. 446-447 en daar genoemde rechtspraak.

59 Over de mogelijkheden van art. 387 en 388 KPK 1997: hoofdstuk 2, § 2.3.3.2.

60 Een dergelijke veroordeling is slechts mogelijk op verzoek van verdachte: art. 387 lid 1 KPK 1997. 
partijen ook gemeen dat geen twijfel mag bestaan over de schuldvraag. ${ }^{61}$ Dit betekent dat de positie van de verdediging anders is dan in een gewone strafrechtelijke procedure waar de vraag of de verdachte het tenlastegelegde feit heeft begaan nog ter discussie staat. Juist om die reden is rechtsbijstand en een actieve opstelling van de verdediging in consensuele procedures van groot belang. ${ }^{62}$ Door het aangaan van een overeenkomst ziet de verdachte immers af van een volledige behandeling van zijn strafzaak door een onpartijdige rechter en dus ook van alle mogelijkheden die een procedure op tegenspraak hem biedt. Een van de belangrijkste taken van de raadsman in dit verband is dan ook om de verdachte goed in te lichten over de consequenties van een dergelijke beslissing. Bovendien kan een advocaat zijn cliënt helpen in te schatten wat de uitkomst van een volledige behandeling zou zijn en dus of - en zo ja tot op welke hoogte - het aangaan van een overeenkomst en het accepteren van een bepaalde straf in zijn voordeel is. Ondanks de belangrijke bijdrage(n) die de raadsman in dit verband kan leveren, is rechtsbijstand in geen van bovengenoemde gevallen van consensuele afdoening dwingend voorgeschreven. ${ }^{63}$ De verdachte kan dus ook zonder advocaat aan de onderhandelingen deelnemen. Slechts in één geval is een mogelijkheid voor toevoeging van rechtsbijstand gecreëerd: wanneer de verdachte een verzoek tot veroordeling zonder bewijsvoering op het onderzoek ter terechtzitting indient, kan de rechter op zijn verzoek een advocaat toevoegen. ${ }^{64}$ Het gebruik van het woord ' $k a n$ ', impliceert dat de rechter op dit punt beslissingsvrijheid heeft: hij is niet verplicht het verzoek van verdachte in te willigen. ${ }^{65}$ Deze toevoeging betreft een vorm van ad hoc rechtsbijstand: de advocaat staat de verdachte bij tijdens de

61 Art. 335 KPK 1997: over 'de omstandigheden waaronder het feit is begaan' en 'de verklaring van de verdachte' mag geen twijfel bestaan, zie art. 387: 'de omstandigheden waaronder het feit is begaan' mogen geen reden tot twijfel geven en art. 388: over 'de verklaring van de verdachte die schuld heeft bekend' mag geen twijfel bestaan. Ten aanzien van laatstgenoemde bekentenis in het kader van art. 388 geldt overigens dat deze ter terechtzitting moet worden afgelegd: voorlezen van een eerder in de procedure afgelegde verklaring is niet voldoende: Grzegorczyk 2004, p. 992 en daar genoemde rechtspraak van het Hooggerechtshof. Voor de modaliteiten genoemd in art. 335 en 387 is overigens niet vereist dat verdachte heeft bekend: dat geen twijfel bestaat 'over de omstandigheden waaronder het feit is begaan' kan in die gevallen ook uit ander bewijsmateriaal blijken: Stefański 1998 I, p. 49 e.v.

62 Niet voor niets is bijstand van een raadsman bij het aangaan van een plea bargain in de Verenigde Staten in de regel verplicht. Over de rol van de verdediging bij het aangaan van dit soort 'overeenkomsten' en onderhandelingen met de prokurator: Gwirdoyń 2004, p. 133-147.

63 Onder welke omstandigheden bijstand van een raadsman wel verplicht is, is eerder besproken in hoofdstuk 4, § 3.1.1.

64 Art. 387 lid 1 KPK 1997. De rechter dient de verdachte over deze mogelijkheid in te lichten wanneer duidelijk is dat rechtsbijstand in het concrete geval noodzakelijk is en de verdachte niet op de hoogte is van zijn recht om een dergelijk verzoek in te dienen.

65 In de literatuur wordt echter benadrukt dat de rechter op dit punt slechts een beperkte beoordelingsvrijheid heeft en dat verzoeken om toevoeging slechts in een beperkt aantal - objectief te bepalen - gevallen zouden mogen worden geweigerd, zoals wanneer de verdachte nog geen verzoek tot veroordeling zonder bewijsvoering ter terechtzitting heeft ingediend, wanneer het verzoek te laat is ingediend of wanneer de verdachte reeds over een gekozen of toegevoegde raadsman beschikt. Zie Kulesza 2005, p. 438-439. 
behandeling van zijn verzoek. Wanneer het verzoek wordt afgewezen, komt de grondslag voor de toevoeging automatisch te vervallen. ${ }^{66}$

De wetgever heeft ten aanzien van de mogelijkheid tot veroordeling zonder onderzoek ter terechtzitting (art. 335) en het overslaan van een deel van de bewijsvoering op de terechtzitting (art. 388) niet in een soortgelijke mogelijkheid tot toevoeging voorzien. Dat terwijl het in eerstgenoemd geval toch om strafbare feiten kan gaan waar een gevangenisstraf van maximaal tien jaar op staat en de overeen te komen straf dus ook van aanzienlijke omvang kan zijn. ${ }^{67}$

\subsubsection{Deelname aan zittingen}

Wat de deelname van de verdediging aan zittingen in het kader van art. 335, 387 of 388 betreft, geldt voor de twee laatstgenoemde gevallen dat de gewone regels van het onderzoek ter terechtzitting van toepassing zijn. Deze twee mogelijkheden worden immers te allen tijde op het onderzoek ter terechtzitting (rozprawa) behandeld. ${ }^{68}$ De verdediging kan zonder beperkingen deelnemen aan deze - in beginsel openbare - zitting: uitgangspunt is dat de verdachte zelfs verplicht is ter terechtzitting te verschijnen. ${ }^{69}$

De behandeling van het verzoek de verdachte zonder onderzoek ter terechtzitting te veroordelen, gebeurt echter niet op het onderzoek ter terechtzitting. Dit verzoek wordt door de prokurator in de akte van beschuldiging opgenomen en de rechter dient de zaak in zo'n geval in de fase voorafgaand aan het onderzoek ter terechtzitting naar de zitting te verwijzen. ${ }^{70}$ De verdediging heeft op grond van art. 339 lid 5 KPK 1997 het recht aan een dergelijke zitting deel te nemen en dient dus ook van de zittingsdatum op de hoogte te worden gesteld. ${ }^{71}$ Wanneer de rechter dat noodzakelijk acht, kan deelname van de verdachte zelfs verplicht zijn. ${ }^{72}$

\subsubsection{Het standpunt van de raadsman}

Aangezien de drie genoemde alternatieve procedures alleen met instemming van verdachte kunnen plaatsvinden, is het van belang te bekijken welke rol de raadsman in de onderhandelingen speelt. Kan de raadsman namens de verdachte instemmen en wat dient er te gebeuren wanneer de verdachte en zijn raadsman van mening verschillen over de te volgen procedure?

66 Grzegorczyk 2004, p. 986. De verdachte hoeft voor dit soort toevoegingen niet aan te tonen dat hij niet in staat is zelf in de kosten van de rechtsbijstand te voorzien: zie ook hoofdstuk 4, § 3.1.3.3.

67 Zie hierover ook Wiliński 2006, p. 575 en daar genoemde literatuur.

68 Ook wanneer de verdachte zijn verzoek tot veroordeling zonder onderzoek ter terechtzitting in een eerder stadium - bijvoorbeeld in het kader van de schriftelijke reactie op de akte van beschuldiging - indient, wordt een en ander op het onderzoek ter terechtzitting besproken (art. 387 lid 5 KPK 1997).

69 Meer over de verplichte aanwezigheid van verdachte hierna in $\S 4.2$.

70 Zie $\$ 3$.

71 Over de deelname van partijen aan zittingen waarop over consensuele afdoening wordt beslist: Steinborn 2005, p. 212-224. Steinborn benadrukt dat het van groot belang is dat de verdediging gebruik maakt van het recht aanwezig te zijn bij dit soort zittingen zodat de rechter zich goed kan informeren voordat over de alternatieve afdoening wordt beslist: Steinborn 2005, p. 213. Zie in gelijke zin ook Kruk 2005, p. 117.

72 Art. 343 lid 5 tweede zin KPK 1997. 
Wat de eerste vraag betreft, geldt dat in het kader van art. 335 en 388 ondubbelzinnig moet blijken dat de verdachte zelf met de alternatieve afdoening instemt. ${ }^{73}$ Dit kan blijken door een verklaring die hij mondeling ter zitting aflegt of door een schriftelijk stuk dat wel door een advocaat mag worden opgesteld maar te allen tijde door verdachte moet zijn ondertekend. ${ }^{74}$ Een verzoek op grond van art. 387 KPK 197 kan alleen door de verdachte worden ingediend: ook dit kan plaatsvinden door een schriftelijk stuk dat door de raadsman is opgesteld zolang het maar door de verdachte is ondertekend. ${ }^{75}$

Over de tweede kwestie - wat dient te gebeuren wanneer advocaat en verdachte het niet eens zijn over de vraag of een alternatieve procedure moet worden gevolgd - bestaat in de Poolse literatuur discussie. In het kader van art. 335 en 388 KPK 1997 - kunnen twee situaties worden onderscheiden: enerzijds het geval waarin de verdachte wel instemt en de raadsman bedenkingen heeft en anderzijds de situatie waarin de verdachte geen toestemming geeft maar de raadsman wel voorstander is van een alternatieve afdoening. ${ }^{76}$ Over laatstgenoemd geval bestaat eensgezindheid: zonder instemming van verdachte kunnen de procedures van art. 335 en art. 388 KPK niet worden gevolgd. ${ }^{77}$ Ten aanzien van de eerste situatie - de verdachte stemt in maar de raadsman heeft bedenkingen - bestaat wel verschil van mening. Volgens Koper dient de prokurator in het kader van art. 335 KPK 1997 waarde te hechten aan het standpunt van de raadsman: het feit dat hij zich tegen alternatieve afdoening verzet, geeft aan dat hij een reële kans aanwezig acht dat een normale procedure een gunstig(er) resultaat voor zijn cliënt zou kunnen hebben. Om die reden zou de prokurator er in zo'n geval van af moeten zien een verzoek op grond van art. 335 KPK 1997 in te dienen bij de rechtbank. ${ }^{78}$

73 Zie onder meer Stefański 2003, p. 23 en Steinborn 2005, p. 241. Dit wordt ook benadrukt door de wettekst: art. 335 lid 1 regelt dat een en ander slechts plaats kan vinden 'met instemming van verdachte' ('uzgodnionych z oskarżonym') - de raadsman wordt niet genoemd - en art. 388 lid 1 bepaalt dat bewijsvoering slechts gedeeltelijk kan plaatsvinden 'met instemming van aanwezige partijen' ('za zgoda obecnych stron'). Zoals bekend wordt de raadsman niet als (proces)partij beschouwd - zie hoofdstuk $3, \S 3.3$.

74 Het is de vraag of - en zo ja, onder welke voorwaarden - een raadsman ter zitting namens zijn afwezige cliënt mondeling mag instemmen met een afdoening op grond van art. 335 of 388 KPK. Gelet op de ratio van het instemmingsvereiste, het feit dat een (door de raadsman opgestelde) schriftelijke instemming door verdachte moet zijn ondertekend en het algemene voorschrift dat de raadsman alleen in het voordeel van zijn cliënt mag handelen, dient er mijns inziens vanuit te worden gegaan dat de raadsman alleen maar namens zijn cliënt mag instemmen wanneer hij daartoe - blijkens een schriftelijk stuk - uitdrukkelijk is gemachtigd.

75 Hofmański e.a. 2007 II, p. 441.

76 Anders is het bij de procedure van art. 387 KPK 1997 die alleen gevolgd kan worden op verzoek van verdachte. Het initiatief ligt bij de verdediging en op het moment dat een verzoek - door de verdachte zelf of namens hem door zijn raadsman - wordt ingediend, is de vraag naar eventuele meningsverschillen tussen advocaat en cliënt in beginsel niet meer relevant.

77 Onder meer: Koper 2001, p. 8-9 en Stefański 2003, p. 23. Dit betekent in geval van art. 335 KPK 1997 dat de prokurator geen verzoek tot veroordeling zonder onderzoek ter terechtzitting bij de rechtbank kan indienen.

78 Koper 2001, p. 8-9. Koper verwijst in dit verband naar Kruszyński die ten aanzien van vergelijkbare problematiek in het kader van art. 388 KPK 1997 hetzelfde standpunt heeft ingenomen: de visie van de raadsman dient in aanmerking te worden genomen. 
Stefański is echter een andere mening toegedaan: hij is van oordeel dat het standpunt van de verdachte altijd doorslaggevend moet zijn - ook wanneer het afwijkt van het standpunt van de raadsman. ${ }^{79}$ Ook Steinborn vindt dat de procedure van art. 335 KPK 1997 wel doorgang kan vinden wanneer de verdachte vóór en de raadsman tegen is. ${ }^{80}$ Steinborn en Stefański benadrukken mijns inziens terecht dat het standpunt van de verdachte in dezen altijd het zwaarst zal moeten wegen. Wanneer zoals Koper voorstelt, voorrang wordt verleend aan de mening van de raadsman is de verdachte niet langer in staat zijn eigen procespositie te bepalen en wordt hem een mogelijkheid onthouden die hij zelf graag zou benutten. Hoe nobel de bedoelingen van de raadsman in een concreet geval ook mogen zijn, ${ }^{81}$ een dergelijke gang van zaken is onverenigbaar met de zelfstandige en onafhankelijke positie die de verdachte in zijn eigen strafzaak moet kunnen innemen en met het recht zich zelf te verdedigen.

\subsection{Conclusie}

Met de opkomst van consensuele procedures in het Poolse strafproces is ook het belang van de voorbereidende fase - waarin vaak over alternatieve afdoening wordt beslist - toegenomen. Dit is een belangrijke ontwikkeling die nieuwe eisen stelt aan en uitdagingen vormt voor de verdediging. ${ }^{82}$ Door de opkomst van alternatieve afdoeningen wordt door vervolging en verdediging steeds meer buiten het onderzoek ter terechtzitting om onderhandeld wat een gunstig effect kan hebben op hun onderlinge verhouding. Mogelijk dat dit de samenwerking in reguliere strafzaken

Zie Kruszyński 1991, p. 496.

79 Dit vloeit volgens hem voort uit de positie die de raadsman in het strafproces inneemt: omdat hij slechts naast en niet in plaats van zijn cliënt optreedt, dient bij verschil van mening voorrang te worden verleend aan het standpunt van verdachte: Stefański 2003, p. 23. Zie over de verhouding tussen raadsman en cliënt: hoofdstuk 3 , $\$ 3.2 .3$ e.v.

80 Steinborn 2005, p. 241. Hij benadrukt echter dat de rechtbank bij de behandeling van het verzoek van de prokurator vervolgens wel bijzondere aandacht zal moeten besteden aan de bezwaren van de raadsman.

81 Doorgaans zal de raadsman geen persoonlijk belang hebben bij de keuze voor een alternatieve of reguliere wijze van afdoening en zijn standpunt slechts baseren op basis van (juridisch) inhoudelijke argumenten. Voor advocaten die op toevoegingsbasis optreden, heeft genoemde beslissing echter wel financiële gevolgen: voor een zaak die op alternatieve wijze is afgedaan, is de vergoeding lager dan wanneer een 'volwaardig' strafproces wordt gevolgd. Het spreekt voor zich dat dergelijke overwegingen het werk van de advocaat niet mogen beïnvloeden en dat het uitoefenen van druk op de verdachte (om welke reden dan ook) tuchtrechtelijke consequenties kan hebben. Er zijn overigens geen gevallen bekend waarin de beslissing in het kader van art. 335, 387 of art. 388 KPK tot problemen heeft geleid in de vertrouwensrelatie tussen advocaat en cliënt: Hofmański en Zabłocki 2008, p. 688.

82 Aan de specifieke taken van de raadsman in het onderhandelingsproces is in de Poolse literatuur - vanwege de relatieve nieuwheid van het verschijnsel maar ook omdat überhaupt weinig over verdedigingstechnieken wordt geschreven - overigens nog niet veel aandacht besteed. Voor een behandeling van dit thema wordt verwezen naar Gwirdoyń 2004 waarin de verschillende taken van de raadsman in onderhandeling met vervolgende instanties aan de hand van Amerikaanse en Canadese bronnen wordt besproken. Genoemd werk van Gwirdoyń is een van de weinige Poolse werken (zo niet het enige) waarin uitgebreid wordt ingegaan op verdedigingstactieken in de verschillende fasen van de strafrechtelijke procedure. 
zal verbeteren en de terughoudende opstelling van advocaten in het vooronderzoek zal verminderen.

De raadsman kan in consensuele procedures een belangrijke rol vervullen door de verdachte voor te lichten over de mogelijke alternatieven en de consequenties van zijn keuze. Dat de verdachte wiens zaak op alternatieve wijze wordt afgedaan, wordt bijgestaan door een advocaat is echter niet vanzelfsprekend. Onder bepaalde omstandigheden is ruimte voor ad hoc toevoeging maar in het gros van de gevallen zal de verdachte zonder rechtsbijstand een beslissing moeten nemen over alternatieve afdoening. Dat terwijl de mogelijkheden van consensuele afdoening zich sinds een aantal jaren lang niet meer beperken tot minder ernstig strafbare feiten. Wanneer er veel op het spel staat (in geval van strafbare feiten waarop een aanzienlijke gevangenisstraf is gesteld) zou ad hoc toevoeging van een raadsman mijns inziens in alle gevallen van consensuele afdoening tot de mogelijkheden moeten behoren.

\section{Verdediging op het onderzoek ter terechtzitting}

\subsection{Algemene opmerkingen}

Het onderzoek ter terechtzitting bestaat uit verschillende fasen en staat onder leiding van de voorzitter. ${ }^{83}$ Wettelijk streven is het onderzoek zoveel mogelijk op de eerste zittingsdag af te ronden. ${ }^{84}$ Strafrechtelijke procedures duren in Polen gemiddeld (te) lang: niet voor niets heeft een aanzienlijk deel van de vele Poolse klachten in Straatsburg betrekking op overschrijding van de redelijke termijn in de zin van art. 6 EVRM. Voor dit probleem kunnen verschillende oorzaken worden genoemd. In de eerste plaats zijn er praktische factoren zoals de beperkte financiële middelen van de rechterlijke macht en de absolute toename van het aantal strafzaken dat jaarlijks moet worden behandeld. ${ }^{85}$ Daarnaast werken bepaalde aspecten van het Poolse strafproces vertraging in de hand. Zo wordt in veel zaken een beroep gedaan op deskundigen terwijl voor verschillende expertises landelijk maar een beperkt aantal specialisten beschikbaar is waardoor vaak lang op deskundigenrapportages moet worden gewacht. Bovendien kost het horen van getuigen op zitting veel tijd en is ook de verplichte aanwezigheid van verdachte een factor

83 In geval van een meervoudige kamer met twee lekenrechters en een professionele rechter - de meest gebruikelijke samenstelling voor de behandeling van een strafzaak in eerste aanleg - wordt de functie van voorzitter te allen tijde vervuld door de professionele rechter. Zie over de verschillende fasen van het onderzoek ter terechtzitting in hoofdstuk 2, §3.2.2.2.

84 Art. 366 KPK 1997. In art. 2 lid 1 sub 4 KPK 1997 wordt de afhandeling van zaken binnen een redelijke termijn tot de centrale doelstellingen van het strafprocesrecht gerekend. In het wetboek van 1969 werd deze doelstelling niet met zoveel woorden genoemd. Een en ander is ook vastgelegd in de Grondwet waarin is bepaald dat rechtszaken 'zonder ongerechtvaardigde vertraging' moeten worden afgedaan (art. 45 Grondwet).

85 De groei van het aantal rechtszaken is een postcommunistisch verschijnsel dat overigens niet alleen op het terrein van het strafrecht zichtbaar is: ook de civiele- en bestuurlijke rechtspleging is de laatste jaren steeds zwaarder belast. Dit is een rechtstreeks gevolg van de democratische en rechtsstatelijke hervormingen als gevolg waarvan de bevoegdheden van rechterlijke instanties zijn uitgebreid, het recht een steeds grotere rol is gaan spelen in de maatschappij en burgers voor de bescherming van hun rechten en vrijheden in toenemende mate een beroep zijn gaan doen op de rechter: Zielinski 2003, p. 116-117. 
die de procedure flink kan vertragen. ${ }^{86}$ Critici menen dat de gemiddeld lange duur van strafzaken ook samenhangt met een gebrekkige organisatie binnen de rechterlijke macht waardoor de beschikbare capaciteit niet ten volle wordt benut. ${ }^{87}$ Ten slotte is niet uitgesloten dat (een deel van) de postcommunistische hervormingen bijdragen aan de gemiddeld lange duur van strafrechtelijke procedures. Rechten en bevoegdheden van procespartijen zijn sinds 1989 immers op verschillende punten uitgebreid en de verwezenlijking hiervan kost uiteraard tijd. ${ }^{8}$

De Poolse wetgever is zich terdege bewust van de redelijke termijn problematiek. Dit blijkt onder meer uit het feit dat de grootschalige wetswijziging die in 2003 is doorgevoerd voor een groot deel was gericht op vereenvoudiging van het strafproces. ${ }^{89}$ Dat deze ontwikkeling van invloed is op de rechten van de verdediging behoeft geen betoog. ${ }^{90}$ De toenemende aandacht voor efficiëntie blijkt ook uit het feit dat 'misbruik van procesrecht' een thema is dat tot een aantal jaren geleden nauwelijks voorkwam in Poolse rechtspraak en literatuur maar de laatste tijd steeds meer aandacht heeft gekregen. Deze ontwikkeling laat zien dat de verdediging in toenemende mate verantwoordelijk wordt gehouden voor een snelle en doelgerichte afhandeling van strafzaken. ${ }^{91}$

Sinds 2004 bestaat er een nationale rechtsingang voor Poolse burgers die van mening zijn dat hun rechtszaak te lang duurt: zij kunnen zich tot een hogere rechter wenden die de instantie die de zaak in behandeling heeft, kan opdragen binnen een gestelde termijn bepaalde maatregelen te nemen en de benadeelde een schadevergoeding kan toekennen. ${ }^{92}$ Deze mogelijkheid die betrekking heeft op zowel civiele- als strafzaken is geïntroduceerd op aandringen van het Europese Hof voor de rechten van de mens dat in de zaak Kudta $t$. Polen constateerde dat binnen het Poolse rechtssysteem - in strijd met art. 13 EVRM - geen rechtsmiddel bestond

86 Hoewel het Poolse strafprocesrecht verschillende mogelijkheden kent om verklaringen uit het vooronderzoek te gebruiken (zie hoofdstuk 2 en hierna $\S 4.4 .1$ ), is het in de praktijk - ook in kleinere strafzaken - gebruikelijk één of meer getuigen op de zitting te horen. Ook het feit dat zaken in steeds meer gevallen in afwezigheid van de verdachte kunnen worden afgedaan, neemt niet weg dat nog steeds voldoende situaties denkbaar zijn waarin het niet verschijnen van de verdachte aan een inhoudelijke behandeling van de zaak in de weg staat. Zie hierna $§ 4.2$.

87 Rechters zouden te veel buiten de zittingzaal - thuis maar ook op het Ministerie van Justitie waar velen een nevenfunctie hebben - werkzaam zijn. Ook wordt gezegd dat er te weinig controle op efficiëntie is en dat er nauwelijks stimuli zijn om zaken snel af te handelen. In een publicatie van Iustitia (de Poolse vereniging van rechters) en de Helsinki Foundation for Human Rights wordt uitgebreid aandacht besteed aan verschillende relatief kleine en goedkope veranderingen zoals de aanwezigheid van een telefoon in de rechtszaal die de rechtspleging efficiënter zouden kunnen maken: Sprawny Sad: zbior dobrych praktyk (Rechtbankkwesties: een verzameling voor een goede praktijk) 2004.

88 Waltoś 1999, p. 1000.

89 Zoals de wijzigingen met betrekking tot het vooronderzoek en het terugdringen van het aantal gevallen van verplichte rechtsbijstand.

90 Zie uitgebreider de hoofdstukken 4 en 5. Over de wetswijziging van 2003 en de gevolgen voor het recht op verdediging: Kulesza 2004, p. 11-28.

91 Zie hierna $\S 5$.

92 Wet van 17 juni 2004 inzake klachten over schending van het recht op behandeling van zaken binnen een redelijke termijn (Ustawa o skardze na naruszenie prawa strony do rozpoznania sprawy w postępowaniu sądowym bez nieuzasadnionej zwłoki). 
tegen de overschrijding van de redelijke termijn. ${ }^{93}$ Van het nieuwe rechtsmiddel wordt in de praktijk vaak gebruik gemaakt. ${ }^{94}$

Wat de openbaarheid van het onderzoek ter terechtzitting betreft, dient onderscheid te worden gemaakt tussen de vraag in welke mate het proces enerzijds toegankelijk is voor procesdeelnemers (interne openbaarheid: jawność wewnętrzną) en anderzijds voor derden (externe openbaarheid: jawność zewnętrzna). ${ }^{95}$ Ten aanzien van de externe openbaarheid geldt de hoofdregel dat het onderzoek ter terechtzitting openbaar en dus voor het publiek toegankelijk is. Uitzonderingen op deze regel zijn slechts toegestaan voor zover de wet daarin voorziet en (gedeeltelijke) behandeling van de zaak achter gesloten deuren noodzakelijk is ter bescherming van bepaalde belangen. ${ }^{96}$ Wanneer de zitting achter gesloten deuren plaatsvindt, kunnen de procesdeelnemers (waaronder de verdachte en zijn raadsman) uiteraard wel deelnemen. De uitspraak dient te allen tijde in het openbaar te worden gedaan. ${ }^{97}$ In geval van een openbare behandeling kan in beginsel eenieder bij het onderzoek ter terechtzitting aanwezig zijn. ${ }^{98}$ Onder bepaalde omstandigheden kan de rechtbank toestaan dat geluids- en/of video-opnamen van het onderzoek ter terechtzitting worden gemaakt.

\subsection{Deelname verdediging}

In het Poolse strafprocesrecht geldt de hoofdregel dat de verdachte niet alleen het recht maar ook de plicht heeft aan het onderzoek ter terechtzitting deel te nemen. De aanwezigheidsplicht geldt niet wanneer zich een van de door de wetgever geformuleerde uitzonderingssituaties voordoet. ${ }^{99}$ Wanneer geen sprake is

93 Kudła t. Polen, EHRM 26-10-2000, nr. 30210/96, § 157.

94 Overigens vaker in civiele zaken dan in strafzaken. Zie voor cijfers over de jaren 2004 en 2005: de appendix bij Interim Resolution CM/ResDH (2007) 28 (concerning the judgments of the European Court of Human Rights in 143 cases against Poland relating to the excessive length of criminal and civil proceedings and the right to an effective remedy) aangenomen door het Comité van Ministers op 4 april 2007, te raadplegen via: <www.coe.int/t/e/general/search.asp>. De schadevergoeding kan maximaal 10.000 złotych (circa 2300 euro) bedragen. In de praktijk worden doorgaans veel lagere bedragen toegekend.

95 Zie onder meer Wiliński 2006, p. 233-234.

96 De wet noemt in dit verband: de zedelijkheid, staatsveiligheid, de openbare orde, de bescherming van het privé-leven van een partij of een andere zwaarwegend individueel belang (art. 355 KPK en art. 45 lid 2 eerste zin Grondwet).

97 Art. 364 KPK 1997 en art. 45 lid 2 tweede zin Grondwet.

98 Mits meerderjarig en - nogal voor de hand liggend - ongewapend: art. 356 KPK 1997. Personen die zich in een staat bevinden die 'onverenigbaar is met de waardigheid van de rechtbank' wordt de toegang tot de rechtszaal geweigerd. Daarvan kan bijvoorbeeld sprake zijn wanneer iemand kennelijk onder invloed van alcohol of drugs is: Hofmański e.a. 2007 II, p. 363.

99 Art. 374 KPK 1997. Om naleving van de aanwezigheidsplicht mogelijk te maken, kan de voorzitter maatregelen treffen waardoor de verdachte de rechtbank niet voor het einde van de zitting kan verlaten. De aanwezigheidsplicht geldt niet voor het moment waarop het vonnis wordt uitgesproken: dat kan te allen tijde in afwezigheid van de verdachte gebeuren. Zie over de aanwezigheid van verdachte op het onderzoek ter terechtzitting onder meer: Grzegorczyk 1999, p. 266-272, Trybuchowska 2002, p. 259-274 en Wiliński 2006, p. 399-408. 
van een wettelijke uitzondering en de verdachte zonder geldige reden afwezig is, beveelt de rechter zijn aanhouding en medebrenging. ${ }^{100}$

Het aantal situaties waarin kan worden afgezien van verplichte deelname van verdachte is met de invoering van het nieuwe wetboek van strafvordering aanzienlijk uitgebreid. Reden hiervoor was dat de ruime aanwezigheidsplicht van verdachten onder het oude strafprocesrecht tot veel oponthoud leidde: de verdachte kon door niet te verschijnen de voortgang van de procedure belemmeren en het kwam geregeld voor dat rechtszaken op deze manier volledig werden stilgelegd. Bovendien werd de aanwezigheidsplicht in de doctrine bekritiseerd vanwege haar paternalistische karakter. ${ }^{101}$ De gevallen waarin het onderzoek ter terechtzitting op grond van het huidige strafprocesrecht in afwezigheid van verdachte kunnen worden behandeld, staan opgesomd in art. 376 en 377. ${ }^{102}$ Kort weergegeven gaat het om de volgende situaties:

- De verdachte heeft na ter zitting een verklaring te hebben afgelegd de zittingzaal zonder toestemming van de voorzitter verlaten. ${ }^{103}$

- De verdachte die ter zitting reeds een verklaring heeft afgelegd, verschijnt na aanhouding van het onderzoek zonder geldige reden niet meer op het onderzoek ter terechtzitting. ${ }^{104}$

- De medeverdachte verschijnt met gerechtvaardigde kennisgeving na aanhouding niet op de zitting. ${ }^{105}$

- De verdachte bevindt zich - bijvoorbeeld door het gebruik van alcohol of drugs - verwijtbaar in zodanige staat dat hij niet aan de zitting deel kan nemen. ${ }^{106}$

- De verdachte die op de hoogte is gesteld van de datum van de zitting, verklaart dat hij niet aanwezig zal zijn of voorkomt dat hij naar de zitting wordt gebracht. ${ }^{107}$

100 Art. 382 KPK 1997.

101 Wąsek-Wiaderek 2003 II, p. 330 en daar genoemde literatuur.

102 Zie over de mogelijkheid het onderzoek ter terechtzitting in afwezigheid van de verdachte te laten plaatsvinden onder meer: Urbaniak 2003.

103 Art. 376 lid 1 KPK 1997: het onderzoek mag in zijn afwezigheid worden voortgezet.

104 Art. 376 lid 2 KPK 1997: het onderzoek mag in zijn afwezigheid worden voortgezet. Het Poolse strafprocesrecht kent twee soorten aanhouding: de onderbreking (przerwa) en de verdaging (odroczenia). Een onderbreking mag maximaal 35 dagen duren. Indien een aanhouding van 35 dagen niet toereikend is, dient de zaak te worden verdaagd en zal het onderzoek op de eerstvolgende zittingsdag opnieuw aanvang moeten nemen.

105 Art. 376 lid 3: de rechtbank kan het onderzoek ter terechtzitting in zijn afwezigheid voortzetten voor zover het niet direct betrekking op hem heeft en indien zijn recht op verdediging daardoor niet wordt beperkt. Hoewel voortzetting van de zaak in afwezigheid van verdachte in de gevallen genoemd in art. 376 lid 1 tot en met 3 KPK 1997 door de wetgever niet afhankelijk is gemaakt van toestemming van de raadsman, pleegt de rechtbank in de praktijk - wanneer wel een raadsman is verschenen - slechts door te gaan wanneer deze namens zijn cliënt aangeeft daar geen bezwaar tegen te hebben of zelfs om voortzetting verzoekt: Kulesza 2005, p. 448. Met andere woorden: de rechtbank is bevoegd maar niet verplicht de zaak voort te zetten en kan - al dan niet op verzoek van de raadsman - alsnog voor aanhouding kiezen wanneer ze aanwezigheid van verdachte wenselijk acht.

106 Art. 377 lid 1 en 2 KPK 1997: de zitting kan in zo'n geval in afwezigheid van verdachte plaatsvinden wanneer hij nog geen verklaring heeft afgelegd. De rechtbank dient voorafgaand aan het nemen van een dergelijke beslissing eerst een arts te raadplegen over de toestand van verdachte. 
Afgezien van eerstgenoemde situatie (verdachte heeft zonder toestemming de zittingzaal verlaten) zijn alle bovengenoemde uitzonderingen nieuw ten opzichte van het wetboek van strafvordering van 1969. ${ }^{108}$ Hierdoor is de betekenis van de aanwezigheidsplicht behoorlijk afgenomen.

Wanneer de zaak in een van bovengenoemde gevallen geheel of gedeeltelijk in afwezigheid van verdachte is behandeld, geldt het vonnis niet als bij verstek. De kwalificatie 'verstekvonnis' ('wyrok zaoczny') wordt in het Poolse strafproces slechts gebruikt voor uitspraken in twee soorten bijzondere procedures: de vereenvoudigde procedure (postepowanie uproszczone) en wanneer op private aanklacht wordt vervolgd. ${ }^{109}$ Indien een regulier strafproces overeenkomstig art. 376 of 377 KPK 1997 in afwezigheid van de verdachte heeft plaatsgevonden, spreekt men van een 'vonnis in afwezigheid van verdachte' ('wyrok pod nieobecność oskarżonego'). ${ }^{110}$ Behalve de situaties dat het onderzoek ter terechtzitting volledig in afwezigheid van verdachte kan worden volbracht, kan hij - wanneer dat noodzakelijk is voor een goed procesverloop - ook tijdelijk uit de zittingzaal worden verwijderd. Dit is mogelijk op bevel van de voorzitter wanneer de verdachte ondanks een waarschuwing de zitting blijft verstoren of wanneer gevreesd wordt dat zijn aanwezigheid de verklaringsvrijheid van medeverdachten, getuigen of deskundigen die moeten worden gehoord teveel zal beperken. ${ }^{111}$ De raadsman mag in genoemde gevallen wel in de zittingzaal blijven. Beide mogelijkheden bestonden ook reeds in het oude wetboek van strafvordering.

De raadsman kan bij afwezigheid van zijn cliënt in bovengenoemde situaties wel gewoon de verdediging voeren, daaraan worden geen bijzondere eisen (zoals het tonen van een machtiging) gesteld. ${ }^{112}$ Aangezien formeel geen sprake is van verstek wanneer de zaak in een normale procedure zonder verdachte wordt afgedaan, is

107 Art. 377 lid 3 KPK 1997: de rechtbank kan de procedure in zijn afwezigheid voortzetten, tenzij deelname van de verdachte noodzakelijk wordt geacht.

108 Wat overigens niet wegneemt dat ook voor de inwerkingtreding van het nieuwe wetboek van strafvordering door de rechtspraak meer uitzonderingen werden toegelaten dan die waarin de wetgever destijds voorzag: zo is de mogelijkheid de zaak voort te zetten wanneer een verdachte na aanhouding van de zaak niet meer ter zitting verschijnt (huidig art. 376 lid 2 KPK), reeds in de jaren tachtig door het Hooggerechtshof geaccepteerd: Czechowicz 1998, p. 81.

109 Deelname van de verdachte is in die gevallen - anders dan volgens de hoofdregel in gewone strafrechtelijke procedures - niet verplicht. Wanneer hij op de juiste wijze is opgeroepen en voorafgaand aan de zitting niet heeft aangegeven verhinderd te zijn, kan de zaak in zijn afwezigheid worden afgedaan (art. 479 en art. 485 KPK 1997).

110 Grajewski 2005, p. 231. Anders dan een verstekvonnis hoeft een dergelijke uitspraak niet ambtshalve aan de verdachte te worden betekend en begint de (zeven dagen-)termijn waarbinnen de verdediging om schriftelijke motivering van de uitspraak kan vragen direct te lopen.

111 Art. 375 en art. 390 KPK 1997. In beide gevallen dient de verdachte na zijn terugkeer onmiddellijk op de hoogte te worden gesteld van datgene wat zich in zijn afwezigheid heeft afgespeeld en in de gelegenheid te worden gesteld daarop te reageren.

112 Enige voorwaarde is dat uit het dossier moet blijken dat de raadsman door de verdachte is benoemd of - in geval van toevoeging - door de rechter is aangewezen. Zie over de benoeming door de verdachte hoofdstuk $2, \S 3.1 .3 .2$. 
de aanwezigheid van de raadsman dus ook niet van invloed op de vraag of de behandeling als op tegenspraak of bij verstek geldt. ${ }^{113}$

In geval van verplichte rechtsbijstand is deelname van de raadsman aan het onderzoek ter terechtzitting dwingend voorgeschreven. ${ }^{114}$ Het feit dat de raadsman niet is verschenen, dient in zo'n geval automatisch tot aanhouding van de zaak te leiden. Of de raadsman zijn afwezigheid van te voren heeft aangekondigd, is daarbij niet relevant: het is simpelweg niet toegestaan de zaak in zijn afwezigheid te behandelen. Wanneer dat wel gebeurt, leidt dat in hoger beroep automatisch tot vernietiging van het vonnis. ${ }^{115}$ Buiten de gevallen van verplichte rechtsbijstand heeft de raadsman het recht maar niet de plicht om bij het onderzoek ter terechtzitting aanwezig te zijn.

Eerder in deze paragraaf is gebleken dat de verdachte vanwege zijn gedrag tijdelijk uit de zittingzaal kan worden verwijderd. Het is de vraag of eenzelfde mogelijkheid ook bestaat ten aanzien van de raadsman. Het huidige wetboek van strafvordering biedt daarvoor in tegenstelling tot het oude strafprocesrecht geen wettelijke grondslag. In art. 325 KPK 1969 was bepaald dat wanneer de raadsman ondanks een waarschuwing van de voorzitter de procesgang bleef verstoren of gedrag bleef vertonen dat niet verenigbaar was met de waardigheid van de rechtbank, hem het recht kon worden ontnomen het woord te voeren en hij bovendien van verdere deelname aan het onderzoek ter terechtzitting kon worden uitgesloten. Wanneer de advocaat daadwerkelijk uit de zittingzaal werd verwijderd - wat in de praktijk overigens zelden tot nooit gebeurde ${ }^{116}$ - diende de rechter op verzoek van verdachte of in geval van verplichte rechtsbijstand ambtshalve een nieuwe raadsman te benoemen. ${ }^{117}$ Kruszyński heeft deze bepaling in het verleden bekritiseerd vanwege het feit dat eenzelfde mogelijkheid niet gold ten aanzien van de prokurator. ${ }^{118}$ Hij zag wel de noodzaak van een dergelijke regel in maar was van mening dat de inhoud op gelijke wijze van toepassing zou moeten zijn op de prokurator. De wetgever heeft echter niet voor deze weg gekozen en de mogelijkheid de raadsman uit de zittingzaal te verwijderen volledig geschrapt. ${ }^{119}$

113 In bijzondere procedures is dit anders: in de vereenvoudigde procedure geldt de behandeling ook als op tegenspraak wanneer alleen de raadsman is verschenen: er is pas sprake van een verstekvonnis wanneer zowel de verdachte als de raadsman afwezig zijn. Hetzelfde geldt voor procedures waarin op private aanklacht wordt vervolgd.

114 Zie uitgebreid over de gevallen van verplichte rechtsbijstand: hoofdstuk 4, § 3.1.1.

115 Art. 439 KPK 1997. Vernietiging van het vonnis vindt echter alleen plaats wanneer dat in het voordeel van verdachte is.

116 Informatie verkregen van Kruszyński, juni 2008.

117 In het geval dat de nieuwe advocaat zijn taak niet onmiddellijk zou kunnen uitoefenen (wat uiteraard alleen mogelijk was wanneer een advocaat werd benoemd die toevallig op dat moment in het gerechtsgebouw aanwezig was) diende de zaak te worden aangehouden.

118 Kruszyński 1991, p. 236-239 en p. 279-280.

119 In theorie is het echter nog steeds mogelijk de raadsman te verwijderen: de voorzitter heeft nog altijd de bevoegdheid eenieder die - na een waarschuwing - de orde blijft verstoren, op te dragen de zittingzaal te verlaten (art. 48 lid 2 wet op de rechterlijke organisatie van 2002 (Prawo o ostroju sądów powszechnych)). De rechter kan over het optreden van de raadsman ook een klacht indienen bij de balie. Zie over deze mogelijkheid - neergelegd in art. 20 KPK 1997 - hoofdstuk 8, § 4.4.1 en 4.4.5. 


\subsection{Informatiepositie verdediging}

Om actief deel te kunnen nemen aan het eindonderzoek dient de verdediging goed op de hoogte te zijn van alles wat zich tot dan toe in de zaak heeft afgespeeld. Inzage in de processtukken is daarvoor onontbeerlijk. Gedurende het vooronderzoek is het voor de verdediging allesbehalve vanzelfsprekend dat alle relevante stukken kunnen worden ingezien. ${ }^{120}$ De aanvang van het eindonderzoek betekent voor de verdediging een enorme verbetering van de informatiepositie. Vanaf dat moment kunnen verdachte en raadsman in beginsel zonder beperking de stukken inzien en daarvan (op eigen kosten) kopieën maken. ${ }^{121}$ Wanneer het dossier zich bij de rechtbank bevindt, kan het daar door de verdediging worden ingezien. ${ }^{122}$ Het is echter ook mogelijk dat het dossier gedurende het eindonderzoek (weer) in handen van de prokurator is. Deze heeft namelijk het recht 'gedurende ieder stadium van de procedure het dossier in te zien en kan verlangen dat het ter inzage naar hem toe worden gestuurd'. ${ }^{123}$ Verzending van het dossier vindt echter slechts plaats:

1. voor zover dat de voortgang van de procedure niet bemoeilijkt en

2. de inzage van de stukken door andere procesdeelnemers - met name de verdachte en zijn raadsman - er niet door wordt beperkt. ${ }^{124}$

Wanneer de prokurator het dossier gedurende het eindonderzoek onder zich heeft, is hij verplicht de verdediging inzage te verschaffen wanneer daarom wordt verzocht. ${ }^{125}$ Hoewel de prokurator dus enigszins wordt bevoordeeld doordat hij het dossier op ieder moment van het eindonderzoek in zijn bezit kan krijgen, worden de belangen van de verdediging - in ieder geval op papier - voldoende beschermd. Dit is een verbetering ten opzichte van het oude strafprocesrecht omdat daarin was bepaald dat de prokurator op ieder moment gedurende het eindonderzoek het dossier kon inzien mits de procedure daardoor niet werd opgehouden. Er werd geen verwijzing gemaakt naar de belangen van de verdediging zodat de prokurator wettelijk niet verplicht was daar rekening mee te houden. Of de huidige regeling ook in de praktijk een verbetering voor de verdediging is, is uiteraard afhankelijk van de vraag of genoemde voorwaarden daadwerkelijk worden nageleefd. ${ }^{126}$ Vanuit de advocatuur klinken geluiden dat dit niet het geval is en dat het gedurende

120 Voor een beperkt aantal documenten geldt een absoluut inzagerecht maar kennisneming van de rest van het dossier kan tot aan het einde van het vooronderzoek door de prokurator worden geweigerd. Zie hoofdstuk 5, §3.

121 Met toestemming van de president van rechtbank kunnen daarvan tegen betaling ook officiële afschriften worden verkregen (art. 156 lid 1 tot en met 3 KPK 1997).

122 Een gedetineerde verdachte kan de rechtbank ook verzoeken het dossier op de plaats van detentie in te zien.

123 Art. 158 lid 1 KPK 1997. De prokurator zal hier om verzoeken wanneer hij - om welke reden dan ook - de stukken niet op de rechtbank wil of kan inzien.

124 Art. 158 lid 1 KPK 1997. Of verzending aan de prokurator de voortgang van de procedure bemoeilijkt, zal uiteraard afhangen van de vraag of de rechtbank - gelet op het stadium waarin de procedure zich bevindt - het dossier zelf op korte termijn nodig heeft. Wanneer de zaak bijvoorbeeld voor langere tijd is aangehouden, hoeft het geen probleem op te leveren dat de rechtbank het dossier tijdelijk uit handen moet geven.

125 Art. 158 lid 2 KPK 1997.

126 Wąsek-Wiaderek 2003 II, p. 284-285. 
het eindonderzoek voor leden van de prokuratura veel eenvoudiger is om toegang tot het dossier te krijgen dan voor advocaten. ${ }^{127}$

\subsection{Bewijsvoering op het onderzoek ter terechtzitting}

De voor de verdediging belangrijkste fase van het onderzoek ter terechtzitting is die waarin de bewijsvoering plaatsvindt (przewód sądowy). ${ }^{128}$ Bewijsvoering kan op verzoek van partijen of ambtshalve - op initiatief van de rechtbank - plaatsvinden. ${ }^{129}$ Voor wat betreft de volgorde van bewijsvoering is het uitgangspunt dat bewijs à charge zoveel mogelijk moet worden gepresenteerd voor ontlastend bewijsmateriaal. ${ }^{130}$ Dit zodat de verdediging weet waartegen ze zich moet weren. ${ }^{131}$

\subsubsection{Onmiddellijkheid: regel of uitzondering?}

De fase van de bewijsvoering wordt beheerst door het onmiddellijkheidsbeginsel (zasada bezpośredniości). Kort gezegd komt dit er op neer dat de zittingsrechter zijn beslissing dient te baseren op bewijsmateriaal dat ter terechtzitting door hem of ten overstaan van hem is gepresenteerd. ${ }^{132}$ Deze regel is echter niet absoluut in de zin dat alleen gebruik zou mogen worden gemaakt van verklaringen van personen die door de zittingsrechter zelf zijn gehoord: het Poolse strafprocesrecht voorziet in een aantal uitzonderingen waarin kan worden volstaan met voorlezing van verklaringen die eerder (en dus niet op het onderzoek ter terechtzitting) door een verdachte, getuige of deskundige zijn afgelegd. Zoals eerder aan de orde is geweest, heeft de wetgever bij de totstandkoming van het nieuwe wetboek van strafvordering van 1997 het zwaartepunt van de strafrechtelijke procedure meer naar het eindonderzoek willen doen verschuiven. ${ }^{133}$ Met het oog op deze doelstelling werd ook het belang van het onmiddellijkheidsbeginsel - dat onder het oude strafprocesrecht door de vele toegestane uitzonderingen veel van zijn betekenis had verloren - opnieuw benadrukt. Als gevolg van de efficiëntieverhogende wijzigingen die in 2003 in het strafprocesrecht zijn doorgevoerd, is het voor de zittingsrechter echter weer eenvoudiger geworden om eerder in de procedure afgelegde verklaringen voor het bewijs te gebruiken.

De uitzonderingen op het onmiddellijkheidsbeginsel komen er in hoofdlijnen op neer dat de rechter kan volstaan met het voorlezen van een verklaring die eerder door de verdachte is afgelegd wanneer hij ter terechtzitting weigert te verklaren, anders verklaart dan voorheen of aangeeft zich bepaalde feiten niet te kunnen herinneren. ${ }^{134}$ Bovendien is het in verschillende situaties toegestaan ervan af te zien

127 Jurkiewicz 2001.

128 Algemeen over verwezenlijking van het recht op verdediging op het onderzoek ter terechtzitting: Kruszyński 1985.

129 Art. 167 KPK 1997. Zie over bewijs ook hoofdstuk 2, § 3.2.2.2. Het moge duidelijk zijn dat de verdachte slechts het recht en nooit de plicht heeft bewijs te leveren: hij is immers niet verplicht zijn onschuld te bewijzen of belastend bewijs tegen zichzelf te leveren (art. 74 lid 1 KPK 1997).

130 Art. 369 KPK 1997.

131 Wiliński 2006, p. 591.

132 Art. 410 KPK 1997. Zie over het onmiddellijkheidsbeginsel ook hoofdstuk 2, § 2.3.3.1 en $\S 3.2 .2 .2$.

133 Zie hoofdstuk 2, § 2.3.3.1.

134 Art. 389 lid 1 KPK 1997. De verklaring die wordt voorgelezen, hoeft niet noodzakelijk 
een getuige op het onderzoek ter terechtzitting te horen en daarvoor in de plaats zijn eerder afgelegde verklaring voor te lezen. ${ }^{135}$ De rechter dient in zijn beslissing een getuige niet op de zitting te horen wel aan te geven op welke grond dat gebeurt. ${ }^{136}$ Ten slotte is gebruik van eerder door de verdachte of een getuige afgelegde verklaringen toegestaan wanneer rechtstreeks horen niet noodzakelijk is en geen van de partijen daartegen bezwaar maken. ${ }^{137}$ De mogelijkheid om in die gevallen af te kunnen wijken van de hoofdregel dat alle bewijs ten overstaan van de rechter naar voren moet worden gebracht, draagt bij aan een snelle en efficiënte behandeling van de strafzaak. De voorwaarde dat deze werkwijze alleen kan worden gevolgd wanneer partijen daartegen geen bezwaar maken, beoogt de belangen van de verdediging te beschermen. Wanneer de verdachte of zijn raadsman zich bijvoorbeeld tegen voorlezing van een bepaalde getuigenverklaring verzet, zal de rechter - indien geen van de eerder genoemde andere uitzonderingssituaties zich voordoet - de betreffende getuige toch op de zitting moeten horen. ${ }^{138}$

Door bovengenoemde uitzonderingen op het onmiddellijkheidsbeginsel kan in een groot aantal gevallen worden volstaan met de verklaring die een verdachte of getuige eerder in het vooronderzoek (of op enig ander moment) heeft afgelegd. Dit gebeurt in de praktijk regelmatig waardoor het onderzoek ter terechtzitting tot op bepaalde hoogte een schriftelijk karakter heeft. Afwijking van het onmid-

afkomstig te zijn uit het vooronderzoek van de betreffende strafzaak: deze kan ook zijn afgelegd in het vooronderzoek of ten overstaan van de rechter in een andere zaak of in een 'andere procedure waarin de wet voorziet'. Wel dient het te allen tijde te gaan om een verklaring die in de hoedanigheid van verdachte ('w charakterze oskarżonego') is afgelegd: verklaringen die de verdachte in het vooronderzoek of in een andere zaak als getuige heeft afgelegd, mogen dus niet worden voorgelezen. Dit verbod is absoluut en geldt zelfs wanneer de verdachte met voorlezing instemt. Aangezien een getuige verplicht is de waarheid te vertellen, zou het gebruik van dergelijke verklaringen in strijd zijn met het zwijgrecht van verdachte en het feit dat verklaren in strijd met de waarheid voor hem geen strafbaar feit oplevert: Bieńkowska e.a. 2004, p. 100 en daar genoemde rechtspraak.

135 Dit is mogelijk indien de getuige ter terechtzitting weigert te verklaren, anders verklaart dan voorheen, aangeeft zich bepaalde feiten niet te kunnen herinneren, zich in het buitenland bevindt, niet kon worden opgeroepen, niet heeft kunnen verschijnen vanwege onoverkomelijke hindernissen, op verzoek van de prokurator niet is opgeroepen op een van de wettelijke gronden of is overleden (art. 391 KPK 1997).

136 In de rechtspraak is benadrukt dat het daarbij niet volstaat te wijzen op de moeilijkheden die met het rechtstreeks horen van de betreffende getuige gepaard gaan en dat de rechtbank bovendien alle mogelijkheden om de getuige op de zitting te kunnen horen, moet hebben uitgeput: Bieńkowska e.a. 2004, p. 100 en daar genoemde rechtspraak. Overigens geldt - net als ten aanzien van de verdachte - dat niet alleen verklaringen kunnen worden voorgelezen die de getuige in het vooronderzoek van de betreffende strafzaak heeft afgelegd. De mogelijkheid staat ook open voor verklaringen die zijn afgelegd in het vooronderzoek of ten overstaan van de rechter in een andere zaak of in een 'andere procedure waarin de wet voorziet' (art. 391 lid 1 KPK 1997).

137 Het gaat hier om minder belangrijk bewijsmateriaal dat aan drie voorwaarden moet voldoen: het moet niet van grote betekenis voor de zaak, niet in strijd met ander bewijsmateriaal en niet innerlijk tegenstrijdig zijn (art. 392 KPK 1997). Zie Grzegorczyk 2004, p. 1008.

138 Art. 393 KPK 1997. Hierbij is wel van belang dat de wettelijke regeling slechts vereist dat partijen er zich niet tegen verzetten: expliciete instemming is dus niet nodig wat betekent dat een en ander ook bij afwezigheid van de verdediging kan plaatsvinden. 
dellijkheidsbeginsel is overigens geen nieuw verschijnsel in het Poolse strafproces: het gebeurde onder het oude strafprocesrecht ook op grote schaal. In de jaren zeventig is in 11 arrondissementen onderzoek gedaan naar deelname van getuigen aan het onderzoek ter terechtzitting. Hieruit bleek dat in meer dan de helft van de gevallen (55\%) werd volstaan met voorlezing van eerder afgelegde verklaringen zonder de getuige op zitting te horen. ${ }^{139}$ Hoewel meer recente onderzoeksgegevens niet beschikbaar zijn, staat vast dat de uitzonderingen op het onmiddellijkheidsbeginsel nog altijd een grote rol spelen in de praktijk. Er is dan ook geen reden om aan te nemen dat de huidige situatie wezenlijk verschilt van het beeld dat door het onderzoek in de jaren zeventig werd geschetst. In de Poolse literatuur wordt zelfs de verwachting uitgesproken dat de rechtspraktijk in de toekomst alleen nog maar verder zal afdrijven van het onmiddellijkheidsbeginsel. ${ }^{140}$ Dit vermoeden wordt versterkt door meer recente ontwikkelingen in de strafrechtspleging - zoals de toenemende betekenis van vormen van consensuele afdoening en de opkomst van de anonieme getuige ${ }^{141}$ - die tot gevolg hebben dat niet (alle) bewijs op het onderzoek ter terechtzitting tot stand komt.

\subsubsection{Wijze van verhoor op de zitting}

In een op tegenspraak gericht onderzoek ter terechtzitting dienen procespartijen actief te kunnen deelnemen aan de verhoren die daar plaatsvinden. Zij moeten zelf vragen kunnen stellen aan verdachten, getuigen en deskundigen om invloed uit te kunnen oefenen op de waarheidsvinding en de beoordeling van het bewijsmateriaal door de rechter. Daarbij is niet alleen van belang dàt er een mogelijkheid tot ondervraging bestaat maar ook op welke wijze daaraan wordt vormgegeven. Van belang is onder meer in welke volgorde de verschillende procesdeelnemers aan de beurt komen. Het oude wetboek van strafvordering zweeg op dit punt ${ }^{142}$ maar de praktijk was dat de rechtbank de ondervraging van verdachten, getuigen en deskundigen domineerde en dat procespartijen pas aan de beurt kwamen nadat de rechter vragen had gesteld. Dit leidde tot een passieve opstelling van prokuratura en verdediging. ${ }^{143}$

Om een actieve inbreng van procespartijen - en daarmee het contradictoire karakter van het onderzoek ter terechtzitting - te stimuleren, is in het huidige strafprocesrecht voor een nieuw systeem van ondervraging gekozen. Deze nieuwe vorm houdt in dat alle personen op de zitting volgens een vaste volgorde dienen te worden ondervraagd. Net als voorheen stelt de voorzitter van de rechtbank eerst een algemene vraag (in de trant van 'wat wilt u over deze zaak kwijt?') om de ondervraagde de kans te geven zich spontaan te uiten. Daarna krijgen de andere procesdeelnemers de kans vragen te stellen. De wettelijk voorgeschreven volgorde

139 Het ging in totaal om 2310 getuigen waarvan er 1073 (45\%) wel rechtstreeks op het onderzoek ter terechtzitting werden gehoord. Over dit onderzoek dat in 1977 werd verricht: Płachta 1985, p. 200-227.

140 Waltoś 2002 II, p. 24.

141 Zie over consensuele afdoening eerder $\S 3$ en over de anonieme getuige hierna $\S$ 4.4.3.3.

142 Er was geen bepaling gewijd aan de volgorde waarin vragen moesten worden gesteld aan personen die op zitting werden gehoord. In de doctrine werd de vraag wie als eerste aan bod moest komen - de rechter of procespartijen - verschillend beantwoord: Trybuchowska 2003, p. 238 en daar genoemde literatuur.

143 Wiliński 2006, p. 590. 
is als volgt: prokurator, hulpaanklager (oskarżyciel positkowy), gevolmachtigde van de hulpaanklager, private aanklager (oskarżyciel prywatny), gevolmachtigde van de private aanklager, civiele partij, gevolmachtigde van de civiele partij, deskundige, de entiteit genoemd in art. 416 KPK 1997 (een natuurlijke- of rechtspersoon die materieel voordeel heeft verkregen door het strafbaar feit en in wiens naam of belang de verdachte handelde), de raadsman, de verdachte en als laatste de rechtbank. ${ }^{144}$ Raadsman en verdachte dienen dus - voordat de rechter vragen stelt - als laatste aan bod te komen. Wanneer een andere procesdeelnemer de kans krijgt aanvullende vragen te formuleren nadat de verdachte vragen heeft gesteld, dient de verdediging opnieuw het woord te krijgen.

Voor het verhoor van getuigen geldt bovendien dat degene op wiens verzoek de betreffende persoon wordt gehoord als eerste de gelegenheid moet krijgen vragen te stellen. ${ }^{145}$ Een door de verdediging opgeroepen getuige dient dus als eerste door de verdachte en zijn raadsman te kunnen worden ondervraagd.

Hoewel de rechter volgens bovengenoemde volgorde in beginsel als laatste aan de beurt is, heeft hij nog wel het recht op ieder moment gedurende de ondervraging aanvullende vragen te stellen. ${ }^{146}$ Met name in de eerste jaren na inwerkingtreding van het nieuwe wetboek van strafvordering werd op grote schaal gebruik gemaakt van deze mogelijkheid waardoor de rechter het proces van ondervraging bleef domineren. Ook vandaag de dag is het verschil met de situatie onder het oude strafprocesrecht niet zo groot als oorspronkelijk werd beoogd: nog regelmatig wordt afgeweken van de voorgeschreven volgorde en worden eerst vragen gesteld door de rechter en pas daarna door de overige procesdeelnemers. ${ }^{147}$ Deze praktijk draagt uiteraard niet bij aan de (beoogde) versterking van het adversaire karakter van het onderzoek ter terechtzitting. ${ }^{148}$

Het ondervragingsrecht is overigens niet voorbehouden aan de professionele rechter: ook lekenrechters kunnen vragen stellen. In de praktijk wordt van deze

144 Art. 370 lid 1 KPK 1997. Vragen worden rechtstreeks tot de verdachte, getuige of deskundige gericht, tenzij de voorzitter anders bepaalt. Deze vorm van ondervragen is ook bekend in andere continentale rechtssystemen: in Frankrijk, Italië en Zweden worden personen op de zitting in dezelfde volgorde gehoord. Zie Waltoś 2002 I, p. 504.

145 Art. 370 lid 2 KPK 1997. Hoewel art. 370 lid 2 KPK 1997 alleen de getuige noemt ('De partij op wiens verzoek de getuige werd toegelaten, dient vragen te kunnen stellen voor alle andere partijen'), wordt er gelet op de ratio van deze bepaling vanuit gegaan dat de regel van overeenkomstige toepassing is op het horen van deskundigen: Grzegorczyk 2004, p. 950. Een systeem waarin de procespartij die de getuige (of deskundige) heeft opgeroepen als eerste vragen mag stellen heeft duidelijke voordelen. In de eerste plaats mag ervan uit worden gegaan dat deze procespartij het beste in staat is om relevante vragen te stellen wat een belangrijke bijdrage kan leveren aan de waarheidsvinding. Ten tweede zal de zittingsrechter beter zijn onpartijdigheid kunnen behouden wanneer hij luistert naar antwoorden op door procespartijen gestelde vragen dan wanneer hij zelf actief vragen moet formuleren. Zie hierover in het kader van de discussie over de wenselijkheid van een Engels systeem van ondervraging in het Nederlandse strafproces (waarvoor overigens uiteindelijk niet is gekozen): Corstens 2005, p. 576-577.

146 Art. 370 lid 3 KPK 1997.

147 Trybuchowska 2003, p. 238, Gwirdoyń 2004, p. 181, Wiliński 2006, p. 592 en Hofmański e.a. 2007 II, p. 389.

148 Kritisch op dit punt: Trybuchowska 2003, p. 238-239 en Hofmański e.a. 2007 II, p. 389. 
mogelijkheid echter zeer terughoudend gebruik gemaakt. ${ }^{149}$ Hoewel hier niet uit mag worden afgeleid dat ze bij de behandeling van de strafzaak geen enkele rol van betekenis spelen, ${ }^{150}$ bestaat wel discussie over het nut van de niet professionele bijzitters. Illustratief in dit verband is dat lekenrechters in Polen spottend ook wel worden aangeduid als 'bloempotten' die slechts een decoratieve functie vervullen in de rechtszaal.

Wanneer de verdachte op het onderzoek ter terechtzitting is verschenen, is hij de eerste persoon die wordt gehoord. De verdachte is anders dan de getuige en de deskundige niet strafbaar wanneer zijn verklaring in strijd met de waarheid is afgelegd. ${ }^{151}$ In de Poolse literatuur bestaat echter vrij brede consensus over het feit dat hieruit niet mag worden afgeleid dat de verdachte net als het recht om te zwijgen dus ook een recht om te liegen heeft: het ontbreken van strafrechtelijke verantwoordelijkheid betekent immers nog niet dat van een absoluut recht kan worden gesproken. ${ }^{152}$

\subsubsection{De verdediging en getuigenbewijs}

Gedurende het vooronderzoek komt het zelden voor dat bewijs op verzoek van een procespartij wordt verzameld ${ }^{153}$ maar tijdens het eindonderzoek verandert deze situatie. Op het onderzoek ter terechtzitting is bewijsvoering op verzoek van partijen de regel en komt het veel minder vaak voor dat dit op initiatief van het leidende procesorgaan (in deze fase: de rechter) gebeurt. ${ }^{154}$ De getuige speelt in de fase van de bewijsvoering een prominente rol.

\subsubsection{Oproepen getuigen}

Wanneer de verdediging op het onderzoek ter terechtzitting één of meer getuigen wil (laten) horen, moet daartoe een verzoek worden ingediend bij de zittingsrechter. Dit kan voorafgaand aan het onderzoek ter terechtzitting of op een later moment zolang de fase van de bewijsvoering ter terechtzitting nog niet is gesloten. ${ }^{155}$ Voor het oproepen van getuigen zijn - net als in het oude strafprocesrecht - in het wetboek van strafvordering geen bijzondere regels opgenomen: bepalend zijn de algemene regels voor het indienen en behandelen van bewijsverzoeken. Wat betreft de vraag hoe de rechter met een bewijsverzoek om moet gaan, geldt dat de

149 Ter illustratie: tijdens de verschillende strafzittingen die ik in Poznań en Lublin heb bijgewoond, is het geen enkele keer voorgekomen dat een lekenrechter een vraag stelde of zich anderszins actief met de zaak bemoeide.

150 Een passieve houding op het onderzoek ter terechtzitting sluit immers niet uit dat wel actief wordt deelgenomen aan de beraadslaging over de schuldvraag en de op te leggen straf.

151 Voor getuigen en deskundigen is deze strafbaarheid vastgelegd in art. 233 lid 1 en 4 KK 1997.

152 De vraag of een verdachte strafbaar is voor het vals beschuldigen van of kwaad spreken over een ander tijdens het afleggen van een verklaring in zijn eigen strafzaak wordt van oudsher verschillend beantwoord door Poolse auteurs. Zie hierover onder meer Kruszyński 1991, p. 80 en Daszkiewicz 2001 p. 252-255.

153 Zie hierover hoofdstuk 5, § 5.5.

154 Waltoś 2002, p. 351.

155 Zie hiervoor $§ 2.2$. 
wetgever een aantal limitatieve gronden voor afwijzing heeft geformuleerd. De rechter dient een bewijsverzoek te weigeren wanneer:

1. de gevraagde bewijslevering niet is toegestaan, ${ }^{156}$

2. de omstandigheid die men wenst te bewijzen niet relevant is voor de te nemen beslissing of reeds is gebleken dat deze omstandigheid in overeenstemming met de beschuldigingen van de eisende partij is,

3. het bewijs niet relevant is voor de vaststelling van de omstandigheden waar het om draait,

4. de gevraagde bewijslevering niet mogelijk is ${ }^{157}$ of

5. het bewijsverzoek op overduidelijke wijze is gericht op vertraging van de procedure. ${ }^{158}$

De onder 5 genoemde grond is nieuw in het Poolse strafprocesrecht: deze is in 2003 ingevoerd om misbruik van de bevoegdheid tot het indienen van bewijsverzoeken door de verdediging tegen te gaan. ${ }^{159}$ Hoewel de bovengenoemde opsomming limitatief is en alle bewijsverzoeken die niet onder een van genoemde categorieën vallen dus zullen moeten worden ingewilligd, bieden de gronden vanwege hun ruime formulering de rechter voldoende mogelijkheden om bepaalde verzoeken af te wijzen. De afwijzende beslissing dient te worden gemotiveerd maar er kan geen rechtsmiddel tegen worden ingesteld. ${ }^{160}$ Het is (uiteraard) wel toegestaan het verzoek in een later stadium van de procedure te herhalen. ${ }^{161}$

Beslissingen over het horen van getuigen worden gedurende het eindonderzoek dus geheel buiten de prokurator om genomen: het verzoek moet worden ingediend bij de zittingsrechter en hij is de enige die erover kan beslissen. ${ }^{162}$ Een dergelijk verzoek kan schriftelijk of mondeling worden ingediend. De wet stelt weinig eisen op dit punt: wel is bepaald dat een bewijsverzoek behalve het gewenste bewijs(middel) - in het geval van een getuige: zijn naam en adresgegevens - ook dient aan te geven welke feiten of omstandigheden men ermee wenst te bewijzen. ${ }^{163}$

156 Bijvoorbeeld horen van een getuige die zich op zijn verschoningsrecht beroept.

157 Bijvoorbeeld het horen van een getuige die reeds is overleden.

158 Art. 170 lid 1 sub 1 tot en met 5 KPK 1997. Zie ook Wiliński 2006, p. 379-385 en Hofmański e.a. 2007 I, p. 750-757.

159 Hierop zal worden teruggekomen in § 5.2.2.

160 Aan de motivering worden eisen gesteld: zo kan niet worden volstaan met een herhaling van de wettelijke weigeringsgronden of met de constatering dat de gevraagde bewijsvoering 'niet noodzakelijk' is: Hofmański e.a. 2007 I, p. 758 en daar genoemde rechtspraak.

161 Art. 170 lid 4 KPK 1997: 'De weigering van een bewijsverzoek sluit niet uit dat het bewijs later - ook wanneer zich geen nieuwe omstandigheden voordoen - wel wordt toegelaten.'

162 Beslissingen op bewijsverzoeken worden gedurende het onderzoek ter terechtzitting genomen door de voorzitter. Dit in tegenstelling tot het vooronderzoek waar bewijsverzoeken van de verdediging tot de prokurator moeten worden gericht. Dit is slechts anders wanneer het gaat om een getuige van wie vermoed wordt dat hij of zij niet meer op het onderzoek ter terechtzitting zal kunnen worden gehoord: in dat geval dient het verzoek tot de rechtbank te worden gericht (art. 316 lid 3 KPK 1997). Zie hoofdstuk 5, § 5.2.2.

163 Ook kan de wijze waarop het bewijs moet worden verkregen, worden aangegeven (art. 169 lid 1 KPK 1997). 
Het staat de verdediging vrij een getuige die (bijvoorbeeld in het vooronderzoek) reeds in haar aanwezigheid is gehoord, toch opnieuw op te laten roepen. Het aantal keren dat een dergelijk verzoek kan worden gedaan, is in beginsel onbeperkt. ${ }^{164}$

\subsubsection{Horen getuigen}

Het verhoor van getuigen vindt plaats volgens de in het voorgaande beschreven vaste volgorde. ${ }^{165}$ De raadsman en de verdachte zijn daarbij als laatste procespartij aan de beurt, tenzij de getuige op hun verzoek wordt gehoord. Procespartijen behoren hun vragen zorgvuldig te formuleren. Voor alle verhoren op de zitting geldt dat de rechter drie categorieën vragen behoort te verbieden (of beter gezegd: wanneer ze gesteld zijn, moet hij voorkomen dat er antwoord op wordt gegeven): suggestieve vragen, irrelevante vragen en 'vragen die om andere redenen ongepast zijn'. ${ }^{166}$ Het gaat hier om een ambtshalve bevoegdheid maar de verdediging of een andere procespartij kan de rechter uiteraard verzoeken dat er - in geval van een in hun ogen ontoelaatbare vraag - gebruik van wordt gemaakt. ${ }^{167}$

\subsubsection{Bijzondere categorieën getuigen}

In het onderstaande zal aandacht worden besteed aan drie categorieën getuigen aan wie - anders dan in het oude wetboek van strafvordering - in het huidige Poolse strafprocesrecht een bijzondere status is verleend: de anonieme getuige, de kroongetuige en het minderjarige slachtoffer in (met name) zedenzaken. ${ }^{168}$ Centraal staat de vraag in hoeverre de rechten van de verdediging worden beïnvloed door de bescherming die door de wetgever aan deze getuigen is geboden.

De anonieme getuige

Het Poolse strafprocesrecht kent verschillende manieren om getuigen te beschermen. Zo kunnen onder bepaalde omstandigheden de adresgegevens van een getuige geheim worden gehouden. ${ }^{169}$ Ook bestaat de mogelijkheid het afleggen

164 Wiliński 2006, p. 483. Ten aanzien van het minderjarige slachtoffer in zedenzaken geldt echter wel een (wettelijke) beperking: zie hierna § 4.4.3.3. Bovendien is het gelet op eerder genoemde weigeringsgronden (art. 170 lid 1 KPK 1997) niet uitgesloten dat de rechter het verzoek een getuige opnieuw te horen, weigert omdat aangenomen wordt dat een nieuw verhoor niets meer zal toevoegen.

165 Zie $\S$ 4.4.2.

166 Art. 171 lid 4 en 6 jo. 370 lid 4 KPK 1997. Laatstgenoemde restcategorie stelt de rechter in staat vragen te verbieden die wel van belang en niet suggestief zijn maar bijvoorbeeld vanwege de wijze waarop ze worden gesteld (op een beledigende wijze of met ongepast taalgebruik) niet kunnen worden toegelaten. Over de drie categorieën: Grzegorczyk 2004, p. 950-951.

167 Over het verbieden van vragen: Kruszyński 1991, p. 233-236. Voor de vraag of de raadsman voorafgaand aan het onderzoek ter terechtzitting contact mag zoeken met getuigen wordt verwezen naar hoofdstuk 5 , § 5.6 en hoofdstuk 8, § 4.3.3.

168 Zie over laatstgenoemde categorie ook: hoofdstuk 5, § 5.2.3.

169 Men spreekt in dit verband ook wel van de beperkt anonieme getuige. Deze mogelijkheid die openstaat wanneer er gerechtvaardigde vrees bestaat dat geweld zal worden gebruikt of bedreigingen zullen worden geuit tegen de getuige of zijn naaste - zal in het gros van de gevallen geen noemenswaardige gevolgen hebben voor de verdediging. De getuige wordt onder normale omstandigheden ter terechtzitting gehoord zodat raadsman en verdachte in beginsel zonder beperkingen gebruik kunnen maken van hun ondervragingsrecht. Bovendien vormen de adresgegevens van de getuige in de meeste gevallen geen voor de ver- 
van een verklaring achter gesloten deuren te laten plaatsvinden of de verdachte tijdelijk uit de zittingzaal te verwijderen. Deze mogelijkheden - die ook reeds in het oude strafprocesrecht bestonden - zijn echter niet toereikend gebleken: in 1995 is gekozen voor de invoering van de volledig anonieme getuige (świadek anonimowy, świadek incognito of świadek utajniony). De regeling is als reactie op de toenemende georganiseerde criminaliteit eerst in november 1995 ingevoerd in het oude wetboek van strafvordering en uiteindelijk in enigszins gewijzigde vorm behouden in het strafprocesrecht van 1997. ${ }^{170}$ Nadere regels over de anonieme getuige in het strafproces zijn gesteld in een verordening van de minister van Justitie. ${ }^{171}$ De anonieme getuigenregeling heeft bij gelegenheid van de wetswijziging van 2003 verschillende veranderingen ondergaan die onder meer tot een versterking van de rechten van de verdediging hebben geleid. ${ }^{172}$

Indien er ten aanzien van een getuige of zijn naasten gerechtvaardigde vrees bestaat voor het leven, de gezondheid, de vrijheid of een aanzienlijk verlies van eigendom, kan de rechtbank of - in het vooronderzoek - de prokurator besluiten de gegevens die tot identificatie van de betreffende getuige kunnen leiden als geheim te classificeren. ${ }^{173}$ De mogelijkheid om iemand als anonieme getuige te horen, is niet beperkt tot een bepaalde categorie (ernstige) strafbare feiten. Hoewel de introductie van de regeling voornamelijk een reactie was op de toenemende omvang en ernst van georganiseerde criminaliteit, heeft de wetgever op dit punt

dediging wezenlijke informatie. Zie hierover: Wiliński 2006, p. 485.

170 Respectievelijk art. 164a KPK 1969 en art. 184 KPK 1997. Algemeen over de anonieme getuige: Hofmański 1998 en Hofmański en Zabłocki 2000.

171 Verordening van 18 juni 2003 inzake de procedure ter geheimhouding van omstandigheden op grond waarvan de identiteit van een getuige kan worden achterhaald en de wijze waarop van de verklaringen van deze getuige proces-verbaal moet worden opgemaakt (Rozporzadzenie Ministra Sprawiedliwości w sprawie postępowania o zachowanie tajemnicy okoliczności umożliwiających ujawnienie tożsamości świadka oraz sposobu postępowania $z$ protokałami z zeznań tego świadka).

172 In welk opzicht de positie van de verdediging is verbeterd, zal in hierna worden uitgewerkt. Voor een overzicht van de veranderingen die de regeling van de anonieme getuige sinds haar totstandkoming in 1995 heeft ondergaan: Hofmański e.a. 2007 I, p. 848850. Meer specifiek over de wijzigingen van 2003: Wiliński 2003 II.

173 Voor 2003 was geregeld dat alleen persoonsgegevens als geheim konden worden geclassificeerd terwijl in de praktijk soms de behoefte bestond ook andere gegevens of zelfs delen van verklaringen niet openbaar te maken: op grond van het oorspronkelijke art. 184 KPK 1997 was niet duidelijk of dat toelaatbaar was. Door de huidige ruime formulering ('gegevens die tot identificatie zouden kunnen leiden') is deze twijfel weggenomen en is het voortaan ook mogelijk om delen van verklaringen geheim te houden indien daaruit de identiteit van de getuige zou kunnen worden afgeleid. Om te voorkomen dat als gevolg van deze wijziging te veel relevante informatie aan de verdediging zou kunnen worden onthouden, is in 2003 aan het eerste lid van art. 184 KPK 1997 toegevoegd dat het slechts mag gaan om gegevens die 'niet van belang zijn voor de betreffende zaak'. Delen van een verklaring (en andere gegevens) mogen dus niet aan de verdediging worden onthouden wanneer deze relevante informatie over het gepleegde strafbare feit of het daderschap van verdachte bevatten. Zie hierover Wąsek-Wiaderek 2003 II, p. 295-306, Hofmański e.a. 2007 I, p. 857 en Grzegorczyk 2004, p. 488. 
geen beperkingen geformuleerd en kan een getuige in beginsel in iedere strafzaak als anoniem worden aangemerkt. ${ }^{174}$

De procedure waarin de beslissing (iemand als anonieme getuige aan te merken) wordt genomen, vindt zowel in het vooronderzoek als tijdens het eindonderzoek plaats in afwezigheid van partijen en wordt geclassificeerd als staatsgeheim. ${ }^{175}$ In de praktijk wordt deze beslissing meestal in het vooronderzoek - en dus door de prokurator - genomen. ${ }^{176}$

De verklaring van een anonieme getuige die met inachtneming van de in art. 184 KPK 1997 genoemde regels is gehoord, mag ter terechtzitting worden voorgelezen en wordt als schriftelijk bescheid (dokument) aangemerkt. ${ }^{177}$ Dat de in het vooronderzoek afgelegde verklaring ter zitting mag worden voorgelezen, ontheft de rechtbank echter niet van de plicht de anonieme getuige zelf te horen. ${ }^{178}$

Het verschijnsel van de anonieme getuige heeft in ieder rechtssysteem waar het wordt aanvaard - en dus ook in Polen - consequenties voor de verdediging. Het is het resultaat van de afweging van twee in beginsel tegenstrijdige belangen: enerzijds het recht van de verdediging om getuigen aan de tand te voelen en anderzijds het recht van getuigen om te worden beschermd tegen de risico's die met het afleggen van een belastende verklaring gepaard kunnen gaan. Het feit dat de identiteit van een anonieme getuige geheim dient te blijven, is van invloed op de mogelijkheden van de verdediging om de betreffende getuige te (doen) ondervragen en de betrouwbaarheid van zijn verklaringen te betwisten. Vraag is dus niet óf de rechten van de verdediging door het optreden van een anonieme getuige worden beperkt maar in welke mate dat gebeurt en of die beperkingen voldoende worden gecompenseerd.

Voor de Poolse regeling is in de eerste plaats van belang dat tegen de beslissing van de prokurator of van de rechtbank iemand als anonieme getuige aan te merken binnen een termijn van drie dagen bezwaar (zażalenie) kan worden ingesteld. De behandeling van het bezwaar is wanneer de bestreden beslissing afkomstig is van de prokurator overgelaten aan de rechtbank en vindt in afwezigheid van partijen plaats. ${ }^{179}$ Wanneer het bezwaar wordt ingewilligd, dient het proces-verbaal van

174 Op dit - in ieder geval in theorie - ruime toepassingsbereik van de regeling is in de Poolse literatuur veel kritiek geuit: zie hierover Grajewski 2005, p. 202. In de praktijk zal het vanwege de proportionaliteitstoets die justitie op dit punt moet uitvoeren en het feit dat sprake moet zijn van reële vrees voor bedreiging van de getuige echter doorgaans wel om zwaardere strafzaken gaan.

175 Art. 184 lid 1 eerste en tweede zin KPK 1997. De verdediging dient een afschrift van de beslissing te ontvangen. De kwalificatie als staatsgeheim betekent dat openbaarmaking van informatie die tijdens de zitting besproken wordt, strafbaar is (art. 265 KK 1997).

176 Laatstgenoemde is dan ook verantwoordelijk voor de bescherming van de getuige: Wiliński 2003 I, p. 468-470. Het verhoor van de anonieme getuige in het vooronderzoek mag nooit door de politie worden verricht.

177 Grzegorczyk 2004, p. 1011.

178 Het Hooggerechtshof heeft in verschillende uitspraken benadrukt dat het daderschap van verdachte niet uitsluitend op grond van de anonieme getuigenverklaring mag worden vastgesteld en dat dus ook ander bewijs voorhanden moet zijn dat de betreffende verdachte als dader aanwijst. Voor een weergave van de rechtspraak van het Hooggerechtshof op dit punt: Kulesza 2005, p. 356.

179 Wanneer het besluit gedurende het eindonderzoek door de rechtbank zelf is genomen, is 
het verhoor te worden vernietigd ${ }^{180}$ en zal de getuige alleen nog onder normale omstandigheden of eventueel als beperkt anonieme getuige in de betreffende strafzaak kunnen worden gehoord. De praktische betekenis van deze bezwaarmogelijkheid is echter uiterst beperkt. In de eerste plaats omdat de verdediging niet of nauwelijks wordt geïnformeerd over de grondslag waarop de beslissing is genomen. Doorgaans wordt de door de wetgever gehanteerde formule ('er bestaat gerechtvaardigde vrees voor het leven, de gezondheid, de vrijheid of een aanzienlijk verlies van eigendom van de getuige of zijn naaste ${ }^{\prime 181}$ ) gekopieerd en krijgt de verdediging dus geen inzicht in de precieze reden voor de beslissing. Juist ook omdat de identiteit van de getuige niet bekend is, is het niet eenvoudig een goed gemotiveerd verweer te voeren tegen de beslissing. Aangezien niet duidelijk is welke gegevens geheim worden gehouden, kan ook moeilijk worden aangevoerd dat deze wel van belang zijn voor de zaak en dus openbaar moeten worden gemaakt. Daar komt bij dat de procedure waarin op het bezwaar wordt beslist geheim is en zonder deelname van partijen plaatsvindt. De verdediging heeft dus niet de mogelijkheid een en ander op een zitting mondeling toe te lichten. Om deze redenen wordt in de Poolse literatuur wel opgemerkt dat de bezwaarmogelijkheid die met de totstandkoming van het wetboek van strafvordering van 1997 nieuw is ingevoerd niet meer dan een fictie is. ${ }^{182}$

De mogelijkheden die de verdediging heeft in het kader van het verhoor van de anonieme getuige betreffen enerzijds het recht om deel te nemen aan een dergelijk verhoor en anderzijds het recht om vragen te stellen aan de getuige. De wettelijke regeling is vrij summier op dit punt. Uit art. 184 KPK 1997 blijkt dat de verhoren door de prokurator en de rechtbank plaats dienen te vinden

- 'op een wijze die voorkomt dat de omstandigheden genoemd in het eerste lid [die tot identificatie van de getuige zouden kunnen leiden, toev. DdV] aan het licht komen' en

- dat de prokurator, de verdachte en zijn raadsman het recht hebben deel te nemen aan het verhoor door de rechter. ${ }^{183}$

In de eerste plaats volgt hieruit dat het deelnamerecht van de verdediging slechts betrekking heeft op de verhoren door de rechter. ${ }^{184}$ Wanneer een anonieme ge-

een hogere rechter bevoegd het bezwaar te beoordelen. Deze bezwaarprocedure wordt net als de procedure waarin de oorspronkelijke beslissing wordt genomen - aangemerkt als staatsgeheim (art. 184 lid 5 KPK 1997).

180 Art. 184 lid 6 KPK 1997.

181 Art. 184 lid 1 KPK 1997.

182 Gwirdoyń 2004, p. 202, Gajewska-Kraczkowska 1997, p. 99-100, Wiliński 2003 I, p. 353 en daar genoemde literatuur. Wiliński voegt hier nog aan toe dat bovendien niet is uitgesloten dat de beslissing iemand als anonieme getuige aan te merken gedurende het vooronderzoek wordt genomen voordat de verdachte officieel als zodanig is aangemerkt. De korte termijn voor het instellen van het bezwaar (drie dagen) gaat dan wel gewoon lopen en kan dus al zijn verstreken voordat de verdachte of zijn raadsman de kans hebben gehad deze mogelijkheid te benutten: Wiliński 2003 I, p. 352-353. Over de effectiviteit van het rechtsmiddel ook: Hofmański e.a. 2007 I, p. 862-863.

183 Art. 184 lid 3 KPK 1997.

184 Sinds de wetswijziging van 2003 volgt dit onverkort uit de tekst van art. 184 lid 3 KPK 1997: daarvoor was de wettelijke regeling op dit punt minder duidelijk maar was men het er in de praktijk en de doctrine over eens dat de verdediging alleen mocht deelnemen aan 
tuige gedurende het vooronderzoek door de prokurator wordt gehoord, kunnen verdachte en raadsman daaraan dus niet deelnemen. ${ }^{185}$ Een getuige die in het vooronderzoek is gehoord, zal echter in het eindonderzoek in beginsel opnieuw moeten worden gehoord door de rechtbank. ${ }^{186}$ De verdediging heeft dan alsnog de gelegenheid bij het verhoor aanwezig te zijn.

Noch uit art. 184 noch uit enige andere bepaling van het wetboek van strafvordering kan worden afgeleid hoe het verhoor van de anonieme getuige kan (of moet) worden vormgegeven. ${ }^{187}$ De eerder genoemde verordening van de minister van Justitie bevat wel een paar aanwijzingen op dit punt maar is zeker niet uitputtend. Vandaar dat wordt aangenomen dat het procesorgaan dat het verhoor uitvoert (rechter of prokurator) in beginsel zelf zal moeten bepalen hoe dat in de gegeven omstandigheden het beste kan plaatsvinden. ${ }^{188}$ Aangezien de verdediging niet kan deelnemen aan het verhoor door de prokurator dient ervan te worden uitgegaan dat daar de minst vergaande maatregelen hoeven te worden getroffen. ${ }^{189}$ Voor het verhoor door de rechter - dat wel kan worden bijgewoond door de verdachte en zijn raadsman - kunnen meer ingrijpende maatregelen noodzakelijk zijn. Dit verhoor kan zowel op het onderzoek ter terechtzitting plaatsvinden als daarbuiten. ${ }^{190}$ De verdediging heeft in beginsel het recht bij al deze verhoren aanwezig te zijn. ${ }^{191}$

het verhoor door de rechter. Zie hierover Wiliński 2003 I, p. 353.

185 De verdediging moet wel inzage kunnen hebben in het proces-verbaal van het verhoor uit het vooronderzoek maar alleen voorzover daaruit niet de identiteit van de getuige kan worden afgeleid.

186 Hofmański e.a. 2007 I, p. 848. Een en ander kan worden afgeleid uit de formulering van art. 184 lid 3 KPK 1997: 'De getuige zal worden ondervraagd door de prokurator en ('także') de rechtbank (...).' Dit was op grond van het oude wetboek van strafvordering anders: toen gold ingevolge art. 164a lid 3 KPK 1969 dat de anonieme getuige door de prokurator of ('lub') de rechtbank moest worden verhoord en kon dus met het verhoor in het vooronderzoek worden volstaan. Mede vanwege de kosten die met het verwezenlijken van een verhoor op de zitting gepaard gaan, gebeurde het maar zelden dat getuigen die in het vooronderzoek waren gehoord ook nog door de rechter aan de tand werden gevoeld: Myczkowski 2003, p. 202.

187 Art. 184 lid 1 KPK 1997 maakt slechts duidelijk dat het verhoor dient te geschieden op een wijze die voorkomt dat de gegevens van de anonieme getuige die geheim dienen te blijven aan het licht komen.

188 De keuze voor een bepaalde methode zal af dienen te hangen van de grootte en de ernst van het gevaar dat aanleiding is geweest de getuige als anoniem aan te merken: Wiliński 2003 I, p. 342.

189 De getuige zal in de regel mondeling en zonder gebruikmaking van technische apparatuur moeten kunnen verklaren: Wiliński 2003 I, p. 372-373.

190 Verhoren buiten het onderzoek ter terechtzitting om zijn op twee manieren mogelijk: enerzijds door het gehele rechterlijke college op een zitting en anderzijds door een speciaal daarvoor aangewezen rechter.

191 Voor de gedetineerde verdachte geldt echter wel een uitzondering: wanneer het verhoor niet door het gehele rechterlijke college maar door een daartoe aangewezen rechter plaatsvindt, hoeft hij alleen naar verhoor te worden gebracht wanneer de rechtbank dat noodzakelijk acht (art. 184 lid 3 laatste zin jo. art. 396 lid 3 KPK 1997). Hofmański gaat er - mijns inziens terecht - van uit dat de gedetineerde verdachte die geen rechtsbijstand heeft te allen tijde in de gelegenheid zal moeten worden gesteld het verhoor van de anonieme getuige bij te wonen: Hofmański e.a. 2007 I, p. 868. 
De voor de verdediging minst bezwarende optie is uiteraard om de getuige lijfelijk aanwezig op de zitting rechtstreeks en mondeling te kunnen horen. Dan zullen echter maatregelen moeten worden getroffen om de identiteit van de getuige verborgen te houden: het uiterlijk en eventueel ook de stem van de getuige kunnen onherkenbaar worden gemaakt. ${ }^{192}$

Het recht van de verdediging om deel te nemen aan het verhoor van de anonieme getuige was voor 2003 aanzienlijk beperkter. In het oorspronkelijke art. $184 \mathrm{KPK}$ 1997 was namelijk niet met zoveel woorden bepaald dat de verdachte en zijn raadsman het recht hadden deel te nemen aan deze verhoren maar slechts dat 'het verhoor van de (anonieme) getuige alleen mag plaatsvinden onder omstandigheden die voorkomen dat de identiteit van de getuige aan het licht komt'. ${ }^{193}$ Op grond van deze formulering was het deelnamerecht van de verdediging niet absoluut: wanneer de rechter van oordeel was dat het verhoor niet zodanig kon worden vormgegeven dat anonimiteit van de getuige werd gegarandeerd, konden de verdachte en zijn raadsman van deelname worden uitgesloten. Aangezien deze situatie onverenigbaar was met de eisen van art. 6 EVRM is art. 184 KPK 1997 in 2003 op dit punt gewijzigd. ${ }^{194}$ De autoriteiten zijn niet langer vrij om te bepalen dat deelname niet mogelijk is: zij zijn verplicht het verhoor op zo'n wijze te organiseren dat de verdediging - zonder gevaar voor onthulling van de identiteit van de getuige - gebruik kan maken van haar recht aanwezig te zijn en vragen te stellen.

De verdediging heeft niet alleen het recht (al dan niet op afstand) bij de verhoren aanwezig te zijn maar moet ook in de gelegenheid worden gesteld de getuige vragen te stellen. Dat laatste is in het wetboek van strafvordering weliswaar niet expliciet geregeld maar kan in ieder geval worden afgeleid uit art. 6 lid 3 sub d EVRM. ${ }^{195}$ De verdediging kan vragen mondeling of schriftelijk stellen: dit is volledig afhankelijk van de wijze waarop het verhoor wordt vormgegeven. Hetzelfde geldt voor de vraag of de raadsman en de verdachte hun vragen rechtstreeks aan de getuige of met tussenkomst van de rechter moeten stellen. ${ }^{196}$

Ten slotte is van belang dat wanneer een getuige - al dan niet in aanwezigheid van de verdediging - is gehoord, nog de mogelijkheid bestaat dat deze verklaring wordt uitgesloten van het bewijs. De beslissing iemand als anonieme getuige aan te merken, kan alsnog door de prokurator of de rechtbank worden ingetrokken wanneer later in de procedure blijkt dat:

192 Wanneer dat niet volstaat, is mogelijk dat de getuige zich achter een wand (van bijvoorbeeld spiegelglas) of in een aparte cabine bevindt. De getuige die tijdens het onderzoek ter terechtzitting wordt gehoord, kan zich ook in een andere ruimte dan de zittingzaal of zelfs in een ander gebouw bevinden. In dergelijke gevallen zal gebruik moeten worden gemaakt van audio- en/ of videotechniek om het verhoor uit te kunnen voeren.

193 Art. 184 lid 4 KPK 1997 (voor wijziging 2003).

194 Zie ook Wiliński 2006, p. 499 en Hofmański e.a. 2007 I, p. 868.

195 Zie ook $\S 4.5$. Ook door het Hooggerechtshof is onder verwijzing naar genoemd artikellid bevestigd dat het recht van de verdachte en zijn raadsman om aanwezig te zijn bij het verhoor ook het recht om vragen te stellen omvat: Wąsek-Wiaderek 2003 II, p. 337 en daar genoemde rechtspraak. Mijns inziens kan een en ander ook worden afgeleid uit het feit dat de wetgever in art. 184 lid 4 KPK 1997 spreekt over 'deelname' ('udziat') van de verdediging wat - anders dan met het werkwoord 'aanwezig zijn' - een actieve opstelling impliceert.

196 Ook de verklaring van de getuige kan zowel schriftelijk als mondeling zijn. Zie Wiliński 2003 I, p.342-377. 
- op het moment dat de beslissing werd genomen geen gerechtvaardigde vrees voor bedreiging bestond,

- de getuige welbewust een valse verklaring heeft afgelegd of

- de identiteit van de betreffende getuige is geopenbaard.

Deze mogelijkheid neergelegd in art. 184 lid 8 KPK 1997 is in 2003 in de anonieme getuigenregeling geïntroduceerd en kan van betekenis zijn voor de verdediging. Zij kan - bijvoorbeeld door middel van een andere getuige - proberen aan te tonen dat de anonimiteit van de getuige niet langer hoeft te worden gewaarborgd. Gelet op de gronden voor intrekking zal dit in de praktijk echter niet eenvoudig zijn. De verdediging is immers niet op de hoogte van de precieze feiten en omstandigheden die aanleiding zijn geweest om de status van anonieme getuige te verlenen waardoor doorgaans moeilijk zal kunnen worden aangetoond dat de vrees voor bedreiging onterecht is. Dan resteert nog de mogelijkheid aan te voeren dat de getuige een valse verklaring heeft afgelegd of dat de identiteit reeds aan het licht is gekomen maar dergelijke situaties zullen zich niet vaak voor doen. ${ }^{197}$

De anonieme getuigenregeling is sinds de totstandkoming ervan in 1995 vanuit verschillende hoeken bekritiseerd. ${ }^{198}$ Belangrijkste punt van kritiek was de positie van de verdediging op grond van art. 184 zoals het oorspronkelijk in het wetboek van 1997 werd geïntroduceerd en dan met name het feit dat de verdachte en zijn raadsman geen absoluut recht hadden deel te nemen aan het verhoor van de anonieme getuige. In de eerste periode na inwerkingtreding van de anonieme getuigenregeling (november 1995 tot december 1996) zijn 291 personen als anonieme getuige gehoord in een strafzaak. ${ }^{199}$ Door gebrek aan ervaring werden de nieuwe regels aanvankelijk niet goed toegepast wat de kritiek op het instituut alleen maar verder deed toenemen. Er werd zelfs voor gepleit de anonieme getuigenregeling weer in te trekken. ${ }^{200}$ Sinds de wetswijziging van 2003 is het algemene oordeel van de doctrine positiever geworden.201 Volgens Wąsek-Wiaderek is de Poolse wetgever in vergelijking met andere Europese landen nog redelijk 'voorzichtig' geweest bij de inperking van de rechten van de verdediging op dit punt.202 Uit een binnen justitie gehouden enquête blijkt dat leden van de rechterlijke macht en prokuratura de anonieme getuigenregeling over het algemeen positief beoordelen. Bijzonder opmerkelijk is dat op de vraag of het verschijnsel van de anonieme getuige een positieve of een negatieve invloed op de positie van de verdachte heeft door iets minder dan de helft van de respondenten (41\%) wordt geantwoord dat de invloed positief is. ${ }^{203} \mathrm{Op}$ de vraag of de effectiviteit van de verdediging erdoor

197 Gwirdoyń 2004, p. 203.

198 Zie hierover ook Bojarski en Van Dijck 2007, p. 275-276.

199 Meer recente gegevens over de inzet van de anonieme getuige zijn helaas niet beschikbaar.

200 Bojarski en Van Dijck 2007, p. 276.

201 Zie onder meer Wiliński 2003 II en (voor een zeer kritische bijdrage) Myczkowski 2003. Voor een overzicht van relevante literatuur over de anonieme getuige wordt verwezen naar: Wiliński 2006, p. 490-491.

202 Wąsek-Wiaderek 2003 II, p. 301. Ter vergelijking wordt de regeling van de anonieme getuige in het Duitse, Nederlandse en Oostenrijkse strafprocesrecht besproken (p. 301-306).

203 Wiliński 2006, p. 491-492. Genoemd onderzoek is uitgevoerd door Wiliński. Iets meer dan $36 \%$ was van mening dat de invloed negatief was en circa $22 \%$ heeft geen antwoord gegeven op deze vraag. Onduidelijk is waarom zoveel respondenten van mening zijn dat 
wordt beïnvloed, antwoordt een ruime meerderheid (63\%) dat van enige negatieve invloed geen sprake is. ${ }^{204}$ Uit hetzelfde onderzoek is bovendien naar voren gekomen dat $58 \%$ van de ondervraagde rechters en leden van de prokuratura van mening is dat het feit dat een anonieme getuige buiten het onderzoek ter terechtzitting is gehoord niet van invloed is op de bewijswaarde van de afgelegde verklaring. Sterker nog: meer dan een derde van de respondenten $(35 \%)$ vond dat de waarde van de verklaring hierdoor positief wordt beïnvloed. Slechts $6 \%$ oordeelde dat het horen van de getuige buiten het onderzoek ter terechtzitting de waarde van het aldus verkregen bewijs wel negatief beïnvloedt. ${ }^{205}$

\section{De kroongetuige}

Naast de anonieme getuige kent de Poolse strafrechtspleging sinds een aantal jaren ook de kroongetuige (świadek koronny): een getuige die zelf wordt verdacht van bepaalde strafbare feiten maar in ruil voor strafvermindering of straffeloosheid belastende verklaringen aflegt over andere (meer 'belangrijke') verdachten. Dit van oorsprong Engelse verschijnsel is niet in het wetboek van strafvordering opgenomen maar geregeld in een aparte wet die oorspronkelijk een tijdelijk karakter had maar in 2006 voor onbepaalde tijd is verlengd. ${ }^{206}$

De introductie van de kroongetuige is - net als de anonieme getuige - ingegeven door de toenemende behoefte om effectiever op te kunnen treden tegen georganiseerde criminaliteit en heeft in de Poolse literatuur tot veel kritiek geleid. ${ }^{207}$

de regeling een positieve invloed heeft op de positie van de verdachte. Bovengenoemde vraag werd in de enquête overigens voorafgegaan door de vraag 'Heeft het verschijnsel van de anonieme getuige invloed op de positie van de verdachte in het strafproces?': circa $37 \%$ was van mening dat een dergelijke invloed mogelijk is, iets meer dan $15 \%$ gaf aan dat toepassing van de regeling altijd gevolgen heeft voor de verdachte, circa $31 \%$ vond dat de positie van de verdachte niet wordt beïnvloed wanneer hij gebruik maakt van alle rechten die hem in dit verband toekomen en de resterende $15 \%$ oordeelde dat de positie van de verdachte niet wordt beïnvloed door de anonieme getuige.

204 Wiliński 2006, p. 492. Iets meer dan $22 \%$ vindt wel dat de mogelijkheden van de verdediging door de anonieme getuige worden beperkt.

205 Wiliński 2003 I, p. 348.

206 De wet op de kroongetuige (ustawa o świadku koronnym) van 25 juni 1997 - in werking getreden op 1 september 1998 - was aanvankelijk voor drie jaar van kracht maar is in 2000 voor zes jaar verlengd (tot september 2006). Met ingang van 1 september 2006 is de wet in gewijzigde vorm opnieuw verlengd waarbij dit keer geen termijn is bepaald.

207 Zie voor een zeer kritische bespreking onder meer Zewelak 2006. Zie ook Bojarski en Van Dijck 2007, p. 276-277. Deze discussie wordt overigens niet alleen in Polen gevoerd: sinds het eind van de jaren tachtig is de figuur van de kroongetuige in verschillende Europese rechtssystemen geïntroduceerd (waaronder Duitsland, Italië en Nederland) en het heeft vrijwel overal een controversieel karakter. In de Poolse discussie speelt niet alleen de morele vraag of dit soort afspraken met (vermeende) criminelen wel door de beugel kan en of de verklaringen die zo worden verkregen wel betrouwbaar zijn maar wordt door sommige auteurs ook aangevoerd dat het instituut van de kroongetuige niet past in een rechtssysteem als het Poolse waarin vervolging op grond van het legaliteitsbeginsel plaatsvindt. Uitgangspunt van het legaliteitsprincipe is immers dat alle strafbare feiten in beginsel vervolgd moeten worden en daarvan zou niet mogen worden afgeweken vanwege het enkele feit dat een verdachte belooft informatie vrij te geven die in andere strafzaken kan worden gebruikt: Grzegorczyk 2004, p. 1611. Voor een bespreking van de belangrijkste argumenten vóór en tegen invoering van de kroongetuige in het Poolse straf- 
Anders dan bij de anonieme getuige staat de mogelijkheid om gebruik te maken van de verklaring van een kroongetuige niet bij alle strafbare feiten open: in de wettelijke regeling wordt een aantal categorieën strafbare feiten opgesomd. Deze lijst is in de loop der jaren echter zodanig uitgebreid dat er nauwelijks nog een beperkende werking vanuit gaat. ${ }^{208}$ De vraag of iemand als kroongetuige mag optreden, wordt beantwoord door de provinciale rechtbank (SO): die - op verzoek van de prokurator - bepaalt of verklaringen van een kroongetuige voor het bewijs kunnen worden gebezigd. ${ }^{209}$ Hoewel de prokurator de enige procesdeelnemer is die een verzoek daartoe kan indienen, hoeft het initiatief niet noodzakelijk van hem uit te gaan: uit praktijkonderzoek blijkt dat ongeveer $50 \%$ van de kroongetuigen deze status op eigen initiatief verkrijgt, in $43 \%$ van de gevallen gebeurt het op aangeven van de prokurator of de politie en in de overige gevallen $(7 \%)$ geven andere personen - zoals de raadsman van verdachte - de aanzet. ${ }^{210}$ De verdediging kan hier dus een actieve rol in spelen.

De rechter kan de verklaring van een kroongetuige alleen toelaten wanneer aan de door de wet gestelde (positieve en negatieve) voorwaarden is voldaan. De kroongetuige dient voordat tegen hem een akte van beschuldiging is ingediend in zijn verklaringen relevante informatie te hebben gegeven die een rol kan spelen bij 'het aan het licht brengen van de omstandigheden waaronder een strafbaar feit is begaan, van overige daders, van andere strafbare feiten of de voorkoming ervan'. Bovendien dient hij te beloven een volledige verklaring af te zullen leggen over de personen die aan het betreffende strafbare feit hebben deelgenomen. ${ }^{211}$

Wat de mogelijkheden van de verdediging betreft, is niet alleen het recht op verdediging van de verdachte in wiens strafzaak een kroongetuige optreedt van belang maar ook de verdediging van de kroongetuige - die immers zelf ook als verdachte wordt aangemerkt.

Voor de positie van de kroongetuige is voornamelijk relevant dat de raadsman slechts beperkte mogelijkheden heeft om deel te nemen aan de procedure waarin wordt beslist over de vraag of zijn cliënt als kroongetuige kan optreden. Voordat de rechtbank een beslissing neemt op het verzoek van de prokurator wordt de verdachte gehoord. De raadsman hoeft niet van dit verhoor op de hoogte te worden

proces: Kowalewska-Borys 2004, p. 102-114.

208 Art. 1 wet op de kroongetuige. Zie hierover ook Bojarski en Van Dijck 2007, p. 278: 'During the last years the scope and application of the Act on Crown Witnesses have gradually been expanded. Initially the Act was strictly meant to target the most serious forms of (organised) crime. The fact that the Act passed despite the evident objections (...), may support the conclusion that the Act was meant as an extraordinary means to address extraordinary situations. However, amendments to the provisions of the Act have made it possible to use crown witness testimonies in rather "ordinary" cases, such as rather small-scale corruption cases.'

209 Art. 5 wet op de kroongetuige. De prokurator dient voor het indienen van een dergelijk verzoek toestemming te hebben van het landelijk parket (prokurator krajowy).

210 Grzegorczyk 2004, p. 1613 (genoemde gegevens zijn resultaten van een praktijkonderzoek uitgevoerd door $Z$. Rau, gepubliceerd in 2002).

211 Alsmede over de omstandigheden waaronder dit feit is begaan (art. 3 wet op de kroongetuige). Behalve deze twee positieve voorwaarden dient de rechter ook te toetsen of sprake is van een van de negatieve voorwaarden die tot gevolg hebben dat de verklaring van de kroongetuige niet voor het bewijs kan worden gebezigd. Een van de negatieve voorwaarden betreft het feit dat de kroongetuige er niet van mag worden verdacht een misdrijf tegen het leven te hebben begaan. 
gesteld tenzij de verdachte daarom heeft verzocht. ${ }^{212}$ Hierbij dient te worden opgemerkt dat het feit dat een verdachte mogelijk als kroongetuige gaat optreden geen grond is voor verplichte rechtsbijstand. Het is dus niet vanzelfsprekend dat de potentiële kroongetuige in zijn 'onderhandelingen' met de prokurator wordt bijgestaan door een raadsman.

Aangezien het verzoek van de prokurator gedurende het vooronderzoek moet worden ingediend, ${ }^{213}$ gelden voor de verdediging bovendien de algemene beperkingen met betrekking tot de inzage van processtukken. De verdediging kan het dossier gedurende het vooronderzoek immers alleen met toestemming van de prokurator inzien en het is in meer ingewikkelde strafzaken niet ongebruikelijk dat deze toestemming wordt geweigerd. ${ }^{214}$ Wanneer de verdediging het dossier nog niet heeft kunnen inzien, zal zij moeilijk kunnen inschatten of een optreden als kroongetuige in het belang van verdachte is. ${ }^{215}$

Voor zowel de advocaat die de kroongetuige bijstaat als de raadsman van de verdachte tegen wie de verklaring wordt gebruikt, is bovendien van belang dat tegen de beslissing de verklaring al dan niet voor het bewijs te bezigen alleen bezwaar kan worden aangetekend door de prokurator. ${ }^{216}$ De verdediging kan van dit rechtsmiddel dus geen gebruik maken.

Voorts is relevant dat de raadsman van de verdachte tegen wie de verklaring wordt gebruikt geen enkele invloed kan uitoefenen op de beslissing van de rechter kroongetuigenbewijs toe te staan. Dit betekent dat de verdediging de betrouwbaarheid van de kroongetuige slechts aan de kaak kan stellen door deel te nemen aan zijn verhoren. Op dat punt gelden - anders dan bij de anonieme getuige voor de verdediging geen bijzondere beperkingen. ${ }^{217}$ De identiteit van de kroongetuige wordt niet geheim gehouden. ${ }^{218}$ Wel moeten bepaalde beschermende maat-

212 Art. 5 lid 3 wet op de kroongetuige. De verdachte dient wel te worden geïnformeerd over de mogelijkheid een dergelijk verzoek in te dienen. De raadsman mag - wanneer hij op de zitting verschijnt - alleen worden toegelaten wanneer zijn cliënt daarmee instemt: Grzegorczyk 2004, p. 1625.

213 In de wet op de kroongetuige wordt dit nergens met zoveel woorden bepaald maar uit het systeem van de wet - en met name het gebruik van het woord 'verdachte' ('podejrzany') kan worden afgeleid dat het verzoek van de prokurator moet worden ingediend voordat in de zaak van de (potentiële) kroongetuige een akte van beschuldiging is ingediend: Kulesza 2005, p. 349.

214 Zie hoofdstuk 5, § 3.

215 De raadsman zou dit probleem alleen kunnen ondervangen door zijn cliënt te adviseren geen verklaringen af te leggen totdat de laatste inzage van de processtukken voor sluiting van het vooronderzoek (op grond van art. 321 KPK 1997, zie hierover hoofdstuk 5, § 3.2.2) heeft plaatsgevonden. Een dergelijke strategie is natuurlijk alleen mogelijk wanneer de raadsman hierover in een vroeg stadium van het vooronderzoek - voordat de eerste verhoren plaatsvinden - met zijn cliënt kan spreken.

216 Art. 5 lid 6 wet op de kroongetuige.

217 Het verhoor ter terechtzitting vindt op verzoek van de kroongetuige wel achter gesloten deuren plaats maar alle procesdeelnemers - en dus ook de verdediging - hebben het recht daarbij aanwezig te zijn. Op verzoek van de kroongetuige kan de rechtbank beslissen dat het horen in afwezigheid van de verdachte gebeurt. Uitgebreider over de gevolgen van de kroongetuigenregeling voor de positie van de verdediging: Kulesza 2005, p. 346-352.

218 Het is zelfs verboden iemand die als kroongetuige is aangemerkt als anonieme getuige te horen (art. 8 wet op de kroongetuige). 
regelen worden genomen: verhoren van kroongetuigen dienen zodanig te worden gepland en georganiseerd dat de veiligheidsrisico's zo klein mogelijk zijn. ${ }^{219}$

Wat betreft de toepassing in de praktijk, geldt dat tot en met 2006 in ongeveer 2000 strafzaken met kroongetuigen is gewerkt terwijl dit slechts in enkele tientallen zaken tot een einduitspraak heeft geleid. ${ }^{220}$ Volgens Bojarski en Van Dijck kan uit de recente aanpassingen en verlengingen van de geldingskracht van de wet op de kroongetuige worden afgeleid dat in de toekomst (nog) frequenter van het instituut gebruik zal worden gemaakt. ${ }^{221}$

\section{Het minderjarige slachtoffer}

In 2003 is een bepaling geïntroduceerd op grond waarvan minderjarige slachtoffers van bepaalde emotioneel zeer belastende feiten in beginsel slechts eenmaal mogen worden gehoord. ${ }^{222}$ De verklaring dient op de het onderzoek ter terechtzitting te worden voorgelezen en wanneer geluidsopnamen van het verhoor zijn gemaakt moeten deze op de zitting worden afgespeeld. ${ }^{223}$ Het verhoor dient - ongeacht in welk stadium van de procedure het plaatsvindt en dus ook gedurende het vooronderzoek - te worden uitgevoerd door de rechtbank in aanwezigheid van een psycholoog en mag worden bijgewoond door de prokurator, de raadsman van verdachte en de advocaat van het slachtoffer. ${ }^{224}$ De verdachte heeft dus geen recht bij dit verhoor aanwezig te zijn.

Op de hoofdregel dat deze categorie getuigen slechts eenmaal mag worden gehoord kan in twee gevallen een uitzondering worden gemaakt. Opnieuw horen is mogelijk:

1. wanneer nieuwe omstandigheden aan het licht zijn gekomen die een nieuw verhoor vereisen of

219 De wet op de kroongetuige voorziet bovendien in allerlei vergaande vormen van getuigenbescherming - waaronder het realiseren van een nieuwe identiteit en indien nodig zelfs aanpassing van het uiterlijk door plastische chirurgie - die de overheid de kroongetuige moet kunnen bieden (art. 14 tot en met 20 wet op de kroongetuige). In de periode september 1998 en september 2001 is het beschermingsprogramma voor kroongetuigen in 65 zaken gebruikt: Bojarski en Van Dijck 2007, p. 277.

220 Zewelak 2006, p. 238. Waarom de inzet van de kroongetuige in de meeste gevallen niet tot een einduitspraak heeft geleid, is in genoemde bijdrage helaas niet uitgewerkt.

221 Bojarski en Van Dijck 2007, p. 278.

222 Art. 185a KPK 1997. Minderjarig in dit verband zijn slachtoffers die op het moment dat ze als getuige worden gehoord de leeftijd van 15 jaar nog niet hebben bereikt. Aanvankelijk had deze regel slechts betrekking op slachtoffers van zedendelicten. In augustus 2005 is de reikwijdte van de bepaling uitgebreid waardoor een en ander ook geldt voor minderjarige slachtoffers van strafbare feiten genoemd in hoofdstuk 26 van het wetboek van strafrecht (feiten tegen familie en verzorgers - przestepstwa przecizwo rodzinie $i$ opicie). Bovendien is bij laatstgenoemde wetswijziging een nieuw art. 185b KPK in het leven geroepen waarin de regels van art. 185a van overeenkomstige toepassing worden verklaard op het verhoor van minderjarige getuigen van bepaalde strafbare feiten (waaronder zedendelicten en geweldsmisdrijven) die weliswaar geen slachtoffer zijn maar vanwege de impact van het feit dat ze hebben waargenomen volgens de wetgever evengoed bijzondere bescherming verdienen. Deze wijzigingen geven blijk van een groeiende aandacht voor de kwetsbare positie van minderjarige slachtoffers.

223 Art. 185a lid 3 KPK 1997.

224 Art. 185a lid 2 KPK 1997. 
2. op verzoek van de verdachte die tijdens het eerste verhoor van het slachtoffer (nog) niet door een raadsman werd bijgestaan. ${ }^{225}$

Laatstgenoemde mogelijkheid is in de praktijk tot regel uitgegroeid. Reden hiervoor is dat het eerste verhoor van slachtoffers in dit soort zaken doorgaans in een heel vroeg stadium van de procedure plaatsvindt wanneer nog geen verdachte is aangewezen (vaak is juist de verklaring van het slachtoffer de aanleiding om iemand als verdachte aan te merken) en dus ook nog geen advocaat in het spel is. ${ }^{226}$ De verdachte kan - afhankelijk van het moment waarop hij bijstand van een raadsman krijgt - zowel tijdens het vooronderzoek als na aanvang van het onderzoek ter terechtzitting verzoeken dat het slachtoffer (eenmalig) opnieuw wordt gehoord. Hij hoeft zijn verzoek niet te motiveren: het enkele feit dat op het moment van het eerste verhoor geen rechtsbijstand werd genoten, is voldoende. ${ }^{227} \mathrm{Net}$ als ten aanzien van het eerste verhoor geldt ook hier dat de getuige - ongeacht in welk stadium van de procedure het verhoor plaatsvindt - door de rechtbank wordt gehoord op een zitting waaraan de raadsman mag deelnemen.

Hoewel de wetgever met de mogelijkheid het verhoor op verzoek van verdachte opnieuw te laten plaatsvinden de gevolgen voor de verdediging zoveel mogelijk heeft willen beperken, roept de gekozen constructie wel vragen op. Belangrijk is vooral of deelname van de raadsman aan het eerste of tweede verhoor voldoende compensatie kan bieden voor het feit dat de verdachte zelf niet aanwezig mag zijn. De Poolse literatuur is mild op dit punt. ${ }^{228}$ Daarbij lijkt echter geen aandacht te worden besteed aan het feit dat de wettelijke regeling geen antwoord geeft op de vraag wat dient te gebeuren wanneer de verdachte niet over rechtsbijstand beschikt. Dat terwijl het gegeven dat verdachte van een zedendelict wordt beschuldigd op zichzelf geen geval van verplichte rechtsbijstand oplevert. ${ }^{229}$ Aangezien alleen de advocaat van verdachte bevoegd is om het verhoor van het minderjarige slachtoffer bij te wonen, blijft voor de verdachte die geen advocaat heeft

225 Art. 185a lid 1 KPK 1997.

226 Hofmański en Zabłocki 2008, p. 689. Om zoveel mogelijk te voorkomen dat minderjarige slachtoffers toch meer dan eens moeten worden verhoord, is het van groot belang dat het moment waarop het eerste verhoor plaatsvindt zorgvuldig wordt gekozen. Hoe vroeger in de procedure dit eerste verhoor plaatsvindt, hoe groter de kans dat de minderjarige getuige - op een van bovengenoemde gronden - nogmaals zal moeten worden gehoord. Zie Hofmański e.a. 2007 I, p. 876.

227 Grzegorczyk 2004, p. 498. De wetgever heeft ook geen eisen gesteld aan de wijze waarop het verzoek moet worden vormgegeven. Het kan dus zowel schriftelijk als mondeling plaatsvinden: Hofmański e.a. 2007 I, p. 875.

228 Verschillende auteurs geven aan dat de bijzondere positie van het minderjarige slachtoffer en de noodzaak deze te beschermen, kan rechtvaardigen dat de verdachte zelf niet in de gelegenheid wordt gesteld rechtstreeks vragen te stellen. Dat de raadsman de mogelijkheid heeft vragen te stellen, wordt als voldoende compensatie voor deze beperking van het ondervragingsrecht (zoals neergelegd in art. 6 lid 3 sub d EVRM) gezien. Zie onder meer Wiliński 2006, 388-389 en 484 en Hofmański e.a. 2007 I, p. 877.

229 Art. 185a KPK 1997 regelt niet dat aan de verdachte die niet over rechtsbijstand beschikt, een advocaat moet worden toegevoegd. Dit betekent dat (slechts) de algemene regels over verplichte rechtsbijstand van toepassing zijn (art. 79 en 80 KPK 1997). De rechtbank kan bijvoorbeeld wel tot toevoeging overgaan wanneer zij van mening is dat in het betreffende geval sprake is van 'omstandigheden die de verdediging bemoeilijken' maar ze is daartoe niet verplicht. Zie over verplichte rechtsbijstand hoofdstuk 4, § 3.1.1. 
alleen de mogelijkheid over om kennis te nemen van het proces-verbaal van het verhoor. De verdachte die niet door een advocaat wordt bijgestaan heeft dus op geen enkel moment in de procedure de mogelijkheid het slachtoffer - in zedenzaken doorgaans de belangrijkste bron van bewijs - te ondervragen.

\subsubsection{De verdediging en deskundigenbewijs}

Gedurende het eindonderzoek worden deskundigen - op verzoek van procespartijen of ambtshalve - benoemd door de rechter. ${ }^{230}$ Inschakeling van een deskundige is noodzakelijk wanneer voor de vaststelling van bepaalde feiten in de strafzaak bijzondere wetenschap vereist is en is in een aantal gevallen zelfs dwingend voorgeschreven. ${ }^{231}$ Deskundigenrapportages kunnen worden verricht door individuen maar ook door wetenschappelijke of gespecialiseerde instituten. Behalve 'deskundigen' ('biegty') kent het Poolse strafprocesrecht ook 'specialisten' ('specjaliści'): laatstgenoemde categorie - die in het vorige wetboek van strafvordering nog niet met zoveel woorden werd genoemd - betreft personen die vanuit hun functie (bijvoorbeeld als politieambtenaar) technische handelingen hebben verricht in het kader van het strafrechtelijke onderzoek zoals het veiligstellen van sporen, maken van berekeningen of foto's. ${ }^{232}$ De deskundige is net als de getuige strafrechtelijk verantwoordelijk wanneer hij bewust in strijd met de waarheid een verklaring aflegt. Afgezien van de nieuwe categorie deskundigen ('specialisten') is de wettelijke regeling ten aanzien van deskundigenbewijs in hoofdlijnen hetzelfde als in het wetboek van strafvordering van 1969.

Wat de mogelijkheden van de verdediging ten aanzien van deskundigenbewijs in het eindonderzoek betreft, geldt in de eerste plaats dat zij de rechter kan verzoeken een bepaalde deskundige te benoemen of (een reeds benoemde deskundige) te horen op het onderzoek ter terechtzitting. Dat laatste kan bijvoorbeeld noodzakelijk zijn om aanvullende informatie te verkrijgen of om onduidelijkheden in de rapportage te laten toelichten. Beide verzoeken gelden als een algemeen bewijsverzoek waarop door de rechter moet worden beslist. Een dergelijk verzoek kan - net als de vraag een bepaalde getuige te horen - slechts worden geweigerd op de door de wetgever limitatief opgesomde gronden. ${ }^{233}$ Wanneer een deskundige op de zitting wordt gehoord, hebben de raadsman en de verdachte het recht vragen te stellen. ${ }^{234}$

Hoewel op papier dus voldoende mogelijkheden bestaan, komt hier in de praktijk weinig van terecht. Volgens Gwirdoyń stelt het verhoor van deskundigen op het

230 Over de benoeming van deskundigen in het vooronderzoek en de mogelijkheden van de verdediging ten aanzien van deskundigenbewijs in dit stadium van de procedure: zie hoofdstuk 5, § 5.2.1.3.

231 Zoals wanneer duidelijkheid moet worden verkregen over de geestelijke gesteldheid van de verdachte (art. 202 lid 1 KPK 1997).

232 Op deze specialisten zijn dezelfde regels van toepassing als ten aanzien van deskundigen met dien verstande dat zij in de hoedanigheid van getuige worden gehoord (art. 206 KPK 1997).

233 Zie § 4.4.3.1.

234 Gelet op de volgorde genoemd in art. 370 KPK 1997 dienen zij daartoe als laatste procespartij de kans te krijgen, tenzij de deskundige op verzoek van de verdediging is opgeroepen: dan dienen ze de deskundige als eerste voor alle andere procespartijen te kunnen ondervragen. Zie over de wettelijke volgorde: § 4.4.2. 
onderzoek ter terechtzitting in de regel niet veel voor: het komt regelmatig voor dat hen alleen gevraagd wordt of ze hun eerder in de rapportage ingenomen standpunt nog steeds onderschrijven. Het is eerder uitzondering dan regel dat procespartijen - waaronder de verdediging - vragen stellen aan deskundigen. ${ }^{235}$ Dit blijkt ook uit (weliswaar verouderd) empirisch onderzoek dat in de jaren tachtig is verricht. Daarbij werden 234 verhoren van deskundigen op het onderzoek ter terechtzitting bestudeerd waarvan minder dan de helft in aanwezigheid van een raadsman werd gehouden. Het feitelijke aandeel van de advocaten in de verhoren was uiterst beperkt: ze waren over het algemeen passief en de vragen die gesteld werden, waren vaak irrelevant of vielen buiten de expertise van de betreffende deskundige. ${ }^{236}$

Ook heeft de verdediging in de praktijk weinig tot geen invloed op de vraag welke deskundige wordt benoemd: deze beslissing is volledig overgelaten aan de rechter. Tegen de benoeming van een bepaalde deskundige staat geen rechtsmiddel open. Het enige dat de verdediging op dit punt kan doen, is aanvoeren dat de gekozen deskundige onbetrouwbaar of ondeskundig is of dat zich een van de andere wettelijke gronden voor diskwalificatie voordoet. ${ }^{237}$ Indien de rechter dit verweer aanvaardt, dient een nieuwe deskundige te worden benoemd.

Het is de verdediging overigens niet verboden zelf een deskundige te benoemen (het deskundigenoordeel wordt dan aangeduid als opinie prywatne) maar hieraan kleven nadelen. Belangrijkste probleem is dat het oordeel van een deskundige die niet door de rechter is benoemd niet voor het bewijs kan worden gebezigd. Het is geen officieel bewijsmiddel maar een document 'dat buiten de strafrechtelijke procedure om is opgesteld'. Dergelijke stukken kunnen op grond van het wetboek van strafvordering niet ter terechtzitting worden voorgelezen en dus ook niet voor het bewijs worden gebezigd. ${ }^{238}$ Enige mogelijkheid om dit mee te laten wegen is om de rechter te vragen de betreffende deskundige alsnog te benoemen. Rechters zijn echter niet snel geneigd een dergelijk verzoek in te willigen omdat ze bang zijn dat een deskundige die op aangeven van de verdediging wordt benoemd te veel de schijn van partijdigheid heeft. ${ }^{239}$ Hoewel de meeste advocaten wel van mening

235 Gwirdoyń 2004, p. 211.

236 Tomaszewski 1988, p.127-132. De auteur vindt deze resultaten van zijn onderzoek met name opvallend vanwege het feit dat advocaten ook in het vooronderzoek weinig tot geen activiteiten ontplooien ten aanzien van deskundigenbewijs: men zou immers verwachten dat deze passiviteit gecompenseerd wordt door een actieve opstelling op het onderzoek ter terechtzitting. Dat dit in de praktijk niet gebeurt, is volgens Tomaszewski vooral een gevolg van het feit dat advocaten doorgaans slecht voorbereid op de zitting verschijnen en daardoor niet in staat zijn om een actieve bijdrage te leveren aan het deskundigenverhoor. Zie over de deskundige in het strafproces ook: Tomaszewski 2000.

237 De omstandigheden die tot diskwalificatie van de deskundige dienen te leiden, zijn opgesomd in art. 196 KPK 1997. Over de reikwijdte van deze bepaling en invulling ervan door de rechtspraak: Gwirdoyń 2004, p. 89-93.

238 Dit blijkt a contrario uit art. 393 lid 3 KPK 1997 waaruit voortvloeit dat particuliere stukken (zoals verklaringen, publicaties, brieven en aantekeningen) die buiten de strafrechtelijke procedure om en niet in het kader van de betreffende strafzaak zijn opgesteld, ter terechtzitting mogen worden voorgelezen: deskundigenrapporten - die wel in het kader van de strafzaak worden opgesteld - mogen derhalve niet worden voorgelezen. Zie ook Grajewski 2005, p. 212.

239 Bron: gesprek Gwirdoyń en Kurowska, december 2005 Warschau. 
zijn dat het toelaatbaar is om in het kader van de verdediging zelf een deskundige te raadplegen, ${ }^{240}$ gebeurt dit in de praktijk zelden omdat de kans klein is dat het uiteindelijk voor het bewijs zal worden geaccepteerd. Bovendien zijn dergelijke rapportages kostbaar en blijven de kosten voor rekening van de verdediging wanneer de deskundige uiteindelijk niet door de rechter wordt benoemd: een groot risico dat veel verdachten niet kunnen nemen.

De verdediging speelt dus slechts een bescheiden rol bij de totstandkoming van deskundigenbewijs. Dat terwijl de deskundige van oudsher een heel belangrijk aandeel heeft in het Poolse strafproces. ${ }^{241}$ Ook de advocatuur is blijkbaar doordrongen van de belangrijke rol die deskundigenrapportages in de Poolse strafrechtspleging vervullen: maar liefst $65 \%$ van de door Gwirdoyń ondervraagde advocaten is van mening dat rechters heel veel waarde hechten aan het oordeel van deskundigen. Gwirdoyń verwacht dat het belang van de deskundige vanwege de snelle ontwikkeling van de forensische wetenschap en de toenemende Angelsaksische invloed op de bewijsvoering in het continentale strafproces in de nabije toekomst alleen maar verder zal toenemen. ${ }^{242}$

\subsubsection{Eigen verdedigingsonderzoek}

In hoofdstuk 5 is duidelijk geworden dat advocaten weinig gebruik maken van de mogelijkheid zelf een deskundige te raadplegen. ${ }^{243}$ Hoewel hiervoor begrijpelijke redenen kunnen worden genoemd - zolang de deskundige niet door de rechter is benoemd, kan zijn rapportage niet voor het bewijs worden gebezigd en zijn de kosten voor rekening van de verdediging - beperkt de terughoudendheid van de advocatuur zich niet tot het (zelf) verzamelen van deskundigenbewijs. In zijn algemeenheid geldt dat Poolse advocaten zelden tot nooit actief op zoek gaan naar (ontlastend) bewijsmateriaal. De opmerkingen die hierover in hoofdstuk 5 in het kader van het vooronderzoek zijn gemaakt, gelden onverkort voor de fase van het eindonderzoek. Zoals daar is besproken, regelt het huidige Poolse strafprocesrecht (net als het oude wetboek van strafvordering) niet of, en zo ja op welke wijze, de raadsman zelf onderzoek mag doen en geven ook de gedragsregels geen antwoord op deze vragen. Uit onderzoek van Gwirdoyń blijkt dat 100\% van de ondervraagde advocaten er - ondanks het ontbreken van duidelijke wettelijke

240 Uit de enquête van Gwirdoyń blijkt dat twee derde van de ondervraagde advocaten van oordeel is dat dit is toegestaan: Gwirdoyń 2004, p. 127. Op de toelaatbaarheid van andere vormen van zelfstandig onderzoek door de verdediging wordt hierna in $\S 4.4 .5$ nog teruggekomen.

241 Illustratief in dit verband is een citaat uit een controversieel artikel van T. Cyprian: '... deskundigen oordelen over de schuld, de rechters over de straf' (T. Cyprian, Biegly wydaja wyrok ('Deskundigen vellen het vonnis'), Prawo i Życie 1969, nr. 13, p. 2). Gwirdoyń is van mening dat dit citaat vandaag de dag mogelijk nog meer actualiteitswaarde heeft dan op het moment van publiceren (in 1969): Gwirdoyń 2004, p. 210.

242 Gwirdoyń 2004, p. 211-212. Tomaszewski zegt hierover dat ondanks de grote invloed van het deskundigenbewijs op de oordeelsvorming van de rechter in uitspraken relatief weinig wordt verwezen naar de gebruikte rapportage: hij spreekt in dit verband van 'de verborgen invloed' van de deskundige: Tomaszewski 1988, p. 180.

243 Zie hoofdstuk 5, § 5.2.5 
grenzen - vanuit gaat dat zelfstandig onderzoek door de verdediging niet is toegestaan. ${ }^{244}$

\subsection{Bewijsvoering op de zitting en het EVRM}

$\mathrm{Nu}$ in kaart is gebracht hoe de bewijsvoering op het onderzoek ter terechtzitting in het Poolse strafproces is vormgegeven en welke mogelijkheden en beperkingen daarbij voor de verdediging gelden, zal worden bekeken hoe een en ander zich verhoudt tot de normen van het EVRM. ${ }^{245}$

Om te beginnen is van belang dat het EHRM doorgaans een terughoudende opstelling aanneemt waar het gaat om de beoordeling van bewijsvoering. ${ }^{246}$ Het Hof laat zich in beginsel niet uit over de wijze waarop bewijs tot stand dient te komen en de vraag of bepaalde bewijsmiddelen toelaatbaar zijn: de beoordeling en waardering van bewijsmateriaal wordt als een taak van de nationale rechter beschouwd. ${ }^{247}$ Aan art. 6 EVRM kunnen echter wel bepaalde criteria worden ontleend over de wijze waarop bewijsvoering dient plaats te vinden en welke mogelijkheden daarbij aan de verdediging moeten worden geboden. ${ }^{248}$

Een van de uitgangspunten in de rechtspraak van het EHRM is dat bewijs in beginsel op het onderzoek ter terechtzitting ten overstaan van de rechter tot stand dient te komen. ${ }^{249}$ Gelet op art. 6 lid 2 EVRM ('eenieder (...) wordt voor onschuldig gehouden totdat zijn schuld in rechte is komen vast te staan') geldt dat de bewijslast in strafzaken bij de vervolging ligt. De verdachte heeft wel het recht de tegen hem bestaande beschuldigingen te (proberen te) weerleggen. ${ }^{250}$ De belangrijkste bevoegdheid die de verdediging in dit verband toekomt, is vastgelegd in art. 6 lid 3 sub d EVRM en betreft de mogelijkheid getuigen op te roepen en te ondervragen. Genoemd artikellid is volgens vaste rechtspraak van het EHRM van overeenkomstige toepassing op het aanstellen en horen van deskundigen. ${ }^{251}$

244 Zie uitgebreider hoofdstuk 5, § 5.2.5.

245 Hierbij dient te worden opgemerkt dat slechts een verkorte weergave van de belangrijkste kaders zal worden gegeven: het hiernavolgende is dus zeker geen uitputtende beschrijving van alle relevante Straatsburgse rechtspraak ten aanzien van genoemde thema's.

246 Zie hoofdstuk 5, § 5.7.

247 Alink en Van Zeben 2006, p. 2. Zie ook Stavros 1993, p. 237: 'In a long series of cases the Convention organs have persistently refused to formulate rules that would require the inadmissability of some types of evidence. Undoubtedly, this reluctance is directly attributed to the absence of a common European standard in the field.'

248 Van Dijk e.a. 2006, p. 585-586 en daar genoemde rechtspraak, zie voor standaardoverwegingen op dit punt bijvoorbeeld Mantovanelli t. Frankrijk, EHRM 18-3-1997, nr. 21497/ 93, § 34: 'Moreover, the Convention does not lay down rules on evidence as such. The Court therefore cannot exclude as a matter of principle and in the abstract that evidence obtained in breach of provisions of domestic law may be admitted. It is for the national courts to assess the evidence they have obtained and the relevance of any evidence that a party wishes to have produced. The Court has nevertheless to ascertain whether the proceedings considered as a whole, including the way in which the evidence was taken, were fair as required by Article 6 para. 1 (...).'

249 '(...) all evidence must in principle be produced in the presence of the accused at a public hearing with a view to adversarial argument': (onder meer) Barberà, Messegué and Jabardo t. Spanje, EHRM 6-12-1988, nr.10590/83 , § 78 en Windisch t. Oostenrijk, EHRM 27-9-1990, nr. $12489 / 86, \S 26$.

250 De verdachte heeft het recht 'to effectively test the case of the prosecution': Stavros 1993, p. 230.

251 Zie onder meer Bönisch t. Oostenrijk, EHRM 6-5-1985, nr. 8658/79, en Brandstetter t. Oosten- 
Deskundigen die door de verdediging zijn opgeroepen, dienen in beginsel op dezelfde wijze te worden behandeld als deskundigen die op verzoek van de vervolging optreden. ${ }^{252}$ Dat partijen gelijke mogelijkheden moeten hebben om getuigen en deskundigen in te schakelen, vloeit bovendien voort uit het equality of arms beginsel dat ten grondslag ligt aan het art. 6 lid 1 EVRM gegarandeerde recht op een eerlijk proces. ${ }^{253}$

Het recht van de verdediging om getuigen op de zitting te horen, is niet absoluut. Het nationale recht mag eisen stellen aan de wijze waarop de verdediging getuigen dient op te roepen en te ondervragen. Het is in beginsel aan de nationale rechter om te bepalen of het horen van een bepaalde getuige noodzakelijk is. Het EHRM kan op dit punt slechts marginaal toetsen: bepalend is of de beslissing van de nationale rechter verenigbaar is met de eisen van het EVRM. De Straatsburgse rechtspraak eist wel dat de afwijzing van een verzoek van de verdediging een bepaalde getuige te willen horen, wordt gemotiveerd. ${ }^{254}$ Wanneer de verdediging niet de kans heeft gehad een getuige op de zitting te ondervragen, toetst het EHRM of de verdedigingsrechten hierdoor zodanig zijn ingeperkt dat niet langer van een eerlijk proces in de zin van art. 6 lid 1 EVRM kan worden gesproken. Uit de rechtspraak van het Europese Hof kan de hoofdregel worden afgeleid dat een veroordeling niet in beslissende mate mag worden gebaseerd op een verklaring van een getuige die de verdediging op geen enkel moment in de procedure heeft kunnen ondervragen: de verdachte dient dus in beginsel op enig moment in de procedure de gelegenheid te worden geboden de getuige te ondervragen en de betrouwbaarheid en geloofwaardigheid van diens verklaring aan de kaak te stellen. ${ }^{255}$

rijk, EHRM 28-8-1991, nr. 11170/84, 12876/87, 13468/87. Het EHRM kent aan het begrip 'getuige' ('witness') in de zin van art. 6 lid 3 sub d EVRM autonome betekenis toe: eenieder die een verklaring aflegt die ter kennis van de rechter komt en voor het bewijs kan worden gebezigd, geldt als getuige in de zin van het EVRM: Alink en Van Zeben 2006, p. 1. Zie ook Stavros 1993, p. 231.

252 Van Dijk 2006, p. 584.

253 Vandaar dat klachten in het kader van art. 6 lid 3 sub d EVRM vaak in samenhang met art. 6 lid 1 worden behandeld. Zie hoofdstuk 5, § 5.7 en Van Dijk e.a. 2006, p. 583 e.v.

254 Van Dijk e.a. 2006, p. 649. Zie bijvoorbeeld: Vidal t. België, EHRM 22-4-1992, nr. 12351/ 86, § 33. Zie ook Stavros 1993, p. 240-241: 'The accused is expected to put forward in his application to the national court the reasons why the examination of a particular witness is necessary. The national court should be expected to give reasons explaining its refusal in order to enable the Convention organs to review whether its decision is correct.'

255 Zie Alink en Van Zeben 2006, p. 3. Deze regel is voor het eerst bevestigd in Unterpertinger t. Oostenrijk, EHRM 24-11-1986, nr. 9120/80. Later herhaald in onder meer Barberà, Messegué and Jabardo t. Spanje, EHRM 06-12-1988, nr. 10590/83, Kostovski t. Nederland, EHRM 20-111989, nr. 11454/85, Windisch t. Oostenrijk, EHRM 27-9-1990, nr. 12489/86 en Delta t. Frankrijk, EHRM 19-12-1990, nr. 11444/85. Zie Stavros 1993, p. 232 e.v. Een Poolse zaak waarin het recht van de verdediging om getuigen te ondervragen centraal stond, is Gossa $t$. Polen (EHRM 9-1-2007, nr. 47986/99). Gossa klaagde erover dat zijn veroordeling mede was gebaseerd op de verklaring van een getuige (medeverdachte) die de verdediging nooit had kunnen ondervragen. Het EHRM was van oordeel dat de procedure in zijn geheel nog als eerlijk kon worden aangemerkt omdat de autoriteiten voldoende moeite hadden gedaan om de getuige - die na haar vrijlating naar de Verenigde Staten was vertrokken en onvindbaar was - op te roepen voor de zitting en omdat de veroordeling niet in beslissende mate op de verklaring van deze getuige was gebaseerd. Zie ook Sawicki t. Polen (ECRM 6-7-1995, nr. 25085/94, ontvankelijkheidsbeslissing) waarin wordt overwogen dat de rechtbank mag 
Of de ondervragingsmogelijkheid gelet op de maatstaf van art. 6 EVRM toereikend is geweest, hangt af van de omstandigheden van het geval: indien dat niet zo is, kan de veroordeling niet 'solely or mainly' op de verklaring van de betreffende getuige worden gebaseerd. ${ }^{256}$

Gevolg van deze benadering is onder meer dat het gebruik van verklaringen afgelegd in het vooronderzoek op zich zelf niet onverenigbaar is met art. 6 lid 1 en 3 (d) EVRM. ${ }^{257}$ Het feit dat het EHRM het ondervragingsrecht van de verdediging tegen de achtergrond van het recht op een eerlijk proces (art. 6 lid 1 EVRM) beoordeelt, heeft tot gevolg dat ruimte is voor afweging van belangen. Het gaat hierbij om het vinden van een compromis tussen de belangen van de verdediging en het belang van de getuige. ${ }^{258}$ De Straatsburgse rechtspraak laat zien dat het onder bepaalde omstandigheden noodzakelijk en gerechtvaardigd kan zijn te voorkomen dat een getuige op de zitting (opnieuw) met de verdachte wordt geconfronteerd. ${ }^{259}$ Zo heeft het Europese Hof onder meer erkend dat minderjarige slachtoffers in zedenzaken een uiterst kwetsbare categorie getuigen vormen aan wie onder omstandigheden bijzondere bescherming moet kunnen worden geboden. ${ }^{260}$ Ook in dit verband geldt echter dat wanneer de bescherming van de getuige bepaalde beperkingen voor de verdediging oplevert, deze zoveel mogelijk door de justitiële autoriteiten moeten worden gecompenseerd. ${ }^{261}$ Het feit dat de verdediging op geen

weigeren een getuige op te roepen die reeds in het vooronderzoek is gehoord wanneer verwacht wordt dat het verhoor niets toe zal voegen.

256 Van Dijk e.a. 2006, p. 644-645. Zie ook hoofdstuk 5, § 5.7. 'De wijze waarop en de mate waarin behoort te worden voorzien in compenserende maatregelen, is dus mede afhankelijk van de aard en omvang van ander (neutraal) bewijsmateriaal, waarin (onderdelen van) de betwiste, belastende getuigenverklaring bevestiging vindt. Ontbreekt echter een adequate poging om een gefrustreerd ondervragingsrecht waar mogelijk te compenseren door andere maatregelen, dan zal een overvloed aan steunbewijs niet snel tot de conclusie leiden dat een en ander past in een eerlijk proces; het recht om de getuige(n) te ondervragen staat immers centraal': Alink en Van Zeben 2006, p. 8.

257 (...) to use as evidence such statements obtained at the pre-trial stage is not in itself inconsistent with paragraphs $3(d)$ and I of Article 6, provided that the rights of the defence have been respected. As a rule, these rights require that an accused should be given an adequate and proper opportunity to challenge and question a witness against him either when he was making his statements or at a later stage of the proceedings.' Zie onder meer Kostovski t. Nederland, EHRM 20-11-1989, nr. 11454/ 85 en Van Mechelen e.a. t. Nederland, EHRM 23-4-1997, nr. 21363/93, 21364/93, 21427/93, 22056/93, Asch t. Oostenrijk, EHRM 26-4-1991, A203, nr. 12398/86, Lüdi t. Zwitserland, EHRM 15-6-1992, A238, nr. 12433/86 en Egmez t. Cyprus, EHRM 21-12-2000, nr. 30873/96.

258 'A consistent effort has consequently been made by the Convention organs to reach a reasonable compromise in their case-law between the public interest in the effective prosecution of criminals, which is arguably served by the admission of the broadest possible range of inculpatory evidence, and the right of the accused to effectively test the prosecutor's case': Stavros 1993, p. 231.

259 Zie onder meer Doorson t. Nederland, EHRM 26-3-1996, nr. 20524/92, § 70: 'It is true that Article 6 does not explicitly require the interests of witnesses in general, and those of victims called upon to testify in particular, to be taken into consideration. However, their life, liberty or security of person may be at stake, as may interests coming generally within the ambit of Article 8 of the Convention. (...) Contracting States should organise their criminal proceedings in such a way that those interests are not unjustifiably imperilled. Against this bakground, principles of fair trial also require that in appropriate cases the interests of the defence are balanced against those of witnesses or victims called upon to testify.'

260 Zie bijvoorbeeld Bocos Cuesta t. Nederland, EHRM 10-11-2005, nr. 54789/00, § 69.

261 Zo oordeelde het Hof onder meer in S.N. t. Zweden, EHRM 2-7-2002, nr. 34209/96: 'The 
enkel moment in de procedure de gelegenheid heeft gehad het slachtoffer te ondervragen terwijl de veroordeling in beslissende mate op diens verklaring is gebaseerd, kan een schendig van art. 6 lid 3 sub d EVRM opleveren. ${ }^{262}$ Een Poolse zaak waarin het horen van minderjarige slachtoffers centraal stond, is W.S. t. Polen ${ }^{263}$ In die zaak was het slachtoffer - met name vanwege haar jonge leeftijd (4) - op geen enkel moment in de procedure ondervraagd. Het EHRM benadrukte hierbij dat de autoriteiten ten onrechte niet hadden overwogen of de betrouwbaarheid van de getuige niet op een minder indringende wijze (dan door middel van een direct getuigenverhoor) kon worden getoetst. ${ }^{264}$ Aangezien de beperkingen die de verdediging op dit punt ondervond op geen enkele wijze waren gecompenseerd, oordeelde het Europese Hof dat art. 6 lid 3 sub d EVRM was geschonden. Overigens was op het moment van de nationale procedure in de zaak van W.S. het huidige art. 185a KPK 1997 betreffende het horen van minderjarige slachtoffers nog niet van kracht. Deze regeling is tot op heden nog niet door het Europese Hof beoordeeld.

Ook het gebruik van anonieme getuigenverklaringen is op zich zelf niet onverenigbaar met het EVRM. Wel wordt in de Straatsburgse rechtspraak benadrukt dat het verschijnsel met de nodige voorzichtigheid moet worden betracht en dat het gebruik van anonieme getuigenverklaringen aan bepaalde voorwaarden is gebonden. ${ }^{265}$ Uit de rechtspraak van het EHRM kunnen verschillende criteria worden

Court accepts that in criminal proceedings concerning sexual abuse certain measures may be taken for the purpose of protecting the victim, provided that such measures can be reconciled with an adequate and effective exercise of the rights of the defence (...). In securing the rights of the defence, the judicial authorities may be required to take measures which counterbalance the handicaps under which the defence labours (...)' (§ 47). In deze zaak waren volgens het EHRM voldoende compenserende maatregelen getroffen voor het feit dat het minderjarige slachtoffer niet op de zitting was gehoord (ter terechtzitting waren een video en een geluidsband van respectievelijk het eerste en het tweede getuigenverhoor afgespeeld) waardoor geen schending van art. 6 lid 3 sub d EVRM werd geconstateerd. Hierbij speelde mogelijk wel een rol dat de verdediging in deze zaak op de hoogte was van de identiteit van de getuige. Het is de vraag of het oordeel van het EHRM even mild zou zijn geweest wanneer dat niet het geval was: Van Dijk e.a. 2006, p. 647. Zie ook B. t. Finland, EHRM 24-4-2007, nr. 17122/02.

262 Zie P.S. t. Duitsland (EHRM 20-12-2001, nr. 33900/96) waarin de veroordeling van klager uitsluitend was gebaseerd op de ten overstaan van de politie afgelegde verklaring van het minderjarige slachtoffer en verklaringen van de moeder over hetgeen haar dochter haar had toevertrouwd en de veranderingen die zij - na het vermeende misbruik - in het gedrag van het kind had geconstateerd. Het slachtoffer was door de rechter niet ondervraagd omdat dit te belastend voor haar zou zijn. Het Europese Hof oordeelde dat het ondervragingsrecht van de verdediging hierdoor te vergaand was beperkt en stelde een schending van art. 6 lid 3 sub d EVRM vast. Zie ook A.M. t. Italië (EHRM 14-12-1999, nr. 37019/97) waarin eveneens een schending werd vastgesteld vanwege het feit dat klager zijn minderjarige slachtoffers - wier verklaringen het enige bewijs vormden in zijn strafzaak - op geen enkel moment in de procedure had kunnen ondervragen.

263 EHRM 19-6-2007, nr. 21508/02.

264 Bijvoorbeeld door een verhoor in aanwezigheid van een gedragsdeskundige of de moeder van het kind waarbij de verdediging schriftelijk vragen kan stellen.

265 Zie onder meer de kritische opmerkingen van het EHRM in Kostovski t. Nederland, EHRM 20-11-1989, nr. 11454/85, § 44: 'The right to a fair administration of justice holds so prominent a place in a democratic society (...) that it cannot be sacrificed to expediency. The Convention does not preclude reliance, at the investigation stage of criminal proceedings, on sources such as anonymous informants. However, the subsequent use of anonymous statements as sufficient evidence to found a 
afgeleid voor de toelaatbaarheid van anonieme getuigenverklaringen: er moet in ieder geval sprake zijn van een 'relevant and sufficient ground' voor handhaving van de anonimiteit van de getuige en de door de justitiële autoriteiten gevolgde procedures moeten voldoende tegenwicht bieden tegen de beperkingen die de verdediging treffen. ${ }^{266}$ Gelet op het belang van rechtstreekse ondervraging van getuigen door de verdediging, gelden ten aanzien van laatstgenoemd punt in ieder geval twee voorwaarden: (a) de raadsman moet in de gelegenheid zijn gesteld de getuige mondeling vragen te stellen en (b) de raadsman moet fysiek aanwezig kunnen zijn bij de ondervraging teneinde het gedrag en de houding van de getuige te kunnen waarnemen en diens betrouwbaarheid en geloofwaardigheid te kunnen testen. Voor zover bekend heeft het gebruik van een anonieme getuigenverklaring in een Poolse zaak (nog) niet in een door het EHRM geconstateerde schending van het EVRM geresulteerd. Er wordt wel geklaagd over de inzet van anonieme getuigen maar dat heeft tot op heden nog niet tot een inhoudelijke behandeling geleid. ${ }^{267}$

Wat de kroongetuige en het EVRM betreft, geldt dat het EHRM zich nog niet vaak over dit verschijnsel heeft uitgelaten. ${ }^{268}$ Het Europese Hof heeft in het verleden erkend dat de kroongetuige in conflict kan komen met art. 6 EVRM maar acht het gebruik van dergelijke getuigenverklaringen niet noodzakelijk strijdig met het EVRM. ${ }^{269}$ Voor de toelaatbaarheid van de inzet van kroongetuigen is niet absoluut noodzakelijk dat een en ander door nationale wetgeving wordt gereguleerd. ${ }^{270}$ Bij beantwoording van de vraag of de inzet van een kroongetuige verenigbaar is met art. 6 EVRM wordt onder meer meegewogen of de verdediging op de hoogte is van de inhoud van de kroongetuigenovereenkomst en de identiteit van de getuige en of ze voldoende mogelijkheden heeft gehad om de overeenkomst en de betrouw-

conviction, as in the present case, is a different matter.' Het EHRM eist in zijn algemeenheid dat verklaringen van getuigen die de verdediging niet rechtstreeks heeft kunnen ondervragen met de nodige behoedzaamheid (extreme care) voor het bewijs worden gebruikt. Zie bijvoorbeeld Doorson t. Nederland, EHRM 26-03-1996, nr. 20524/92, \& 76, Visser t. Nederland, EHRM 14-2-2002, nr 26668/95, § 44 en S.N. t. Zweden, EHRM 2-7-2002, nr. 34209/96, § 53 ('(...) evidence obtained from a witness under conditions in which the rights of the defence cannot be secured to the extent normally required by the Convention should be treated with extreme care').

266 Van der Velde 2004 I, 3.6.12, p. 6-9. Dat de redenen voor anonimiteit behalve 'relevant' ook 'sufficient' ('voldoende') dienen te zijn, houdt in dat het een feitelijke grondslag moet hebben: de ernst van het misdrijf is in dat verband niet voldoende.

267 Zie bijvoorbeeld Goral t. Polen, EHRM 7-11-2002, nr. 38654/97 (ontvankelijkheidsbeslissing) en Rybacki t. Polen, EHRM 9-10-2007, nr. 52479/99 (ontvankelijkheidsbeslissing). De klacht van Goral werd niet ontvankelijk verklaard vanwege het feit dat de nationale rechtsmiddelen niet waren uitgeput en de klacht van Rybacki werd ongegrond verklaard omdat er volgens het EHRM gegronde redenen waren de identiteit van de getuigen niet bekend te maken, de verdediging de gelegenheid had gehad via de rechtbank vragen te stellen aan de twee anonieme getuigen en er voldoende aanvullend bewijs was.

268 Van Dijk e.a. 2006, p. 647 en daar genoemde rechtspraak.

269 '(...) the use of statements made by witnesses in exchange for immunity or other advantages may put in question the fairness of the hearing granted to an accused and is capable of raising delicate issues since, by their very nature, such statements are open to manipulation and may be made purely in order to obtain advantages or for personal revenge. However, the use of this kind of statement does not in itself suffice to render the proceedings unfair': Verhoek $t$. Nederland, EHRM 271-2004, nr. 54445/00 (ontvankelijkheidsbeslissing).

270 Zo is onder meer duidelijk geworden in Lorsé t. Nederland, EHRM 27-1-2004, nr. 44484/98 (ontvankelijkheidsbeslissing). 
baarheid van de betreffende getuige te onderzoeken. ${ }^{271}$ Ook voor kroongetuigenbewijs geldt dus het uitgangspunt dat de procedure in zijn geheel moet worden bekeken: bepalend is of de verdachte een eerlijke en effectieve mogelijkheid ('a fair and effective opportunity') heeft gehad om de met de kroongetuige gesloten overeenkomst te betwisten. Of van een dergelijke mogelijkheid sprake is, is volledig afhankelijk van de concrete omstandigheden van het geval. Er is (nog) geen rechtspraak van het EHRM waarin de huidige Poolse kroongetuigenregeling tegen het Straatsburgse licht is gehouden.

\subsection{Pleiten}

Wanneer de fase van de bewijsvoering is afgesloten, krijgt de raadsman de gelegenheid een slotpleidooi te houden.272 $\mathrm{Er}$ zijn in beginsel geen beperkingen voor wat betreft de vorm, duur of inhoud van dit slotpleidooi. Het spreekt voor zich dat het in de praktijk volledig afhankelijk zal zijn van de omvang en de ingewikkeldheid van de zaak hoe hier invulling aan wordt gegeven. ${ }^{273}$ Met name voor de lagere rechterlijke instanties zijn slotpleidooien - van zowel de verdediging als de prokuratura - doorgaans zeer kort en bondig. ${ }^{274}$ In 1975 bedroeg een gemiddeld pleidooi 6 minuten en 36 seconden (variërend van minimaal 6 seconden tot maximaal 29 minuten) en in 19808 minuten en 40 seconden (variërend van 1 minuut tot 30 minuten). ${ }^{275}$

Wanneer de raadsman zijn slotpleidooi heeft afgerond, krijgt de verdachte de gelegenheid als laatste het woord te voeren. ${ }^{276}$ Het feit dat zijn advocaat daarvoor al aan het woord is geweest, doet daar niets aan af. De verdachte is gelet op zijn zwijgrecht uiteraard niet verplicht van zijn laatste woord gebruik te maken. Wanneer hij ten onrechte niet in de gelegenheid wordt gesteld het laatste woord te voeren, kan dat in hoger beroep tot vernietiging van het vonnis leiden. ${ }^{277}$ Indien de prokurator nog op het slotpleidooi van de raadsman of het laatste woord van verdachte reageert, dient de verdediging opnieuw als laatste aan het woord te worden gelaten.

271 Verhoek $t$. Nederland, EHRM 27-1-2004, nr. 54445/00 (ontvankelijkheidsbeslissing). Zie ook Erdem t. Duitsland, EHRM 5-7-2001, nr. 38321/97 en Cornelis t. Nederland, EHRM 25-4-2004, nr. 994/03 (ontvankelijkheidsbeslissing).

272 Zie over de slotpleidooien en de volgorde waarin partijen aan bod dienen te komen hoofdstuk 2, § 3.2.2.2.

273 Zie hierover ook Grajewski 2005, p. 225 en daar genoemde literatuur.

274 Volgens Waltoś is er geen reden aan te nemen dat dit in de nabije toekomst noemenswaardig zal veranderen: Waltoś 2002 I, p. 509.

275 Ter vergelijking: een slotpleidooi van de prokurator duurde in 1975 gemiddeld 4 minuten en 30 seconden (variërend van 1 tot 10 minuten) en in 19805 minuten en 40 seconden (variërend van 1 tot 20 minuten): Waltoś 2002 I, p. 510 en daar genoemde literatuur. Meer recente gegevens zijn - voor zover bekend - helaas niet beschikbaar.

276 Over het laatste woord van verdachte: Wiliński 2006, p. 428-431.

277 Het Hooggerechtshof heeft in het verleden benadrukt dat de regel dat verdachte het laatste woord moet worden gegeven onderdeel uitmaakt van het recht op verdediging en dus niet slechts een regel van procesorde is: Grajewski 2005, p. 225 en daar genoemde rechtspraak van het Hooggerechtshof. 


\subsubsection{Vrijheid van verdediging}

Van belang is hoever de raadsman mag gaan wanneer hij het woord voert. Uitgangspunt is dat hij alles mag zeggen dat in het belang van de verdediging is maar dat dat wel op een fatsoenlijke wijze dient te gebeuren. ${ }^{278}$ De advocaat komt in beginsel vrijheid van meningsuiting (in woord en geschrift) toe. ${ }^{279}$ Misbruik van deze vrijheid kan ten aanzien van bepaalde procesdeelnemers slechts tuchtrechtelijk worden gestraft. ${ }^{280}$ Uit de gedragsregels kunnen echter wel enige beperkingen worden afgeleid. In de eerste plaats is het de advocaat niet toegestaan de rechtbank welbewust van verkeerde informatie te voorzien. ${ }^{281}$ De raadsman mag dus niet liegen. Een advocaat kan echter niet verantwoordelijk worden gehouden voor de juistheid van informatie die hij van zijn cliënt heeft verkregen. Wel dient hij terughoudend te zijn in het aanvoeren van 'drastische of onwaarschijnlijke omstandigheden'. ${ }^{282}$ Ook is in de gedragsregels vastgelegd dat iedere advocaat 'behoedzaamheid' dient te betrachten bij het doen van uitlatingen. ${ }^{283} \mathrm{Hij}$ behoort zich bovendien beheerst en tactvol te gedragen tegenover de rechtbank en andere instanties waarvoor hij verschijnt, ook indien andere procesdeelnemers zich ter terechtzitting ongepast gedragen. ${ }^{284}$ Ten aanzien van andere procesdeelnemers geldt dat de advocaat ervoor zorg dient te dragen dat door zijn optreden, uitspraken of door de vragen die hij stelt de waardigheid van andere partijen niet wordt geschonden. ${ }^{285}$ Het uitoefenen van felle kritiek op justitiële instanties wordt binnen de hiervoor genoemde grenzen wel geaccepteerd maar vooral in kleinere arrondissementen komt het wel voor dat advocaten in dit opzicht voorzichtiger (moeten) zijn. Daar hebben advocaten immers vaak te maken met dezelfde leden van de politie of de prokuratura en bestaat de vrees dat te vergaande kritiek op hun optreden wel eens schadelijk zou kunnen zijn voor toekomstige strafzaken. ${ }^{286}$

Indien de rechtbank van oordeel is dat de raadsman te ver gaat in zijn uitlatingen, kan ze hem waarschuwen en in het uiterste geval verbieden verder te spreken. ${ }^{287}$ In de praktijk wordt van deze mogelijkheid echter zeer terughoudend gebruik gemaakt. ${ }^{288}$ Wanneer de rechtbank van oordeel is dat de raadsman door zijn optreden zijn procesverplichtingen ernstig heeft geschonden, kan - zoals eerder aan de orde is geweest - een klacht worden ingediend bij de balie.289

278 Krzemiński 2003, p. 74.

279 Art. 8 Advocatenwet.

280 Zie over de vrijheid van meningsuiting en de (strafrechtelijke) immuniteit die de advocaat in dit verband toekomt: hoofdstuk 8, § 4.3.5.

281 Art. 11 gedragsregels.

282 Art. 15 gedragsregels.

283 Art. 17 gedragsregels.

284 Art. 27 lid 1 en 2 gedragsregels.

285 Art. 28 gedragsregels. Op deze en andere gedragsregels wordt teruggekomen in hoofdstuk $8, \S 4.3$.

286 Informatie verkregen van Kruszyński, juni 2008.

287 Deze bevoegdheid kan worden ontleend aan art. 372 KPK 1997 op grond waarvan de voorzitter alle beslissingen kan nemen die noodzakelijk zijn om rust en orde op de zitting te bewaren.

288 Waltoś 2002 I, p. 509.

289 Art. 20 KPK 1997. Zie ook hoofdstuk 8, § 4.4.1. 


\subsubsection{Stijl van verdedigen}

Het spreekt voor zich dat de manier waarop in een strafzaak wordt gepleit in ieder rechtssysteem sterk afhankelijk is van verschillende factoren zoals de persoonlijkheid van de advocaat, het soort zaak en de specifieke omstandigheden van het geval. Toch kunnen van land tot land verschillen worden waargenomen in de wijze waarop door advocaten het woord wordt gevoerd op de zitting. ${ }^{290}$ Het is echter niet eenvoudig iets zinnigs te zeggen over de Poolse stijl van verdedigen (als die al bestaat). In de literatuur wordt hier niet of nauwelijks aandacht aan besteed en het is moeilijk algemene conclusies af te leiden uit de zittingen die ik heb bijgewoond en de advocaten die ik heb zien pleiten. De stijl van verdedigen wisselde sterk en was duidelijk afhankelijk van het soort zaak en de sfeer op de zitting. ${ }^{291}$ In sommige zaken werd uitvoerig en enthousiast gesproken in andere zaken werd volstaan met een kort, zakelijk betoog. Theatrale toestanden heb ik niet waargenomen en over het algemeen genomen, lijkt de stijl van Poolse advocaten redelijk nuchter en sober te zijn.

\subsection{Conclusie}

De wijze waarop vandaag de dag invulling wordt gegeven aan het onderzoek ter terechtzitting verschilt niet wezenlijk van de situatie onder het oude strafprocesrecht: anders dan de fase van het vooronderzoek heeft dit stadium van de procedure geen fundamentele of structurele wijzigingen ondergaan. Daaraan bestond ook geen behoefte omdat op de oude wettelijke regeling van het onderzoek ter terechtzitting - vanuit het perspectief van de verdediging - niet zoveel kon worden aangemerkt. De problemen waarmee de verdediging in strafzaken gedurende het communisme ter zitting werd geconfronteerd, hadden andere oorzaken: ze waren vooral een gevolg van enerzijds het feit dat de raadsman in het vooronderzoek geen rol van betekenis kon spelen terwijl de resultaten van die procesfase wel van doorslaggevend belang waren in het eindonderzoek en anderzijds de scheve machtsverhoudingen tussen de verschillende procesdeelnemers als gevolg waarvan de prokurator ook in het eindonderzoek meer de feitelijke leiding over de zaak had dan de rechter.

Het is echter niet zo dat de wettelijke regeling van het eindonderzoek helemaal geen veranderingen heeft ondergaan. Zo zijn - onder druk van de toenemende behoefte aan een snelle en efficiënte afdoening van strafzaken - de mogelijkheden om de zaak in afwezigheid van verdachte af te doen aanzienlijk uitgebreid en meer uitzonderingen geformuleerd op de regel dat alle bewijs in beginsel ter terechtzitting moet worden gepresenteerd. Een ander punt betreft de wijze waarop personen ter zitting worden ondervraagd. Op grond van het huidige art. 370 lid 1 KPK 1997 dienen vragen aan verdachten, getuigen en deskundigen in de regel eerst door procespartijen en pas daarna door de rechter te worden gesteld. In het oude strafprocesrecht was de volgorde andersom: eerst de rechter en daarna pas de andere procesdeelnemers. Met deze wijziging werd beoogd dat partijen een meer actieve

290 Zie voor een bespreking van de situatie in een aantal West-Europese landen: Prakken en Spronken 2003.

291 Ook de sfeer op de zitting wisselde sterk: in een aantal zaken was deze - door een zeer strenge opstelling van de voorzitter - uiterst gespannen, in andere zaken heerste een meer gemoedelijke sfeer. 
bijdrage zouden gaan leveren aan de bewijsvoering op het onderzoek ter terechtzitting maar tot op heden heeft het niet tot de gewenste verandering van de praktijk geleid: verhoren worden nog altijd gedomineerd door de zittingsrechter en procespartijen nemen - zeker waar het gaat om deskundigenverhoren - vaak een passieve houding aan.

In zijn algemeenheid zijn er geen redenen aan te nemen dat de wijze waarop bewijsvoering op het onderzoek ter terechtzitting in het Poolse strafproces wordt vormgegeven problemen oplevert in het licht van het EVRM. Er zijn weliswaar ruime uitzonderingen op het onmiddellijkheidsbeginsel geformuleerd maar gebruik van verklaringen uit het vooronderzoek is - zoals uit de Straatsburgse rechtspraak blijkt - op zichzelf niet strijdig met art. 6 EVRM zolang de rechten van de verdediging voldoende worden gecompenseerd en de procedure in zijn geheel nog als eerlijk kan worden aangemerkt. Zelfs het gebruik van een verklaring van een getuige die de verdediging op geen enkel moment in de procedure heeft kunnen ondervragen, is toelaatbaar wanneer de autoriteiten voldoende inspanningen hebben getoond de getuige op te roepen en de veroordeling niet 'alleen of in beslissende mate' op de betreffende verklaring wordt gebaseerd.

De positie en rol van verdachten, getuigen en deskundigen op het onderzoek ter terechtzitting is niet noemenswaardig veranderd. Wel relevant is dat - in de strijd tegen de georganiseerde criminaliteit - in de jaren negentig twee bijzondere categorieën getuigen in het Poolse strafproces zijn geïntroduceerd: de anonieme getuige en de kroongetuige. Ook het minderjarige slachtoffer geniet op grond van het huidige strafprocesrecht bijzondere bescherming. De gekozen constructies lijken op het eerste gezicht tegemoet te komen aan de eisen van het EVRM maar hebben wel degelijk vergaande gevolgen voor de verdediging. Voor de anonieme getuige geldt dat de rechten van de verdediging in de oorspronkelijke regeling onvoldoende werden gerespecteerd. Met de wetswijziging van 2003 is deze situatie aanzienlijk verbeterd. Toch zijn de mogelijkheden van de verdediging in een aantal opzichten nog zeer beperkt. Zo kan er nauwelijks worden opgetreden tegen de beslissing iemand als anonieme getuige te kwalificeren en zal het in de praktijk meestal niet mogelijk zijn effectief gebruik te maken van de mogelijkheid de anonieme getuigenverklaring uit te sluiten van het bewijs. Of de verdedigingsrechten bij de inzet van anonieme getuigen voldoende worden gerespecteerd, is volledig afhankelijk van de wijze waarop het verhoor van de betreffende getuige in de praktijk wordt vormgegeven. Aangezien de wetgever op dit punt geen nadere regels heeft gesteld en de inrichting van het verhoor is overgelaten aan de justitiële autoriteiten zal telkens aan de hand van de concrete omstandigheden van het geval moeten worden beoordeeld of de rechten van de verdediging daarbij in voldoende mate zijn gerespecteerd. Vanuit Straatsburgs perspectief is daarbij met name van belang dat in ieder geval aan de raadsman de gelegenheid wordt geboden de getuige rechtstreeks te ondervragen.

Voor wat de Poolse regeling van de kroongetuige betreft, bestaan de beperkingen voor de verdediging er voornamelijk uit dat op de beslissing iemand als kroongetuige aan te merken geen invloed kan worden uitgeoefend en dat daartegen geen rechtsmiddel kan worden ingesteld. Uit de rechtspraak van het EHRM blijkt dat de inzet van kroongetuigen op zichzelf niet onverenigbaar is met het EVRM en dat ook hier weer doorslaggevend is of de procedure in zijn geheel nog als eerlijk 
kan worden aangemerkt. Daarbij wordt veel waarde gehecht aan de opstelling van de nationale autoriteiten en de vraag of er voldoende ander (belastend) bewijsmateriaal voorhanden is.

De wettelijke constructie ten aanzien van minderjarige slachtoffers is - gelet op de kwetsbare positie van deze categorie getuigen - te begrijpen. Ook in de Straatsburgse rechtspraak wordt erkend dat het noodzakelijk kan zijn minderjarige slachtoffers in zedenzaken extra bescherming te bieden. Dit laat echter onverlet dat effectuering van het ondervragingsrecht op grond van de Poolse regeling problematisch kan zijn wanneer de verdachte niet over rechtsbijstand beschikt. De mogelijkheid van ad hoc toevoeging zou een uitkomst kunnen bieden wanneer de verdachte niet reeds door een raadsman wordt bijgestaan en hij de getuige wel wenst te horen. Daarmee zou kunnen worden voorkomen dat de verdediging geen enkele gelegenheid heeft gehad een getuige die belastend verklaart te ondervragen. Ten slotte een opmerking ten aanzien van deskundigenbewijs. Ook hiervoor geldt dat de verdediging - in ieder geval op papier - toereikende mogelijkheden heeft om op dit punt een rol van betekenis te spelen. In de praktijk gebeurt dit echter niet of nauwelijks: de verdediging heeft weinig tot geen invloed op de keuze van de deskundige en van het recht deskundigen op de zitting te ondervragen wordt weinig gebruik gemaakt. De mogelijkheden om zelf een deskundige te benoemen zijn uiterst beperkt. Deze situatie is niet alleen een gevolg van een terughoudende opstelling van de advocatuur maar hangt ook samen met de houding van de rechterlijke macht en bewijstechnische aspecten. ${ }^{292}$ Aangezien in het Poolse strafproces steeds meer betekenis wordt toegekend aan deskundigenbewijs is het belangrijk dat de verdediging een grotere rol gaat spelen in de totstandkoming ervan.

\section{Misbruik van procesrecht}

\subsection{Opkomst van een nieuw verschijnsel}

'Misbruik van procesrecht' is een tamelijk nieuw fenomeen in Polen dat pas sinds een aantal jaren regelmatig opduikt in rechtspraak en literatuur. De opkomst van de discussie over het verschijnsel is onlosmakelijk verbonden met het feit dat in de Poolse strafrechtspleging steeds meer de nadruk is komen te liggen op efficiënte procesvoering: een tendens die in ieder rechtssysteem onvermijdelijke consequenties heeft voor de mogelijkheden van de verdediging.

Voor het begrip 'misbruik van procesrecht' ('nadużycia prawa do obrony', letterlijk: 'misbruik van het recht op verdediging') wordt in de Poolse rechtspraak, wetgeving of literatuur geen eenduidige of vastomlijnde definitie gegeven. Het wordt met name gebruikt om aan te geven dat de verdediging procedurele rechten of bevoegdheden aanwendt met een ander doel dan waarvoor ze door de wetgever zijn verleend. ${ }^{293}$ In rechtspraak van het Hooggerechtshof is benadrukt dat rechten

292 Een rapportage van een door de verdediging ingeschakelde deskundige kan alleen voor het bewijs worden gebruikt wanneer de deskundige alsnog door de rechter wordt benoemd, zie $\S 4.4 .4$.

293 Het concept 'misbruik van het recht op verdediging' vloeit volgens Wiliński voort uit de overtuiging dat 'verwezenlijking van verdedigingsrechten niet kan worden gebaseerd op het doorbreken van de orde die in het recht moet bestaan en niet op zodanige wijze mag plaatsvinden dat voortgang van het proces onmogelijk wordt gemaakt': Wiliński 2006, p. 519. Wiliński benadrukt dat zowel individueel handelen van de verdachte of zijn raadsman als gezamenlijk optre- 
die aan de verdachte zijn toegekend om zijn recht op verdediging te realiseren 'niet mogen worden misbruikt om een regelmatig verloop van het strafproces onmogelijk te maken'. ${ }^{294}$

Veel verschillende soorten handelen (of nalaten) kunnen als misbruik worden gekwalificeerd. Wiliński onderscheidt drie categorieën:

1. het instrumenteel gebruik van rechten (instrumentalne wykorzystanie uprawnień) waarbij deze worden gebruikt binnen de wettelijke grenzen maar met een ander doel dan waarvoor ze verleend zijn,

2. de ongegronde uitbreiding van de reikwijdte van rechten (bezpodstawne rozszerzenie ich zakresu) en

3. andere activiteiten waarbij zonder gebruikmaking van aan de verdachte toegekende rechten op onrechtmatige wijze bescherming van de positie van verdachte wordt nagestreefd (dokonaniu czynu bezprawnego). ${ }^{295}$

In literatuur en rechtspraak wordt vooral aandacht besteed aan 'obstructie' ('obstrukcja'): een vorm van misbruik waarbij de verdediging de voortgang van de procedure beoogt te belemmeren. Het begrip 'obstructie' wordt door Waltoś gedefinieerd als het 'gebruik maken van procedurele rechten met het doel het verloop van de procedure onmogelijk te maken of te bemoeilijken'. ${ }^{296}$ Aangezien vrijwel alle bevoegdheden van de verdediging kunnen worden aangewend om de procedure te vertragen, kan geen limitatieve opsomming worden gegeven van alle verdedigingshandelingen die onder omstandigheden als 'obstructie' zouden kunnen worden aangemerkt. ${ }^{297}$ Zowel handelen als nalaten van de verdediging kan obstructie opleveren: in de Poolse literatuur wordt in dit verband onderscheid gemaakt tussen 'actieve' en 'passieve' vertraging. ${ }^{298}$ Een voorbeeld van eerstgenoemde vorm

den van beiden misbruik van het recht op verdediging kan opleveren: Wiliński 2006, p. 520. Volgens Grzegorczyk mag de verdediging haar rechten niet misbruiken voor doeleinden die onverenigbaar zijn met een regelmatig procesverloop ('dla celów godzàcych w prawidtowy tok procesu'): Grzegorczyk 2004, p. 45. Hofmański geeft aan dat wanneer procesrechten door de verdediging worden gebruikt voor een ander doel dan waarvoor ze verleend zijn ('korzystanie ze uprawnień w sposób naruszający funkcję przepisów gwaracyjnych') dat misbruik van het recht op verdediging kan opleveren: Hofmański e.a. 2007 I, p. 68.

294 Uitspraak van 10 februari 2004 (III KK 282/03, LEX nr. 84 462) genoemd in Kulesza 2005, p. 392.

295 Wiliński 2006, p. 521. De eerste en tweede categorie onderscheiden zich dus van de derde doordat eerstgenoemde twee vormen van misbruik nog wel op gebruikmaking van procedurele rechten of bevoegdheden kunnen worden gebaseerd - rechten worden met een verkeerd doel gebruikt of te ruim uitgelegd - terwijl voor handelen dat onder de derde categorie valt geen wettelijke grondslag bestaat. Een voorbeeld van laatstgenoemd optreden is het overhalen van een getuige om een valse verklaring af te leggen.

296 Waltoś 2002, p. 502. Waltoś benadrukt daarbij dat obstructie slechts een van de verschillende vormen van misbruik is. Rechten kunnen immers ook worden aangewend met andere intenties (dan vertraging) die onverenigbaar zijn met de algemene doelstellingen van het strafproces: Waltoś 2005: p. 619-620.

297 Zie voor een uitgebreide - maar zeker niet uitputtende - opsomming: Waltoś 2005, p. 620-622.

298 Gwirdoyń 2004, p. 309 en 317. Kruszyński vindt doelbewuste vertraging van het proces door de raadsman geen probleem zolang het in het voordeel van de cliënt is: 'In furthering the interests of the accused, it is permissible for the lawyer to deliberately prolong the duration of the trial': Kruszyński 2007 I, p. 200. 
is het niet verschijnen op de zitting wanneer deelname van verdachte en/of raadsman verplicht is. Een voorbeeld van actieve vertraging is het indienen van grote aantallen (zinloze) bewijsverzoeken. ${ }^{299}$

\subsection{Wetswijzigingen gericht op voorkoming misbruik}

Er is geen algemene wettelijke bepaling in het Poolse (straf)recht die misbruik van procesrecht verbiedt. In de literatuur wordt wel gesproken over de mogelijkheid een dergelijk verbod in te voeren maar heersende mening is dat hiertoe geen noodzaak bestaat. ${ }^{300} \mathrm{Bij}$ gebrek aan een algemene wettelijke regeling, zal de rechter in ieder concreet geval zelfstandig moeten bepalen of naar zijn mening sprake is van misbruik (of meer specifiek: obstructie). Zoals hierna zal worden uitgewerkt, biedt de wet ten aanzien van het indienen van bewijsverzoeken op dit punt wel enige houvast: sinds 2003 is in het wetboek van strafvordering bepaald dat de rechter bewijsverzoeken die 'overduidelijk zijn gericht op vertraging van de procedure' mag afwijzen. Dit is overigens niet de enige maatregel die de wetgever heeft getroffen om te voorkomen dat procedures onevenredig worden vertraagd door de opstelling van de verdachte en/of zijn raadsman. De laatste jaren zijn verschillende wetswijzigingen doorgevoerd die (mede) tot doel hadden het risico op misbruik door de verdediging te verkleinen. Een aantal van de belangrijkste aanpassingen zal hier worden besproken.

\subsubsection{Verplichte deelname verdachte en/of raadsman}

Eerder is aan de orde geweest dat de verplichte aanwezigheid van verdachte met name op grond van het oude strafprocesrecht tot problemen leidde: de verdachte kon door niet op de zitting te verschijnen inhoudelijke behandeling van zijn zaak voorkomen en zo de procedure stilleggen. Om dergelijke situaties in de toekomst zoveel mogelijk te voorkomen heeft de wetgever het aantal gevallen waarin de zaak in afwezigheid van verdachte mag worden afgedaan in het wetboek van strafvordering van 1997 aanzienlijk uitgebreid. ${ }^{301}$ Hiermee is de kans dat het aanwezigheidsrecht kan worden 'misbruikt' om voortgang van de zaak te frustreren aanzienlijk verkleind.

Om dezelfde reden zijn eveneens wijzigingen aangebracht in de regeling van de verplichte rechtsbijstand. Ook de regel dat verdachten onder bepaalde omstandigheden verplicht moeten worden bijgestaan door een raadsman kan vanuit het oogpunt van efficiëntie problemen opleveren. In de gevallen van verplichte rechtsbijstand die het Poolse strafprocesrecht kent, kan het onderzoek ter terechtzitting immers geen doorgang vinden zonder aanwezigheid van de advocaat van verdachte. Hoewel een advocaat niet zomaar kan wegblijven op zittingen waarvan hij op de hoogte is gesteld ${ }^{302}$ is de rechtbank bij zijn afwezigheid gedwongen de

299 Gwirdoyń 2004, p. 307-330. Op het indienen van bewijsverzoeken wordt teruggekomen in $\S 5.2 .2$.

300 Gwirdoyń wijst onder meer op de praktische bezwaren die aan een wettelijk verbod op misbruik van procesrecht kleven: hoe kan de intentie van de verdediging worden bewezen en welke sanctie dient erop te staan? Gwirdoyń 2004, p.304-306. Zie ook Kulesza 2005, p. 366, Waltoś 2005, p. 619 en Wiliński 2006, p. 535.

301 Zie $\S 4.2$.

302 Hij heeft (anders dan zijn cliënt) als professionele procesdeelnemer immers bepaalde verantwoordelijkheden op dit punt waardoor aan zijn optreden ook gedragsrechtelijke 
zaak aan te houden. De reden van afwezigheid en of de rechter tijdig op de hoogte is gesteld, is daarbij niet relevant. Dit is een van de redenen waarom het aantal gevallen waarin verdachten moeten worden bijgestaan door een advocaat de laatste jaren is teruggedrongen. ${ }^{303}$ Ten slotte is sinds de wetswijziging van 2003 niet meer voorgeschreven dat de laatste inzage van de processtukken voor sluiting van het vooronderzoek in geval van verplichte rechtsbijstand in aanwezigheid van de raadsman behoort plaats te vinden. ${ }^{304}$ Hierdoor is de raadsman op geen enkel moment in het vooronderzoek meer verplicht te verschijnen en kan de procedure in dit stadium dus niet meer worden vertraagd door afwezigheid van de advocaat. Door bovengenoemde wijzigingen is het op grond van het huidige strafprocesrecht voor de verdediging een stuk minder eenvoudig om op passieve wijze een strafzaak te vertragen. ${ }^{305}$

\subsubsection{Indienen bewijsverzoeken}

Een wetswijziging die overduidelijk was gericht op het voorkomen dan wel terugdringen van misbruik van procesrecht is de introductie van de mogelijkheid bewijsverzoeken af te wijzen wanneer ze enkel en alleen zijn bedoeld om de procedure te vertragen. Deze regel - vormgegeven naar Duits voorbeeld 306 - is in 2003 opgenomen in art. 170 lid 1 sub 5 KPK 1997 en bepaalt dat de rechter een bewijsverzoek dient af te wijzen wanneer het 'op overduidelijke wijze is gericht op vertraging van de procedure' ${ }^{307}$ Het biedt een strafvorderlijke mogelijkheid te voorkomen dat de verdediging de voortgang van een strafzaak doelbewust kan vertragen door grote aantallen (zinloze) bewijsverzoeken in te dienen zoals het oproepen van tientallen getuigen van wie duidelijk is dat ze niets nieuws zullen verklaren. ${ }^{308}$ Weigering op deze grond is ook mogelijk wanneer een bewijsver-

consequenties kunnen worden verbonden. Zie gedragsregel 30 eerste en tweede lid: ' 1 . De advocaat is verplicht de rechtbank of het orgaan waarvoor hij optreedt, op de hoogte te stellen van het feit dat hij niet aan een handeling kan deelnemen, 2. De advocaat is verplicht zijn afwezigheid toe te lichten.'

303 Ook is de mogelijkheid gecreëerd een verleende toevoeging gebaseerd op twijfel aan de geestelijke gezondheid van verdachte (een geval van verplichte rechtsbijstand) in de loop van de procedure weer in te trekken wanneer deze twijfel onterecht blijkt te zijn (art. 79 lid 4 KPK 1997). Zie uitgebreider hoofdstuk 4, § 3.

304 Art. 321 lid 3 KPK 1997.

305 Gwirdoyń 2004, p. 317.

306 Art. 244 lid 3 van het Duitse wetboek van strafvordering. Deze bepaling schijnt in de Duitse praktijk overigens zelden te worden toegepast. Volgens Waltoś mag daaraan echter niet zonder meer de conclusie worden verbonden dat de regel dus geen betekenis heeft: er kan immers een belangrijke preventieve werking vanuit gaan. Vandaar dat hij het wel degelijk zinvol vindt dat deze bepaling ook in het Poolse strafprocesrecht is geïntroduceerd: Waltoś 2005, p. 627.

307 Art. 170 lid 1 sub 5 KPK 1997. Zie over deze bepaling waarin een limitatieve opsomming wordt gegeven van de gronden waarop de rechter een bewijsverzoek kan afwijzen: $\S$ 4.4.3.1.

308 Hierbij dient overigens te worden opgemerkt dat de wettelijke mogelijkheid van art. 170 lid 1 sub 5 KPK 1997 op bewijsverzoeken van alle procespartijen - en dus niet alleen de verdediging - ziet. In de praktijk gaat het uiteraard voornamelijk om verzoeken van de verdediging omdat dat in de meeste gevallen de enige procespartij zal zijn die baat kan hebben bij vertraging van de procedure. Volgens Waltoś heeft dat vooral te maken met de 
zoek met opzet in een laat stadium van de procedure wordt gedaan of telkens wordt ingetrokken of herhaald. ${ }^{309}$

Reeds voor de invoering van art. 170 lid 1 sub 5 KPK 1997 was in de rechtspraak duidelijk geworden dat de rechtspraktijk behoefte had aan een dergelijke weigeringsgrond. In februari 2002 bepaalde de hoger beroepsinstantie van Lublin dat het indienen van bewijsverzoeken door de verdediging onder bepaalde omstandigheden als 'obstructie' kan worden gekwalificeerd. In de zaak die ten grondslag lag aan genoemde uitspraak was in de eindfase van de procedure door de verdediging een groot aantal zinloze bewijsverzoeken ingediend die betrekking hadden op feiten die allang vaststonden en ook bekend waren bij de verdediging. De hoger beroepsinstantie benadrukt in haar uitspraak eerst dat het wetboek van strafvordering weliswaar geen expliciete grond bevat waarop ongefundeerde bewijsverzoeken die zijn bedoeld om de procedure te vertragen, kunnen worden afgewezen maar voegt daaraan toe dat dergelijke verzoeken - wanneer duidelijk is dat het recht erdoor wordt misbruikt - niet ingewilligd hoeven te worden. Toegespitst op de zaak komt de rechter tot het oordeel dat het indienen van verschillende ongefundeerde bewijsverzoeken door de verdachte en zijn advocaten op het allerlaatste moment (op de laatste zittingsdag van een procedure die zeer veel tijd in beslag had genomen) en met betrekking tot feiten die de verdediging reeds aan het einde van het vooronderzoek bekend waren overduidelijk een poging is om de procedure te vertragen:

'Het recht op verdediging is hier in instrumentele zin gebruikt teneinde het regelmatig verloop van de procedure te bemoeilijken, en niet als recht om de onschuld van verdachte aan te tonen. ${ }^{\prime 310}$

psychologische gevolgen van een langdurig strafproces die hoofdzakelijk in het voordeel van de verdediging zijn: de zaak verliest de aandacht van de media en de maatschappij, getuigen zullen zich het feitelijk gebeuren minder goed kunnen herinneren et cetera: Waltoś 2005, p. 615. Hierop dient te worden aangevuld dat vertraging lang niet altijd in het belang van de verdediging hoeft te zijn: ook de verdachte kan - zeker wanneer hij zich in voorlopige hechtenis bevindt - wel degelijk gebaat zijn bij een voortvarende behandeling van zijn strafzaak. Niet voor niets garandeert art. 6 EVRM eenieder tegen wie een vervolging is gericht het recht op berechting binnen een redelijke termijn. Kulesza merkt in dit verband bovendien op dat ook de raadsman zelf niet altijd voordeel heeft bij een aanhouding. Binnen de advocatuur schijnt daar zelfs een gezegde voor te bestaan: 'Een aangehouden zitting is als een echtgenote, ze komt altijd op het verkeerde moment terug.' Zie Kulesza 2005, p. 369.

309 Over de verschillende wijzen waarop de procedure door het indienen van bewijsverzoeken kan worden vertraagd: Gwirdoyń 2004, p. 321-330

310 Uitspraak SA Lublin 6 februari 2002 (II Aka 222/01, Wokanda 2002-5) genoemd in WąsekWiaderek 2005, p. 709, Waltoś 2005, p. 614 en Kulesza 2005, p. 393. De zinsnede dat het recht op verdediging in instrumentele zin kan worden gebruikt om de procedure te bemoeilijken en niet als recht om de onschuld van verdachte aan te tonen, ontleende de hoger beroepsinstantie van Lublin aan een uitspraak van het Hooggerechtshof van 6 juni 2001 (II KKN 96/01, OSNKW 2001/11-12, 95) waarin werd bepaald dat men zich niet op een schending van het recht op verdediging kan beroepen wanneer welbewust en uit eigen keus geen gebruik wordt gemaakt van de mogelijkheden die de verdediging worden geboden haar rechten te verwezenlijken. In cassatie werd door de verdediging geklaagd over het feit dat ze niet in de gelegenheid was gesteld bepaalde getuigen te ondervragen. Volgens het Hooggerechtshof had de feitenrechter weliswaar bepaald dat de verdediging niet bij het verhoor van de betreffende getuigen aanwezig mocht zijn maar had de verdachte er 
Met deze uitspraak - waarin overigens een zeer beperkte en moeilijk met de presumptie van onschuld te verenigen invulling wordt gegeven aan het recht op verdediging - werd duidelijk dat de wetgeving op dit punt aanvulling behoefde. Aan deze behoefte werd niet lang daarna tegemoet gekomen met de introductie van art. 170 lid 1 sub 5 KPK 1997.

De inwerkingtreding van art. 170 lid 1 sub 5 KPK 1997 heeft veel stof doen opwaaien in de literatuur. Verschillende auteurs hebben zich kritisch over de bepaling uitgelaten: zo is Zgryzek van mening dat de regel gevaar oplevert voor de (contradictoire) bewijsvoering op het onderzoek ter terechtzitting omdat het bij advocaten de indruk kan wekken dat een actieve houding op dit punt niet lonend is. ${ }^{311}$ Andere auteurs wijzen erop dat terughoudend gebruik zal moeten worden gemaakt van de mogelijkheid bewijsverzoeken op bovengenoemde grond af te wijzen: weigering zou alleen mogelijk moeten zijn wanneer overduidelijk is dat het verzoek enkel en alleen tot doel heeft om de procedure te vertragen. ${ }^{312}$ Bovendien kan een weigering pas op art. 170 lid 1 sub 5 KPK 1997 worden gebaseerd wanneer geen van de andere in dat artikellid genoemde weigeringsgronden van toepassing is. ${ }^{313}$

Omdat art. 170 lid 1 sub 5 KPK 1997 betrekkelijk nieuw is en geen statistische gegevens op dit punt beschikbaar zijn, is het (vooralsnog) moeilijk te zeggen hoe deze bepaling functioneert in de praktijk. Wel staat vast dat het geen dode letter is en dat de mogelijkheid bewijsverzoeken op deze grond af te wijzen wel degelijk door rechterlijke instanties wordt benut. Het Hooggerechtshof heeft inmiddels een aantal uitspraken gewezen waarin de beslissing van de feitenrechter om een

bij het verhoor van de betreffende getuigen aanwezig mocht zijn maar had de verdachte er bewust voor gekozen geen gebruik te maken van het alternatief vragen schriftelijk op te geven.

311 Wąsek-Wiaderek 2005, p. 711 en daar genoemde literatuur.

312 Met andere woorden: er mag geen twijfel bestaan over de intentie van de verdediging en met het bewijsverzoek moeten geen feiten of omstandigheden kunnen worden vastgesteld die van belang zijn voor het nemen van een beslissing in de betreffende zaak. Wanneer dat laatste wel het geval is, wordt immers niet voldaan aan de voorwaarde dat vertraging van de procedure het enige doel van het verzoek is. Deze voorwaarde is van groot belang omdat ieder bewijsverzoek in beginsel een bepaalde mate van vertraging tot gevolg zal hebben: om te voorkomen dat de rechten van de verdediging op dit punt illusoir worden gemaakt, dient afwijzing dus slechts plaats te vinden wanneer met het verzoek niets anders wordt nagestreefd dan oponthoud van de procedure: Grzegorczyk 2004, p. 435 en Wąsek-Wiaderek 2005, p. 711-712. Zie ook Bieńkowska e.a. 2004, p. 263 en Hofmański e.a. 2007 I, p. 756-757. Ook Wiliński benadrukt dat de rechtbank - voordat een bewijsverzoek wordt afgewezen - te allen tijde in overweging zal moeten nemen of er niet een reële mogelijkheid is dat de bewijshandeling nieuwe belangrijke feiten of omstandigheden aan het licht zal brengen. Dat een bewijsverzoek dat mogelijk de onschuld van verdachte kan aantonen nooit als misbruik mag worden bestempeld, is reeds ruim voor de inwerkingtreding van art. 170 lid 1 sub 5 KPK 1997 - ook bevestigd in de rechtspraak: 'het indienen door verdachte of raadsman van belangrijke bewijsverzoeken die erop zijn gericht te bewijzen dat verdachte het tenlastegelegde strafbare feit niet heeft begaan, kan in geen enkel geval worden aangemerkt als misbruik van het recht op verdediging': uitspraak hoger beroepsinstantie (SA) Białystok, 26 februari 1998, II Aka 137/97, OSA 1999-7/8, nr. 60 genoemd in Wiliński 2006, p. 529.

313 Waltoś 2005, p. 624. 
bewijsverzoek van de verdediging op grond van art. 170 lid 1 sub $5 \mathrm{KPK}$ af te wijzen, in stand werd gehouden. ${ }^{314}$

\subsubsection{Neerleggen verdediging in geval van verplichte rechtsbijstand}

Het is altijd mogelijk dat de raadsman de verdediging van zijn cliënt voortijdig moet neerleggen. De noodzaak hiertoe kan bijvoorbeeld ontstaan wanneer een conflict over de te volgen verdedigingsstrategie ertoe heeft geleid dat tussen advocaat en cliënt geen vertrouwensrelatie meer bestaat. Hoe de rechtbank dient te reageren wanneer de verdediging in een geval van verplichte rechtsbijstand ter terechtzitting aangeeft niet langer met elkaar samen te willen of kunnen werken, is wettelijk geregeld. Het is een gevoelige kwestie omdat een dergelijke situatie voor veel oponthoud kan zorgen: de zaak zal immers pas doorgang kunnen vinden wanneer een nieuwe advocaat is benoemd. Tot een aantal jaren geleden kwam het regelmatig voor dat de verdediging een onderling conflict fingeerde om een aanhouding af te dwingen. Vaak bleek het verschil van mening bij de hervatting van het onderzoek ter terechtzitting ineens te zijn 'opgelost' en werd de verdediging alsnog op oude voet voortgezet. Deze vanuit het oogpunt van efficiëntie onwenselijke situatie was voornamelijk een gevolg van een - sinds de inwerkingtreding van het nieuwe wetboek van strafvordering - tekortschietende wettelijke regeling. Om dit te verduidelijken, zal eerst kort worden geschetst hoe de kwestie in het oude strafprocesrecht was geregeld.

\subsubsection{Situatie voor inwerkingtreding nieuw strafprocesrecht}

De vraag wat dient te gebeuren wanneer in geval van verplichte rechtsbijstand de betrekking tussen raadsman en verdachte wordt opgezegd, werd in het oude wetboek van stafvordering beantwoord in art. $324 \mathrm{KPK}$ :

'Wanneer de verdachte in een geval van verplichte rechtsbijstand na aanvang van het onderzoek ter terechtzitting de betrekking met zijn raadsman beëindigt, dient de raadsman zijn werkzaamheden te veroullen totdat een nieuwe advocaat de zaak overneemt, tenzij de rechtbank anders bepaalt.'

De reikwijdte van deze bepaling was duidelijk. In de eerste plaats stond vast dat de regel alleen betrekking had op de fase van het eindonderzoek ('na aanvang van het onderzoek ter terechtzitting') en op situaties waarin de betrekking tussen raadsman en cliënt op initiatief van laatstgenoemde werd beëindigd ('wanneer de verdachte (...) de betrekking met zijn raadsman beëindigt'). ${ }^{315}$ Uit laatstgenoemde zinsnede kon bovendien worden opgemaakt dat art. 324 KPK 1969 alleen zag op gevallen van verplichte rechtsbijstand waarbij gebruik werd gemaakt van een gekozen raadsman: uitgangspunt was (en is) immers dat bijstand van een advocaat die niet is gekozen maar - al dan niet op verzoek van verdachte - door de rechter is toegevoegd alleen door een nieuwe rechterlijke beslissing kan worden ingetrokken. Behalve dat over de reikwijdte van genoemde bepaling geen twijfel bestond, was ook duidelijk wat diende te gebeuren wanneer een verdachte inderdaad ter terechtzitting aangaf niet langer gebruik te willen maken van de diensten van zijn

314 Informatie verkregen van Wąsek-Wiaderek, juni 2008.

315 De bepaling was dus niet van toepassing wanneer de advocaat verklaarde niet langer namens de verdachte te willen optreden. 
(verplichte en door hem zelf gekozen) advocaat: de oude advocaat moest zijn taken voortzetten totdat zijn werkzaamheden werden overgenomen door een nieuwe raadsman, tenzij de rechtbank anders bepaalde. Hierdoor had de rechtbank in de hand wat er in dit soort gevallen diende te gebeuren en kon ze zelfstandig beoordelen of de 'oude' advocaat zonder schending van het recht op verdediging zijn taken tijdelijk kon voortzetten. Of een en ander tot aanhouding en dus tot vertraging van de strafzaak zou leiden, was dus geheel overgelaten aan de rechter waardoor art. 324 KPK 1969 niet door de verdediging kon worden aangewend om de procedure op te houden. ${ }^{316}$

\subsubsection{Huidig juridisch kader}

Bij de totstandkoming van het nieuwe wetboek van strafvordering is er om onduidelijke redenen toch voor gekozen om de inhoud van de bepaling te veranderen. Anders dan art. 324 KPK 1969 had de nieuwe regeling - nu opgenomen in art. 378 KPK 1997 - betrekking op zowel gekozen als toegevoegde (verplichte) rechtsbijstand. Art. 378 KPK 1997 luidde oorspronkelijk:

'1. Indien na aanvang van het onderzoek ter terechtzitting de betrekking tussen verdachte en raadsman in een geval van verplichte rechtsbijstand door een van beiden wordt opgezegd, benoemt de president van de rechtbank een nieuwe advocaat wanneer ook de oorspronkelijke advocaat ambtshalve is toegevoegd, in geval van een gekozen raadsman zal de rechtbank daarentegen een geschikte termijn dienen te bepalen waarbinnen de verdachte een nieuwe advocaat kan aanwijzen, indien die tijd ongebruikt verstrijkt, wordt alsnog een raadsman benoemd door de president van de rechtbank. Wanneer dat noodzakelijk is, zal de zaak worden aangehouden.

2. Tenzij de betrekking is beëindigd vanwege een verschil van mening over de invulling van de verdediging, dient de oorspronkelijke advocaat zijn werkzaamheden voort te zetten totdat een nieuwe advocaat de verdediging op zich heeft genomen.'

Voornaamste verschil met de oude situatie was dat de rechtbank op basis van dit artikel geen enkele controle kon uitoefenen op de gronden voor het beëindigen van de betrekking en de vraag of de oorspronkelijke (gekozen of toegevoegde) advocaat zijn werkzaamheden zonder schending van het recht op verdediging kon voortzetten totdat een nieuwe advocaat de zaak zou overnemen. ${ }^{317}$ Art. 378 KPK bepaalde immers dat de oude advocaat niet langer hoefde op te treden wanneer de beëindiging van de betrekking met de cliënt het resultaat was van 'een verschil van mening over de invulling van de verdediging'. Dit betekende dat wanneer de verdachte of zijn raadsman ter terechtzitting verklaarde dat zij niet langer samen konden werken vanwege afwijkende opvattingen over de verdedigingsstrategie de zaak hoe dan ook moest worden aangehouden om de verdachte in de gelegenheid te stellen een nieuwe advocaat te benoemen of toevoeging van een nieuwe advocaat door de president van de rechtbank mogelijk te maken. ${ }^{318}$ Op deze

316 Over art. 324 KPK 1969: Paprzycki 2002, p. 303-304 en Zabłocki 2000, p. 129-130.

317 Dat de rechtbank niet bevoegd was een nader onderzoek in te stellen naar de gegrondheid en oprechtheid van het verzoek van verdachte of raadsman om een nieuwe advocaat te benoemen, werd ook bevestigd door de rechtspraak van het Hooggerechtshof (uitspraak 23 februari 1999, I KZP 30/98, OSNKW 3-4/1999, genoemd in Grzegorczyk 2004, p. 968 en Wiliński 2006, p. 534).

318 Dat de verdediging op deze wijze zelfs in geval van toegevoegde rechtsbijstand aanhouding van de zaak en benoeming van een nieuwe advocaat kon afdwingen, werd in de 
wijze kon de verdediging vrij eenvoudig een aanhouding afdwingen, wat - zoals eerder aangegeven - in de praktijk dan ook regelmatig gebeurde.

Dat het oorspronkelijke art. 378 KPK 1997 door de verdediging kon worden aangewend om uitstel van de zaak te bewerkstelligen, heeft de wetgever doen besluiten de bepaling - voor de eerste maal in 2000 en voor de tweede maal in 2007 op een aantal punten aan te passen. ${ }^{319}$ De belangrijkste wijzigingen betreffen de volgende punten:

- Het benoemen van een nieuwe advocaat is voortaan niet meer voorbehouden aan de president van de rechtbank: zowel in geval van gekozen als bij toegevoegde rechtsbijstand kan de benoeming plaatsvinden door de zittingsrechter (rechtbank) en hoeft de zaak dus niet meer te worden aangehouden wanneer een nieuwe raadsman al beschikbaar is.

- De rechter is niet langer verplicht de verdachte in geval van gekozen rechtsbijstand eerst de tijd ('een geschikte termijn') te geven waarbinnen hij zelf een nieuwe advocaat kan benoemen: de rechtbank kan direct tot benoeming overgaan als blijkt dat de verdachte zelf niet voor vervanging heeft gezorgd.

- Het verzoek van verdachte of raadsman tot opheffing van hun onderliggende betrekking moet in geval van toegevoegde rechtsbijstand voortaan worden gemotiveerd. ${ }^{320}$

- De rechtbank kan bepalen dat de verdediging moet worden voortgezet totdat een nieuwe advocaat is benoemd wanneer ze van mening is dat voortzetting geen schadelijke gevolgen heeft voor de verdediging: de verklaring dat verschil van mening bestaat over de invulling van de verdediging is dus niet langer doorslaggevend.

literatuur bekritiseerd. Zie Grzegorczyk 2004, p. 968.

319 Sinds 20 juni 2007 (wet van 9 mei 2007) luidt art. 378 KPK 1997:

' 1 . Indien een verdachte in een geval van verplichte rechtsbijstand een gekozen raadsman heeft en de onderlinge betrekking door een van beiden wordt opgezegd, benoemt de president van de rechtbank of de rechtbank een nieuwe advocaat, voor zover de verdachte zelf geen raadsman heeft benoemd. Wanneer dat noodzakelijk is, zal de zaak worden aangehouden.

2. Wanneer de verdachte wordt bijgestaan door een toegevoegde raadsman, wordt laatstgenoemde op gerechtvaardigd verzoek van hemzelf of verdachte ontheven van zijn verplichtingen en wordt aan verdachte een nieuwe advocaat toegewezen.

3. Wanneer in de gevallen genoemd in lid 1 en 2 een nieuwe raadsman wordt toegewezen, bepaalt de rechtbank tegelijkertijd of de oorspronkelijke raadsman zonder schade toe te brengen aan het recht op verdediging zijn verplichtingen kan blijven vervullen totdat een nieuwe advocaat de verdediging op zich neemt'.

Het tweede lid beperkt zich niet tot gevallen van verplichte rechtsbijstand: dit deel van de regeling is dus van toepassing op alle gevallen van toegevoegde rechtsbijstand. Zie Hofmański e.a. 2007 II, p. 410 en 413.

320 Deze eis vloeit voort uit het feit dat de nieuwe wettekst luidt dat wijziging van een toegevoegde raadsman alleen 'op gerechtvaardigd verzoek' van een van beiden kan plaatsvinden De wetgever heeft niet bepaald op welke wijze een dergelijk verzoek moet worden ingediend zodat moet worden aangenomen dat het zowel schriftelijk als mondeling mag geschieden. Tegen een afwijzende beslissing van de rechter staat overigens geen bezwaar open. Wanneer het verzoek van de raadsman afkomstig is, geldt bovendien art. 28 lid 1 van de Advocatenwet waarin is bepaald dat een advocaat slechts vanwege 'zwaarwegende gronden' mag weigeren rechtsbijstand te verlenen. 
Door bovengenoemde wijzigingen is het voor de verdediging in ieder geval in theorie een stuk minder eenvoudig geworden door creatief gebruik van art. 378 KPK een aanhouding af te dwingen. ${ }^{321}$ Keerzijde is echter dat de uitbreiding van de bevoegdheden van de (zittings)rechter op dit punt ten koste is gegaan van de onafhankelijkheid van de verdediging. Dat de rechter kan bepalen of voortzetting van de verdediging mogelijk is, betekent een aanzienlijke beperking van het recht van verdachte zelf invulling te geven aan zijn verdediging. Bovendien vormt het feit dat de rechtbank in geval van gekozen rechtsbijstand direct over kan gaan tot benoeming van een andere advocaat een inbreuk op het recht op vrije advocatenkeuze. Overigens bestaat nog steeds onduidelijkheid over de reikwijdte van de huidige bepaling. Niet zeker is of art. 378 KPK 1997 alleen betrekking heeft op het eindonderzoek of van toepassing is op alle fasen van het strafproces. ${ }^{322}$ De Poolse literatuur is verdeeld op dit punt. Gelet op de plaatsing van het artikel - in een hoofdstuk dat algemene bepalingen over het onderzoek ter terechtzitting bevat mag echter worden aangenomen dat de bepaling alleen betrekking heeft op het eindonderzoek. ${ }^{323}$ Voor deze uitleg pleit ook dat een apart artikel is gewijd aan de vraag onder welke omstandigheden in het vooronderzoek een nieuwe advocaat toegevoegd kan worden.

\subsection{Misbruik van procesrecht en het EVRM}

Op de meer principiële vragen of de verdachte en zijn raadsman misbruik kunnen maken van hun verdedigingsrechten en of aan de raadsman een publieke taak kan (of moet) worden toegedicht, wordt in de rechtspraak van het Europese Hof

321 Of alle veranderingen in de praktijk het door de wetgever gewenste effect zullen hebben, wordt door sommige auteurs echter betwijfeld. Zo verwacht Paprzycki dat de eis dat het verzoek tot opheffing van de betrekking tussen raadsman en verdachte in geval van toegevoegde rechtsbijstand voortaan gemotiveerd moet worden weinig meerwaarde zal hebben. De rechtbank kan - in tegenstelling tot onder het oude art. 378 KPK 1997 - nu weliswaar zelfstandig bepalen of ze de door de verdediging aangevoerde gronden voldoende acht maar deze beslissing is volgens Paprzycki nog steeds sterk afhankelijk van hetgeen door de verdachte of zijn raadsman wordt aangevoerd. Mogelijk is immers dat wordt volstaan met de stelling dat een verschil van mening bestaat over de te volgen verdedigingsstrategie - de advocaat kan met een beroep op zijn geheimhoudingsplicht weigeren meer specifieke informatie vrij te geven en de verdachte kan hetzelfde doen met een beroep op zijn recht op verdediging (hij kan aanvoeren dat meer concrete omstandigheden in het belang van een effectieve verdediging nog niet openbaar kunnen worden gemaakt) - in welk geval de rechtbank min of meer gedwongen is ermee in te stemmen dat de verdediging definitief wordt neergelegd en de zaak aan te houden: Paprzycki 2002, p. 308-310. Zie over art. 378 KPK 1997 ook: Bojańczyk 2005.

322 Reden hiervoor is het feit dat de zinsnede 'na aanvang van het onderzoek ter terechtzitting' (zie art. 378 lid 1 oorspronkelijk) bij de wetswijziging van 2000 is komen te vervallen.

323 Zo wordt onder meer aangenomen door Grzegorczyk: Grzegorczyk 2004, p. 969. Hofmański is echter een andere mening toegedaan. Hij beargumenteert onder verwijzing naar de historische betekenis van art. 378 KPK 1997 en de parlementaire geschiedenis van de wetswijziging van 2000 dat het artikel wel degelijk ook buiten het onderzoek ter terechtzitting om (bijvoorbeeld in het vooronderzoek of op zittingen in de voorbereidende fase) van toepassing is: Hofmański e.a. 2007 II, p. 411-412.

324 Art. 81 lid 2 KPK 1997: 'De president van de rechtbank die bevoegd is van de zaak kennis te nemen, kan op gerechtvaardigd verzoek van de verdachte of zijn raadsman een nieuwe advocaat toewijzen ter vervanging van de oude.' Zie hoofdstuk 4, § 3.1.3.3. 
geen algemeen antwoord gegeven. Dit betekent echter niet dat de Straatsburgse rechtspraak helemaal geen betekenis voor dit thema heeft. Er kunnen namelijk wel gezichtspunten aan worden ontleend die van belang zijn voor de vraag in hoeverre de overheid van de verdediging mag verwachten dat zij zich coöperatief opstelt en bijdraagt aan een efficiënt procesverloop.

In de eerste plaats is van belang dat het EHRM ervan uitgaat dat het in beginsel aan de verdachte en zijn advocaat is overgelaten om te bepalen hoe de verdediging wordt ingevuld. ${ }^{325}$ Deze vrijheid is echter niet absoluut. Evidente tekortkomingen van de zijde van de raadsman vereisen onder omstandigheden dat de overheid ingrijpt: dan gaat het echter om situaties waarin de raadsman zich onvoldoende inzet voor de verdediging en niet om gevallen waarin hem wordt verweten door strategisch gebruik van bevoegdheden het strafproces te frustreren. ${ }^{326}$ Zoals gezegd, laat het EHRM zich over dat laatste punt niet expliciet uit maar er is wel rechtspraak waarin de opstelling van de verdediging een relevante factor is bij beoordeling van de zaak. Zo wordt door het EHRM wel erkend dat bij beoordeling van de redelijke termijn rekening wordt gehouden met het gedrag van verdachte. Zie bijvoorbeeld Klamecki $t$. Polen ${ }^{327}$ waarin klager (de verdachte) stelselmatig niet op zittingen verscheen, verschillende keren het vertrouwen in zijn advocaat had opgezegd en een aantal ongefundeerde wrakingsverzoeken had gedaan. Het Europese Hof stemt in met het standpunt van de Poolse regering dat Klamecki zich schuldig heeft gemaakt aan 'delaying tactics' en concludeert dat art. 6 lid 1 EVRM (redelijke termijn) niet is geschonden. ${ }^{328}$ In het verleden werd in de Poolse rechtspraak zelfs aangenomen dat het doelbewust vertragen van de procedure door verdachte een grond kon zijn voor het overschrijden van de 2-jaars termijn van de voorlopige hechtenis. ${ }^{329}$ In Jabłoński t. Polen ${ }^{330}$ heeft het EHRM echter duidelijk gemaakt dat een dergelijke overschrijding van de maximumtermijn in beginsel niet kan worden gerechtvaardigd door het gedrag van verdachte. Zie in dit verband ook (onder andere) de zaken Kąkol t. Polen, ${ }^{331}$ Osinski t. Polen ${ }^{332}$ en Malikowski t. Polen $^{333}$ waarin 'the defendants obstructiveness and the abuse of the rights of the defence' wel wordt beschouwd als een factor die mogelijk van invloed is op de termijn van de voorlopige hechtenis maar in de gegeven omstandigheden de lange duur van de detentie niet kon rechtvaardigen.

Uit bovengenoemde rechtspraak blijkt dat het EHRM behalve naar het optreden van nationale overheden zo nu en dan ook kritisch naar de opstelling van de ver-

325 De standaardoverweging op dit punt luidt: 'Owing to the legal profession's independence, the conduct of the defence, is essentially a matter between the defendant and his representative; under Article 6 par. 3 (c) the Contracting States are required to intervene only if a complaint is brought to their attention.' Zie bijvoorbeeld Imbrioscia t. Zwitserland, EHRM 24-11-1993, nr. 13972/88, § 41 .

$326 \mathrm{Al}$ is uiteraard niet uitgesloten dat een raadsman door zijn passiviteit de voortgang van de procedure blokkeert (bijvoorbeeld door niet op te komen dagen op zittingen).

327 EHRM 28-3-2002, nr. 25415/95, § 92 e.v.

328 § 94-95.

329 Zie over deze termijn: hoofdstuk 5, § 4.2.

330 EHRM 21-12-2002, nr. 33492/96.

331 EHRM 6-9-2007, nr. 3994/03.

332 EHRM 16-10-2007, nr. 13732/03.

333 EHRM 16-10-2007, nr. 15154/03. 
dediging kijkt. Het gaat dan voornamelijk om situaties waarin wordt geklaagd over overschrijding van de redelijke termijn - van de procedure in zijn geheel of van de voorlopige hechtenis - en waarin de regering aanvoert dat de verdediging het deels aan zichzelf te wijten heeft dat het allemaal (te) lang heeft geduurd. Voor het overige is het Europese Hof terughoudend op dit punt omdat de vrijheid van verdachte en raadsman om zelf invulling te geven aan de verdediging als een belangrijk uitgangspunt wordt beschouwd. Daarmee is moeilijk verenigbaar dat een advocaat die binnen de grenzen van de wet gebruik maakt van de verdedigingsmogelijkheden misbruik van procesrecht wordt verweten. Dan is het immers niet meer de verdediging zelf maar de overheid die bepaalt wat in het belang van de verdachte dient te gebeuren.

\subsection{Conclusie}

In het voorgaande is duidelijk geworden dat misbruik van procesrecht (of: misbruik van het recht op verdediging) binnen de Poolse strafrechtspleging van een relatief onbekend verschijnsel is uitgegroeid tot een begrip dat steeds vaker opduikt in rechtspraak, literatuur en wetgeving. Opvallend is dat in de Poolse literatuur en rechtspraak in dit verband voornamelijk aandacht wordt besteed aan een bepaalde vorm van misbruik, te weten het tactisch aanwenden van procedurele mogelijkheden om het proces te vertragen (obstructie). Een andere mogelijke vorm - het benutten van zogenaamde vormfouten om een voor de verdachte zo gunstig mogelijke einduitspraak te bewerkstelligen ${ }^{334}$ - die onder meer in de Nederlandse rechtspraktijk veel aandacht krijgt, lijkt niet of nauwelijks een rol te spelen. Zonder hier in te gaan op de meer principiële kwestie of een dergelijk optreden van de verdediging in een rechtsstaat wel als misbruik mag worden bestempeld, is voor de Poolse situatie van belang dat dit soort verwijten blijkbaar niet (of in ieder geval in veel mindere mate) aan de verdediging worden gemaakt. Dat wel veel aandacht wordt besteed aan obstructie is een logisch gevolg van het eerder genoemde feit dat efficiëntie de laatste jaren centraal is komen te staan in het Poolse strafproces. De verdediging wordt daarbij in toenemende mate verantwoordelijk gehouden voor een soepel en snel procesverloop. ${ }^{335}$ Ten aanzien van de raadsman is dit onlosmakelijk verbonden met de principiële vraag of er grenzen kunnen worden gesteld aan zijn partijdigheid en of hij onder bepaalde omstandigheden behalve ten opzichte van zijn cliënt ook loyaal dient te zijn aan de rechtspleging. ${ }^{336}$

334 Het verwijt aan de verdediging is dan dat door haar toedoen in het strafproces teveel aandacht wordt gevraagd voor het optreden van politie en justitie terwijl het zou moeten gaan om het (vermeende) handelen of nalaten van verdachte. Bovendien wordt in dit verband wel de vraag gesteld of de maatschappelijke verantwoordelijkheid van de advocaat er niet aan in de weg zou moeten staan dat hij door een beroep te doen op vormfouten een (gevaarlijke) verdachte zijn straf laat ontlopen. Over misbruik van verdedigingsrechten in het Nederlandse strafproces: Spronken 2001, p. 163-164 en p. 316-333.

335 Aangezien wordt aangenomen dat misbruik zowel het handelen van de verdachte, het optreden van de raadsman als het gedrag van beiden gezamenlijk kan betreffen, wordt er blijkbaar vanuit gegaan dat deze verantwoordelijkheid zowel voor de verdachte als voor zijn advocaat geldt. Zie Wiliński 2006, p. 520.

336 Zie voor de Poolse opvattingen over de (publieke) functie van de raadsman: hoofdstuk 3. Zoals daar is vastgesteld, wordt de publieke functie van de advocaat in strafzaken in meer recente literatuur vooral in een rechtsstatelijk kader geplaatst: het algemeen belang is 
De laatste jaren zijn verschillende wetswijzigingen doorgevoerd ter voorkoming van obstructie door de verdediging. In de meeste gevallen gaat het daarbij om aanpassingen van bepalingen die in de ogen van de overheid in het verleden te eenvoudig konden worden aangewend om de procedure te vertragen. In sommige gevallen zijn de gevolgen van deze incidentele wijzigingen voor de verdediging groter dan men op het eerste gezicht zou denken. Zo hebben de wijzigingen op het gebied van (verplichte) deelname van de verdediging tot gevolg dat de zaak in steeds meer gevallen in afwezigheid van verdachte en/of een (verplichte) raadsman kan worden afgedaan. In gevallen van verplichte rechtsbijstand is deelname van een advocaat op geen enkel moment in het vooronderzoek meer dwingend voorgeschreven. In het kader van art. 378 KPK 1997 (neerleggen van de verdediging) geldt dat de huidige regeling de rechter wel erg veel mogelijkheden biedt zich te mengen in de relatie tussen advocaat en cliënt en de wijze waarop de verdediging wordt ingevuld. Zoals kan worden afgeleid uit de rechtspraak van het EHRM dient de overheid grote terughoudendheid te betrachten waar het gaat om de beoordeling van de kwaliteit en de inhoud van de verdediging. Dat door de rechter kan worden bepaald of terecht wordt beweerd dat de verhouding tussen raadsman en cliënt onherstelbaar is verstoord, is daarmee moeilijk verenigbaar. Bovendien blinkt de nieuwe bepaling niet uit in helderheid. ${ }^{337}$

Bij slechts een van de wijzigingen ter voorkoming van misbruik heeft de wetgever ervoor gekozen expliciet te verwijzen naar het verschijnsel 'obstructie'. Ten aanzien van het indienen van bewijsverzoeken is sinds 2003 immers bepaald dat een verzoek moet worden afgewezen wanneer het 'overduidelijk is gericht op vertraging van de procedure'. ${ }^{338}$ Wat de praktische toepassing van deze bepaling betreft, geldt dat niet altijd met zekerheid zal kunnen worden vastgesteld met welk doel de verdediging een bepaald verzoek indient. ${ }^{339}$ Afwijzing op deze grond zal - zoals ook benadrukt in de Poolse literatuur - slechts mogen plaatsvinden wanneer er geen enkele twijfel over kan bestaan dat het de verdediging slechts om vertraging van de procedure te doen is. Het feit dat een (ongewoon) hoog aantal bewijsverzoeken wordt ingediend of dat dit in een laat stadium van de procedure gebeurt, zijn slechts factoren die bij die beoordeling een rol kunnen spelen en mogen op zichzelf nooit beslissend zijn.

\section{Conclusie verdediging in het eindonderzoek}

De positie van de verdediging in het eindonderzoek heeft met de totstandkoming van het nieuwe strafprocesrecht geen grote veranderingen ondergaan. Het onderzoek ter terechtzitting is qua structuur en bevoegdheden van partijen niet noemens-

gebaat bij effectieve rechtsbijstand aan verdachten, niet alleen omdat daarmee rechterlijke dwalingen kunnen worden voorkomen maar ook omdat het bieden van rechtsbescherming en het bewaken van procedurele voorschriften als zelfstandige rechtsstatelijke belangen worden erkend.

337 Bijvoorbeeld de onduidelijkheid over de vraag of de regel alleen betrekking heeft op het onderzoek ter terechtzitting of ook op andere fasen van het strafproces komt niet ten goede aan een heldere en eenduidige praktijk.

338 Art. 170 lid 1 sub 5 KPK 1997.

339 De verdediging dient wel aan te geven welke feiten of omstandigheden ze beoogt te bewijzen (art. 169 KPK 1997) maar verder dan dat gaat de motiveringsplicht niet. 
waardig gewijzigd en op basis van de wettelijke regeling kunnen geen grote problemen worden geconstateerd met het oog op de eisen van het EVRM.

Dat er geen structurele wijzigingen zijn doorgevoerd, wil echter niet zeggen dat het eindonderzoek van vandaag de dag in geen enkel opzicht verschilt van de wijze waarop deze fase van het strafproces gedurende het communisme werd vormgegeven.

In de eerste plaats is van belang dat de voorbereidende fase een steeds belangrijker stadium in het strafproces is geworden - vooral vanwege de beslissingen over consensuele afdoening die daar kunnen worden genomen - en dat de mogelijkheden van de verdediging in dit verband aanzienlijk zijn verbeterd. In vergelijking met het oude strafprocesrecht heeft de verdediging veel ruimere bevoegdheden om deel te nemen aan zittingen die in de voorbereidende fase worden gehouden en waarop voor de verdachte belangrijke beslissingen kunnen worden genomen.

In de tweede plaats is een aantal wijzigingen doorgevoerd die het adversaire karakter van het eindonderzoek beoogden te versterken. Het was immers een van de doelstellingen van de postcommunistische wetgever de gelijkheid tussen vervolging en verdediging op het onderzoek ter terechtzitting te vergroten en een actieve opstelling van procespartijen te stimuleren. ${ }^{340}$ De introductie van de mogelijkheid voor de verdediging een schriftelijke reactie te formuleren op de akte van beschuldiging en de wijziging van de volgorde waarin personen (verdachten, getuigen en deskundigen) op de zitting moeten worden ondervraagd, dienden daaraan bij te dragen. Gebleken is echter dat beide wijzigingen slechts (zeer) beperkte betekenis hebben voor de praktijk en de verhoudingen op het onderzoek ter terechtzitting niet of nauwelijks hebben veranderd.

In de derde plaats is het zwaartepunt binnen de strafrechtspleging de laatste jaren steeds meer op efficiëntie komen te liggen wat tot een herwaardering van de positie van de verdediging heeft geleid. Deze tendens beperkt zich overigens zeker niet tot Polen of het voormalig Oostblok maar is in vele rechtssystemen in en buiten Europa merkbaar. Specifiek voor de situatie waarin Polen zich bevindt, is wel dat de postcommunistische hervorming van het straf(proces)recht hierdoor sterk wordt beïnvloed nu meer recente crimineelpolitieke ontwikkelingen steeds verder verwijderd lijken te raken van de oorspronkelijke doelstellingen van de transitie. Vrij snel na de inwerkingtreding van het nieuwe strafprocesrecht is men tot de conclusie gekomen dat de nieuwe balans tussen rechtsbescherming en instrumentaliteit die in het wetboek van strafvordering van 1997 was gevonden onvoldoende tegemoet zou kunnen komen aan de op efficiëntie gerichte eisen van de praktijk. Als gevolg van een toename van (zichtbare en georganiseerde) criminaliteit en een steeds zwaardere belasting van het strafrechtelijk apparaat is het gros van de wetswijzigingen die sinds 2000 zijn doorgevoerd vooral gericht op een zo efficiënt mogelijk procesverloop. Verschillende in dit hoofdstuk beschreven ontwikkelingen kunnen hierdoor worden verklaard, zoals:

- de uitbreiding van het aantal uitzonderingen op het onmiddellijkheidsbeginsel waardoor het eenvoudiger is resultaten van het vooronderzoek voor het bewijs te bezigen,

340 Zie hoofdstuk 2, § 2.3.3. 
- de toename van het aantal gevallen waarin het onderzoek ter terechtzitting in afwezigheid van de verdachte kan worden afgedaan,

- de uitbreiding van de mogelijkheid strafzaken door middel van alternatieve, consensuele methodes - in plaats van de klassieke wijze van berechting - af te doen en

- de introductie van de anonieme getuige en de kroongetuige ter vergemakkelijking van de strijd tegen de georganiseerde criminaliteit.

Al deze ontwikkelingen staan haaks op het oorspronkelijke streven van de postcommunistische wetgever de scheve verhouding tussen het voor- en het eindonderzoek te herstellen en meer nadruk te leggen op het onderzoek ter terechtzitting. De behoeften van de huidige, instrumentele praktijk hebben duidelijk gemaakt dat wat op papier wellicht een mooi evenwicht leek te zijn in werkelijkheid onvoldoende tegemoet kwam aan de toenemende druk op het strafrechtelijk apparaat. Gevolg hiervan is dat de aandacht voor de positie van de verdediging meer naar de achtergrond is verschoven en dat allerlei (nieuwverworven) vormen van rechtsbescherming opnieuw onder de loep worden genomen. Binnen bovengenoemde tendens past ook de opkomst van het fenomeen misbruik van procesrecht. De introductie van dit verschijnsel is gelet op de situatie waarin de Poolse strafrechtspleging zich bevindt begrijpelijk maar ook riskant te noemen. Begrijpelijk omdat de rechterlijke macht en de wetgever zich vanwege de hoge werkdruk en capaciteitsbeperkingen genoodzaakt zien op te treden tegen verdachten en advocaten die bepaalde procedurele mogelijkheden benutten om de zaak te vertragen. Riskant omdat het gevaar bestaat dat de verdediging die nog maar net gewend probeert te raken aan haar nieuwe rol in een meer op tegenspraak gerichte procedure wordt afgeschrikt een actieve opstelling aan te nemen in het strafproces. Zoals eerder is gebleken, nemen Poolse advocaten met name in het vooronderzoek maar op bepaalde punten ook gedurende het onderzoek ter terechtzitting (bijvoorbeeld voor wat betreft hun aandeel in de waarheidsvinding) in strafrechtelijke procedures een passieve houding aan. In sommige gevallen speelt daarbij een rol dat binnen de advocatuur de opvatting bestaat dat de rechter een al te actieve opstelling niet zal kunnen waarderen. Het risico bestaat dat advocaten uit angst te worden beticht van misbruik nog voorzichtiger zullen worden.

Niet uit het oog mag worden verloren dat bij een normaal procesverloop dient te worden ingecalculeerd dat de verdediging gebruik maakt van haar rechten en bevoegdheden en dat kost nu eenmaal tijd. Zoals ook wordt benadrukt in de Straatsburgse rechtspraak is het aan de verdachte en zijn raadsman om te bepalen hoe de verdediging wordt gevoerd en een overheid die dit uitgangspunt niet of onvoldoende respecteert, komt als snel in conflict met twee kernwaarden die ten grondslag liggen aan het functioneren van de advocaat: onafhankelijkheid en principiële partijdigheid. 



\section{Hoofdstuk 7}

\section{Vrij verkeer en verschoningsrecht}

\section{Inleiding}

De in de voorgaande hoofdstukken besproken procedurele mogelijkheden die de verdediging in de fase van het vooronderzoek en op het onderzoek ter terechtzitting tot haar beschikking heeft, hebben met elkaar gemeen dat ze in de eerste plaats zijn toegekend aan de verdachte en dat de raadsman ze als het ware afleidt van zijn cliënt. ${ }^{1}$ Behalve deze procedurele mogelijkheden die verdachte en raadsman met elkaar delen, zijn er ook bevoegdheden die betrekking hebben op de uitoefening van de rol van de verdediger, te weten het vrij verkeer en het verschoningsrecht. Anders dan bevoegdheden die aan de verdachte en zijn raadsman toekomen (zoals het recht op inzage van processtukken, het horen van getuigen, deelname aan onderzoekshandelingen et cetera) gaat het daarbij niet zozeer om de mogelijkheid om in het kader van een strafrechtelijke procedure bepaalde handelingen in het belang van de verdediging te kunnen verrichten maar om het creëren of waarborgen van de juiste omstandigheden die voor het vervullen van de functie van raadsman noodzakelijk zijn. ${ }^{2}$ Deze twee thema's - het vrij verkeer en het verschoningsrecht - staan in het onderhavige hoofdstuk centraal.

Zowel het vrij verkeer als het verschoningsrecht zijn gebaseerd op de veronderstelling dat vertrouwelijkheid een essentieel element van de verdediging is. Degene die bijstand van een advocaat vraagt, dient er immers vanuit te kunnen gaan dat alles wat hij met zijn rechtsbijstandverlener bespreekt vertrouwelijk blijft. Dit geldt in het bijzonder voor de cliënt in strafzaken die met zijn advocaat informatie moet kunnen uitwisselen die - zou deze openbaar worden gemaakt - nadelig kan zijn voor het verloop of de uitkomst van zijn proces.

Het belang van vertrouwelijke communicatie tussen raadsman en cliënt betreft overigens niet alleen het individuele belang van de verdachte (of de verdediging) ${ }^{3}$ maar ook een maatschappelijk belang. Immers, wanneer vertrouwelijkheid niet kan worden gegarandeerd en daardoor het vertrouwen in de advocatuur daalt, zullen burgers minder snel professioneel juridisch advies vragen waardoor verwezenlijking van het recht op verdediging in gevaar kan komen. ${ }^{4}$

1 Wat overigens niet wegneemt dat de raadsman op bepaalde punten ruimere bevoegdheden heeft dan zijn cliënt: in de voorgaande hoofdstukken zijn verschillende voorbeelden genoemd van verdedigingsrechten die ruimere mogelijkheden bieden aan de raadsman dan aan de verdachte (zoals de - voor de gedetineerde verdachte beperkte mogelijkheden om aanwezig te zijn op zittingen waarop over de voorlopige hechtenis wordt beslist of om deel te nemen aan onderzoekshandelingen die in het vooronderzoek plaatsvinden).

2 Spronken 2001, p. 334.

3 Vertrouwelijkheid is ook essentieel voor de raadsman: wanneer een cliënt niet alle relevante informatie met hem durft te delen, bemoeilijkt dat het geven van passend juridisch advies en dus de verdediging.

4 Zie in dit verband ook art. 2.3.1 van de gedragscode voor advocaten in de Europese Unie (CCBE code of conduct, te raadplegen via: http://www.ccbe.org/): 'Het ligt in het wezen van de taak van de advocaat, dat hem van de zijde van zijn cliënt geheimen 
Het recht op contact tussen de raadsman en zijn gedetineerde cliënt wordt in de hierna te bespreken strafvorderlijke bepalingen ${ }^{5}$ als recht van de verdachte geformuleerd en dus niet expliciet aan de advocaat toegekend. Hieruit mag echter niet worden afgeleid dat het recht op vrij verkeer niet (ook) aan de raadsman toekomt. Immers, het recht van de verdachte om zijn advocaat te kunnen contacteren en met hem overleg te kunnen voeren, impliceert dat de raadsman toegang moet worden verleend tot zijn cliënt. ${ }^{6}$ Ten slotte geldt meer algemeen ook in het kader van het vrij verkeer dat rechten die aan de verdachte zijn toegekend - behoudens de door de wetgever bepaalde uitzonderingen - ook aan zijn advocaat toekomen. ${ }^{7}$

Wanneer een verdachte van zijn vrijheid is beroofd - en dientengevolge beperkte mogelijkheden heeft om in contact te treden met de buitenwereld - is voor vertrouwelijk overleg in ieder geval vereist dat hij in de gelegenheid wordt gesteld om een advocaat te contacteren en vrij met hem moet kunnen communiceren. Deze garanties vallen onder het vrij verkeer. ${ }^{8}$

Behalve door het vrij verkeer wordt de vertrouwelijkheid van de relatie tussen advocaat en cliënt ook beschermd door het verschoningsrecht. Dit recht - dat overigens niet alleen de advocatuur betreft maar ook van belang is voor andere vertrouwensberoepen zoals artsen en geestelijken en voor bepaalde categorieën getuigen $^{9}$ - houdt in de eerste plaats in dat de advocaat niet mag worden gedwongen als getuige informatie prijs te geven die hij in de hoedanigheid van rechtsbijstandverlener heeft verkregen. Het is dan ook onlosmakelijk verbonden met het beroepsgeheim van de advocaat dat eveneens tot doel heeft de vertrouwelijkheid tussen raadsman en cliënt te beschermen. Effectieve bescherming van genoemde vertrouwelijkheid vereist echter niet alleen dat de rechtsbijstandverlener zich ten overstaan van de rechter op zijn verschoningsrecht kan beroepen maar ook dat vertrouwelijke gegevens niet op andere wijze door justitiële auto-

worden toevertrouwd en dat vertrouwelijke mededelingen worden gedaan. Zonder de waarborg van het beroepsgeheim kan er geen vertrouwen bestaan. Het beroepsgeheim wordt derhalve erkend als essentieel en fundamenteel recht en als plicht van de advocaat. De verplichting van de advocaat met betrekking tot het beroepsgeheim dient zowel de belangen van de rechtsbedeling als de belangen van de cliënt. Zij dient derhalve een bijzondere bescherming van de Staat te genieten.'

5 Art. 73 en 245 KPK 1997.

6 Bovendien brengt de ratio van het vrij verkeer met zich dat vertrouwelijkheid van communicatie ook het uitgangspunt dient te zijn wanneer het op initiatief van de raadsman plaatsvindt. Hoewel in art. 245 lid 1 KPK 1997 is geregeld dat de aangehoudene 'op zijn verzoek' een advocaat moet kunnen consulteren, wordt aangenomen dat het initiatief ook van de advocaat mag uitgaan. Zie hierover hoofdstuk 4, § 2.2.2.1.

7 Het verschoningsrecht is daarentegen (ook op grond van het Poolse strafprocesrecht) wel een exclusief recht van de raadsman: het komt niet aan verdachte toe en kan dus ook niet van hem worden afgeleid.

8 Het recht op vrij verkeer omvat dus ook de toegang tot rechtsbijstand. De vraag vanaf welk moment en onder welke voorwaarden na aanhouding recht op rechtsbijstand bestaat, is aan de orde gekomen in hoofdstuk 4 , § 2 . In dit hoofdstuk zal worden bekeken of - en zo ja, op welke wijze(n) - het contact tussen advocaat en gedetineerde cliënt kan worden beperkt.

9 Zoals echtgenoten en andere familieleden. Hier zal echter slechts aandacht worden besteed aan het professionele verschoningsrecht van de advocaat in strafzaken. 
riteiten kunnen worden verkregen. Dit betekent dat ook bij de toepassing van opsporingsmethoden en dwangmiddelen de vertrouwelijkheid van het contact tussen raadsman en cliënt zoveel mogelijk zal moeten worden gerespecteerd.

In het eerste deel van dit hoofdstuk zal worden uitgewerkt hoe het recht op vrij verkeer in het Poolse strafprocesrecht is vormgegeven. Daarbij zal eerst aandacht worden besteed aan de situatie gedurende het communisme toen het gebrek aan vertrouwelijke communicatie met een gedetineerde cliënt een van de belangrijkste obstakels voor de verdediging was. Vervolgens zal worden bekeken of - en zo ja, in hoeverre - het huidige strafprocesrecht op dit punt meer garanties biedt waarbij tevens aan de orde zal komen hoe een en ander zich verhoudt tot de op dit punt geldende Straatsburgse normen.

In deel twee van dit hoofdstuk zal de regeling en de reikwijdte van het verschoningsrecht van de Poolse advocaat worden onderzocht. Daarbij zal duidelijk worden dat het huidige strafprocesrecht een verschoningsrecht toekent aan de advocaat maar dat dit recht - voor wat betreft de mogelijkheid de advocaat als getuige te horen - slechts een absoluut karakter heeft voor zover het gaat om informatie die is verkregen in de hoedanigheid van raadsman (obrońca). ${ }^{10}$ Zoals nog zal blijken, bestaat in alle andere gevallen de mogelijkheid de geheimhoudingsplicht van de advocaat onder bepaalde omstandigheden op te heffen.

Ten slotte zal worden bekeken in hoeverre het huidige Poolse strafprocesrecht het beroepsgeheim van de advocaat bescherming biedt bij huiszoeking, inbeslagneming en het afluisteren en opnemen van telefoongesprekken. Ook hier zal de huidige wettelijke regeling voor zover relevant worden vergeleken met het oude strafprocesrecht en worden getoetst aan het EVRM en bijbehorende rechtspraak van het Europese Hof voor de rechten van de mens. Hierbij dient te worden opgemerkt dat er in dit hoofdstuk niet naar is gestreefd alle wijzen waarop het verschoningsrecht van de advocaat (of meer algemeen de vertrouwelijkheid van het contact tussen advocaat en cliënt) binnen de kaders van het strafproces in het gedrang kan komen uitputtend te bespreken. Gekozen is voor een aantal meer klassieke strafvorderlijke bevoegdheden (huiszoeking, inbeslagneming en telefoontap) maar dit neemt niet weg dat vertrouwelijkheid van communicatie ook een punt van discussie kan zijn bij andere opsporingsmethoden zoals observatie. Ook heeft Polen ter implementatie van de Europese witwasrichtlijn ${ }^{11}$ wetgeving in het leven geroepen die aan de advocaat de verplichting oplegt melding te maken van bepaalde financiële transacties. ${ }^{12}$ Deze en andere thema's zullen hier

10 De advocaat die rechtsbijstand in een strafzaak verleent, krijgt pas de status van raadsman (obrońca) wanneer zijn cliënt officieel als verdachte (podejrzany) is aangemerkt. Zie eerder hoofdstuk 4, § 2.2.2.2 en hierna § 6.1

11 Council Directive 91/308/EEC.

12 Wet van 16 november 2000 inzake de bestrijding van de invoering van vermogen afkomstig uit illegale of onbekende bron in financiële transacties en inzake de bestrijding van de financiering van terrorisme (Ustawa o przeciwdziataniu wprowadzaniu do obrotu finansowego wartości majątkowych pochodzacych z nielegalnych lub nieujawnionych źródet oraz o przeciwdziałaniu finansowaniu terroryzmu). Oorspronkelijk had deze wet alleen gevolgen voor financiële instanties maar sinds maart 2004 is de werking ervan uitgebreid tot (onder meer) advocaten en juridisch adviseurs. Zij hebben een meldplicht - die derogeert aan hun geheimhoudingsplicht - wanneer uit feiten of omstandigheden blijkt dat geld uit illegale bron afkomstig is. De invoering van deze meldplicht 
- vanwege de beperkte betekenis voor de advocaat in strafzaken - verder buiten beschouwing worden gelaten.

\section{Deel I: Vrij verkeer}

Een burger die in Polen wordt aangehouden, kan voor maximaal 72 uur door de politie van zijn vrijheid worden beroofd. ${ }^{13}$ Daarna is vrijheidsberoving zolang er nog geen onherroepelijke veroordeling ligt, slechts mogelijk in de vorm van voorlopige hechtenis. Het contact tussen advocaat en cliënt is voor beide stadia afzonderlijk geregeld: voor de fase van de politiedetentie geldt art. 245 KPK 1997 en gedurende de voorlopige hechtenis is art. 73 KPK 1997 en een aantal bepalingen uit het wetboek betreffende de tenuitvoerlegging van straffen $(K K W)^{14}$ van toepassing. Beide regimes zullen hierna afzonderlijk worden behandeld. Daarbij zal eerst aandacht worden besteed aan de mogelijkheden in persoon (tijdens bezoek) overleg te voeren en daarna worden besproken in hoeverre raadsman en verdachte vertrouwelijk met elkaar kunnen corresponderen. Aangezien de voorlopig gehechte verdachte niet het recht heeft telefonisch met zijn raadsman te overleggen, zal deze vorm van communicatie buiten beschouwing blijven. ${ }^{15}$

\section{Persoonlijk overleg}

\subsection{Situatie voor inwerkingtreding nieuw strafprocesrecht}

Een van de grootste problemen waar de advocaat in strafzaken gedurende het communisme mee werd geconfronteerd, betrof het contact met de gedetineerde cliënt. De aangehoudene kon - net als op grond van het huidige strafprocesrecht voorafgaand aan een eventueel bevel voorlopige hechtenis maximaal drie dagen van zijn vrijheid worden beroofd maar of, en zo ja, op welke wijze in deze fase contact mocht worden gelegd met een advocaat was niet wettelijk geregeld. Hierdoor was niet duidelijk of de aangehoudene in het stadium voorafgaand aan de voorlopige hechtenis het recht had een advocaat te consulteren. Een advocaat kon - totdat zijn cliënt officieel als verdachte was aangemerkt en in voorlopige hechtenis was genomen - wel proberen toegang te krijgen maar er bestond geen enkele wettelijke garantie dat een dergelijk verzoek zou worden gehonoreerd. ${ }^{16}$

Het contact tussen advocaat en cliënt gedurende de fase van voorlopige hechtenis was wel wettelijk geregeld. Art. 64 KPK 1969 luidde:

heeft binnen beide beroepsgroepen tot veel verzet geleid.

13 Zie ook hoofdstuk 4, § 2.1.

14 De fase van de tenuitvoerlegging van vonnissen is in het Poolse strafprocesrecht in een afzonderlijke codificatie geregeld: het wetboek betreffende de tenuitvoerlegging van straffen (Kodeks Karny Wykonawczy). Zie eerder hoofdstuk 2, § 3.2.3.3.

15 Dat telefonisch overleg niet mogelijk is, blijkt uit art. 217c KKW 1997 waarin is bepaald dat een gedetineerde gedurende voorlopige hechtenis geen gebruik mag maken van een telefoon of andere technische communicatiemiddelen. Het kan ook worden afgeleid uit de regeling van het vrij verkeer in het wetboek van strafvordering (hierna te bespreken art. 73 KPK 1997) omdat daarin slechts persoonlijk overleg en correspondentie tussen raadsman en cliënt wordt genoemd.

16 Zie over het recht op rechtsbijstand na aanhouding op grond van het oude wetboek van strafvordering hoofdstuk 4, § 2.2.1. 
'1. De beschuldigde die zich in voorlopige hechtenis bevindt, mag in afwezigheid van anderen met zijn raadsman overleg voeren en met hem corresponderen.

2. In het vooronderzoek kan de prokurator die toestemming verleent voor dit overleg bepalen dat hijzelf of een door hem aangewezen persoon daarbij aanwezig zal zijn en in uitzonderlijke gevallen weigeren toestemming te verlenen voor het overleg. Het toezicht of de weigering toestemming te verlenen kunnen niet meer plaatsvinden nadat de verdachte en zijn raadsman op de hoogte zijn gesteld van de datum waarop de processtukken kunnen worden ingezien, zelfs niet wanneer de prokurator daarna nog om aanvulling van de stukken vraagt.'

Uit deze bepaling kan worden afgeleid dat de prokurator gedurende het communisme drie mogelijkheden had. Hij kon voor het bezoek:

- toestemming verlenen zonder te bepalen dat het gesprek onder toezicht zou moeten plaatsvinden,

- toestemming verlenen onder de voorwaarde dat hijzelf of een door hem aangewezen derde bij het overleg aanwezig zou zijn en

- in uitzonderlijke gevallen (w wyjatkowych wypadkach) geen toestemming verlenen.

Beide laatstgenoemde beperkingen op het vrij verkeer konden plaatsvinden tot het moment waarop de verdediging was ingelicht over de mogelijkheid de stukken voor een laatste keer gedurende het vooronderzoek in te zien. ${ }^{17}$ De betekenis van deze temporele beperking op de mogelijkheid het overleg te verbieden of onder toezicht te laten plaatsvinden was echter uiterst beperkt: de prokurator bepaalde immers zelf wanneer de mededeling over de inzagemogelijkheid werd gedaan en kon het moment dus net zolang uitstellen als dat - ook met het ook op de gevolgen voor het vrij verkeer - noodzakelijk werd geacht. Hierdoor kon persoonlijk contact tussen raadsman en verdachte in de praktijk voor de duur van vrijwel het gehele vooronderzoek worden beperkt of verboden.

Hoewel de redactie van art. 64 KPK 1969 er geen twijfel over liet bestaan dat onbeperkt contact tussen raadsman en verdachte ook gedurende het vooronderzoek de regel behoorde te zijn en de beperkingen genoemd in lid 2 slechts bij wijze van uitzondering mochten worden toegepast, ${ }^{18}$ was de praktijk juist omgekeerd. Verzoeken van advocaten om hun voorlopig gehechte cliënten te bezoeken werden meestal afgewezen zonder dat werd gemotiveerd waarom sprake was van een 'uitzonderlijk geval' in de zin van art. 64 KPK 1969. Wanneer bij wijze van uitzondering wel toestemming werd verleend, gebeurde dat veelal onder de voorwaarde dat het gesprek onder toezicht van de prokurator zou plaatsvinden. In de

17 Bedoeld is de laatste mogelijkheid tot inzage van de processtukken voor sluiting van het vooronderzoek (art. 277 KPK 1969), zie hierover hoofdstuk 5, § 3.3.2.

18 Hetgeen ook in de literatuur veelvuldig werd benadrukt. Zie onder anderen Mazur 1971, p. 62, Grzegorczyk 1980, p. 60 en Grzegorczyk 1988, p. 174. Grzegorczyk was van mening dat de mogelijkheid het persoonlijk overleg tussen raadsman en cliënt te verbieden alleen als 'laatste redmiddel' mocht worden ingezet wanneer een 'regelmatig verloop van de procedure' onvoldoende kon worden gegarandeerd door aanwezigheid van een toezichthouder bij het gesprek. Hiervan kon volgens Grzegorczyk slechts sprake zijn wanneer er een reëel gevaar bestond dat het contact zou worden misbruikt om het onderzoek te dwarsbomen of wanneer 'buitenprocedurele' factoren - zoals ziekte van de gedetineerde, een epidemie of opstand in de inrichting - aan het bezoek in de weg stonden. 
literatuur werd dan ook veel geklaagd over het feit dat art. 64 KPK 1969 niet in overeenstemming met de bedoeling van de wetgever werd toegepast. ${ }^{19}$

Dat toestemming voor overleg in de praktijk vaak werd geweigerd, wordt ook bevestigd door de in hoofdstuk 5 eerder genoemde praktijkonderzoeken die in de jaren zeventig zijn verricht naar de activiteiten van leden van de prokuratura en de advocatuur in het vooronderzoek. Overigens werd hierbij ook duidelijk dat veel advocaten niet eens de moeite namen om toestemming voor bezoek te vragen: tijdens het in 1970 verricht onderzoek gaf meer dan drie kwart van de ondervraagde leden van de prokuratura aan 'zeer zelden' dergelijke verzoeken van advocaten te ontvangen. ${ }^{20}$ De antwoorden van de respondenten uit de advocatuur bevestigden dit: bijna de helft gaf aan nooit toestemming te vragen om een cliënt te mogen bezoeken, $26 \%$ zei dat zelden te doen en een minderheid van $24 \%$ antwoordde dat deze actie altijd werd ondernomen in geval van een gedetineerde cliënt. Als belangrijkste redenen hiervoor werden opgegeven: het feit dat een dergelijke inspanning zinloos was $(63 \%$, niet duidelijk is waarom dit werd aangenomen) en dat de kans zeer klein was dat toestemming zou worden verleend $(15 \%)$.

Bijkomend probleem was dat het op grond van het oude wetboek van strafvordering niet duidelijk was of tegen beslissingen op grond van art. 64 lid 2 KPK 1969 nu wel of geen rechtsmiddel openstond. ${ }^{21}$ De onduidelijkheid op dit punt kwam ook tot uitdrukking in de praktijk: de ene keer werd het bezwaar in behandeling genomen en de andere keer werd het niet ontvankelijk verklaard omdat een dergelijk rechtsmiddel niet aan de wet zou kunnen worden ontleend. ${ }^{22}$

Bovengenoemde problematiek met betrekking tot het vrij verkeer die niet alleen betrekking had op het persoonlijk overleg maar ook de briefwisseling tussen raadsman en verdachte betrof, ${ }^{23}$ had vanzelfsprekend grote consequenties voor de mogelijkheden van de verdediging om een rol van betekenis te spelen in het voor-

19 Zie onder anderen Mazur 1971, p. 62-63, Afenda e.a. 1972, p. 51, Lewiński 1974, p. 28 en De Virion 1974, p. 35. Deze kritiek was om voor de hand liggende redenen grotendeels afkomstig uit de advocatuur maar ook leden van de prokuratura erkenden dat de wijze waarop art. 64 KPK 1969 in de praktijk werd toegepast te wensen overliet. Zie bijvoorbeeld de bijdrage van Prusak (prokurator) waarin hij benadrukt dat vervolgende instanties de neiging hebben de raadsman uit het vooronderzoek te weren: Prusak 1974, p. 18.

20 Zie over het praktijkonderzoek van 1970 en dat van 1977 en 1979: Grzegorczyk 1980, p. 178-180.

21 Aangezien dit voor wat betreft beslissingen ten aanzien van het vrij verkeer nergens expliciet was bepaald, kon de bevoegdheid alleen worden ontleend aan het algemene art. 268 KPK 1969 ('Gedurende het vooronderzoek kan door personen die geen partij zijn en wiens rechten zijn geschonden bezwaar worden aangetekend tegen beslissingen (postanowienia i zarzadzenia). Deze personen alsmede partijen kunnen eveneens bezwaar aantekenen tegen andere handelingen (czynności) die hun rechten schenden'). Deze bepaling was voor verschillende interpretaties vatbaar waardoor het de verdediging weinig houvast bood.

22 Wanneer het bezwaar tegen beslissingen over het vrij verkeer wel in behandeling werden genomen, duurde het vaak heel lang voordat een beslissing op dit rechtsmiddel werd genomen. Zie de door Afenda e.a. genoemde praktijkvoorbeelden waarbij sommige beslissingen op bezwaar pas na aanvang van het onderzoek ter terechtzitting aan de verdediging bekend werden gemaakt: Afenda e.a. 1972, p. 51-53.

23 Zie hierna $\S 3.1$. 
onderzoek. De prokurator kon de raadsman - door hem de toegang tot zijn cliënt te ontzeggen - zolang hij dat noodzakelijk achtte uit het vooronderzoek weren.

\section{Wijzigingen 1989}

De ernst van bovengenoemde problemen en de noodzaak tot wijziging ervan werd in 1989 door de wetgever erkend toen de regeling van het vrij verkeer - bij een van de eerste grootschalige wetswijzigingen die de strafrechtspleging diende aan te passen aan de nieuwe politieke situatie - werd veranderd. ${ }^{24}$ Art. 64 KPK 1969 werd op twee belangrijke punten gewijzigd:

1. de mogelijkheid toestemming te weigeren werd geschrapt: de enige resterende beperking op het persoonlijk overleg was de mogelijkheid het gesprek onder toezicht te laten plaatsvinden en

2. tegen de beslissing van de prokurator dat het gesprek tussen advocaat en cliënt onder toezicht diende plaats te vinden, kon bezwaar (zażalenie) worden ingesteld bij de rechtbank..$^{25}$

Hoewel met deze twee aanpassingen de positie van de verdediging aanzienlijk verbeterde, werd de regeling van het vrij verkeer een aantal jaren later - bij de totstandkoming van het huidige wetboek van strafvordering - opnieuw herzien.

\subsection{Huidig juridisch kader: stadium van politiedetentie}

Gedurende de vrijheidsberoving na aanhouding - de zogenaamde politiedetentie wordt het vrij verkeer beheerst door art. 245 lid 1 KPK 1997:

'De aangehoudene dient op zijn verzoek en op een wijze die de omstandigheden toelaten onmiddellijk in de gelegenheid te worden gesteld een advocaat te contacteren en rechtstreeks met hem overleg te voeren; degene die de aanhouding heeft verricht, kan bepalen dat hij bij dit overleg aanwezig zal zijn.'

Met de introductie van art. 245 KPK 1997 is een wettelijke grondslag gecreëerd voor effectuering van het recht op rechtsbijstand gedurende de politiedetentie. ${ }^{26}$ Aan eenieder die is aangehouden, komen in dit verband twee afzonderlijke rechten toe: ten eerste om onmiddellijk in de gelegenheid te worden gesteld een advocaat te raadplegen teneinde hem op de hoogte te stellen van de aanhouding en ten tweede om rechtstreeks met hem overleg te kunnen voeren. ${ }^{27}$ Hoewel het eerste contact met de advocaat niet noodzakelijk telefonisch maar ook via fax of zelfs email zou kunnen plaatsvinden, heeft art. 245 KPK 1997 voor het overige geen betrekking op schriftelijke communicatie met de advocaat.

24 Het gaat hier om de wetswijziging van 29 mei 1989 eerder genoemd in hoofdstuk 2, § 2.2.2.4.

25 De introductie van dit rechtsmiddel - dat werd opgenomen in een nieuw derde lid - was ongetwijfeld ingegeven door het verlangen de rechterlijke controle over het vooronderzoek te versterken. Zoals hierna nog zal blijken, was het echter geen lang leven beschoren.

26 Zoals eerder besproken, kende het wetboek van strafvordering van 1969 geen overeenkomstige bepaling waardoor onduidelijk was of een advocaat in dit vroege stadium van de procedure wel mocht optreden.

27 De politie dient de aangehoudene onmiddellijk op de hoogte te stellen van zijn recht een advocaat te contacteren (art. 244 lid 2 KPK 1997). 


\subsection{1. 'Rechtstreeks overleg'}

Wat precies onder 'rechtstreeks overleg' moet worden verstaan, is niet helemaal duidelijk. ${ }^{28}$ Belangrijkste vraag is of het hierbij slechts om een gesprek onder vier ogen gaat of dat de aangehoudene aan art. 245 lid 1 KPK 1997 ook het recht kan ontlenen om de zaak in een telefoongesprek met zijn advocaat inhoudelijk te bespreken. Laatstgenoemde ruime uitleg verdient de voorkeur. ${ }^{29}$ Dit heeft immers tot gevolg dat ook de aangehoudene wiens advocaat om welke reden dan ook niet op korte termijn naar het politiebureau kan komen - een situatie die vanwege het ontbreken van een piketdienst en de gemiddeld hoge werklast van de advocatuur zeker niet ondenkbaar is - toch juridisch advies kan krijgen. Daarmee wordt het meest recht gedaan aan de ratio van art. 245 lid 1 KPK 1997: verwezenlijking van het recht op rechtsbijstand in de eerste fase na aanhouding.

\subsubsection{Toezicht gedurende politiedetentie}

Dat persoonlijk overleg tussen advocaat en cliënt in dit vroege stadium van de procedure ook vertrouwelijk kan plaatsvinden is niet vanzelfsprekend: het orgaan dat de aanhouding heeft verricht - doorgaans de politie - heeft de bevoegdheid bij het gesprek aanwezig te zijn. ${ }^{30}$ De wetgever heeft geen voorwaarden verbonden aan deze voor de verdediging ingrijpende toezichtmogelijkheid: er hoeft dus geen sprake te zijn van bepaalde gronden zoals het vermoeden dat misbruik zal worden gemaakt van het vrij verkeer. Uit art. 245 KPK 1997 blijkt niet dat het toezicht slechts bij wijze van uitzondering mag worden toegepast. Wanneer de politie de aanwezigheid van een toezichthouder om welke reden dan ook noodzakelijk acht, kan de beslissing daartoe worden genomen zonder tussenkomst van prokurator of rechter en zonder dat daartegen een rechtsmiddel openstaat. ${ }^{31}$ Ook van belang is dat de toezichthouder zich in dezelfde ruimte en dus binnen gehoorafstand van het gesprek tussen advocaat en cliënt mag bevinden. ${ }^{32} \mathrm{Op}$ de gevolgen van dit

28 Zie hierover uitgebreider hoofdstuk 4, § 2.2.2.1.

29 Deze ruime uitleg van het begrip 'rechtstreeks overleg' wordt ook verdedigd in de Poolse literatuur: Ludwiczek 2003, p. 228 en Gwirdoyń 2004, p. 63.

30 Art. 245 lid 1 laatste zin KPK 1997. Een letterlijke interpretatie van 'degene die de aanhouding heeft verricht' zou betekenen dat alleen de specifieke persoon die bij de aanhouding betrokken was, bevoegd is bij het gesprek met de advocaat aanwezig te zijn. Aangezien dit (bijvoorbeeld vanwege wisselende diensten) in de praktijk tot problemen zou kunnen leiden, wordt ervan uitgegaan dat de wetgever hiermee niet doelt op een concreet persoon maar op het orgaan waarvan hij deel uitmaakt. Het toezicht mag dus door een collega worden uitgeoefend: Grzegorczyk 2004, p. 633. Gwirdoyń benadrukt dat het telkens slechts om één persoon mag gaan: Gwirdoyń 2004, p. 63.

31 Grzegorczyk 2004, p. 633.

32 In art. 245 lid 1 KPK 1997 is geregeld dat de toezichthouder 'aanwezig' kan zijn bij het gesprek. Door Gwirdoyń is de vraag gesteld of uit het gebruik van de term 'aanwezig' ('obecny') moet worden afgeleid dat de toezichthouder 'slechts' het recht heeft om het gesprek te aanschouwen (visueel toezicht) of dat hij ook de inhoud van het overleg moet kunnen volgen (auditief toezicht). Hij is van mening dat laatstgenoemde uitleg niet uit de door de wetgever gekozen bewoordingen blijkt: dan had gebruik van de term 'deelname' ('udziat': een werkwoord dat bijvoorbeeld wel in het kader van de bepalingen ten aanzien van onderzoekshandelingen in het vooronderzoek is gebruikt - zie art. 315 tot en met 318 KPK 1997) meer voor de hand gelegen. Ook Ludwiczek is van mening dat degene die als toezichthouder bij een gesprek tussen de aangehoudene en zijn advocaat 
auditief en visueel toezicht voor de verdediging en de vraag of dit verenigbaar is met de eisen van het EVRM zal hierna in § 2.6.3 worden teruggekomen.

Het CPT heeft zich in haar laatste twee landenrapporten over Polen kritisch uitgelaten over de toezichtmogelijkheid van art. 245 lid 1 KPK 1997. In 2000 werd hierover opgemerkt dat:

(...) to be fully effective as a means of preventing ill-treatment, the right of access to a lawyer must include the right to talk to him in private. Consequently, the CPT recommends that Section 245, paragraph 1, of the Code of Criminal Procedure be amended accordingly and that, pending such an amendment, an instruction be given to officials who apprehend suspects that they should not make use of the possibility to be present during meetings between detained persons and their lawyers'. 33

Omdat de Poolse regering tot op heden op dit punt geen actie heeft ondernomen, heeft het CPT genoemde kritiek herhaald in het rapport van 2004:

'In the report on the 2000 visit, the CPT stressed that, to be fully effective as a means of preventing ill-treatment, the right of access to a lawyer must include the right to talk to him in private, and recommended that Section 245, paragraph 1 of the Code of Criminal Procedure (which authorizes the officer who apprehended the detainee to be present during meetings with the lawyer) be amended accordingly. The Committee notes with concern that this recommendation has not yet been implemented. Admittedly, the information gathered during the 2004 visit indicates that police officers rarely make use of the power to be present when detainees meet their lawyers; however, the fact that such a possibility exists is unacceptable. Consequently, the CPT calls upon the Polish authorities to amend Section 245, paragraph 1, of the Code of Criminal Procedure so as to ensure that persons detained by the police have in all cases the right to talk to a lawyer in private. ${ }^{34}$

\subsection{Huidig juridisch kader: fase van voorlopige hechtenis}

Wanneer eenmaal voorlopige hechtenis is bevolen, geldt art. 73 KPK 1997 dat aan iedere voorlopige gehechte verdachte het recht toekent om - mondeling of schriftelijk - overleg te voeren met zijn raadsman. Bovendien is in deze bepaling geregeld wanneer en onder welke voorwaarden dit overleg kan worden beperkt. Art. 73 KPK 1997 luidt:

'1. De beschuldigde die zich in voorlopige hechtenis bevindt, mag in afwezigheid van anderen met zijn raadsman overleg voeren en met hem corresponderen.

aanwezig is aan de wet niet het recht kan ontlenen om ook de inhoud van de conversatie te kunnen volgen: Ludwiczek 2003, p. 229. Hoe wenselijk deze interpretatie vanuit het oogpunt van de verdediging ook moge zijn: feit blijft dat de wijze waarop het toezicht moet worden uitgeoefend niet wettelijk is gespecificeerd waardoor dus niet is uitgesloten dat de toezichthouder zich binnen gehoorafstand van het gesprek bevindt. Aan de uitleg van Gwirdoyń en Ludwiczek zou wel de conclusie kunnen worden verbonden dat een gesprek tussen advocaat en cliënt niet mag worden verboden op de enkele grond dat de toezichthouder - bijvoorbeeld vanwege de taal die wordt gesproken - de inhoud ervan niet zal kunnen volgen.

33 Report CPT 2000, p. 25.

34 Report CPT 2004, p. 15. De Poolse regering heeft in haar antwoord op dit rapport niet op deze kritiek gereageerd en (dus) ook niet aangegeven welke stappen zullen worden ondernomen om eraan tegemoet te komen. Het is dan ook niet waarschijnlijk dat er op korte termijn daadwerkelijk iets zal veranderen. 
2. In het vooronderzoek kan de prokurator die toestemming verleent voor dit overleg in uitzonderlijke gevallen bepalen dat hijzelf of een door hem aangewezen persoon daarbij aanwezig zal zijn.

3. De prokurator kan eveneens bepalen dat correspondentie tussen verdachte en raadsman wordt gecontroleerd.

4. De beperkingen genoemd in lid 2 en 3 mogen niet worden voortgezet of uitgevoerd na de eerste veertien dagen van de voorlopige hechtenis.'

Hoewel in het eerste lid alleen de 'beschuldigde'('oskarżony') wordt genoemd, komt het daar genoemde recht op gelijke wijze toe aan de verdachte (podejrzany) wiens strafzaak zich nog in de fase van het vooronderzoek bevindt. ${ }^{35}$ Uit dit eerste lid van art. 73 KPK 1997 blijkt dat de voorlopig gehechte verdachte het recht heeft met zijn raadsman overleg te voeren en te corresponderen.

Zoals eerder aangegeven, is voor de vraag onder welke voorwaarden een gedetineerde bezoek kan ontvangen niet alleen het wetboek van strafvordering maar ook het wetboek betreffende de tenuitvoerlegging van straffen relevant. In art. 215 KKW 199736 is het volgende bepaald:

'1. Degene die zich in voorlopige hechtenis bevindt, heeft het recht met zijn raadsman, gevolmachtigde advocaat of juridisch adviseur (radca prawny) in afwezigheid van andere personen overleg te voeren en met hem te corresponderen. Indien het orgaan, tot wiens beschikking de voorlopig gehechte staat, bepaalt dat hijzelf of een door hem aangewezen persoon bij dat overleg aanwezig zal zijn, vindt het bezoek plaats op de wijze zoals door dat orgaan bepaald.

2. Degene die zich in voorlopige hechtenis bevindt, dient de mogelijkheid te hebben zijn verdediging voor te bereiden'.

In deze bepaling is niet opgenomen onder welke voorwaarden en voor welke termijn het bezoek van de raadsman aan zijn voorlopig gehechte cliënt kan worden beperkt: hiervoor dient te allen tijde het meer specifieke art. $73 \mathrm{KPK}$ te worden geraadpleegd. ${ }^{37}$ Het bepaalde in het tweede lid van art. $215 \mathrm{KKW}$ is duidelijk ontleend aan art. 6 EVRM $^{38}$ maar of het daadwerkelijk enige meerwaarde biedt,

35 Bepalingen waarin de term 'beschuldigde' in algemene zin wordt gebruikt, gelden immers ook voor de verdachte (art. 71 lid 3 KPK 1997). Eerder is duidelijk geworden dat men in het Poolse strafproces op twee manieren de officiële status van verdachte kan verkrijgen: door middel van de uitreiking van een schriftelijke beslissing tot bekendmaking van de beschuldigingen of door in de hoedanigheid van verdachte (over betrokkenheid bij een bepaald strafbaar feit) te worden verhoord. De enkele aanhouding is in dit opzicht dus niet voldoende en totdat een van de twee bovengenoemde handelingen heeft plaatsgevonden, wordt formeel dan ook niet van een 'verdachte' maar van een 'aangehoudene' ('zatrzymany') of een 'verdachte persoon' ('osoba podejrzana') gesproken. Deze categorie personen kan aan art. 73 KPK 1997 dus geen rechten ontlenen: voor hen geldt de regeling van art. 245 KPK 1997. Zie hoofdstuk 2, § 3.1.3.1 en hoofdstuk 4, § 2.1.

36 Dat onderdeel uitmaakt van het hoofdstuk 'voorlopige hechtenis' en derhalve alleen betrekking heeft op gedetineerden die zich in voorlopige hechtenis bevinden.

37 Voor wat betreft het contact tussen raadsman en verdachte dient art. 215 KKW 1997 dus altijd in samenhang met art. 73 KPK 1997 te worden gelezen. Uitgangspunt behoort immers te zijn dat het vrij verkeer aan geen andere beperkingen kan worden onderworpen dan die zijn voorzien in het wetboek van strafvordering. Zie ook Hofmański e.a. 2007 I, p. 411.

38 Art. 6 lid 3 sub b EVRM garandeert eenieder tegen wie een vervolging is ingesteld 'het recht te beschikken over de tijd en faciliteiten die nodig zijn voor de voorbereiding van de verdediging'. 
is de vraag. Het is op zich mooi dat is vastgelegd dat eenieder die zich in voorlopige hechtenis bevindt de gelegenheid moet hebben zijn verdediging voor te bereiden maar wat dit concreet betekent, is niet uitgewerkt. ${ }^{39}$

Wanneer eenmaal een veroordeling is uitgesproken en een cliënt in het kader van een opgelegde vrijheidsstraf is gedetineerd, geldt de hoofdregel van art. 8 lid 3 eerste zin KKW 1997:

'Een veroordeelde die van zijn vrijheid is beroofd kan in afwezigheid van anderen overleg voeren met zijn raadsman, gevolmachtigde advocaat of juridisch adviseur (...).'

Uitzonderingen op deze regel zijn niet voorzien zodat ervan uit moet worden gegaan dat persoonlijk overleg tussen een advocaat en zijn veroordeelde cliënt nooit aan enig toezicht (of andere beperking) mag worden onderworpen.

\subsubsection{Toestemmingsvereiste}

De raadsman die een bezoek wil brengen aan zijn voorlopig gehechte cliënt dient daarvoor gedurende het vooronderzoek - net als onder het oude strafprocesrecht toestemming te krijgen van de prokurator. ${ }^{40}$ In tegenstelling tot de situatie voor 1989 kan toestemming voor het bezoek van de raadsman gedurende het vooronderzoek op grond van de huidige regeling niet meer worden geweigerd: het verzoek behoort niet meer dan een formaliteit te zijn. Aan de wijze waarop het verzoek moet worden ingediend, worden in de praktijk geen strenge eisen gesteld: het kan zowel mondeling als schriftelijk. ${ }^{41}$

Na sluiting van het vooronderzoek valt de gedetineerde niet langer onder de verantwoordelijkheid van de prokurator en moet aan de rechtbank toestemming worden gevraagd voor het bezoek aan een (nog niet veroordeelde) cliënt. ${ }^{42}$ De rechtbank kan een dergelijk verzoek nooit afwijzen en is ook niet bevoegd het bezoek van de raadsman nog aan enige beperking te onderwerpen.

In sommige gevallen heeft meer dan één justitieel orgaan zeggenschap over de voorlopig gehechte verdachte, bijvoorbeeld wanneer in verschillende strafzaken voorlopige hechtenis tegen hem is bevolen. Regel is dan dat de advocaat die zijn cliënt wenst te bezoeken aan elk orgaan (dat de leiding heeft in de betreffende strafzaak: prokurator of rechtbank) afzonderlijk toestemming moet vragen. ${ }^{43}$ Dit voorschrift wordt vanuit de advocatuur bekritiseerd. Volgens Gąsiorowska - advocate

39 Het wetboek van strafvordering bevat geen vergelijkbare bepaling en zoals eerder is vastgesteld, komt dit streven in ieder geval onvoldoende tot uitdrukking waar het gaat om de inzage van processtukken. Zie hoofdstuk 5, § 3 .

$40 \quad$ Art. 73 lid 2 KPK 1997.

41 De mondelinge toestemming kan zowel telefonisch als in persoon op het kantoor van de prokurator worden verleend. De advocaat dient de schriftelijk verleende toestemming mee te nemen wanneer hij zijn cliënt gaat bezoeken.

42 Zie ook Hofmański e.a. 2007 I, p. 411.

43 Deze verplichting is opgenomen in een verordening van de minister van Justitie inzake administratieve handelingen in verband met de tenuitvoerlegging van voorlopige hechtenis alsmede straffen en vrijheidsbenemende dwangmiddelen en de documentatie van deze handelingen, d.d. 13 januari 2004 (Rozporządzenie Ministra Sprawiedliwości w sprawie czynności administracyjnych związanych z wykonywaniem tymczasowego aresztowania oraz kar i środków przymusu skutkujących pozbawienie wolności oraz dokumemtowania tych czynności), art. 102 lid 1 sub 2. 
te Warschau - is het in de praktijk vaak moeilijk of zelfs onmogelijk om toestemming van alle betrokken organen te krijgen omdat de raadsman in veel gevallen niet over alle benodigde informatie beschikt. ${ }^{44}$ Bovendien kan het andere orgaan een prokurator of rechtbank zijn aan de andere kant van het land met alle praktische moeilijkheden van dien. ${ }^{45}$

\subsubsection{Toezicht gedurende voorlopige hechtenis}

Net als onder het oude strafprocesrecht kan de prokurator bepalen dat hijzelf of een door hem aangewezen persoon (bijvoorbeeld een politieagent) bij het gesprek tussen advocaat en cliënt aanwezig zal zijn. ${ }^{46}$ Uit het geheel van art. 73 KPK 1997 vloeit voort dat dit toezicht slechts onder bepaalde voorwaarden mag worden toegepast:

- er dient sprake te zijn van een 'uitzonderlijk geval' ('w szczególnie uzasadnionym wypadku'), ${ }^{47}$

- toezicht is slechts mogelijk gedurende de eerste veertien dagen van de voorlopige hechtenis ${ }^{48}$ en

- de beslissing het gesprek onder toezicht te laten plaatsvinden mag alleen worden genomen gedurende het vooronderzoek door de prokurator die toestemming voor het betreffende bezoek verleent. ${ }^{49}$

De eerste twee beperkingen zijn nieuw ten opzichte van het oude strafprocesrecht. Opvallend is bovendien dat de in 1989 geïntroduceerde mogelijkheid bij de rechtbank bezwaar aan te tekenen tegen de beslissing van de prokurator niet is behouden..$^{50}$

Indien de prokurator beslist dat toezicht op het persoonlijk overleg in een bepaalde zaak noodzakelijk is, worden raadsman, verdachte en de penitentiaire inrichting waar laatstgenoemde verblijft daarvan schriftelijk op de hoogte gesteld. ${ }^{51}$ Deze beslissing geldt in beginsel voor de gehele in art. 73 lid 4 KPK 1997 genoemde termijn zodat ieder bezoek van de advocaat gedurende de eerste twee weken van de voorlopige hechtenis alleen onder toezicht mag plaatsvinden. Net als bij het toezicht gedurende de politiedetentie ${ }^{52}$ bevindt de toezichthouder zich in een

44 Zo komt het volgens Gąsiorowska regelmatig voor dat in het dossier niet alle zaken staan vermeld waarin tegen de betreffende verdachte voorlopige hechtenis is bevolen.

45 Gąsiorowska is dan ook van mening dat met de verplichting een onnodige en onevenredige last op de schouders van de raadsman wordt gelegd die feitelijk een beperking van het recht op vrij verkeer tot gevolg heeft waarvoor art. 73 KPK 1997 geen wettelijke grondslag biedt: Gąsiorowska 2005.

46 Art. 73 lid 2 KPK 1997.

$47 \quad$ Art. 73 lid 2 KPK 1997.

48 Art. 73 lid 4 KPK 1997. De termijn van de voorlopige hechtenis wordt berekend vanaf de dag van aanhouding (art. 265 KPK 1997).

49 Bevoegd is de prokurator die de leiding heeft over de strafzaak.

50 Op de inhoud en betekenis van deze wijzigingen wordt teruggekomen in § 2.4.

51 Voorlopige hechtenis wordt in de regel doorgebracht in een speciaal daarvoor ingerichte penitentiaire inrichting genaamd areszt śledczy. Zoals onder meer uit rapporten van het CPT blijkt, bestaat de populatie van zo'n huis van bewaring soms ook voor een aanzienlijk deel uit veroordeelde gedetineerden: Report CPT 2004, p. 35 en 40.

52 Op grond van art. 245 KPK 1997. Zie § 2.2.2. 
dergelijk geval in dezelfde ruimte als de advocaat en zijn cliënt zodat de inhoud van het gesprek in beginsel door hem kan worden gevolgd. ${ }^{53}$

Voor het tijdstip en de duur van het bezoek, geldt dat de advocaat zijn cliënt in beginsel alleen kan bezoeken gedurende de officiële 'openingstijden' van de penitentiaire inrichting. Met toestemming van de directeur van de betreffende inrichting kan van deze regel worden afgeweken en het bezoek op een ander tijdstip plaatsvinden. ${ }^{54}$ Duur en frequentie van het bezoek van de advocaat zijn in beginsel onbeperkt. ${ }^{55}$

\subsection{Evaluatie juridisch kader}

Wat het vrij verkeer gedurende de politiedetentie betreft, dient in ieder geval als een vooruitgang te worden beschouwd dat in het huidige strafprocesrecht is vastgelegd dat in dit stadium recht op contact met een advocaat bestaat en dat de aangehoudene van dit recht op de hoogte moet worden gesteld.56 Minder gunstig voor de verdediging is dat de mogelijkheid toezicht uit te oefenen op het overleg aan geen enkele beperking is verbonden en bovendien tegen deze beslissing geen rechtsmiddel is opengesteld. Het staat de politie volledig vrij bij ieder gesprek dat gedurende de politiedetentie tussen advocaat en cliënt plaatsvindt binnen gehoorafstand aanwezig te zijn waardoor het contact in deze uiterst belangrijke fase van de procedure aanzienlijk kan worden beperkt. ${ }^{57}$

Voor het vrij verkeer gedurende de voorlopige hechtenis is positief is dat het sinds 1989 niet meer mogelijk is het contact tussen raadsman en cliënt volledig te verbieden: in het verleden werd op grote schaal misbruik gemaakt van deze (vrijwel ongeclausuleerde) mogelijkheid en er mag van uit worden gegaan dat wanneer er omstandigheden zijn die een verbod zouden kunnen rechtvaardigen - zoals het vermoeden dat het vrij verkeer wordt misbruikt om de waarheidsvinding te belemmeren - in de regel ook zal kunnen worden volstaan met het uitoefenen van toezicht op het overleg.

Sinds de inwerkingtreding van het nieuwe wetboek van strafvordering is wettelijk vastgelegd dat de beslissing persoonlijk overleg onder toezicht te laten plaatsvinden alleen mogelijk is 'in uitzonderlijke gevallen' ('w szczególnie uzasadnionym wypadku'). Hoewel vaststaat dat de wetgever hiermee het uitzonderlijke karakter van genoemde beperking van het vrij verkeer heeft willen benadrukken, zijn de gebruikte bewoordingen zodanig vaag dat het zeer de vraag is of ze daadwerkelijk enige toegevoegde waarde hebben. Noch in art. 73 KPK 1997 noch op enige andere plaats in het wetboek van strafvordering is uitgewerkt welke concrete omstandig-

53 Of deze vorm van toezicht verenigbaar is met het EVRM komt aan de orde in § 2.6.3.

54 Art. 102 lid 3 van eerder genoemde verordening van de minister van Justitie inzake administratieve handelingen in verband met de tenuitvoerlegging van voorlopige hechtenis alsmede straffen en vrijheidsbenemende dwangmiddelen en de documentatie van deze handelingen, d.d. 13 januari 2004.

55 Art. 23 lid 1 en 4 van een verordening van de minister van Justitie inzake de regeling van de tenuitvoerlegging van voorlopige hechtenis, d.d. 25 augustus 2003 (Rozporzadzenie Ministra Sprawiedliwości w sprawie regulaminu organizacyjno-porzàdkowego wykonywania tymczasowego aresztowania). De algemene regel dat bezoek maximaal 60 minuten mag duren, geldt niet voor het bezoek van de raadsman.

$56 \quad$ Nieuw art. 245 en art. 244 lid 2 KPK 1997.

57 De praktijk komt aan de orde in $\S 2.5$. 
heden kunnen rechtvaardigen dat een raadsman zijn cliënt alleen onder toezicht mag spreken: gaat het daarbij alleen om bescherming van de advocaat en de veiligheid binnen een penitentiaire inrichting of mag het toezicht ook worden ingezet om de inhoud van een gesprek te controleren wanneer bijvoorbeeld vermoedens bestaan dat het vrij verkeer zal worden misbruikt om de opsporing te belemmeren? De rechtspraak over art. 73 KPK 1997 is schaars en er zijn geen rechterlijke uitspraken waarin invulling wordt gegeven aan de woorden 'in uitzonderlijke gevallen' ${ }^{58}$

Dat het gebruik van dit soort vage termen bepaalde risico's met zich brengt is meer dan eens gesignaleerd in de Poolse literatuur. Zo heeft Kruszyński erop gewezen dat het ontbreken van (heldere) wettelijke criteria voor de toepassing van supervisie op persoonlijk overleg tussen raadsman en verdachte in de praktijk een 'gevaarlijke vrijheid' oplevert. Volgens hem dient elke beperking op het vrij verkeer - vanwege de enorme impact die het heeft op de verdediging - als 'absolute uitzondering op de regel' te worden beschouwd en alleen plaats te vinden wanneer bijzondere omstandigheden dat noodzakelijk maken. ${ }^{59}$

De toevoeging 'in uitzonderlijke gevallen' verplicht de prokurator overigens wel zijn beslissing te motiveren: hij behoort aan te geven welke omstandigheden toezicht in een concreet geval noodzakelijk maken. In de praktijk stelt deze motivering echter weinig voor: in de regel wordt volstaan met de inhoud van de wettelijke bepaling die de beperking mogelijk maakt (art. 73 lid 2 KPK 1997) en een standaardformulering dat toezicht in het belang van het vooronderzoek noodzakelijk is. De tweede nuancering die de regeling van het vrij verkeer in het nieuwe wetboek van strafvordering heeft ondergaan, is dat het toezicht op het overleg tussen raadsman en verdachte alleen nog maar kan worden opgelegd gedurende de eerste veertien dagen van de voorlopige hechtenis. Deze veertien dagen termijn - in het verleden meer dan eens voorgesteld in de literatuur ${ }^{60}$ - dient als een belangrijke verbetering te worden beschouwd. Door gezaghebbende Poolse auteurs wordt zelfs verdedigd dat de regeling van het vrij verkeer door deze temporele beperking volledig in overeenstemming is met de Straatsburgse norm. ${ }^{61}$

58 Informatie verkregen van Wąsek-Wiaderek en Gwirdoyń, juni 2008.

59 Kruszyński 1991, p. 155. Zie ook Kruszyński 1993, p. 376 waar hij over het criterium 'uitzonderlijk geval' - dat destijds nog slechts in voorstellen tot wijziging van het strafprocesrecht was opgenomen - zegt dat de door de wetgever gekozen bewoordingen 'niet scherp en onduidelijk' zijn: hij wijst er op dat voor de ene prokurator al sprake kan zijn van een uitzonderlijk geval wanneer een verdachte zegt onschuldig te zijn en voor de ander (pas) wanneer er daadwerkelijk gevaar voor collusie bestaat. Hij formuleert drie criteria waar beperkingen op het vrij verkeer te allen tijde aan zouden moeten voldoen: 1. doelmatigheid (przydatnośc, letterlijk: bruikbaarheid): de beperking dient bij te dragen aan het realiseren van de doelstellingen van het strafproces; 2. noodzakelijkheid of subsidiariteit (koniecznośc): vast dient te staan dat minder vergaande maatregelen niet toereikend zijn en 3. proportionaliteit (proporcjonalności): de beperking dient in verhouding te staan tot de graad van verdenking, de ernst van de zaak, de te verwachten straf et cetera. Zie Kruszyński 1989, p. 77. De nuancering die Kruszyński hiermee beoogt aan te brengen, is duidelijk. Hij werkt echter niet uit hoe deze - eveneens tamelijk vage criteria - in de wettelijke regeling van het vrij verkeer verwerkt zouden kunnen worden waardoor de praktische waarde van zijn suggesties beperkt blijft.

60 Zie bijvoorbeeld Kruszyński 1991, p. 164.

61 Hofmański 1997, p. 45-46 Hofmański e.a. 2004, p. 380, Hofmański e.a. 2007 I, p. 410. 
Tegen de beslissing het gesprek onder toezicht te laten plaatsvinden kan op grond van het huidige strafprocesrecht geen bezwaar meer worden ingesteld: het rechtsmiddel dat in 1989 werd geïntroduceerd, is in het nieuwe wetboek van strafvordering niet behouden. De wetgever is er blijkbaar van uitgegaan dat behoud van de bezwaarmogelijkheid niet langer zinvol was omdat toezicht op grond van de nieuwe regeling alleen gedurende de eerste veertien dagen mogelijk is. ${ }^{62}$ Het schrappen van dit rechtsmiddel heeft overigens niet tot veel ophef geleid in de literatuur. ${ }^{63}$ Toch valt mijns inziens niet in te zien waarom de mogelijkheid een rechtsmiddel in te stellen tegen de beslissing van de prokurator door de 14-dagen regel overbodig of zinloos zou zijn geworden. Gezien de ruime beoordelingsvrijheid die de vage formulering van art. 73 KPK 1997 de prokurator biedt en de vergaande gevolgen die het toezicht voor de verdediging heeft, zou rechterlijke controle op deze beslissing zeker zinvol zijn. Rechterlijke toetsing zou de prokurator aansporen zijn beslissing goed te overdenken en te motiveren en bovendien meer duidelijkheid kunnen verschaffen over de concrete omstandigheden die toezicht (al dan niet) kunnen rechtvaardigen. ${ }^{64}$ Dat het toezicht alleen gedurende de eerste veertien dagen van de voorlopige hechtenis mogelijk is, doet hier niets aan af: het gaat immers om een essentieel stadium van de procedure waardoor de beperking grote gevolgen kan hebben voor de verdediging en het aanvechten ervan dus juist wenselijk en zinvol kan zijn. Het mogelijke argument dat de beperking al zal zijn opgeheven voordat op het bezwaar is beslist, zou eenvoudig kunnen worden ondervangen door de behandeling van het rechtsmiddel aan een korte termijn te verbinden. ${ }^{65}$

\subsection{Persoonlijk overleg in de praktijk}

\subsubsection{Gedurende politiedetentie}

Het komt in de eerste fase na aanhouding zelden voor dat aangehoudenen bezoek ontvangen van een advocaat. Voornaamste reden voor deze praktijk is het feit dat in dit stadium van de procedure nog geen recht op kosteloze rechtsbijstand bestaat. Hierdoor is effectuering van de in art. 245 lid 1 KPK genoemde rechten voorbehouden aan een selecte groep verdachten die de kosten van een advocaat

Hofmański baseert deze conclusie op de overtuiging dat dit soort beperkingen op het vrij verkeer volgens het EHRM zijn toegestaan zolang ze slechts tijdelijk en in de beginfase van het vooronderzoek kunnen worden toegepast. Over de Straatsburgse rechtspraak § 2.6.3.

62 Zo wordt ook aangenomen in de literatuur. Zie bijvoorbeeld Czekaj 1998, p. 44 en Kulesza 2005, p. 405.

63 Zo heeft Grzegorczyk hierover opgemerkt dat indien moet worden gekozen tussen enerzijds behoud van de bezwaarmogelijkheid gecombineerd met de regel dat toezicht voor de duur van vrijwel het gehele vooronderzoek mogelijk is en anderzijds de regel dat de beperking op het vrij verkeer alleen gedurende de eerste veertien dagen van de voorlopige hechtenis mogelijk is, laatstgenoemde optie - waarvoor de wetgever heeft gekozen - duidelijk de voorkeur verdient: Grzegorczyk 2004, p. 264.

65 Het spreekt bovendien voor zich dat een beslissing naar aanleiding van een dergelijk bezwaar sowieso binnen (zeer) korte termijn zou moeten worden genomen om niet als mosterd na de maaltijd te komen. Ook Kruszyński is er in het verleden van uitgegaan dat de temporele beperking van het toezicht op het vrij verkeer de behoefte aan een rechtsmiddel niet noodzakelijk doet verdwijnen: Kruszyński 1991, p. 164. 
zelf kunnen dragen. Bovendien kennen de meeste verdachten geen advocaat en heeft de politie geen enkele verplichting behulpzaam te zijn op dit punt: er zijn op politiebureaus geen advocatenlijsten beschikbaar en als de aangehoudene niet ten minste een achternaam kan noemen, wordt hij niet in de gelegenheid gesteld te bellen. Verder blijkt doorgaans te worden meegedeeld dat men recht heeft op slechts één telefoontje en wordt er meestal de voorkeur aan gegeven deze mogelijkheid te benutten om een familielid te bellen. ${ }^{66}$ Omdat advocaten zelden cliënten bezoeken in de fase van politiedetentie heeft de toezichtmogelijkheid genoemd in art. 245 lid 1 KPK 1997 in kwantitatief opzicht slechts een zeer beperkte betekenis. In het (tamelijk zeldzame) geval dat een advocaat wel een bezoek brengt aan zijn cliënt in de eerste fase na aanhouding is het overigens eerder regel dan uitzondering dat de politie bepaalt 'in het belang van het onderzoek' bij het gesprek aanwezig te willen zijn. ${ }^{67}$ Dit roept de vraag op of behalve eerder genoemde factoren ook de onmogelijkheid om vertrouwelijk overleg te voeren van invloed is op de mate waarin advocaten actief zijn gedurende de politiedetentie: er wordt weinig gebruik gemaakt van de toezichtmogelijkheid omdat advocaten wegblijven maar het is niet uitgesloten dat dit wegblijven mede een gevolg is van het feit dat overleg in dit stadium slechts mogelijk is in aanwezigheid van de politie. Deze vicieuze cirkel speelt in ieder geval een belangrijke rol in de eerste fase van de voorlopige hechtenis. ${ }^{68}$

\subsubsection{Gedurende voorlopige hechtenis}

Uit gesprekken met advocaten is gebleken dat de advocatuur over het algemeen weinig problemen ervaart bij het bezoeken van gedetineerde cliënten. Vrijwel alle advocaten met wie in Warschau, Poznań en Lublin is gesproken gaven aan altijd toestemming te krijgen voor het bezoek aan een voorlopig gehechte cliënt en laatstgenoemde doorgaans onder gunstige omstandigheden te kunnen spreken. Een enkeling was minder positief: een advocate uit Poznań merkte op dat het wel voorkomt dat de prokurator zegt geen tijd te hebben om de advocaat bij het bezoek te vergezellen. Hierdoor kan de beslissing dat overleg alleen onder toezicht mag plaatsvinden er feitelijk op neer komen dat de advocaat gedurende de eerste veertien dagen van de voorlopige hechtenis geen toegang heeft tot zijn cliënt. Van deze praktijk wordt ook melding gemaakt in de literatuur. ${ }^{69}$ Hoewel niet duidelijk is op welke schaal deze problemen zich voordoen, staat vast dat ze tot gevolg kunnen hebben dat een advocaat feitelijk nog steeds voor bepaalde tijd de toegang tot zijn gedetineerde cliënt wordt ontzegd. Een dergelijke gang van zaken is in strijd met de ratio van de wettelijke regeling van het vrij verkeer op grond waarvan het

66 Zie hierover hoofdstuk $4, \S 2.4$.

67 Daniuk e.a. 2006, p. 25.

68 Zie hierna § 2.6.1.

69 Gąsiorowska geeft aan dat het vaak moeilijk is de prokurator die de leiding heeft over de betreffende strafzaak te pakken te krijgen. Bovendien stelt zij - net als de advocate in Poznań - dat de beslissing dat het bezoek alleen onder toezicht mag plaatsvinden feitelijk een (tijdelijk) verbod op toegang tot de verdachte kan betekenen omdat het regelmatig voorkomt dat de prokurator de eerstkomende dagen geen tijd heeft om met de advocaat mee te gaan naar de plaats van detentie. In zo'n geval zit er voor de advocaat niets anders op dan te wachten tot de prokurator - of de door hem aangewezen toezichthouder - tijd heeft en bereid is om een bezoek te brengen aan de betreffende verdachte: Gąsiorowska 2005. 
sinds 1989 niet langer is toegestaan het persoonlijk contact tussen raadsman en verdachte te verbieden.

Het komt in de praktijk niet heel vaak voor dat een gesprek tussen advocaat en cliënt gedurende de eerste veertien dagen van de voorlopige hechtenis onder toezicht plaatsvindt. ${ }^{70}$ Wanneer het gebeurt, gaat het meestal om grote, ingewikkelde strafzaken waarin zware feiten als georganiseerde criminaliteit, corruptie, of terrorisme centraal staan. Dat van de toezichtmogelijkheid relatief weinig gebruik wordt gemaakt, is ook een gevolg van het feit dat veel advocaten ervoor kiezen het eerste bezoek aan hun cliënt te plannen ná de eerste veertien dagen van de voorlopige hechtenis zodat vertrouwelijk overleg gegarandeerd is. ${ }^{71}$ Een strategie die weliswaar kan voorkomen dat in een niet-vertrouwelijke sfeer overleg moet worden gevoerd maar waarvoor de verdediging wel een hoge prijs betaalt. ${ }^{72}$

Uit het voorgaande mag overigens niet worden afgeleid dat het bepaalde in art. 73 lid 2 KPK 1997 een dode letter is. Het gebeurt wel degelijk met enige regelmaat dat de prokurator gebruik maakt van zijn bevoegdheid het vrij verkeer te beperken. ${ }^{73}$

Tegen de beslissing van de prokurator toezicht uit te oefenen op het overleg tussen advocaat en cliënt kan door de verdediging weliswaar geen bezwaar worden ingesteld maar het is wel mogelijk hiertegen een klacht (skarga) in te dienen. ${ }^{74}$ Dat van deze mogelijkheid zelden tot nooit gebruik wordt gemaakt, is gelet op het voorgaande niet verrassend. Een advocate uit Poznań merkte in dit verband bovendien op dat het indienen van een klacht sowieso zinloos is omdat het toezicht tegen de tijd dat de hogere prokurator een beslissing heeft genomen allang weer is opgeheven. Anderen gaven aan van deze mogelijkheid geen gebruik te maken om de prokurator niet te zeer tegen zich in het harnas te jagen. ${ }^{75}$

\subsection{Toezicht op overleg: schending recht op verdediging?}

De wijze waarop in het kader van art. 245 en art. 73 KPK 1997 toezicht kan worden uitgeoefend op het overleg tussen advocaat en verdachte doet de vraag rijzen of

70 Depa 2004, p. 44.

71 Deze praktijk word ook gesignaleerd door Kruszyński 2007 I, p. 195: 'Defence lawyers seldom agree to such a restriction [the supervision, toev. DdV] and will often wait until the first 14 day period has expired, advising their client to refuse to provide an explanation in the meantime'. Zie ook Daniuk 2006, p. 38.

72 Hierop wordt teruggekomen in $\$ 2.6$.

73 Daniuk 2006, p. 38. Verschillende advocaten die ik Lublin, Poznań en Warschau heb gesproken, hadden in één of meer zaken meegemaakt dat de prokurator bij overleg met een cliënt aanwezig was. Logischerwijze zal de frequentie van het toezicht bij meer ervaren strafpleiters die in relatief veel zware strafzaken optreden gemiddeld hoger zijn dan bij advocaten die zich op kleinere schaal met het strafrecht bezig houden.

74 Deze mogelijkheid staat open tegen iedere beslissing of gedraging van de prokurator: art. 295 e.v. van de verordening inzake de interne organisatie van de prokuratura d.d. 27 augustus 2007 (Rozporządzenie Ministra Sprawiedliwości regulamin wewnętrznego urzędowania powszechnych jednostek organizacyjnych prokuratury).

75 Laatstgenoemd argument wordt overigens vaker en in verschillende contexten gebruikt. Veel advocaten lijken zich erbij neer te leggen dat de prokurator nog altijd heer en meester is over het vooronderzoek - in de woorden van een advocate uit Lublin: 'during preliminary investigation the prokurator is like God' - en stemmen hun eigen optreden in deze fase van de procedure daar blijkbaar op af. 
het recht op verdediging door de huidige regeling en de daarop gebaseerde praktijk niet onevenredig wordt geschaad. In dit verband is enerzijds vooral problematisch dat de huidige wetgeving niet duidelijk omschrijft op welke grond(en) het vrij verkeer kan worden beperkt en anderzijds dat de toezichthouder zich binnen gehoorafstand van het gesprek tussen raadsman en cliënt kan bevinden. Bij dit laatste punt zal hier wat langer worden stilgestaan.

Het spreekt voor zich dat het feit dat een derde paar oren de inhoud van het gesprek kan volgen, betekent dat de verdachte zich niet in alle vrijheid kan uiten en bij alles wat hij zegt rekening moet houden met het feit dat de betreffende informatie - in het verdere verloop van zijn strafzaak of tijdens zijn detentie - tegen hem kan worden gebruikt. Dit maakt een inhoudelijke bespreking van de zaak onmogelijk waardoor de raadsman wordt gehinderd in het vervullen van zijn taak. Bijvoorbeeld het bespreken van een verdedigingsstrategie (zoals de keuze tussen zwijgen of bekennen) of het voorbereiden van een klacht over de behandeling door opsporingsorganen is in de aanwezigheid van een vertegenwoordiger van 'de tegenpartij' zo goed als onmogelijk.

Hierbij dient te worden benadrukt dat het voor de vraag of een gesprek in vertrouwen kan plaatsvinden in beginsel niet relevant is of de toezichthouder daadwerkelijk meeluistert en of hij zich op enigerlei wijze mag mengen in het gesprek. In de Poolse literatuur wordt aangevoerd dat de toezichthouder (zowel in het kader van het toezicht gedurende de politiedetentie als gedurende de voorlopige hechtenis) slechts het recht heeft het gesprek te observeren en zich niet mag bemoeien met datgene wat wordt besproken. Hij zou bijvoorbeeld niet het recht hebben te verbieden dat bepaalde onderwerpen worden aangesneden. ${ }^{76} \mathrm{Nog}$ afgezien van de vraag of deze uitleg ook in de praktijk wordt gehanteerd, levert het de verdediging weinig op: zolang een toezichthouder zich binnen gehoorafstand bevindt en dientengevolge in staat is de inhoud van het gesprek te volgen, tast zijn aanwezigheid per definitie de vertrouwelijkheid van het gesprek en daarmee ook van de advocaat-cliënt relatie in de kern aan. ${ }^{77}$ Ook het feit dat in de Poolse rechtspraak is benadrukt dat degene die op grond van art. 73 lid 2 KPK 1997 toezicht heeft gehouden op een gesprek tussen raadsman en verdachte niet als getuige mag worden gehoord over datgene wat hij tijdens dat gesprek heeft vernomen, biedt in dit verband nauwelijks enige bescherming. ${ }^{78}$ Dit vormt immers geen enkele garantie

76 Volgens Łyczywek dient dit te worden afgeleid uit het feit dat de wetgever slechts heeft geregeld dat de toezichthouder bij het gesprek aanwezig mag zijn (passief) en niet dat hij daaraan mag deelnemen (actief): Łyczywek 1989, p. 55. De auteur doelde hierbij op art. 64 KPK 1969 maar aangezien in art. 73 en art. 245 lid 1 KPK 1997 ook slechts over 'aanwezigheid' ('obećności') bij het overleg wordt gesproken, gelden zijn opmerkingen onverkort voor de huidige regeling van (toezicht op) het vrij verkeer.

77 Ook het EHRM gaat ervan uit dat de gerechtvaardigde vrees dat er wordt afgeluisterd onder omstandigheden een ontoelaatbare inbreuk op de vertrouwelijkheid tussen advocaat en cliënt kan betekenen. Zie Castravet t. Moldavië, EHRM 13-3-2007, nr. 23393/05, hierna genoemd in $\S 2.6 .3$.

78 In november 1993 hield de hoger beroepsinstantie (SA) van Krakau het oordeel van de lagere rechter in stand die had geweigerd een door de prokurator aangewezen toezichthouder als getuige te horen over datgene wat er tijdens het overleg was besproken. Volgens de appelrechter was in eerste aanleg terecht geoordeeld dat een dergelijke bewijsvoering een schending van het recht op verdediging en het verschoningsrecht van 
dat de informatie die tijdens het overleg tussen cliënt en advocaat is opgevangen niet op andere - voor de verdediging minder zichtbare - wijze door opsporende of vervolgende instanties in de betreffende strafzaak zal worden gebruikt. ${ }^{79}$

In het onderstaande zal eerst aandacht worden besteed aan de vraag hoe binnen de advocatuur over deze problematiek wordt gedacht. Daarna zal een uitspraak van het Grondwettelijk Hof worden besproken waarin antwoord is gegeven op de vraag of het in art. 73 lid 2 KPK 1997 geregelde toezicht een inbreuk op het grondwettelijk gegarandeerde recht op verdediging vormt. Ten slotte zal de kwestie in het licht van het EVRM worden geplaatst en aan de hand van Straatsburgse rechtspraak worden bekeken hoe genoemd toezicht zich verhoudt tot de eisen van art. 6 en 8 van het verdrag.

\subsubsection{Standpunt advocatuur}

De binnen de advocatuur heersende opvattingen over het mogelijke toezicht op het persoonlijk overleg zijn uiterst mild. ${ }^{80}$ Het wordt over het algemeen niet als problematisch beschouwd omdat het slechts in uitzonderlijke gevallen wordt toegepast en bovendien een tijdelijk karakter heeft. ${ }^{81}$ Een bekende strafpleiter uit Warschau gaf bovendien aan in de praktijk vaak mee te maken dat de toezichthouder gedurende het overleg vaak voor korte tijd de ruimte verlaat zodat er 'altijd wel een paar minuten zijn om in alle vrijheid over de zaak te spreken'.

Het milde standpunt van de advocatuur in deze kwestie lijkt - zoals ten aanzien van meer punten waarop de mogelijkheden van de verdediging in het vooronderzoek aanzienlijk wordt beperkt ${ }^{82}$ - onlosmakelijk te zijn verbonden met de

de raadsman opleverde: uitspraak van 25 november 1993, SA Krakau, KZS 11994, nr. 1,30, genoemd in: Kwiatkowski 2005, p. 169.

79 De informatie kan bijvoorbeeld aanleiding zijn om het onderzoek in een bepaalde richting voort te zetten.

80 Het gaat in deze paragraaf hoofdzakelijk om het toezicht in het kader van art. 73 KPK 1997 omdat - zoals hiervoor is besproken - het eerste contact tussen raadsman en cliënt meestal in dit stadium plaatsvindt.

81 Ook in de literatuur worden weinig woorden vuil gemaakt aan de toezichtmogelijkheid en de gevolgen die het kan hebben voor de vertrouwelijkheid van het gesprek en de relatie tussen advocaat en cliënt. Sommige auteurs wijzen en passant wel op de negatieve consequenties van een dergelijke beperking en mogelijke onverenigbaarheid met het EVRM - zoals Grzegorczyk 1980, p. 175 en 178 en Kruszyński 2007 I, p. 195: 'Even though this [supervision, toev. DdV] contravenes European Court of Human Rights jurisprudence, it constitutes Polish law and it cannot be appealed' - maar het is geen thema waar op grote schaal aandacht aan wordt besteed. Zie ook Wiliński die met enige voorzichtigheid vaststelt dat het toezicht op het vrij verkeer gedurende de eerste veertien dagen van de voorlopige hechtenis 'twijfelachtig' is en dat bij eventuele toekomstige hervormingen van het strafprocesrecht zal moeten worden bekeken of het niet een te vergaande beperking oplevert: Wiliński 2006, p. 517-518. Hofmański is van mening dat uit het feit dat het toezicht op grond van art. 73 KPK 1997 slechts voor beperkte duur kan plaatsvinden, mag worden afgeleid dat de regeling voldoet aan de Straatsburgse norm. Ter ondersteuning van dit standpunt verwijst hij (onder andere) naar de uitspraak in de zaak S. t. Zwitserland - zie hierna § 2.6.3.2 - waaruit volgens hem voortvloeit dat dit soort beperkingen zijn toegestaan zolang ze slechts in de beginfase van het vooronderzoek worden toegepast: Hofmański 1997, p. 45-46 en Hofmański e.a. 2004, p. 380.

82 Denk aan de in de praktijk uiterst beperkte mogelijkheden van raadsman en verdachte 
binnen de beroepsgroep heersende opvattingen over (de noodzaak van actieve) verdediging in het vooronderzoek. De raadsman neemt in de gemiddelde strafzaak gedurende het vooronderzoek om verschillende redenen een tamelijk passieve houding in: het 'echte werk' begint voor de verdediging pas wanneer de akte van beschuldiging is ingediend en de zaak voor de rechter komt. ${ }^{83}$ Vanuit deze optiek is natuurlijk eenvoudig te verklaren dat het toezicht op het vrij verkeer gedurende de eerste veertien dagen van de voorlopige hechtenis door de meeste advocaten niet bezwaarlijk wordt gevonden. Veel advocaten kiezen ervoor hun cliënten pas na verloop van de eerste veertien dagen te bezoeken. ${ }^{84}$ Wanneer een eerste bezoek wel onder toezicht plaatsvindt, wordt dit opgelost door tijdens dit gesprek slechts persoonsgegevens uit te wisselen en nog niet inhoudelijk op de zaak in te gaan. ${ }^{85}$ Dit laat zien dat advocaten het toezicht an sich wel degelijk als beletsel voor een vertrouwelijk gesprek met de cliënt beschouwen. ${ }^{86}$ Maar omdat het slechts tijdelijk kan worden toegepast in een fase van de procedure die volgens de heersende opvatting niet van groot belang is voor de verdediging lijken de meeste advocaten zich er goed mee te kunnen verenigen en hun werkwijze er op aan te passen.

\subsubsection{Standpunt Grondwettelijk Hof}

In 2004 heeft het Grondwettelijk Hof zich gebogen over de vraag of de toezichtmogelijkheid van art. 73 lid 2 KPK 1997 verenigbaar is met de Grondwet. ${ }^{87}$ Aanleiding hiervoor was een klacht van ene Rutkowski jegens wie gedurende een deel van zijn strafzaak overeenkomstig art. 73 lid 2 KPK 1997 was bepaald dat de gesprekken met zijn raadsman alleen onder toezicht van een derde konden plaatsvinden. De klacht bestond uit twee delen. In de eerste plaats werd aangevoerd dat het genoemde toezicht een schending van het grondwettelijk gegarandeerde recht op verdediging opleverde. De motivering van dit deel van de klacht was gebaseerd op het gegeven dat het recht op verdediging - neergelegd in art. 42 lid 2 van de Grondwet - alleen in overeenstemming met art. 31 lid 3 van de Grondwet beperkt mag worden hetgeen inhoudt dat de beperking in een democratische samenleving noodzakelijk dient te zijn in het belang van veiligheid of openbare orde. ${ }^{8}$ Volgens klager kon van een dergelijke noodzaak bij bezoek van advocaten

om gedurende het vooronderzoek inzage te krijgen in de processtukken. Zie daarover hoofdstuk $5, \S 3$.

83 Zie hoofdstuk 4 en 5.

84 Zie hiervoor $§ 2.5$.

85 Bron: gesprek Kruszysńki, Warschau januari 2007. Meestal zal de verdachte dan worden geadviseerd zolang van zijn zwijgrecht gebruik te maken.

86 Kruszyński 2007 I, p. 195. Een advocate uit Lublin merkte op vanwege de mogelijke beperking van art. 73 lid 2 KPK 1997 cliënten nooit gedurende de eerste twee weken van de voorlopige hechtenis te bezoeken omdat het volgens haar geen enkel nut heeft een zaak te bespreken in de aanwezigheid van een prokurator of politieagent.

87 Uitspraak van 17 februari 2004 (SK 39/02).

88 Op grond van art. 31 lid 3 Grondwet kunnen constitutionele rechten en vrijheden slechts worden beperkt voor zover bij de wet voorzien en noodzakelijk in een democratische samenleving in het belang van de veiligheid of openbare orde of ter bescherming van het milieu, de gezondheid, de goede zeden of de rechten en vrijheden van anderen. Deze beperkingsystematiek komt vrijwel letterlijk overeen met die van art. 8 lid 2 EVRM. Inbreuken op het constitutionele recht op verdediging worden in de eerste plaats dus getoetst aan de criteria van art. 8 (recht op privé-, familie- en gezinsleven) en niet aan art. 
geen sprake zijn omdat zij dienen te voldoen aan bepaalde (in de Advocatenwet genoemde) eisen en dus niet zomaar 'willekeurige personen' zijn. Met andere woorden: gelet op de bijzondere status van de advocaat zou het niet nodig moeten zijn extra maatregelen te treffen om veiligheid en openbare orde bij bezoek aan gedetineerden te garanderen. In het tweede - niet nader gemotiveerde - deel van de klacht werd aangevoerd dat het feit dat tegen een beslissing op grond van art. 73 lid 2 KPK 1997 geen bezwaar kan worden ingesteld strijdig is met art. 78 Grondwet waarin een recht op het aantekenen van beroep tegen in eerste aanleg genomen beslissingen is vastgelegd. ${ }^{89}$

Het Grondwettelijk Hof wijst de klacht van Rutkowski op beide onderdelen af. Ten aanzien van de vermeende schending van het grondwettelijke recht op verdediging overweegt het Hof - na eerst het belang van het recht op rechtsbijstand in het algemeen en het recht op vrij verkeer in het bijzonder te hebben onderstreept - dat het toezicht op het persoonlijk overleg een uitzonderlijk karakter heeft aangezien het door bijzondere omstandigheden van het concrete geval moet worden gerechtvaardigd en bovendien slechts gedurende een relatief korte periode kan worden toegepast. Met name gezien de beperkte duur van het toezicht dat daardoor volgens het Grondwettelijk Hof 'geen wezenlijke invloed op de processituatie van verdachte kan hebben' en 'geen beletsel voor de voorbereiding van de verdediging vormt', kan het niet als een bovenmatige inbreuk op het recht op verdediging worden beschouwd. Immers: 'Feitelijk kan de verdediging [ook met het toezicht, toev. DdV] zowel in materiële als in formele zin worden gerealiseerd, ${ }^{90}$ is er geen wezenlijk beletsel voor het contact tussen raadsman en verdachte en is de enige beperking de openlijke aanwezigheid van een derde persoon.' Het Grondwettelijk Hof benadrukt de openlijkheid van het toezicht nog extra door er op te wijzen dat bij de uitvoering van art. 73 lid 2 KPK 1997 nooit (heimelijk) gebruik mag worden gemaakt van technische hulpmiddelen en het toezicht dus altijd zichtbaar is voor raadsman en verdachte. Opvallend is dat het Hof in de beoordeling van de huidige situatie verschillende keren herinnert aan de wetgeving van 1928 en 1969 en de daarop gebaseerde praktijk waarin het mogelijk en gebruikelijk was het vrij verkeer voor de duur van vrijwel het gehele vooronderzoek te beperken of zelfs te verbieden: ter illustratie wordt daarbij verwezen naar de jaren tachtig toen politieke verdachten vaak wekenlang geen contact met hun raadsman mochten hebben en wanneer wel toestemming werd verleend voor het overleg dit in de regel onder toezicht van de prokurator of een door hem aangewezen derde moest plaatsvinden. Gelet op deze geschiedenis dient art. 73 KPK 1997 en met name het feit dat toezicht alleen nog gedurende de eerste veertien dagen van de voorlopige hechtenis mogelijk is volgens het Hof als een belangrijke verbetering te worden beschouwd. Over de formulering van art. 73 lid 2 KPK 1997 zegt het Grondwettelijk Hof slechts dat de gekozen bewoordingen ('een uitzonderlijk geval') inderdaad aanleiding voor discussie kunnen geven maar dat het aan de prokurator is om aan de hand van de

6 (eerlijk proces).

89 Art. 78 Grondwet: 'Eenieder heeft het recht bezwaar aan te tekenen tegen uitspraken en beslissingen die in eerste aanleg zijn genomen. Uitzonderingen op deze regel en de wijze waarop dergelijke bezwaren behoren plaats te vinden, dienen bij wet te worden voorzien.'

90 Zie over het onderscheid tussen materiële en formele verdediging: hoofdstuk 2, § 3.1.3.2. 
concrete omstandigheden van het geval te bepalen of toezicht noodzakelijk is om de doelstellingen van het strafproces te bereiken.

Ook het tweede deel van de klacht van Rutkowski - over het ontbreken van een rechtsmiddel - wordt afgewezen. Het Hof merkt hierbij in de eerste plaats op dat het door klager aangevoerde art. 78 lid 2 Grondwet waarin een recht op rechtsmiddelen is opgenomen niet absoluut is en dat art. 73 lid 2 KPK 1997 een van de uitzonderingen is. Bovendien is het volgens het Hof onjuist te stellen dat op een beslissing op grond van art. 73 lid 2 KPK 1997 geen enkele controle kan worden uitgeoefend: er kan immers wel een klacht (skarga) worden ingediend bij een hogere prokurator. ${ }^{91}$

\subsubsection{Vertrouwelijk overleg en het EVRM}

\subsubsection{Relevante bepalingen}

Waar het gaat om het recht op vrij verkeer tussen raadsman en cliënt, is niet alleen art. 6 maar ook art. 8 EVRM van belang. Het recht op vertrouwelijke communicatie tussen advocaat en gedetineerde cliënt wordt in art. 6 EVRM weliswaar niet met zoveel woorden genoemd ${ }^{92}$ maar wordt er - volgens vaste rechtspraak - wel ingelezen. ${ }^{93}$ Ook in de rechtspraak met betrekking tot art. 8 EVRM waarin het recht op respect voor het privé-leven, het familie- en gezinsleven, de woning en correspondentie is gegarandeerd, wordt het belang van een vertrouwensrelatie tussen advocaat en cliënt benadrukt. Voor wat betreft art. 6 EVRM kunnen inbreuken op het vrij verkeer afhankelijk van de concrete klacht zowel onder de noemer van lid $3 \mathrm{sub} b$ (recht op faciliteiten ter voorbereiding van de verdediging) als in het kader van lid 3 sub c (recht op bijstand van een advocaat) worden behandeld. ${ }^{94}$ Wanneer het gaat om de verdediging in het kader van procedures ten aanzien van de voorlopige hechtenis is ook art. 5 lid 4 EVRM van belang. ${ }^{95}$

91 Zie $§ 2.5$. Opvallend is overigens dat de Procureur Generaal zich in deze zaak wel op het standpunt heeft gesteld dat het tweede deel van de klacht gegrond was en dus dat ten onrechte geen rechtsmiddel openstaat tegen de beslissing op grond van art. 73 lid 2 KPK 1997. De PG benadrukt hierbij het belang van toezicht op deze categorie beslissingen omdat de formulering van de wetgever ('in een uitzonderlijk geval') verschillend geïnterpreteerd kan worden. Zie uitgebreid over deze uitspraak van het Grondwettelijk Hof: Kulesza 2005, p. 397-406.

92 Zie ook art. 14 lid 3 sub b Internationaal Verdrag inzake burgerrechten en politieke rechten: 'eenieder heeft bij het bepalen van de gegrondheid van een tegen hem ingestelde strafvervolging het recht te beschikken over voldoende tijd en faciliteiten die nodig zijn voor de voorbereiding van verdediging en zich te verstaan met een door hemzelf gekozen raadsman'. Hieruit kan in ieder geval het recht op toegang tot een advocaat worden afgeleid. Dat communicatie tussen beiden vertrouwelijk moet kunnen plaatsvinden blijkt niet met zoveel woorden uit genoemde bepaling maar wordt er wel ingelezen door het mensenrechtencomité.

93 Zie onder meer Can t. Oostenrijk, ECRM 12-7-1984, B79 en EHRM 30-9-1985, A96, nr. $9300 / 81$.

94 Sub b wanneer de verdediging door de beperkingen niet de noodzakelijke faciliteiten heeft gehad voor de voorbereiding van de verdediging en sub c wanneer door de wijze waarop de communicatie heeft plaatsgevonden inbreuk is gemaakt op het recht op effectieve rechtsbijstand.

95 Zie Castravet t. Moldavië, EHRM 13-3-2007, nr. 23393/05: 'Since the applicant was in essence complaining that (...) he could not confer with his lawyer about issues related to the 
Art. 8 EVRM is met name relevant voor wat betreft het recht op ongecontroleerde briefwisseling. Wanneer de inbreuk op het vrij verkeer (mede) betrekking heeft op correspondentie tussen raadsman en cliënt is art. 8 EVRM in het geding. ${ }^{96}$ Genoemde bepaling heeft ook betekenis voor de bescherming van het verschoningsrecht van de advocaat. Zo heeft het EHRM bepaald dat advocatenkantoren als 'woning' in de zin van art. 8 EVRM dienen te worden aangemerkt waardoor in geval van een huiszoeking aan deze bepaling kan worden getoetst. Ook het afluisteren en opnemen van telefoongesprekken van een advocaat valt onder de reikwijdte van art. 8 EVRM. ${ }^{97}$

Hoewel art. 6 en art. 8 EVRM dus beide van belang zijn voor het recht op vertrouwelijke communicatie tussen raadsman en cliënt, bestaan tussen de twee artikelen verschillen die consequenties hebben voor de wijze waarop (mogelijke) inbreuken worden getoetst. Om te beginnen is in art. 8 EVRM - anders dan in art. 6 - een beperkingsclausule opgenomen: de in het eerste lid gegarandeerde rechten mogen onder de in lid 2 genoemde voorwaarden beperkt worden. Inbreuken dienen te voldoen aan de in art. 8 lid 2 EVRM genoemde voorwaarden wat inhoudt dat ze bij wet moeten zijn voorzien ('in accordance with the law'), een van de in het tweede lid genoemde doelstellingen behoren te dienen ('legitimate aim') en noodzakelijk moeten zijn in een democratische samenleving ('necessary in a democratic society'). Dat een dergelijke beperkingsclausule in art. 6 ontbreekt, betekent echter niet dat de daar opgenomen rechten absoluut zijn. Bij inbreuken op art. 6 EVRM wordt immers altijd de strafrechtelijke procedure in zijn geheel bekeken. Doorslaggevend is of de verdachte - ondanks de vastgestelde beperkingen - nog een eerlijk proces in de zin van art. 6 lid 1 heeft gehad. Het recht op vertrouwelijke communicatie is dus noch op grond van art. 6 noch op grond van art. 8 EVRM absoluut.

Een tweede verschil tussen beide bepalingen is dat over een schending van art. 6 alleen door de verdachte (degene jegens wie een vervolging is gericht) kan worden geklaagd. Klachten op grond van art. 8 EVRM kunnen daarentegen worden ingediend door eenieder die van mening is dat een van zijn privacyrechten is geschonden. Een advocaat kan op grond van art. 8 EVRM dus zelfstandig klagen over (bijvoorbeeld) schending van zijn briefgeheim. Over inbreuken op de vertrouwensrelatie die onder art. 6 EVRM vallen, kan alleen door de cliënt worden geklaagd. ${ }^{98}$

\subsubsection{Recht op vertrouwelijk bezoek}

Aangezien het recht op vrij verkeer niet absoluut is, dient te worden bekeken onder welke omstandigheden beperkingen zijn toegestaan. Zoals gebruikelijk geeft het EHRM in abstracto geen antwoord op deze vraag maar kunnen aan de Straatsburgse rechtspraak wel richtlijnen worden ontleend die van belang zijn voor beoordeling van de Poolse situatie.

proceedings concerning his right to liberty, the Court considers that Article $5 \S 4$ is the more appropriate Article in this case' (\$ 45). Zoals besproken in hoofdstuk 5, § 3.5 en 4.6 zijn bepaalde garanties uit art. 6 EVRM van overeenkomstige toepassing op procedures die in het kader van de voorlopige hechtenis worden gevoerd.

96 Spronken 2001, p. 469.

97 Zie voor Straatsburgse jurisprudentie over huiszoeking en telefoontap bij advocaten hierna respectievelijk $§ 7.8$ en 8.6.

98 Zie ook Daamen 2007, p. 32-33. 
Belangrijk in dit verband is de zaak S. t. Zwitserland ${ }^{99}$ waarin het Europese Hof het belang van vertrouwelijke communicatie tussen raadsman en cliënt benadrukt door te overwegen dat:

'(...) an accused's right to communicate with his advocate out of hearing of a third person is part of the basic requirements of a fair trial in a democratic society and follows from Article 6 para. 3 (c) (...) of the Convention. If a lawyer were unable to confer with his client and receive confidential instructions from him without such surveillance, his assistance would lose much of its usefulness, whereas the Convention is intended to guarantee rights that are practical and effective (...)'.100

Het door de Zwitserse regering gevoerde verweer dat toezicht in de zaak van S. noodzakelijk was vanwege het collusiegevaar dat de (geplande) samenwerking tussen de advocaat van S. met de advocaat van een medeverdachte kon opleveren, werd niet geaccepteerd omdat er volgens het EHRM op zich niets op tegen is dat advocaten van medeverdachten hun verdedigingsstrategie bespreken en op elkaar afstemmen. ${ }^{101}$ In latere rechtspraak heeft het EHRM overwogen dat alleen 'zeer zwaarwegende gronden' ('very weighty reasons') een inbreuk op het vrij verkeer kunnen rechtvaardigen. ${ }^{102}$ Afhankelijk van het moment in de procedure kan ook incidenteel toezicht een schending van art. 6 EVRM opleveren. ${ }^{103}$ Ook de vraag of de verdachte voor het contact met zijn raadsman reeds een verklaring heeft afgelegd, is een factor van betekenis - zo kan worden afgeleid uit de zaak Öcalan t. Turkije. ${ }^{104}$ Kern van de klacht van Öcalan was dat het eerste bezoek van zijn advocaten had plaatsgevonden onder visueel en auditief toezicht van leden van de veiligheidsdiensten en een rechter en dat volgende bezoeken werden afgeluisterd. Het Europese Hof tilt er zwaar aan dat Öcalan op geen enkel moment in de procedure vertrouwelijk met zijn advocaten heeft kunnen overleggen en merkt daarbij op dat het feit dat klager op het moment dat hij voor het eerst met zijn advocaten overleg kon voeren reeds verklaringen had afgelegd de noodzaak voor vertrouwelijk overleg alleen maar versterkte: men moest immers in vertrouwen een verdedigingsstrategie kunnen voorbereiden. Uit de uitspraak blijkt ook dat in beginsel de minst vergaande vorm van supervisie dient te worden toegepast waarbij auditief

99 EHRM 28-11-1991, A220, nr. 12629/87, 13965/88.

$100 \S 48$.

$101 \S 49$.

102 Lanz t. Oostenrijk, EHRM 21-1-2001, nr. 24430/94: 'Surveillance by the investigating judge of the contacts of a detainee with his defence counsel is a serious interference with an accused's defence rights and very weighty reasons should be given for its justification (...) ' (\$52).

103 Zo bleek in Brennan t. Verenigd Koninkrijk (EHRM 16-10-2001, nr. 39846/98) waarin het eerste overleg tussen advocaat en cliënt onder visueel en auditief toezicht van een politieagent had plaatsgevonden. Hoewel dit slechts eenmalig was gebeurd en klager zijn advocaat daarna nog vele malen vertrouwelijk had kunnen spreken, stelde het EHRM toch een schending van art. 6 lid 3 sub c EVRM vast. Dit gelet op het feit dat het eerste overleg een zeer belangrijk moment in de procedure vormde en dat de aanwezigheid van de politieagent overduidelijk van invloed was geweest op de vertrouwelijkheid. Het Europese Hof benadrukte hierbij dat het niet aan klager is om aan te tonen dat het verloop of de uitkomst van zijn proces is beïnvloed door de beperking op het vrij verkeer (\$ 58). Zie ook hoofdstuk $4, \S 2.5$ en hoofdstuk $5, \S 2.5$.

104 EHRM 12-3-2003 (eerste aanleg) en 12-5-2005 (Grand Chamber), nr. 46221/99. 
toezicht als ultimum remedium moet worden beschouwd. ${ }^{105}$ Recente rechtspraak van het EHRM laat bovendien zien dat het voor een schending van art. 6 EVRM niet noodzakelijk is dat men daadwerkelijk is afgeluisterd: de gerechtvaardigde vrees dat informatie ter kennis van de autoriteiten komt, kan voldoende zijn. ${ }^{106}$ Bepalend is of 'an objective, fair minded and informed observer would have feared interception of lawyer-client discussions or eavesdropping'. ${ }^{107}$

Ten aanzien van de Poolse situatie is met name interessant of het toezicht binnen gehoorafstand - zoals de mogelijkheid van art. 73 lid 2 KPK 1997 en ook de supervisie in het kader van art. 245 lid 1 KPK 1997 in de praktijk wordt uitgevoerd verenigbaar is met het EVRM. Deze vraag is tot op heden niet beantwoord door het EHRM. Op dit moment is hierover wel een klacht aanhangig. ${ }^{108}$ De van diefstal verdachte Rybacki had op verschillende momenten in het vooronderzoek slechts onder toezicht met zijn advocaat kunnen spreken. Het betrof hier wel nog de situatie onder het oude strafprocesrecht (art. 64 KPK 1969) op grond waarvan deze beperking van het vrij verkeer nog voor de duur van vrijwel het gehele vooronderzoek mogelijk was. Dat neemt echter niet weg dat de uitkomst van deze zaak van belang kan zijn voor de huidige situatie omdat de klacht meer algemeen het ontbreken van een mogelijkheid tot vertrouwelijk overleg in het vooronderzoek betreft. Volgens de Poolse regering - die niet ontkent dat op het overleg tussen Rybacki en zijn raadsman op verschillende momenten toezicht is uitgeoefend - is dit geen probleem omdat de beperkingen later in de procedure volledig zijn gecompen-

105 Voor wat betreft de door de regering aangevoerde redenen voor het toezicht (beveiliging van klager) oordeelt het EHRM dat er geen enkele reden was aan te nemen dat de advocaten - die door Öcalan zelf waren aangesteld - zijn veiligheid in gevaar zouden kunnen brengen en dat visueel toezicht voldoende zou zijn geweest: uitspraak d.d. 12-5-2005, § 133134. De Grand Chamber volgt op dit punt het oordeel van het EHRM in eerste aanleg.

106 Zo blijkt uit een opmerkelijke zaak tegen Moldavië (Castravet t. Moldavië, EHRM 13-3-2007, nr. 23393/05): 'The Court considers that an interference with the lawyer-client privilege, and thus, with a detainee's right to defence, does not necessarily require an actual interception or eavesdropping to have taken place. A genuine belief held on reasonable grounds that their discussion was being listened to might be sufficient, in the Court's view, to limit the effectiveness of the assistance which the lawyer could provide. Such a belief would inevitably inhibit a free discussion between lawyer and client and hamper the detained person's right effectively to challenge the lawfulness of his detention' (§ 51). De klacht van Castravet - gedetineerd in een speciaal detentiecentrum voor verdachten van economische delicten - bestond eruit dat hij zijn advocaat alleen had kunnen spreken gescheiden door een glazen wand. Omdat die wand min of meer geluidsdicht was en er geen gaten in zaten, moest er geschreeuwd worden om elkaar te verstaan en konden er bovendien geen stukken worden overlegd. Volgens de regering was een en ander noodzakelijk vanwege veiligheidsredenen en ter voorkoming van strafbare feiten.

$107 \S 52$. Het EHRM was van mening dat de vrees voor afluisteren - gelet op het feit dat de situatie in genoemd detentiecentrum ernstig werd bekritiseerd door de Moldavische balie en dat een onderzoek naar de aanwezigheid van afluisterapparatuur door de autoriteiten was geweigerd - in de zaak van Castravet gerechtvaardigd was en constateerde een schending van art. 5 lid 4 EVRM. Zoals eerder opgemerkt, werd de klacht over het persoonlijk overleg in deze zaak behandeld onder de noemer van art. 5 lid 4 EVRM omdat het om een procedure in het kader van de voorlopige hechtenis ging. Zie over de situatie in het Moldavische detentiecentrum ook: Sarban t. Moldavië, EHRM 4-10-2005, nr. 3456/05 en Modorca t. Moldavië, EHRM 10-5-2007, nr. 14437/05.

108 Rybacki t. Polen, EHRM 9-10-2007, nr. 52479/99 (ontvankelijkheidsbeslissing). 
seerd. ${ }^{109}$ Het Europese Hof heeft de klacht ontvankelijk verklaard en het is dus wachten op een inhoudelijke behandeling.

\section{Correspondentie}

\subsection{Situatie voor inwerkingtreding nieuw strafprocesrecht}

Voor de inwerkingtreding van de nieuwe strafrechtelijke codificaties van 1997 bestond onduidelijkheid over de vraag of - en zo ja, onder welke voorwaarden briefwisseling van een gedetineerde verdachte met zijn raadsman kon worden gecontroleerd. Het wetboek van strafvordering van 1969 besteedde geen aandacht aan deze kwestie: in art. 64 lid 1 KPK 1969 was slechts bepaald dat een verdachte in voorlopige hechtenis het recht had om met zijn raadsman te corresponderen. In uitzonderingen op dit recht werd noch in art. 64 noch op enige andere plaats in het wetboek van strafvordering voorzien. ${ }^{110}$ Het wetboek betreffende de tenuitvoerlegging van straffen (KKW) van 1969 voorzag daarentegen in een zeer ruime controlebevoegdheid. In art. 89 lid 2 van deze codificatie was in algemene bewoordingen bepaald:

'correspondentie van voorlopig gehechte verdachten is onderhevig aan censuur door het orgaan tot wiens beschikking de gedetineerde staat tenzij dit orgaan anders beslist'.

'Censuur' betekende dat kennis kon worden genomen van de inhoud van het geschrevene en daarin wijzigingen kunnen worden aangebracht door delen van de tekst te verwijderen of onleesbaar te maken. ${ }^{111}$ Met welk doel en onder welke voorwaarden correspondentie mocht worden gecontroleerd, was niet nader omschreven. Ook werd geen onderscheid gemaakt in verschillende soorten correspondentie: briefwisseling met de raadsman werd niet expliciet genoemd en was dus ook niet met zoveel woorden van bovengenoemde toezichtmogelijkheid uitgesloten.

Als gevolg van deze uiterst beknopte wettelijke regeling werd in de literatuur van de jaren zeventig en tachtig hevig gediscussieerd over de vraag of correspondentie tussen raadsman en verdachte - die op grond van het wetboek van strafvordering aan geen enkele beperking was onderworpen - wel onder de reikwijdte van art. 89 lid 2 KKW kon vallen. In deze discussie over de precieze verhouding tussen art. 64 KPK 1969 en art. 89 lid 2 KKW 1969 konden grofweg drie standpunten worden onderscheiden. ${ }^{112}$ De eerste was dat controle van briefwisseling tussen raadsman en gedetineerde in geen geval was toegestaan omdat het wetboek van strafvordering hiervoor geen grondslag bood en art. 89 lid 2 KKW 1969 geen betrekking had op deze vorm van correspondentie. ${ }^{113}$ Een tweede categorie auteurs - die van mening was dat laatstgenoemd standpunt van weinig realiteitszin

109 Aangezien klager vanaf een bepaald moment in de procedure wel onbeperkt contact met zijn advocaat had mogen hebben (\$ 6).

110 De beperkingen waarin art. 64 lid 2 KPK 1969 voorzag, hadden immers slechts betrekking op het persoonlijk overleg tussen raadsman en cliënt. Zie daarover § 2.1.

111 Deze bevoegdheid kwam gedurende het vooronderzoek toe aan de prokurator en werd tijdens het eindonderzoek uitgeoefend door de rechtbank.

112 Over deze drie standpunten: Grzegorczyk 1988, 185-186.

113 Zie bijvoorbeeld Mazur 1971, p. 63. Deze zienswijze werd in de literatuur wel bekritiseerd: zie bijvoorbeeld Grzegorczyk 1988, p. 185 en Nowikowski 1980, p. 65-72, p. 69. 
getuigde $^{114}$ - bepleitte dat briefwisseling tussen raadsman en verdachte wel degelijk onderhevig was aan censuur om de eenvoudige reden dat dit niet met zoveel woorden door de wetgever was verboden. ${ }^{115}$ Een derde en laatste interpretatie was dat controle van brieven van of naar de raadsman alleen mogelijk was op grond van art. 64 lid 2 KPK 1969. 116 Aangezien correspondentie niet met zoveel woorden in laatstgenoemde bepaling werd genoemd, kon deze bevoegdheid alleen worden gecreëerd door een ruime invulling te geven aan het in art. 64 lid 1 KPK 1969 gehanteerde begrip 'overleg' ('porozumienie'). ${ }^{117}$

Wat ook zij van bovenstaande discussie, in de praktijk werd art. $89 \mathrm{KKW}$ uitgelegd en toegepast als een onbeperkte controlebevoegdheid op grond waarvan alle correspondentie van voorlopige gehechte verdachten - ook de brieven van en naar hun advocaat - in beginsel gedurende alle fasen van de strafrechtelijke procedure ${ }^{118}$ kon worden gecensureerd. Zo blijkt onder meer uit hierna te bespreken Straatsburgse jurisprudentie tegen Polen. ${ }^{119}$ De Poolse regering beriep zich in de zaken Klamecki ${ }^{120}$ en Kwiek ${ }^{121}$ - waarin onder meer werd geklaagd over censuur op de correspondentie tussen raadsman en cliënt - op het feit dat de wetgever met art. 89 lid 2 KKW 1969 in een ongeclausuleerde controlebevoegdheid had voorzien

114 Het was immers moeilijk vol te houden dat persoonlijk overleg tussen raadsman en cliënt wel aan beperkingen onderhevig kon zijn en briefwisseling in het geheel niet: Kruszyński 1991, p. 167.

115 Zie onder meer Nowikowski 1980, p. 69-70 en Grzegorczyk 1988, p. 185. Zij waren van mening dat art. 64 lid 1 KPK 1969 slechts het algemene recht op correspondentie regelde en niet bepaalde onder welke voorwaarden dit recht kon worden beperkt: dat was geregeld in het wetboek betreffende de tenuitvoerlegging van straffen op grond waarvan correspondentie tussen raadsman en verdachte niet met zoveel woorden was uitgesloten van censuur. Auteurs die dit standpunt vertegenwoordigden, benadrukten echter wel dat de prokurator deze vorm van correspondentie gelet op de ratio van art. 64 KPK lid 2 KPK 1969 (onbeperkt overleg is de regel en bezoek onder toezicht de uitzondering) zoveel mogelijk vrij zou moeten laten van censuur: Lipczyńska 1970, p.72.

116 Zo is onder meer betoogd door Cieślak en Doda. Volgens deze redenering kon een dergelijke bevoegdheid niet aan art. 89 lid 2 KKW 1969 worden ontleend omdat een zodanige uitleg van laatstgenoemde bepaling tot de vreemde consequentie zou leiden dat controle van correspondentie gedurende het gehele strafproces mogelijk zou zijn terwijl op persoonlijk overleg alleen gedurende het vooronderzoek toezicht kon worden uitgeoefend.

117 Wanneer daaronder ook briefwisseling zou worden begrepen, zou de prokurator aan deze bepaling de bevoegdheid kunnen ontlenen om niet alleen persoonlijk overleg maar ook briefwisseling tussen raadsman en verdachte gedurende het vooronderzoek aan beperkingen te onderwerpen. Zie Cieślak 1980, p. 84. Grzegorczyk heeft zich tegen deze uitleg van art. 64 KPK 1969 verzet: volgens hem was duidelijk dat de wetgever in art. 64 lid 2 KPK 1969 alleen in toezicht op persoonlijk overleg had willen voorzien: aan de prokurator was immers slechts de bevoegdheid verleend om te bepalen dat hijzelf of een door hem aangewezen derde bij het gesprek aanwezig zou zijn, over het openen en controleren van brieven werd niets gezegd. Zie Grzegorczyk 1988, p. 186.

$118 \mathrm{Al}$ werd er in de literatuur zoals eerder opgemerkt wel voor gepleit dat deze toezichtmogelijkheid analoog aan art. 64 lid 2 KPK 1969 in de praktijk niet na sluiting van het vooronderzoek zou mogen plaatsvinden. Zie bijvoorbeeld Lipczyńska 1970, p. 74 en Cieślak 1980, p. 84.

119 Zie §3.5.

120 Klamecki t. Polen (no. 2), EHRM 3-4-2003, nr. 31583/96.

121 Kwiek t. Polen, EHRM 30-5-2006, nr. 51895/99. 
op grond waarvan autoriteiten alle correspondentie van de voorlopig gehechte verdachte mochten controleren.

\subsection{Huidig juridisch kader}

Bovengenoemde hoofdregel dat alle correspondentie van voorlopig gehechte verdachten in beginsel is onderworpen aan censuur (art. 89 lid $2 \mathrm{KKW}$ ) is in het huidige wetboek betreffende de tenuitvoerlegging van straffen behouden. ${ }^{122}$ In tegenstelling tot voorheen zijn nu echter wel aanvullende regels vastgesteld voor de briefwisseling tussen raadsman en cliënt. Deze kunnen worden gevonden in art. 73 KPK 1997 en art. 8 lid 3 KKW 1997.

Op de in art. 73 lid 1 KPK 1997 vastgelegde hoofdregel dat de voorlopig gehechte verdachte (in vrijheid) met zijn raadsman mag corresponderen is in het derde lid een uitzondering gecreëerd: de prokurator kan bepalen 'dat correspondentie tussen raadsman en verdachte wordt gecontroleerd' ${ }^{123}$ Ook voor deze beperking op het vrij verkeer geldt op grond van lid 4 dat ze alleen gedurende de eerste veertien dagen van de voorlopige hechtenis kan worden toegepast. ${ }^{124}$ Opvallend is dat in art. 73 lid 3 KPK 1997 alleen de correspondentie van 'verdachte' ('podejrzanego') wordt genoemd en bovendien alleen de prokurator de bevoegdheid wordt verleend om te bepalen dat briefwisseling moet worden gecontroleerd. Hieruit moet worden afgeleid dat controle van deze categorie correspondentie alleen mogelijk is gedurende het vooronderzoek en dat de rechtbank aan deze bepaling geen soortgelijke bevoegdheid kan ontlenen. ${ }^{125}$

Anders dan ten aanzien van het toezicht op het persoonlijk overleg (dat alleen in 'uitzonderlijke gevallen' mag worden toegepast) heeft de wetgever hier niet expliciet het uitzonderlijk karakter van de beperking aangegeven. Art. 73 lid 3 KPK 1997 regelt slechts in algemene bewoordingen dat correspondentie tussen raadsman en verdachte op bevel van de prokurator kan worden gecontroleerd: noch in dit artikel noch in enige andere bepaling van het wetboek van strafvordering is nader omschreven welke grond(en) of concrete omstandigheden een dergelijke beslissing kunnen rechtvaardigen. Aanvullende voorwaarden voor de wijze waarop (en de voorwaarden waaronder) correspondentie tussen raadsman en gedetineerde mag worden gecontroleerd, kunnen wel worden ontleend aan art. 8 lid 3 KKW 1997. Deze regel luidt - voor zover hier relevant - als volgt:

'Een veroordeelde die van zijn vrijheid is beroofd, kan in afwezigheid van anderen overleg voeren met zijn raadsman, gevolmachtigde advocaat of juridisch adviseur. Briefwisseling met deze personen is niet onderhevig aan censuur en mag niet worden tegengehouden en gesprekken die onder vier ogen of via de telefoon worden gevoerd, mogen niet worden ge-

$122 \mathrm{Nu}$ vastgelegd in art. 217a KKW 1997.

123 Art. 73 lid 1: 'De beschuldigde die zich in voorlopige hechtenis bevindt, mag in afwezigheid van anderen met zijn raadsman overleg voeren en met hem corresponderen' en lid 3: 'De prokurator kan eveneens bepalen dat correspondentie tussen verdachte en raadsman wordt gecontroleerd.'

124 Deze termijn geldt ook voor het toezicht op het persoonlijk overleg: zie hiervoor $\S 2.3$.

125 Het vooronderzoek is immers het enige stadium van de strafrechtelijke procedure waarin van een 'verdachte' wordt gesproken. Dit betekent dat de mogelijkheid correspondentie tussen raadsman en gedetineerde te controleren ook komt te vervallen wanneer de akte van beschuldiging wordt ingediend vóórdat de eerste veertien dagen van de voorlopige hechtenis zijn verstreken: Hofmański e.a. 2004, p. 380 en Hofmański e.a. 2007 I, p. 413. 
controleerd. Toezicht op correspondentie met een raadsman kan plaatsvinden door middel van openen van een brief maar uitsluitend wanneer er een gerechtvaardigd vermoeden bestaat dat de brief verboden voorwerpen bevat (letterlijk: voorwerpen waarvoor een verbod geldt ze in het bezit te hebben, te bewaren, over te dragen, te verzenden of te verhandelen). Het openen dient in aanwezigheid van de veroordeelde plaats te vinden en de penitentiaire rechter dient op de hoogte te worden gesteld van de grond (voor) en het resultaat [van de interventie, toev. DdV] (...).'

Uit deze bepaling - die weliswaar alleen de veroordeelde gedetineerde noemt maar van overeenkomstige toepassing is op de verdachte die zich in voorlopige hechtenis bevindt ${ }^{126}$ - kan worden afgeleid dat correspondentie met de raadsman:

1. niet mag worden gecensureerd of tegengehouden,

2. slechts mag worden geopend wanneer er een 'gerechtvaardigd vermoeden bestaat dat de brief verboden voorwerpen bevat' waarbij geldt dat

3. openen te allen tijde in aanwezigheid van de gedetineerde dient te gebeuren.

Dat deze briefwisseling niet mag worden gecensureerd, betekent dat de envelop alleen mag worden geopend om de inhoud te controleren: de brief mag niet worden gelezen en ook is het niet toegestaan delen van de tekst onleesbaar te maken of er veranderingen in aan te brengen. ${ }^{127}$ De eis dat alle brieven van en naar de raadsman slechts in aanwezigheid van de gedetineerde mogen worden geopend, biedt laatstgenoemde de mogelijkheid er persoonlijk op toe te zien dat zijn correspondentie inderdaad niet wordt gelezen.

\subsection{Evaluatie juridisch kader}

De onduidelijkheid die er op grond van het oude strafprocesrecht ten aanzien van de controle van correspondentie tussen raadsman en verdachte bestond, is in de huidige regeling opgeheven. De wetgever heeft duidelijk gemaakt dat deze vorm van briefwisseling in beginsel een bijzondere status geniet en slechts onder bepaalde voorwaarden mag worden gecontroleerd. Zoals hierna nog zal worden uiteengezet, is de noodzaak van deze veranderingen verschillende keren bevestigd in uitspraken van het Europese Hof voor de rechten van de mens. ${ }^{128}$ Belangrijk is dat:

- controle van correspondentie tussen raadsman en verdachte een wettelijke grondslag heeft gekregen in het wetboek van strafvordering (art. 73 lid 3 KPK 1997),

126 Dit vloeit voort uit art. 242 lid 1 KKW 1997 waarin is bepaald dat waar in het algemene deel van het wetboek - waarvan art. 8 onderdeel uitmaakt - de term 'veroordeelde' wordt gebruikt, de betreffende bepaling van overeenkomstige toepassing is op degene die zich in voorlopige hechtenis bevindt. Bovendien is in art. $214 \mathrm{KKW} 1997$ geregeld dat de voorlopig gehechte verdachte tenminste dezelfde rechten heeft als de veroordeelde gedetineerde, voor zover in hoofdstuk 15 (dat specifiek betrekking heeft op de voorlopige hechtenis) niet anders is bepaald.

127 Zie in dit verband art. 242 KKW 1997 lid 6 en 7 waarin de termen 'toezicht' ('nadzór') en 'censuur' ('cenzura') op correspondentie nader worden omschreven. Onder 'toezicht' dient te worden verstaan dat een brief wordt geopend ter controle van de inhoud, 'censuur' betekent dat kennis wordt genomen van de inhoud van het geschrevene en wijzigingen kunnen worden aangebracht door delen van de tekst te verwijderen of onleesbaar te maken.

128 Zie $\S 3.5$. 
- toezicht alleen nog gedurende de eerste veertien dagen van de voorlopige hechtenis is toegestaan (art. 73 lid 3 en 4 KPK 1997) ${ }^{129}$ en dat

- nadere voorwaarden zijn gesteld aan de wijze waarop de controle van deze in beginsel geprivilegieerde correspondentie in de praktijk moet worden vormgegeven (art. 8 lid 3 KKW 1997).

De verbeteringen ten opzichte van de oude regeling zijn evident: de - in ieder geval in theorie - onbeperkte mogelijkheid correspondentie tussen raadsman en verdachte gedurende alle fasen van de strafrechtelijke procedure te censureren, is gereduceerd tot de bevoegdheid van de prokurator om slechts tijdelijk brieven van en naar de raadsman in aanwezigheid van de gedetineerde te mogen openen ter controle op verboden voorwerpen.

\subsection{Correspondentie in de praktijk}

De nieuwe regels en voorwaarden die de correspondentie tussen raadsman en verdachte moeten beschermen, kunnen uiteraard alleen betekenis hebben wanneer ze ook daadwerkelijk door de autoriteiten worden toegepast. Omdat weinig bekend is over de praktijk, is het niet mogelijk een eenduidig antwoord te geven op de vraag of dit (in voldoende mate) gebeurt.

Het beeld dat uit de Straatsburgse rechtspraak tegen Polen naar voren komt, ${ }^{130}$ is echter niet al te rooskleurig. De laatste jaren wordt nog steeds met enige regelmaat geklaagd over controle van correspondentie met advocaten en dit heeft al verschillende malen tot een schending van art. 8 EVRM geleid. Grootste probleem daarbij is dat brieven niet in aanwezigheid van de gedetineerde worden geopend of met een stempel 'gecensureerd' worden doorgezonden waardoor niet zeker is dat overeenkomstig art. 73 KPK 1997 geen kennis is genomen van de inhoud. Nog veel vaker is de Poolse regering op de vingers getikt waar het gaat om briefwisseling van gedetineerden met Straatsburgse organen. Hierover wordt heel veel geklaagd en talloze klachten hebben reeds tot een schending van art. 8 EVRM geleid. Hoewel daar natuurlijk niet uit mag worden afgeleid dat ook brieven van en naar advocaten op grote schaal worden gecontroleerd, laat het in ieder geval zien dat de Poolse autoriteiten het niet zo nauw nemen met de beschermde status die de wetgever aan deze vormen van correspondentie heeft verleend.

Er zijn ook kritische geluiden vanuit de advocatuur dat de voorvallen waarover bij het EHRM wordt geklaagd geen incidenten zijn en dat de huidige praktijk ten aanzien van controle van correspondentie nog steeds te wensen over laat. Zo blijkt uit een bijdrage van Cichon - advocaat te Krakau - in een Pools dagblad waarin hij betoogt dat de briefwisseling tussen een voorlopig gehechte verdachte en zijn raadsman nog altijd aan teveel beperkingen onderhevig is. ${ }^{131}$

De advocaten die ik in Polen over vertrouwelijkheid van correspondentie met gedetineerde cliënten heb gesproken, hadden verschillende ervaringen op dit punt. Zo gaf een advocaat uit Lublin aan in vijftien jaar praktijk nog nooit te hebben meegemaakt dat zijn correspondentie met een gedetineerde cliënt was geopend.

129 Deze termijn van veertien dagen was - net als in het kader van het toezicht op persoonlijk overleg - voor de inwerkingtreding van het nieuwe wetboek van strafvordering in de literatuur voorgesteld door Kruszyński: Kruszyński 1991, p. 169-171.

130 Zie hierna § 3.5 .

131 Cichoń 2004. 
Een aantal andere advocaten had wel ooit geopende - en dus gecontroleerde correspondentie van cliënten ontvangen. Moeilijkheid is uiteraard dat een advocaat wanneer hij een geopende brief van een cliënt ontvangt, niet kan weten of deze toch niet ook is gelezen. Dat kan slechts worden beoordeeld door de gedetineerde die om die reden altijd bij het openen aanwezig dient te zijn. Veel hangt dus af van de vraag hoe consequent deze waarborg wordt nageleefd in de praktijk.

\subsection{Vertrouwelijke correspondentie en het EVRM}

Het recht op vertrouwelijke correspondentie valt onder de reikwijdte van art. 8 EVRM en kan worden ingeperkt met inachtneming van de in art. 8 lid 2 genoemde voorwaarden. ${ }^{132}$ Nationale wetgeving die voorziet in beperkingen op de in art. 8 EVRM genoemde rechten dient volgens vaste rechtspraak van het EHRM aan bepaalde kwaliteitseisen te voldoen: de wettelijke basis dient toegankelijk (accessible) en voorzienbaar (foreseeable) te zijn. Indien onvoldoende duidelijk is op welke gronden en voor welke duur controle van correspondentie mogelijk is, kan dat resulteren in een schending van art. 8 EVRM. ${ }^{133}$ Wanneer de controle tevens tot een inperking van verdedigingsrechten leidt, kan het bovendien een schending van art. 6 EVRM opleveren. ${ }^{134}$

Uit de rechtspraak van het EHRM kan worden afgeleid dat een bepaalde mate van controle op correspondentie van gedetineerden in beginsel toelaatbaar is:

'(...) some measure of control over prisoners' correspondence is called for and is not of itself incompatible with the Convention, regard being paid to the ordinary and reasonable requirements of imprisonment (...). In assessing the permissible extent of such control in general, the fact that the opportunity to write and to receive letters is sometimes the prisoner's only link with the outside world should, however, not be overlooked.'135

132 Bij wet voorzien, ter realisatie van een van de in lid 2 genoemde doelstellingen en noodzakelijk in een democratische samenleving. Zie eerder $\$$ 2.6.3.1.

133 Zie bijvoorbeeld Domenichini t. Italië, EHRM 15-11-1996, nr. 15943/90. Een voorbeeld van een zaak waarin de controle naar het oordeel van het Europese Hof wel voldoende basis vond in nationale regelgeving is Erdem t. Duitsland, EHRM 5-7-2001, nr. 38321/97. De correspondentie tussen Erdem - die werd verdacht van deelname aan de Koerdische Arbeiderspartij PKK - en zijn raadsman was door een rechter gecontroleerd. Deze vorm van toezicht was voorzien in het Duitse strafprocesrecht en alleen mogelijk in geval van verdenking van deelname aan een terroristische organisatie. Het EHRM achtte deze inbreuk in overeenstemming met de eisen van art. 8 lid 2 EVRM omdat het slechts in een beperkte, nauwkeurig omschreven categorie gevallen mogelijk was, met voldoende waarborgen was omkleed (toezicht kon alleen door een rechter worden uitgevoerd die niet betrokken was bij de hoofdzaak en de inhoud van de correspondentie geheim diende te houden) en gerechtvaardigd was in de strijd tegen het terrorisme. Bovendien had Erdem nog wel onbeperkt mondeling overleg kunnen voeren met zijn advocaat. Een argument dat zoals eerder opgemerkt in de zaak Campbell overigens niet door het Europese Hof werd geaccepteerd.

134 Zie Labita t. Italië, EHRM 6-4-2000, nr. 26772/95, § 187-188.

135 Campbell t. Verenigd Koninkrijk, EHRM 25-3-1992, A233, nr. 13590/88, § 45. De briefwisseling van klager (die tot een levenslange gevangenisstraf was veroordeeld) met zijn advocaat was verschillende keren geopend en gelezen. 
Voor wat betreft de omstandigheden waaronder briefwisseling met een advocaat moet kunnen plaatsvinden, geldt dat gedetineerden in beginsel in alle vertrouwelijkheid met hun advocaat moeten kunnen corresponderen:

'that such correspondence be susceptible to routine scrutiny, particularly by individuals or authorities who may have a direct interest in the subject matter contained therein, is not in keeping with the principles of confidentiality and professional privilege attaching to relations between a lawyer and his client'.136

Het openen van brieven van en naar een advocaat is volgens het Europese Hof slechts toegestaan wanneer er een redelijk vermoeden bestaat dat deze ongeoorloofde voorwerpen bevatten. In een dergelijk geval mag een brief echter slechts worden geopend - niet gelezen - en dienen voorzorgsmaatregelen te worden getroffen (zoals het openen van de brief in aanwezigheid van de gedetineerde) om te voorkomen dat toch kennis wordt genomen van de inhoud van de brief. Lezen is slechts geoorloofd in uitzonderlijke omstandigheden wanneer er op grond van objectieve feiten een redelijk vermoeden bestaat dat de briefwisseling wordt misbruikt in de zin dat

'(...) the contents of the letter endanger prison security or the safety of others or are otherwise of a criminal nature. What may be regarded as "reasonable cause" will depend on all the circumstances but it presupposes the existence of facts or information which would satisfy an objective observer that the privileged channel of communication was being abused (...)'.137

Gelet op de hoofdlijnen die uit bovengenoemde rechtspraak kunnen worden afgeleid, is het niet verwonderlijk dat de oude Poolse regeling van artikel 89 lid 2 KKW 1969 de Straatsburgse toets der kritiek niet heeft kunnen doorstaan. Dit werd voor het eerst duidelijk in de zaak Niedbała ${ }^{138}$ waarin klager aanvoerde dat een brief die hij tijdens zijn voorlopige hechtenis - onder andere in verband met vermeend geweldsmisbruik door de politie - aan de Ombudsman had geschreven door de autoriteiten was onderschept en gelezen. Bij de beoordeling van de wettelijke basis voor deze inbreuk op artikel 8 EVRM kwam het Europese Hof tot de conclusie dat het destijds geldende Poolse recht (artikel 89 lid 2 KKW 1969) onvoldoende duidelijkheid bood voor wat betreft de reikwijdte van de controlebevoegdheid en de wijze waarop deze moest worden toegepast. De inbreuk was daardoor 'not in accordance with the law' en in strijd met artikel 8 EVRM. Het Europese Hof benadrukte daarbij conform zijn vaste rechtspraak dat de kwali-

136 Idem, § 47.

137 Idem, § 48. Toegepast op de omstandigheden van het geval in de zaak van Campbell leidde dit tot de conclusie dat art. 8 EVRM was geschonden. De argumenten van de regering - dat de controle niet tot een beperking van het vrij verkeer had geleid omdat Campbell nog wel zonder toezicht met zijn advocaat had kunnen spreken en dat het toezicht op de correspondentie noodzakelijk was geweest omdat niet alle advocaten even integer zouden zijn - werden door het EHRM niet geaccepteerd: zie § 49-52. Zie verder onder meer ook Foxley t. Verenigd Koninkrijk, EHRM 20-6-2000, nr. 33274/96 waarin het feit dat correspondentie die Foxley van zijn juridisch adviseurs ontving, was geopend, gelezen en gekopieerd tot een schending van art. 8 EVRM leidde omdat deze vergaande inbreuken volgens het EHRM niet als 'noodzakelijk in een democratische samenleving' konden worden aangemerkt.

138 Niedbała t. Polen, EHRM 4-7-2000, nr. 27915/95. 
teitseisen die aan nationale wetgeving mogen worden gesteld, in ieder geval met zich brengen dat de betreffende regels

'must indicate with reasonable clarity the scope and manner of exercise of the relevant discretion conferred on the public authorities so as to ensure to individuals the minimum degree of protection to which citizens are entitled under the rule of law in a democratic society (...). 139

De Poolse regelgeving ten aanzien van controle van correspondentie voldeed volgens het Europese Hof niet aan deze kwaliteitseisen. ${ }^{140}$

Zoals gezegd, ging het in de Niedbała-zaak om correspondentie met een Ombudsman maar de overwegingen van het Europese Hof zijn later ook toegepast in zaken waarin briefwisseling met een advocaat centraal stond. Zo was in Klamecki tegen Polen ${ }^{141}$ de correspondentie van klager - waaronder brieven van en naar zijn advocaat - op grote schaal geopend en gecensureerd. Onder verwijzing naar de uitspraak in Niedbała concludeerde het EHRM dat ook in dit geval de inbreuk niet in overeenstemming was met de wet en derhalve een schending van artikel 8 EVRM opleverde. ${ }^{142}$

Aangezien genoemde uitspraken tegen Polen betrekking hebben op de situatie voor 1997 is daarmee nog geen antwoord gegeven op de vraag of de huidige regelgeving en praktijk in overeenstemming is met de eisen van art. 8 lid 2 EVRM. In het voorgaande is duidelijk geworden dat de wetgeving ten aanzien van controle van correspondentie in 1997 - en dus reeds ruim voor de Niedbała-uitspraak - is aangepast. ${ }^{143}$ Ondanks de doorgevoerde wijzigingen die het toezicht aan strenge voorwaarden hebben verbonden, ontvangt het EHRM nog steeds regelmatig Poolse klachten waarin (ex)gedetineerden aanvoeren dat hun correspondentie ten onrechte aan controle is onderworpen. Een groot deel van deze klachten heeft betrekking

$139 \S 79$.

140 'Polish law, as it stood at the material time, allowed for automatic censorship of prisoner's correspondence by the authorities conducting criminal proceedings. Thus, the applicable provisions did not draw any distinction between the different categories of persons with whom the prisoners could correspond. (...) Moreover, the relevant provision had not laid down any principles governing the exercise of this censorship. In particular, they failed to specify the manner and time-frame within which it should be effected. As the censorship was automatic, the authorities were not obliged to give a reasoned decision specifying grounds on which it had been effected' (\$ 81). Het EHRM heeft dit standpunt ten aanzien van de Poolse censuur-regels van voor 1 september 1998 later nog verschillende keren herhaald. Zie bijvoorbeeld Radaj t. Polen (EHRM 28-112002, nr. 29537/95, 35453/97) en Sałapa t. Polen (EHRM 19-12-2002, nr. 35489/97) waarin de toelaatbaarheid van censuur op correspondentie met Straatsburgse organen centraal stond. In Sałapa wordt aan de punten van kritiek genoemd in de Niedbała-uitspraak nog toegevoegd dat de destijds geldende regelgeving (1) ten onrechte niet duidelijk maakte of de gedetineerde op de hoogte moest worden gesteld van eventuele wijzigingen die in zijn uitgaande correspondentie werden aangebracht en (2) niet voorzag in een rechtsmiddel tegen de beslissing correspondentie te censureren $(\$ 97)$.

141 Klamecki t. Polen (no. 2), EHRM 3-4-2003, nr. 31583/96.

$142 \S 137$ e.v. Ook in Kwiek t. Polen (EHRM 30-5-2006, nr. 51895/99) is het controleren van correspondentie tussen raadsman en cliënt op grond van art. 89 lid 2 KKW 1969 in strijd met art. 8 EVRM bevonden.

143 Zie eerder $\S 3.2$. 
op brieven van en naar Straatsburgse instanties. ${ }^{144}$ Reeds vele malen heeft het EHRM - die deze kwestie soms zelfs ambtshalve behandelt - in dit verband een schending van art. 8 EVRM geconstateerd. ${ }^{145}$ Ook is sinds de inwerkingtreding van de nieuwe regelgeving nog verschillende keren met succes geklaagd over ongeoorloofd toezicht op correspondentie met een advocaat. In het gros van die gevallen ging het er om dat niet kon worden uitgesloten dat de autoriteiten kennis hadden genomen van de inhoud van de brief van of naar de raadsman. Gelet op de betekenis van art. 73 KPK 1997 dat een verbod op censuur omvat ${ }^{146}$ leidt het EHRM hier telkens uit af dat een dergelijke beperking op het vrij verkeer niet 'in accordance with the law' is. ${ }^{147}$

Het bovenstaande laat zien dat de problemen die het Europese Hof in dit verband constateert vooral een gevolg zijn van het onjuist of niet toepassen van de geldende wet- en regelgeving. De nieuwe regels ten aanzien van controle op corres-

144 Deze vorm van correspondentie heeft na 1 september 1998 ook een geprivilegieerde status gekregen. Dit komt er in grote lijnen op neer dat brieven van en naar Straatsburg niet mogen worden gecensureerd en slechts onder dezelfde voorwaarden als ten aanzien van briefwisseling met de raadsman mogen worden geopend (art. 8 lid 3 jo. 103 KKW 1997).

145 Een selectie van uitspraken waarin de controle van correspondentie met Straatsburgse organen tot een schending van art. 8 EVRM heeft geleid: Mianowski t. Polen (EHRM 1612-2003, nr. 42083/98), Wasitewski t. Polen (EHRM 6-12-2005, nr. 63905/00), G.K. t. Polen (EHRM 20-1-2004, nr. 38816/97), Pisk-Piskowski t. Polen (EHRM 14-6-2005, nr. 92/03), Drozdowski t. Polen (EHRM 6-12-2005, nr. 20841/02), Tomczyk Prokopyszyn t. Polen (EHRM 28-3-2006, nr. 64283/01), Michta t. Polen (EHRM 4-5-2006, nr. 13425/02), Dzyruk t. Polen (EHRM 4-7-2006, nr. 77832/01), Cabata t. Polen (EHRM 8-8-2006, nr. 23042/02), Cegtowski t. Polen (EHRM 8-8-2006, nr. 3489/03), Euczko t. Polen (EHRM 3-10-2006, nr. 73988/01), Gąsiorowski t. Polen (EHRM 17-10-2006, nr. 7677/02), Oleksy t. Polen (EHRM 28-11-2006, nr. 64284/01), Maksym t. Polen (EHRM 19-12-2006, nr. 14450/02) en Stępniak t. Polen (EHRM 29-1-2008, nr. 29366/03).

146 Het is - onder bepaalde omstandigheden - immers slechts toegestaan kennis te nemen van de inhoud van de envelop (niet van de inhoud van de brief).

147 Zie in dit verband bijvoorbeeld Kozimor t. Polen (EHRM 12-4-2007, nr. 10816/02), Zborowski t. Polen (EHRM 15-1-2008, nr. 45133/06), Pawlak t. Polen (EHRM 15-1-2008, nr. 39840/05), zie met name de overweging in $\S 66$ : 'As regards the censorship of the letter from the applicant's lawyer, the Court reiterates that the confidentiality of the applicant's letters addressed to and sent by his legal counsel must be respected, save for reasonable cause. It is clearly in the general interest that any person who wishes to consult a lawyer should be free to do so under conditions which favour full and uninhibited discussion. It is for this reason that the lawyer-client relationship is, in principle, privileged. Similar considerations apply to a prisoner's correspondence with a lawyer concerning contemplated or pending proceedings where the need for confidentiality is equally pressing. That such correspondence be susceptible to routine scrutiny, is not in keeping with the principles of confidentiality and professional privilege attaching to relations between a lawyer and his client. In the Campbell $v$ the United Kingdom case (...) the Court found no reason to distinguish between the different categories of correspondence with lawyers which, whatever their purpose, concern matters of a private and confidential character' en Bobel t. Polen (EHRM 22-1-2008, nr. 20138/03). Zie ook Otomański t. Polen (EHRM 16-10-2007, nr. 4612/03 ontvankelijkheidsbeslissing) waarin een klacht over controle van correspondentie met de raadsman op formele gronden niet ontvankelijk werd verklaard. Opvallend is dat de Poolse regering in bovengenoemde zaken doorgaans niet inhoudelijk reageert op de verwijten ten aanzien van censuur: meestal wordt volstaan met een verweer op formele gronden (zoals een beroep op niet-ontvankelijkheid wegens niet-uitputting van nationale rechtsmiddelen). 
pondentie lijken op zichzelf de Straatsburgse toets wel te kunnen doorstaan. ${ }^{148}$ Het Europese Hof heeft in haar uitspraken tegen Polen al talloze malen benadrukt dat ze op basis van de huidige praktijk - ook ten aanzien van geprivilegieerde vormen van correspondentie met Straatsburg en met advocaten - vaak niet anders kan dan er van uitgaan dat de inhoud van een brief gelezen is. Dit omdat brieven van gedetineerden vaak het stempel 'ocenzurowano' ('gecensureerd') dragen. Onder die omstandigheden ziet het Europese hof zich genoodzaakt ervan uit te gaan dat van de inhoud is kennisgenomen. ${ }^{149}$

\section{Conclusie vrij verkeer}

Gedurende het communisme was het voor de advocaat in strafzaken vrijwel onmogelijk om vertrouwelijk met een gedetineerde cliënt te communiceren. De wetgeving bood de verdediging op dit punt zeer weinig bescherming.

De inwerkingtreding van de nieuwe strafrechtelijke codificaties heeft zeker verandering in deze situatie gebracht: het recht op contact tussen advocaat en aangehouden cliënt is wettelijk gegarandeerd (art. 245 KPK 1997) en het huidige art. 73 KPK biedt meer waarborgen dat een voorlopig gehechte verdachte in vertrouwen overleg kan voeren of kan corresponderen met zijn advocaat. Bovendien is controle op briefwisseling aan strenge voorwaarden verbonden en mogen brieven van en naar de raadsman niet worden gelezen.

Problematisch aan de huidige praktijk is echter dat wanneer persoonlijk overleg - gedurende de politiedetentie of de eerste veertien dagen van de voorlopige hechtenis - alleen onder toezicht mag plaatsvinden de toezichthouder zich doorgaans binnen gehoorafstand van het gesprek bevindt. Dit is een ingrijpende inbreuk op het vertrouwelijk overleg waarvoor geen duidelijke wettelijke voorwaarden zijn geformuleerd en die niet onderhevig is aan enige vorm van rechterlijke controle. Vooral omdat de beperking alleen in de beginfase van het vooronderzoek mogelijk is, wordt het in de Poolse rechtspraak en literatuur niet als een (groot) probleem beschouwd. Het is opmerkelijk hoe eenvoudig het Grondwettelijk Hof in de uit-

148 Onder meer in de zaak Matwiejczuk t. Polen (EHRM 2-12-2003, nr. 37641/97) heeft het EHRM geoordeeld dat de nieuwe bepalingen op dit punt voldoende specifiek zijn: '(...) these provisions were adequately accessible. Furthermore, bearing in mind impossibility of attaining absolute certainty in the framing of laws and the risk that the search for certainty may entail excessive rigidity, the Court accepts that the provisions were formulated with sufficient precision and indicated the scope of discretion conferred' (\$ 101). De zaak Matwiejczuk had weliswaar betrekking op correspondentie met Straatsburgse organen maar een deel van de beoordeelde regelgeving geldt eveneens voor brieven van en naar de raadsman. Ook in latere rechtspraak waarin de nieuwe regelgeving wel in het kader van een klacht over briefwisseling met een raadsman werd beoordeeld, zijn voor zover bekend door het EHRM geen tekortkomingen in de wettelijke regeling geconstateerd.

149 De standaardoverweging op dit punt luidt dat 'as long as the Polish autorities continue the practice of marking detainee's letters with the ocenzurowano stamp, the Court has no alternative but to presume that those letters have been opened and read (...)'. Zie bijvoorbeeld Kozimor t. Polen, EHRM 12-4-2007, nr. 10816/02, § 50. Daarbij wordt in overweging genomen dat 'in the Polish language, the word ocenzurowane means that a competent authority, after having controlled the content of a particular communication, decides to allow its delivery or expedition. Consequently, the Court presumes that this letter has been opened and read'. Zie onder meer Pawlak t. Polen, EHRM 15-1-2008, nr. 39840/05, § 61. 
spraak van februari 2004 tot het oordeel is gekomen dat het toezicht een te verwaarlozen inbreuk op het recht op verdediging vormt omdat het slechts tijdelijk en niet heimelijk mag worden toegepast. De opmerking van het Hof dat het recht op verdediging ook in aanwezigheid van een derde zonder beletsel kan worden gerealiseerd, gaat voorbij aan de gevolgen die het toezicht kan (en in veel gevallen ook zal) hebben voor de vereiste vertrouwelijkheid tussen advocaat en cliënt. Ook de advocatuur lijkt zich niet al te druk te maken over het toezicht en haar optreden er op aan te passen door cliënten in de regel niet gedurende de eerste veertien dagen te bezoeken of het bij een oppervlakkig gesprek te houden. Dat dergelijke oplossingen tot gevolg hebben dat een cliënt in een doorslaggevend stadium van de procedure verstoken blijft van effectieve rechtsbijstand wordt daarbij over het hoofd gezien. In de eerste dagen van de voorlopige hechtenis worden doorgaans de meest belangrijke verhoren afgenomen en wordt de verdachte geconfronteerd met allerlei vragen en dilemma's - zoals de keuze tussen zwijgen of verklaren - die bepalend kunnen zijn voor het verdere verloop van de strafzaak. Juist dan heeft een verdachte behoefte aan en belang bij een inhoudelijke bespreking van zijn zaak met zijn raadsman. Weliswaar wordt het toezicht in de praktijk alleen in uitzonderlijke gevallen (zwaardere strafzaken) toegepast maar daar staat weer tegenover dat juist in deze uitzonderingssituaties doorgaans ook het meest op het spel staat voor de verdachte.

Ook uit de rechtspraak van het EHRM kan worden afgeleid dat de verdediging in de eerste fase na aanhouding vertrouwelijk overleg moet kunnen voeren. Voor beperkingen op het recht op vrij verkeer dienen zwaarwegende gronden te worden aangevoerd en in beginsel zal met visueel toezicht moeten kunnen worden volstaan. Dat auditief toezicht in Polen - wanneer de prokurator gebruik maakt van zijn bevoegdheid op grond van art. 73 KPK 997 - regel is in plaats van uitzondering is daarmee niet in overeenstemming. Overigens heeft het EHRM ook duidelijk gemaakt dat bij de beoordeling van de vraag of auditief toezicht tot een verdragsschending heeft geleid, niet altijd doorslaggevend is of daadwerkelijk vertrouwelijke informatie door de autoriteiten wordt opgevangen. Of de prokurator of politieagent die bij het gesprek aanwezig is daadwerkelijk meeluistert (voor zover het al mogelijk is dat niet te doen) is dus niet noodzakelijk relevant: schijn kan onder omstandigheden voldoende zijn voor een schending van art. 6 EVRM. Voor wat betreft de controle van correspondentie tussen raadsman en gedetineerde cliënt geldt dat de huidige wettelijke regeling de verdediging veel meer bescherming biedt dan voorheen. Ingevolge het oude art. 89 lid 2 KKW kon alle correspondentie van gedetineerden routinematig worden gecensureerd en werd briefwisseling met de raadsman op geen enkele manier beschermd. Deze oude situatie is - weliswaar toen de nationale wetgeving op dit punt inmiddels was aangepast - ook bekritiseerd door het EHRM. Op grond van de huidige wet- en regelgeving ${ }^{150}$ is de bevoegdheid correspondentie tussen raadsman en cliënt te controleren aan strengere voorwaarden verbonden waardoor deze vorm van toezicht niet meer automatisch maar slechts nog in geval van een gerechtvaardigd vermoeden van misbruik en alleen gedurende de eerste veertien dagen van de voorlopige hechtenis kan worden toegepast. Bovendien mogen brieven alleen

150 Het wetboek van strafvordering en het wetboek betreffende de tenuitvoerlegging van straffen. 
worden geopend om de inhoud van de envelop op verboden voorwerpen te controleren en dient dat te allen tijde in aanwezigheid van de gedetineerde plaats te vinden. Met bovengenoemde voorwaarden komt de nieuwe regeling in belangrijke mate tegemoet aan de eisen die het EHRM op dit punt heeft gesteld. Aangezien de rechtspraak van het Europese Hof de mogelijkheid openlaat dat correspondentie tussen raadsman en verdachte in bepaalde uitzonderlijke gevallen kan worden gelezen, biedt het Poolse recht in dit verband ogenschijnlijk zelfs meer bescherming dan door Straatsburg wordt verlangd. Door de controlebevoegdheid op deze wijze aan strenge voorwaarden en waarborgen te verbinden, heeft de wetgever meer duidelijkheid geboden op de punten waaraan in de wettelijke regeling van voor 1997 ten onrechte geen aandacht was besteed. De nieuwe regelgeving lijkt dus in abstracto de Straatsburgse toets te kunnen doorstaan. Meer recente Straatsburgse rechtspraak laat echter zien dat het toezicht op de correspondentie met de raadsman in de praktijk niet altijd met volledige inachtneming van de wettelijke voorwaarden wordt uitgevoerd. Ook vanuit de advocatuur klinken hierover kritische geluiden. ${ }^{151}$

Waar het gaat om correspondentie met Straatsburgse organen blijkt de naleving van regels evenzeer problematisch: de Poolse regering is hierover al talloze malen door het Europese Hof op de vingers getikt. Hoewel natuurlijk niet met zekerheid kan worden gezegd dat deze schendingen altijd moedwillig gebeuren, staat vast dat de autoriteiten er nog onvoldoende op toe zien dat geprivilegieerde briefwisseling van voorlopig gehechte verdachten de bescherming krijgt die het op grond van de huidige wettelijke regeling (en gelet op de bijzondere status van deze vormen van correspondentie) verdient. In verlegenheid gebracht door het toenemend aantal klachten dat op dit punt in Straatsburg - soms zelfs ambtshalve door het EHRM - aan de orde wordt gesteld, heeft de minister van Buitenlandse zaken er enige tijd geleden bij de minister van Justitie op aangedrongen ervoor te zorgen dat deze situatie snel zal verbeteren. De tijd en vooral ook toekomstige rechtspraak van het Europese Hof zal moeten uitwijzen of dit ook daadwerkelijk gebeurt.

\section{Deel II: Verschoningsrecht}

\section{Inleiding}

Dat de Poolse advocaat alle informatie die hij tijdens het uitoefenen van zijn functie verneemt geheim dient te houden, is vastgelegd in de Advocatenwet en de voor de advocatuur geldende gedragsregels. ${ }^{152}$ In art. 6 lid 1 Advocatenwet is bepaald dat de advocaat verplicht is 'alles geheim te houden, wat hij tijdens het verlenen van rechtsbijstand heeft vernomen' en art. 19 lid 1 van de gedragsregels bevat de verplichting 'geheim te houden alsmede te beveiligen tegen openbaring en ongewenst gebruik, alles wat de advocaat in verband met het uitvoeren van zijn professionele verplichtingen heeft vernomen'. ${ }^{153}$ Het gebruik van het woord

151 Zie Chicoń 2004.

152 Zie uitgebreid over de gedragsregels: hoofdstuk 8, § 4 .

153 Interessant aan deze formulering is dat de advocaat ook een inspanningsverplichting wordt opgelegd: hij moet niet alleen nalaten vertrouwelijke informatie vrij te geven maar dient ook 'te beveiligen tegen openbaring'. Van hem wordt dus verwacht dat hij zich actief inzet voor bescherming van het beroepsgeheim. De volledige tekst van beide be- 
'alles' ('wszystko') in beide bepalingen maakt duidelijk dat het beroepsgeheim zich uitstrekt over alle informatie - ongeacht de bron - die een advocaat bij het verrichten van zijn werkzaamheden verkrijgt. Niet naleving van deze verplichting is niet alleen in tuchtrechtelijk maar ook in strafrechtelijk opzicht relevant: schending van het beroepsgeheim is strafbaar gesteld. ${ }^{154}$

Voor een effectieve bescherming van het beroepsgeheim is echter meer nodig dan het vastleggen van een geheimhoudingsplicht. Voorkomen moet worden dat een advocaat kan worden gedwongen als getuige of op andere wijze informatie vrij te geven die hij in de uitoefening van zijn functie heeft verkregen. Vandaar dat in het Poolse strafprocesrecht aan de advocaat ${ }^{155}$ een professioneel verschoningsrecht is toegekend. Op grond van dit verschoningsrecht kan de advocaat zijn geheimhoudingsplicht ook ten opzichte van de rechter handhaven en wordt een uitzondering gemaakt op de getuigplicht die in beginsel op iedere burger rust.

palingen luidt als volgt. Art. 6 Advocatenwet: '1. Een advocaat is verplicht alles geheim te houden wat hij tijdens het verlenen van rechtsbijstand heeft vernomen. 2 . De professionele geheimhoudingsplicht kan niet in tijd worden beperkt. 3. Een advocaat kan niet worden ontheven van zijn verplichting feiten geheim te houden die hij heeft vernomen tijdens het verlenen van rechtsbijstand of tijdens de behandeling van een zaak.'

Art. 19 gedragsregels: '1. Een advocaat is verplicht alle informatie die hij tijdens het uitoefenen van zijn functie verkrijgt geheim te houden en veilig te stellen dat dergelijke informatie niet openbaar wordt of onrechtmatig wordt gebruikt. 2. Stukken en informatie die deel uitmaken van de dossiers van een advocaat zijn vertrouwelijk. 3 . Alle informatie, aantekeningen en documentatie met betrekking tot een zaak die zijn verkregen van een cliënt of een derde blijven - ongeacht waar ze worden bewaard vertrouwelijk. 4. Een advocaat dient er zorg voor te dragen dat zijn collega's en andere medewerkers die door hem zijn aangenomen de vertrouwelijkheid van zijn beroepsgeheim in acht zullen nemen. 5. Een advocaat die gebruik maakt van een computer of andersoortige elektronische apparatuur voor het opslaan van gegevens dient software en andere maatregelen te hanteren die voorkomen dat de gegevens worden geopenbaard. 6. De elektronische overdracht van informatie vereist bijzondere zorg en maakt het noodzakelijk dat de cliënt wordt geïnformeerd over het gevaar van openbaarmaking dat met het gebruik van dergelijke middelen gepaard gaat. 7 . De geheimhoudingsplicht is niet in tijd beperkt. 8. Een advocaat is niet gerechtigd de rechtbank te voorzien van bewijs in de vorm van een verklaring van een getuige die ofwel een advocaat ofwel een juridisch adviseur is teneinde informatie openbaar te maken die tijdens het verrichten van zijn/haar professionele verplichtingen is verkregen.'

154 Art. 266 lid 1 KK 1997. In deze bepaling wordt overigens geen specifieke aandacht besteed aan de professionele geheimhouder die als getuige in een strafzaak zijn beroepsgeheim schendt. Ook is nergens met zoveel woorden bepaald dat een getuige voorafgaand aan zijn verhoor op de hoogte moet worden gesteld van de mogelijkheid strafbaar te zijn op grond van art. $266 \mathrm{KK}$. Sommige auteurs zijn van mening dat iemand niet strafrechtelijk mag worden vervolgd voor schending van zijn beroepsgeheim wanneer vertrouwelijke informatie wordt vrijgegeven tijdens het afleggen van een verklaring in de hoedanigheid van getuige. Volgens deze redenering dient het optreden als getuige een groter maatschappelijk belang dat niet tegelijkertijd als schadelijk voor de samenleving (en dus strafwaardig) kan worden aangemerkt. Zie hierover: Sowiński 2004, p. 159-160.

155 En een aantal andere professionele geheimhouders waaronder juridisch adviseurs, notarissen, artsen, journalisten en geestelijken. 


\section{Horen advocaat als getuige}

Op grond van art. 180 lid 1 KPK 1997 geldt de hoofdregel dat eenieder die verplicht is een ambts- of beroepsgeheim te bewaren, mag weigeren als getuige een verklaring af te leggen over de omstandigheden waarover zijn geheimhoudingsplicht zich uitstrekt. Hoewel dit artikellid regelt dat degene die verplicht is een beroepsgeheim te bewaren, $m a g$ (' $m \circ g q^{\prime}$ ') weigeren te verklaren wanneer datgene waarover hij wordt ondervraagd onder zijn beroepsgeheim valt, blijkt uit de Advocatenwet en de gedragsregels dat de advocaat hiertoe gehouden is. ${ }^{156}$ Strafvorderlijk heeft de advocaat dus het recht geen verklaring af te leggen, gedragsrechtelijk is hij daartoe verplicht.

Dit betekent echter niet dat een advocaat in geen enkel geval als getuige kan worden gehoord over feiten of omstandigheden die onder zijn professionele geheimhoudingsplicht vallen. In de regeling van het verschoningsrecht is voorbehouden dat de geheimhoudingsplicht onder bepaalde omstandigheden door de justitiële autoriteiten kan worden opgeheven. Voor het antwoord op de vraag onder welke voorwaarden dit ten aanzien van advocaten mogelijk is, dient onderscheid te worden gemaakt tussen het absolute verschoningsrecht van de advocaat die als raadsman rechtsbijstand aan een verdachte heeft verleend (obrońca) en het relatieve (of voorwaardelijke) verschoningsrecht van de advocaat die niet als verdediger in een strafzaak is opgetreden (adwokat).

\subsection{Het absolute verschoningsrecht van de raadsman}

Op grond van art. 178 sub 1 KPK 1997 geldt dat niet als getuige mag worden gehoord 'een raadsman (obrońca) of een advocaat die optreedt op grond van art. 245 lid 1 KPK 1997 'voor zover het gaat om feiten die hij heeft vernomen 'tijdens het verlenen van rechtsbijstand of de behandeling van een zaak'. ${ }^{157}$ Gezien de absolute formulering van deze bepaling - die als instructienorm tot justitiële autoriteiten is gericht - zijn op dit verbod geen uitzonderingen mogelijk. Een advocaat mag dus nooit worden gedwongen te verklaren over feiten of omstandigheden waarvan hij tijdens zijn werk als raadsman in een strafzaak kennis heeft genomen. ${ }^{158}$

Het is overigens pas sinds de wetswijziging van 2003 dat bovengenoemde regel zich ook uitstrekt over de advocaat die op basis van art. 245 lid 1 KPK 1997 rechts-

156 Zowel art. 6 lid 1 Advocatenwet als art. 19 lid 1 van de gedragsregels beginnen immers met de woorden 'De advocaat is verplicht' ('Adwokat obowiazany jest').

157 Het verbod heeft kennelijk uitsluitend betrekking op informatie die hij verkrijgt tijdens de uitoefening van zijn functie en strekt zich dus niet uit over kennis die hij 'privé' opdoet wanneer hij niet aan het werk is als rechtsbijstandverlener.

158 In dit verband dient de eerder in dit hoofdstuk genoemde rechterlijke uitspraak - waarin is bepaald dat degene die in het kader van art. 73 lid 2 KPK 1997 als toezichthouder bij een gesprek tussen raadsman en verdachte aanwezig is geweest niet als getuige mag worden gehoord over de inhoud van dit overleg - in herinnering te worden geroepen. De rechter baseerde zijn standpunt namelijk op de overweging dat wanneer het horen van de toezichthouder als getuige wel zou worden toegestaan het verbod van art. 178 sub 1 KPK 1997 (in strijd met de bedoeling van de wetgever) zou kunnen worden omzeild. De informatie die men niet van de raadsman mag verkrijgen, zou dan immers eenvoudig via deze andere weg kunnen worden verkregen wat in strijd zou zijn met het absolute karakter van het in art. 178 sub 1 KPK 1997 neergelegde verschoningsrecht. Uitspraak van 25 november 1993, SA Krakau (KZS 11994, nr. 1, 30), genoemd in Kwiatkowski 2005, p. 169. 
bijstand verleent aan een aangehouden - nog niet als verdachte aangemerkte persoon. Een advocaat die rechtsbijstand verleent in de fase van politiedetentie krijgt pas de status van 'raadsman' ('obrońca') wanneer zijn cliënt formeel als verdachte (podejrzany) is aangemerkt. ${ }^{159}$ Aangezien art. 178 sub 1 KPK 1997 voor de wetswijziging van 2003 alleen de raadsman noemde, was het volgens de wet wel mogelijk een advocaat als getuige te horen over feiten die hij bij het verlenen van rechtsbijstand op grond van art. 245 lid 1 KPK 1997 in het vroegste stadium van een strafzaak had vernomen. In 2003 is het eerste lid van art. 178 sub 1 KPK 1997 aangevuld met de woorden 'of een advocaat die optreedt op grond van art. 245 lid $1 \mathrm{KPK}^{\prime}$ waardoor de absolute bescherming van het verschoningsrecht voortaan onverkort geldt voor de advocaat die vanwege een formaliteit weliswaar (nog) niet als raadsman kan worden aangemerkt maar deze functie feitelijk wel vervult. ${ }^{160}$ Hierbij dient te worden opgemerkt dat het voor de bescherming op grond van art. 178 KPK 1997 niet relevant is of de advocaat later in de procedure ook daadwerkelijk als raadsman van de betreffende verdachte optreedt: ook wanneer de rechtsbijstandverlener alleen in de eerste fase na aanhouding actief is, komt hem het absolute verschoningsrecht toe. ${ }^{161}$

Niet duidelijk is of het bepaalde in art. 178 sub 1 KPK 1997 ook 'verbiedt' dat de daar genoemde personen als getuige worden opgeroepen. Hierover wordt verschillend gedacht: Grzegorczyk is bijvoorbeeld van mening dat dit inderdaad het geval is en dat de raadsman dus niet hoeft te reageren op een dergelijke oproep om als getuige te verschijnen. ${ }^{162}$ Anderen - zoals Hofmański en Sowiński - betogen dat de bepaling slechts regelt dat de raadsman niet hoeft te verklaren over bepaalde feiten. Volgens deze redenering is de raadsman als ieder ander verplicht om te verschijnen wanneer hij als getuige wordt opgeroepen. ${ }^{163}$ Wanneer de letterlijke tekst van art. 178 sub 1 KPK 1997 als uitgangspunt wordt genomen, lijkt deze laatste (beperkte) interpretatie de juiste te zijn. De bepaling regelt immers niet dat de raadsman niet als getuige mag worden opgeroepen maar 'slechts' dat het niet is toegestaan hem in de hoedanigheid van getuige te verhoren (przestuchiwać) over feiten die onder zijn geheimhoudingsplicht vallen.

159 Zie hoofdstuk 4, § 2.2.2.2

160 Voor genoemde wetswijziging werd de beperkte bescherming van het beroepsgeheim van de advocaat die in het kader van art. 245 lid 1 KPK 1997 rechtsbijstand heeft verleend, bekritiseerd in de literatuur: Ludwiczek 2001, p. 109-116. Over de ratio van de wetswijziging: Hofmański e.a. 2007 I, p. 815-816.

161 Sowiński 2004, p. 169.

162 Grzegorczyk 2004, p. 468. Deze mening wordt onder meer gedeeld door Hofmański: zie Hofmański e.a. 2007 I, p. 815.

163 Eenieder die wordt opgeroepen als getuige is verplicht te verschijnen en om een verklaring af te leggen (art. 177 lid $1 \mathrm{KPK}$ ). Pas op het moment dat datgene waarover hij wordt ondervraagd onder zijn professionele geheimhoudingsplicht valt, kan hij zich op zijn wettelijke verschoningsrecht beroepen. Wanneer van te voren al duidelijk is dat datgene waarover de raadsman zal moeten getuigen (volledig) onder zijn beroepsgeheim valt, dienen de autoriteiten volgens Sowiński wel af te zien van het oproepen van de raadsman: Sowiński 2004, p. 26-28. Zie hierover ook: Kwiatkowski 2005, p. 168-169. 


\subsection{Het relatieve verschoningsrecht van de advocaat}

Voor feiten en omstandigheden die niet samenhangen met het optreden als raadsman of als advocaat op grond van art. 245 lid 1 KPK 1997 geldt een apart regime. Het gaat in dit soort gevallen natuurlijk in de eerste plaats om optreden in niet-strafrechtelijke procedures maar dat hoeft niet altijd het geval te zijn. Advocaten die in een strafzaak niet de verdachte maar bijvoorbeeld de private aanklager of het slachtoffer bijstaan, doen dat ook niet in de hoedanigheid van 'raadsman' en vallen dus ook onder de hierna te noemen regeling.

Voor de advocaat niet zijnde raadsman geldt art. 180 KPK 1997 waarvan het eerste lid de mogelijkheid introduceert dat een geheimhoudingsplicht die verbonden is aan een bepaald ambt of beroep door de rechtbank of prokurator kan worden opgeheven. ${ }^{164}$ Dit is ten aanzien van een aantal beroepsgroepen - waaronder de advocatuur - uitgewerkt in art. 180 lid 2 eerste zin KPK 1997. ${ }^{165}$ Daar is bepaald dat een advocaat als getuige kan worden gehoord over zaken die onder zijn beroepsgeheim vallen wanneer

1. dat 'noodzakelijk is voor een behoorlijke rechtspleging' ('niezbędne dla dobra wymiaru sprawiedliwości') en

2. de feiten niet op basis van ander bewijsmateriaal kunnen worden vastgesteld.

Deze beslissing tot opheffing van de geheimhoudingsplicht van de advocaat kan alleen worden genomen door de rechtbank. ${ }^{166}$ Tegen de beslissing van de rechtbank - die wordt genomen op een zitting waaraan partijen niet kunnen deelnemen - staat bezwaar (zażalenie) open. ${ }^{167}$ Wanneer een advocaat na toepassing van deze mogelijkheid tot opheffing van zijn geheimhoudingsplicht als getuige wordt gehoord, gebeurt dat op een besloten (niet voor het publiek toegankelijke) zitting. ${ }^{168}$

Als een advocaat zich - na bovengenoemde opheffing van zijn geheimhoudingsplicht - blijft beroepen op zijn professionele verschoningsrecht en weigert een verklaring af te leggen, kunnen bepaalde maatregelen tegen hem worden genomen. In het wetboek van strafvordering is een aantal sancties opgenomen die kunnen worden opgelegd aan procesdeelnemers die hun procedurele verplichtingen niet nakomen. ${ }^{169}$ De getuige die 'zonder rechtvaardiging weigert te verschijnen' of 'zonder toestemming van het orgaan dat de procedure leidt, verdwijnt voordat

164 'Personen met een professionele geheimhoudingsplicht (...) mogen weigeren een verklaring af te leggen over omstandigheden waarover die verplichting zich uitstrekt, tenzij de geheimhoudingsplicht door de rechtbank of de prokurator is opgeheven.'

165 De regeling van art. 180 lid 2 KPK 1997 is behalve op advocaten ook van toepassing op notarissen, juridisch adviseurs, artsen en journalisten.

166 De in art. 180 lid 1 KPK 1997 genoemde mogelijkheid dat het beroepsgeheim ook kan worden opgeheven door de prokurator geldt dus niet ten aanzien van de in lid 2 genoemde beroepsgroepen. Wanneer de prokurator het gedurende het vooronderzoek noodzakelijk vindt een advocaat als getuige te horen over feiten die onder zijn beroepsgeheim vallen, zal hij daartoe een verzoek moeten indienen bij de rechtbank die daarop binnen een termijn van zeven dagen een beslissing moet nemen.

167 Art. 180 lid 2 tweede en derde zin KPK 1997. Zie over dit rechtsmiddel: Stefański 1998 II, p. 119-120 en Hofmański e.a. 2007 I, p. 828.

168 Art. 181 lid 1 KPK 1997.

169 Deze zijn geregeld in hoofdstuk 31 van het wetboek van strafvordering getiteld 'disciplinaire straffen'('kary porządkowe'). 
de procedure is beëindigd' kan een geldboete van maximaal 3000 złotych (circa 760 euro) worden opgelegd. ${ }^{170}$ De geldboete kan ook worden opgelegd wanneer een getuige zonder rechtvaardiging weigert te verklaren. De getuige die na het opleggen van een boete nog steeds weigert te spreken, kan ten slotte maximaal dertig dagen in hechtenis worden genomen. ${ }^{171}$ Aangezien in deze regeling geen onderscheid wordt gemaakt naar het soort getuige kunnen alle bovengenoemde maatregelen in beginsel ook worden toegepast op de advocaat die weigert voor de rechtbank te verschijnen of zich blijft beroepen op zijn professionele verschoningsrecht. Het Hooggerechtshof heeft echter wel bepaald dat ten aanzien van professionele geheimhouders terughoudend moet worden omgesprongen met de (ingrijpende) mogelijkheid een weigerachtige getuige in hechtenis te nemen. ${ }^{172}$

Formeel bevindt de advocaat zich als getuige in ieder geval in een lastig parket: wanneer hij een verklaring aflegt, handelt hij in beginsel in strijd met de gedragsregels met alle mogelijke tuchtrechtelijke gevolgen van dien. Wanneer hij niet verklaart, kunnen hem strafvorderlijk sancties worden opgelegd. Bovendien is onder bepaalde omstandigheden zelfs een strafvervolging tegen de advocaat mogelijk: niet uitgesloten is dat de weigering te getuigen wordt aangemerkt als obstructie van het strafproces wanneer een verdachte daardoor tegen vervolging of veroordeling wordt beschermd. ${ }^{173}$

\subsection{Situatie voor inwerkingtreding nieuw strafprocesrecht}

Het verschoningsrecht van de advocaat was op grond van het oude wetboek van strafvordering in grote lijnen op dezelfde wijze geregeld als in het huidige strafprocesrecht. Slechts op een aantal punten bestaan noemenswaardige verschillen.

Ten aanzien van de advocaat die niet als raadsman kon worden aangemerkt, gold het algemene en summiere art. 163 KPK 1969 (huidig art. 180 KPK 1997) waarin was bepaald dat:
'personen die een professionele geheimhoudingsplicht hebben (...) mogen weigeren te ver- klaren over feiten waarover deze verplichting zich uitstrekt, tenzij hun geheimhoudings- plicht door de prokurator of de rechtbank is opgeheven'.

Een eerste verschil met de huidige regeling is dat de geheimhoudingsplicht overeenkomstig deze bepaling zowel door de prokurator (gedurende het vooronderzoek) als door de rechtbank (na aanvang van het onderzoek ter terechtzitting) kon worden opgeheven. Tijdens het vooronderzoek kon de prokurator hierover dus zelfstandig een beslissing nemen zonder tussenkomst van de rechtbank.

Ten tweede was de bevoegdheid van de prokurator en de rechtbank om de geheimhoudingsplicht van een advocaat op te heffen en hem als getuige te horen in de

170 Bovendien kan in beide situaties de aanhouding en gedwongen medebrenging van de getuige worden bevolen (art. 285 lid 1 en lid 2 KPK 1997).

171 Art. 287 lid 1 en 2 jo. art. 285 lid 1 KPK 1997.

172 Uitspraak van 19 januari 1995 (I KZP 15/94, OSNKW 1-2/1995, 1). Deze zaak betrof een journalist die werd gedwongen als getuige op te treden maar aangenomen mag worden dat de opmerking van het Hooggerechtshof voor alle professionele verschoningsgerechtigden - en dus ook voor de advocaat - geldt.

173 Strafbaar gesteld in art. 239 KK. Zie Sowiński 2004, p. 165-166. 
regeling van 1969 aan geen enkele voorwaarde verbonden: het was dus in beginsel in alle gevallen en onder alle omstandigheden mogelijk. ${ }^{174}$

Ten derde is van belang dat de advocaat op grond van het oude strafprocesrecht geen rechtsmiddel kon instellen tegen de beslissing van de prokurator of de rechtbank tot opheffing van de geheimhoudingsplicht: het huidige wetboek van strafvordering biedt deze mogelijkheid wel.

Ook het oude stafprocesrecht voorzag in de mogelijkheid de weigerachtige (advocaat-)getuige een geldboete op te leggen of in hechtenis te nemen. ${ }^{175}$

Voor de raadsman (obrońca) gold op grond van art. 161 KPK 1969 (huidig art. 178 KPK 1997) op dezelfde wijze als vandaag de dag dat hij niet als getuige kon worden gehoord over feiten die hij bij het uitoefenen van zijn functie had vernomen. Het enige - maar niettemin belangrijke - verschil met de huidige regeling op dit punt is dat sinds 2003 ook feiten waarvan een advocaat kennis neemt wanneer hij in het kader van art. 245 lid 1 KPK 1997 in de eerste fase na aanhouding optreedt op gelijke wijze worden beschermd. ${ }^{176}$

\subsection{Evaluatie juridisch kader}

De bescherming van het beroepsgeheim is in de huidige regeling van het verschoningsrecht op een aantal punten verbeterd. Positief zijn de volgende wijzigingen:

- Het absolute verschoningsrecht van de raadsman is sinds 2003 ook van toepassing op de advocaat die in het kader van art. 245 lid 1 KPK 1997 (in de eerste fase na aanhouding) rechtsbijstand heeft verleend.

- Voordat een advocaat als getuige kan worden gehoord over feiten die onder zijn beroepsgeheim vallen, dient te allen tijde toestemming te worden verleend door de rechtbank: de prokurator heeft op dit punt geen zelfstandige beslissingsbevoegdheid meer. ${ }^{177}$

174 In de literatuur werd overigens wel bepleit dat het horen van de advocaat alleen in bepaalde gevallen zou mogen plaatsvinden. Kaftal was bijvoorbeeld van mening dat de geheimhoudingsplicht slechts kon worden opgeheven wanneer 1) de vereiste gegevens niet op andere wijze konden worden vastgesteld, 2) de inhoud van de verklaring betrekking had op de schuldvraag 3) en het maatschappelijk gevaar dat met het strafbaar feit gepaard ging, zo groot was dat de inbreuk op het beroepsgeheim van de advocaat erdoor kon worden gerechtvaardigd: Kaftal 1965. Łojewski vond dat het opheffen van de geheimhoudingsplicht van de advocaat vooral gerechtvaardigd was wanneer met de inhoud van de verklaring de onschuld van een verdachte zou kunnen worden aangetoond: Łojewski 1967.

175 Art. 242 lid 1 jo. 244 lid 1 en 2 KPK 1969. Het uiteindelijke horen van de advocaat wiens geheimhoudingsplicht officieel was opgeheven, vond eveneens plaats op een nietopenbare zitting (art. 164 lid 1 KPK 1969).

176 Dit neemt echter niet weg dat reeds voor de inwerkingtreding van het nieuwe wetboek van strafvordering en dus ook voor genoemde uitbreiding van het verschoningsrecht van de raadsman in de literatuur een ruime invulling werd gegeven aan art. 161 KPK 1969. Zo waren Ereciński en Płachta van mening dat het absolute verschoningsrecht ook kon worden ingeroepen wanneer rechtsbijstand was verleend aan iemand die nog niet formeel (als verdachte of beschuldigde) bij een strafzaak was betrokken: Ereciński en Płachta 1985, p. 130.

177 Dit is positief omdat de prokurator als leider van het vooronderzoek (te) veel belang heeft bij het laten plaatsvinden van het verhoor en zich dus moeilijker een objectief en onpartijdig oordeel zal kunnen vormen over de noodzaak de geheimhoudingsplicht in een concreet geval op te heffen. Murzynowski heeft hierover terecht opgemerkt dat de bevoegdheid die 
- Tegen de beslissing van de rechtbank de geheimhoudingsplicht van de advocaat op te heffen, kan voortaan bezwaar worden ingesteld bij een hogere rechter.

- Het uitzonderlijke karakter van deze inbreuk op het beroepsgeheim is in het nieuwe wetboek van strafvordering meer benadrukt door in art. 180 lid 2 KPK 1997 op te nemen dat het slechts mogelijk is wanneer dat 'noodzakelijk is voor een behoorlijke rechtspleging' (1) en de informatie die men wenst te verkrijgen niet op basis van ander bewijsmateriaal kan worden verkregen (2).

Op laatstgenoemd punt kan echter ook kritiek worden uitgeoefend. Vergeleken met de (veel te) ruime regeling van 1969 dient in beginsel iedere precisering als verbetering te worden beschouwd maar dit neemt niet weg dat de door de wetgever gekozen formulering voor wat betreft het eerste criterium te wensen overlaat. De woorden 'noodzakelijk voor een behoorlijke rechtspleging' zijn immers uiterst vaag en laten veel beoordelingsvrijheid aan de rechter. ${ }^{178}$ Duidelijk is dat de wetgever hiermee heeft willen aangeven dat het horen van de advocaat (een van) de doelstellingen van het strafproces zal moeten dienen maar het onderscheidend vermogen - en dus ook de toegevoegde waarde - van dit criterium lijkt beperkt: immers, wanneer een advocaat die bijvoorbeeld een slachtoffer heeft bijgestaan over informatie beschikt die van wezenlijk belang is voor de waarheidsvinding in een bepaalde zaak zal al snel aan deze voorwaarde zijn voldaan. Ook het tweede criterium roept vragen op. Er mag vanuit worden gegaan dat de rechtbank in de meeste gevallen niet van te voren weet waarvan de advocaat precies kennis heeft en waarover hij tijdens zijn verhoor als getuige zal gaan verklaren. Onduidelijk is hoe in deze omstandigheden kan worden beoordeeld of deze feiten niet (ook) op andere wijze zouden kunnen worden vastgesteld.

\subsection{Verhouding art. 180 KPK 1997 en art. 6 Advocatenwet}

Het absolute karakter van de in art. 6 lid 1 Advocatenwet neergelegde verplichting ('De advocaat is verplicht alles geheim te houden wat hij in verband met het verlenen van rechtsbijstand heeft vernomen') wordt nogmaals bevestigd door het vervolg van deze bepaling waarin is vastgelegd dat de professionele geheimhoudingsplicht niet in tijd kan worden beperkt (lid 2) en dat de advocaat niet kan worden bevrijd van zijn geheimhoudingsplicht ten aanzien van feiten die hij tijdens het verlenen van rechtsbijstand of de behandeling van een zaak heeft vernomen (lid 3). Het moge duidelijk zijn dat deze bepaling en met name laatstgenoemd derde lid moeilijk verenigbaar is met de in het voorgaande beschreven mogelijkheid van art. 180 lid 2 KPK 1997 de geheimhoudingsplicht van advocaten onder bepaalde omstandigheden toch op te heffen.

\subsubsection{Standpunten literatuur}

De tegenstrijdigheid die de Advocatenwet en het strafprocesrecht op dit punt vertonen, zorgt al tientallen jaren voor een levendige discussie in de juridische literatuur. De kwestie speelde reeds ten tijde van het eerste Poolse wetboek van

de prokurator op grond van het oude strafprocesrecht in dit verband had het evenwicht in de verhouding tussen advocaat en openbaar aanklager in ernstige mate verstoorde en een negatieve invloed had op de positie van de raadsman in het strafproces: Murzynowski 1994, p. 56.

178 Het criterium 'noodzakelijk voor een behoorlijke rechtspleging' wordt ook in de Poolse literatuur vanwege zijn vaagheid bekritiseerd: Sowiński 2004, p. 212. 
strafvordering van 1928: ook toen bevatte het strafprocesrecht een bepaling die het mogelijk maakte dat een advocaat als getuige kon worden gehoord terwijl de wetgeving van de balie in een absolute geheimhoudingsplicht voorzag. ${ }^{179}$ Twistpunt in de doctrine betreft de vraag welke bepaling volgens het aloude adagium lex specialis derogat legis generale nu voorrang behoort te krijgen. Een aanzienlijke groep auteurs is van mening dat de bepaling uit het strafprocesrecht bijzonder is ten opzichte van het meer algemene artikel over het beroepsgeheim uit de Advocatenwet. ${ }^{180}$ Op grond van deze redenering dient art. 180 lid 2 KPK 1997 voorrang te krijgen op het bepaalde in art. 6 Advocatenwet zodat het - in de door de wet bepaalde omstandigheden - wel degelijk mogelijk is een advocaat als getuige te horen over feiten die hij bij het uitoefenen van zijn functie heeft vernomen.

Een tegenovergesteld standpunt wordt onder anderen vertegenwoordigd door Krzemiński. ${ }^{181}$ Hij betoogt al decennia lang dat de bepaling uit de Advocatenwet waarin het beroepsgeheim absoluut wordt geformuleerd voorrang dient te krijgen op de regeling van het verschoningsrecht in het wetboek van strafvordering. ${ }^{182}$ Zijn voornaamste argument hiervoor is dat de regel uit de Advocatenwet slechts tot de advocatuur is gericht waardoor deze ten opzichte van de bepalingen uit het wetboek van strafvordering - die een veel ruimer bereik hebben - als bijzonder (lex specialis) moet worden aangemerkt. Volgens deze redenering is het nooit toegestaan een advocaat als getuige te horen over feiten die onder zijn geheimhoudings. plicht vallen. ${ }^{183}$

\subsubsection{Standpunt advocatuur}

Het zal niet verbazen dat de balie in deze discussie hetzelfde standpunt inneemt als Krzemiński: zij gaat ervan uit dat het beroepsgeheim van de advocaat te allen tijde absoluut is en dat uitzonderingen in de zin van art. 180 lid 2 KPK 1997 dus niet mogelijk zijn. Dat blijkt onder meer uit het feit dat de interne regelgeving op dit punt nooit is aangepast: in zowel de Advocatenwet als de gedragsregels blijft de formulering van de geheimhoudingsplicht absoluut en in geen van beide rege-

179 Het betrof respectievelijk art. 92 lid 1 KPK 1928 en art. 53 Advocatenwet 1950 (later art. 7 Advocatenwet 1963).

180 Zie bijvoorbeeld Hofmański e.a. 2007 I, p. 830.

181 Advocaat en een van de voornaamste auteurs op het gebied van de advocatuur en haar beroepsethiek.

182 Zie bijvoorbeeld Krzemiński 1959, p. 31-39 en Krzemiński 1994, p. 66-70 waarin hij stelt dat wanneer wordt toegestaan dat de geheimhoudingsplicht wordt opgeheven, de advocaat 'kroongetuige' tegen - en daarmee de grootste vijand van - zijn eigen cliënt kan worden wat het grondwettelijk recht op verdediging tot een dode letter zou maken (p. 66). Meer recent: Krzemiński 1998, p. 34 en Krzemiński 2003, p. $93-99$ waarin de auteur opnieuw vurig betoogt dat op het beroepsgeheim van de advocaat geen uitzonderingen mogen worden gemaakt: zoals er volgens Krzemiński geen halve waarheid bestaat, kan ook geen sprake zijn van een half - lees: voorwaardelijk - beroepsgeheim (p. 99).

183 Het standpunt van Krzemiński is niet zonder kritiek gebleven. Zo is Kwiatkowski - aanhanger van eerstgenoemd standpunt dat art. 180 lid 2 KPK 1997 voorrang heeft op art. 6 van de Advocatenwet - van mening dat Krzemiński een verkeerde maatstaf hanteert bij beantwoording van de vraag welke regel lex specialis is. Volgens hem is namelijk niet doorslaggevend tot hoeveel personen een bepaalde norm zich richt maar dient uit te worden gegaan van de meer abstracte vraag welke bepaling de uitzondering op de regel formuleert: Kwiatkowski 2005, p. 211. 
lingen is ooit een verwijzing opgenomen naar de strafvorderlijke mogelijkheid om de geheimhoudingsplicht van de advocaat op te heffen. Bovendien heeft de Hoogste Raad van de balie in het verleden officieel bevestigd dat de geheimhoudingsplicht van de advocaat een absoluut karakter heeft en noch door de rechtbank noch door de prokurator kan worden opgeheven. ${ }^{184}$ Deze stellingname van de advocatuur wordt door sommige auteurs onrealistisch gevonden. Zo is volgens Sowiński het absolute karakter van het beroepsgeheim van de advocaat niet meer dan een idée fixe van de balie. Hij is van mening dat de interne regelgeving van de advocatuur op een aantal punten overduidelijk in strijd is met art. 180 lid 2 KPK 1997 en derhalve aanpassing behoeft. ${ }^{185}$

\subsubsection{Standpunt rechtspraak}

In de jaren negentig heeft het Hooggerechtshof - op verzoek van de toenmalige minister van Justitie - getracht meer helderheid te verschaffen in bovengenoemde problematiek. In een uitspraak van juni 1994 heeft het Hof in dit verband aansluiting gezocht bij het door de wetgever gehanteerde onderscheid tussen raadsman (obrońca) en advocaat (adwokat) en benadrukt dat een advocaat nooit als getuige mag worden gehoord over feiten die hij als raadsman tijdens het verlenen van rechtsbijstand of de behandeling van een zaak heeft vernomen. ${ }^{186}$ Voor de advocaat die niet als raadsman is opgetreden, geldt dat hij mag weigeren te verklaren over omstandigheden die onder zijn geheimhoudingsplicht vallen, tenzij de rechtbank of prokurator hem van deze geheimhoudingsplicht bevrijdt. Dat laatste was ten tijde van de uitspraak mogelijk op grond van art. 163 KPK 1969: het huidige art. 180 KPK 1997. ${ }^{187}$ Het Hooggerechtshof oordeelt dat art. 163 KPK 1997 als lex specialis voorrang dient te krijgen op art. 6 Advocatenwet omdat laatstgenoemde regel zich tot alle advocaten richt terwijl de strafvorderlijke bepaling slechts betrekking heeft op een beperkte groep advocaten (zij die niet als raadsman kunnen worden aangemerkt) en op de bijzondere situatie dat men een advocaat als getuige in een strafzaak wenst te horen. Het Hof benadrukt daarbij wel dat autoriteiten terughoudend gebruik dienen te maken van hun bevoegdheid de geheimhoudingsplicht van advocaten op te heffen: dit mag slechts gebeuren wanneer de te ver-

184 Besluit NRA (Naczelna Rada Adwokacka: Hoogste Raad van de balie) van 12 december 1993. Dit was overigens niet de eerste keer dat de balie dit gezichtspunt verkondigde: gelijkluidende besluiten waren eerder genomen in 1934 en 1958. Rond de helft van de jaren zestig heeft de beroepsorganisatie - volgens Krzemiński onder druk van het communistisch regime - eenmalig een meer gematigd standpunt ingenomen: in haar besluit van oktober 1966 oordeelde de Hoogste Raad van de balie dat een advocaat als getuige kon worden gehoord wanneer zijn geheimhoudingsplicht door rechtbank of prokurator was opgeheven. Met het besluit van 1993 is weer teruggekeerd naar het oude standpunt dat iedere uitzondering op het beroepsgeheim van de advocaat ontoelaatbaar moet worden geacht: Krzemiński 1998, p. 28-31 en Krzemiński 2003, p. 90-92.

185 Sowiński 2004, p. 175-176.

186 Uitspraak van 16 juni 1994 (I KZP 5/94, OSNKW 1994, nr. 7-8, 41).

187 Interessant detail is dat de voorzitter van de kamer van het Hooggerechtshof die uitspraak heeft gedaan in bovengenoemde zaak - Murzynowski - in een van zijn wetenschappelijke bijdragen ervoor heeft gepleit art. 163 KPK 1969 zodanig aan te passen dat de mogelijkheid de geheimhoudingsplicht op te heffen, beperkt zou worden tot bepaalde categorieën strafbare feiten en bovendien tot de exclusieve bevoegdheid van de rechtbank zou gaan behoren: Gajewska-Kraczkowska 2006, p. 199. 
krijgen verklaring 'onmisbaar is voor de totstandkoming van een juiste uitspraak in de betreffende zaak'. Deze toevoeging was van belang omdat de bevoegdheid van de rechtbank en prokurator om de geheimhoudingsplicht op te heffen op grond van het destijds geldende strafprocesrecht aan geen enkele nadere voorwaarde was verbonden. 188

Tien jaar later - in 2004 - heeft het Grondwettelijk Hof zich gebogen over de vraag of art. 180 lid 2 KPK 1997 verenigbaar is met de Grondwet. ${ }^{189}$ Aanleiding voor deze zaak was een klacht van vier juridisch adviseurs ${ }^{190}$ die waren opgeroepen om te getuigen in een strafzaak tegen de directeur van een onderneming die ze van juridisch advies hadden voorzien (de zogenaamde Optimus-zaak). Nadat de geheimhoudingsplicht van de juridisch adviseurs overeenkomstig art. 180 lid 2 KPK 1997 door de rechtbank was opgeheven en deze beslissing - naar aanleiding van een door de juridisch adviseurs ingesteld bezwaar - door de hogere rechter in stand werd gehouden, bleven de vier juristen weigeren te getuigen. Als reactie hierop werd tegen hen strafvervolging ingesteld wegens obstructie van het strafproces. ${ }^{191}$ Deze procedure is uiteindelijk voortijdig beëindigd en heeft dus niet tot een veroordeling geleid maar de juridisch adviseurs benadrukten in hun klacht bij het Grondwettelijk Hof dat het nog altijd mogelijk was dat zij door toepassing van strafvorderlijke sancties (geldboete of hechtenis) alsnog zouden worden gedwongen om een verklaring af te leggen. Hun klacht dat art. 180 lid 2 KPK 1997 strijd oplevert met de Grondwet ${ }^{192}$ werd gesteund door de nationale Ombudsman die onder meer betoogde dat de wettelijke criteria voor het opheffen van de geheimhoudingsplicht - het feit dat het horen van de geheimhouder noodzakelijk moet zijn voor een behoorlijke rechtspleging en dat het bewijs niet op andere wijze moet kunnen worden verkregen - onvoldoende duidelijk zijn en in de praktijk tot willekeur kunnen leiden. Het Grondwettelijk Hof was echter niet overtuigd en kwam tot de conclusie dat art. 180 lid 2 KPK 1997 niet in strijd is met de door de klagers aangevoerde bepalingen van de Grondwet. Over de verhouding van de absolute geheimhoudingsplicht neergelegd in de Wet op de juridisch adviseurs en art. 180 lid 2 KPK 1997 zegt het Hof - net als het Hooggerechtshof in 1994 - dat deze in een lex specialis - lex generalis verhouding tot elkaar staan zodat laatstgenoemde regel voorrang dient te krijgen. ${ }^{193}$ Het Grondwettelijk Hof geeft toe dat het begrip

188 Zoals eerder aangegeven, is dat in de huidige regeling van art. 180 lid 2 KPK 1997 wel gebeurd waarbij de wetgever - met het criterium 'noodzakelijk voor een behoorlijke rechtspleging' en de eis dat het horen van de advocaat de enige manier is waarop de noodzakelijke informatie kan worden verkregen - duidelijk aansluiting heeft gezocht bij bovengenoemde uitspraak van het Hooggerechtshof. Zie hiervoor $\S 6.2$.

189 Uitspraak van 22 november 2004 (SK 64/03, OTK-A 2004, nr. 10, 107). Zie ook Kulesza 2005, p. 396.

190 Aangezien de positie van de juridisch adviseur in dit soort kwesties gelijk is aan de advocaat (die niet in de hoedanigheid van raadsman is opgetreden) is deze uitspraak ook van betekenis voor de advocatuur: beide beroepsgroepen vallen immers onder de reikwijdte van art. 180 lid 2 KPK 1997 en hebben op grond van hun eigen regelgeving een absolute geheimhoudingsplicht. Zie over de verhouding tussen juridisch adviseurs en advocaten hoofdstuk 2, §3.1.3.2.

191 Art. 239 lid 1 KK 1997

192 Om precies te zijn art. 2, 17, 31 lid 3, 42 lid 1, 45 lid 1, 49 en 51 lid 2 Grondwet.

193 Een redenering die ongetwijfeld ook op zal gaan voor art. 6 Advocatenwet en art. 180 lid 2 KPK 1997. 
'behoorlijke rechtspleging' heel algemeen is maar benadrukt daarbij dat het tweede criterium (de afwezigheid van ander bewijs) wel voldoende specifiek en meetbaar is voor de rechter die over de opheffing van de geheimhoudingsplicht dient te beslissen. Ten slotte overweegt het Hof dat binnen de juridische beroepsgroepen alleen absolute bescherming van het beroepsgeheim wordt gegarandeerd aan de raadsman en dat art. 42 lid 2 (recht op verdediging) de enige grondwettelijke bepaling is waaraan een recht op respect voor dat beroepsgeheim kan worden ontleend.

\subsection{Verschoningsrecht in de praktijk}

De wettelijke mogelijkheid de geheimhoudingsplicht van een advocaat op te heffen teneinde hem als getuige te kunnen horen, wordt in de praktijk niet vaak gebruikt. ${ }^{194}$ Toch is het bepaalde in art. 180 lid 2 KPK 1997 zeker geen dode letter te noemen. Zo heeft zich in 2005 nog een zaak voorgedaan in Warschau waarbij een advocaat door de rechter werd gedwongen om in een strafzaak als getuige een verklaring af te leggen over informatie die hij tijdens het verlenen van rechtsbijstand aan een slachtoffer (in het kader van een strafrechtelijke procedure) had verkregen. Hiertoe was door de prokurator - die de advocaat wenste te horen - eerst zonder succes een verzoek ingediend bij de districtsrechtbank (SR) en tegen deze afwijzende beslissing was vervolgens bezwaar aangetekend bij de provinciale rechtbank (SO) die vervolgens met het verzoek instemde. Laatstgenoemde instantie was van oordeel dat opheffen van het verschoningsrecht van de advocaat in de gegeven omstandigheden gerechtvaardigd was omdat duidelijk was geworden dat de advocaat over voor de strafzaak relevante informatie beschikte en dat een behoorlijke rechtspleging eiste dat de dader zijn strafrechtelijke verantwoordelijkheid niet zou ontlopen.

Reagerend op deze beslissing van de provinciale rechtbank deed de balie een dringend beroep op de prokuratura om van de opheffing van het verschoningsrecht in deze zaak geen gebruik te maken en de betreffende advocaat niet als getuige te horen. ${ }^{195}$ Daarbij werd met nadruk gewezen op de gevaren die het in de praktijk brengen van art. 180 lid 2 KPK 1997 oplevert voor de relatie tussen advocaat en cliënt en de basisvereisten voor behoorlijke juridische dienstverlening. Ondanks deze interventie van de balie vond het verhoor toch doorgang: de advocaat werd in september 2005 in aanwezigheid van een vertegenwoordiger van de NRA en een plaatselijke deken gehoord maar bleef zich op zijn beroepsgeheim beroepen en weigerde een verklaring af te leggen. ${ }^{196}$ De prokuratura koos er niet voor om de zaak op de spits te drijven door de advocaat door middel van een geldboete of hechtenis alsnog te dwingen een verklaring af te leggen maar liet het er ook niet helemaal bij zitten. Er werd een onderzoek gestart om na te gaan of de advocaat

194 Bron: gesprek Hermeliński, januari 2007 Warschau. Zie ook Kruszyński: 'In practice, the duty of confidentiality, and professional privilege, is respected. The Code of Criminal Procedure does, in theory, permit the lawyer who is not the defence lawyer to be 'released' from the obligation of secrecy on the order of the court but in practice this seldom occurs': Kruszyński 2007 I, p. 201.

195 Besluit van 6 september 2005.

196 De balie had in eerder genoemd besluit van 6 september 2005 kenbaar gemaakt dat wanneer het verhoor ondanks haar protest toch zou plaatsvinden zij graag een vertegenwoordiger van de NRA bij het verhoor aanwezig zou laten zijn. 
strafrechtelijk kon worden vervolgd. Het resultaat van dit onderzoek is niet bekend maar vaststaat wel dat er geen veroordelingen hebben plaatsgevonden. ${ }^{197}$

Bovengenoemde gang van zaken illustreert dat justitiële autoriteiten (zowel de prokuratura als de rechterlijke macht) er blijkbaar niet voor terug deinzen om art. 180 lid 2 KPK 1997 toe te passen wanneer dat in de gegeven omstandigheden en met het oog op de waarheidsvinding in een concrete strafzaak noodzakelijk wordt geacht. ${ }^{198}$ Het optreden van de NRA in dezen toont dat de balie veel waarde hecht aan bescherming van het beroepsgeheim en actief stelling neemt wanneer gebruik wordt gemaakt van de wettelijke mogelijkheid om het verschoningsrecht van de advocaat te doorbreken.

Dat deze praktijk niet alleen de advocatuur maar ook andere juridische beroepsgroepen zoals de juridisch adviseurs raakt, is reeds aan de orde geweest bij bespreking van de uitspraak van het Grondwettelijk Hof naar aanleiding van de Optimus-zaak. ${ }^{199}$ Overigens verzet ook de beroepsorganisatie van juridisch adviseurs zich fel tegen deze aantasting van het beroepsgeheim. ${ }^{200}$

\subsection{De verdachte advocaat en het verschoningsrecht}

Aangezien de bepalingen waarin de geheimhoudingsplicht van de advocaat is vastgelegd (art. 6 Advocatenwet en art. 19 gedragsregels) geen onderscheid maken naar de hoedanigheid waarin de advocaat om vertrouwelijke informatie wordt gevraagd, dient ervan uit te worden gegaan dat de plicht tot geheimhouding onverkort geldt wanneer een advocaat wordt verhoord als verdachte. Het in art. 178 en art. 180 lid 2 KPK 1997 neergelegde verschoningsrecht is in dit verband in ieder geval niet van toepassing omdat deze bepalingen slechts betrekking hebben op situaties waarin de advocaat (of raadsman) als getuige wordt gehoord. Aangezien iedere verdachte het recht heeft om te zwijgen, ${ }^{201}$ staat het de verdachte advocaat of raadsman natuurlijk wel vrij om ook in het kader van een tegen hem lopende strafzaak geen informatie vrij te geven die hij in het kader van zijn beroepsuitoefening heeft verkregen. Sterker nog, gezien de onvoorwaardelijke formulering van het beroepsgeheim is hij daartoe zelfs verplicht. ${ }^{202}$ Met betrekking tot deze verplichting rijst vervolgens de vraag of dit in bepaalde gevallen geen ontoelaatbare inbreuk op het recht op verdediging tot gevolg kan hebben. De mogelijkheid bestaat immers dat de geheimhoudingsplicht voor de verdachte advocaat tot gevolg heeft dat hij (voor hemzelf) ontlastende informatie niet mag vrijgeven omdat die onder zijn beroepsgeheim valt. Aan deze problematiek wordt in de Poolse wet-

197 Over deze zaak: Agacka-Indecka 2005 I en II.

198 Volgens een - weliswaar enigszins verouderde - bijdrage van Gajewska-Kraczkowska stemt observatie van de praktijk op dit punt 'niet optimistisch': Gajewska-Kraczkowska 1999, p. 199.

199 Zie § 6.5.3.

200 Hetgeen onder meer blijkt uit de (door genoemde beroepsgroep) ingediende klacht bij het Grondwettelijk Hof. Zie eerder § 6.5.3.

201 Art. 175 lid 1 KPK 1997: ‘De beschuldigde (lees ook: verdachte) heeft het recht verklaringen af te leggen: hij mag echter zonder opgave van redenen weigeren antwoord te geven op bepaalde vragen of weigeren verklaringen af te leggen. Over dit recht dient hij te worden geïnformeerd.'

202 Zoals eerder aangegeven, kan een schending van het beroepsgeheim zowel straf- als tuchtrechtelijk worden gesanctioneerd. 
geving en literatuur niet of nauwelijks aandacht besteed. Wel heeft het Hooggerechtshof zich in de jaren zestig zijdelings over deze kwestie uitgelaten: in een uitspraak van november 1962 bepaalde het Hof dat de geheimhoudingsplicht niet onder alle omstandigheden een absoluut karakter hoefde te hebben. Een uitzondering zou volgens het Hof zijn toegestaan wanneer een cliënt zelf de inhoud van de gesprekken met zijn advocaat bekend heeft gemaakt en deze inhoud centraal staat in een straf- of tuchtrechtelijke procedure tegen de advocaat. Onder dergelijke omstandigheden dient het recht op verdediging van de verdachte advocaat volgens het Hooggerechtshof voorrang te krijgen op de geheimhoudingsplicht. ${ }^{203}$ Op deze uitspraak is kritiek uitgeoefend in de literatuur. ${ }^{204}$

Zoals gezegd is de geheimhoudingsplicht in de huidige Advocatenwet en gedragsregels nog steeds ongeclausuleerd geformuleerd en wordt in het strafprocesrecht nog altijd geen aandacht besteed aan de positie van de verdachte advocaat en de vraag of zijn geheimhoudingsplicht onverkort geldt wanneer hij als verdachte wordt gehoord. Dit betekent dat er vanuit moet worden gegaan dat vertrouwelijke informatie - ook wanneer de advocaat naar zijn betrokkenheid bij een strafbaar feit wordt gevraagd - geheim zal moeten blijven. Gelet op de uitspraak van het Hooggerechtshof van 1962 die zijn betekenis nog niet lijkt te hebben verloren, kan op deze regel slechts uitzondering worden gemaakt wanneer de inhoud van de betreffende informatie onderwerp is van een tucht- of strafrechtelijke procedure die tegen de advocaat loopt en de cliënt de inhoud van de gesprekken reeds zelf openbaar heeft gemaakt.

\subsection{Verschoningsrecht en het EVRM}

In het eerste deel van dit hoofdstuk is - in het kader van het vrij verkeer - reeds aan de orde geweest dat vertrouwelijkheid van communicatie tussen gedetineerden en hun advocaat bescherming geniet op grond van het EVRM. ${ }^{205}$ Wanneer het beroepsgeheim van de advocaat in het gedrang komt door de toepassing van opsporingsbevoegdheden kan art. 8 EVRM een rol van betekenis spelen. ${ }^{206}$ Zoals hierna nog zal worden uiteengezet, heeft het EHRM zich in dit verband onder meer uitgelaten over de toelaatbaarheid van huiszoekingen en telefoontaps bij advocaten. ${ }^{207}$ Deze rechtspraak laat zien dat advocaten ook in het kader van hun beroepsuitoefening recht hebben op bescherming van hun privacy en dat bij de toepassing van genoemde opsporingsbevoegdheden voldoende waarborgen moeten

203 Over deze uitspraak: Łojewski 1964, p. 21-28.

204 Volgens Kaftal is de door het Hof toegestane uitzondering in strijd met het beroepsgeheim zoals geformuleerd in de Advocatenwet: op grond van deze regeling maakt het voor de reikwijdte van het verschoningsrecht immers geen verschil of een advocaat in de hoedanigheid van getuige, verdachte of anderszins wordt gehoord. Kaftal stelde voor het wetboek van strafvordering aan te vullen met een regel waaruit blijkt dat het verboden is om van een verdachte advocaat te verlangen dat hij verklaart over feiten die onder zijn beroepsgeheim vallen: Kaftal 1963, p. 10-14. Genoemde bijdrage van Kaftal dateert reeds van 1963 maar noch in 1969 noch in 1997 is het wetboek van strafvordering op de door hem voorgestelde (of soortgelijke) wijze aangevuld.

205 Zie $\S 2.6 .3$ en 3.5.

206 Over de werking van de beperkingsclausule van art. 8 lid 2 EVRM: § 2.6.3.1.

207 Zie hierna $\S 7.8$ en $\S 8.6$. 
worden ingebouwd die een dergelijke bescherming kunnen garanderen. ${ }^{208}$ Ook in dit verband geldt dat een inbreuk op de vertrouwelijkheid tussen advocaat en cliënt behalve een schending van art. 8 EVRM tevens een inbreuk op art. 6 EVRM kan opleveren wanneer daardoor het recht op effectieve verdediging is geschonden. ${ }^{209}$

Het EHRM heeft zich vooralsnog niet uitgelaten over de vraag of het verenigbaar is met art. 8 (en/of 6) EVRM om een advocaat in de hoedanigheid van getuige te horen over feiten die hij tijdens de uitoefening van zijn functie heeft vernomen. Gelet op bestaande rechtspraak - waarin door het Europese Hof veel waarde wordt gehecht aan de vertrouwelijkheid tussen advocaat en cliënt en strenge eisen worden gesteld aan de voorwaarden en omstandigheden waaronder daarop inbreuken mogen worden gemaakt - is echter niet aannemelijk dat een overheid die een advocaat dwingt te getuigen tegen zijn eigen cliënt genade zal vinden in Straatsburg.

\section{Huiszoeking en inbeslagneming bij advocaten}

De geheimhoudingsplicht van de advocaat kan - behalve door hem als getuige te horen - ook in het gedrang komen door toepassing van strafvorderlijke dwangmiddelen en opsporingsbevoegdheden. In feite vormt dit zelfs een grotere bedreiging voor de vertrouwelijkheid omdat het in de praktijk vaker voorkomt en in geval van bepaalde methodes zoals de telefoontap zelfs op voor de betrokkene(n) onzichtbare wijze gebeurt. Het verschoningsrecht zou illusoir worden wanneer autoriteiten bij de uitoefening van dit soort bevoegdheden geen rekening hoeven te houden met de bijzondere positie van de advocaat als professionele geheimhouder. De informatie die ze niet van hem kunnen verkrijgen door hem als getuige te horen, zou dan immers eenvoudig via een andere weg kunnen worden verzameld. Dit speelt onder meer bij de bevoegdheden huiszoeking en inbeslagneming: wanneer de woning of het kantoor van een advocaat wordt doorzocht, kan op grote schaal vertrouwelijke informatie (dossiers, elektronische gegevens et cetera) aan politie en justitie worden blootgesteld. Het is in eerste instantie aan de wetgever om de professionele verschoningsgerechtigde de bescherming te bieden die hem op dit punt toekomt.

\subsection{Algemene regels huiszoeking en inbeslagneming}

In hoofdstuk 25 van het wetboek van strafvordering is geregeld door wie en op welke wijze een huiszoeking moet worden uitgevoerd en onder welke voorwaarden voorwerpen in beslag mogen worden genomen. ${ }^{210}$ Een huiszoeking (przeszukanie) hoeft naar Pools strafprocesrecht niet altijd te zijn gericht op het vinden van zaken. De bevoegdheid kan ook worden aangewend om bepaalde personen te vinden: 'woningen en andere plaatsen' kunnen worden doorzocht met het doel 'een ver-

208 Spronken 2001, p. 483.

209 Zie in het kader van het vrij verkeer $\S$ 2.6.3.1. Standaardoverweging van het EHRM in dit verband is dat '(...) where a lawyer is involved, an encroachment on professional secrecy may have repercussions on the proper administration of justice and hence on the rights guaranteed by Article 6 of the Convention' (bijvoorbeeld Smirnov t. Rusland, EHRM 7-6-2007, nr. 71362/01).

210 Art. 217 tot en met 236a KPK 1997. Onder dezelfde voorwaarden mag ook aan het lichaam van een persoon worden gezocht inclusief zijn kleding en de voorwerpen die hij bij zich draagt (art. 219 lid 1 KPK 1997). 
dachte persoon te vinden, aan te houden of zijn gedwongen medebrenging mogelijk te maken' of teneinde zaken te vinden 'die als bewijs in een strafzaak kunnen dienen of vatbaar zijn voor inbeslagneming'. Wanneer het zoeken gericht is op het vinden van bepaalde zaken hoeft het dwangmiddel dus niet tegen een verdachte gericht te zijn. Wel dient er te allen tijde sprake te zijn van 'een gerechtvaardigde grond om aan te nemen dat de betreffende persoon of zaak zich op de (te doorzoeken) plaats bevindt'. ${ }^{211}$

Een huiszoeking wordt uitgevoerd door de prokurator of door de politie. ${ }^{212}$ Voorafgaand dient aan degene wiens woning wordt doorzocht een schriftelijk bevel gedurende het vooronderzoek afkomstig van de prokurator en gedurende het eindonderzoek van de rechtbank - te worden overhandigd. In het vooronderzoek is de prokurator dus zelfstandig bevoegd een huiszoeking te bevelen: hij heeft daartoe geen rechterlijke machtiging nodig. ${ }^{213}$

\subsection{Bijzondere regels huiszoeking en inbeslagneming bij advocaten}

Bovengenoemde wettelijke regeling van de huiszoekingsbevoegdheid bevat geen speciale voorwaarden voor de huiszoeking van het kantoor of de woning van een advocaat. ${ }^{214}$ In de voor de advocatuur geldende gedragsregels is wel een aanvullende voorwaarde opgenomen voor de wijze waarop een kantoor of woning van een advocaat moet worden doorzocht. In art. 20 van de gedragsregels is bepaald dat wanneer het kantoor of de woning van een advocaat wordt doorzocht, hij (de advocaat) verplicht is te eisen dat een vertegenwoordiger van de balie bij deze actie aanwezig is. De lokale raad van de balie waar de betreffende advocaat onder valt, dient van deze vordering op de hoogte te worden gesteld. Het is vervolgens de verantwoordelijkheid van de lokale raad om ervoor te zorgen dat een vertegenwoordiger van de balie ${ }^{215}$ zich naar het kantoor of de woning van de advocaat begeeft om bij de huiszoeking aanwezig te zijn en er op toe te zien dat het beroepsgeheim daarbij niet of zo min mogelijk wordt geschonden. ${ }^{216}$ Zoals gezegd, gaat het hier om een gedragsregel en niet om een instructienorm aan de justitiële autoriteiten. ${ }^{217}$ Wat precies de rol van de waarnemer bij de huiszoeking is, is niet wettelijk geregeld.

Hoewel een huiszoeking bij een advocaat afgezien van bovengenoemde gedragsregel dus onder dezelfde voorwaarden kan plaatsvinden als bij iedere andere burger zijn wel bijzondere regels gecreëerd voor de situatie dat tijdens de huiszoeking of inbeslagneming documenten worden aangetroffen die (mogelijk) onder het beroepsgeheim van de advocaat vallen. In die situaties wordt - net als in het

211 Art. 219 lid 1 KPK 1997.

212 Art. 220 lid 1 KPK 1997.

213 Art. 220 lid 2 en 224 lid 1 KPK 1997. In spoedgevallen kan men ook zonder eerstgenoemd schriftelijk bevel een woning of plaats betreden maar dan dient het orgaan dat de huiszoeking verricht - meestal de politie - alsnog onverwijld (niezwłocznie) toestemming te vragen bij de rechtbank of de prokurator.

214 Voor huiszoekingen verricht in overheids- en militaire gebouwen heeft de wetgever wel bijzondere regels gecreëerd: zie art. 222 KPK 1997.

215 Dat kan de plaatselijke deken zijn maar ook een collega-advocaat die geen speciale functie binnen de beroepsorganisatie vervult.

216 Krzemiński 2003, p. 103-104.

217 Op de consequenties hiervan wordt teruggekomen in $§ 7.6$. 
kader van het verschoningsrecht waarop de geheimhouder zich ten overstaan van de rechter kan beroepen wanneer hij als getuige wordt gehoord - onderscheid gemaakt tussen de raadsman en de advocaat. De wetgever heeft afzonderlijke regimes (of eigenlijk: handelwijzen) in het leven geroepen voor:

1. stukken die onder het beroepsgeheim vallen van de advocaat die niet als raadsman wordt aangemerkt en

2. documenten die betrekking hebben op het uitvoeren van de functie van raadsman (obrońca).

Ad 1.

Wanneer degene wiens woning of kantoor wordt doorzocht of van wie documenten in beslag worden genomen, verklaart dat bepaalde geschriften of andere documenten informatie bevatten die onder het beroepsgeheim van de advocaat valt, dient degene die de huiszoeking uitvoert de betreffende stukken 'onmiddellijk ('niezwłocznie') en zonder kennis te nemen van de inhoud in een verzegelde verpakking over te dragen aan de prokurator of de rechtbank' ${ }^{218}$ De bevoegdheid kennis te nemen van de inhoud komt toe aan het orgaan dat ook bevoegd is de beslissing te nemen dat een huiszoeking moet worden verricht: gedurende het vooronderzoek is dat de prokurator en daarna de rechtbank. ${ }^{219}$

Ad 2.

Voor documenten die (mogelijk) betrekking hebben op het optreden als raadsman (obrońca) geldt een andere, strengere regel. Wanneer een raadsman of een andere persoon van wie de afgifte van bepaalde zaken wordt verlangd, verklaart dat geschriften of andere documenten die tijdens de huiszoeking zijn gevonden betrekking hebben op feiten die samenhangen met het uitvoeren van de functie van raadsman dient het orgaan dat de huiszoeking verricht deze documenten bij de betreffende persoon achter te laten, zonder kennis te nemen van de inhoud. Op deze hoofdregel geldt één uitzondering: wanneer een dergelijke verklaring afkomstig is van een persoon die zelf geen raadsman is en aan de juistheid ervan wordt getwijfeld, dient het orgaan de documenten - wederom zonder ze te lezen - in een verzegelde verpakking aan de rechtbank te sturen. ${ }^{220}$ Anders dan in de in het eerste lid van art. 225 KPK 1997 genoemde werkwijze mogen stukken die (mogelijk) onder het

218 Art. 225 lid 1 KPK 1997. In dit artikellid wordt de advocaat overigens niet met zoveel woorden genoemd: de regel heeft betrekking op alle 'beroeps- of andere geheimen die door de wet worden beschermd'.

219 Wanneer een huiszoeking wordt uitgevoerd door de politie, zijn politieambtenaren dus niet bevoegd zelf kennis te nemen van de inhoud van de stukken om de juistheid van de verklaring van de advocaat te controleren. $\mathrm{Zij}$ dienen de documenten ongelezen voor te leggen aan de prokurator of de rechtbank die vervolgens zal toetsen of de inhoud ervan inderdaad onder het beroepsgeheim valt. Als er al een prokurator bij de huiszoeking aanwezig is, is verzegelde verzending niet nodig: hij kan dan direct ter plaatse kennis nemen van de inhoud van de stukken en bepalen of ze in beslag kunnen worden genomen of bij de advocaat moeten worden gelaten. Zie Grzegorczyk 2004, p. 594 en Hofmański e.a. 2007 I, p. 1030-1031.

220 Een en ander is geregeld in art. 225 lid 3 KPK 1997. Het begrip 'raadsman' dient in dit verband volgens Grzegorczyk ruim te worden uitgelegd en ook betrekking te hebben op de advocaat die op grond van art. 245 KPK 1997 in de eerste fase na aanhouding bijstand verleent: Grzegorczyk 2004, p. 595-596. 
beroepsgeheim van de raadsman vallen dus alleen ter toetsing aan de rechtbank worden gezonden: de prokurator is in geen geval bevoegd van deze stukken kennis te nemen.

Samengevat zijn er dus twee scenario's mogelijk zijn: ten eerste die waarin de raadsman of een derde verklaart dat de stukken onder de geheimhoudingsplicht van de raadsman vallen en deze verklaring door het orgaan dat de huiszoeking verricht voor waar wordt aangenomen en ten tweede de situatie dat een derde - bijvoorbeeld de secretaresse van een advocatenkantoor - een dergelijke verklaring doet en aan de juistheid ervan wordt getwijfeld. In het eerste geval dienen de betreffende stukken ongelezen te worden achtergelaten en in het tweede geval worden de stukken ter toetsing aan de rechtbank voorgelegd. Het is van belang dat op grond van deze regeling alleen kan worden getwijfeld aan de verklaring van een persoon die níet de functie van raadsman vervult: de raadsman dient dus te allen tijde op zijn woord te worden geloofd. Wanneer de rechtbank - na de stukken te hebben gelezen - van mening is dat ze inderdaad onder het beroepsgeheim vallen, worden ze in een verzegelde verpakking teruggestuurd aan de advocaat. ${ }^{221}$ Indien de rechtbank niet tot een dergelijk oordeel komt, kan inbeslagneming van de betreffende documenten worden bevolen tegen welke beslissing voor de raadsman wel bezwaar open staat. 222

\subsection{Gebruik voor het bewijs van vertrouwelijke informatie}

Uit bovengenoemde regeling blijkt hoe tijdens een huiszoeking en bij inbeslagneming om moet worden gegaan met documenten die mogelijk onder het beroepsgeheim van de advocaat vallen. Of, en zo ja op welke wijze, dergelijke informatie vervolgens voor het bewijs in een strafzaak mag worden gebruikt, is een geheel andere vraag. In art. 226 KPK 1997 is geregeld dat voor het gebruik voor het bewijs van stukken die onder het beroepsgeheim vallen de 'verboden en beperkingen neergelegd in de artikelen 178 tot en met 181 van overeenkomstige toepassing zijn'. Dit betekent dat het in art. 178 sub 1 KPK 1997 neergelegde absolute verschoningsrecht van de raadsman van toepassing is op alle schriftelijke informatie die hij tijdens de uitoefening van zijn functie heeft ontvangen.

Voor het in art. 226 KPK 1997 genoemde verbod is niet relevant op welke wijze de betreffende stukken zijn verkregen: ook wanneer ze niet door inbeslagneming maar op andere - al dan niet toevallige wijze - in handen van de prokurator of de rechtbank zijn gekomen, geldt dat ze niet voor het bewijs mogen worden gebruikt. Voor het gebruik voor het bewijs van documenten die onder het beroepsgeheim van de advocaat - die noch als raadsman noch in het kader van art. 245 lid 1 KPK rechtsbijstand heeft verleend - vallen, geldt art. 180 lid 2 KPK 1997. Dit betekent dat dergelijke stukken alleen als bewijsmiddel mogen dienen wanneer dat 'noodzakelijk is voor een behoorlijke rechtspleging' en de betreffende informatie niet op andere wijze kan worden verkregen. ${ }^{223}$

221 Tegen deze beslissing kan door de prokurator geen rechtsmiddel worden ingesteld: Grzegorczyk 2004, p. 595.

222 Op grond van art. 236 KPK 1997.

223 Hierover wordt door de rechtbank een beslissing genomen waartegen bezwaar kan worden aangetekend. Wanneer de rechter inderdaad beslist dat bepaalde documenten die onder het beroepsgeheim van de advocaat vallen voor het bewijs mogen worden 


\subsection{De verdachte advocaat en huiszoeking/inbeslagneming}

De regel dat documenten direct ongelezen moeten worden overgedragen aan de prokurator of de rechtbank ${ }^{224}$ wanneer degene wiens woning of kantoor wordt doorzocht, verklaart dat deze informatie bevatten die onder het beroepsgeheim van de advocaat (niet raadsman) valt, geldt niet wanneer de stukken in het bezit zijn van een 'persoon die wordt verdacht van een strafbaar feit'. ${ }^{225}$ Wanneer een advocaat zelf verdachte is, mogen alle stukken die in zijn woning of kantoor worden gevonden in beginsel worden gelezen en in beslag worden genomen.

Dit geldt echter niet wanneer het gaat om documenten die onder het beroepsgeheim van de raadsman vallen. Op die situatie is immers een afzonderlijke, strengere regel van toepassing. ${ }^{226}$ Aangezien op deze regel geen uitzondering is gecreëerd voor het geval dat de raadsman zelf verdacht wordt van een strafbaar feit is in dit soort gevallen niet relevant of jegens de betreffende advocaat een verdenking bestaat. Ook in deze context geniet het beroepsgeheim van de raadsman dus volledige bescherming.

\subsection{Situatie voor inwerkingtreding nieuw strafprocesrecht}

De bevoegdheden huiszoeking en inbeslagneming waren in het oude wetboek van strafvordering niet veel anders geregeld dan in het huidige strafprocesrecht. Aan de regeling in zijn algemeenheid zal hier verder dan ook geen aandacht worden besteed. De vraag hoe bij beide dwangmiddelen om moest worden gegaan met documenten die mogelijk onder het beroepsgeheim van de advocaat vallen, werd wel enigszins anders beantwoord. Hoofdregel was dat wanneer de bewoner van een pand verklaarde dat bepaalde documenten die tijdens een huiszoeking werden gevonden onder de reikwijdte van zijn beroepsgeheim vielen, de betreffende stukken zonder te worden gelezen en in een verzegelde verpakking aan de prokurator dienden te worden gestuurd. ${ }^{227}$ Deze regel had betrekking op alle professionele geheimhouders zodat genoemde procedure zowel voor de advocaat als de raadsman gold. Voor een antwoord op de vraag hoe de prokurator vervolgens met de mogelijk vertrouwelijke stukken diende om te gaan en wat moest gebeuren wanneer documenten inderdaad onder het beroepsgeheim van een advocaat of raadsman bleken te vallen, werd verwezen naar de bepalingen die betrekking hadden op het verschoningsrecht van de raadsman en de advocaat. ${ }^{228}$ Hieruit moet worden

gebruikt, behoort het voorlezen van deze stukken - net als het horen van de advocaat als getuige - plaats te vinden op een niet-openbare terechtzitting.

224 Art. 225 lid 1 KPK 1997.

225 'Osoba podejrzana o popetnienie przestępstwa' (art. 225 lid 2 KPK 1997). Deze uitzondering beperkt zich niet tot bepaalde strafbare feiten maar ziet op alle mogelijke verdenkingen.

226 Art. 225 lid 3 KPK 1997: wanneer degene bij wie de huiszoeking wordt verricht, verklaart dat stukken onder de reikwijdte van zijn beroepsgeheim als raadsman vallen, dienen de betreffende documenten in beginsel ongelezen ter plaatse achter te worden gelaten. Zie § 7.2.

227 Art. 196 lid 2 KPK 1969 eerste zin. Deze regel was echter niet van toepassing wanneer de documenten in het bezit waren van iemand die werd verdacht van een strafbaar feit, aldus art. 196 lid 4 KPK 1969.

228 Art. 161 (sub 1), 163 en 164 KPK 1969, die in de regeling ten aanzien van huiszoeking bij professionele geheimhouders van overeenkomstige toepassing waren verklaard (art. 196 lid 2 laatste zin KPK 1969). 
afgeleid dat stukken die naar het oordeel van de prokurator inderdaad onder het beroepsgeheim van de raadsman vielen, dienden te worden teruggezonden en dus ook niet voor het bewijs konden worden gebezigd. Voor stukken die onder de reikwijdte van de geheimhoudingsplicht van de advocaat (niet raadsman) vielen, gold dat de prokurator of rechtbank konden beslissen dat deze toch in beslag konden worden genomen. ${ }^{229}$ Aangezien geen bijzondere voorwaarden werden gesteld aan de beslissing een advocaat als getuige in een strafzaak te horen, kon ook de beslissing tot inbeslagneming van documenten die onder zijn beroepsgeheim vielen in alle gevallen worden genomen. De regel dat huiszoekingen in een woning of op een kantoor van een advocaat in aanwezigheid van een vertegenwoordiger van de balie dienden plaats te vinden, werd pas in 1987 in de gedragsregels opgenomen en bestond gedurende het grootste gedeelte van de communistische periode dus niet.

\subsection{Evaluatie juridisch kader}

Gelet op het voorgaande, moet in ieder geval worden geconcludeerd dat de positie van de advocaat als professioneel geheimhouder vandaag de dag beter wordt beschermd dan op grond van het oude strafprocesrecht:

- Op grond van het oude wetboek van strafvordering was de prokurator - ook wanneer het beroepsgeheim van de raadsman in het geding was - te allen tijde bevoegd kennis te nemen van documenten die mogelijk onder de geheimhoudingsplicht vielen. Op dit punt biedt de huidige regeling de advocaat meer bescherming: wanneer hij verklaart dat bepaalde stukken onder zijn beroepsgeheim als raadsman vallen, dient hij op zijn woord te worden geloofd en moeten de documenten ongelezen ter plaatse te worden achtergelaten. ${ }^{230}$

- Ten aanzien van stukken die onder het beroepsgeheim van de advocaat (niet raadsman) vallen, gold onder de oude regeling dat de rechtbank of de prokurator zonder enige nadere voorwaarde(n) kon bepalen dat deze toch in een strafzaak zouden mogen worden gebruikt. ${ }^{231}$ In het huidige strafprocesrecht geldt dat documenten die onder het beroepsgeheim van de advocaat vallen slechts op beslissing van de rechtbank en onder bepaalde voorwaarden voor het bewijs mogen worden gebezigd: in dit verband gelden dezelfde voorwaarden als voor het horen van een advocaat als getuige zodat vast moet komen te staan dat gebruik van de stukken noodzakelijk is voor een behoorlijke rechtspleging en de inhoud ervan niet op andere wijze kan worden vastgesteld. ${ }^{232}$

- De regeling van 1969 besteedde geen afzonderlijke aandacht aan de vraag of inbeslaggenomen of op andere wijze verkregen documenten die onder het beroepsgeheim van de advocaat vielen, in een strafzaak voor het bewijs konden worden gebruikt. Hierdoor was niet uitgesloten dat vertrouwelijke stukken die

229 Dit op grond van art. 163 KPK 1969.

230 Art. 225 lid 3 KPK 1997, slechts wanneer deze verklaring wordt gedaan door een persoon die zelf geen raadsman is en aan de juistheid ervan wordt getwijfeld, kunnen de stukken in een vergezelde verpakking ter toetsing naar de rechtbank worden gezonden. De prokurator mag dus nooit kennis nemen van de inhoud van deze categorie documenten.

231 Art. 163 KPK 1997.

232 Art. 226 jo. art. 180 lid 2 KPK 1997. Ook hier geldt echter de nuancering dat met name de eerstgenoemde voorwaarde de rechtbank behoorlijk wat beoordelingsruimte laat waardoor de toegevoegde waarde ervan onzeker is (zie § 6.4). 
op andere wijze waren verkregen toch voor het bewijs konden worden gebezigd. ${ }^{233}$ Het huidige art. 226 KPK 1997 biedt in dit soort gevallen de nodige aanvullende bescherming.

Afgezien van bovengenoemde verbeteringen, zijn er nog steeds verschillende punten in de huidige regeling die - gelet op de noodzakelijke bescherming van het beroepsgeheim van de advocaat - op zijn minst zwak te noemen zijn:

- Of huiszoeking bij een professionele geheimhouder daadwerkelijk noodzakelijk is, hoeft niet vooraf door een rechter te worden getoetst: de prokurator kan in het vooronderzoek zelfstandig - zonder tussenkomst van de rechter - bevelen dat een dergelijke plaats moet worden doorzocht.

- De enige bijzondere regel over de wijze waarop een huiszoeking bij een advocaat dient te worden uitgevoerd, is opgenomen in de voor de advocatuur geldende gedragsregels (aanwezigheid van een vertegenwoordiger van de balie). De exacte betekenis van deze regel is echter onduidelijk. Zoals ook overwogen door het EHRM is de aanwezigheid van een 'onafhankelijke waarnemer' een belangrijke waarborg ter voorkoming van de schending van het beroepsgeheim wanneer een kantoor of de woning van een advocaat wordt doorzocht. ${ }^{234}$ In de Poolse situatie maakt deze norm echter 'slechts' deel uit van de gedragsregels en is dus alleen gericht tot de advocatuur. Bovendien is niet uitgewerkt welke rol de vertegenwoordiger bij de huiszoeking precies dient te vervullen. Het is de verantwoordelijkheid van de advocatuur dat deze regel wordt verwezenlijkt: de bij een huiszoeking betrokken autoriteiten hebben geen enkele wettelijke verplichting op dit punt. Het orgaan dat de huiszoeking verricht, is niet gehouden te wachten tot de vertegenwoordiger van de balie arriveert. ${ }^{235}$ Dit betekent ook dat een huiszoeking die zonder de aanwezigheid van een dergelijke waarnemer is uitgevoerd niet (zonder meer) onrechtmatig is. ${ }^{236}$ Door het initiatief op dit punt volledig aan de advocatuur over te laten is ook onduidelijk wat dient te gebeuren wanneer een huiszoeking wordt verricht in de woning of het kantoor van een advocaat zonder dat deze zelf aanwezig is en dus ook zijn in art. 20 van de gedragsregels genoemde 'verplichting' niet kan nakomen. Voor de politie en prokuratura geldt in ieder geval geen strafvorderlijke verplichting te wachten met het uitvoeren van de huiszoeking totdat de onafhankelijke waarnemer is gearriveerd.

233 Hetzelfde gold voor de situatie waarin tijdens een huiszoeking - om welke reden dan ook niet was verklaard dat (bepaalde) stukken onder het beroepsgeheim van de raadsman of advocaat vielen. Aangezien geen enkele wettelijke bepaling zich daartegen verzette, konden deze stukken in beginsel zonder problemen in beslag worden genomen en voor het bewijs worden gebezigd.

234 Niemietz t. Duitsland, EHRM 16-12-1997, A251-B, nr. 13710/88. Zie hierna § 7.8.

235 Waarmee natuurlijk niet is gezegd dat dit in de praktijk niet toch gebeurt: het gaat er hier slechts om dat het strafprocesrecht het niet voorschrijft.

236 De enige conclusie die aan het niet naleven van art. 20 kan worden verbonden, is immers dat de gedragsregels in de gegeven omstandigheden zijn geschonden maar dat is een gevolgtrekking die in beginsel alleen consequenties kan hebben voor de betrokken advocaat zelf. Denkbaar is dat een advocaat zijn professionele verplichtingen schendt wanneer hij de lokale balie ten onrechte niet op de hoogte stelt van een huiszoeking die op zijn kantoor wordt verricht. 
- De procedures genoemd in art. 225 lid 1 en 3 KPK 1997 gelden op grond van de wettelijke regeling alleen wanneer degene bij wie de huiszoeking wordt verricht of van wie de afgifte van bepaalde stukken worden geëist, verklaart dat zijn beroepsgeheim hierdoor in het geding komt. Strikt genomen is degene die de huiszoeking verricht dus niet verplicht zelf actie te ondernemen wanneer hij vermoedt dat bepaalde informatie onder het beroepsgeheim van een advocaat of raadsman valt: het lezen en in beslag nemen van deze stukken is - zolang daartegen niet wordt geprotesteerd - niet door de wetgever verboden en zou dus in beginsel zonder beperking kunnen plaatsvinden. ${ }^{237}$ Door de wettelijke waarborgen volledig afhankelijk te maken van deze externe factor - de verklaring van een derde - bestaat het risico dat bescherming van het beroepsgeheim van de advocaat en de raadsman niet in alle gevallen gewaarborgd is.

- De prokurator is gedurende het vooronderzoek zelfstandig bevoegd kennis te nemen van documenten die mogelijk onder het beroepsgeheim van de advocaat (niet raadsman) vallen. Wanneer de prokurator tot de conclusie komt dat bepaalde informatie inderdaad onder de reikwijdte van het beroepsgeheim valt, mag de betreffende documentatie weliswaar niet in beslag worden genomen maar dat laat onverlet dat van de vertrouwelijke inhoud wel kennis is genomen door een orgaan dat belast is met opsporing en vervolging van strafbare feiten.

- Bescherming van het beroepsgeheim bij huiszoeking vervalt volledig wanneer de advocaat zelf als verdachte wordt aangemerkt. Aangezien de wetgever in dit verband niet heeft gespecificeerd dat het om verdenking van bepaalde (ernstige) strafbare feiten moet gaan, is het enkele feit dat een advocaat wordt verdacht van enig strafbaar feit in beginsel voldoende om de bescherming die het verschoningsrecht op dit punt biedt, op te heffen. Daar komt bij dat geen (wettelijke) waarborgen zijn gecreëerd die er in zo'n geval voor zorgen dat de uitzondering alleen betrekking heeft op stukken die daadwerkelijk in verband staan met het strafbare feit waarvan de advocaat wordt verdacht. Hierdoor is de bescherming van belangen van cliënten die daarmee niets van doen hebben onvoldoende gegarandeerd.

- Ten slotte dient te worden opgemerkt dat het door de wetgever gehanteerde onderscheid advocaat - raadsman (het beroepsgeheim van de raadsman geniet ook bij huiszoeking en inbeslagneming een verdergaande bescherming dan het beroepsgeheim van de advocaat die niet als raadsman optreedt) in de praktijk waarschijnlijk niet altijd even eenvoudig te maken zal zijn. De meeste Poolse advocaten hebben zich niet in het strafrecht gespecialiseerd maar treden - met name op basis van toevoeging - wel met enige regelmaat als raadsman in strafzaken op. Er zijn dus genoeg advocaten die in beide hoedanigheden optreden en het zal bij een huiszoeking lang niet altijd op voorhand duidelijk zijn welke documenten wel en welke documenten niet onder het beroepsgeheim van de raadsman vallen.

237 Deze situatie kan zich bijvoorbeeld voordoen wanneer een advocaat niet zelf bij de huiszoeking van zijn kantoor aanwezig is en de mogelijk wel aanwezige personen (zoals een secretaresse) zich niet tegen inbeslagneming verzetten. 


\subsection{Huiszoeking en inbeslagneming bij advocaten in de praktijk}

Over de wijze waarop bovengenoemde regels in de praktijk functioneren en in hoeverre de gesignaleerde onduidelijkheden daadwerkelijk praktische betekenis hebben, is zeer weinig bekend. Er bestaat niet of nauwelijks rechtspraak op dit punt. ${ }^{238}$ Het schijnt een enkele keer wel voor te komen dat een huiszoeking wordt verricht bij een advocaat - zo is een aantal gevallen bekend uit de afgelopen jaren van huiszoekingen bij advocaten die werden verdacht van omkoping - maar het is geen thema waar veel over gesproken of geschreven wordt. Ook door de advocatuur wordt weinig aandacht aan het onderwerp besteed waaruit mag worden afgeleid dat het niet iets is waar de balie zich grote zorgen over maakt.

\subsection{Huiszoeking en inbeslagneming bij advocaten en het EVRM}

Het is vaste Straatsburgse rechtspraak dat een advocatenkantoor onder de bescherming van art. 8 EVRM valt en dat huiszoekingen bij advocaten met de nodige rechtswaarborgen dienen te worden omkleed. ${ }^{239}$ In het nationale recht dient in ieder geval voldoende precies te worden omschreven onder welke omstandigheden en voorwaarden het beroepsgeheim van de advocaat bij huiszoeking en inbeslagneming wordt beschermd. ${ }^{240}$ De aanwezigheid van een onafhankelijke waarnemer wordt door het EHRM expliciet genoemd als een van de mogelijke beschermende maatregelen die in dit verband zouden kunnen worden getroffen. Het Europese Hof vindt het in beginsel niet problematisch dat een dergelijke waarnemer door de overheid wordt aangewezen. ${ }^{241}$ De bescherming van art. 8 EVRM strekt zich

238 Informatie verkregen van Wąsek-Wiaderek en Gwirdoyń, juni 2008.

239 Zo is onder meer bevestigd in Niemietz t. Duitsland, EHRM 16-12-1997, A251-B, nr. 13710/88. Tegen de klacht dat de huiszoeking op het advocatenkantoor van Niemietz een schending van art. 8 EVRM had opgeleverd, was door de Duitse regering aangevoerd dat dit artikel - dat respect voor het privé-leven betreft - in deze zaak niet van toepassing was omdat het om een werkplek ging. Het Europese Hof wees dit verweer af door te overwegen dat een dergelijke strikte scheiding tussen zakelijke activiteiten en het privé-leven niet kan worden gemaakt: '(...) it is, after all, in the course of their working lives that the majority of people have a significant, if not the greatest, opportunity of developing relationships with the outside world'. Een zodanig onderscheid is met name moeilijk te maken waar het de uitoefening van vrije beroepen zoals de advocatuur betreft omdat '(...) work in that context may form part and parcel of his [a person exercising a liberal profession, toev. DdV] life to such a degree that it becomes impossible to know in what capacity he is acting at a given moment of time'. Gelet op het feit dat de opdracht tot huiszoeking en inbeslagneming in casu zonder enige beperking was geformuleerd en niet was voorzien in 'any special procedural safeguards, such as the presence of an independent observer' concludeert het EHRM dat art. 8 EVRM is geschonden. Zie meer recent ook Smirnov t. Rusland, EHRM 7-6-2007, nr. 71362/01.

240 Zie Petri Sallinen e.a. t. Finland, EHRM 27-9-2005, 50882/99. In deze zaak oordeelde het EHRM dat de huiszoeking niet 'in accordance with the law' was omdat het Finse recht op dit punt onvoldoende duidelijk was: 'In the context of searches and seizures, the domestic law must provide some protection to the individual against arbitrary interference with Article 8 rights. Thus, the domestic law must be sufficiently clear in its terms to give citizens an adequate indication as to the circumstances in and conditions on which public authorities are empowered to resort to any such measure. (...) The court would emphasize that search and seizure represent a serious interference with private life, home and correspondence and must accordingly be based on a "law" that is particularly precise. It is essential to have clear, detailed rules on the subject' (\$ 82 en 90).

241 Zo bleek in Tamosius t. Verenigd Koninkrijk, EHRM 19-9-2002, nr. 6200/00 (ontvankelijk- 
overigens niet alleen uit over papieren stukken maar is eveneens van toepassing op informatie die in elektronische bestanden is opgeslagen. ${ }^{242}$

In een recente zaak tegen Bulgarije heeft het EHRM duidelijk uiteen gezet hoe dient te worden beoordeeld of een huiszoeking bij een advocaat verenigbaar is met art. 8 EVRM. ${ }^{243}$ Klager Iliya Stefanov - een Bulgaarse advocaat - was de vaste juridische adviseur van een bedrijf dat verdacht werd van afpersing. Het kantoor van klager (die ook als getuige was gehoord over de afpersing) was op last van de rechter door de politie doorzocht waarbij onder meer een computer en een dertigtal floppydisks in beslag waren genomen. Bij de huiszoeking waren twee 'onafhankelijke' waarnemers aanwezig, te weten twee buren van Iliya Stefanov. Bij beantwoording van de vraag of de doorzoeking noodzakelijk was in een democratische samenleving in de zin van art. 8 EVRM dient volgens het Europese Hof in ieder geval te worden beoordeeld:

1. in hoeverre het nationale recht voorziet in 'effective safeguards against abuse or arbitrariness' en

2. hoe de betreffende waarborgen in de concrete zaak hebben gefunctioneerd.

Omstandigheden die daarbij volgens het Europese Hof in overweging dienen te worden genomen, zijn: de ernst van het strafbare feit in het kader waarvan de huiszoeking plaatsvindt, of voor de huiszoeking een rechterlijk bevel of (achteraf) rechterlijke goedkeuring is gegeven, of de rechterlijke beslissing op een redelijke verdenking was gebaseerd en of de grenzen van het bevel tot huiszoeking voldoende nauwkeurig waren omschreven. Wat de uitvoering van de huiszoeking bij advocaten betreft, benadrukt het Europese Hof nogmaals het belang van de aanwezigheid van een onafhankelijk waarnemer 'to ensure that material subject to legal professional privilege is not removed' en dient tenslotte in aanmerking te worden genomen welke repercussies de huiszoeking kunnen hebben voor het werk en de reputatie van de betrokkene. ${ }^{244}$

Getoetst aan deze criteria stelt het EHRM vast dat het feit dat er voor de huiszoeking bij Iliya Stefanov een rechterlijk bevel was afgegeven op zichzelf nog geen garantie voor bescherming tegen misbruik vormde: in het bevel was niet gespecificeerd welk bewijsmateriaal men dacht te kunnen vinden of op welke wijze dat relevant zou kunnen zijn voor het onderzoek naar de afpersing. Bovendien was niet nader omschreven hoe om zou moeten worden gegaan met informatie die onder het verschoningsrecht zou (kunnen) vallen. Ook is het Europese Hof van mening dat de uitvoering van de huiszoeking bij Iliya Stefanov te rigoureus is

heidsbeslissing). waarin een klacht over schending van art. 8 EVRM bij huiszoeking van een advocatenkantoor niet ontvankelijk werd verklaard. Het EHRM hechtte hierbij vooral waarde aan het feit dat voor de huiszoeking een rechterlijke machtiging was verleend en dat een onafhankelijke waarnemer bij de zoeking aanwezig was geweest. Het argument van klager dat deze waarnemer (counsel) niet onafhankelijk was omdat hij door justitie was aangewezen, werd door het Europese Hof niet geaccepteerd omdat niet aannemelijk was gemaakt dat de waarnemer op een of ander moment een inschattingsfout zou hebben gemaakt.

242 Zo blijkt onder meer uit Wieser en Bicos Beteiligungen GMBH t. Oostenrijk, EHRM 16-102007, nr. 74336/01.

243 Iliya Stefanov t. Bulgarije, EHRM 22-5-2008, nr. 65755/01.

$244 \S 38$. 
geweest door onder meer zijn computer - die voor professionele doeleinden werd gebruikt en dus vrijwel zeker vertrouwelijke informatie bevatte - en tientallen floppydisks in beslag te nemen. Tenslotte merkt het EHRM op dat de twee onafhankelijke waarnemers (in casu buren van klager) niet 'legally qualified' waren om onafhankelijk van de opsporingsambtenaren te bepalen welk materiaal onder het beroepsgeheim van de advocaat viel. Een en ander leidt tot de conclusie dat art. 8 EVRM is geschonden. ${ }^{245}$

Uit het bovenstaande kan worden afgeleid dat het nationale recht voldoende duidelijkheid moet bieden over de omstandigheden waaronder het beroepsgeheim van advocaten bij huiszoeking en inbeslagneming bescherming wordt geboden. Daarbij is bovendien van belang dat niet kan worden volstaan met het bieden van formele waarborgen, er dient daadwerkelijk een beschermend effect van de garanties uit te gaan: het rechterlijk bevel tot huiszoeking dient aan bepaalde inhoudelijke eisen te voldoen, onafhankelijke waarnemers dienen 'legally qualified' te zijn et cetera.

Er is geen Straatsburgse rechtspraak tegen Polen op dit punt maar het is gelet op hetgeen eerder in $\S 7.6$ uiteen is gezet de vraag of het huidige Poolse recht - ondanks de nuanceringen en verbeteringen die ten opzichte van het oude strafprocesrecht kunnen worden geconstateerd - het beroepsgeheim van de advocaat bij huiszoeking en inbeslagneming in voldoende mate beschermd. Gelet op de criteria die uit de Straatsburgse rechtspraak kunnen worden afgeleid, zou onder meer problematisch kunnen zijn dat voor een huiszoeking bij een advocaat gedurende het vooronderzoek geen rechterlijke machtiging noodzakelijk is, dat de rol van de onafhankelijk waarnemer (die als lid van de balie overigens wel 'legally qualified' is in de zin van de rechtspraak van het EHRM) niet nader is uitgewerkt, dat zijn aanwezigheid bovendien niet als instructienorm aan de autoriteiten is geformuleerd maar 'slechts' in de gedragsregels is opgenomen en dat de prokurator in het vooronderzoek zelfstandig stukken kan inzien die onder het beroepsgeheim van de advocaat (niet raadsman) vallen. Nog afgezien van de wijze waarop deze regels in de praktijk worden nageleefd, is dus allesbehalve zeker dat de huidige Poolse regelgeving in het licht van art. 8 EVRM op dit punt voldoende specifieke, beschermende waarborgen biedt.

\section{Tappen telefoongesprekken waaraan advocaat deelneemt}

Een andere opsporingsmethode die gevolgen kan hebben voor het beroepsgeheim van de advocaat is de telefoontap. Belangrijk verschil met eerder genoemde be-

$245 \S 39-45$. Zie voor een extreem geval waarin een schending van art. 8 EVRM werd gebaseerd op het feit dat advocatenkantoren waren doorzocht zonder enige (adequate) beschermende waarborgen: Elci e.a. t. Turkije, EHRM 13-11-2003, nr. 23145/93, 25091/94 en Taner Kiliç t. Turkije, EHRM 24-10-2006, nr. 70845/01. Zie ook Mancevschi t. Moldavië, EHRM 7-10-2008, nr. 33066/04 waarin het EHRM benadrukt dat de behoefte aan beschermende waarborgen nog groter is wanneer de advocaat bij wie de huiszoeking wordt verricht recent iemand heeft bijgestaan in de strafzaak die aanleiding voor de huiszoeking heeft gevormd: '(...) the applicant had represented a person in the criminal case in connection with which the search had been ordered. The search could thus have led to the finding of items or documents obtained by the applicant as the accused's representative, with obvious repercussions for the accused's rights guaranteed under Article 6 of the Convention. Therefore, an even higher degree of caution was required before a search could be authorised in the applicant's home and office' (\$ 49). 
voegdheden (huiszoeking en inbeslagneming) is dat het afluisteren en opnemen van telefoongesprekken heimelijk gebeurt waardoor de advocaat niet op de hoogte is van de inbreuk op de vertrouwelijke communicatie met zijn cliënt. Anders dan bij de huiszoeking zal hij zich daar dus ook niet vooraf tegen kunnen verzetten. Bijkomend probleem is dat ook voor de afluisterende autoriteiten van te voren niet altijd duidelijk is dat informatie zal worden verkregen die onder het beroepsgeheim van een professionele geheimhouder valt. Een verdachte die wordt getapt kan immers plotseling telefonisch contact opnemen met zijn advocaat. Hoe moet worden omgegaan met dit soort 'toevallig verkregen' vertrouwelijke informatie en is het onder omstandigheden ook toegestaan de telefoon van een advocaat te tappen? In het onderstaande zal worden onderzocht of - en zo ja - op welke wijze het Poolse strafprocesrecht antwoord geeft op bovenstaande vragen.

\subsection{Algemene regels afluisteren en opnemen telecommunicatie}

Het controleren en opnemen van telefoongesprekken (tappen) is geregeld in hoofdstuk 26 van het wetboek van strafvordering en kan in de regel alleen plaatsvinden op bevel van de rechtbank. ${ }^{246}$ Gedurende het vooronderzoek neemt de rechter een dergelijke beslissing op verzoek van de prokurator. In geval van spoed kan de prokurator bij wijze van uitzondering ook zelfstandig beslissen dat bepaalde telefoonnummers afgeluisterd zullen worden. ${ }^{247}$ Het beluisteren van de opgenomen gesprekken is in beginsel voorbehouden aan de rechter en de prokurator maar kan - in geval van spoed - ook door de politie gebeuren wanneer rechtbank of prokurator daarvoor toestemming verlenen. ${ }^{248}$ De telefoontap kan worden toegepast om

1. bewijs in een aanhangige strafzaak vast te stellen en te verkrijgen of

2. te voorkomen dat een nieuw strafbaar feit wordt gepleegd. ${ }^{249}$

Dit is echter niet toegestaan ten aanzien van alle soorten strafbare feiten: de wetgever heeft een (groot) aantal categorieën strafbare feiten opgesomd waarbij een telefoontap mogelijk is. ${ }^{250}$ Zowel wanneer men het afluisteren wenst in te zetten ter verkrijgen van bewijs in een aanhangige strafzaak als wanneer het wordt gebruikt om te voorkomen dat een nieuw strafbaar feit wordt gepleegd, dient het - gepleegde of nog te plegen - delict onder een van de daar genoemde categorieën te vallen. Genoemde opsomming is limitatief maar ruim geformuleerd. Er wordt niet verwe-

246 Art. 237 tot en met 242 KPK 1997. Overigens is naast deze regeling in het wetboek van strafvordering ook in bijzondere wetgeving voorzien in de mogelijkheid onder bepaalde omstandigheden telefoongesprekken af te luisteren wanneer (nog) geen strafrechtelijke procedure loopt. Deze zogenaamde 'buitenprocedurele' vorm van afluisteren (podstuch pozaprocesowy) - geregeld in de Politiewet en de Wet op de binnenlandse veiligheidsdienst - zal hier verder buiten beschouwing worden gelaten. Voor een beknopte bespreking in het Engels wordt verwezen naar Kruszyński 2007 I, p. 189-190. Onduidelijk is of materiaal dat op deze wijze is verkregen direct voor het bewijs mag worden gebruikt in een strafzaak. Zie hierover Hofmański e.a. 2007 I, p. 1066-1067.

247 Deze beslissing dient vervolgens wel binnen drie dagen ter goedkeuring aan de rechtbank te worden overlegd. Art. 237 lid 2 KPK 1997.

248 Art. 237 lid 6 KPK 1997. Hoewel de wettekst dit in het midden laat, wordt er vanuit gegaan dat afluisteren van telecommunicatie alleen is toegestaan wanneer de gesprekken ook worden opgenomen: Hofmański e.a. 2007 I, p. 1061.

249 Art. 237 lid 1 KPK 1997.

250 Deze opsomming is te vinden in art. 237 lid 3 KPK 1997. 
zen naar specifieke delictsomschrijvingen maar er worden omschrijvingen gegeven van datgene waar het strafbaar feit betrekking op moet hebben, wil afluisteren gerechtvaardigd zijn. ${ }^{251}$

De telefoontap kan worden ingezet tegen eenieder die wordt verdacht van een strafbaar feit maar nog niet formeel als verdachte is aangemerkt (osoba podejrzana), tegen een (officiële) verdachte (podejrzany) of beschuldigde (oskarżony) en onder bepaalde omstandigheden ook tegen derden. ${ }^{252}$ Dat laatste is in twee gevallen toegestaan:

1. wanneer het gaat om iemand 'met wie de beschuldigde [of verdachte persoon of verdachte, toev. DdV] in contact zou kunnen treden' of

2. een persoon 'die in verband zou kunnen staan met de dader of een nog te plegen strafbaar feit' ${ }^{253}$

De kring van personen die kunnen worden afgeluisterd, is dus zeer ruim geformuleerd: in theorie kan iedere burger immers tot een van de twee laatstgenoemde restcategorieën behoren. ${ }^{254}$ Het afluisteren en opnemen van telefoongesprekken mag maximaal drie maanden duren. ${ }^{255}$ Wanneer het afluisteren is beëindigd, dient de rechtbank de vernietiging van de opnames te bevelen voor zover ze niet van belang zijn voor de strafrechtelijke procedure: vernietiging vindt ook plaats wanneer de beslissing van de prokurator tot afluisteren - die daartoe zoals vermeld in spoedgevallen gerechtigd is - niet door de rechtbank wordt bekrachtigd. ${ }^{256}$ De beslissing tot afluisteren dient in beginsel direct aan de betrokkene bekend te worden gemaakt maar dit kan worden opgeschort voor zolang dat met het oog op het onderzoeksbelang noodzakelijk is. ${ }^{257}$ Wanneer een verdachte wordt getapt, is

251 Genoemd zijn onder andere: moord en doodslag, het veroorzaken van gevaar voor de openbare veiligheid of het veroorzaken van een ramp, mensenhandel, ontvoering, het eisen van losgeld, het kapen van een vliegtuig of een schip, beroving en afpersing met geweld, een aanslag tegen de soevereiniteit en onafhankelijkheid van de staat, een aanslag tegen de grondwettelijke orde van de staat, haar centrale overheidsorganen of tegen haar krijgsmacht, spionage of het onthullen van een staatsgeheim, het verzamelen van wapens, explosieven of radioactief materiaal, het vervalsen van geld en het vervaardigen, verhandelen of smokkelen van verdovende middelen.

252 Art. 237 lid 4 KPK 1997. Zie voor de verschillende verdachtenbegrippen: hoofdstuk 2, §3.1.3.1.

253 Grzegorczyk benadrukt dat er voor wat betreft de eerste categorie wel duidelijke aanwijzingen moeten bestaan dat de verdachte inderdaad contact met de betreffende persoon zal opnemen. Het kan daarbij gaan om personen uit de familie- of kennissenkring van verdachte, collega's et cetera: Grzegorczyk 2004, p. 610.

254 Zie ook Musiałik 1998, p. 89 en Hofmański e.a. 2007 I, p. 1066.

255 In 'uitzonderlijke gevallen' ('w szczególnie uzasadnionym wypadku') mag deze maximale termijn worden verlengd met nog eens drie maanden waardoor het middel in uitzonderingsgevallen voor ten hoogste een half jaar kan worden ingezet (art. 238 lid 1 KPK 1997). Bevoegd tot verlenging is de rechter die het oorspronkelijke bevel heeft gegeven. Volgens Hofmański betekent de voorwaarde 'uitzonderlijke gevallen' dat het om zware strafbare feiten moet gaan: Hofmański e.a. 2007 I, p. 1068.

256 Art. 237 lid 3 KPK 1997.

257 Deze informatie wordt schriftelijk aan de betrokkene medegedeeld en vermeldt in ieder geval welk orgaan het initiatief ertoe heeft genomen, hoe lang het heeft geduurd en het telefoonnummer dat is afgeluisterd: Kruszyński 2007 I, p. 189. 
het om voor de hand liggende redenen eerder regel dan uitzondering dat de tap tijdelijk geheim wordt gehouden. Bekendmaking kan echter niet later plaatsvinden dan 'het moment waarop de procedure rechtsgeldig wordt beëindigd' ('do czasu prawomocnego zakończenia postępowania'). ${ }^{258}$ Wat in dit verband precies onder 'beeindiging van de procedure' moet worden verstaan, is niet helemaal duidelijk en onderwerp van discussie in de literatuur. Strikt genomen is een procedure pas beëindigd wanneer de einduitspraak onherroepelijk is geworden: volgens deze uitleg zou de bekendmaking van de tap onder omstandigheden kunnen worden uitgesteld tot de uitspraak in hoger beroep. ${ }^{259}$ Sommige auteurs verzetten zich tegen deze ruime uitleg en zijn van mening dat met 'beëindiging van de procedure' in deze context wordt bedoeld het deel van de procedure waarin de telefoontap heeft plaatsgevonden. Wanneer er in het vooronderzoek wordt getapt, zou de betrokkene dan op zijn laatst voor sluiting van het vooronderzoek over de telefoontap moeten worden geïnformeerd. ${ }^{260}$ Grzegorczyk wijst deze beperkte uitleg af: hij is van mening dat de letter van de wet niet uitsluit dat het onderzoeksbelang (dat het uitstel van de mededeling rechtvaardigt) ook na een bepaalde fase van het strafrechtelijk onderzoek blijft voorbestaan. In deze uitleg - die het meest lijkt overeen te stemmen met de bedoeling van de wetgever - wordt het moment waarop uitstel van de mededeling niet langer mogelijk is slechts bepaald door de vraag of het onderzoeksbelang nog bestaat. ${ }^{261}$

Tegen de beslissingen tot afluisteren en opnemen van telecommunicatie kan bezwaar worden ingesteld. Wanneer de beslissing is genomen door de prokurator dient het rechtsmiddel te worden beoordeeld door de rechtbank. ${ }^{262}$ Omdat betrokkenen in de regel pas na beëindiging van de telefoontap op de hoogte worden gesteld, komt het rechtsmiddel meestal neer op een toetsing ex post. Wanneer het bezwaar

258 Art. 239 KPK 1997: 'De bekendmaking van de beslissing tot afluisteren en opnemen van telefoongesprekken aan de betrokkene kan worden uitgesteld voor zolang dat in het belang van het onderzoek noodzakelijk is maar niet later plaatsvinden dan het moment waarop de procedure rechtsgeldig wordt beëindigd.'

259 Zo wordt onder meer benadrukt door Kurzępa: Kurzępa 1999, p. 91.

260 Zie onder meer Ponikwia 2002, p. 142.

261 Grzegorczyk 2004, p. 617-618. Hofmański deelt deze mening: volgens hem zijn de autoriteiten - ook wanneer de telefoontap reeds is geëindigd - zolang de strafrechtelijke procedure nog loopt niet verplicht de betrokkene te informeren. Hij benadrukt daarbij echter dat het in de praktijk niet vaak zal voorkomen dat de verdediging lang van deze informatie verstoken blijft: in de regel zal bij de laatste inzage van de processtukken voor sluiting van het vooronderzoek of gedurende het eindonderzoek kennis kunnen worden genomen van de informatie die hierover in het dossier is opgenomen: Hofmański e.a. 2007 I, p. 1069-1070. Overigens gaat ook het EHRM ervan uit dat het moment waarop iemand moet worden geïnformeerd over de toepassing van (geheime) opsporingsbevoegdheden wordt bepaald door het onderzoeksbelang: '(...) the fact that persons concerned by such measures [of secret surveillance, toev. DdV] are not apprised of them while the surveillance is in progress or even after it has ceased cannot by itself warrant the conclusion that the interference was not justified under the terms of paragraph 2 of Article 8, as it is the very unawareness of the surveillance which ensures its efficacy. However, as soon as notification can be made without jeopardising the purpose of the surveillance after its termination, information should be provided to the persons concerned'. Zie Association for European Integration and Human Rights and Ekimdzhiev t. Bulgarije, EHRM 28-6-2007, nr. 62540/00, §90.

262 Art. 240 KPK 1997. Indien de bestreden beslissing afkomstig is van de rechtbank dient bezwaar te worden aangetekend bij een hogere rechter. 
gegrond wordt verklaard, kan dat ertoe leiden dat de resultaten van de tap niet voor het bewijs mogen worden gebezigd. ${ }^{263}$

\subsection{Toelaatbaarheid afluisteren en opnemen telefoongesprekken advocaat}

Aangezien advocaten in bovengenoemde regeling niet met zoveel woorden zijn uitgesloten, moet worden geconcludeerd dat het afluisteren van de telefoon van een advocaat - in ieder geval in theorie - is toegestaan. Dat hiervoor niet is vereist dat de advocaat zelf wordt verdacht van een strafbaar feit blijkt uit de ruime kring van personen die kunnen worden afgeluisterd. Het is immers zeer goed mogelijk dat de advocaat van een verdachte behoort tot de categorie personen 'met wie de beschuldigde (verdachte) in contact zou kunnen treden'. ${ }^{264}$ Voor bescherming van het beroepsgeheim van de advocaat is niet alleen van belang of hij zelf getapt kan worden: vertrouwelijke gesprekken kunnen immers ook worden afgeluisterd en opgenomen wanneer een cliënt wiens telefoon wordt getapt, contact opneemt met zijn advocaat. Ook voor deze situatie zijn in het Poolse strafprocesrecht geen bijzondere regels voorzien.

Onduidelijk is hoe de wettelijke mogelijkheid gesprekken met advocaten op te nemen en af te luisteren, zich verhoudt tot het verschoningsrecht van de advocaat dat - zoals bekend - voor wat betreft informatie die in de hoedanigheid van raadsman is verkregen absoluut is geformuleerd en in alle andere gevallen slechts onder bepaalde voorwaarden kan worden doorbroken. ${ }^{265}$ In de literatuur wordt door verschillende auteurs waaronder Grzegorczyk het standpunt ingenomen dat personen die een absoluut verschoningsrecht hebben - zoals de raadsman - niet mogen worden afgeluisterd. ${ }^{266}$ Ook Musiałik en Dudka zijn van mening dat afluisteren van een raadsman vanwege zijn absolute verschoningsrecht in geen geval is toegestaan. ${ }^{267}$

Wat betreft de vraag of ook het afluisteren van de advocaat die niet als raadsman optreedt ontoelaatbaar moet worden geacht, zijn zowel Dudka als Musiałik van mening dat een dergelijk absoluut verbod niet aan het huidige strafprocesrecht kan worden ontleend. Het verschoningsrecht van de advocaat kan immers onder bepaalde omstandigheden op bevel van de rechtbank worden opgeheven ${ }^{268}$ waaruit volgens beide auteurs moet worden afgeleid dat ook afluisteren van deze categorie geheimhouders niet is uitgesloten. Zij zijn het er echter wel over eens dat dit slechts bij wijze van uitzondering zou mogen gebeuren. Volgens Musiałik dient daarbij - net als voor de beslissing een advocaat als getuige te horen - bepalend te zijn of door middel van de telefoontap voor de strafzaak essentiële in-

263 Hofmański e.a. 2007 I, p. 1070-1071.

264 De eerste van de twee restcategorieën waarin art. 237 lid 4 KPK 1997 voorziet.

265 Art. 178 sub 1 en art. 180 lid 2 KPK 1997. Zie hiervoor $§ 6.1$ en 6.2.

266 Grzegorczyk 2004, p. 610-611.

267 Musiałik verwijst ter ondersteuning van dit standpunt niet alleen naar art. 178 sub 1 KPK 1997 maar ook naar de wijze waarop huiszoeking en inbeslagneming bij de raadsman is geregeld: aangezien het beroepsgeheim van de raadsman ook onder die omstandigheden bijzondere bescherming wordt geboden, mag ervan uit worden gegaan dat dit ook het geval dient te zijn bij het toepassen van andere opsporingsmethoden zoals de telefoontap, Musiałik 1998, p. 92-93.

268 Art. 180 lid 2 KPK 1997. 
formatie kan worden verkregen die niet op andere wijze kan worden vastgesteld. ${ }^{269}$ Ook Dudka benadrukt dat afluisteren van een advocaat alleen mag plaatsvinden wanneer dat absoluut noodzakelijk is voor de waarheidsvinding en stelt voor de wet zodanig te wijzigen dat het beluisteren van deze gesprekken nooit door de politie (en dus te allen tijde slechts door prokurator of rechtbank) mag worden gedaan. Dudka is bovendien van mening dat wanneer tijdens het afluisteren blijkt dat er gesprekken worden gevoerd die onder het beroepsgeheim van de raadsman vallen de verkregen gegevens onmiddellijk zullen moeten worden vernietigd. ${ }^{270}$ Opvallend is dat de discussie in de literatuur zich vooral concentreert op de vraag of het toelaatbaar is de telefoon van een advocaat te tappen: hoe het zit met de getapte cliënt die telefonisch contact opneemt met zijn advocaat komt niet of nauwelijks aan de orde. ${ }^{271} \mathrm{Op}$ de vraag wat in dit soort situaties dient te gebeuren, wordt dus noch door de wetgever noch in de literatuur een antwoord gegeven.

\subsection{Situatie voor inwerkingtreding nieuw strafprocesrecht}

Oorspronkelijk voorzag het wetboek van strafvordering van 1969 niet in de mogelijkheid telecommunicatie af te luisteren of op te nemen. Wel kon de prokurator of de rechtbank op grond van art. 198 KPK 1969 de afgifte van bepaalde 'correspondentie of zendingen' eisen van post-, telecommunicatie- en douanekantoren en transportbedrijven voor zover de inhoud ervan van belang was voor een aanhangige strafrechtelijke procedure. Een klein aantal auteurs was destijds van mening dat de bevoegdheid tot opnemen en afluisteren van telefoongesprekken - hoewel die niet met zoveel woorden in deze bepaling werd genoemd - toch aan art. 198 KPK 1969 kon worden ontleend. Immers, door een ruime uitleg te geven aan het begrip 'correspondentie' ('korespondencja') zou de bepaling niet alleen betrekking hebben op briefwisseling maar ook van toepassing kunnen zijn op andere (minder traditionele) vormen van communicatie waarbij gebruik wordt gemaakt van technische hulpmiddelen zoals via de telefoon. ${ }^{272}$ Dit standpunt werd door anderen echter fel bekritiseerd waarbij er op werd gewezen dat bepalingen die inbreuk maken op grondrechten - zoals het recht op verdediging - nooit ruim mogen worden uitgelegd zodat ervan uit moest worden gegaan dat het strafprocesrecht geen wettelijke grondslag bood voor het opnemen en afluisteren van telefoongesprekken. 273

Aan deze onduidelijkheid kwam definitief een einde toen art. 198 KPK 1969 bij wetswijziging van 18 december 1982 werd aangevuld: voortaan bood het de rechtbank en de prokurator de mogelijkheid de opname van telefoongesprekken te bevelen die van belang waren voor een aanhangige strafzaak. ${ }^{274}$ Zonder in te gaan op

269 Musiałik 1998, p. 91-92.

270 Dudka 1998, p. 76-82.

271 Wiliński merkt slechts terloops op dat het opnemen en afluisteren van telefoongesprekken van een verdachte zijn recht op (vertrouwelijke) communicatie met een raadsman kan beperken: Wiliński 2006, p. 517.

272 Waaronder Gubiński en Sawicki: zie Musiałik 1998, p. 87.

273 Dit standpunt werd onder meer verdedigd door Młynarczyk en Osiecki: zie Musiałik 1998, p. 87,

274 Art. 198 KPK 1969 voorzag alleen in de mogelijkheid tot het afluisteren van telefoongesprekken: de regeling had anders dan het huidige wetboek van strafvordering geen betrekking op andere vormen van telecommunicatie. 
de details van de in art. 198 KPK 1969 opgenomen regeling dient in ieder geval te worden opgemerkt dat het huidige strafprocesrecht de voorwaarden voor het afluisteren en opnemen van telefoongesprekken nauwkeuriger omschrijft. ${ }^{275}$ Dit zal worden toegelicht in de hiernavolgende paragraaf.

In het oude art. 198 KPK 1969 werd - net als in de huidige regeling van de telefoontap - geen antwoord gegeven op de vraag of ook de advocaat mocht worden afgeluisterd. Hoewel ook in de literatuur weinig aandacht aan deze kwestie werd besteed, konden in ieder geval twee verschillende standpunten worden onderscheiden: enerzijds dat het afluisteren van telefoongesprekken van personen met een geheimhoudingsplicht wel mogelijk was maar slechts wanneer daarvoor toestemming was verleend door een 'superieur' of 'disciplinair' orgaan (op welk soort organen hierbij werd gedoeld, is niet geheel duidelijk) en anderzijds dat professionele geheimhouders nooit mochten worden afgeluisterd omdat dit zou betekenen dat zij ten onrechte gelijk zouden worden gesteld met verdachten die er vanwege hun criminele activiteiten vanuit dienden te gaan dat dergelijke maatregelen tegen hen konden worden genomen. ${ }^{276}$

\subsection{Evaluatie juridisch kader}

Een verschil tussen de oude en de nieuwe regeling van de telefoontap is dat in art. 198 KPK 1969 geen aandacht werd besteed aan de vraag wie nu eigenlijk kon worden afgeluisterd. Het middel kon in beginsel tegen iedere (al dan niet verdachte) persoon worden aangewend voor zover verwacht werd dat de inhoud van de telefoongesprekken van betekenis zou kunnen zijn voor een lopende strafzaak. ${ }^{277}$ In het huidige wetboek van strafvordering is wel een opsomming gegeven van de verschillende categorieën personen wier telefoongesprekken kunnen worden afgeluisterd. Deze opsomming is echter zo ruim - vooral voor wat betreft de derden die zelf niet van een strafbaar feit worden verdacht - dat de regeling op dit punt nauwelijks meer duidelijkheid biedt dan voorheen. ${ }^{278}$ Een tweede punt van verschil betreft de maximale duur van de telefoontap. In de regeling van 1969 was de bevoegdheid niet aan een maximumtermijn verbonden terwijl nu is voorgeschreven dat het afluisteren en opnemen van telefoongesprekken ten hoogste drie (en in uitzonderingsgevallen zes) maanden mag duren. ${ }^{279}$ Bovendien is de bevoegdheid verder aan banden gelegd door te bepalen dat de telefoontap alleen kan worden ingezet wanneer het een van de door de wetgever genoemde strafbare feiten betreft. Ook die beperking ontbrak in art. 198 KPK 1969 op grond waarvan afluisteren in beginsel mogelijk was ten aanzien van ieder strafbaar feit. Een laatste verschil tussen de oude en de nieuwe regeling betreft de bevoegdheid van de prokurator: op grond van art. 198 KPK 1969 kon hij gedurende het vooronderzoek zelfstandig beslissen over de telefoontap terwijl dergelijke beslissingen vandaag de dag in beginsel zijn voorbehouden aan de rechtbank. ${ }^{280}$ De huidige wet-

275 Kurzępa 1999 en Grzegorczyk 2004, p. 609-610. Kritisch over art. 198 KPK 1969: Młynarczyk 1996.

276 Over beide standpunten (waarvan de tweede weinig recht doet aan het vermoeden van onschuld): Musiałik 1998, p. 87-88. Zie in dit verband ook: Dudka 1998, p. 77.

277 Musiałik 1998, p. 86.

278 Zie in gelijke zin: Dudka 1999, p. 75,

279 Art. 238 lid 1 KPK 1997.

280 Tenzij het gaat om een spoedgeval: dan kan de prokurator ingevolge art. 237 lid 2 KPK 1997 
telijke regeling is op een aantal punten dus met meer wettelijke waarborgen omkleed.

Noch in de oude noch in de nieuwe wettelijke regeling van de telefoontap wordt antwoord gegeven op de vraag of gesprekken met de raadsman ook kunnen worden afgeluisterd en - zo ja - onder welke voorwaarden dat dient te gebeuren. Bovendien is nergens geregeld wat dient te gebeuren wanneer een getapte verdachte telefonisch contact opneemt met zijn advocaat.

In de literatuur wordt er blijkbaar vanuit gegaan dat een raadsman nooit en een advocaat (die niet in de hoedanigheid van raadsman optreedt) slechts onder bepaalde voorwaarden mag worden afgeluisterd. De vraag hoe moet worden gehandeld wanneer een getapte verdachte zijn advocaat belt, blijft echter ook daar onbesproken. Auteurs die verdedigen dat de advocaat in strafzaken nooit getapt mag worden, zoeken daarvoor aansluiting bij het absolute verschoningsrecht van de raadsman zoals neergelegd in art. 178 lid 1 KPK 1997. Hoe wenselijk deze uitleg ook moge zijn, feit is dat de wetgever een dergelijk verbod tot afluisteren van de raadsman nergens heeft geëxpliciteerd: zoals gezegd is de advocaat noch de raadsman uitgesloten van de kring van personen wier telefoongesprekken op grond van art. 237 KPK 1997 kunnen worden afgeluisterd. Het is de vraag of hieruit moet worden afgeleid dat het opnemen en afluisteren van telefoongesprekken van advocaten zonder meer mogelijk is. De oplossing die in de literatuur wordt besproken - analoge toepassing van art. 178 sub 1 en 180 lid 2 KPK 1997 - is hoogstwaarschijnlijk het meest in overeenstemming met de ratio van deze beide bepalingen en dus met de bedoeling van de wetgever maar feit blijft dat zowel art. 178 als art. 180 lid 2 KPK 1997 slechts betrekking hebben op het horen van de raadsman en de advocaat als getuige en in de regeling betreffende het opnemen en afluisteren van telecommunicatie nergens van overeenkomstige toepassing worden verklaard.

Bovendien is niet duidelijk hoe de theoretische oplossing die in de literatuur wordt geboden in de praktijk moet worden vormgegeven. Immers, het onderscheid tussen raadsman en advocaat is op papier wellicht eenvoudig maar in werkelijkheid lastig te maken. ${ }^{281}$ Het problematische van de telefoontap is nu juist dat van te voren nooit kan worden gezegd waarop de inhoud van de afgeluisterde gesprekken betrekking zal hebben. Dit roept de vraag op hoe bij de beslissing of de telefoontap in een concreet geval toelaatbaar is, moet worden omgegaan met het in de literatuur gemaakte onderscheid tussen raadsman en advocaat. Duidelijk is dat het in ieder geval niet toelaatbaar zal zijn de raadsman van een verdachte in een bepaalde strafzaak af te luisteren maar daarmee is slechts een beperkt aantal situaties gedekt. In alle andere gevallen blijven veel vragen bestaan. Mag een advocaat die

zelf de beslissing tot afluisteren en opnemen van telecommunicatie nemen. Dit besluit dient vervolgens binnen drie dagen ter goedkeuring aan de rechtbank te worden overlegd.

281 De kwalificatie 'raadsman' verwijst slechts naar een hoedanigheid waarin een advocaat in een strafzaak kan optreden: het betreft geen aparte (als zodanig te herkennen) beroepsgroep. Integendeel: iedere raadsman is in eerste instantie advocaat. Slechts een beperkt deel van de Poolse advocatuur houdt zich uitsluitend met het strafrecht bezig maar ook de overige leden die niet gespecialiseerd zijn in het strafrecht kunnen vanwege de voor eenieder geldende verplichting zaken op basis van toevoeging te doen bij een strafzaak worden betrokken. In beginsel kan iedere advocaat dus zo nu en dan als raadsman optreden waardoor het onderscheid moeilijk op voorhand kan worden gemaakt. Zie eerder ook § 7.6. 
niet als raadsman voor een bepaalde verdachte optreedt wel worden getapt en zo ja, onder welke voorwaarden? Dient daarbij - zoals in de literatuur wordt geopperd - inderdaad aansluiting te worden gezocht bij de regeling van het relatieve verschoningsrecht zodat afluisteren alleen toelaatbaar is wanneer het bewijsmateriaal dat op die manier kan worden verkregen absoluut onmisbaar is voor de waarheidsvinding en niet op andere wijze kan worden verkregen? En als ervan uit moet worden gegaan dat de telefoonlijn van een advocaat inderdaad onder die omstandigheden mag worden getapt: wat dient er vervolgens te gebeuren wanneer tijdens het afluisteren wel gesprekken worden gevoerd die samenhangen met het optreden als raadsman (in een andere zaak) en dus onder het absolute verschoningsrecht van de advocaat vallen?282 En hoe dient met dit soort situaties om te worden gegaan wanneer de advocaat zelf als verdachte wordt getapt? Kan in zo'n geval de vertrouwelijkheid van gesprekken met cliënten die niets met de verdenking te maken hebben nog worden gegarandeerd of wordt deze opgeofferd in het belang van de waarheidsvinding in de strafzaak tegen de advocaat?

Het huidige strafprocesrecht biedt op geen van deze vragen een eenduidig antwoord.

\subsection{Telefoontap bij advocaten in de praktijk}

Het is goed mogelijk dat veel van bovengenoemde vragen louter theoretisch zijn. Over de vraag of - en zo ja in welke mate - het voorkomt dat telefoongesprekken van advocaten worden getapt, is helaas geen informatie beschikbaar. Volgens Kruszyński worden gegevens over de toepassing van de telefoontap bewust geheim gehouden. ${ }^{283}$ Overigens is het - ondanks het gebrek aan wettelijke waarborgen en de met geheimzinnigheid omhulde praktijk - niet iets waar de advocatuur zich erg druk over lijkt te maken. Er wordt zowel door de balie als in de literatuur niet of nauwelijks aandacht aan besteed.

\subsection{Telefoontap bij advocaten en het EVRM}

Het afluisteren en opnemen van telefoongesprekken vormt een inbreuk op het in art. 8 neergelegde recht op eerbiediging van het privé-leven en correspondentie en dient dus in overeenstemming met art. 8 lid 2 EVRM bij de wet te zijn voorzien. ${ }^{284}$ Zoals eerder aangegeven, stelt de voorwaarde dat de inbreuk 'in over-

282 Zoals eerder besproken, zijn sommige auteurs - zoals Dudka - van mening dat deze gesprekken onmiddellijk zullen moeten worden vernietigd maar feit blijft dat het huidige strafprocesrecht daartoe niet verplicht. Momenteel is slechts voorgeschreven dat opnames op bevel van de rechtbank moeten worden vernietigd wanneer de inhoud niet van betekenis is voor de strafrechtelijke procedure of wanneer de beslissing van een prokurator (een) bepaalde telefoonlijn(en) af te luisteren niet door de rechtbank wordt goedgekeurd. Bovendien is niet uitgesloten dat behalve de rechtbank en de prokurator ook de politie kennisneemt van de inhoud van deze gesprekken die onder het beroepsgeheim vallen waardoor - ook wanneer ze later worden vernietigd - toch het gevaar bestaat dat de verkregen informatie op een of andere manier wordt gebruikt bij de voortzetting van een lopende procedure of de aanvang van een nieuw onderzoek.

283 'In practice, telephone tapping is used only in respect of the most serious crimes. However, it is difficult to specify how often such methods are used because any information relating to them is kept secret': Kruszyński 2007 I, p. 188.

284 Het is vaste rechtspraak van het EHRM dat telefoongesprekken worden gedekt door de in art. 8 EVRM gehanteerde begrippen 'private life' en 'correspondence', zie onder andere 
eenstemming met de wet' moet zijn ook eisen aan de kwaliteit van wetgeving. Dat het nationale recht voldoende duidelijk en precies moet zijn, geldt volgens het EHRM in het bijzonder wanneer het - zoals bij de telefoontap - gaat om 'secret measures of surveillance or interception of communications by public authorities' omdat de burger in die gevallen moet kunnen inschatten wanneer en onder welke omstandigheden hij de inzet van dat soort geheime maatregelen kan verwachten. ${ }^{285}$ Het EHRM heeft in het kader van de beoordeling van de Franse afluisterbepalingen een aantal criteria genoemd waaraan nationale regelgeving in ieder geval dient te voldoen. Om misbruik te voorkomen dient in ieder geval in (geschreven of ongeschreven) recht te zijn vastgelegd:

1. welke (categorieën) personen kunnen worden afgeluisterd,

2. ten aanzien van welke strafbare feiten dit mogelijk is,

3. voor welke termijn afluisteren is toegestaan,

4. hoe processen-verbaal van de afgeluisterde gesprekken dienen te worden opgesteld en

5. wanneer opnames moeten worden gewist of vernietigd. 286

Gelet op deze kwaliteitscriteria is duidelijk dat het Poolse strafprocesrecht in vergelijking met het oude wetboek van strafvordering - toen op nagenoeg alle genoemde punten onduidelijkheid bestond - belangrijke en noodzakelijke vooruitgang heeft geboekt. Op de meer specifieke vraag of de huidige Poolse tapregeling in abstracto in alle opzichten aan de eisen van het EVRM voldoet zal hier niet worden ingegaan. Wel is van belang om te bekijken hoe de mogelijkheid telefoongesprekken van advocaten af te luisteren zich verhoudt tot het EVRM.

Uit de rechtspraak van het EHRM kan worden afgeleid dat het nationale recht voor wat betreft het afluisteren van advocaten in ieder geval antwoord dient te geven op de vraag welke informatie onder het beroepsgeheim van de advocaat valt en door wie wordt beoordeeld of afgeluisterde gesprekken vertrouwelijke informatie bevatten. Bovendien staat vast dat wanneer de uitvoering van een dergelijke taak wordt overgelaten aan iemand van de uitvoerende macht daarop in

Klass e.a. t. Duitsland, 6-9-1978, A28, nr. 5029/71, Malone t. Verenigd Koninkrijk, EHRM 2-81984, A82, nr. 8691/79, en Halford t. Verenigd Koninkrijk, EHRM 25-6-1997, nr. 20605/92.

285 Zie onder andere Halford $t$. Verenigd Koninkrijk, EHRM 25-6-1997, nr. 20605/92 (§ 49).

286 Kruslin t. Frankrijk, EHRM 24-4-1990, A176-A, nr. 11801/85 en Huvig t. Frankrijk, EHRM 24-4-1990, A176-B, nr. 11105/84, § 35. Dit waren de punten waarop het Franse recht volgens het Europese Hof tekortschoot. De waarborgen die de nationale regeling wel bood - het feit dat de beslissing tot afluisteren was voorbehouden aan een onafhankelijke rechter, dat tegen deze beslissing een rechtsmiddel kon worden ingesteld, dat listen, valstrikken en provocaties waren verboden en dat de vertrouwelijkheid van gesprekken tussen raadsman en verdachte moest worden beschermd - werden door het EHRM positief bevonden zodat daaruit zou kunnen worden afgeleid dat nationale regelgeving in beginsel ook aan die punten aandacht behoort te besteden, zie $\S 34$. Zie voor de eisen die in het licht van art. 8 EVRM aan nationale 'secret surveillance measures' mogen worden gesteld ook de uitspraak in de zaak Association for European Integration and Human Rights and Ekimdzhiev t. Bulgarije (EHRM 28-6-2007, nr. 62540/00) waarin het Bulgaarse recht op dit punt uitgebreid door het Europese Hof wordt getoetst en - vanwege het feit dat aan de autoriteiten ruime (geheime) opsporingsbevoegdheden waren toegekend zonder voldoende waarborgen tegen misbruik - uiteindelijk een schending van art. 8 EVRM wordt geconstateerd. 
ieder geval toezicht dient te worden uitgeoefend door een onafhankelijke rechter. ${ }^{287}$ In zijn algemeenheid geldt dat het Europese Hof veel waarde hecht aan de vraag of in de nationale tapregeling in rechterlijk toezicht is voorzien. ${ }^{288}$

Wanneer een advocaat in de hoedanigheid van verdachte wordt getapt, is van belang dat de gevolgde procedure bepaalde waarborgen biedt ter bescherming van belangen van cliënten die met strafvervolging niets te maken hebben. ${ }^{289}$

Wanneer we deze voorwaarden toepassen op de Poolse situatie wordt al snel duidelijk dat het Poolse recht aan genoemde punten geen of in ieder geval onvoldoende aandacht besteedt. In de strafvorderlijke tapregeling wordt de advocaat of het beroepsgeheim geen enkele keer genoemd en dus ook niet van toepassing uitgesloten. Daardoor is in ieder geval in theorie de mogelijkheid opengelaten

287 Zie Kopp t. Zwitserland, EHRM 25-3-1998, nr. 23224/94. In deze zaak waren gedurende ongeveer drie weken alle telefoonlijnen van het advocatenkantoor van Kopp afgeluisterd. Voor wat betreft de vraag of deze inbreuk op art. 8 EVRM voldoende duidelijk was vastgelegd in het Zwitserse recht oordeelde het Europese Hof dat de nationale wetgeving in het kader van de telefoontap weliswaar bescherming bood aan de professionele geheimhouder maar dat niet duidelijk was op welke wijze en door wie het onderscheid moest worden gemaakt tussen informatie die wel en niet onder de reikwijdte van het beroepsgeheim valt. Het is volgens het EHRM op zijn zachtst gezegd verbazingwekkend dat deze toetsing in het geval van Kopp werd overgelaten aan een medewerker van een postkantoor zonder enige controle door een onafhankelijke rechter. Dat geldt des te meer nu het hier gaat om '(...) the sensitive area of the confidential relations between a lawyer and his clients, which directly concern the rights of the defence' (\$ 74).

288 Zo bleek onder meer in Aalmoes t. Nederland, EHRM 25-11-2004, nr. 16269/02 (ontvankelijkheidsbeslissing). De klacht - ingediend door een groot aantal Nederlandse strafrechtadvocaten - werd door het EHRM ongegrond verklaard. Belangrijkste reden hiervoor was het feit dat de (nieuwe) Nederlandse tapregeling op verschillende momenten in rechterlijk toezicht voorziet waardoor volgens het EHRM in voldoende mate aan de eisen van art. 8 lid 2 EVRM wordt tegemoetgekomen. In de woorden van het EHRM: 'The suggestion that information conveyed by or to a lawyer in the latter's professional capacity is susceptible to interception, particularly by criminal investigation authorities who may have a direct interest in obtaining such information, is not in keeping with the principles of confidentiality and professional privilege attaching to relations between a lawyer and his or her clients. It is for this reason that, in principle, lawyers have in their professional contacts with their clients a reasonable expectation of protection and respect for their professional privacy. In order to secure respect for this reasonable expectation, it is therefore required that the interception of telecommunications be subject to an adequate system of supervision. In this area, faced with evolving and sophisticated technology and the possibility of human error or abuse, the Court considers that it is in principle desirable to entrust the supervisory control to a judge.' Deze uitspraak is overigens vatbaar voor kritiek omdat het Europese Hof eraan voorbij lijkt te gaan dat door de vervolging kennis kan worden genomen van de inhoud van telefoongesprekken die onder het beroepsgeheim van de advocaat vallen. Bovendien wordt erg veel waarde gehecht aan het rechterlijk toezicht dat de facto weinig voorstelt en dus niet of nauwelijks een waarborg kan worden genoemd.

289 Mulders t. Nederland, ECRM 6-4-1995, nr. 23231/94. In casu oordeelde de Europese Commissie voor de rechten van de mens dat de oude situatie in het Nederlandse strafprocesrecht - op grond waarvan gesprekken die onder het beroepsgeheim vielen door de onderzoeksrechter moesten worden vernietigd - voldeed aan de voorwaarden genoemd in art. 8 lid 2 EVRM. Ook van belang is de zaak Lambert t. Frankrijk (EHRM 24-8-1998, nr. 23618/94) waarin werd vastgesteld dat ook de advocaat die als derde - dus niet als verdachte - wordt getapt een rechtsingang moet hebben om de rechtmatigheid van de tap te kunnen laten toetsen. Zie Spronken 2001, p. 479. 
dat een advocaat - in de hoedanigheid van verdachte of als derde partij - wordt afgeluisterd zonder dat is geregeld hoe in zo'n geval met het beroepsgeheim van de advocaat moet worden omgegaan. ${ }^{290} \mathrm{Er}$ zijn geen bijzondere regels gecreëerd die antwoord geven op de vraag wie bepaalt welke gesprekken er onder het beroepsgeheim vallen en wat er vervolgens met deze vertrouwelijke informatie dient te gebeuren. Op grond van de algemene regeling geldt dat de prokurator en in bepaalde gevallen de politie kennis kunnen nemen van de inhoud van de gesprekken en dat de opnames slechts worden vernietigd wanneer ze niet van betekenis blijken te zijn voor de strafrechtelijke procedure: er bestaat dus geen garantie dat vertrouwelijke gegevens - ook al worden ze vernietigd - niet toch voor het strafrechtelijk onderzoek worden gebruikt. Hierdoor mist de huidige regeling voldoende duidelijke waarborgen die advocaten en hun cliënten dienen te beschermen tegen inbreuken op hun vertrouwensrelatie. Hoewel er nog geen rechtspraak tegen Polen beschikbaar is die dit bevestigd, is een schending van art. 8 EVRM in de praktijk dus niet ondenkbaar.

\section{Conclusie verschoningsrecht}

Voor wat betreft de mogelijkheid een advocaat als getuige te horen, geldt dat het verschoningsrecht in het huidige strafprocesrecht met meer waarborgen is omkleed dan in het oude wetboek van strafvordering. Zo is de beslissing een advocaat als getuige te horen over feiten die hij in het kader van zijn beroepsuitoefening heeft vernomen aan nadere voorwaarden verbonden en onderworpen aan meer rechterlijke controle dan voorheen. Ondanks deze precisering bestaat nog altijd veel discussie over de verhouding tussen de absoluut geformuleerde geheimhoudingsplicht in de Advocatenwet en de strafvorderlijke mogelijkheid een advocaat onder bepaalde omstandigheden als getuige te horen. De hoogste nationale rechterlijke instanties - het Hooggerechtshof en het Grondwettelijk Hof - hebben echter aangegeven dat de strafvorderlijke regel als lex specialis dient te worden beschouwd en dus voorrang moet krijgen op de bepaling uit de Advocatenwet.

Het komt in de praktijk wel voor dat een advocaat als getuige wordt opgeroepen maar het gaat om incidenten. De balie verzet zich hier fel tegen en beschouwt dergelijke acties als een ernstige aantasting van de vertrouwelijkheid die tussen advocaat en cliënt dient te bestaan. Het beroepsgeheim van de raadsman geniet - anders dan wanneer het niet om het optreden in een strafzaak gaat - wel absolute bescherming op grond van het strafprocesrecht.

Voor de positie van de advocaat als verschoningsgerechtigde bij huiszoekingen en telefoontaps is - zowel in de wettelijke regeling als in de doctrine - veel minder aandacht. Het lijkt erop dat deze onderwerpen bij de voorbereiding van het nieuwe strafprocesrecht minder prioriteit hebben gehad dan de regeling van het vrij verkeer en de mogelijkheid advocaten als getuige te horen. Dat terwijl uit de rechtspraak van het EHRM kan worden afgeleid dat de vertrouwelijkheid van het contact tussen advocaat en cliënt ook zoveel mogelijk beschermd dient te worden bij de toepassing van opsporingsbevoegdheden. Dit betekent in ieder geval dat de

$290 \mathrm{Al}$ is voor wat betreft de raadsman gebleken dat sommige auteurs van mening zijn dat zijn absolute verschoningsrecht zich daartegen verzet. 
nationale procedure voldoende duidelijk moet zijn en bepaalde rechtswaarborgen moet bieden.

Van de twee genoemde opsporingsbevoegdheden bevat de regeling van de huiszoeking nog verreweg de meeste waarborgen. De bescherming van het verschoningsrecht op dit punt is - ook met het oog op de eisen van het EVRM - in vergelijking met het oude strafprocesrecht in een aantal opzichten verbeterd. Toch laat de huidige regeling nog de nodige vragen onbeantwoord. Zo is onder meer onduidelijk hoe het door de wetgever in dit verband gemaakte onderscheid tussen raadsman en advocaat in de praktijk functioneert, is de functie van de onafhankelijke waarnemer die (op grond van de gedragsregels) namens de balie aanwezig dient te zijn bij de huiszoeking niet uitgewerkt, is voor een huiszoeking in het vooronderzoek geen rechterlijke machtiging vereist en roept het feit dat de wettelijke waarborgen waarin het strafprocesrecht voorziet pas betekenis krijgen wanneer de advocaat (bij wie de huiszoeking wordt verricht) tegen inbeslagneming van bepaalde stukken protesteert, de vraag op wat dient te gebeuren wanneer een dergelijk protest uitblijft.

De grootste onduidelijkheid bestaat echter op het terrein van de telefoontap. Het huidige strafprocesrecht voorziet in ruime mogelijkheden telefoonverkeer af te luisteren - ook van personen die niet als verdachte worden aangemerkt - en daarbij is op geen enkele wijze voorzien in bijzondere regels of waarborgen die kunnen voorkomen dat kennis wordt genomen van informatie die onder het beroepsgeheim van de advocaat valt. Hoe hier in de praktijk mee wordt omgegaan, is niet bekend. In de literatuur wordt wel verdedigd dat de raadsman vanwege zijn absolute verschoningsrecht niet mag worden afgeluisterd maar een dergelijk verbod is nergens verankerd in de wet. Aangezien de huidige regels geen duidelijk antwoord bieden op de vraag of, en zo ja, onder welke voorwaarden afluisteren van een advocaat is toegestaan en welke waarborgen daarbij in acht moeten worden genomen om het beroepsgeheim zo veel mogelijk te kunnen beschermen, is het zeer de vraag of het Poolse recht op dit punt in overeenstemming is met de eisen van het EVRM. 



\section{Hoofdstuk 8}

\section{De Poolse advocatuur: organisatie, beroepscultuur en ethiek}

'How the legal profession thinks is a major factor affecting the deep strucure of the sources of law. How the legal profession is organized is an important institutional factor in understanding the way in which legal systems develop and change'

U. Mattei

\section{Inleiding}

In een onderzoek naar de gevolgen van postcommunistische hervormingen voor de verdediging in strafzaken is het zinvol ook aandacht te besteden aan de beroepsgroep in zijn algemeenheid. Enerzijds omdat het kan illustreren hoe de transitie van een communistisch systeem naar een democratische rechtsstaat van invloed is op de (opvattingen over de) rol en de positie van de advocatuur en anderzijds omdat de organisatie en het functioneren van de beroepsgroep - met name hoe de toetreding is geregeld en op welke wijze toezicht wordt uitgeoefend op het functioneren van individuele leden - het optreden van de advocaat in strafzaken beïnvloeden.

Het afgelopen decennium is in toenemende mate kritiek uitgeoefend op de geprivilegieerde positie van de Poolse advocatuur wat uiteindelijk heeft geresulteerd in verschillende vergaande hervormingen die de autonomie van de balie aanzienlijk hebben gereduceerd. Deze ontwikkelingen zullen in dit hoofdstuk worden besproken aan de hand van drie hoofdthema's: de structuur van de beroepsorganisatie, de beroepscultuur en het gedragsrecht (beroepsethiek). Voor wat het eerste thema betreft, zal eerst aandacht worden besteed aan de historische ontwikkeling van de beroepsgroep in het algemeen en de gevolgen van het communistisch regime voor de onafhankelijkheid van de balie in het bijzonder. Daarna zal stil worden gestaan bij de veranderingen die de balie - als gevolg van toenemende kritiek op haar gesloten en elitaire karakter - de laatste jaren heeft ondergaan. ${ }^{1}$

$\mathrm{Na}$ een korte beschouwing over de beroepscultuur die binnen de Poolse balie heerst, zal worden overgegaan tot een bespreking van het gedragsrecht. Daarbij zal in de eerste plaats de geschiedenis van de gedragsregels worden bekeken en aan de orde komen in hoeverre het gedragsrecht zich heeft aangepast aan (of is beïnvloed door) de ontwikkelingen die het Poolse rechtssysteem sinds het einde van de jaren tachtig heeft doorgemaakt. Hierna zullen de belangrijkste gedragsrechtelijke bepalingen die het optreden van de advocaat in strafzaken normeren, thematisch worden besproken. Ten slotte zal aandacht worden besteed aan de procedurele aspecten van de tuchtrechtspraak waarbij achtereenvolgens de organisatie van het tuchtrechtelijk toezicht en het functioneren ervan in de praktijk aan bod zullen komen.

1 Hierbij moet worden opgemerkt dat deze hervormingen ten tijde van de afronding van dit onderzoek nog steeds gaande waren: het gaat hier dus niet om een beschrijving van een afgerond proces maar om de illustratie van een ontwikkeling. 


\section{Beroepsorganisatie}

\subsection{Structuur}

Alle advocaten en advocaat-stagiaires in Polen maken deel uit van een landelijke balie die zowel op centraal als op regionaal niveau is georganiseerd. De structuur van de balie en de bevoegdheden van de verschillende organen zijn vastgelegd in de Advocatenwet. ${ }^{2}$

De centrale leiding is in handen van de Hoogste Raad (Naczelna Rada Adwokacka: NRA) die gevestigd is in Warschau. Op regionaal niveau is de balie onderverdeeld in 24 kamers (izby adwokackie): ieder lid van de beroepsorganisatie dient bij een van deze kamers ingeschreven te staan. ${ }^{3}$ Aan het hoofd van iedere kamer staat een regionale raad (Okregowa Rada Adwokacka: ORA). ${ }^{4}$ De Hoogste Raad bestaat uit een voorzitter (prezes), 24 gekozen advocaten en de 24 dekens van de verschillende kamers. De dagelijkse leiding is in handen van een presidium dat onder anderen bestaat uit een voorzitter, 2 vice-voorzitters, een secretaris, een penningmeester en iemand die als aanklager in tuchtrechtelijke procedures optreedt (rzecznik dyscyplinarny). Tevens is er een nationale vergadering (Krajowy Zjazd Adwokatury) samengesteld uit vertegenwoordigers van alle kamers die eens in de drie jaar samenkomt en onder andere tot taak heeft de leden van de Hoogste Raad (met uitzondering van de dekens) en de Hoogste tuchtrechtelijke instantie te kiezen. Op centraal niveau bestaat ook de Hoogste tuchtrechtelijke instantie (Wyższy Sąd Dyscyplinarny) - waarover meer bij de bespreking van het tuchtrecht later in dit hoofdstuk - en een centraal orgaan dat belast is met het toezicht op de financiële en economische activiteiten van de beroepsorganisatie (Wyższa Komisja Rewizyjna).

Vergelijkbare organen bestaan op regionaal niveau: iedere kamer beschikt over een eigen tuchtrechtelijke instantie (sad dyscyplinarny izby adwokackiej) en een commissie die zich bezig houdt met de financiën (komisja rewyzyjna izby adwokackiej). De regionale raden die aan het hoofd van de verschillende kamers staan, zijn samengesteld uit een deken (dziekan) en een per kamer (tussen de 5 en de 15) variërend aantal leden. De deken maakt onderdeel uit van het presidium van de regionale raad waartoe ook een vice-deken, een penningmeester, een secretaris en een aanklager in tuchtrechtzaken behoren. Leden van de verschillende binnen de balie werkzame organen worden door en uit de beroepsgroep gekozen.

De advocatuur beschikt over een eigen tijdschrift genaamd Palestra (zoals de balie in het Pools wordt aangeduid) dat eens in de twee maanden verschijnt en waarin door zowel advocaten als externe auteurs wordt gepubliceerd over actuele thema's. ${ }^{5}$ Het blad kent een lange geschiedenis - de eerste uitgave verscheen reeds in 1924 - en heeft in de loop der jaren een belangrijke plaats ingenomen in de Poolse juridische literatuur.

De balie is ruim vertegenwoordigd op het internet. Er is een algemene site - die deels ook in het Engels veel informatie biedt over onder verschillende thema's zo-

2 Prawo o Adwokaturze, wet van 26 mei 1982, hierna aangeduid als (de) Advocatenwet.

3 De Hoogste Raad en de kamers hebben rechtspersoonlijkheid (art. 10 Advocatenwet).

4 De 24 regionale raden zijn gevestigd in: Białystok, Bielsko-Biała, Bydgoszcz, Częstochowa, Gdańsk, Katowice, Kielce, Koszalin, Kraków, Lublin, Łódź, Olsztyn, Opole, Płock, Poznań, Radom, Rzeszów, Siedlce, Szczecin, Toruń, Wałbrzych, Warschau, Wrocław en Zielona Góra.

5 Zie <www.palestra.pl>. 
als de organisatiestructuur, relevante regelgeving en actualiteiten. Ook de Hoogste Raad en een aantal regionale raden beschikken over een eigen website. ${ }^{6}$ De balie is lid van verschillende internationale organisaties waaronder de IBA (International Bar Association) en de CCBE (Council of Bars and Law Societies of Europe).

Er bestaat geen aparte organisatie voor of vereniging van strafrechtadvocaten. ${ }^{7}$ Dit hangt waarschijnlijk samen met het feit dat er binnen de Poolse advocatuur van oudsher een bepaalde weerstand tegen specialisatie bestaat: een advocaat wordt geacht van alle markten thuis te zijn en dient dus in beginsel binnen alle rechtsgebieden te kunnen opereren. De laatste jaren komt specialisatie binnen de advocatuur als gevolg van de zich ontwikkelende vrije markteconomie echter steeds meer voor. Het strafrecht behoort daarbij niet tot de meest populaire rechtsgebieden: veelal gaat de voorkeur uit naar meer 'commerciële' terreinen van het recht zoals handels- en ondernemingsrecht die sinds de opkomst van de vrije markt sterk in ontwikkeling - en in vergelijking met het strafrecht - financieel interessanter zijn.

Om toe te kunnen treden tot de balie dient aan een aantal algemene voorwaarden te worden voldaan. ${ }^{8}$ Een aspirant-advocaat dient:

1. een onberispelijke reputatie te hebben en gedrag te vertonen dat garandeert dat hij het beroep van advocaat op de juiste wijze zal uitoefenen,

2. in het bezit van alle publieke rechten en volledig beschikkingsbevoegd te zijn,

3. een Poolse rechtenopleiding ${ }^{9}$ te hebben afgerond en de bijbehorende titel te hebben verkregen ${ }^{10}$ en

4. de advocatenstage binnen Polen te hebben afgerond en het bijbehorende eindexamen met goed gevolg te hebben afgelegd. ${ }^{11}$

In 2005 is de Advocatenwet - onder druk van toenemende kritiek dat de advocatuur onvoldoende toegankelijk zou zijn voor jonge juristen - aangepast. De belangrijkste veranderingen betreffen de wijze waarop de examens van de kandidaten worden georganiseerd en de vraag onder welke omstandigheden een jurist met relevante werkervaring van een van de toelatingseisen (stage en/of examens) mag worden vrijgesteld. ${ }^{12}$

Alleen juristen die lid zijn van de balie mogen zich advocaat (adwokat) noemen en met deze titel zijn ze in beginsel bevoegd in alle soorten zaken rechtsbijstand

6 De site van de Hoogste Raad is te vinden op: <www.bip.adwokatura.pl $>$. Voorbeelden van sites van regionale raden: <www.rada-adwokacka.poznan.pl/mp-bin/index>, <www. adwokatura.krakow.pl> en <www.ora-warszawa.com.pl>.

7 Zoals de Nederlandse Vereniging van Strafrecht Advocaten.

$8 \quad$ Zie ook hoofdstuk 2, § 3.1.3.2.

9 De universitaire rechtenopleiding duurt vijf jaar. Voor meer informatie over (de ontwikkeling van) de juridische opleiding in Polen: Gostynski en Garfield 1993.

10 Ook mogelijk is dat de kandidaat een rechtenopleiding buiten Polen heeft afgerond die door Polen wordt erkend.

11 Deze cumulatieve voorwaarden zijn neergelegd in art. 65 Advocatenwet.

12 In § 2.4 zal dieper worden ingegaan op de totstandkoming en de gevolgen van genoemde wetswijziging. 
te verlenen. Slechts gedurende de stageperiode - de advocaat-stagiaire wordt aangeduid als aplikant - gelden op dit punt bepaalde beperkingen. ${ }^{13}$

De laatste jaren fluctueerde het aantal leden van de balie tussen de 7000 en 8000 . Een aanzienlijk deel van de leden van de balie - ongeveer een vierde - staat wel ingeschreven maar is vanwege hoge leeftijd of andere werkzaamheden niet (meer) actief. Het aantal actieve advocaten is dus beduidend lager.

In Polen wordt veelvuldig de kritiek geuit dat het aantal advocaten in verhouding tot het aantal inwoners (circa 38 miljoen) veel te klein is en dat de toegang tot en de kwaliteit van rechtsbijstand hierdoor negatief wordt beïnvloed. ${ }^{14}$ De advocatuur is niet de enige beroepsgroep die zich bezig houdt met het verlenen van rechtsbijstand: er is ook nog een afzonderlijke balie van juridisch adviseurs. ${ }^{15}$ Deze groep is veel groter (circa 22.000) maar heeft voor het grootste gedeelte wel een ander werkterrein dan de advocaat. De juridisch adviseur is een overblijfsel uit de communistische periode toen deze beroepsgroep hoofdzakelijk rechtsbijstand verleende aan staatsondernemingen. ${ }^{16}$ In de loop der jaren is het werkterrein van de juridisch adviseur geleidelijk aan uitgebreid - ook tot het bijstaan van individuele burgers - en zodoende op een aantal punten gelijk geworden aan dat van de advocaat. Er is echter nog steeds een aanzienlijk aantal taken dat wel door de advocaat en niet door de juridisch adviseur kan worden uitgevoerd. Dit speelt met name ook in strafzaken: de juridisch adviseur kan slechts in overtredingszaken optreden waardoor zijn rol binnen de strafrechtspleging uiterst beperkt is.

\subsection{Geschiedenis}

De Poolse advocatuur kent een lange geschiedenis. Reeds in documenten uit de $14^{\mathrm{e}}$ en $15^{\mathrm{e}}$ eeuw wordt melding gemaakt van het beroep van 'verdediger'. ${ }^{17} \mathrm{Er}$ was

13 Voor het optreden in strafzaken is in dit verband van belang dat een stagiaire gedurende de eerste zes maanden van zijn opleiding alleen een advocaat mag vervangen voor de laagste rechterlijke instantie (SR). Na verloop van de eerste anderhalf jaar mag hij voor alle rechterlijke instanties waaronder de provinciale rechtbank $(\mathrm{SO})$ en de appelinstanties (SA) optreden met uitzondering van het Hooggerechtshof en het Grondwettelijk Hof (art. 77 Advocatenwet).

14 Op deze discussie zal worden teruggekomen in § 2.4.2.

15 Een aantal jaren geleden is serieus gediscussieerd over samenvoeging van de twee balies maar dit is - voornamelijk als gevolg van verzet van de advocatuur - niet gerealiseerd. Deze discussie is recent door de nieuwe minister van justitie (Ćwiąkalski) opnieuw leven in geblazen.

16 De communistische ideologie ging er weliswaar vanuit dat het recht geleidelijk aan zou verdwijnen en dus ook dat juristen een uitstervende beroepsgroep vormden maar dit nam niet weg dat in de lange en moeizame weg naar de communistische samenleving - met name binnen staatsondernemingen - behoefte bestond aan professionele rechtsbijstand: 'Marxism relies on economic rather than legal institutions. Yet these Marxist institutions needed assistance in dealing with the legal issues inevitably arising for complex economic enterprises. State enterprises perpetuated the need for jurisconsults-legal advisers to solve the problems faced by these institutions': Meyer 1995, p. 1026 (over de juridisch adviseur in de Sovjet-Unie aan het einde van de jaren dertig). Zie over rechtsbijstand en het communisme uitgebreider hoofdstuk 3.

17 Zo werd in de zogenaamde 'Nieszawa privileges' uit 1454 al voorzien in de ambtshalve toevoeging van een vertegenwoordiger door de rechtbank wanneer een partij niet in staat was zelf zijn belangen te behartigen: Czeszejko-Sochacki 1978, p. 181. Zie ook Krzemiński 1998 p. 7 en Krzemiński 2003, p. 11. 
in deze tijd echter nog geen sprake van een georganiseerde beroepsgroep en er bestond dus ook geen wettelijke regeling waarin de structuur en het functioneren van de advocatuur was vastgelegd. De totstandkoming van een dergelijke organisatie met bijbehorende wettelijke status heeft door de bezetting en verdeling van het Poolse grondgebied in 1795 tot het begin van de $20^{\mathrm{e}}$ eeuw op zich laten wachten. ${ }^{18}$ Gedurende de 123 jaar durende bezetting gold voor de advocatuur in de verschillende delen van het voormalig Pools grondgebied de wetgeving van de bezettende buurlanden. ${ }^{19}$

Toen Polen aan het einde van Wereldoorlog I weer onafhankelijk werd, stond de oprichting van een eigen, nationale balie hoog op de politieke agenda. In 1918 - het jaar van de herwonnen onafhankelijkheid - verscheen het zogenaamde 'tijdelijke statuut' van de Poolse balie waarin werd voorzien in tijdelijke oplossingen voor de meest urgente problemen. Aangezien de structuur en organisatie van de advocatuur hiermee voor het eerst wettelijk was vastgelegd, wordt 1918 wel beschouwd als het 'geboortejaar' van de Poolse balie. ${ }^{20}$ De organisatie was - net als vandaag de dag - opgebouwd uit een centraal orgaan (Hoogste Raad te Warschau) en decentrale organen (kamers en regionale raden) waarvan de leden democratisch werden gekozen. Deze structuur is in de loop der jaren grotendeels hetzelfde gebleven. Tuchtrechtspraak vond plaats in twee instanties waarvan alleen advocaten deel konden uitmaken. Door middel van deze organen kon de balie volledig zelfstandig opereren. ${ }^{21}$ De enige uitzondering op de autonomie was de bevoegdheid van de minister van Justitie beslissingen van de Hoogste Raad te vernietigen wegens strijd met het recht.

Het statuut van 1918 had zoals gezegd slechts een tijdelijk karakter en in 1932 kwam de eerste definitieve wettelijke regeling van de Poolse balie tot stand die wederom was gebaseerd op autonomie van de advocatuur. De liberale Advocatenwet van 1932 werd in 1938 als gevolg van de totalitaire invloeden die kenmerkend waren voor de laatste jaren van het interbellum op een aantal punten gewijzigd. Een van de consequenties van deze wetswijziging was dat de balie een deel van haar onafhankelijkheid moest afstaan. De minister van Justitie kreeg op verschillende punten meer invloed op de advocatuur: zo diende een aantal leden van de Hoogste Raad door hem te worden aangewezen en kreeg hij de bevoegdheid de toelating van nieuwe leden tot overvolle kamers tijdelijk op te schorten. Ondanks deze inperking van de autonomie heeft de Poolse balie zich voorafgaand aan Wereldoorlog II kunnen ontwikkelen tot een zelfstandige beroepsgroep met een solide positie in de samenleving. ${ }^{22}$

18 Zie ook hoofdstuk 2, § 2.1.

19 Czeszejko-Sochacki 1978, p. 181. Zie over de geschiedenis van de balie ook: Bojarski 2006, p. 225-226,

20 In 2008 viert de balie haar 90-jarig jubileum.

21 Vandaar dat de regeling van 1918 door Krzemiński 'de meest moderne tekst van toenmalig Europa' wordt genoemd: Krzemiński 2003, p. 12.

22 Op dit punt dient onderscheid te worden gemaakt tussen enerzijds de landen van Centraal-Europa (met name Polen, Tsjechië en Hongarije) waar de advocatuur de WestEuropese tradities volgde en kon uitgroeien tot een groep zelfstandig opererende juristen die deel uitmaakte van de intellectuele elite en anderzijds het grootste gedeelte van de Balkan waar een dergelijke ontwikkeling door de Turkse overheersing onmogelijk werd gemaakt: Meyer 1995, p. 1021. 
Gedurende Wereldoorlog II werd de kracht van de balie zwaar op de proef gesteld. De beroepsorganisatie werd gedwongen leden met een Joodse achtergrond van de lijst te schrappen - wat stelselmatig werd geweigerd - en uiteindelijk tot een verboden organisatie uitgeroepen. Dit weerhield de balie er echter niet van haar activiteiten ondergronds voort te zetten. De vastberadenheid waarmee ondanks alle risico's verzet werd gevoerd, toont de grote onderlinge verbondenheid en moed die de advocatuur in deze tijd kenmerkten. ${ }^{23}$ Het aantal slachtoffers onder advocaten was enorm: meer dan de helft van de leden van de balie $(56 \%)$ overleefde de oorlog niet. $^{24}$

\subsubsection{De communistische periode}

$\mathrm{Na}$ de oorlog diende de advocatuur - net als de rechterlijke macht en de prokuratura - opnieuw georganiseerd te worden. De eerste stap in de richting van de 'wederopbouw' was de (her)oprichting van de eerste regionale raad van Lublin (1944). De wet van 1932 bleef formeel van kracht maar al snel werd duidelijk dat de balie aan de eisen van de nieuwe tijd moest worden aangepast. In een regime waar het recht als politiek instrument volledig in dienst van de overheid stond, kon de advocatuur niet langer volledig autonoom blijven. De vooroorlogse balie werd door de nieuwe machthebbers beschouwd als 'een van de meest achterlijke instituten' die met het oog op 'maatschappelijke bruikbaarheid' gereorganiseerd diende te worden. ${ }^{25}$ De politieke basis voor de hervorming van de balie werd gelegd op twee bijeenkomsten van Poolse juristen die in 1949 en 1950 onder leiding van de communistische partij en de regering werden georganiseerd. Tijdens deze bijeenkomsten werd benadrukt dat een nieuw tijdperk was aangebroken voor de Volksrepubliek Polen en dat het noodzakelijk was met het verleden te breken en een socialistische samenleving op te bouwen gebaseerd op de marxistisch-leninistische doctrine. ${ }^{26}$ Een nieuwe Advocatenwet die deze doelstellingen diende te verwezenlijken zou nog enige jaren op zich laten wachten (1950) maar dat betekende niet dat alles in de tussentijd bij het oude bleef. De wet van 1932 werd op verschillende punten gewijzigd waarbij met name de decreten van mei 1945 en januari 1946 het vermelden waard zijn. De regeling van 1945 had onder andere tot gevolg dat de bevoegdheden van de minister van Justitie werden uitgebreid ${ }^{27}$ en zogenaamde verificatiecommissies in het leven werden geroepen die moesten controleren of leden van de balie 'behaved well during the occupations and were worthy of belonging to the profession'.28 Het decreet van januari 1946 had ook belangrijke consequenties

23 Volgens Czeszejko-Sochacki geldt dit overigens niet alleen voor de advocatuur: 'The period of occupation is remarkable for a glorious display of patriotism, internationalism and heroism by all Polish lawyers: judges, public prosecutors and attorneys': Czeszejko-Sochacki 1978, p. 183.

24 Krzemiński 1998, p. 8.

25 Zo werd het verwoord door de toenmalig plaatsvervangend minister van Justitie T. Rek: Rek 1950, p. 22. Een en ander betekende dat de balie van een vrije beroepsgroep en een 'bourgeois kapitalistisch instituut' moest worden omgevormd tot een - in communistische zin - 'democratische organisatie'.

26 Siekanowicz 1959 II, p. 295.

27 Leden van regionale raden en disciplinaire organen konden voortaan worden aangewezen door de minister.

28 Nagorski 1962, p. 87. Tegen beslissingen van deze commissie - die bestond uit een afge- 
voor de advocatuur. De minister van Justitie schrapte het toelatingsexamen en de praktijkstage waardoor de toetreding tot de balie werd vergemakkelijkt. Voormalige leden van de rechterlijke macht die - als gevolg van gelijksoortige wijzigingen binnen hun eigen beroepsgroep - plaats hadden moeten maken voor niet juridisch geschoolde rechters konden zo eenvoudig doorstromen naar de advocatuur. Dit alles maakte het mogelijk bij de toetreding tot de juridische beroepen meer waarde te hechten aan loyaliteit aan het communistisch regime dan aan professionele kwalificaties (opleiding, stage en examens). ${ }^{29}$

\subsubsection{De Advocatenwet van 1950: inperking van de autonomie}

In juni 1950 werd een nieuwe Advocatenwet aangenomen waardoor de regeling van 1932 kwam te vervallen. De wet van 1950 diende de advocatuur volledig aan te passen aan de nieuwe politieke situatie. Illustratief in dit verband is een citaat uit het verslag van de parlementaire behandeling van de wet van 1950:

'The real aims and tasks of the (prewar) Bar were determined by its function as an organ servile to capital; it was not only a true reflection of capitalism but an active force helping capital to establish and secure its position, and doing everything (it could) to help this system reach its aims and carry out its designs... Our aim is to bring about an essential change in the approach of the attorney at law to his profession by introducing such organization of the Bar as will free it of its exclusive, or rather exclusively mercenary character. The practice of the legal profession cannot be based on conflict between interests of the individual and the government, since in our system there is no such conflict.' ${ }^{30}$

De nieuwe taakstelling van de balie bleek onder andere uit het feit dat in een van de eerste bepalingen van de nieuwe wet aan de advocatuur de verplichting werd opgelegd om 'samen te werken met rechtbanken en andere autoriteiten teneinde de rechtsorde van de Volksrepubliek Polen te beschermen en rechtsbijstand te verlenen in overeenstemming met de wet en de belangen van de arbeidersbevolking ${ }^{\prime}{ }^{31}$ Met laatstgenoemde verwijzing werd de balie gebonden aan de doelstellingen van het nieuwe politieke regime: wat in het belang van arbeiders was, werd immers bepaald door de communistische partij. ${ }^{32}$ De wet van 1950 breidde de bevoegd-

vaardigde van de minister van Justitie, vertegenwoordigers van de rechterlijke macht en leden van de advocatuur - kon geen beroep worden ingesteld.

30 Zoals geciteerd in Rosada 1955, p. 265. Zie ook Damaška over de positie van de balie in een 'activist state': 'Because a fully activist state dislikes associations independent of the state, it may abolish the organized bar so that counsel are selected from lawyers who are not institutionally organized. Another possibility is to retain bar associations, but to see to it that they turn into quasi-official agencies in the service of the justice system. To prevent their excessive amalgation with the client's interests, members of the bar may be put on straight salary or compensated according to some remunerative scheme compatible with various branches of the state's legal salariat', Damaška 1986, p. 176 en Clark: 'A liberal, independent legal profession and socialist law are mutually inconsistent. (...) Free lawyers, representing traditional private interests and values, clearly must be marginalized if not eliminated': Clark 1999, p. 49.

31 Art. 2 Advocatenwet 1950.

32 Lammich 1976, p. 180-181: '(...) dabei ist zu vermerken, daß die "Interessen der Werktätigen" gründsatzlich mit den Interessen des sozialistischen Staates identifiziert werden und daß die maßgebliche Entscheidung darüber, was im "Interessen der Werktätigen" liegt, in der herrschenden Doktrin und in der Praxis der kommunistische Partei (Polnische Vereinigte Arbeiterspartei) vorbehalten ist.' 
heden van de minister van Justitie zo ver uit dat van autonomie niet langer sprake was. Zo kreeg hij het algemene toezicht over de balie, kon hij beslissingen van alle organen ongeldig verklaren wanneer hij van mening was dat het besluit 'in strijd met de wet of een bedreiging voor het algemeen belang was' en was hij bevoegd op dezelfde gronden organen van de balie te ontbinden en te vervangen door - door hemzelf aangewezen - tussenpersonen. ${ }^{33}$ De minister maakte ruimschoots gebruik van laatstgenoemde bevoegdheid. ${ }^{34}$ Behalve het toezicht op het functioneren van de verschillende organen van de balie kreeg de minister ook zeggenschap over individuele leden van de advocatuur. Zo werd de beslissing een nieuw lid te laten toetreden - wat nog altijd tot de bevoegdheid van de regionale raden behoorde - pas rechtsgeldig wanneer de minister van Justitie daartegen geen bezwaar aantekende. ${ }^{35}$ De nieuwe wet schreef voor dat alleen personen tot de balie konden worden toegelaten die de garantie boden dat zij hun functie in overeenstemming met de opdracht van de advocatuur in de Volksrepubliek Polen zouden vervullen. ${ }^{36}$

In plaats van de eed die advocaten voorheen moesten afleggen, introduceerde de wet van 1950 een politiek geladen belofte waarin de advocaat (onder andere) trouw moest beloven aan de Volksrepubliek Polen en diende te verklaren zich in zijn handelen te laten leiden door beginselen van waardigheid, eerlijkheid en maatschappelijke gerechtigheid. Hiermee werd uitdrukking gegeven aan de nieuwe taakstelling van de advocaat die niet langer eenzijdig de belangen van zijn cliënt mocht behartigen maar te allen tijde ook rekening diende te houden met het algemeen belang zoals vertegenwoordigd door de overheid. ${ }^{37}$ Eenmaal toegetreden tot de balie stond een advocaat onder streng toezicht. Hij was verplicht de voortgang en zijn handelen in iedere zaak schriftelijk vast te leggen en zijn werk werd beoordeeld door de regionale raad die daarbij niet alleen aandacht moest besteden aan professionele en ethische aspecten maar het functioneren van de advocaat ook diende te evalueren vanuit 'een maatschappelijk perspectief' ${ }^{38}$ Optreden in zaken die in eerste aanleg door de provinciale rechtbank werden behandeld - de grotere en vaak politiek geladen strafzaken - was voorbehouden aan advocaten die daarvoor toestemming hadden gekregen van de minister van Justitie. ${ }^{39}$ Uiteraard werd deze goedkeuring alleen verleend aan 'loyale' advocaten van wie een 'correcte opstelling' in de procedure kon worden verwacht. ${ }^{40}$ De in 1945 geïntro-

33 Respectievelijk art. 5, 6 en 7 Advocatenwet 1950.

34 Gsovski en Grzybowski 1959, p. 773-774 en Siekanowicz 1959 II, p. 296.

35 Art. 48 Advocatenwet 1950. De minister beschikt vandaag de dag nog steeds over een dergelijk 'vetorecht' (art. 69 lid 2 Advocatenwet).

36 Art. 43 Advocatenwet 1950, zie ook eerdergenoemd art. 2. Deze voorwaarde voor toetreding was absoluut terwijl andere toelatingseisen - een afgeronde juridische opleiding, een voltooide praktijkstage en een succesvol afgelegd toelatingsexamen - in concrete gevallen wel door de minister van Justitie vervallen konden worden verklaard (art. 46 Advocatenwet 1950).

37 Zie over de gevolgen van het communisme voor de rol en taakopvatting van de advocaat: hoofdstuk 3.

38 Art. 58 en 60 Advocatenwet 1950.

39 Art. 51 Advocatenwet 1950.

40 Volgens Damaška is een dergelijke maatregel kenmerkend voor een 'activist state': 'It seems normal to expect that mechanisms for matching counsel with cases will be developed by an activist justice system. (...) the theory of excluding some lawyers from certain lawsuits makes good sense to a government that finds legal assistance to the party permissible only if it will advance 
duceerde verificatiecommissie werden in de Advocatenwet van 1950 behouden: advocaten die op moment van inwerkingtreding van de nieuwe wet reeds lid waren van de balie werden door deze commissies aan een controle onderworpen. Een groot aantal oudere advocaten werd als gevolg van deze 'zuiveringen' geroyeerd. De advocaten die de verificatiecommissies wel doorstonden, werden onderworpen aan 'politieke scholing' op speciale seminars en binnen de hierna nog te noemen collectieven. ${ }^{41}$ Bovendien kon iedere advocaat zonder voorafgaande disciplinaire procedure door de regionale raad van de lijst worden geschrapt wanneer geen garantie (meer) bestond dat hij zijn professionele verplichtingen 'in overeenstemming met de taken van de balie in de Volksrepubliek Polen' zou verrichten. ${ }^{42}$ Disciplinaire maatregelen konden worden genomen in geval van 'gedrag in strijd met de belangen van de arbeidersbevolking, beginselen van wetgeving, gelijkheid of waardigheid of in geval van schending van professionele verplichtingen'. ${ }^{43}$ Deze bepalingen boden voldoende mogelijkheden om 'niet loyale' advocaten alsnog uit de beroepsorganisatie te zetten.

Ook van belang is dat de balie niet langer autonoom was in het afhandelen van de tuchtrechtspraak. Disciplinaire organen waren voortaan samengesteld uit een advocaat, een rechter en een vertegenwoordiger van de provinciale volksraden en bestonden dus niet meer alleen uit advocaten. Deze situatie zou voortduren tot 1956 toen nieuwe verkiezingen binnen de balie werden gehouden en het zelfbestuur van de beroepsgroep voor een groot deel werd hersteld.

\subsubsection{Het collectief}

Een laatste onderdeel van de Advocatenwet van 1950 dat hier vermelding verdient, is de introductie van het collectief (zespót adwokacki) dat naar voorbeeld van de Sovjet-Unie in de meeste landen van Centraal- en Oost-Europa als samenwerkingsvorm voor advocaten werd voorgeschreven. ${ }^{44}$ Vanuit ideologisch oogpunt was het ontstaan van de collectieven goed te verklaren: in de eerste plaats paste deze manier van werken - waarbij de nadruk lag op eenheid en gemeenschappelijke verantwoordelijkheid - binnen de communistische opvattingen over arbeid en maatschappij. Daar kwam bij dat de werkzaamheden van deze groepsverbanden gemakkelijker konden worden gecontroleerd dan de activiteiten van advocaten die op individuele basis werkten. Op het niveau van ieder collectief werd toezicht uitgeoefend door een groepshoofd. Om het bestuur van de collectieven in lijn met de heersende politieke doelstellingen te laten verlopen, probeerde de communistische partij zoveel mogelijk invloed uit te oefenen op de benoeming van deze hoofden. De leider van het collectief nam een belangrijke plaats in: alleen hij kon zaken aannemen ${ }^{45}$ en toewijzen aan zijn medewerkers. Wanneer een cliënt te kennen gaf voorkeur te hebben voor een bepaalde advocaat diende deze keuze in beginsel te worden gehonoreerd. Een derde reden waarom het collectief goed binnen de communistische ideologie paste, was het feit dat het rechtsbijstand toe-

the change of obtaining accurate results': Damaška 1986, p. 176-177.

41 Siekanowicz 1959 II, p. 299.

42 Art. 79 Advocatenwet 1950.

43 Art. 95 Advocatenwet 1950.

44 Joegoslavië nam in dit verband een uitzonderingspositie in, daar bleef de advocatuur gedurende het communisme in particuliere praktijk werken: Meyer 1995, p. 1038. 
gankelijker zou kunnen maken voor de werkende klasse. ${ }^{46}$ Het collectief diende ook de kwaliteit van het werk van advocaten te verhogen: de samenwerkingsvorm moest leiden tot 'verhoging van het ideologische en professionele niveau van zijn leden' ${ }^{47}$ Behalve de verwijzing naar 'het ideologische niveau' - waarmee duidelijk werd gedoeld op politieke loyaliteit - was dus ook wettelijk bepaald dat collectieven moesten bijdragen aan een verhoging van het werkniveau van advocaten. ${ }^{48}$ Laatstgenoemde doelstelling van de wetgever werd echter niet bereikt. Integendeel: in de literatuur wordt beschreven dat het niveau van de advocatuur in de jaren na 1950 verslechterde. Voor deze ontwikkeling kunnen verschillende oorzaken worden genoemd. In de eerste plaats natuurlijk het feit dat bij de toetreding van nieuwe leden minder - in sommige gevallen zelfs geen - waarde werd gehecht aan juridische kwaliteiten en vaardigheden. Een tweede oorzaak hing samen met de regel dat bij het toewijzen van zaken binnen de collectieven de keuzevrijheid van cliënten in beginsel moest worden gerespecteerd. Dit betekende in de praktijk vaak dat zaken werden verdeeld zonder in aanmerking te nemen of de betreffende advocaten wel in staat waren deze te behandelen. Bovendien had het feit dat de voorkeur van cliënten doorslaggevend was tot gevolg dat sommige advocaten uit winstbejag oneerlijke concurrentie gingen voeren:

\begin{abstract}
'A new kind of lawyer called a 'shark' sprang up in this atmosphere. (...) Knowing that the manager of the collective was bound by the client's choice of an attorney they solicited employment through various methods of demagogic advertising, claiming to be 'famous attorneys', spreading the rumor of their friendly relations with judges and district attorneys and their ability to win cases.(..) Lawyers of high professional ethics who were successful before joining a collective law office lost their clients to their 'shark'colleagues. As a result managers of collectives looked on helplessly as long lines formed before the desks of 'successful lawyers' while highly qualified lawyers sat idle, reading newspapers or playing chess. This led to the pauperization of the legal profession (...)'.49
\end{abstract}

Ook had de introductie van de collectieven in de praktijk niet of nauwelijks de door de wetgever beoogde gemeenschappelijke vorm van (samen)werken tot gevolg: advocaten bleven - ook binnen de structuur van het collectief - individueel werken waardoor de collectieven niet meer waren dan 'erweiterte private Anwaltskanzleien, in denen jeder auf eigene Rechnung arbeitete'. ${ }^{50}$

46 Deze doelstelling - neergelegd in art. 72 van de Advocatenwet van 1950 - was waarschijnlijk gebaseerd op de veronderstelling dat grootschalige advocatencollectieven duidelijker herkenbaar en gemakkelijker te bereiken zouden zijn dan kleine kantoren of zelfstandig werkende advocaten.

47 Art. 73 Advocatenwet 1950.

48 Voor de bespreking van het collectief volgens de wet van 1950 is gebruik gemaakt van Nagorski 1962, p. 88 en Gsovski en Grzybowski 1959, p. 772-773.

49 Siekanowicz 1959 II, p. 301.

50 Gralla 1964, p. 177. Zie ook Siekanowicz 1959 II, p. 299-300 en daar vermelde literatuur: 'Everyday law practice, however, was far from what it was claimed to be by the law and official statements. Collective law offices were opposed by many lawyers, and those in the largest cities such as Warsaw, Cracow, Poznan and Katowice were more reminiscent of old lawyers' partnerships than of collective law offices of a socialist type. The majority of lawyers made only a formal liquidation of their individual law offices. They took their desks and clients into the collective law offices and, what was more important, also their habits and 'encumbrances' from the capitalist period.' 
Samengevat had de wet van 1950 grote gevolgen voor de advocatuur. In theorie beschikten de organen van de balie nog over een bepaalde mate van autonomie maar in feite had de overheid - door de uitgebreide bevoegdheden van de minister van Justitie - de touwtjes in handen. De introductie van nieuwe voorwaarden voor lidmaatschap, het toezicht op het functioneren van de advocaat en de vergaande mogelijkheden in te grijpen wanneer 'ongewenst gedrag' werd vertoond, dienden te garanderen dat de leden van de balie bij de uitoefening van hun taken binnen de grenzen van het overheidsbeleid (lees: het beleid van de communistische partij) zouden blijven.

\subsubsection{Na 1950: gedeeltelijk herstel onafhankelijkheid}

In de tweede helft van de jaren vijftig vond als gevolg van het overlijden van Stalin een verzachting van het politieke regime plaats. ${ }^{51}$ Hierdoor werd ruimte gecreeerd voor hervorming en werd de roep om aanpassing van de meest repressieve elementen van de strafrechtspleging steeds luider. Dit had ook gevolgen voor de organisatie van de advocatuur. Tijdens een bijeenkomst van de Poolse Juristen Vereniging werd herstel van de autonomie van de balie en vrije verkiezing van haar organen geëist en het voornemen geuit de professionele en morele standaard van de beroepsgroep te verhogen. ${ }^{52}$ Met dit doel werd in november 1956 een wetswijziging aangenomen die de regeling van 1950 op een aantal belangrijke punten beoogde aan te passen. Om te beginnen werden de bevoegdheden van de minister van Justitie aan banden gelegd. ${ }^{53}$ Een ander gevolg van de wetswijziging was dat het niet langer mogelijk was voorwaarden voor toelating (afgeronde juridische opleiding, voltooide stage en slagen voor toelatingsexamen) in concrete gevallen buiten toepassing te laten. De beroepsgroep werd dus weer gesloten voor niet-juristen. Ook was de minister niet meer bevoegd bezwaar te maken tegen de toetreding van bepaalde leden en kwam de regel dat het optreden voor provinciale rechtbanken in eerste aanleg was voorbehouden aan advocaten die daarvoor toestemming hadden gekregen van de minister van Justitie te vervallen. ${ }^{54}$ De verificatiecommissies - die sinds 1945 hadden bestaan - werden afgeschaft en ook de mogelijkheid een lid van de balie zonder disciplinaire procedure te royeren wanneer niet (meer) kon worden gegarandeerd dat hij zijn professionele verplichtingen 'in overeenstemming met de taken van de balie in de Volksrepubliek Polen' zou verrichten, kwam door

51 Zie hoofdstuk 2, § 2.2.2.

52 Siekanowicz 1959 II, p. 305.

53 Zo was hij niet langer bevoegd om alle organen van de balie te ontbinden: een dergelijke beslissing kon alleen nog betrekking hebben op regionale raden of de Hoogste Raad. Ook de mogelijkheid om beslissingen van organen ongeldig te verklaren, werd ingeperkt. De formulering van de grond voor een dergelijk besluit werd van 'strijd met de wet of dreigende schending van het algemeen belang' gewijzigd in 'strijd met de wet of het algemeen belang' waardoor de enkele dreiging van onverenigbaarheid met het algemeen belang niet langer voldoende was (art. 6 Advocatenwet 1950 zoals aangepast in 1956). Dit neemt overigens niet weg dat de bepaling ook na deze redactionele wijziging zeer vaag en voor ruime uitleg vatbaar was.

54 Art. 46, 48 en 51 werden geschrapt. De voorwaarde dat ieder nieuw lid de garantie moest bieden zijn functie in overeenstemming met de opdracht van de advocatuur in de Volksrepubliek Polen te zullen vervullen, bleef wel behouden (art. 43). 
de wetswijziging te vervallen. ${ }^{55}$ De onafhankelijkheid van de tuchtrechtspraak werd vergroot doordat disciplinaire organen - anders dan onder de oorspronkelijke regeling van 1950 - voortaan alleen nog uit advocaten mochten bestaan. ${ }^{56}$ Wat de structuur van de balie betreft, is van belang dat in 1956 een nieuw centraal orgaan in het leven werd geroepen: de nationale vergadering bestaande uit vertegenwoordigers van de regionale raden en bevoegd om de leden van de andere organen op centraal niveau (zoals de Hoogste Raad) te kiezen en hun beslissingen goed te keuren. In 1956 werden nieuwe, vrije verkiezingen gehouden binnen de balie om de samenstelling van de verschillende organen opnieuw vast te stellen. ${ }^{57}$

\subsubsection{Eind jaren vijftig: verscherpt toezicht}

Het herstel van de autonomie dat met de wetswijziging van 1956 werd gerealiseerd, was slechts van korte duur. Al snel werd duidelijk dat het communistisch regime zich moeilijk kon verenigen met de ontwikkelingen die zich binnen de balie hadden voorgedaan. De vrije verkiezingen hadden ertoe geleid dat belangrijke posities binnen de balie werden ingenomen door advocaten die de vooroorlogse tradities van de advocatuur voortzetten en een 'onvriendelijke houding' innamen ten opzichte van de ontwikkeling van de Volksrepubliek Polen. ${ }^{58}$ Vandaar dat in 1958 opnieuw een wetswijziging werd doorgevoerd: dit keer niet op initiatief van de Poolse Juristen Vereniging of de balie maar in opdracht van het Ministerie van Justitie. Deze wet was weliswaar minder omvangrijk dan die van 1956 maar had toch een aantal noemenswaardige veranderingen tot gevolg. De bevoegdheden van de minister van Justitie werden op een aantal punten weer uitgebreid. Zo kon hij kamers voortaan verzoeken in individuele gevalleen een tuchtrechtelijke procedure te starten en was hij bevoegd advocaten - in afwachting van een tuchtrechtelijke uitspraak - te schorsen. Bovendien werd zijn vetorecht waarmee hij de toetreding van nieuwe leden kon dwarsbomen (in 1956 geschrapt) in ere hersteld. Zijn bevoegdheid om regionale raden te ontbinden, werd aangevuld met de mogelijkheid na ontbinding zelf een vervangend lichaam samen te stellen waarvan niet alleen advocaten maar ook rechters deel konden uitmaken. ${ }^{59}$

De wijzigingen van 1958 betekenden grotendeels een terugkeer naar de situatie voor 1956 en maakten duidelijk dat de tijd nog lang niet rijp was voor een onafhankelijke

55 Art. 79 werd geschrapt. Gevolg hiervan was dat tegen een advocaat die in politiek of ander opzicht tekortschoot alleen nog disciplinaire maatregelen konden worden genomen: Siekanowicz 1959 II, p. 307.

56 Ingrijpen van buitenaf was dus niet langer mogelijk. Voor de bespreking van de wet van november 1956 is gebruik gemaakt van Gsovski en Grzybowski 1959, p. 786-788 en Nagorski 1962, p. 88-89.

57 Siekanowicz 1959 II, p. 305-307. Als gevolg van de wijziging van 1956 gold dat de organen van de balie voortaan voor drie in plaats van één jaar werden gekozen. Hiermee werd de continuiteit in het bestuur van de advocatuur vergroot.

58 Siekanowicz 1959 II, p. 309.

59 Een dergelijk orgaan had wel slechts een tijdelijk karakter: binnen zes maanden dienden verkiezingen voor een nieuwe raad plaats te vinden. Siekanowicz 1959 II, p. 309-313. Volgens Siekanowicz hadden de wijzigingen van 1958 tot gevolg dat de balie opnieuw werd omgevormd tot '(...) an instrumentality of the government which, through the Minister of Justice, can control it according to political requirements' (p. 313). 
balie. Dit werd opnieuw bevestigd in de tweede helft van de jaren zestig toen een nieuwe Advocatenwet werd aangenomen.

\subsubsection{De Advocatenwet van 1963}

Onder de wet van 1963 bleef de balie in verschillende opzichten gebonden aan de overheid. Een van de belangrijkste gevolgen van de nieuwe regeling was dat het beroep van advocaat voortaan alleen nog vanuit collectieven mocht worden uitgeoefend. ${ }^{60}$ De organisatie en het functioneren van de collectieven was in de regeling van 1963 uitgebreider geregeld dan in de wet van 1950 maar de hoofdlijnen bleven hetzelfde. Een collectief bestond uit 20 tot 25 advocaten en stond onder leiding van een hoofd dat werd aangewezen door de regionale raad van het betreffende arrondissement. Alleen de leider van het collectief kon zaken aannemen en verdelen onder de beschikbare medewerkers waarbij eventuele voorkeur van een cliënt in beginsel moest worden gerespecteerd. Collectieven waren in beginsel verplicht rechtsbijstand te verlenen: zaken mochten alleen op 'zwaarwegende gronden' worden geweigerd. De kosten voor de verleende rechtsbijstand moesten worden betaald aan het collectief: deze inkomsten werden vervolgens in gelijke delen uitbetaald aan de verschillende advocaten. Het tegen betaling aannemen van zaken buiten het collectief om was een zonde waarop een zware sanctie was gesteld: een advocaat die zich daaraan schuldig maakte, kreeg een beroepsverbod opgelegd. ${ }^{61}$ Hoewel het inkomen laag was, bood de samenwerkingsvorm advocaten wel enige financiële zekerheid (vast inkomen, vakantiegeld, doorbetaling in geval van ziekte) waardoor het dagelijks leven van de advocaat in bepaalde opzichten beter was dan dat van de gemiddelde burger. ${ }^{62}$

Behalve het collectief nam ook de minister van Justitie wederom een belangrijke plaats in binnen de regeling van de advocatuur. Het eerste artikel van de wet van 1963 bepaalde weliswaar dat de beroepsorganisatie op zelfbestuur was gefundeerd maar in feite was de balie door verschillende vergaande bevoegdheden van de minister van Justitie nog altijd in veel opzichten afhankelijk van de uitvoerende macht. De minister was nog steeds belast met het hoogste toezicht over de organisatie en kon beslissingen van haar organen wegens strijd met de wet of het algemeen belang vernietigen. ${ }^{63}$ Tevens kon hij zelfstandig bepalen dat een collectief of regionale raad diende te worden opgeheven. ${ }^{64}$ De taakstelling van de advocatuur

60 Art. 3 van de Advocatenwet van 1963 schreef voor dat een advocaat vanuit een collectief of een 'maatschappelijk rechtshulpbureau' diende te werken. Laatstgenoemde samenwerkingsvorm - die ook reeds onder de wet van 1950 bestond en tot doel had 'onder gunstige voorwaarden rechtsbijstand te verlenen aan arbeiders' - kwam in de praktijk nauwelijks voor: Lammich 1976, p. 177. Gevolg was dat particuliere samenwerkingsvormen verdwenen en alle advocaten uiteindelijk in collectieven werkzaam waren: in 1975 waren er in Polen meer dan 400 collectieven, Garlicki 1980, p. 509.

61 Art. 96 lid 1 Advocatenwet 1963.

62 In de woorden van Meyer: 'Under Communism, life for advokats was one of contrasts and conflicting emotions. On one level, they were denied many of the basic perquisites typical of the profession in the West. On another level, they enjoyed a rather comfortable lifestyle within the constraints imposed by the Communist system': Meyer 1995, p. 1029.

63 Art. 13 en 14 Advocatenwet 1963. Deze bevoegdheid had geen betrekking op beslissingen van disciplinaire organen.

64 Art. 33 en 47 Advocatenwet 1963. Ontbinding van een regionale raad was alleen mogelijk wanneer de minister van mening was dat het handelen of nalaten van het desbetreffende 
bleef hetzelfde als in de wet van 1950: het verlenen van rechtsbijstand diende nog steeds in overeenstemming met de wet en de belangen van de arbeidersbevolking plaats te vinden zodat het optreden van advocaten verbonden bleef aan de communistische ideologie. ${ }^{65}$ Net als onder de wet van 1950 kon een kandidaat pas worden toegelaten wanneer tegen een positieve beslissing van de regionale raad geen bezwaar was gemaakt door de minister van Justitie. ${ }^{66}$

\subsubsection{Conclusie}

Na 1944 is de regulering van de balie sterk beïnvloed door de politieke omstandigheden. De wetten van 1950 en 1963 hebben de organisatie van de advocatuur en ook de individuele beroepsuitoefening op verschillende manieren aan de overheid (communistische partij) gebonden: met name de verschillende vergaande bevoegdheden van de minister van Justitie en de verplichting om in collectieven te werken, zijn in dit opzicht van belang geweest. ${ }^{67}$

Hierop moet wel worden aangevuld dat de Poolse balie in vergelijking met andere landen van Centraal- en Oost-Europa gedurende het communisme nog een redelijke mate van autonomie heeft weten te behouden. ${ }^{68}$ Kenmerkend is dat de beroepsorganisatie zowel gedurende Wereldoorlog II als gedurende het communistisch regime altijd is blijven vechten voor behoud van haar onafhankelijkheid. Zoals hierna nog zal blijken, heeft de politieke omwenteling van 1989 voor wat betreft dat laatste punt niet zoveel veranderingen teweeg gebracht. De democratische rechtsstaat stelt nieuwe eisen aan de beroepsorganisatie die volgens critici nog onvoldoende worden waargemaakt. In de discussie over noodzakelijke hervormingen neemt de balie een conservatieve houding aan waarbij de autonomie van de balie wordt beschouwd als een verworvenheid die koste wat kost moet worden beschermd en geen enkele beperking duldt.

\subsubsection{Totstandkoming van de huidige Advocatenwet}

In 1982 werd de wet van 1963 vervangen door een nieuwe regeling die vandaag de dag nog steeds van kracht is. Hoewel de Advocatenwet van 1982 totstandkwam in een van de meest repressieve periodes uit de Poolse communistische geschiede-

orgaan in strijd met het recht of het algemeen belang was (art. 47 lid 1 Advocatenwet 1963). De beslissing een collectief op te heffen was daarentegen aan geen enkele voorwaarde verbonden (art. 33 Advocatenwet 1963). Voor andere organen - wederom met uitzondering van disciplinaire commissies - gold dat de minister individuele leden ervan kon schorsen (art. 11 lid 4 Advocatenwet 1963).

65 Art. 2 Advocatenwet 1963.

66 Art. 68 lid 2 Advocatenwet 1963. Tegen het bezwaar van de minister stond geen rechtsmiddel open. Wat de toetreding betreft, is bovendien van belang dat de loyaliteitseis ook na 1963 behouden bleef: nog altijd diende een advocaat voor toetreding tot de balie trouw te beloven aan de Volksrepubliek Polen. Bovendien moest een kandidaat nog steeds kunnen garanderen het beroep van advocaat in overeenstemming met 'de taken van de advocatuur in de Volksrepubliek Polen' uit te zullen oefenen. Een advocaat die deze garantie niet meer kon bieden, werd geroyeerd (art. 63 en 78 lid 1 sub 8 Advocatenwet 1963). Over de wet van 1963: Czeszejko-Sochacki 1975, p. 9-19.

67 Volgens Gralla geven beide wetten ondubbelzinnig blijk van wantrouwen van de overheid ten opzichte van de vrije advocatuur: Gralla 1964, p. 175.

68 Bojarski 2006, p. 226, 
nis ${ }^{69}$ was het in vergelijking met de wetgeving van 1950 en 1963 een liberale regeling waarin het zelfbestuur van de advocatuur op een aantal belangrijke punten werd hersteld.

Dat de balie minder aan de overheid is gebonden, blijkt onder meer uit de formulering van de algemene doelstelling van de beroepsorganisatie waarin niet langer wordt verwezen naar de belangen van de arbeidersbevolking (of een gelijksoortige formulering). Volgens de nieuwe taakstelling behoort de advocatuur rechtsbijstand te verlenen, zich in te zetten voor de bescherming van individuele rechten en vrijheden en zich bezig te houden met de vorming en toepassing van het recht ${ }^{70}$ : een opdracht zonder enige politieke lading. Bovendien hoeven advocaten in de eed die ze voorafgaand aan toetreding dienen af te leggen - anders dan op grond van de wetten van 1950 en 1963 - geen trouw meer te beloven aan de Volksrepubliek Polen. ${ }^{71}$

Een andere belangrijke wijziging betreft het feit dat advocaten sinds 1982 niet langer verplicht zijn om in collectieven samen te werken: het collectief bleef als mogelijke samenwerkingsvorm wel bestaan maar is niet langer dwingend voorgeschreven. Ook speelt de minister van Justitie in de regeling van 1982 een minder prominente rol dan voorheen: zo is hij niet langer belast met het algemeen toezicht op de advocatuur en heeft hij minder vergaande bevoegdheden om in te grijpen in het functioneren van de balie. ${ }^{72}$

Ondanks bovengenoemde verbeteringen was de balie niet helemaal tevreden met de oorspronkelijke versie van de wet van $1982 .{ }^{73}$ De minister van Justitie bleef op bepaalde punten toezicht uitoefenen op de balie: zo kon hij nog altijd bezwaar maken tegen toetreding van een kandidaat en zo invloed uitoefenen op de vraag wie als advocaat kon optreden en de balie de opdracht geven een tuchtrechtelijke procedure te starten tegen een bepaalde advocaat. Ook het feit dat het niet langer verplicht was om vanuit een collectief te werken, betekende voor de praktijk een minder grote verandering dan op het eerste gezicht het geval leek te zijn. Voor het oprichten van particuliere advocatenkantoren moest immers toestemming van de

69 Van 1981 tot 1983 heerste immers een militair regime dat de afbrokkelende macht van de communistische partij met harde hand probeerde te herstellen. Zie over de staat van beleg en de gevolgen voor de strafrechtspleging: hoofdstuk 2, § 2.2.2.3.

70 Art. 1 huidige Advocatenwet.

71 Voor het overige is de eed wel grotendeels hetzelfde gebleven. Hij luidt als volgt: 'Ik beloof plechtig dat ik me in mijn werk als advocaat volledig zal inzetten voor de bescherming van burgerlijke rechten en vrijheden en de versterking van de rechtsorde van de Republiek Polen, dat ik mijn taken ijverig, consciëntieus en in overeenstemming met het recht zal vervullen met inachtneming van mijn beroepsgeheim en me in mijn gedrag zal laten leiden door waardigheid, eerlijkheid, fatsoen en sociale rechtvaardigheid' (art. 5 Advocatenwet).

72 Dat laatste geldt onder meer voor de mogelijkheid invloed uit te oefenen op de besluitvorming: waar de minister voor 1982 nog bevoegd was beslissingen van organen van de balie op te heffen wegens strijd met het recht of het algemeen belang is hij op grond van de nieuwe Advocatenwet slechts gerechtigd beslissingen wegens strijd met het recht voor te leggen aan het Hooggerechtshof.

73 Krzemiński is van mening dat de wet van 1982 vaak ten onrechte 'democratisch' wordt genoemd en dat de advocatuur in feite opnieuw in een keurslijf werd geperst dat 'niet minder dwingend was dan voorheen': Krzemiński 1998, p. 10. 
minister van Justitie worden verkregen en die werd in de regel geweigerd. ${ }^{74}$ Direct na de val van het communistisch regime werd door de balie gestart met de voorbereiding van voorstellen tot wijziging van de wet van 1982 maar het zou tot 1997 duren voordat de regeling daadwerkelijk werd aangepast. Door de wetswijziging van 1997 werd de vrijheid van advocaten om zelf een samenwerkingsvorm te kiezen verder uitgebreid en voor het oprichten van een eigen particulier kantoor hoefde niet langer toestemming van de minister van Justitie te worden verkregen. ${ }^{75}$ Een aantal andere bevoegdheden van de minister van Justitie is noch door de wet van 1997 noch door latere wetswijzigingen aangepakt en dus tot op de dag van vandaag behouden gebleven. De minister kan bijvoorbeeld nog altijd bevelen dat een tuchtrechtelijke procedure wordt gestart tegen een bepaalde advocaat en is nog steeds bevoegd de toetreding van nieuwe leden te dwarsbomen. ${ }^{76}$ In de praktijk wordt van deze bevoegdheden echter niet of nauwelijks gebruik gemaakt zodat de betekenis ervan uiterst beperkt is.

Zoals hierna nog zal worden uiteengezet, heeft de toenemende kritiek op het functioneren van de balie geleid tot (deels inmiddels tot wet verheven) voorstellen het overheidstoezicht op de advocatuur weer te vergroten. De balie verzet zich hier hevig tegen en beschouwt iedere vorm van invloed van buitenaf als een onaanvaardbare aantasting van haar autonomie. Meer dan eens wordt daarbij verwezen naar de situatie gedurende het communisme. Om deze discussie over de verhouding tussen de balie en de overheid goed te kunnen begrijpen, zal eerst aandacht worden besteed aan de meer algemene vraag waarom onafhankelijkheid voor de advocatuur zo belangrijk is.

\subsection{Algemene opmerkingen over onafhankelijkheid}

Niet alleen in Polen maar in vrijwel alle democratische rechtssystemen wordt onafhankelijkheid van de advocatuur als een fundamentele beroepswaarde beschouwd. ${ }^{77}$ Dit wordt bevestigd door verschillende Europese en internationale regelingen waaronder de zogenaamde Havana Principles van de Verenigde Naties, de code of ethics van de CCBE, de International Code of Ethics van de International Bar

74 Krzemiński 1998, p. 10. Sommige advocaten kozen er zelf voor om in collectieven te blijven werken vanwege de hoge kosten (voor bijvoorbeeld huur, personeel en verzekering) die met een eigen kantoor gepaard gingen: Gajewska-Kraczkowska 1992, p. 1126-1127.

75 Een ander gevolg van de wijziging van 1997 was dat de balie ook werd opengesteld voor advocaten die niet de Poolse nationaliteit bezitten. Voor advocaten uit EU-lidstaten werd de mogelijkheid gecreëerd om toe te treden tot de beroepsgroep zonder een stageperiode in Polen te hoeven voltooien. Over deze en andere onderdelen van de wetswijziging van 1997: Jaworski 1997, p. 6-16 en Krzemiński 1998, p. 10-14.

76 De beslissing van een regionale raad een advocaat of advocaat-stagiaire toe te laten, wordt pas definitief wanneer de minister zich (binnen dertig dagen nadat hij van deze beslissing op de hoogte is gesteld) daar niet tegen verzet. Tegen de beslissing van de minister kan een rechtsmiddel worden ingesteld bij de bestuursrechter (art. 69 Advocatenwet).

77 In de woorden van Mullerat: 'Independence is the quintessence of the lawyer's activity. There is no free society and no free man without competent and independent lawyers', geciteerd in The role and responsibilities of the lawyer in a society in transition 1997: bijeenkomst georganiseerd door de Raad van Europa in samenwerking met de Hongaarse balie, de CCBE en INTERIGHTS, Budapest, 9-11 December 1997, p. 37. 
Association en een aanbeveling van de Raad van Europa. ${ }^{78}$ In deze documenten is de eis van onafhankelijkheid als volgt geformuleerd:

'Laywers shall be entitled to form and join self-governing professional associations to represent their interests, promote their continuing education and training and protect their professional integrity. The executive body of the professional associations shall be elected by its members and shall exercise its functions without external influence' ${ }^{\prime}{ }^{79}$

'The many duties to which a lawyer is subject require the lawyer's absolute independence from all other influences, especially such as may arise from his or her personal interests or external pressure. Such independence is as necessary to trust in the process of justice as the impartiality of a judge. A lawyer must therefore avoid any impairment of his or her independence and be careful not to compromise his or her professional standards in order to please the client, the court or third parties. This independence is necessary in noncontentious matters as well as in litigation. Advice given by a lawyer to the client has no value if the lawyer gives it only to ingratiate him- or herself, to serve his or her personal interest or in response to outside pressure.' 80

'Governments shall ensure that lawyers (...) are able to perform all of their professional functions without intimidation, harassment or improper influence. ${ }^{\prime} 1$

'Lawyers shall preserve independence in the discharge of their duties. ${ }^{82}$

'1. All necessary measures should be taken to respect, protect and promote the freedom of exercise of the profession of lawyer without discrimination and without improper interference from the authorities or the public (...) 2. Decisions concerning the authorisation to practice as a lawyer or to accede to this profession, should be taken by an independent body. Such decisions, whether or not they are taken by an independent body, should be subject to a review by an independent and impartial judicial authority. 3. Lawyers should enjoy freedom of belief, expression, movement, association and assembly, and, in particular, should have the right to take part in public discussions on matters concerning the law and the administration of justice and to suggest legislative reforms. 4. Lawyers should not suffer or be threatened with any sanctions or pressure when acting in accordance with their professional standards.(...).' ${ }^{\prime 83}$

78 De 'Basic principles on the role of lawyers' van de VN - aangenomen op 7 september 1990 te Havana, en bekrachtigd door Resolutie 45/121 van de Algemene Vergadering van de VN op 14 december 1990 - zijn te raadplegen op: <www.unhchr.ch/html/menu3/b/h_comp 44.htm>. De Europese gedragscode van de CCBE - waarvan de laatste versie is aanvaard op 19 mei 2006 - kan worden geraadpleegd op: <www.ccbe.org/fileadmin/user_upload/ NTCdocument/2006_code_enpdf1_1182240432.pdf>. De International Code of Ethics van de International Bar Association dateert uit 1958 (voor het laatst aangepast in 1988) en is te raadplegen op: <www.ibanet.org/images/downloads/international_ethics.pdf>, de aanbeveling van het comité van Ministers over de vrijheid het beroep van advocaat uit te oefenen (Recommendation Committee of Ministers on the Freedom of exercise of the profession of lawyer) is aangenomen op 25 oktober 2000 en kan worden geraadpleegd via: <http://www.coe.int/ defaultEN.asp>.

Regel 24 Havana Principles.

Regel 2.1 Code of Ethics CCBE.

81 Regel 16 Havana Principles.

82 Regel 3 International Code of Ethics IBA.

83 Regel uit de aanbeveling van de Raad van Europa (Recommendation Committee of Ministers on the Freedom of exercise of the profession of lawyer). 
Zoals uit bovengenoemde citaten blijkt, is de betekenis van het begrip onafhankelijkheid niet eenduidig. Het wordt de ene keer geformuleerd als instructienorm jegens de overheid ('Governments shall ensure that (...)'), de andere keer wordt benadrukt dat het ook een plicht van de advocaat zelf is om onafhankelijk in zijn beroepsuitoefening te zijn ('A lawyer must therefore avoid any impairment of his or her independence'). ${ }^{84}$ Dit is onlosmakelijk verbonden met het feit dat onafhankelijkheid in deze context verschillende aspecten kent: de advocaat dient niet alleen onafhankelijk te zijn ten opzichte van de overheid (waaronder begrepen de rechter en het openbaar ministerie) maar ook van zijn cliënt (in de zin dat hij zich niet met hem dient te vereenzelvigen), een eventuele werkgever, andere derden en ten slotte ook van zichzelf (zijn eigen belangen). ${ }^{85}$

De vorm van onafhankelijkheid die hier centraal staat - die ten opzichte van de overheid $^{86}$ - heeft niet alleen betrekking op het functioneren van de individuele advocaat maar vooral ook op dat van de beroepsorganisatie: algemeen erkend wordt dat de advocatuur een zelfregulerende professie dient te zijn die niet onder druk mag worden gezet door externe (politieke) factoren. Onafhankelijkheid ten opzichte van de overheid is met name van belang op het terrein van het publiekrecht - zoals in bestuurs- en vooral ook strafzaken - waar de burger en dus ook de advocaat die hem bijstaat zich tegenover de staat geplaatst ziet. ${ }^{87}$

Hoewel over de ratio van onafhankelijkheid ten opzichte van de overheid dus geen twijfel hoeft te bestaan, is niet helemaal duidelijk wat een en ander dient te betekenen voor de praktijk. Of er grenzen kunnen worden gesteld aan het zelfbestuur en - zo ja - op welke wijze en in welke mate dat toelaatbaar is, wordt niet duidelijk. Buiten kijf staat dat de wijze waarop gedurende het communisme invloed werd uitgeoefend op het functioneren van de Poolse advocatuur de onafhankelijke

84 Over onafhankelijkheid als plicht van de advocaat: 'Independence constitutes the most important feature of lawyers and most other duties to which a lawyer is subject are derived from this duty of independence': The role and responsibilities of the lawyer in a society in transition 1997, p. 39.

85 Hierbij dient te worden opgemerkt dat voor wat betreft de invulling van het begrip onafhankelijkheid belangrijke verschillen kunnen worden ontdekt tussen de common law en de civil law rechtstraditie: met name in de VS wordt onafhankelijkheid van de advocaat ten opzichte van de cliënt - die in Europese continentale systemen wel wordt bepleit - met argusogen bekeken: 'A related distinction is that, while professional independence is the cornerstone principle governing lawyers in all legal systems, the same principle has different meanings in the United States and European civil law countries. Whereas in the first this concept primarily refers to the importante of the profession retaining a degree of self-regulation vis-à-vis interferences by the legislature and other governmental bodies, European civil law countries generally embrace an ideology of professional independence and autonomy from the client that is alien to, and stands in contrast with, the U.S. lawyer's primary committent to the latter': Goldstein Bolocan 2002, p. 10-11.

86 In § 4.3.2 zal worden teruggekomen op de onafhankelijkheid die de raadsman ten opzichte van zijn cliënt in acht dient te nemen.

87 Het belang van een onafhankelijke advocatuur wordt ook erkend in de rechtspraak van het EHRM. Zoals in het kader van de vraag of de overheid zich mag bemoeien met de inhoud en kwaliteit van de door de advocaat geleverde rechtsbijstand (zie bijvoorbeeld Artico $t$. Italië, EHRM 13-5-1980, nr. 6694/74) en de vraag of strafrechtelijke reacties op uitlatingen van advocaten verenigbaar zijn met de vrijheid van meningsuiting (art. 10 EVRM), zie onder meer Schöpfer t. Zwitserland, EHRM 20-5-1998, nr. 25405/94, Nikula t. Finland, EHRM 21-3-2002, nr. 31611/96 en Steur t. Nederland, EHRM 28-10-2003, nr. 39657/98. Meer over de vrijheid van meningsuiting van de advocaat hierna in $\S 4.3 .5$. 
positie van de beroepsgroep en de individuele advocaat op onaanvaardbare wijze heeft aangetast. De Advocatenwet van 1982 heeft het zelfbestuur van de balie aanvankelijk voor het overgrote deel hersteld maar dit principe van zelfregulering is momenteel aan erosie onderhevig 88 doordat het functioneren van de balie de laatste jaren zozeer onder vuur is komen te liggen dat vanuit de maatschappij en uiteindelijk ook vanuit de politiek in toenemende mate voor meer overheidstoezicht is gepleit. Een van de kernpunten van dit pleidooi betreft de wens de toegang tot de beroepsgroep te vergroten.

\subsection{Toetreding}

De Poolse balie is een hechte organisatie waarvoor tot voor kort een strenge selectie gold die door de beroepsgroep zelf werd georganiseerd. Binnen de advocatuur heerst van oudsher een sterke overtuiging dat lang niet alle juristen geschikt zijn om het beroep van advocaat uit te oefenen ${ }^{89}$ : men moet niet alleen over voldoende praktische kwaliteiten (juridische vaardigheden) beschikken maar ook de normen en waarden uitdragen die passen in de traditie en het esprit de corps van de beroepsgroep. De selectieprocedure was er volgens de balie op gericht ook deze aspecten te toetsen.

Voor juni 2005 was het aantal advocaat-stagiaires dat ieder jaar werd toegelaten uiterst beperkt. Mede vanwege het grote animo voor de advocatuur en de toename van het aantal rechtenstudenten was de kans om advocaat te worden klein. Uiteindelijk is onder politieke druk verandering aangebracht in deze situatie: een wijziging van de Advocatenwet heeft een nieuwe selectieprocedure geïntroduceerd die voor een belangrijk deel in handen van de minister van Justitie is.

In deze paragraaf zal eerst kort worden uiteengezet hoe de procedure voor genoemde wetswijziging was vormgegeven, tot welke kritiek dit heeft geleid en hoe de balie hier in het verleden op heeft gereageerd. Vervolgens zal worden besproken welke gevolgen genoemde wijziging van de Advocatenwet heeft gehad en hoe de wetgever een deel van deze wijziging als gevolg van een uitspraak van het Grondwettelijk Hof in april 2006 weer heeft moeten aanpassen.

\subsubsection{Situatie voor wijziging Advocatenwet (juni 2005)}

De reguliere weg om te kunnen toetreden tot de balie bestond - en bestaat overigens nog steeds - uit drie etappes: een toelatingsexamen, een stageperiode en een afsluitend examen. ${ }^{90}$ Voor de wijziging van de Advocatenwet (2005) bestond het toe-

88 Dat is overigens niet alleen in Polen het geval: ook in andere Europese landen zoals Denemarken, Engeland, Italië en Nederland kan een dergelijke ontwikkeling worden waargenomen. Zie hierover bijvoorbeeld Goldschmidt 2007.

89 In de hierna te bespreken discussie over openstelling van de balie is door een advocaat wel eens de vergelijking gemaakt met de medische wereld: zoals niet alle artsen geschikt zijn om chirurg te worden, zo zijn ook niet alle juristen geschikt voor de advocatuur.

90 De stageperiode duurt drieëneenhalf jaar en wordt onder begeleiding van een ervaren advocaat (patron) doorgebracht op een advocatenkantoor. De stagiaire is ook verplicht een soort buitenstage te vervullen: tenminste een half jaar dient te worden doorgebracht bij een rechtbank, de prokuratura, een notariskantoor of een ander door de regionale raad aangewezen orgaan (art. 76 lid 1 Advocatenwet). Naast het werk in de dagelijkse praktijk dient de advocaat-stagiaire ook wekelijks een dag onderwijs te volgen dat door de balie wordt verzorgd. 
latingsexamen uit twee onderdelen: een schriftelijk en een mondeling deel. Examinering vond plaats op het niveau van de regionale raden die daarbij een grote mate van autonomie genoten: in regelgeving van de Hoogste Raad was weliswaar vastgelegd op welke wijze de examens dienden te worden uitgevoerd maar het opstellen van de vragen en het afnemen van de toetsen was voorbehouden aan de regionale raden zelf. ${ }^{91}$ De schriftelijke toets bestond uit 100 vragen. ${ }^{92}$ Het mondeling werd binnen twee weken na het schriftelijk examen ten overstaan van een (zevenkoppige) examencommissie gehouden. ${ }^{33} \mathrm{Op}$ basis van de eindscore werd uiteindelijk bepaald of een positief advies werd gegeven aan de regionale raad die uiteindelijk over toelating moest beslissen.

Ook het afsluitend examen bestond uit een schriftelijk en een mondeling deel. De laatste mondelinge toets werd wederom ten overstaan van de examencommissie gehouden. Ook voor dit mondeling gold dat de commissie zelf de vragen kon bepalen. ${ }^{94}$ Wanneer de kandidaat op een van de behandelde thema's een ontoereikend antwoord gaf, was hij voor het mondeling gezakt.

Voor een aantal categorieën juristen was het mogelijk op een eenvoudiger manier toe te treden tot de balie. Onder anderen hoogleraren en juristen die ten minste drie jaar als rechter, prokurator of notaris hadden gewerkt, konden advocaat worden zonder stageperiode en afsluitend examen. ${ }^{95}$ Als gevolg hiervan was het niet ongebruikelijk dat rechtenstudenten na hun afstuderen eerst examen deden voor de rechterlijke macht of prokuratura om vervolgens meer kans te maken op een plaats in de advocatuur.

De belangrijkste reden voor de grote populariteit van de advocatuur was (en is nog steeds) vooral gelegen in de overtuiging dat het van alle juridische beroepen het

91 Bijzondere regels ten aanzien van het toelatingsexamen waren voorafgaand aan de wijziging van de Advocatenwet van 2005 vastgelegd in de Regeling toelatingsexamen voor de stageperiode van de advocatuur (Regulamin konkursu na aplikacje adwokacka uchwalony przez Naczelna Radę Adwokacka) aangenomen door de Hoogste Raad d.d. 28 september 2002. In iedere kamer van de balie werden examencommissies aangewezen. Deze bestonden in beginsel uitsluitend uit advocaten. In de regeling van 2002 is de mogelijkheid geïntroduceerd om ook vertegenwoordigers uit de academische wereld tot de examencommissies toe te laten maar de betekenis van deze wijziging - die de objectiviteit van toetredingsprocedures diende te vergroten - was beperkt omdat het aanwijzen van deze externe waarnemer niet verplicht was.

92 Voor elk goed antwoord werd 1 punt verdiend en alleen kandidaten die 85 punten of meer op het schriftelijk deel behaalden, werden toegelaten tot het mondeling examen. Hoewel het formuleren van de vragen was voorbehouden aan de regionale raad was in eerder genoemde regelgeving van de Hoogste Raad wel vastgelegd welke onderwerpen moesten worden gedekt.

93 Elk van de zeven commissieleden beoordeelde het mondeling op een schaal van 10 zodat voor dit examenonderdeel maximaal 70 punten kon worden behaald

94 In regelgeving van de Hoogste Raad werd wel een aantal thema's opgesomd dat tijdens de mondelinge eindtoets aan de orde kon komen maar daarnaast was ook bepaald dat de regionale raad 'andere onderwerpen' mocht aansnijden. In feite kon dus vrijwel alles worden gevraagd.

95 Art. 66 lid 1 Advocatenwet (oud). Zoals hierna nog zal worden uiteengezet zijn de mogelijkheden voor juristen met relevante werkervaring om eenvoudiger toe te treden tot de balie in 2005 aanzienlijk uitgebreid. 
meest winstgevend zou zijn. ${ }^{96}$ Dit is in de praktijk echter lang niet altijd het geval: met name jonge - pas beginnende - advocaten hebben soms moeite het hoofd boven water te houden.

\subsubsection{De advocatuur: een gesloten beroepsgroep?}

De wijze waarop de balie over de toetreding van nieuwe leden besliste, heeft in de loop der jaren tot steeds meer maatschappelijke kritiek geleid. Belangrijkste punten in deze discussie waren het feit dat de balie haar aantal leden bewust klein zou houden om zo concurrentie te voorkomen en dat de selectieprocedures niet eerlijk zouden zijn. ${ }^{97}$ Hierna zal op beide aspecten dieper worden ingegaan.

\subsubsection{Aantal advocaten ontoereikend}

Een veelgehoord punt van kritiek betreft de omvang van de advocatuur: het aantal advocaten zou ontoereikend zijn en zich onvoldoende hebben aangepast aan de toename van het aantal rechtszaken die sinds de omwenteling van 1989 kan worden geconstateerd. Dit heeft volgens critici belangrijke gevolgen voor verwezenlijking van het recht op rechtsbijstand: als gevolg van de ongelijke verhouding tussen vraag en aanbod zijn de kosten voor het raadplegen van een advocaat (te) hoog en het ontbreken van enige vorm van concurrentie binnen de advocatuur zou een negatieve invloed hebben op de kwaliteit van de verleende bijstand. Bovendien zijn met name in kleinere plaatsen vaak slechts één of twee advocaten actief zodat de keuze voor de burger uiterst beperkt is. Het kleine aantal advocaten zou ook gevolgen hebben voor de effectiviteit en efficiëntie van de rechtspleging. Advocaten nemen teveel zaken aan waardoor ze vaak verschillende verplichtingen op een dag hebben en zaken moeten worden aangehouden. In dezelfde lijn past het argument dat te veel zaken nu zonder rechtsbijstand worden afgedaan terwijl de deelname van een advocaat (of juridisch adviseur) de voortgang van het proces zou kunnen bespoedigen..$^{98}$ Ten slotte zou de kleinschaligheid van de advocatuur leiden tot een 'ons kent ons' mentaliteit die een nadelig effect zou hebben op de effectiviteit van de tuchtrechtspraak. ${ }^{99}$

Wanneer we kijken naar de groei van het aantal advocaten in de periode 19952004 blijkt inderdaad dat het aantal leden van de balie in dit decennium slechts

96 'Obtaining an apprenticeship is very competitive, especially for the more desired professions like the Advokatura which is perceived as the most lucrative of the legal professions': Gostynski en Garfield 1993, p. 271.

97 In het verleden werd binnen de balie een numerus clausus gehanteerd: in ieder kamer werd jaarlijks het minimum en maximum aantal leden vastgesteld dat uiteraard van invloed was op het aantal stageplaatsen dat werd opengesteld. Deze bevoegdheid van de kamers - gebaseerd op art. 40 sub 4 van de oorspronkelijke Advocatenwet (1982) - is inmiddels geschrapt.

98 Het standpunt dat de ineffectiviteit van de Poolse rechtspleging niet alleen in de organisatie van de rechterlijke macht en het gebrek aan financiële middelen moet worden gezocht maar ook samenhangt met het ontoereikende aantal advocaten dat niet beantwoordt aan de maatschappelijke behoefte is in het verleden onder meer ingenomen door professor E. Łętowska, voormalig Ombudsvrouw.

99 Over de (effectiviteit van) tuchtrechtspraak meer in $\S 4.4 .5$ van dit hoofdstuk. Bovengenoemde punten van kritiek zijn onder andere verwoord door de HFHR in Monitoring Report 2003, p. 62-63. 
in beperkte mate is toegenomen. Het totaal aantal (actieve en niet-actieve) leden inclusief advocaat-stagiaires bedroeg in 1995: 7277 en in 2004: 7795. ${ }^{100}$ Gelet op de sterke toename van het aantal rechtszaken is dit een uiterst beperkte groei. ${ }^{101}$ Vergeleken met andere landen heeft Polen een lage 'advocatendichtheid': uitgaande van een totaal van 5733 (2004) actieve advocaten op een bevolking van 38 miljoen komt Polen op een gemiddelde van 15 advocaten per 100.000 inwoners - een cijfer dat in vergelijking met bijvoorbeeld Duitsland of Nederland zeer laag is. ${ }^{102}$ Deze cijfers worden door voorstanders van hervormingen dan ook veelvuldig aangehaald.

De discussie over het beperkte aantal beschikbare plaatsen binnen de advocatuur is de laatste jaren nog versterkt door een toename van het aantal rechtenstudenten. Deze groei wordt niet alleen veroorzaakt door een toename van het aantal inschrijvingen aan de elf universiteiten die een rechtenopleiding verzorgen ${ }^{103}$ maar ook door de opkomst van privé-onderwijsinstellingen die eenzelfde opleiding aanbieden. Het aantal stageplaatsen in de advocatuur (en ook in andere juridische praktijkberoepen zoals de juridisch adviseurs) heeft zich niet of nauwelijks aangepast aan deze groei waardoor de concurrentie bij toelatingsexamens nog verder toenam en de kans om toe te kunnen treden tot de balie alleen maar kleiner werd.

100 In aanmerking genomen dat een aanzienlijk deel van deze advocaten niet actief was - het aantal leden dat het beroep niet uitoefende, schommelde in genoemde periode tussen de 2000 en 2800 - moet voor een realistisch beeld uit worden gegaan van een lager totaal variërend tussen 4409 (1995) en 5733 (2004).

101 Het aantal stageplaatsen is overigens nog sterker toegenomen: tussen 1995 en 2004 is dit aantal geleidelijk aan gegroeid van 391 tot 1245 en dus verdrievoudigd. Alle genoemde aantallen zijn door de balie gepubliceerd in rapporten die vierjaarlijks verschijnen: Sprawozdania organów adwokatury 1998-2001 (p. 94) en Sprawozdania organów adwokatury 2001-2004 (p. 22).

102 In Nederland bedraagt het gemiddeld aantal advocaten op 100.000 inwoners 85 (13.600 advocaten op een inwonersaantal van circa 16 miljoen). In Duitsland ligt deze verhouding nog veel hoger: daar zijn op iedere 100.000 burgers circa 168 advocaten actief (138.000 advocaten op ongeveer 82 miljoen inwoners). Zie voor respectievelijk de Nederlandse en de Duitse cijfers: <www.advocatenorde.nl/algemeen/organisatie/wat_doet_de_orde. asp > en <www.brak.de/seiten/08_02.php>. Statistieken over aantallen advocaten in de verschillende landen van Europa zijn ook te vinden op de site van de CCBE (Council of Bars and Law Societies of Europe): <www.ccbe.org/en/documents/stat_en.htm>.

103 Het huidige studentenaantal aan de faculteit voor rechtsgeleerdheid van de Universiteit van Warschau is drie tot vier maal groter dan in de jaren tachtig. Slechts een klein deel van deze studenten zal na hun afstuderen aan de slag kunnen in de praktijk (rechterlijke macht, prokuratura of advocatuur): 'An der Warschaur rechtswissenschaftlichen Fakultät studierten heutzutage 6000 Studenten, davon ca. 1000 im letzten Sudienjahr, und nicht mehr als 100 von diesen würden künftig in den Gerichten und Anwaltschaften tätig sein. Für die restlichen 90\% der Absolventen des juristischen Studiums müsse aber auch eine Chance geschaffen werde, eine Arbeit nach dem Studiums irgendwo anders zu finden und dies stelle eine zusätzliche Aufgabe für die Polnische Universitäten dar': Supron-Heidel 2004, p. 157. Zie ook Gostynski en Garfield 1993 over het feit dat veel juristen noodgedwongen een andere loopbaan kiezen: 'Those who fail to obtain an apprenticeship can reapply in future years, but many unsuccessful candidates simply go on to pursue non-legal careers in business and government. Because Poland does not forbid non-laywers from giving legal advice, some graduates in recent years have taken jobs in Poland's burgeoning private sector and may actually be rendering legal advice even though they are not legal professionals in the traditional sense' (p. 271-272). 
De balie heeft zich in officiële standpunten altijd verzet tegen de kritiek op haar omvang. Zij is van mening dat bovengenoemde cijfers een vertekend beeld geven omdat de juridisch adviseurs ten onrechte niet worden meegerekend terwijl zij toch een wezenlijk deel van de rechtsbijstandsverlening voor hun rekening nemen. ${ }^{104}$ Ook worden er praktische en meer principiële argumenten tegen uitbreiding genoemd. Er zou om verschillende redenen geen ruimte zijn om de beroepsgroep voor meer personen open te stellen. In de eerste plaats zou het volgens de balie vanwege beperkte financiële middelen en het feit dat niet alle kantoren stagiaires kunnen plaatsen en niet alle advocaten bereid en geschikt zijn om als patroon op te treden - praktisch onmogelijk zijn om nog meer advocaten op te leiden. Wat de concurrentie betreft, geldt voor de balie dat het beroep van advocaat een soort roeping is die niet onderhevig kan zijn aan de beginselen van vrije marktwerking: aan advocaten worden hoge eisen gesteld en wanneer de beroepsgroep te veel open wordt gesteld, zal niet langer kunnen worden gegarandeerd dat ieder lid van de balie aan deze kwaliteitsstandaard voldoet. ${ }^{105}$ Met name ten aanzien van dit laatste punt is duidelijk hoe lijnrecht de voorstanders van hervorming en de balie tegenover elkaar staan: door de een wordt aangevoerd dat gebrek aan concurrentie een lage kwaliteit van rechtsbijstand tot gevolg heeft terwijl de ander van mening is dat de toegang tot de beroepsgroep juist wordt beperkt om een hoog niveau binnen de advocatuur te kunnen garanderen.

\subsubsection{Nepotisme}

De balie had in het verleden veel vrijheid bij de invulling van de examens en de beslissing welke kandidaten wel en niet tot de stageperiode werden toegelaten. ${ }^{106}$ Regionale raden waren grotendeels vrij in het opstellen van examenvragen en ook wanneer maximaal werd gescoord op het meer uniforme schriftelijke examen was de kandidaat nog volledig afhankelijk van de mondelinge toets waarbij vragen konden worden gesteld over allerlei uiteenlopende (ook niet juridische) thema's. De maatschappelijke kritiek richtte zich dan ook in het bijzonder op deze procedures: ze zouden niet objectief zijn, niet zijn gebaseerd op uniforme criteria en blijk geven van willekeur en bevoordeling van familieleden (nepotisme). ${ }^{107}$

104 Wanneer de juridisch adviseurs wel in de berekening worden meegenomen, resulteert dat in een gemiddelde van ongeveer 72 advocaten en juridisch adviseurs per 100.000 inwoners.

105 Zie Monitoring Report 2003 (p. 64) waar een aantal van de tegenargumenten van de balie is opgesomd.

106 Zie hiervoor $\S 2.4 .1$.

107 Kritiekpunten onder andere genoemd in Monitoring Report 2003, p.62-63. Zie bijvoorbeeld ook Gostynski en Garfield 1993: 'The criteria by which apprenticeships are awarded is not entirely clear and, in some instances, may have little to do with a candidate's academic achievements. Professor Gostynski [hoogleraar aan de Universiteit van Silesia in Katowice, toev. DdV] notes that traditionally, the best way to obtain an apprenticeship with the Advokatura has been to be the son or daughter of an advocate' (p. 272) en Dietrich 2000, p. 22-23: 'A final barrier to justice is the closed nature of the bar in some countries. In Poland, several lawyers and law students reported that the final examination to be admitted to the bar, adiministered orally, may consist of any number of questions on non-legal topics, making it impossible to prepare for and easy to be administered subjectively. "Access to justice is very difficult - the bar is a gentleman's club," a Polish NGO leader said. (...) Others reported that a law school graduate must either be related to or a family friend of a lawyer to win one of the coveted apprenticeships.' 
Dat familieconnecties een rol van betekenis speelden in de toetredingsprocedure wordt buiten de balie als een vaststaand feit beschouwd. Advocaten zelf zijn verdeeld op dit punt: in officiële reacties werd in het verleden doorgaans ontkend dat zonen en dochters van advocaten meer kans zouden maken op een stageplaats. Een enkele keer werd op dit punt iets meer 'toegegeven'. Zo heeft de voormalig voorzitter van de Hoogste Raad Rymar over het vermeende nepotisme ooit het volgende gezegd:

'Het kan voorkomen dat van twee volledig gelijk gekwalificeerde kandidaten, de commissie het kind van een advocaat kiest. Uit de documenten van de examens kan worden afgeleid dat bij de stages kinderen van advocaten in lichte mate oververtegenwoordigd zijn, maar het examen is eerlijk: het heeft een schriftelijk deel en van het mondeling deel wordt schriftelijk verslag gemaakt.' 108

Zijn collega Kubas (voormalig vice-voorzitter van de Hoogste Raad) ging nog een stap verder door te verdedigen dat familieconnecties wel degelijk een rol mogen spelen bij de beslissing nieuwe kandidaten toe te laten:

'Ik denk dat er niets mis mee is wanneer uit twee gelijkwaardige kandidaten - met de nadruk op gelijkwaardig - de balie het kind van een advocaat kiest. Het overerven van de beroepstraditie is immers niets afkeurenswaardigs. ${ }^{109}$

De discussie leek zich dus niet zozeer toe te spitsen op de vraag of het voorkwam dat familieconnecties een rol speelden maar meer op welke schaal dat gebeurde en of dat wel of niet bezwaarlijk was.

Over de omvang van het nepotisme zijn geen betrouwbare gegevens beschikbaar. In de literatuur is wel opgemerkt dat het voor kinderen van advocaten, juridisch adviseurs en notarissen maar liefst vier keer eenvoudiger zou zijn om toe te treden tot deze beroepsgroepen dan kandidaten zonder familieconnecties. ${ }^{110}$ Door de balie werd vaak tegengeworpen dat het gros van de advocaten geen familieleden binnen de beroepsgroep heeft. Zo heeft de deken van Krakau een aantal jaren geleden in een reactie op de kritiek gesteld dat $70 \%$ van de circa 100 stagiaires in zijn arrondissement geen familiebanden had binnen de advocatuur. ${ }^{111}$ Ook stelden vertegenwoordigers van de balie zich in de discussie over de toetredingsprocedures meer dan eens op het standpunt dat de kritische geluiden vooral afkomstig waren van afgewezen kandidaten die niet aan de door de advocatuur gestelde eisen

108 Uitspraak van Rymar gedaan in Gazeta Wyborcza d.d. 12-3-2002.

109 Uitspraak van Kubas in Prawo i życie, november 2001.

110 Domagalski noemt ten aanzien van juridisch adviseurs de volgende cijfers: in de periode 1999-2003 werden 3100 van de 13800 kandidaten geselecteerd. Van de 466 kandidaten die zoon of dochter van een juridisch adviseur waren, werden er 321 doorgelaten. Het absolute aantal nieuwe leden dat zoon of dochter van een juridisch adviseur is, is dus beperkt maar deze cijfers laten wel zien dat deze categorie kandidaten (om welke reden dan ook) wel een grotere kans heeft om te worden toegelaten. De situatie in de advocatuur is volgens Domagalski vergelijkbaar. Hij noemt het voorbeeld van Białystok waar tussen 1999 en 2003 respectievelijk 4, 6, 4, 9 en 15 nieuwe leden werden toegelaten waarvan telkens de meerderheid (te weten respectievelijk 3, 4, 4, 6 en 7) familie van een advocaat was. Dezelfde verhoudingen bestonden in Siedlce en Koszalin. In grotere steden zoals Krakau en Warschau zijn de percentages volgens Domagalski echter lager: Domagalski 2004.

111 Ingezonden brief van Ławrowski (deken) in Tygodnik Powszechny te raadplegen via: $<$ http://tygodnik.onet.pl/>. 
konden voldoen. Met andere woorden: de kritiek zou niet op feiten zijn gebaseerd en slechts voortkomen uit frustratie en afgunst. ${ }^{112}$

\subsubsection{Evaluatie kritiek advocatuur}

Aangezien de toetredingsprocedures sinds de val van het communisme niet wezenlijk zijn veranderd, lijkt de toenemende kritiek op de geslotenheid van de balie vooral samen te hangen met het feit dat de samenleving en daarmee ook de verwachtingen van de burger een ingrijpende ontwikkeling hebben doorgemaakt. De opkomst van de democratische rechtsstaat en de vrije markteconomie heeft belangrijke gevolgen gehad voor de balie. De bevoorrechte positie van de advocatuur - die voor 1989 niet of nauwelijks ter discussie stond - wordt niet langer als vaststaand feit geaccepteerd en lijkt geleidelijk aan zijn maatschappelijke legitimatie te hebben verloren. Het elitaire karakter van de beroepsgroep en de weinig transparante selectieprocedures zijn moeilijk verenigbaar met het democratische principe dat burgers in beginsel gelijke kansen moeten hebben. ${ }^{113}$ Bovendien is het argument dat het beroep van advocaat niet aan de beginselen van vrije marktwerking onderhevig kan worden gemaakt minder vanzelfsprekend in een maatschappij die op deze beginselen is gefundeerd en waarin rechtsbijstandverlenging steeds meer wordt gezien als een 'gewone' commerciële activiteit. ${ }^{114}$

Wat de toetreding betreft, staat vast dat de selectieprocedures van voor 2005 bijzonder veel vrijheid lieten aan de regionale balies. Met name het mondelinge deel van het toelatingsexamen vormde een weinig objectief toetsingsmoment dat door de regionale balies naar vrijheid kon worden ingevuld. Het feit dat daarbij over zeer uiteenlopende (ook niet-juridische) thema's vragen konden worden gesteld, betekende dat de balie de mogelijkheid had om het de ene kandidaat moeilijker te maken dan de andere. Tijdens mijn verblijf in Poznań en Lublin werden zowel door advocaten als door afgewezen kandidaten voorbeelden genoemd van opmerkelijke vragen die hen tijdens de mondelinge examens waren gesteld: over de Braziliaanse Grondwet, het Russische volkslied, expressionistische schilderkunst et cetera. Op zichzelf valt te verdedigen dat de balie behalve juridische kennis en vaardigheden ook de algemene ontwikkeling van haar toekomstige leden wil toetsen maar het behoeft geen betoog dat het vrijwel onmogelijk is om je op een examen voor te

112 Zie Monitoring Report 2003, p. 64. Dit standpunt blijkt ook uit een uitspraak van Naumann (lid van de Hoogste Raad) gedaan in een andere context maar met eenzelfde boodschap: 'A thesis funding the basic reason of limited access to ex officio legal aid in the insufficient number of attorneys and legal advisers is based on a false prerequisite. A proper starting point for making such accusations, could only be a declaration of people who found it difficult to obtain help although they wanted or requested it. Meanwhile, all publications attacking the attorneys and legal advisor's corporations for limiting the number of new apprentices, take into consideration only opinions of those who would like to become members of the corporation (...)': Monitoring Report 2003, p. 70.

113 De vrijheid een beroep te kiezen is een door de Poolse Grondwet gegarandeerd burgerrecht (art. 65 lid 1: eenieder heeft het recht een beroep te kiezen en uit te oefenen, uitzonderingen dienen bij wet te zijn voorzien).

114 Vergelijkbare ontwikkelingen - uiteraard zonder de scherpe tegenstellingen die een politieke omwenteling zoals in Polen met zich brengt - doen zich ook in Nederland voor. Ook daar kan de opkomst van een meer marktgeoriërenteerde benadering worden waargenomen die het functioneren van de advocatuur en bepaalde traditionele waarden die daar mee samenhangen sterk beïnvloeden. Zie daarover het rapport van de Commissie Van Wijmen: Een maatschappelijke orde 2006. 
bereiden wanneer zo'n breed scala van onderwerpen aan bod kan komen en dat een dergelijke aanpak alle ruimte biedt voor willekeur.

In de discussie over de omvang van de advocatuur zijn de cijfers over de advocatendichtheid en de groei van de advocatuur over de laatste paar jaren veelzeggend: deze gegevens laten duidelijk zien dat Polen in vergelijking met andere Europese landen relatief weinig advocaten heeft en dat de omvang van de advocatuur zich nauwelijks heeft aangepast aan het toegenomen aantal rechtszaken. De verweren die de balie op dit punt inbrengt, zijn weinig steekhoudend. Het argument dat de juridisch adviseurs ten onrechte niet worden meegerekend, gaat slechts ten dele op. De juridisch adviseur heeft immers een beperkt werkterrein en is niet (of slechts zeer beperkt) bevoegd rechtsbijstand te verlenen op het terrein van het strafrecht. Ook het argument dat onvoldoende plaatsen beschikbaar zijn voor meer stagiaires is niet helemaal zuiver: een toename van het aantal advocaten zou immers ook tot een groei van het aantal stageplaatsen leiden. Hierbij moet echter wel worden opgemerkt dat de verantwoordelijkheid voor de discrepantie tussen het aantal gegadigden en het aantal beschikbare plaatsen niet alleen bij de balie kan worden gelegd: het is immers de vraag of de praktijk de enorme groei van het aantal rechtenstudenten wel aankan en of faculteiten en (vooral ook) de privé-onderwijsinstellingen die als paddestoelen uit de grond lijken te schieten wel voldoende rekening houden met de maatschappelijke behoefte aan juristen.

Het argument van de balie dat de kans klein is om tot de beroepsgroep te worden toegelaten omdat het beroep van advocaat alleen door de beste juristen kan worden uitgeoefend, kan alleen overtuigen wanneer duidelijk blijkt dat een selectieprocedure daadwerkelijk alleen de kandidaten met de meeste kennis en vaardigheden 'filtert' en een hoge kwaliteit rechtsbijstand garandeert maar daarover bestond in de situatie voor juni 2005 op zijn zachtst gezegd twijfel. ${ }^{115}$

Tijdens mijn verblijf in Poznań en Lublin is door verschillende advocaten bevestigd dat familieconnecties in het verleden wel degelijk een belangrijke rol speelden bij de selectie van nieuwe advocaten. Illustratief in dit verband is een opmerking van een advocate uit Lublin die op mijn vraag of het volgens haar moeilijk is om te worden toegelaten tot de balie antwoordde dat het 'makkelijk is voor degenen die volgens de balie lid moeten worden'. Dezelfde advocate gaf aan dat het feit dat ze de dochter van een bekende advocaat is ongetwijfeld heeft meegespeeld bij haar toetreding en dat familiebanden van groot belang zijn binnen de advocatuur. Een andere advocaat uit Lublin vertelde zelf te hebben ervaren dat het met de juiste connecties mogelijk was van te voren de vragen van een mondeling examen doorgespeeld te krijgen. Hierbij dient overigens wel te worden opgemerkt dat de kracht en betekenis van familiebanden binnen de advocatuur per regio verschilt. Dit heeft onder meer te maken met de grootte van het arrondissement en de vraag of er van oudsher veel advocatenfamilies gevestigd zijn. ${ }^{116}$ Hoewel het niet mogelijk is een uitspraak te doen over de mate waarin kandidaten met de juiste connecties in het verleden zijn bevoordeeld ten opzichte van degenen zonder invloedrijke familie-

115 Zie over de kwaliteit van de verleende rechtsbijstand in - met name toegevoegde - strafzaken: Monitoring Report 2003, p. 78 e.v. en hoofdstuk 4, § 3.4.3.

116 Lublin behoort tot een van de arrondissementen waar familiebanden binnen de regionale balie van oudsher een belangrijke rol spelen, dit verschijnsel is bijvoorbeeld in de balie van Warschau (groter, moderner en minder traditioneel) veel minder bekend. 
leden kan wel met zekerheid worden gezegd dat nepotisme in bepaalde regio's een rol heeft gespeeld. De wijze waarop de balie deze kritiek in het verleden heeft proberen te weerleggen, is mijns inziens weinig overtuigend. Bijvoorbeeld het argument van de deken van Krakau dat $70 \%$ van de advocaten in zijn arrondissement geen familie binnen de balie heeft, bewijst mijns inziens niet dat nepotisme in het verleden geen enkele rol van betekenis heeft gespeeld. Daarvoor is immers slechts bepalend of het deel dat wel familieconnecties heeft, bij toetreding om die reden is bevoordeeld ten opzichte van de andere kandidaten. Bovendien is onduidelijk hoe ruim of beperkt het begrip 'familielid' in deze berekeningen wordt uitgelegd. De balie heeft het in dit verband vaak alleen over leden wier vader of moeder advocaat is terwijl in de praktijk ook andere connecties een rol konden spelen. ${ }^{117}$ Ook het verweer dat kritiek over nepotisme alleen afkomstig zou zijn van afgewezen kandidaten kan niet worden volgehouden. De discussie over de toetredingsprocedures werd zeker niet alleen door teleurgestelde aspirant-advocaten gevoerd. Over de zwakke punten van de toetredingsprocedures (het gebrek aan transparantie en objectiviteit, nepotisme) bestond buiten de balie vrij brede consensus.

Concluderend kan worden gezegd dat de balie zich in ieder geval weinig heeft ingespannen om de schijn van oneerlijkheid waarmee de selectie van nieuwe advocaten was omhuld, op te heffen. De toetredingsprocedures bleven ondanks alle kritiek zodanig ingericht dat het negatieve beeld van vriendjespolitiek en nepotisme bij de buitenwereld alleen maar sterker werd. ${ }^{118}$ De argumenten die werden aangevoerd voor behoud van de oude situatie waren voornamelijk gebaseerd op de exclusiviteit van de beroepsgroep (aan een advocaat worden hoge eisen gesteld waaraan lang niet iedere jurist kan voldoen), de autonomie van de balie (het kiezen van nieuwe leden behoort tot de bevoegdheden van de beroepsorganisatie) en praktische argumenten (plaatsen van meer advocaat-stagiaires is onmogelijk, een toename van het aantal advocaten zal leiden tot ongezonde concurrentie). ${ }^{119}$ Wat daarbij opvalt, is dat de aangevoerde gronden hoofdzakelijk betrekking hebben op de belangen van de beroepsgroep zelf: het algemeen belang wordt zelden of nooit genoemd. ${ }^{120}$

117 Zo vertelde een advocaat uit Poznań dat - hoewel zijn ouders geen advocaat zijn - andere familiebanden (ooms in de advocatuur en een grootvader die hoogleraar in het recht was) zijn toetreding tot de balie ongetwijfeld hadden vergemakkelijkt.

118 Dit wil overigens niet zeggen dat de balie tot 2005 geen enkele poging heeft gedaan om de procedures aan te passen. Met name de eerder genoemde regeling van de Hoogste Raad van 2002 (Regeling toelatingsexamen voor de stageperiode van de advocatuur van 28 september 2002) diende de uniformiteit en objectiviteit van de examinering te vergroten. Deze wijzigingen waren echter zo bescheiden van aard dat daarmee onvoldoende tegemoet werd gekomen aan de toenemende kritiek.

119 Zie voor een opsomming van de argumenten van de balie tegen hervorming: Monitoring Report 2003, p. 64.

120 Vandaar dat de balie wel wordt verweten te veel als een soort vakbond voor haar eigen belangen op te komen en te weinig oog te hebben voor de verplichtingen die zij heeft als public trust profession. Bron: gesprek Hołda (advocaat, hoogleraar en medewerker HFHR), oktober 2004 Lublin. De HFHR wijst in dit verband ook op art. 17 van de Grondwet waarin aan het zelfbestuur van public trust professions wordt opgedragen erop toe te zien dat deze beroepen op de juiste wijze worden uitgevoerd 'in overeenstemming met het 


\subsubsection{Onvermijdelijke hervormingen}

De conservatieve houding van de balie heeft uiteindelijk tot een polarisatie van de discussie geleid. Het werd steeds duidelijker dat eventuele (grootschalige) hervormingen niet van de beroepsgroep zelf uit zouden gaan en dus van buitenaf zouden moeten worden afgedwongen. ${ }^{121}$ Als reactie hierop heeft Prawo i Sprawidliwość (Recht en Rechtvaardigheid, de conservatieve partij van de huidige president van Polen: Lech Kaczyński122) de geslotenheid van de juridische beroepen tot een van haar speerpunten gemaakt en in 2003 een wetsvoorstel ingediend waarin vergaande wijzigingen van de toetredingsprocedures voor de advocatuur, de juridisch adviseurs en het notariaat waren opgenomen. Voorgesteld werd de toelatingsexamens naar onder meer Duits en Tsjechisch voorbeeld voortaan te laten uitvoeren door staatscommissies waarin advocaten slechts een minderheid zouden hebben.

Het zal niet verbazen dat de balie zich fel tegen dit voorstel heeft verzet: de door PiS voorgestelde wijzigingen zouden een aanslag op de autonomie van de beroepsorganisatie zijn omdat beslissingen over toetreding van nieuwe leden te allen tijde door de balie zelf dienen te worden genomen. ${ }^{123}$ Zich realiserend dat (enige mate van) hervorming niet uit kon blijven, heeft de balie in 2003 vervolgens zelf een eigen voorstel tot wijziging van de Advocatenwet opgesteld. In dit - uiteraard meer gematigde - voorstel werd onder meer de mogelijkheid geïntroduceerd om in examencommissies een vertegenwoordiger van het Ministerie van Justitie en een academicus toe te laten. Het toelatingsexamen zou volgens dit voorstel nog steeds uit een schriftelijk en een mondeling deel bestaan maar de uniformiteit van de schriftelijke toets zou worden vergroot door de vragen voortaan centraal door de Hoogste Raad te laten opstellen ${ }^{124}$ en de toelatingstoets in het hele land jaarlijks op hetzelfde moment te laten plaatsvinden.

\subsubsection{Het oordeel van het Grondwettelijk Hof}

De discussie over welke hervorming nu het meest passend was, nam in 2004 een belangrijke wending door een uitspraak van het Grondwettelijk Hof over een aantal bepalingen uit de Advocatenwet. ${ }^{125}$ Aanleiding voor deze uitspraak was de zaak

algemeen belang en met het doel dit algemeen belang te beschermen' en stelt daarbij de retorische vraag of de balie deze doelstelling bereikt door de toegang tot de beroepsgroep te beperken: Monitoring Report 2003, p. 63.

121 'In der Praxis erzueg dies freilich eine Diskrepanz zwischen den eingefrorenen Strukturen der Weiterbildung der Referendare und den Bedürfnissen der Studenten, der Rechtswissenschaft und der Rechtspflege. Darüber hinaus habe man in Polen mit einem gewissen Monopol und mit einem geschlossenen Kreis von Advokaten und Rechtsberatern zu tun. Es sei extrem schwierig und erfordere Geduld, eine Referendarstelle für diese Berufe zu bekommen. Der Grund dafür liege darin, dass die Rechtsberater und Advokaten vehement versuchten, ein beschränktes Monopol für die bereits in diesem Beruf tätigen zu behalten. (...) Sie [de balies van juridisch adviseurs en advocaten, toev. DdV] würden von sich aus nichts ändern. Sie verfolgten eigene Interessen und würden bei alten Strukturen bleiben wollen. Die Lobbykraft dieser Gruppen sei enorm hoch. Ohne Druck von außen, von der jungen Generation, von den Parlemantiern und der öffentlichen Meinung, würden diese Probleme nicht gelöst': Supron-Heidel 2004, p. 158.

122 Zie ook hoofdstuk 2, § 2.3.4.

123 Zie over het standpunt van de balie in deze (onder anderen): Fedorowicz 2004.

124 Waardoor deze niet meer per arrondissement zouden verschillen maar voor alle kandidaten hetzelfde zouden zijn.

125 Uitspraak van 18 februari 2004 (P21/02), te raadplegen op: <www.trybunal.gov.pl>. 
van Kłaczyński die zonder succes toelatingsexamen voor de advocatuur had gedaan en tegen deze afwijzing beroep had ingesteld bij de bestuursrechter. Deze legde in dit verband een rechtsvraag voor aan het Grondwettelijk Hof waarin centraal stond of de bepalingen uit de Advocatenwet waarin was geregeld dat het tot de bevoegdheid van de kamers van de balie behoort om een minimum en maximum aantal leden vast te stellen (art. $40 \mathrm{sub} 4$ ) en de bepaling waaruit voortvloeit dat de Hoogste Raad in interne regelgeving mag bepalen op welke wijze toelatingsexamens zullen plaatsvinden (art. 58 sub 12j) verenigbaar waren met de Grondwet. ${ }^{126}$

Het Hof achtte beide bepalingen in strijd met de Grondwet. Ten aanzien van art. 40 sub 4 oordeelde het Hof dat het enkele feit dat het aantal nieuwe advocaatstagiaires gebonden is aan een door de beroepsorganisatie vastgesteld maximum op zichzelf niet onverenigbaar is met het recht een beroep te kiezen en uit te oefenen zoals neergelegd in art. 65 lid 1 Grondwet. ${ }^{127}$ De wijze waarop een dergelijk maximum moet worden vastgesteld, dient echter wel aan bepaalde eisen te voldoen: het dient te gebeuren aan de hand van transparante, vooraf vastgestelde en openbaar gemaakte regels die zijn gebaseerd op objectieve criteria en op uniforme wijze worden toegepast. Bovendien behoren de voorwaarden waaronder het maximum moet worden vastgesteld, in de wet te zijn opgenomen. Vandaar dat art. 40 sub 4 Advocatenwet - waarin slechts was geregeld dat de verschillende kamers van de balie bevoegd zijn om een maximum aantal leden vast te stellen zonder dat nadere invulling werd gegeven aan de wijze waarop van deze bevoegdheid gebruik moest worden gemaakt - in strijd met de Grondwet werd geacht. ${ }^{128}$ Over art. 58 sub 12j oordeelde het Grondwettelijk Hof dat op grond van deze bepaling interne regelgeving kon worden gecreëerd op basis waarvan de rechten van personen die nog niet tot de beroepsgroep behoorden, konden worden ingeperkt. ${ }^{129}$

Zie voor een samenvatting in het Engels: <www.trybunal.gov.pl/eng/summaries/ P_21_02_GB.pdf>.

126 Het Grondwettelijk Hof boog zich in deze zaak eveneens over overeenkomstige bepalingen uit de wet ten aanzien van juridisch adviseurs die - net als de Advocatenwet dateert uit 1982. Aanleiding voor deze beoordeling was in dat geval ook de afwijzing van een juriste die toelatingsexamen had gedaan voor de balie van juridisch adviseurs. Dit gedeelte van de uitspraak zal hier verder buiten beschouwing worden gelaten.

127 'Eenieder heeft het recht een beroep te kiezen en uit te oefenen. Uitzonderingen dienen bij wet te zijn voorzien.'

128 Meer specifiek art. 2 (waarin is vastgelegd dat Polen een democratische rechtsstaat is - aan dat rechtsstaatprincipe is het beginsel van rechtszekerheid verbonden) en 65 lid 1 (vrijheid van beroep) in combinatie met art. 31 lid 3 Grondwet (beperkingen op grondrechten dienen te zijn vastgelegd in de wet en noodzakelijk te zijn in een democratische samenleving voor de bescherming van veiligheid of openbare orde, of ter bescherming van het milieu, volksgezondheid of de publieke moraal, of de rechten en vrijheden van andere personen). Het Grondwettelijk Hof heeft in bovengenoemde uitspraak wel benadrukt dat ten tijde van de totstandkoming van de bestreden bepalingen uit de Advocatenwet een andere Grondwet van kracht was waarin de vrijheid een beroep te kiezen en uit te oefenen nog niet was gegarandeerd. De ongrondwettelijkheid van de regels kon op dat moment dus niet door de balie worden voorzien. Dit neemt mijns inziens echter niet weg dat de regels na totstandkoming van de nieuwe Grondwet - die reeds dateert uit 1997 - in overeenstemming met de Grondwet hadden kunnen worden gebracht. Zie over de uitspraak onder meer: Kroner 2004.

129 Immers: de vrijheid van kandidaten om een beroep te kiezen, kon door genoemde regeling van de toetredingsprocedure aan banden worden gelegd. 
Dat terwijl de wijze waarop een dergelijke beperking kon worden opgelegd in de Advocatenwet niet nader was omschreven en dus slechts kon worden ontleend aan de interne regelgeving die niet als algemeen verbindend in de zin van de Grondwet kon worden beschouwd. Dit leidde het Hof tot de conclusie dat ook art. 58 sub $12 \mathrm{j}$ onverenigbaar was met de Grondwet. ${ }^{130}$

De uitspraak van het Grondwettelijk Hof maakte duidelijk dat de Advocatenwet zou moeten worden aangepast en ook dat dit snel zou moeten gebeuren: nu de bepaling ten aanzien van de toetredingsprocedures onconstitutioneel was bevonden, zouden geen nieuwe toelatingsexamens kunnen worden gehouden zolang de Advocatenwet niet was aangepast. ${ }^{131}$

Over de reikwijdte van de uitspraak werd echter verschillend gedacht. Voorstanders van hervorming beschouwden haar (uiteraard) als bewijs dat de toetredingsprocedures niet door de beugel konden en dat grootschalige hervormingen noodzakelijk waren. De balie was daarentegen van mening dat de soep niet zo heet gegeten hoefde te worden. Het Grondwettelijk Hof had immers niet zozeer de inhoud van de omstreden bepalingen bekritiseerd, maar slechts geconstateerd dat datgene wat op basis van die artikelen geregeld kon worden niet in de juiste bron was vastgelegd. Hieraan zou volgens de balie met eenvoudige aanpassingen van de wet tegemoet kunnen worden gekomen door de voorwaarden voor de numerus clausus en de toetredingsprocedures nader te omschrijven in de Advocatenwet zelf: een oplossing waarin het eerder genoemde wetsvoorstel van de balie voorzag.

\subsubsection{Wijziging van de Advocatenwet (2005)}

Het voorstel van de balie werd uiteindelijk te licht bevonden en het verdergaande ontwerp van PiS werd - in enigszins gewijzigde vorm - tot wet verheven. Door deze wijziging ${ }^{132}$ is het eenvoudiger geworden om toe te treden tot de balie. Dit is op twee manieren gerealiseerd:

- toelatings- en afsluitende examens worden voortaan georganiseerd door staatscommissies onder leiding van de minister van Justitie wat de objectiviteit van deze toetsen vergroot en

- het aantal mogelijkheden om via een vereenvoudigde procedure (zonder stageperiode en/of afsluitend examen) advocaat te kunnen worden is aanzienlijk uitgebreid.

De belangrijkste wijzigingen op deze twee punten worden hier kort weergegeven:

130 Meer specifiek art. 87 lid 1 op grond waarvan alleen 'wetten, geratificeerde internationale overeenkomsten en verordeningen' als algemeen verbindende rechtsbronnen worden erkend.

131 Gunstig voor de balie was dat vlak voor genoemde uitspraak de examens van 2005 waren begonnen: aangezien deze nog op basis van de oude regelgeving konden worden voortgezet, was de toetreding van nieuwe leden voor dat jaar in ieder geval veilig gesteld.

132 'Wet tot wijziging van de Advocatenwet en enige andere wetten', aangenomen in juni 2005 en in werking getreden in september van hetzelfde jaar. Zoals eerder vermeld heeft de wijziging niet alleen betrekking op de Advocatenwet maar ook op de wet betreffende de juridische adviseurs en het notariaat. De wijzigingen ten aanzien van de twee laatstgenoemde beroepsgroepen zijn van dezelfde aard als de veranderingen die betrekking hebben op de advocatuur en zullen hier verder buiten beschouwing worden gelaten. 
- Het toelatingsexamen (egzamin konkursowy) bestaat alleen nog uit een schriftelijke toets samengesteld uit een vast aantal meerkeuzevragen die ieder jaar in het hele land op dezelfde datum wordt gehouden. Bij het behalen van een bepaalde (minimum)score, dient de kandidaat automatisch te worden toegelaten tot de stageperiode. ${ }^{133}$

- Het afsluitend examen (egzamin adwokacki) dat aan het einde van de stageperiode wordt afgelegd, bestaat uit een schriftelijk en een mondeling deel en wordt eveneens eens per jaar in het hele land op dezelfde datum gehouden. Het behalen van een bepaald (mimum)aantal punten voor het schriftelijk deel garandeert dat de kandidaat wordt toegelaten tot het mondeling. De kandidaat die voor het schriftelijk en het mondeling samen een bepaalde minimumscore behaalt, is geslaagd en dient te worden ingeschreven als advocaat.

- De voorbereiding van en het toezicht op beide examens staan onder leiding van door de minister van Justitie benoemde examencommissies. De commissie die toezicht houdt over de uitvoering van het toelatingsexamen bestaat uit zeven leden: drie vertegenwoordigers van het ministerie van Justitie, twee vertegenwoordigers van de balie, een academicus en een prokurator. ${ }^{134}$ De minister van Justitie stelt jaarlijks een hoeveelheid vragen en thema's vast die bij het afsluitend examen aan de orde dienen te komen. Zowel het schriftelijk als het mondeling deel van deze toets wordt beoordeeld door leden van de examencommissie. ${ }^{135}$

- De categorieën juristen die via de buitenweg kunnen toetreden tot de balie is aanzienlijk uitgebreid teneinde de doorstroming tussen verschillende juridische beroepen te vergroten. ${ }^{136}$ Een van de belangrijkste veranderingen die de wetswijziging op dit punt heeft teweeg gebracht, is dat personen die zijn geslaagd voor het examen van rechter, prokurator, juridisch adviseur of notaris - ook wanneer ze nog niet in de praktijk hebben gewerkt - advocaat kunnen worden zonder de stageperiode en zonder het afsluitend examen af te hoeven leggen. ${ }^{137}$

133 De regionale raden hebben op dit punt dus geen beoordelingsvrijheid meer: iemand die voor het toelatingsexamen is geslaagd, dient te worden aanvaard als advocaat-stagiaire. Weigering is alleen mogelijk wanneer niet aan een van de algemene voorwaarden voor toetreding is voldaan.

134 Voor het toelatingsexamen van 2005 werd een aparte (soort overgangs)regeling getroffen: in dat jaar werden de examens - die wel in het hele land op dezelfde door de minister van Justitie te bepalen datum dienden plaats te vinden - nog uitgevoerd door de balie zelf.

135 Bij het schriftelijk deel gebeurt dit telkens door twee leden van de commissie die de opgestelde stukken onafhankelijk van elkaar beoordelen.

136 Zoals eerder aangegeven, bestond de mogelijkheid om advocaat te worden zonder stageperiode en afsluitend examen reeds voor de wijziging van 2005 voor bepaalde academici (hoogleraren en wetenschappers met een hoge academische graad) en een aantal categorieën juristen die ten minste drie jaar in de praktijk (als rechter, prokurator, juridisch adviseur of notaris) werkzaam waren geweest.

137 Ook is een aantal nieuwe categorieën juristen geïntroduceerd die zonder een stageperiode dienen te worden toegelaten tot het afsluitend examen: deze mogelijkheid staat bijvoorbeeld open voor kandidaten die in de rechtsgeleerdheid zijn gepromoveerd of die ten minste vijf jaar lang bij de rechterlijke macht als referendarz (een soort senior-gerechtssecretaris) of assistent van een rechter hebben gewerkt. Alle nieuwe regels met betrekking tot toetreding zijn te vinden in art. 65 tot en met 79 van de Advocatenwet. 
De wetswijziging heeft de inhoud en vorm van de stage overigens niet wezenlijk veranderd: deze duurt nog altijd drieëneenhalf jaar en dient onder begeleiding van een patroon te worden doorgebracht op een advocatenkantoor. ${ }^{138}$ De structuur van de toetredingsprocedure is dus hetzelfde gebleven - toelatingsexamen, stageperiode, afsluitend examen - maar door de rigoureuze veranderingen in de wijze van examinering heeft de balie de zeggenschap over de toetreding van nieuwe leden grotendeels uit handen moeten geven. De examens worden nu beheerd door examencommissies waarin advocaten slechts een minderheid vormen. De nieuwe toetredingsprocedure is objectiever. Niet alleen omdat het nu in handen is van een onafhankelijke commissie maar vooral ook vanwege het feit dat het examen alleen nog uit een schriftelijke toets bestaat die voor alle kandidaten in het hele land dezelfde inhoud heeft. Nu iedere kandidaat die voor de schriftelijke meerkeuzetoets voldoende punten heeft gehaald in beginsel tot de balie dient te worden toegelaten, is er geen ruimte meer om - zoals voorheen tijdens het mondelinge deel van het toelatingsexamen kon gebeuren - op welke grond dan ook nog een nadere selectie te laten plaatsvinden.

\subsubsection{The story continues...}

De balie heeft zich niet bij de nieuwe situatie neergelegd en een deel van de nieuwe bepalingen voorgelegd aan het Grondwettelijk Hof. En niet zonder succes: in april 2006 heeft het Hof een aantal van de omstreden artikelen uit de Advocatenwet in strijd met de Grondwet verklaard. 139 De belangrijkste kritiek van het Hof betrof de invloed van de balie (of liever: het ontbreken daarvan) op de afsluitende examens en de uitbreiding van de mogelijkheden om via een vereenvoudigde procedure tot de beroepsgroep te kunnen toetreden.

Ten aanzien van het eerste punt oordeelt het Hof - kort weergegeven - dat de nieuwe wetgeving de zeggenschap van de balie over de afsluitende examens te ver heeft ingeperkt door de bevoegdheden over te dragen aan examencommissies waarin advocaten slechts een minderheid kunnen vormen. Dit levert strijd op met art. 17 lid 1 Grondwet: volgens die bepaling dient de beroepsorganisatie er op toe te zien dat haar leden hun functie naar behoren vervullen. Zonder wezenlijke inspraak in de toetreding van nieuwe leden is dat volgens het Hof niet mogelijk. Over het tweede punt zegt het Grondwettelijk Hof dat het op grond van de gewijzigde Advocatenwet voor juristen in sommige gevallen te eenvoudig is geworden om zonder stageperiode en/of afsluitend examen lid te kunnen worden van de balie. Dit geldt in de eerste plaats voor de categorie die het examen voor rechter, prokurator, juridisch adviseur of notaris succesvol hebben afgelegd en om die reden zonder stageperiode en zonder afsluitend examen advocaat kunnen worden toegelaten. Hierdoor kunnen ook juristen zonder enige praktijkervaring in de advocatuur aan de slag. Ook de mogelijkheid bepaalde categorieën juristen met een aantal jaren werkervaring toe te laten tot het afsluitend examen zonder dat ze de stageperiode hoeven te doorlopen, gaat volgens het Hof te ver. Beide regelingen miskennen het belang van de stageperiode waarin advocaten worden voorbereid op zelfstandige uitoefening van het beroep en leveren dan ook strijd op met eerder genoemd art. 17 lid 1 van de Grondwet.

138 De stageperiode is het enige onderdeel waar de balie nog volledige zeggenschap over heeft.

139 Uitspraak van 19 april 2006 (K 6/06), te raadplegen op: <www.trybunal.gov.pl>. 
De uitspraak van het Grondwettelijk Hof heeft duidelijk gemaakt dat de wetgever bij de hervorming van de Advocatenwet op een aantal punten is doorgeschoten. De bepalingen die in strijd met de Grondwet zijn verklaard, hebben hun geldingskracht met ingang van 31 december 2006 verloren. Door deze aanpassingen zijn de scherpste kantjes van de nieuwe regeling verdwenen maar de politiek heeft zich door de uitspraak van het Grondwettelijk Hof niet uit het veld laten slaan. Zoals hierna nog zal worden uitgewerkt, is in 2007 nog een aantal wetswijzigingen voorbereid en (in sommige gevallen ook) doorgevoerd die de autonomie van de balie voornamelijk op het terrein van het tuchtrecht verder aantasten. ${ }^{140}$

\section{Beroepscultuur}

De Poolse advocatuur is van oudsher een soort adelstand - tot aan het einde van de 18 eeuw werden voornamelijk leden van de adel tot de balie toegelaten - en nog steeds hecht de beroepsgroep erg aan haar status van officium nobile. Zoals ook in de gedragsregels tot uitdrukking komt, wordt 'de waardigheid van het beroep' als een fundamentele beroepswaarde beschouwd. ${ }^{141}$

Illustratief voor het adellijke karakter is dat advocaten worden aangesproken met de term 'mecenas' ('heer'). De balie is trots op haar status en doet er alles aan om deze te behouden. Zoals in het voorgaande eerder is benadrukt, is haar geprivilegieerde positie in de Poolse samenleving de laatste jaren echter aan het wankelen gebracht. De maatschappelijke visie op de advocaat is beduidend minder positief dan gedurende het communisme: waar hij voor 1989 vooral werd beschouwd als iemand die streed tegen onrecht en opkwam voor belangrijke rechten en vrijheden van onderdrukte burgers wordt de advocaat vandaag de dag vooral met argwaan bekeken. ${ }^{142}$ Ook in de media wordt - op kritische wijze en vaak in negatieve zin veel aandacht besteed aan het optreden van advocaten. In de steeds feller wordende strijd om zelfbehoud en het gevecht tegen de toenemende maatschappelijke en politieke kritiek is de advocatuur door buitenstaanders uit verschillende hoeken meer dan eens verweten een arrogante, starre houding aan te nemen.

Het aandeel vrouwen binnen de balie bedraagt volgens de statistieken van het CCBE ongeveer een vierde. ${ }^{143}$ Hoewel geen vergelijkbare cijfers beschikbaar zijn over de periode voor 1989 staat wel vast dat juridische beroepen en in het bijzonder de advocatuur gedurende het communisme vanwege het lage aanzien van deze professies een relatief hoog percentage vrouwen kende. ${ }^{144}$

140 Deze wijzigingen en de tendens die eraan ten grondslag ligt, hebben uiteindelijk internationale aandacht gekregen van de CCBE en de International Bar Association's Human Rights Institute (IBAHRI). Zie hierna § 4.4.5.

141 Zie over de gedragsregels hierna $\S 4$.

142 In de woorden van Hermeliński: 'We doen nog steeds hetzelfde werk: dat waar we voorheen voor geroemd werden, worden we nu voor bekritiseerd (...)'. Bron: gesprek Hermeliński, juni 2003 Warschau.

143 In 2006 waren volgens de statistieken van de CCBE 2524 van de in totaal 8488 advocaten vrouw: <www.ccbe.eu/fileadmin/user_upload/NTCdocument/table_number_lawye rs1_1179905628.pdf>.

144 Dit lage aanzien was onlosmakelijk verbonden met de Marxistische overtuiging dat het recht (en daarmee ook de jurist) geleidelijk aan zou verdwijnen en met het bereiken van de communistische samenleving volledig overbodig zou worden: 'Gender bias pervaded Communist societies despite their egalitarian rethoric. Women in Communist countries, as in 
Poolse advocaten zijn traditioneel generalisten maar specialisatie komt de laatste jaren steeds meer voor. ${ }^{145}$ Wat het gebruik van het EVRM betreft, geldt dat het merendeel van de advocaten geen behoorlijke kennis van Straatsburgse rechtspraak heeft. ${ }^{146} \mathrm{Er}$ is een beperkt aantal advocaten dat zich ermee bezighoudt maar de gemiddelde advocaat maakt niet of nauwelijks gebruik van de mogelijkheden die het EVRM biedt. ${ }^{147}$ Voor deze situatie kunnen verschillende oorzaken worden genoemd. Om te beginnen speelt een rol dat internationale mensenrechten pas sinds het begin van de jaren negentig geleidelijk aan een plaats hebben verworven in de Poolse rechtsorde. ${ }^{148}$ Tot voor kort werd in juridische opleidingen niet of nauwelijks aandacht besteed aan het EVRM. De meeste advocaten zijn op dit punt dus niet goed opgeleid. Bovendien is het gros van de uitspraken van het EHRM slechts beschikbaar in het Engels en/of het Frans: talen die lang niet alle Poolse advocaten beheersen. Mogelijk speelt ook een rol dat het Poolse recht de laatste jaren zoveel veranderingen heeft ondergaan (en nog steeds ondergaat) dat juristen er al een hele kluif aan hebben om goed op de hoogte te blijven van recente ontwikkelingen op eigen nationale rechtsgebieden. Om daarnaast ook nog kennis te nemen van Europese normen en bijbehorende rechtspraak is voor veel advocaten wellicht te veel gevraagd. Om gelijksoortige redenen zijn ook rechters - van met name lagere feitelijke instanties - slecht bekend met het EVRM. Hoogstwaarschijnlijk besteedt de advocatuur ook daarom maar weinig aandacht aan de Straatsburgse normen: de kans dat het gehoor zal vinden bij de rechter is immers zeer gering. Op dit punt kan echter wel een ontwikkeling worden waargenomen waarbij met name hogere instanties als het Hooggerechtshof en het Constitutioneel Hof in toenemende mate gebruik maken van en verwijzen naar het EVRM. ${ }^{149}$

\section{Ethiek}

\subsection{Inleiding}

Het tuchtrechtelijk toezicht is in handen van de balie zelf. Het optreden van advocaten wordt getoetst aan een geschreven gedragscode en een aantal algemene

the West, often were guided toward lower prestige occupations. The low prestige of the Bar relative to the procuracy and other state positions meant that many women became advocats': Meyer 1995, p. 1036.

145 Zie eerder $\S 2.1$.

146 Zie hierover ook hoofdstuk 2, § 2.3.1.2.

147 Dat terwijl de advocatuur een belangrijke rol zou kunnen spelen in de - wijze waarop en de mate waarin - verdragsnormen in de nationale rechtspleging worden geïmplementeerd. Zie hierover Drzemczewski en Nowicki 2001, p. 677: 'An important role in the process of society's familiarization with the Convention falls with members of the Bar, who must learn to use the ECHR in their daily work. The Convention's real legal value before domestic courts depends largely on the legal practitioner and his determination and expertise in formulating appropriate arguments based on knowlegde of the Convention's case-law.'

148 Zie ook hoofdstuk 2, § 2.3.1.

149 'The limited application of international law argument by Polish courts is apparently a remnant of the judicial culture inherited from the communist period. Judges were then obliged to apply only national legislation and approach it in narrowly interpreted terms. To change this pattern a great deal of work is necessary. Good examples from the highest judicial institutions pave way for a change, but it will take a longer time to alter the approach to law among ordinary lawyers': Kamiński 2004, p. 223. 
bepalingen uit de Advocatenwet. ${ }^{150}$ Het gedrag van de advocaat in strafzaken wordt bovendien genormeerd door een aantal bepalingen uit het materiële en het formele strafrecht.

Hierna zal eerst kort aandacht worden besteed aan de geschiedenis van de gedragsregels waarna de belangrijkste normen voor het optreden van de raadsman de revue zullen passeren. Ten slotte zal in worden gegaan op de organisatie en het functioneren van de tuchtrechtspraak. Ook in laatstgenoemd verband wordt de balie veelvuldig bekritiseerd: behalve de discussie over nepotisme en bewust klein houden van het aantal leden is een ander veelgehoord punt van kritiek dat het tuchtrechtelijk toezicht op de advocatuur niet effectief zou zijn en dat de balie onvoldoende zou instaan voor de kwaliteit van de door haar leden verleende rechtsbijstand. Zoals hierna nog zal blijken, heeft de wetgever recent een aantal maatregelen genomen die de kwaliteitscontrole op de advocatuur dienen te verbeteren.

\subsection{Geschiedenis}

De eerste officiële Poolse gedragscode voor advocaten dateert uit 1961. Een eerste aanzet daartoe had echter al veel eerder plaatsgevonden toen een aantal advocaten uit Warschau in 1886 een questionnaire opstelde waarmee werd beoogd de belangrijkste standpunten over professionele ethiek van de advocaat in strafzaken ${ }^{151}$ in kaart te brengen. De vragen maakten veel discussie los en de auteurs ontvingen veel reacties die helaas nooit zijn gepubliceerd. Het initiatief heeft op dat moment niet tot een codificatie van gedragsregels geleid maar de kwestie herleefde in de twintigste eeuw. In 1919 werd in Warschau de Algemene Vergadering van de Poolse balie gehouden en een van de agendapunten was het codificatievraagstuk. Bij die gelegenheid werd echter aangenomen dat zou moeten worden volstaan met een verzameling van de belangrijkste regels uit de tuchtrechtspraak. Uiteindelijk werd in 1935 door de lokale raad van Warschau toch een commissie aangesteld die de taak kreeg gedragsregels voor de advocatuur op te stellen. Het werk van deze

150 Zoals eerder al aan de orde is geweest, zijn er ook internationale gedragscodes voor advocaten die - in ieder geval in theorie - ook voor de Poolse advocaat gelden. In dit verband is vooral de gedragscode van de CCBE van belang (zie § 2.3). De door de CCBE vertegenwoordigde balies dienen hun gedragsregels zoveel mogelijk in overeenstemming te brengen met deze Europese gedragscode teneinde grensoverschrijdend optreden van advocaten te vergemakkelijken. De CCBE speelt een niet onbelangrijke rol in de ontwikkelingen die de Poolse advocatuur de laatste jaren doormaakt: de organisatie houdt toezicht op de (voorgenomen) hervormingen en heeft in het recente verleden meer dan eens haar ongenoegen uitgesproken over wijzigingen die - volgens de organisatie - de autonomie van de Poolse balie te veel aantasten. Zie hierna ook $\S$ 4.4.5. Andere internationale gedragscodes zijn de eerder genoemde Basic principles on the role of lawyers van de $\mathrm{VN}$ en de International Code of Ethics van de International Bar Association (zie eveneens $\S 2.3$ ). Voor zover kan worden overzien, lijken laatstgenoemde internationale regels een uiterst beperkte betekenis te hebben voor het Poolse gedragsrecht. Zie over de internationale gedragscodes: Spronken 2001, p. 499-500.

151 'Kwestionarusz do etyki obrończej'. De vragenlijst bestond uit iets meer dan 100 vragen zoals 'wat is de taakomschrijving van de raadsman?', 'welke eisen stelt deze taakomschrijving aan zijn privé-leven?', 'mag het beroepsgeheim worden geschonden en, zo ja, in welke gevallen?', 'staat het de raadsman vrij bij de verdediging feiten te verzinnen?' en 'mag de schuld op een medeverdachte worden geschoven zonder voldoende bewijzen en zonder noodzaak voor de verdediging van de cliënt?'. 
commissie verliep moeizaam. Voornaamste reden was dat er onder advocaten veel verdeeldheid bestond over vraag of een dergelijke regeling wel noodzakelijk was. Sommige advocaten waren van mening dat de eer en de waardigheid van het beroep niet zouden kunnen worden 'gevangen' in geschreven bepalingen. Bovendien bestond de angst dat de gedragsregels slechts een minimumstandaard van beroepsethiek zouden vastleggen en dat er geen enkele stimulans van uit zou gaan om dat minimumniveau te ontstijgen. Er waren echter ook voldoende voorstanders en het werk aan de gedragsregels werd zelfs gedurende Wereldoorlog II voortgezet. ${ }^{152}$ In 1958 stelde de Hoogste Raad van de balie opnieuw een commissie samen die de taak kreeg een gedragscode op te stellen. Dit resulteerde in 1961 in de eerste verzameling geschreven gedragsregels voor de advocatuur. Belangrijk punt van discussie was of de regeling als 'wet' ('kodeks') moest worden aangeduid. Voor die benaming is uiteindelijk bewust niet gekozen om de regels een niet te dwingend karakter te geven en de tuchtrechter de nodige ruimte te bieden bij toepassing en interpretatie ervan. ${ }^{153}$ Vandaar dat de gedragscode werd (en vandaag de dag nog steeds wordt) aangeduid als een 'verzameling beginselen', voluit: 'een verzameling beginselen van de ethiek van de advocaat en de waardigheid van het beroep'. ${ }^{154}$

Het feit dat er tot 1961 geen geschreven gedragscode was, betekent niet dat er voor die tijd geen tuchtrechtelijk toezicht plaatsvond. ${ }^{155}$ De tuchtrechter toetste het gedrag van advocaten aan ongeschreven beginselen, uitgangspunten die uit eerdere tuchtrechtspraak konden worden afgeleid of door organen van de balie waren vastgesteld en aan een aantal gedragsnormerende bepalingen uit het wetboek van strafvordering en de Advocatenwet. Heel duidelijk waren de grenzen voor het optreden van advocaten echter niet. Vooral laatstgenoemde categorie bevatte niet of nauwelijks concrete aanwijzingen: zo regelde de Advocatenwet van 1950 onder meer dat de advocaat geen rechtsbijstand mocht verlenen 'in strijd met de algemene belangen van de gemeenschappelijke economie' en dat disciplinaire maatregelen zouden worden genomen wanneer zijn gedrag 'in strijd met de belangen van de arbeidersbevolking' was. ${ }^{156}$ Door deze vage normen was het voor de advocatuur onduidelijk welk gedrag nu wel en niet was toegestaan. ${ }^{157}$ De gedragsregels van 1961 bevatten overigens geen - met genoemde bepalingen uit de Advocatenwet vergelijkbare - politiek geladen gedragsnormen. Reden hiervoor is dat de gedrags-

152 Hoewel er nog geen officiële - door de balie uitgevaardigde - regeling van het gedragsrecht was, werd er wel veel over geschreven. Belangrijke bijdragen zijn onder meer: Waśkowski 1932, Basseches en Korkis 1938 en Ruff 1939. Voor de jaren na Wereldoorlog II is vooral het werk van Janczewski van groot belang: hij publiceerde vlak voor de totstandkoming van de gedragsregels zijn werk 'Waardigheid van het beroep advocaat' waarin uitvoerig op verschillende gedragsrechtelijke thema's wordt ingegaan: Janczewski 1960.

153 De gedragsregels hebben - anders dan bijvoorbeeld de Advocatenwet en het wetboek van strafvordering - ook niet de status van wet omdat ze niet door de wetgever maar door de balie zijn uitgevaardigd.

154 'Zbiór zasad etyki adwokackiej i godności zawodu'. Voor bovenstaande beschrijving van de historische ontwikkeling van het tuchtrecht is gebruik gemaakt van Czeszejko en Krzemiński 1971, p. 67-78, Krzemiński 1975 en Czeszejko-Sochaki 1975.

155 Zie eerder $\S 4.2$.

156 Art. 53 en 95 Advocatenwet 1950.

157 Siekanowicz 1959 II, p. 300-303. Zie over de Advocatenwet van 1950 ook § 2.2.1.1. 
code anders dan de Advocatenwet zelfstandig en dus zonder politieke inmenging door de advocatuur kon worden opgesteld. Vandaar ook dat de politieke omwenteling van eind jaren tachtig voor de gedragsregels weinig tot geen gevolgen heeft gehad. De veranderingen die in de loop der jaren in de gedragsregels zijn aangebracht, betreffen hoofdzakelijk incidentele wijzigingen die de regeling dienden aan te passen aan de eisen van de moderne tijd: inhoud en opzet zijn daarbij niet wezenlijk veranderd.

Sinds 1961 is een aantal keren een nieuwe versie van de gedragscode uitgevaardigd: in 1970, 1987, 1993 en in 1998. Laatstgenoemde versie is - weliswaar in gewijzigde vorm - nog steeds van kracht. ${ }^{158}$ De huidige gedragscode bestaat uit 69 bepalingen en is (net als in 1961 en de versies erna) ingedeeld in zeven hoofdstukken. ${ }^{159}$ Op basis van deze regels kunnen drie categorieën professionele 'overtredingen' worden onderscheiden, te weten: schending van plichten ten opzichte van

1. de rechter of een ander orgaan waarvoor de advocaat verschijnt,

2. andere advocaten of

3. de cliënt. ${ }^{160}$

\subsection{Belangrijkste gedragsrechtelijke bepalingen voor de raadsman}

Voor beantwoording van de vraag welke grenzen aan het optreden van de advocaat in strafzaken worden gesteld, vormen de gedragsregels de belangrijkste maar zeker niet de enige bron: relevante bepalingen zijn ook te vinden in strafwetgeving - het materiële en het formele strafrecht - en in de Advocatenwet. Sommige thema's zijn zelfs in verschillende bronnen geregeld, zoals het beroepsgeheim en het verbod cliënten met tegenstrijdige belangen bij te staan. ${ }^{161}$

In het onderstaande zullen de belangrijkste regels die van belang (kunnen) zijn voor het optreden van de advocaat in strafzaken de revue passeren. Daarbij zal niet alleen aandacht worden besteed aan de gedragsregels maar ook aan bepalingen uit de Advocatenwet en het materiële en formele strafrecht. Relevante tuchtrechtspraak zal vanwege de beperkte beschikbaarheid ervan slechts incidenteel aan de orde komen. Zoals hierna nog zal worden besproken, wordt de tuchtrechtspraak sinds de jaren negentig niet of nauwelijks meer gepubliceerd. ${ }^{162}$ Ook de

158 Besluit Hoogste Raad d.d. 10 oktober 1998, nr. 2/XVIII/98, de laatste versie dateert van 19 november 2005. De gedragsregels van 1998 zijn onder meer te raadplegen op de website van de Hoogste Raad: <www.nra.pl/nra.php>. Een vertaling in het Engels is beschikbaar op de website van de CCBE: <www.ccbe.org>.

159 1. algemene bepalingen, 2. de beroepsuitoefening, 3. de verhouding tot rechterlijke instanties en andere organen, 4 . de verhouding tot andere advocaten, 5 . de verhouding tot cliënten, 6 . het functioneren van de advocaat binnen de balie, en 7 . slotbepalingen.

160 Hofmański en Zabłocki 2008, p. 692.

161 Het beroepsgeheim is - zoals in hoofdstuk 7 reeds uitgebreid aan de orde is geweest - zowel in de Advocatenwet (art. 6) als in de gedragsregels (art. 19) vastgelegd. Het verschoningsrecht van de advocaat dat onlosmakelijk met het beroepsgeheim is verbonden, is geregeld in art. 178 en 180 KPK 1997. Het verbod twee of meer cliënten met tegenstrijdige belangen bij te staan is in algemene zin vastgelegd in art. 46 van de gedragsregels en - meer specifiek voor de advocaat in strafzaken - in art. 85 KPK 1997.

162 Daarvoor werden belangrijke uitspraken gepubliceerd in Palestra - het tijdschrift van de balie. 
handboeken tuchtrecht zijn voor het overgrote deel gebaseerd op rechtspraak van voor Wereldoorlog II en de jaren vijftig, zestig en zeventig. ${ }^{163}$ In het onderstaande zal dan ook worden volstaan met een incidentele vermelding van relevante overwegingen van de tuchtrechter ter illustratie.

\subsubsection{Algemene bepalingen}

In het eerste deel van de gedragscode is een aantal regels opgenomen waarin wordt aangegeven hoe een advocaat zich - in zijn algemeenheid - dient te gedragen. Het betreft hier tamelijk universele gedragsregels die in vrijwel alle gedragscodes terug te vinden zijn. Om te beginnen is bepaald dat elk gedrag dat schadelijk kan zijn voor het imago van de beroepsgroep en het vertrouwen dat er in wordt gesteld, een schending van de waardigheid van het beroep oplevert. ${ }^{164}$ Iedere advocaat is verplicht de gedragsregels na te leven en de waardigheid van het beroep in ere te houden. ${ }^{165}$ Tuchtrechtelijke verantwoordelijkheid bestaat niet alleen voor het overtreden van de gedragsregels of het schenden van de waardigheid van het beroep tijdens de beroepsuitoefening maar ook voor optreden in het privé-leven. ${ }^{166}$ De advocaat dient zijn taken naar eer en geweten uit te oefenen, eerlijk en consciëntieus te zijn en zich volledig voor zijn zaken in te zetten. ${ }^{167}$

\subsubsection{Verhouding tot de cliënt}

Een van de belangrijkste richtlijnen voor het optreden van de raadsman is de strafvorderlijke regel dat alleen handelingen in het voordeel van verdachte mogen worden verricht. ${ }^{168}$ Op zichzelf een 'normale' gedragsnorm maar bijzonder is wel dat deze in het wetboek van strafvordering is opgenomen. Zoals besproken in hoofdstuk 3, § 3.3.1.2 worden in de doctrine drie perspectieven onderscheiden van waaruit kan worden beoordeeld of in een concreet geval aan het voorschrift van art. 86 lid $1 \mathrm{KPK}$ is voldaan:

- de objectieve beoordeling waarbij er vanuit wordt gegaan dat alle handelingen die in objectieve zin - ex post of ex ante - negatief blijken te zijn voor verdachte ontoelaatbaar zijn,

- de subjectieve beoordeling waarbij de wil van de raadsman bepalend is ${ }^{169}$ en

- de gemengde opvatting waarin beide uitgangspunten worden verenigd zodat zowel handelingen die naar hun aard in het nadeel van verdachte zijn als handelingen waarvan in de concrete omstandigheden duidelijk is dat ze schadelijk kunnen zijn voor verdachte ontoelaatbaar zijn. ${ }^{170}$

163 Bovendien wordt daarin geen casusbeschrijving gegeven maar slechts de belangrijkste overweging uit de uitspraak vermeld. Zie § 4.4.4.

164 Art. 1 lid 2 gedragsregels.

165 Art. 1 lid 3 gedragsregels.

166 Art. 4 gedragsregels.

167 Art. 8 gedragsregels.

168 Art. 86 lid 1 KPK 1997.

169 Dat de advocaat met de verkeerde bedoelingen heeft gehandeld kan worden afgeleid uit de aard van de handeling - bijvoorbeeld het indienen van een bewijsverzoek dat tot belastend bewijsmateriaal leidt.

170 Grzegorczyk 2004, p. 300 en meer uitgebreid Kruszyński 1991, p. 51-58. 
Omdat volgens deze regel bepalend is wat in het voordeel van verdachte is - en niet wat de verdachte wil - rijst de vraag of een advocaat handelingen mag verrichten tegen de kennelijke wil van zijn cliënt. Met andere woorden: wie bepaalt wat in het voordeel van verdachte is? In de doctrine wordt aangenomen dat de zelfstandige positie die de raadsman in het strafproces inneemt, betekent dat hij zelf een oordeel dient te vormen over wat in de gegeven omstandigheden voordelig is. ${ }^{171}$ Kruszyński benadrukt bovendien dat dit een logische consequentie van de publieke taak van de raadsman is: aangezien het in het algemeen belang is dat iemand die onschuldig is niet wordt gestraft en dat de straf bij een schuldige verdachte niet hoger uitvalt dan de mate van zijn schuld dient wat in het voordeel van verdachte is te worden geobjectiveerd en zelfstandig door de raadsman te worden bepaald. Zo is de raadsman - indien noodzakelijk - vrij om onafhankelijk van de wil van zijn cliënt bewijsverzoeken in te dienen, zijn bekentenis of toerekeningsvatbaarheid in twijfel te trekken et cetera. ${ }^{172}$ Hoewel dit soort situaties vanwege het vereiste vertrouwen tussen raadsman en cliënt zoveel mogelijk vermeden zal dienen te worden, is het op zichzelf dus niet verboden tegen de wil van de cliënt te handelen. ${ }^{173}$

De advocaat dient partijdig te zijn: in de gedragsregels is vastgelegd dat het doel van zijn optreden is het behartigen van de belangen van zijn cliënt. ${ }^{174} \mathrm{Hij}$ dient de belangen van zijn cliënt 'dapper en eervol'('w sposób odważny i honorowy') te beschermen zonder zijn eigen belangen daarbij in acht te nemen. ${ }^{175}$

De advocaat is volledig vrij en onafhankelijk in zijn beroepsuitoefening ${ }^{176}$ en neemt - zoals eerder vermeld - ten opzichte van zijn cliënt een zelfstandige positie in. Laatstgenoemd uitgangspunt ligt ook ten grondslag aan art. 86 lid 2 KPK waarin is geregeld dat deelname van de raadsman aan het strafproces persoonlijke deelname van de verdachte niet uitsluit. Ze kunnen dus afzonderlijk van elkaar optreden in de procedure. De advocaat is geen spreekbuis van verdachte: hij dient zelfstandig te beoordelen welke tactiek of strategie in het gegeven geval het meest gunstig is voor verdachte. ${ }^{177}$ Zelfstandigheid van de raadsman betekent ook dat hij een schending van de beroepsethiek niet kan rechtvaardigen door aan te voeren dat hij in opdracht van zijn cliënt handelde. ${ }^{178}$

De relatie tussen advocaat en cliënt is gebaseerd op vertrouwen, een advocaat dient zich terug te trekken wanneer blijkt dat de cliënt het vertrouwen in hem heeft

171 Zie Hofmański e.a. 2007 I, p. 480.

172 Dit standpunt is algemeen aanvaard in de Poolse doctrine: Kruszyński 1991, p. 38-39 en daar genoemde literatuur.

173 Anders dan bijvoorbeeld in Nederland waar in de gedragsregels is opgenomen dat een advocaat geen handelingen mag verrichten tegen de kennelijke wil van verdachte (regel 9 sub 1 gedragsregels Nederlandse Orde van Advocaten).

174 Art. 6 gedragsregels.

175 Art. 43 gedragsregels.

176 Art. 7 gedragsregels.

177 De zelfstandigheid van de raadsman betekent bovendien dat hij de procedurele bevoegdheden die hij aan zijn cliënt ontleent in beginsel zelfstandig kan uitoefenen. Zoals besproken in hoofdstuk $3, \S 3.3$ gelden op dit punt wel enkele uitzonderingen: zo kan de raadsman niet in naam van de verdachte instemmen met een consensuele afdoening en namens hem geen verklaringen afleggen die voor het bewijs kunnen worden gebruikt. Zie ook hoofdstuk 6, § 3.1.2.

178 Art. 10 gedragsregels. 
verloren. ${ }^{179}$ Hij behoort de voortgang van de zaak te bewaken en zijn cliënt daarover te informeren en op de hoogte te stellen van de uitkomst. ${ }^{180}$ Wat het honorarium betreft, geldt dat de verschuldigde vergoeding door advocaat en cliënt samen wordt vastgesteld. Wanneer een cliënt zijn betalingsverplichtingen niet nakomt, geeft dat de advocaat niet het recht de overhandiging van documentatie achter te houden of zijn werkzaamheden op te schorten zolang de betaling niet is voldaan. ${ }^{181}$

\subsubsection{Beroepsgeheim}

Zoals besproken in hoofdstuk 7 is de advocaat verplicht alle informatie die hij tijdens het uitoefenen van zijn functie verkrijgt, geheim te houden. ${ }^{182}$ Deze verplichting - van wezenlijk belang voor de vertrouwensrelatie tussen advocaat en cliënt - is zowel in de Advocatenwet als in de gedragsregels vastgelegd. ${ }^{183}$ Het beroepsgeheim geniet ook strafvorderlijke bescherming: de raadsman beschikt over een absoluut verschoningsrecht op grond waarvan hij zijn geheimhoudingsplicht ten overstaan van de rechter kan handhaven. ${ }^{184}$ De advocaat in strafzaken kan dus nooit worden gedwongen als getuige informatie prijs te geven die hij in de uitoefening van zijn functie heeft verkregen.

\subsubsection{Tegenstrijdige belangen}

Het is de raadsman verboden verdachten bij te staan wiens belangen tegenstrijdig zijn. ${ }^{185}$ Immers, wanneer het belang van verdachte A strijdig is met dat van verdachte $\mathrm{B}$ zal de raadsman zich nooit volledig voor beide cliënten kunnen inzetten. Vandaar dat in de rechtspraak is bevestigd dat het bijstaan van cliënten met tegenstrijdige belangen een schending van het recht op verdediging - zoals neergelegd in art. 6 KPK 1997 - oplevert. ${ }^{186}$

Van tegenstrijdige belangen is volgens het Hooggerechtshof onder meer sprake wanneer verdachten elkaar beschuldigen omdat in zo' $n$ geval 'de verdediging van één verdachte onvermijdelijk schadelijk is voor de belangen van de andere verdachte'. De enkele schijn van tegenstrijdigheid is niet voldoende, bijvoorbeeld het

179 Art. 51 gedragsregels.

180 Art. 49 gedragsregels.

181 Art. 53 en 54 gedragsregels.

182 Het belang van het beroepsgeheim wordt van oudsher erkend binnen de Poolse advocatuur: er werd reeds lang voor de totstandkoming van de eerste Advocatenwet en (geschreven) gedragsregels over geschreven. Zo blijkt bijvoorbeeld uit een publicatie van advocaat D. Torosiewicz uit het jaar 1822, genoemd in Krzemiński 1998, p. 22.

183 Art. 6 lid 1 Advocatenwet en art. 19 lid 1 gedragsregels. Zie uitgebreider hoofdstuk 7, § 5 .

184 Art. 178 sub 1 KPK 1997. De advocaat die niet als raadsman kan worden aangemerkt, kan ingevolge art. 180 lid 2 KPK 1997 onder bepaalde voorwaarden wel als getuige worden gehoord. Deze strafvorderlijke mogelijkheid is strijdig met bovengenoemde regelgeving van de advocatuur (Advocatenwet en gedragsregels) waarin het beroepsgeheim onvoorwaardelijk en absoluut is geformuleerd. Ook in de regeling van bepaalde strafvorderlijke dwangmiddelen en opsporingsbevoegdheden is de bescherming van het beroepsgeheim van de advocaat onvoldoende gegarandeerd. Zie hierover hoofdstuk 7 , § 7 en 8 .

185 Art. 85 KPK 1997 en art. 46 gedragsregels (laatstgenoemde regel geldt niet alleen voor optreden in strafzaken).

186 Uitspraak SA Lublin d.d. 18 december 2002 (II AKa 297/02, Prok. i Prawo 2003, nr. 12, p. 25), zie Kulesza 2005, p. 396. 
verdedigen van ontkennende medeverdachten is in beginsel toelaatbaar voor zover en zolang ze elkaar niet beschuldigen. ${ }^{187}$

Het verdedigen van verdachten met tegenstrijdige belangen is ook niet toegestaan wanneer de betreffende cliënten ermee instemmen. ${ }^{188}$

Wie waakt over het bestaan (of ontstaan) van tegenstrijdige belangen en wat dient te gebeuren wanneer tegenstrijdigheid wordt geconstateerd? In de eerste plaats is het uiteraard de advocaat zelf die ervoor zorg dient te dragen dat de belangen van zijn cliënten niet onverenigbaar zijn. Wanneer tegenstrijdigheid wordt vastgesteld, dient hij de betrekking met de betrokken cliënten te beëindigen. Maar wat dient te gebeuren wanneer de rechter van oordeel is dat sprake is van tegenstrijdige belangen en de verdediging dit standpunt niet deelt? In het oude strafprocesrecht was deze kwestie niet met zoveel woorden geregeld en de doctrine was verdeeld: sommige auteurs waren van mening dat de rechtbank in zo'n geval zou moeten kunnen ingrijpen, anderen meenden dat dit moest worden overgelaten aan de balie omdat de rechter niet bevoegd is de verdachte te beperken in zijn vrijheid een advocaat te kiezen. ${ }^{189}$ In het nieuwe wetboek van strafvordering is op aandringen van de doctrine wettelijk geregeld dat - wanneer de rechtbank vaststelt dat sprake is van tegenstrijdige belangen - in geval van een gekozen raadsman de verdachte een termijn wordt geboden een nieuwe advocaat te kiezen en in geval van toegevoegde rechtsbijstand door de rechter een nieuwe raadsman wordt aangewezen. ${ }^{190}$

\subsubsection{Weigeren of neerleggen verdediging}

Een advocaat mag slechts op 'belangrijke gronden' (' $z$ ważnych powodów') weigeren rechtsbijstand te verlenen. De (aspirant-)cliënt dient over deze gronden te worden geïnformeerd. Bij twijfel beslist de balie en wanneer een advocaat op basis van toevoeging optreedt, kan hij slechts van zijn verplichtingen worden ontheven door het orgaan dat hem heeft aangewezen. ${ }^{191}$

Wat het neerleggen van de verdediging na aanvang van het onderzoek ter terechtzitting betreft, is van belang dat deze mogelijkheid de laatste jaren aan steeds strengere wettelijke voorwaarden is verbonden. Het gebeurde in het verleden regelmatig dat raadsman en/of cliënt op de zitting het vertrouwen in elkaar opzegden om zo een aanhouding van de zaak af te dwingen. Door verschillende wijzigingen in de wettelijke regeling van het neerleggen van de verdediging op de zitting (art.

187 Grzegorczyk 2004, p. 298 en daar genoemde rechtspraak van het Hooggerechtshof en Hofmański e.a. 2007 I, p. 476-477 en daar genoemde rechtspraak van het Hooggerechtshof. Zie over tegenstrijdige belangen ook: Gajewska-Kraczkowska 1992, p. 1135.

188 Op dit punt kan overigens een belangrijk verschil worden gesignaleerd tussen common law en civil law rechtssystemen: in bijvoorbeeld het Amerikaanse strafproces kan toestemming van de cliënt het verbod tegenstrijdige belangen te behartigen namelijk wel opheffen. Dit onderscheid is onlosmakelijk verbonden met een verschil in opvattingen over de onafhankelijkheid van de advocaat en zijn verhouding tot de cliënt: 'The different approaches to conflicts reflect a different conceptualization of the independence and role of the lawyer in the two systems, and a European legal culture that is seemingly less "client-centered" than in the United States': Goldstein Bolocan 2002, p. 37.

189 Kruszyński 1991, p. 94-98, Grzegorczyk 2004, p. 298 en Hofmański e.a. 2007 I, p. 479

190 Art. 85 lid 2 en 3 KPK 1997. Ook gedurende het vooronderzoek komt deze bevoegdheid aan de rechtbank toe. Tegen deze beslissingen van de rechtbank kan zowel door de verdachte als door de raadsman bezwaar worden aangetekend.

191 I.e. de (president van de) rechtbank. Zie art. 28 Advocatenwet. 
378 Sv) heeft de wetgever strategisch gebruik van deze mogelijkheid in de toekomst zoveel mogelijk willen voorkomen. ${ }^{192}$

\subsubsection{Waarheidsvinding}

In hoofdstuk 3 is stilgestaan bij de historische ontwikkeling van de rolopvatting van de advocaat in strafzaken. Een van de conclusies was dat de huidige betekenis van de publieke functie van de raadsman niet inhoudt dat hij actief behulpzaam moet zijn bij de waarheidsvinding maar 'slechts' dat hij door zijn deelname een eerlijke en contradictoire procesvoering mogelijk dient te maken. Dit betekent echter niet dat deze hoofddoelstelling van het strafproces (het vaststellen van de materiële waarheid) geen enkele grens stelt aan het optreden van de raadsman. Zo mag hij de waarheidsvinding niet moedwillig verstoren en dus ook niet doelbewust onjuiste informatie verschaffen aan de rechtbank. ${ }^{193}$ Hij is weliswaar niet verantwoordelijk voor de waarheidsgetrouwheid van feiten die hij van zijn cliënt verneemt maar dient wel terughoudend te zijn in het aanvoeren van 'drastische en onaannemelijke' feiten en omstandigheden. ${ }^{194}$ Omstreden is of de raadsman bewijsmateriaal mag aandragen wanneer hij niet overtuigd is van de betrouwbaarheid ervan of wanneer het gevaar bestaat dat het vervalst is. De heersende mening is dat de rechter (en niet de advocaat) verantwoordelijk is voor de beoordeling van bewijsmateriaal. Het kan onder omstandigheden wel tuchtrechtelijk laakbaar zijn maar levert in beginsel geen strafbaar feit op. Strafrechtelijke verantwoordelijkheid bestaat - voor zowel de raadsman als zijn cliënt - wel wanneer door het aanvoeren van vals bewijsmateriaal de verdenking op een andere persoon wordt gevestigd. ${ }^{195}$ In zijn algemeenheid geldt dat een advocaat geen rechtsbijstand mag verlenen die zou kunnen bijdragen tot het plegen van een strafbaar feit of die ertoe zou kunnen leiden dat iemand zicht onttrekt aan zijn strafrechtelijke verantwoordelijkheid voor een nog te plegen strafbaar feit. ${ }^{196}$ Het voert te ver alle strafbare feiten op te sommen waaraan de raadsman zich tijdens zijn beroepsuitoefening schuldig zou kunnen maken. Een belangrijke categorie in dit verband vormen de feiten opgesomd in titel 15 van het wetboek van strafrecht (przestepstwa przeciwko wymiarowi sprawiedliwości: delicten tegen de rechtspleging). In de literatuur wordt aangenomen dat de raadsman in beginsel net als ieder ander strafrechtelijk verantwoordelijk is wanneer hij zich schuldig maakt aan een van de daar genoemde feiten. Zo is het bijvoorbeeld strafbaar een getuige aan te zetten tot het afleggen van een valse verklaring, bewijs weg te maken of een verdachte te helpen vluchten. Er zijn echter ook uitzonderingen: de raadsman kan bijvoorbeeld niet worden gestraft voor het niet melden van een strafbaar feit wanneer het door zijn cliënt is gepleegd. Ook is het niet strafbaar bewijsmateriaal te verzwijgen dat ontlastend is voor een medeverdachte voor zover het aan het licht brengen ervan in het nadeel van de cliënt zou zijn. ${ }^{197}$ Ten slotte is van belang dat een handeling van de raadsman die op grond

192 Zie hierover uitgebreider hoofdstuk 6, § 5.2.3.

193 Art. 11 gedragsregels. Algemeen over de verhouding tussen het recht op verdediging en het beginsel van materiële waarheidsvinding (zasada prawdy materialnej): Wiliński en Górecki 2006, p. 51.

194 Art. 15 gedragsregels.

195 Een en ander is strafbaar gesteld in art. 235 KK 1997. Zie Hofmański en Zabłocki 2008, p. 681.

196 Art. 15 gedragsregels.

197 Huidig art. 236 en 240 KK 1997. Zie Kruszyński 1991, p. 69-70 en Masłowska 2006, p. 198. 
van het strafprocesrecht is toegestaan nooit een overtreding van het materiële strafrecht kan opleveren. ${ }^{198}$

De raadsman mag zijn cliënt niet adviseren te liegen. ${ }^{199}$ In de literatuur wordt echter aangenomen dat dit niet betekent dat de raadsman ook moet ingrijpen wanneer hij weet of ernstige reden heeft te vermoeden dat zijn cliënt niet de waarheid spreekt. ${ }^{200}$ Een andere vraag is of hij de verdachte mag adviseren gebruik te maken van zijn zwijgrecht. De gedragsregels zwijgen op dit punt. In de Poolse doctrine wordt het geven van een dergelijk advies door de meeste auteurs aanvaard. In oudere literatuur kunnen op dit punt echter wel uitzonderingen worden gevonden: zo heeft Łyczywek in het verleden het standpunt verdedigd dat de raadsman wel over het zwijgrecht mag informeren maar zijn cliënt niet mag adviseren er gebruik van te maken. ${ }^{201}$

Eerder is opgemerkt dat de raadsman niet verplicht is actief mee te werken aan de waarheidsvinding. Een andere - net zo belangrijke - vraag is of hij daartoe wel bevoegd is. Met andere woorden: in hoeverre mag de raadsman zelf op zoek gaan naar ontlastend bewijsmateriaal? Zoals eerder besproken, is deze kwestie in Polen niet geregeld. Hoewel hieruit moet worden afgeleid dat het dus niet verboden is, blijkt uit onderzoek dat advocaten er wel vanuit gaan dat eigen onderzoeksactiviteiten door de verdediging niet zijn toegestaan. Het gebeurt in de praktijk dan ook zelden dat een Poolse advocaat actief op zoek gaat naar ontlastend bewijsmateriaal. ${ }^{202}$ In de gedragsregels wordt ook geen antwoord gegeven op de vraag of het de raadsman vrijstaat buiten de zitting om contact op te nemen met getuigen. Ook hier geldt dat uit het feit dat een dergelijke handelwijze nergens expliciet is verboden, lijkt te moeten worden afgeleid dat het in beginsel is toegestaan. De doctrine is echter verdeeld op dit punt. Kruszyński acht het toelaatbaar zolang de getuige nog niet is opgeroepen voor de zitting en niet door de raadsman onder druk wordt gezet of gechanteerd. ${ }^{203}$ Sommige andere Poolse auteurs zijn van mening dat het niet is

198 Kruszyński 1991, p. 90.

199 Kruszyński 1991, p. 80 e.v.: een dergelijk advies is zeker een schending van de beroepsethiek maar is het ook strafrechtelijk relevant? Kruszyński vindt van niet: de verdachte die liegt is immers niet strafbaar waardoor het voor hem min of meer een toelaatbare manier van verdedigen is. Dat de raadsman hem adviseert van deze mogelijkheid gebruik te maken, kan dus niet als een strafbaar feit worden beschouwd. In gelijke zin (het advies in strijd met de waarheid te verklaren is wel laakbaar in tuchtrechtelijk opzicht maar niet in strafrechtelijke zin): Masłowska 2006, p. 200.

200 Kruszyński 1991, p. 117-118 en daar genoemde literatuur. Kruszyński benadrukt dat de raadsman weliswaar zelf geen leugenachtige verklaring voor zijn cliënt mag verzinnen, noch hem mag adviseren te liegen maar wanneer hij (laatstgenoemde) dat uit zichzelf doet, dient de raadsman zich daarbij neer te leggen. Zie ook Kruszyński 1985, p. 103-104 waar hij benadrukt dat liegen weliswaar moreel verwerpelijker is dan zwijgen maar dat de verdachte nu eenmaal niet kan worden verplicht de waarheid te vertellen en dat door hem afgelegde leugens dus geaccepteerd dienen te worden.

201 Łyczywek 1989, p. 41-42. Kruszyński verwerpt dit door te benadrukken dat het zwijgrecht een belangrijk recht van de verdachte is dat onderdeel kan uitmaken van de verdedigingsstrategie. Er is dus niets immoreels aan het niet verklaren of het niet bekennen van schuld: Kruszyński 1991, p. 19, zie in gelijke zin: Masłowska 2006, p. 199-200.

202 Zie uitgebreider: hoofdstuk 5, § 5.2.5.

203 Hij beschouwt het zelfs als een belangrijk onderdeel van de voorbereiding van de verdediging: Kruszyński 1991, p. 70 e.v. Zie in gelijke zin: Masłowska 2006, p. 201. Dat geen 
toegestaan. ${ }^{204}$ Volgens Gajewska-Krackowska gebeurt het in de praktijk zelden tot nooit dat een advocaat voor de zitting contact zoekt met een getuige omdat men bang is voor de gevolgen. ${ }^{205}$ Onderzoek van Gwirdoyń laat echter een iets genuanceerder beeld zien: enquêtes onder advocaten tonen aan dat de advocatuur verdeeld is op dit punt. Meer dan de helft van de ondervraagde advocaten gaf aan van mening te zijn dat elke vorm van contact met een getuige ontoelaatbaar is $(22,5 \%$ : 'absoluut ontoelaatbaar', 27,5\% 'ontoelaatbaar' en 10\% 'min of meer ontoelaatbaar' ('raczej niedopuszczalne')). Van de overige $40 \%$ vindt het merendeel (30\%) het ethisch verantwoord buiten de zitting om contact met een getuige te hebben. ${ }^{206}$

\subsubsection{Vrij verkeer}

Zoals besproken in hoofdstuk 7 heeft de raadsman het recht een gedetineerde cliënt te bezoeken en om telefonisch of schriftelijk met hem te communiceren. Dit overleg dient - behoudens enkele belangrijke wettelijke uitzonderingen die gedurende de eerste veertien dagen van de voorlopige hechtenis kunnen worden toegepast zonder toezicht of tussenkomst van de autoriteiten plaats te kunnen vinden. In de relevante strafvorderlijke bepalingen ${ }^{207}$ is niet nader omschreven hoe de raadsman met deze privileges dient om te gaan. Beperkingen op het vrij verkeer zijn door de wetgever ook niet gekoppeld aan het vermoeden dat misbruik wordt gemaakt van de contactmogelijkheden. ${ }^{208}$ De enige - tamelijk voor de hand liggende - norm op dit punt is te vinden in de gedragsregels waarin is bepaald dat de advocaat bij bezoek aan een gedetineerde cliënt 'de waardigheid van het beroep' dient te bewaren. ${ }^{209}$

druk mag worden uitgeoefend op de getuige betekent overigens niet dat de raadsman familieleden van de verdachte niet op hun verschoningsrecht mag wijzen en hen niet mag adviseren daarvan gebruik te maken. Een dergelijke handelwijze dient niet te worden beschouwd als ontoelaatbare druk maar als juridisch advies: Kruszyński 1991, p. 73, Gajewska-Kraczkowska 1992, p. 1143 en daar genoemde literatuur en Masłowska 2006, p. 202. Zie over dit thema ook Gwirdoyń 2004, p. 116-117 en hoofdstuk 5, § 5.2.5.

204 Bijvoorbeeld Łyczywek 1989, p. 93.

205 De rechtbank kan het feit dat er contact is geweest met de raadsman gebruiken om de geloofwaardigheid van de getuige te betwisten. Bovendien is het volgens GajewskaKraczkowska niet nodig contact te leggen met getuigen omdat de gewenste informatie ook door inzage van de stukken kan worden verkregen: Gajewska-Kraczkowska 1992, p. 1142. Dat laatste argument is niet sterk: het is immers goed mogelijk dat de raadsman informatie wil verkrijgen die niet in het proces-verbaal van verhoor is opgenomen of dat hij gedurende het vooronderzoek niet over de gewenste informatie kan beschikken omdat inzage in de stukken wordt geweigerd.

206 De overige 10\% gaf aan hierover geen mening te hebben. Zie Gwirdoyń 2004, p. 116.

207 Art. 73 en art. 245 KPK 1997.

208 Gedurende de fase van politiedetentie is toezicht altijd mogelijk en gedurende de eerste veertien dagen van de voorlopige hechtenis 'in uitzonderlijke gevallen'. Zie uitgebreider hoofdstuk 7, § 2.2.2 en 2.3.2.

209 Art. 29 gedragsregels. In het handboek gedragsrecht van Krzemiński wordt bij deze regel slechts (een deel van) één tuchtrechtelijke uitspraak genoemd: 'De advocaat aan wie als raadsman (...) de vrijheid toekomt in persoon met een gedetineerde verdachte te spreken, dient bijzonder consciëntieus de voorschriften van de penitentiaire inrichting na te leven. Het niet naleven van een van die regels, betekent voor de advocaat als publiek vertrouwenspersoon (jako osoba zaufania publicznego) een zware tuchtrechtelijke overtreding.' Uitspraak van Hoogste tuchtrechtelijke instantie 1958: Krzemiński 2003, p. 123-124. 


\subsubsection{Immuniteit en vrijheid van meningsuiting}

De advocaat geniet bij het uitoefenen van zijn functie vrijheid van meningsuiting in woord en geschrift binnen de door het recht en de balie vastgestelde grenzen. Misbruik van deze vrijheid kan ten aanzien van bepaalde procesdeelnemers (te weten 'procespartijen, hun advocaat of raadsman, voogden, getuigen, deskundigen of tolken') slechts tuchtrechtelijk worden gestraft. ${ }^{210}$ De advocaat geniet in die gevallen dus strafrechtelijke immuniteit wat hem een bepaalde mate van vrijheid van verdediging geeft. ${ }^{211}$ De immuniteit geldt niet voor belediging van de rechter of de prokurator. ${ }^{212}$

De gedragsregels benadrukken dat de advocaat zorgvuldig met zijn vrijheden op dit punt moet omgaan. ${ }^{213}$ Zo is geregeld dat hij bij het uitoefenen van de vrijheid van meningsuiting terughoudend en behoedzaam moet zijn in zijn uitlatingen. ${ }^{214}$ Wanneer het noodzakelijk is 'drastische feiten aan te dragen of uitlatingen te doen' dient de advocaat dat op zodanige wijze te doen dat de waardigheid van de rechtbank en van de beroepsgroep niet in het gedrang komen. ${ }^{215}$ Hij dient, zelfs wanneer andere procespartijen zich onbehoorlijk gedragen, tactvol en kalm te blijven en de eer van andere procesdeelnemers niet aan te tasten. ${ }^{216}$

Ter illustratie een aantal - deels uit de civiele rechtspraktijk afkomstige - voorbeelden uit de tuchtrechtspraak over dit thema:

- 'Ontactische of ongepaste opmerkingen van de voorzitter van de rechtbank kunnen niet als rechtvaardiging dienen voor gelijksoortige opmerkingen van de advocaat' (uitspraak Hooggerechtshof 1967),

- 'Het gebruik van de woorden 'gelogen en leugen' gericht tot een burgerlijke partij is tuchtrechtelijk verwijtbaar' (uitspraak Hoogste tuchtrechtelijke instantie 1970),

- 'Het staat een advocaat niet vrij, zelfs niet in reactie op het optreden van een vertegenwoordiger van de tegenpartij, stekelige toespelingen, hatelijke opmerkingen en dergelijke te maken' (uitspraak Hoogste tuchtrechtelijke instantie 1974),

- 'De opmerking dat de rechter de bepalingen van het burgerlijk procesrecht niet kent, is ontoelaatbaar. Het ondergraaft de autoriteit van de rechter en de advocaat en is in strijd met de beroepsethiek' (uitspraak lagere tuchtrecht 1986). ${ }^{217}$

210 Art. 8 Advocatenwet.

211 Zie daarover ook hoofdstuk 6, § 4.6.1. Zie over de vrijheid van meningsuiting van de advocaat in het kader van art. 10 EVRM onder meer: Schöpfer $t$. Zwitserland, EHRM 20-51998, nr. 25405/94, Nikula t. Finland, EHRM 21-3-02, nr. 31611/96 en Steur t. Nederland, EHRM 28-10-2003, nr. 39657/98.

212 De opsomming in art. 8 Advocatenwet is limitatief en kan dus niet met andere procesdeelnemers worden uitgebreid: Krzemiński 1998, p. 38.

213 Dat er grenzen zijn aan wat de advocaat in strafzaken wel en niet mag zeggen, werd reeds voor de eerste geschreven gedragsregels - in 1938 verwoord door F. Payen: 'De raadsman mag alles uitspreken wat in het belang van de verdediging is maar dat betekent niet dat hij de fatsoensnormen mag overschrijden', citaat opgenomen in Krzemiński 2003, p. 74. De immuniteit van de advocaat is een veelbesproken thema in de (vooral oudere) Poolse literatuur.

214 Art. 17 gedragsregels.

215 Art. 16 gedragsregels.

216 Art. 27 lid 2 en art. 28 gedragsregels.

217 Zie voor deze en andere voorbeelden uit de tuchtrechtspraak: Krzemiński 1998, p. 37-46 en Krzemiński 2003, p. 77-86 en p. 121-123. 
De immuniteit van de advocaat is een veelbesproken thema in de (veelal oudere) Poolse literatuur. ${ }^{218}$ Het behoeft geen betoog dat vooral gedurende het communisme veel werd geschreven over de vraag naar de reikwijdte van de vrijheid van meningsuiting van de advocaat. In de beroepsopleiding wordt aandacht besteed aan hoe advocaten de vrijheid van meningsuiting kunnen gebruiken zonder er misbruik van te maken. ${ }^{219}$

\subsubsection{Omgang met autoriteiten}

De advocaat dient zich in zijn contacten met de rechtbank en andere organen 'bescheiden en tactvol op te stellen' ('zachować umiar i takt'). ${ }^{220}$ Wanneer hij niet in staat is naar de zitting te komen, dient hij de rechtbank - of enig ander orgaan waarvoor hij moet verschijnen - daarover te informeren. De advocaat dient zijn afwezigheid te motiveren. ${ }^{221}$ De rechtbank moet ook op de hoogte worden gesteld wanneer de raadsman volgens afspraak en met instemming van zijn cliënt niet verschijnt. ${ }^{222}$ Het is in de praktijk een veel voorkomend verschijnsel dat advocaten niet (tijdig) op de zitting verschijnen. Dit is de rechterlijke macht een doorn in het oog: veel van de klachten die rechters bij de balie indienen over optreden van advocaten betreft hun (onaangekondigde) afwezigheid op de zitting. ${ }^{223}$ Een recente wetswijziging dient verandering aan te brengen in deze situatie. Sinds mei 2007 kan de raadsman die zonder opgave van (een geldige) reden niet op de zitting verschijnt of deze zonder toestemming van de rechter voortijdig verlaat, een geldboete van maximaal 10.000 złotych (circa 2700 euro) worden opgelegd. ${ }^{224}$

\subsubsection{Evaluatie gedragsregels}

Bovenstaande normen overziend, valt in de eerste plaats op dat opvallend vaak wordt gerefereerd aan tamelijk ouderwetse begrippen als 'de waardigheid van het beroep'. De eer van de advocatenstand en het vertrouwen in de beroepsgroep

218 Zie bijvoorbeeld: Kaftal 1962, Cieślak 1963 en Gardocka 1984.

219 Gajewska-Kraczkowska 1992, p. 1144.

220 Art. 27 lid 1 gedragsregels.

221 Art. 30 gedragsregels.

222 Uitspraak Hoogste tuchtrechtelijke instantie 30 maart 1963, genoemd in: Krzemiński 2003, p. 125.

223 Volgens Wróblewski - advocaat en aanklager in tuchtrechtzaken in Lublin - klaagt de rechterlijke macht hierover vaak ten onrechte omdat het veel voorkomt dat bij het bepalen van zittingsdata onvoldoende rekening wordt gehouden met beschikbaarheid van de advocaat: 'Usually the biggest problem is the absence during the court session. And with respect to this absence it is very important to clarify that when the client complains about this absence usually it concerns four or five times that his advocat was not present. When the court informs about the absence it is usually already after the first time the advocat was not present. It is not the case that the advocat does not go without a reason. The most important reason is that at the same time he has another case and - very important - normally the advocat informs the court beforehand about this collision and asks the court to set another date. Often the court denies this request and does not change this date. The collusion of terms happens quite often in Poland. It is not because of the fact - as we read in the newspaper - that advocats have too many cases, no: it is because of the way terms are set out by the court. If they would set them in a correct way there would be no collision of terms. If the court secretaries would set out the term one or two months upfront or set out the term after calling the office of the advocat collisions could be avoided. It would be better for the court and for the advocats', bron: gesprek Wróblewski, oktober 2004 Lublin.

224 Art. 285 lid 1a KPK 1997, ingevoerd eind mei 2007. 
nemen blijkbaar een centrale plaats in binnen de gedragsregels en de Advocatenwet. Hierdoor ontstaat de indruk dat de gedragsregels en de tuchtrechtspraak voornamelijk zijn bedoeld om het belang van de beroepsgroep te beschermen en niet - of in ieder geval in mindere mate - om concrete normen voor een behoorlijke beroepsuitoefening te bieden.

Behalve het gebruik van algemene begrippen ${ }^{225}$ valt op dat de gedragsregels voor het overgrote deel een algemeen karakter hebben en dat niet of nauwelijks specifieke aandacht wordt besteed aan de verdediging in strafzaken. Dit is op zich begrijpelijk omdat de gedragsregels voor alle advocaten (en dus niet alleen voor de raadsman) gelden maar het betekent wel dat de advocaat er voor zijn optreden in strafzaken weinig concrete richtlijnen aan kan ontlenen. Uiteraard wordt in tuchtrechtspraak nadere invulling gegeven aan de gedragsregels en de advocaat dient in zijn beroepsuitoefening rekening te houden met de uitspraken van de tuchtrechter. ${ }^{226}$ Echter, zoals in § 4.4.4 nog aan de orde zal komen, worden disciplinaire beslissingen vandaag de dag niet - of slechts incidenteel - gepubliceerd. Het is dus de vraag hoe advocaten op regelmatige basis kennis kunnen nemen van de wijze waarop gedragsregels door de tuchtrechter zijn ingevuld.

Kenmerkend voor het Poolse gedragsrecht is ook dat de onafhankelijkheid ten opzichte van de cliënt sterker lijkt te worden benadrukt dan de onafhankelijkheid ten opzichte van de rechterlijke macht en de overheid. Dit blijkt onder meer uit het feit dat de rechter zich op verschillende manieren kan bemoeien met de inhoud en kwaliteit van de verdediging: zoals de mogelijkheden om zich te mengen in tegenstrijdige belangen- en andere vertrouwenskwesties die tussen advocaat en cliënt kunnen spelen.227 De nadruk op de onafhankelijkheid ten opzichte van de cliënt blijkt onder meer uit de wijze waarop de centrale gedragsnorm - dat iedere raadsman slechts in het voordeel van verdachte mag handelen - wordt uitgelegd: de wens van verdachte is daarbij niet doorslaggevend en het is dan ook niet bij voorbaat uitgesloten dat een advocaat tegen de wil van zijn cliënt handelt. De advocaat is dus dominus litis, niet de verdachte. ${ }^{228}$

Onlosmakelijk verbonden met laatstgenoemd punt over de onafhankelijkheid ten opzichte van de rechterlijke macht en de cliënt is ook het feit dat een aantal belang-

225 Wat overigens niet alleen kenmerkend is voor de Poolse gedragscode maar een typisch continentaal verschijnsel kan worden genoemd. Zo zijn gedragsregels voor advocaten in bijvoorbeeld de Verenigde Staten veel preciezer geformuleerd: 'While codes in the United States are more legalistic and formal, and their principles are more likely to be expressed as rules rather than standards, civil law codes frame their norms in more general, less precise terms.' Ook de aandacht voor de verhouding tussen advocaten onderling (in de Poolse gedragscode zeer uitvoerig geregeld) en de verantwoordelijkheden van de balie voor de opleiding van advocaat-stagiares is typerend voor Europese, continentale gedragscodes: in common law landen is de aandacht vooral gevestigd op de advocaat als individu en zijn verhouding tot de cliënt: '(...) unlike ethics codes in the United States, civil law codes include provisions emphasizing the collegiality of the Bar, the duties that lawyers owe to one another, and the responsibilities of lawyers for the training and education of lawyers-asprirants': Goldstein Bolocan 2002, p. 9.

226 In art. 2 van de gedragsregels is vastgelegd dat de advocaat zich in gevallen die niet door de gedragsregels worden gedekt, onder meer moet laten leiden door de regels die zijn vastgelegd in de tuchtrechtspraak.

227 Respectievelijk art. 85 lid 2 en 3 en 378 KPK 1997. Zie over de regeling van art. 378 KPK ook hoofdstuk $6, \S 5.2 .3$.

228 Zie ook hoofdstuk 3, § 3.3.1.1. 
rijke gedragsnormen (mede) in het wetboek van strafvordering is opgenomen. Dit heeft tot gevolg dat handhaving ervan niet (alleen) in handen van de tuchtrechter is maar ook tot de bevoegdheden van de strafrechter behoort. De onlangs geïntroduceerde strafvorderlijke mogelijkheid een geldboete op te leggen aan advocaten die hun professionele verplichtingen niet nakomen, is een duidelijk voorbeeld van rechterlijk toezicht op het functioneren van de verdediging.

\subsubsection{Bijzondere regels kosteloze rechtsbijstand?}

Een andere belangrijke vraag is of de huidige gedragsregels in voldoende mate garanderen dat de in Polen verleende rechtsbijstand aan een bepaalde kwaliteitsstandaard voldoet. Volgens de HFHR is dit zeker niet het geval en deze organisatie pleit dan ook voor de formulering van meer specifieke gedragsregels voor het verlenen van kosteloze rechtsbijstand:

'It seems that it would be sensible to develop more detailed standards of ex officio legal aid: the list of duties of a lawyer hired by the State for an indigent person. The existing principles of professional ethics are too general and refer to reliability, conscientiousness, but not, for example, directly to the duty to contact the client before the trial, or the duty to keep case files for each client.(...) The Polish state "hires" an ex officio lawyer, pays him or her renumeration and does not control the quality of service in any way. ${ }^{229}$

Het standpunt van de HFHR is begrijpelijk gelet op de (sterke) aanwijzingen dat de kwaliteit van rechtsbijstand in toevoegingszaken vaak lager is vergeleken met het optreden voor betalende cliënten. ${ }^{230}$ Mijns inziens schuilt in het formuleren van dergelijke bijzondere gedragsregels echter wel het gevaar dat de indruk wordt gewekt dat voor optreden op basis van toevoeging een andere maatstaf geldt dan voor optreden op gekozen basis. Dat terwijl de boodschap nu juist zou moeten zijn dat voor beide categorieën dezelfde standaard dient te gelden en de advocaat in zijn praktijkuitoefening op dit punt geen onderscheid zou moeten maken. Een verhoging van de kwaliteit van rechtsbijstand in toevoegingszaken zou naar mijn mening dan ook niet zozeer moeten worden gezocht in de formulering van bijzondere gedragsregels als wel in (meer) efficiënt tuchtrechtelijk toezicht en sanctionering van advocaten die zich onvoldoende inzetten voor de zaken die hen worden toegevoegd. Op de efficiëntie van de tuchtrechtspraak wordt teruggekomen in § 4.4.5.

\subsubsection{Nadere normering optreden in strafzaken?}

Het is mijns inziens wel wenselijk meer concrete regels te formuleren voor het verlenen van bijstand in strafzaken. Het Poolse strafrechtssysteem heeft de laatste vijftien jaar ingrijpende veranderingen doorgemaakt en ondergaat deze vandaag de dag nog steeds. Al deze wijzigingen hebben ongetwijfeld gevolgen voor de rol van de raadsman maar daar is tot op heden (te) weinig expliciete aandacht aan besteed. ${ }^{231}$ Zoals in de voorgaande hoofdstukken duidelijk is geworden, zijn de rechten en bevoegdheden van de verdediging in met name het vooronderzoek op een aantal punten uitgebreid. Deze nieuwe mogelijkheden - zoals het verlenen van

229 Monitoring Report 2003, p. 129.

230 Zie hierover hoofdstuk 4, § 3.4.3.

231 Zie over de ontwikkeling van het denken over de rol van de advocaat in strafzaken: hoofdstuk 3. 
bijstand na aanhouding en het bijwonen van politieverhoren ${ }^{232}$ - leiden onherroepelijk tot nieuwe dilemma's en vragen. De gedragsregels zijn tot op heden niet of nauwelijks 'meegegroeid' met deze nieuwe strafvorderlijke bevoegdheden van de advocaat en de praktijkvragen die daarmee gepaard kunnen gaan. Dat terwijl vrijwel alle (en dus ook de niet in het strafrecht gespecialiseerde) advocaten door toevoeging met enige regelmaat in aanraking komen met het strafrecht. Daar komt bij dat de verdediging in strafzaken de laatste jaren in toenemende mate verantwoordelijk wordt gehouden voor een efficiënt verloop van het strafproces. Het verschijnsel 'misbruik van procesrecht' is sterk in ontwikkeling waarbij de verdediging steeds vaker wordt verweten de voortgang van de procedure te frustreren door strategisch gebruik van procedurele bevoegdheden. ${ }^{233}$ De balie kan - door zelf duidelijke gedragsnormen op te stellen voor de raadsman - proberen te voorkomen dat grenzen aan het optreden van de advocaat in strafzaken eenzijdig door de wetgever worden bepaald. ${ }^{234} \mathrm{Om}$ een voorbeeld te noemen: specifieke gedragsnormen op het terrein van eigen onderzoek door de verdediging zouden de Poolse raadsman meer duidelijkheid kunnen bieden over wat in dit verband wel en niet is toegestaan (wanneer en onder welke voorwaarden mag contact worden gelegd met getuigen en deskundigen, mag de raadsman een derde inschakelen om bepaalde onderzoekshandelingen te verrichten et cetera) ${ }^{235}$ en op die manier kunnen bijdragen aan een meer actieve opstelling van de verdediging op dit punt. ${ }^{236}$

Het is mijns inziens (mede) de verantwoordelijkheid van de beroepsgroep om te voorkomen dat de positie van de raadsman onder druk van de steeds sterker wordende behoefte aan meer repressieve en efficiënte strafrechtspleging zover wordt gemarginaliseerd dat de minimumvoorwaarden voor een effectieve verdediging worden aangetast. Duidelijke formulering van deze minimumvoorwaarden is daarvoor onontbeerlijk. De advocatuur heeft een eigen verantwoordelijkheid op dit punt maar die is tot op heden onvoldoende genomen. Voor zover bekend zijn tot nu toe vanuit de balie geen concrete initiatieven ontplooid om meer specifieke gedragsregels voor de advocaat in strafzaken op te stellen of om anderszins een actieve bijdrage te leveren aan de discussie over de veranderende rol en taakop-

232 Zie uitgebreid over de strafvorderlijke bevoegdheden van de raadsman in het voor- en het eindonderzoek: hoofdstuk $4, \S 2$, hoofdstuk 5, en hoofdstuk 6 .

233 Zie hierover uitgebreid hoofdstuk 6, § 5.

234 In Nederland is dit een aantal jaren geleden gebeurd: de Nederlandse Vereniging van Strafrecht Advocaten heeft in 2003 de normen en minimumvoorwaarden voor een effectieve verdediging neergelegd in een aparte regeling: het zogenaamde 'Statuut voor de Verdediging'. Dit statuut bevat niet alleen een omschrijving van de taken en verplichtingen van de raadsman (zoals normen ten aanzien van vrije advocatenkeuze, het belang van de cliënt versus andere belangen en de vertrouwensrelatie tussen raadsman en verdachte) maar voorziet ook in een aantal taakstellende normen over de bevoegdheden en garanties die de overheid de advocaat moet bieden om zijn taak naar behoren uit te kunnen oefenen (zoals regels omtrent het vrij verkeer, het verschoningsrecht, de informatiepositie en de uitingsvrijheid van de verdediging).

235 Zie bijvoorbeeld regel 28 tot en met 31 van eerder genoemd Statuut voor de Verdediging waarin dergelijke, specifieke regels over eigen onderzoek door de verdediging zijn opgenomen.

236 Zie over de huidige (uiterst passieve) praktijk ten aanzien van eigen verdedigingsonderzoek onder meer hoofdstuk $5, \S 5.2 .5$ en hoofdstuk 6 , § 4.4.5. 
vatting van de raadsman. Mogelijk speelt hierbij een rol dat Polen geen specialistenvereniging voor strafrechtadvocaten kent die in de discussie over de positie van de raadsman het initiatief zou kunnen nemen. Meer inhoudelijk zou mee kunnen wegen dat men vreest dat meer specifieke gedragsregels de vrijheid van de individuele advocaat teveel aan banden zouden leggen. ${ }^{237}$ Duidelijke aanwijzingen voor een dergelijk standpunt zijn er echter niet.

\subsection{Organisatie van de tuchtrechtspraak}

De organisatie van de tuchtrechtspraak is geregeld in de Advocatenwet. In het onderstaande zal de huidige structuur en het verloop van de tuchtrechtelijke procedure in hoofdlijnen worden besproken. Daarna zal aandacht worden besteed aan de kritiek die de laatste jaren op het tuchtrechtelijk toezicht wordt uitgeoefend en aan de (voorgestelde) wijzigingen die daar recent het gevolg van zijn geweest.

\subsubsection{Huidige structuur}

De tuchtrechtspraak is zowel in eerste als in tweede aanleg in handen van de balie. In eerste aanleg wordt rechtgesproken door de tuchtrechtelijke instantie van het arrondissement waar de advocaat staat ingeschreven: zoals opgemerkt in § 2.1 beschikt iedere advocatenkamer over een eigen tuchtrechtelijk orgaan (sad dyscyplinarny izby adwokackiej). Tegen de beslissing van laatstgenoemde instantie kan beroep worden ingesteld bij de Hoogste tuchtrechtelijke instantie (Wyższy Sąd Dyscyplinarny) te Warschau. Beide instanties bestaan alleen uit advocaten. Onder bepaalde omstandigheden kan tegen een uitspraak in tweede aanleg van de Hoogste tuchtrechtelijke instantie door partijen, de minister van Justitie, de Nationale Ombudsman en de voorzitter van de Hoogste Raad van de balie een rechtsmiddel worden ingesteld bij het Hooggerechtshof. Deze mogelijkheid - die in 2000 in het leven is geroepen - staat alleen open wanneer sprake is van een ernstige schending van het recht of wanneer de opgelegde sanctie overduidelijk niet in verhouding staat tot de geconstateerde schending van de gedragsregels. Het beroep wordt beoordeeld door drie rechters van het Hooggerechtshof: hiermee is een beperkte rechterlijke controle mogelijk op de voor het overige volledig door de advocatuur gedomineerde tuchtrechtspraak. ${ }^{238}$ Over de betekenis van deze mogelijkheid bestaat discussie maar vaststaat dat er wel gebruik van wordt gemaakt. ${ }^{239}$

Van belang is dat klachten over het optreden van advocaten niet alleen afkomstig kunnen zijn van een cliënt die zich benadeeld voelt maar in strafzaken ook door de rechter of de prokurator kunnen worden ingediend. Laatstgenoemde mogelijkheid is vastgelegd in art. 20 van het wetboek van strafvordering waarin is geregeld dat de rechtbank en gedurende het vooronderzoek de prokurator de regionale balie kunnen inlichten over 'overduidelijke schendingen van procesverplichtingen' door

237 Dit argument werd immers bij de totstandkoming van de gedragsregels van 1961 ook veelvuldig gehoord en het moge inmiddels duidelijk zijn dat de onafhankelijkheid van de advocaat binnen de Poolse advocatuur als een zeer groot goed wordt beschouwd.

238 Over het buitengewoon beroep: art. 91a tot en met 91e Advocatenwet.

239 Ter illustratie: in de periode 1 januari 2004 tot 1 november 2004 heeft het Hooggerechtshof in 24 tuchtrechtzaken tegen advocaten recht gesproken. In de meeste gevallen werd de advocaat onzorgvuldigheid verweten, zoals het laten verlopen van een appeltermijn of onredelijkheid bij de facturering (Hofmański en Zabłocki 2008, p. 692). 
advocaten. ${ }^{240}$ Hoewel binnen de rechterlijke macht blijkbaar wordt getwijfeld over de vraag of het indienen van een dergelijke klacht wel zinvol is - zie hierna $\S 4.4 .5$ - wordt in de praktijk wel gebruik gemaakt van de mogelijkheid de balie in te lichten over het optreden van een bepaalde advocaat.

Dat de balie door de prokuratura op 'fouten' van advocaten wordt gewezen, komt daarentegen veel minder vaak voor. Dit verschil kan mogelijk worden verklaard door een verschil in positie tussen de prokurator en de rechter (denkbaar is dat de leden van de prokuratura zich niet aangewezen voelen om over het optreden van de advocatuur te waken) maar heeft waarschijnlijk vooral te maken met het eerder besproken feit dat advocaten in de praktijk weinig actief zijn in dit deel van de strafrechtelijke procedure. ${ }^{241}$

De balie kan ook zelf het initiatief nemen tot een tuchtrechtelijke procedure, bijvoorbeeld naar aanleiding van berichten in de media over het optreden van een bepaalde advocaat. Ten slotte kan een tuchtrechtzaak op aangeven van de minister van Justitie worden geopend: hij heeft op grond van de Advocatenwet de bevoegdheid te bevelen dat tegen een bepaalde advocaat een tuchtrechtelijke procedure wordt gestart. ${ }^{242}$ Beide initiatieven - zowel van de balie zelf als van de minister van Justitie komen in de praktijk echter zelden tot nooit voor. ${ }^{243}$

\subsubsection{Verloop van de procedure}

Zaken worden bij de tuchtrechter aangebracht door een speciaal daarvoor aangewezen aanklager (rzecznik dyscyplinarny ${ }^{244}$ ). Burgers die ontevreden zijn over het optreden van hun advocaat hebben dus geen rechtstreekse toegang tot de tuchtrechter: alleen de aanklager is bevoegd een zaak aan te brengen en zijn tussenkomst is dus te allen tijde verplicht.

Een tuchtrechtelijke procedure bestaat uit verschillende stadia. Uitgaande van de (meest voorkomende) situatie dat de balie een klacht ontvangt, is de gang van zaken in hoofdlijnen als volgt. De deken stuurt de door de regionale balie ontvangen klachten door naar een secretaris (sekretarz) die voor de aanklager een eerste selectie maakt. Dit gebeurt door de betreffende advocaat kort (vaak telefonisch) te horen

240 Daarbij kan gedacht worden aan situaties waarin een advocaat zonder van zich te laten horen niet verschijnt bij de laatste inzage van de stukken voor sluiting van het vooronderzoek, niet komt opdagen bij het verhoor van zijn cliënt (die overeenkomstig art. 301 KPK 1997 heeft verzocht in het bijzijn van zijn raadsman te worden verhoord) of zich niet heeft voorbereid op de ondervraging van door de verdediging opgeroepen getuigen: Grzegorczyk 2004, p. 119. Zie over de klachtmogelijkheid van art. 20 KPK 1997 ook hoofdstuk 4, § 3.4.3.3.

241 Zie over de activiteiten van advocaten in het vooronderzoek: hoofdstuk 4 en 5.

242 Art. 90 lid 2 Advocatenwet.

243 De HFHR bepleit dat de minister van Justitie meer gebruik zou moeten maken van zijn bevoegdheden op dit punt: 'The Department of the Bar and the Legal Advisers of the Ministry of Justice should undertake actions aimed at making disciplinary responsibility real. The Minister of Justice has certain supervisory powers towards the legal professional corporations which he does not use in practice. Thus, the failure of the Ministry of Justice to undertake actions is not a result of the lack of statutory powers or lack of issues to be dealt with, but rather a lack of the will to act': Monitoring Report 2003, p. 128.

244 Letterlijk: 'disciplinair woordvoerder'. Deze functie - die ook alleen door advocaten kan worden vervuld - bestaat op het niveau van de regionale balies en er is een aanklager aangesloten bij de Hoogste Raad voor de procedures bij de Hoogste tuchtrechtelijke instantie. 
over de klacht. De advocaat heeft in dit verband een spreekplicht. Wanneer uit de reactie kan worden opgemaakt dat de klacht onredelijk of ongefundeerd is, ${ }^{245}$ is de zaak daarmee doorgaans afgedaan: klager ontvangt dan een brief van de balie waarin wordt uitgelegd dat ze geen noodzaak tot verder onderzoek ziet. De klachten die (mogelijk) wel gefundeerd zijn, worden doorgestuurd naar de aanklager die vervolgens verschillende beslissingen kan nemen. Wanneer hij daarvoor voldoende grond aanwezig acht, kan hij direct een tuchtrechtelijk procedure starten. Deze procedure bestaat uit drie stadia: een onderzoek (dat net als in strafzaken wordt aangeduid als dochodzenie), vervolgens de behandeling ter zitting door de tuchtrechter (postępowanie przed sądem dyscyplinarnym) en ten slotte de tenuitvoerlegging (postępowanie wykonawcze). ${ }^{246}$ Het onderzoek heeft tot doel de precieze omstandigheden vast te stellen waaronder het vermeende handelen of nalaten van de advocaat heeft plaatsgevonden en te bepalen of een en ander voldoende ernstig is om aan de tuchtrechter voor te leggen. Wanneer nog veel onduidelijkheid bestaat, kan de aanklager eerst nog zogenaamde 'handelingen ter opheldering' ('czynności wyjaśniajace') uitvoeren naar aanleiding waarvan vervolgens kan worden besloten of het instellen van een officieel onderzoek wel noodzakelijk is.

\subsubsection{Sancties}

De tuchtrechter heeft verschillende sancties tot zijn beschikking. De constatering dat het gedrag van een advocaat inderdaad niet door de beugel kan, kan leiden tot het uitspreken van een waarschuwing (upomnienie) of berisping (nagana), het opleggen van een geldboete, een schorsing (voor de duur van minimaal drie maanden tot maximaal 5 jaar) en - de meest vergaande straf - royement. ${ }^{247}$ Voor het uitspreken van een vermaning hoeft overigens niet altijd een tuchtrechtelijke procedure te worden gevolgd: in minder ernstige gevallen kan de deken van de lokale balie zelfstandig of op aangeven van de aanklager een dergelijke waarschuwing geven. ${ }^{248}$

\subsubsection{Openbaarheid tuchtrechtspraak}

Tot voor kort waren zittingen van de tuchtrechter niet voor het publiek toegankelijk: ze mochten alleen worden bijgewoond door partijen, leden van de balie en vertegenwoordigers van het ministerie van Justitie. Zelfs wanneer in tuchtrechtzaken beroep bij het Hooggerechtshof werd ingesteld, was de behandeling van de zaak niet openbaar. ${ }^{249}$ Het geheime karakter van de disciplinaire procedures heeft in het

245 Het gesprek met de betreffende advocaat 'helps to seperate the totally unjustified or even absurd complaints from the founded ones'. Bron: gesprek Wróblewski (advocaat en aanklager in tuchtrechtzaken), oktober 2004 Lublin.

246 Art. 95c Advocatenwet.

247 Zie art. 81 Advocatenwet.

248 Tegen deze beslissing van de deken kan beroep worden ingesteld bij de tuchtrechter (art. 85 Advocatenwet).

249 Dit ondervond ook Bojarski (medewerker HFHR, zelf geen advocaat) toen hij enige jaren geleden met wat media aanwezig wilde zijn bij de behandeling van het eerste door partijen ingestelde cassatieberoep in een tuchtrechtzaak tegen een advocaat. De leden van het Hooggerechtshof weigerden hem de toegang tot de zitting onder verwijzing naar de (toenmalige) regel in de Advocatenwet die luidde dat zittingen in tuchtrechtzaken niet openbaar zijn. Bron: gesprek Bojarski, Warschau juni 2003. Het is overigens de vraag of de redenering van het Hooggerechtshof klopt: de betreffende bepaling van de Advocatenwet had 
verleden tot veel kritiek geleid ${ }^{250}$ en uiteindelijk is de Advocatenwet op dit punt aangepast: sinds juni 2007 geldt dat tuchtrechtelijke procedures in beginsel openbaar zijn en dat sluiting van de deuren slechts in beperkte gevallen mogelijk is. ${ }^{251}$

Tuchtrechtelijke uitspraken worden vandaag de dag niet of nauwelijks gepubliceerd. Dit gebeurde in de eerste decennia van de communistische periode (jaren veertig en vijftig) nog wel regelmatig maar het kwam geleidelijk aan steeds minder voor dat tuchtrechtspraak openbaar werd gemaakt. Volgens de balie is dit geen principiële maar een praktische keuze (gebrek aan financiële middelen en ruimte voor publicatie). Opvallend is dat in Palestra wel incidenteel oude tuchtrechtelijke uitspraken worden gepubliceerd (onder het kopje Palestra 'przed lata': de balie 'jaren geleden'). Zoals in $\S 4.3$ reeds werd opgemerkt, wordt ook in recente uitgaven van handboeken gedragsrecht vooral oude tuchtrechtspraak verwerkt: uitspraken van na de jaren zeventig zijn zeldzaam. ${ }^{252} \mathrm{Er}$ is - hoogstwaarschijnlijk mede als gevolg van het feit dat uitspraken van de tuchtrechter niet gepubliceerd worden - veel minder discussie over tuchtrechtelijke kwesties in de huidige Poolse literatuur dan in de jaren vijftig, zestig en zeventig. Overigens heeft de tuchtrechter sinds kort wel de mogelijkheid te bepalen dat zijn beslissing in een bepaalde zaak wordt gepubliceerd in Palestra, het tijdschrift van de balie. ${ }^{253}$

immers slechts betrekking op de behandeling door de tuchtrechter (rozprawa przed sadem dyscyplinarnym) en het is dus niet vanzelfsprekend dat deze regel ook van toepassing was op zittingen bij reguliere rechterlijke instanties zoals het Hooggerechtshof.

250 Dit geldt overigens niet alleen voor de advocatuur maar ook voor andere beroepsgroepen. Zie Szumiło-Kulczycka en Waltoś 2003, p. 1053 en daar genoemde literatuur. Geheime tuchtrechtspraak bij juridische beroepen is een typisch Europees, continentaal verschijnsel: 'In contrast to the United States where some degree of transparancy is generally guaranteed, disciplinary proceedings against lawyers [in continental Europe, toev. DdV] are generally decided by members of the legal profession, and are confidential in nature, raising questions as to their overall fairness and efectiveness': Goldstein Bolocan 2002, p. 11. Belangrijke vraag is of het niet openbare karakter van tuchtrechtspraak verenigbaar is met het in art. 6 lid 1 EVRM neergelegde recht op een eerlijke en openbare behandeling. Zie meer algemeen over de betekenis van art. 6 EVRM voor de tuchtrechtspraak: Kidd 1987 en Szumiło-Kulczycka en Waltoś 2003, p. 1047 en p. 1060-1061. De rechtspraak van het EHRM laat zien dat wel ruimte is voor uitzonderingen op de regel van openbaarheid maar dat deze telkens tegen de omstandigheden van het concrete geval moeten worden beoordeeld. Factoren die daarbij een rol kunnen spelen zijn (onder meer): het beroepsgeheim, het privé-leven van de beroepsbeoefenaar of de cliënt en de vraag of de advocaat op ondubbelzinnige wijze afstand heeft gedaan van zijn recht op een openbare behandeling. Het gaat hier om uitzonderingen die in individuele gevallen gerechtvaardigd kunnen zijn: bij voorbaat alle behandelingen van tuchtrechtzaken achter gesloten deuren laten plaatsvinden - zoals in Polen tot voor kort gebeurde - lijkt dan ook onverenigbaar te zijn met het EVRM.

251 Het gaat hier om de wetswijziging van 29 maart 2007, in werking getreden in juni van dat jaar. Sluiting van de deuren is mogelijk wanneer dat noodzakelijk is gelet op het beroepsgeheim van de advocaat of wanneer sprake is van een van de reeds bestaande wettelijke gronden die een uitzondering op openbaarheid van rechtspraak rechtvaardigen (zie hoofdstuk 6, § 4.1).

252 Sinds kort zijn excerpten van deze oude rechtspraak ook gepubliceerd op de website van de Hoogste tuchtrechtelijke instantie: <http:// wsd.adwokatura.pl/wsd.php>.

253 Nieuw art. 81 lid 6 Advocatenwet, onderdeel van eerdergenoemde wijziging van de Advocatenwet van maart 2007. Onduidelijk is of deze publicatiemogelijkheid vooral bedoeld is als een soort bijkomende straf of voornamelijk zal worden gebruikt wanneer 


\subsubsection{Effectiviteit tuchtrechtspraak}

De kritiek die de laatste jaren op het functioneren van de balie wordt uitgeoefend, betreft in toenemende mate ook het tuchtrechtelijk toezicht. In het verleden is onder meer vanuit non-gouvernementele organisaties als de HFHR en de Stefan Batory Foundation gepleit voor veranderingen op dit terrein en - zoals hierna nog zal blijken - heeft de problematiek uiteindelijk ook de aandacht van de wetgever gekregen. Belangrijkste punt van kritiek betreft de effectiviteit van het disciplinair toezicht: de advocatuur zou niet adequaat reageren op klachten van burgers en advocaten zouden elkaar teveel het hand boven het hoofd houden. ${ }^{254}$ De HFHR baseert dit voornamelijk op de vele klachten die zij ontvangt van burgers die ontevreden zijn over de kwaliteit van de (vaak op basis van toevoeging) verleende rechtsbijstand en die geen gehoor hebben gekregen bij de balie:

'All responsibility lies with professional bodies, which have been widely criticized as not fulfilling this task properly. The state, though legally capable of doing so, does not use its power in this respect. (...) The Helsinki Foundation for Human Rights often receives complaints after the complaint [about different kinds of attorney conduct, with most clients complaining about ex officio lawyers, toev. DdV] was lodged with the disciplinary board but then was insufficiently explained or even ignored, the applicant believes; in some instances the complaint receives no answer at all. As follows from the experiences of the HFHR the quality of legal services and the oversight of the profession constitute a subject that hardly enjoys any interest at all [decurs. DdV]. No surveys are conducted in this area. The professional corporation may settle disciplinary cases at their absolute discretion, which sometimes leads to overlooking the unprofessional conduct of the lawyers. 255

Volgens de HFHR maken veel rechters geen gebruik van de mogelijkheid bij de balie een klacht in te dienen over het optreden van een advocaat in een concrete strafzaak $^{256}$ omdat ze ervan uitgaan dat dit toch geen effect heeft:

'The judges we interviewed were generally of the opinion that it made no sense for them to lodge complaints with local councils of the Bar, as the councils tend to ignore them. (...) Generally, judges do not discipline lawyers who do not fulfill their obligations. The only recourse for unsatisfied clients includes a motion to the court for a change of lawyer, or a disciplinary complaint to a professional body. (...) The disciplinary procedure is often ineffective. As the procedure is still secret (this is also true for disciplinary hearings) there exist no means of ensuring transparency and accountability to civil society or the media regarding the process. The disciplinary procedure, in fact, is widely criticized for its ineffectiveness.' 257

publicatie van de uitspraak vanuit 'educatief' oogpunt belangrijk is.

254 Volgens Wróblewski (advocaat en aanklager in tuchtrechtelijke zaken in Lublin) wordt in dit verband door critici wel eens met weemoed aan de communistische periode terug gedacht: 'Sometimes people complain about the way there complaint to the bar was dealt with say that this was better during communism because then they could inform the party committee and steps would be taken.' Bron: gesprek Wróblewski, oktober 2004 Lublin.

255 Monitoring Report 2003, p. 123.

256 Vastgelegd in art. 20 KPK 1997.

257 Monitoring Report 2003, p. 123-124. De (vermeende) ineffectiviteit van tuchtrechtspraak wordt zo nu en dan ook aan de orde gesteld door gezaghebbende Poolse auteurs. Zie bijvoorbeeld Hofmański en Zabłocki 2008, p. 693: 'Es besteht eine große Diskrepanz zwischen der - unseres Erachtens - zufriedenstellenden Rechtslage und der praktischen Anwendung der Vorschriften durch die Organe der Rechtsanwaltskammern. Die Disziplinarverfahren 
Het zal niet verbazen dat de balie deze kritiek niet deelt: zij is van mening dat het toezicht wel degelijk effectief is en dat de tuchtrechtelijke organen van de advocatuur veel actiever zijn dan bij andere beroepsgroepen het geval is. De toename van het aantal klachten die de laatste jaren kan worden geconstateerd, is volgens de balie vooral een resultaat van het feit dat burgers - met de opkomst van de democratische rechtsstaat - mondiger zijn geworden en sneller voor hun rechten opkomen dan voorheen. Bovendien moet volgens de balie in ogenschouw worden genomen dat een aanzienlijk deel van de klachten ongefundeerd is..$^{258}$

De gegrondheid van bovengenoemde kritiek op de tuchtrechtspraak is in abstracto moeilijk vast te stellen. Daarvoor zou moeten worden onderzocht hoeveel klachten ten onrechte niet tot een tuchtrechtelijke procedure leiden en een dergelijk onderzoek is tot op heden (voor zover bekend) niet uitgevoerd. Er zijn slechts beperkte gegevens beschikbaar over het functioneren van het tuchtrechtelijk toezicht zodat de buitenwereld überhaupt weinig inzicht krijgt in de wijze waarop klachten door de balie worden afgehandeld. Momenteel wordt niet centraal geregistreerd hoeveel klachten worden ingediend en welk percentage daarvan uiteindelijk tot een officiële aanklacht leidt. De enige bron die op dit punt bestaat, is de vierjaarlijkse uitgave van de balie (Sprawozdania Organów Adwokatury: Rapporten van de organen van de advocatuur) waarin onder meer wordt aangegeven hoeveel zaken door de aanklager zijn behandeld en waarin dat heeft geresulteerd, hoeveel zaken zelfstandig door de deken zijn afgehandeld, hoeveel keren onderzoek is ingesteld en hoeveel zaken in hoger beroep aan de Hoogste tuchtrechtelijke instantie zijn voorgelegd. 259

Het tuchtrechtelijk toezicht is momenteel in alle opzichten vooral een interne aangelegenheid. De burger kan een klacht indienen maar of, en zo ja op welke wijze, daar iets mee gebeurt, is volledig overgelaten aan de beoordelingsvrijheid van de advocatuur. Daar is op zichzelf niet zoveel mis mee maar het gebrek aan transparantie op dit punt wekt blijkbaar wel argwaan bij de buitenwereld.

Net als de in $\S 2.4$ besproken kwestie over toetreding roept ook de discussie over het tuchtrechtelijk toezicht de vraag op hoe absoluut de autonomie van de balie is (of dient te zijn). De advocatuur heeft het verleden in officiële standpunten laten weten tuchtrechtelijk toezicht te beschouwen als een interne aangelegenheid die alleen door advocaten zelf kan worden 'beheerd'. De HFHR bestrijdt dit door

werden oft verschleppt, so dass nicht selten Verjährung eintritt, was die berechtigten Interessen der geschädigten Personen beeinträchtigt.'

258 Sprawozdania Organów Adwokatury 2001-2004, p. 125.

259 Waar het gaat om het aantal veroordelingen wordt in zeer algemene bewoordingen aangegeven op welke gronden dit heeft plaatsgevonden - bijvoorbeeld $x$ keer schending beroepsverplichting, $x$ keer schending beroepsethiek, $x$ keer schending vrijheid van meningsuiting - maar veel duidelijkheid biedt dit niet. Zoals terecht benadrukt door Hofmański is niet duidelijk op grond van welke criteria het onderscheid tussen enerzijds de categorie schending van beroepsverplichtingen en anderzijds schending van beroepsethiek wordt gemaakt. Bovendien wordt in de weergave van de gegevens geen onderscheid gemaakt tussen optreden in straf- en in andere zaken zodat ook op dit punt geen duidelijkheid wordt geboden: Hofmański en Zabłocki 2008, p. 693. 
te benadrukken dat de kwaliteit van rechtsbijstand een kwestie van maatschappelijk belang is en dus niet alleen de advocatuur maar alle burgers betreft. ${ }^{260}$

Ondanks verzet van de balie heeft de wetgever uiteindelijk toch actie ondernomen. Door een recente wetswijziging is art. 20 KPK 1997 zodanig aangevuld dat - wanneer de rechter of de prokurator bij de balie klaagt over het optreden van een advocaat in een bepaalde strafzaak - de deken daarop binnen dertig dagen dient te reageren. ${ }^{261}$ Wanneer hij dat nalaat kan de rechtbank een boete van maximaal 10.000 złotych (ongeveer 2700 euro) opleggen. Op deze manier hoopt de wetgever de balie te stimuleren actief op te treden wanneer door justitiële organen over een advocaat wordt geklaagd.

Bovendien is de Advocatenwet in 2007 op een aantal punten gewijzigd waardoor de bevoegdheden van de minister van Justitie met name op het terrein van de tuchtrechtspraak verder zijn toegenomen. Zo kan de minister voortaan beroep aantekenen tegen uitspraken of beslissingen waarmee disciplinaire procedures worden beëindigd en kan hij opdracht geven tot het starten van een tuchtrechtelijke procedure tegen een bepaalde advocaat - ook wanneer de balie zelf van mening is dat daarvoor geen gronden bestaan. ${ }^{262}$

In een ander veelbesproken wetsvoorstel uit 2007 - dat uiteindelijk niet tot wet is verheven - werd geopperd voor een aantal juridische beroepen waaronder de advocatuur één uniforme tuchtrechtelijke procedure in te voeren. ${ }^{263}$ De tuchtrechtspraak zou volledig in handen komen van de reguliere rechterlijke macht en de functie van aanklager zou worden vervuld door leden van de prokuratura. ${ }^{264}$ Het moge duidelijk zijn dat de consequenties van deze wetswijziging verstrekkend zouden zijn. Door de bevoegdheid recht te spreken in tuchtrechtzaken zowel in eerste als in tweede aanleg over te hevelen naar de rechterlijke macht en de functie van aanklager te laten vervullen door een prokurator zou de rol van de balie in disciplinaire aangelegenheden tot een minimum worden gereduceerd. Het wetsvoorstel was dan ook uiterst omstreden. ${ }^{265}$

260 'The goal of a disciplinary procedure is not only to punish or provide moral compensation to an injured person (if such exists) but also, which should be emphasized, to protect all potential future clients of a lawyer': Monitoring Report 2003, p. 128.

261 Wetswijziging van 9 mei 2007.

262 Respectievelijk art. 88a en art. 90 lid 2 Advocatenwet, ingevoerd bij wet van 29 maart 2007.

263 Dit wetsvoorstel betreffende een tuchtrechtelijke procedure voor verschillende juridische beroepen (Ustawa o postępowaniu dyscyplinarnym wobec osób wykonujących niektóre zawody prawnicze) betrof behalve de advocatuur ook de rechterlijke macht, de prokuratura, het notariaat en de juridisch adviseurs.

264 Bij de hoger beroepsinstanties en het Hooggerechtshof zouden tuchtrechtelijke kamers in het leven worden geroepen die respectievelijk in eerste en in tweede aanleg recht zouden spreken in tuchtrechtzaken.

265 De balie had vooral moeite met de rol die de prokuratura in de voorgestelde procedure zou vervullen. Dat de functie van openbaar aanklager in tuchtrechtzaken zou worden uitgeoefend door een lid van de prokuratura - ondergeschikt aan de minister van Justitie en in veel zaken de tegenpartij van de advocaat - werd beschouwd als een onaanvaardbare aantasting van de onafhankelijkheid van de advocatuur. Dit standpunt is onder anderen verwoord door Rymar, voormalig voorzitter van de Hoogste Raad van de balie. Deze kritiek werd onder meer gedeeld door Bojarski (HFHR) die ook van mening was dat het volledig onderbrengen van de tuchtrechtspraak bij de rechterlijke macht te ver zou gaan. Zelfs de voorstanders van hervormingen op het gebied van de tuchtrechtspraak waren 
Mede naar aanleiding van laatstgenoemd wetsvoorstel hebben de Poolse ontwikkelingen ten aanzien van de advocatuur uiteindelijk ook internationale aandacht getrokken van de CCBE en IBAHRI (International Bar Association's Human Rights Institute). Omdat bij deze organisaties bezorgdheid bestond over de gevolgen van recente wetsvoorstellen en -wijzigingen voor de autonomie van juridische beroepsgroepen is in september 2007 een bezoek gebracht aan Polen. Naar aanleiding van dit bezoek is een rapport uitgebracht waarin de CCBE en IBAHRI hun zorg uitspreken over onder meer de recente wijzigingen in de Advocatenwet van 2007 en de voorgestelde invoering van één uniforme tuchtrechtelijke procedure voor verschillende juridische beroepsgroepen. ${ }^{266}$ Volgens genoemde organisaties is de voormalige regering van Polen ${ }^{267}$ druk bezig geweest de onafhankelijkheid van juridische beroepsgroepen zoveel mogelijk te reduceren en de (mogelijke) gevolgen van deze wijzigingen worden fel bekritiseerd:

'The former Government of Poland, led by the Law and Justice Party [PiS, toev. DdV], appears to have been embarking upon a campaign to gain control over the courts, the legal profession and the prosecution system. This campaign primarily took the form of numerous legislative amendments designed to empower the Minister of Justice with a variety of controls over these bodies. The Polish government was unconcerned with Constitutional limitations and binding international law, and had openly declared its animosity towards the judiciary, legal professional associations and prosecutors. It is not yet known what the position of the new government will be on these important issues (...). The last Polish government exhibited hostility and suspicion in its dealings with the legal profession, treating the legal profession (comprising individual members and legal professional associations) as a threat. Recent comments made about the legal profession by the former government evidence the government's intention to destroy the independent self-governing organisations within the legal profession. These steps clearly breach the Polish Constitution, international standards protecting freedom of association, and the UN Basic Principles on the Role of Lawyers and the new government must ensure that this does not continue. The constraints proposed or imposed by the last Polish government upon lawyers seriously undermine the effective functioning of the justice system and the ability of lawyers to carry out professional duties freely. They also undermine public confidence in the justice system. The delegation notes that there are issues in Poland regarding the closed nature of the profession. These should also be adressed by both the government and the legal profession working collaberatively.'268

De nieuwe Poolse regering wordt aanbevolen reeds inwerking getreden wetgeving en wetsvoorstellen die de onafhankelijkheid van de advocatuur inperken, in te trekken. Dit advies is in ieder geval opgevolgd voor wat betreft het wetsvoorstel over de uniforme tuchtrechtelijke procedure: dit project is inmiddels van tafel verdwenen. De nabije toekomst zal moeten uitwijzen welke gevolgen de politieke ont-

dus kritisch over de rigoureuze consequenties van het wetsvoorstel.

266 Justice under Siege: a report on the rule of law in Poland 2007. Dit rapport ziet zoals gezegd niet alleen op ontwikkelingen met betrekking tot advocaten en juridisch adviseurs maar ook op (voorgestelde) wetgeving die de onafhankelijkheid van de rechterlijke macht en de prokuratura betreft. Laatstgenoemde categorie zal hier verder buiten beschouwing worden gelaten.

267 Enkele dagen na het bezoek van de delegatie werden nieuwe parlementaire verkiezingen uitgeroepen als gevolg waarvan PiS niet langer de grootste partij is en een nieuwe regering onder leiding van Donald Tusk (Burgerplatform) is aangetreden. PiS is nu de grootste oppositiepartij. Zie ook hoofdstuk 2, § 2.3.4.

268 Justice under Siege: a report on the rule of law in Poland 2007, p. 87-92. 
wikkelingen voor het overige zullen hebben voor de positie van de advocatuur. Duidelijk is al wel dat de extreme koers die door PiS is uitgezet door de nieuwe Poolse regering niet zal worden gevolgd en de verwachting is dan ook dat meer respect zal worden getoond voor de autonomie van de balie.

\section{Conclusie}

De Poolse balie maakt roerige tijden door. Paradoxaal genoeg lijkt het erop dat ze in de huidige democratische maatschappij nog harder voor haar autonomie moet vechten dan gedurende het communisme. Zeker in vergelijking tot andere Centraalen Oost-Europese landen heeft de Poolse balie in de jaren 1944-1989 nog een redelijke mate van onafhankelijkheid weten te behouden. Dat betekent echter niet dat het communistisch regime geen enkele gevolgen heeft gehad voor de advocatuur. Net als de ontwikkelingen op het gebied van het straf(proces)recht die parallel liepen aan de meer en minder repressieve perioden van het communistisch regime $^{269}$ zijn ook de veranderingen die de balie doormaakte, verbonden met deze politieke golfbewegingen. Voornamelijk in de Advocatenwet van 1950 en 1963 kunnen meer dan genoeg punten worden gevonden waarop de wetgever de beroepsgroep aan de overheid heeft willen binden: de prominente rol van de minister van Justitie, de verificatiecommissies die de advocatuur moesten 'zuiveren' van politiek onbetrouwbare leden en de verplichting in collectieven te werken, zijn hier duidelijke voorbeelden van.

Dat de advocatuur zich ondanks alles staande heeft weten te houden en niet ten onder is gegaan aan de gevolgen van het communistisch regime is een hele prestatie die ongetwijfeld bijdraagt aan de trotse houding die de beroepsgroep vandaag de dag inneemt. De laatste jaren hebben echter laten zien dat de samenleving de monopoliepositie van de advocatuur niet langer als vanzelfsprekend accepteert. De behoefte aan zelfbehoud en onafhankelijkheid die onder het communistisch regime werd begrepen, wordt nu fel bekritiseerd. De balie wordt vooral verweten concurrentie doelbewust tegen te gaan, onvoldoende oog te hebben voor de kwaliteit van verleende rechtsbijstand en de toelating van nieuwe leden niet te baseren op objectieve criteria. Het argument van de balie dat zij zelf haar zaken moet kunnen regelen omdat aantasting van de autonomie de ondergang van de beroepsgroep betekent, blijkt in deze discussie niet langer overtuigend te zijn: in een democratische rechtsstaat dienen burgers gelijke kansen te hebben ${ }^{270}$ en dient rechtsbijstand daadwerkelijk effectief te zijn waardoor de aandacht minder op de rechten en meer op de plichten van de advocatuur is komen te liggen.

Uiteindelijk heeft de wetgever geprobeerd verandering aan te brengen in de situatie door een nieuw systeem van toelating te introduceren waarbij de examinering uniformer en transparanter is en - vanwege de centrale rol van de minister van Justitie - voor een belangrijk deel uit handen van de balie is genomen. Grote vraag is of hiermee de onafhankelijkheid van de advocatuur op ontoelaatbare wijze is aangetast. Deze onafhankelijkheid wordt universeel als een groot goed beschouwd - zo blijkt ook uit verschillende Europese en internationale regelingen zoals de gedragscode voor advocaten binnen de EU van de CCBE en de Basic principles on

269 Zie hoofdstuk 2, § 2.2.

270 Wat onder meer betekent dat de kansen om het beroep van advocaat te kiezen voor iedere (gekwalificeerde) jurist gelijk dienen te zijn. 
the role of lawyers van de VN - en wordt gezien als conditio sine qua non voor een onafhankelijk optreden van de individuele advocaat. Of er grenzen kunnen worden gesteld aan deze onafhankelijkheid en - zo ja - welke mate van overheidstoezicht nog acceptabel is, wordt echter nergens bepaald. Deze vraag is ook niet in zijn algemeenheid te beantwoorden. Voor de Poolse situatie geldt mijns inziens dat hervormingen niet uit konden blijven en door de conservatieve houding van de balie uiteindelijk wel moesten worden afgedwongen. Onafhankelijkheid is een belangrijke waarde maar wanneer er sterke aanwijzingen bestaan dat bevoegdheden vooral worden aangewend om eigen belangen te dienen en de kwaliteit van rechtsbijstand daaronder lijdt, is inmenging van buitenaf onvermijdelijk. Het behoort immers ook tot de (fundamentele) verantwoordelijkheden van de advocatuur een bijdrage te leveren aan een behoorlijke rechtspleging en wanneer deze taak onvoldoende wordt vervuld, is het aan de overheid om daar verandering in aan te brengen. Hoewel gehekeld door de advocatuur zelf, kan niet worden miskend dat de hervormingen die in 2005 in de Advocatenwet zijn doorgevoerd positieve aspecten hebben die het algemeen belang dienen. De toetredingsprocedure is transparanter geworden en biedt meer garantie voor een selectie op basis van kwaliteitseisen dan voorheen. Als het openbreken van de balie uiteindelijk tot een noemenswaardige toename van het aantal advocaten leidt, zal onderlinge concurrentie juridische bijstand waarschijnlijk ook goedkoper maken. In theorie kunnen deze wijzigingen dus bijdragen aan de toegankelijkheid en betaalbaarheid van rechtsbijstand. 271

Wat het tuchtrecht betreft, geldt dat de gedragsregels niet of nauwelijks zijn beïnvloed door de transitie die Polen heeft doorgemaakt. De historische ontwikkeling van de gedragsregels laat zien dat de inhoud en opzet ervan - sinds de totstandkoming van de eerste geschreven gedragscode in 1961 - niet noemenswaardig is veranderd. De belangrijkste normen overziend, valt in ieder geval op dat veel gebruik wordt gemaakt van open normen en dat 'de waardigheid van het beroep' een belangrijke rol speelt. Er wordt veel aandacht besteed aan de eer van de advocatenstand en het vertrouwen dat in de beroepsgroep moet (kunnen) worden gesteld. De gedragsregels bieden weinig concrete normen voor een behoorlijke beroepsuitoefening. Aangezien de tuchtrechtspraak de laatste decennia niet of nauwelijks is gepubliceerd, kan de advocaat ook daar weinig aanvullende regels uit afleiden. Het gedragsrecht heeft hierdoor een statisch karakter en is in de hedendaagse literatuur dan ook veel minder onderwerp van discussie dan in de jaren zestig en zeventig.

In de gedragsregels is vooral ook weinig specifieke aandacht voor het optreden van de advocaat in strafzaken. Enkele aanvullende richtlijnen kunnen worden gevonden in de strafwetgeving maar erg duidelijk is dit allemaal niet. De strafrechtspleging heeft de laatste jaren ingrijpende veranderingen doorgemaakt en deze hebben ook de taak van de raadsman veranderd: dit vereist nieuwe, duidelijke normen waarin

271 Het is nog te vroeg om te bepalen of deze doelstellingen ook daadwerkelijk zullen worden bereikt. Vooralsnog laten de cijfers over 2006 en 2007 geen toename van het (absolute) aantal advocaten zien maar wel een groei van het aantal stagiaires: in 2006 bedroeg het totaal aantal advocaten 8965, waarvan 754 stagiaires (8 procent) en in 2007 waren deze cijfers respectievelijk 8965 (aantal advocaten) en 1290 (aantal stagiaires). Dit betekent dat het percentage stagiaires tussen 2006 en 2007 is gestegen van 8 naar 14 procent. 
door de balie tot op heden in onvoldoende mate is voorzien. Huidige ontwikkelingen binnen het strafprocesrecht laten een steeds grotere nadruk op efficiëntie zien die onherroepelijk consequenties heeft voor de positie van de verdediging. De balie dient deel te nemen aan de discussie door aan te geven welke verworvenheden niet kunnen worden opgeofferd en over welke rechten, bevoegdheden en privileges de raadsman in ieder geval moet kunnen beschikken om zijn cliënt effectief te kunnen bijstaan. Dit betekent dat de beroepsgroep in de toekomst meer aandacht zal moeten hebben voor het belang van de cliënt: tot op heden hebben vooral de belangen van de balie zelf in het middelpunt van de belangstelling gestaan.

Ook de tuchtrechtspraak is veelvuldig onderwerp van kritiek. Het tuchtrechtelijk toezicht zou inefficiënt zijn en hoewel de juistheid van deze kritiek - vanwege het gebrek aan gegevens op dit punt - niet kan worden beoordeeld, is wel duidelijk dat het gebrek aan transparantie in de tuchtrechtspraak bijdroeg aan de negatieve beeldvorming op dit punt. Plannen om meer openbaarheid en objectiviteit in de tuchtrechtspraak te realiseren, kunnen dan ook alleen maar worden toegejuicht. Niet alleen in het licht van de eisen van art. 6 EVRM maar vooral ook omdat effectief tuchtrechtelijk toezicht van groot belang is voor het bewaken en behouden van een bepaalde mate van kwaliteit in de rechtsbijstandverlening. Dat de wetgever dit door recente wetswijzigingen - zoals de regel dat de deken binnen dertig dagen dient te reageren op een klacht - probeert te realiseren, is op zich zelf positief.

Alles overziend, kan worden geconcludeerd dat de Poolse balie tot nu toe een wat moeizame rol heeft gespeeld in het democratiseringsproces. ${ }^{272}$ Hierbij moet echter niet worden vergeten dat de advocatuur sinds 1989 voor grote uitdagingen is gesteld. De grootschalige en elkaar snel opvolgende wijzigingen in wet- en regelgeving waarmee de praktijk is geconfronteerd, vereisten een enorm aanpassingsvermogen. Omdat democratisering ook betekent dat burgers in toenemende mate een beroep doen op de rechtspleging is bovendien de werklast van de advocatuur aanzienlijk toegenomen. ${ }^{273}$ De groeiende kritiek op het functioneren van de balie heeft in een bepaald opzicht een contraproductief effect gehad. De advocatuur is zich steeds defensiever gaan opstellen waardoor de kritiek alleen maar toenam en hervormingen uiteindelijk door de politiek moesten worden afgedwongen. Hoewel de staatsbemoeienis oorspronkelijk dus een begrijpelijke reactie is geweest op

272 Dit is overigens een verschijnsel dat ook in andere postcommunistische landen van Europa kan worden geconstateerd. Volgens Meyer heeft dit alles te maken met het feit dat advocaten op een bepaalde manier toch gewend zijn geraakt aan hun rol en functie in de communistische maatschappij: 'Some advocats may have been careerists rather than dedicated believers in the party's dogma, but all were trained in a system where "minimization of the law" was routine. Advocats from such backgrounds are inclined to serve patterns which served them well in their prior lives.' Meyer is van mening dat teveel advocaten in de Centraalen Oost-Europese regio de democratische veranderingen vooral hebben beschouwd als 'an opportunity to make money rather than to promote social reform'. Dat terwijl het succes van de transitie voor een groot deel van hen afhankelijk is: '(...) lawyers are more than simply providers of legal services: they are essential agents in the admininistration of justice. Given the importance of private lawyers to the functioning of modern commerce and free societies, their succes in making the transformation is critical to the establishment of the rule of law in the postCommunist environment'. Zie Meyer 1995, p. 1019.

273 De advocatuur heeft er (tot de min of meer opgelegde wijziging van de Advocatenwet in 2005) echter zelf voor gekozen de grootte van de beroepsgroep niet of nauwelijks aan te passen aan deze nieuwe situatie. 
de conservatieve houding van de balie laten recente wetswijzigingen en wetsvoorstellen zien dat de overheid te ver is doorgeschoten in het streven de beroepsgroep aan de overheid te binden. Zoals ook gesignaleerd door internationale organisaties als de CCBE en de IBAHRI dient deze ontwikkeling een halt toe te worden geroepen om te voorkomen dat noodzakelijk toezicht overgaat in ongezonde overheidsinmenging die schadelijk is voor het functioneren van de individuele advocaat. 



\section{Hoofdstuk 9}

\section{Eindconclusies}

'It is the spirit and not the form of law that keeps justice alive'

E. Warren

\section{Inleiding}

In de voorgaande hoofdstukken is onderzocht welke gevolgen postcommunistische hervormingen hebben gehad voor de positie van de verdediging in het Poolse strafproces. De nadruk lag daarbij enerzijds op de vraag naar het verloop van een dergelijk transitieproces waarbij de overheid binnen relatief korte termijn een hoger niveau van rechtsbescherming tracht te realiseren en anderzijds op de factoren die van invloed zijn op het effect van doorgevoerde hervormingen. Het doel van dit laatste hoofdstuk is om de belangrijkste bevindingen systematisch weer te geven en te interpreteren om zodoende antwoord te kunnen geven op de vraagstelling die in dit onderzoek centraal stond. Deze vraagstelling - die uiteenvalt in drie deelvragen die hierna achtereenvolgens zullen worden behandeld - luidt:

'In hoeverre en op welke wijze zijn in het Poolse postcommunistische transitieproces wijzigingen doorgevoerd die een effectieve verdediging in strafzaken beogen te garanderen, welke factoren hebben een rol gespeeld bij de implementatie van deze wijzigingen en welke lessen kunnen hieruit worden getrokken over de (mogelijke) effecten van een door de overheid geïnitieerde optimalisering van verdedigingsrechten?'

\section{Postcommunistische hervormingen gericht op een effectieve verdediging}

Aan dit onderzoek ligt de veronderstelling ten grondslag dat de rol die de verdediging in een bepaald strafproces vervult sterk afhankelijk is van de aard, structuur en cultuur van dat strafproces. Hierbij is van belang dat de structuur van een strafproces - en dus ook de positie van procesdeelnemers daarin - onlosmakelijk zijn verbonden met de wijze waarop overheidsgezag is vormgegeven. ${ }^{1}$ Deze verbanden impliceren dat een (wezenlijke) verandering in overheidsstructuur ook consequenties heeft voor het strafproces en de positie van de verdediging daarin. Onderzocht is in hoeverre dit ook geldt voor de rol van de verdediging in het Poolse strafproces gelet op de politieke ontwikkelingen van eind jaren tachtig en de ingrijpende systeemwisseling die ze tot gevolg hebben gehad. Daarbij is behalve aan positiefrechtelijke kaders en de wijze waarop deze in de praktijk functioneren ook aandacht besteed aan de rol van de doctrine en de vraag in hoeverre opvattingen over de taak en functie van de advocaat in strafzaken door de politieke ontwikkelingen zijn beïnvloed.

\subsection{Verdediging in strafzaken gedurende het communisme}

Het bieden van rechtsbescherming aan verdachte burgers vereist dat wordt erkend dat tussen het individu en de overheid een belangenconflict kan bestaan. Kenmer-

1 Voor een uitgebreide bespreking van deze correlaties wordt verwezen naar Damaška 1975 en 1986, zie ook hoofdstuk 3, § 1 en hierna § 2.2.1. 
kend voor communistische regimes is dat de mogelijkheid van een dergelijk conflict niet wordt aanvaard: uitgangspunt is dat er één gemeenschappelijk belang bestaat en dat de overheid en de individuele burger in beginsel hetzelfde doel nastreven. Dit komt op verschillende manieren tot uitdrukking in het socialistisch strafproces en de uiterst marginale rol die daarin voor de verdediging is weggelegd.

\subsubsection{Tussen wetgeving en cultuur: obstakels voor effectieve verdediging gedurende het communisme}

In communistisch Polen manifesteerde de zwakke positie van de verdediging zich met name in de fase van het vooronderzoek. De raadsman had slechts beperkte mogelijkheden om in dit stadium van de procedure een rol van betekenis te spelen. Deze beperkingen waren deels een gevolg van de wijze waarop (en de mate waarin) verdedigingsrechten in wet- en regelgeving waren vormgegeven. Dit blijkt vooral uit de volgende punten:

- een wettelijke grondslag voor het verlenen van rechtsbijstand na aanhouding ontbrak,

- inzage van het dossier en deelname aan onderzoekshandelingen kon gedurende het gehele vooronderzoek eenvoudig worden geweigerd,

- deelname aan zittingen waarop over de voorlopige hechtenis werd beslist, was niet was toegestaan en

- vertrouwelijke communicatie tussen raadsman en gedetineerde cliënt was als gevolg van ruime en ingrijpende toezichtmogelijkheden niet gegarandeerd.

De oorzaak van de problemen waarmee de verdediging in strafzaken gedurende het communisme werd geconfronteerd, dient echter niet alleen in de wettelijke normering van verdedigingsrechten te worden gezocht. Sterker nog, het strafprocesrecht bood in verschillende opzichten op papier nog behoorlijk wat ruimte aan de verdachte en zijn raadsman. Dit was in de eerste plaats een gevolg van het feit dat ook in het socialistisch strafproces werd erkend dat een bepaalde mate van tegenspraak een positieve bijdrage zou kunnen leveren aan het proces van waarheidsvinding. Vandaar dat het Poolse wetboek van strafvordering van 1969 het tegensprekelijk karakter van het strafproces (in ieder geval op papier) op een aantal punten had vergroot. Een tweede verklaring voor de wettelijke mogelijkheden die het strafprocesrecht de verdediging bood, kan worden gevonden in het feit dat symboolwetgeving - bedoeld om de buitenwereld gerust te stellen - een bekend verschijnsel was in de communistische systemen van Centraal- en OostEuropa en ook in de strafwetgeving kon worden gesignaleerd. ${ }^{2}$

Minstens zo belangrijk voor de zwakke positie van de verdediging was de structuur van het strafproces - de verhouding tussen de afzonderlijke procesfasen - en de feitelijke rol van de verschillende procesdeelnemers daarin. De machtige positie van de prokurator en de ondergeschiktheid van de zittende magistratuur aan de overheid maakten dat het vooronderzoek zonder twijfel het belangrijkste stadium van de

2 'The most prominent similarity [between criminal law systems of communist Central and Eastern Europe, toev. DdV] was the discrepancy between the seemingly progressive character of the legal code and the brutal and arbitrary nature of the state security apparatus in action. In each of these nations, either punitive measures were hidden within generally liberal rhetoric in the code text itself, or else prosecutors and judges simply declined to follow the letter of the law, knowing that their actions were immune from collateral challenges', Siegelbaum 2002, p. 84. 
procedure was waarop sinds het verdwijnen van de functie van rechter-commissaris in 1950 nauwelijks enig rechterlijk toezicht werd uitgeoefend. In theorie was de prokurator belast met het toezicht op de rechtsbescherming in het vooronderzoek maar vanwege diens primaire focus op criminaliteitsbestrijding en zijn gebondenheid aan de communistische partij kwam daar in de praktijk weinig van terecht. Door wettelijke uitzonderingen in de praktijk tot regel te verheffen, kon de prokurator de verdediging uit het vooronderzoek weren. Dit gebeurde onder meer op het terrein van het vrij verkeer: de strafvorderlijke mogelijkheid persoonlijk overleg tussen advocaat en cliënt bij wijze van uitzondering te verbieden, groeide in de dagelijkse praktijk uit tot regel. Wat de inzage van processtukken betreft, was de wettelijke regel dat de verdediging met toestemming van de prokurator het dossier moest kunnen inzien maar in werkelijkheid werd inzage stelselmatig geweigerd. Het onderzoek ter terechtzitting had door de afhankelijke positie van de rechterlijke macht en de grote waarde die aan bewijs uit het vooronderzoek werd toegekend niet of nauwelijks toegevoegde waarde zodat de mogelijkheden die in dat stadium aan de verdediging werden geboden veelal mosterd na de maaltijd waren.

Een laatste relevante factor was de houding van de advocatuur zelf. De oorzaak van de passieve opstelling van de advocatuur in het vooronderzoek kon niet alleen worden gevonden in wettelijke beperkingen en de overheersende rol van de prokurator maar was ook gelegen in de overtuiging dat een afwachtende houding in dit stadium van de procedure een goede verdedigingsstrategie is: een opvatting die ook vandaag de dag nog leeft binnen de Poolse advocatuur. ${ }^{3}$ Gedurende het communisme kon deze houding binnen de advocatuur zelf eenvoudig worden 'gerechtvaardigd' door de wettelijke en feitelijke obstakels waarmee de advocaat in strafzaken werd geconfronteerd: een argument dat na 1989 door de hervormingen in het strafproces geleidelijk aan minder overtuigend zou worden.

\subsubsection{De beperkte doorwerking van het communistisch gedachtegoed}

Hoewel het voorgaande wellicht anders doet vermoeden, is het communistisch ideeëngoed nooit echt geworteld in de Poolse maatschappij. Het was een van bovenaf opgelegde politieke ideologie waarvoor in Polen - onder meer vanwege de sterke positie van de rooms-katholieke kerk - weinig vruchtbare voedingsbodem bestond. Gedurende de gehele communistische periode is vanuit verschillende hoeken en op verschillende manieren verzet geboden tegen de sovjetoverheersing. Deze strijdbare houding kwam ook tot uitdrukking in de strafrechtspleging. In dit verband is vooral van belang dat er ondanks de politieke beïnvloeding van het strafproces die vooral de prokuratura en de rechterlijke macht betrof sprake was van 1) een relatief onafhankelijke advocatuur en 2) een zelfstandige, kritische houding van de doctrine.

\section{Ad. 1 Relatieve onafhankelijkheid van de advocatuur}

Hoewel de regulering van de balie na 1944 wel door de politiek werd beïnvloed, ${ }^{4}$ heeft de advocatuur zich hier altijd tegen verzet en is ze voor haar auto-

3 Op dit punt wordt hierna nog teruggekomen.

4 Zie hoofdstuk 8 over de Advocatenwet van respectievelijk 1950 en 1963 waardoor de balie en de individuele beroepsuitoefening op verschillende manieren - zoals door vergaand toezicht door de minister van Justitie en de verplichting om in collectieven te werken - aan de overheid werden gebonden. 
nomie blijven vechten. Hierdoor heeft de beroepsgroep gedurende het communisme - zeker in vergelijking met andere landen van Centraal- en Oost-Europa - nog een redelijke mate van zelfstandigheid weten te behouden. Opvallend is onder meer dat de van overheidswege opgelegde verplichting om in collectieven te werken in de praktijk nauwelijks het door de politiek gewenste effect had: advocaten bleven zoals voorheen op individuele basis werken en van gemeenschappelijke samenwerking zoals met de collectieven werd beoogd, was nauwelijks sprake.

De sterke drang naar onafhankelijkheid en het strijdbare karakter van de Poolse balie bleek overigens ook reeds tijdens Wereldoorlog II: na te zijn uitgeroepen tot een verboden organisatie werden de activiteiten met gevaar voor eigen leven ondergronds voortgezet. Het autonome optreden in de oorlog en gedurende de daaropvolgende overheersing door de Sovjet-Unie heeft de balie gevormd en is uiteindelijk ook van invloed geweest op haar rol in het democratiseringsproces aan het eind van de $20^{\text {e }}$ eeuw. ${ }^{5}$

\section{Ad. 2 Zelfstandige en kritische houding van de doctrine}

Een tweede voorbeeld van de beperkte doorwerking van het communistisch ideeëngoed kan worden gevonden in de stellingname van wetenschappers in de Poolse rechtsgeleerde literatuur waarin de repressieve kenmerken van het socialistisch strafproces veelvuldig werden bekritiseerd. Vooral de beperkte (wettelijke) mogelijkheden van de verdediging waren regelmatig onderwerp van kritiek en er werd voornamelijk in de jaren zestig en zeventig veel gediscussieerd over het - feitelijke en wenselijke - aandeel van de raadsman in het vooronderzoek. Vanuit rechtswetenschappelijke hoek werden veelvuldig voorstellen tot wijziging van het straf(proces)recht gedaan en hervorming van de strafrechtspleging groeide uiteindelijk uit tot een van de speerpunten van de politieke verzetsbeweging. Het is belangrijk dit te benadrukken omdat het aangeeft dat de oorspronkelijke wens van de postcommunistische wetgever de strafrechtspleging aan te passen eerst en vooral werd ingegeven door een diepgewortelde onvrede met de status quo en niet door andere - minder 'idealistische' - drijfveren zoals het streven zo snel mogelijk aansluiting te vinden bij West-Europa om toetreding tot organen als de Raad van Europa en de Europese Unie met alle voordelen van dien zo snel mogelijk te kunnen realiseren.

De onafhankelijke, kritische houding van de Poolse doctrine kwam ook tot uitdrukking in de ontwikkeling van (het denken over) de taakopvatting van de raadsman. De opvattingen hierover zijn in de periode 1945-1989 niet of nauwelijks door de heersende politieke denkbeelden beïnvloed. Er is weinig aansluiting gezocht bij sovjetliteratuur op dit punt en zelfs de auteurs die de publieke verantwoordelijkheden van de raadsman in het socialistisch strafproces benadrukten, gingen daarbij niet zover dat het belang van de verdachte ondergeschikt werd gemaakt aan het belang van de gemeenschap. Met andere woorden: de publieke functie van de raadsman is tijdens het communisme in de Poolse doctrine niet sterk ontwikkeld en het belang van de cliënt is steeds vooropgesteld.

\subsection{Verdediging in strafzaken sinds 1989}

Geconstateerd is dat de beperkte rol van de verdediging in strafzaken gedurende het communisme deels het gevolg was van ontoereikende wettelijke mogelijkheden

5 Zie hierna $\S 3.1 .4$. 
maar vooral ook het resultaat was van factoren van meer rechtsculturele aard. Voornamelijk de machtsverhoudingen tussen de verschillende procesdeelnemers en de passieve houding van de advocatuur waren in laatstgenoemd verband bepalend. De wettelijke ruimte die de verdediging nog wel werd geboden had daardoor in de praktijk slechts beperkte betekenis. De relatief autonome positie die de advocatuur had weten te behouden, stond er niet aan in de weg dat de dagelijkse strafrechtspraktijk zowel in het vooronderzoek als op het onderzoek ter terechtzitting werd gedomineerd door de prokuratura die onder directe invloed van de communistische partij stond. De Poolse overheid van na 1989 wenste dit beeld te veranderen en het was in de eerste plaats de verantwoordelijkheid van de postcommunistische wetgever om de wettelijke basis te leggen voor de gewenste hervormingen in de strafrechtspleging. Voor wat betreft de vernieuwde wettelijke regeling van het strafprocesrecht is om te beginnen een aantal algemene constateringen van belang.

\subsubsection{Algemene constateringen over de transitie van het strafprocesrecht}

Bij de postcommunistische hervorming van het strafproces stonden verschillende doelstellingen centraal waaronder:

- het realiseren van meer rechterlijke controle op het vooronderzoek,

- een evenwichtiger verhouding tussen voor- en eindonderzoek,

- het versterken van het adversair karakter van het onderzoek ter terechtzitting en

- het creëren van meer gelijkwaardigheid tussen vervolging en verdediging.

Gelet op deze doelstellingen is het niet verwonderlijk dat het zwaartepunt van de hervormingen vooral in de fase van het vooronderzoek was gelegen. Daar waren de problemen vanuit rechtsstatelijk en rechtsbeschermend perspectief immers ook het grootst.

Van belang is dat de huidige vormgeving van het strafproces geen radicale breuk met het verleden laat zien. In de nieuwe strafrechtelijke codificaties van 1997 zijn de hoofdlijnen van het strafproces - voornamelijk voor wat betreft structuur en procesdeelnemers - grotendeels hetzelfde gebleven. Dat de politieke omwenteling slechts beperkte gevolgen heeft gehad voor de structuur van het strafproces is te verklaren door het feit dat het socialistisch strafproces en het strafproces zoals dat in de continentale, civil law rechtstraditie wordt vormgegeven in wezen twee zijden van dezelfde medaille zijn. Beide procedures zijn immers gerelateerd aan een overheidsvorm die het strafproces niet beschouwt als een strijd tussen twee partijen waarin de overheid geen zelfstandig belang heeft maar als een proces waarin - zij het in verschillende mate - de crimineelpolitieke doelstellingen van de overheid tot uitdrukking dienen te komen. ${ }^{6}$ Het behoeft geen betoog dat het socialistisch strafproces in deze beleidsimplementerende functie veel verder gaat door het strafproces enkel en alleen als politiek instrument te beschouwen en

6 Niet voor niets worden door Damaška - waar het gaat om de samenhang tussen enerzijds de structuur van overheidsgezag en anderzijds de vormgeving en doelstelling van gerechtelijke procedures - vooral de common law en civil law landen als twee uitersten tegenover elkaar gesteld. De socialistische landen zijn in zijn theoretisch kader op dezelfde lijn te plaatsen als de civil law landen en worden gekenmerkt door strafrechtelijke procedures waarin niet de procespartijen maar een door of vanwege de overheid uitgevoerd onderzoek de kern van de procedure vormen. Zie voor een uitgebreide analyse: Damaška 1975 en 1986. 
daarbij het belang van de individuele (verdachte) burger grotendeels gelijk te stellen aan het gemeenschappelijk belang. Dit betreft echter vooral de aard van het strafproces en op dat punt heeft de ineenstorting van het communistisch regime wel degelijk gevolgen gehad. In dat verband zijn vooral de gewijzigde (heersende) opvattingen over de verhouding tussen staat, recht en individu van belang. Tot de beginselen van een democratische rechtsstaat hoort dat wordt erkend dat ook de overheid gebonden is aan het recht en dat belangen van individuele burgers bescherming verdienen: in het bijzonder wanneer de overheid zoals in het strafrecht diep ingrijpt in hun persoonlijke levenssfeer. Wat dit concreet betekent voor de positie van de verdediging en in hoeverre de cultuur van het strafproces daarbij nog een rol speelt, zal in de hiernavolgende paragraaf aan de orde komen.

Met het feit dat de structuur van het strafproces niet ingrijpend is gewijzigd, hangt samen dat de wetgever opvallend dicht bij de eigen historische en culturele achtergrond is gebleven. Van oudsher is de Poolse rechtsontwikkeling beïnvloed door vooral het Duitse en het Franse recht maar de inspiratie voor het nieuwe wetboek van strafvordering is hoofdzakelijk gevonden in het eigen strafprocesrecht van voor Wereldoorlog II en in de socialistische wetgeving van 1969.

Dat de totstandkoming van het nieuwe wetboek van strafvordering vooral een nationale aangelegenheid is geweest, blijkt ook uit het feit dat niet of nauwelijks sprake geweest van import van vreemde rechtsfiguren van over de grens. ${ }^{7}$ Meer recent kan in het Poolse strafprocesrecht wel de opkomst van verschijnselen met een Angelsaksische achtergrond worden geconstateerd - zoals de toename van consensuele afdoeningsmethoden en de introductie van de kroongetuige - maar dat is een ontwikkeling die onder meer onder invloed van het EVRM ook in andere (nietpostcommunistische) Europese landen gaande is en dus niet kenmerkend voor de transitie kan worden genoemd.

Voor het feit dat Polen weinig gebruik heeft gemaakt van buitenlandse oplossingen kunnen verschillende verklaringen worden genoemd. In de eerste plaats speelt een rol dat men na de ineenstorting van het communistisch regime kon teruggrijpen naar de eigen nationale civil law rechtstraditie van voor het communistisch tijdperk. Hierdoor was het niet noodzakelijk vreemde regels of instituten in het rechtssysteem te implanteren om aansluiting te vinden bij de continentale rechtsfamilie. ${ }^{8}$ In de tweede plaats heeft hoogstwaarschijnlijk ook de Poolse onafhankelijkheidsdrang een rol gespeeld. Na zoveel jaren vreemde overheersing (waarbij ook de periode voor Wereldoorlog II niet moet worden vergeten) bestond vooral behoefte aan eigen, nationale wetgeving met zo min mogelijk bemoeienis van andere landen. ${ }^{9}$

$7 \quad$ In bijvoorbeeld Rusland zijn wel voorbeelden van dergelijke legal transplants te ontdekken (zoals de introductie van adversaire elementen ontleend aan de common law rechtstraditie in het van oudsher inquisitoire Russische strafproces, zie uitgebreider: Pomorski 2006). Het gebruik van de term legal transplant is in de rechtsvergelijking overigens omstreden. Een van de bezwaren tegen deze formulering is dat de woorden door de associatie met orgaantransplantatie zouden impliceren dat datgene wat wordt overgeplaatst bij de donor verdwijnt wat in de juridische betekenis natuurlijk niet juist is. Zie hierover onder anderen: Badó 2007, p. 103-104.

8 In dit verband dienen de Centraal-Europese landen te worden onderscheiden van de Oost-Europese landen waarvan een deel een dergelijke achtergrond ontbeert.

9 Illustratief in dit verband is dat de Central and Eastern European Law Initiative van de American Bar Association - een van de Westerse 'zendelingen' die een belangrijke rol 


\subsubsection{Voornaamste wijzigingen gericht op effectieve verdediging}

De nadruk van de postcommunistische wijzigingen die een effectieve verdediging in strafzaken beoogden te garanderen, lag overduidelijk op het vooronderzoek. De belangrijkste betreffen de volgende punten:

- de introductie van een expliciet wettelijk recht op rechtsbijstand direct na aanhouding,

- de introductie van een expliciet wettelijk recht op rechtsbijstand tijdens verhoren,

- verbetering van de informatievoorziening voorafgaand aan het eerste verhoor (letter of rights),

- verbetering van de regeling van het vrij verkeer (waarborgen vertrouwelijke communicatie),

- een uitbreiding van de gevallen van verplichte (en dus kosteloze) rechtsbijstand,

- een uitbreiding van de wettelijke mogelijkheden voorlopige hechtenis aan te vechten,

- een uitbreiding van het recht deel te nemen aan onderzoekshandelingen en

- een uitbreiding van het recht deel te nemen aan zittingen (voornamelijk met betrekking tot voorlopige hechtenis).

In de fase van het eindonderzoek is slechts een beperkt aantal wijzigingen doorgevoerd die de positie van de verdediging (be)treffen. Het gaat daarbij vooral om de uitbreiding van het recht van de verdediging om deel te nemen aan zittingen in de voorbereidende fase en wijzigingen die het tegensprekelijk karakter van het onderzoek ter terechtzitting dienden te vergroten zoals de introductie van de wettelijke mogelijkheid voor de verdediging om schriftelijk te reageren op de akte van beschuldiging.

Van belang is dat veel wijzigingen niet zozeer bestonden uit een volledig nieuwe wettelijke regeling maar uit een herformulering van reeds bestaande procedurele rechten en bevoegdheden. De aanpassingen in de regeling van het vrij verkeer en de inzage van processtukken zijn hier voorbeelden van. Dat hervormingen vooral bestonden uit een uitbreiding of nuancering van bestaande regels is overigens niet zo verwonderlijk gelet op het eerder genoemde feit dat het socialistische strafprocesrecht in bepaalde opzichten op papier nog redelijk 'gunstig' was voor de verdediging. Op een beperkt aantal punten heeft de wetgever - daarbij soms geinspireerd door het EVRM ${ }^{10}$ - echter wel voor de introductie van volledig nieuwe verdedigingsrechten gekozen. Bijvoorbeeld in het kader van het optreden van de raadsman na aanhouding (nieuw art. 245 KPK 1997), het verlenen van bijstand tijdens verhoren (nieuw art. 301 KPK 1997) en de deelname aan zittingen waarop over de voorlopige hechtenis wordt beslist (onder meer art. 249 lid 3 en 5 KPK 1997).

\section{De impact van hervormingen: relevante factoren?}

De inwerkingtreding van de nieuwe Poolse strafrechtelijke codificaties van 1997 betekende gelet op de hiervoor genoemde wijzigingen - in ieder geval op papier - wel degelijk een versterking van de positie van de verdediging in voornamelijk de fase van het vooronderzoek. Echter, met het bieden van bepaalde wettelijke garanties

hebben gespeeld bij de hervorming van Oost-Europese rechtssystemen - oorspronkelijk een vestiging had in Polen maar in de loop der jaren uit het land is vertrokken.

10 Zie over de invloed van het EVRM op het hervormingsproces hierna §3.2. 
of mogelijkheden is een effectieve verdediging uiteraard nog niet gerealiseerd: minstens van even groot belang is tot op welke hoogte de verdediging in de praktijk daadwerkelijk van nieuwe of uitgebreide mogelijkheden kan en wil profiteren. Wat het effect van de wijzigingen betreft, zijn er sterke aanwijzingen dat de positiefrechtelijke ontwikkelingen nog niet tot wezenlijke veranderingen van de praktijk hebben geleid.

\subsection{Het effect van hervormingen gericht op effectieve verdediging}

Voor de beperkte impact van de postcommunistische wetswijzigingen op het functioneren van de verdediging kan niet één oorzaak worden genoemd maar zijn verschillende factoren van belang. De belangrijkste die in dit onderzoek aan het licht zijn gekomen, zullen hier op een rij worden gezet.

\subsubsection{Op wezenlijke punten resterende tekortkomingen in wettelijke regeling}

Van groot belang is dat de wettelijke regeling op een aantal wezenlijke punten nog tekortkomingen vertoont die hun weerslag hebben op de mate waarin verdedigingsrechten in de praktijk kunnen worden geëffectueerd. Deze tekortkomingen manifesteren zich voornamelijk op het terrein van drie voor de verdediging fundamentele thema's, te weten:

a. de kosteloze rechtsbijstand,

b. de informatiepositie van de verdediging en

c. het vrij verkeer en het verschoningsrecht.

\section{Ad a. Kosteloze rechtsbijstand}

Ten aanzien van de kosteloze rechtsbijstand geldt dat de (nog altijd) onduidelijke wettelijke grondslag voor het toekennen van gefinancierde rechtshulp bijdraagt aan een praktijk waarin de rechter teveel ruimte heeft om verzoeken die - gelet op de financiële situatie van verdachte - zouden moeten worden ingewilligd toch af te wijzen. ${ }^{11}$ Een groot deel van de Poolse bevolking is niet in staat om zelf in de kosten van de verdediging te voorzien en dus afhankelijk van gefinancierde rechtshulp. De tekortkomingen in het toevoegingssysteem zijn dan ook van grote invloed op de wijze waarop en de mate waarin verdachten hun grondwettelijk recht op rechtsbijstand (en daarmee hun recht op verdediging) kunnen effectueren. Deze problematiek is het meest nijpend in de eerste fase na aanhouding: het nieuwe strafprocesrecht garandeert weliswaar dat de aangehoudene onverwijld met een advocaat moet kunnen overleggen en de verdachte heeft tegenwoordig het recht op zijn verzoek in aanwezigheid van een raadsman te worden gehoord maar omdat het feitelijk onmogelijk is in dit stadium van de procedure een advocaat toegevoegd te krijgen, zijn deze verdedigingsrechten voorbehouden aan een beperkte categorie verdachten die zelf een advocaat kan betalen. De voornaamste reden voor de problemen op het terrein van de gefinancierde rechtshulp is - weinig verrassend - gelegen in de beperkte financiële armslag van de overheid. Gehinderd door deze financiële beperkingen maar ook door een gebrek aan aandacht voor

11 Nog even afgezien van de vraag of de rechter wel de aangewezen persoon is hierover te beslissen. 
de problematiek in de eerste jaren van het transitieproces heeft de overheid er tot op heden weinig aan gedaan de problemen die op dit punt bestaan, te verlichten. ${ }^{12}$

\section{Ad $b$. De informatiepositie van de verdediging}

Voor wat betreft de informatiepositie van de verdediging, is van belang dat de huidige wettelijke regeling nog steeds mogelijk maakt dat - met uitzondering van een aantal categorieën documenten - inzage van het dossier gedurende het gehele vooronderzoek eenvoudig kan worden geweigerd. Weigering dient volgens de wetgever weliswaar uitzondering te zijn maar de praktijk laat een ander beeld zien. In strafzaken van enig gewicht is het eerder regel dan uitzondering dat inzage gedurende het vooronderzoek wordt geweigerd. Hierbij speelt een grote rol dat de huidige wettelijke regeling niet specificeert dat het inzien van processtukken door de verdediging alleen in uitzonderlijke gevallen of op bepaalde zwaarwegende gronden mag worden geweigerd. Dit lijkt op het eerste gezicht wellicht een betrekkelijk gering gebrek maar de gevolgen ervan voor de praktijk zijn groot. De beperkingen die de verdediging bij de inzage van processtukken ondervindt, zijn zonder meer van invloed op de mate waarin van andere verdedigingsrechten gebruik kan worden gemaakt. Effectief gebruik van veel procedurele mogelijkheden - zoals het betwisten van de rechtmatigheid van de voorlopige hechtenis en het verzoeken om bepaalde onderzoekshandelingen - is immers in grote mate afhankelijk van de mate waarin de verdediging kan beschikken over relevante informatie met betrekking tot de strafzaak. In die zin heeft de inzageproblematiek dus een remmende werking op andere verdedigingsmogelijkheden. Overigens is de wettelijke regel dat inzage gedurende het vooronderzoek door de prokurator kan worden geweigerd in een recente uitspraak van het Grondwettelijk Hof in strijd met de Grondwet verklaard waardoor de wetgever nu wordt gedwongen op dit punt actie te ondernemen. ${ }^{13}$ Het is nog onduidelijk hoe de nieuwe regeling er uit zal komen te zien maar gelet op de kritiek van het Grondwettelijk Hof zal de beoordelingsruimte die de prokuratura in dit verband heeft in ieder geval moeten worden verkleind.

\section{Ad c. Vrij verkeer en verschoningsrecht}

Ook de wijze waarop de vertrouwelijkheid van de relatie tussen advocaat en cliënt wettelijke bescherming wordt geboden, laat nog aanzienlijke tekortkomingen zien. De beperkingen in het kader van het vrij verkeer hebben vooral betrekking op het feit dat de huidige wettelijke regeling nog altijd mogelijk maakt dat persoonlijk bezoek tussen advocaat en cliënt in de eerste fase na aanhouding en gedurende de eerste veertien dagen van de voorlopige hechtenis onder toezicht (binnen gehoorafstand) van de prokurator of een politieagent plaatsvindt. Van deze toezichtmogelijkheid wordt weliswaar niet op grote schaal gebruik gemaakt maar dat neemt niet weg dat het een groot effect heeft op de praktijk. Het belangrijkste gevolg is dat de advocatuur haar optreden erop aanpast: de enkele mogelijkheid dat de prokurator tot dergelijk toezicht kan beslissen, is voor veel advocaten aanleiding om het eerste bezoek aan een gedetineerde cliënt uit te stellen tot na de eerste twee weken van de voorlopige hechtenis of te beperken tot een puur formeel gesprek waarin de zaak nog niet inhoudelijk wordt besproken. Hierdoor is de toezicht-

12 Dit ondanks de inzet van mensenrechtenorganisaties als de HFHR die zich de laatste jaren hebben ingespannen om het probleem onder de aandacht van de politiek te brengen.

13 Uitspraak van 3 juni 2008, K 42/07. Zie eerder hoofdstuk 5, § 3.6 en hierna § 3.2.2. 
mogelijkheid ook zonder dat er uitvoering aan wordt gegeven van invloed op de mogelijkheid van verdachten in een vroeg stadium van de procedure effectief gebruik te maken van hun recht op rechtsbijstand.

Voor het verschoningsrecht van de advocaat geldt dat de problemen variëren van resterende onduidelijkheden in de wettelijke regeling (dit geldt in ieder geval voor de regeling van huiszoeking en inbeslagneming en - in mindere mate - voor de regels over het horen van geheimhouders als getuigen) tot het volledig ontbreken van wettelijke waarborgen die het beroepsgeheim van de advocaat dienen te beschermen (zoals in de regeling van de telefoontap). Op een aantal punten is het professionele verschoningsrecht onder het nieuwe strafprocesrecht beter geregeld - zo is het horen van een advocaat als getuige aan nadere voorwaarden verbonden en is de huiszoeking bij advocaten met meer wettelijke waarborgen omkleed - maar de vele vragen die nog steeds bestaan, maken een effectieve bescherming ervan onzeker. Zo is onder meer onduidelijk hoe het door de wetgever gehanteerde onderscheid tussen 'advocaat' en 'raadsman' in de praktijk moet worden toegepast en welke rol de vertegenwoordiger van de balie heeft bij huiszoekingen. Voor de telefoontap schuilt het probleem in het feit dat aan de positie van de advocaat als beroepsgeheimhouder in het geheel geen aandacht is besteed door de wetgever terwijl de huidige wettelijke regeling het opnemen van telecommunicatie in een groot aantal gevallen en ten aanzien van een grote groep (niet alleen verdachte) personen mogelijk maakt.

Onvoldoende rechterlijk toezicht en vage bewoordingen

Ten slotte is van belang dat op bepaalde voor de verdediging kwetsbare punten in de wettelijke regeling nog altijd onvoldoende in rechterlijk toezicht is voorzien en dat de wetgever - waar nuancering van wettelijke normering noodzakelijk was in een aantal belangrijke bepalingen voor (te) vage, onduidelijke bewoordingen heeft gekozen.

Om met het eerste te beginnen: tegen een aantal in het kader van de rechtsbijstandverlening belangrijke beslissingen staat geen rechtsmiddel open of kan alleen bezwaar worden ingediend bij het orgaan dat de beslissing heeft genomen (prokuratura). Dat laatste geldt bijvoorbeeld in het kader van de inzage van processtukken: tegen een negatieve beslissing op een verzoek het dossier in te zien, staat sinds de inwerkingtreding van het nieuwe wetboek van strafvordering weliswaar een rechtsmiddel open maar omdat dit wordt behandeld door de prokuratura zelf kan aan de effectiviteit ervan serieus worden getwijfeld. Nog altijd wordt de prokurator op dit punt meer onafhankelijkheid - en een meer magistratelijke rol toegedicht dan gelet op zijn aandeel in de opsporing en vervolging realistisch is. ${ }^{14}$ Een voorbeeld van een punt waarop helemaal geen rechtsmiddel openstaat, is de beslissing over toekenning van kosteloze rechtsbijstand. Een beslissing die van zo grote invloed is op de rechtspositie van verdachte en op basis van de huidige wettelijke regeling op zeer onduidelijke gronden wordt genomen, zou zeker zolang de wettelijke criteria op dit punt niet zijn aangescherpt ter toetsing aan een hogere rechter moeten kunnen worden voorgelegd. Hetzelfde geldt voor de beslissing toezicht uit te oefenen op het overleg of de correspondentie tussen advocaat en cliënt.

14 Het is de vraag in hoeverre de nog door te voeren wijzigingen als gevolg van de eerder genoemde uitspraak van het Grondwettelijk Hof op dit punt tot veranderingen zullen leiden. 
Tegen deze inperking van het recht op verdediging - waarover zonder tussenkomst van de rechter door de prokurator wordt beslist - staat momenteel geen rechtsmiddel open.

Voorbeelden van vage bewoordingen die onvoldoende bijdragen aan de vereiste precisering van wettelijke bevoegdheden kunnen onder meer worden gevonden in laatstgenoemde regeling van het vrij verkeer en de deelname aan onderzoekshandelingen in het vooronderzoek. De voor verschillende interpretaties vatbare terminologie die de wetgever in deze context heeft gebruikt, ${ }^{15}$ draagt niet of in ieder geval onvoldoende bij aan een wezenlijke verandering van de praktijk. Een van de vanuit verdedigingsperspectief problematische aspecten van het socialistisch strafproces was immers nu juist dat autoriteiten (te) veel vrijheid hadden wettelijke regels naar eigen inzicht uit te leggen en toe te passen.

Ook in de context van de kosteloze rechtsbijstandvoorziening is het gebruik van vage bewoordingen van invloed op de praktijk. In de eerste plaats doordat de onduidelijke grondslag voor toekenning van kosteloze rechtsbijstand op verzoek van verdachte sinds 1989 niet is gewijzigd of gepreciseerd. ${ }^{16}$ In de tweede plaats doordat de enige nuancering die de regeling in het nieuwe strafprocesrecht op dit punt wel heeft ondergaan ${ }^{17}$ zo algemeen en onduidelijk is geformuleerd dat de meerwaarde ervan uiterst beperkt is. De onduidelijkheid over de wettelijke grondslag voor toekenning van kosteloze rechtsbijstand en de vraag hoe de verdachte moet aantonen dat hij niet zelf in de kosten van de verdediging kan voorzien, heeft tot gevolg dat de rechter veel beoordelingsvrijheid heeft die - voornamelijk vanwege budgettaire beperkingen - doorgaans niet in het voordeel van verdachten wordt benut. $^{18}$

\subsubsection{Ontbreken praktische randvoorwaarden}

Van groot belang voor het in de praktijk brengen van nieuwe of uitgebreide verdedigingsrechten is bovendien dat een aantal van de nieuwe wettelijke mogelijkheden niet of onvoldoende is aangevuld met de noodzakelijke praktische randvoorwaarden. Dit maakt effectuering problematisch. Dit probleem doet zich voornamelijk voor in het kader van de rechtsbijstandverlening in de eerste fase na aanhouding. Het nieuwe strafprocesrecht kent de verdachte in dit vroege stadium van de procedure weliswaar een expliciet recht op rechtsbijstand toe maar de voorzieningen die noodzakelijk zijn voor verwezenlijking van dit recht ontbreken grotendeels. Zo is er - zoals hiervoor al eerder is opgemerkt - in deze eerste fase na aanhouding geen recht op door de overheid gefinancierde rechtsbijstand, zijn er door de overheid en de balie geen bijzondere praktische regelingen of voorzieningen getroffen die kunnen garanderen dat voor iedere aangehoudene op korte termijn

15 Zoals 'in uitzonderlijke gevallen' ('w szczególnie uzasadnionym wypadku') en 'in geval van een zwaarwegend onderzoeksbelang'('na ważny interes śledztwa').

16 Bepalend is of verdachte 'in staat is de kosten van de verdediging te dragen zonder daarmee nadeel toe te brengen aan zijn eigen noodzakelijke levensonderhoud en dat van zijn familie'.

17 De toevoeging 'op passende wijze' ('w sposób należyte') die betrekking heeft op de manier waarop de verdachte zijn financieel onvermogen dient aan te tonen.

18 Waarbij onder meer een rol speelt dat de kosten die met een toevoeging gepaard gaan uit een algemeen budget van de rechtbank moeten worden betaald, zie hierover hoofdstuk 4 , $\S 3.4 .1$. 
een advocaat beschikbaar is en zijn autoriteiten op geen enkele manier verplicht de aangehoudene behulpzaam te zijn bij het vinden van een advocaat. Verwezenlijking van het recht op rechtsbijstand na aanhouding is hierdoor in de praktijk voorbehouden aan een selecte groep verdachten die een advocaat kent en in staat is de kosten van de verdediging zelf te dragen.

De problemen die op dit punt bestaan, worden nog versterkt door de onduidelijke rechtspositie die de verdachte in de eerste fase na aanhouding heeft. Het onderscheid tussen 'verdachte persoon' ('osoba podejrzana') en 'verdachte' ('podejrzany') is weliswaar in theorie redelijk eenvoudig te maken maar kan in de praktijk - vooral waar het gaat om het zwijgrecht ${ }^{19}$ - tot onduidelijkheden leiden die van grote invloed zijn op de rechtspositie van de aangehoudene. De Poolse wetgever heeft tot op heden nagelaten deze onduidelijkheid op te heffen door genoemd onderscheid te laten vervallen en iemand direct na aanhouding de status van verdachte te verlenen met alle procedurele waarborgen die daaraan zijn gekoppeld. ${ }^{20}$ Wat hiervoor de reden is, kan niet met zekerheid worden gezegd: aan de ratio van het onderscheid en de noodzaak tot behoud ervan worden in Poolse bronnen weinig woorden vuil gemaakt. Juist omdat een duidelijke verklaring voor het formele onderscheid tussen 'verdachte' en 'verdachte persoon' ontbreekt, is niet uitgesloten dat het vooral wordt behouden omdat het opsporingsbelang gediend kan zijn bij de onduidelijke status die de aangehoudene hierdoor in de eerste fase na aanhouding heeft. Politie en justitie kunnen door iemand nog niet als verdachte aan te merken, voorkomen (of in ieder geval: tijdelijk uitstellen) dat hij op de hoogte moet worden gesteld van een aantal wezenlijke rechten waaronder het zwijgrecht. De zogenaamde letter of rights waarin een aantal belangrijke rechten schriftelijk is vastgelegd, dient namelijk pas voorafgaand aan het eerste verhoor te worden overhandigd: eventuele belastende verklaringen die de aangehoudene voor die tijd aflegt, mogen weliswaar niet voor het bewijs worden gebruikt maar kunnen hem uiteraard wel beperken in zijn verklaringsvrijheid bij latere verhoren en bovendien richtinggevend zijn voor het opsporingsonderzoek. De letter of rights - een novum in het nieuwe wetboek van strafvordering - boet hierdoor aanzienlijk aan betekenis in.

\subsubsection{Verschuivende zwaartepunten: ontwikkelingen in criminele politiek}

Een derde factor die van invloed is op het effect van de oorspronkelijk door de wetgever beoogde hervormingen is gelegen in meer recente ontwikkelingen op het terrein van de criminele politiek.

Het transitieproces dat de Poolse strafrechtspleging sinds het eind van de jaren tachtig doormaakt, eindigde uiteraard niet op het moment van inwerkingtreding van de nieuwe strafrechtelijke codificaties. Integendeel: in zekere zin werd toen pas een begin gemaakt. Nieuwe regels kunnen immers pas betekenis krijgen wanneer ze daadwerkelijk deel gaan uitmaken van de dagelijkse praktijk. Hierbij is een aanzienlijke remmende werking uitgegaan van de (vermeende) toename van criminaliteit als gevolg waarvan uiteindelijk nieuwe wetswijzigingen zijn doorgevoerd die de

19 Autoriteiten zijn niet verplicht de aangehoudene op zijn zwijgrecht te wijzen - deze verplichting ontstaat pas op het moment dat het eerste officiële verhoor aanvangt. Zie hoofdstuk 4 § 2.2.2.3.

20 Zoals recent ook is voorgesteld in de Poolse doctrine. Zie Daniuk e.a. 2006, p. 54-55. 
balans in het strafproces weer meer naar de kant van instrumentaliteit hebben doen uitslaan.

Hoewel een toenemende roep om repressie de laatste jaren duidelijk hoorbaar is in vrijwel alle Europese landen (en ook daarbuiten) kan in dit verband tot op bepaalde hoogte wel van een postcommunistisch verschijnsel worden gesproken. Alle landen van Centraal- en Oost-Europa hebben sinds de ineenstorting van het communistisch regime te maken gehad met sterk toenemende gevoelens van onveiligheid bij de bevolking. Of dit daadwerkelijk het gevolg is van stijgende criminaliteitscijfers wordt betwist. ${ }^{21}$ Hoe (on)realistisch de nieuwe gevoelens van onveiligheid ook moge zijn, feit is dàt ze er zijn en dat postcommunistische overheden geneigd zijn hier sterk op te reageren. Deze gevoeligheid voor maatschappelijke behoeftes kan enerzijds worden verklaard vanuit de neiging van postcommunistische regeringen om - in de hoop op stabiliteit - zoveel mogelijk tegemoet te komen aan de wensen van de kiesgerechtigde burger. ${ }^{22}$ Hierbij speelt waarschijnlijk ook mee dat de overheid met de ineenstorting van het communistisch regime een heel andere taak heeft gekregen en door alle privatiseringen de burger op bepaalde gebieden (zoals de sociale zekerheid) nog weinig te bieden heeft. Dit soort leemtes kan worden opgevuld door op een ander terrein - in dit geval de criminaliteitsbestrijding - een grotere rol te gaan spelen en de burger als compensatie voor de weggevallen vormen van overheidsvoorzieningen zoveel mogelijk veiligheid te garanderen. ${ }^{23}$ Anderzijds weegt ongetwijfeld mee dat de 'bruikbaarheid' van het strafrecht als politiek instrument deze categorie landen na decennialange communistische ervaringen op dit punt nog vers in het geheugen ligt. ${ }^{24}$

Bovengenoemde ontwikkelingen hebben in Polen tot gevolg gehad dat het strafrechtelijk klimaat steeds punitiever is geworden en de aandacht in het strafprocesrecht

21 Er lijkt wel sprake te zijn van veranderingen in soort en type criminaliteit - vooral een groei in georganiseerde criminele activiteiten - maar de vergelijking met de communistische periode geeft een enigszins vertroebeld beeld aangezien over dat tijdvlak nauwelijks betrouwbare criminaliteitscijfers beschikbaar zijn. Bovendien wordt in een vrije samenleving door de media veel meer aandacht besteed aan dit soort zaken waardoor het lijkt alsof het een grotere rol speelt. Zie Siegelbaum 2002, p. 104.

22 '(...) the postcommunist governments must please the voters, and in solving social policy puzzles they are naturally keen to hear what the public has to say (...). This is not just because the new governments are inherently more benevolent to the community than the communist governments used to be. The reason is rather more simple and less romantic: hearing what the community wants to say about social policy enables governments to make politically informed and strategically considered decisions, whose success is probably somewhat more likely than the success of any decisions that would be made in isolation from the public': Fatic 1997, p. 152-153. Zie uitgebreid over de vraag of meer repressie wel het antwoord is op de criminaliteitsproblematiek: Czapska en Kury 2002.

23 Zie meer algemeen over de link tussen de gedaanteverwisseling van de Westerse verzorgingsstaat en de verscherping van de strafrechtelijke aanpak die niet zozeer het gevolg is van stijgende criminaliteitscijfers maar vooral dient als 'techniek om de sociale problemen onzichtbaar te maken, problemen die de staat als bestuurlijk hendel van de collectiviteit en het algemeen belang, niet langer wil of kan benaderen': Wacquant 2004 (p. 20).

24 'Due to the states' historical impulse to counter the security threat posed by crime with heavyhanded autocracy, the explosion of crime in Eastern and Central Europe (or at least the widespread perception of one) has tested the resolve of the fledgling democracies to the rule of law': Siegelbaum 2002, p. 74 
weer meer op instrumentaliteit is komen te liggen. ${ }^{25}$ In een dergelijke sfeer ontstaat al gauw de neiging nieuwverworven vormen van rechtsbescherming op te offeren om tegemoet te komen aan de wens met een efficiënt en effectief strafproces het tij van de criminaliteitscrisis - hoe (ir)reëel deze ook moge zijn - te kunnen keren.

Meer recente wetswijzigingen laten zien dat de Poolse wetgever de oorspronkelijke doelstellingen van de postcommunistische hervormingen van het strafproces vrij snel weer uit het oog lijkt te zijn verloren. Vooral de grootschalige wijziging van 2003 waarbij tweederde van het strafprocesrecht werd aangepakt, is hier een goed voorbeeld van. De toenemende aandacht voor efficiëntie blijkt onder meer uit:

- de uitbreiding van uitzonderingen op het onmiddelijkheidsbeginsel,

- de deformalisering van het vooronderzoek,

- de toename van de mogelijkheden om strafzaken op alternatieve (consensuele) wijze of in afwezigheid van verdachte af te doen en

- de introductie van de anonieme getuige en de kroongetuige.

Sommige van de meer recente wetswijzigingen geven blijk van een groeiende eigen verantwoordelijkheid van de verdediging. ${ }^{26}$ Bovendien wordt aan de raadsman in toenemende mate een publieke functie toegekend. De opkomst van het fenomeen misbruik van procesrecht illustreert dit. ${ }^{27}$ De omvang van het verschijnsel is vooralsnog weliswaar beperkt maar dat de term de laatste jaren opduikt in de rechtspraak en bovendien aanleiding heeft gevormd voor verschillende wetswijzigingen geeft blijk van een tendens waarin het belang van de verdediging - net als in het socialistisch strafproces - op bepaalde punten weer ondergeschikt wordt gemaakt aan het belang van de maatschappij bij een snelle en effectieve afhandeling van strafzaken.

In de discussie over de meer recente ontwikkelingen binnen het strafprocesrecht wordt wel beargumenteerd dat deze aanpassingen noodzakelijk zijn omdat de postcommunistische wetgever de weegschaal oorspronkelijk teveel naar de kant van de rechtsbescherming heeft doen uitslaan. Dit standpunt is in retrospectief - gelet op toenemende druk die de laatste jaren op het strafrechtelijk apparaat is komen te liggen - weliswaar begrijpelijk maar mijns inziens niet juist. Om te beginnen is de wetgever aan het eind van de jaren negentig niet over één nacht ijs gegaan: aan de totstandkoming van de nieuwe strafrechtelijke codificaties is een langdurige voorbereiding vooraf gegaan en het heeft na de ineenstorting van het communistisch regime meer dan zeven jaar geduurd voordat het nieuwe wetboek van strafvordering inwerking trad. Kijkend naar de oorspronkelijke regeling van het strafprocesrecht kan niet worden volgehouden dat de positie van de verdediging daarin

25 Zie ook Krajewski 2004. Overigens dient wel onderscheid te worden gemaakt tussen enerzijds toenemende nadruk op punitiviteit en anderzijds streven naar meer efficiëntie in de strafrechtspleging. Het eerste is immers een politiek-inhoudelijke keuze terwijl het tweede - in theorie - neutraal is en niet noodzakelijk is verbonden met de doelstellingen die men met het strafrecht beoogt te bereiken. Het effect dat beide trends op de positie van de verdediging hebben, is echter veelal gelijk.

26 Zoals de regeling van de inzage van de processtukken voor sluiting van het vooronderzoek die sinds de wetswijziging van 2003 nog slechts plaatsvindt wanneer de verdachte of zijn raadsman daarom vraagt, zie hoofdstuk 5, § 3.2.2.

Zie hierover: hoofdstuk 6, §5. 
onevenredig veel ruimte werd geboden. Zoals in het voorgaande duidelijk is geworden, geldt immers dat in het nieuwe strafprocesrecht op wezenlijke punten nauwelijks veranderingen zijn doorgevoerd waardoor nog altijd aanzienlijke beperkingen voor de verdediging gelden die ook in het licht van het $\mathrm{EVRM}^{28}$ vatbaar zijn voor kritiek. Bovendien hebben veel nieuwe verdedigingsrechten slechts betekenis op papier omdat de praktische randvoorwaarden voor effectuering ervan niet (of onvoldoende) zijn vervuld. Onder die omstandigheden kan moeilijk worden volgehouden dat deze rechten teveel in de weg zouden staan aan een efficiënte procesvoering. ${ }^{29}$ Het standpunt dat de wetgever zich momenteel genoodzaakt ziet de scheve balans van het oorspronkelijke strafprocesrecht te herstellen, lijkt dan ook vooral een gelegenheidsargument te zijn dat de toenemende nadruk op efficiëntie en repressie moet kunnen rechtvaardigen. ${ }^{30}$

De verwachting is dat de nieuwe regering die in 2007 aan de macht is gekomen op strafrechtelijk terrein een andere, minder repressieve koers zal gaan varen. Momenteel (zomer 2008) wordt gewerkt aan een grootschalige wijziging van het wetboek van strafvordering die mogelijk een nieuwe fase in de transitie van het Poolse strafprocesrecht zal gaan markeren. ${ }^{31} \mathrm{Op}$ moment van afronding van dit onderzoek was de inhoud en de toekomst van dit wetsontwerp echter nog onzeker.

\subsubsection{Cultuur binnen de advocatuur: 'old habits die hard'}

De drie bovengenoemde factoren zouden de indruk kunnen wekken dat de oorzaken voor de geringe impact van postcommunistische hervormingen enkel en alleen bij de wetgever c.q. de overheid moeten worden gezocht. Dat is zeker niet het geval. Vooral ook de opstelling van de advocatuur is in twee opzichten van grote betekenis geweest. In de eerste plaats vanwege de mate waarin en de wijze waarop door advocaten gebruik wordt gemaakt van nieuwe (of uitgebreide) verdedigingsmogelijkheden en in de tweede plaats vanwege de rol die de beroepsgroep in het democratiseringsproces vervult.

\subsubsection{Aanwenden verdedigingsmogelijkheden}

In verschillende opzichten lijkt het optreden van de raadsman in een gemiddelde strafzaak vandaag de dag niet veel af te wijken van de situatie gedurende het communisme. Dit geldt met name voor de fase van het vooronderzoek - omdat daar het zwaartepunt van de postcommunistische hervormingen was gelegen - maar ook in het eindonderzoek blijkt de inbreng van de advocaat niet wezenlijk te zijn veranderd. De beperkte wijzigingen die zijn doorgevoerd om het onderzoek ter terechtzitting een meer tegensprekelijk karakter te geven (zoals de mogelijkheid schriftelijk te reageren op de akte van beschuldiging en de gewijzigde volgorde van verhoren

28 Zie hierna §3.2.2.

29 Wel was er in de oorspronkelijke regeling van het nieuwe strafprocesrecht een aantal specifieke bevoegdheden die (te) eenvoudig tot ongewenste vertraging van de procedure konden leiden (zoals de regeling voor het neerleggen van de verdediging op het onderzoek ter terechtzitting, zie hoofdstuk $6, \S 5.2 .3$ ) maar die kunnen niet de conclusie rechtvaardigen dat de wetgever over de gehele linie te ver is gegaan in het bieden van rechtsbescherming aan de verdachte.

30 Het is niet voor niets een standaardargument dat vaak door overheden wordt gebruikt om de rechten van de verdediging in te perken.

31 Zie eerder hoofdstuk 2, § 2.3.4. 
die op de zitting worden uitgevoerd) hebben in de praktijk niet of nauwelijks betekenis en de inbreng van de raadsman in de waarheidsvinding is nog altijd beperkt. Dat het aandeel van advocaten in het vooronderzoek in de eerste jaren na inwerkingtreding van het nieuwe wetboek van strafvordering niet noemenswaardig is veranderd, heeft veel te maken met de binnen de Poolse balie heersende overtuiging dat verdediging in strafzaken vooral een activiteit is die op het onderzoek ter terechtzitting plaatsvindt. Dit wordt door veel advocaten gepresenteerd als een welbewuste verdedigingstrategie: het onderzoek ter terechtzitting onder leiding van een onafhankelijke rechter biedt een veel gunstiger forum dan het vooronderzoek waarin de raadsman in veel opzichten afhankelijk is van de prokurator. Op dit strategie-argument valt gelet op het belang van het vooronderzoek voor de rest van de strafrechtelijke procedure natuurlijk het nodige af te dingen. Rechtsbijstand aan verdachten is immers meer dan het indienen van bewijsverzoeken en het pleiten op de zitting. Het geven van voorlichting en advies, het gezamenlijk bepalen van een verdedigingsstrategie, het informeren over de voortgang van de zaak en ook het bieden van een luisterend oor - allemaal activiteiten die voor een belangrijk deel in het vooronderzoek plaats zullen moeten vinden - zijn op zijn minst van even groot belang. Mijn indruk is dat in werkelijkheid ook andere - minder principiële factoren de passiviteit van advocaten in de eerste fase van het strafproces kunnen verklaren. Ten eerste is de advocatuur in de loop der jaren gewend geraakt aan een bepaalde praktijk waarin het vanwege de vele wettelijke beperkingen en de geldende machtsverhoudingen vrijwel onmogelijk was een rol van betekenis te spelen in het vooronderzoek. Nu veel van deze beperkingen zijn opgeheven en niet langer als argument voor stilzitten kunnen worden aangevoerd, blijkt dat veel advocaten helemaal niet zitten te wachten op een uitbreiding van (tijdrovende) verdedigingsmogelijkheden in het vooronderzoek. Daarbij speelt onder meer een rol dat de advocatuur vanwege de steeds schever wordende verhouding tussen het groeiend aantal strafzaken en de beperkte omvang van de beroepsgroep sinds 1989 te maken heeft gekregen met een toenemende werklast. Ook tijdgebrek lijkt dus aan genoemde passiviteit ten grondslag te liggen. ${ }^{32}$ Ten slotte zijn ook financiële overwegingen waarschijnlijk van invloed aangezien de hoogte van de vergoedingen in toevoegingszaken en de wijze waarop deze worden toegekend een actieve opstelling in het vooronderzoek niet bepaald stimuleren. Wat de oorzaak voor de passieve opstelling ook moge zijn, feit is dat deze afbreuk doet aan de oorspronkelijke bedoelingen van de postcommunistische wetgever om aan het recht op verdediging in het vooronderzoek meer inhoud en betekenis te geven.

Opvallend is dat de passiviteit van Poolse advocaten in het vooronderzoek in de huidige rechtswetenschappelijke literatuur veel minder vaak onderwerp van discussie is dan gedurende het communisme. Zoals hiervoor reeds werd opgemerkt, werd met name in de jaren zestig en zeventig door de doctrine veel gedebatteerd over (en empirisch onderzoek gedaan naar) de rol van de raadsman in het vooronderzoek en de redenen die aan zijn passieve opstelling ten grondslag lagen. Vandaag de dag lijkt de rechtswetenschap haar handen vol te hebben aan het bijhouden

32 Bij het spreken over 'hèt optreden van de Poolse advocaat in strafzaken' ligt uiteraard het gevaar van generalisatie op de loer. Benadrukt dient te worden dat het hier om een algemeen beeld gaat en dat er ongetwijfeld advocaten zijn die hier in hun dagelijkse praktijk sterk van afwijken en die door bovengenoemde kenschets dus te kort worden gedaan. 
en becommentariëren van de talrijke wetswijzigingen. Daarbij gaat de aandacht vooral uit naar de letter van de wet ${ }^{33}$ en minder naar het functioneren van wettelijke regels in de praktijk. Grootschalige onderzoeken naar het optreden van de advocaat in het strafproces zoals verricht in de jaren zeventig ${ }^{34}$ zijn sinds de inwerkingtreding van het nieuwe strafprocesrecht voor zover bekend niet meer verricht.

\subsubsection{Conservatisme van de balie}

Ook de beroepsorganisatie heeft een rol van betekenis gespeeld in het transitieproces. De balie heeft de laatste jaren laten zien vooral aandacht te hebben voor bescherming van haar eigen belangen. De discussie over autonomie op het terrein van toetreding en beroepsethiek heeft daarbij vrijwel alle aandacht van de beroepsgroep opgeslokt waardoor de belangen van de rechtszoekende burger niet de aandacht hebben gekregen die ze verdienen. Hoewel een autonome, onafhankelijke beroepsgroep uiteraard ook in het belang van de rechtszoekende is, heeft de conservatieve opstelling van de balie naar mijn mening niet bijgedragen aan een wezenlijke verbetering van de positie van de verdediging in strafzaken. Er is weinig actie ondernomen om bestaande wettelijke of praktische beperkingen op te heffen en om een bepaalde kwaliteit van rechtsbijstand in strafzaken te garanderen. Zo heeft de balie bijvoorbeeld weinig gedaan om de problemen in het kader van het toezicht op het vrij verkeer en inzake de kosteloze rechtsbijstandvoorziening aan de kaak te stellen. De gelatenheid en passiviteit op deze - voor de verdediging in strafzaken - essentiële punten staat in schril contrast tot de actieve, strijdlustige houding die de advocatuur inneemt als het gaat om kwesties die de onafhankelijkheid van de beroepsgroep betreffen. Ook van belang is dat tot op heden betrekkelijk weinig aandacht is besteed aan de gedragsrechtelijke normering van het optreden van de raadsman. De huidige gedragsregels bieden nauwelijks concrete aanknopingspunten voor de verdediging in strafzaken en hebben sinds 1989 geen noemenswaardige veranderingen ondergaan. Dat terwijl het nieuwe strafprocesrecht en de uitgebreide of nieuwe verdedigingsmogelijkheden die daarmee gepaard zijn gegaan daartoe toch wel aanleiding hebben gegeven. Enige herbezinning van de positie van de raadsman en een (her)formulering van wat wel en niet van hem mag worden verwacht (taken en verantwoordelijkheden) was zeker op zijn plaats geweest. Ook omdat uit onderzoek is gebleken dat Poolse advocaten in geval van twijfel over de toelaatbaarheid van een bepaalde actie eerder voor de veilige weg (niets doen) kiezen dan actief op zoek te gaan naar de grenzen van wat wel en niet geoorloofd is. Sommigen zien hierin een typisch postcommunistische houding die erop neerkomt dat alleen die handelingen worden verricht die expliciet zijn toegestaan in plaats van het - meer democratisch of liberale - uitgangspunt dat alles wat niet uitdrukkelijk is verboden in beginsel toelaatbaar moet worden geacht. ${ }^{35}$ Meer speci-

33 Zie over het legistisch karakter van de Poolse literatuur: hoofdstuk 1, § 6 .

34 Zie onder meer hoofdstuk 5, § 3.4.

35 Zoals verwoord door D. Swenson (Amerikaanse hoogleraar, Katholieke Universiteit Lublin) die op dit punt een vergelijking maakt met de Verenigde Staten: 'there is a mentality difference that doesn't just apply to lawyers but to everyone. In the USA people assume they can do something until someone tells them they can't, and even then they are likely to argue. In the postcommunist mentality the automatic assumption is: we can't do it either because it is not allowed or it won't do any good. I think this mentality applies in the legal field as well and it effects the way people do their job, they only do the formal minimum.' Bron: gesprek Swenson, september 2004,Lublin. 
fieke gedragsregels zouden ertoe kunnen bijdragen dat de advocaat in strafzaken zich zekerder voelt en een minder afwachtende houding aanneemt. Daarbij moet dan niet alleen worden gedacht aan het opstellen van gedragsregels die bepaalde gedragingen verbieden en de grenzen aan het optreden van de advocaat bepalen maar vooral ook aan het formuleren van gedragsrechtelijke verplichtingen tot (bepaalde vormen van) positief handelen die duidelijk maken wat in het kader van een effectieve verdediging in ieder geval dient te gebeuren.

Samengevat komt het erop neer dat de karaktertrekken van die balie die voor 1989 een al te vergaande invloed van het communistisch regime wisten te voorkomen, er sinds de politieke omwenteling aan in de weg hebben gestaan dat de beroepsorganisatie zich aanpast aan de eisen van de moderne tijd. Hoewel de mentaliteitsverandering die de Poolse advocatuur nodig heeft zich moeilijk door wettelijke regels of andersoortig overheidsingrijpen laat afdwingen, zouden de door de overheid geïnitieerde wijzigingen in de toetredingsprocedure ${ }^{36}$ op de langere termijn kunnen bijdragen aan de gewenste cultuuromslag. Simpelweg omdat het hierdoor eenvoudiger is geworden voor jonge, meer idealistische juristen om tot de beroepsgroep te worden toegelaten. Wat het effect hiervan op de lange termijn zal zijn, is nu echter nog moeilijk te zeggen.

\subsection{De normerende werking van het EVRM}

In dit onderzoek is ook aandacht besteed aan de vraag hoe de positie van de verdediging op grond van huidige wetgeving en praktijk zich verhoudt tot de voorwaarden die op grond van het Europees Verdrag tot bescherming van de rechten van de mens en de fundamentele vrijheden en de rechtspraak van het Europese Hof voor de rechten van de mens aan een effectieve verdediging kunnen worden gesteld. Geanalyseerd is in hoeverre de Poolse hervormingen op dit punt daadwerkelijk aansluiten bij de normen van het EVRM. Op basis van deze bevindingen kan een inschatting worden gemaakt van de mate waarin Straatsburgse uitgangspunten een relevante factor zijn (geweest) in dit onderdeel van het transitieproces. Voordat daartoe wordt overgegaan, zal eerst een aantal algemene opmerkingen worden gemaakt over de normerende werking van het EVRM in Polen.

\subsubsection{Algemene opmerkingen}

In de eerste plaats is van belang dat de landen van het voormalig Oostblok in hun relatie tot het EVRM een geheel andere positie innemen dan de 'oude democratieën' van Europa die betrokken zijn geweest bij de totstandkoming van het verdrag. Centraal- en Oost-Europese landen hebben zelf geen aandeel gehad in het opstellen van de normen van het EVRM: dit verschil in vertrekpunt vormt een belangrijke complicerende factor in de implementatie van verdragsnormen. ${ }^{37}$ Een van de prak-

Zie over de postcommunistische mentaliteit ook Milej 2004, p. 511: 'Not posing any problem in order to live a quiet life is still a virtue. This attitude was certainly born out of fear which was so real in the past times. Although it is not the case anymore, the brains are still enslaved and the said attitude remains. The rule of law begins in the heads; otherwise transition will not be completed.'

36 Zie hoofdstuk 8, § 2.4.3.

37 In de woorden van Seymour: 'The original members of the Council of Europe have had over thirty years to adjust their domestic law to the requirements of the ECHR. They decided themselves what substantive rights the ECHR would embrace in 1949 and some played a significant part in drafting 
tische consequenties van de 'late' toetreding van Polen is dat het lange tijd heeft geduurd voordat de pijnpunten van de huidige wettelijke regeling en praktijk aan het EHRM konden worden voorgelegd. Poolse burgers hebben weliswaar vanaf het begin ruimschoots gebruik gemaakt van het individueel klachtrecht maar tot voor kort had het gros van de zaken tegen Polen waarin strafvorderlijke kwesties centraal stonden betrekking op het oude strafprocesrecht van voor 1997.38 Omdat de strafwetgeving inmiddels was gewijzigd, was de betekenis van veel van deze uitspraken - en daarmee ook de normerende werking die ervan uitging - beperkt. Ook dient eraan te worden herinnerd dat de doorwerking van internationale mensenrechten in het nationale recht voor de postcommunistische rechtssystemen een relatief nieuw verschijnsel is dat tot voor kort geen onderdeel uitmaakte van de rechtscultuur. Gewend geraakt aan de jarenlange communistische terughoudende opstelling ten aanzien van internationaal recht en daarin vastgelegde individuele rechten en vrijheden heeft de Poolse rechtspleging erg moeten wennen aan het idee dat de normen van het EVRM rechtstreeks doorwerken. ${ }^{39}$ Hoewel de laatste jaren op dit punt zeker vooruitgang is geboekt, is de doorwerking van verdragsnormen in de dagelijkse strafrechtspraktijk - voornamelijk vanwege een gebrek aan kennis bij de meeste (feiten)rechters en advocaten - nog altijd beperkt. Dat de verdediging weinig gebruik maakt van Straatsburgse argumenten en dat deze als ze al worden aangevoerd bij lagere rechterlijke instanties doorgaans weinig gehoor vinden, is mede van invloed op de mate waarin het EVRM corrigerend kan werken. Hogere rechterlijke instanties zoals het Grondwettelijk Hof en het Hooggerechtshof spelen daarentegen wel een belangrijke rol in de implementatie van Straatsburgse regels in het Poolse strafproces. ${ }^{40}$

Dit zijn uiteraard niet de enige omstandigheden die de mate waarin het EVRM doorwerkt in de nationale (straf)rechtspleging beïnvloeden. Een tweetal andere factoren - waarvan de betekenis zich zeker niet beperkt tot Polen maar die ook in andere lidstaten een rol spelen - kan worden gevonden in het karakter van de rechtspraak van het EHRM. Hierbij is in de eerste plaats van belang dat uitspraken van het Europese Hof altijd sterk zijn verbonden met de omstandigheden van

the final document. Moreover, the jurisprudence has evolved gradually over a period of decades and member states have influenced that jurisprudence by the representations they have made before the Commission and Court. (...) If this is the case for founding members of the ECHR then one wonders how easy will it be for the new members of the Council of Europe to adapt their laws and practices to ensure compliance with the requirements of the Convention and its sophisticated jurisprudence', Seymour 1993, p. 250. Specifiek over Polen heeft Hofmański in dit verband geschreven dat: 'After half a century of totalitarism in Poland (...) it is a startling advance into a very different world in which human rights has matured over the same half-century. Our legislative and national practice which had developed under different standards for decades is compelled to confront new human rights standards which have been gradually but progressively carried to higher levels by the Strasbourg organs. Thus, the difficulties of Poland's task of incorporating the European Convention now that it has ratified it, must be measured on a different scale to that applied to Western European Countries', Hofmański 1995, p. 52-53.

38 De gemiddeld lange duur van strafechtelijke procedures en de Straatsburgse eis van uitputting van nationale rechtsmiddelen spelen hierbij uiteraard een rol.

39 Zie hoofdstuk 2, § 2.3. Wat overigens niet wegneemt dat deze terughoudendheid ook in andere - niet postcommunistische landen - kan worden gesignaleerd (zoals onder meer in Duitsland en het Verenigd Koninkrijk). 
het concrete geval. Bij beantwoording van de vraag of sprake is geweest van een eerlijk proces wordt immers telkens de procedure in zijn geheel bekeken. ${ }^{41}$ Een veroordelende uitspraak betekent maar zelden dat een nationale wettelijke regeling in abstracto wordt afgekeurd en er wordt doorgaans veel beoordelingsruimte gelaten aan (respectievelijk wetgevers en rechters van) lidstaten om omstreden regels verdragsconform aan te passen of uit te leggen. Of - en zo ja, welke - consequenties een uitspraak van het EHRM voor de strafrechtspleging heeft, is dus in grote mate afhankelijk van de interpretatie die er door nationale autoriteiten aan wordt gegeven. Een tweede beperking die gelegen is in de aard van de Straatsburgse rechtspraak betreft het feit dat het Europese Hof zich terughoudend opstelt waar het gaat om de kwaliteit van de verdediging. Vast uitgangspunt is immers dat de inhoud van de verdediging onafhankelijk door de raadsman en zijn cliënt moet kunnen worden bepaald en dat nationale autoriteiten en ook het EHRM zich daar in beginsel niet in mogen mengen. ${ }^{42}$ Dit betekent dat de mogelijkheden van het Europese Hof uiterst beperkt zijn wanneer de effectiviteit van de verdediging - zoals in Polen vooral in toevoegingszaken nogal eens het geval lijkt te zijn - in belangrijke mate wordt beinvloed door het optreden van de advocaat. Klachten die enkel betrekking hebben op de inhoud van de verdediging worden in de regel niet in behandeling genomen.

Ten slotte is ook de 'zachte aanpak' van de Raad van Europa van belang. Hiermee wordt gedoeld op de uiterst beperkte mogelijkheden die de organisatie heeft om in te grijpen wanneer een lidstaat niet aan haar verdragsverplichtingen voldoet. ${ }^{43}$ Elke lidstaat is weliswaar verplicht eigen uitspraken in acht te nemen ${ }^{44}$ maar nergens is bepaald dat ook rechtspraak tegen andere landen in de nationale wetgeving en praktijk moet worden 'verwerkt'. ${ }^{45}$ De snelle toetreding van veel postcommunistische landen in de eerste helft van de jaren negentig heeft laten zien dat voor lidmaatschap niet is vereist dat de transitie naar een democratische rechtsstaat reeds grotendeels is gerealiseerd: in die zin is de toetreding tot de Raad van Europa en de ratificatie van het EVRM meer te beschouwen als een intentieverklaring dan als een garantie dat aan de eisen van laatstgenoemd verdrag is voldaan. ${ }^{46} \mathrm{Er}$ valt veel te zeggen voor het 'open' beleid van de Raad van Europa - gebaseerd op het uitgangspunt dat de transitie en de realisatie van verdragsconforme rechtspleging in postcommunistische landen beter kan worden gerealiseerd 'onder de vleugels

41 Zie ook hoofdstuk 1, § 5.5 hoofdstuk 5, § 5.7.

42 'It follows from the independence of the legal profession from the State that the conduct of the defence is essentially a matter between the defendant and his counsel, whether counsel be appointed under a legal aid scheme or be privately financed. The Court agrees with the Commission that the competent national authorities are required under Article $6 \S 3$ (c) to intervene only if a failure by legal aid counsel to provide effective representation is manifest or sufficiently brought to their attention in some other way': Kamasinski t. Oostenrijk, EHRM 19-12-1989, nr. 9783/82, § 65.

43 Een voorbeeld van een uitzondering op deze regel: de interim-maatregel die het Europese Hof in 1999 tegen Turkije nam in de zaak tegen Öcalan (waarbij Turkije de garantie moest bieden dat Öcalan effectieve bijstand van zijn advocaten zou kunnen hebben).

44 Art. 46 lid 1 EVRM: 'De Hoge Verdragsluitende Partijen verbinden zich ertoe zich te houden aan de einduitspraak van het Hof in de zaken waarbij zij partij zijn.'

45 En al zou een dergelijke verplichting wel bestaan, dan nog beschikt de Raad van Europa niet over bindende instrumenten om naleving af te dwingen.

46 Dat geldt tot op bepaalde hoogte natuurlijk ook voor de oudere lidstaten uit WestEuropa: vrijwel dagelijks laat de rechtspraak van het EHRM zien dat ook in die landen overeenstemming met het EVRM geen vanzelfsprekendheid is. 
van de Raad van Europa' dan daarbuiten - maar het is de vraag of met de snelle toetreding de stimulans om de rechtspleging in overeenstemming te brengen met de eisen van het EVRM niet is afgenomen.

\subsubsection{Straatsburgse criteria voor effectieve verdediging en het Poolse strafprocesrecht}

Om te beginnen staat vast dat het Europees Verdrag tot bescherming van de rechten van de mens een rol van betekenis heeft gespeeld bij de oorspronkelijke postcommunistische hervormingen van het strafproces en de positie van de verdediging daarin. Zeker in de eerste jaren na de politieke omwenteling zijn verschillende veranderingen doorgevoerd met de intentie de nationale strafvorderlijke regelgeving (meer) in overeenstemming te brengen met de Straatsburgse norm. Een belangrijk voorbeeld - dat weliswaar niet direct betrekking heeft op de positie van de verdediging maar wel tot de meest voorname postcommunistische hervormingen van het Poolse strafprocesrecht wordt gerekend - betreft de overheveling van de bevoegdheid over voorlopige hechtenis te oordelen van de prokurator naar de rechtbank. Een wijziging die noodzakelijk was gelet op de eisen van art. 5 lid 3 EVRM. ${ }^{47}$

Specifiek voor de verdediging is in ieder geval van belang dat in het wetboek van strafvordering van 1997 verschillende nieuwe bepalingen zijn opgenomen en wijzigingen zijn doorgevoerd die aansluiten bij de voorwaarden voor een effectieve verdediging zoals geformuleerd door het EHRM. Hierbij dient onder meer te worden gedacht aan de volgende thema's:

- de wettelijke garantie van rechtsbijstand in de eerste fase na aanhouding (nieuw art. 245 en 301 KPK 1997),

- de introductie van de mogelijkheid voor de verdediging om bij de rechtbank bezwaar in te stellen tegen aanhouding en detentie door de politie (nieuw art. 247 KPK 1997),

- de uitbreiding van de mogelijkheden van de raadsman om deel te nemen aan zittingen waarop over de voorlopige hechtenis wordt beslist (onder meer art. 249 lid 5 KPK 1997) en

- het aan banden leggen van de mogelijkheid briefwisseling tussen advocaat en gedetineerde cliënt aan controle te onderwerpen (art. 73 KPK en 8 KKW 1997).

Als gevolg hiervan is het Poolse strafproces - in ieder geval op papier - op bepaalde punten meer 'Straatsburgproof' geworden. In sommige opzichten biedt het Poolse strafprocesrecht zelfs meer bescherming dan de (minimum)garanties die in het EVRM besloten liggen. Dit geldt in ieder geval voor het expliciete recht van de raadsman aanwezig te mogen zijn bij verhoren van zijn cliënt aangezien de rechtspraak van het Europese Hof inmiddels heeft laten zien dat een dergelijk (onvoorwaardelijk) aanwezigheidsrecht niet aan art. 6 EVRM kan worden ontleend.

Benadrukt dient te worden dat bovengenoemde wijzigingen lang niet altijd plaatsvonden als reactie op een 'veroordelende' uitspraak van het Europese Hof tegen Polen - integendeel: de meeste hervormingen zijn in een vroeg stadium van de transitie doorgevoerd waarbij dergelijke rechtspraak tegen Polen (nog) niet beschikbaar was en de wetgever slechts inspiratie kon putten uit uitspraken tegen andere

47 Aangezien de prokurator niet kon worden aangemerkt als judicial officer in de zin van art. 5 lid 3 EVRM. Zie hoofdstuk 2, § 2.3.2. 
landen. De wijzigingen in het kader van de controle op de correspondentie zijn daar een goed voorbeeld van: de nieuwe wettelijke regeling dat briefwisseling tussen raadsman en verdachte uitsluitend in de aanwezigheid van de gedetineerde geopend mag worden wanneer er een gerechtvaardigd vermoeden bestaat dat deze verboden voorwerpen bevat, is duidelijk geënt op de vaste rechtspraak van het EHRM op dit punt. ${ }^{48}$ Pas nadat deze nieuwe regels in het Poolse strafprocesrecht waren geïncorporeerd, werd de oude regeling - op grond waarvan alle correspondentie van voorlopig gehechte verdachten onbeperkt kon worden gecontroleerd in verschillende zaken tegen Polen door het EHRM in strijd met art. 8 EVRM geoordeeld.

Hoewel het Poolse strafprocesrecht dus op verschillende punten wijzigingen heeft ondergaan die een effectieve verdediging zoals gegarandeerd door art. 6 EVRM onder gunstiger omstandigheden dan voor 1989 mogelijk zouden moeten maken, resteren er vanuit Straatsburgs perspectief ook nog (wezenlijke) problemen. Deze hebben - zoals in het bovenstaande eerder is benadrukt - voornamelijk betrekking op:

- het terrein van de gefinancierde rechtshulp,

- de toegang tot (kosteloze) rechtsbijstand in de eerste fase na aanhouding,

- de inzage van processtukken gedurende het vooronderzoek,

- het persoonlijk overleg tussen advocaat en cliënt en

- de bescherming van het beroepsgeheim bij de toepassing van opsporingsbevoegdheden.

Een deel van deze 'pijnpunten' is inmiddels reeds bevestigd in uitspraken van het Europese Hof tegen Polen en in sommige gevallen - zoals ten aanzien van de toegang tot kosteloze rechtsbijstand in de eerste fase na aanhouding en het toezicht op het overleg tussen advocaat en cliënt - ook gesignaleerd door het CPT. De wetgever heeft daarin tot op heden echter geen aanleiding gezien om tot (verdergaande) wijzigingen over te gaan.

Dit geldt ook voor de regeling (en de daarop gebaseerde praktijk) van de inzage van processtukken in het vooronderzoek: in de dagelijkse strafrechtspraktijk een van de grootste obstakels voor de verdediging. Uit verschillende uitspraken tegen Polen blijkt inmiddels dat een al te rigide toepassing van de wettelijke regeling op dit punt - art. 156 lid 5 KPK 1997 - in geval van voorlopige hechtenis strijd op kan leveren met art. 5 en 6 EVRM. ${ }^{49}$ Vooralsnog heeft genoemde bepaling sinds de inwerkingtreding van het nieuwe wetboek van strafvordering echter geen veranderingen ondergaan. Wel is ingrijpen door de nationale wetgever zeer recent 'afgedwongen' door het Grondwettelijk Hof. Laatstgenoemde instantie heeft - onder verwijzing naar relevante Straatsburgse rechtspraak op dit punt - art. 156 lid 5 KPK 1997 in strijd met het constitutionele recht op verdediging geoordeeld waardoor wetswijziging nu niet langer uit kan blijven. ${ }^{50}$ Dit is een sprekend voorbeeld van de belangrijke rol van het Grondwettelijk Hof in de doorwerking van internationale

48 Met name Campbell t. Verenigd Koninkrijk, EHRM 25-3-1992, A233, nr. 13590/88, zie hoofdstuk 7, § 3.5.

49 Chruściński t. Polen, EHRM 6-11-2007, nr. 22755/04 en Łaszkiewicz t. Polen, EHRM 15-1-2008, nr. 28481/03, zie hoofdstuk 5, § 3.5 .

50 Zie over deze uitspraak van 3 juni 2008 (K 42/07) ook hoofdstuk 5, § 3.6. 
mensenrechten: door een nationale bepaling onder verwijzing naar Straatsburgse normen ongrondwettelijk te verklaren, wordt de wetgever gedwongen actie te ondernemen.

De problematiek in het kader van het (auditief) toezicht op persoonlijk overleg tussen advocaat en gedetineerde cliënt is nog niet inhoudelijk behandeld door het EHRM. Gelet op de bestaande Straatsburgse jurisprudentie waaruit duidelijk blijkt dat auditief toezicht zoveel mogelijk vermeden dient te worden, is echter zeer waarschijnlijk dat dit onderdeel van de regeling van het vrij verkeer - of in ieder geval de praktische uitwerking ervan - de toets der kritiek niet zal kunnen doorstaan. Dat het feit dat de toezichthouder zich binnen gehoorafstand bevindt, moeilijk verenigbaar is met art. 6 EVRM wordt ook wel bevestigd in de Poolse literatuur maar het is zeker geen onderwerp waar veel woorden aan vuil worden gemaakt. Overigens heeft het Grondwettelijk Hof op dit punt geen soelaas kunnen bieden: een klacht over het toezicht en de gevolgen ervan voor het grondwettelijk recht op verdediging werd in 2004 niet gegrond verklaard..$^{51}$ Inmiddels is over deze kwestie wel een zaak in Straatsburg aanhangig. ${ }^{52}$ Hoewel deze klacht betrekking heeft op het oude strafprocesrecht ${ }^{53}$ kan de uitspraak wel degelijk van belang zijn voor de huidige situatie aangezien het meer algemeen het ontbreken van een mogelijkheid tot vertrouwelijk overleg in het vooronderzoek betreft. Veel zal echter afhangen van de manier waarop de uitspraak door het Europese Hof wordt geformuleerd en in hoeverre daarin aan de Poolse autoriteiten ruimte wordt gelaten voor de interpretatie dat dit soort toezicht geen strijd oplevert met een eerlijk proces zolang het slechts tijdelijk van aard is en de verdachte later in de procedure alsnog de mogelijkheid heeft om ongehinderd met zijn advocaat te overleggen. ${ }^{54}$

Uit bovenstaande voorbeelden kan mijns inziens worden afgeleid dat de normerende werking van het EVRM sterk afhankelijk is van de vraag in hoeverre een bepaalde kwestie binnen de landsgrenzen (door nationale autoriteiten, de advocatuur en tot op bepaalde hoogte ook de doctrine) als problematisch wordt beschouwd. Dit blijkt ook uit de wijze waarop en de mate waarin het beroepsgeheim van de advocaat bescherming wordt geboden in de wettelijke regeling van bepaalde opsporingsbevoegdheden. Een blik op de Poolse strafvorderlijke regeling van met name de telefoontap leert immers dat de positie van de advocaat als professionele geheimhouder daarin op geen enkele manier wordt beschermd. ${ }^{55}$ Dat terwijl de rechtspraak van het Europese Hof er geen twijfel over laat bestaan dat het nationale recht bepaalde waarborgen moet bieden wanneer het - zoals in Polen - mogelijk is dat gesprekken waaraan advocaten deelnemen, worden afgeluisterd. Dat de bescherming van het beroepsgeheim op dit punt tekortschiet, is in Polen echter geen (wezenlijk) onderwerp van discussie. Noch de advocatuur noch de literatuur lijkt

51 Zie over deze uitspraak d.d. 17 februari 2004: hoofdstuk 7, § 2.6.2.

52 Rybacki t. Polen, EHRM 9-10-2007, nr. 52479/99 (ontvankelijkheidsbeslissing). Zie hoofdstuk 7, § 2.6.3.2.

53 Art. 64 KPK 1969: op grond waarvan toezicht op het vrij verkeer nog voor de duur van vrijwel het gehele vooronderzoek mogelijk was.

54 Dat dit momenteel het heersende standpunt is, blijkt uit het verweer van de Poolse regering in de zaak Rybacki ( $\$ 6$ van de ontvankelijkheidsbeslissing).

55 Zie hoofdstuk 7, §8. 
zich er druk over te maken en daarmee is er blijkbaar ook weinig stimulans voor de wetgever om op dit punt actie te ondernemen.

Het voorgaande rechtvaardigt de conclusie dat de normerende werking van het EVRM - in ieder geval waar het gaat om die aspecten van het Poolse strafproces die een effectieve verdediging beogen te garanderen - in de loop der jaren lijkt te zijn afgezwakt. Met de totstandkoming van het nieuwe strafprocesrecht in 1997 zijn bepaalde stappen gezet om de positie van de verdediging in het strafproces meer in overeenstemming te brengen met de eisen van het Europees Verdrag maar al snel werd duidelijk dat er grenzen aan dit streven waren gesteld. ${ }^{56}$ Naarmate het transitieproces vorderde, de strafrechtspleging steeds meer oplossingen moest bieden voor urgente problemen en de complexiteit van strafrechtelijke vraagstukken en bijbehorende wetgeving toenam, is de aandacht in het wetgevingsproces steeds meer op instrumentele (politieke) en minder op rechtsbeschermende (mensenrechtelijke) perspectieven komen te liggen. Deze ontwikkeling laat zien dat het rechtsstatelijk elan uit de beginfase van de transitie al vrij snel plaats heeft moeten maken voor de praktische behoeftes van effectieve criminaliteitsbestrijding. Dat het Straatsburgse argument hierdoor aan kracht heeft verloren, blijkt in ieder geval uit het feit dat de wetgever tot op heden geen actie heeft ondernomen de niet geringe probleempunten op te heffen die het huidige strafprocesrecht - gelet op de eisen die op grond van het EVRM aan een effectieve verdediging mogen worden gesteld vandaag de dag nog steeds laat zien.

\section{Slotbeschouwing: Poolse lessen over de 'maakbaarheid' van effectieve verdediging}

Dit boek is begonnen met een korte beschouwing over de pogingen die de laatste jaren op Europees niveau zijn ondernomen om te komen tot gemeenschappelijke minimumwaarborgen voor het bieden van rechtsbescherming aan burgers binnen de EU. ${ }^{57}$ De onderhandelingen die in dit verband tot op heden tussen lidstaten zijn gevoerd, illustreren hoe ingewikkeld het is om eensgezindheid te bereiken over dergelijke minimumgaranties die vervolgens door nationale overheden in het strafproces moeten worden geïmplementeerd. Naar aanleiding hiervan is de vraag opgeworpen wat het (mogelijk) effect is van dit soort initiatieven waarbij - zoals in Polen sinds de ineenstorting van het communistisch regime is gebeurd - door aanpassing van het strafproces wordt getracht een bepaalde standaard van rechtsbescherming te garanderen. De laatste vraag die in deze conclusie dan ook niet onbeantwoord mag blijven, is wat het Poolse transitieproces ons leert over de mogelijke effecten van een door de overheid geïnitieerde optimalisering van verdedigingsrechten. Met andere woorden: welke inzichten bieden de ontwikkelingen

56 Dat de invloed van het Europees Verdrag op de ontwikkeling van het strafprocesrecht geleidelijk aan zou afnemen, werd met een vooruitziende blik in 1995 reeds voorspeld door Hofmański (een Poolse autoriteit op het gebied van het EVRM): 'Parliament's efforts to take account of the Convention in its legislation, however have increased. (...) The fear, however, is that such efforts will diminish, especially in respect to penal procedural guarantees. (...) There are loud voices calling for all-out war against the threat of crime, even if it means constricting human rights': Hofmański 1995, p. 50-51.

57 Zie hoofdstuk 1, § 2. 
die in dit onderzoek onder de loep zijn genomen over de 'maakbaarheid' van het recht op een effectieve verdediging?

Het transitieproces dat zich in Polen heeft voltrokken, heeft om te beginnen laten zien dat het in de wet opnemen van bepaalde rechten en bevoegdheden nog niet betekent dat deze ook in de praktijk kunnen worden geëffectueerd. Dat is op zich zelf niets nieuws maar interessant is wel dat het Poolse voorbeeld aan het licht heeft gebracht welke factoren van invloed zijn op de vraag of papieren verdedigingsrechten ook daadwerkelijk (kunnen) bijdragen aan een effectieve verdediging.

\subsection{De waarde van wetgeving: formulering, effectief toezicht en onderlinge samenhang}

Ten eerste is geconstateerd dat de factoren die het effect van dit soort hervormingen bepalen voor een deel in de wetgevingssfeer liggen. Daarbij is in de eerste plaats uiteraard van belang op welke wijze een bepaalde wettelijke regeling wordt vormgegeven. Het gebruik van vage bewoordingen en de mate waarin daarbij wordt voorzien in effectief toezicht op besluitvorming zijn in dit verband relevant. Vooral in een rechtssysteem dat tracht af te rekenen met een praktijk waarin aan de met opsporing en vervolging belaste autoriteiten teveel beoordelingsvrijheid werd gegeven, is van groot belang dat wettelijke bepalingen zorgvuldig worden geformuleerd zodat zo min mogelijk twijfel bestaat over de vraag op welk moment en onder welke condities en voorwaarden bepaalde bevoegdheden kunnen worden uitgeoefend. Indien op voor de verdediging essentiële punten nog een ruime beoordelingsmarge aan politie of justitie wordt gegeven (bijvoorbeeld bij het verlenen van toestemming voor effectuering van bepaalde verdedigingsrechten zoals de inzage van het procesdossier of deelname aan onderzoekshandelingen) is vervolgens van belang dat daarbij in effectief toezicht wordt voorzien. Wanneer het openbaar ministerie vooral belast is met opsporing en vervolging van strafbare feiten en dientengevolge de voor de controle op de rechtsbescherming noodzakelijke onafhankelijkheid ontbeert, veronderstelt effectief toezicht in beginsel dat het door de rechtbank wordt uitgeoefend. De effectiviteit van toezicht wordt uiteraard niet alleen bepaald door de vraag welke persoon of instantie met de uitoefening ervan is belast. Ook van belang is op welke wijze het wordt vormgegeven: binnen welke termijn van een bezwaarmogelijkheid gebruik kan worden gemaakt, hoe snel erop dient te worden beslist, welke sanctiemogelijkheden kunnen worden toegepast et cetera. Om een (Pools) voorbeeld te noemen: de mogelijkheid de beslissing van de prokurator dat persoonlijk contact tussen raadsman en cliënt gedurende de eerste veertien dagen van de voorlopige hechtenis alleen onder toezicht kan plaatsvinden, te laten toetsen door een rechter - een rechtsmiddel waarin het huidige Poolse strafprocesrecht zoals bekend niet voorziet - is gelet op de betrekkelijk korte periode waarbinnen de supervisie kan worden uitgeoefend alleen zinvol wanneer daarop binnen zeer korte termijn dient te worden beslist.

Het onderzoek heeft bovendien laten zien dat het effect van een wettelijke norm niet alleen wordt beïnvloed door de wijze waarop deze wordt geformuleerd maar ook door de onderlinge samenhang met andere regels: veel verdedigingsrechten zijn afhankelijk van andere rechten waardoor ze niet op zich zelf maar in een bepaalde context dienen te worden beoordeeld.58 Ook dit aspect is nog in de wetgevings-

58 Zie meer algemeen over de procedurele vormgeving van de individuele vrijheid van verdachten en de verschillende - onderling samenhangende - voorwaarden die daaraan 
sfeer gelegen. Het Poolse strafprocesrecht demonstreert dat wanneer een wettelijke regeling op bepaalde wezenlijke punten nog tekortkomingen vertoont andere hervormingen die een effectieve verdediging beogen te garanderen veel van hun betekenis kunnen verliezen. Zo zijn de resterende beperkingen in de wettelijke regeling van de kosteloze rechtsbijstand (de onduidelijke wettelijke grondslag en het ontbreken van een recht op toevoeging na aanhouding), de informatiepositie van de verdediging (de ruime mogelijkheden om inzage te weigeren) en het vrij verkeer (met name het auditieve toezicht op persoonlijk overleg) bepalend voor de wijze waarop de verdediging in het vooronderzoek functioneert en vormen ze een belangrijke verklaring waarom de verschillen met het communistisch tijdperk in de praktijk niet zo groot zijn als men wellicht zou verwachten. Bijvoorbeeld de ruimte die op grond van het huidige strafprocesrecht aan de prokurator wordt geboden om de verdachte en zijn raadsman gedurende het vooronderzoek inzage in het dossier te weigeren, heeft een grote invloed op de mate waarin de verdediging gebruik kan maken van een aantal andere bevoegdheden die zij in het vooronderzoek heeft. Het effect van de tamelijk ruime wettelijke mogelijkheden die onder meer in het kader van de bewijsvergaring en de voorlopige hechtenis in het nieuwe strafprocesrecht aan de raadsman worden geboden, boeten hierdoor aanzienlijk aan betekenis in. Het Poolse strafprocesrecht illustreert ook hoe bepalend definities in dit verband kunnen zijn. Zo is het onderscheid tussen 'verdachte' en 'verdachte persoon' van doorslaggevende invloed op de reikwijdte van verschillende verdedigingsrechten. Dit geldt onder meer voor het recht om voorafgaand aan het eerste verhoor schriftelijk te worden geïnformeerd over bepaalde belangrijke rechten en bevoegdheden (letter of rights): de echte waarde van deze regeling - in het nieuwe strafprocesrecht geïntroduceerd om de rechtspositie van verdachten te verbeteren - kan alleen worden beoordeeld door de betekenis van het onderscheid tussen 'verdachte' en 'verdachte persoon' in aanmerking te nemen. ${ }^{59}$ De praktische waarde van een wettelijk gegarandeerd recht wordt dus niet alleen bepaald door de reikwijdte van de betreffende wettelijke regeling en de mate waarin op de naleving daarvan effectief toezicht kan worden uitgeoefend maar ook door de inhoud van andere wettelijke regels die op het betreffende recht van invloed zijn.

\subsection{Effectuering van wettelijke normen: praktische randvoorwaarden, rechtscultuur en stabiliteit in regelgeving}

Een tweede constatering is dat als de wetgever er gelet op bovengenoemde punten in slaagt een adequate wettelijke regeling te realiseren die een effectieve verdediging in strafzaken op papier mogelijk maakt, de verwezenlijking ervan vervolgens afhankelijk is van verschillende factoren die nog slechts voor een deel binnen de invloedssfeer van de wetgever - of meer algemeen: de overheid - liggen.

In de eerste plaats is van belang of behalve de wettelijke garanties ook de praktische randvoorwaarden zijn vervuld die nodig zijn om invulling te geven aan wettelijke rechten en bevoegdheden. De wijze waarop en de mate waarin de noodzakelijke condities voor effectuering van het recht op verdediging zijn gerealiseerd, kan

kunnen worden gesteld ook: Peters 1975, p. 104 e.v.

59 Genoemde schriftelijke informatie wordt immers pas overhandigd wanneer iemand formeel als verdachte is aangemerkt en kan om die reden na aanhouding nog aanzienlijke tijd worden onthouden. 
tot op bepaalde hoogte door de overheid worden beïnvloed. Het gaat hierbij onder meer om het bieden van een adequaat stelsel van gefinancierde rechtshulp en praktische voorzieningen die rechtsbijstandverlening direct na aanhouding kunnen garanderen. ${ }^{60}$ Aan het Poolse transitieproces kan een aantal voorbeelden worden ontleend die laten zien dat het ontbreken van dergelijke faciliteiten tot gevolg kan hebben dat een recht dat in theorie een aanzienlijke verbetering van de rechtspositie van verdachten betekent in de praktijk niet meer is dan een lege huls. ${ }^{61}$ Dat deze voorzieningen niet worden gerealiseerd, heeft behalve met financiële beperkingen ook te maken met de mentaliteit die vereist is om daadwerkelijk handen en voeten te willen geven aan nieuwe of uitgebreide wettelijke mogelijkheden. ${ }^{62}$ Dit brengt me bij een tweede punt. Voor het toepassen of effectueren van wettelijke regels die een effectieve verdediging beogen te garanderen, is namelijk ook de binnen de strafrechtspleging heersende rechtscultuur van belang en die ligt grotendeels buiten de invloedssfeer van de overheid. Hierbij dient te worden benadrukt dat de praktische betekenis van verdedigingsrechten niet alleen afhankelijk is van de vraag in hoeverre ze door (opsporende, vervolgende en berechtende) autoriteiten worden gerespecteerd maar ook van de vraag of - en zo ja in welke mate - ze door de advocatuur worden benut. Wat laatstgenoemd punt betreft, heeft het Poolse transitieproces in ieder geval twee dingen duidelijk gemaakt: enerzijds hoe belangrijk de rol van de balie als beroepsgroep en de daarbinnen levende opvattingen en tradities zijn voor de dagelijkse praktijk en anderzijds hoe moeilijk het is om daar van buitenaf invloed op uit te oefenen. De opvatting dat een actieve verdediging in het vooronderzoek doorgaans niet in het voordeel van de verdediging is, blijkt tot op heden hardnekkiger te zijn dan het streven van de postcommunistische wetgever om de rol van de raadsman in deze fase van de procedure meer inhoud te geven. Dit illustreert hoe belangrijk het is dat voor initiatieven die de overheid onderneemt om een effectieve verdediging mogelijk te maken ook draagvlak bestaat bij degenen die er (beroepsmatig) in de praktijk invulling aan moeten gaan geven.

In de derde plaats moet niet worden vergeten dat het ontstaan van een dergelijk draagvlak - en de rechtsculturele veranderingen die daar mogelijk mee gepaard dienen te gaan - wel de nodige tijd moeten worden gegund. Op de implementatie van wetswijzigingen die de positie van de verdediging beogen te versterken, is immers ook van invloed of nieuwe wettelijke regels voldoende tijd krijgen om te 'gedijen' in de dagelijkse strafrechtspraktijk. Het straf(proces)recht is een dynamisch rechtsgebied dat sterk wordt beïnvloed door heersende opvattingen over criminaliteit en de wijze waarop daartegen moet worden opgetreden. De Poolse transitie heeft laten zien hoe snel een oorspronkelijk streven om de verdediging in het straf-

60 Zoals eerder opgemerkt, is het waarborgen van het recht op kosteloze rechtsbijstand ook in belangrijke mate afhankelijk van het wettelijke kader waarin het is uitgewerkt. Minstens van even groot belang is echter of dit wettelijke kader wordt aangevuld met de praktische voorzieningen en faciliteiten die noodzakelijk zijn om gratis rechtsbijstand te kunnen bieden op het moment dat verdachten daar behoefte aan hebben.

61 Dit geldt onder meer voor de wettelijke garantie van het recht op rechtsbijstand direct na aanhouding.

62 Anders kan niet worden verklaard waarom ook betrekkelijk eenvoudige en goedkope aanpassingen in sommige gevallen (zoals het ter beschikking stellen van lijsten met advocaten op politiebureaus om rechtsbijstand in de eerste fase na aanhouding te vergemakkelijken) uitblijven. 
proces meer ruimte te bieden, kan worden ingehaald door nieuwe ontwikkelingen op het terrein van de criminele politiek die vooral op een snelle en effectieve misdaadbestrijding zijn gericht. Wanneer deze gewijzigde opvattingen uiteindelijk in wetswijzigingen worden omgezet, bestaat het gevaar dat het nieuwe evenwicht in het strafproces al weer wordt verstoord voordat de praktijk er ook maar enigszins aan heeft kunnen wennen.

\subsection{De betrekkelijkheid van de normerende werking van het EVRM}

Een derde en laatste constatering betreft de rol van het EVRM en de normerende werking die van dit verdrag uitgaat wanneer men op nationaal niveau een bepaalde graad van rechtsbescherming tracht te realiseren. Een veelgehoord argument van de tegenstanders van eerdergenoemd Europees initiatief om te komen tot gemeenschappelijke procedurele waarborgen voor verdachten in strafzaken is dat het EVRM daarin al voorziet en dat een tweede Europees instrument dus overbodig is. ${ }^{63}$ De waarde van dit argument is natuurlijk afhankelijk van de mate waarin het Europees Verdrag daadwerkelijk kan bijdragen aan een hogere graad van rechtsbescherming in de lidstaten van de Raad van Europa. ${ }^{64}$ Ook op dit punt bieden de ontwikkelingen die het Poolse strafprocesrecht sinds de val van het communisme en de ratificatie van het EVRM heeft doorgemaakt bepaalde inzichten.

Ratificatie van het verdrag betekent natuurlijk nog niet dat nationale regelgeving en praktijk volledig in overeenstemming met Straatsburgse normen zijn: de rechtspraak van het EHRM laat zien dat problemen met de naleving van verdragsbepalingen zich niet beperken tot Polen of de postcommunistische landen maar in alle lidstaten van de Raad van Europa kunnen worden gesignaleerd. Dat in dit onderzoek is vastgesteld dat de situatie in Polen op bepaalde punten strijdig is met de voorwaarden die op grond van het EVRM aan een effectieve verdediging kunnen worden gesteld, is dan ook weinig verrassend. Opvallend is wel dat een aantal van deze 'pijnpunten' zoals de problematiek in het kader van de inzage van processtukken en het toezicht op het vrij verkeer ${ }^{65}$ ook in Polen wordt geconstateerd zonder dat dit tot op heden tot overheidsingrijpen heeft geleid. Het Poolse transitieproces illustreert mijns inziens dat de normerende werking die van het EVRM uitgaat beperkingen kent en van veel verschillende - onder meer rechtsculturele en crimineelpolitieke - factoren afhankelijk is waarop door Straatsburg niet of nauwelijks invloed kan worden uitgeoefend. Het zou echter verkeerd zijn uit deze beperkte normerende werking van het EVRM af te leiden dat Straatsburgse normen geen enkele rol van betekenis kunnen spelen wanneer men op nationaal niveau een verhoging van de graad van rechtsbescherming tracht te realiseren. Het EVRM en de rechtspraak van het EHRM bieden belangrijke inzichten in de eisen die in een democratische rechtsstaat aan een eerlijk proces moeten worden gesteld en welke randvoorwaarden daarbij moeten worden vervuld om een effectieve verdediging te kunnen garanderen. Deze uitgangspunten zouden de primaire bron van inspiratie

63 Zie hoofdstuk $1, \S 2$.

64 En vervolgens natuurlijk ook van de vraag in hoeverre van een kaderbesluit (waarin de gemeenschappelijke waarborgen op EU niveau zouden worden vastgelegd) een sterkere normerende werking kan worden verwacht omdat het een ander soort instrument is dan het EVRM.

65 Zie § 3.2.2. 
moeten zijn voor elke lidstaat die door aanpassing van het strafproces de positie van de verdediging tracht te versterken. Of dat ook gebeurt en op welke wijze daarbij invulling wordt gegeven aan de normen die aan het EVRM kunnen worden ontleend, is echter grotendeels overgelaten aan de beoordelingsvrijheid van de betreffende lidstaat.

\subsection{Effectieve verdediging als 'maakbaar' recht: mogelijkheden en beperkingen van juridische instrumenten}

Wat betekent dit alles nu voor wetswijzigingen en andersoortige overheidsinitiatieven die zijn bedoeld om de positie van de verdediging in een strafproces te versterken? Uit de Poolse ontwikkelingen kan in ieder geval worden afgeleid dat de factoren die de effectiviteit van dit soort initiatieven bepalen (formulering en onderlinge samenhang van wettelijke normen, effectief toezicht, praktische randvoorwaarden, rechtscultuur en stabiliteit in regelgeving) uiterst complex zijn. ${ }^{66}$ Dit betekent mijns inziens dat de praktische waarde van elk rechtsinstrument - ongeacht van welke aard en op welk niveau (nationaal of internationaal) - dat bedoeld is om bij te dragen aan de verwezenlijking van het recht op effectieve verdediging volledig afhankelijk zal zijn van de wijze waarop het wordt vormgegeven en in hoeverre daarbij met eerdergenoemde factoren rekening wordt gehouden. Het Poolse transitieproces heeft geillustreerd, dat wat de vormgeving betreft in ieder geval van fundamenteel belang is:

1. hoe precies en concreet wettelijke rechten en bevoegdheden worden geformuleerd, de meerwaarde van een instrument zal afnemen naarmate de daarin geformuleerde rechten vager worden omschreven en voor verschillende interpretaties vatbaar zijn;

2. in welke mate bij het creëren van procedurele waarborgen rekening wordt gehouden met de onderlinge samenhang met andere rechten: naast de inhoud van de concrete voorgenomen wijziging is de wettelijke context waarbinnen deze zal functioneren van minstens even groot belang wat betekent dat bij het opstellen van normen gericht op een effectieve verdediging altijd naar deze samenhang zal moet worden gekeken;

3. of, en zo ja, op welke wijze in effectief (rechterlijk) toezicht wordt voorzien dat kan worden uitgeoefend op het moment dat het ertoe doet zodat de naleving van rechten ook daadwerkelijk door de verdediging kan worden afgedwongen en

4. of het rechtsinstrument waarborgen biedt dat binnen een strafrechtssysteem ook de praktische condities worden vervuld en faciliteiten worden geboden die noodzakelijk zijn om 'papieren' procedurele rechten en bevoegdheden te kunnen effectueren.

Van een rechtsinstrument dat niet of in onvoldoende mate rekening houdt met de onder 1 tot en met 4 genoemde factoren kan serieus worden betwijfeld of het enig

66 Elk van de blootgelegde factoren speelt mijns inziens een eigen, zelfstandige rol: in zijn algemeenheid kan dan ook niet worden gezegd dat één of meer bepaalde factoren zwaarder wegen en dus meer aandacht verdienen dan andere. Wel zal uiteraard van tijd en plaats afhankelijk zijn in hoeverre de verschillende factoren de effectiviteit van verdediging in de dagelijkse strafrechtspraktijk beïnvloeden. Om een voorbeeld te noemen: de sterke invloed van het conservatisme van de Poolse balie is een verschijnsel dat zich lang niet in alle rechtssystemen zal voordoen en dus ook niet overal dezelfde impact zal hebben. 
effect zal sorteren en daadwerkelijk zal kunnen bijdragen aan een verbetering van de positie van de verdediging. De twee andere factoren die in dit onderzoek aan het licht zijn gekomen - de heersende rechtscultuur en stabiliteit in regelgeving - stellen op zich zelf weliswaar geen concrete eisen aan de inhoud van een juridisch instrument dat effectieve verdediging tracht te garanderen maar spelen een meer secundaire rol. Onder meer vanwege de onafhankelijkheid van de advocatuur zijn er beperkingen gesteld aan de invloed die overheden op dit punt kunnen uitoefenen. ${ }^{67}$

Terugkerend naar de discussie over het ontwerp kaderbesluit procedurele waarborgen, blijft de vraag of een dergelijk EU-instrument daadwerkelijk zal kunnen bijdragen aan een optimalisering van verdedigingsrechten in de landen van de Europese Unie. Hetgeen in $\S 4.3$ is uiteengezet over de (beperkte) normerende werking van het EVRM rechtvaardigt mijns inziens in ieder geval de conclusie dat het wel degelijk zinvol kan zijn om in aanvulling op het Straatsburgse toezichtsmechanisme te voorzien in andere Europese instrumenten die mogelijk op meer dwingende wijze een bepaalde graad van rechtsbescherming in het strafproces zouden kunnen garanderen. De meerwaarde van een EU-kaderbesluit is daarbij in ieder geval gelegen in het feit dat door middel van een dergelijk instrument in potentie meer druk kan worden uitgeoefend op strafrechtssystemen om bepaalde aanpassingen in nationale wetgeving te realiseren. ${ }^{68}$ Kaderbesluiten dienen geïmplementeerd te worden en wanneer dat niet - of niet op de juiste wijze - gebeurt, heeft de EU in tegenstelling tot de Raad van Europa wel verschillende mogelijkheden om haar lidstaten tot de orde te roepen. ${ }^{69}$ Dit betekent dat op deze wijze niet alleen meer invloed zou kunnen worden uitgeoefend op de (kwaliteit van) wettelijke normering van verdedigingsrechten maar ook dat lidstaten zouden kunnen worden gedwongen er praktische invulling aan te geven. Bovendien zou een kaderbesluit op de lange termijn kunnen bijdragen aan een mentaliteitsverandering bij degenen die nieuwe of gewijzigde wettelijke mogelijkheden in de praktijk dienen te brengen. Het dwingende karakter van het instrument zou er immers voor kunnen zorgen dat nieuwe garanties die in nationale regelgeving moeten worden geboden

67 Zo kunnen advocaten bijvoorbeeld niet gedwongen worden van bepaalde procedurele bevoegdheden gebruik te maken.

68 Dit heeft niet alleen te maken met een verschil in toezichtsmechanismen tussen de EU en de Raad van Europa (zie hierna) maar ook met het feit dat beide organisaties een geheel ander doel nastreven: het EVRM strekt primair tot het bieden van minimumgaranties en heeft niet als zelfstandig doel het bewerkstelligen van eenvormigheid tussen nationale rechtssystemen terwijl de Europese Unie ook op strafprocesrechtelijk terrein wel degelijk een zekere harmonisatie tracht te realiseren. Zie Van Kempen 2006, p. 87-88.

69 Veel zal uiteraard afhankelijk zijn van de wijze waarop en de mate waarin door de EU niet alleen de papieren naleving van het kaderbesluit wordt getoetst maar ook wordt gecontroleerd of bijpassende en effectieve handhavingstructuren in het leven zijn geroepen: Van Gestel 2006, p. 209 e.v. Momenteel wordt de omzetting van kaderbesluiten door de Raad en de Commissie beoordeeld in een zogenaamde evaluatieprocedure. Daarnaast bestaan ook nog twee algemene procedures die beide in handen van de lidstaten zijn: de bemiddelingsprocedure (art. 35 lid 7 EU-Verdrag) en de prejudiciële procedure (art. 35 lid 1 tot en met 4 EU-Verdrag). Zie uitgebreid over de implementatie van kaderbesluiten: Borgers e.a. 2006. Hoe deze toezichtsmechanismen zich in de toekomst zullen ontwikkelen, is volledig afhankelijk van wat er met de huidige pijlerstructuur (en dus met het Verdrag van Lissabon) zal gebeuren. 
niet 'sneuvelen' zodra de criminele politiek om welke reden dan ook (tijdelijk) minder oog heeft voor rechtsbeschermende waarborgen. Hierdoor wordt de strafrechtspraktijk de tijd geboden om eraan gewend te raken. Ook verwezenlijking van dit effect zal echter volledig afhankelijk zijn van de vraag in hoeverre het kaderbesluit met inachtneming van de eerder genoemde vier factoren voorziet in duidelijke, ${ }^{70}$ concrete en realiseerbare rechten.

\section{Ter afsluiting}

Het recht op effectieve verdediging is een fundamenteel onderdeel van het recht op een eerlijk proces dat in iedere democratische rechtsstaat dient te worden gegarandeerd. Overheden hebben bepaalde verantwoordelijkheden op dit punt waarbij het bieden van wettelijke garanties - zoals ook wordt benadrukt in de rechtspraak van het Europese Hof voor de rechten van de mens - niet voldoende is: rechten mogen niet alleen papieren betekenis hebben maar dienen praktisch en effectief te zijn. In dit onderzoek is duidelijk geworden hoe moeilijk het is deze opdracht te vervullen. Niet alleen omdat het al een ingewikkelde opgave is om te komen tot een adequate wettelijke regeling van verdedigingsrechten maar ook omdat de vraag of deze rechten uiteindelijk inderdaad praktisch en effectief zijn van veel verschillende factoren afhankelijk is. Factoren die voor een deel buiten de invloedssfeer van de nationale autoriteiten liggen en waarop ook het EVRM maar een beperkt normerend effect heeft. Dit verklaart waarom het voor Polen - ondanks de gunstige uitgangspositie en de diepgewortelde behoefte aan democratische hervormingen binnen de strafrechtspleging - zo lastig is gebleken om daadwerkelijk inhoud te geven aan het recht op effectieve verdediging.

De postcommunistische context waarbinnen dit alles zich heeft afgespeeld, betekent mijns inziens niet dat de betekenis van deze constateringen zich tot de grenzen van Polen of het voormalig Oostblok beperkt. Deze specifieke historische en politieke achtergrond heeft hoogstens invloed gehad op de mate waarin de onderscheiden factoren een rol hebben gespeeld maar niet op het feit dat ze van belang zijn geweest. En dat houdt in dat het Poolse transitieproces lessen heeft geleerd die van betekenis kunnen zijn voor elk initiatief - ongeacht in welke vorm of op welk niveau - dat effectieve verdediging in strafzaken beoogt te garanderen.

70 Het belang van duidelijk geformuleerde normen weegt des te zwaarder wanneer zoals bij een kaderbesluit nog een 'vertaalslag' moet worden gemaakt door omzetting in nationaal recht. Hoe vager de norm, hoe meer ruimte lidstaten krijgen om er een eigen interpretatie aan te geven die zoveel mogelijk in overeenstemming met reeds bestaande regelgeving is zodat vergaande aanpassingen van het strafprocesrecht kunnen worden voorkomen. De ontwikkelingen die zich in het kader van het ontwerp kaderbesluit ten aanzien van de aanvang van het recht op rechtsbijstand hebben voorgedaan, illustreren dit: de oorspronkelijke - duidelijke en concrete - regel dat dit recht zou moeten gelden vanaf het eerste moment van arrestatie en tijdens politieverhoren is uiteindelijk 'uitgekleed' tot de regel dat recht op rechtsbijstand 'zo spoedig mogelijk' moet worden gegarandeerd. De beschermende werking die van een dergelijke algemene norm kan uitgaan, is uiteraard uiterst beperkt. Zie hoofdstuk $1, \S 2$. 



\section{Bijlage 1 \\ Relevante wetsbepalingen}

\section{Art. 6 KPK 1997 (recht op verdediging)}

Aan verdachte komt het recht op verdediging toe, waaronder begrepen het recht op bijstand van een raadsman, waarover hij dient te worden geïnformeerd.

\section{Art. 71 KPK 1997 (definitie verdachte en beschuldigde)}

1. Als verdachte wordt aangemerkt degene jegens wie een beslissing tot bekendmaking van de beschuldigingen is genomen of die zonder een dergelijke beslissing tijdens een verhoor in de hoedanigheid van verdachte op de hoogte is gesteld van de tegen hem bestaande beschuldigingen.

2. Als beschuldigde wordt aangemerkt degene jegens wie een akte van beschuldiging is ingediend bij de rechtbank of jegens wie door de prokurator een verzoek tot voorwaardelijke beëindiging van de procedure is ingediend.

3. Waar in onderhavig wetboek [van strafvordering, toev. DdV] de term 'beschuldigde' in algemene zin wordt gebruikt, is de betreffende bepaling van overeenkomstige toepassing op de verdachte.

\section{Art. 73 KPK 1997 (vrij verkeer gedurende voorlopige hechtenis)}

1. De beschuldigde die zich in voorlopige hechtenis bevindt, mag in afwezigheid van anderen met zijn raadsman overleg voeren en met hem corresponderen.

2. In het vooronderzoek kan de prokurator die toestemming verleent voor dit overleg in uitzonderlijke gevallen bepalen dat hijzelf of een door hem aangewezen persoon daarbij aanwezig zal zijn.

3. De prokurator kan eveneens bepalen dat correspondentie tussen verdachte en raadsman wordt gecontroleerd.

4. De beperkingen genoemd in lid 2 en 3 mogen niet worden voortgezet of uitgevoerd na de eerste veertien dagen van de voorlopige hechtenis.

\section{Art. 77 KPK 1997 (maximum aantal advocaten)}

De beschuldigde mag zich op een het zelfde moment door niet meer dan drie raadslieden laten bijstaan.

\section{Art. 78 lid 1 KPK 1997 (toevoeging op verzoek verdachte)}

1. De beschuldigde, die geen gekozen raadsman heeft, kan verzoeken dat hem ex officio een raadsman wordt toegevoegd, wanneer op passende wijze wordt aangetoond dat hij niet in staat is de kosten van de verdediging te dragen zonder daarmee nadeel toe te brengen aan zijn eigen noodzakelijke levensonderhoud en dat van zijn familie.

\section{Art. 79 lid 1 en 2 KPK 1997 (verplichte rechtsbijstand)}

1. In een strafrechtelijke procedure dient de beschuldigde door een raadsman te worden bijgestaan wanneer

1) hij minderjarig is

2) hij doof, stom of blind is

3) er gerechtvaardigde redenen zijn om aan zijn geestelijke gezondheid te twijfelen

4) (geschrapt)

2. De beschuldigde dient ook door een raadsman te worden bijgestaan wanneer de rechtbank van mening is dat er sprake is van omstandigheden die de verdediging bemoeilijken. 


\section{Art. 80 eerste zin KPK 1997 (verplichte rechtsbijstand)}

De beschuldigde dient door een raadsman te worden bijgestaan wanneer de strafzaak in eerste aanleg wordt behandeld door een provinciale rechtbank en hij van zijn vrijheid wordt beroofd of wordt beschuldigd van een strafbaar feit waarop minimaal drie jaar gevangenisstraf staat.

\section{Art. 81 KPK 1997 (ambtshalve toevoeging raadsman)}

1. Indien de beschuldigde in de gevallen omschreven in art. 78 lid 1, art. 79 lid 1 en 2 en art. 80 geen gekozen raadsman heeft, dient hem ambtshalve een raadsman te worden toegevoegd door de president van de rechtbank die bevoegd is van de zaak kennis te nemen.

2. Op gerechtvaardigd verzoek van de beschuldigde of zijn raadsman kan de president van de rechtbank die bevoegd is van de zaak kennis te nemen een nieuwe raadsman toevoegen in plaats van degene die oorspronkelijk aangewezen was.

\section{Art. 85 lid 1 en 2 KPK 1997 (tegenstrijdige belangen)}

1. De raadsman mag verschillende beschuldigden bijstaan, indien hun belangen niet onderling tegenstrijdig zijn.

2. Wanneer tegenstrijdige belangen worden vastgesteld door de rechtbank wordt een beslissing genomen waarin de beschuldigde een termijn wordt gesteld voor de benoeming van een nieuwe raadsman. In het geval van een ambtshalve toegevoegde raadsman zal de rechtbank een nieuwe raadsman aanwijzen. Tegen deze beslissing staat bezwaar open.

\section{Art. 86 KPK 1997 (handelen in voordeel verdachte en persoonlijke deelname verdachte)}

1. De raadsman mag alleen proceshandelingen verrichten die in het voordeel van de beschuldigde zijn.

2. Dat een raadsman in de procedure optreedt, sluit persoonlijke deelname van de beschuldigde niet uit.

\section{Art. 156 lid 5 eerste zin KPK 1997 (inzage processtukken gedurende vooronderzoek)}

5. Tenzij de wet anders bepaalt, is gedurende het vooronderzoek inzage in de processtukken, het maken van afschriften en kopieën en de afgifte tegen betaling van gewaarmerkte afschriften of kopieën voor partijen, raadslieden, gevolmachtigden en wettelijk vertegenwoordigers slechts mogelijk met toestemming van degene die het vooronderzoek leidt. ${ }^{1}$

\section{Art. 170 lid 1 KPK 1997 (beoordeling bewijsverzoeken)}

1. Een bewijsverzoek dient te worden afgewezen indien:

1) de gevraagde bewijslevering niet is toegestaan,

2) de omstandigheid die men wenst te bewijzen niet relevant is voor de te nemen beslissing of reeds is gebleken dat deze omstandigheid in overeenstemming is met de beschuldigingen van de eisende partij,

3) het bewijs niet relevant is voor de vaststelling van de omstandigheden waar het om draait,

4) de gevraagde bewijslevering niet mogelijk is,

5) het bewijsverzoek op overduidelijke wijze is gericht op vertraging van de procedure.

\section{Art. 178 sub 1 KPK 1997 (absoluut verschoningsrecht raadsman)}

Niet als getuige mag worden gehoord:

1) een raadsman of een advocaat die optreedt op grond van art. 245 lid 1 voor zover het gaat om feiten die hij heeft vernomen tijdens het verlenen van rechtsbijstand of de behandeling van een zaak.

1 Art. 156 lid 5 KPK 1997 is op 3 juni 2008 door het Grondwettelijk Hof ongrondwettelijk verklaard. 


\section{Art. 180 lid 2 eerste zin KPK 1997 (relatief verschoningsrecht advocaat)}

2. Personen die in de hoedanigheid van notaris, advocaat, juridisch adviseur, arts of journalist een professionele geheimhoudingsplicht hebben, kunnen slechts dan worden gehoord over feiten die onder hun beroepsgeheim vallen indien dat noodzakelijk is voor een behoorlijke rechtspleging en de feiten niet op basis van ander bewijsmateriaal kunnen worden vastgesteld.

\section{Art. 245 lid 1 KPK 1997 (rechtsbijstand na aanhouding)}

1. De aangehoudene dient op zijn verzoek en op een wijze die de omstandigheden toelaten onmiddellijk in de gelegenheid te worden gesteld een advocaat te contacteren en rechtstreeks met hem overleg te voeren; degene die de aanhouding heeft verricht, kan bepalen dat hij bij dit overleg aanwezig zal zijn.

\section{Art. 249 lid 3 en 5 KPK 1997 (beslissingen voorlopige hechtenis - deelname verdediging)}

3 . Voordat een preventieve maatregel wordt toegepast, dient de rechtbank of de prokurator de beschuldigde te horen, tenzij dit niet mogelijk is omdat laatstgenoemde onvindbaar is of zich in het buitenland bevindt. De benoemde raadsman dient te worden toegelaten tot het verhoor wanneer hij verschijnt; hij hoeft echter niet van het plaatsvinden van het verhoor op de hoogte te worden gesteld, tenzij de verdachte daarom vraagt en het informeren van de raadsman de voortzetting van het verhoor niet bemoeilijkt. De rechtbank dient de prokurator op de hoogte te stellen van de datum van het verhoor. (...)

5. De prokurator en de raadsman hebben het recht deel te nemen aan zittingen waarop over de verlenging van de voorlopige hechtenis of over het bezwaar tegen toepassing of verlenging van voorlopige hechtenis wordt beslist. Het niet verschijnen van de prokurator of de raadsman staat, wanneer zij op de juiste wijze zijn opgeroepen, niet in de weg aan de behandeling van de zaak.

\section{Art. 300 KPK 1997 (informatie procedurele rechten en verplichtingen)}

De verdachte dient voorafgaand aan het eerste verhoor op de hoogte te worden gesteld van zijn rechten: om verklaringen te leggen of om te weigeren een verklaring af te leggen of vragen te beantwoorden, om verzoeken tot onderzoekshandelingen in te dienen, om zich te laten bijstaan door een raadsman, om bekend te worden gemaakt met de processtukken voor sluiting van het vooronderzoek, alsmede van het recht genoemd in art. 301 en de verplichtingen en consequenties genoemd in art. 74, 75, 138 en 139. Deze informatie dient schriftelijk aan de verdachte te worden overhandigd; de verdachte dient ontvangst ervan te bevestigen door middel van zijn handtekening.

\section{Art. 301 KPK 1997 (rechtsbijstand tijdens verhoor)}

Op zijn verzoek dient de verdachte in aanwezigheid van een benoemde raadsman te worden verhoord. Het niet verschijnen van de raadsman staat er niet aan in de weg dat het verhoor doorgang vindt.

\section{Art. 315 KPK 1997 (onderzoekshandelingen op verzoek verdediging)}

1. De verdachte en zijn raadsman alsmede het slachtoffer en zijn gevolmachtigde kunnen verzoeken indienen tot het verrichten van onderzoekshandelingen.

2. De partij die het verzoek heeft ingediend, alsmede zijn raadsman of gevolmachtigde, kan niet worden geweigerd deel te nemen aan de handeling indien dat wordt verzocht. Het bepaalde in art. 318 tweede zin is van overeenkomstige toepassing.

\section{Art. 316 KPK 1997 (onderzoekshandelingen die niet kunnen worden herhaald)}

1. Wanneer een onderzoekshandeling die gedurende het vooronderzoek wordt verricht niet op het onderzoek ter terechtzitting zal kunnen worden herhaald, hebben de verdachte, het slachtoffer en hun wettelijk vertegenwoordiger, gevolmachtigde of raadsman het recht daaraan deel te nemen tenzij het gevaar bestaat dat uitstel van de onderzoekshandeling verlies of aantasting van het bewijsmateriaal tot gevolg zal hebben. 
2. De verdachte die van zijn vrijheid is beroofd, wordt niet in de gelegenheid gesteld aan de onderzoekshandeling deel te nemen wanneer uitstel dreigt te leiden tot verlies of aantasting van het bewijsmateriaal.

3. Wanneer het gevaar bestaat dat een getuige niet op het onderzoek ter terechtzitting zal kunnen worden gehoord, kunnen partijen, de prokurator of een ander orgaan dat de procedure leidt de rechtbank verzoeken dat de getuige door de rechtbank wordt gehoord.

\section{Art. 317 KPK 1997 (overige onderzoekshandelingen)}

1. Partijen en hun raadsman of gevolmachtigde, wanneer deze reeds in de zaak zijn benoemd, dienen op hun verzoek eveneens te worden toegelaten tot onderzoekshandelingen die in het vooronderzoek worden verricht.

2. In uitzonderlijke gevallen kan de prokurator met het oog op zwaarwegende onderzoeksbelangen deelname aan handelingen weigeren of weigeren de aanwezigheid van een gedetineerde verdachte te realiseren wanneer dat bijzondere moeilijkheden met zich zou brengen.

\section{Art. 318 KPK 1997 (deskundigenbewijs)}

Wanneer deskundigenbewijs wordt toegelaten (...), dient aan de verdachte en zijn raadsman alsmede aan het slachtoffer en zijn gevolmachtigde de beslissing tot toelating van de deskundige te worden overhandigd, dienen zij in de gelegenheid te worden gesteld deel te nemen aan een eventueel verhoor van de deskundige en kennis te kunnen nemen van zijn rapportage indien deze op schrift wordt gesteld. Deelname van de verdachte die van zijn vrijheid is beroofd, hoeft niet te worden gerealiseerd wanneer dat bijzondere moeilijkheden met zich zou brengen.

\section{Art. 321 lid 1, 3, 4 en 5 KPK 1997 (inzage processtukken voor sluiting vooronderzoek)}

1. Indien er gronden bestaan voor sluiting van het vooronderzoek stelt het orgaan dat het onderzoek leidt de verdachte en zijn raadsman op hun verzoek op de hoogte van de datum waarop de bekendmaking van de stukken zal plaatsvinden, waarbij de verdediging tevens wordt geïnformeerd over de mogelijkheid de stukken in overeenstemming met het belang en de complexiteit van de zaak eerder dan genoemde datum in te zien. (...)

3. De raadsman heeft het recht aanwezig te zijn wanneer de verdachte voor sluiting van het vooronderzoek met de stukken wordt bekendgemaakt.

4. Het ongerechtvaardigd niet verschijnen van de verdachte of zijn raadsman, staat niet in de weg aan de voortgang van de procedure.

5. Binnen drie dagen nadat de verdachte voor sluiting van het vooronderzoek met de stukken is bekendgemaakt, kunnen partijen verzoeken tot aanvulling van het onderzoek indienen. Art. 315 lid 2 is van overeenkomstige toepassing. (...)

\section{Art. 338 lid 2 KPK 1997 (schriftelijke reactie akte van beschuldiging en indienen bewijsverzoeken)}

2. De beschuldigde heeft het recht om binnen zeven dagen na ontvangst van de akte van beschuldiging daarop schriftelijk te reageren en dient over dit recht te worden geïnformeerd.

\section{Art. 378 KPK 1997 (toewijzen nieuwe raadsman)}

1. Indien een verdachte in een geval van verplichte rechtsbijstand een gekozen raadsman heeft en de onderlinge betrekking door een van beiden wordt opgezegd, benoemt de president van de rechtbank of de rechtbank een nieuwe advocaat, voor zover de verdachte zelf geen raadsman heeft benoemd. Wanneer dat noodzakelijk is, zal de zaak worden aangehouden.

2. Wanneer de verdachte wordt bijgestaan door een toegevoegde raadsman, wordt laatstgenoemde op gerechtvaardigd verzoek van hemzelf of verdachte ontheven van zijn verplichtingen en wordt aan verdachte een nieuwe advocaat toegewezen.

3. Wanneer in de gevallen genoemd in lid 1 en 2 een nieuwe raadsman wordt toegewezen, bepaalt de rechtbank tegelijkertijd of de oorspronkelijke raadsman zonder schade toe te brengen 
aan het recht op verdediging zijn verplichtingen kan blijven vervullen totdat een nieuwe advocaat de verdediging op zich neemt .

\section{Art. 8 lid 3 KKW 1997 (vrij verkeer - vrijheidsberoving algemeen)}

3. Een veroordeelde die van zijn vrijheid is beroofd, kan in afwezigheid van anderen overleg voeren met zijn raadsman, gevolmachtigde advocaat of juridisch adviseur. Briefwisseling met deze personen is niet onderhevig aan censuur en mag niet worden tegengehouden en gesprekken die onder vier ogen of via de telefoon worden gevoerd, mogen niet worden gecontroleerd. Toezicht op correspondentie met een raadsman kan plaatsvinden door middel van openen van een brief maar uitsluitend wanneer er een gerechtvaardigd vermoeden bestaat dat de brief verboden voorwerpen bevat (letterlijk: voorwerpen waarvoor een verbod geldt ze in het bezit te hebben, te bewaren, over te dragen, te verzenden of te verhandelen). Het openen dient in aanwezigheid van de veroordeelde plaats te vinden en de penitentiaire rechter dient op de hoogte te worden gesteld van de grond (voor) en het resultaat [van de interventie, toev. DdV] (...).

\section{Art. 215 KKW 1997 (vrij verkeer - voorlopige hechtenis)}

1. Degene die zich in voorlopige hechtenis bevindt, heeft het recht met zijn raadsman, gevolmachtigde advocaat of juridisch adviseur in afwezigheid van andere personen overleg te voeren en met hem te corresponderen. Indien het orgaan, tot wiens beschikking de voorlopig gehechte staat, bepaalt dat hijzelf of een door hem aangewezen persoon bij dat overleg aanwezig zal zijn, vindt het bezoek plaats op de wijze zoals door dat orgaan bepaald.

2. Degene die zich in voorlopige hechtenis bevindt, dient de mogelijkheid te hebben zijn verdediging voor te bereiden. 



\section{Bijlage 2 \\ Informatie die conform art. 300 KPK 1997 voorafgaand aan het verhoor schriftelijk aan de verdachte wordt overhandigd (Engels en Pools)}

\section{Instructions for the suspect concerning his/her rights and duties}

1. The suspect has the right to:

- submit explanations (art. 300 k.p.k).

- refrain from submitting explanations or answering questions (art. 300 k.p.k.).

- apply for permission to voluntary accept the responsibility (art. 142 k.k.s ).

- apply for performing acts of inquiry or investigation and being present at hearing of evidence (art. 300 k.p.k.).

- use the assistance of the defense counsel (art. 300 k.p.k.).

- final acquaintance with procedure materials (art. 300 k.p.k.).

- demand to be cross-examined with the participation of appointed counsel whose absence does not hinder the hearing (art. 301 k.p.k.).

- apply for or express agreement to the aggrieved party's petition to send the case to the institution or trustworthy person for mediatory proceedings (art. 23a §1 k.p.k.).

- use the free services of an interpretor, in case he/she does not have a sufficient command of the Polish language (art $72 \S 1$ k.p.k.).

- take advantage of being sentenced without trial if the circumstances defined in art. $335 \S 1$ k.p.k. exist.

2. The suspect is obliged to yield to:

- external examination of the body and other examinations not connected with violation of body integrity, it is also legal to take prints and photographs and show the suspect to other people for identification purposes (art $74 \S 2$ sub 1 k.p.k.).

- psychological and psychiatric tests and examinations involving operations on the body, with the exception of surgical ones, on condition that they are performed by a qualified health service employee conforming with the indications of medical knowledge, they do not threaten the suspect's health, when carrying out these examinations is indispensable; in particular the suspect is obliged, keeping the above mentioned conditions in mind, to yield to blood, hair sampling or organism secretions (art. $74 \S 2$ sub 2 k.p.k.).

- taking by the police officer of the cheek mucosa swab if this is indispensable and there is no fear of putting in danger the health of the suspect or other people (art $74 \S 2$ sub 3 k.p.k.).

3. The suspect remaining at large:

- is obliged to turn up at each call during the penal proceedings and to notify the organ conducting the proceedings about each change of residence or sojourn in excess of 7 days; in case the suspect fails to turn up without justified reason, he/she can be detained and forcibly fetched (art $75 \S 1$ and 2 k.p.k.).

- in case the suspect stays abroad it is his/her duty to indicate the accommodation address for correspondence, otherwise the letter sent to the last known address in the country, or if such address does not exist, the letter attached to the records of the proceedings shall be regarded as delivered (art. 138 k.p.k.).

- if the suspect, fails to give a new address, changes the place of residence, or does not live at the indicated address, the letter sent to this address during the proceedings is regarded as delivered (art 139 of k.p.k.).

Hereby I acknowledge the receipt of the instructions concerning my rights and duties before the first interrogation.

(signature suspect) 


\section{Pouczenie o uprawnieniach i obowiązkach podejrzanego}

1. Podejrzanemu przysługuje prawo do:

- składania wyjaśnień.

- odmowy składania wyjaśnień lub odmowy odpowiedzi na pytania.

- składnia wniosków o dokonanie czynności śledztwa lub dochodzenia, obecności przy czynnościach dowodowych.

- korzystania z pomocy obrońcy.

- żądania przesłuchania go z udziałem ustanowionego obrońcy, którego niestawiennictwo nie tamuje przesłuchania (art. 300, 301 k.p.k.).

- korzystania z bezpłatnej pomocy tłumacza, jeżeli nie włada w wystarczającym stopniu językiem polskim (art. 72 § 1 k.p.k.).

- złożenia wniosku o skierowanie sprawy do instytucji lub osoby godnej zaufania w celu przeprowadzenia postępowania mediacyjnego albo wyrażenia zgody na jego przeprowadzenie za zgodą pokrzywdzonego (art. 23a § 1 k.p.k.).

- złożenia przez niego lub jego obrońcę wniosku o powiadomienie go o terminie końcowego zaznajomienia z materiałami śledztwa - dochodzenia i terminie uprzedniego przejrzenia akt sprawy.

- końcowego zaznajomienia z materiałami śledztwa - dochodzenia.

\section{Podejrzany jest obowiązany poddać się:}

- oględzinom zewnętrznym ciała oraz innym badaniom nie połączonym z naruszeniem integralności ciała, wolno także w szczególności od podejrzanego pobrać odciski palców, fotografować go oraz okazać w celach rozpoznawczych innym osobom (art. 74 § 2 pkt 1 k.p.k.).

- badaniom psychologicznym i psychiatrycznym oraz badaniom połączonym z dokonaniem zabiegów na jego ciele, z wyjątkiem chirurgicznych, pod warunkiem, że dokonywane są przez uprawnionego do tego pracownika służby zdrowia, z zachowaniem wskazań wiedzy lekarskiej i nie zagrażają zdrowiu podejrzanego, jeżeli przeprowadzenie tych badań jest nieodzowne; w szczególności podejrzany jest obowiązany - przy zachowaniu tych warunków - poddać się pobraniu krwi, włosów lub wydzielin organizmu (art. 74 § 2 pkt 2 k.p.k.).

- pobraniu wymazu ze śluzówki policzków, jeżeli jest to nieodzowne i nie zachodzi obawa, że zagrażałoby to jego zdrowiu lub innych osób (art. 74 § 2 pkt 3 k.p.k.).

\section{Podejrzany pozostający na wolności:}

- obowiązany jest stawić się na każde wezwanie w toku postępowania karnego oraz zawiadomić organ prowadzący postępowanie o każdej zmianie miejsca zamieszkania lub pobytu trwającego dłużej niż 7 dni. W razie nie usprawiedliwionego niestawiennictwa podejrzanego można zatrzymać i sprowadzić przymusowo (art. 75 § 1 i 2 k.p.k.).

- jeżeli przebywa za granicą ma obowiązek wskazać adresata dla doręczeń w kraju; w razie nie uczynienia tego pismo wysłane na ostatnio znany adres $w$ kraju, albo jeżeli adresu tego nie ma, załączone do akt sprawy uważa się za doręczone (art. 138 k.p.k.).

- jeżeli podejrzany, nie podając nowego adresu, zmienia miejsce zamieszkania lub nie przebywa pod wskazanym przez siebie adresem, pisma wysłane pod tym adresem, uważa się za doręczone (art. 139 k.p.k.).

Potwierdzam odbiór pouczenia o uprawnieniach i obowiązkach przed pierwszym przesłuchaniem.

dnia.

(podpis podejrzanego) 


\section{Summary}

This dissertation focuses on the right to legal assistance in Polish criminal procedure. The book comprises nine chapters. In Chapter 1 an account is given of the substance and scope of the study. The author explains why Poland was chosen as an object of study and what the immediate reason was for conducting the research. It is important to emphasize in this respect that the right to effective legal assistance is one of the main premises underlying the concept of 'fair trial' as guaranteed by Article 6 of the European Convention on Human Rights. Since the rights laid down in the European Convention are not only meant to be 'theoretical', but must be 'practical and effective' as well, there is no question that governments have a responsibility in the matter. This raises the question as to how the right to legal assistance may be guaranteed in everyday practice. A number of years ago, an initiative was taken within the context of the European Union to formulate minimum procedural safeguards for suspects and defendants in criminal proceedings, which should provide a common standard of legal protection in the Member States of the European Union. ${ }^{1}$ This initiative has prompted considerable debate among the Member States. For reasons of their own, some countries have even been strongly opposed to the whole idea. These developments at European Union level clearly illustrate how difficult it is to reach consensus on the substance and extent of a minimum level of legal protection for suspects in criminal proceedings. This calls for reflection on the (possible) effects of such initiatives and - more abstractly on the question as to how legal instruments may in effect contribute to a higher degree of legal protection and a stronger position for the defence in criminal cases. The Polish criminal justice system provides a valuable object of study for gaining more insight into the issue. The demise of Communism in 1989 marked the beginning of a transitional process, in the course of which Poland changed from a totalitarian state into a democratic country based on the rule of law. This transition has had numerous consequences for the criminal justice system, more specifically the position of the defence in criminal proceedings. Within a relatively short period of time, measures had to be taken by the government to guarantee, to the largest extent possible, the right to effective legal assistance. A critical analysis of these developments in post-Communist Poland may provide an insight into such a transitional process, so as to establish what factors determine the effect of the (legal) changes aimed at strengthening the position of the defence. In analysing the effect of the Polish reforms, a reference is made to the standard set by the European Convention on Human Rights and the preconditions underlying the right to a real and effective defence that can be derived from the case law of the European Court of Human Rights. Through analysing whether - and to what extent - the Polish reforms are influenced by, and comply with, the European standard, it is possible to determine the actual impact of the Convention, and its (added) value, on a country that intends to increase the degree of legal protection provided for in its criminal justice system.

1 Green Paper on Procedural Safeguards for Suspects and Defendants throughout the European Union, Brussels, 19-2-2003, COM (2003) 75. 
In consequence, the thesis question of this dissertation reads as follows:

'To what extent and in which way have measures aimed at guaranteeing effective criminal defence rights been implemented during the Polish post-Communist transitional process; what were the relevant factors in implementing these measures; and what can be learned from this as regards the (possible) effects of such initiatives taken by the government to strengthen the position of the defence?'

In order to answer the thesis question, four sub-questions were formulated:

1. How is the position of the defence regulated in current Polish legislation?

2. To what extent do the current rules differ from the situation under Communist rule?

3. How does the current situation compare with the preconditions for an effective criminal defence that can be derived from the European Convention on Human Rights?

4. What factors determine the effect of the implemented reforms on the position of the defence?

The study focuses on a number of fundamental aspects of the right to effective legal assistance. The moment at which the right to legal assistance becomes operative and the right to free legal assistance are first discussed (Chapter 4). Subsequently, several procedural rights enabling an effective defence during preliminary investigations and at trial are featured (Chapters 5 and 6). The following procedural rights for the defence are successively examined: the right to be present at client interrogations; the right to be informed about the case; the right to challenge pre-trial detention and the possibility to influence or take part in pre-trial fact-finding activities; the right to participate in consensual proceedings; the right to be present at court hearings; and the possibilities open to the defence to influence the gathering of evidence at trial and the final judicial decision-making. Another important aspect of the right to effective legal assistance concerns the right to confidential communication between defence counsel and his client (Chapter 7). Lastly, since also the bar itself is a relevant factor in rendering criminal defence rights effective, attention is paid to the professional association of Polish attorneys (adwokatura), its history, its culture and its professional ethics (Chapter 8).

Chapter 2 consists of two parts. The first part contains an historical description of Polish criminal procedure from the period between the two World Wars until the coming into force of the current criminal legislation at the end of the nineties. The focus is on the effect of Communist rule on the Polish criminal justice system during the period between 1944 and 1989. Polish criminal procedure - which was rather liberal up to World War II - underwent radical changes, particularly during the first decade of the Communist era. These changes were mainly aimed at intensifying its effectiveness and repressive character. As a result, the level of legal protection provided to suspects/accused (podejrzany/oskarżony) decreased drastically. The 'post-Stalinist' years (after 1956) constituted a less repressive period, but in spite of the strong call for change expressed by the general public and by legal scholars, significant reform of criminal procedure was not to be realized until the second half of the eighties. The most important goals of post-Communist legal reform of criminal procedure were the following: strengthening judicial control of pre-trial 
investigation; achieving a more balanced relation between the pre-trial stage and court proceedings; emphasizing the adversarial character of court proceedings; and improving the degree of legal protection afforded to suspects/accused and victims.

The second part of Chapter 2 offers an outline of current Polish criminal procedure. It discusses the protagonists in criminal court proceedings, i.e. the judge, the prosecutor (prokurator), citizens (and the various ways in which they may participate in criminal proceedings, e.g. as lay judges or private prosecutors) and lastly the defendant and his counsel. Although several important changes were introduced after 1989, the current design of Polish criminal procedure ${ }^{2}$ is not radically different from the former criminal process: by and large the main features - the various stages of the proceedings and the role of the parties to the proceedings - have remained the same.

Chapter 3 deals with the effect of Communist rule on the conception of the role of defence counsel in criminal proceedings. This historical account is provided to explain current ideas concerning the position of the defence and to show their relation to the prevailing view of defence counsel's role in criminal proceedings during the Communist era.

It is well known that the position of the defence is closely related to the organisation of the criminal process. ${ }^{3}$ Under Communist rule, criminal law was mainly regarded as a political instrument: a useful tool to fight the enemies of the Communist regime and - thus - to help achieve the government's objectives. The achievement of a Communist society was considered to be in everyone's interest and, in consequence, one of the characteristics of Socialist criminal procedure was that personal interests that conflicted with the common interest, were not acknowledged. This conception of criminal law and criminal procedure made defence counsel's task to defend the personal interests of the suspect/accused more difficult. The complexity of this matter is illustrated on the basis of Soviet literature, in which the role of counsel for the defence and the limits of this role in the criminal process were discussed extensively. Important questions were inter alia: is defence counsel allowed to continue his activities when he is convinced that his client is guilty?; are there circumstances in which defence counsel is obliged to actively contribute to the conviction of his client?; and are there exceptions to the rule of professional privilege where disclosing confidential information is in the public interest? Although there was much debate about these matters, the prevailing opinion in Soviet literature was that defence counsel's public duty superseded his responsibility as - a partial - defender of the personal interests of his clients. A closer look at Polish legal literature on the subject shows that the public duty of the defence counsel was propagated not nearly as strongly as was done in the Soviet Union. The most drastic opinion in this respect - the idea of defence counsel as an assistant to the court (pomocnik sadu) - was only expressed by a limited number of authors during the early years of Polish Communism. For the remaining part, the conception of the role of defence counsel was not considerably affected by the Communist

2 As laid down in the Code of Criminal Procedure of 1997 (KPK 1997), which replaced the Code of 1969 (KPK 1969).

3 In turn, the organization of the criminal procedure is linked with the organization of state authority. See Damaška 1986. 
regime. In consequence, pre-1989 Polish literature on the subject is not fundamentally different from contemporary legal writings.

In Chapter 4 two fundamental aspects of the right to legal assistance are discussed:

1. the moment at which the right to legal assistance becomes operative; and

2. provision of free legal assistance (i.e. legal aid) by the government.

With regard to the right to legal assistance, it is described that under current criminal procedural law an important safeguard has been incorporated in the new Article $245 \S 1$ KPK 1997. It provides that an arrested person, at his request, must be given the opportunity to contact a lawyer by any means available and to be in direct communication with him. ${ }^{4}$ In theory, this provision - in conformity with the standard set in the European Convention on Human Rights - enables the arrested person to consult a lawyer in the first stages of police questioning, at which time he needs to take important decisions that will affect the remainder of the proceedings. However, exercising this right of consultation is complicated by several factors. The most important is the fact that in this stage of the proceedings, there is no right to free legal assistance. Furthermore, the arrested person is merely informed of his right of access to counsel, but is not provided with the necessary information of how to go about it. In addition, the arrested person must be able to provide the name of a lawyer and there is no established on-call duty system for providing legal assistance upon arrest during evenings or on weekends. As a result, the procedural safeguard of Article 245 KPK 1997 can only be enjoyed by arrested persons who already know a lawyer and are able to pay for legal assistance themselves. With respect to free legal assistance (legal aid), a distinction must be made between cases of mandatory legal assistance and the provision of legal assistance at the request of the suspect/accused. Under Polish criminal procedure, there are several situations in which a suspect/accused must be defended by counsel. ${ }^{5}$ If - in these circumstances - the suspect/accused does not avail of a defence counsel of his own choosing, counsel must be appointed ex officio. In the remaining cases, defence counsel may be appointed by the court, if the suspect/accused is able to duly prove that he is unable to pay the costs of the defence without prejudicing his own and his family's subsistence. The current legal framework governing mandatory legal assistance and the appointment of counsel at the request of the suspect/accused is not fundamentally different from the pre-1989 situation governed by the 1969 Code of Criminal Procedure. More specifically, until now the legal provision regulating the appointment of defence counsel at the request of the suspect/accused has not been affected by post-Communist legal reforms. This is especially striking, since it is a well-known fact that the Polish legal-aid system has revealed several significant and urgent problems. ${ }^{6}$ Major shortcomings are the following:

4 The person who made the arrest, may reserve the right to be present when such a conversation takes place.

5 For example, when the suspect/accused is deaf, dumb or blind or when there is good reason to doubt his sanity.

6 See, for instance, the outcome of a survey conducted by the Helsinki Foundation for Human Rights: Monitoring Report 2003. 
- the legal basis for free legal assistance at the request of the suspect/accused is unclear;

- for budgetary reasons courts are only able to award a small percentage of the requests;

- there is no right to free legal assistance upon arrest; in most cases, the appointment of counsel at the request of the suspect/accused is restricted to the trial stage;

- denial of a suspect's/accused's request for legal assistance is not open to appeal; and

- services provided by defence counsel in legal-aid cases are often of poor quality, because - among other reasons - the expertise and availability of counsel are not taken into account.

As a result, there is no guarantee, generally speaking, that Polish citizens are provided with effective assistance of a legal-aid lawyer as required by Article 6 of the European Convention of Human Rights where the interests of justice so require or where they have insufficient means to pay for legal assistance themselves. Despite considerable debate and the preparation of several proposals for (legal) reform, to this day, no specific action has been taken to alter the situation and provide satisfactory solutions to remedy the above shortcomings.

Chapter 5 deals with several rights that enable effective legal assistance by counsel during the preliminary investigation stage. Four procedural rights afforded to the defence are successively discussed: 1 . the right of counsel to be present during interrogations of his client; 2 . the right to be informed about the case; 3 . the possibilities to challenge pre-trial detention; and 4 . the right to take part in pre-trial fact-finding activities.

With respect to the first issue, it should be noted that the preceding 1969 Code of Criminal Procedure did not provide the suspect with an express right to be questioned in the presence of his counsel: this right was only introduced in the present Code of Criminal Procedure and is currently laid down in Article 301 KPK 1997. In theory, the article is an important safeguard, providing an even higher degree of legal protection than seems to be required by the European Convention on Human Rights. ${ }^{7}$ In practice, however, the legal provision is of limited significance. This is closely related to the fact, as referred to above, that only a selective group of suspects is able to avail themselves of professional legal assistance in the early stages of questioning by the police. For this reason, in the majority of cases a counsel will not have been appointed (yet) in the early stages of preliminary investigation during which the most important interrogations take place.

The second issue dealt with in this chapter - the right to be informed about the case is also of fundamental importance to the right to effective legal assistance. Under the current Polish rules of criminal procedure, the provisions governing counsel's access to the case-file are for the most part the same as those under the 1969 Code

7 Since, according to the case law of the European Court of Human Rights, the presence of counsel on the occasion of police questioning is considered a particularly important safeguard against the suspect/accused being compelled to speak, but it is not viewed as an indispensable precondition of 'fairness' within the meaning of Article $6 \S 1$ of the Convention. See the case law referred to in Chapter 5, § 2.5. 
of Criminal Procedure. ${ }^{8}$ The legal framework governing the possibilities for the defence to be informed about the case has been changed to some extent, however. For example, the new Code of Criminal Procedure lists a number of documents which the defence must always be allowed to examine and provides for the possibility of lodging an appeal with the prosecutor when a request to examine the casefile has been denied. Despite these improvements, it can be argued that the current legal framework still leaves something to be desired. More specifically, it is particularly unfortunate that the post-Communist legislator did not opt for (a) specification of the circumstances under which it may be justified to deny the defence access to the case-file during the preliminary investigation stage; (b) creation of specific procedural safeguards for suspects/accused held in pre-trial detention; (c) limitation of the possibility of denying access to the case-file to a specific term and/or (d) providing the defence with the right to lodge an appeal with the court, instead of with the prosecutor, when access to documents is denied. The shortcomings of the current legal framework are not of a merely theoretical nature: permission to examine the case-file is often denied in practice. This constitutes a major impediment to effectively realizing criminal defence rights during the preliminary investigation stage. These problems have also been detected by the European Court of Human Rights and, more recently, by the Polish Constitutional Court. ${ }^{9}$ The latter held the provision that in the preliminary investigation stage counsel may only examine the case-file upon the permission of the police or the prosecutor (Art. $156 \S 5 \mathrm{KPK}$ 1997) to be unconstitutional. As a result of this judgment, the provision needs to be changed. ${ }^{10}$

The third issue discussed in this chapter concerns the right of the defence to challenge pre-trial detention. This is particularly important since pre-trial detention used to be one of the weakest features of the Polish criminal justice system under Communist rule and in this respect the rights of the defence were severely limited. The most important restriction was that, as a rule, decisions on the application for or an extension of pre-trial detention were taken in the presence of the prosecutor, but in the absence of counsel and his client. ${ }^{11}$ Under the new Code of Criminal Procedure, this inequality has been largely removed by providing counsel with the right to be present at all court hearings in which decisions on pre-trial detention are taken. Although this is a major improvement, the fact that only the position of defence counsel was strengthened, not that of his client, could prove a problem. After all, the case law of the European Court on Human Rights shows that - although the right of the suspect/accused to be present at court hearings dealing with his pre-trial detention is not absolute - attendance by his counsel cannot in all

8 The most striking similarity is that during the preliminary investigation stage examination of the case-file may only take place upon the permission of the organ conducting the proceedings (i.e. the prosecutor or the police). See Art. $156 \S 5$ KPK 1997 and Art. 143 § 3 KPK 1969.

9 See the case law against Poland referred to in Chapter $5, \S 3.5$.

10 Judgment of the Constitutional Court of June 3rd 2008, K 42/07.

11 A more general objection was that in the preliminary investigation stage the order for pretrial detention was given by the prosecutor. It is considered one of the most fundamental changes of post-Communist Polish criminal procedure that the power to take such decisions was transferred to the courts. 
circumstances compensate for the absence of the suspect/accused and in general the court should hear the detainee in person at regular intervals. ${ }^{12}$

The final topic discussed in this Chapter deals with the right of the defence to take part in fact-finding activities before trial, i.e. the right to file requests for fact-finding activities and the right to take part in such activities carried out ex officio or at the request of the defence. In general, the current legal framework governing the rights of the defence in this respect to a large extent resembles the situation under the 1969 Code of Criminal Procedure. It should be noted, however, that in some respects the possibilities open to the defence to take part in fact-finding activities during the preliminary investigation stage have slightly improved with the coming into effect of the new Code of Criminal Procedure. For example, the grounds for denying a request by the defence to be present at a fact-finding activity were tightened and the possibility to have witnesses heard by the court before trial was introduced. As a result, the defence has sufficient opportunities, in theory, to participate in factfinding activities carried out during the preliminary investigation stage. In practice however, Polish defence lawyers still tend to remain passive at this point in the proceedings. Research shows that defence lawyers seldom make use of their rights in this respect. In addition, there is no tradition among Polish lawyers to conduct their own investigation into the circumstances of the case. Although it is not prohibited by rules of professional ethics, it is generally believed that criminal offences are to be investigated exclusively by judicial authorities.

The findings described in Chapter 5 justify the conclusion that the new 1997 Code of Criminal Procedure has strengthened the adversarial character of preliminary investigations in several ways. However, there are strong indications that the enhanced rights afforded to the defence have not resulted in a noticeable change in practice. Not only because of remaining procedural difficulties for the defence in accessing the case-file, but also because of practical reasons, e.g. no free legal assistance upon arrest, and considerations of a traditional, or even strategic, nature, such as counsel being used to remain passive before trial and believing this is often the best defence strategy.

The rights of the defence during trial are discussed in Chapter 6. Although this stage of the criminal proceedings was not as greatly affected by post-Communist legal reforms as the preliminary investigation stage, a number of important changes can be detected. First, it should be noted that the preparatory phase of the trial stage, i.e. the preliminary verification of the charge (wstepna kontrola oskarżenia) and the preparation of the first-instance hearing (przygotowanie organizacyjne rozprawy głównej), has gained in importance. Nowadays, there are more possibilities for the defence to participate in hearings that take place in the preparatory phase than under the 1969 Code of Criminal Procedure. This is significant, because at these hearings decisions may be taken that considerably affect the accused. Second, the post-Communist legislator has introduced a number of changes aimed at strengthening the adversarial character of the trial hearing. Examples are the opportunity offered to the defence to file a written response to the act of accusation before the commencement of the trial and the change to the order in which persons - the defendant, witnesses and expert witnesses - are examined at trial. However, until now,

12 See the case law referred to in Chapter $5, \S 4.6$. 
both changes have had only limited effect in practice. Third, it should be pointed out that in the past few years, like in many other countries, reform of criminal procedure became dominated by considerations of efficiency. Not long after the 1997 Code of Criminal Procedure had entered into force, it was found that, due to, inter alia, the rise in crime and increasing caseloads, the newly established balance between legal protection and effective crime control had to be adapted. Several more recent developments in criminal procedure can be explained on the basis of this new trend, such as (1) an increase in the number of exceptions to the principle of immediacy, i.e. the use of witness statements made before trial; (2) an increase in the categories of cases in which the trial hearing may be conducted in the absence of the accused; (3) a broadening of the possibilities of opting for alternative settlement procedures (porozumienia karnoprocesowe); and (4) the introduction of anonymous witnesses (świadek anonimowy) and 'crown witnesses'13 (świadek koronny) to combat organised crime. These developments show that during the past few years the focus of the legislator has primarily been on the instrumentalist function of criminal law, i.e. efficient crime fighting, so that, in comparison to the situation during the first decade of post-Communist legal reform, there is less room for and interest in legal protection of those suspected or accused of having committed a criminal offence. The final issue discussed in this Chapter, namely the rise of the phenomenon of 'abuse of procedural rights by the defence' ('nadużycia prawa do obrony'), can also be considered typical of this trend. Until recently, this was a comparatively unknown phenomenon in Polish legislation, legal literature and case law. In the past few years, several amendments were made to criminal procedural law with the aim of preventing abuse of procedural rights. Striking is that the Polish interpretation of 'abuse' mainly concerns the strategic use of rights with a view to delay the proceedings. This is another example of the focus on efficiency in criminal politics.

In Chapter 7 two fundamental issues regarding the confidential nature of the attorney/client relationship are examined:

1. the way in which counsel is allowed to communicate with his detained client; and

2. the degree in which judicial authorities observe counsel's professional privilege of non-disclosure.

As to communication with clients, a distinction is made between face-to-face communication and exchange of letters (correspondence). In short, current criminal procedure offers counsel better guarantees of a confidential visit with his detained client: it is no longer possible to disallow such meetings; supervision is only permitted in 'particularly justified circumstances' ('w szczególnie uzasadnionym wypadku') and limited to the first fourteen days of pre-trial detention. Nevertheless, the exact meaning of the wording 'particularly justified circumstances' is not clear and in practice supervision means that a third person, i.e. a police officer or the prosecutor, is present within earshot of the conversation. This is in breach of Article 6 of the European Convention on Human Rights and the case law of the European Court, in

13 The term 'crown witness' refers to the deployment of suspects who have turned state's evidence. 
which it was clearly established that an accused's right to communicate with his lawyer out of earshot of a third person is one of the basic conditions of a fair trial. ${ }^{14}$ Regarding the confidential nature of correspondence it should be noted that the current legal framework offers more protection to the defence in comparison to the situation under Communist rule. Under the old Code of Execution of Sentences (Kodeks Karny Wykonawczy) of 1969 it was allowed to censor all correspondence of suspects/accused in pre-trial detention, with the inclusion of letters addressed to and sent by counsel. This situation, which was clearly in violation of Articles 6 and 8 of the European Convention on Human Rights, changed with the entering into force of the new Code of Criminal Procedure and the new Code of Execution of Sentences of 1997. Today, control of the correspondence between a detained suspect and his counsel is regulated by criminal procedural law (Art. 73 § 3 KPK 1997) and restricted in several ways. ${ }^{15}$ Nevertheless, the case law of the European Convention on Human Rights against Poland shows that in practice these legal safeguards are not always observed.

As regards the second issue - observance of counsel's professional privilege of non-disclosure by judicial authorities - it should be pointed out that in this respect the right to confidentiality implies two guarantees: 1 . Counsel cannot be forced to disclose confidential information in the capacity of witness; and 2. There must be sufficient procedural safeguards to prevent confidential communication being intercepted by judicial authorities through the use of certain investigative methods.

Starting with the first guarantee, it is important to emphasize that current Polish criminal procedural law better protects the professional privilege of attorneys (adwokat), and more specifically that of counsel for the defence (obronca), than the protection offered by the 1969 Code of Criminal Procedure. For example, the conditions under which a lawyer may be heard as a witness regarding facts covered by his obligation to maintain professional secrecy, are now specified by statute. This power of the judicial authorities - although rarely exercised in practice - clearly clashes with counsel's duty to observe professional secrecy as formulated, in absolute terms, in the Polish Attorneys' Act (Prawo o Adwokaturze) and the rules of professional ethics. For this reason, this matter is of great concern to the Polish Bar Association.

The second guarantee - the existence of safeguards to prevent that confidential communication comes to the knowledge of judicial authorities through the employment of certain investigative methods - has obviously been of less concern to the postCommunist legislator. In this study, two investigative methods have been examined: the powers of search and seizure and the interception of telephone communication. Whereas the current legal framework covering search and seizure offers some safeguard in protecting data governed by the attorney-client privilege, the rules covering interception of telephone communication provide no protection whatsoever. This is not compatible with the case law of the European Court of Human Rights. The protection offered by Article 8 of the European Convention implies that it should at least be specified in national provisions allowing interception of a lawyer's

14 See the case law referred to in Chapter 7, § 2.6.3.2.

15 Supervision is only possible during the first fourteen days of pre-trial detention and limited to checking the contents of the envelope in the presence of the detained where there is reasonable cause to believe that it contains an illicit enclosure. 
privileged telephone communication what information is covered by professional privilege and which person(s) determine(s) which intercepted information is confidential. ${ }^{16}$

In Chapter 8 several aspects of the profession of attorney-at-law (adwokat) are discussed. Firstly, the organisation of the Bar and its history are dealt with. In short, the adwokatura as a professional association was to a certain extent influenced by the Communist regime after World War II. The Attorneys' Acts of 1950 and 1963 encroached in more than one way on the independence of the profession by, for instance, granting far-reaching supervisory powers to the Minister of Justice and the abolition of individual practice through the introduction of (mandatory) collective law practices. However, in comparison to the situation in other countries of Centraland Eastern Europe under Communist rule, the Polish Bar was able to maintain a considerable degree of independence.

More recent developments with respect to the Polish Bar Association show that the professional association has faced substantial criticism over the past few years. One widely criticized aspect of the legal profession concerns the examination and admission of new members to the Bar: examination proceedings were not transparent and there were frequent allegations of nepotism. Furthermore, the Bar Association has been accused of deliberately keeping the number of its members as low as possible in order to control competition. Eventually, as a result of a judgment by the Polish Constitutional Court, in 2005 the Attorneys' Act was amended; a more uniform admission procedure was introduced and the discretionary power of the Bar Association to deny access to the profession was weakened.

The second part of Chapter 8 concerns the professional ethics governing the conduct of Polish lawyers. After a description of the history of the rules governing professional ethics, attention is paid to the current rules of professional conduct with special reference to the rules applying to counsel. Characteristic of the Polish rules of professional ethics are the following: the existence of many references to the dignity of the profession' and similar, vague concepts relating to the honour of the profession of lawyer, such as reliability and conscientiousness; heavy emphasis on lawyers' independence from clients; and the absence of rules specifically formulated to govern the actions of counsel in criminal cases. The author recommends the creation of specific professional rules for defence counsel and the formulation of explicit criteria for realising an effective criminal defence. Not only because of the fact that post-Communist changes in criminal procedure constitute new challenges for counsel but also because of the more recent trend to increase the instrumentalist function of criminal law that may ultimately lead to marginalization of the position of the defence. The final issue discussed in this chapter is the way in which disciplinary proceedings are conducted by the Bar Association. As a result of increasing criticism relating to insufficient disciplinary supervision by the Bar Association, a number of legislative amendments were drafted, such as the introduction of the possibility for the trial judge to impose a fine where the Bar Association fails to respond - within a certain time-limit - to a complaint concerning the conduct of one of its members. 
In general, the findings described in Chapter 8 show that the Polish Bar is of a rather conservative nature and that its main concern over the past few years has been to protect its independence. As a result, the profession held a somewhat difficult position in the democratization process and eventually the government forced changes upon it.

In Chapter 9 the most important findings of the research are summarized and an answer is provided to the three respective parts of the thesis question.

Under Communist rule, the possibilities of effectively exercising defence rights were severely limited in several respects. These limitations were not only the result of shortcomings in procedural rights and privileges afforded to the defence, but were also interrelated with the organization of criminal proceedings and the imbalance in the distribution of powers between the prosecution and the judiciary. ${ }^{17}$ In numerous ways, post-Communist legislative changes have improved the position of the defence. Examples are the introduction of an express right to legal assistance upon arrest and during interrogation; limitation of the power to supervise confidential communication between counsel and his client; and a broadening of the possibilities for the defence to take part in fact-finding activities and hearings.

Research has shown that the actual impact of these legislative changes aimed at improving the right to an effective defence - which seems to be rather limited in practice - is influenced by several factors. In brief, these factors relate to the following:

a. the current legal framework continues to have its shortcomings, such as the use of vague concepts and the absence of effective, judicial control, in matters that are essential to an effective defence;

b. the practical preconditions for realising the right to an effective defence are not (fully) met;

c. more recent developments in criminal politics reveal an ever-greater focus on efficiency and repression which eventually lead to less consideration for legal protection; and

d. the prevailing legal culture, in particular the attitude among members of the Bar, which conveys that remaining passive during the preliminary investigation stage is considered the best strategy in most cases, strongly impacts on the implementation of rights for the defence.

As regards the influence of the European Convention on Human Rights, the study demonstrates that the effect of these international norms on Polish criminal procedure is limited. Admittedly, several important instances of Polish legislative reform of criminal procedure were clearly inspired by the European Convention, but in some aspects the current situation continues to violate Articles 5, 6 and 8 of the Convention. ${ }^{18}$ There are several reasons for the Convention's limited influence, such as the so-called 'soft approach' characterising the Council of Europe and the fact that

17 However, in spite of these problems encountered in practice, the relative independence of the Polish Bar and legal scholars show that Communist ideology has had a limited impact only on Polish legal thinking.

18 One example is supervision by the authorities of attorney-client communication, entailing that a third person will be present within earshot of their conversation. 
the implementation of international human rights norms in the national criminal justice system is a relatively new phenomenon for the Polish legal system. In general, it seems that with the passage of time and the increasing new demands made on the criminal justice system, the European Convention has lost part of its normalising effect on Polish criminal procedure.

In conclusion, the Polish transitional process shows that introducing statutory procedural rights and powers for the defence does not necessarily entail realisation of these rights and powers in practice. Although this is hardly surprising in itself, the Polish example has revealed which factors influence the actual effect of legal reform initiatives that are meant to guarantee and improve the effectiveness of criminal defence. It is hoped that these findings may be of benefit to other future, national or international, legal instruments aimed at guaranteeing the right to a 'real and effective' defence in criminal procedure. 


\section{Streszczenie}

Przedmiotem niniejszej rozprawy naukowej jest prawo do uzyskania pomocy prawnej $\mathrm{w}$ postępowaniu karnym $\mathrm{w}$ Polsce. Praca składa się $\mathrm{z}$ dziewięciu rozdziałów. Rozdziat 1 zawiera prezentację istoty i zakresu przeprowadzonych badań. Autorka wyjaśnia w nim, dlaczego wybrała Polskę jako przedmiot badań oraz jaki był bezpośredni powód ich przeprowadzenia. Należy tutaj podkreślić, że prawo do skutecznej pomocy prawnej stanowi jedną z głównych przesłanek, na których oparta jest koncepcja rzetelnego procesu sądowego, gwarantowanego przez art. 6 Europejskiej Konwencji Praw Człowieka. W związku z tym, że prawa zagwarantowane w Europejskiej Konwencji nie powinny stanowić jedynie "teorii", lecz także mieć wymiar "praktyczny i skuteczny", niekwestionowana odpowiedzialność w tym względzie spoczywa na rządach państw. Powstaje pytanie, w jaki sposób prawo do uzyskania pomocy prawnej może zostać zagwarantowane w codziennej praktyce. Wiele lat temu w kontekście Unii Europejskiej podjęto inicjatywę określenia minimalnych gwarancji proceduralnych dla podejrzanych/oskarżonych $\mathrm{w}$ postępowaniu karnym, mających wyznaczać wspólny standard ochrony prawnej w państwach członkowskich Unii Europejskiej. ${ }^{1}$ Inicjatywa ta wywołała $w$ tych państwach wielką dyskusję. Mając ku temu własne powody, niektóre kraje są nawet zdecydowanie przeciwne całemu pomysłowi. Te wydarzenia na szczeblu Unii Europejskiej wyraźnie pokazują, jak trudno jest osiągnąć zgodę co do istoty i zakresu minimalnej ochrony prawnej podejrzanych $w$ postępowaniach karnych. Skłania to do refleksji nad (ewentualnymi) skutkami takich inicjatyw oraz - bardziej ogólnie - nad pytaniem o to, w jaki sposób instrumenty prawne mogą faktycznie przyczynić się do zwiększenia ochrony prawnej i wzmocnienia pozycji obrony w sprawach karnych.

$\mathrm{Na}$ lepsze zrozumienie tej kwestii pozwala przykład polskiego wymiaru sprawiedliwości w sprawach karnych, który stanowi cenny przedmiot analizy. Upadek komunizmu w 1989 r. był jednocześnie początkiem procesu transformacji, w którym totalitarne państwo polskie przekształciło się w państwo demokratyczne, kierujące się zasadami praworządności. Ta przemiana ma oczywiście szereg konsekwencji dla wymiaru sprawiedliwości w sprawach karnych, a bardziej konkretnie - dla pozycji obrony w postępowaniu karnym. W stosunkowo krótkim czasie konieczne stało się podjęcie przez rząd kroków mających na celu zagwarantowanie $\mathrm{w}$ możliwie jak największym stopniu prawa do skutecznej pomocy prawnej. Krytyczna analiza wydarzeń, jakie miały miejsce w Polsce po upadku komunizmu, może pozwolić na zrozumienie procesu transformacji oraz ustalenie, jakie czynniki decydują o skutkach zmian (prawnych) mających na celu wzmocnienie pozycji obrony. Przeprowadzone w Polsce reformy analizowane są w odniesieniu do standardu, jaki wyznacza Europejska Konwencja Praw Człowieka, oraz warunków wstępnych leżących u podstaw prawa do prawdziwej i skutecznej obrony w sprawach karnych, jakie można wywieść z prawa precedensowego Europejskiego Trybunału Praw Człowieka. Analizując, czy - i w jakim stopniu - standard europejski miał wpływ na przeprowadzone w Polsce reformy

1 Zielona księga w sprawie gwarancji proceduralnych podejrzanych i oskarżonych $\mathrm{w}$ postępowaniu karnym, Bruksela, 19-2-2003, COM (2003) 75. 
oraz czy są one z nim zgodne, można ustalić faktyczne oddziaływanie Konwencji oraz jej wartości (dodanej) w kraju, który zamierza zwiększyć stopień ochrony prawnej przewidzianej $\mathrm{w}$ ramach istniejącego $\mathrm{w}$ nim wymiaru sprawiedliwości w sprawach karnych.

W związku z tym główne pytanie postawione w niniejszej pracy brzmi następująco:

‘W jakim zakresie oraz w jaki sposób w procesie transformacji po upadku komunizmu w Polsce wprowadzono rozwiąania majace na celu zagwarantowanie praw zwiąanych ze skuteczna obrona w sprawach karnych; jakie czynniki odegraty role we wprowadzaniu tych rozwiązan; oraz jakie płyna stąd wnioski dotyczace (ewentualnych) skutków inicjatyw podejmowanych przez rząd w celu wzmocnienia pozycji obrony?'

Aby odpowiedzieć na tak postawione główne pytanie, zostały sformułowane cztery pytania pomocnicze:

1. Jak obecne ustawodawstwo polskie reguluje kwestię pozycji obrony?

2. Na ile obecne przepisy różnią się od tych, które istniały w okresie komunizmu?

3. Jak wygląda obecna sytuacja w świetle warunków wstępnych dla skutecznej obrony w sprawach karnych, które można wywieść z Europejskiej Konwencji Praw Człowieka?

4. Jakie czynniki decydują o wpływie wdrażanych reform na pozycję obrony?

Praca koncentruje się na szeregu podstawowych aspektów prawa do uzyskania skutecznej pomocy prawnej. Po pierwsze, przedmiotem zainteresowania jest moment, w którym zaczyna działać prawo do pomocy prawnej. Omawia się także prawo do nieodpłatnej pomocy prawnej (Rozdział 4). Następnie przedstawiono w niej kilka uprawnień procesowych, które umożliwiają skuteczną obronę podczas postępowania przygotowawczego i na etapie samego procesu sądowego (Rozdział 5 i 6). Badane są po kolei następujące uprawnienia procesowe obrony: prawo do udziału w przesłuchaniu klienta, prawo do bycia informowanym o sprawie, prawo do kwestionowania tymczasowego aresztowania oraz możliwość wywierania wpływu na przedprocesowe czynności śledztwa albo uczestniczenia w takich czynnościach, prawo do udziału w postępowaniu konsensualnym, prawo do udziału w posiedzeniach sądu, a także możliwość wywierania przez obronę wpływu na zbieranie materiału dowodowego podczas procesu sądowego oraz na wydanie ostatecznego wyroku. Inny ważny aspekt prawa do skutecznej pomocy prawnej dotyczy prawa do zachowania poufnego charakteru komunikacji pomiędzy obrońcą i jego klientem (Rozdział 7). Wreszcie, poświęca się uwagę adwokaturze, jej historii, kulturze oraz etyce zawodowej - ze względu na istotną rolę, jaką odgrywa ona w zapewnianiu skuteczności uprawnień obrony w sprawach karnych (Rozdział 8).

Rozdział drugi składa się z dwóch części. Część pierwsza zawiera opis historii postępowania karnego w Polsce począwszy od okresu międzywojennego aż do wejścia w życie obecnych przepisów prawa karnego pod koniec lat dziewięćdziesiątych. Główny przedmiot zainteresowania stanowi wpływ rządów komunistycznych na wymiar sprawiedliwości w sprawach karnych w Polsce w latach 1944-1989. Radykalne zmiany w postępowaniu karnym w Polsce - które do wybuchu drugiej wojny światowej było dość liberalne - nastąpiły szczególnie w pierwszej dekadzie okresu komunizmu. Ich głównym celem było zwiększenie 
skuteczności i represyjnego charakteru tego postępowania. Spowodowało to radykalne ograniczenie ochrony prawnej podejrzanych/oskarżonych. Tzw. okres postalinowski (po roku 1956) charakteryzowało zmniejszenie represji, jednak pomimo wielu postulatów wprowadzenia zmian, zgłaszanych przez ogół społeczeństwa i przez badaczy prawa, do drugiej połowy lat osiemdziesiątych nie została przeprowadzona żadna gruntowna reforma postępowania karnego. Do najważniejszych celów przeprowadzonej w okresie postkomunistycznym reformy postępowania karnego należały: wzmocnienie kontroli sądów nad czynnościami przedprocesowymi, bardziej wyważona relacja pomiędzy etapem przedprocesowym a postępowaniem sądowym, podkreślenie kontradyktoryjności postępowania sądowego oraz zwiększenie ochrony prawnej przewidzianej dla podejrzanych/oskarżonych i ofiar.

W drugiej części Rozdziału 2 przedstawiono w zarysie obecną sytuację postępowania karnego w Polsce. Omówiono głównych uczestników postępowania sądowego w sprawie karnej, tzn. sędziego, prokuratora, obywateli (oraz różne formy ich udziału w postępowaniu karnym, np. jako ławnicy lub oskarżyciele prywatni), a wreszcie oskarżonego i jego obrońcę. Chociaż po roku 1989 wprowadzono kilka istotnych zmian, to obecna formuła postępowania karnego w Polsce ${ }^{2}$ nie różni się radykalnie od jego wcześniejszych koncepcji: główne cechy charakterystyczne - poszczególne etapy postępowania oraz rola występujących w nim stron - pozostały w dużym stopniu niezmienione.

Rozdziat trzeci zawiera omówienie wpływu rządów komunistycznych na koncepcję roli obrońcy w postępowaniu karnym. Przedstawione w nim tło historyczne służy wyjaśnieniu obecnych koncepcji dotyczących pozycji obrony oraz zestawieniu ich $\mathrm{z}$ dominującym poglądem na temat roli obrońcy $\mathrm{w}$ postępowaniu karnym $\mathrm{w}$ okresie komunizmu.

Wiadomo, że pozycja obrony jest ściśle związana z organizacją procesu karnego. ${ }^{3}$ W okresie komunizmu prawo karne było uważane głównie za instrument polityki: przydatne narzędzie do walki z wrogami reżimu komunistycznego, a więc - pomoc w osiągnięciu celów stawianych sobie przez władzę. Uważano, że budowanie społeczeństwa komunistycznego leży w interesie każdego i w związku z tym jedną z cech charakterystycznych postępowania karnego okresu socjalizmu był brak uznania praw jednostki, jeżeli były one sprzeczne z interesem ogółu. Takie postrzeganie prawa karnego i postępowania karnego utrudniało zadanie obrońcy, polegające na obronie indywidualnych praw podejrzanego/oskarżonego. Złożoność tej kwestii ilustruje literatura radziecka, w której szeroko omówiona została rola obrońcy oraz jej granice w procesie karnym. Do ważnych pytań należały między innymi: czy obrońca może kontynuować swoje czynności, jeżeli jest przekonany o winie swojego klienta?; czy istnieją okoliczności, w których obrońca ma obowiązek aktywnie przyczynić się do skazania swojego klienta?; oraz czy istnieją wyjątki od zasady zachowania tajemnicy zawodowej, gdy ujawnienie informacji poufnych leży w interesie społecznym? Chociaż przeprowadzono na ten temat wiele dyskusji, to $\mathrm{w}$ literaturze radzieckiej przeważała opinia, że obowiązek obrońcy wobec

2 Zgodnie z treścią Kodeksu postępowania karnego z 1997 r., który zastąpił Kodeks z $1969 \mathrm{r}$.

$3 \quad$ Z kolei organizacja postępowania karnego jest powiązana ze sposobem organizacji władzy państwowej. Zob. Damaška 1986. 
społeczeństwa jest ważniejszy niż spoczywająca na nim - jako osobie działającej na korzyść swoich klientów - odpowiedzialność związana z obroną ich indywidualnych praw. Dokładniejsza analiza polskiej literatury z zakresu prawa poświęconej temu tematowi pokazuje, że spoczywający na obrońcy obowiązek wobec społeczeństwa nie był w niej aż tak propagowany jak miało to miejsce w Związku Radzieckim. Najbardziej radykalną opinię w tym względzie - postrzeganie obrońcy jako pomocnika sądu - podzielała jedynie ograniczona liczba autorów w pierwszych latach komunizmu w Polsce. Według pozostałych reżim komunistyczny nie miał większego wpływu na koncepcję roli obrońcy. W związku z tym dotycząca tego tematu literatura polska sprzed roku 1989 nie różni się zasadniczo od współczesnych opracowań.

W Rozdziale 4 omówione zostały dwa podstawowe aspekty prawa do uzyskania pomocy prawnej:

1. moment, w którym zaczyna działać prawo do uzyskania pomocy prawnej; oraz

2. zapewnianie nieodptatnej pomocy prawnej (tj. obrońcy wyznaczonego z urzędu) przez państwo.

W kwestii prawa do uzyskania pomocy prawnej przedstawiono informację o tym, że w ramach obowiązującego prawa karnego procesowego wprowadzone zostało ważne zabezpieczenie zawarte w nowym art. 245 § 1 KPK z 1997 r. Artykuł ten przewiduje, że zatrzymanemu na jego żądanie należy niezwłocznie umożliwić nawiązanie w dostępnej formie kontaktu $\mathrm{z}$ adwokatem, a także bezpośrednią $\mathrm{z}$ nim rozmowę. ${ }^{4}$ Teoretycznie przepis ten - zgodnie ze standardem, jaki wyznacza Europejska Konwencja Praw Człowieka - daje zatrzymanemu możliwość skonsultowania się z prawnikiem na pierwszych etapach prowadzonych przez policję przesłuchań, kiedy to musi on podejmować ważne decyzje mające wpływ na dalszy przebieg postępowania. Jednakże istnieje kilka czynników, które komplikują korzystanie z prawa do konsultacji. Najważniejszy z nich jest taki, że na tym etapie postępowania nie przysługuje prawo do nieodpłatnej pomocy prawnej. Ponadto, zatrzymany jest co najwyżej informowany o przysługującym mu uprawnieniu do korzystania z pomocy obrońcy, ale nie otrzymuje niezbędnych informacji o tym, jak uzyskać taką pomoc. Ponadto, zatrzymany musi być w stanie podać nazwisko adwokata, a nie istnieje żaden system dyżurów umożliwiający świadczenie pomocy prawnej w przypadku zatrzymań lub aresztowań dokonywanych wieczorami lub w weekendy. W wyniku tego z zabezpieczenia proceduralnego przewidzianego w art. 245 KPK z 1997 r. mogą korzystać jedynie ci zatrzymani, którzy znają już adwokata i są w stanie sami ponieść koszty pomocy prawnej.

Jeżeli chodzi o nieodptatna pomoc prawną (korzystanie z pomocy obrońcy wyznaczonego z urzędu), to należy dokonać rozróżnienia pomiędzy przypadkami obowiązkowego świadczenia pomocy prawnej i sytuacjami, kiedy pomoc prawna świadczona jest na wniosek podejrzanego/oskarżonego. W polskim postępowaniu karnym przewidziano kilka sytuacji, w których podejrzany/

4 Zatrzymujący może zastrzec, że będzie obecny podczas takiej rozmowy. 
oskarżony musi mieć obrońcę. ${ }^{5}$ Jeżeli - w takiej sytuacji - podejrzany/oskarżony nie skorzysta z możliwości samodzielnego wyboru obrońcy, to obrońca musi zostać wyznaczony z urzędu. W pozostałych przypadkach obrońcę może wyznaczyć sąd, jeżeli podejrzany/oskarżony potrafi należycie wykazać, że nie jest $\mathrm{w}$ stanie ponieść kosztów obrony bez uszczerbku dla utrzymania siebie i swojej rodziny. Obecne ramy prawne, które regulują kwestię obowiązkowej pomocy prawnej i wyznaczenia obrońcy na wniosek podejrzanego/ oskarżonego, nie różnią się zasadniczo od ram istniejących przed rokiem 1989, kiedy obowiązywał Kodeks postępowania karnego z 1969 r. Dokładniej rzecz ujmując, przeprowadzone po upadku komunizmu reformy prawa nie spowodowały zmian dotychczasowego przepisu regulującego kwestię wyznaczenia obrońcy na wniosek podejrzanego/ oskarżonego. Dziwi to szczególnie dlatego, że, jak wiadomo, istniejący w Polsce system pomocy prawnej stwarza kilka istotnych i wymagających pilnego rozwiązania problemów. ${ }^{6}$ Ma on następujące poważne wady:

- niejasna podstawa prawna dla świadczenia nieodpłatnej pomocy prawnej na wniosek podejrzanego/oskarżonego;

- $\mathrm{z}$ powodów finansowych sądy są w stanie rozpatrzyć pozytywnie jedynie niewielki procent takich wniosków;

- nieodpłatna pomoc prawna nie zaczyna przysługiwać z chwilą aresztowania; w większości przypadków możliwość wyznaczenia obrońcy na wniosek podejrzanego/oskarżonego ograniczona jest do etapu samego procesu sądowego;

- w przypadku odmownego załatwienia wniosku podejrzanego/oskarżonego o pomoc prawną nie ma możliwości odwołania się; oraz

- w przypadku spraw z udziałem obrońcy wyznaczonego z urzędu jakość świadczonych usług jest często niska, ponieważ - między innymi - nie bierze się pod uwagę fachowej wiedzy i dyspozycyjności obrońcy.

W związku z tym, ogólnie rzecz biorąc, nie ma gwarancji, że obywatele polscy otrzymają skuteczną pomoc prawną od adwokata wyznaczonego z urzędu, zgodnie z wymogami Artykułu 6 Europejskiej Konwencji Praw Człowieka, gdy będzie wymagać tego dobro wymiaru sprawiedliwości lub gdy nie będą oni mieli wystarczających środków na samodzielne pokrycie kosztów pomocy prawnej. Pomimo poważnej dyskusji i przygotowania kilku propozycji reformy (prawa), do chwili obecnej nie zostały podjęte żadne konkretne działania prowadzące do zmiany tego stanu rzeczy i przedstawienia satysfakcjonujących rozwiązań, które umożliwiłyby usunięcie powyższych wad.

Rozdziat 5 dotyczy kilku uprawnień umożliwiających świadczenie skutecznej pomocy prawnej przez obrońcę na etapie postępowania przygotowawczego. Omawia się w nim po kolei następujące uprawnienia procesowe obrony: 1 . prawo obrońcy do uczestniczenia w przesłuchaniach klienta; 2. prawo do bycia informowanym o sprawie; 3. możliwość zakwestionowania tymczasowego aresz-

5 Na przykład, jeżeli podejrzany/oskarżony jest głuchy, niemy lub niewidomy albo gdy zachodzi uzasadniona wątpliwość co do jego poczytalności.

6 Zob. np. wynik badania przeprowadzonego przez Helsińską Fundację Praw Człowieka: Raport z monitoringu 2003. 
towania; oraz 4. prawo do uczestniczenia w przedprocesowych czynnościach śledztwa.

W przypadku pierwszego zagadnienia należy zauważyć, że poprzedni Kodeks postępowania karnego z 1969 r. nie przyznawał podejrzanemu wyraźnego prawa do bycia przesłuchiwanym $\mathrm{w}$ obecności swojego obrońcy: prawo to zostało wprowadzone dopiero w obecnym Kodeksie postępowania karnego i w tej chwili przewiduje je w art. 301 KPK z 1997 r. Teoretycznie artykuł ten stanowi ważne zabezpieczenie, zapewniające jeszcze większą ochronę niż wydaje się to wynikać z Europejskiej Konwencji Praw Człowieka. ${ }^{7}$ Jednakże w praktyce przepis ten ma ograniczone znaczenie. Jest to ściśle związane ze wspomnianym wyżej faktem, że tylko ograniczona grupa podejrzanych jest w stanie skorzystać z fachowej pomocy prawnej na wczesnych etapach przesłuchań prowadzonych przez policję. Z tego powodu w większości przypadków na wczesnych etapach postępowania przygotowawczego, kiedy prowadzone są najważniejsze przesłuchania, nie ma (jeszcze) wyznaczonego obrońcy.

Drugie zagadnienie omawiane w tym rozdziale - prawo do bycia informowanym o sprawie - ma również zasadnicze znaczenie dla prawa do skutecznej pomocy prawnej. Zgodnie z obecnie obowiązującymi w Polsce zasadami postępowania karnego postanowienia regulujące kwestię dostępu obrońcy do akt sprawy są zasadniczo takie same jak te, które istniały w ramach Kodeksu postępowania karnego z 1969 r. ${ }^{8}$ Jednakże Ramy prawne regulujące kwestię możliwości uzyskiwania przez obronę informacji dotyczących sprawy zostały do pewnego stopnia zmienione. Na przykład w nowym Kodeksie postępowania karnego wyszczególniono szereg dokumentów, które należy zawsze udostępnić obronie do przeanalizowania, oraz przewidziano możliwość złożenia zażalenia do prokuratora w przypadku odmowy udostępnienia akt sprawy. Pomimo tych usprawnień, można stwierdzić, że obecne ramy prawne nadal wymagają dopracowania. Ściślej mówiąc, szczególnie niefortunne jest to, że postkomunistyczny ustawodawca nie zdecydował się na (a) sprecyzowanie okoliczności, w jakich uzasadniona może być odmowa udostępnienia obronie akt sprawy na etapie postępowania przygotowawczego; (b) ustanowienie określonych zabezpieczeń proceduralnych dla podejrzanych/oskarżonych przebywających w areszcie tymczasowym; (c) ograniczenie możliwości odmowy udostępnienia akt sprawy do określonego terminu oraz/lub (d) zapewnienie obronie prawa do złożenia zażalenia w sądzie zamiast u prokuratora w przypadku odmowy udostępnienia dokumentów. Wady obecnych ram prawnych nie mają charakteru jedynie teoretycznego: odmowa dostępu do akt sprawy w praktyce występuje bardzo często. Stanowi to główną

$7 \quad$ Z uwagi na to, że zgodnie z prawem precedensowym Europejskiego Trybunału Praw Człowieka obecność obrońcy podczas przesłuchań prowadzonych przez policję uważana jest za szczególnie ważne zabezpieczenie przed zmuszaniem podejrzanego/ oskarżonego do mówienia, ale nie jest ona postrzegana jako niezbędny warunek wstępny "rzetelności" w rozumieniu art. $6 \S 1$ Konwencji. Zob. prawo precedensowe, o którym mowa w Rozdziale 5, § 2.5.

8 Najbardziej uderzające podobieństwo polega na tym, że na etapie postępowania przygotowawczego dostęp do akt sprawy możliwy jest jedynie za zgodą organu prowadzącego to postępowanie (tj. prokuratora lub policji). Zob. art. 156 § KPK 1997 oraz art. 143 § 3 KPK 1969. 
przeszkodę w skutecznym realizowaniu uprawnień obrony w sprawach karnych na etapie postępowania przygotowawczego. Problemy te zostały wskazane również przez Europejski Trybunał Praw Człowieka, a ostatnio przez Trybunał Konstytucyjny RP. ${ }^{9}$ Według ostatniego z wyżej wymienionych postanowienie, zgodnie z którym na etapie postępowania przygotowawczego obrońca ma prawo wglądu w akta sprawy jedynie za zgodą policji lub prokuratora (art. $156 \S 5 \mathrm{KPK}$ 1997), jest niezgodne $z$ konstytucją. Orzeczenie to świadczy o tym, że istnieje potrzeba wprowadzenia zmian $\mathrm{w}$ tym postanowieniu. ${ }^{10}$

Trzecie zagadnienie omawiane $\mathrm{w}$ tym rozdziale dotyczy prawa obrony do kwestionowania tymczasowego aresztowania. Ma to szczególnie znaczenie, ponieważ tymczasowe aresztowanie było jedną z najsłabszych stron polskiego wymiaru sprawiedliwości w sprawach karnych w okresie rządów komunistycznych i w tym zakresie uprawnienia obrony były poważnie ograniczone. Najważniejsze ograniczenie polegało na tym, że decyzje w sprawie wniosków o zastosowanie lub przedłużenie tymczasowego aresztowania zazwyczaj podejmowane były w obecności prokuratora, ale bez udziału obrońcy i jego klienta. ${ }^{11}$ Zgodnie z nowym Kodeksem postępowania karnego ten brak równości został w dużym stopniu usunięty dzięki zapewnieniu obrońcy prawa do uczestniczenia we wszystkich posiedzeniach sądu, podczas których podejmowane są decyzje dotyczące tymczasowego aresztowania. Stanowi to zasadniczą poprawę, ale fakt, że wzmocniona została jedynie pozycja obrońcy, a nie jego klienta, może okazać się problemem. Z prawa precedensowego Europejskiego Trybunału Praw Człowieka wynika przecież, że - aczkolwiek prawo podejrzanego/oskarżonego do uczestniczenia $\mathrm{w}$ posiedzeniach sądu dotyczących zastosowania wobec niego aresztu tymczasowego nie jest nieograniczone - obecność obrońcy nie może we wszystkich sytuacjach rekompensować nieobecności podejrzanego/oskarżonego i ogólnie rzecz biorąc sąd powinien w regularnych odstępach czasu wysłuchać samego zatrzymanego. ${ }^{12}$

Ostatni omawiany w tym rozdziale temat dotyczy prawa obrony do uczestniczenia w przedprocesowych czynnościach śledztwa, tj. prawa do składania wniosków o dokonanie czynności śledztwa oraz prawa do uczestniczenia w takich czynnościach prowadzonych z urzędu lub na wniosek obrony. Generalnie, obecne ramy prawne regulujące kwestię uprawnień obrony $\mathrm{w}$ tym względzie $\mathrm{w}$ dużym stopniu przypominają sytuację, jaka istniała w okresie obowiązywania Kodeksu postępowania karnego z 1969 r. Należy jednak zauważyć, że pod niektórymi względami możliwości związane $\mathrm{z}$ uczestniczeniem obrony $\mathrm{w}$ czynnościach śledztwa na etapie postępowania przygotowawczego uległy niewielkiej poprawie z chwilą wejścia w życie nowego Kodeksu postępowania karnego. Na przykład, mocno ograniczone zostały podstawy do odrzucenia wniosku obrony o udział w czynnościach śledztwa i wprowadzono możliwość przesłuchiwania świadków przez sąd przed rozpoczęciem procesu. W wyniku tego obrona ma teoretycznie

9 Zob. prawo precedensowe wobec Polski, o którym mowa w Rozdziale 5, § 3.5.

10 Wyrok Trybunału Konstytucyjnego z dnia 3 czerwca 2008 r., K 42/07.

11 Bardziej ogólne zastrzeżenie było takie, że na etapie postępowania przygotowawczego nakaz aresztowania tymczasowego wydawał prokurator. Za jedną z zasadniczych zmian dokonanych w postępowaniu karnym w postkomunistycznej Polsce uważa się przekazanie uprawnienia do wydawania takich decyzji sądom.

12 Zob. prawo precedensowe, o którym mowa w Rozdziale 5, § 4.6. 
wystarczającą możliwość uczestniczenia w czynnościach śledztwa na etapie postępowania przygotowawczego. Jednakże w praktyce obrońcy w Polsce nadal mają zwyczaj przyjmowania biernej postawy na tym etapie postępowania. Badania wykazały, że obrońcy rzadko korzystają z przysługujących im w tym względzie uprawnień. Ponadto, wśród polskich adwokatów nie istnieje tradycja samodzielnego ustalania okoliczności związanych z daną sprawą. Nie zakazują tego zasady etyki zawodowej, ale panuje ogólne przekonanie, że przestępstwa karne mają badać wyłącznie organy sądowe.

Ustalenia przedstawione w Rozdziale 5 stanowią uzasadnienie dla wniosku, że nowy Kodeks postępowania karnego z 1997 r. pod kilkoma względami wzmocnił kontradyktoryjny charakter postępowań przygotowawczych. Jednakże istnieją przesłanki mocno świadczące o tym, że przyznanie obronie większych uprawnień nie spowodowało zauważalnej zmiany w praktyce. Nie tylko z powodu nadal istniejących trudności proceduralnych związanych z dostępem do akt sprawy, na jakie napotyka obrona, lecz również z powodów praktycznych, np. braku możliwości korzystania z nieodpłatnej pomocy prawnej w chwili aresztowania, a także względów natury tradycyjnej, a nawet strategicznej, takich jak przyzwyczajenie obrońcy do przyjmowania biernej postawy $\mathrm{w}$ fazie przedprocesowej i przekonanie, że jest to często najlepsza strategia obrony.

Uprawnienia przysługujące obronie podczas procesu sądowego zostały omówione w Rozdziale 6. Chociaż na ten etap postępowania karnego postkomunistyczne reformy systemu prawa nie miały aż tak wielkiego wpływu jak na postępowanie przygotowawcze, to daje się zauważyć szereg istotnych zmian. Po pierwsze, należy zauważyć, że wzrosło znaczenie etapu przygotowań do procesu sądowego, tj. wstępnej kontroli oskarżenia, oraz przygotowanie organizacyjne rozprawy głównej. Obecnie obrona ma większą możliwość uczestniczenia w posiedzeniach odbywających się w fazie przygotowawczej, niż miało to miejsce w okresie obowiązywania Kodeksu postępowania karnego z 1969 r. Jest to istotne, ponieważ podczas tych posiedzeń mogą być podejmowane decyzje mające poważny wpływ na sytuację oskarżonego. Po drugie, w okresie postkomunistycznym ustawodawca wprowadził szereg zmian mających na celu wzmocnienie kontradyktoryjności rozprawy. Przykładem jest umożliwienie obronie wniesienia pisemnej odpowiedzi na akt oskarżenia przed rozpoczęciem procesu sądowego oraz zmiana kolejności, w jakiej podczas procesu odbywa się przesłuchanie poszczególnych osób - oskarżonego, świadków i biegłych. Jednakże, jak do tej pory, obie zmiany mają w praktyce jedynie ograniczony skutek. Po trzecie, należy zauważyć, że w okresie ostatnich kilku lat - podobnie jak w wielu innych krajach - w reformie postępowania karnego zaczęły dominować względy skuteczności. Niedługo po wejściu w życie Kodeksu postępowania karnego z 1997 r. stwierdzono, że m. in. z powodu wzrostu przestępczości i coraz większego nagromadzenia tego rodzaju spraw nowo ustanowiona równowaga pomiędzy ochroną prawną a skutecznym ściganiem przestępstw wymaga dostosowania do tej sytuacji. Ten nowy trend może stanowić uzasadnienie dla kilku dokonanych ostatnio posunięć w sferze postępowania karnego, takich jak (1) zwiększenie liczby wyjątków od zasady bezpośredniości, tj. korzystania z zeznań świadków złożonych przed rozpoczęciem procesu; (2) rozszerzenie kategorii spraw, w których rozprawa sądowa może odbyć się bez obecności oskarżonego; (3) zwiększenie możliwości wyboru 
alternatywnych porozumień karnoprocesowych; oraz (4) wprowadzenie świadków anonimowych i świadków koronnych w celu zwalczania przestępczości zorganizowanej. Posunięcia te świadczą o tym, że przez ostatnich kilka lat ustawodawca koncentrował się głównie na instrumentalnej funkcji prawa karnego, tj. na skutecznym zwalczaniu przestępczości, i w związku z tym w porównaniu z sytuacją, jaka istniała w pierwszej dekadzie reformy prawa przeprowadzanej po upadku komunizmu, mniej miejsca i uwagi poświęca się ochronie prawnej osób podejrzanych lub oskarżonych.

Za typową dla tej tendencji można również uznać ostatnią kwestię omawianą w tym rozdziale, a mianowicie nasilające się zjawisko "nadużycia prawa do obrony". Do niedawna w polskim ustawodawstwie, literaturze prawniczej i prawie precedensowym zjawisko to było stosunkowo mało znane. W okresie kilku minionych lat $\mathrm{w}$ prawie karnym procesowym wprowadzono kilka zmian, których celem jest zapobieganie nadużywaniu uprawnień procesowych. Znamienne jest to, że stosowana w Polsce interpretacja "nadużycia" dotyczy głównie strategicznego korzystania z uprawnień w celu opóźnienia postępowania. Jest to kolejny przykład skoncentrowania na skuteczności w polityce karnej.

W Rozdziale 7 analizowane są dwie podstawowe kwestie dotyczące poufnego charakteru relacji adwokat-klient:

1. sposób, w jaki obrońca może komunikować się ze swoim klientem, który został zatrzymany; oraz

2. stopień respektowania przez organy sądowe prawa obrońcy do nieujawniania pewnych informacji w ramach tajemnicy zawodowej.

Porozumiewanie się z klientami może mieć formę bezpośredniej rozmowy lub wymiany pism (korespondencji). Krótko mówiąc, w obecnym postępowaniu karnym obrońca ma lepiej zagwarantowaną poufność spotkania z przebywającym w areszcie klientem: nie można już zabronić takich spotkań; nadzór dozwolony jest jedynie $w$ "szczególnie uzasadnionym wypadku" i został ograniczony do pierwszych czternastu dni przebywania w areszcie tymczasowym. Niemniej jednak, dokładne znaczenie sformułowania "szczególnie uzasadniony wypadek" nie jest jasne i w praktyce nadzór oznacza przebywanie osoby trzeciej, tj. funkcjonariusza policji lub prokuratora, w odległości pozwalającej na słyszenie prowadzonej rozmowy. Stanowi to naruszenie art. 6 Europejskiej Konwencji Praw Człowieka i prawa precedensowego Europejskiego Trybunału, w którym wyraźnie stwierdzono, że prawo oskarżonego do odbycia rozmowy ze swoim adwokatem $\mathrm{w}$ taki sposób, aby nie słyszała ich osoba trzecia, jest jednym $\mathrm{z}$ podstawowych warunków rzetelnego procesu. ${ }^{13}$

Jeżeli chodzi o poufny charakter korespondencji, to należy zauważyć, że w porównaniu z sytuacją, jaka istniała $\mathrm{w}$ okresie komunizmu, obecne ramy prawne zapewniają obronie większą ochronę. Zgodnie z Kodeksem karnym wykonawczym z 1969 r. dozwolona była cenzura całej korespondencji podejrzanych/oskarżonych przebywających $\mathrm{w}$ areszcie tymczasowym, w tym również adresowanych do obrońcy i wysyłanych przez niego pism. Ta sytuacja, stanowiąca jawne naruszenie art. 6 i 8 Europejskiej Konwencji Praw Człowieka, uległa zmianie wraz z wejściem

13 Zob. prawo precedensowe, o którym mowa w Rozdziale 7, § 2.6.3.2. 
w życie nowego Kodeksu postępowania karnego i nowego Kodeksu karnego wykonawczego w 1997 r. Obecnie kwestię kontrolowania korespondencji pomiędzy przebywającym w areszcie podejrzanym i jego obrońcą reguluje prawo karne procesowe (art. $73 \S 3$ KPK 1997) i istnieje kilka sposobów ograniczenia tej kontroli. ${ }^{14}$ Jednakże prawo precedensowe Europejskiej Konwencji Praw Człowieka pokazuje, że w praktyce te zabezpieczenia prawne nie zawsze są $\mathrm{w}$ Polsce respektowane.

W drugiej kwestii - respektowania przez organy sądowe prawa obrońcy do nieujawniania informacji w ramach tajemnicy zawodowej - należy zauważyć, że w tym względzie prawo do poufności oznacza gwarantowanie dwóch rzeczy: 1. Obrońca nie może zostać zmuszony do ujawnienia informacji poufnych w charakterze świadka; oraz 2. Muszą istnieć wystarczające zabezpieczenia proceduralne uniemożliwiające przechwytywanie informacji poufnych przez organy sądowe dzięki stosowaniu określonych metod prowadzenia postępowania.

Jeżeli chodzi o pierwszą gwarancję, to należy podkreślić, że obecne polskie prawo karne procesowe lepiej chroni prawo do zachowania tajemnicy zawodowej adwokata, a bardziej konkretnie - obrońcy, niż miało to miejsce w okresie obowiązywania Kodeksu postępowania karnego z 1969 r. Na przykład, warunki, na jakich można przesłuchać adwokata w charakterze świadka w celu uzyskania informacji, co do których ma on obowiązek dochować tajemnicy zawodowej, określa obecnie ustawa. To uprawnienie organów sądowych - chociaż rzadko stosowane w praktyce - stoi w wyraźnej sprzeczności z obowiązkiem dochowania tajemnicy zawodowej przez obrońcę zgodnie z bezwzględnie obowiązującymi przepisami ustawy Prawo o adwokaturze oraz zasadami etyki zawodowej. Dlatego kwestia ta ma ogromne znaczenie dla adwokatury.

Druga gwarancja - istnienie zabezpieczeń uniemożliwiających poznanie informacji poufnych przez organy sądowe w wyniku zastosowania określonych metod prowadzenia postępowania - ma oczywiście dla ustawodawcy okresu postkomunistycznego mniejsze znaczenie. W niniejszej pracy przeanalizowano dwie metody prowadzenia postępowania: uprawnienia do przeszukiwania i konfiskaty oraz do podsłuchiwania rozmów telefonicznych. O ile obecne ramy prawne dotyczące przeszukiwania i konfiskaty przewidują pewne zabezpieczenia służące ochronie danych objętych tajemnicą komunikacji pomiędzy adwokatem i klientem, to przepisy regulujące kwestię podsłuchiwania rozmów telefonicznych nie przewidują żadnej ochrony. Jest to niezgodne z prawem precedensowym Europejskiego Trybunału Praw Człowieka. Z treści art. 8 Europejskiej Konwencji zapewniającego ochronę prawa do prywatności wynika, że przepisy prawa krajowego zezwalające na podsłuchiwanie rozmów telefonicznych adwokata stanowiących tajemnicę zawodową powinny przynajmniej określać, jakie informacje objęte są tajemnicą zawodową oraz kto decyduje o tym, które $\mathrm{z}$ podsłuchiwanych informacji mają charakter poufny. ${ }^{15}$

14 Nadzór możliwy jest tylko podczas pierwszych czternastu dni przebywania w areszcie tymczasowym i ogranicza się do sprawdzenia zawartości koperty w obecności zatrzymanego, jeżeli istnieje uzasadnione przypuszczenie, że zawiera ona niedozwolony załącznik.

15 Zob. prawo precedensowe, o którym mowa w Rozdziale 7, § 8.6. 
W Rozdziale 8 omówiono kilka aspektów zawodu adwokata. Po pierwsze, przedstawiono w nim ustrój i historię adwokatury. Krótko mówiąc, na adwokaturę jako ogół adwokatów i aplikantów adwokackich pewien wpływ po drugiej wojnie światowej miał reżim komunistyczny. Ustawy Prawo o adwokaturze z 1950 r. i 1963 r. naruszyły w różny sposób niezależność tej grupy zawodowej, przyznając np. daleko idące uprawnienia nadzorcze Ministrowi Sprawiedliwości oraz likwidując indywidualne kancelarie i wprowadzając (obowiązkową) wspólną praktykę adwokacką. Jednakże w porównaniu z sytuacją, jaka istniała w innych krajach Europy Środkowo-Wschodniej pod rządami komunistycznymi, polska adwokatura była w stanie zachować stosunkowo dużą niezależność.

Niedawne wydarzenia dotyczące adwokatury pokazują, że przez ostatnich kilka lat środowisko to było przedmiotem poważnej krytyki. Jeden z szeroko krytykowanych aspektów środowiska prawniczego dotyczy sposobu przeprowadzania egzaminów i przyjmowania nowych członków do adwokatury: procedury egzaminacyjne nie były przejrzyste i często pojawiały się zarzuty nepotyzmu. Ponadto adwokatura została oskarżona o celowe utrzymywanie jak najmniejszej liczby członków, aby w ten sposób kontrolować konkurencję. W końcu, w wyniku wyroku wydanego przez Trybunał Konstytucyjny RP w 2005 r. dokonano zmian w ustawie Prawo o adwokaturze: wprowadzono bardziej ujednoliconą procedurę przyjmowania nowych członków i osłabiono prawo adwokatury do swobodnego decydowania o odmowie przyjęcia do tej grupy zawodowej.

Druga część Rozdziału 8 dotyczy etyki zawodowej określającej sposób postępowania prawników w Polsce. Po przestawieniu historii zasad etyki zawodowej zwraca się uwagę na obecne zasady profesjonalnego postępowania ze szczególnym uwzględnieniem zasad dotyczących obrońcy. Obowiązujące w Polsce zasady etyki zawodowej charakteryzuje: istnienie wielu odniesień do "godności zawodu" i podobnych ogólnikowych pojęć dotyczących honoru zawodu adwokata, takich jak rzetelność i sumienność, położenie dużego nacisku na niezależność adwokatów od klientów oraz brak konkretnych zasad, które określałyby sposób postępowania obrońcy w sprawach karnych. Autorka zaleca ustanowienie określonych zasad postępowania dla zawodu obrońcy oraz sformułowanie jasnych kryteriów realizowania skutecznej obrony w sprawach karnych nie tylko dlatego, że wprowadzone po upadku komunizmu zmiany w postępowaniu karnym stanowią nowe wyzwania dla obrońcy, lecz również ze względu na utrzymującą się ostatnio tendencję do zwiększania instrumentalnej roli prawa karnego, która ostatecznie może doprowadzić do marginalizacji pozycji obrony. Ostatnim zagadnieniem omawianym w tym rozdziale jest sposób prowadzenia postępowania dyscyplinarnego przez adwokaturę. W wyniku rosnącej krytyki sprawowania nadzoru dyscyplinarnego przez adwokaturę, który uznano za niewystarczający, opracowano szereg zmian legislacyjnych, takich jak wprowadzenie możliwości nałożenia kary pieniężnej przez sędziego prowadzącego rozprawę, jeżeli w określonym terminie adwokatura nie odpowie na skargę dotyczącą zachowania jednego z jej członków.

Ogólnie rzecz biorąc, wnioski przedstawione w Rozdziale 8 świadczą o tym, że adwokatura w Polsce jest dość konserwatywna oraz że przez ostatnich kilka lat najważniejszą sprawą dla niej była ochrona własnej niezależności. W związku z tym procesie demokratyzacji środowisko to zajmowało dość trudną pozycję, aż w końcu rząd wymusił na nim zmiany. 
W Rozdziale 9 przedstawiono streszczenie najważniejszych wniosków z badań i udzielono odpowiedzi na cztery pytania pomocnicze dotyczące podstawowej tezy.

W czasach komunizmu możliwości skutecznego wykonywania uprawnień przez obronę były pod kilkoma względami poważnie ograniczone. Ograniczenia te wynikały nie tylko z wad, jakimi obciążone były przyznane obronie uprawnienia i przywileje procesowe, lecz miały również związek ze sposobem organizacji postępowania karnego i brakiem równowagi w rozdziale uprawnień pomiędzy prokuraturą i władzą sądowniczą. ${ }^{16}$ Wprowadzone po upadku komunizmu zmiany legislacyjne spowodowały pod wieloma względami wzmocnienie pozycji obrony. Do przykładów należy wprowadzenie wyraźnego prawa do uzyskania pomocy prawnej z chwilą zatrzymania oraz podczas przesłuchań, ograniczenie uprawnień do nadzorowania poufnej komunikacji pomiędzy obrońcą i jego klientem oraz rozszerzenie możliwości uczestniczenia przez obronę $\mathrm{W}$ czynnościach śledztwa i posiedzeniach sądu.

Badania wykazały, że o faktycznym oddziaływaniu zmian legislacyjnych mających na celu wzmocnienie prawa do skutecznej obrony - które w praktyce wydaje się być dość ograniczone - decyduje kilka czynników. Pokrótce, są one związane z następującymi sprawami:

a. obecne ramy prawne nadal mają swoje wady, takie jak posługiwanie się ogólnikowymi pojęciami i brak skutecznej kontroli sądowej w sprawach, które mają zasadnicze znaczenie dla skutecznej obrony,

b. praktyczne warunki wstępne dla wykonania prawa do skutecznej obrony nie są (do końca) spełnione,

c. ostatnie wydarzenia w polityce karnej świadczą o coraz większym skoncentrowaniu na skuteczności i represji, co w efekcie spowoduje poświęcenie mniejszej uwagi ochronie prawnej, oraz

d. dominująca kultura prawna - szczególnie postawa członków adwokatury - w myśl której pozostawanie biernym na etapie postępowania przygotowawczego uważane jest w większości przypadków za najlepszą strategię, ma silny wpływ na wprowadzanie w życie uprawnień obrony.

Jeżeli chodzi o oddziaływanie Europejskiej Konwencji Praw Człowieka, to w pracy wykazano, że te międzynarodowe normy mają ograniczony wpływ na postępowanie karne w Polsce. Wprawdzie istnieje kilka ważnych przykładów czerpania inspiracji z Europejskiej Konwencji podczas przeprowadzania reformy postępowania karnego w Polsce, ale pod niektórymi względami obecna sytuacja nadal stanowi naruszenie art. 5, 6 i 8 Konwencji. ${ }^{17}$ Istnieje kilka powodów, dla których wpływ Konwencji jest ograniczony, takich jak tzw. "łagodne podejście" charakterystyczne dla Rady Europy oraz fakt, że wdrażanie międzynarodowych norm dotyczących praw człowieka w krajowym wymiarze sprawiedliwości w

16 Jednakże, pomimo napotykania na te problemy w praktyce, względna niezależność polskiej adwokatury oraz opinie badaczy prawa świadczą o tym, że ideologia komunistyczna miała jedynie ograniczony wpływ na sposób myślenia prawników w Polsce.

17 Jednym z przykładów jest nadzorowanie przez władze komunikacji pomiędzy adwokatem i klientem, polegające na tym, że przy rozmowie obecna jest osoba trzecia, która jest w stanie ją słyszeć. 
sprawach karnych jest w Polsce stosunkowo nowym zjawiskiem. Ogólnie rzecz biorąc, wydaje się, że w miarę upływu czasu oraz rosnących wymagań wobec systemu sprawiedliwości w sprawach karnych, w polskim postępowaniu karnym rola Europejskiej Konwencji jako dokumentu wyznaczającego pewne normy uległa częściowemu osłabieniu.

Reasumując, proces zmian zachodzących w Polsce pokazuje, ze wprowadzenie ustawowych praw i uprawnień procesowych obrony niekoniecznie pociąga za sobą ich realizowanie $\mathrm{w}$ praktyce. Chociaż samo $\mathrm{w}$ sobie nie jest to raczej zaskakujące, przykład Polski pozwala wskazać czynniki, które decydują o faktycznym oddziaływaniu inicjatyw związanych z reformą prawną, mających na celu zagwarantowanie i zwiększenie skuteczności obrony w sprawach karnych. Jest nadzieja, że wnioski te zostaną wykorzystane w innych przyszłych - zarówno krajowych jak i międzynarodowych - instrumentach prawnych, mających na celu zagwarantowanie prawa do "prawdziwej i skutecznej" obrony $\mathrm{w}$ postępowaniu karnym.

Agata Malecka 



\section{Literatuur en jurisprudentie}

\section{Access to Justice in Central and Eastern Europe 2003}

Access to Justice in Central and Eastern Europe - Country Reports, gepubliceerd door the Public Interest Law Initiative, INTERIGHTS, Bulgarian Helsinki Committee en Polish Helsinki Foundation for Human Rights, Hongarije 2003, te raadplegen op: <www.pili. org/en/content/view/51/53/>.

Afenda e.a. 1972

S. Afenda, J. Kasprzycki en A. Zelga, $W$ sprawie wyktadni i stosowania art. 64 i 143 § 3 k.p.k. ('Over de uitleg en toepassing van art. 64 en 143 lid 3 Sv'), Palestra 1972-10, p. 50-55.

\section{Agacka-Indecka 2005 I}

J. Agacka-Indecka, Tajemnica zawodowa adwokata - znaczace rozstrzygnięcia sąów (część I) ('Het beroepsgeheim van de advocaat - belangrijke rechterlijke beslissingen (deel I)'), Palestra 2005-7/8, p. 121-122.

\section{Agacka-Indecka 2005 II}

J. Agacka-Indecka, Tajemnica zawodowa adwokata - znaczące rozstrzygnięcia sądów (część II) ('Het beroepsgeheim van de advocaat - belangrijke rechterlijke beslissingen (deel II)'), Palestra 2005-9/10, p. 66-69.

\section{Alink en Van Zeben 2006}

M.J. Alink en P.D.J. Van Zeben, Getuigen in het Nederlands strafproces, Nijmegen: Wolf Legal Publishers 2006.

\section{Badó 2007}

A. Badó, Legal Transplant, Law Importation, Normative Optimism and Pessimism, in: A. Jakab (e.a.) (red.), The Transformation of the Hungarian Legal Order 1985-2005 - Transition to the Rule of Law and Accession to the European Union, Alphen aan de Rijn: Kluwer 2007, p. 103-107.

\section{Bárd 1999}

K. Bárd, Trial and Sentencing: Judicial Independence, Training and Appointment of Judges, Structure of Criminal Procedure, Sentencing Patterns, the Role of the Defence in the Countries in Transition, European Journal of Crime, Criminal law and Criminal Justice 1999-4, p. 433-447.

\section{Barry en Berman 1968}

D.D. Barry en H.J. Berman, The Soviet Legal Profession, Harvard Law Review 1968-1, vol. 82, p. $1-41$.

\section{Basseches en Korkis 1938}

J. Basseches en J. Korkis, Ustrój adwokatury oraz zasady etyki adwokackiej ('De organisatie van de advocatuur en ethische beginselen van de advocaat'), Lwów: Wydawnictwo Prawnicze 1938.

\section{Beirne en Sharlett 1980}

P. Beirne en R. Sharlett (red.), Selected Writings on Marxism and Law, Londen: Academic Press 1980.

\section{Beyer e.a. 1995}

A. Beyer, C. Cobley en A. Klip, Witness Evidence, Article 6 of the European Convention on Human Rights and the Principle of Open Justice, in: P. Fennell (e.a.) (red.), Criminal Justice in Europe: a Comparative Study, Oxford: Clarendon Press, p. 283-300. 


\section{Bieńkowska 1997}

B.T. Bieńkowska, Kontradyktoryjność postępowania przed sądem I instancji w nowym k.p.k. ('Het contradictoire karakter van de procedure in eerste aanleg volgens het nieuwe wetboek van strafvordering'), Prokuratura i Prawo 1997-12, p. 53-69.

\section{Bieńkowska 1998}

B.T. Bieńkowska, Aktywność stron w postępowaniu przygotowawczym w nowym kodeksie postępowania karnego ('Activiteit van partijen in het vooronderzoek volgens het nieuwe wetboek van strafvordering'), Prokuratura i Prawo 1998-3, p. 7-31.

\section{Bieńkowska e.a. 2004}

B. Bienkowska, P. Kruszyński, C. Kulesza en P. Piszczek, Wykład prawa karnego procesowego ('Uitleg van het strafprocesrecht'), Białystok: Temida 22004.

\section{Bojańczyk 2005}

A. Bojańczyk, W sprawie dopuszczalności dalszego petnienia obowiązków przez obrońcę w situacji ustania stosunku obrończego z wyboru - uwagi na marginesie art. 81 i 378 k.p.k. ('Over de toelaatbaarheid van het voortzetten van werkzaamheden door de raadsman wanneer zijn betrekking als gekozen raadsman is beëindigd - kanttekeningen bij art. 81 en 378 Sv'), Palestra 2005-3/4, p. 72-83.

\section{Bojarski 1999}

Ł. Bojarski, Czy institucja obrony z urzędu wymaga zmian? ('Dient het instituut van de toegevoegde verdediging gewijzigd te worden?'), Palestra 1999-5/6, p. 52-62.

\section{Bojarski 2003}

Ł. Bojarski, Access to Legal Aid: Information about the Project, in: Access to Justice in Central and Eastern Europe: A Source Book, gepubliceerd door the Public Interest Law Initiative, INTERIGHTS, Bulgarian Helsinki Committee en Polish Helsinki Foundation for Human Rights, Hongarije 2003, te raadplegen op: <www.pili.org/en/content/55/53>.

\section{Bojarski 2006}

Ł. Bojarski, Samorząd Zawodowy a solidarność zawodowa ('Zelfbestuur versus beroepssolidariteit'), in: H. Izdebski en P. Skuczynski (red.), Etyka zawodów prawniczych - etyka prawnicza, Warschau: Lexis Nexis 2006, p. 219-238.

\section{Bojarski en Van Dijck 2007}

J. Bojarski en M. van Dijck, Combating Business Crime in Poland, Tilburg Law Review 2007-3, p. 257-282.

\section{Boksem 2007}

J. Boksem, Met raad en daad - gedachten over de positie van de verdediger in strafzaken, oratie uitgesproken op 2 maart 2007 bij de aanvaarding van het ambt van bijzonder hoogleraar verdediging in strafzaken aan de Universiteit Maastricht, Deventer: Kluwer 2007.

\section{Bonsal 1961}

D.B. Bonsal, The Judiciary and the Bar - Socialist Legality vs. the Rule of Law, Texas Law Review 1961-1, vol. 40, p. 1-17.

\section{Boratyński e.a. 2005}

K.T. Boratyński, A. Górski, A. Sakowicz en A. Ważny, Kodeks postępowanie karnego - komentarz ('Wetboek van strafvordering - commentaar'), Warschau: C.H. Beck 2005.

\section{Borgers e.a. 2006}

M.J. Borgers, F.G.H. Kirsten en J.B.H.M. Siebelink (red.), Implementatie van kaderbesluiten, Nijmegen: Wolf Legal Publishers 2006.

\section{Brants 2008}

C.H. Brants, Strafrechtsvergelijking, Delikt en Delinkwent 2008-3, p. 214-242. 


\section{Brzezinski 1993}

M. Brzezinski, The Emergence of Judicial Review in Eastern Europe. The Case of Poland, The American Journal of Comparative Law 1993, vol. 41, p. 153-200.

\section{Brzezinski en Garlicki 1995 I}

M.F. Brzezinski en L. Garlicki, Judicial Review in Post-Communist Poland. The Emergence of a Rechtsstaat?, Stanford Journal of International Law 1995, vol. 31, p. 13-59.

\section{Brzezinski en Garlicki 1995 II}

M.F. Brzezinski en L. Garlicki, Polish Constitutional Law, in: S. Frankowski en B. Stephan III (red.), Legal Reform in Postcommunist Europe. The View from Within, Dordrecht (etc.): Nijhoff 1995, p. 21-50.

\section{Burnham e.a. 2004}

W. Burnham, P.B. Maggs en G.M. Dalinenko, Law and Legal System of the Russian Federation (third edition), Parker School of Foreign and Comparative Law Columbia University, New York: Juris 2004.

\section{Cape e.a. 2007}

E. Cape. J. Hodgson, T. Prakken en T. Spronken (red.), Suspects in Europe - Procedural Rights at the Investigative Stage of the Criminal Process in the European Union, Antwerpen/Oxford: Intersentia 2007.

\section{Chankowska 2003}

J. Chankowska Prawo oskarżonego do milczenia ('Het recht van verdachte om te zwijgen'), Prokuratura i Prawo 2003-3, p. 129-140.

\section{Chloros 1992}

A.G. Chloros, Common Law, Civil Law and Socialist Law: Three Leading Systems of the World, Three Kinds of Legal Thought, in: C. Varga (red.), Comparative Legal Cultures, Aldershot: Dartmouth 1992, p. 83-98.

\section{Cholewinski 1998}

R. Cholewinski, The Protection of Human Rights in the New Polish Constitution, Fordham International Law Journal 1998, vol. 22, p. 236-291.

\section{Cichoń 2004}

C. Cichoń, Adwokatura doceniana, ale nie u nas ('De advocatuur wordt gerespecteerd, maar niet bij ons'), Rzeczpospolita 5-3-2004.

\section{Cieślak 1963}

M. Cieślak, Zagadnienie immunitetu adwokackiego ('Kwesties aangaande de immuniteit van de advocaat'), Palestra 1963-7/8, p. 4-17.

\section{Cieślak 1970}

M. Cieślak, Nowe prawo karne procesowe Polski Ludowej ('Het nieuwe strafprocesrecht van de Volksrepubliek Polen'), Palestra 1970-3, p. 24-35.

\section{Cieślak 1980}

M. Cieślak, W kwestii cenzury korespondencji tymczasowo aresztowanego ze swym obrońca, ('Over het censureren van correspondentie tussen de voorlopig gehechte verdachte en zijn raadsman'), Palestra 1980-8/9, p. 81-84.

\section{Cieślak 1992}

M. Cieślak, Die Reform des Strafverfahrens in Polen, Zeitschrift für die gesamte Strafrechtswissenschaft 1992-2, vol. 104, p. 472-485.

\section{Cieślak en Janczukowicz 1998}

W. Cieślak en K. Janczukowicz, Kodeksy Karne 1969-1997. Zestawienia Porównawcze ('Strafrechtelijke codificaties 1969-1997. Vergelijkende samenstellingen'), Sopot: Lex 1998. 


\section{Clark 1999}

D.S. Clark, Comparing the Work and Organization of Lawyers Worldwide: The Persistence of Legal Traditions, in: J.J. Barceló en R. C. Cramton (red.), Lawyer's Practice and Ideals: A Comparative View, Den Haag: Kluwer 1999, p. 9-155.

\section{Corstens 2005}

G.J.M. Corstens, Het Nederlands strafprocesrecht, Deventer: Kluwer 2005.

\section{Country Report 2002}

Access to Justice Country Report: Poland, gepubliceerd door the Polish Helsinki Foundation for Human Rights (Ł. Bojarski) 2002, te raadplegen op: <www.pili.org/2005r/dmdocu ments/CR_Poland.pdf>.

\section{Czapska en Kury 2002}

J. Czapska en H. Kury (red.), The Myth of Repression or: The importance of Crime Prevention, Krakau: Zakamycze 2002.

\section{Czechowicz 1998}

B. Czechowicz, Udziat oskarżonego i obrońcy $w$ czynnościach procesowych w świetle nowego kodeksu postępowania karnego ('Deelname van de verdachte en de raadsman aan proceshandelingen in het licht van het nieuwe wetboek van strafvordering'), in: L. Bogunia (red.): Nowa Kodyfikacja prawa karnego - tom II, Wrocław: Wydawnictwo Uniwersytetu Wrocławskiego p. 76-80.

\section{Czechowicz 2001}

B. Czechowicz, Zmiana obrońcy w toku procesu w przypadku obrony obligatoryjnej - uwagi do art. 378 k.p.k. ('Wijziging van raadsman gedurende het proces in geval van verplichte rechtsbijstand - opmerkingen bij art. $378 \mathrm{~Sv}$ '), Palestra 2001-7/8, te raadplegen op: <www. palestra.pl/index.php?go=artykul\&id=441>.

\section{Czekaj 1998}

M. Czekaj, Udział obrońcy w postępowaniu przygotowawczym w nowym kodeksie postępowania karnego ('Deelname van de raadsman aan het vooronderzoek in het nieuwe wetboek van strafvordering'), Prokuratura i Prawo 1998-1, p. 36-48.

\section{Czernicka en Tuleya 2005}

M. Czernicka en J. Tuleya, Kodeks postępowanie karnego ('Het wetboek van strafvordering'), Warschau: C.H. Beck 2005.

\section{Czeszejko-Sochacki 1975}

Z. Czeszejko-Sochacki, Le barreau en République Populaire de Pologne, Droit Polonais Contemporain 1975-2, vol. 26, p. 9-19.

\section{Czeszejko-Sochacki 1978}

Z. Czeszejko-Sochacki, Organization of the courts, the public prosecutor's office and the bar, in: The law in Poland: the chosen problems (uitgave van the Polish Lawyers Association) Warschau: Wydawnictwo Prawnicze 1978, p. 156-188.

\section{Czeszejko en Krzemiński 1971}

Z. Czeszejko en Z. Krzemiński, Odpowiedzialność dyscyplinarna adwokatów ('Tuchtrechtelijke aansprakelijkheid van advocaten'), Warschau: Wydawnictwo Prawnicze 1971, p. 67-78.

\section{Daamen 2007}

H.M.W. Daamen, Verdediging in vertrouwen - de bescherming van de vertrouwensrelatie tussen strafrechtadvocaat en cliënt in Nederland en Italië, Tilburg: Celsus Juridische Uitgeverij 2007.

\section{Dąb 1954}

A. Dąb, Prawo do obrony ('Het recht op verdediging'), Państwo i Prawo 1954-3, p. 444-465. 


\section{Dahs 2005}

H. Dahs, Handbuch des Strafverteidigers, Keulen: Verlag dr. Otto Schmidt 2005.

\section{Damaška 1973}

M.R. Damaška, Evidentiary Barriers to Conviction and Two Models of Criminal Procedure A Comparative Study, University of Pennsylvania Law Review 1973, vol. 121, p. 506-589.

\section{Damaška 1975}

M.R. Damaška, Structures of Authority and Comparative Criminal Procedure, Yale Law Journal 1975, vol. 84, p. 480-544 .

\section{Damaška 1986}

M.R. Damaška, The Faces of Justice and State Authority - a comparative approach to the legal process, New Haven (etc.): Yale University Press 1986.

\section{Daniuk e.a. 2006}

B. Daniuk, M. Derezińska, W. Hermeliński. P. Kładoczny en A. Sędek, Prawo do obrony w postępowaniu przygotowawczym na tle dostępu do pomocy prawnej w postępowaniu karnym ('Het recht op verdediging in het vooronderzoek en de toegang tot rechtsbijstand in het strafproces'), rapport uitgegeven door de Poolse balie, Warschau: NRA 2006.

\section{Daszkiewicz 1957}

W. Daszkiewicz, Obowiązki obrońcy a jego osobiste przekonanie o winie oskarżonego ('De verplichtingen van de raadsman en zijn persoonlijke overtuiging over de schuld van de verdachte'), Państwo i Prawo 1957-1, p. 69-86.

\section{Daszkiewicz 2001}

W. Daszkiewicz, Prawo Karne Procesowe. Zagadnienia Ogólne, t. 1 ('Strafprocesrecht. Algemene kwesties. Dl. 1'), Poznań: Branta 2001.

\section{David en Brierly 1978}

R. David en J.E.C. Brierly, Major Legal Systems in the World Today. An Introduction to the Comparative Study of Law, Londen: Stevens 1978.

\section{Davies 2005}

N. Davies, God's Playground - a History of Poland in two Volumes, Oxford (etc.): Oxford University Press 2005.

\section{De Virion 1974}

T. de Virion, Kontradyktoryjność postępowania przygotowawczego ('Tegenspraak in het vooronderzoek'), Palestra 1974-1, p. 33-40.

\section{Depa 2004}

W. Depa, Prawa oskarżonego do obrony de lege lata ('Het recht op verdediging volgens het huidige recht'), Krakau: ABW 2004.

\section{Dietrich 2000}

M.K. Dietrich, Legal and Judicial Reform in Central and Eastern Europe and the Former SovietUnion - Voices from five Countries, gepubliceerd door de Worldbank, Washington 2000, te raadplegen op: <http://siteresources.worldbank.org/ECAEXT/Resources/ljr_eca.pdf>.

\section{Dodge 1979}

C.R. Dodge, A World without Prisons, Lexington (etc.): Lexington Books 1979.

\section{Domagalski 2004}

M. Domagalski, Korporacje dla krewnych ('Beroepsgroep voor bloedverwanten'), Rzeczpospolita 27-4-2004. 


\section{Drzemczewski en Nowicki 2001}

A. Drzemczewski en M.A. Nowicki, Poland, in: R. Blackburn en J. Polakiewicz (red.), Fundamental Rights in Europe - The European Convention on Human Rights and its Member States 1950-2000, Oxford: Oxford University Press 2001.

\section{Dudka 1998}

K. Dudka, Kontrola korespondencji i podstuch w polskim procesie karnym ('Controle van correspondentie en afluisteren in het Poolse strafproces'), Lublin: Wydawnictwo Uniwersytetu Marii Curie-Skłodowskiej 1998.

\section{Dudka 1999}

K. Dudka, Podsluch komputerowy w polskim procesie karnym - wybrane zagadnienia praktyczne ('Het tappen van computers in het Poolse strafproces - een aantal praktische kwesties'), Prokuratura i Prawo 1999-1, p. 69-79.

\section{Een maatschappelijke orde 2006}

Een maatschappelijke orde, Rapport van de Commmissie Van Wijmen d.d. 24-4-2006, te raadplegen op: <www.justitie.nl/images/Advocatuur_tcm74-115174_tcm34-20054.pdf>.

\section{Ereciński en Płachta 1985}

T. Ereciński en M. Płachta, Rola zeznań na tle zasady swobodnej oceny dowodów ('De rol van de getuigenverklaring en het beginsel van vrije bewijswaardering'), in: M. Dobrowolska (e.a.), Świadek w procesie sądowym, Warschau: Wydawnictwo Prawnicze 1985, p. 121-227.

\section{Fatić 1997}

A. Fatić, Crime and Social Control in 'Central'-Eastern Europe - A Guide to Theory and Practice, Ashgate: Aldershot (etc.) 1997.

\section{Fedorowicz 2004}

H. Fedorowicz, Palestra chce zmian ale nie rewolucji ('De balie wil veranderingen maar geen revolutie'), Rzeczpospolita 12-1-2004.

\section{Feldbrugge 1959}

F.J.M. Feldbrugge, Schuld in het sowjet strafrecht, Utrecht (etc.): Dekker \& Van de Vegt 1959.

\section{Feldbrugge 1985}

F.J.M. Feldbrugge, Schuld in het sovjet strafrecht, Ars Aequi 1985-12, p. 681-688.

\section{Fijnaut 2001}

C.J.C.F. Fijnaut, De toelating van de raadsman tot het politiële verdachtenverhoor. Een status questionis op de drempel van de eenentwintigste eeuw, in: M.S. Groenhuijzen en G. Knigge (red.), Onderzoeksproject strafvordering 2001, Tweede interimrapport - Het vooronderzoek in strafzaken, Deventer: Gouda Quint 2001, p. 671-772.

\section{Fitzpatrick 1983}

C.A. Fitzpatrick (red.), Poland under Martial Law. A report on Human Rights by the Polish Helsinki Watch Committee, New York: Helsinki Watch Committee 1983.

\section{Frankowski 1982 I}

S. Frankowski, The Polish Criminal Justice System after World War Two. Selected Problems, University of Pittsburgh Law Review 1982, vol. 44, p. 139-161.

\section{Frankowski 1982 II}

S. Frankowski, Polish Supreme Court Directives as Sources of Criminal Law, in: W.E. Butler (red.), Anglo Polish Legal Essays, New York: Transnational Publishers 1982, p. 55-74.

\section{Frankowski 1987 I}

S. Frankowski, The Procuracy and the Regular Courts as the Palladium of Individual Rights and Liberties. The Case of Poland, Tulane Law Review 1987-61, p. 1307-1338. 


\section{Frankowski 1987 II}

S.J. Frankowski, Poland, in: G.F. Cole, S.J. Frankowski en M.G. Gertz (red.), Major Criminal Justice Systems. A Comparative Survey, Newbury Park (etc.): Sage 1987, p. 221-261.

\section{Frankowski 1991}

S. Frankowski, The Independence of the Judiciary in Poland. Reflections on Andrzej Rzeplinski's Sadownictwo w Polsce Ludowej (The Judiciary in People's Poland), Arizona Journal of International and Comparative Law 1991, vol. 8, p. 33-52.

\section{Frankowski 1992}

S. Frankowski, Pre-trial Detention in Poland. A Comparative and International Law Perspective, in: S. Frankowski en D. Shelton (red.), Preventive Detention. A Comparative and International Law Perspective, Dordrecht (etc.): Nijhoff 1992, p. 243-298.

\section{Frankowski en Wąsek 1993}

S. Frankowski en A. Wąsek, Evolution of the Polish Criminal Justice System After World War Two. An Overview, European Journal of Crime, Criminal Law and Criminal Justice 1993-2, p. 143-166.

\section{Fredrich-Michalska en Stachurska-Marcińczak 1997}

I. Fredrich-Michalska en B. Stachurska-Marcińczak (red.), Kodeks karny. Kodeks postępowania karnego. Kodeks karny wykonawczy: nowe kodeksy karne z 1997 r. z uzasadnieniami ('Wetboek van Strafrecht. Wetboek van Strafvordering. Wetboek van tenuitvoerlegging: Nieuwe strafrechtelijke codificaties van 1997 met motivering'), Warschau: Wydawnictwo Prawnicze 1998.

\section{Friedman en Zile 1964}

L. Friedman en Z.L. Zile, Soviet Legal Profession: Recent Developments in Law and Practice, Wisconsin Law Review 1964, p. 32-77.

\section{Gajewska-Krackowska 1992}

H. Gajewska-Kraczkowska, The bar in Poland: professional ethics and the legal position of the defense counsel in criminal cases, Capital University Law Review 1992, vol. 21, p. 1125-1144.

\section{Gajewska-Kraczkowska 1997}

H. Gajewska-Kraczkowska, Świadek incognito: między efektywność ścigania a prawem do obrony ('De anonieme getuige: tussen effectiviteit van vervolging en het recht op verdediging'), in: P. Kruszyński (red.), Węzłowe zagadnienia procedury karnej - księga ku czci prof. Andrzeja Murzynowskiego - Studia Iuridica 1997-33, Warschau: Wydawnictwa Unywersytetu Warszawskiego 1997, p. 95-103.

\section{Gajewska-Kraczkowska 2006}

H. Gajewska-Kraczkowska, Tajemnicza zawodowa ('Het beroepsgeheim'), in: H. Izdebski en P. Skuczynski (red.), Etyka zawodów prawniczych - etyka prawnicza, Warschau: Lexis Nexis 2006, p. 192-203.

\section{Gajewska-Kraczkowska en Palmer 1991}

H. Gajewska-Kraczkowska en J. W. Palmer, Introduction of criminal procedure in the socialist countries of Eastern Europe, Warschau: Warsaw University 1991.

\section{Gardocka 1984}

T. Gardocka, Immunitet adwokacki w prawie o adwokaturze z 1982 roku ('Immuniteit van de advocaat in de Advocatenwet van 1982'), Palestra 1984-3/4, p. 9-13 .

\section{Garlicki 1980}

L. Garlicki, Legal Profession in Poland, Saint Louis University Law Journal 1980, vol. 24, p. 486-513. 


\section{Gąsiorowska 2005}

M.M. Gąsiorowska, Nieprawidtowe praktyki w zakresie zarzadzenia zgody na widzenie wydawanej obrońcy ('De onrechtmatige praktijk met betrekking tot het verlenen van toestemming voor bezoek van de raadsman'), Palestra 2005-1/2, p. 85-87.

\section{Gessner e.a. 1996}

V. Gessner, A. Hoeland en V. Csaba (red.), European legal cultures, Aldershot (etc): Dartmouth 1996.

\section{Ginter 2004}

J. Ginter, Judicial Independence and Capacity in the EU accessing Countries, in: R. Alleweldt (e.a.) (red.), Human Rights and the Rule of Law, Krakau: Zakamycze 2004, p. 351-355.

\section{Gökay 2001}

B. Gökay, Eastern Europe since 1970, Harlow (etc.): Longman 2001.

\section{Goldschmidt 2007}

J. Goldsmidt, Lawyering today and tomorrow and the core values of the profession, lezing ter gelegenheid van het vijfjarig jubileum van de Vlaamse balie op 24-5-2007 te Brussel, te raadplegen op: <www.ccbe.org/fileadmin/user_upload/NTCdocument/Lawyering_to day _and_1_1189500260.doc>.

\section{Goldstein Bolocan 2002}

M. Goldstein Bolocan (red.), Professional Legal Ethics - a Comparative Perspective, CEELI Concept Paper Series 8-7-2002, te raadplegen op: <http://papers.ssrn.com/s013/papers. cfm?abstract_id=321700>.

\section{Gostynski en Garfield 1993}

Z. Gostynski en A. Garfield, Taking the other road: Polish legal education during the past thirty years, Temple International Law and Comparative Law Journal 1993, vol. 7, p. 243-286.

\section{Grajewski 2005}

J. Grajewski, Przebieg procesu karnego ('Het verloop van het strafproces'), Warschau: C.H. Beck 2005.

\section{Grajewski 2006}

J. Grajewski (red.), Kodeks Postępowanie Karnego - komentarz tom 1 ('Het Wetboek van Strafvordering - commentaar deel 1), Krakau: Zakamycze 2006.

\section{Grajewski en Lammich 1981}

J. Grajewksi en S. Lammich, Criminal Policy in Poland in Light of the Criminal Code of 1969, Review of Socialist Law 1981-4, vol. 7, p. 407-423.

\section{Gralla 1964}

E. Gralla, Die Anwaltschaft in Polen, Jarbuch für Ostrecht 1964-2, p. 173-186.

\section{Grzegorczyk 1979}

T. Grzegorczyk, Pozycja obrońcy w procesie karnym ('De positie van de raadsman in het strafproces'), Palestra 1979-4, p. 1-17.

\section{Grzegorczyk 1980}

T. Grzegorczyk, O uprawnieniach obrońcy w postępowaniu przygotowawczym ('Over de rechten van de raadsman in het vooronderzoek'), Palestra 1980-8/9, p. 55-71.

\section{Grzegorczyk 1988}

T. Grzegorczyk, Obrońca w postępowaniu przygotowawczym ('De raadsman in het vooronderzoek'), Wydawnictwo Uniwersytetu Łódzkiego 1988. 


\section{Grzegorczyk 1999}

T. Grzegorczyk, Orzekanie pod nieobecność oskarżonego w postępowaniu karnym zwyczajnym w świetle nowego kodeksu postępowania karnego ('Berechting in afwezigheid van verdachte in het reguliere strafproces in het licht van het nieuwe wetboek van strafvordering'), in: T. Nowak (red.), Nowe prawo karne procesowe. Zagadnienia wybrane. Księga ku czci Profesora Wiesława Daszkiewicz, Poznań: Printer 1999.

\section{Grzegorczyk 2000}

T. Grzegorczyk, Obrona z urzędu w nowym kodeksie postępowania karnego ('De toegevoegde raadsman in het nieuwe wetboek van strafvordering'), in: J. Czapska (e.a.) (red.), Zasady procesu karnego wobec wyzwań wspótczesności - księgia ku czci profesora S. Waltosia, Warschau: Wydawnictwo Prawnicze PWN 2000, p. 311-323.

\section{Grzegorczyk 2004}

T. Grzegorczyk, Kodeks Postępowania Karnego: Komentarz ('Wetboek van Strafvordering: Commentaar), Krakau: Zakamycze 2004.

\section{Grzegorczyk en Tylman 1998}

T. Grzegorczyk en J. Tylman, Polskie Postępowanie Karne ('Het Poolse strafproces'), Warschau: Wydawnictwo Prawnicze PWN 1998.

\section{Grzegorczyk en Tylman 2001}

T. Grzegorczyk en J. Tylman, Polskie Postępowanie Karne ('Het Poolse strafproces'), Warschau: Wydawnictwo Prawnicze PWN 2001.

\section{Grzeszczyk 1997}

W. Grzeszczyk, Nowe rozwiązania części ogólnej kodeks postępowanie karnego z 1997 ('Nieuwe oplossingen in het algemeen deel van het wetboek van strafvordering van 1997'), Prokuratura i Prawo 1997-9, p. 52-75.

\section{Grzeszczyk 2003}

W. Grzeszczyk, Glówne kierunki zmian kodeksu post postępowania karnego (cz. II) ('Algemene richtingen van wijzigingen van het wetboek van strafvordering (dl. 2)'), Prokuratura $i$ Prawo 2003-6, p. 7-16.

\section{Gsovksi en Grzybowksi 1959}

V. Gsovski en K. Grzybowksi, Government, Law and Courts in the Soviet Union and Eastern Europe, Londen: Stevens 1959.

\section{Gubanski 2004}

J. Gubanksi, Comparative Criminal Justice. Special Investigation Techniques during the Criminal Trial - Disclosure Issues in Polish and American (USA) Legal Systems, Crime Law and Social Change 2004-1, vol. 41, p. 15-32.

\section{Gwirdoyń 2004}

P. Gwirdoyń, Zarys kriminalistycznej taktyki obrony ('Een overzicht van verdedigingstactieken'), Krakau: Zakamycze 2004.

\section{Haberfield 1997}

M.A. Haberfield, Poland: 'the Police are not the Public and the Public are not the Police' Transformation from Militia to Police, Policing: an International Journal of Police Strategy and Management 1997-4, vol. 20, p. 641-654.

\section{Hazard 1941}

J.N. Hazard, Soviet Criminal Procedure, Tulane Law Review 1941, p. 220-240.

\section{Hazard 1946}

J.N. Hazard, The Lawyer under Socialism, Wisconsin Law Review 1946, p. 90-108. 


\section{Hazard 1969}

J.N. Hazard, Communists and their Law - a Search for the Common Core of the Legal Systems of the Marxian Socialist States, Chicago (etc.): University of Chicago Press 1969.

\section{Hazard 1971}

J.N. Hazard, Area Studies and Comparison of Law: The Experience with Eastern Europe, The American Journal of Comparative Law 1971, p. 645-654.

\section{Hazard 1978}

J.N. Hazard, Settling Disputes in Soviet Society - the formative years of legal institutions, New York: Octagon Books 1978.

\section{Henckaerts en Van der Jeught 1998}

J. Henckaerts en S. van der Jeught, Human rights protection under the new constitutions of Central Europe, Loyola of Los Angeles International and Comparative Law Journal 1998, vol. 20, p. 475-506.

\section{Hermann 1996}

J. Hermann, Models for the Reform of the Criminal Trial in Eastern Europe: A Comparative Perspective, St. Louis-Warsaw Transatlantic Law Journal 1996, p. 127-151.

\section{Hermeliński 1998}

W. Hermeliński, Country Report: Poland, The Parker School Journal of East European Law 1998-1/2, p. 173-183.

\section{Hofmański 1995}

P. Hofmański, Poland after Ratification of the European Convention on Human Rights and Fundamental Freedoms, Helsinki Monitor 1995-1, p. 45-55.

\section{Hofmański 1997}

P. Hofmański, Nowe Polskie prawo karne w świetle europejskich standardów w zakresie ochrony prawczłowieka ('Het nieuwe Poolse strafrecht in het licht van de Europese standaard voor bescherming van de rechten van de mens'), Warschau: Program Unii Europejskiej Phare/ Tacis Demokracja 1997.

\section{Hofmański 1998}

P. Hofmański, Świadek anonimowy w procesie karnym ('De anonieme getuige in het strafproces'), Krakau: Zakamycze 1998.

\section{Hofmański 1999}

P. Hofmański (red.), Kodeks Postępowania karnego: kommentarz T. 2 ('Het wetboek van strafvordering: commentaar Dl. 2'), Warschau: Wydawnictwo C. H. Beck 1999.

\section{Hofmański e.a. 2004}

P. Hofmański (e.a.) (red.), Kodeks postępowanie karnego: kommentarz Tom I ('Wetboek van strafvordering: commentaar Deel I'), Warschau: Wydawnictwo C.H. Beck 2004.

\section{Hofmański e.a. 2007 I}

P. Hofmański, E. Sadzik en K. Zgryzek, Kodeks Postępowanie Karnego, Tom I Komentarz ('Wetboek van Strafvordering, deel I Commentaar'), Warschau: Wydawnictwo C.H. Beck 2007.

\section{Hofmański e.a. 2007 II}

P. Hofmański, E. Sadzik en K. Zgryzek, Kodeks Postępowanie Karnego, Tom II Komentarz ('Wetboek van Strafvordering, deel II Commentaar'), Warschau: Wydawnictwo C.H. Beck 2007.

\section{Hofmański en Zabłocki 2000}

P. Hofmański en S. Zabłocki, Świadek anonimowy - niespetnione nadzieje ('De anonieme getuige niet vervulde verwachtingen'), in: J. Czapska (e.a.) (red.), Zasady procesu karnego wobec wyzwań wspótczesności - księga ku czci profesora S. Waltosia, Warschau: Wydawnictwo Prawnicze 2000, p. 678-697. 


\section{Hofmański en Zabłocki 2008}

P. Hofmański en S. Zabłocki, Landesbericht Polen, in: T. Weigend, S. Walther en B. Grunewald (red.), Strafverteidigung vor neuen Herausforderungen, Berlijn: Duncker \& Humblot 2008, p. 263-284.

\section{Hołda 1991}

Z. Hołda, The Polish Criminal Justice System and Recent Political Developments, lezing gehouden aan de Universiteit van Hong Kong op 1 mei 1990, Hong Kong: Social Sciences Research Centre 1991.

\section{Holmes 1997}

L. Holmes, Post-communism: An introduction, Cambridge (etc.): Polity Press 1997.

\section{Hoon Chun 2001}

J.D. Hoon Chun, The Legal System of Poland, in: K. Redden en L. L. Schlueter (red.), Modern Legal Systems Encyclopedia, Buffalo: Hein 2001.

\section{Huskey 1986}

E. Huskey, The Politics of the Soviet Criminal Process: Expanding the Right to Counsel in Pre-Trial Proceedings, American Journal of Comparative Law 1986, vol. 34, p. 93-112.

\section{Izydorczyk 2002}

J. Izydorczyk, Praktyka stosowania tymczasowego aresztowania ('Toepassing van voorlopige hechtenis in de praktijk'), Łódź: Wydawnictwo Uniwersytetu Łódźkiego 2002.

\section{Janczewski 1960}

S. Janczewski, Godność zawodu adwokackiego ('De waardigheid van het beroep van advocaat'), Warschau: Wydawnictwo Prawnicze 1960.

\section{Janik 1977}

E. Janik (vert. en inl.), Das polnische Strafuerfahrensgesetzbuch, Berlijn (etc.): De Gruyter 1977.

\section{Jarocki en Kruszewski 1974}

Z. Jarocki en I.F. Kruszewski, Uwagi na temat kontradyktoryjności postępowania przygotowawczego $i$ aktywnego w nim udziału obrońcy ('Opmerkingen over het contradictoire karakter van het vooronderzoek en actieve deelname van de raadsman daaraan'), Palestra 1974-8/9, p. 88-98.

\section{Jaworski 1997}

C. Jaworski, Adwokatura po zmianie ustawy ('De advocatuur na wijziging van de wet'), Palestra 1997-3/4, p. 6-16.

\section{Judicial Independence in Poland 2001}

Judicial Independence in Poland - Monitoring the EU Accession Process, Open Society Institute 2001, te raadplegen op: <www.eumap.org/reports/2001/judicial/sections/poland/judicial_poland.pdf>.

\section{Jurkiewicz 2001}

G. Jurkiewicz, Większa siła. Sądy dyskryminują adwokatów w udostępnianu akt ('Een grotere kracht. Rechterlijke instanties discrimineren advocaten bij de inzage van processtukken'), Rzeczpospolita 5-3-2001.

\section{Justice under Siege: a report on the rule of law in Poland 2007}

Justice under Siege: a report on the rule of law in Poland - An International Bar Association Human Rights Institute/Council of Bars and Law Societies of Europe Report, november 2007, te raadplegen op: <www.ccbe.eu/fileadmin/user_upload/NTCdocume nt/11_2007_Nov06_Report1_1194344860.pdf>.

\section{Kaftal 1962}

A. Kaftal, O niektórych zagadnieniach immunitetu adwokackiego ('Over enkele kwesties aangaande de immuniteit van de advocaat'), Palestra 1962-11, p. 3-9. 


\section{Kaftal 1963}

A. Kaftal, O niektórych zagadnieniach przestrzegania tajemnicy zawodowej przez adwokatapodejrzanego w procesie karnym ('Over enkele vragen met betrekking tot het in acht nemen van het beroepsgeheim door de advocaat als verdachte in het strafproces') Palestra 1963-4, p. 10-14.

\section{Kaftal 1965}

A. Kaftal, W sprawie zwolnienia adwokata od zachowania tajemnicy zawodowej ('Inzake het opheffen van het beroepsgeheim van de advocaat'), Palestra 1965-7/8, p. 120-125

\section{Kaftal 1989}

A. Kaftal, Model postępowania przygotowawczego w prawiem polskim ('Een model voor het vooronderzoek in het Poolse recht'), Studia Prawnicze 1989-1, p. 41-46.

\section{Kalinowski 1962}

S. Kalinowski, Stanowisko obrońcy w polskim procesie karnym ('De positie van de raadsman in het Poolse strafproces'), Palestra 1962-8, p. 3-20.

\section{Kálmán 1960}

L. Kálmán, The Lawyer in Communism - Memoirs of a Lawyer behind the Iron Curtain, Boston: St. Paul Editions 1960.

\section{Kamiński 2004}

I.C. Kamiński, The Role of the EU and the Council of Europe in Poland. A Hope for the Case of Aleksander Kwaśniewski v. the Daily Newspaper Życie?, in: R. Alleweldt (e.a.) (red.), Human Rights and the Rule of Law, Krakau: Zakamycze 2004, p. 217-233.

\section{Kedzia 1991}

Z. Kedzia, The Place of Human rights Treaties in the Polish Legal Order, European Journal of International Law 1991-2, vol. 2, p. 133-140.

\section{Kenney 1973}

W.S. Kenney (inl.), The Penal Code of the Polish Republic (vert. door W.S. Kenney en T. Sadowski), South Hackensack (etc.): Rothman (etc.) 1973.

\section{Kidd 1987}

C.F.J. Kidd, Disciplinary Proceedings and the right to a fair criminal trial under the European Convention on Human Rights, International and Comparative Law Quarterly 1987, vol. 36, p. 856-872.

\section{Klejnowska 2004}

M. Klejnowska, Oskarżony jako osobowe źródło informacji o przestępstwie ('De verdachte als bron van informatie over het strafbare feit'), Krakau: Zakamycze 2004.

\section{Klich 1996}

A. Klich, Human Rights in Poland. The Role of the Constitutional Tribunal and the Commissioner for Citizens' Rights, Saint Louis-Warsaw Transatlantic Law Journal 1996, p. 33-63.

\section{Kmiecik 2000}

R. Kmiecik, Prawo do milczenia zatrzymanej osoby podejrzanej - w świetle reguty nemo tenetur ('Het zwijgrecht van de aangehouden verdachte persoon - in het licht van het nemo tenetur beginsel'), Prokuratura i Prawo 2000-7/8, p. 17-22.

\section{Knapp 1974}

W. Knapp, Der Verteidiger - ein Organ der Rechtspflege?, Keulen (etc.): Carl Heymanns Verlag KG 1974. 


\section{Kontradyktoryjność postępowanie przygotowawczego 1974}

Kontradyktoryjność postępowanie przygotowawczego ('Het contradictoire karakter van het vooronderzoek'), met bijdragen van J. Gorgul, F. Prusak, J. Szlaszewski, J. Lewiński, E. Mazur en T. de Virion, Palestra 1974-1, p. 9-40.

\section{Koper 2001}

R. Koper, Zgoda oskarżonego jako warunek skazania bez rozprawy ('Instemming van verdachte als voorwaarde voor veroordeling zonder onderzoek ter terechtzitting'), Palestra 2001-5/6, p. 7-18.

\section{Kosowska-Gąstoł 2004}

B. Kosowska-Gąstol, The evolution of the Polish Constitutional Tribunal and its Contribution to Establishing the Rule of Law, in: R. Alleweldt (e.a.) (red.), Human Rights and the Rule of Law, Krakau: Zakamycze 2004, p. 85-105.

\section{Kowalewska-Borys 2004}

E. Kowalewska-Borys, Świadek koronny - w ujęciu dogmatycznym ('De kroongetuige - volgens de dogmatiek'), Krakau: Zakamycze 2004.

\section{Krajewski 1985}

K. Krajewski, Poland: The Procurator and Preparatory Proceedings in Polish Criminal Procedure, Comparative Law Yearbook 1985-9, p. 69-82.

\section{Krajewski 2004}

K. Krajewski, Crime and Criminal Justice in Poland, European Journal of Criminology 2004-1, p. 377-407.

\section{Kroner 2004}

J. Kroner, Trybunat Konstytucyjny uchylit przepisy z poprzedniej epoki ('Het Grondwettelijk Hof heeft geoordeeld over voorschriften uit een vorig tijdperk'), Rzeczpospolita 19-2-2004.

\section{Kruk 2005}

E. Kruk, Wyrok skazujacy sadu pierwszej instancji w trybie art. 335 KPK ('Het veroordelend vonnis in eerste aanleg op grond van art. 335 Sv'), Krakau: Zakamycze 2005.

\section{Kruszyński 1985}

P. Kruszyński, Realizcja prawo do obrony na rozprawie głównej ('Verwezenlijking van het recht op verdediging op het onderzoek ter terechtzitting'), Studia Iuridica 1985-13, Warschau: Wydawnictwa Unywersytetu Warszawskiego 1985, p. 95-109.

\section{Kruszyński 1989}

P. Kruszyński, Udział obrońcy w postępowaniu przygotowawczym w ś wietle postulatów de lege ferenda ('Deelname van de raadsman aan het vooronderzoek in het licht van voorstellen tot wijziging'), Palestra 1989-8/9, p. 68-83.

\section{Kruszyński 1991}

P. Kruszyński, Stanowisko prawne obrońcy w procesie karnym ('De positie van de raadsman in het strafproces'), Białystok: Dział Wydaw. Filii UW 1991.

\section{Kruszyński 1993}

P. Kruszyński, Obrońca w projektach kodeksu postępowania karnego ('De raadsman in projecten voor het wetboek van strafvordering'), in: S. Waltoś (red.), Problemy kodyfikacji prawa karnego: księgia ku czci profesora Mariana Cieślak, Krakau: Perfekt 1993, p. 371-379.

\section{Kruszyński 1994}

P. Kruszyński, Obrońca w postępowaniu sądowym ('De raadsman in de procedure voor de rechter'), Warschau: Biblioteka Palestry 1994. 


\section{Kruszyński 1998}

P. Kruszyński, Prawo podejrzanego do obrony w nowym k.p.k. ('Het recht van de verdachte op verdediging in het nieuwe wetboek van strafvordering'), in: E. Skrętowicz (red.), Nowy kodeks postępowania karnego. Zagadnienia węzłowe, Krakau: Zakamycze 1998, p. 141-152.

\section{Kruszyński 2007 I}

P. Kruszyński, The Investigative Stage of the Criminal Process in Poland, in: E. Cape (e.a.) (red.), Suspects in Europe - Procedural Rights at the Investigative Stage of the Criminal Process in the European Union, Antwerpen/Oxford: Intersentia 2007, p. 181-206.

\section{Kruszyński 2007 II}

P. Kruszyński, Case Study: Poland, in: E. Cape (e.a.) (red.), Suspects in Europe - Procedural Rights at the Investigative Stage of the Criminal Process in the European Union, Antwerpen/ Oxford: Intersentia 2007, p. 259-265.

\section{Krygier 1990}

M. Krygier, Marxism and the Rule of Law - Reflections after the Collapse of Communism, Law and Social Inquiry 1990, vol. 15, p. 633-663.

\section{Krzemiński 1959}

Z. Krzemiński, Problem tajemnicy zawodowej adwokata w świetle przepisów prawnych ('De problematiek van het beroepsgeheim in het licht van (een aantal) rechtsregels'), Palestra 1959-10, p. 31-39.

\section{Krzemiński 1975}

Z. Krzemiński, Geneza i ewolucja zasad etycznych w polskiej adwokaturze ('Het ontstaan en de ontwikkeling van ethische beginselen binnen de Poolse advocatuur'), Palestra 1975-5/6, p. $10-12$.

\section{Krzemiński 1994}

Z. Krzemiński, Wystapienia przed Sądem Najwyższym na posiedzeniu w dniu 16 VI 1994 r. poprzedzającym wydanie uchwały składu siedmu sędziów (Sygn. I KZP 5/94) w sprawie tajemnicy zawodowej adwokatów ('Optreden voor het Hooggerechtshof op de zitting van 16-6-1994, voorafgaand aan een beslissing van zeven rechters (I KZP/94) inzake het beroepsgeheim van de advocaat'), Palestra 1994 -9/10, p. 66-70.

\section{Krzemiński 1998}

Z. Krzemiński, Prawo o Adwokaturze - komentarz ('De Advocatenwet - commentaar'), Warschau: C.H. Beck 1998.

\section{Krzemiński 2003}

Z. Krzemiński, Etyka adwokacka - teksty, orzecznictwo, komentarz ('Ethiek van de advocaat teksten, rechtspraak en commentaar'), Krakau: Zakamycze 2003.

\section{Kubiak 1989}

J.R. Kubiak, Veranderingen binnen de strafrechtssystemen van Oost-Europese landen: een poging tot theoretische generalisatie, Justitiële Verkenningen 1989-4, p. 8-20.

\section{Kubiak 1996}

J. Kubiak, The Secret Criminal Trials in Poland during the Stalinist Period, as Illustrated by the Secret Sectin of the Warsaw Court during 1950-1954, in: V. Gessner, A. Hoeland en V. Csaba (red.), European Legal Cultures, Aldershot (etc.): Dartmouth 1996.

\section{Kucherov 1956}

S. Kucherov, The Legal Profession in Pre- and Post-Revolutionary Russia, The American Journal of Comparative Law 1956, vol. 5, p. 443-470. 


\section{Kucherov 1970}

S. Kucherov, The organs of Soviet administration of justice: their history and operation, Leiden: Brill 1970.

\section{Kudrulek en Kwasiński 2006}

J. Kudrulek en R. Kwasiński, Pisma procesowe w postępowaniu przygotowawczym - wzory pism ('Voorbeelden van processtukken uit het vooronderzoek'), Szczytno: WSPol 2006.

\section{Kulesza 2004}

C. Kulesza, Obrońca w postępowaniu przygotowawczym - wybrane aspekty ('De raadsman in het vooronderzoek - verschillende aspecten'), in: A. Marek (red.), Wspólczesne problemy procesu karnego i jego efektywności - księga pamiątkowa profesora Andrzeja Bulsiewicza, Toruń: Tnoik 2004, p. 201-215.

\section{Kulesza 2005}

C. Kulesza, Efektywność udziału obrońcy w procesie karnym - w perspektywie prawnoporównawczej ('De effectiviteit van de deelname van de raadsman aan het strafproces - in rechtsvergelijkend perspectief'), Krakau: Zakamycze 2005.

\section{Kurczewski 1999}

J. Kurczewski, The Rule of Law in Poland, in: J. Přibáň en J. Young (red.), The Rule of law in Central Europe. The Reconstruction of Legality, Constitutionalism and Civil Society in the PostCommunist Countries, Aldershot (etc.): Ashgate/Dartmouth 1999, p. 181-253.

\section{Kurczewski 2001}

J. Kurczewski, Sociology of Law in Poland, The American Sociologist 2001-2, p.85-98.

\section{Kurzępa 1999}

B. Kurzępa, Kontrola i utrwalanie rozmów telefonicznych wedlug kodeksu postępowania karnego ('Afluisteren en opnemen van telefoongesprekken volgens het wetboek van strafvordering'), Prokuratura i Prawo 1999-3, p. 77-92.

\section{Kwakman 2006}

N.J.M. Kwakman, Het recht op inzage in de processtukken: EHRM-proof?, Strafblad 2006-6, p. 500-508.

\section{Kwiatkowski 2005}

Z. Kwiatkowski, Zakazy dowodowe w procesie karnym ('Bewijsverboden in het strafproces'), Krakau: Zakamycze 2005.

\section{Lammich 1976}

S. Lammich, Das Justizrechts des Volksrepubliks Polen: Verfassung der Gerichte, der Staatsanwaltschaft, der Advokatur und des Notariats, Berlijn: Berlin Verlag 1976.

\section{Leszczyński 1995}

L. Leszczyński, International Standards of Human Rights in Polish Constitutional Regulations and Practice, International Law Journal 1995-3, vol. 29, p. 685-695.

\section{Lévay 2000}

M. Lévay, Social Changes and Risging Crime Rates - The Case of Central and Eastern Europe, European Journal of Crime, Criminal Law and Criminal Justice 2000-1, p. 35-50.

\section{Lewiński 1974}

J. Lewiński, Kontradyktoryjność postępowania przygotowawczego ('Het contradictoire karakter van het vooronderzoek'), Palestra 1974-1, p. 25-29.

\section{Lipczyńska 1956}

M. Lipczyńska, Stanowisko oskarżonego w procesie karnym polski ludowej ('De positie van de verdachte in de volksrepubliek Polen'), Warschau: Wydawnictwo Prawnicze 1956. 


\section{Lipczyńska 1970}

M. Lipczyńska, Problematyka kontaktów obrońcy z oskarżonym aresztowanym - w świetle nowego kodeksu postępowania karnego oraz kodeksu karnego wykonawczegov ('De problematiek van contact tussen raadsman en gedetineerde verdachte - in het licht van het nieuwe wetboek van strafvordering en wetboek betreffende de tenuitvoerlegging van straffen'), Palestra 1970-2, p. $62-74$.

\section{Łojewski 1964}

K. Łojewski, Jeszcze o tajemnicy zawodowej adwokata ('Nogmaals over het beroepsgeheim van de advocaat'), Palestra 1964-12, p. 21-28.

\section{Łojewski 1967}

K. Łojewski, Problematyka tajemniczy zawodowej adwokata ('De problematiek van het beroepsgeheim van de advocaat'), Palestra 1967-3, p. 32-38.

\section{Łos 1988}

M. Łos, Communist Ideology, Law and Crime: a Comparative View of the USSR and Poland, 1988, New York: St. Martin's Press 1988.

\section{Ludwiczek 2001}

A. Ludwiczek, Situacja prawna adwokata udzielajacego zatrzymanemu pomocy prawnej w trybie art. $245 \S 1$ k.p.k. ('De juridische status van de advocaat die rechtsbijstand verleent aan de aangehoudene op grond van art. 245 lid 1 Sv'), Problemy prawa karnego 2001-24, p. 104-116.

\section{Ludwiczek 2003}

A. Ludwiczek, Forma porozumienia się zatrzymanego z adwokatem w trybie art. 245 § $1 \mathrm{KPK}$ ('Vormen van overleg tussen aangehoudene en advocaat in de zin van art. 245 lid 1 Sv'), in: P. Hofmański en K. Zgryzek (red.), Wspótczesne problemy procesu karnego i wymiaru sprawiedliwości. Księgia ku czci Profesora Kazimierza Marszała, Katowice: Wydawnictwo Uniwersytetu Śląskiego 2003, p. 224-235.

\section{Ludwikowksi 1987}

R.R. Ludwikowski, Socialist Legal Theory in the Post-Pashukanis Era, Boston College International and Comparative Law Review 1987-2, p. 323-342.

\section{Łyczywek 1989}

R. Łyczywek, Adwokat jako obrońca w Polskim procesie karnym ('De advocaat als raadsman in het Poolse strafproces'), Warschau: Wydawnictwo Prawnicze 1989.

\section{Maciejewska 2000}

S. Maciejewska, Nowe gwarancje prawa do obrony przyznane podejrzanemu w kodeksie postępowania karnego z 1997 roku ('Nieuwe garanties in het kader van het recht op verdediging toegekend aan de verdachte door het wetboek van strafvordering van 1997'), in: L. Bogunia (red.), Nowa kodyfikacja prawa karnego - tom $V$, Wrocław: Wydawnictwo Unywersitetu Wrocławskiego 2000, p. 113-129.

\section{Malfliet 1987}

K. Malfliet, Inleiding tot het recht en de politieke instellingen van de Oost-Europese staten, Leuven: Acco 1987.

\section{Marguery 2008}

T.P. Marguery, Unity and Diversity of the Public Prosecution Services in Europe - a study of the Czech, Dutch, French and Polish systems, proefschrift Rijksuniversiteit Groningen 2008.

\section{Marszał 1997}

K. Marszał, Polski Proces Karny ('Het Poolse strafproces'), Katowicze: Volumen 1997. 


\section{Masłowska 2004}

A. Masłowksa, Obrońca podejrzanego w postępowaniu przygotowawczym po nowelizacji kodeksu postępowania karnego ('De raadsman van verdachte in het vooronderzoek na wijziging van het wetboek van strafvordering'), in: Z. Sobolewski (e.a.) (red.), Problemy znowelizowanej procedury karnej, Warschau: Zakamycze 2004, p. 349-360.

\section{Masłowska 2006}

A. Masłowska Ukrywanie prawdy w postępowaniu karnym przez obrońce oskarżonego ('Verhullen van de waarheid in het strafproces door de raadsman van verdachte'), in: Z. Sobolewski en G. Artymiak (red.), Zasada prawdy materialnej, Krakau: Kantor Wydawniczy Zakamycze 2006, p. 197-203.

\section{Mazur 1971}

E. Mazur, Udziat adwokata w postępowaniu przygotowawczym ('Deelname van de raadsman aan het vooronderzoek'), Palestra 1971-6, p. 56-73.

\section{Mendys 1974}

W. Mendys, Kilka uwag dotyczacych kontradyktoryjnośći postępowania przygotowawczego ('Enkele opmerkingen over het contradictoire karakter van het vooronderzoek'), Palestra 1974-8/9, p. 85-88.

\section{Meyer 1995}

W.D. Meyer, Facing the post-communist reality: lawyers in private practice in Central and Eastern Europe and the republics of the former Soviet Union, Law and Policy in international business 1995, vol. 26, p. 1019-1059.

\section{Migdał 1954}

T. Migdał, Rola obrońca w procesie karnym ('De rol van de raadsman in het strafproces'), Nowe Prawo 1954-1, p. 37-48.

\section{Milej 2004}

T. Milej, Some General Impressions on Judiciary and Fair Trial in Central and Eastern European Countries, in: R. Alleweldt (e.a.) (red.), Human Rights and the Rule of Law, Krakau: Zakamycze 2004, p. 503-519.

\section{Młynarczyk 1996}

Z. Młynarczyk, Kontrola i utrwalanie rozmów telefonicznych w procesie karnym ('Afluisteren en opnemen van telefoongesprekken in het strafproces'), Prokuratura i Prawo 1996-2/3, p. 47-51.

\section{Monitoring Report 2003}

Ł. Bojarski, Access to Legal Aid in Poland: Monitoring Report, Warschau 2003, te raadplegen op: <www.hfhrpol.waw.pl/pliki/Access_to_Legal_Aid_in_Poland.pdf>.

\section{Murzynowski 1984}

A. Murzynowski, Penal Procedure Law, in: L. Kurowski, General Principles of Law of the Polish People's Republic, Warschau: Polish Scientific Publishers 1984.

\section{Murzynowski 1987}

A. Murzynowski, Udziat obrońcy w postępowaniu przugotowawczym de lege lata ('Deelname van de raadsman aan het vooronderzoek de lege lata'), Palestra 1987-12, p. 38-58.

\section{Murzynowski 1989}

A. Murzynowski, The Works on Reform of the Polish Penal Procedure, Droit Polonais Contemporain 1989-1-4, p. 57-71. 


\section{Murzynowski 1994}

A. Murzynowski, Refleksje na tle Uchwaty Naczelnej Rady Adwokackiej dotyczacej tajemnicy adwokackiej ('Een beschouwing over de beslissingen van de Hoogste Raad van de balie met betrekking tot het beroepsgeheim'), Palestra 1994-11, p. 52-58.

\section{Musiałik 1998}

G. Musiałik, Dopuszczalność stosowania podstuchu telekomunikacyjnego w stosunku do osób zobowiazanych do zachowania tajemnicy zawodowej na gruncie Kodeksu postępowania karnego z 1997 roku ('Toelaatbaarheid van afluisteren van telecommunicatie ten aanzien van professionele geheimhouders op grond van het wetboek van strafvordering van 1997'), Palestra 1998-11/12, p. 86-95.

\section{Musiałik 2000}

G. Musiałik, Problem krontroli i utrwalania rozmów zatrzymanego z adwokatem ('Het probleem van het controleren en opnemen van gesprekken tussen aangehoudene en advocaat'), Problemy Prawa Karnego 2000-23, p. 51-68.

\section{Myczkowski 2003}

M. Myczkowski, Zasada prawa oskarżonego do obrony a dowód z zeznań świadka incognito ('Het recht op verdediging en de anonieme getuigeverklaring als bewijsmiddel'), in: L. Bogunia (red.), Nowa kodyfikacja prawa karnego - tom XII, Wrocław: Wydawnictwo Uniwersytetu Wrocławskiego 2003, p. 199-206.

\section{Nagorski 1962}

Z. Nagorski, The legislation of the Polish People's Republic 1958-1959, in: K. Grzybowksi (e.a.) (red.), Studies in Polish Law: Law in Eastern Europe Volume 6, Leiden: Sythoff 1962, p. 78-120.

\section{Nowikowski 1980}

I. Nowikowski, Prawo tymczasowo aresztowanego do korespondencji z obrońca ('Het recht van de voorlopig gehechte verdachte om met zijn raadsman te corresponderen'), Palestra 19806, p. 65-72.

\section{Paprzycki 2002}

L.K. Paprzycki, Zmiana obrońcy w toku rozprawy na podstawie art. 378 K.P.K ('Het wijzigen van de raadsman op het onderzoek ter terechtzitting op grond van art. $378 \mathrm{~Sv}^{\prime}$ ), in; S. Stachowiak, Wspólczesny Polski proces karny, Poznań: Poznańska Drukarnia Naukowe 2002, p. 301-310.

\section{Patyulin 1981}

V. Patyulin, The Socialist Conception of Human Rights, in: Human Rights in Socialist Society, Moskou: Novosti Press Agency Publishing House 1981, p. 7-36.

\section{Peters 1972}

A.A.G. Peters, Het rechtskarakter van het strafrecht, Utrechtse oratie, Deventer: Kluwer 1972.

\section{Peters 1975}

A.A.G. Peters, Individuele vrijheid en de positie van verdachten in het strafproces, in: M.J. Gunning (e.a.) (red.), Recht als kritische discussie - een selectie uit het werk van A.A.G. Peters, Arnhem: Gouda Quint 1993, p. 79-106.

\section{Pipko en Pipko 1987}

S. Pipko en R. Pipko, Inside the Soviet Bar: A View from the Outside, The International Lawyer 1987-3, vol. 21 , p. 853-872.

\section{Płachta 1985}

M. Płachta, Realizcja zasady bezpośredności w odniesieniu do dowodu z zeznań świadków ('Verwezenlijking van het onmiddellijkheidsbeginsel ten aanzien van getuigenbewijs'), in: S. Waltoś (red), Swiadek w procesie sadowym, Warschau: Wydawnictwo Prawnicze 1985, p. 200-227. 


\section{Płachta 1990}

M. Płachta, The Formation of the Polish Legal System During the Changes in the Structure of the Government: 1944-1949, Review of Socialist Law 1990-1, vol. 16, p. 57-79.

\section{Polony 1974}

J. Polony, Korzystanie przez strony $i$ ich przedstawicieli $z$ uprawnień do uczestniczenia w czynnościach postępowania przygotowawczego ('Gebruik van het recht tot deelname aan handelingen in het vooronderzoek door partijen en hun vertegenwoordigers'), Nowe Prawo 1974-2, p. 154-158.

\section{Pomorski 1975}

S. Pomorski, Lay Judges in the Polish Criminal Courts: A Legal and Empirical Description, Case Western Reserve Journal of International Law 1975-2, vol. 7, p. 198-209.

\section{Pomorski 1981}

S. Pomorski, Communists and their Criminal Law - Reflections on Igor Andrejew's 'Outline of the criminal law of socialist states', Review of Socialist Law 1981-7, p. 7-34.

\section{Pomorski 2006}

S. Pomorski, Modern Russian Criminal Procedure - the adversarial principle and guilty plea, Criminal Law Forum 2006-2, p. 129-148.

\section{Pomorski en Defert 1980}

S. Pomorski en K. Defert, Universally Accepted Norms and Their Application in National Legal Systems. A Comparative Study of Polish and American Criminal Law and Their Interaction with Modern International Human Rights Legislation, Denver Law Journal 1980, vol. 57, p. 467-544.

\section{Ponikwia 2002}

K. Ponikwia, Uwagi krytyczne do art. 239 k.p.k. ('Kritische opmerkingen bij art. 239 Sv'), Prokuratura i Prawo 2002-10, p. 141-145.

\section{Prakken 2003}

T. Prakken, De Nederlandse raadsman in Frankrijk, in: T. Prakken en T. Spronken (red.), Handboek verdediging, Deventer: Kluwer 2003, p. 919-958.

\section{Prusak 1973}

F. Prusak, Normatywne i pragmatyczne czynniki określające zakres udziału obrońcy w postępowaniu przygotowawczym ('Wettelijke en praktische factoren die de omvang van het aandeel van de raadsman aan het vooronderzoek bepalen'), Palestra 1973-6, p. 34-47.

\section{Prusak 1974}

F. Prusak, Kontradyktoryjność postępowania przygotowawczego ('Tegenspraak in het vooronderzoek'), Palestra 1974-1, p. 15-21.

\section{Przyborowska-Klimczak 1996}

A. Przyborowska-Klimczak, Poland's Obligations concerning Human Rights under International Conventions, East European Human Rights Review 1996-1, vol. 2, p. 95-118.

\section{Razi 1960}

G.M. Razi, Legal Education and the Role of the Lawyer in the Soviet Union and the Countries of Eastern Europe, California Law Review 1960, vol. 48, p. 776-804.

\section{Razowski 2005}

T. Razowski, Formalne i merytoryczna kontrola oskarżonia w polskim procesie karnym ('De formele en inhoudelijke controle van de akte van beschuldiging in het Poolse strafproces'), Krakau: Kantor Wydawniczy Zakamycze 2005. 


\section{Rek 1950}

T. Rek, Zakres i cele reformy adwokatury ('Omvang en doelstellingen van de hervorming van de advocatuur'), Państwo i Prawo 1950-10, 21-36.

\section{Rekosh 2002}

E. Rekosh, Still No Justice for All, 2002, te raadplegen op: <www.pili.org/en/content/ view/121/26>.

\section{Report CPT 1996}

Report to the Polish Government on the visit to Poland carried out by the European Committee for the Prevention of Torture and Inhuman and Degrading Treatment or Punishment (CPT) from 30 June to 12 July 1996, te raadplegen op: <www.cpt.coe.int/documents/pol/1998-13-inf-eng.htm>.

\section{Report CPT 2000}

Report to the Polish Government on the visit to Poland carried out by the European Committee for the Prevention of Torture and Inhuman or Degrading Treatment or Punishment (CPT) from 8 to 19 May 2000, te raadplegen op: <www.cpt.coe.int/documents/pol/2002-09-inf-eng.pdf>.

\section{Report CPT 2004}

Report to the Polish Government on the visit to Poland carried out by the European Committee for the Prevention of Torture and Inhuman or Degrading Treatment or Punishment (CPT) from 4 to 15 October 2004, te raadplegen op: <www.cpt.coe.int/documents/pol/2006-11-inf-eng. pdf>.

\section{Response government report CPT 2000}

Response of the Polish Government to the report of the European Committee for the Prevention of Torture and Inhuman or Degrading Treatment or Punishment (CPT) on its visit to Poland from 8 to 19 May 2000, te raadplegen op: <www.cpt.coe.int/documents/pol/2002-10-inf-eng.pdf>.

\section{Response government report CPT 2004}

Response of the Polish Government to the report of the European Committee for the Prevention of Torture and Inhuman or Degrading Treatment or Punishment (CPT) on its visit to Poland from 4 to 15 October 2004, te raadplegen op: <www.cpt.coe.int/documents/pol/2006-12-inf-eng.pdf>.

\section{Révész 1967}

L. Révész, Justiz im Ostblock - Richter und Strafrecht, Keulen: Verlag Wissenschaft und Politik 1967.

\section{Rosada 1955}

S. Rosada, Poland: The Bar, in: V. Gsovski (red.), Highlights of current legislation and activities in Mid-Europe 1955, p. 265-267.

\section{Röttgering 2006}

A. Röttgering, Het ontwerp-kaderbesluit procedurele rechten in strafprocedures, in: M.J. Borgers, F.G.H. Kristen en J.B.H.M. Simmelink (red.), Implementatie van Kaderbesluiten, Nijmegen: Wolf Legal Publishers 2006, p. 159-172.

\section{Ruff 1939}

J. Ruff, Dyscyplina adwokatury ('Discipline van de advocauur'), Warschau: Księgarnia Powszechnia 1939.

\section{Schaff 1953}

L. Schaff, Proces Karny Polski Ludowej - Wyklad Zasad Ogólnych ('Het strafproces in de Poolse Volksrepubliek - Bespreking van algemene beginselen'), Warschau: Wydawnictwo Prawnicze, 1953.

\section{Seymour 1993}

D. Seymour, The Extension of the European Convention on Human Rights to Central and Eastern Europe: Prospects and Risks, Connecticut Journal of International Law 1993, vol. 8, p. 243-261. 


\section{Siegelbaum 2002}

J.H. Siegelbaum, The Right Amount of Rights: Calibrating Criminal Law and Procedure in PostCommunist Central and Eastern Europe, International Law Journal 2002, vol. 20, p. 73-124.

\section{Siekanowicz 1959 I}

P. Siekanowicz, Poland, in: V. Gsovski en K. Grzybowski, Governments, Law and Courts in the Soviet Union and Eastern Europe (vol.1), Londen: Stevens 1959, p. 728-788.

\section{Siekanowicz 1959 II}

P. Siekanowicz, Poland: The Polish bar at the crossroads, in: V. Gsovski (red.), Highlights of current legislation and activities in Mid-Europe 1959, p. 293-313.

\section{Slapnicka 1963}

H. Slapnicka, Soviet law as model: the people's democracies in the succession states, Natural Law Forum 1963, vol. 8, p. 106-121.

\section{Śliwiński 1948}

S. Śliwiński, Polski proces karny przed sądem powszechnym - Zasady ogólne ('Het Poolse strafproces voor de gewone rechtbank - Algemene beginselen'), Warschau 1948.

\section{Śliwiński 1961}

S. Śliwiński, Polski proces karny - przed sadem powszechnym ('Het Poolse strafproces - voor de gewone rechtbank'), Warschau: Państwowe Wydawnictwo Naukowe 1961.

\section{Sowiński 2004}

P.K. Sowiński, Prawo świadka do odmowy zeznań w procesie karnym ('Het recht van getuigen om te weigeren een verklaring af te leggen in het strafproces'), Warschau: Beck 2004.

\section{Spaniol 1990}

M. Spaniol, Das Recht auf Verteidigerbeistand im Grundgesetz und in der Europäischen Menschenrechtskonvention, Berlijn: Duncker \& Humblot 1990.

\section{Sprawny Sąd: zbior dobrych praktyk 2004}

Sprawny Sad: zbior dobrych praktyk ('Rechtbankkwesties: een verzameling voor een goede praktijk') rapport uitgegeven door Iustitia en Helsinki Watch committee, bewerkt door $€$. Bojarski, 2004, te raadplegen op: <www.hfhrpol.waw.pl/index_pliki/pdf/sprawny_sad 2.pdf>.

\section{Sprawozdania organów adwokatury 1998-2001}

Sprawozdania organów adwokatury ('Rapporten van de organen van de advocatuur 1998$2001^{\prime}$ ), rapport opgesteld door de nationale vergadering van de balie, Warschau 24 en 25 november 2001.

\section{Sprawozdania organów adwokatury 2001-2004}

Sprawozdania organów adwokatury ('Rapporten van de organen van de advocatuur 2001$\left.2004^{\prime}\right)$, rapport opgesteld door de nationale vergadering van de balie, Warschau 20 en 21 november 2004.

\section{Spronken 2001}

T.N.B.M. Spronken, Verdediging: een onderzoek naar de normering van het optreden van advocaten in strafzaken, Deventer: Gouda Quint 2001.

\section{Spronken 2002}

T.N.M.B. Spronken, noot bij Brennan t. Verenigd Koninkrijk, EHRM 16-10-2001, European Human Rights Cases 2002-1, p. 3-9. 


\section{Spronken 2003}

T.N.M.B. Spronken, A Place of Greater Safety - Bespiegelingen over een Europees Statuut voor de Strafrechtadvocaat, oratie uitgesproken op 10 oktober 2003 bij de aanvaarding van het ambt van bijzonder hoogleraar verdediging in strafzaken aan de Universiteit Maastricht, Deventer: Kluwer 2003.

\section{Spronken 2006}

T. Spronken, Advocaat bij politieverhoor: een blik over de grens, Nieuwsbrief Strafrecht 2006, p. 107-110.

\section{Spronken en Attinger 2005}

T. Spronken en M. Attinger, Procedural Rights: Existing Level of Safeguards in the European Union, gepubliceerd door de Europese Unie, 12 december 2005.

\section{Stachowiak 1997}

S. Stachowiak, Przestuchanie podejrzanego $z$ udziatem obrońcy ('Het verhoor van verdachte in aanwezigheid van de raadsman'), Prokuratura i Prawo 1997-12, p 21-24.

\section{Stachowiak 2001}

S. Stachowiak, Zakres informacji procesowej przekazywanej podejrzanemu przed $i$ w toku przestuchiwania ('De reikwijdte van de informatie die voorafgaand aan en tijdens het verhoor aan de verdachte dient te worden meegedeeld'), Prokuratura i Prawo 2001-3, p. 7-17.

\section{Stando-Kawecka 2001}

B. Stando-Kawecka, Poland, in: D. van Zyl Smit en F. Dünkel, Imprisonment Today and Tomorrow, Den Haag (etc.): Kluwer 2001, p. 508-550.

\section{Stavros 1993}

S. Stavros, The Guarantees of Accused Persons Under Article 6 of the European Convention on Human Rights, Dordrecht (etc.): Martinus Nijhoff Publishers 1993.

\section{Stefański 1997}

R.A. Stefański, Zatrzymanie wedtug nowegu kodeksu postępowania karnego ('Aanhouding en daaropvolgende vrijheidsberoving volgens het nieuwe wetboek van strafvordering'), Prokuratura i Prawo 1997-10, p. 32-60.

\section{Stefański 1998 I}

R.A. Stefański, Wniosek prokuratora o skazanie oskarżonego bez rozprawy ('Het verzoek van de prokurator tot veroordeling van verdachte zonder terechtzitting'), Prokuratura i Prawo 1998-2, p. 46-57.

\section{Stefański 1998 II}

R.A. Stefański, Ujawnienie tajemnicy zawodowej przez świadka w nowym kodeksie postępowania karnego ('Het onthullen van een beroepsgeheim door een getuige in het nieuwe wetboek van strafvordering'), Prokuratura i Prawo 1998-4, p. 115-125.

\section{Stefański 2003}

R.A. Stefański, Skazanie bez rozprawy w znowelizowanym kodeksie postępowania karnego ('Veroordeling zonder onderzoek ter terechtzitting in het herziene wetboek van strafvordering'), Prokuratura i Prawo 2003-6, p. 17-38.

\section{Steinborn 2005}

S. Steinborn, Porozumienia w Polskim procesie karnym ('De overeenkomst in het Poolse strafproces'), Krakau: Zakamycze 2005.

\section{Suproń-Heidel 2004}

A. Supron-Heidel, Dritter Diskussionsbericht: Die polnische jurustische Infrastruktur, in: C. D. Classen (e.a.) (red.), Polens Rechtstaats am Vorabends des EU-Beitritts, Tübingen: Mohr Siebeck 2004, p. 153-166. 


\section{Swidlicki 1988}

A. Swidlicki, Political Trials in Poland 1981-1986, Londen (etc.): Croom Helm 1988.

\section{Sypnowich 1990}

C. Sypnowich, The Concept of Socialist Law, Oxford: Clarendon Press 1990.

\section{Szewczyk 1997}

M. Szewczyk, Polish Criminal Law in Light of the European Convention on Human Rights and Fundamental Freedoms, European Journal of Crime, Criminal Law and Criminal Justice 1997-1, vol. 5, p. 79-88.

\section{Szumiło-Kulczycka en Waltoś 2003}

D. Szumiło-Kulczycka en S. Waltoś, Poland: Principles of criminal procedure and their application in disciplinary proceedings in Poland, Revue Internationale de Droit Pénal 2003-3/4, vol. 74, p. 1041-1061.

\section{The Role and Responsibilities of the Lawyer in a Society in Transition 1997}

The Role and Responsibilities of the Lawyer in a Society in Transition, verslag van een bijeenkomst georganiseerd door de Raad van Europa in samenwerking met de Hongaarse balie, de CCBE en INTERIGHTS, Budapest, 9-11 december 1997.

\section{Tomaszewski 1988}

T. Tomaszewski, Przestuchanie biegłego w postępowaniu karnym ('Het deskundigenverhoor in het strafproces'), Warschau: Wydawnictwo Prawnicze 1988.

\section{Tomaszewski 2000}

T. Tomaszewski, Dowód z opinii biegłego w procesie karnym ('Deskundigenbewijs in het strafproces'), Krakau: Wydawnictwo Instytutu Ekspertyz Sądowych 2000.

\section{Trybuchowska 2002}

E. Trybuchowska, Obecność oskarżonego na rozprawie głównej de lege lata i de lege ferenda ('De aanwezigheid van de verdachte op het onderzoek ter terechtzitting de lege lata en de lege ferenda'), in: L. Bogunia (red.), Nowa kodyfikacja prawa karnego - tom XI, Wrocław: Wydawnictwo Uniwersytetu Wrocławskiego 2002.

\section{Trybuchowska 2003}

E. Trybuchowska, Uksztattowanie kontradyktoryjności w polskim procesie karnym ('Vormgeven aan het beginsel van tegenspraak in het Poolse strafproces'), in: L. Bogunia (red.), Nowa Kodyfikacja Prawa Karnego - tom XII, Wrocław: Wydawnictwo Uniwersytetu Wrocławskiego 2003, p. 227-241.

\section{Trzcińska 2002}

A. Trzcińska, Inicjatywa dowodowa podejrzanego w trakcie postępowenia przygotowawczego ('Het bewijsinitiatief van verdachte gedurende het vooronderzoek'), in: S. Stachowiak (red.), Wspótczesny polski proces karny, Poznań: Poznańska drukarnia naukowa 2002.

\section{Tylman 1994}

J. Tylman, Rechtsstaatliche Möglichkeiten einer Vereinfachung des Strafverfahrens in Polen, in: A. Eser, G. Kaiser en E. Weigend (red.), Von totalitärem zu rechtsstaatlichem Strafrecht. Kiminalpolitische Reformtendenzen im Strafrecht osteuropäischer Länder: internationales Symposium in Buchenbach bei Freiburg im Breisgau vom 27.-31. Mai 1992, Freiburg im Breisgau: MaxPlanck-Institut für ausländisches und internationales Strafrecht 1994, p. 533-550.

\section{Uildriks 2005}

N.A. Uildriks, Police reform and human rights: opportunities and impediments in post-communist societies, Antwerpen/Oxford: Intersentia (etc.) 2005 


\section{Uildriks en Van Reenen 2003}

N.A. Uildriks en P. van Reenen, Policing post-communist societies: police-public violence, democratic policing and human rights, Antwerpen/Oxford: Intersentia (etc.) 2003.

\section{Ulč 1972}

O. Ulč, The Judge in a Communist State - a View from within, Columbus: Ohio University Press 1972.

\section{Urbaniak 2003}

M.J. Urbaniak, Rozpoznawanie spraw pod nieobećność oskarżonego ('De behandeling van zaken in afwezigheid van verdachte'), Poznań: Kalisz 2003.

\section{Van der Velde 2004 I}

J. Van der Velde, Rechtsbijstand, in: A. W. Heringa, J. Schokkenbroek en J. van der Velde (red.), Art. 6 Eerlijk proces, EVRM Rechtspraak en Commentaar 2004 (aanvulling 62), Den Haag: Sdu 2004.

\section{Van der Velde 2004 II}

J. Van der Velde, Vrijheidsontneming, in: A. W. Heringa, J. Schokkenbroek en J. van der Velde (red.), Art. 5, EVRM Rechtspraak en Commentaar 2004 (aanvulling 62), Den Haag: Sdu 2004.

\section{Van Dijk e.a. 2006}

P. van Dijk (red.) Theory and Practice of the European Convention on Human Rights, Antwerpen/ Oxford: Intersentia 2006.

\section{Van Gestel 2006}

R.A.J. van Gestel, 102 praktijkvragen over de implementatie van Europees recht - op zoek naar richtlijnen voor de omzetting van kaderbesluiten, in : M.J. Borgers, F.G.H. Kirsten en J.B.H.M. Siebelink (red.), Implementatie van kaderbesluiten, Nijmegen: Wolf Legal Publishers 2006, p. 205-224.

\section{Van Kempen 2006}

P.H.P.H.M.C, Communautaire doorwerking en straf(proces)recht - over toepassing van directe werking, conforme interpretatie en staatsaansprakelijkheid in strafzaken en het belang bij ruimere implementatiemarges, in: M.J. Borgers, F.G.H. Kirsten en J.B.H.M. Siebelink (red.), Implementatie van kaderbesluiten, Nijmegen: Wolf Legal Publishers 2006, p. 73-125.

\section{Vos 2000}

L. Vos, De strijd van de witte adelaar. Geschiedenis van Polen, Leuven: Acco 2000.

\section{Wacquant 2004}

L. Wacquant, Straf de Armen - het nieuwe beleid van de sociale onzekerheid, Berchem: Epo 2004.

\section{Waltoś 1979}

S. Waltoś (red. en inl.), Code of Criminal Procedure of the Polish People's Republic (vert. door M. Abrahamowicz), Warschau: Wydawnictwo Prawnicze 1979.

\section{Waltoś 1991}

S. Waltoś, Untersuchungshaft und Festnahme im Polnischen Recht im Lichte der Menschenrechtenstandards, in: A. Eser, G. Kaiser en E. Weigend (red.), Strafrechtsreform in Polen und Deutschland, Untersuchungshaft, Hilfeleistungspflicht und Unfallflucht. 4. deutsch-polnisches Kolloquium über Strafrecht und Kriminologie, Schloss Ringberg am Tegernsee, vom 1.-5. April 1990, Baden-Baden: Nomos 1991, p. 247-262. 


\section{Waltoś 1999}

S. Waltoś, Die neue polnischen Strafprozeßordnung im Vergleich mit dem deutschen Strafprozeßrecht, in: T. Weigend en G. Küpper (red.), Festschrift für Hans Joachim Hirsch zum 70. Geburtstag am 11. April 1999, Berlijn (etc.): De Gruyter 1999, p. 995-1014.

\section{Waltoś 2002 I}

S. Waltoś, Proces Karny - Zarys Systemu ('Het strafproces - een overzicht van het systeem'), Warschau: Wydawnictwo Prawnicze 2002.

\section{Waltoś 2002 II}

S. Waltoś, Wizja procesu karnego XXI wieku ('Een visie op het strafproces van de 21e eeuw'), Prokuratura i Prawo 2002, p. 7-27.

\section{Waltoś 2003}

S. Waltoś, Główne nurty nowelizcji procedury karnej ('Hoofdlijnen van de herziening van het strafproces'), Państwo i Prawo 2003-4, p. 5-46.

\section{Waltoś 2005}

S. Waltoś, O obstrukcji procesowej, czyli kilka uwag o nadużyciu prawa procesowego ('Over obstructie van het proces, ofwel enkele opmerkingen over misbruik van procesrecht'), in: L. Leszczyński (e.a.) (red.), W kręgu teorii i praktyki prawa karnego - księga poświęcona pamięci profesora Andrzeja Waska, Lublin: Wydawnictwo Uniwersytetu Marii Curie-Skłodowskiej 2005, p. 614-627.

\section{Wąsek-Wiaderek 2000}

M. Wąsek- Wiaderek, The principle of 'equality of arms' in criminal procedure under Article 6 of the European Convention on Human Rights and its functions in criminal justice of selected European countries. A comparative view, Leuven Law series vol. 13, Leuven: Leuven University Press 2000.

\section{Wąsek-Wiaderek 2003 I}

M. Wąsek-Wiaderek, Dostęp do akt sprawy oskarżonego tymczasowo aresztowanego i jego obrońcy w postęowaniu przygotowawczym - standard europejski a prawo polskie ('Inzage van de processtukken door de voorlopig gehechte verdachte en zijn raadsman - de Europese standaard en het Poolse recht'), Palestra 2003-3/4, p. 55-71.

\section{Wąsek-Wiaderek 2003 II}

M. Wąsek-Wiaderek, Zasady równości stron w Polskim procesie karnym w perspektywie prawnoporównawczej ('Het beginsel van equality of arms in het Poolse strafproces in rechtsvergelijkend perspectief'), Krakau: Zakamycze 2003.

\section{Wąsek-Wiaderek 2005}

M. Wąsek-Wiaderek, Oddalenie wniosku dowodowego zmierzającego w sposób oczywisty do przedtużenia postępowania w polskiej procedurze karnej ('Afwijzen van bewijsverzoeken die overduidelijk zijn gericht op vertraging van de procedure in het Poolse strafproces'), in: L. Leszczyński (e.a.) (red.), W kręgu teorii i praktyki prawa karnego - księga poświęcona pamięci profesora Andrzeja Waska, Lublin: Wydawnictwo Uniwersytetu Marii Curie-Skłodowskiej 2005, p. 709-718.

\section{Wąsek en Frankowski 1995}

A. Wąsek en S. Frankowski, Polish Criminal Law and Procedure, in: S. Frankowski en B. Stephan III (red.), Legal Reform in Postcommunist Europe. The View from Within, Dordrecht (etc.): Nijhoff 1995, p. 275-308.

\section{Waśkowski 1932}

E. Waśkowski, Zadanie adwokatury - Zasady etyki adwokackiej ('De taak van de advocatuur: ethische beginselen voor de advocaat'), Warschau: Drukarnia Rolnicza 193.2 


\section{Waszczynski 1966}

J. Waszczynski, The Criminal Process in the Polish People's Republic, in: J. A. Coutts (red.), The Accused: a Comparative Study, Londen: Stevens \& Sons 1966, p. 257-267.

\section{Ważny 2004}

A. Ważny, Porozumienia procesowe po nowelizacji kodeksu postępowanie karnego ('Consensuele afdoening na herziening van het wetboek van strafvordering'), in: S. Sobolewski (e.a.) (red.), Problemy znowelizowanej procedury karnej, Krakau: Zakamycze 2004, p. 244-266.

\section{Weigend 1991}

E. Weigend, Strafprozessrechtsreform in Polen der Entwurf einer neuen Strafprozessordnung, in: A. Eser, G. Kaiser en E. Weigend (red.), Strafrechtsreform in Polen und Deutschland, Untersuchungshaft, Hilfeleistungspflicht und Unfallflucht. 4. deutsch-polnisches Kolloquium über Strafrecht und Kriminologie, Schloss Ringberg am Tegernsee, vom 1.-5. April 1990, Baden-Baden: Nomos 1991, p. 33-45.

\section{Weigend 2003}

E. Weigend, Grundzüge der neuen polnischen Strafprozessordnung von 1997, Zeitschrift für die gesamte Strafrechtswissenschaft 2003-1, vol. 115, p. 153-174.

\section{White 2001}

S. White, Communism and its collapse: the making of the contemporary world, Londen: Routledge 2001.

\section{Wierzbowski 2001}

M. Wierzbowski, Watching Law Obedience in Poland. Supreme Administrative Court, Constitutional Tribunal and Representative of Citizens Rights, in: K. Redden en L.L. Schlueter (red.), Modern Legal Systems Encyclopedia, Buffalo: Hein 2001.

\section{Wiliński 2003 I}

P. Wiliński, Świadek incognito w Polskim procesie karnym ('De anonieme getuige in het Poolse strafproces'), Krakau: Zakamycze 2003.

\section{Wiliński 2003 II}

P. Wiliński, Świadek incognito w znowelizowanym kodeksie postępowania karnego ('De anonieme getuige in het herziene wetboek van strafvordering'), Prokuratura i Prawo 2003-6, p. 54-72.

\section{Wiliński 2005}

P. Wiliński, Przestuchanie świadka na odległość w postępowaniu karnym ('Horen van getuigen op afstand in het strafproces'), Przeglad Sadowy 2005-6, p. 16-27.

\section{Wiliński 2006}

P. Wiliński, Zasada prawa do obrony w Polskim procesie karnym ('Het recht op verdediging in het Poolse strafproces'), Krakau: Zakamycze 2006.

\section{Wiliński en Górecki 2006}

P. Wiliński en P. Górecki, Zasada prawdy a zasada prawa do obrony ('Het beginsel van materiële waarheid en het recht op verdediging'), in: Z. Sobolewski en G. Artymiak (red.), Zasada prawdy materialnej, Krakau: Kantor Wydawniczy Zakamycze 2006, p. 43-54.

\section{Witkowska 2002}

J. Witkowska, Obrona obligatoryjna w przypadku istnienia uzasadnionych wattliwości co do poczytalności oskarżonego ('Verplichte verdediging in geval van gerechtvaardigde twijfel aan de toerekeningsvatbaarhed van verdachte'), in: L. Bogunia (red.), Nowa kodyfikacja prawa karnego - tom XI, Wrocław: Wydawnictwo Uniwersytetu Wrocławskiego 2002, p. 275-293. 


\section{Wołpiuk 1994}

W.J. Wołpiuk, Civic Rights in Poland in the Face of European Standards, Droit Polonais Contemporain 1994-1/4, p. 91-104.

\section{Zabłocki 2000}

S. Zabłocki, Nowela k.p.k z dnia 20 lipca 2000r ('De wijziging van het wetboek van strafvordering van 20 juli 2000'), Warschau: Dom Wydawniczy ABC 2000, p. 125-136.

\section{Zagórski 2004}

J. Zagórski, Zatrzymanie przez policję oraz umieszczenie w policyjnych izbach zatrzymań ('Aanhouding door de politie en plaatsing in politiecellen'), Państwo i Prawo 2004-9, p. 84-97.

\section{Zajadło 1990}

J. Zajadło, Some Remarks on the Relation of International Law to Internal Law in the Polish Legal System, in: A. Rosas (red.), International Human Rights Norms in Domestic Law. The Finnish and Polish Perspective, Helsinki: Lakimiesliiton Kustannus 1990, p. 15-24.

\section{Zakrewska 1992}

J. Zakrewska, Konstytucyjna zasada państwa prawnego w praktyce Trybunatu Konstytucyjnego ('Het grondwettelijk beginsel van de rechtsstaat in de praktijk van het Grondwettelijk Hof'), Państwo i Prawo 1992-7, p. 3-14.

\section{Zawadzki en Kubicki 1969}

S. Zawadzki en L. Kubicki, L'élément populaire et le juge professionel dans la procedure penale en Pologne, Revue de Droit Pénal et de Criminologie 1969, p. 919-935.

\section{Zawadzki en Kubicki 1970}

S. Zawadzki en L. Kubicki (red.), Udział ławników w postępowaniu karnym. Opinie a rzeczywistość ('Deelname van lekenrechters aan het strafproces. Meningen en realiteit'), Warschau: Wydawnictwo Prawnicze 1970.

\section{Zewelak 2006}

A. Zewelak, Ustawa o świadek koronnym - spojrzenie praktyczne ('De wet op de kroongetuige - een blik op de praktijk'), L. Bogunia (red.), Nowa kodyfikacja prawa karnego - tom XX, Wrocław: Wydawnictwo Uniwersytetu Wrocławskiego 2006.

\section{Zielinski 2003}

Zielinski, Changes in Court Decision-Making in Poland since 1989, in: J. Přibáň (red.) (e.a.), Systems of Justice in Transition - Central European Ecperiences since 1989, Aldershot: Ashgate 2003, p. 109-120. 


\section{Jurisprudentie}

\section{Rechtspraak EHRM}

- $\quad$ EHRM 6-9-1978 (Klass e.a.t. Duitsland), A28, nr. 5029/71

- EHRM 13-5-1980 (Artico t. Italië), A37, nr. 6694/74

- EHRM 23-6-1981 (Le Compte, Van Leuven en De Meyere t. België), nr. 6878/75, 7238/75

- EHRM 14-12-1981 (Jespers t. België), nr. 8403/78

- EHRM 10-2-1983 (Albert and Le Compte t. België), nr. 7299/75, 7496/75

- EHRM 25-4-1983 (Pakelli t. Duitsland), nr. 8398/78

- EHRM 9-4-1984, (Goddi t. Italië), A76, nr. 8966/80

- EHRM 2-8-1984 (Malone t. Verenigd Koninkrijk), A82, nr. 8691/79

- EHRM 6-5-1985 (Bönisch t. Oostenrijk), nr. 8658/79

- EHRM 30-9-1985 (Can t. Oostenrijk), A96, nr. 9300/81.

- EHRM 24-11-1986 (Unterpertinger t. Oostenrijk), nr. 9120/80

- EHRM 29-11-1988 (Brogan e.a. t. Verenigd Koninkrijk), A145-B, nr. 11209/84, 11234/84, $11266 / 84,11386 / 85$

- EHRM 6-12-1988 (Barberà, Messegué and Jabardo t. Spanje), nr. 10590/83

- EHRM 30-3-1989 (Lamy t. België), nr. 10444/83

- EHRM 7-7-1989 (Bricmont t. België), nr. 10857/84

- EHRM 25-10-1989 (Bezicheri t. Italië), nr. 11400/85

- EHRM 20-11-1989 (Kostovski t. Nederland), nr. 11454/85

- EHRM 19-12-1989 (Kamasinski t. Oostenrijk), nr. 9783/82

- EHRM 24-4-1990 (Huvig t. Frankrijk), A176-B, nr. 11105/84

- EHRM 24-4-1990 (Kruslin t. Frankrijk), A176-A, nr. 11801/85

- EHRM 27-9-1990 (Windisch t. Oostenrijk), nr. 12489/86

- EHRM 19-12-1990 (Delta t. Frankrijk), nr. 11444/85

- EHRM 26-4-1991 (Asch t. Oostenrijk), A203, nr. 12398/86

- EHRM 24-5-1991 (Quaranta t. Zwitserland), nr. 127441/87

- EHRM 28-8-1991 (F.C.B. t. Italië), nr. 12151/86

- EHRM 28-8-1991 (Brandstetter t. Oostenrijk), nr. 11170/84, 12876/87, 13468/87

- EHRM 28-11-1991 (S. t. Zwitserland), A220, nr. 12629/87, 13965/88

- EHRM 12-12-1991 (Toth t. Oostenrijk), nr. 11894/85

- EHRM 25-3-1992 (Campbell t. Verenigd Koninkrijk), A233, nr. 13590/88

- EHRM 22-4-1992 (Vidal t. België), nr. 12351/86

- EHRM 15-6-1992 (Lüdi t. Zwitserland), A238, nr. 12433/86

- EHRM 24-9-1992 (Herczegfalvy t. Oostenrijk), nr. 10533/83

- EHRM 25-9-1992 (Croissant t. Duitsland), nr. 13611/88

- EHRM 16-12-1992 (Edwards t. Verenigd Koninkrijk), nr. 13071/87

- EHRM 21-9-1993 (Kremzow t. Oostenrijk), A268-B, nr. 12350/86

- EHRM 24-11-1993 (Imbrioscia t. Zwitserland), nr. 13972/88

- EHRM 13-7-1995 (Kampanis t. Griekenland), A318-B, nr. 17977/91

- EHRM 26-9-1995 (Diennet t. Frankrijk), nr. 18160/91

- EHRM 8-2-1996 (Murray t. Verenigd Koninkrijk), nr. 18731/91

- EHRM 26-3-1996 (Doorson t. Nederland), nr. 20524/92

- EHRM 10-6-1996 (Benham t. Verenigd Koninkrijk), nr. 19380/92

- EHRM 15-11-1996 (Domenichini t. Italië), nr. 15943/90

- EHRM 25-11-1996 (Silva Rocha t. Portugal), nr. 18165/91

- EHRM 18-3-1997 (Mantovanelli t. Frankrijk), nr. 21497/93

- EHRM 23-4-1997 (Van Mechelen e.a. t. Nederland), nr. 21363/93, 21364/93, 21427/93 
- EHRM 25-6-1997 (Halford t. Verenigd Koninkrijk), nr. 20605/92

- EHRM 25-11-1997 (Zana t. Turkije), Reports 1997-VII, nr. 18954/91,

- EHRM 16-12-1997 (Niemietz t. Duitsland), A251-B, nr. 13710/88

- EHRM 25-3-1998 (Kopp t. Zwitserland), nr. 23224/94

- EHRM 25-3-1998 (Belziuk t. Polen), Reports 1998-II, nr. 23103/93

- EHRM 21-4-1998 (Daud t. Portugal), nr. 22600/93

- EHRM 20-5-1998 (Schöpfer t. Zwitserland), nr. 25405/94

- EHRM 20-5-1998 (Gautrin e.a. t. Frankrijk), nr. 21257/93, 21258/93, 21259/93

- EHRM 24-8-1998 (Lambert t. Frankrijk), nr. 23618/94

- EHRM 28-10-1998 (Assenov e.a. t. Bulgarije), Reports 1998-VIII, nr. 24760/94

- EHRM 25-3-1999 (Nikolova t. Bulgarije), nr. 31195/96

- EHRM 9-3-1999 (Lindner t. Duitsland), nr. 32813/96

- EHRM 14-12-1999 (Dougan t. Verenigd Koninkrijk), nr. 44738/98

- EHRM 14-12-1999 (A.M. t. Italië), nr. 37019/97

- EHRM 16-2-2000 (Jasper t. Verenigd Koninkrijk), nr. 27052/95

- EHRM 16-2-2000 (Fitt t. Verenigd Koninkrijk), nr. 29777/96

- EHRM 6-4-2000 (Labita t. Italië), nr. 26772/95

- EHRM 2-5-2000 (Condron t. Verenigd Koninkrijk), nr. 35718/97

- EHRM 6-6-2000 (Averill t. Verenigd Koninkrijk), nr. 36408/97

- EHRM 6-6-2000 (Magee t. Verenigd Koninkrijk), nr. 28135/95

- EHRM 20-6-2000 (Foxley t. Verenigd Koninkrijk), nr. 33274/96

- EHRM 4-7-2000 (Niedbata t. Polen), nr. 27915/95

- EHRM 11-7-2000 (Dikme t. Turkije), nr. 20869/92

- EHRM 11-7-2000 (Trzaska t. Polen), nr. 25792/94

- EHRM 25-7-2000 (Mattoccia t. Italië), nr. 23969/94

- EHRM 10-10-2000 (Graužinis t. Litouwen), nr. 37975/97

- EHRM 19-10-2000 (Wtoch t. Polen), nr. 2778/95

- EHRM 26-10-2000 (Kudta t. Polen), nr. 30210/96

- EHRM 21-12-2000 (Egmez t. Cyprus), nr. 30873/96

- EHRM 31-1-2001 (Lanz t. Oostenrijk), nr. 24430/94

- EHRM 13-2-2001 (Garcia Alva t. Duitsland), nr. 23541/94

- EHRM 13-2-2001 (Lietzow t. Duitsland), nr. 24479/94

- EHRM 13-2-2001 (Schöps t. Duitsland), nr. 25116/94

- EHRM 5-7-2001 (Erdem t. Duitsland), nr. 38321/97

- EHRM 16-10-2001 (Brennan t. Verenigd Koninkrijk), nr. 39846/98

- EHRM 18-12- 2001 (R.D. t. Polen), nr. 29692/96, 34612/97

- EHRM 20-12-2001 (P.S. t. Duitsland), nr. 33900/96

- EHRM 14-2-2002 (Visser t. Nederland), nr 26668/95

- EHRM 21-3-2002 (Nikula t. Finland), nr. 31611/96

- EHRM 28-3-2002 (Klamecki t. Polen), nr. 25415/95

- EHRM 23-4-2002 (Zhelezov t. Rusland), nr. 48040/99

- EHRM 20-6-2002 (Berliński t. Polen), nr. 27715/95, 30209/96

- EHRM 25-6-2002 (Migoń t. Polen), nr. 24244/94

- EHRM 27-6-2002 (Eryk Kawka t. Polen), nr. 33885/96

- EHRM 2-7-2002 (Dacewicz t. Polen), nr. 34611/97

- EHRM 2-7-2002 (S.N. t. Zweden), nr. 34209/96

- EHRM 19-9-2002 (Tamosius t. Verenigd Koninkrijk), nr. 6200/00

- EHRM 10-10-2002 (Czekalla t. Portugal), nr. 38830/97

- EHRM 7-11-2002 (Goral t. Polen), nr. 38654/97 
- EHRM 28-11-2002 (Radaj t. Polen) , nr. 29537/95, 35453/97

- EHRM 19-12-2002 (Satapa t. Polen), nr. 35489/97

- EHRM 21-12-2002 (Jabloński t. Polen), nr. 33492/96

- EHRM 9-1-2003 (Shishkov t. Bulgarije), nr. 38822/97, 38822/97

- EHRM 14-1-2003 (Lagerblom t. Zweden), nr. 26891/95

- EHRM 12-3-2003 (Öcalan t. Turkije), ), nr. 46221/99

- EHRM 3-4-2003 (Klamecki t. Polen (no. 2)), nr. 31583/96

- EHRM 3-7-2003 (Telecki t.Polen), nr. 56552/00

- EHRM 28-10-2003 (Steur t. Nederland), nr. 39657/98

- EHRM 13-11-2003 (Elci e.a. t. Turkije), nr. 23145/93, 25091/94

- EHRM 2-12-2003 (Matwiejczuk t. Polen), nr. 37641/97

- EHRM 16-12-2003 (Mianowski t. Polen), nr. 42083/98

- EHRM 8-1-2004 (A. t. Finland), nr. 44998/98

- EHRM 20-1-2004 (G.K. t. Polen), nr. 38816/97

- EHRM 27-1-2004 (Lorsé t. Nederland), nr. 44484/98

- EHRM 27-1-2004 (Verhoek t. Nederland), nr. 54445/00

- EHRM 20-4-2004 (Mamaç e.a. t. Turkije), nr. 29486/95, 29487/95, 29853/96

- EHRM 22-4-2004 (Sarikaya t. Turkije), nr. 25143/94, 27098/95

- EHRM 25-4-2004 (Cornelis t. Nederland), nr. 994/03

- EHRM 27-4-2004 (M.B.t. Polen), nr. 34091/96

- EHRM 25-11-2004 (Aalmoes t. Nederland), nr. 16269/02

- EHRM 18-1-2005 (Kehayov t. Bulgarije), nr. 41035/98

- EHRM 12-5-2005 (Öcalan t. Turkije) (Grand Chamber), nr. 46221/99

- EHRM 14-6-2005 (Pisk-Piskowski t. Polen), nr. 92/03

- EHRM 28-7-2005 (Czarnecki t. Polen), nr. 75112/01

- EHRM 27-9-2005 (Petri Sallinen e.a. t. Finland), nr. 50882/99

- EHRM 4-10-2005 (Sarban t. Moldavië), nr. 3456/05

- EHRM 10-11-2005 (Bocos Cuesta t. Nederland), nr. 54789/00

- EHRM 6-12-2005 (Wasitewski t. Polen), nr. 63905/00

- EHRM 6-12-2005 (Drozdowski t. Polen ), nr. 20841/02

- EHRM 15-12-2005 (Hurter t. Zwitserland), nr. 53146/99

- EHRM 25-4-2006 (Ahmet Mete t. Turkije), nr. 77649/01

- EHRM 25-4-2006 (Gołek t. Polen), nr. 31330/02

- EHRM 27-4-2006 (Sannino t. Italië), nr. 30961/03

- EHRM 4-5-2006 (Celejewski t. Polen), nr. 17584/04

- EHRM 4-5-2006 (Michta t. Polen), nr. 13425/02

- EHRM 28-3-2006 (Tomczyk Prokopyszyn t. Polen), nr. 64283/01

- EHRM 30-5-2006 (Kwiek t. Polen), nr. 51895/99

- EHRM 20-6-2006 (Drabek t. Polen), nr. 5270/04

- EHRM 27-6-2006 (Tabor t. Polen), nr. 12825/02

- EHRM 4-7-2006 (Dzyruk t. Polen), nr. 77832/01

- EHRM 6-7-2006 (Telecki t. Polen), nr. 56552/00

- EHRM 8-8-2006 (Cabata t. Polen), nr. 23042/02

- EHRM 8-8-2006 (Cegtowski t. Polen), nr. 3489/03

- EHRM 10-8-2006 (Padalov t. Bulgarije), nr. 54784/00

- EHRM 3-10-2006 (Euczko t. Polen), nr. 73988/01

- EHRM 17-10-2006 (Gasiorowski t. Polen), nr. 7677/02

- EHRM 24-10-2006 (Taner Kiliç t. Turkije), nr. 70845/01

- EHRM 28-11-2006 (Oleksy t. Polen), nr. 64284/01 
- EHRM 12-12-2006 (Depa t. Polen), nr. 62324/00

- EHRM 19-12-2006 (Duda t. Polen), nr. 67016/01

- EHRM 19-12-2006 (Maksym t. Polen), nr. 14450/02

- EHRM 9-1-2007 (Gossa t. Polen), nr. 47986/99

- EHRM 16-1-2007 (Wedler t. Polen), nr. 4415/98

- EHRM 13-3-2007 (Castravet t. Moldavië), nr. 23393/05

- EHRM 12-4-2007 (Kozimor t. Polen), nr. 10816/02

- EHRM 24-4-2007 (B. t. Finland), nr. 17122/02

- EHRM 26-4-2007 (Salduz t. Turkije), nr. 36391/02

- EHRM 10-5-2007 (Modorca t. Moldavië), nr. 14437/05

- EHRM 22-5-2007 (Kaszczyniec t. Polen), nr. 59526/00

- EHRM 7-6-2007 (Smirnov t. Rusland), nr. 71362/01

- EHRM 19-6-2007 (W.S. t. Polen), nr. 21508/02

- EHRM 28-6-2007 (Association for European Integration and Human Rights and Ekimdzhiev t. Bulgarije), nr. 62540/00

- EHRM 6-9-2007 (Kakol t. Polen), nr. 3994/03

- EHRM 9-10-2007 (Rybacki t. Polen), nr. 52479/99

- EHRM 16-10-2007 (Osiński t. Polen), nr. 13732/03

- EHRM 16-10-2007 (Malikowski t. Polen), nr. 15154/03

- EHRM 16-10-2007 (Otomański t. Polen), nr. 4612/03

- EHRM 16-10-2007 (Wieser en Bicos Beteiligungen GMBH t. Oostenrijk), nr. 74336/01

- EHRM 23-10-2007 (Turcan en Turcan t. Moldavië), nr. 39835/05

- EHRM 6-11-2007 (Chruśhiński t. Polen), nr. 22755/04

- EHRM 8-1-2008 (Marczuk t. Polen), nr. 4646/02

- EHRM 15-1-2008 (Easzkiewicz t. Polen), nr. 28481/03

- EHRM 15-1-2008 (Pawlak t. Polen), nr. 39840/05

- EHRM 15-1-2008 (Zborowski t. Polen), nr. 45133/06

- EHRM 22-1-2008 (Bobel t. Polen), nr. 20138/03

- EHRM 29-1-2008 (Stepniak t. Polen), nr. 29366/03

- EHRM 22-5-2008 (Iliya Stefanov t. Bulgarije), nr. 65755/01

- EHRM 7-10-2008 (Mancevschi t. Moldavië), nr. 33066/04

\section{Rechtspaak ECRM}

- ECRM 12-7-1984 (Can t. Oostenrijk), B79, nr. 9300/81

- ECRM 6-4-1995 (Mulders t. Nederland), nr. 23231/94

- ECRM 6-7-1995 (Sawicki t. Polen), nr. 25085/94

- ECRM 10-9-1997 (Kornienko t. Polen), nr. 29261/95

- ECRM 20-5-1998 (Nikolova t. Bulgarije), nr. 31195/96

\section{Poolse rechtspraak}

\section{Hoger beroepsinstanties}

- SA Krakau 25-11-1993 (KZS 11994, nr. 1, 30)

- SA Białystok 26-2-1998 (II Aka 137/97, OSA 1999-7/8, nr. 60)

- SA Lublin 6-2-2002 (II Aka 222/01, Wokanda 2002-5)

- SA Lublin 18-12-2002 (II Aka 297/02, Prok. i Prawo 2003, nr. 12)

\section{Hooggerechtshof}

- SN 9-6-1967 (VI KZP 68/65, OSPiKa 1967, nr. 9, 89) 
- $\quad$ SN 24-11-1973 (II KZ 220/73, OSNKW 1974, nr. 3, 56)

- SN 25-7-1979 (V KRN 102/79 en V KRN 1213/79)

- SN 20-3- 1986 (I KR/86, OSPiKA 1987, nr. 7-8)

- SN 16-6- 1994 (I KZP 5/94, OSNKW 1994, nr. 7-8, 41)

- SN 19-1-1995 (I KZP 15/94, OSNKW 1-2/1995, 1)

- SN 8-9-1996, III KKN 67/96, Wokanda 1-2, 1997, p. 8)

- SN 19-3-1997 (IV KKN 326/96, OSNKW 1997, nr. 7/8, 64)

- $\quad$ SN 29-7-1997 (II KKN 313/97)

- $\quad$ SN 5-8-1998 (III KKN 307/98)

- $\quad$ SN 23-2-1999 (I KZP 30/98, OSNKW 3-4/1999)

- SN 6-6-2001 (II KKN 96/01, OSNKW 2001/11-12, 95)

- SN 29-1-2002 (II KKN 386/99, Prok. i Prawo 2002, nr. 10, p. 6)

- SN 13-11-2002 (V KKN 375/01)

- SN 4-2-2003 (IV KK 379/02, LEX nr. 75448)

- SN 9-2-2004 (V KK 194/03)

- SN 10-2-2004 (III KK 282/03, LEX nr. 84 462)

- SN 17-2-2004 (II KK 277/02, OSNKW 2004, nr. 4, 43)

- SN 6-12-2004 (SK 29/04)

\section{Grondwettelijk Hof}

- TK 17-2-2004 (SK 39/02)

- TK 18-2-2004 (P 21/02)

- TK 22-11-2004 (SK 64/03)

- TK 19-4-2006 (K 6/06)

- TK 3-6-2008 (K 42/07) 


\section{Curriculum Vitae}

Dorris de Vocht werd geboren op 2 september 1977 te Eindhoven. In 1995 deed zij eindexamen gymnasium aan het Hertog Jan College te Valkenswaard. Vanaf 1995 studeerde zij Nederlands recht (vakthematische richting strafrecht) aan de faculteit der rechtsgeleerdheid van de Universiteit Maastricht waar zij in 2000 afstudeerde (cum laude). Sinds oktober 2000 is zij verbonden aan de vakgroep Strafrecht en Criminologie van eerder genoemde faculteit: eerst als docent, daarna als junior-onderzoeker en vanaf september 2007 tot heden als universitair docent straf(proces)recht. Zij maakt onderdeel uit van de onderzoeksschool Rechten van de Mens en is sinds de afronding van dit proefschrift betrokken bij verschillende rechtsvergelijkende onderzoeken naar de effectiviteit van verdediging in strafzaken. Daarnaast verzorgt zij onderwijs in de blokken strafrecht en verdediging en rechtsmiddelen in strafzaken. 